\title{
Reproponer el vacío. La intervención en el patrimonio arquitectónico en el cambio de siglo, en España e Italia. Estudio sobre la recomposión de la pérdida en espacios abovedados
}

LUIS BOSCH ROIG 



\section{REPROPONER EL VACÍO}

La intervención en el patrimonio arquitectónico en el cambio de siglo, en España e Italia. Estudio sobre la recomposición de la pérdida en espacios abovedados.

TESIS DOCTORAL PRESENTADA POR LUIS BOSCH ROIG DIRECTORES: VICENTE MAS LLORENS Y ELISA VALERO RAMOS 


\title{
Colección Tesis Doctorales
}

\author{
(c) Luis Bosch Roig
}

( $)$ 2014, de la presente edición: Editorial Universitat Politècnica de València Telf.: 963877012 / www.lalibreria.upv.es

ISBN: 978-84-9048-193-6 (versión CD)

Queda prohibida la reproducción, distribución, comercialización, transformación, y en general, cualquier otra forma de explotación, por cualquier procedimiento, de todo o parte de los contenidos de esta obra sin autorización expresa y por escrito de sus autores. 


\section{AGRADECIMIENTOS}

Quiero agradecer la ayuda prestada en la elaboración de esta investigación...

a mis directores de tesis, Elisa Valero Ramos y Vicente Mas Llorens, que con paciencia y gran experiencia me han ayudado a concretar mis ideas en algo determinado y coherente;

a mi padre, Ignacio Bosch Reig, que ha seguido de cerca y con gran entusiasmo el desarrollo de esta investigación, aportando pertinentes matices, y a quien le debo mi interés por la arquitectura y por la intervención en el patrimonio;

a los arquitectos Juan Carlos Arnuncio y José Ignacio Linazasoro, que han mostrado una gran disponibilidad y amabilidad concediéndome entrevistas y respondiendo a todas aquellas preguntas que les he realizado posteriormente, por sus magníficas obras que han sido una fuente de inspiración fundamental para esta tesis, y porque sin su maestría en la disciplina arquitectónica esta investigación se vería muy mermada;

a los profesores del Dipartimento di Storia, Disegno e Restauro dell'Architettura de la Sapienza-Università di Roma: Mario Docci, Maria Piera Sette, Marina Docci, Christian Rosolino, Maria Grazia Turco, Stefano Marani y Alessandro Sartor, por su ayuda durante mi estancia en Roma;

a Valeria, que me enseña cada día a disfrutar de la satisfacción del trabajo bien hecho, que confía en mí, me apoya incondicionalmente, y a quien quiero y admiro profundamente;

a Mari Carmen, que con su metódico y constante trabajo me ha ayudado mucho en el apartado gráfico;

a Maurizio Boriani, Sandro Pittini, Juan Ignacio Lasagabaster Gómez, Giorgio Volpe, Emanuele Fidone, Jorge Torres, Giorgio Grassi y Marco Ceccarelli, por su ayuda prestada en la recopilación de documentación y gestión de la tesis;

a todos aquellos que se nombran en la investigación, en los que me he apoyado para elaborar la investigación;

a Laura, Carmen y demás compañeros por el apoyo que me han brindado durante este tiempo;

y también el cariño y ánimo de mi madre, mis hermanos y demás familiares y amigos;

porque sin vuestra ayuda esta tesis no hubiera sido posible, sinceramente... 



\section{ÍNDICE}

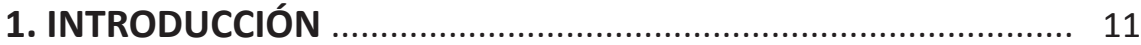

1.1. Antecedentes y ámbito de actuación.............................. 12

1.2. Objetivos................................................................ 15

1.3. Fuentes y metodología............................................. 16

2. CRITERIOS DE INTERVENCIÓN ............................................. 21

2.1. Evolución de los criterios de intervención en el patrimonio arquitectónico a lo largo de la historia.......... 22

2.2. Recapitulación de los criterios de intervención en la reflexión actual.

\section{LA RECOMPOSICIÓN DE LA PÉRDIDA}

EN ESPACIOS ABOVEDADOS

4. ESTUDIO DE CASOS

4.1. Oratorio di San Filippo Neri.

Pierluigi Cervellati. Bolonia. 1997-99

4.2. Capilla de los Condes de Fuensaldaña.

Juan Carlos Arnuncio. 1996-2002

4.3. Iglesia de las Escuelas Pías.

José Ignacio Linazasoro. Madrid. 1996-2004 254

4.4. Basílica de San Pedro.

Emanuele Fidone. Siracusa. 2002-2008 296

5. ESTUDIO COMPARATIVO 329

6. CONCLUSIONES 365

CONCLUSIONI

7. GLOSARIO

8. BIBLIOGRAFÍA

9. ANEXOS

9.1. Entrevista a Juan Carlos Arnuncio. 438

9.2. Entrevista a José Ignacio Linazasoro 458

9.3. Entrevista a Giorgio Grassi 


\section{RESUMEN}

REPROPONER EL VACÍO. La intervención en el patrimonio arquitectónico en el cambio de siglo, en España e Italia. Estudio sobre la recomposición de la pérdida en espacios abovedados.

La presente investigación se inscribe en el ámbito de la intervención en el patrimonio arquitectónico, en España e Italia en el cambio de siglo, y presta especial atención a los monumentos con espacios abovedados parcialmente derruidos, que han sido intervenidos mediante una reproposición de la pérdida, permitiendo de este modo su adaptación a nuevas necesidades, utilizando la transformación como vehículo para su continuidad.

Se plantea como objetivo principal la reflexión sobre las diferentes maneras de abordar estas intervenciones, mediante un estudio de los criterios de intervención y su evolución a través de la historia, a partir de las reflexiones de los críticos y arquitectos del ámbito espacial y temporal indicado, y apoyado por el análisis de actuaciones concretas.

Por otro lado se reflexiona sobre los diferentes espacios abovedados presentes a lo largo de la historia, estableciendo paralelismos entre edificios históricos, arquitectura moderna, y actuaciones sobre el patrimonio. Un discurso que trata de ver la creación como una reinterpretación de la realidad pasada y presente, de tal manera que se produzcan mecanismos naturales de relación entre antiguo y nuevo.

La investigación se completa con un análisis profundo de cuatro casos de gran relevancia en el campo de la intervención en el patrimonio, con el propósito de reflexionar sobre algunas estrategias posibles, sus fundamentos y mecanismos proyectuales a la hora de enfrentarse a estas arquitecturas incompletas, con la intención de reproponer el vacío.

Las conclusiones deducidas tras este proceso de reflexión ponen de manifiesto la importancia de la sensibilidad del proyectista hacia la lectura de la preexistencia y su entorno, no sólo como condicionantes fundamentales del proyecto arquitectónico, sino también como valores evocadores capaces de potenciar la creación de un nuevo espacio arquitectónico. En síntesis, una transformación que incorpore la fuerza de la memoria, pero mediante su relectura desde el presente, para garantizar su continuidad como patrimonio vivo. 


\section{RIASSUNTO}

RIPROPORRE IL VUOTO. L'intervento nel patrimonio architettonico a cavallo dell'ultimo secolo, in Spagna ed Italia. Studio sulla ricomposizione delle perdite in spazi a volta.

Questa ricerca rientra nell'ambito di applicazione degli interventi sul patrimonio architettonico, in Spagna ed in Italia nei decenni a cavallo dell'ultimo secolo, e fa particolare attenzione ai monumenti in spazi, con coperture a volta, parzialmente distrutti e che hanno subito un intervento di ricostruzione delle perdite, consentendo in questo modo l'adattamento ai nuovi bisogni, utilizzando la trasformazione come veicolo per la continuità.

Si propone come principale obiettivo la riflessione sui diversi modi di affrontare questi interventi, attraverso lo studio dei criteri di intervento e la loro evoluzione nel corso della storia, partendo dalle riflessioni di critici e architetti nel ambito spaziale e temporale indicato, e supportato dall'analisi di azioni specifiche.

D'altra parte si riflette sui diversi spazi con copertura a volta presenti nel corso della storia, disegnando un parallelismo tra edifici storici, architettura moderna, e gli interventi sul patrimonio. Un discorso che cerca di vedere la creazione come una reinterpretazione della realtà passata e presente, in modo che si producano meccanismi naturali nel rapporto tra antico e nuovo.

La ricerca si completa con una dettagliata analisi di quattro casi di grande importanza nel campo della intervenzione nel patrimonio, con il proposito di riflettere su alcune possibili strategie, i suoi fondamenti e meccanismi progettuali quando ci si affrontano queste architetture incomplete, con l'intenzione di riproporre il vuoto.

Le conclusioni dedotte dopo questo processo di riflessione sottolineano l'importanza della sensibilità del progettista verso la lettura della preesistenza e del suo intorno, non solo come condizioni fondamentali della progettazione architettonica, ma anche come valori evocativi capaci di valorizzare la creazione di un nuovo spazio architettonico. In sintesi, una trasformazione che incorpori la forza della memoria, ma attraverso la sua rilettura dal presente, per garantirne la sua continuità come patrimonio vivo. 


\section{RESUM}

REPROPOSAR EL BUIT. La intervenció en el patrimoni arquitectònic en el canvi de segle, a Espanya i Itàlia. Estudi sobre la recomposició de la pèrdua en espais voltats.

La present investigació s'inscriu en l'àmbit de la investigació en el patrimoni arquitectònic, a Espanya i Itàlia en el canvi de segle, i presta especial atenció als monuments amb espais voltats parcialment derruïts, que han sigut intervinguts mitjançant una reproposició de la pèrdua, el que permet d'aquesta manera la seua adaptació a les noves necessitats, utilitzant la transformació com a vehicle per a la seua continuïtat.

Es planteja com a objectiu principal la reflexió sobre les diferents formes de tractar aquestes intervencions, mitjançant un estudi dels criteris d'intervenció i la seua evolució al llarg de la història, a partir de les reflexions dels crítics $i$ arquitectes de l'àmbit espacial i temporal indicat, i recolzat per l'anàlisi d'actuacions concretes.

D'altra banda es reflexiona sobre els diferents espais voltats presents al llarg de la història, s'estableixen paral-lelismes entre edificis històrics, arquitectura moderna, i actuacions sobre el patrimoni. Un discurs que tracta de veure la creació com una reinterpretació de la realitat passada i present, de tal manera que es produïsquen mecanismes naturals de relació entre antic i nou.

La investigació es completa amb una anàlisi profunda de quatre casos de gran rellevància en el camp de la intervenció en el patrimoni, amb el propòsit de reflexionar sobre algunes estratègies possibles, els seus fonaments i mecanismes projectuals a l'hora d'enfrontar-se a aquestes arquitectures incompletes, amb la intenció de reproposar el buit.

Les conclusions deduïdes al final d'aquest procés de reflexió posen de manifest la importància de la sensibilitat del projectista cap a la lectura de la preexistència i el seu entorn, no sols com a condicionants fonamentals del projecte arquitectònic, sinó també com valors evocadors capaços de potenciar la creació d'un nou espai arquitectònic. En síntesi, una transformació que incorpore la força de la memòria, però mitjançant la seua relectura des del present, per garantir la seua continuïtat com patrimoni viu. 


\section{ABSTRACT}

REPRUPOSING THE VOID. The intervention in the architectural heritage in the century, in Spain and Italy. Study on the restructuring of the loss vaulted spaces.

This research falls within the scope of the intervention on the architectural heritage in Spain and Italy at the turn of the century, and pays special attention to the monuments with partially collapsed vaulted spaces, which have been operated by a loss reproposition, thereby permitting adaptation to changing needs, using as a carrier for processing continuity.

It is proposed as main objective reflection on the different ways to approach these interventions, through a study of the intervention criteria and its evolution through history, from the reflections of critics and architects indicated spatial and temporal scope, and supported by the analysis of specific actions.

On the other hand, we examine the different vaulted spaces present throughout history, drawing parallels between historical buildings, modern architecture, and actions on the assets. A speech about seeing creation as a reinterpretation of the past and present reality, so that natural mechanisms occurring relationship between old and new.

The research is completed with a detailed analysis of four cases of great importance in the field of intervention in equity, in order to reflect on possible strategies, its foundations and projective mechanisms when faced with these architectures incomplete, intend to re-propose the void.

The conclusions drawn after this process of reflection, highlight the importance of the designer's sensitivity towards reading of pre-existence and its environment, not only as fundamental determinants of architectural design, but also as evocative value capable of enhancing the creation of a new architectural space. In short, a transformation that incorporates the power of memory, but through his rereading from the present, to ensure its continuity as a living heritage. 



\section{introducción}




\section{INTRODUCCIÓN}

\section{ANTECEDENTES Y ÁMBITO DE ACTUACIÓN}

La presente investigación busca continuar con la investigación iniciada en el Trabajo Final del Master Oficial en Conservación del Patrimonio Arquitectónico con título "La Reconstrucción Parcial en la Rehabilitación del Patrimonio Arquitectónico en España desde los años 80" defendida en diciembre de 2010 con calificación de Sobresaliente 9.

El germen de aquel trabajo surgió a raíz de mi experiencia de colaboración en el "proyecto de intervención de los Puentes de Serranos y de la Trinidad de Valencia", dirigido por el arquitecto Ignacio Bosch Reig, en el que se realizaron trabajos de reconstrucción parcial de algunos elementos desaparecidos. En el desarrollo del proyecto se llevaron a cabo gran variedad de estudios de diversas soluciones proyectuales, antes de optar por la solución que se realizaría finalmente.

Por otro lado, el proyecto planteado en el Taller de Intervención del Master Oficial en Conservación del Patrimonio, consistente en la realización de un nuevo acceso al teatro romano de Sagunto, también proponía la reflexión sobre la manera de actuar en un elemento patrimonial parcialmente destruido. La variedad de soluciones planteadas en el curso sobre el mismo problema, producía un interesante abanico propositivo, en el que se podían intuir ciertas actitudes con mayor acierto que otras en su relación con la preexistencia.

Estas experiencias me hicieron replantearme cuales podían ser los criterios y soluciones que produjeran una mayor adecuación entre las nuevas intervenciones y el monumento preexistente.

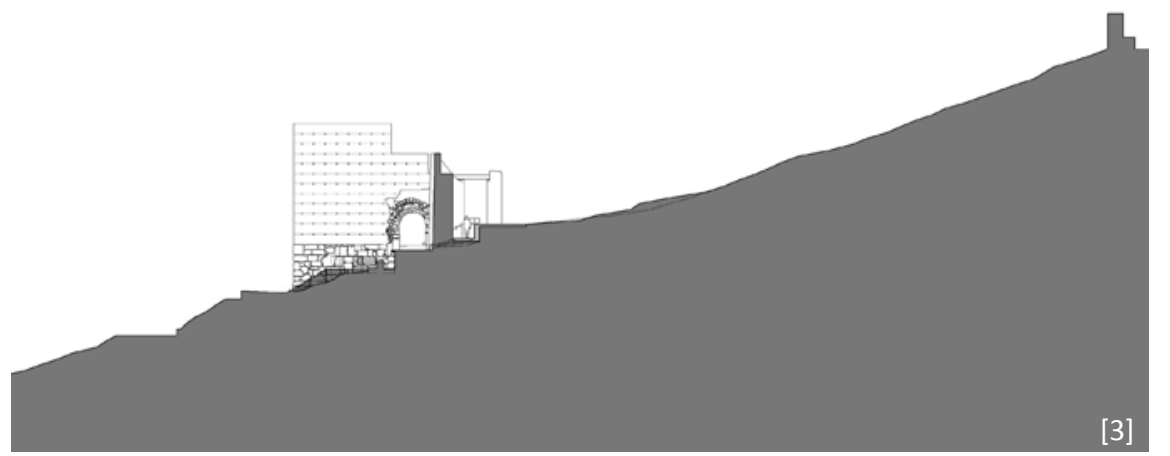

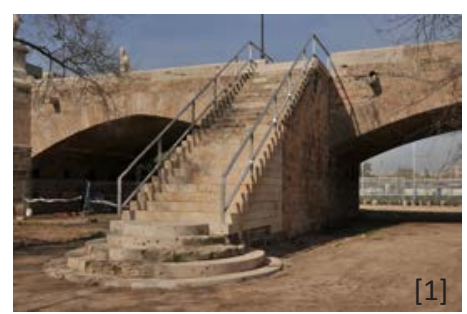

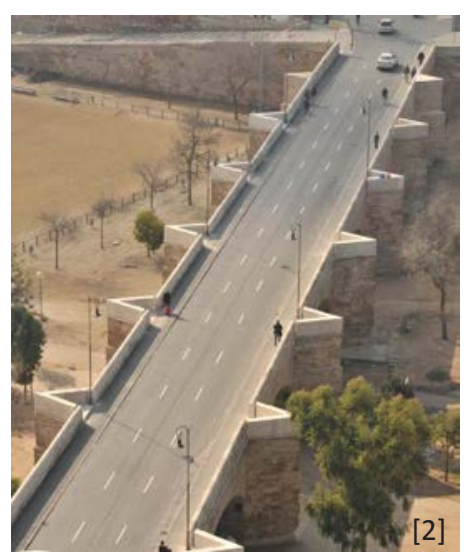

[1] Vista de la intervención sobre una de las escaleras del puente histórico de la Trinidad de Valencia.

[2] Vista general donde se aprecia la intervención sobre los arrimaderos del puente hidtórico de Serranos de Valencia.

[3] Imagen del proyecto de nuevo acceso y centro de visitantes en el castillo de Sagunto para el ejercicio del Taller de Intervención del Máster de Conservación del Patrimonio Arquitectónico. 
El tema de la intervención en el patrimonio ha sido objeto de disertación por los estudiosos de la materia a lo largo del tiempo. Las diversas maneras de enfrentarse a ello, incluso contrapuestas, ha producido y produce largos y encendidos debates, haciendo evidente que, al igual que en todo proyecto de arquitectura, no existe una única manera "correcta" de actuar. Sin embargo en el reconocimiento de las actuaciones realizadas a lo largo del tiempo si que se observan soluciones más interesantes que otras, pues alcanzan una relación con el monumento de mayor interés propositivo.

De manera resumida se pueden concretar en cuatro grandes grupos las distintas maneras de actuar en el patrimonio. Por un lado esta la actitud derivada de los planteamientos teóricos de John Ruskin, que defiende la no actuación más allá de la pura conservación del monumento. Por otro lado la postura derivada de las teorías de Viollet-le-Duc que defiende la repristinación siguiendo el lenguaje y la lógica propia del monumento. Una tercera vía, basada en las teorías del denominado restauro científico, busca actuar remarcando la diferencia entre lo nuevo y lo antiguo tratando de preservar la claridad de las distintas fases históricas que se suceden en el monumento. Finalmente la cuarta vía propone una actuación críticacreativa que busque recuperar la unidad del monumento respetando las huellas del tiempo y sin cometer falsos históricos.

En la evolución de esta última vía parece estar el camino más adecuado en la intervención en el patrimonio. Se trata en todo caso de entender la actuación como un proyecto de arquitectura con unos condicionantes específicos dados por el monumento sobre el que se interviene, y en el que las nuevas aportaciones tengan hacia él una sensibilidad al menos a la altura del valor del conjunto sobre el que se actúa.

Concretando el ámbito de actuación, me ha interesado el caso en el que en un monumento se deba reintegrar un faltante de cierta entidad, de tal manera que sea objeto de la actuación la elaboración de un proyecto contemporáneo en el que se deba estudiar la forma y materialidad del nuevo elemento teniendo en cuenta las características de la parte desaparecida y la relación de lo nuevo con lo preexistente.

Dada la gran variedad de tipologías edificatorias que pueden afectar a este tipo de actuación, me he decidido por centrarme en una de la que pueda recoger suficientes ejemplos y que pueda contener una mayor complejidad proyectual. Habiendo reconocido como tipologías más habituales los teatros, las fortalezas y las iglesias, finalmente he decidido optar por centrarme en una tipología que, si bien parte de la última de ellas, evita identificar una función en concreto, pero si busca especificar la forma de ese espacio. Así pues en la elección de "espacios abovedados" se concentra el interés por la intervención sobre un tipo de edificio que contiene un espacio cerrado superiormente con un elemento arquitectónico de cierta complejidad formal como es el caso de la bóveda. 
La extensión del tema de estudio a Italia, permite por un lado analizar ejemplos de otro ámbito cultural distinto al español, y así establecer un punto de comparación externo que ayude a entender mejor las actuaciones, y por otro lado conocer la actualidad sobre el tema en uno de los países más comprometidos con la intervención en el patrimonio y que por tanto, con toda seguridad, tiene mucho que aportar al tema estudiado.

Finalmente la acotación temporal busca darle a la investigación la máxima actualidad a un tema que está en continuo desarrollo -aunque siempre vuelva sobre los mismos conceptos- y donde es importante la evolución pues la arquitectura construida es materia fundamental de estudio en el proyecto de arquitectura. 


\section{OBJETIVOS}

El presente trabajo de investigación tiene como objetivo general, arrojar luz sobre la adecuación de determinadas soluciones proyectuales en un momento y contexto determinados, y referidas a un tipo concreto de intervención en el patrimonio como es el caso de la recomposición parcial de la pérdida en espacios abovedados.

La bondad de la investigación estriba en la elaboración de un documento de apoyo a la reflexión del proyecto. No busca sin embargo, en ningún momento, establecer un conjunto de reglas a aplicar al proyecto. Sin embargo, el valor creativo del proyecto arquitectónico no exime del trabajo de racionalización de las características de las soluciones aportadas, para comprender los aciertos y desaciertos producidos y tratar de aprender de ellos para evitarlos en el futuro.

Con ello, se trata de abstraer, desde la racionalidad, principios generales que puedan ser transmitidos y asimilados, estableciendo como proceso el análisis de ejemplos arquitectónicos, y tratando en su estudio extraer resultados aplicables a futuras actuaciones. Por lo tanto la presente investigación opta por llevar a cabo una serie de análisis de obras con unas características concretas, relacionadas con el tema estudiado, de las que poder extraer conocimientos aplicables. Al mismo tiempo se entiende necesario realizar un estudio del entorno teórico en el que se desarrollan estos ejemplos analizados, para comprenderlos mejor y así obtener las claves necesarias para el análisis.

Este objetivo general se puede subdividir en los siguientes objetivos concretos:

1- Revisar los criterios de actuación sobre el patrimonio, a lo largo de la historia, expuestos por los críticos españoles e italianos actuales.

2- Reconocer los criterios actuales de actuación en la reconstrucción parcial de monumentos en España e Italia.

3- Recopilar y aclarar los diversos términos que se emplean en este ámbito de estudio.

4- Estudiar en profundidad una selección de ejemplos de actuación, analizando tanto la obra como al autor.

5- Realizar un análisis comparativo de las soluciones estudiadas, identificando las diferencias y similitudes de cada una de ellas, y reflexionando del porqué de éstas.

6- Extraer conclusiones que arrojen luz sobre la adecuación de determinadas soluciones proyectuales. 


\section{FUENTES Y METODOLOGÍA}

La presente investigación se organiza en cinco partes diferenciadas: una primera parte de exposición crítica de criterios de intervención a lo largo de la historia, desde la antigüedad hasta nuestros días, haciendo especial hincapié en los espacios abovedados, y a través del punto de vista de los críticos italianos y españoles actuales; una segunda parte de exposición crítica de espacios abovedados presentes en la arquitectura y su reflejo en diversas actuaciones de intervenciones; una tercera parte de análisis crítico de cuatro casos de intervención en espacios abovedados con recomposición de la pérdida; una cuarta parte de reflexión mediante un estudio comparativo de los casos analizados; y por último la exposición de las conclusiones de la investigación.

Tanto para la selección de ejemplos a analizar como para el estudio de criterios teóricos se han empleado las fuentes documentales consideradas de relevancia en la cultura arquitectónica española e italiana durante el período temporal concreto que abarca la investigación. Se trata de una lectura más o menos interesada de textos de los que se van extrayendo reflexiones y obras que se interpretan como de mayor interés, pero tratando de abarcar diversas maneras de entender la intervención en el patrimonio arquitectónico.

Por otro lado, dada la necesidad de obtener un buen número de ejemplos que hicieran el estudio más interesante, no se ha querido ceñir la investigación a una tipología de bóveda concreta que definiera un tipo de espacio similar, sino que por el contrario se ha potenciado la diversidad en la definición formal y material del elemento para reconocer los diversos tipos de espacios producidos.

Las fuentes generales empleadas para el estudio de criterios de intervención han consistido en libros y revistas periódicas de España e Italia publicados desde los años 90 hasta la actualidad. Por un lado se han consultado las siguientes revistas españolas: Arquitectura, Quaderns d'arquitectura i urbanisme y El Croquis, así como las especializadas en restauración como Loggia, R\&R y la Revista electrónica del Patrimonio histórico. Por otro lado se han consultado las siguientes revistas italianas: Casabella, Domus, Lotus, Costruire in laterizio, Opus, Palladio y Recupero e conservazione.

La consulta de libros se ha centrado tanto en la recopilación de jornadas y congresos, como en las monografías de determinados autores actuales comprometidos con la intervención en el patrimonio arquitectónico. En este sentido cabe recalcar la gran importancia que ha tenido la estancia realizada en Roma entre los meses de septiembre y diciembre de 2011, en la que mi acercamiento a docentes como Maria Piera Sette, Marina Docci, Christian Rosolino, Maria Grazia Turco, Stefano Marani o Alessandro 
Sartor me ha permitido dirigir la mirada hacia determinados críticos y arquitectos. También cabe destacar el contacto establecido con Maurizio Boriani, director del departamento de proyectos de Milán, muy implicado en el tema de la intervención en el patrimonio.

También se ha considerado necesario completar el contenido de estudio mediante la incorporación de algunas referencias bibliográficas que, aunque quedan fuera del ámbito temporal estudiado, son de gran relevancia histórica en el ámbito de la investigación.

A las fuentes escritas se debe añadir las visitas de arquitectura realizadas tanto en Italia como en España, que me han permitido verificar los criterios de intervención en la experiencia directa del espacio arquitectónico.

Respecto a las fuentes empleadas para el estudio de los casos, se ha acudido a todas las publicaciones de las que se ha podido tener acceso, lo cual ha sido variable en función de cada obra. Por otro lado, en el caso de los arquitectos españoles se ha llevado a cabo una entrevista personal para tratar de profundizar tanto en la obra estudiada como en la visión personal de la arquitectura del autor. Sin embargo, por cuestiones de tiempo y accesibilidad no se ha podido realizar entrevistas a los arquitectos italianos, lo cual queda pendiente para una revisión futura de la Tesis, posterior a la defensa.

Para la selección de obras se ha buscado analizar en profundidad aquellas que cumpliendo con los requisitos de selección indicados, tuvieran un reconocimiento de la crítica o una repercusión en el panorama arquitectónico. Si bien la idea inicial era la de analizar un mayor número de casos, se ha preferido reducirlo para poder dedicar mayo profundidad al estudio. En cualquier caso cabe mencionar que en el proceso de reconocimiento de los criterios de actuación se presentan diversos ejemplos de actuación que ayudan a contextualizar los casos seleccionados. Por otro lado se ha intentado que la selección de ejemplos abarque soluciones que aporten distintas visiones de afrontar el problema estudiado. Las obras seleccionadas son las siguientes:

San Filippo Neri, Bolonia, 1997-99. Pier Luigi Cervellati.

Patio Herreriano, Valladolid, 1996-2002. Juan Carlos Arnuncio.

Escuelas Pías de San Fernando, Madrid, 1996-2004. José Ignacio Linazasoro. Basílica de San Pedro en Siracusa, 2002-08. Emanuele Fidone.

En el proceso de análisis de casos se ha llevado a cabo un redibujo de la documentación gráfica de los proyectos, así como la elaboración de esquemas gráficos conceptuales. Con ello se busca profundizar en la comprensión de las obras, así como una vía para expresar los conceptos con mayor unidad y claridad. 
Por último cabe mencionar que se han visitado las obras in situ para reconocer de primera mano desde el entorno en el que se encontraban hasta la visión próxima y detallada de la solución material empleada, así como constatar su evolución a lo largo del tiempo. 




\section{criterios de intervención}




\subsection{EVOLUCIÓN DE LOS CRITERIOS DE INTERVENCIÓN EN EL PATRIMONIO ARQUITECTÓNICO}

\section{DESDE LA ANTIGÜEDAD HASTA EL SIGLO XIV}

\subsection{La antigüedad}

En la antigüedad se ignora el valor de la arquitectura sobre la que se opera si no coincide con la sensibilidad propia del momento en que se interviene, sometiendo el viejo edificio a las nuevas necesidades. ${ }^{1}$ La ausencia de una conciencia histórica, permite entender el pasado como materia disponible sobre la que actuar para satisfacer las necesidades de cada momento, adoptándose actuaciones de destrucción, reconstrucción o transformación inducidas por razones políticas, religiosas, funcionales o de gusto. ${ }^{2}$

En las actuaciones sobre los edificios preexistentes relevantes, símbolos de la cultura del momento, se busca resaltar la integridad de la arquitectura para transmitir su consistencia y hacer legible su significado. ${ }^{3}$ Se produce un continuo proceso de construcción, destrucción y reconstrucción, caracterizado por tres factores: la valoración del lugar, construyendo los nuevos monumentos sobre los restos de los antiguos; la evolución o transformación tipológica, perfeccionando la arquitectura precedente con los nuevos conocimiento; y la expresión del nuevo monumento como símbolo renovado de poder. ${ }^{4}$ Este es el caso del Partenón de Atenas (ej.1) o del Panteón de Roma (ej.2), en los que se observa la preponderancia por un proceso de sustitución arquitectónica. Por otro lado cabe mencionar la presencia de otro tipo de actuaciones más discretas como es el caso de las adaptaciones de casas señoriales a espacios de culto religioso en la antigua Roma, las denominadas Domus Ecclesiae.

\section{Ejemplo 1: Partenón de Atenas}

Francisco Javier Saenz de Oiza comenta las sucesivas transformaciones que sufre el Templo a lo largo de la historia, destruyéndose y reconstruyéndose hasta tres veces: "sobre el Partenón se monta el Ekapartenon o Templo de los Cien Pies, después el segundo Partenón y después el tercer Partenón". La clave para Saenz de Oiza es justificar lo que se destruye, pues "el balance para los griegos siempre era positivo". ${ }^{5}$
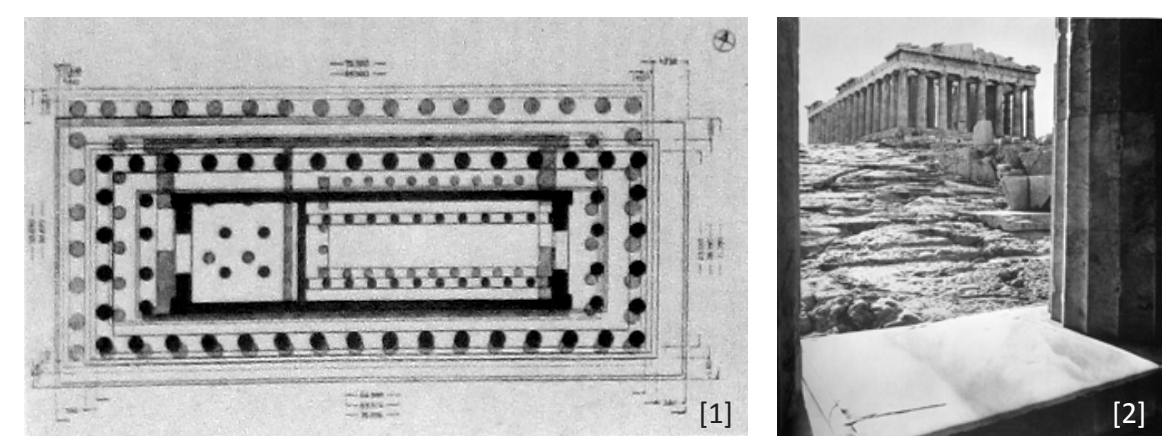

1 CAPITEL, A.: "Proyectar para una arquitectura dada". El Croquis, no 42, Madrid, 1990, p. 65

2 SETTE, M.P.: II restauro in architettura: quadro storico. Torino, Ed. Utet, 2001, p. 4

3 SETTE, M.P.: Op. Cit., 2001, p. 4

4 BOSCH REIG, I.: “Intervención en el patrimonio: un continuo proceso de innovación". Restauración y Reahbilitación, $R \& R$, no 79, p. 20

5 SAENZ DE OIZA, F.J.: "Superposición y adaptación de nuevas estructuras en edificios antiguos". En: CABALLERO ZOREDA, L. (dir.): Curso de mecánica y tecnología de los edificios antiguos. Madrid: Colegio Oficial de Arquitectos de Madrid, 1987, p. 133
[1] Los sucesivos Partenones. (SAENZ DE OIZA: 1987, p. 133)

[2] Atenas. Acrópolis. Vista del Partenón desde los Propíleos. (NORBERG-SCHULZ: 1999, p. 37) 
6 HERNÁNDEZ MARTíNEZ, A.: La Clonación Arquitectónica. Madrid: Ediciones Siruela, 2007, p.59

7 CAMPO BAEZA, A.: "Giudici ingiusti e ignoranti". Domus, no 756, enero 1994, p.82-83

[3] Sección del Panteón donde se representa una posible configuración original de su composición interior. (Recupero e conservazione, no 80,2008, p. 45)

[4] Vista interior. (Imagen del autor.)

[5] Vista interior. Piranesi. (Biblioteca Digital Dioscórides. Universidad Complutense de Madrid: <dioscorides.ucm.es>)
Cabría mencionar, a propósito de esta cuestión, las transformaciones de los templos originalmente construidos con madera en monumentos hechos de piedra para aumentar su permanencia a lo largo del tiempo. $\mathrm{O}$ incluso, la destrucción y reconstrucción ritual de los templos sintoístas en Japón, donde es más importante el mantenimiento de las tradiciones artesanales que el respeto a la materialidad del monumento. ${ }^{6}$

\section{Ejemplo 2: Panteón de Roma}

El Panteón de Roma expresa muy bien este concepto de reconstrucción como renovación de las fábricas. Fundado el año 27 a.C. por Marco Vipsanio Agrippa y remodelado por Domiziano y Trajano, es completamente reelaborado por Adriano entre el 120 y el 124 d.C. y posteriormente será transformado en el año 202 por Settimo Severo y Caracalla.

Es interesante mencionar a este respecto, el ensayo que escribe Alberto Campo Baeza sobre el Panteón, en defensa de la actuación de reconstrucción del Teatro Romano de Sagunto. Campo Baeza narra la hipotética oposición de arqueólogos e historiadores, a la que se habría visto sometido el emperador Adriano en su propuesta de reconstrucción del Panteón, sila obra se hubiera realizado hoy. Con ello pone en evidencia como el juicio injusto, inmoral e ignorante de algunos hombres no pudo, ni puede, detener la acción transformadora ligada al paso del tiempo. ${ }^{7}$
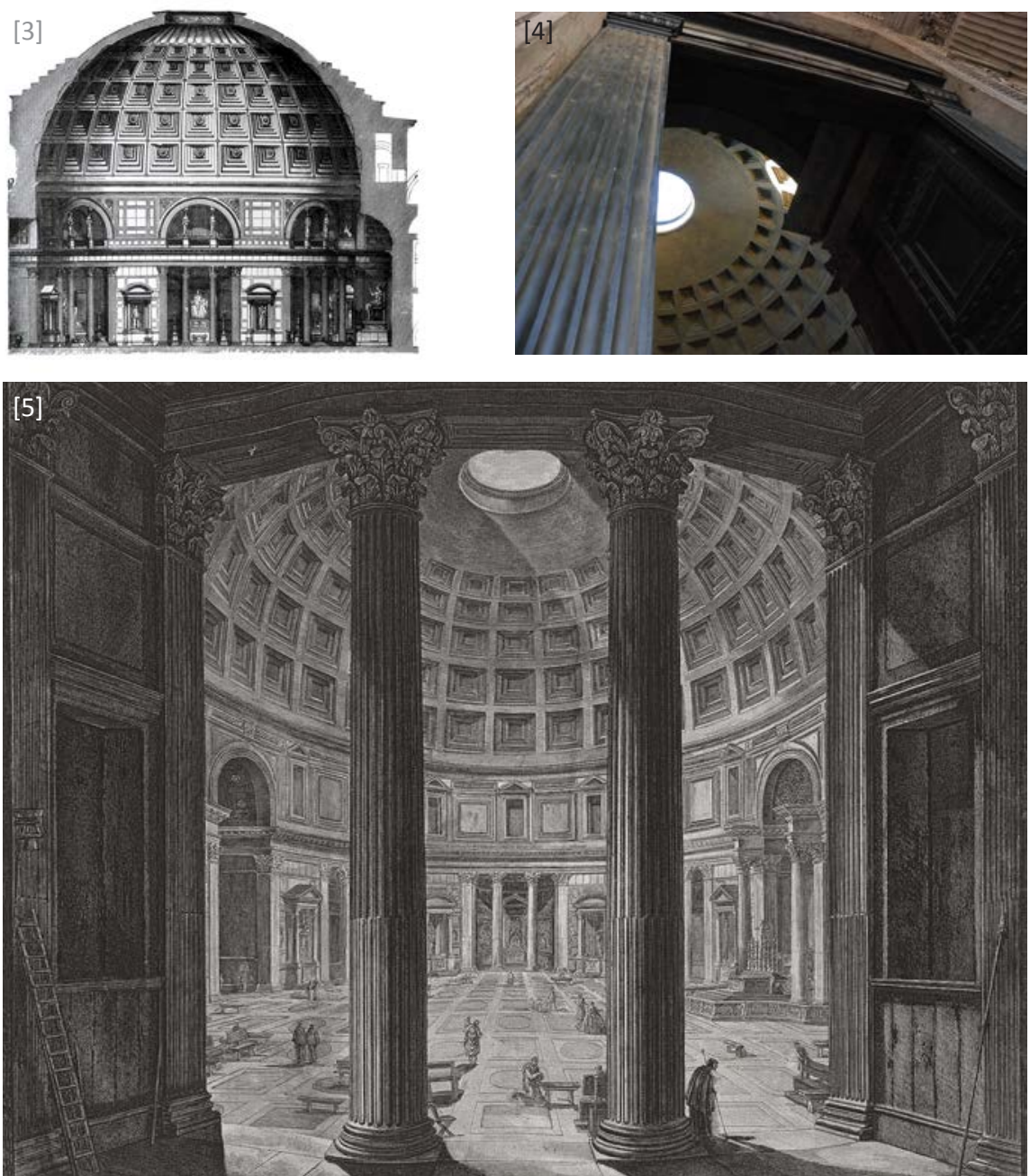
El Panteón busca representar el cosmos como la morada de los dioses, mediante la construcción de una gran cúpula de geometrías perfectas. Este concepto simbólico de la perfección divina de la bóveda celeste se buscará reproducir en la obra nueva pero también en las actuaciones sobre las preexistencias.

Cabe mencionar la reflexión de José Ignacio Linazasoro, sobre la evolución del elemento abovedado en el imperio romano. Una tendencia hacia una búsqueda de ligereza de la cúpula, mediante la reducción de los puntos de apoyo, para producir una sensación de ingravidez del elemento. ${ }^{8}$

\subsection{La edad media}

En la edad media, la consideración simbólica de los restos, unido a razones prácticas y económicas, llevará a la supervivencia de algunas preexistencias, priorizando su transformación sobre su sustitución, adecuando sus fábricas para adaptarlas a las nuevas necesidades y completándolas con el lenguaje de la época. La obra del pasado no se percibe como un evento histórico concluido, sino como algo abierto, apto para recibir nuevas actuaciones. Este es el caso de la transformación de muchos monumentos romanos, por la implantación del cristianismo en el imperio, sobre todo en el caso de las basílicas donde los restos aportan a las nuevas construcciones la fuerza y la gloria de las antiguas. ${ }^{9}$ Sin embargo también es cierto que en otros casos los edificios son destruidos poco a poco utilizándolos como canteras para los nuevos edificios. Un claro ejemplo de transformación es la Catedral de Siracusa en la que se evidencia un proceso de superposición arquitectónica (ej.3).

\section{Ejemplo 3: Catedral de Siracusa}

El templo dórico de Atenea, con origen en el siglo $\mathrm{V}$ a.C., destruido y reconstruido en sucesivas ocasiones en el mismo lugar, es convertido en catedral a finales del siglo VII mediante el cierre de los intercolumnios y la apertura de arcadas en la cella. En el siglo XVII sufrirá diversas modificaciones en su interior consistentes en la construcción de nuevas capillas y transformación del ábside. En el siglo XVIII se llevará a cabo la fachada barroca. ${ }^{10}$
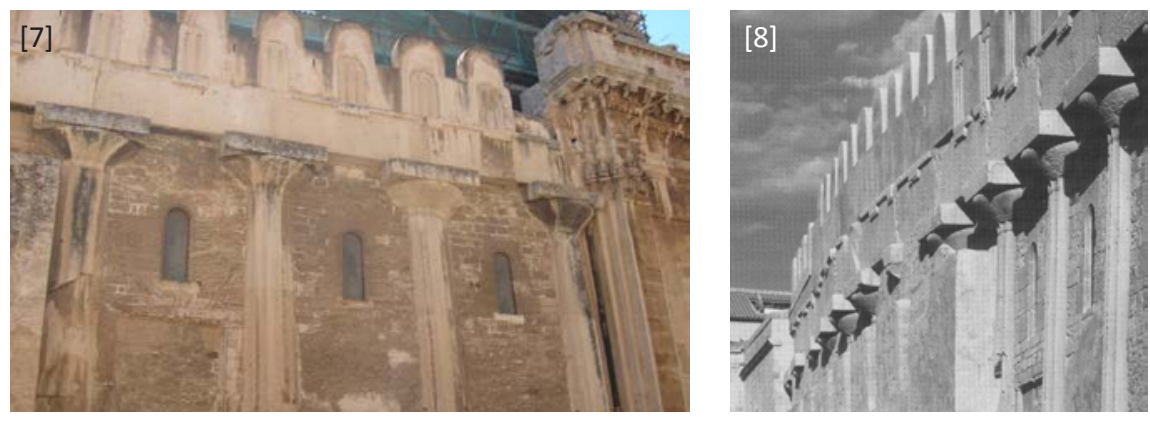

A propósito de esta obra, Vincenzo Latina comenta que éste "es un ejemplo de como lo nuevo y lo antiguo pueden convivir" y nos enseña que "para conservar es necesario innovar". Para Latina la Catedral de Siracusa introduce una lección de gran contemporaneidad al mostrar como "durante milenios las múltiples intervenciones actuadas sobre el Templo no borran las diferentes culturas, al contrario las integran". ${ }^{11}$
8 LINAZASORO, J.I.: “La Renovación Proyectual en el Bajo Imperio y la Crisis del Clasicismo Grecorromano. diciembre-enero 1986-87". En: LINAZASORO, J.I.: Escrito en el tiempo. Pensar la arquitectura. Buenos Aires, NobuKo / UP Universidad de Palermo, 2003, p.31

9 SETTE, M.P.: Op. Cit., 2001, p. 6

10 SETTE, M.P.: Op. Cit., 2001, p. 12-13

11 LATINA, V.: "Architettura contemporanea e Antico. Microinterventi nell'isola di Ortigia, Siracusa". En: CORNOLDI, A.; RAPPOSELLI, M.: Emanuele Fidone, Vincenzo Latina, Bruno Messina. 'Restauri' Iblei. Padova, II Poligrafo,2007, pp. 23-24

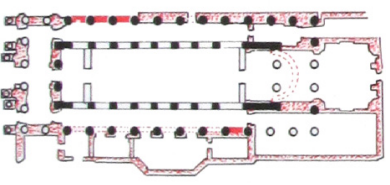

[6] Planta de la Cateral de Siracusa y las diferentes fases del edificio. (VAES: Lotus, no 65, 1990, p. 34)

[7] Vista exterior de la Catedral de Siracusa. (de la MATA: <misviajesconhistoria.blogspot.com>)

[8] Vista exterior de la Catedral de Siracusa. (UGOLINI: 2010, p.25) 
12 SETTE, M.P.: Op. Cit., 2001, p. 14

13 NORBERG-SCHULZE, CHR.: Arquitectura occidental. Barcelona, G.G., 2001 (1979), p.80

14 SETTE, M.P.: Op. Cit., 2001, p. 14
[9] San Juan del Hospital. Vista interior. (Iglesia de San Juan del Hospital: <www.sanjuandelhospital.es>)

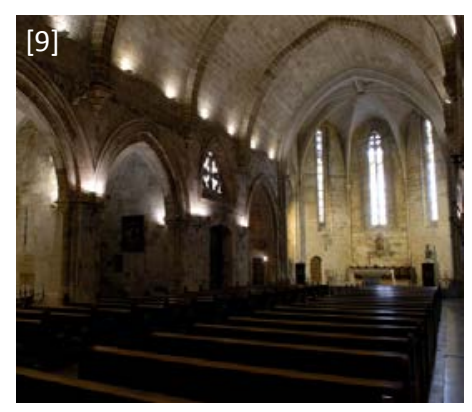

Así, las actuaciones medievales pretenden reinterpretar la preexistencia, configurando un complejo entramado entre las formas nuevas y las del pasado, para crear una unidad que se muestre como representativa de su tiempo. Siendo, precisamente, esta búsqueda de la unidad en la multiplicidad y la multiplicidad en la unidad, la característica representativa de la cultura medieval. Por otro lado, las iglesias medievales se construyen sobre los muros de las viejas basílicas cristianas introduciendo bóvedas en el lugar de las precedentes cubiertas de madera, añadiendo el transepto y abandonando el atrio. ${ }^{12}$ Las bóvedas buscan potenciar la presencia divina en el espacio de la nave, antes enfatizado solamente en el ábside, introduciendo con ello una mayor tensión vertical en el espacio. Como afirma Norberg-Schulz "Dios se vuelve más cercano y, en consecuencia, se debilita la división simbólica entre la nave y el presbiterio". ${ }^{13}$

Con el gótico nace un nuevo ideal de belleza que se materializa en una nueva concepción formal y espacial, lo que produce también un cambio en las relaciones con la antigüedad. En las actuaciones sobre las arquitecturas romanas, la cultura gótica actúa desmembrando y fraccionando los restos para luego englobarlos "en un nuevo organismo, siempre en perfecta euritmia". ${ }^{14}$ Mientras que las actuaciones góticas sobre los monumentos románicos se aplican como añadidos que amplían los antiguos monumentos, tanto en extensión como en altura, en un proceso de yuxtaposición, transmitiendo la verticalidad, apertura y luminosidad del nuevo estilo. Este es el caso de la iglesia de San Juan del Hospital de Valencia (ej. 4).

En España la dominación cristiana sobre los árabes produce una destrucción de los edificios más simbólicos, como es el caso de las Alcazabas, sobre las que se construyen nuevas fortificaciones, o las mezquitas que se desmontan para construir catedrales góticas. Otros edificios más prácticos, como los baños árabes, se mantienen como uso compartido de árabes y cristianos por sus valores de purificación, pero son destruidos en su mayoría tras la expulsión de los moriscos en 1609.

\section{Ejemplo 4: Iglesia de San Juan del Hospital de Valencia}

La iglesia de San Juan del Hospital expresa con claridad el concepto de yuxtaposición medieval. En el acceso un arco gótico se alza sobre otro románico de medio punto, siguiendo un nuevo eje sensiblemente desplazado del primitivo, y se abre un óculo con una cruz de ocho puntas en representación de la orden de San Juan. En el interior la superposición de un gótico primitivo sobre un espacio románico se aprecia en el espacio oscuro de la nave de geometrías regulares cubierta con bóveda de cañón de poca altura y sensiblemente apuntada, con escasas aberturas, compensada con potentes contrafuertes, y construida con pequeños sillares de piedra. El espacio de la nave se remata en el presbiterio con una cabecera poligonal de cinco lados cubierta con bóveda de crucería iluminada con ventanales rasgados que dan mayor verticalidad al espacio del altar, muestra evidente de un gótico más avanzado. 


\section{DESDE EL SIGLO XV HASTA EL SIGLO XVII}

Como indica Ignasi de Solà-Morales, "la reflexión previa a la intervención aparece por primera vez en el momento en que hay una conciencia de la historia. La conciencia de la diferencia, de que hay un pasado y un presente." Y no es hasta el clasicismo que se establece una definición de cuál es la relación entre la intervención y la arquitectura existente. Sin embargo la conciencia de la historia en este momento es muy esquemática, reduciéndose a dos visiones contrapuestas: la visión positiva de la cultura de la antigüedad, contra la visión negativa de la construcción medieval. ${ }^{15}$ Por lo que, la actitud ante la preexistencia variará en función de su origen estilístico.

\subsection{Actuaciones sobre arquitecturas clásicas}

La admiración por el mundo grecorromano supone la realización de profundos estudios que quedan patentes en la producción de diversos tratados de arquitectura de grandes arquitectos como Alberti, Serlio, Vignola o Palladio, así como el redescubrimiento de textos clásicos como los diez libros de arquitectura de Vitrubio.

Las actuaciones sobre obras de la antigüedad se plantean con admiración, completando los faltantes con el estilo y proporciones clásicas para devolverles su integridad original, pero sin una pretensión de fidelidad arqueológica, sino de búsqueda de la perfección como símbolo de la belleza. Este es el caso de la propuesta de Rafael para completar los Dioscuros, Castor y Polux, del Quirinale, obra originalmente de Fidias y Praxíteles, del siglo $\mathrm{V}$ a.C. (ej.5).

Sin embargo las obras clásicas también se emplean como canteras o como soporte para la construcción de nuevos palacios renacentistas y barrocos, como es el caso de la colonización del teatro de Marcelo en Roma transformado por Peruzzi en palacio para la familia Savelli-Orsini, o la inserción del palacio de los Corbos en las ruinas del templo de Diana en Mérida.

Un caso algo singular es la actuación sobre la iglesia de Santa Maria degli Angeli de Roma (ej.6), en la que Miguel Ángel demuestra su respeto por el edificio romano, reduciendo su intervención al mínimo.

En esta línea es interesante la reflexión que hace Leonardo da Vinci, para quien "un buen arquitecto ha de ser un buen restaurador, un buen reconstructor, pues sólo quien es capaz de dominar la concordantia partium podrá resolver la discordantia que arruina y deshace una obra de arquitectura, colmando en sabia metamorfosis sus excitantes vacíos". ${ }^{16}$ Con ello deja patente su gran admiración por la arquitectura clásica y las leyes que la rigen.
15 de SOLÁ-MORALES, I.: "Teorías de la intervención arquitectónica". Quaderns d'Arquitectura i Urbanisme, № 155, Ed. Col.legi d'Arquitectes de Catalunya, 1982, p. 31

16 Gaetana Cantone, "La città di marmo", Officina Edizione, pp. 82-83. Extraído de: USTÁRROZ, A.: La lección de las ruinas. Barcelona, Ed. Fundación Caja de Arquitectos, 1997, p.26 
17 SAENZ DE OIZA, F.J.: Op. Cit., pp. 123-135

18 USTÁRROZ, A.: La lección de las ruinas. Barcelona, Ed. Fundación Caja de Arquitectos, 1997, p.13

19 SETTE, M.P.: Op. Cit., 2001, pp. 1617

20 MARCONI, P.: "H.2.1. Aprocci Metodologici. Ragioni del restauro di ripristino". En: ZEVI L.: /l manuale del restauro architettonico. Roma, Ed. Mancosu, 2001, H88

21 GIZZI, S.: "L'anastilosi tra restauro architettonico e restauro archeologico". En: GONZÁLEZ, A.; DIEZ, M.: I Bienal de la restauración: L'Hospitalet de Llobregat (Barcelona), del 23 al 26 de noviembre del 2000. Barcelona: Diputació de Barcelona. 2002, p. 81
Cabe también mencionar las actuaciones de transformación que se realizan sobre los propios edificios renacentistas o barrocos, para darles mayor contenido simbólico. Éste es el caso de las intervenciones consistentes en la realización de pinturas al fresco en bóvedas o falsas cúpulas como en la actuación de San Ignacio de Roma, donde Andrea Pozzo prolonga la altura del espacio a través de la perspectiva convirtiendo el cerramiento superior en un cielo ficticio. ${ }^{17}$

\section{Ejemplo 5: Dioscuros, Castor y Polux, del Quirinale. Siglo XV}

Rafael se pone a la altura de los autores, y propone terminar el grupo escultórico convirtiéndose en coautor de la obra. Para Alberto Ustárroz este es un ejemplo de como la "ruina" es capaz de inspirar un nuevo proyecto en perfecta armonía con el original. ${ }^{18}$

La solución final, realizada por Somanzi, Olivieri y Vacca sigue las mismas directrices rafaelescas, pero lo hace modificando el tipo de mármol empleado originalmente, algo no apreciado en la época, lo que supone como indica Maria Piera Sette la reducción de su retribución económica. ${ }^{19}$ Con este ejemplo se hace evidente el cambio que se ha producido en la sensibilidad hacia el pasado. Esta diferenciación material, que hoy se vería como un acto de autenticidad histórica, en aquel momento se vio como un error que reducía la armonía del conjunto. Una visión que aún hoy es defendida por autores como Paolo Marconi, quien apoya la reconstrucción mimética de monumentos hundidos de manera traumática. ${ }^{20}$

Otra cuestión que surge a raíz de este ejemplo, es el de la escala de la pérdida. Para Stefano Gizzi "las porciones originales no deberían ser inferiores a un cierto porcentaje". A este propósito Gizzi reproduce la elocuente cita del escultor del siglo XVIII Cavaceppi, quien afirma que "Sería ridículo querer de una Nariz, o poco más, componer una cabeza: de un Pie una Figura; de una Asa de un Vaso un Vaso entero". ${ }^{21}$ Probablemente la cuestión de la escala de la pérdida sea una de las claves a la hora de decidir el criterio de intervención.
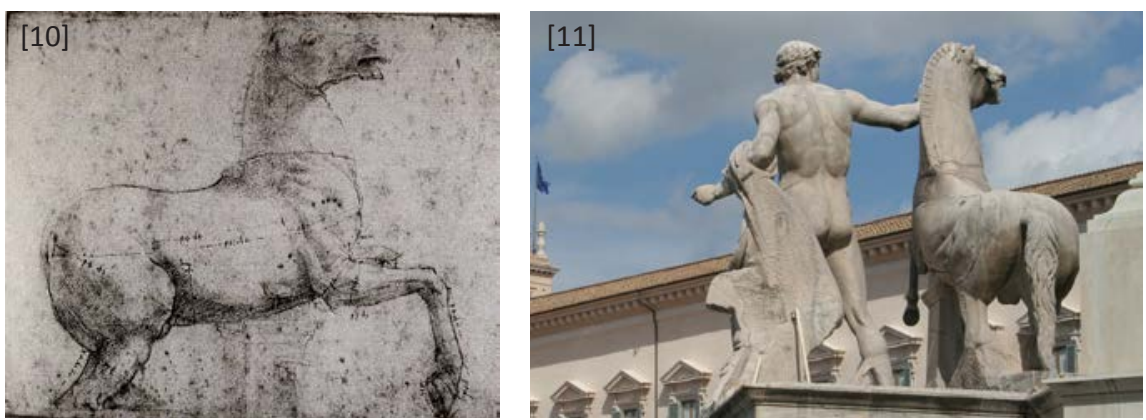

Ejemplo 6: S. Maria degli Angeli, Roma. Miguel Angel. 1561-1566

El Papa Pio IV encarga a Miguel Ángel la transformación de las Termas de Diocleciano en iglesia para aumentar el culto religioso así como para ayudar a conservar el edificio histórico. Miguel Ángel concibe el proyecto como una intervención mínima consistente en una leve modificación del interior, manteniendo la imagen de ruina en el exterior, dando la imagen de una actuación incompleta. Para Vasari, Miguel Ángel con 86 años se sentía profundamente preocupado por la muerte y la salvación del alma. Algo que transmitirá con gran expresividad en su última 
escultura, la Pietà de Rondanini, en la que renuncia a la idealización de la realidad y apuesta por un lenguaje más espiritual. La imagen pagana producida por Miguel Ángel en la iglesia es rechazada por los sucesivos Papas, siendo Luigi Vanvitelli en 1749 el encargado de darle la imagen actual al edificio. ${ }^{22}$

Es importante mencionar que con esta obra Miguel Ángel, no solo demuestra su admiración por la arquitectura clásica, sino que va más allá al respetar la imagen de su ruina, realizando una actuación con un carácter de imperfecta e inacabada, un non finito que transmite el concepto de un eterno devenir. Miguel Ángel admira la belleza de la ruina, prescindiendo incluso de la necesidad del ornamento. Así parece mostrar en la obra lo que había expresado Alberti en palabras al calificar la belleza como una "característica propia e innata de todo cuerpo que quepa considerar hermoso", y la ornamentación "un aditamento más que un elemento consustancial", una "ayuda secundaria de la belleza, un elemento complementario". ${ }^{23}$
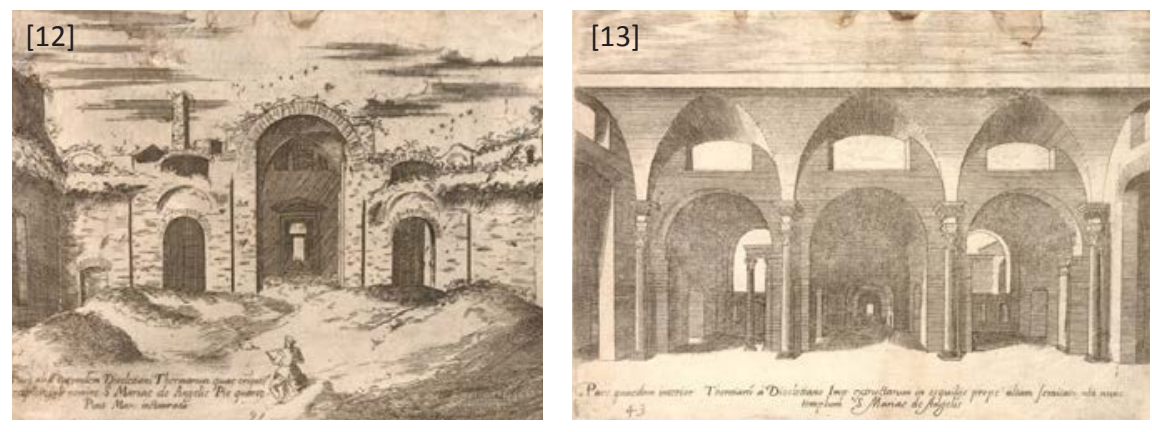

\subsection{Actuaciones sobre arquitecturas medievales}

Las actuaciones sobre preexistencias medievales plantean mayor complejidad, ya que exigen resolver una paradoja: por un lado el rechazo a las formas medievales presente en la cultura renacentista y por otro lado la búsqueda de la belleza en las intervenciones, que exige respetar la preexistencia. Como indica Alberti, la belleza surge cuando se logra la armonía entre las partes, es decir cuando éstas siguen un orden que establece una correspondencia mutua entre ellas. ${ }^{24}$ Como comenta Erwin Panofsky, para alcanzar este requisito fundamental, surgen en la práctica tres caminos posibles de actuación: la remodelación de la preexistencia según los criterios de la manera moderna, la continuación en estilo gótico del edificio medieval, o la búsqueda de una solución de compromiso entre ambos criterios. ${ }^{25}$

El objetivo de la manera moderna es el de "unificar la totalidad del espacio como escenario de la vida humana", eliminando mediante el instrumento de la arquitectura, la diversidad de la ciudad medieval muy presente en las iglesias románicas y góticas. Así, la arquitectura es un instrumento de intervención que tiene su propia congruencia, que se relaciona con las
22 JOKILEHTO, J.: A History of Architectural Conservation. The University of York, 1986 (Edición electrónica, 2005), p.44

23 ALBERTI, L.B.: De Re Aedificatoria. (Traducción de Javier Fresnillo Núñez). Akal, 1991, pp. 246-247

24 ALBERTI, L.B.: Op. Cit., 1991, p.384

25 PANOFSKY, E.: Meaning in the Visual Arts. New York, 1955 (Versión en español: El significado de las artes visuales. Madrid, Ed. Alianza, 1983, p. 210

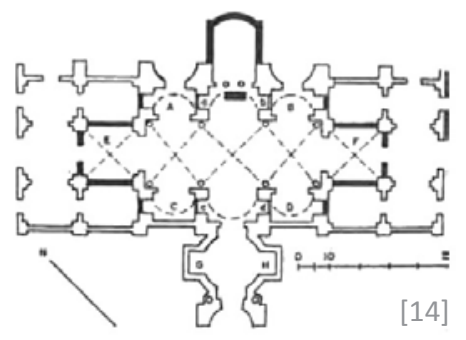

[12] Santa Maria degli Angeli. Vista interior de la nave central. Antonio Dosio. (Census Database: <census. bbaw.de>)

[13] Santa Maria degli Angeli. El acceso de Miguel Ángel. Antonio Dosio. (Census Database: <census. bbaw.de>)

[14] Santa Maria degli Angeli. Planta en la que se aprecian las construcciones de Miguel Ángel. (JOKILEHTO: 2005, p. 43) 
26 de SOLÁ MORALES, I.: Op. cit., 1982 , p. 31

27 JOKILEHTO, J.: Op. Cit., 1986/2005, p. 29

28 SETTE, M.P.: Op. cit., 2001, p. 22 arquitecturas existentes sometiéndolas en busca de la unidad. ${ }^{26}$ Este es el caso de las propuestas de actuación sobre la Basílica de San Pedro de Roma (ej.7), la actuación de Alberti en el Templo Malatestiano de Rimini (ej.8), la actuación de Palladio en la Basílica de Vicenza (ej.9) o la actuación de Borromini en San Juan de Letrán, en Roma (ej.10).

\section{Ejemplo 7: San Pedro de Roma}

Dado el mal estado de la estructura de la Basílica, con evidentes desplomes en sus paramentos, Alberti propone la reconstrucción por tramos de sus muros en aquellas zonas afectadas, pero la propuesta no se lleva a cabo. Posteriormente Nicolás V encarga en 1452 a Rossellino el proyecto de una nueva basílica, que reforzara y ampliara la preexistente, para ensalzar su grandeza. La propuesta de Rossellino, probablemente apoyado por Alberti, se concibe como una nueva envolvente que refuerza la antigua nave, amplia el transepto y crea un nuevo coro de dimensiones monumentales. La actuación se interrumpe con la cimentación y parte de la altura de los muros construida. ${ }^{27}$ Con esta propuesta se apuesta por la superposición arquitectónica, antes que la sustitución, sin embargo para la construcción de la nueva iglesia el Papa ordena derribar el Coliseo para con sus piedras construir el nuevo edificio, demostrando una preferencia por unas arquitecturas que por otras en función de su valor simbólico.

En 1505 el Papa Julio Il encarga a Bramante la creación de una nueva basílica acorde a la estética renacentista. Bramante decide demoler el edificio paleocristiano y crear un nuevo proyecto apoyado en el trazado de Rossellino. Con ello Bramante manifiesta total indiferencia por la realidad física heredada, pero con la convicción de poder transmitir con mayor perfección el valor de su significado, tal y como lo hicieran los antiguos con la reconstrucción de sus templos.
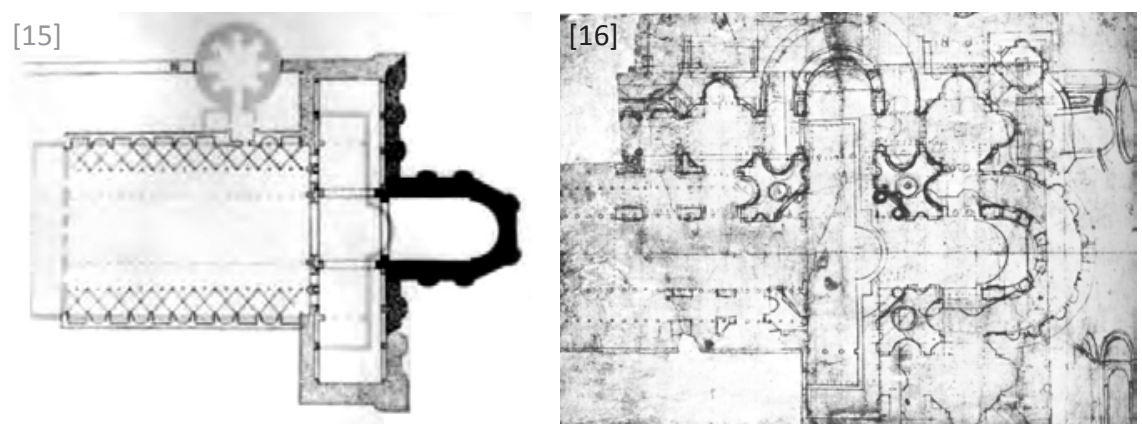

[15] San Pedro de Roma. Planta donde se muestra la propuesta de Rosellino y Alberti para la consolidación y ampliación de la antigua basílica. (JOKILEHTO: 2005, p. 29)

[16] San Pedro de Roma. Se observa que el nuevo proyecto de Bramante sigue las trazas del ábside y el transepto iniciados por Rossellino. (NORBERG-SCHULZ: 1999, p. 126)
Es interesante destacar la gran polémica que desata el derribo de la antigua iglesia de San Pedro, que le supone a Bramante el apodo de "rovinante" (destructor), demostrando una sensibilidad popular no sólo por el significado simbólico del monumento, sino también por su realidad construida. Sensibilidad que se enfatiza por el surgimiento, en el ámbito de la iglesia, de la convicción de que el arte del pasado es más respetuoso que el moderno y que la dignidad de un edificio viene asociada a su antigüedad. ${ }^{28}$ 


\section{Ejemplo 8: Templo Malatestiano de Rimini. Alberti. 1450-66}

En San Pedro, Alberti buscará modificar la imagen del antiguo edificio gótico mediante la construcción de una envolvente clásica con arco triunfal y arquería romana, separada de los muros existentes, y la colocación de una gran cúpula que le dotara de una nueva concepción central. Pero con ello Alberti no se preocupa solo de cambiar la imagen para adaptarla a las nuevas necesidades, sino que actúa dando permanencia a los valores del pasado sin negar la libertad de acción de la nueva cultura.

Como comenta Ignasi de Solà Morales, Alberti debe adaptar su modelo a las condiciones concretas del edificio previo, generándose con ello una tensión entre la contundente superposición del nuevo modelo y la permanencia en el interior de la antigua iglesia, cambiándole el sentido al edificio existente, pero sin negarlo del todo. ${ }^{29}$ También José Ignacio Linazasoro hace hincapié en la voluntad de Alberti de hacer evidente la superposición entre la nueva estructura construida y la antigua gótica, expresando con ello una manera de actuar alejada del purismo, y centrada en la confrontación y la suma de fragmentos. ${ }^{30}$
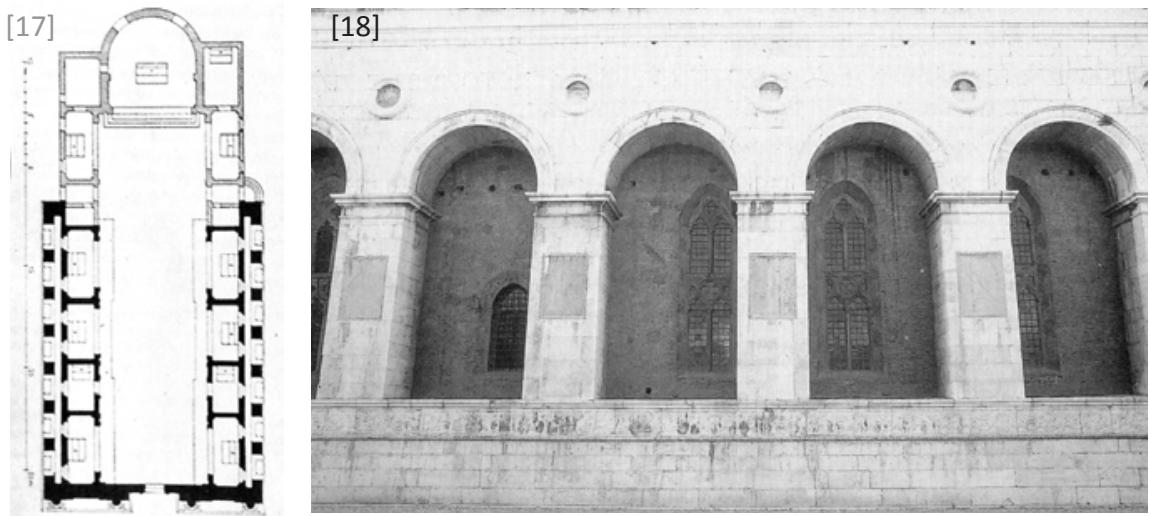

\section{Ejemplo 9: Basilica de Vicenza. Palladio. 1549}

El edificio medieval sufre problemas estructurales en sus muros debido al gran peso de su cubierta, por lo que surge la necesidad de llevar a cabo su reparación. Palladio se plantea la misma estrategia que Alberti en Rimini, y propone la creación de una nueva envolvente que refuerza el edificio preexistente y asegura su permanencia. La nueva loggia compuesta por una estructura compositiva de serlianas, permite dar una nueva imagen renacentista al edificio en la ciudad, pero sin ocultar la anterior construcción medieval.
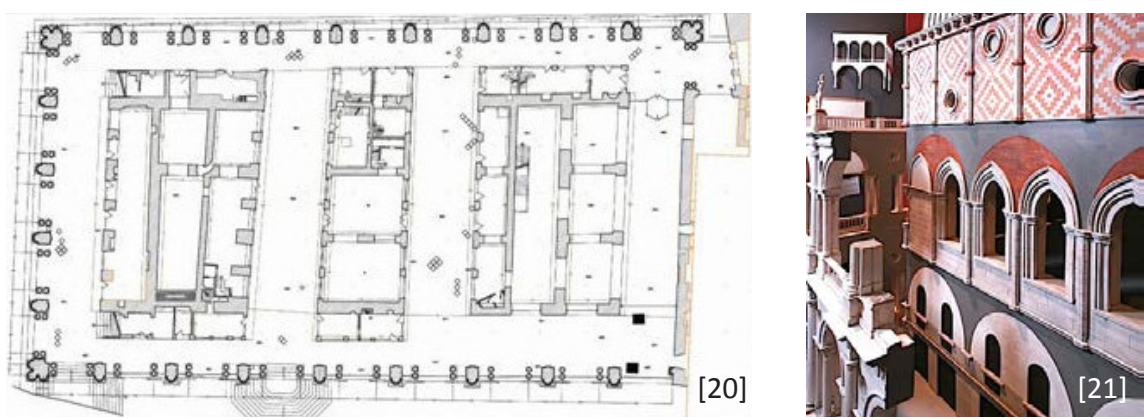

29 de SOLÁ MORALES, I.: Op. cit., 1982 , p. 31

30 Ideas extraídas de la entrevista realizada a José Ignacio Linazasoro, en Madrid, en diciembre de 2012, pregunta 10 (ver anexo)

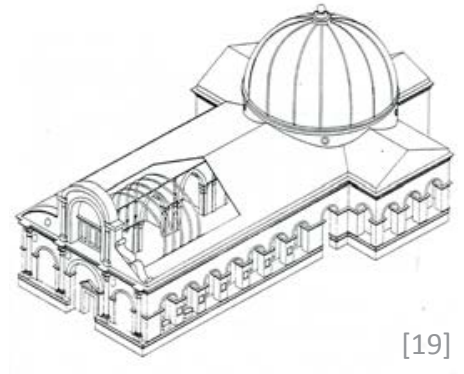

[17] Templo Malatestiano. Planta. El revestimiento albertiano engloba totalmente la estructura de la antigua iglesia de San Francisco (siglo XIII) y ésta a su vez se integra en la nueva unidad. (SETTE: 2001, p. 19)

[18] Templo Malatestiano. Imagen en la que se aprecia la superposición entre la nueva estructura y la antigua estructura gótica. (RIVERA: 2008, p. 48)

[19] Templo Malatestiano. Axonometría según la hipótesis reconstructiva del projecto albertiano. (NOGUERA: 1989, p. 27)

[20] Basílica de Vicenza. Planta. (MARCONI: <www.paolomarconiarchitetto.it>)

[21] Basílica de Vicenza. Modelo del proyecto de Andrea Palladio. (Manchester School of Architecture: <www.msa.mmu.ac.uk>) 
31 SETTE, M.P.: Op. cit., 2001, p. 24

32 MARIANI, M.: Monumenti nel tempo. Per una storia del restauro in Abruzzo e nel Molise. Carucci, Roma, p.93. Extraído de: SETTE, M.P.: Op. cit., 2001, p. 20

33 SETTE, M.P.: Op. cit., 2001, p. 22

34 MARCONI, P.: Materia e significato: la questione del restauro architettonico. Roma, Ed. GLF editori Laterza, 1999, p. 80
Ejemplo 10: San Juan de Letrán en Roma, Borromini. 1650

Borromini transforma la antigua iglesia medieval, ocultando su estructura adintelada en un nuevo sistema compositivo clásico, dando curvatura a la cara interior del muro de fachada. El techo plano original debía de haberse cubierto con una bóveda, acompañando así el ritmo curvo de los muros. Por otro lado cabe destacar los fragmentos medievales que introduce Borromini en el nuevo orden, operación que realiza sin perder la unidad y el carácter barroco del conjunto.

Este es un ejemplo de la nueva atención hacia la preexistencia que surge a partir del siglo XVII. Los restos se mantienen con mayor asiduidad en las obras modernas, confiriéndoles más el valor de reliquia que el de documento histórico. Así se difunde la práctica de englobar o poner en evidencia en la obra nueva elementos del pasado. Un fenómeno por el que, en ciertos edificios religiosos, se emplean más formas del pasado que actuales, permitiendo con ello la supervivencia de formas medievales. ${ }^{31}$
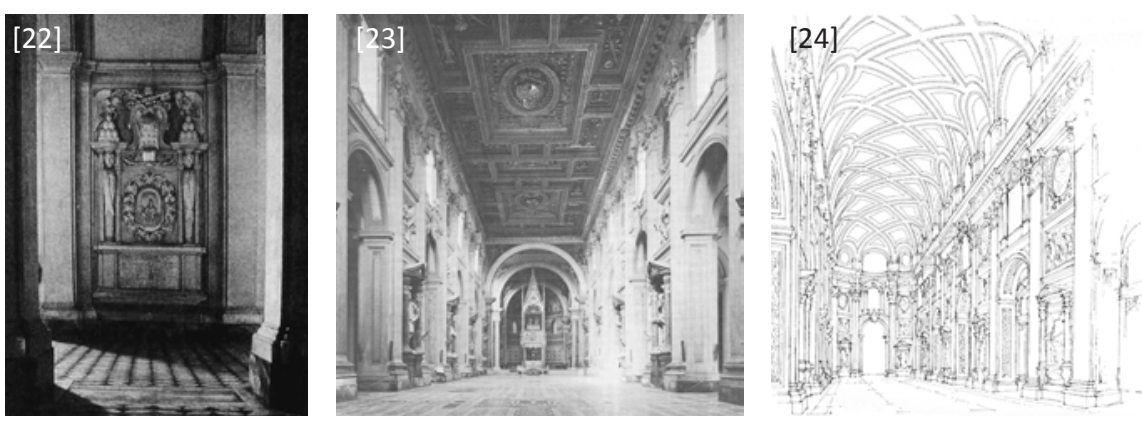

Cuando no es posible conectar íntimamente los nuevos aportes con los elementos preexistentes, en modo de constituir sistemas unitarios, se acude a la solución en estilo, que Panofski denomina como "sumisión a la conformidad" y que Miarelli Mariani define como intervención "retrospectiva". ${ }^{32}$ Este es el caso de las propuestas para la iglesia de San Petronio en Bolonia (ej.11). Se trata de casos de nueva construcción sobre edificios existentes con la finalidad de completarlos, ya que si fuera necesario reconstruirlos se acudiría al lenguaje clásico, tal y como se ha visto en el caso de San Pedro de Roma.

\section{Ejemplo 11: San Petronio de Bolonia}

La fachada de la iglesia había quedado incompleta y la tradición gótica de la ciudad imponía que se terminara mediante una solución en estilo. Algunos de los grandes protagonistas del renacimiento como Peruzzi (1522) o Palladio (1577) elaboran propuestas que buscan relacionarse convenientemente con la preexistencia. Scamozzi alaba la solución palladiana por la "maestría con la que combinó el gótico y el romano de manera tan ingeniosa". Mientras que el arquitecto barroco Gerolamo Rainaildi adoptará el estilo gótico para completar las bóvedas del interior de la iglesia. ${ }^{33}$

Paolo Marconi hace hincapié en la gran cantidad de propuestas góticas que proponen los arquitectos clásicos del momento, entre ellos Peruzzi (1521-22), Vignola (1544) o Giulio Romano (1545-46). Con ello Marconi trata de defender la legitimidad de la imitación de los estilos del pasado, frente a la fobia existente por el falso antiguo surgida a raíz del auge del "mercado del arte (...) que favorece a lo inédito y lo inusitado sobre lo habitual y lo tradicional". ${ }^{34}$ 

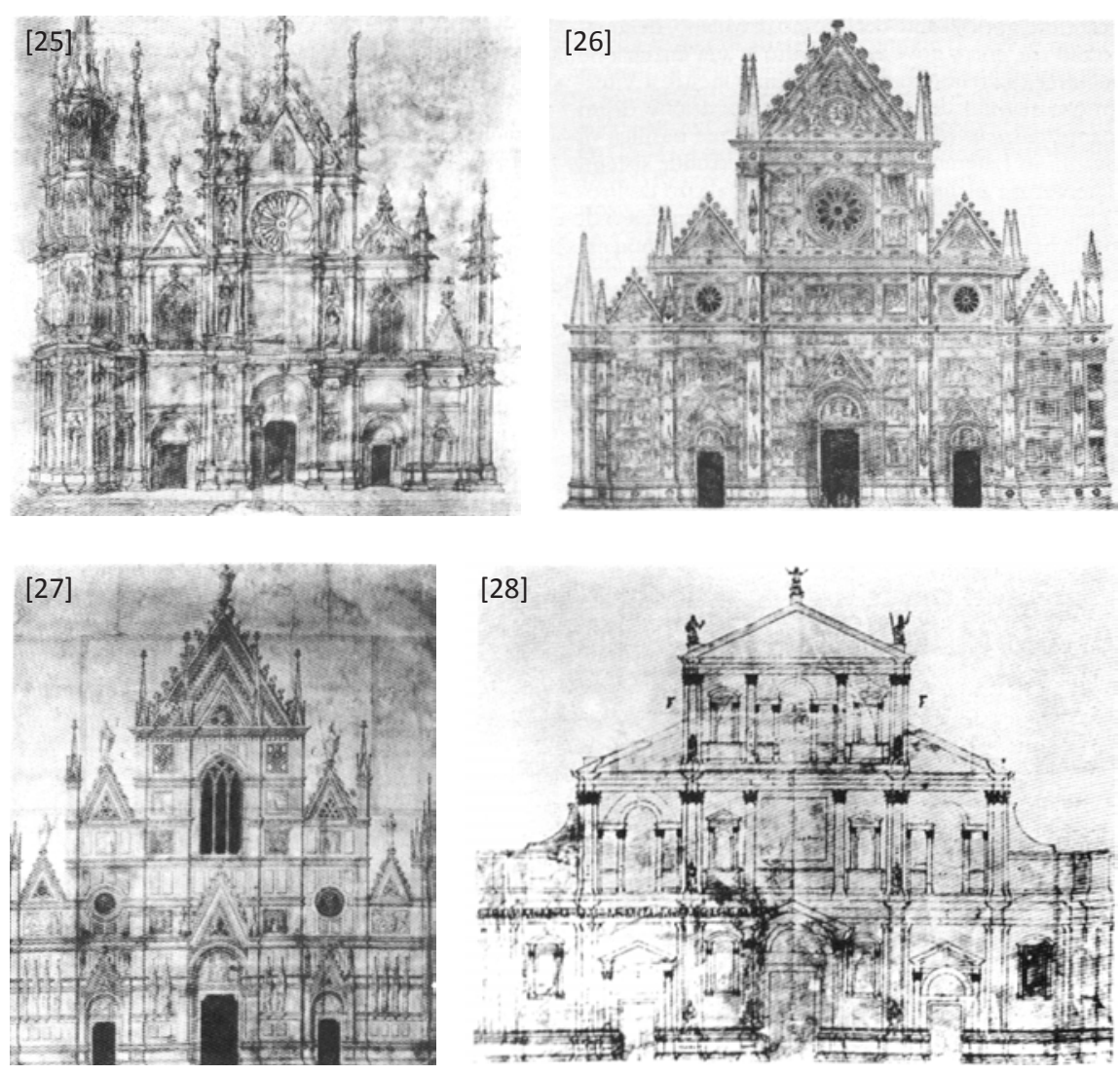

La solución del compromiso busca la compatibilidad entre las partes de la arquitectura, de tal manera que se inserte lo nuevo en lo antiguo sin estridencias. Los nuevos añadidos tratan de relacionarse con la arquitectura preexistente a través de las proporciones y del ritmo y no mediante estilismos. ${ }^{35}$ Este es el caso de la cúpula para Santa Maria dei Fiori de Brunelleschi (ej.12), de la actuación de transformación de San Stefano Rotondo (ej.13) o la actuación de Alberti en Santa Maria Novella (ej.14).

\section{Ejemplo 12: Cúpula de Santa Maria dei Fiori. Brunelleschi}

Brunelleschi diseña una nueva cúpula de planta octogonal con una forma que se integra sin estridencias en el edificio medieval. El gran diámetro de la cúpula supone un reto técnico. Por un lado Brunelleschi aumenta la altura del tambor, peralta la cúpula y la remata con linterna, para reducir las cargas horizontales, y por otro lado la construye mediante una bóveda de ladrillo en espina de pez reforzada con nervios en el extradós, para evitar el uso de cimbras. La cúpula se muestra al exterior como un referente en la ciudad, pero que se integra con armonía en el conjunto urbano gracias a la combinación de los nervios de piedra y las tejas de terracota, materiales y tonos empleados en las edificaciones vecinas.

Para Saenz de Oiza el gran mérito de Brunelleschi es el de atreverse a colocar sobre una iglesia medieval el símbolo de una nueva era, la del renacimiento, a través de una innovación técnica que supone una revolución formal. ${ }^{36}$
35 SETTE, M.P.: Op. cit., 2001, p. 10

36 SAENZ DE OIZA, F.J.: Op. cit., 1987, pp. $123-135$

[25] San Petronio. Propuesta de Peruzzi, 1522. (MARCONI: 1999, p. 82)

[26] San Petronio. Propuesta de Giulio Romano, 1545-46. (MARCONI: 1999, p. 82)

[27] San Petronio. Propuesta de Vignola, 1544. (MARCONI: 1999, p. 83)

[28] San Petronio. Propuesta de Palladio, 1577. (MARCONI: 1999, p. 84)

[29] Cúpula de Santa Maria dei Fiori. (CHING: 1997, p. 77)

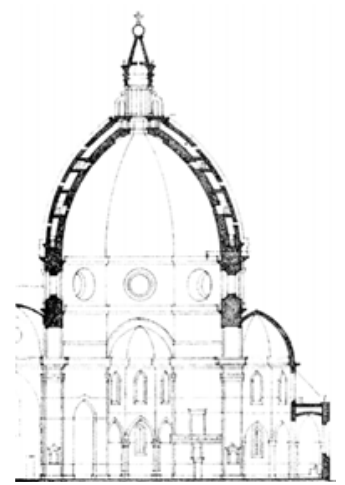


37 JOKILEHTO, J.: Op. cit., 1986/2005, p. 30

[30] San Stefano Rotondo. Croquis de Francesco di Giorgio Martini. (JOKILEHTO: 2005, p. 30)

[31] San Stefano Rotondo. Axonometría de la intervención de Rosselino. (JOKILEHTO: 2005, p. 30)

[32] Vista actual interior de San Stefano Rotondo.

[33] Santa Maria Novella. Análisis de los trazados reguladores que componen la fachada. (RIVERA: 2008, p. 48)

[34] Santa Maria Novella. Imagen de la fachada. (NORBERG-SCHULZ: 1999, p. 122)
Ejemplo 13: San Stefano Rotondo. Rossellino. 1454

El edificio original, construido entre 468-483, estaba rodeado por un deambulatorio abierto con columnatas y arcos que conectaban con cuatro capillas con patios entre ellas. La intervención de Rossellino supone una transformación del monumento consistente en el cierre de la columnata del deambulatorio, la demolición de las capillas, la construcción de un nuevo pórtico de entrada, el cierre de parte de los huecos originales y el cierre de la cubierta de la nave central con estructura de madera. Ante la intervención promovida por el Papa Nicolas, Francesco di Giorgio Martini denuncia la mala actuación y reclama mediante un croquis una imagen más clásica del edificio, con una arcada perimetral y la presencia de una gran cúpula como cierre del espacio central. ${ }^{37}$

Se observan en este ejemplo dos maneras muy distintas de interpretar el edificio original, produciendo con ello dos espacios completamente diferentes, uno más arcaico y cerrado, otro más elaborado y abierto.
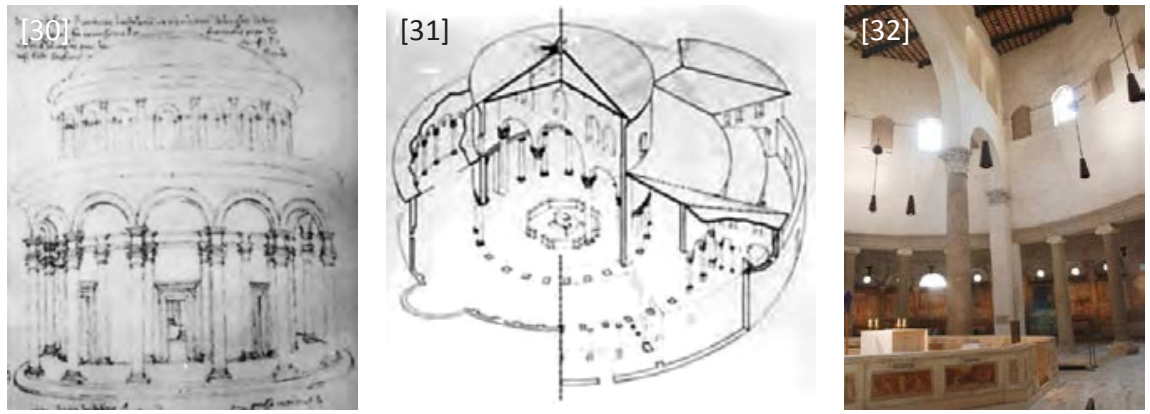

\section{Ejemplo 14: Santa Maria Novella en Florencia, de Alberti}

Alberti propone una nueva fachada que busca introducir un lenguaje equilibrado entre el estilo gótico de la iglesia y las proporciones clásicas. Alberti se apoya en la relectura de los motivos decorativos del Baptisterio de San Giovanni en Florencia para la definición de los paramentos de la nueva fachada, mientras que la estructura de la composición presenta rasgos clásicos a través de un primer nivel con un orden de cuatro columnas rematado en un friso, sobre el que se ubica un segundo nivel más estrecho organizado con cuatro pilastras y rematado con frontón triangular.
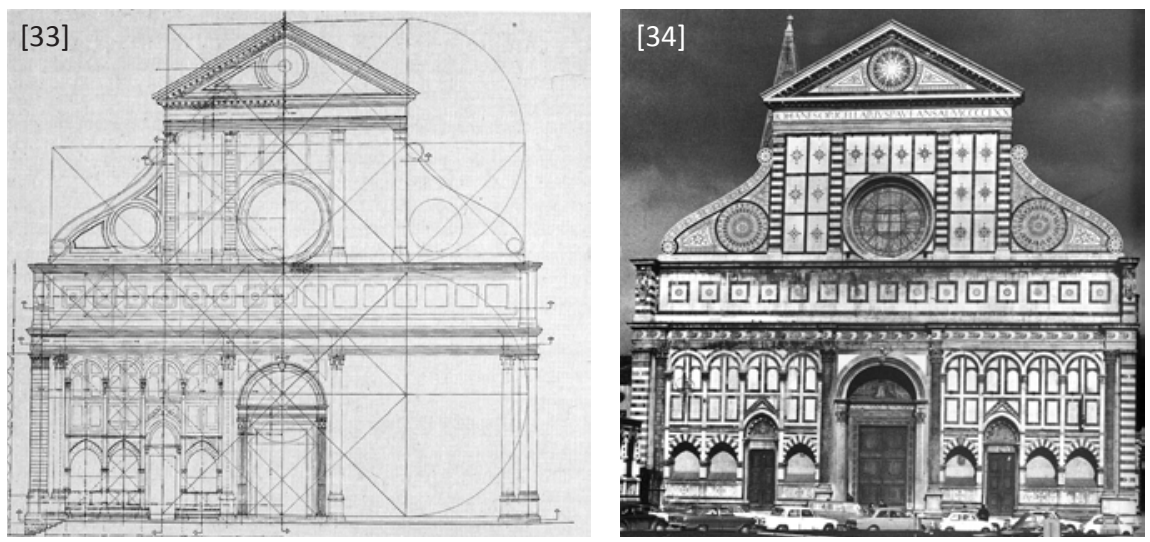

Evolución de los criterios de intervención en el patrimonio arquitectónico 
En España la llegada tardía del clasicismo hace que durante los siglos XV y $X V I$ se siga construyendo en estilo gótico, en convivencia con un incipiente renacimiento. Esto hará que las actuaciones en estilo gótico sean bastante habituales, pero dentro de un proceso de reelaboración clásica. Este es el caso de las bóvedas que construye Francesc Baldomar en diversos monumentos de la ciudad de Valencia (ej.15), la traza de Juan de Ribero Rada para la terminación de la catedral de Salamanca (ej.16) o la actuación de Juan de Vallejo en la reconstrucción de la linterna de la Catedral de Burgos (ej.17).

\section{Ejemplo 15: Francesc Baldomar}

Baldomar construye bóvedas aristadas, sin nervaduras, manteniendo la técnica de la estereotomía pétrea propia de la arquitectura gótica, pero concebidas con un excepcional dominio de la geometría. Este es el caso de las bóvedas presentes en edificios valencianos como el elemento de conexión entre la Catedral y la torre del Miguelete (1458), las Torres de Quart (1441-60) o la Capilla Real en el Convento de Santo Domingo (1451-59). Así sus obras desprenden un lenguaje a caballo entre la complejidad constructiva gótica y la continuidad formal clásica. La gran complejidad en la ejecución de los elementos debido a la unidad formal y constructiva de estructura y plementería, lo convierten en un caso singular en la historia de la arquitectura. ${ }^{38}$
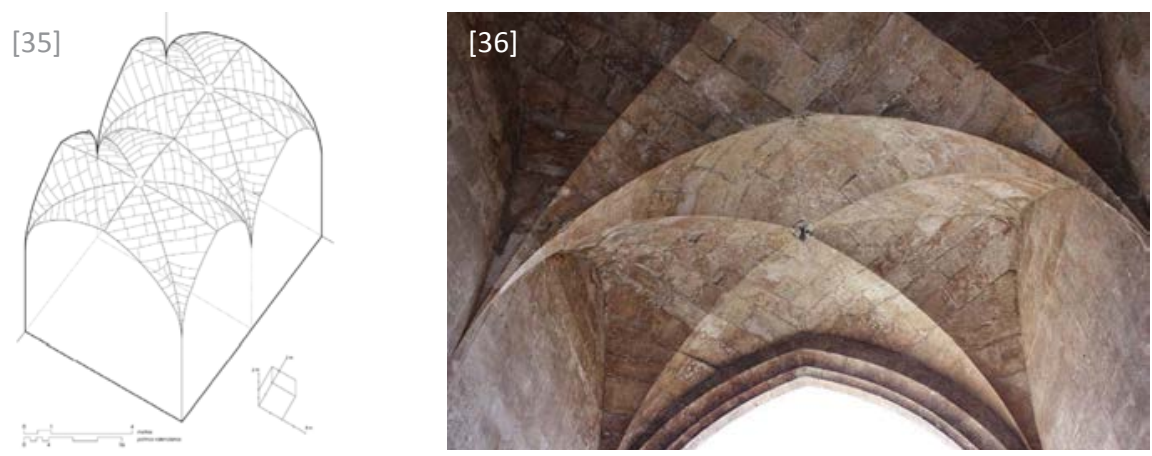

Ejemplo 16: Cabecera de la catedral de Salamanca

A finales del siglo XVI se produce un debate sobre como terminar la catedral, construida hasta la altura del transepto, surgiendo posturas a favor del estilo gótico y posturas a favor del renacentista. Juan de Ribero Rada traza la cabecera en estilo gótico, pero lo hace sustituyendo la planta poligonal por un diseño ortogonal clásico, combinando las formas de estética medieval con el concepto de espacio clásico. ${ }^{39}$

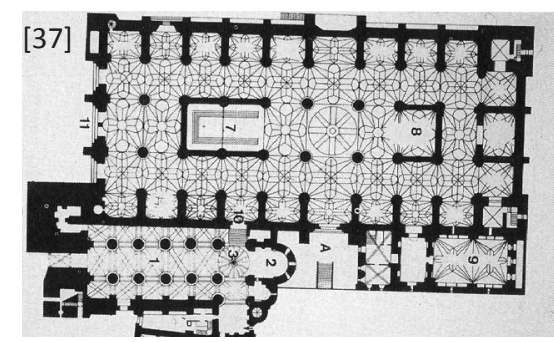

38 Sobre este tema se pueden consultar:

ZARAGOZÁ CATALÁN, A.: Arquitectura gótica valenciana. Valencia, Generalitat Valenciana, 2000.

NATIVIDAD VIVÓ, P.; CALVO LÓPEZ, J.: “Levantamiento arquitectónico e hipótesis sobre la estereotomía de la bóveda aristada de las Torres de Quart de Valencia". X Congreso Internacional Expresión Gráfica aplicada a la Edificación, APEGA 2010.

SÁNCHEZ SIMÓN, I.: "Traza y montea de la bóveda de la Capilla del Real del convento de Santo Domingo de Valencia. La arista del Triángulo de Reuleaux entre las aristas de la bóveda". Actas del séptimo congreso internacional de historia de la construcción, Santiago 2629 de octubre de 2011

39 RIVERA BLANCO, J.: "Teoría e Historia de la Intervención en Monumentos Españoles hasta el Romanticismo" (1989). En: De varia restauratione. Teoría e historia de la restauración arquitectónica. Madrid: Abada editores, 2008, p. 59
[35 y 36] Torres de Quart. Perspectiva militar cenital del intradós de la bóveda aristada y vista cenital del intradós de la bóveda aristada en la tribuna central de las Torres de Quart. (NATIVIDAD; CALVO: 2010, pp. 437 y 433 )

[37] Catedral de Salamanca. Planta. (RIVERA: 2008, p. 18) 
40 Ideas extraídas de la entrevista realizada a José Ignacio Linazasoro, en Madrid, en diciembre de 2012, pregunta 12 (ver anexo)
[38 y 39] Catedral de Burgos. Vistas del cimborrio. (Fotografías de Luis Fernández. En: Ocio y cultura: $<$ www.deocioycultura.blogspot. com>)

[40] Mezquita de Córdoba. Superposición de estratos. (Imagen del autor.)

[41] Mezquita de Córdoba. Planta en la que se dibujan la "primera" catedral de estilo gótico y el gran crucero de Hernán Ruiz. (MONEO: Arquitectura, no 256, 1985)
Ejemplo 17: Linterna de la Catedral de Burgos. Juan de Vallejo

José Ignacio Linazasoro menciona la peculiaridad de esta obra en cuanto solución de equilibrio entre el lenguaje gótico y renacentista, de tal manera que si uno mira la linterna desde la lejanía la ve completamente integrada en el sistema compositivo gótico, pero si uno se acerca y observa los detalles se da cuenta que la actuación es totalmente renacentista. ${ }^{40}$
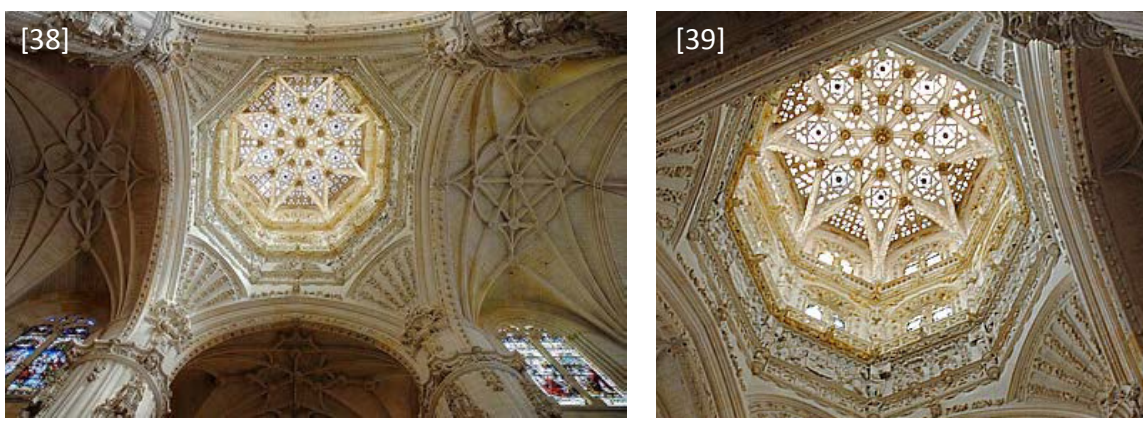

Desde el punto de vista del contraste destacan las intervenciones de inserción de la Catedral tardogótica en la mezquita de Córdoba (ej.18) o el Palacio de Carlos V en la Alhambra de Granada (ej.19). Ambas actuaciones se entienden desde la necesidad de cada cultura de apropiarse de las preexistencias imponiendo los símbolos del nuevo poder. A pesar de la aparente violencia de las nuevas actuaciones contra los monumentos sobre los que se insertan, éstas deben verse desde el punto de vista histórico y entender el respeto que se tuvo con las preexistencias al permitir la convivencia entre antiguo y nuevo, siendo culturas totalmente distintas.

\section{Ejemplo 18: Catedral en la mezquita de Córdoba. Hernán Ruiz, 1523}

Con la caída de Granada en 1492, se reclama una transformación profunda de la mezquita, que ya contaba con culto cristiano aportado mediante discretas actuaciones anteriores. En 1523 Carlos I encarga el proyecto a Hernán Ruiz el Viejo, que debía insertar en el edificio una nueva catedral que lo cristianizara definitivamente. El nuevo edificio se apoya en las estructuras preexistentes, respetando el orden de la malla de columnas de la mezquita.
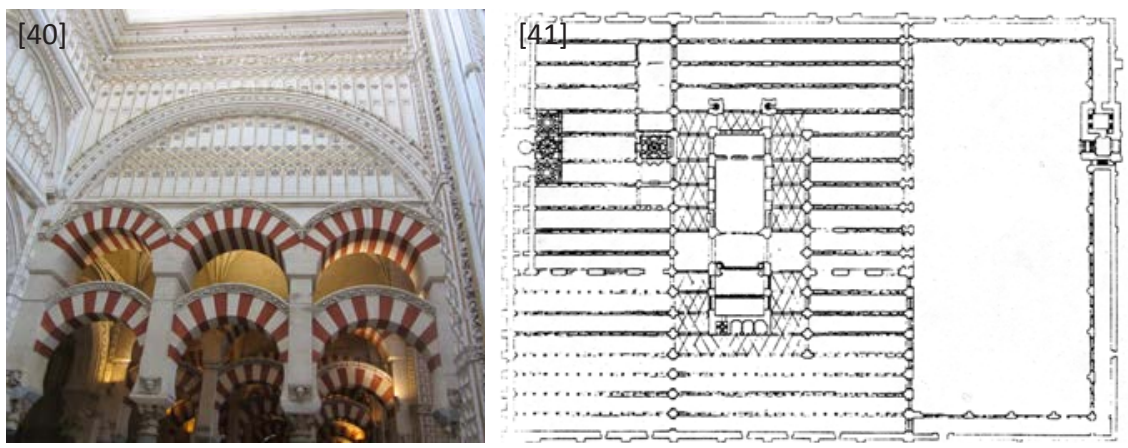
La catedral introduce una nueva luz en el interior del ambiente continuo de la mezquita que da un nuevo sentido al espacio. El respeto a los estratos preexistentes en la definición de la nueva arquitectura se evidencia en el desmontaje y remontaje de estructuras islámicas para la construcción de los grandes soportes de la nueva catedral. El estilo empleado denota un renacimiento demasiado joven capaz de resolver los muros en estilo clásico pero que debe acudir al gótico para resolver algunas de las bóvedas, lo que denota la convivencia entre estilos distintos.

Como dice Rafael Moneo "la obra de Hernán Ruiz fue realizada con talento y habilidad", teniendo en cuenta la gran dificultad que suponía "insertar una catedral tardogótica en la estructura continua y frágil de la mezquita (...) sin causar daños de consideración a la vieja estructura". Para Moneo, de manera paradójica, la nueva catedral favoreció la unidad de la mezquita, que había sido ampliada durante los siglos, "adquiriendo coherencia al envolver el cuerpo de la iglesia cristiana". ${ }^{41}$

\section{Ejemplo 19: Palacio de Carlos V, Granada. Pedro Machuca, 1527}

Carlos $\mathrm{V}$ toma posesión de la Alhambra de Granada con la inserción de su residencia en los palacios Nazaríes, asegurando con ello la permanencia de los antiguos edificios en el tiempo. Pedro Machuca inserta el nuevo edificio sin ignorar la importancia de los espacios preexistentes, creando cierta armonía en el perfil del conjunto.

Para Antón Capitel, el palacio de Carlos V en la Alhambra de Granada, más allá de su aparente contraste, es capaz de extraer de los edificios nazaríes y del lugar "algunos de los instrumentos proyectuales que, por analogía, usará para constituirse a sí mismo", de tal manera que "el palacio nuevo guarda los valores de la Alhambra, añadiéndole los suyos y los de la propia y original conjunción que forman". ${ }^{42}$

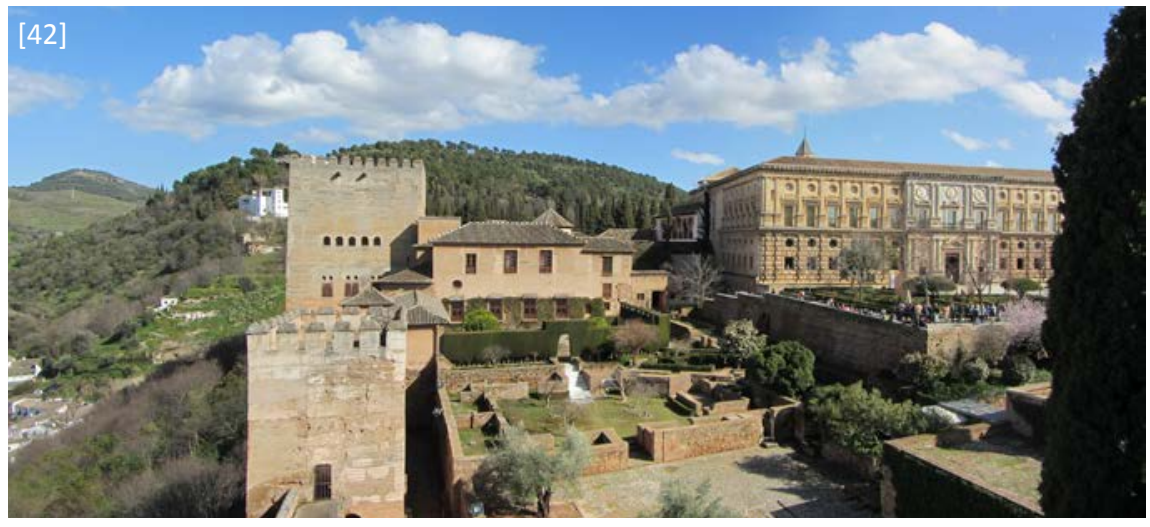

En el siglo XVII el auge del Barroco hace que se busque actualizar edificios medievales mediante su recubrimiento con nuevas decoraciones. Este tipo de actuación es muy común en Valencia en edificios góticos como la Catedral (presbiterio, 1674-82) (ej.20), la iglesia del convento de la Trinidad (1685-86) o la iglesia de los Santos Juanes, extendiéndose hasta el siglo XVIII en edificios como la iglesia de San Martín o el interior de la propia Catedral.
41 MONEO, R.: "La vida de los edificios. Las ampliaciones de la Mezquita de Córdoba". Arquitectura nํ256, 1985, pp.33-34

42 CAPITEL, A.: "La analogía como instrumento proyectual en los edificios históricos". En: POL, F. (dir.): Arquitectura Recuperada. Madrid: Universidad Internacional Menéndez Pelayo, 1989, pp. 13-16
[42] Imagen de conjunto del Palacio de Carlos V y los Palacios Nazaríes. (Imagen del autor.) 
43 RIVERA BLANCO, J.: Op. cit., 1989/2008, p. 91

44 Bonelli, R.: Architettura e restauro. Venecia, Neri Pozza, 1959, p. 13. Extraído de: SETTE, M.P.: Op. cit., (2001), p. 33

45 BOSCH REIG, I.: "Intervención en el patrimonio: un continuo proceso de innovación". En: A.A.V.V.: Las herramientas del arquitecto 2. Valencia, Ed. Ediciones Generales de la Construcción, 2004

46 JOKILEHTO, J.: Op. cit., 1986/2005, p. 89

\section{Ejemplo 20: Catedral de Valencia}

Entre 1674 y 1682 Juan Pérez Castiel recubre el presbiterio de la Catedral en barroco ocultando unas pinturas de estilo renacentista que han sido redescubiertas recientemente.

Posteriormente, entre 1774 y 1792, Antonio Gilabert recubre el resto de elementos del interior de la nave ocultando totalmente los signos del gótico. Esta última actuación también será eliminada parcialmente en una actuación de restauración realizada en el siglo $\mathrm{XX} .^{43}$

Estas actuaciones no se tratan ya de intervenciones de consolidación a través de un nuevo estilo, como ocurre por ejemplo en Vicenza, sino de puras actuaciones de enriquecimiento ornamental exigidas por la nueva cultura del barroco. No se busca tanto la permanencia mediante la lectura de la superposición de dos estratos de la historia, sino de la creación de un nuevo monumento sin necesidad de destruirlo, aprovechando sus valores físicos.

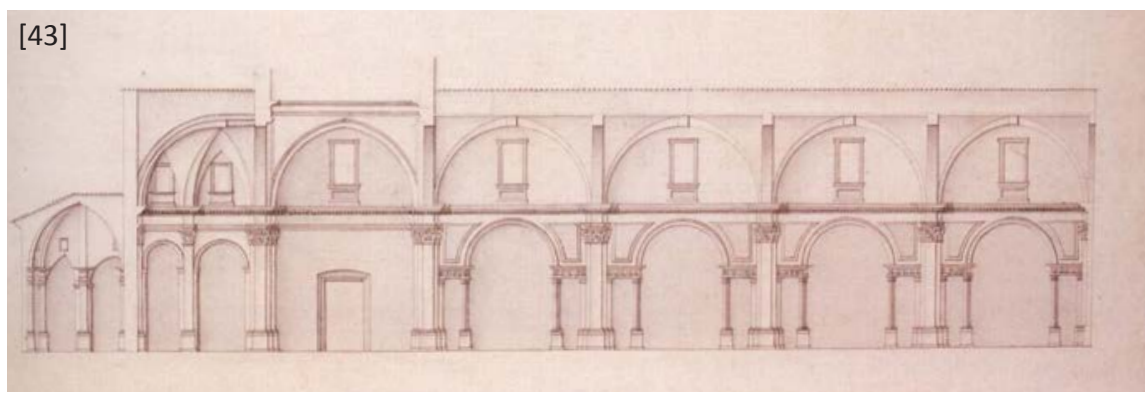

[43] Catedral de Valencia. Proyecto de renovación académica. Antonio Gilabert. (Museo de Bellas Artes de Valencia: 1997, p. 79)

\section{Siglo XVIII}

EI XVIII es el siglo de la Ilustración. Surge la búsqueda por comprender el origen de las cosas. Las excavaciones en Pompeya, Herculano, Ostia y Tívoli hacen aflorar la sensibilidad por el conocimiento de lo antiguo. Winckelmann trata de explicar la razón de la belleza de las obras de arte mediante la distinción entre lo original y lo añadido, lo que lleva al nacimiento de la restauración moderna, una operación que busca extraer el origen de la obra, con una motivación histórica de distinción entre pasado y presente. ${ }^{44}$ Se valora la obra antigua por lo que es en sí misma y no por lo que puede suponer su uso actualizado, dirigiendo las actuaciones hacia la conservación de la obra como documento testigo de otra época, lo que lleva a la negación de la innovación y a la protección total del monumento con demolición de añadidos posteriores arbitrarios. ${ }^{45}$

Cavaceppi, el restaurador de esculturas más activo en Roma, sigue estas indicaciones en sus restauraciones, y en caso de duda prefiere mantener la escultura sin completar dejando los extremos irregulares para mostrar de manera didáctica la fractura del original. ${ }^{46}$ Además Cavaceppi se preocupa 
por el tratamiento superficial de las obras antiguas, denunciando las restauraciones que buscan eliminar las marcas del tiempo puliendo la superficie y dañando la obra. También el pintor italiano Crespi defiende mantener la pátina en los cuadros, ya que su limpieza reduciría el valor de la obra. ${ }^{47}$

En arquitectura se observa una transición que va desde las actitudes de intervenciones "compositivas" de siglos anteriores hacia el reconocimiento de los edificios del pasado, por lo que son en sí mismos, buscándose conservar el monumento como documento testigo de otra época. Un buen ejemplo de esta transición, tal y como comenta Javier Rivera, es el arquitecto español Ventura Rodríguez que constituye un paradigma de la evolución de la restauración arquitectónica. Sus intervenciones muestran una evolución que va desde la imposición del estilo barroco sobre las preexistencias como en la fachada de la catedral de El Burgo de Osma, pasando por soluciones intermedias como la transformación del Colegio Mayor de Santa Cruz en Valladolid, hasta soluciones conservacionistas como su propuesta de "refuerzo estructural" de la torre la catedral vallisoletana (ej.21). ${ }^{48}$

Ejemplo 21: Torre de la catedral de Valladolid. 1761

Ventura Rodríguez propone el enzunchado de la torre con cadenas de hierro para evitar su deformación estructural. ${ }^{49}$

A propósito de estas actuaciones, es interesante destacar la intervención en el Transparente de la Catedral de Toledo (1729-32), una solución que busca emplear una vía intermedia que no renuncia a lo nuevo pero sabe adaptarse prestando cierta atención a lo antiguo (ej.22).

Ejemplo 22. Transparente de la Catedral de Toledo. Narciso Tomé. 1729-32 Narciso Tomé realiza un grupo escultórico en el trasaltar mayor y para darle luz perfora una de las bóvedas y construye un nuevo ventanal en el muro absidial. Así, a través de una operación "quirúrgica" sobre el edificio gótico, logra un interesantísimo efecto luminoso donde, la ocultación de la fuente de luz, convierte al conjunto en una escena de gran espiritualidad. ${ }^{50}$
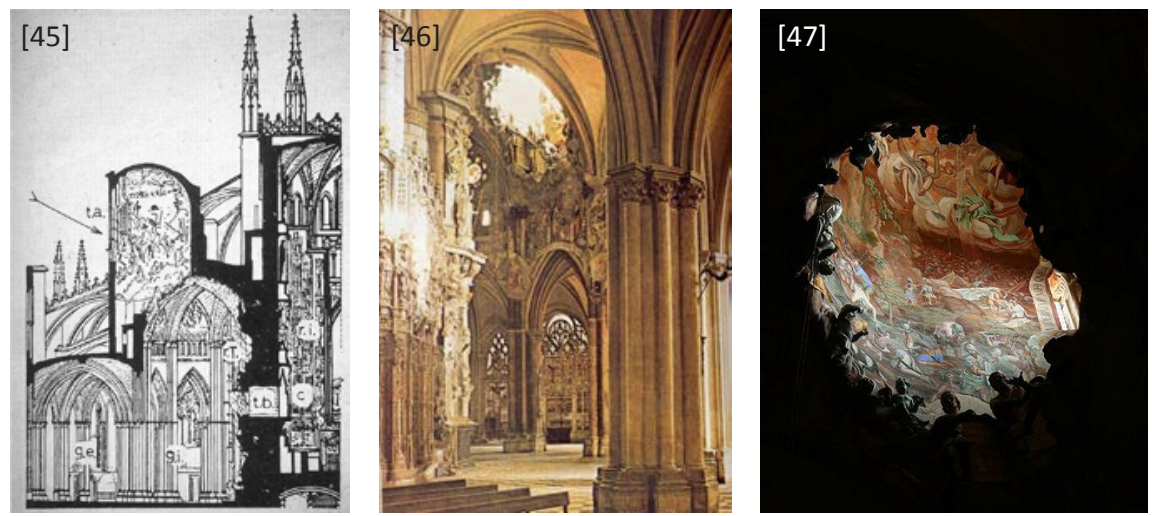

47 JOKILEHTO, J.: Op. cit., 1986/2005, p. 99

48 RIVERA BLANCO, J.: Op. cit., 1989/2008, p. 72

49 RIVERA BLANCO, J.: Op. cit., 1989/2008, pp. 100-101

50 RIVERA BLANCO, J.: Op. cit., 1989/2008, p. 53

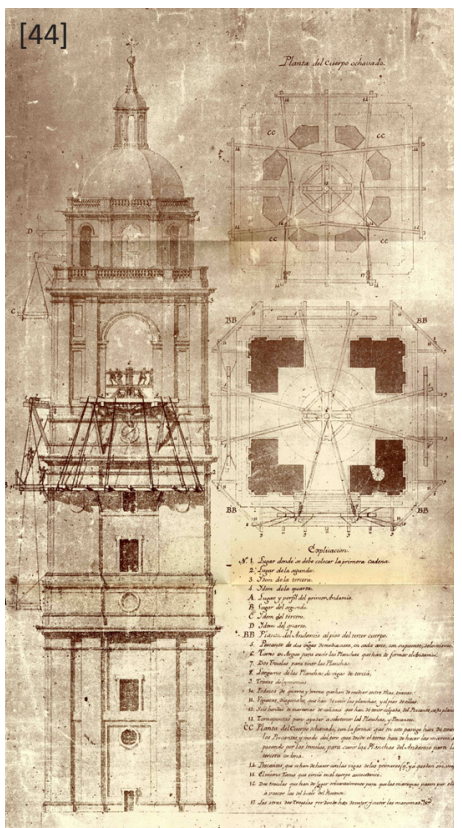

[44] Catedral de Valladolid. Proyecto de V. Rodríguez para la torre. (RODRÍGUEZ: 1987)

[45] Catedral de Toledo. Situación de la nueva abertura. (RIVERA: 2008, p. 53)

[46] Catedral de Toledo. Vista de la nueva abertura y la entrada de luz. (E-peristilo: <peristilo.wordpress. com>)

[47] Catedral de Toledo. Detalle del transparente. (MARTÍNEZ: 8 enero 2013. <manuelblasmartinezmapes. blogspot.com>) 
51 REPRESA BERMEJO, I.: “La expresión plástica en la degradación". En: REPRESA, I. (dir.): Restauración Arquitectónica II. Valladolid: Universidad de Valladolid, 1998, p. 145

52 PIZZA, A.: "Ruinas, Forma, Proyecto". En: A.A.V.V.: Cuadernos IV. Arquitectura y Patrimonio. Junta de Anadlucía. 1994. pp. 31, 32
Por otro lado surge un interés hacia el valor plástico de la ruina. Ignacio Represa pone el ejemplo del proyecto de Mausoleo para el Príncipe de Gales, de William Chambers, de 1751, (ej.23) en el que contrapone un interior claramente definido, basado en la arquitectura romana, con un exterior inacabado que se integra en un ambiente paisajista expresándose como ruina pintoresca. Se produce así un contraste entre "la sensualidad de la ruina" del exterior y el "academicismo de la reconstrucción" en el interior, como protegida, cobijada, rescatada. ${ }^{51}$

Ejemplo 23. Mausoleo del Príncipe Federico de Gales. William Chambers. 1752 Chambers representa su proyecto del mausoleo como si se tratara de un templo antiguo que se encuentra en estado de ruina.

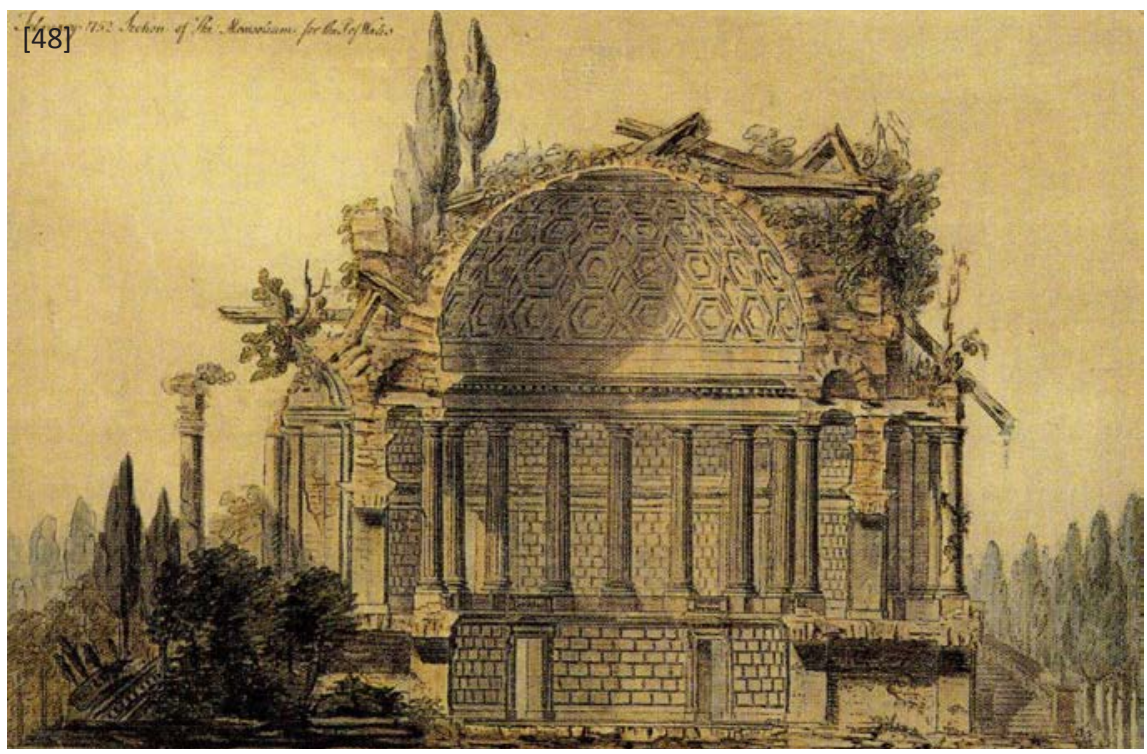

También Giovanni Battista Piranesi a través de sus grabados introduce una nueva interpretación de las ruinas clásicas. En las láminas de las Carceri, Piranesi representa lugares inventados compuestos por sucesiones de espacios fragmentados, que tomando como referencia elementos del pasado constituyen su propia configuración. Para Antonio Pizza, estos grabados muestran "la crisis lingüística del orden clásico", pero sobre todo, expresan el nacimiento de un nuevo "sistema de pensamiento, ratificador de las nuevas realidades existenciales". Un nuevo pensamiento basado en el reconocimiento del valor de la suma de partes imperfectas..$^{52}$ Con ello Piranesi representa una nueva mirada sobre la arquitectura y sobre el pasado que aporta nuevas cuotas de libertad de acción. Piranesi en sus grabados está creando un nuevo mundo a partir de las ruinas, entendidas como un material clave en la nueva composición. Este es el caso del grabado del Campo de Marte en Roma realizado por Piranesi en 1762. (ej.24) 
Ejemplo 24. Campo de Marte en Roma. Piranesi. 1762

Piranesi superpone plantas de diversos edificios conformando una hipotética reconstrucción de la ciudad. Se trata de una ficción que busca reflexionar sobre la superposición de la historia a lo largo del tiempo, configurando un conjunto de fragmentos que conviven a pesar de sus orígenes dispares.

Para José Morales, con su gravado Piranesi expresa el cambio que se produce desde el objeto unitario en el que el todo explica las partes, a una suma de elementos en la que caben las contradicciones, no hay una ley que lo explica todo sino un conjunto de relaciones yuxtapuestas, una recomposición de vestigios de diversas épocas, en la que se entiende el todo por la parte. ${ }^{53}$

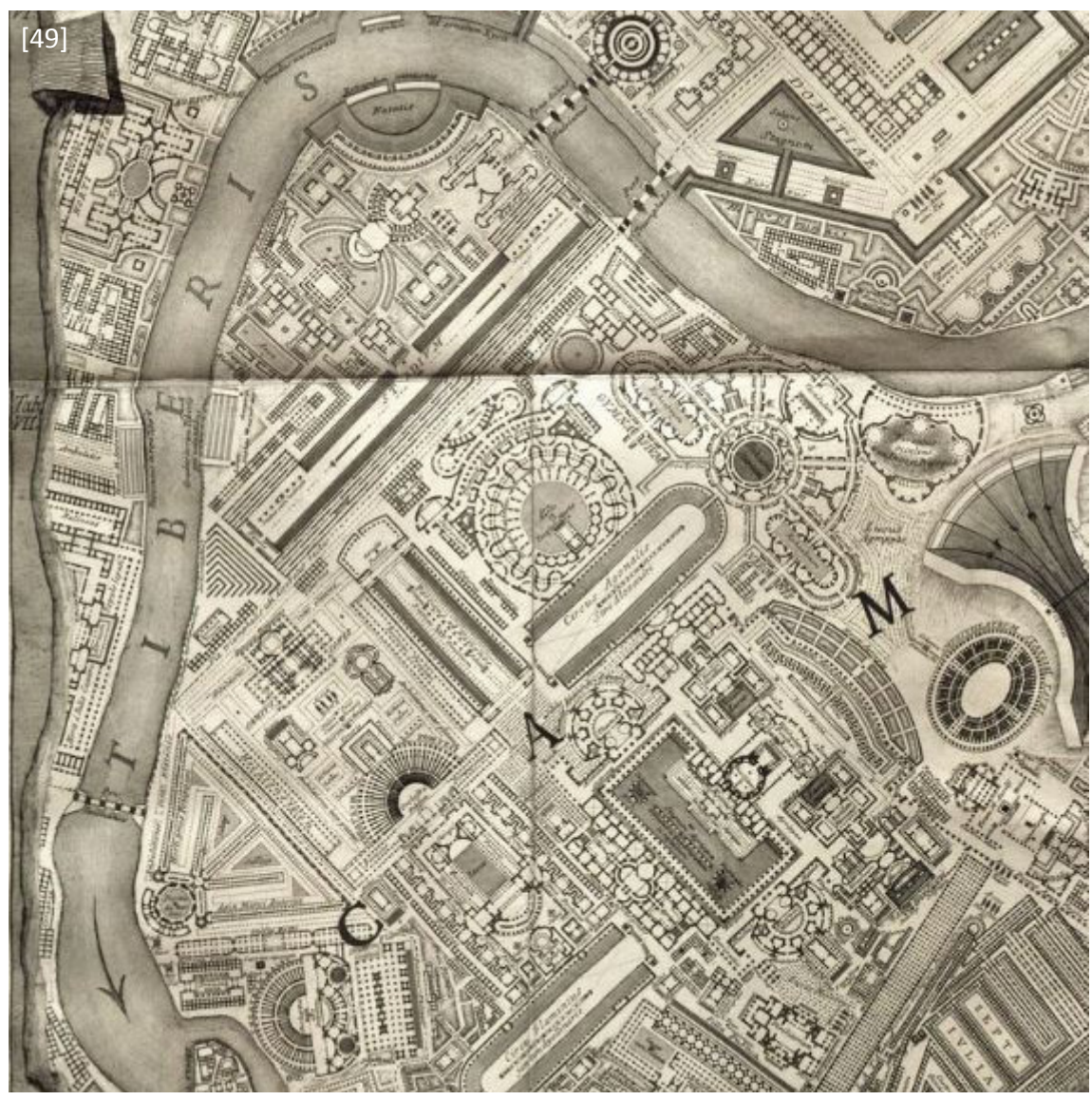

\section{Siglo XIX}

En el siglo XIX se observa que las posiciones que prevalecen son esencialmente tres: la postura de los que buscan completar la obra en el estilo original, al entender la ruina como un testimonio histórico mutilado y reconocible; la postura de los que apuestan por conservar la ruina al entenderla como una nueva obra, mezcla de arte y naturaleza, de gran belleza y fascinante melancolía; y la postura relacionada con la restauración moderna que buscará el respeto del pasado, evitando imitaciones que desacrediten su autenticidad. ${ }^{54}$
53 MORALES, J.: "La Construcción del Olvido. Memoria, Historia, Proyecto". En: A.A.V.V.: Cuadernos IV. Arquitectura y Patrimonio. Junta de Andalucía. 1994. p. 48

54 SETTE, M.P.: Op. cit., 2001, p. 36
[49] Campo di Marzio. Piranesi. (Lainformacion.com: <especiales. lainformacion.com>) 
55 JOKILEHTO, J.: Op. cit., 1986/2005, pp. $140-141$

56 QUATREMÈRE DE QUINCY, M.: Dictionnaire historique de l'architecture. Tomo segundo. Término Restaurer. Paris, 1832, p.375-376 (Consultado en formato digital en la web del INHA)
[50] Coliseo. Vista de la actuación dirigida por Rafaelle Stern en 1806. (Imagen del autor)

[51] Coliseo. Alzado y sección de la actuación dirigida por Stern. (JOKILEHTO: 2005, p.128)
Estas tres posturas se pueden ver representadas en cierta medida en las actuaciones llevadas a cabo en el Coliseo (ej.25) y en el Arco de Tito de Roma (ej.26), en el primer cuarto del siglo XIX. En primer lugar está la postura de la pura conservación del material original, presente en el potente refuerzo realizado en 1806 en el Coliseo; en segundo lugar la reconstrucción en estilo propuesta en 1923 por Valadier en el mismo edificio, "imitando cuidadosamente lo antiguo"; y entre ambas posturas la actuación en el Arco de Tito que propone la conservación de las partes preexistentes y la reconstrucción de los elementos faltantes con materiales distintos y formas simplificadas, en una consciente distinción entre nueva actuación y resto antiguo. ${ }^{55}$

Posteriormente Quatremère de Quincy recogerá en su diccionario histórico de la arquitectura (1832) la actuación en el Arco de Tito como actuación ejemplar, en la que se ha eliminado "de forma muy afortunada" aquello que distorsionaba y "se han restaurado muy sabiamente sus partes mutiladas". Indicando dos caminos de actuación posibles: en primer lugar la actuación sobre "fragmentos" que deberá medirse en función de su mayor o menor interés y el grado de ruina del monumento, siendo a menudo suficiente "su apuntalamiento para asegurarle su existencia durante muchos siglos más"; y en segundo lugar, a semejanza de la actuación en el Arco de Tito, indica que en edificios con columnas y entablamentos "deberá bastar con restituir en bloque las partes faltantes, será necesario olvidar los detalles en la masa de manera que el observador pueda distinguir claramente la obra antigua de aquello que se ha restituido sólo para completar el conjunto". ${ }^{56}$

Ejemplo 25. Coliseo. 1806: Palazzi, Camporesi y Stern. 1823: Valadier

La actuación en el Coliseo, dirigida por Rafaelle Stern en 1806, consistió en la construcción de un potente contrafuerte de ladrillo para evitar el derrumbe de unas arcadas del edificio que presentaban "un desplome de al menos tres palmos". Stern ejecutó el refuerzo sin recolocar los sillares desplazados, produciendo la congelación de la imagen de la ruina, una imagen romántica cargada de emotividad y de un gran poder evocador, que permanece como testimonio de la historia.
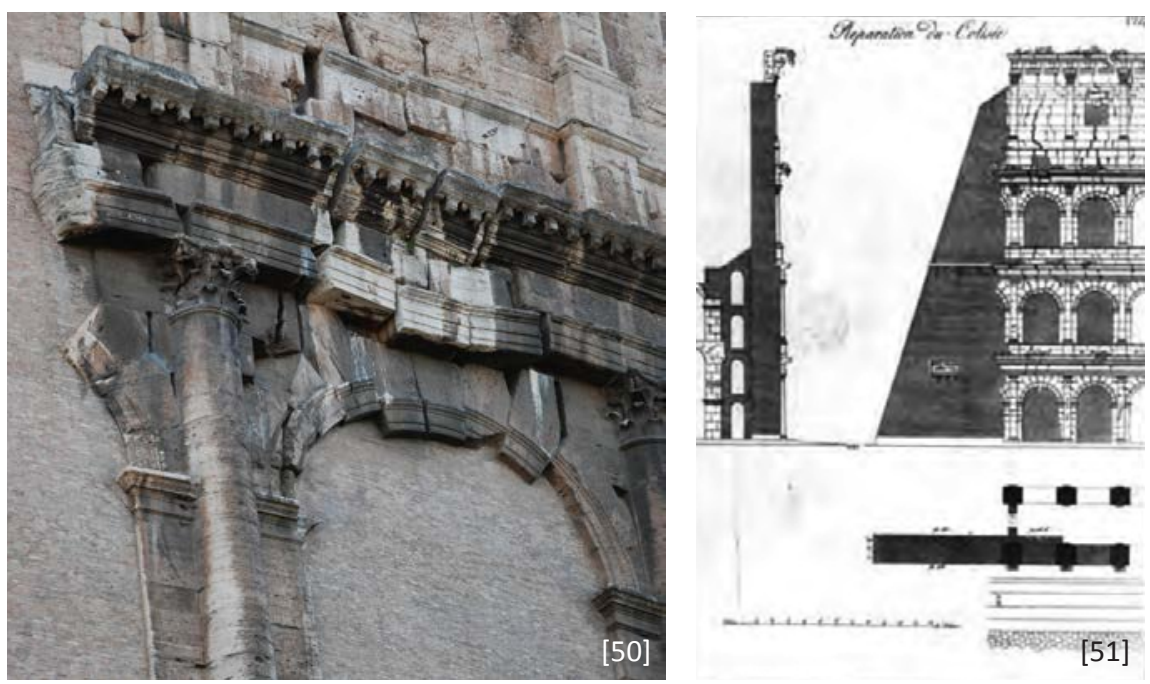
Posteriormente Valadier, entre 1923 y 1926 reconstruirá algunas de las arcadas faltantes reproduciendo hasta el mínimo detalle la forma de los originales, pero sustituyendo parte del mármol por ladrillo por razones económicas. Finalmente la fábrica de ladrillo quedó vista, potenciando la distinción con el original, pero como indica el propio Valadier estaba previsto que se recubriera "con una pátina al fresco para que se viera como si fuera travertino". Valadier llego a proponer esta solución para reconstruir la totalidad del monumento.

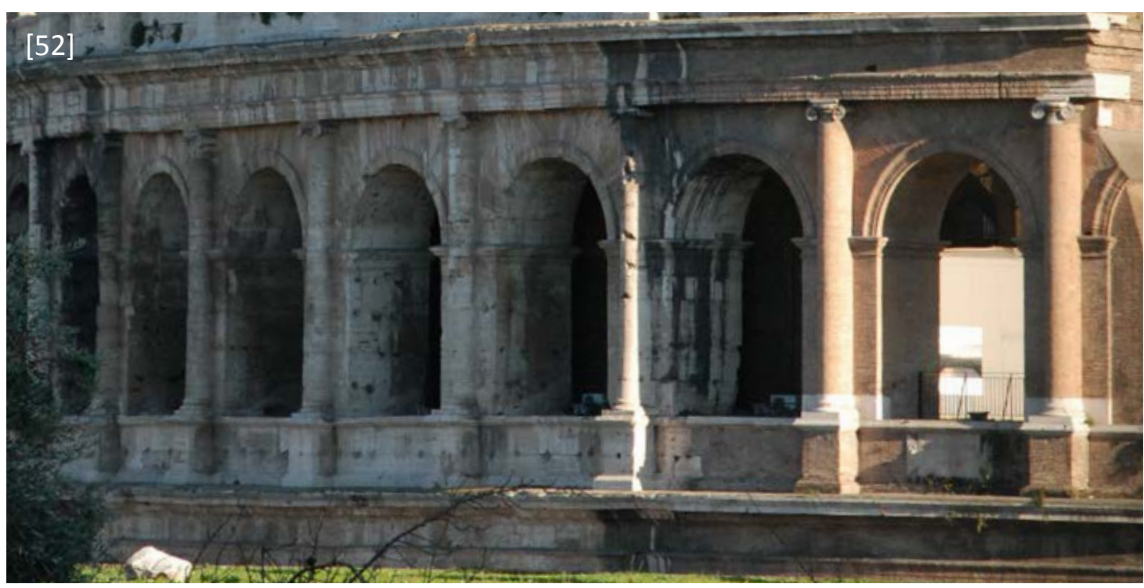

\section{Ejemplo 26. Arco de Tito. 1817-23. Stern, Valadier y Camporesi}

La actuación en el Arco de Tito, dirigida por Stern consistía en la reconstrucción de las partes faltantes mediante un cambio de material y una simplificación formal, de tal manera que resultara más económico y permitiera diferenciar la nueva actuación. A la muerte de Stern, en 1920, Giuseppe Valadier continúa los trabajos ocupándose "con toda la debida diligencia a la cuestión principal, que era eliminar el defecto que se encontraba en el monumento, para después restituir todo a su lugar"57, recolocando con ello los sillares preexistentes desplazados y perdiendo con ello la imagen de ruina que Stern había mantenido en la intervención del Coliseo.

Con esta actuación se logra de una manera armónica con el resto original, recuperar la unidad desaparecida del elemento a la vez que hacer distinguible las partes nuevas de las antiguas. Es remarcable la justificación de la solución planteada que realiza Valadier en la memoria de la intervención, acompañada con una representación detallada del monumento antes y después de la intervención, documentación presentada en defensa a las críticas surgidas tras la finalización de las obras.
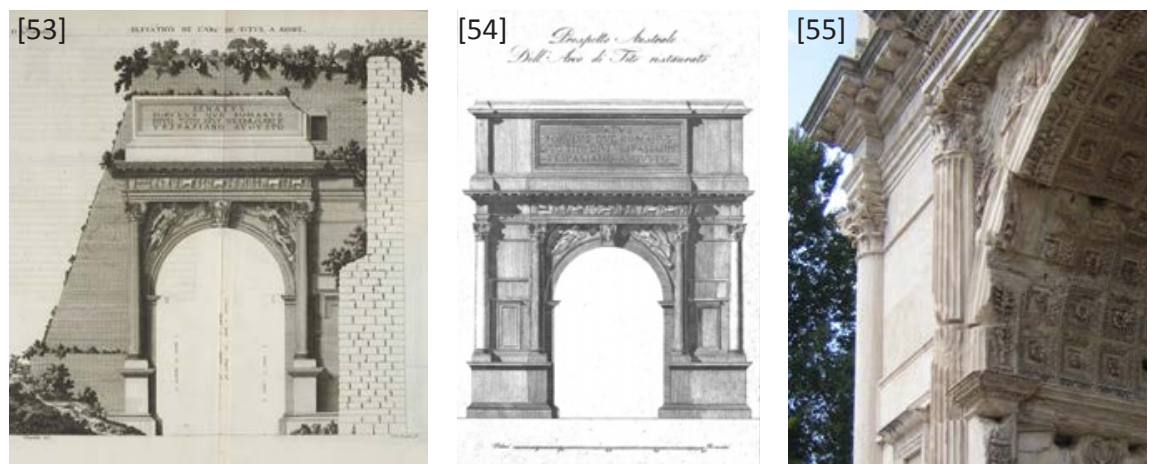

57 VALADIER, G.: Narrazione artistica dell'operato finora nel Restauro dell'arco di Tito, 1822, p.8

[52] Coliseo. Vista de la actuación de Valadier, 1923-1926. (Imagen del autor)

[53] Arco de Tito. Alzado antes de la restauración. (DESGODETS: 1682, p. 189)

[54] Arco de Tito. Alzado después de la restauración. (VALADIER: 1822, tav. III)

[55] Arco de Tito. Vista tras los trabajos de Giuseppe Valadier. (Imagen del autor.) 
59 SETTE, M.P.: Op. cit., 2001, p. 44
[56] San Pablo Extramuros. Detalle de la unión entre la preexistencia y la nueva reconstrucción. (Imagen del autor.)

[57] San Pablo Extramuros. Vista interior actual. (Imagen del autor.)

[58] San Pablo Extramuros. Vista interior antes del incendio de 1823. Piranesi, 1749. (Biblioteca Digital Dioscórides. Universidad Complutense de Madrid: <dioscorides. ucm.es>)

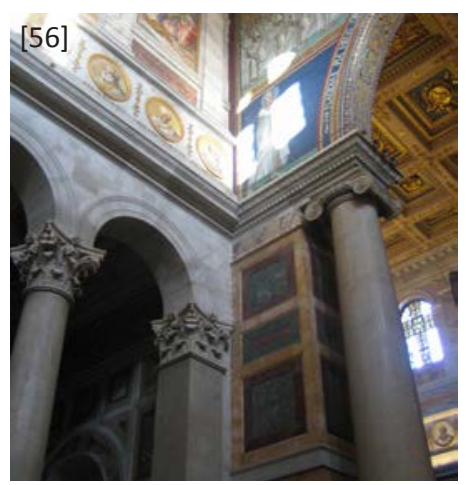

\subsection{La restauración en estilo}

La restauración en estilo supone actuar sobre cada monumento "según el estilo que le es debido", evitando las intervenciones que buscan completar los monumentos según la "manera del tiempo". Pero bajo el amparo de la unidad de estilo surgirán diferentes vías de intervención, según la fidelidad de las nuevas actuaciones al edificio original, variando desde actuaciones encaminadas a la recuperación del estado inicial del edificio hasta actuaciones más innovadoras que completarán, modificarán o añadirán nuevos elementos a los monumentos pero siempre dentro de la unidad estilística.

En Italia, la reconstrucción de la Basílica de San Pablo extramuros de Roma puede ser considerada como el primer ejemplo de restauración reglada dirigida a la reintegración del estado originario del monumento (ej.27). EI Papa León XII establece en 1825 que no se deberá introducir, en su reconstrucción, ninguna innovación a no ser que tenga como finalidad excluir elementos posteriores a su fundación original. Se concibe el monumento como una unidad completa y perfecta, significativa de un determinado lugar y tiempo, inmutable y no contaminable con añadidos de otros repertorios formales, que se debe restituir a su unidad estilística original. ${ }^{58}$

Por otro lado se producen concursos para realizar las fachadas incompletas de numerosas iglesias entre las que destacan Santa Croce (ej.28) y Santa Maria del Fiore en Florencia. Las actuaciones siguen el estilo del edificio original, buscando equilibrio y discreción, y las modestas circunstancias económicas suelen llevar a emplear materiales más humildes que los originales y a simplificar sensiblemente la forma.

\section{Ejemplo 27. San Pablo Extramuros}

La reconstrucción de la basílica supone un momento de polémica entre eruditos y arquitectos. El abad Carlo Fea defiende la postura papal y de los eruditos, de repristinar la Basílica. El abad indica que debe excluirse toda innovación, así como sustituir integralmente aquellos elementos deteriorados. Defiende la sustitución de las preciadas 24 columnas de mármol frigio que definían la nave central por otras nuevas de mármol de carrara en lugar de reutilizar los restos originales como revestimiento de nuevas columnas con alma de travertino. ${ }^{59}$
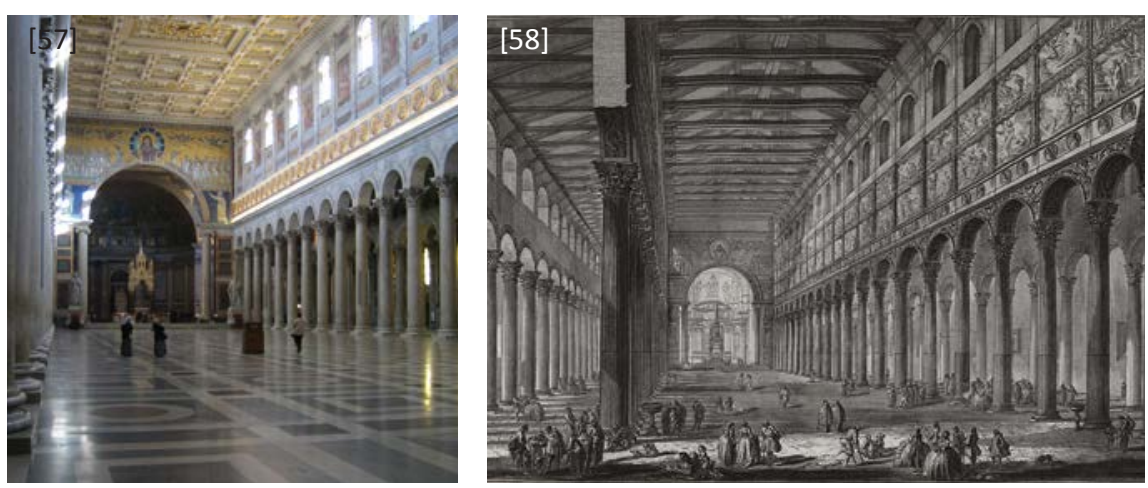
Se observa por tanto no tanto una búsqueda de autenticidad material, sino de recuperación de la perfección arquitectónica original. Por otro lado cabe mencionar la propuesta de Valadier, quien dada la dimensión de la pérdida propone la construcción de un nuevo templo neoclásico antes que una falsa reconstrucción. ${ }^{60}$

\section{Ejemplo 28. Fachada de la iglesia de Santa Croce. 1847-54}

La iglesia comenzada en 1294 bajo proyecto de Arnolfo di Cambio, es consagrada en 1443 sin terminarse su fachada. En 1847 el arquitecto Niccolò Matas y el escultor Lorenzo Bartolini proyectan varias soluciones alternativas basándose en las principales obras de la arquitectura medieval toscana. La solución definitiva muestra cierto carácter abstracto obtenido mediante la reducción de elementos escultóricos y el empleo de motivos geométricos enfatizados con la policromía de los mármoles.
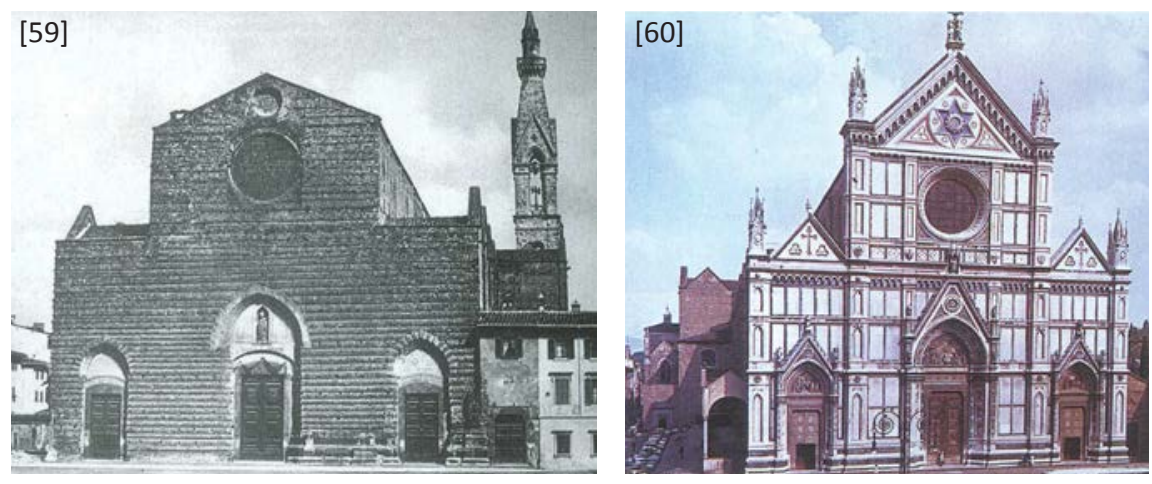

En Francia, dentro de un entorno de exaltación de la arquitectura gótica como estilo nacional, se crea en 1830 la figura del inspector general de monumentos históricos franceses. Su primer encargado, Louis Vitet, expresará que "el principal mérito de una restauración es pasar desapercibido" siendo necesario "olvidar el tiempo en el que se vive para hacerse contemporáneo de todo aquello que se restaura", y exigirá actuar a través de un proceso inductivo riguroso a partir de los fragmentos preexistentes. ${ }^{61}$ Su sucesor en el cargo, Prosper Mérimée, introduce el "criterio analógico" en la reconstrucción de elementos desaparecidos, consistente en copiar los motivos de monumentos de la misma época y provincia. ${ }^{62}$

Viollet-le-Duc, figura fundamental en la intervención en el patrimonio del siglo XIX, defiende que en la restauración sólo valen operaciones orientadas a restituir científicamente una interpretación contemporánea del objeto de la intervención, afirmando que "restaurar un edificio no es conservarlo, repararlo o rehacerlo, es restablecerlo a un estado completo que puede no haber existido nunca en un determinado momento". ${ }^{63}$ Para ello introduce la necesidad de entender el propio discurso del edificio a
60 MORA ALONSO-MUÑOYERRO, S.: La Restauración Arquitectónica en España. Criterios y Teorías (1840-1936). Madrid, Kaher II, 2002

61 LEÓN, P.: La vie des monuments français. Destruction-Restauration. Paris, Picard, 1951, p.192. Extraído de SETTE, óp. cit. (2001), p. 48

62 SETTE, M.P.: Op. cit., 2001, p. 48

63 VIOLLET-LE-DUC, E.: "Restauration". En: Dictionnaire raisonné de l'architecture française du Xle au XVle siecle. Tomo octavo. The Project Gutenberg Ebook, 2009 (1854-68)
[59] S. Croce. La fachada incompleta en una fotografía anterior a la restauración. (CARBONARA: 1997)

[60] S. Croce. Fachada actual tras la restauración de Niccolò Matas. (CARBONARA:1997) 
64 de SOLÀ-MORALES, I.: Op. cit. 1982, pp. 33-34

65 SETTE, M.P.: Op. cit., 2001, pp. 5456

66 BOSCH REIG, I.: "Intervención en el patrimonio: un continuo proceso de innovación". En: A.A.V.V.: Las herramientas del arquitecto 2. Valencia, Ed. Ediciones Generales de la Construcción, 2004

67 GALLEGO FERNÁNDEZ, P.L.: "Viollet le Duc: La Restauración Arquitectónica y el Racionalismo Arqueológico Fin de Siglo". En: FERNÁNDEZ MUÑOZ, A.L.: Restauración Arquitectónica. Valladolid: Universidad de Valladolid, 1992, pp. 3539 intervenir de tal manera que la nueva actuación sea una continuidad de su propia lógica, ya que entiende que la coherencia del estilo gótico permite deducir las partes desaparecidas a partir de las partes restantes. ${ }^{64}$ Viollet no dudará en desmontar las partes "impuras", que no responden a lo que él entiende por la "perfección" del gótico, y volver a construirlas según la razón del estilo.

Para Maria Piera Sette, Viollet-le-Duc parece anticipar en sus teorías los conceptos de restauración que serán codificados posteriormente por Camillo Boito. Desde sus primeros escritos, más allá de defender el principio fundamental de la unidad estilística y aceptar la compleción de monumentos por analogía, hablará del conocimiento de la obra como presupuesto esencial de toda intervención así como de conceptos como la distinción de las partes, el respeto de las trazas, el empleo con rigor de los mejores y más apropiados materiales, la asignación de un uso adecuado al monumento, la necesidad de soluciones diversas caso por caso, y la existencia de una jerarquía de valores que determinan las prioridades en la restauración. Sin embargo a lo largo de sus obras hará una interpretación bastante libre de estos criterios, pudiendo observarse una evolución desde actitudes más "científicas", como en la Madeleine de Vézelay (ej.29) o Notre-Dame de Paris (ej.30), a otras más creativas como en el Castillo de Pierrefonds y la Fortificación de Carcassonne (ej 31), en las que llevará a cabo amplias modificaciones, interpretaciones y reelaboraciones personales. ${ }^{65}$

Para Ignacio Bosch, Viollet-le-Duc no busca tanto responder a cuestiones de fidelidad histórica como a cuestiones de coherencia interna con el propio proyecto arquitectónico, lo que necesariamente supondrá una transformación de lo anterior. Con ello Viollet retoma el espíritu de "la libertad de acción del artista" defendida por Piranesi, y la aplica a la intervención sobre los bienes heredados planteando una actitud "moderna" que defiende la permanencia del pasado mediante la transformación del presente para conformar una nueva identidad. ${ }^{66}$

Pedro Luis Gallego Fernández hace hincapié en que Viollet concibe una historia de la construcción gótica muy bien razonada pero cargada de falsedades. Viollet, en oposición al clasicismo académico de la época, rechaza el origen romano del gótico y busca asentarlo en las raíces bizantinas y orientales. A raíz de esto su discípulo Paul Abadie restaura, a partir de 1852, la Catedral de Saint Font de Périgueux reconstruyendo las cúpulas para ajustarlas a lo que Viollet había definido en su diccionario como lógico y racional en la arquitectura, convirtiendo "la iglesia más representativa de la región de Aquitania en el modelo más perfecto de iglesia bizantina". ${ }^{67}$

Para Antón Capitel la restauración en estilo supuso intervenciones en las que el arquitecto mezcló por un lado la interpretación del monumento y por otro lado la creación de nuevas aportaciones, ya que la reconstrucción de la forma prístina no era posible realmente. Por muy rigurosos que fueran 
los arquitectos, los criterios dependían de su propia sensibilidad, por lo que las actuaciones eran en gran parte sus propios ejercicios de revival, "tendiendo a identificar lo bueno y bello con lo coherente y verdadero". ${ }^{68}$

La aplicación de las teorías de Viollet por parte de sus discípulos, sin estudiar el monumento y su historia, y sin respetar las preexistencias, sino atendiendo exclusivamente a sus teorías de recuperación de la forma prístina, supuso la pérdida de valores históricos de los edificios sobre los que se intervino.

\section{Ejemplo 29. Iglesia de la Madeleine de Vézelay, 1840-59}

Viollet busca restituir al complejo su propia coherencia a través del respeto de las estratificaciones históricas y de los valores arqueológico-documentales. ${ }^{69}$
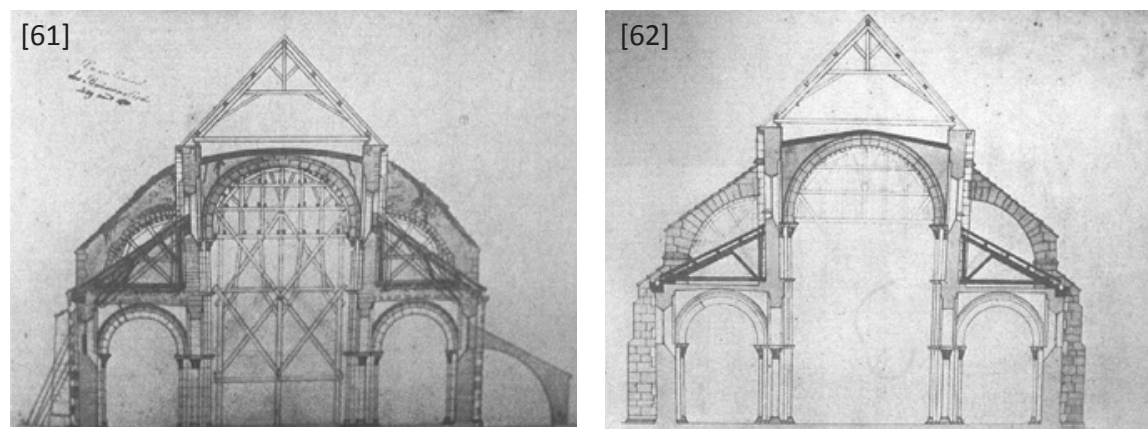

\section{Ejemplo 30. Notre-Dame de Paris. Encargada a Viollet y Lassus en 1844}

Viollet realiza un gran número de modificaciones para devolver al edificio su esplendor original, entre las que constan la inserción del rosetón y la aguja del crucero, pero renuncia a completar las dos torres de fachada, aunque realiza estudios de su composición.
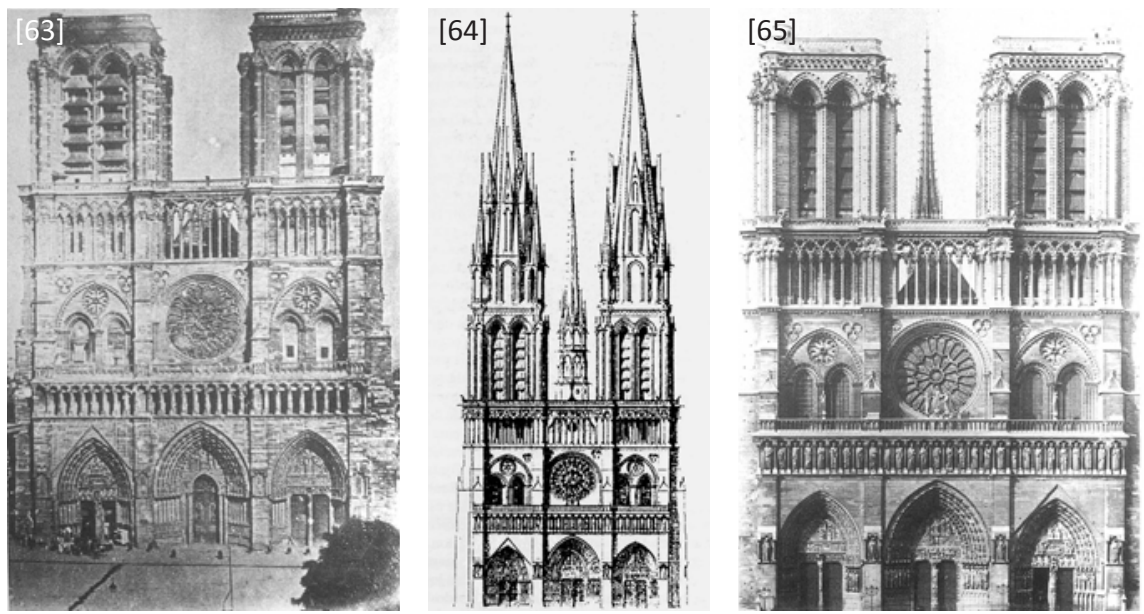
restauración. Madrid, Alianza Forma, 1988, 2009

69 SETTE, M.P.: Op. cit., 2001, p. 52

[61] Iglesia de la Madeleine de Vézelay. La sección antes de la restauración. (CARBONARA: 1997)

[62] Iglesia de la Madeleine de Vézelay. La sección después de la restauración.(CARBONARA:1997)

[63] Notre-Dame de París. La fachada antes de la restauración. (CARBONARA: 1997)

[64] Notre-Dame de París. Estado ideal según Viollet. (FERNÁNDEZ. En: V.V.A.A.: 1997, p. 64)

[65] Notre-Dame de París. La fachada después de la restauración. (CARBONARA:1997) 
70 FERNÁNDEZ, R. "2. Notas para una introducción a la teoría y práctica restauradora". En: A.A.V.V. : Teoría e Historia de la Restauración. Madrid, MRRP, 1997, pp. 46-99

71 RIVERA BLANCO, J.: "Teoría e Historia de la Intervención en Monumentos Españoles hasta el Romanticismo" (1989). En: De varia restauratione. Teoría e historia de la restauración arquitectónica. Madrid: Abada editores, 2008, pp. 110-115

72 MORA ALONSO-MUÑOYERRO, S.: La Restauración Arquitectónica en España. Criterios y Teorías (1840-1936). Madrid, Kaher II, 2002
[66] Castillo de Pierrefonds. Vista antes de la restauración. (PEVSNER: 1969 ,p. 39)

[67] Castillo de Pierrefonds. Vista después de la restauración. (PEVSNER: 1969 ,p. 39)
Ejemplo 31. Castillo de Pierrefonds y Fortificación de Carcassonne

Viollet plantea la necesidad de llevar al monumento a un estado ideal. Inicialmente plantea un trabajo científico hasta que se le encarga su adaptación a nuevas necesidades funcionales, momento en el cual introduce modificaciones sobre el edificio que tratan de enfatizar su monumentalidad, siempre desde la recreación medieval. ${ }^{70}$
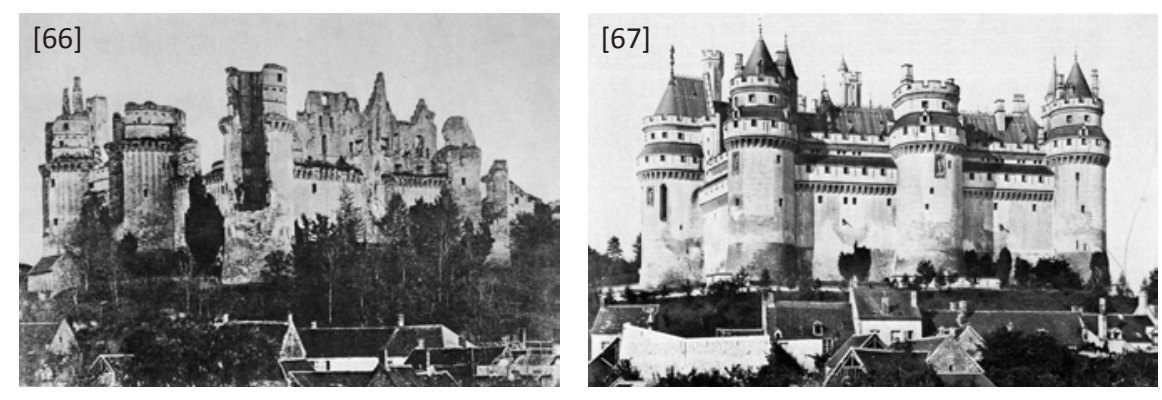

En España la Guerra de la Independencia y las sucesivas Desamortizaciones de la primera mitad del siglo XIX producen una gran perdida en numerosos monumentos que obliga a publicar en 1850 una Real Orden prohibiendo las alteraciones y destrucciones en monumentos y abogando por restaurar respetando el estilo primitivo. ${ }^{71}$ Con ello se vuelve la mirada hacia la arquitectura medieval desde la obsesión por la unidad de estilo en la búsqueda de la imagen del monumento "como debía haber sido". Se apuesta por soluciones más o menos creativas que aseguren la belleza del conjunto, sin distinguir lo nuevo de lo viejo, y siempre bajo la atenta mirada de la Academia de Bellas Artes de San Fernando. Este es el caso de las actuaciones en la Catedral de León (ej.32), en la Catedral de Sevilla (ej.33) y en la Catedral de Barcelona (ej.34), entre otros.

Cabe mencionar, sin embargo, una actitud distinta en el caso de actuaciones sobre monumentos de estilos distintos al medieval. Así por ejemplo en la Alhambra de Granada, Rafael Contreras propone eliminar la labor corrosiva del tiempo reproduciendo las yeserías faltantes, pero las pinta con colores vivos que evidencian la nueva actuación. Sin embargo los académicos se lamentan de que las intervenciones de reconstrucción hacían desaparecer su "carácter de antigüedad, lo cual constituía su verdadero mérito".

\section{Ejemplo 32. Restauración de la Catedral de León}

En 1859 Matías Laviña propone desmontar y volver a construir con esmero, machones, arcos, bóvedas, aprovechando el mayor número de piezas que sea posible y reponiendo las que resulten inutilizadas, siempre con los mismos "perfiles, plantillas y carácter". Defiende el empleo de los nuevos materiales, pero siempre de manera que permanezcan ocultos a la vista. ${ }^{72}$ 
En 1879 Juan de Madrazo actúa en la fachada sur tratando de que la catedral vuelva a su primitivo estado "mediante obras en exacta armonía con el carácter y el estilo del edificio, y sin incongruencias ni anacronismos que nos deshonren". Madrazo busca componer "inspirándose en el pensamiento filosófico que encierra" el monumento, tal y como afirma Fernández Casanova. ${ }^{73}$ Comenta Susana Mora que Madrazo fue uno de los pocos arquitectos españoles dedicados a los trabajos de restauración que captó profundamente las intenciones de Viollet. Intenciones que más allá de la unidad de estilo buscan, en palabras de Hautecoeur, "Ia producción de un aparato conceptual capaz de explicar toda la gramática estilística gótica a partir de reconocimientos constructivos".74

En 1887 Demetrio de los Ríos plantea para la fachada oeste dos opciones: por un lado su remontaje en estilo plateresco, y por otro lado una fachada nueva en estilo gótico en consonancia con la fachada sur. La Academia se mostrará partidaria de esta segunda opción.
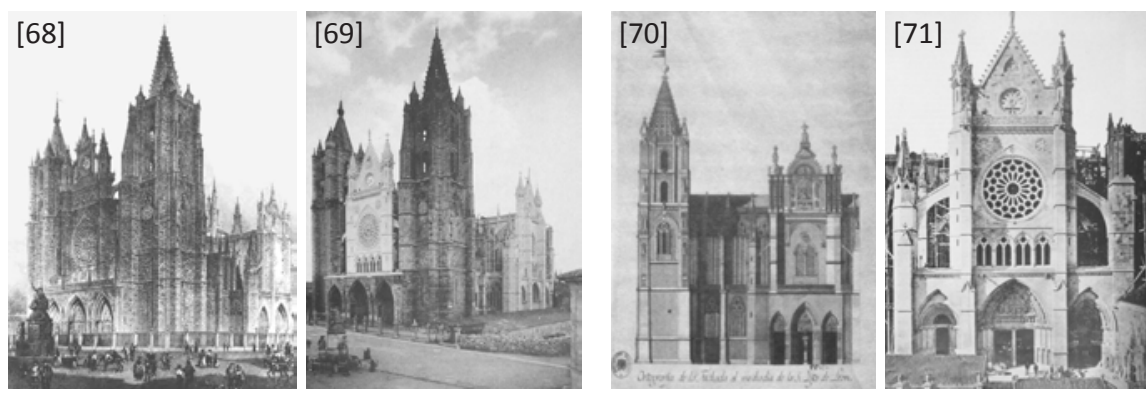

\section{Ejemplo 33. Catedral de Sevilla}

En 1866 Demetrio de los Ríos propone la construcción de las portadas de la nave del crucero de la Catedral de Sevilla, a través de criterios analógicos, basándose en la puerta de los Leones de la Catedral de Toledo, pero la obra no llega a ejecutarse.

Posteriormente Adolfo Fernández Casanova propone aplicar a las portadas principales el principio compositivo adoptado en el resto de portadas del edificio, así como la reconstrucción del cimborrio del crucero hundido en 1888. Pero abogará por limitar las demoliciones a lo imprescindible para conservar su autenticidad, mostrando ya un incipiente interés por respetar la materia original del monumento.
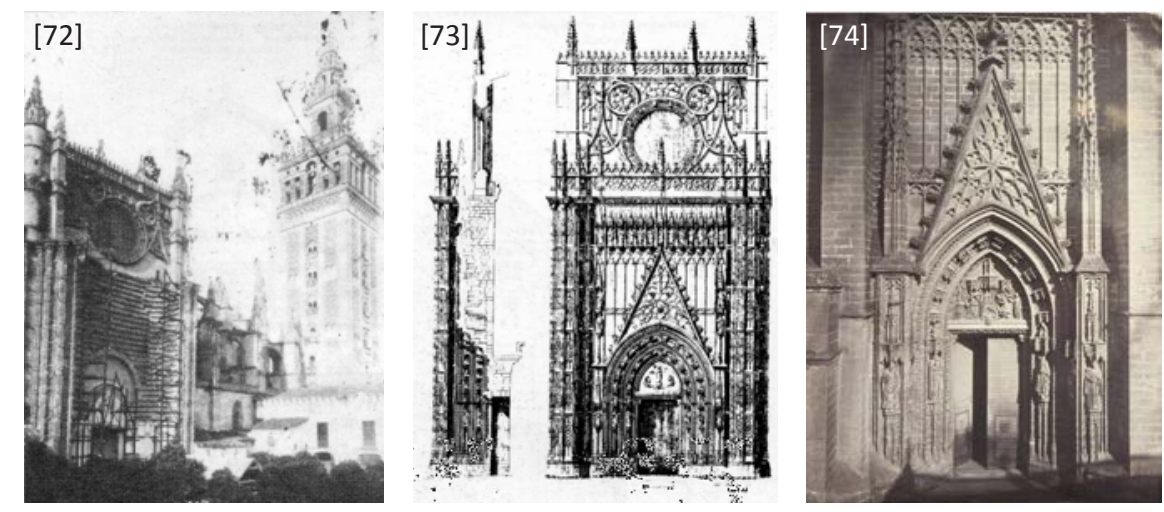

73 MORA ALONSO-MUÑOYERRO, S.: Op. cit., 2002, p.33

74 MORA ALONSO-MUÑOYERRO, S.: Op. cit., 2002, p.74

[68 y 69] Catedral de León. Fachada Oeste antes y después de la restauración. (MORA: Basa, no 13, 1990, p. 12)

[70 y 71] Catedral de León. Fachada Sur antes y después de la restauración. (MORA: Basa, no 13, 1990, p. 9)

[72] Catedral de Sevilla. Estado alrededor de 1800. (MORA: 2002, p. 72)

[73] Catedral de Sevilla. Proyecto de restauración de A. Fernández Casanova. Portada hastial norte. (MORA: 2002, p. 72)

[74] Catedral de Sevilla. Modelo del proyecto de portada para el hastial sur del crucero. (Museo Nacionaldel Prado: <www.museodelprado. es>) 
75 JOKILEHTO, J.: Op. cit., 1986/2005, pp. $123-132$

76 JOKILEHTO, J.: Op. cit., 1986/2005, p. 131

[75] Catedral de Barcelona. Estado de la fachada antes del inicio de las obras. (C.O.A.M.: 1987, p. 30)

[76] Catedral de Barcelona. Primera fase de las obras de restauración. (C.O.A.M.: 1987, p. 30)

[77] Catedral de Barcelona. Estado de la fachada una vez terminada su restauración. (C.O.A.M.: 1987, p. 31)

[78] Templo Vespasiano. Valadier. (VALADIER: 1810, capitulo V, tav. III)

\section{Ejemplo 34. Catedral de Barcelona}

El edificio permanecía inacabado desde 1448, quedando por terminar la fachada, y el coronamiento general de la iglesia y claustro. En 1887, José Oriol Mestres termina la fachada en estilo gótico. Posteriormente Mestres y Augusto Font construyen el cimborrio basándose en las leyes compositivas del claustro.
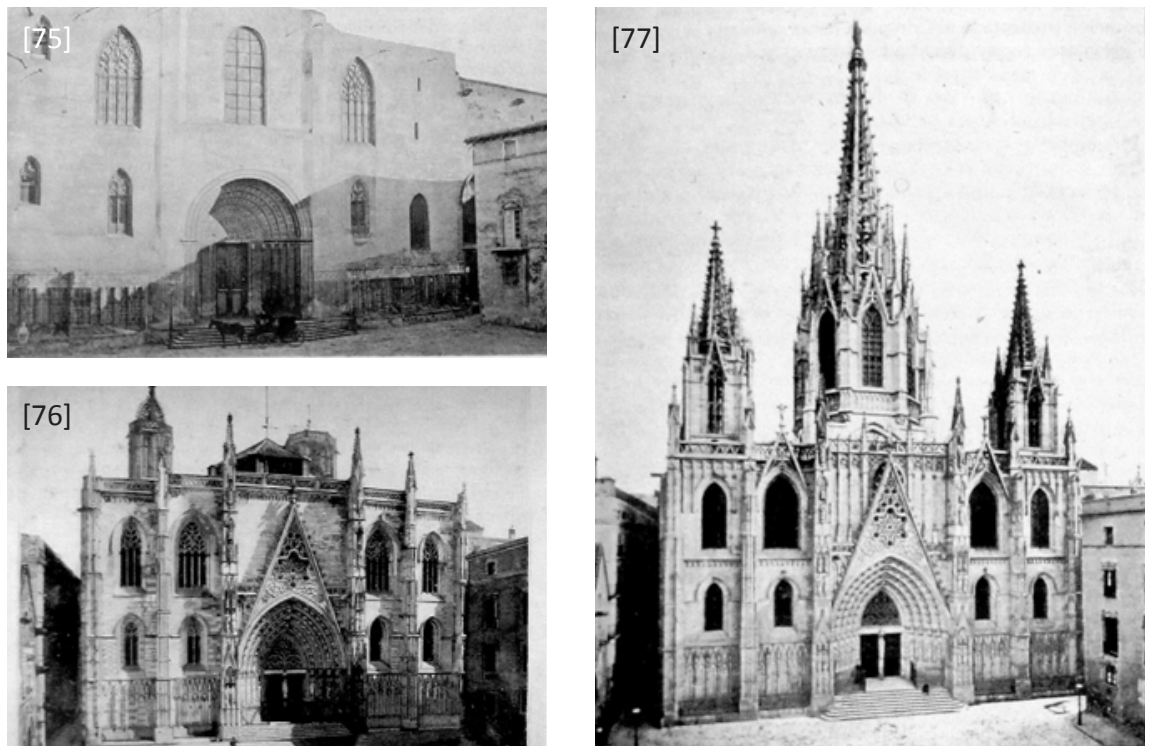

\subsection{La restauración conservativa}

Durante los primeros años del siglo XIX crece en Roma la conciencia por el valor patrimonial debido al desarrollo de nuevas teorías y conceptos artísticos, así como por la pérdida reciente de obras de arte, lo que llevará a su catalogación para frenar el expolio. En 1802 se nombra como inspector de Bellas Artes al gran escultor Antonio Canova, de claras tendencias conservadoras, que opinaba que sería un sacrilegio restituir los faltantes de los grandes grupos escultóricos como el del Partenón. Bajo su control se llevarán a cabo obras como el potente refuerzo de Stern en el Coliseo, así como la restauración del Templo de Vesta y de las tres columnas restantes del Templo de Vespasiano, todas con un claro carácter conservativo (ej.35)..$^{75}$

\section{Ejemplo 35. Templo de Vespasiano. Camporesi. 1810}

En 1810 se decide excavar y consolidar las tres columnas restantes del templo de Vespasiano, llamado el templo de Jupiter Tonante, ubicado en el Foro Romano. Dado el mal estado de la base de apoyo, se decide desmontar las columnas, construir un nuevo basamento diseñado por Camporesi en travertino, diferente del mármol original, y recolocar las partes uniéndolas con grapas de hierro. ${ }^{76}$ 

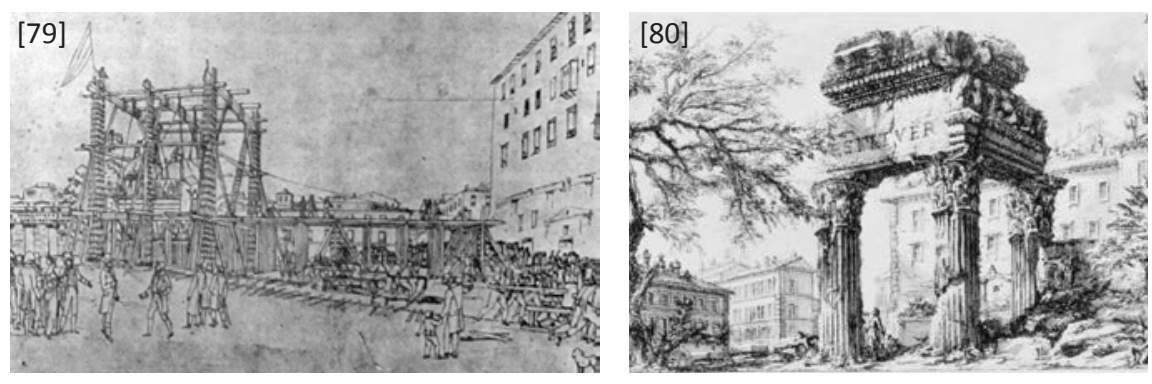

En los años 40 se produce en Inglaterra un debate sobre los principios de conservación y restauración de las iglesias medievales, creándose dos bandos: el de los restauradores y el de los antirrestauradores. Los primeros apostaban por la reconstrucción en estilo de la arquitectura original para recuperar sus valores funcionales y prácticos, mientras que los segundos se muestran a favor de la exclusiva protección y conservación de la materia original. Éstos defendían el valor histórico de los monumentos y entendían que no era posible recrearlos con su mismo significado en un tiempo distinto. ${ }^{77}$ Ya en los años 70 se subrayará la importancia del monumento como documento histórico, instando a respetarse todas las épocas. También cabe destacar que el desarrollo de los nuevos materiales permitirá reforzar las fábricas reduciendo la necesidad de desmontarlas y reconstruirlas, así como limitando la apariencia "antiestética" de los refuerzos.

Entre los antirrestauradores destaca la figura de John Ruskin, quien niega cualquier acción positiva en la actuación en un monumento, afirmando que no se debe hacer nada ni para completarlo ni para mejorarlo, solo mantenerlo como está. ${ }^{78}$ Para Ruskin, restaurar una obra que nos ha sido consignada por el tiempo significa hacer una copia destruyendo así, de modo definitivo e irreparable, el edificio que se restaura. Como alternativa propone la protección de la obra, la sustentación de aquellas zonas murarias abiertas o inestables con elementos de hierro o puntales de madera, justificando su aspecto como necesarias para evitar la pérdida de parte de la obra. ${ }^{79}$ Para Ruskin se trata de una cuestión moral, y prefiere la degradación natural del monumento o su sustitución por una nueva obra, antes que someterlo a una restauración falsa que lo prive de la memoria: "Miradfrente a frente a la necesidad, yaceptadla, destruid el edificio, arrojad las piedras a los rincones más apartados, y rehacedlo de mortero a vuestro gusto, más hacedlo honradamente, no lo reemplacéis por una mentira" ${ }^{80}$

Por otro lado Ruskin le otorga un valor especial al paisaje, entendiendo que la arquitectura deberá estar en comunión con la naturaleza, y defiende que la estrecha imitación de las formas naturales es la vía más justa para alcanzar la belleza. En esta línea es interesante mencionar la propuesta de la "La Tumba de Hutten" realizada por Caspar D. Friedrich en 1823, en la que toma la ruina de un ábside de una iglesia gótica transformando su espacio abierto en un "íntimo interior", mediante la disposición de un árbol que reconstruye las bóvedas desaparecidas, recuperando la luz de las vidrieras frente a la luz cenital presente en la ruina. ${ }^{81}$ (ej.36)
77 JOKILEHTO, J.: Op. cit., 1986/2005, p. 298

78 de SOLÀ-MORALES, I.: Op. cit. 1982, p. 34

79 SETTE, M.P.: Op. cit., 2001, p. 74

80 RUSKIN, J.: The seven lamps of architecture. Capítulo 6, apartado XVIII. Traducción extraída de una cita realizada por Dionisio Hernández Gil de: HERNÁNDES-GIL, D.: "Datos Históricos sobre la Restauración de Monumentos", pp. 25-32. En: A.A.V.V.: 50 Años de Protección del Patrimonio Histórico Artístico. 1933-1983. Madrid: Ministerio de Cultura, 1983

81 REPRESA BERMEJO, I.: "La expresión plástica en la degradación". En: REPRESA, I. (dir.): Restauración Arquitectónica II. Valladolid: Universidad de Valladolid, 1998, p. 145

[79] Templo Vespasiano durante las operaciones de desmontaje del arquitrabe. (GIZZI. En: González; Díez: 2002, p. 88)

[80] Templo Vespasiano antes de la intervención. Piranesi, 1756. (Universitätsbibliothek Heidelberg: <digi.ub.uni-heidelberg.de>) 
82 FIDONE, E.: "Framenti. II progetto e la potenza rinnovatrice delle rovine". En: UGOLINI, A.: Ricomporre la Rovina. Firenze: Alinea Editrice, 2010, pp. 26-31

83 OTERI, A.M.: Rovine. Roma, Ed. Argos, 2009, p. 24

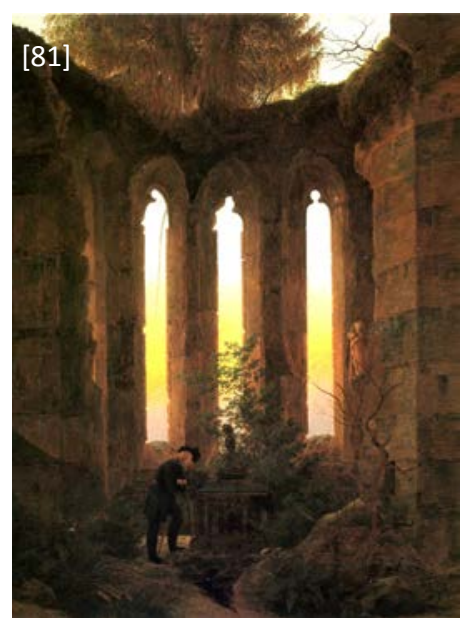

[81] Tumba de Hutten. 1823. (Caspar David Friedrich: <www.caspardavidfriedrich.org $>$ )

[82] Joseph Michael Gandy. Vista del área de la cúpula, 1811. (Repro Arte: <www.reproarte.com>)

[83] Joseph Michael Gandy. El Banco de Inglaterra en ruinas, 17981832. (OTERI: 2009, p. 24)

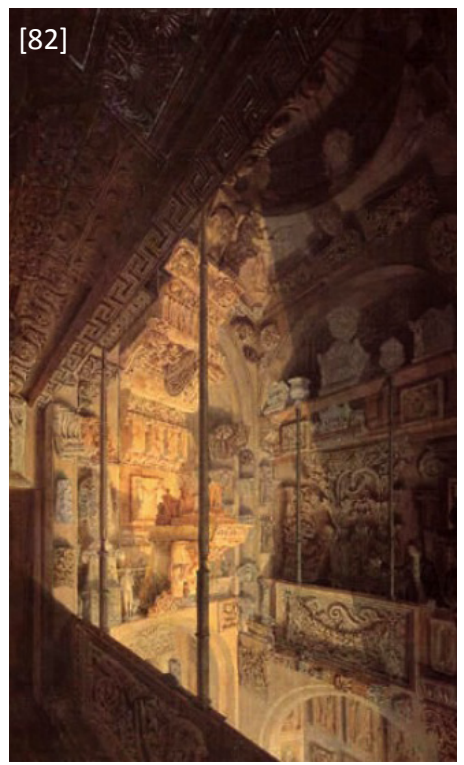

Ejemplo 36. Tumba de Hutten. Caspar D. Friedrich. 1823

A propósito de la valoración de la conservación de la imagen de la ruina arquitectónica es interesante mencionar la actividad del arquitecto inglés John Soane. Éste construye entre 1788 y 1833 el Banco de Inglaterra, cuya sala central la concibe como un espacio con reminiscencias a las bóvedas arruinadas de la arquitectura romana (ej.37). Soane llegará incluso a encargar representaciones del edificio reducido a estado de ruina, buscando exaltar con ello la grandiosidad de la obra a través de la fuerza que sólo el estado de ruina consigue evocar, esto es, la manifestación de sus aspectos de solidez constructiva y matérica. Como dice Emanuele Fidone parece que Soane inserta la obra en "una suerte de temporalidad cíclica, natural y eterna, en la cual se encuentran inmersas las antiguas ruinas romanas, en las que se inspira". También en el proyecto para su casa en la calle Lincoln's Inn Fields de Londres (ej.38), Soane busca esta eternidad de la ruina al englobar en su arquitectura un "grandioso caleidoscopio de fragmentos arquitectónicos y decorativos de diversas épocas". 82

Ejemplo 37. Banco de Inglaterra. John Soane. 1788-1833

La representación de un hipotético estado de ruina de la rotonda de la bolsa situada en el interior del banco, realizada por Joseph Michael Gandy en 1830, será una premonición de su demolición que se producirá en $1925 .{ }^{83}$

Ejemplo 38. Casa en la calle Lincoln's Inn Fields. 1792-1837

En la representación del patio-museo de la casa realizada por Joseph Michael Gandy en 1812 se observa como la luz que penetra cenitalmente ilumina los fragmentos de restos arqueológicos ayudando a potenciar la imagen misteriosa de una ruina.

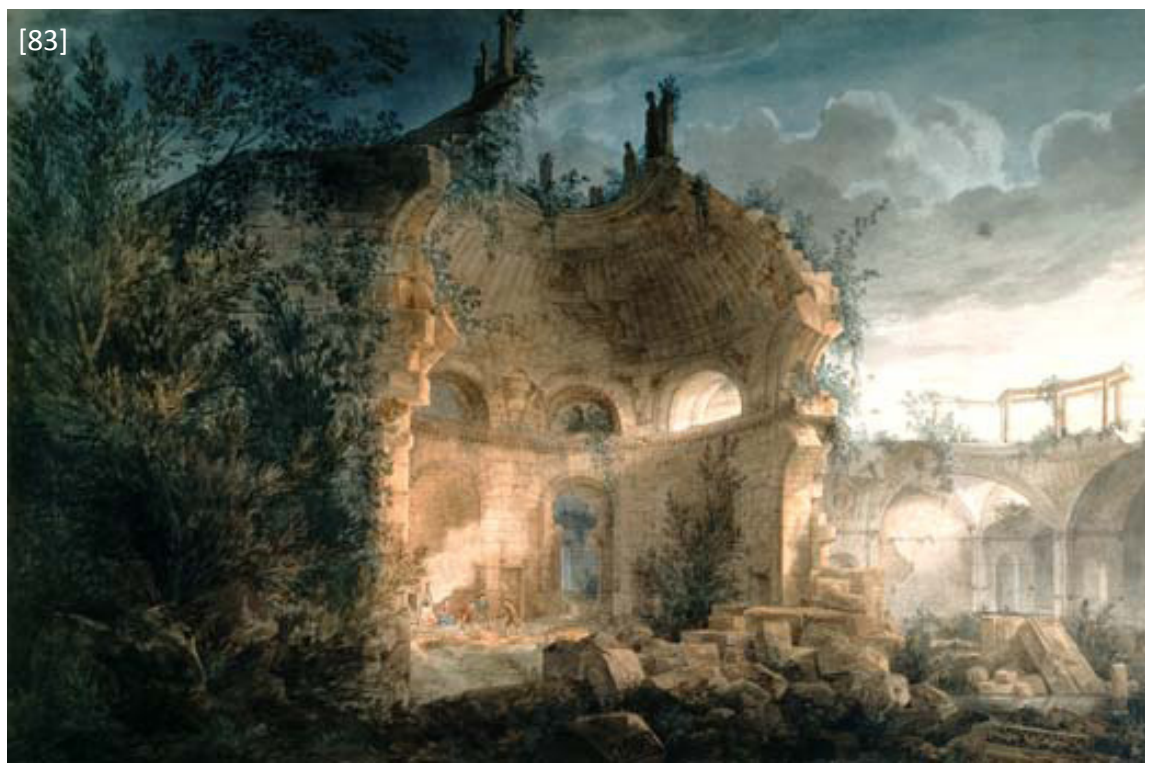


Para Antón Capitel la actitud de Ruskin supone una interpretación de la belleza como algo natural frente al orden artificial, valorando cuestiones de tipo ornamental frente a temas estrictamente arquitectónicos, iniciando con ello las bases de una "perversión crítica que prima la visión superficial del monumento y disloca el entendimiento del mismo al comprender el ornato como algo ajeno, desgajado y superpuesto al plan".

Por otro lado, el rechazo a la restauración en estilo, que derivará en el concepto de falso histórico, se apoyará no sólo en su percepción inmoral sino también en la falsedad constructiva debido al empleo de técnicas modernas que "frente a la literaria escena de las ruinas (...) ofrece la escenografía del pastiche como alternativa inútil, cuando no insidiosa por su capacidad de satisfacción de mentalidades no avisadas".

Finalmente Capitel resume de las enseñanzas de Ruskin lo que para él debería ser "una regla de oro del tratamiento de los edificios y ciudades valiosas del pasado: si la mixtificación histórica y la obra no completamente cualificada como tal constituyen las alternativas, son preferibles el abandono e incluso la desaparición" ${ }^{84}$

\subsection{La diferencia entre antiguo y nuevo. El restauro filológico}

La aparición en 1813 de Guy de Gisors, inspector enviado a Roma durante la ocupación napoleónica, producirá un cambio en el criterio de las intervenciones sobre los monumentos. Éste se muestra a favor de la reconstrucción de las partes desaparecidas de los monumentos, entendiendo como suficiente que las actuaciones den una idea de "sus formas y proporciones originales, ya sea en piedra o ladrillo, pero haciéndolo de tal manera que la reconstrucción reproduzca el contorno exacto de las partes que se pretenden definir", criterio que se aplicará en la intervención del Arco de Tito. ${ }^{85}$ Posteriormente, en los años 40 y 50, el arquitecto Luigi Canina realizará nuevas reconstrucciones en el Coliseo usando el mármol y ladrillo y evidenciando la diferenciación formal (ej.39).

Ejemplo 39. Actuaciones en el Coliseo. Luigi Canina. 1844

Canina reconstruye ocho arcos ubicados en la zona del acceso oeste del Coliseo. Emplea ladrillo y algunos elementos de travertino en aquellas partes con necesidad de mayor resistencia.
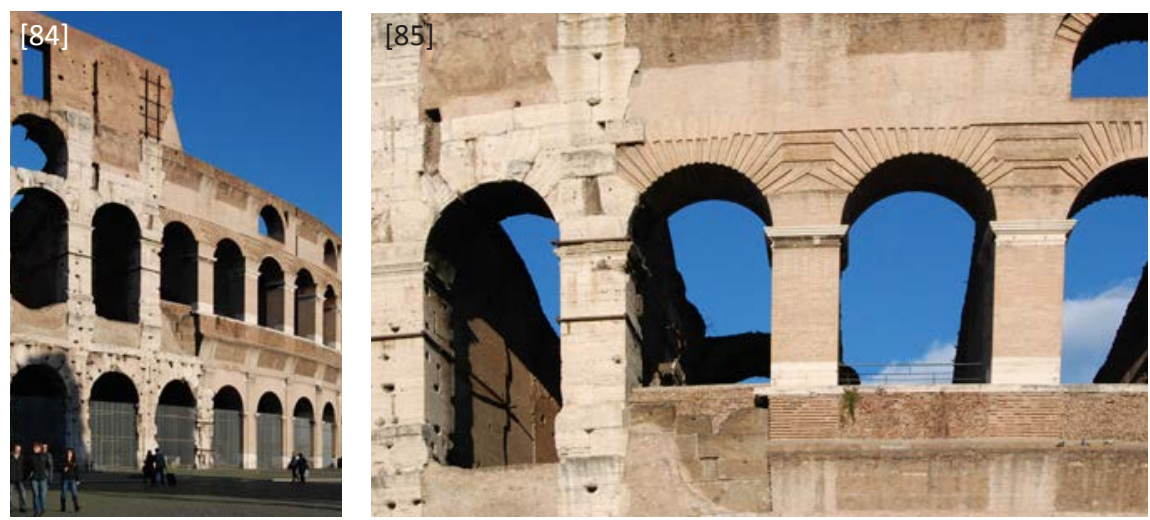

84 CAPITEL, A.: Metamorfosis de monumentos y teorías de la restauración. Madrid, Alianza Forma, 1988, 2009

85 “(...)al menos lo necesario como para dar una idea exacta de sus formas y proporciones originales, ya fuera en piedra o ladrillo, pero reproduciendo el contorno exacto de las partes a definir" JOKILEHTO, J.: Op. cit., 1986/2005, p. 134

[84 y 85] Reconstrucción de Luigi Canina en el Coliseo. (Imágenes del autor) 
86 Atti, IV, 1883, p. 119, 121. Extraído de: SETTE, M.P.: Op. cit., 2001, p. 81

87 Fragmento extraído de: HERNÁNDES-GIL, D.: "Datos Históricos sobre la Restauración de Monumentos", pp. 25-32. En: A.A.V.V.: 50 Años de Protección del Patrimonio Histórico Artístico. 1933-1983. Madrid: Ministerio de Cultura, 1983

88 Atti, IV, 1883, p. 59. Extraído de: SETTE, M.P.: Op. cit., 2001, p. 82
En el IV congreso de los arquitectos e ingenieros italianos celebrado en Roma en 1883, Camilo Boito plantea que los añadidos de partes que nunca hayan existido "sean visibles y distintas del mejor modo posible" y para hacerlo se emplee "el estilo moderno", mientras que para las partes destruidas y no terminadas se sugiere volver a proponer las formas primitivas, pero realizándolas con materiales distintos. Boito propone también conservar las modificaciones introducidas en diversas épocas en el edificio primitivo, a no ser que enmascaren o desfiguren algunas de sus partes notables. ${ }^{86}$ Con ello busca conjugar la defensa de la memoria histórica del monumento propuesta por los conservadores con la recuperación de su imagen unitaria original buscada por los restauradores.

Camilo Boito resume en estos versos "la regla de oro del restaurador":87

"Guardar debo en los viejos monumentos

su venerable pintoresco estilo,

y si añadidos y acabados preveo

que, a mi pesar, evitar no consigo,

haré de modo que todos entiendan

que mi obra es por entero moderna"

El congreso aprueba los siete puntos del famoso documento, que constituye el manifiesto del restauro filológico, recogiendo las ideas existentes en el ámbito de la restauración y convirtiéndolas en normativa: 88

1. La consolidación debe preferirse a la reparación, y ésta a la restauración.

2. Los añadidos de partes que nunca han existido deben ser realizadas según la manera moderna.

3. La sustitución de partes destruidas o no terminadas en origen deben llevarse a cabo según las formas primitivas pero con materiales distintos; en las restauraciones arqueológicas se deben emplear formas simplificadas.

4. Las obras de consolidación deben reducirse a lo mínimo indispensable, especialmente en los monumentos que deben su belleza a los mármoles, mosaicos, pinturas e incluso a las marcas del tiempo.

5. Los añadidos introducidos en el edificio en épocas sucesivas deben ser mantenidos.

6. La restauración de los monumentos debe estar acompañada, en todas sus fases, por estudios y documentaciones.

7. Una lápida deberá recordar, sobre el monumento, la fecha y las principales obras de restauración efectuadas. 


\subsection{El restauro histórico}

El restauro histórico defiende que las intervenciones deben ser guiadas por la documentación existente sobre los monumentos para realizar una intervención lo más exacta posible a su historia, tratando de eliminar toda aportación creativa en el proceso de restauración. Pero en la práctica la documentación no basta para garantizar la objetividad del resultado y en muchos casos se hace necesario completar el dato documental con invenciones o con analogías, tal y como ocurría en la restauración estilística. Por lo que se puede entender como una "variante objetiva del restauro estilístico". ${ }^{99}$ Luca Beltrami, discípulo de Camillo Boito, será uno de los impulsores de esta actitud en su intervención en el Castello Sforcesco de Milán (ej.40) y ya entrado el siglo XX, será Gaetano Moretti quien siga estos criterios en la reconstrucción del campanile de San Marcos en Venecia (ej.41), obra con la que se popularizará en las reconstrucciones el dicho "com'era e dov'era" para referirse a las actuaciones de repristinación tal y como eran y donde estaban antes de su destrucción, algo que será muy habitual a lo largo del siglo XX en monumentos derruidos por acciones traumáticas. ${ }^{90}$

\section{Ejemplo 40. Castello Sforcesco. 1893}

Beltrami realiza un preciso levantamiento del edificio y un concienzudo estudio de investigación histórica. Pero la falta de documentación le hace acudir a la reproducción de las formas preexistentes reutilizando en la medida de lo posible los materiales originales. Como dice Liliana Grassi, Beltrami no hace "otra cosa que hacer legítimo el restauro estilístico a través de una concienzuda búsqueda de documentación histórica a sufragio de las reconstrucciones". ${ }^{91}$

\section{Ejemplo 41. Reconstrucción del Campanile de San Marcos en Venecia. Gaetano} Moretti. 1903-1912

El Campanile se hunde en 1902, dañando la loggetta Sansoviniana y la esquina de la Biblioteca marciana. Se lleva a cabo un cuidado proyecto de repristinación, empleando para su reconstrucción materiales tradicionales, para la configuración de la forma exterior, y modernos, para la estructura interior realizada en hormigón armado.
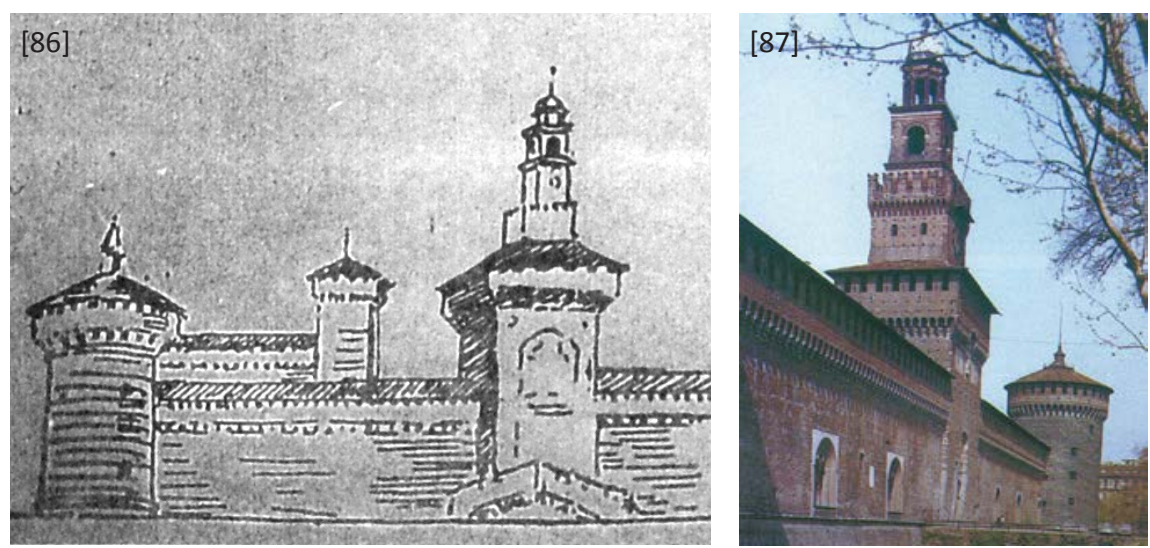

89 Miarelli Mariani, 1979, p. 112. Extraído de: SETTE, M.P.: Op. cit., 2001, p. 85

90 SETTE, M.P.: Op. cit., 2001, p. 110112

91 (Grassi, 1960, p.440). Extraído de: SETTE, M.P.: Op. cit., 2001, p. 108-109

[86] Castello Sforcesco. Documento recogido por Beltrami para la reconstrucción. (SETTE: 2001, p. 109)

[87] Castello Sforcesco. Vista actual del lado occidental con la torre de Filarete reconstruida. (CARBONARA: 1997)

[88] Campanile de San Marcos. Vista tras la reconstrucción. (RIVERA: 2008, p. 157)

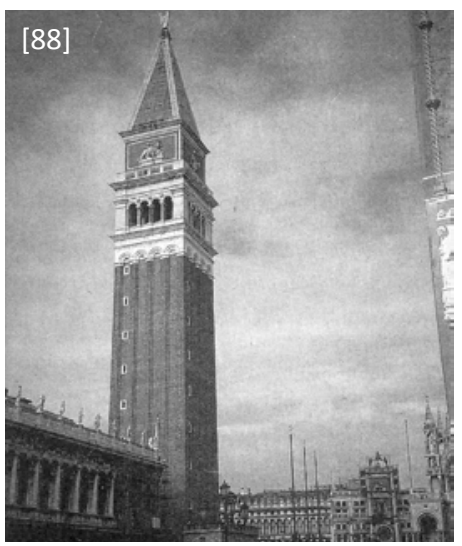




\subsection{Los valores del monumento}

92 SETTE, M.P.: Op. cit., 2001, p. 113

93 CLOQUET, 1901-02. Extraído de: SETTE, M.P.: Op. cit., 2001, p. 114

94 RIEGL, 1903. Extraído de: SETTE, M.P.: Op. cit., 2001, pp. 115-119

95 PIZZA, A.: “Ruinas, Forma, Proyecto". En: A.A.V.V.: Cuadernos IV. Arquitectura y Patrimonio. Junta de Anadlucía. 1994. p. 36

Con el restauro filológico ya no se persigue devolver la unidad estilística sino recuperar sus valores artísticos e históricos, por lo que se hace necesario concretar cuales son esos valores. Además el monumento debe satisfacer un valor de uso que satisfaga las exigencias de la contemporaneidad, algo que ya había preocupado a Viollet-le-Duc quien indica que si bien todos los edificios deben tener un uso, éste debe ser apropiado al edificio y debe satisfacer adecuadamente las exigencias para evitar futuros cambios. ${ }^{92}$

A finales del siglo XIX, Louis Cloquet distingue los monumentos en dos tipos: monumentos muertos y monumentos vivos. El valor de los primeros es el de pertenecer al pasado, de tal manera que sólo pueden ser conservados. Los segundos son aquellos que tiene un valor de uso que es inseparable de su belleza moral, y por lo tanto pueden ser restaurados y ampliados para adaptarlos a las exigencias modernas. ${ }^{93}$

Posteriormente Alois Riegl realiza un exhaustivo análisis de los diferentes valores presentes en los monumentos. El valor histórico lo entiende como testimonio de una época que ya no existe, pero matiza que éste debe seleccionarse según su importancia; el valor artístico, que debido a su naturaleza testimonial se considera también histórico, es un valor objetivo para los antiguos ya que depende de cumplir ciertas reglas, pero subjetivo para los modernos ya que depende de los ideales figurativos de cada sujeto y cada momento; en tercer lugar introduce el valor de antigüedad que hace referencia al paso del tiempo sobre una obra, como es el caso de las ruinas.

Por otro lado Riegl distingue tres tipos de monumentos cuyo valor varía en función de la importancia que suponen en la memoria de cada momento. Los monumentos intencionales tienen la voluntad de conmemorar un momento preciso del pasado, siendo éste el único interés en la antigüedad y en toda la edad media; los monumentos histórico-artísticos interesan a partir del Renacimiento, preferentemente aquellos que se muestran como ejemplares en cada momento; finalmente los monumentos antiguos valorados por demostrar haber existido desde hace mucho tiempo.

Por último es interesante la distinción que hace Riegl entre el "valor de uso" de un monumento, en cuanto que es capaz de satisfacer las necesidades prácticas, y el "valor de arte" capaz de satisfacer las necesidades espirituales. Y defiende el empleo práctico de los monumentos aunque posean un cierto valor de antigüedad. ${ }^{94}$

Antonio Pizza indica que para Riegl el único trabajo de reconstrucción posible de las herencias del pasado es el del historiador, no el del arquitecto, pero sólo a través de sus instrumentos específicos como la simulación, el pensamiento ola palabra. "De estaforma la historia yel proyecto se disociany siguen caminos bifurcados". La historia buscará el análisis y el conocimiento, mientras que el proyecto deberá reflejar la modernidad de su disciplina. ${ }^{95}$ 


\section{SIGLO XX. HASTA LA 2a GUERRA MUNDIAL}

En los primeros años del siglo XX la desconfianza en los nuevos lenguajes arquitectónicos como mecanismo para diferenciar lo antiguo de lo nuevo producirá el mantenimiento de las actuaciones estilísticas. Esta cuestión queda patente en las reflexiones que hace Vicente Lampérez al plantearse la reconstrucción de la fachada de la Catedral de Cuenca (ej.42).

\section{Ejemplo 42. Reconstrucción de la fachada de la Catedral de Cuenca. Vicente Lampérez. 1907}

En la memoria de la actuación, Lampérez se plantea tres soluciones posibles: la reconstrucción de la fachada barroca demolida, que descarta porser de mala calidad; la construcción de una nueva fachada en estilo actual, que descarta por entender que el modernismo de la época sólo provocaría un perjuicio a la preexistencia; la construcción en el mismo estilo gótico de la catedral, que acepta como sistema para acercarse a lo que pude ser la solución original. Lampérez propone construir la fachada mediante "un nuevo proyecto en estilo ojival del siglo XIII, tratando de acercarse a las formas presumibles de la que existió". Como indica Dionisio Hernández Gil, la solución realizada está muy lejos del efecto que buscaba, ya que el estilo neogótico empleado no logra integrar la fachada con el resto de la iglesia. ${ }^{96}$
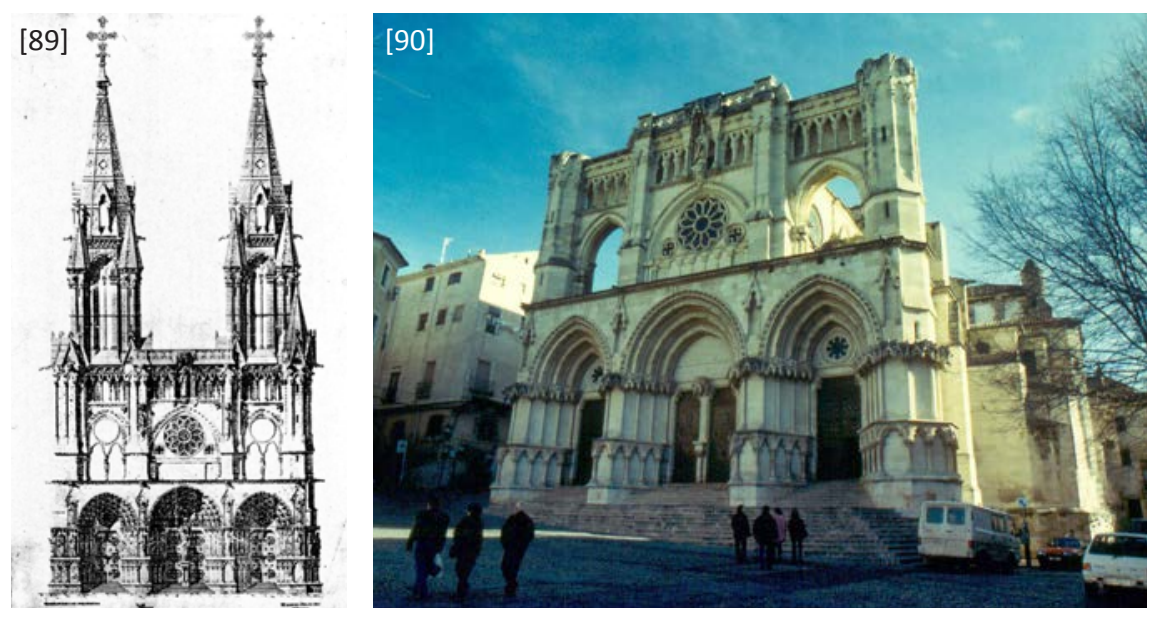

Frente a este tipo de actuaciones se impulsará la distinción entre antiguo y nuevo a través de la simplificación formal, retomando los criterios empleados en Roma a principios del Siglo XIX, y se crearán leyes que regulen las nuevas teorías de restauración.

Así, en 1931 se realiza un congreso en Atenas sobre restauración arquitectónica del que surge la denominada "Carta de Atenas" que recoge los argumentos de Camilo Boito añadiéndose dos nuevas cuestiones: la relación con las nuevas tecnologías y la relación del monumento con su entorno. La primera indicará que las nuevas tecnologías son útiles siempre y cuando no alteren el carácter del edificio existente, y la segunda retomará los conceptos urbanísticos de Giovannoni de conservación del entorno del
96 HERNÁNDES-GIL, D.: "Datos Históricos sobre la Restauración de Monumentos", pp. 25-32. En: A.A.V.V.: 50 Años de Protección del Patrimonio Histórico Artístico. 1933-1983. Madrid: Ministerio de Cultura, 1983

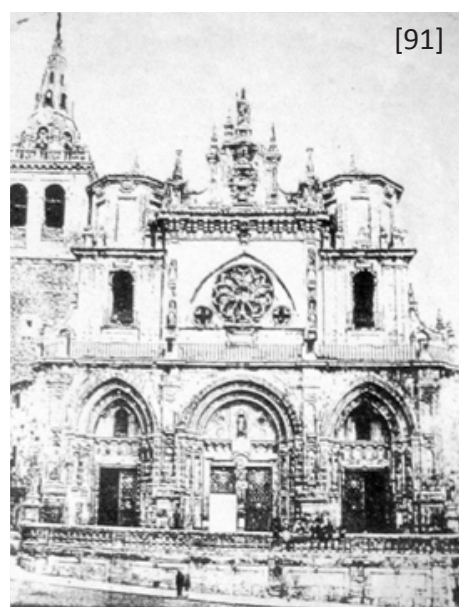

[89 y 90] Catedral de Cuenca. Proyecto y vista actual. (ÁLVAREZ-BUILLA. En: XVII Congreso Internacional de Conservación y Restauración de Bienes Culturales. Día de la arquitectura: 2008 , pp. 62 y 65)

[91] Catedral de Cuenca. Fachada antes de la "restauración". (MORA: 2002, p. 32) 
97 de SOLÀ-MORALES, I.: Op. cit. 1982, p. 35

98 A.A.V.V.: 50 Años de Protección del Patrimonio Histórico Artístico. 19331983. Madrid: Ministerio de Cultura, 1983, pp.69-79

99 CAPITEL, A.: Metamorfosis de monumentos y teorías de la restauración. Madrid, Alianza Forma, 1988, 2009

100 SETTE, M.P.: Op. cit., 2001, p. 122128

101 SETTE, M.P.: Op. cit., 2001, p. 137 monumento. El propio Giovannoni redactará a finales de 1931 la Carta Italiana del Restauro que se concreta como una versión de la Carta de Atenas, haciendo especial hincapié en la diferenciación de los añadidos. ${ }^{97} \mathrm{~A}$ estos criterios se los identificará con el nombre de "restauración científica".

En España, la ley de patrimonio española en 1933 buscará eliminar las prácticas repristinadoras. Así, en su artículo 19, la ley hace hincapié en la mínima intervención y diferenciación de añadidos: "Se proscribe todo intento de reconstitución de los monumentos, procurándose por todos los medios de la técnica su conservación y consolidación, limitándose a restaurar lo que fuera absolutamente indispensable y dejando siempre reconocibles las adiciones". 98

La consolidación de los criterios filológicos llevará a la conformación de tres tipos de restauración: la restauración arqueológica, dirigida a consolidar las ruinas, permitiéndose operaciones de anastilosis a través de materiales claramente diferenciados; las restauraciones conservativas, tendentes a realizar mínimas operaciones de consolidación manteniendo el carácter pintoresco del monumento; y las restauraciones arquitectónicas, que buscarán atender a la restitución de la unidad del monumento mediante simplificaciones formales diferenciadoras. ${ }^{99}$

Por otro lado el nacimiento del movimiento moderno impulsará la estética del contraste entre la historia y la modernidad, mientras que algunos arquitectos comprometidos con la herencia arquitectónica del pasado propondrán la reinterpretación de los mecanismos compositivos de los monumentos para alcanzar una unidad equilibrada.

\subsection{La simplificación formal}

Giovannoni trata de ampliar las teorías de su maestro en la búsqueda por concretar una posición intermedia entre los conservadores puros y los restauradores en estilo, que produzca un equilibrio entre los valores históricos y artísticos del monumento. Para ello actúa empleando formas simplificadas, reducidas al puro esquema constructivo, lo que suponen una cierta renuncia a la arquitectura. Para Maria Piera Sette, esta renuncia "representa el verdadero límite de su pensamiento y de su obra" (ej.43). ${ }^{100}$

Ejemplo 43. Restauración de la Iglesia Vaticana de Santo Stefano Maggiore degli Abissini. Gustavo Giovannoni. 1931-1933

Giovannoni realiza una potente actuación que contempla trabajos de consolidación, eliminación, refuerzo con contrafuertes externos y vigas de hierro, y repristinación dejando visibles algunos elementos de las antiguas columnatas y empleando fragmentos recuperados y materiales reutilizados. En las actuaciones Giovannoni busca salvaguardar las estructuras auténticas remarcando el carácter moderno de las integraciones empleando formas simplificadas o marcando con siglas las partes nuevas. ${ }^{101}$ 

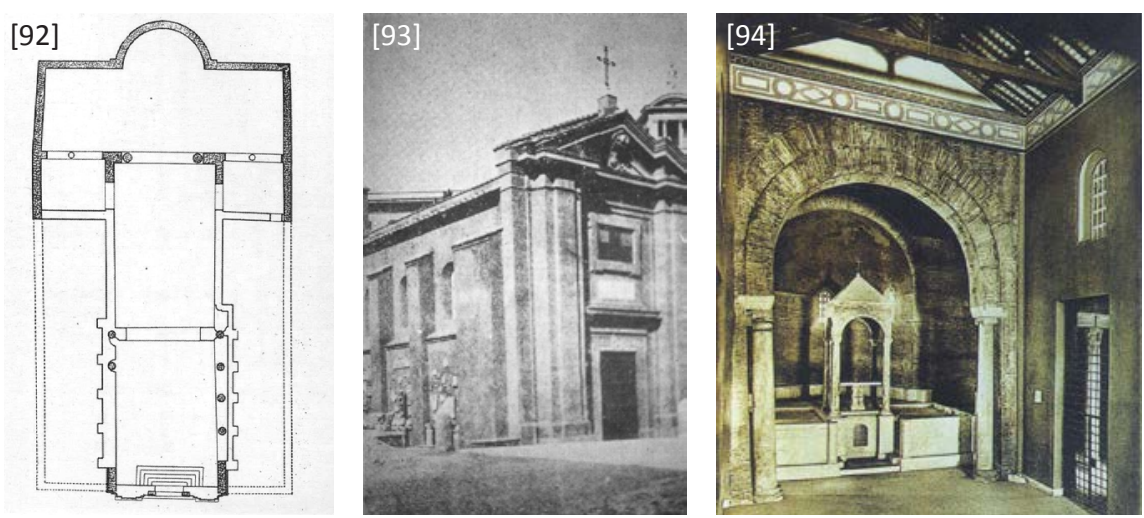

102 SETTE, M.P.: Op. cit., 2001, p. 140

103 MARELLI MARIANI, 1990-92, P.953-972. Extraído de: SETTE, M.P.: Op. cit., 2001, pp. 140-141

Como comenta Maria Piera Sette, los criterios de simplificación empleados son indiferentes al tipo de obra, siendo más adecuados cuando las partes a reintegrar son de pequeña dimensión, pero resultan inadecuadas al aplicarse a partes fundamentales del edificio, algo que se hace muy evidente en la actuación de terminación de la Iglesia de Santa Maria degli Angeli en Florencia (ej.44). Para Sette estos resultados deberían haber hecho reflexionar sobre los límites de actuación de los postulados filológicos, "una meditación que habría permitido aclarar que, en determinadas ocasiones, se debe conservar lo que ha permanecido o, como alternativa, aceptar operaciones creativas, que den vida a nuevas obras, insertando elementos o partes supervivientes de la fábrica antigua". ${ }^{102}$

\section{Ejemplo 44. Terminación de la Iglesia de Santa Maria degli Angeli en Florencia.} Rodolfo Sabatini. 1933-37

La iglesia de planta octogonal proyectada por Brunelleschi en 1434, quedó interrumpida habiéndose completado los muros hasta una altura de unos siete metros. En 1933 Rodolfo Sabatini retoma el proyecto de Brunelleschi y propone dos opciones. Una que retoma las formas originales, y otra en la que, siguiendo los preceptos del restauro filológico, propone una simplificación de las formas. La solución adoptada manifiesta la invalidez del recurso empleado al producir lo que Miarelli Mariani define como "una triste parodia de la inacabada imagen brunellesquiana". ${ }^{103}$
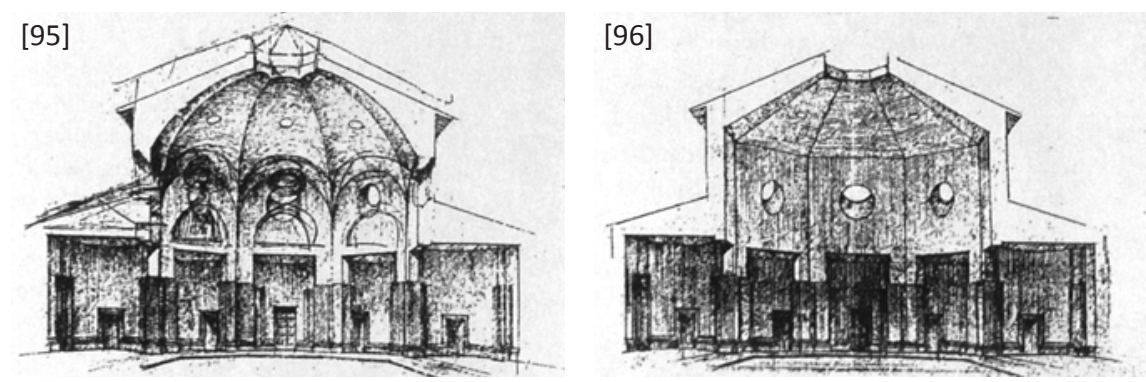

[92] Santo Stefano Maggiore. Planta de la iglesia después de la restauración. (CARBONARA: 1997)

[93] Santo Stefano Maggiore. Vista exterior tras la restauración. (RIVERA: 2008, p. 167)

[94] Santo Stefano Maggiore. Vista interior tras la restauración. (CARBONARA: 1997)

[95 y 96] Santa Maria degli Angeli. Las dos propuestas de Sabatini. (SETTE: 2001, p. 141) 
104 MORA ALONSO-MUÑOYERRO, S.: La Restauración Arquitectónica en España. Criterios y Teorías (1840-1936). Madrid, Kaher II, 2002, p.125

105 MORA ALONSO-MUÑOYERRO, S.: Op. cit., 2002, p.125

106 MORA ALONSO-MUÑOYERRO, S.: Op. cit., 2002, p.133

107 CAPITEL, A.: Metamorfosis de monumentos y teorías de la restauración. Madrid, Alianza Forma, 1988, 2009
[97 y 98] Patio de Yeso del Alcázar de Sevilla. Restauración según el criterio del Marqués de Vega Inclán. (MORA: Basa, no 13, 1990, p. 18)

[99] Patio de Yeso del Alcázar de Sevilla tras la intervención del Marqués de Vega Inclán. (MORA. En: III Simposio sobre Restauración Monumental. Barcelona: 1993, p. 17)
EnEspañaentrelasactuaciones más conservadoras destacan las del Marqués de Vega Inclán en el Patio de Yeso del Alcázar deSevilla (ej.45), donde propone reconstruir la estructura de los elementos faltantes, sobre la que coloca los restos de ornamentación existentes y deja sin completar los faltantes. Con ello busca mostrar la autenticidad del fragmento frente a la falsedad de la integración, buscando conservar el aspecto de ruina del monumento. ${ }^{104}$

Ejemplo 45. Restauración del patio de Yeso del Alcázar de Sevilla. Marqués de Vega Inclán. 1913

Vega Inclán actúa buscando transmitir la autenticidad de los elementos, haciendo evidentes los elementos de refuerzo, mientras que las lagunas se tratan con un fondo neutro. Como indica Susana Mora, el tratamiento empleado entra dentro de lo que Camillo Boito califica como "restauro pictórico". Sus actuaciones, en la línea de los conservacionistas ingleses, no serán entendidas por algunos arquitectos de la época como Vicente Lampérez, quien anclado aún en los preceptos de la restauración estilística, se mostrará en contra de la actuación de Vega Inclán definiéndola como una "ortopedia constructiva sin vestidura estética". ${ }^{105}$
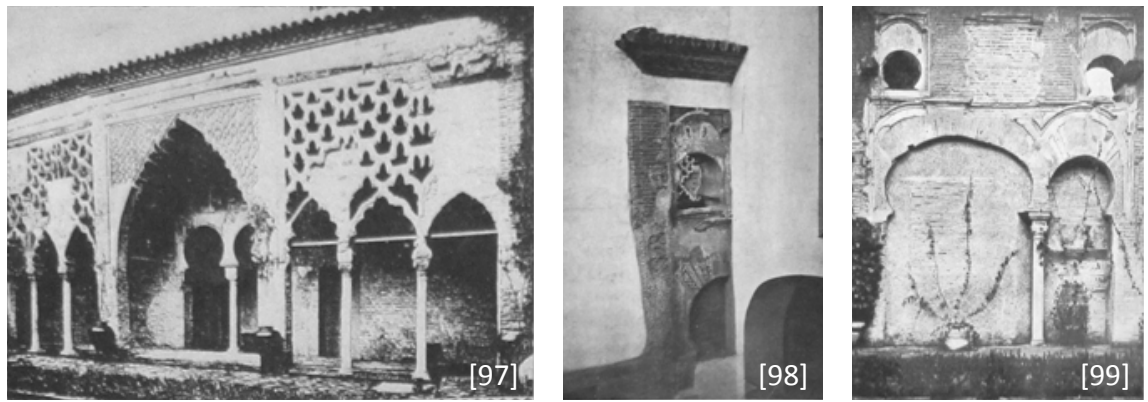

Por otro lado destaca la figura de Leopoldo Torres Balbás y sus actuaciones en la Alhambra de Granada (ej.46), donde busca el equilibrio entre la integración y la diferenciación en la adición de faltantes, tratando de recuperar la armonía del conjunto sin perder la autenticidad histórica. Sin embargo, como indica Susana Mora, a diferencia de las actuaciones del Marqués de Vega Inclán, Torres Balbás no tendrá reparo en ocultar los refuerzos de hormigón dejando los muros antiguos casi como encofrados, algo que para Mora conlleva a que "en muchos casos los elementos arquitectónicos no sean ya más que mera escenografía". ${ }^{106}$

Para Antón Capitel, la paradoja entre la mitificación de la autenticidad original manteniendo la apariencia vetusta y la permisividad por la consolidación de las fábricas con nuevos materiales siempre que no sean visibles, supone favorecer "un sentimiento inmediato e ingenuo, falseado y visualista de los restos arquitectónicos". ${ }^{107}$ 
Ejemplo 46. Torre de las Damas de la Alhambra de Granada. Leopoldo Torres Balbás

En este sentido es significativa su propuesta de reintegrar el motivo romboidal que se superpone a los arcos de la Torre de las Damas de la Alhambra, a través de un "tejido nuevo" que diera el mismo efecto que el antiguo sin reproducirlo exactamente. Para Antonio González sus actuaciones en la Alhambra de Granada supusieron una interesante manera de reconstrucción, sin necesidad de acudir a la copia, mediante el empleo de la "reintegración de la imagen". ${ }^{108}$
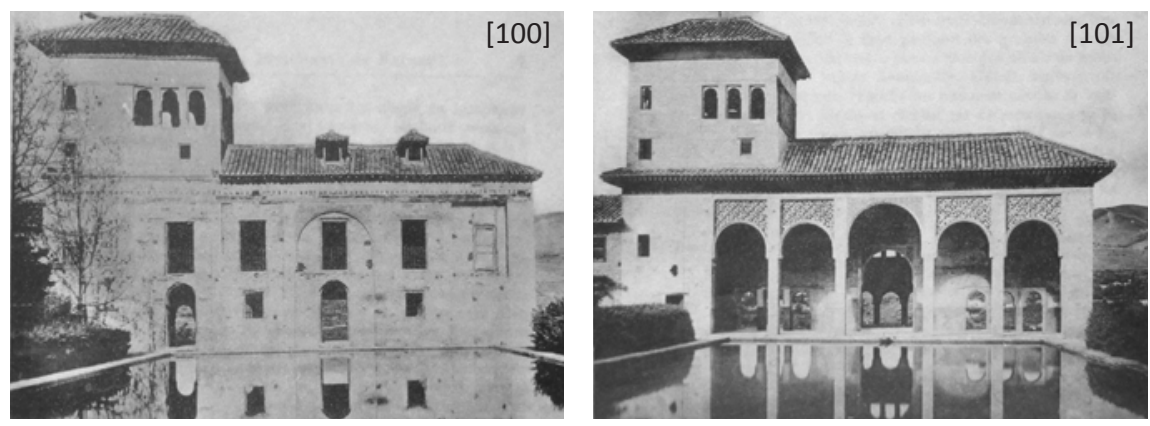

\subsection{El respeto del contexto urbano}

Giovannoni, retomandolasideasurbanísticasdeCamiloSite, proponeampliar el concepto de monumento al contexto urbano, abogando por respetar el ambiente que proporcionan las arquitecturas menores que componen los centros históricos. De estas arquitecturas valora no solo su vetustez sino también su volumetría, ya que permiten mantener la perspectiva visual de un monumento. Para compatibilizar este respeto al entorno del monumento con la necesaria renovación de los centros históricos propone sustituir las demoliciones masivas o "esponjamientos" defendidos en el entorno de los CIAM para la creación de amplias plazas y zonas verdes, por el "saneamiento" del tejido urbano consistente en el vaciado puntual de algunos edificios (ej.47). Giovannoni se muestra en contra de la capacidad de la arquitectura moderna para configurar los centros históricos llegando a afirmar que "lo viejo es propio del centro, lo nuevo de la periferia". ${ }^{109}$

\section{Ejemplo 47. Giovannoni. Trento. Torre del Águila / Catedral de Valencia}

Giovannoni explica con este dibujo como la destrucción del tejido urbano adherido a los monumentos puede distorsionar su escala y percepción.
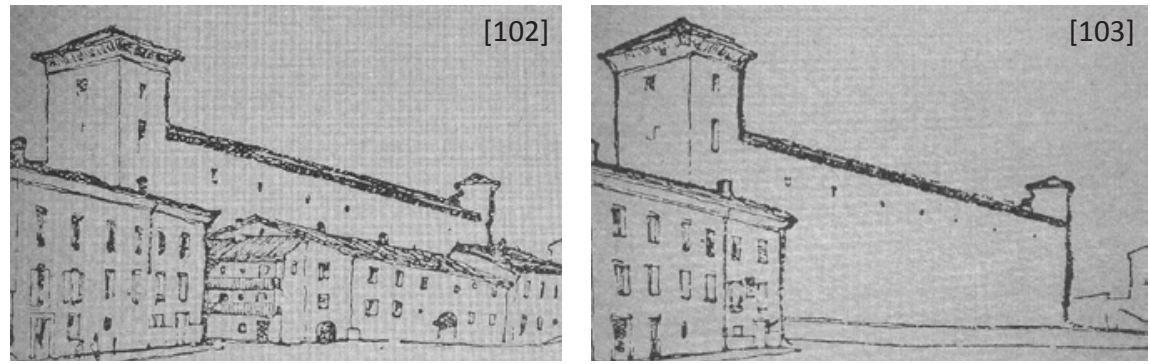

108 GONZÁLEZ, A.: La Restauración Objetiva: Método SCCM de Restauración Monumental: Memoria SPAL 19931998. Barcelona, Ed. Diputació de Barcelona, 1999, p. 65

109 GIOVANNONI, G.: Vecchie cittá ed edilizia nuova. Torino, 1931, p. 255
[100 y 101] La Torre de las Damas de la Alhambra de Granada, antes y después de la intervención de Leopoldo Torres Balbás. (MORA. En: Basa, 1990, no 13, p. 19)

[102 y 103] Torre del Águila. Trento. (RIVERA: 2008, p. 165) 
110 CAPITEL, A.: Metamorfosis de monumentos y teorías de la restauración. Madrid, Alianza Forma, 1988, 2009

111 ESTEBAN CHAPAPRÍA, J.: La Conservación del Patrimonio Español durante la II República (1931-1939). Barcelona: Fundación Caja de Arquitectos, 2007, pp.57-58

112 GARCÍA NAVARRO, J.J.: "Marceliano Coquillat y Llofriu, Restauración de Santa María de Elche". En: Catálogo de la Exposición "Les Empremtes del Temps". Ayuntamiento de Elche, 2009
Algo similar ocurre en la fachada de la catedral de Valencia recayente a la plaza de la reina. La conformación de la nueva plaza como resultado del derribo de parte del tejido urbano produce una fuerte alteración en la percepción de la catedral, concebida originalmente entre calles estrechas con fuertes visuales fugadas.

Aunque en la práctica el saneamiento impulsado por Giovannoni vino asociada a actuaciones de transformación y reconstrucción para mantener la idea de ambientación, al menos permitió llevar a cabo una postura intermedia entre las actitudes conservacionistas, que pretendían congelar los centros históricos, y las actitudes modernas que planteaban crear grandes vacíos por razones higienistas. Como comenta Antón Capitel, la conservación del ambiente encontró en el llamado "novecentismo" un gran aliado, al buscar a través de mecanismos de análisis y rediseño de los elementos formales del lugar relacionarse con la arquitectura histórica. Arquitectos como Otto Wagner, Adolf Loos o Berlage son un buen ejemplo de ello. ${ }^{110}$

\subsection{El empleo de nuevos materiales.}

En los primeros años del siglo $X X$ se populariza el empleo de nuevos materiales, como el hormigón y el acero para el refuerzo y reconstrucción, pero siempre de manera que queden ocultos a la vista. El empleo del acero, con una trayectoria más dilatada, se emplea con mayor asiduidad, como es el caso del proyecto de restauración de la Catedral de la Seu d'Ugell o la reconstrucción de la cúpula de la Basílica de Santa María de Elche (ej.48). Mientras que el hormigón armado, de creación más reciente, si bien ya se había empleado en algunas actuaciones, se empieza a extender a partir de su generalización y perfeccionamiento con motivo de las reconstrucciones llevadas a cabo tras la primera guerra mundial, como la reconstrucción de las cubiertas de la Catedral de Reims (ej.49). ${ }^{111}$

Ejemplo 48. Basílica de Santa María de Elche. Marceliano Coquillat. 1902-1906 Coquillat propone el desmontaje de la cúpula en mal estado y su reconstrucción con un alma de estructura de hierro con la finalidad de reducir el peso sobre los muros y dar mayor resistencia y estabilidad al elemento. La estructura se reviste con rasilla revestida de cal reproduciendo las piezas de cantería, para mantener el aspecto de la cúpula original. ${ }^{112}$
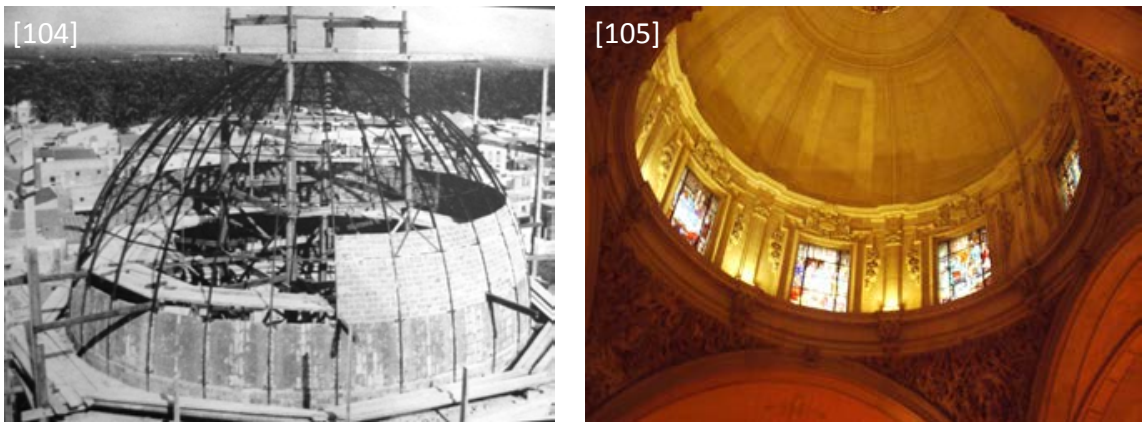

Evolución de los criterios de intervención en el patrimonio arquitectónico 
Ejemplo 49. Reconstrucción de las cubiertas de la Catedral de Reims. 1919-38 La cubierta de madera se destruye a causa del fuego producido por los bombardeos de la primera guerra mundial. Dada las grandes dimensiones necesarias para reponer la estructura desaparecida, se recurre a la fabricación de un sistema de triángulos de hormigón armado prefabricados en obra. La alta resistencia del nuevo sistema permitió reducir las cargas sobre los muros. ${ }^{113}$

\subsection{El caso por caso, la armonía y la calidad}

Giovannoni hace hincapié en la complejidad histórica y artística presente en los monumentos, afirmando la dificultad de establecer "uniformidad de criterios" 114 y la necesidad de aceptar transacciones "entre historia y arte, entre viejo y nuevo, entre lo que se quiere y lo que se puede hacer". ${ }^{115}$

En la misma línea que Giovannoni, Torres Balbás afirma que "Cada viejo edificio presenta un problema diferente, y debe ser tratado de manera distinta. Es pueril intentar dar reglas generales para la reparación de los monumentos" y añade que "lo único útil y sensato" es fijar como orientación general el "máximo respeto a la obra antigua". ${ }^{116}$

En esta misma línea se manifiesta Ambrogio Annoni cuando afirma que no existe un método general en la restauración, sino sólo una única norma fundamental: "frente al monumento, él mismo es el maestro"117, por lo que se debe estudiar individualmente, "caso por caso", cada obra, y extraer los criterios más adecuados en función de las necesidades.

Annoni rechaza la momificación de los monumentos, y apuesta por su valorización como parte del proceso de restauración, pero mediante criterios que huyan de la falsificación y el mimetismo. ${ }^{118}$ En este sentido es interesante destacar la intervención que realiza en la Basílica de S. Vincenzo (ej.50), en la que desestima la recomposición en estilo de la nave lateral desaparecida para evitar la falsificación, y propone cerrar el muro abierto de la nave central mediante una gran cristalera. Con ello Annoni es fiel a su pensamiento que resume con las siguientes palabras: "Hoy se piensa que la restauración no sólo debe ser arte, ni sólo ciencia, deben ser ambas juntas, para lo cual necesitamos un gran sentido del equilibrio, de cultura, de amor. Para la restauración no se intentará solo una reconstrucción estilística o histórica, sino de conservación, sistematización y revalorización del edificio". ${ }^{119}$

\section{Ejemplo 50. Basílica de S. Vincenzo. Ambrogio Annoni. 1910-1934}

El cerramiento de vidrio propuesto se coloca a haces exteriores, detrás de los arcos de separación entre la nave central y la nave lateral desaparecida. Con ello Annoni logra recrear la amplitud espacial original y aporta una nueva transparencia que expande el interior hacia el exterior. ${ }^{120}$ Por otro lado, se deja la huella de los muros de la nave lateral en el pavimento para recordar la traza del elemento desaparecido.
113 ESTEBAN CHAPAPRÍA, J.: Op. cit., 2007, pp.57-58

114 GIOVANNONI, 1913, "Restauri di monumenti", p.501. Extraído de: SETTE, óp. cit. (2001), p. 124

115 SETTE, M.P.: Op. cit., 2001, p. 124

116 TORRES BALBÁS, Sobre monumentos y otros escritos, 1933, pp. 269-277. Extraído de: ESTEBAN CHAPAPRÍA, J.: La Conservación del Patrimonio Español durante la II República (1931-1939). Barcelona: Fundación Caja de Arquitectos, 2007, pp.57-58

117 ANNONI, 1946. Extraído de: SETTE, M.P.: Op. cit., 2001, p. 152

118 ANNONI, 1946. Extraído de: SETTE, M.P.: Op. cit., 2001, p. 152

119 Annoni, 1946, p.14. Extraído de: BORTOLOTTO, S.; PALO, M.C.: "Basílica de S. Vincenzo, Galliano di Cantù (Como): la vetrata di chiusura della navata maggiore". En Progettare per il costruito. Dibattito teorico e progetti in Italia nella seconda metà del XX secolo. Milano, Ed. CittàStudi Edizioni, 2008, p.127

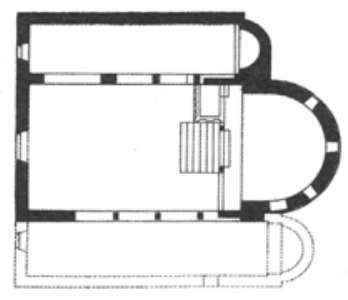

[106]

[106] Basílica de S. Vicenzo. Planta. (BORIANI: 2008, p. 125) 
120 BORTOLOTTO, S.; PALO, M.C.: "Basílica de S. Vincenzo, Galliano di Cantù (Como): la vetrata di chiusura della navata maggiore". En Progettare per il costruito. Dibattito teorico $e$ progetti in Italia nella seconda metà del XX secolo. Milano, Ed. CittàStudi Edizioni, 2008, pp.125-130

121 TORRES BALBÁS, L.: “LOS Monumentos Históricos y Artísticos: Destrucción y Conservación. Legislación y Organización de sus Servicios y su Inventario". 1919. En: A.A.V.V.: Cuadernos de Restauración V. Madrid, Cuadernos del Instituto Juan de Herrera de la Escuela de Arquitectura de Madrid, 1998, pp. 34-46

122 TORRES BALBÁS, L.: “LOS Monumentos Históricos y Artísticos: Destrucción y Conservación. Legislación y Organización de sus Servicios y su Inventario". 1919. En: A.A.V.V.: Op. cit., 1998, pp. 34-46

123 CAPITEL, A.: Metamorfosis de monumentos y teorías de la restauración. Madrid, Alianza Forma, 1988, 2009

[107 y 108] Basílica de S. Vicenzo. Cerramiento de vidrio y huella de la nave lateral. (BORIANI: 2008, p. 130)
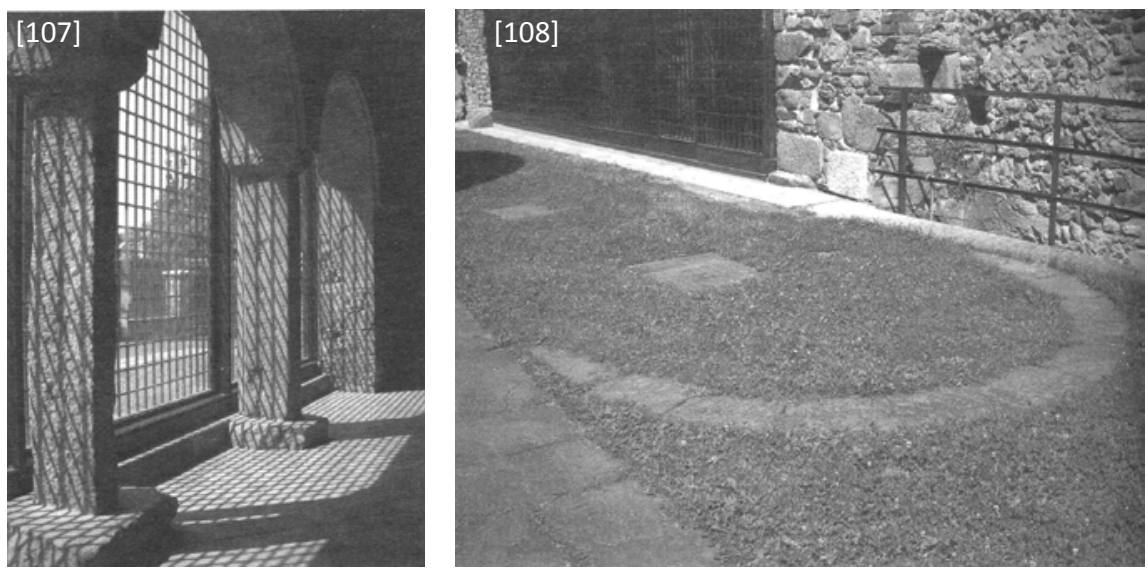

Torres Balbás defiende la realización de obra nueva en los casos de absoluta necesidad por peligro de pérdida del monumento. En tal caso, defiende la obra realizada "con materiales modernos y en estilo moderno, como se realizó siempre hasta nuestros tiempos de restauraciones". Y alude al concepto de armonía para que las adiciones y el monumento "adquieran un pleno valor reunidos". En esta línea, Torres Balbás advierte que el riesgo a la hora de crear nuevas adiciones a los monumentos, no está en el carácter moderno de la actuación, sino en las limitaciones del autor. ${ }^{121}$ Un arquitecto mediocre creará una obra "insignificante, vulgar e inexpresiva, pobre de concepto y mezquina de ejecución", mientras que la obra de "un verdadero artista, por revolucionarias que sean las formas que dé a sus creaciones, siempre armonizarán con las de los artífices medievales que fueron también grandes renovadores". ${ }^{122}$

Para Antón Capitel es clave la cuestión de la calidad y el papel de los añadidos que modifican la unidad de la obra original. Capitel entiende que los añadidos, además de ser testigos históricos del monumento, también suelen ser "ejercicios arquitectónicos de altísimo nivel en cuanto se plantearon y resolvieron uno de los problemas más difíciles y ambiciosos de la disciplina compositiva, armonizar una obra anterior con una arquitectura contemporánea que obligadamente ha de buscar recursos técnicos y formales capaces de lograrlo". ${ }^{123}$

\subsection{El contraste de las vanguardias}

Para la arquitectura moderna, ya no se permitirá hacer historicismo de nueva planta pero tampoco se hablará de intervenir sobre los edificios históricos, más allá de su conservación por sus valores arquitectónicos y culturales. Al evitar la reflexión sobre la arquitectura histórica y enfocar el interés por las nuevas posibilidades formales impulsadas por las vanguardias, se producirá habitualmente un contraste a modo de collage entre arquitecturas modernas y antiguas. 
Como indica Ignasi de Solà-Morales, las técnicas de fotomontaje empleadas por los arquitectos modernos subrayan este contraste. Pero estos contrastes no buscan desautorizar la arquitectura histórica, sino utilizarla como material que permite hacer destacar la nueva arquitectura. Como dice Le Corbusier, "Ias nuevas dimensiones modernas y la puesta en valor de los tesoros históricos aportan una gracia encantadora". ${ }^{124}$

Para Alois Riegl, la actitud del comienzo del siglo XX se caracteriza por la búsqueda del contraste entre novedad y vetustez. Riegl define el valor de antigüedad o vetustez (Alteswert) de la arquitectura histórica como un valor subjetivo, puramente psicológico, producido por lo antiguo. Ya no interesa la información contenida en la obra de arte, sino que lo que se aprecia es el testimonio de la temporalidad que un monumento le ofrece, la manifestación del transcurrir del tiempo histórico. De la misma manera, el valor de lo nuevo viene dado por la perfección de los nuevos sistemas de producción, que ofrecen un desafío al paso del tiempo, de tal manera que la puesta en relación de ambos momentos, el histórico y el nuevo, refuerza su valor. ${ }^{125}$

Sin embargo, como apunta Ignasi de Solà-Morales, más allá de las diferencias evidentes, existe una sensibilidad común entre restauradores y modernos frente al material histórico y a su lectura. En ambos casos se busca el contraste entre las texturas y tonos de la arquitectura antigua y la pura geometría de la nueva. ${ }^{126}$ Así, mientras que en la Carta de Atenas de los restauradores de 1931 se defiende "el empleo juicioso de todos los recursos de la técnica moderna" y el empleo de materiales nuevos reconocibles en la anastilosis de ruinas, en la Carta de Atenas de 1933, surgida de los CIAM, se indica que no se tolerará bajo ninguna forma "el uso de estilos del pasado, bajo pretextos de estética, en las construcciones nuevas erigidas en las zonas históricas" ya que ello produciría consecuencias nefastas.

En esta línea se enmarcan arquitecturas como las de Le Corbusier o Mies van der Rohe, quienes más allá de las apariencias, beberán de la historia de la arquitectura para llevar a cabo sus composiciones arquitectónicas, pero a través de un proceso de abstracción y esencialización formal, propiciados por las posibilidades de los nuevos materiales, buscarán crear nuevas concepciones espaciales radicalmente distantes de la arquitectura tradicional.

\subsection{La reinterpretación de la historia desde la arquitectura}

Frente a las posturas más vanguardistas destacan otras actitudes que ven en la historia una fuente irrenunciable para la creación arquitectónica. Así, Adolf Loos defenderá la formación clásica como base de la nueva arquitectura por haber demostrado su valor de permanencia y universalidad en el tiempo y en el espacio, pero entenderá que los nuevos tiempos han superado la necesidad del ornamento y han aceptado las formas esenciales llevadas a su "pura y simple construcción". ${ }^{127}$

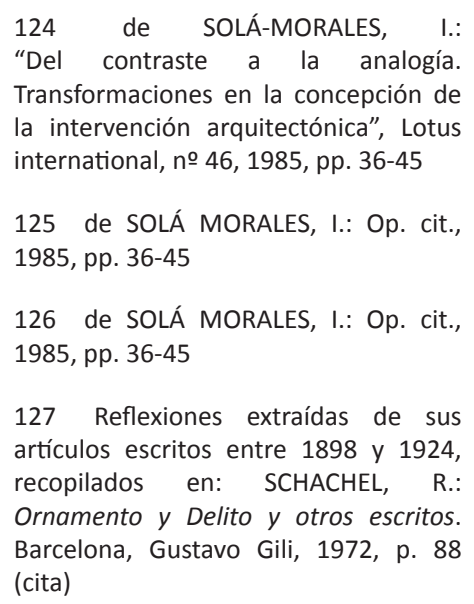


128 Reflexiones extraídas de sus artículos escritos entre 1898 y 1924, recopilados en: SCHACHEL, R.: Ornamento y Delito y otros escritos. Barcelona, Gustavo Gili, 1972, p. 247 (cita)

129 ALONSO DEL VAL, M.A.: "La arquitectura como límite". Arquitectura, no 274, Madrid, Ed. COAM, 1988, p. 31

130 de SOLÁ MORALES, I.: Op. cit., 1985, pp. $36-45$

[109] Ayuntamiento de Göteborg. Diferentes propuestas para la fachada principal. (WREDE: 1983)

[110] Ayuntamiento de Göteborg. Vista actual de la fachada principal. (Erik Gunnar Asplund: <www.erikgunnarasplund.com>)

[111] Ayuntamiento de Göteborg. Planta. (WREDE: 1983)

[112] Ayuntamiento de Göteborg. Patio interior. Vista desde el edificio preexistente hacia la ampliación. (Erik Gunnar Asplund: <www.erikgunnarasplund.com>)
Para Loos la nobleza de los materiales y la calidad del trabajo compensan la ausencia de ornamentación, pues la belleza viene determinada por la adecuación práctica del objeto y la transmisión de sensaciones a través de la materia y la forma, donde ambas cumplen una relación intrínseca. Loos abogará por conservar los sistemas constructivos tradicionales si las nuevas técnicas no suponen mejoras, y entenderá la forma como resultado del proceso proyectual y no como objetivo. Además defenderá la transformación de la arquitectura del pasado afirmando que "lo de hoy debe construirse sobre lo de ayer; del mismo modo como lo de ayer se construyó sobre lo de anteayer". ${ }^{128}$

Esta línea cuyo origen podría remitirse al siglo XVIII y las teorías de Laugier, y que en el siglo XIX retomarán Schinkel y Semper, en los inicios del siglo XX se verá reflejada en las obras de arquitectos como Berlage, Otto Wagner o el propio Loos. Ya en los años 30 Erik Gunnar Asplund llevará a cabo la ampliación del Ayuntamiento de Göteborg, un interesante ejemplo de relación entre antiguo y nuevo (ej.51).

Ejemplo 51. Ayuntamiento de Göteborg. Erik Gunnar Asplund.

En esta actuación Asplund buscará una solución que proporcione la identidad de unidad al conjunto antiguo-nuevo. "Asplund Llega a un compromiso difícil y realmente magistral porque aúna gran parte de los valores de la nueva arquitectura sin perder la presencia de aquello que constituye el germen del proyecto". ${ }^{129}$ "Lo que parece marcar la pauta es la interpretación de los rasgos dominantes en el edificio antiguo con el fin de hacerse eco de ellos en la parte que se trataba de añadir". A través de la analogía, entre los datos relevantes del edificio histórico y las nuevas formas de la ampliación, mediante una "controlada dosificación de las relaciones entre semejanza y diversidad", se obtiene una propuesta equilibrada con la preexistencia. ${ }^{130}$
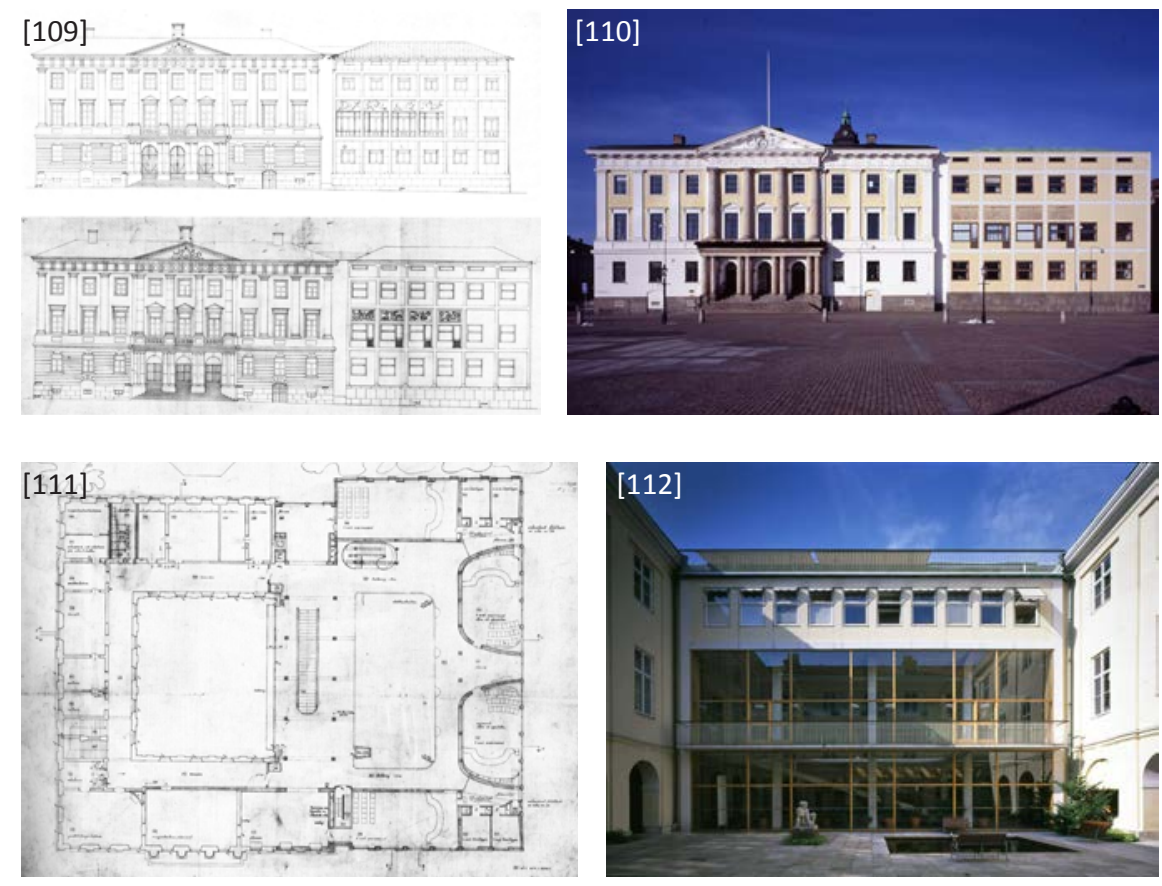

Evolución de los criterios de intervención en el patrimonio arquitectónico 
En otra línea se sitúan los arquitectos que emplean la reinterpretación del ornamento para relacionarse con la historia. Este es el caso de arquitectos como Gaudí cuyo estilo modernista armonizará con las arquitecturas góticas en actuaciones como la terminación del templo de la Sagrada Familia de Barcelona o en la restauración de la Catedral de Mallorca (ej.52).

\section{Ejemplo 52. Restauración de la Catedral de Mallorca. Antoni Gaudi. 1912}

En esta actuación Gaudí plantea aportaciones creativas, en una actitud de comprensión del mensaje del monumento, como vehículo para resolver el diálogo entre lo viejo y lo nuevo. En palabras del arquitecto "Hagamos arquitectura sin arqueología: ante todo están las relaciones entre las cosas, en una situación predispuesta; por esto no debemos copiar las formas, sino estar en condición de producirlas dentro de un determinado carácter, poseyendo su espíritu". ${ }^{131}$

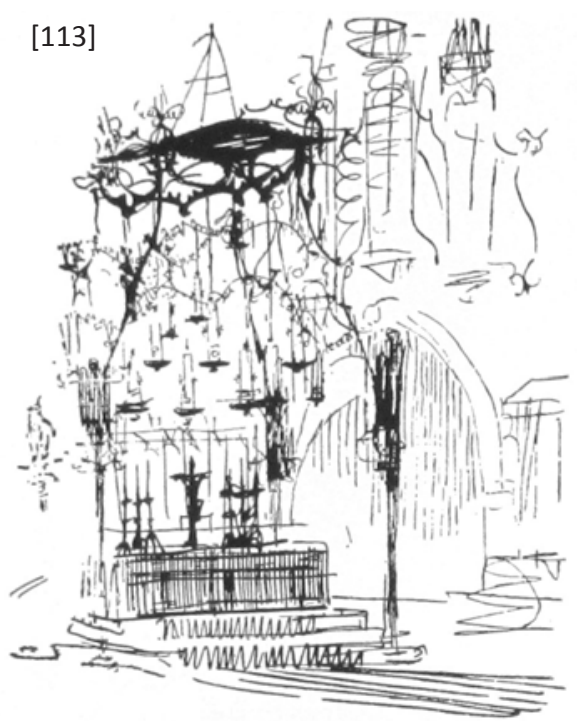

131 GONZÁLEZ, A.: Op. cit., 1999, p. 63
[113] Catedral de Mallorca. Proyecto de nuevo baldaquino para el altar mayor. (Arquitectura, no $244-$ 245,1983, p. 38)

[114] Catedral de Mallorca. Modelo del Baldaquino hecho en cartón, cera y listones de madera. (Arquitectura, no 244-245, 1983, p. 39) 


\section{SIGLO XX. DE LA POSGUERRA A LA CARTA DE VENECIA}

132 SETTE, M.P.: Op. cit., 2001, p. 165166

133 RIVERA, J.: Op. cit., 2000, p. 31

134 SETTE, M.P.: Op. cit., 2001, pp. $168-171$
La gran destrucción producida por la segunda guerra mundial supone actuar con urgencia sobre los monumentos los cuales sufren diversos niveles de deterioro que abarcan desde pérdidas parciales hasta la ruina total del edificio. Además la variedad de sentimientos presentes tras el dramático acontecimiento afectará en gran medida sobre la diversidad de soluciones adoptadas, produciendo un cambio en el discurso de la restauración.

Roberto Pane comenta este cambio indicando que de las motivaciones de gusto o predilección cultural, se pasa a la imperiosa necesidad de salvar los restos, siendo lícita cualquier tipo de actuación, desde actuaciones de conservación de la ruina como testigo de la guerra, hasta la reconstrucción ex novo del monumento desaparecido. Ante esta situación, algunos autores como Giovanonni retoman la restauración en estilo, mientras que otros como Pane apuestan por intervenciones de creación arquitectónica que vayan más allá de la pura restauración. ${ }^{132}$

En los años sesenta, tras la experiencia de las actuaciones de la posguerra, se buscará codificar las reflexiones vertidas en aquellos años a través de los escritos de personajes como Renato Bonelli, Cesare Brandi o mediante documentos normativos como la Carta de Venecia.

En España, durante la dictadura franquista, los criterios de intervención estarán marcados por la Dirección General de Bellas Artes y por los arquitectos de las siete zonas que mantenían las teorías francesas del siglo XIX, buscando devolver al monumento sus características originarias mediante la pureza del estilo. ${ }^{133}$

\subsection{La reconstrucción de la posguerra. La repristinación}

Los criterios de las Cartas de restauración orientados hacia la mínima intervención y la distinción producen resultados satisfactorios cuando se actúa sobre monumentos levemente dañados, pero se muestran insatisfactorios cuando los trabajos se realizan sobre monumentos que han perdido en gran parte o totalmente su definición formal.

Cuando las pérdidas son de partes considerables del monumento el problema se encuentra en que no es posible mantener el criterio de la mínima intervención y la distinción prevista para pequeñas integraciones, por lo que ante la falta de mecanismos se acaba optando por la repristinación. En ocasiones se aprovecha la coyuntura para devolver el edificio a un estado histórico anterior al existente en el momento de su destrucción, con la convicción de que una formulación precedente, tal vez revelada por los daños, posea mayor calidad y sea preferible. Este es el caso de la Iglesia de Santa Clara en Nápoles, donde perdida por completo la decoración barroca, se decide recuperar la estructura medieval original (ej.53). ${ }^{134}$ 
Ejemplo 53. Iglesia de Santa Clara, Nápoles. G. Rosi, A. Rusconi. 1953

La desaparición del revestimiento barroco, saca a la luz las estructuras medievales que se consolidan e integran con cierta libertad interpretativa, pero aceptada por muchos críticos por la excepcionalidad de la situación. Se busca distinguir los nuevos añadidos mediante la simplificación de los elementos decorativos de los elementos estructurales, mientras que los grupos escultóricos supervivientes se montan y reintegran con estuco. ${ }^{135}$
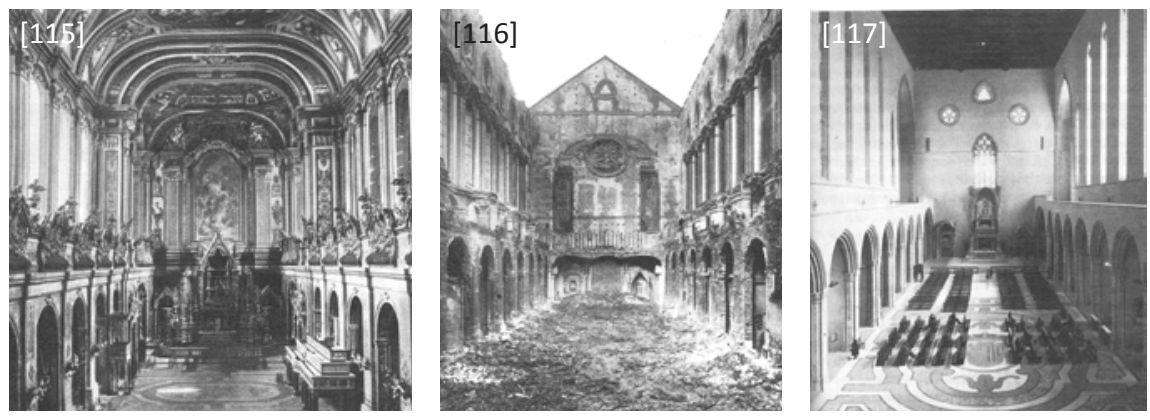

Cuando la desaparición del monumento es total se dan dos situaciones distintas. Si el monumento está compuesto por sillares de piedra, se justifica la repristinación como recomposición por "anastilosis" (ej.54). Mientras que si el monumento está construido con fábricas de ladrillo se acepta su repristinación por cuestiones prácticas, culturales, humanas y sicológicas especiales (ej.55). ${ }^{136}$

Ejemplo 54. Puente de Santa Trìnita, Florencia. R. Gizdulich. 1958

Se reconstruye el monumento reproduciendo con cuidado el original desaparecido. Para ello se emplean los mismos materiales, utilizando incluso los fragmentos caídos al fondo del río, y se recolocan con técnicas tradicionales.
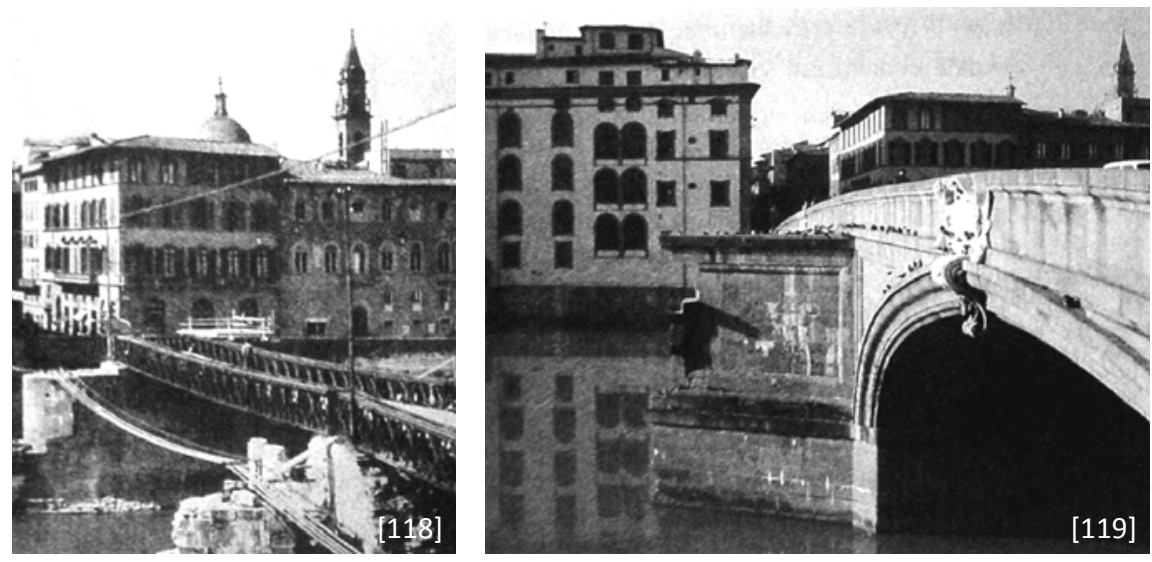

135 SETTE, M.P.: Op. cit., 2001, p. 171

136 SETTE, M.P.: Op. cit., 2001, p. 172
[115 y 116] Iglesia de Santa Clara. Vista interior antes y después de los daños bélicos. (BORIANI: 2008, p. 14)

[117] Iglesia de Santa Clara. Vista interior después de la restauración. (BORIANI: 2008, p. 15)

[118] Puente de Santa Trìnita. Imagen anterior a la reconstrucción. (SETTE: 2001, p. 175)

[119] Puente de Santa Trìita. Imagen después de la reconstrucción. (SETTE: 2001, p. 175) 
137 GAZZOLA, P.: II ponte di Castelvecchio a Verona. Valdonega, Verona, 1951, p.50. Texto extraído del libro: BORIANI, M.: "La teoría e la prassi del restauro italiano nel secondo dopoguerra". En Progettare per il costruito. Dibattito teorico e progetti in Italia nella seconda metà del XX secolo. Milano, Ed. CittàStudi Edizioni, 2008, p.14

138 PAGANO, 1943, p.6. Extraído de: BORIANI, M.: "La teoría e la prassi del restauro italiano nel secondo dopoguerra". En Progettare per il costruito. Dibattito teorico e progetti in Italia nella seconda metà del XX secolo. Milano, Ed. CittàStudi Edizioni, 2008, p.17

139 PICA, 1943, pp. 3-6. Extraído de: SETTE, M.P.: Op. cit., 2001, p. 174

140 PICA, "Dichiarazione iniziale, 1943, p.6. Extraído de: BORIANI, M.: "La teoría e la prassi del restauro italiano nel secondo dopoguerra". En Progettare per il costruito. Dibattito teorico e progetti in Italia nella seconda metà del XX secolo. Milano, Ed. CittàStudi Edizioni, 2008, p.17
Ejemplo 55. Ponte di Castelvecchio y Ponte di Pietra en Verona. Piero Gazzola Piero Gazzola reconstruye el Ponte di Castelvecchio y el Ponte di Pietra en Verona, recomponiéndolos con materiales originales e integrando con materiales análogos las partes destruidas. Gazzola actúa sabiendo que los principios de la Carta del restauro no permiten la reconstrucción, pero lo justifica diciendo que la parte destruida representaba una pequeña parte del total pero muy significativa y necesaria desde el punto de vista ambiental, cuya falta reducía el valor del complejo arquitectónico. ${ }^{137}$
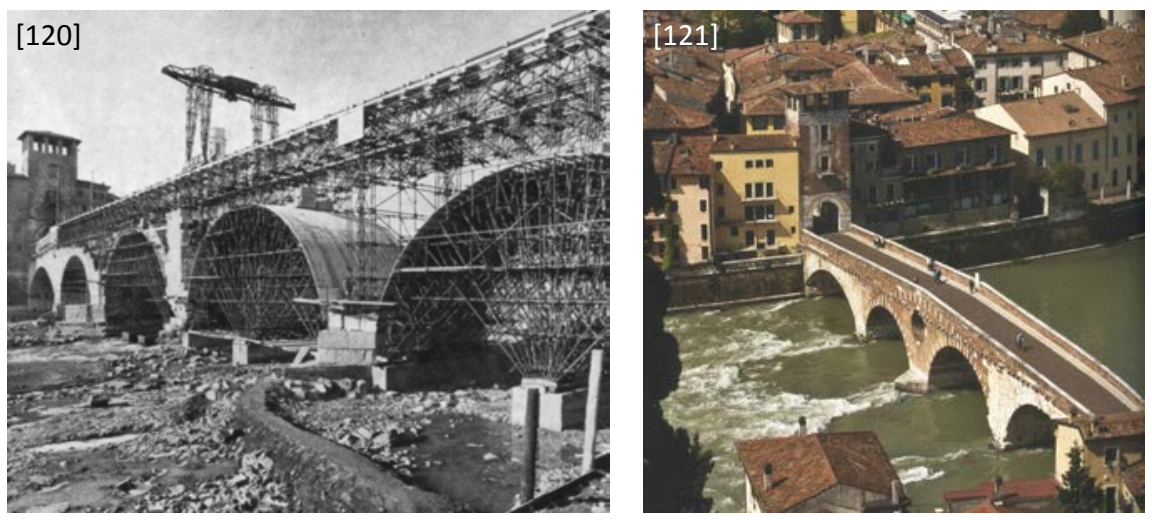

\subsection{La reconstrucción de la posguerra. Las actuaciones críticas}

Frente a las actuaciones de repristinación, surgen diversas críticas que alertan del peligro de falsificación de las reconstrucciones miméticas. En 1943 Giuseppe Pagano rechaza la mímesis por la imposibilidad técnica y material, por ser irrespetuoso con la originalidad de lo antiguo, por suponer un gasto económico alto, y por respeto al valor estético propio de la ruina. ${ }^{138}$

Pero la restauración científica impulsada por Giovannoni no da soluciones alternativas adecuadas. Para Agnoldomenico Pica el problema de la restauración científica es que trata a los monumentos como piezas de coleccionista para ser contempladas y se centra en la resolución de daños menores. Frente a estos métodos inoperativos Pica reivindica una restauración moderna que a través de lo nuevo sea capaz de resolver los problemas de un edificio gravemente dañado. ${ }^{139}$

Pero Pica, consciente de la dificultad de relacionar lo nuevo con lo antiguo, advertirá de la necesidad de una reflexión meditada de cada actuación: "será una sutil cuestión de sensibilidad y de medida, será necesario saber distinguir donde conviene someterse o distinguirse, donde atreverse a contaminarse y donde mantener el contraste entre antiguo y moderno". Y añadirá que "nuestra arquitectura no habrá dado la máxima prueba de madurez y firmeza hasta que no haya sabido medirse a este análisis". ${ }^{140}$ 
En este sentido es interesante la reflexión de Ranuccio Bianchi Bandinelli acerca de los peligros de la reconstrucción de las ciudades dañadas por la guerra, advirtiendo no sólo de la falsificación de la repristinación sino también del peligro opuesto consistente en la reconstrucción indiscriminada con hormigón y vidrio. ${ }^{141}$ En todas estas reflexiones se hace evidente la necesidad de un camino intermedio entre la repristinación y la arquitectura moderna que permita alcanzar un equilibrio entre lo antiguo y lo nuevo. Algo que ya se venía planteando desde hacía años, aunque de manera algo tímida, y que ahora, con las pérdidas producidas por la guerra, se hacía urgente resolver. Así, surgirán ideas como las de Ambrogio Annoni encaminadas a recuperar ciertos caracteres volumétricos y arquitectónicos de las partes destruidas pero sin reproponerlos en su integridad. ${ }^{142}$

En esta línea puede insertarse la obra iniciada en aquellos años por el propio Annoni, y desarrollada por Lilliana Grassi sobre el ex Ospedale Maggiore de Milán (ej.56), que abarca todo tipo de actuaciones en función de las necesidades de cada parte del edificio; o también la intervención de Hans Döllgast en la Alte Pinakothek en Múnich (ej.57), que muestra una evolución desde propuestas más modernas a otras más atentas a la preexistencia. Ambas obras apuestan por hacer evidente la destrucción material de la guerra, resaltando la desnudez de las partes completadas, la fragmentación de las líneas de contacto o incluso en el caso del Ospedale la conservación en estado de ruina de algunos elementos. Esta estética de la fábrica de ladrillo desnuda será retomada por algunos arquitectos modernos, como Lewerentz, Kahn y otros, que verán en la arquitectura incompleta de la ruina un reflejo de la realidad cultural del momento.

\section{Ejemplo 56. Restauración del ex Ospedale Maggiore de Milán. Liliana Grassi.} 1947-66

El edificio de origen renacentista, fue iniciado por Filarete en 1456, y completado en fases sucesivas a lo largo de la historia. Los bombardeos producidos en 1943, destruyen partes del edificio original, lo que se suma a las alteraciones formales y estructurales producidas sobre el mismo a lo largo del tiempo. ${ }^{143}$ El criterio de actuación es el de tener en cuenta tanto el nuevo uso, como sede universitaria, como la importancia de la preexistencia.

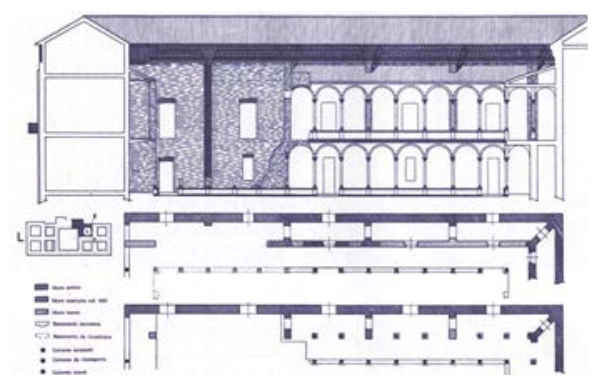

[122]

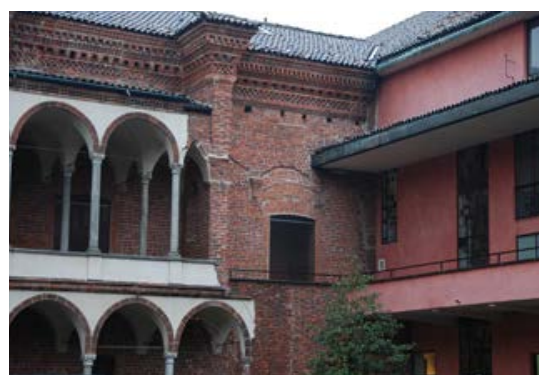

[123]
141 BIANCHI BANDINELLI, 1945 (1995, p.52). Extraído de: BORIANI, M.: "La teoría e la prassi del restauro italiano nel secondo dopoguerra". En Progettare per il costruito. Dibattito teorico $e$ progetti in Italia nella seconda metà del XX secolo. Milano, Ed. CittàStudi Edizioni, 2008, pp.6-8

142 ANNONI, 1946, P.24. Extraído de: BORIANI, M.: "La teoría e la prassi del restauro italiano nel secondo dopoguerra". En Progettare per il costruito. Dibattito teorico e progetti in Italia nella seconda metà del XX secolo. Milano, Ed. CittàStudi Edizioni, 2008, p.16

143 GRASSI, L.: Lo "spedale di poveri" del Filarete : storia e restauro. Milano, Ed. Università degli studi di Milano, 1972, p.36
[122] Ex Ospedale Maggiore. Alzado y proyecto de restauración de la fachada noreste del claustro de la "Ghiacciaia" (REPISHTI: Lotus, 2010, no 144 , p. 128)

[123] Ex Ospedale Maggiore. Vista desde el interior del claustro de la "Ghiacciaia" tras la intervención de Liliana Grassi. (Imagen del autor.) 
[124 y 125] Ex Ospedale Maggiore. Actuación sobre la fachada recayente a la calle Francesco Sforza. (Imágenes del autor)

[126] Ex Ospedale Maggiore. Alzado y proyecto de restauración de la fachada recayente a la calle Francesco Sforza. (REPISHTI: Lotus, 2010, no 144, , p. 127)

[127] Vista de las ruinas de la Alte Pinakotheke en 1949. (NERDINGER: Casabella, no 636, 1996, pp. 47 y 52)
En la actuación sobre el gran claustro barroco (1947-58), se recomponen los pórticos abatidos por las bombas, pero se dejan incompletas aquellas zonas donde no es posible recuperar el material auténtico, mediante un sistema de diferenciación a base de un teselado de la superficie, evitando así falsas restituciones. ${ }^{144}$

En la fachada recayente a la calle Francesco Sforza se realizan numerosos estudios para dar una solución adecuada al vacío producido, incluida la reconstrucción integral siguiendo el estilo original. Sin embargo, se entiende que esta solución "no habría podido justificarse culturalmente". ${ }^{145}$ Finalmente se opta por adoptar diferentes soluciones que tratan de recomponer los tramos de fachada desaparecidos pero haciendo evidente la distinción entre lo nuevo y lo antiguo, y resaltando cierto aspecto de ruina.

En la actuación sobre el Claustro de la "Ghiacciaia” (1961-66) Liliana Grassi actúa reconstruyendo con materiales recuperados sólo dos de los lados, ya que de los otros lados no quedaban restos originales. Lo hace mostrando con claridad el estado ruinoso producido por los bombardeos, mediante la anastilosis de los fragmentos recuperados, en una actuación que se muestra inacabada. ${ }^{146}$

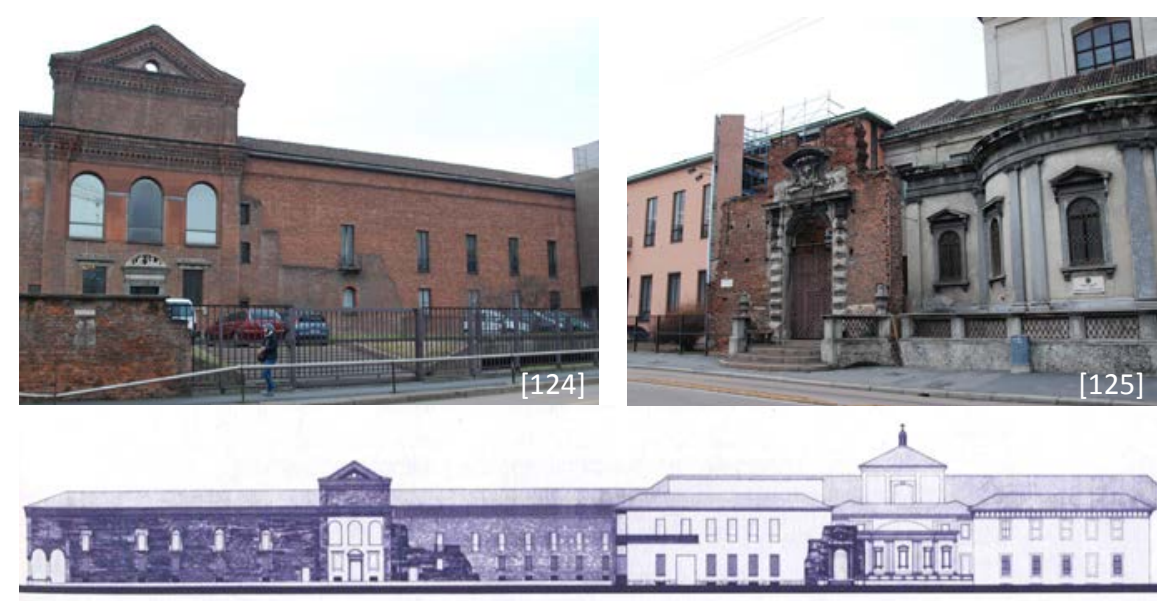

[126]

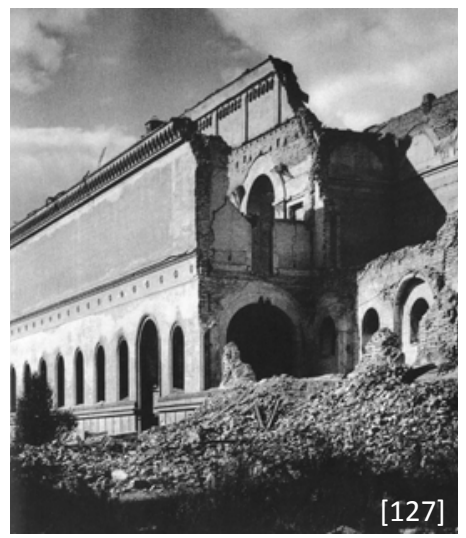

Ejemplo 57. Alte Pinakothek en Múnich. Hans Döllgast. 1952-57

El museo construido entre 1826 y 1836 por el arquitecto Leo von Klenze, de estilo clásico, es parcialmente destruido por los bombardeos de la segunda guerra mundial. La escasez económica permite llevar a cabo un proyecto de reconstrucción, frente a otras propuestas de demolición y construcción de un nuevo edificio. Döllgast propone completar el edificio respetando las fachadas destruidas y manteniendo visibles las heridas producidas por las bombas, pero realizando algunas modificaciones importantes en el edificio como la reubicación del acceso principal y las escaleras, rediseñando con ello el recorrido funcional del edificio. ${ }^{147}$ Inicialmente Döllgast realiza una estructura provisional de protección del edificio, construida a base de siete tubos de acero de $24 \mathrm{~cm}$ de diámetro, sosteniendo la cubierta reconstruida para recuperar la envolvente del edificio original. En una de sus propuestas Döllgast propone mantener esta estructura 
y cerrar el espacio con un muro de vidrio que diferenciara con claridad lo antiguo de lo nuevo. Finalmente se decide por lo que él mismo denomina una "reconstrucción creativa", consistente en la abstracción del muro de fachada original y su traducción al estilo moderno, mediante la construcción de un muro de ladrillo visto, con piezas recuperadas, dando al edificio un aspecto constructivo romano. El muro nuevo mantiene las líneas generales de la composición original al reproducir el ritmo de los huecos, impostas y cornisas. Los tubos de acero pierden su función portante, pero permiten recordar el ritmo de la logia destruida. ${ }^{148}$
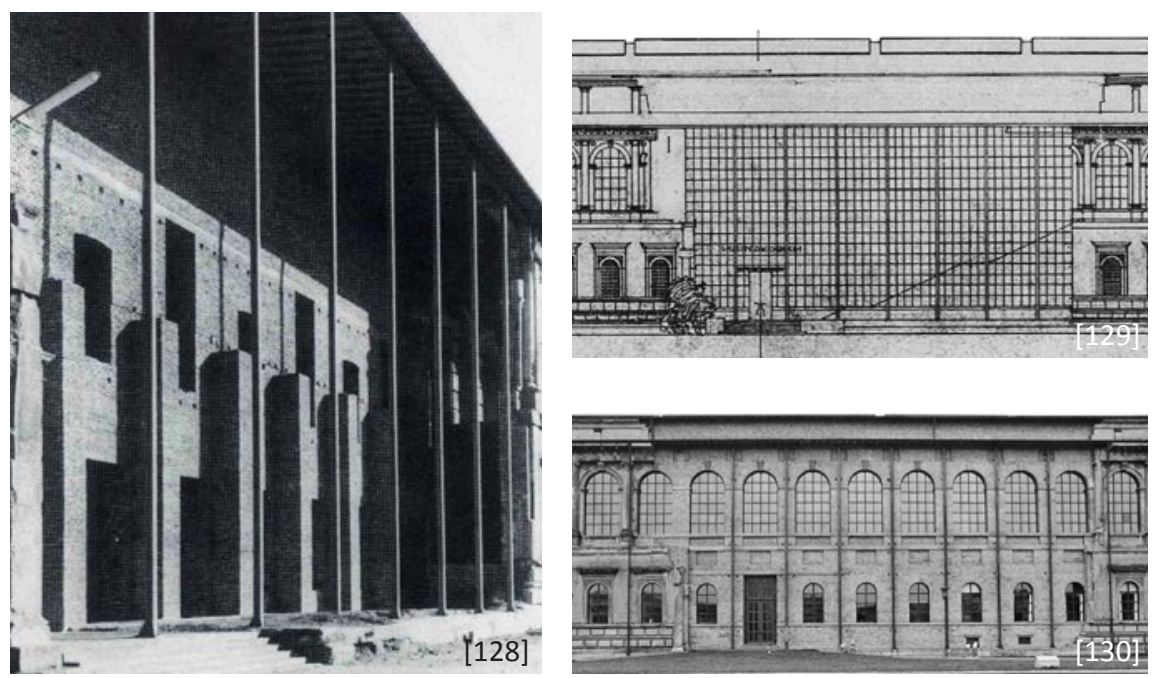

147 NERDINGER, W.: “Hans Döllgast. Ricostruzione della Alte Pinakothek a Monaco". Casabella no636, AgostoLuglio 1996, p. 48

148 NERDINGER, W.: Op. cit., 1996, p. 50

149 PANE, 1944, p.12. Extraído de: SETTE, M.P.: Op. cit., 2001, p. 176

150 PANE, 1950, p.12. Extraído de: SETTE, M.P.: Op. cit., 2001, p. 174

151 ROGERS, 1955, 1957 y 1958. Extraído de: BORIANI, M.: "La teoría e la prassi del restauro italiano nel secondo dopoguerra". En Progettare per il costruito. Dibattito teorico e progetti in Italia nella seconda metà del XX secolo. Milano, Ed. CittàStudi Edizioni, 2008, pp. $20-21$

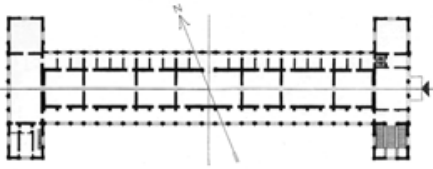

[131]

Ante la gran dificultad de intervenir sobre las construcciones destruidas y la gran diversidad de casos presentes, Roberto Pane reclama la individualidad de cada caso y no descarta la eliminación de elementos si con ello se busca recuperar la belleza de la obra: "se deberá siempre enjuiciar si ciertos elementos tienen o no carácter artístico, porque, en caso negativo, aquello que enmascara u ofende imágenes de verdadera belleza será completamente legítimo abolirlo". ${ }^{149}$ Por todo ello Pane reclamará la necesaria creatividad del arquitecto restaurador y no sólo el conocimiento de la crítica y la historia. ${ }^{150}$

En la búsqueda por la relación entre modernidad y tradición surgen arquitectos que ensayarán con diferentes estrategias proyectuales. Entre ellos Ernesto Nathan Rogers impulsa una mirada crítica a la modernidad, en la búsqueda de un lenguaje formal que evite el contraste y apueste por la continuidad dialéctica del proceso histórico, ${ }^{151}$ como demostrará como parte del equipo de arquitectos BBPR en la adaptación museística del Castello Sforzesco (ej.58) o en la Torre Velasca donde de alguna manera se resume esta fusión entre modernidad y tradición. En esta búsqueda pero de manera mucho más transformadora Carlo Scarpa actuará en obras como el Palazzo Abatellis o el Castelvecchio de Verona (ej.59), reinterpretando el edificio histórico y fundiéndolo con sus nuevas aportaciones para configurar un nuevo conjunto de gran valor arquitectónico.

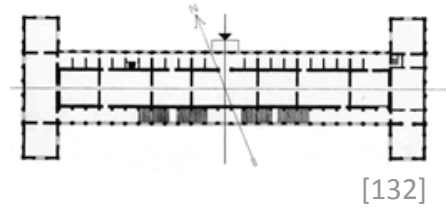

[128] Vista de la estructura provisional de protección diseñada por Döllgast. (NERDINGER: Casabella, no 636, 1996, pp. 47 y 52)

[129 y 130] Propuesta con cerramiento de vidrio y solución definitiva resuelta con muro de ladrillo. (NERDINGER: Casabella, no 636, 1996, pp. 50 y 53)

[131 y 132] Alte Pinakotheke. Planta de Leo van Kleze y planta con la intervención de Dölgast, con indicación del cambio de acceso. (NERDINGER: Casabella, ㄲo 636, 1996, p. 48) 
152 CAPITEL, A.: Metamorfosis de monumentos y teorías de la restauración. Madrid, Alianza Forma, 1988, 2009

153 LOS, S.; FRAHM, K.: Carlo Scarpa. Köln, Ed. Benedikt Taschen, 1994, p. 12, 14,16

154 LOS, S.; FRAHM, K.: Op. cit., 1994, p. 30,32

\section{Ejemplo 58. Adaptación museística del Castello Sforzesco. BBPR}

Para Antón Capitel esta búsqueda de adecuación a las preexistencias ambientales produjo "una actitud, ecléctica y arriesgada, de objetivo ambiental" que se tradujo en un lenguaje "diverso, adaptable, permeable ante las sugerentes posibilidades analógicas de las arquitecturas y los sistemas antiguos de composición, (...) señalando todavía un instrumento fructífero de acción proyectual". ${ }^{152}$

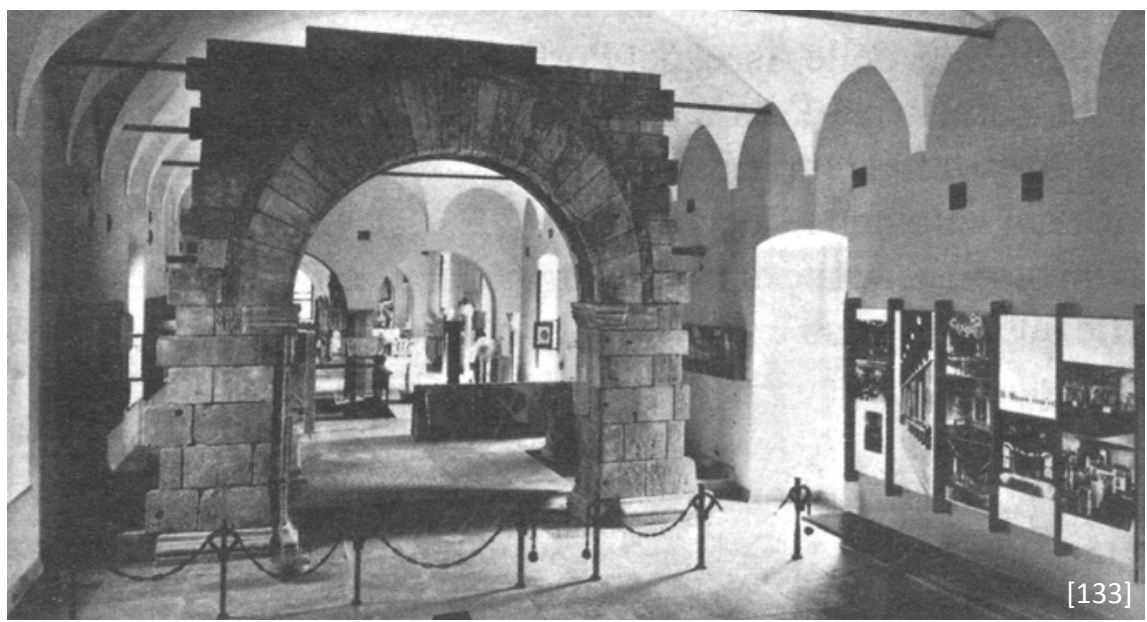

\section{Ejemplo 59. Castelvecchio de Verona}

Scarpa consideraba que la pérdida del ornamento estaba haciendo enmudecer a la arquitectura, por lo que defiende que es fundamental estudiar los puntos de unión entre los elementos que componen el espacio ya que son las uniones las que permiten explicar la razón de ser de las partes en el conjunto. En este sentido Scarpa retoma el concepto de descomposición del espacio introducido por el neoplasticismo por el interés que encuentra en la creación de nuevos mecanismos de unión que permitan recomponer el espacio, y así poder introducir el ornamento sin dar la espalda al lenguaje moderno. ${ }^{153}$ Por lo tanto Scarpa actúa descomponiendo el todo en fragmentos incompletos que hace dialogar para recomponer un nuevo conjunto. ${ }^{154}$
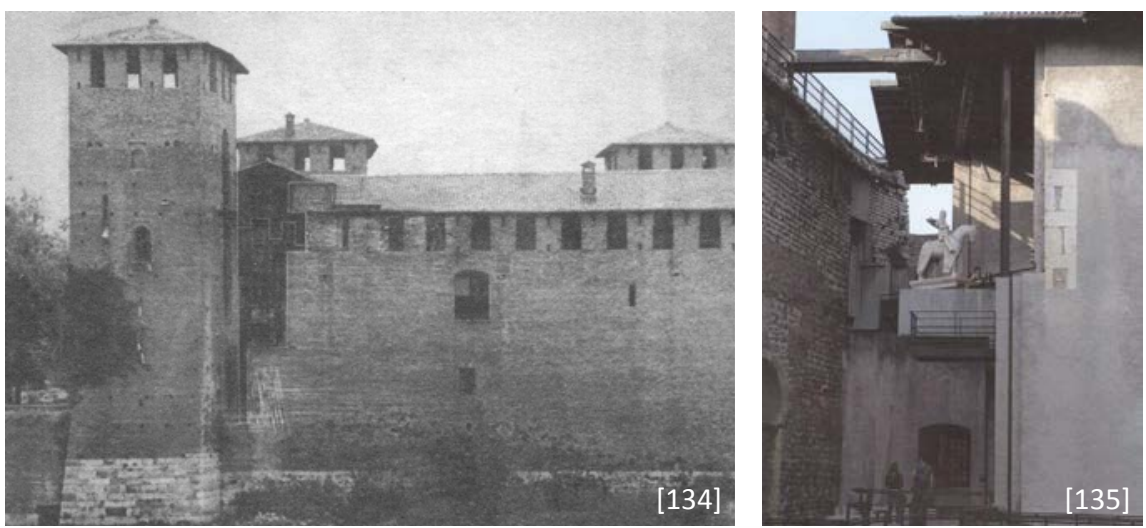

[133] Castello Sforzesco. Una de las salas del museo. (BORANI: 2008, p. 147)

[134] Castelvecchio. Vista de la fachada recortada. (BORANI: 2008, p. 149)

[135] Castelvecchio. Vista de la estatua de Cangrande della Scalla. (CARBONARA: 2011, p. 48) 
En el museo de Castelvecchio, Scarpa busca desentrañar las relaciones existentes entre los diversos períodos de construcción, tratando de hacer visible la historia a través de la yuxtaposición ordenada de sus fragmentos. Los nuevos elementos añadidos se superponen sobre los antiguos, separándose para permitir su lectura con claridad, mientras que a través de las texturas de los materiales se busca establecer un diálogo entre ellos. Es significativa la decisión de demoler un fragmento de fachada para hacer evidentes las diversas capas que componen la construcción, buscando incluso enfatizar la operación mediante la colocación en el nuevo hueco de la estatua de Cangrande della Scala. ${ }^{155}$

Para Ignasi de Solá Morales Carlo Scarpa consigue una analogía con lo antiguo a base de introducir "imágenes rediseñadas de arquitecturas del pasado" a lo largo de un recorrido, permitiendo al espectador establecer asociaciones entre lo histórico y los nuevos elementos. ${ }^{156}$

En España, dentro del devenir paralizante de la dictadura franquista, destaca la actuación realizada por Dionisio Hernándes Gil en la intervención en el Convento de San Benito en Alcántara (ej.60).

\section{Ejemplo 60. Convento de San Benito en Alcantára. Dionisio Hernández Gil. 1962-}

\section{5}

Hernández Gil completa el espacio ocupado por las bóvedas desaparecidas, mediante unas bóvedas tabicadas que retoman la técnica tradicional para configurar una forma moderna y distinta a la del elemento desaparecido. Con ello se busca reinterpretar la tradición desde la modernidad, y así insertar, con armonía, lo nuevo en lo viejo, dejando patente la perdida y la superposición de un nuevo estrato en la historia del edificio. ${ }^{157}$
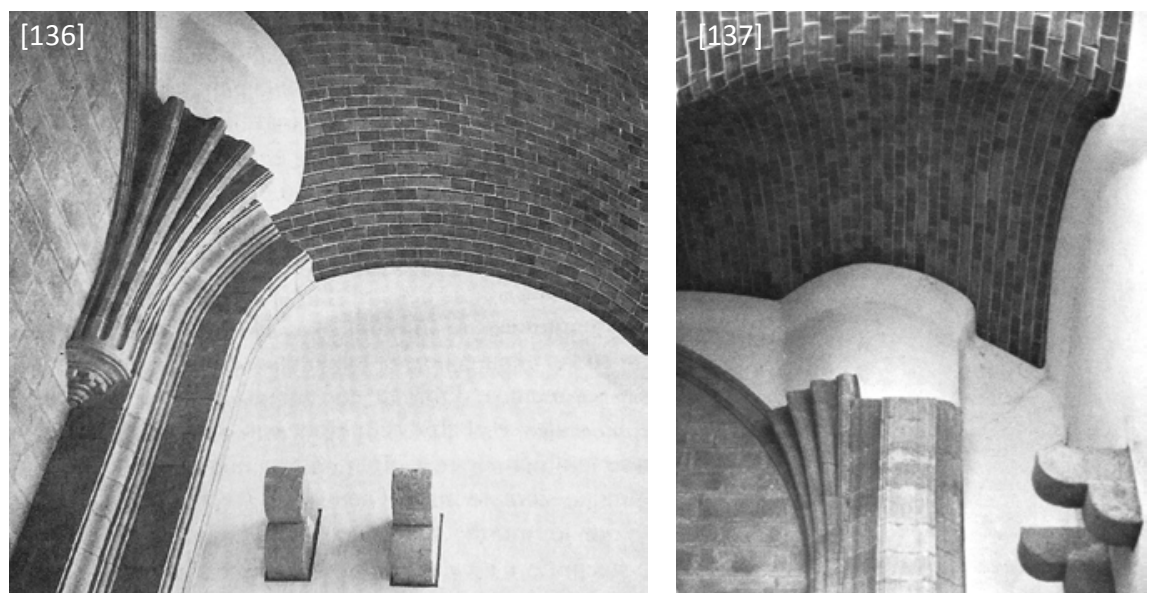

\subsection{La restauración crítica y la Carta de Venecia}

Todas estas reflexiones críticas con la Carta de Atenas, la repristinación y el movimento moderno son sistematizadas por Renato Bonelli en lo que será denominado como el restauro crítico. Bonelli ve la restauración como la unión dialéctica de un proceso crítico y de un acto creativo, de tal manera que se produce una contraposición entre dos impulsos diferentes: por un
155 LOS, S.; FRAHM, K.: Op. cit., 1994, p. $72-89$

156 de SOLÁ MORALES, I.: Op. cit., 1985, pp. 36-45

157 CAPITEL, A.: “En busca de la modernidad pendiente". En: BALDELLOU, M. A.; CAPITEL, A.: Arquitectura española del siglo XX. Madrid: Espasa Calpe. 1995-2001, p. 447

[136] Convento de San Benito. Bóvedas tabicadas tras la intervención de Dionisio Hernández Gil. (CAPITEL. En: BALDELLOU: 1995-2001)

[137] Convento de San Benito. Queda patente la pérdida y la superposición del nuevo estrato. (A.A.V.V.: 1983, p. 16) 
158 BONELLI, voz Restauro architettonico en la Enciclopedia Universale dell'Arte. 1963, col. 344 Extraído de: CARBONARA, G.: La Reintegrazione dell'Imagine. Roma, Bulzoni, 1976, pp. 58-60

159 BRANDI, C.: Teoria del Restauro. Roma, Edizioni di Storia e Letteratura, 1963. (Versión en español: Teoría de la Restauración. Madrid, Ed. Alianza, 1988) Extraído de: SETTE, óp. cit. (2001), pp. 176-178 lado el respeto hacia la realidad de la obra y por otro lado la necesidad de asumir una intervención dirigida a modificar su forma para acrecentar el valor del monumento. El puro interés testimonial es considerado inaceptable, y se da al valor artístico la prevalencia absoluta, por lo que lo primero será identificar la calidad artística del monumento, y toda operación se dirigirá al objetivo de reintegrar y conservar el valor expresivo de la obra, eliminando lo que la disturbe o desfigure, y recomponiendo las partes faltantes mediante un acto crítico-creativo. ${ }^{158}$

Por otro lado Cesare Brandi realiza una amplia y sistemática reconsideración del problema. Para Brandi es fundamental el reconocimiento de la obra de arte, llegando a definir la restauración como "momento metodológico del reconocimiento de la obra de arte, en su consistencia física y en su doble polaridad estética e histórica, con vistas a su transmisión al futuro". Brandi introduce dos axiomas fundamentales:

1. La materia entendida como lugar de manifestación de la imagen. Por lo que hace hincapié en la consistencia física de la obra ya que supone la transmisión de la imagen al futuro.

2. La necesidad de armonía entre la historia y la estética de la obra de arte, lo que deriva en el concepto del "restablecimiento de la unidad potencial de la obra de arte, siempre que esto sea posible sin cometer una falsificación artística o histórica, y sin borrar huella alguna del transcurso de la obra de arte a través del tiempo". ${ }^{159}$

En 1964 se redacta la "Carta de Venecia" en la que destacan conceptos como la utilización del monumento para asegurar su conservación, la insistencia en la conservación del ambiente en sus volúmenes y colores, la posibilidad de supresión de estructuras superpuestas de poco interés advirtiendo que la unidad de estilo no es el fin de la restauración, la necesaria armonía en la restitución de partes faltantes evitando falsificaciones mediante su distinción con el sello de la contemporaneidad, el necesario equilibrio entre las nuevas adiciones y el monumento, y el rechazo de la reconstrucción de ruinas más allá de su anastilosis. A estas cuestiones se sumarán más tarde los conceptos de reversibilidad (Carta Italiana del Restauro, 1972) y de mínima intervención (Carta de Amsterdam, 1975).

A propósito de estas cuestiones es interesante destacar las actuaciones del arquitecto Franco Minissi que, en colaboración directa con Cesare Brandi, propondrá toda una serie de actuaciones que pretenderán "reconstituir" la imagen completa del monumento, sin acudir a su reconstrucción. Mediante el empleo de materiales transparentes modernos se buscará evocar la forma original manteniendo la imagen de ruina inacabada. Una búsqueda de equilibrio que sin embargo no dará buenos resultados debido a que la supuesta inmaterialidad de los añadidos "transparentes" adquirirá una fuerte presencia producida por los reflejos, contrastes de consistencia y textura, y degradación material. (ej.61, 62, 63) 
Ejemplo 61. Villa romana del Casale en Piazza Armerina. Franco Minissi. 1956-60 La intervención de Franco Minissi busca recrear los volúmenes y los espacios internos perdidos a través una reinterpretación del elemento de cubierta, realizado mediante superficies vidriadas cuya transparencia permite la legibilidad del carácter de ruina de las estructuras supervivientes. ${ }^{160}$

Al igual que en el teatro de Eraclea Minoa, la solución realizada por Minissi se ha terminado por desmontar sustituyéndose por una solución en madera de fuerte impacto en el conjunto. Para Emanuele Fidone la nueva solución retoma la idea de Minissi de reconstruir el volumen original, pero lo hace creando unos ambientes completamente cerrados anulando la abstracción de la estructura original. ${ }^{161}$

Para Bruno Messina la solución de Minissi consistía en una adecuación de los extraordinarios mosaicos presentes en la Villa capaz de evocar la volumetría original, y no una reconstrucción de la espacialidad y de las condiciones de luz originales. Mientras que la nueva solución pierde de vista precisamente estos mosaicos que son la única realidad objetiva y singular de la Villa. ${ }^{162}$
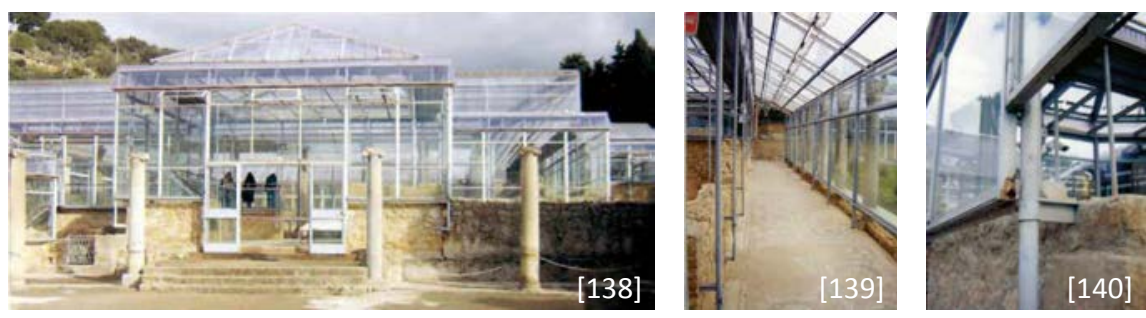

\section{Ejemplo 62. Protección del teatro de Eraclea Minoa. 1963}

Para Claudio Varagnoli en esta obra Minissi acepta la realidad de la ruina y busca la capacidad didáctica del proyecto, apostando por materiales modernos transparentes y reversibles que la pongan en evidencia. ${ }^{163}$

Giovanni Carbonara reflexiona sobre la durabilidad de la actuación de Minissi que si bien se planteaba como la más respetuosa con la imagen de la ruina, con el tiempo se ha deteriorado rápidamente y se ha terminado por sustituir por una cubierta banal. Sin embargo defiende la actuación frente a otras de "mayor impacto", como la del teatro romano de Sagunto, y achaca el problema al tipo de material empleado, por lo que se muestra en contra de que no se haya recuperado el mismo concepto con nuevos materiales. ${ }^{164}$
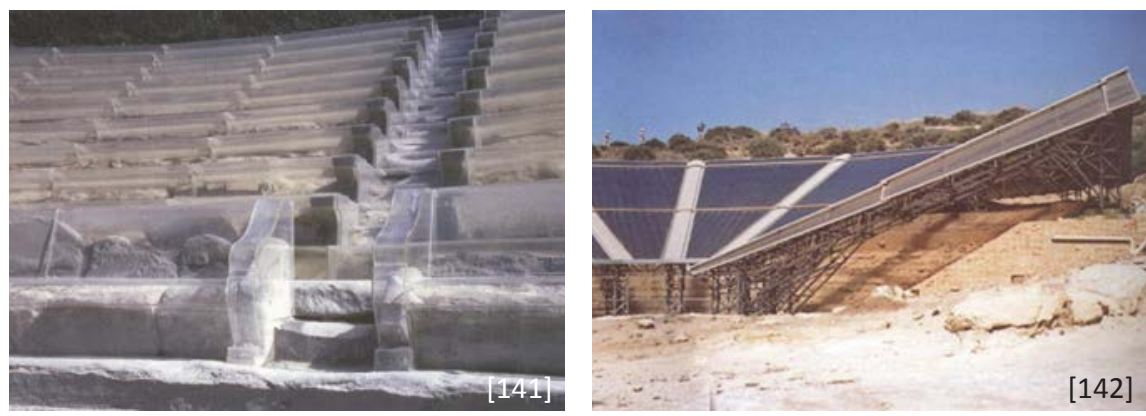

160 CAVALLERI, F.: "Un terzo livello di riflessione: alcuni elementi costruttivi". En Progettare per il costruito. Dibattito teorico e progetti in Italia nella seconda metà del XX secolo. Milano, Ed. CittàStudi Edizioni, 2008, pp. 103-121

161 CORNOLDI, A.; RAPPOSELLI, M.: "Nuovo e antico. Intervista a Emanuele Fidone, Vicenzo Latina e Bruno Messina". En: CORNOLDI, A.; RAPPOSELLI, M.: Emanuele Fidone, Vincenzo Latina, Bruno Messina. 'Restauri' Iblei. Padova, II Poligrafo,2007, p. 18

162 CORNOLDI, A.; RAPPOSELLI, M.: "Nuovo e antico. Intervista a Emanuele Fidone, Vicenzo Latina e Bruno Messina". En: CORNOLDI, A.; RAPPOSELLI, M.: Op. cit., 2007, p. 18

163 VARAGNOLI, C.: "Edifici da edifici: la cicezione del passato nell'architettura italiana, 1990-2000". L'industria delle costruzioni, no 368, Ed. ANCE, 2002, pp. 4

164 CARBONARA, G.: Architettura d'oggi e restauro. Un confronto anticonuovo. Torino, Ed. Utet, 2011, p. 140

[138, 139 y 140] Villa romana del Casale. Vista exterior, vista interior y detalle de la intervención de Franco Minissi en la Villa romana del Casale en Piazza Armerina. (DEZZI: $L^{\prime}$ ingegnere edilizia ambiente territorio, $\mathrm{n}$ ㅇ 11, 2007, p. 53)

[141] Teatro de Eraclea Minoa. Imagen de la actuación de Minissi. (CARBONARA: 2011, p. 139)

[142] Teatro de Eraclea Minoa. Nueva cubierta colocada en sustitución de la actuación de Minissi (CARBONARA: 2011, p. 140) 
165 CARBONARA, G.: La Reintegrazione dell'immagine. Roma, Bulzoni Editore, 1976, fig. 13, 51-52

166 CAPITEL, A.: Metamorfosis de monumentos y teorías de la restauración. Madrid, Alianza Forma, 1988, 2009
Ejemplo 63. Intervención en la iglesia de San Nicolò Regale. 1964

Para Giovanni Carbonara en esta actuación se peca de un exceso de naturalismo al tratar de representar, mediante la estructura metálica, el despiece de los sillares desaparecidos, preocupándose más por "restablecer la representación que la estructura de la imagen". ${ }^{165}$
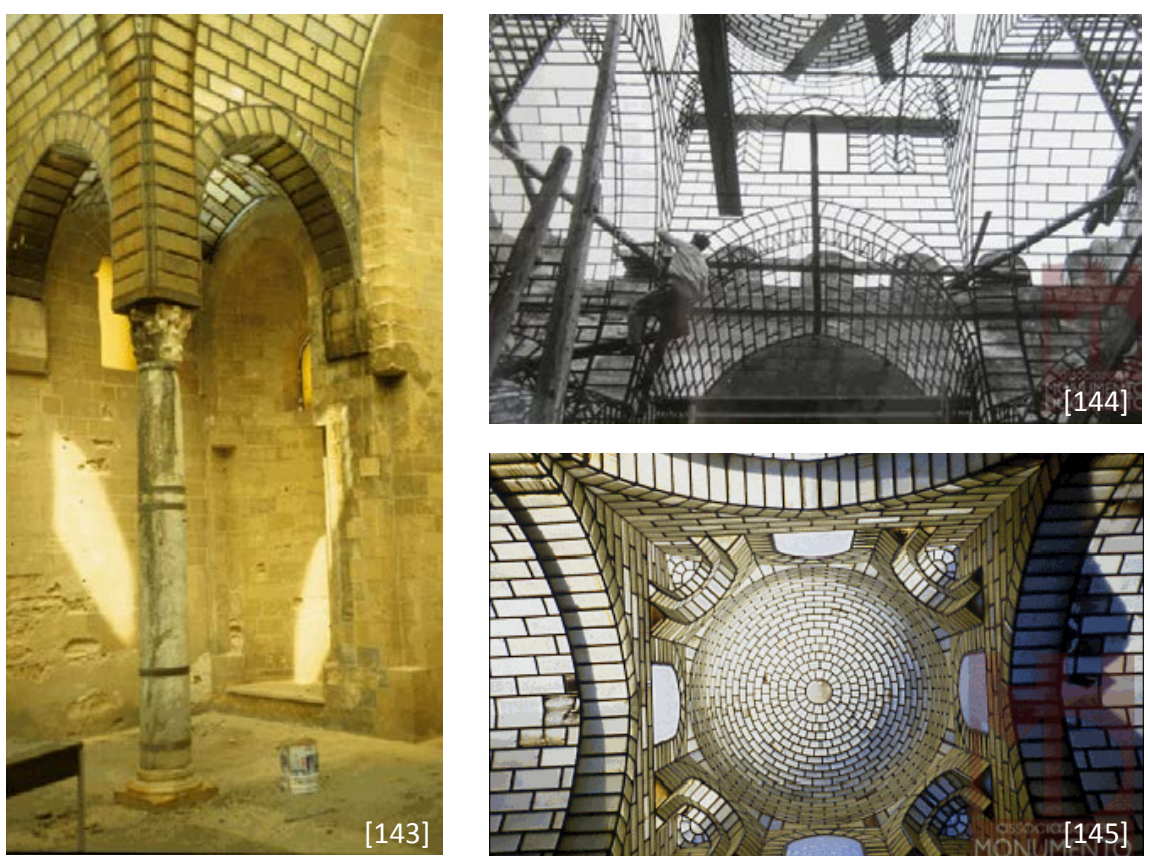

En 1966, Aldo Rossi criticará el concepto de ambiente entendido como algo epidérmico, definido por volúmenes y alineaciones, e insistirá en una definición más profunda del término que trate a la edificación como "tipos" con una estructura formal generalizable, en la que existe una relación intrínseca entre su planimetría y fachada. También hará hincapié en la individualidad de los modos constitutivos de cada ciudad mediante el concepto de "locus", que se deberán identificar e interpretar adecuadamente para trasladarlos a la obra nueva y así obtener la necesaria relación con la ciudad histórica. ${ }^{166}$ 


\section{DEL SIGLO XX AL XXI. TRES VÍAS DE RELACIÓN ANTIGUO-NUEVO.}

En el último tercio del siglo XX se seguirán perfilando las tres vías existentes de intervención sobre el patrimonio: la conservación, la reconstrucción y la innovación. Pero en muchas ocasiones estas vías no se entenderán como excluyentes, sino como ingredientes de una actuación que beberá de todas ellas para alcanzar una solución adecuada a cada caso.

En Italia, las intervenciones estarán muy guiadas por las prescripciones indicadas en las Cartas de restauración. Por un lado surgirán corrientes derivadas de las indicaciones de la restauración crítica, que buscarán devolver la unidad original perdida del monumento pero mediante actuaciones reinterpretativas que expresen la realidad del momento. Conceptos como la reconstrucción tipológica, la reintegración de la imagen o la anastilosis indirecta irán encaminadas a dar solución a esta corriente. Por otro lado permanecerán las actuaciones de conservación orientadas a mantener la autenticidad material de las ruinas. Al mismo tiempo irán ganando presencia las actuaciones de repristinación sobre monumentos devastados por acciones violentas.

En España, la reinstauración de la democracia vendrá acompañada de cambios de gestión del patrimonio, que producirán un giro radical en la intervención sobre los monumentos. Se ampliará drásticamente el número de actuaciones tendentes a asegurar la estabilidad y estanqueidad de los monumentos, así como a dotarlos de un nuevo uso que asegure su conservación, y se enfocarán las restauraciones como problemas generales de arquitectura a resolver desde el proyecto, buscando implicar en la intervención de edificios a los arquitectos más activos en la obra nueva. ${ }^{167}$ El mandato desde las Cartas de Restauración de la diferenciación de las nuevas actuaciones facilitó la actuación de los arquitectos modernos en los edificios y los centros históricos desarrollándose una nueva sensibilidad en la restauración y definiendo un amplio y rico repertorio de soluciones formales de integración entre antiguo y nuevo. ${ }^{168}$

Esto permitirá la adición de nuevos elementos que generarán actuaciones más o menos respetuosas con las preexistencias. Frente a la aparición de actuaciones con contenidos de fuerte contraste surgirá la teoría de la intervención analógica, planteada por Ignasi de Solá Morales y Antón Capitel, que propondrá como objetivo primordial la búsqueda de la armonía entre lo antiguo y lo nuevo mediante la determinación de las leyes compositivas de sus elementos arquitectónicos. Para Capitel "Una interpretación auténtica de la obra podrá llegar a ser tan próxima como contemporánea, insertándose en una intención no neutralista, sino de mejora de lo heredado en el interior de sus potencialidades arquitectónicas, de sus propios valores y sugerencias". ${ }^{169}$

A continuación se expone una selección de ejemplos de intervención sobre el patrimonio arquitectónico agrupados en tres categorías: conservación, repristinación y reinterpretación.
167 HUMANES, A.: "Introducción". En: A.A.V.V.: Intervenciones en el Patrimonio Arquitectónico (1980-1985). Madrid: Dirección General de Bellas Artes y Archivos, 1990, pp. 15-18

168 BOSCH REIG, I.: "Intervención en el patrimonio: un continuo proceso de innovación". En: A.A.V.V.: Las herramientas del arquitecto 2. Valencia, Ed. Ediciones Generales de la Construcción, 2004

169 CAPITEL, A.: “La analogía como instrumento proyectual en los edificios históricos". En: POL, F. (dir.): Arquitectura Recuperada. Madrid: Universidad Internacional Menéndez Pelayo, 1989, p. 17

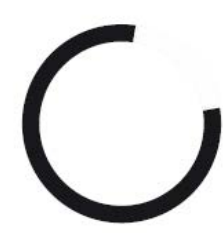

CONSERVACIÓN

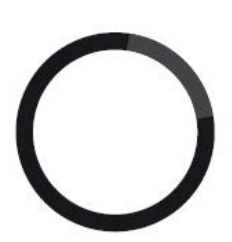

REPRISTINACIÓN

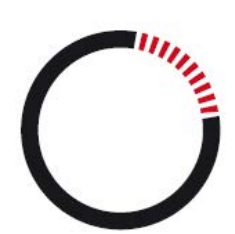

REINTERPRETACIÓN 
170 DEZZI BARDESCHI, M.: “H.1.2. Aprocci Metodologici. Progetto di conservazione. Cura del Costruito". En: ZEVI L.: II manuale del restauro architettonico. Roma, Ed. Mancosu, 2001, H30-H31

171 CARBONARA, G.: Architettura d'oggi e restauro. Un confronto anticonuovo. Torino, Ed. Utet, 2011, p. 47

172 DEZZI BARDESCHI, M.: “H.1.2. Aprocci Metodologici. Progetto di conservazione. Cura del Costruito". En: ZEVI L.: /l manuale del restauro architettonico. Roma, Ed. Mancosu, 2001, H45

\subsection{La conservación}

La vía de la conservación sostiene la congelación de la realidad construida del monumento, manifestando su carácter de ruina. En ocasiones esto supone la pérdida del espacio interior cubierto, quedando el monumento como parte de un paisaje exterior delimitado por sus fábricas. Este es el caso de las abadías de Rievaulx y de Tintern, de la iglesia de Santa Maria della Spasimo en Palermo, o de la catedral de St. Michael en Coventry.

En otras ocasiones se busca dotar de mayor uso al monumento pero sin perder el carácter de ruina conservada. En estos casos se aboga por hacer evidente su autenticidad material mediante la clara distinción de los nuevos elementos que se añaden para garantizar su conservación.

Marco Dezzi Bardeschi defiende esta línea de actuación a través de la critica del culto actual a la imagen extrínseca del monumento que se impone sobre la cultura material que tal imagen ha producido, otorgándose así mayor valor a la apariencia visible que a la consistencia de la fábrica. Así Dezzi Bardeschi se opone a criterios de construcción en estilo, reintegración de la imagen, o "liberación" del monumento por entender que con ello se elimina la historia para reemplazarla por otra nueva. ${ }^{170}$

Dezzi Bardeschi entiende que la adición de nuevos elementos por cuestiones funcionales debe hacerse con un carácter de "plena autonomía y clara legibilidad" respecto a la preexistencia. De tal manera que se lea con claridad la actuación como suma de dos operaciones distintas: la conservación de lo existente, entendido como valor heredado; y la adición de lo nuevo, como nuevo valor aportado. ${ }^{171}$ Para Dezzi Bardeschi el mantener la memoria del derrumbe o de la laguna haciendo reconocible la nueva intervención, "es la mejor manera de recuperar una relación con la historia y con su dimensión progresiva que, de otra manera, tiene el riesgo de disolverse en el mito eterno del presente, la ilusión de la eliminación de los hechos dolorosos que no hemos conseguido prevenir y evitar". ${ }^{172}$

En general se apuesta por la mínima intervención sobre la materia preexistente. Se asume la "contaminación" del monumento con elementos externos de refuerzo y otros elementos que permitan hacer visitables los restos, adiciones que por su propia condición de elementos auxiliares logran diferenciarse de las preexistencias. En el cuidado diseño del detalle de estos elementos están las claves para lograr una buena relación entre lo antiguo y lo nuevo. Los nuevos elementos se separan completamente de los antiguos, mostrando su autonomía, y la materialidad empleada suele acudir a soluciones "ligeras" a base de elementos metálicos, maderas y vidrios.

Sin embargo en ocasiones estos añadidos adquieren excesivo protagonismo y contraste, alterando sustancialmente la imagen previa a la intervención. En este sentido Ignacio Represa indica que en muchos casos el mantenimiento de lagunas y faltantes conlleva una manipulación formal 
que a menudo supone una mayor "agresión", para la integridad plástica del objeto, que la disposición de leves y equilibradas correcciones, que asuman las pérdidas que suponen una situación degradada, y propongan resolverlas mediantes procesos de "redefinición formal" que sumen a los aspectos plásticos de la preexistencia una propuesta arquitectónica. ${ }^{173}$

Es una solución habitual en la actuación sobre restos arqueológicos o ruinas, donde la escala de la pérdida es muy grande, y los nuevos añadidos se plantean como sistemas independientes que se superponen para hacer visitables los restos, o para protegerlos de las inclemencias del tiempo. Pero también es una solución recurrida en el interior de monumentos para adaptarlos a las nuevas necesidades funcionales.

Otro peligro de estas actitudes es que se produzca una conservación indiscriminada de los restos sin una reflexión sobre su valor. Se observa incluso que en ocasiones el excesivo proteccionismo de los restos produce espacios con poco uso que convierten las actuaciones en insostenibles, o que desaprovechan posibilidades de mayor disfrute. Este es el caso del teatro romano de Cartagena, analizado con mayor profundidad en la categoría de reinterpretación, donde la musealización del gran espacio público genera un paisaje contemplativo a modo de un gigantesco monumento a la cultura romana en el centro mismo de la ciudad.

En el caso de la protección de ruinas arqueológicas, generalmente se opta por estructuras que salvan las grandes luces sin introducir pilares intermedios, y permitiendo una iluminación de los restos. Sin embargo no se suele atender a la configuración arquitectónica de las preexistencias. Este es el caso de la actuación en las ruinas romanas de la Olmeda donde el elemento de cerramiento atiende a una reflexión sobre la vibración de los árboles presentes en el paisaje, mientras que las referencias a la arquitectura de la ruina se resuelven con elementos ligeros incorporados en el interior del gran espacio. Frente a este criterio destacan otras actuaciones más preocupadas por el espacio del resto arqueológico como la de Joäo Luis Carrilho da Graça en la Plaza nueva del castillo de San Jorge, comentada en la categoría de reinterpretación, o el proyecto de protección de la villa romana de Valdetorres del Jarama, en Madrid, de José Ignacio Linazasoro, en el que con la nueva arquitectura se recrea el impluvium de la casa romana.

Dentro de esta categoría se pueden mencionar actuaciones como la intervención sobre los mercados de Trajano (ej.64), el monasterio de Carracedo (ej.65), musealización del Ospedale de Santa Maria della Scala en Siena (ej.66), la intervención sobre las termas de Diocleciano de Roma (ej.67), o algunas actuaciones sobre palacios de la ciudad de Pisa realizadas por Massimo Carmassi (ej.68).
173 REPRESA BERMEJO, I.: “La expresión plástica en la degradación". En: REPRESA, I. (dir.): Restauración Arquitectónica II. Valladolid: Universidad de Valladolid, 1998, p. 152 
Ejemplo 64. Mercados de Trajano, Roma. Giorgio Croci, Studio Labics, Luigi Franciosini y otros

En las actuaciones de musealización de la nave principal, destacan los cerramientos realizados con polimetilmetacrilato, que tratan de reducir la presencia de los cerramientos al mínimo al eliminar casi completamente los elementos de carpintería y resolver todo con materiales transparentes de mayor ligereza que el vidrio.

Por otro lado, destacan las intervenciones de conformación de los nuevos recorridos exteriores mediante pasarelas construidas en acero y madera, que se diferencian con claridad respecto a los restos antiguos.
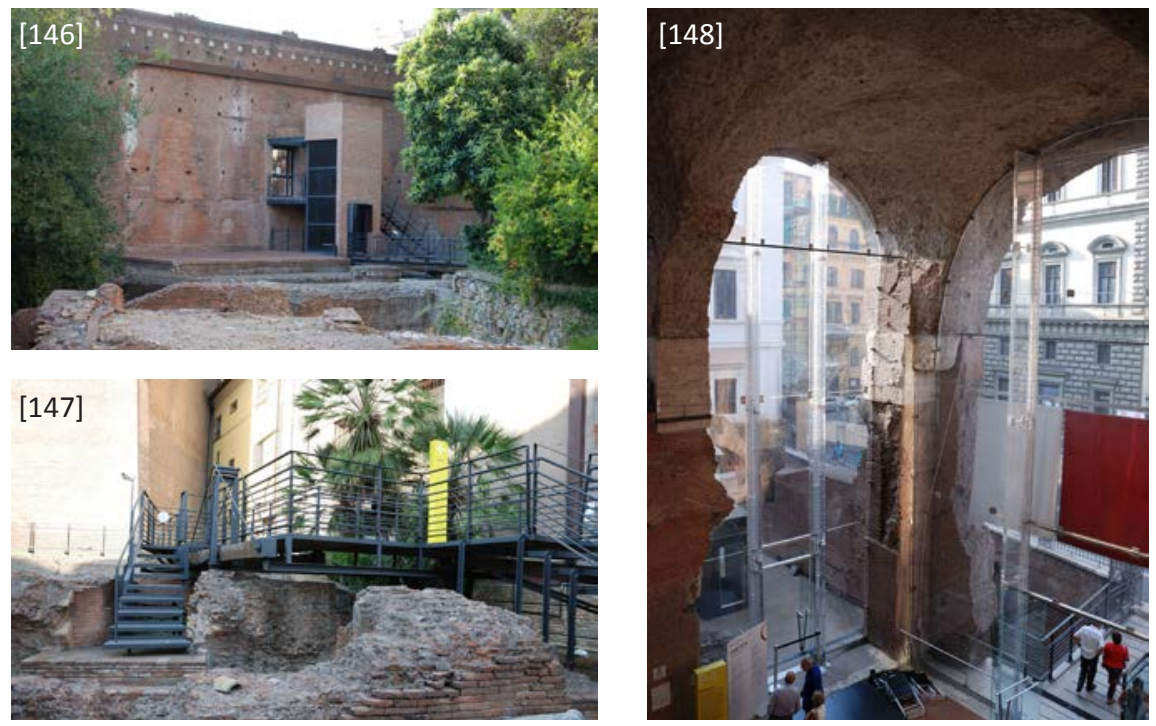

[146 y 147] Mercados de Trajano. Vista de los nuevos recorridos exteriores. Pasarelas de acero y madera. (Imágenes del autor.)

[148] Mercados de Trajano. Vista de los cerramientos de polimetilmetacrilato en la nave principal. (Imágenes del autor.)

[149] Monasterio de Carracedo. Vista exterior tras la restauración. (A.A.V.V.: 1997, p.162)

[150] Monasterio de Carracedo. Vista de las bóvedas en el interior de la Cocina de la Reina tras la restauración. (ICRBD: 1987, p. 159)
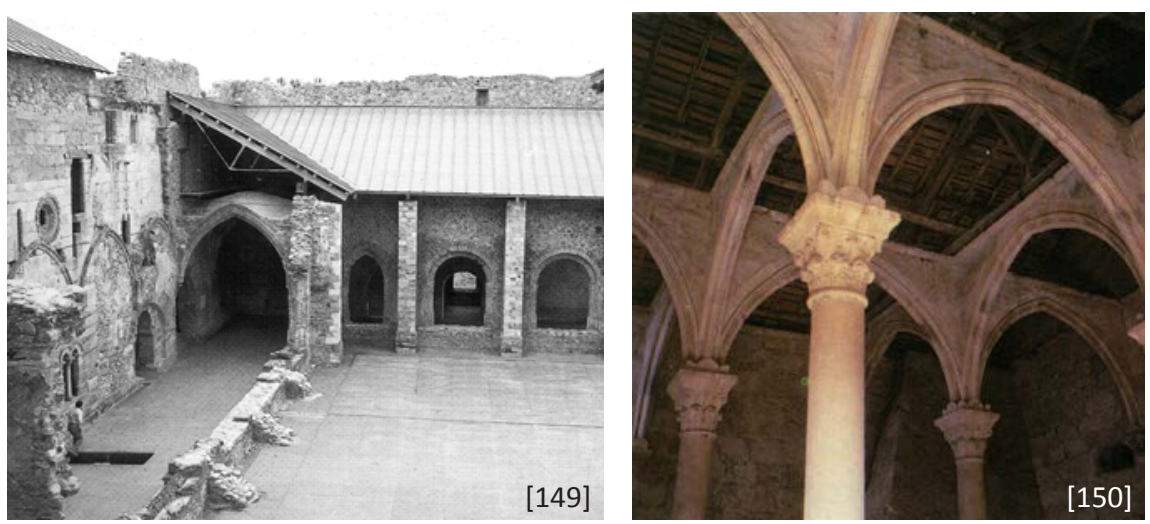
Respecto a esta intervención Alfonso Jiménez critica las justificaciones literarias de Pérez Arroyo de "invocación del espíritu ruskiniano" ya que en el fondo la adecuación de la intervención es un problema perceptivo. Así Jiménez afirma que el discurso le suena a "música celestial, pues aquellas mutiladas ruinas cistercienses se han convertido en el fondo perceptivo sobre el que destacan las figuras protagonistas de unas formas nuevas, nada neutras, pertenecientes a una moda estilística perfectamente identificable e histórica como todas". ${ }^{174}$

\section{Ejemplo 66. Musealización del Ospedale de Santa Maria della Scala en Siena. Guido Canali}

Canali busca establecer un diálogo entre antiguo y nuevo mediante la creación de un sistema moderno, modular y ligero, que a través de la calidez y textura de la madera se integra en armonía con los muros antiguos, y a través de la resistencia del acero permite definir los expositores con elementos delgados de poca presencia.

Giovanni Carbonara se refiere a su forma de actuar como una "restauración ligera", que conserva lo antiguo y crea lo nuevo "con la sensibilidad de saber detenerse a tiempo y traducir en estímulo poético todos los materiales con los que trabaja". ${ }^{175}$
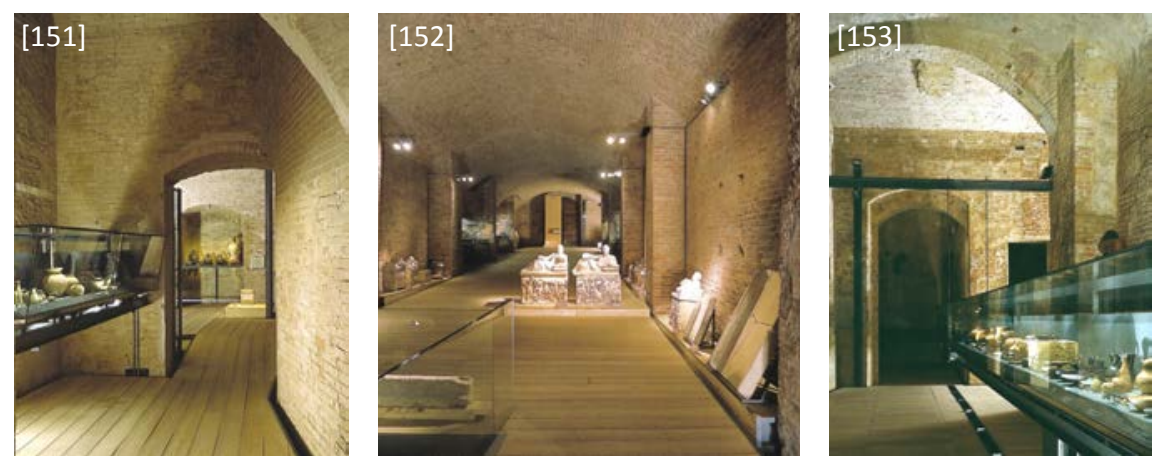

Ejemplo 67. Sala octogonal de las termas de Diocleciano de Roma. 1983. Giovanni Bulian

El objetivo principal de Bulian es el de conservar integralmente el monumento para permitir la lectura de su historia a través de las diversas intervenciones que ha venido sufriendo a lo largo del tiempo. Así, en la sala octogonal Bulian mantiene la estructura geodésica preexistente, perteneciente a su uso anterior
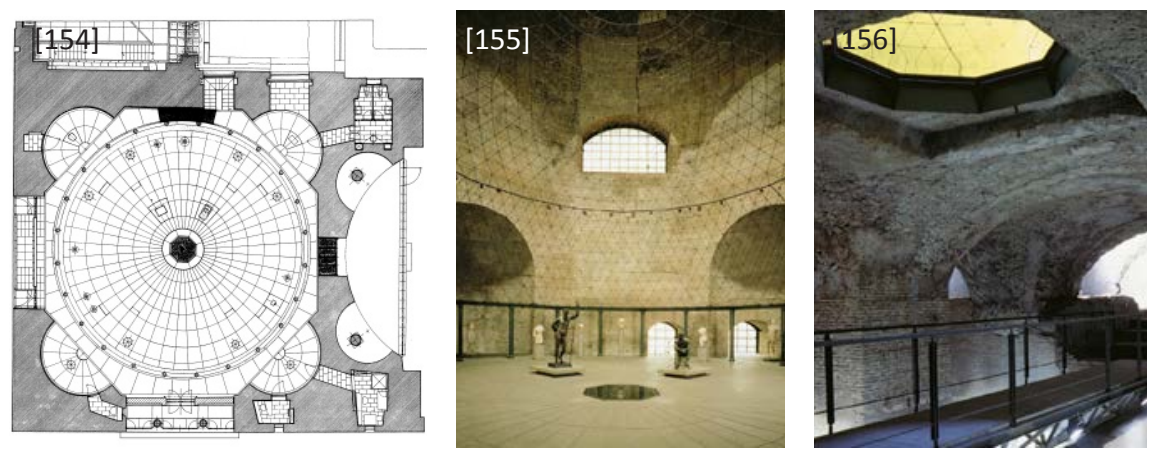

174 JIMÉNEZ, A.: “Enmiendas parciales a la teoría del restauro. (I) Imágenes y palabras". Loggia, no 4, Valencia, 1997, p. 12

175 CARBONARA, G.: Architettura d'oggi e restauro. Un confronto anticonuovo. Torino, Ed. Utet, 2011, p. 54
[151 y 152] Ospedale de Santa Maria della Scalla. Vistas interiores tras la intervención. (Imágenes de Francesco Castagna. En: CANALLI: Construire in laterizio, $\mathrm{n}=87,2002$, pp.32 y 33)

[153] Ospedale de Santa Maria della Scalla. Vista interior tras la intervención. (CANALLI: Construire in laterizio, $\mathrm{n}$ ㅇ 100, 2004, p. 123)

[154] Sala Ottogona. Planta. (BULIAN: Construire in laterizio, no 78, 2000, p. 10)

[155 y 156] Sala Ottogona. Vista interior y vista de la zona arqueológica inferior. (BULIAN: Construire in laterizio, no 78, 2000, pp. 11 y 15) 
como planetario, por ser un elemento potenciador de la unidad geométrica del espacio. También el nuevo pavimento de piedra de la sala busca con su despiece potenciar la organización geométrica del espacio a través de una materialidad que convive en armonía con las tonalidades de los muros romanos.

Por otro lado el óculo central abierto en el pavimento permite iluminar la zona arqueológica del nivel inferior cuyos restos se recorren a base de pasarelas de acero y vidrio claramente diferenciadas de las fábricas preexistentes. ${ }^{176}$

\section{Ejemplo 68. Actuaciones sobre diversos palacios en Pisa. Massimo Carmassi.} 1981-1995

Massimo Carmassi ha venido realizando durante años actuaciones de restauración de casas y palacios de la ciudad de Pisa para su adaptación a las nuevas necesidades de habitabilidad. En todos estos trabajos Carmassi busca intervenir mediante el empleo de sutiles estructuras de acero, madera y vidrio, con la intención de hacerlas pasar desapercibidas frente a la gran carga histórica de los muros desnudos, a menudo decorados con motivos pictóricos, rescatados como fragmentos tras los revocos y diversas capas superpuestas a lo largo del tiempo.

Es de destacar el exquisito trabajo gráfico presente en todas las representaciones de los proyectos de intervención, que expresan con claridad el gran valor que se otorga a las preexistencias históricas.
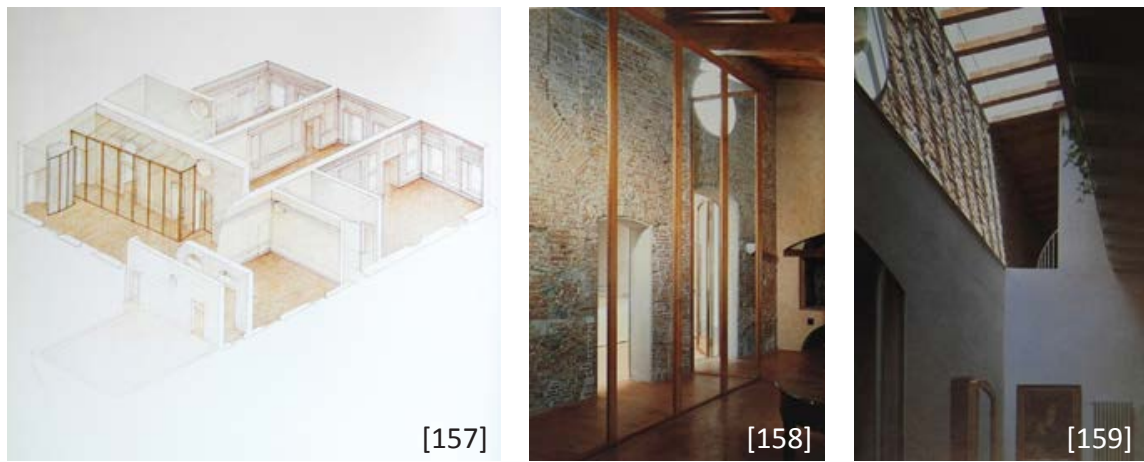

Más allá del ámbito tradicional de la intervención sobre el patrimonio, cabe mencionar las actuaciones de conservación sobre edificios más recientes que poseen ciertos valores proporcionados por las nuevas inquietudes culturales. Este es el caso de las actuaciones de conservación sobre edificios industriales como la Centrale Montemartini en el Museo Capitolino de Roma en 1997; el Matatoio de Roma; la Nave de Motores de Pacífico en Madrid realizada en 2006 por Carlos Puente; La Sala de Turbinas de la Tate Modern de Londres realizada por Herzog \& De Meuron en 2001; el centro cultural El Tanque de Tenerife realizado en 2005 por AMP. En ocasiones este tipo de intervenciones buscan conservar todas las heridas del pasado, incluso las más recientes, potenciando la idea de una arquitectura en proceso, abierta a nuevas actuaciones, este es el caso de El Palais de Tokyo de Paris, actuación de lacatón y Vassal de 1999-2000; la recuperación del Matadero Madrid en especial las actuaciones de Arturo Franco en 2006. 


\subsection{La repristinación}

La vía de la repristinación consiste en la búsqueda por devolver el esplendor original al edificio degradado. Es defendida por numerosos historiadores del arte y arqueólogos, que creen en la capacidad actual de clonación de edificios desaparecidos, mediante una aproximación científica, que se apoya en la interpretación de documentos descriptivos de los monumentos. ${ }^{177}$

Mediante una actitud opuesta a la de la conservación material, se propone eliminar aquellas partes degradadas sustituyéndolas por reproducciones realizadas con las técnicas y materiales originales. Paolo Marconi, defiende esta postura diciendo que la restauración "debe ocuparse de restituir a la arquitectura su capacidad de comunicación mediante el léxico que le es propio" ${ }^{178}$, y rechaza la sustitución a base de simplificaciones esquemáticas. Frente a la acusación de falso histórico Marconi alega que, con las nuevas técnicas, es fácil analizar una obra y distinguir si se trata de un original o una copia, y defiende la postura de la copia sobre la convicción de que "siempre será mejor conformar un buen duplicado más que una absurda caricatura sinceramente moderna". ${ }^{179}$

Además Marconi resalta el valor simbólico de las reconstrucciones en el caso de los dolorosos derrumbes producidos por destrucciones bélicas, atentados terroristas, terremotos, incendios, etc.: "sin aquel monumento, aquel ambiente quedaría mutilado y privado de significado de manera insoportable". ${ }^{180}$ Algo que explica la historiadora Pilar García Cuetos indicando que en los casos dramáticos derivados de las guerras, es la sociedad la que reclama una reconstrucción fiel y exacta de la imagen que tenía del monumento o de la ciudad, porque forman parte de la historia nacional pero también son el escenario vital de la población. ${ }^{181}$

Por otro lado, Marconi reconoce que la arquitectura histórica no es, casi nunca, el fruto de un único proyecto originario, sino de múltiples ajustes proyectuales, restauraciones y transformaciones. Por lo que el proyecto de ripristino debe saber distinguir las fases históricas involutivas de aquellas evolutivas e identificar entre ellas cuales merecen ser eliminadas y cuales reintegradas para la conservación del significado arquitectónico. ${ }^{182}$

Para poder llevar a cabo estas actuaciones de reproposición de las formas originales, se acude a los criterios analógicos, apoyados en diversas fuentes de entre las que destacan los manuales que recogen elementos propios de las arquitecturas históricas. Como apunta la profesora Sette, se trata de documentos de gran ayuda en la reelaboración de las partes faltantes pero muy peligrosos si se emplean sin una reflexión de adaptación al edificio en el que se aplican. ${ }^{183}$

Para Ascensión Hernández Martínez en esta actitud existe un rechazo a la arquitectura contemporánea, una falta de fe en la capacidad creativa de la cultura y la sociedad actuales, originado por la crisis y desorientación del mundo posmoderno, que provoca el consiguiente refugio en la
177 SETTE, M.P.: Op. cit., 2001, pp. 196-197

178 MARCONI, 1993, p.147. Extraído de: SETTE, M.P.: // restauro in architettura: quadro storico. Torino, Ed. Utet, 2001, p. 198

179 MARCONI, P.: “H.2.1. Aprocci Metodologici. Ragioni del restauro di ripristino". En: ZEVI L.: II manuale del restauro architettonico. Roma, Ed. Mancosu, 2001, H88 y $\mathrm{H} 98$

180 MARCONI, P.: “H.2.1. Aprocci Metodologici. Ragioni del restauro di ripristino". En: ZEVI L.: Op. cit., 2001, H88

181 HERNÁNDEZ MARTÍNEZ, A.: La Clonación Arquitectónica. Madrid: Ediciones Siruela, 2007, p.65

182 MARCONI, P.: “H.2.1. Aprocci Metodologici. Ragioni del restauro di ripristino". En: ZEVI L.: Op. cit., 2001, H98

183 SETTE, M.P.: Op. cit., 2001, p. 199 
184 HERNÁNDEZ MARTÍNEZ, A.: La Clonación Arquitectónica. Madrid: Ediciones Siruela, 2007, p.42

185 HERNÁNDEZ MARTíNEZ, A.: Op. cit., 2007, p.112

186 HERNÁNDEZ MARTíNEZ, A.: Op. cit., 2007, pp.43-45 historia y la fetichización consoladora de sus productos. ${ }^{184}$ En este sentido, la justificación de la reconstrucción mediante repristinación parece ir enfocada a la evocación del pasado "para ocultar o cubrir las desilusiones que provoca el presente". 185

Como ejemplos de esta vía de actuación se pueden mencionar la reconstrucción de teatros consumidos por las llamas, como la Fenice de Venecia (ej.69) o el Liceo de Barcelona, la reconstrucción de monumentos destruidos por acciones bélicas como la Frauenkirche de Dresde (ej.70) o el pórtico de San Giorgio in Velabro (ej.71), las reconstrucciones de monumentos destruidos por terremotos como el Duomo di Sant'Angelo dei Lombardi o el Duomo de Noto (ej.72), la restitución de partes degradadas de monumentos como en el caso de la galería de la Casa de Europa (ej.73), y la clonación de monumentos de culto como el pabellón de Mies van der Rohe en Barcelona o el Pabellón de L'Espirit Nouveau de Le Corbusier.

\section{Ejemplo 69. Teatro de la Fenice de Venecia. Proyecto inicial de Aldo Rossi}

La reconstrucción del Teatro de la Fenice provocó un gran revuelo en el debate de la intervención arquitectónica. Por un lado Aldo Rossi justifica el empleo de la mímesis por ser un lugar que expresa el valor de la colectividad, mientras que otros, como Mauro Carosi, escenógrafo del nuevo teatro, se justifican diciendo que no se ha hecho una copia literal, sino que se ha buscado evocar el espíritu del teatro original. Por otro lado Bruno Zevi lo interpreta como una actitud de temor ante la incapacidad proyectual de la nueva arquitectura, y Mario Botta denuncia que el incendio era un hecho histórico que no podía hacerse desaparecer. ${ }^{186}$

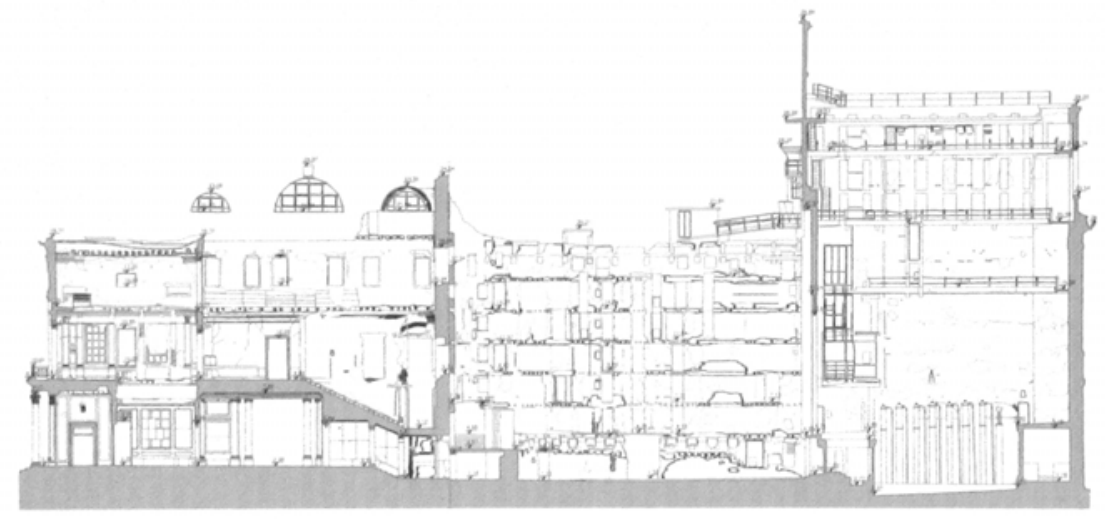

[160]

Ejemplo 70. Reconstrucción de la Frauenkirche. Dresde

En un principio los restos fueron admirados como monumento a la paz, perodespués pasaron a simbolizar la incapacidad para afrontar la reconstrucción por parte del régimen comunista, como consecuencia del atraso social y económico en que éste se veía inmerso en comparación con el desarrollo de la otra Alemania. Finalmente su reconstrucción se convertiría en el símbolo de la reunificación política alemana.
[160] Teatro de la Fenice. Sección transversal del teatro en estado de ruina, tras el incendio. (BRANDOLINI: Lotus, no 103, 1999, p. 46) 
Los sillares recuperados se integraron en la nueva construcción dándole un aspecto de puzle por el contraste entre los sillares originales reutilizados, más oscuros, y los nuevos bastante más claros. En la decoración interior se decidió recrear el colorido barroco mediante una invención de artistas contemporáneos pero buscando restituir el "espíritu" de los constructores del siglo XVIII. ${ }^{187}$
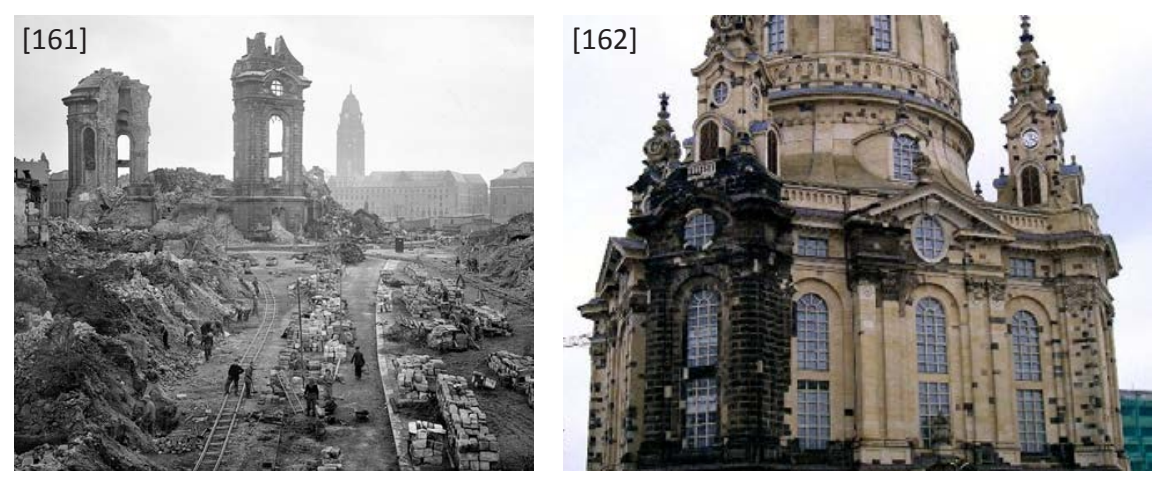

\section{Ejemplo 71. San Giorggio al Velabro}

La actuación realizada en San Giorggio al Velabro trata de devolver al monumento su estado inicial previo al del atentado terrorista. El criterio empleado es el de re-prístino, completando miméticamente los elementos desaparecidos, aunque realizando referencias sutiles a la contemporaneidad de la actuación. Por ejemplo en la reconstrucción de la pilastra derecha las juntas se ejecutan más regulares que las preexistentes y se retranquean respecto a la cara exterior. Sin embargo, tal y como indica Miarelli Mariani, la restitución de la cornisa del entablamento "presenta un molesto aspecto de recién hecho" muy distinto del resto de las partes. Mariani también critica el revestimiento continuo de la fachada con el que se ha recuperado el aspecto deI XIX, consolidándolo, reintegrándolo y coloreándolo, lo que ha producido "una tinta banal (...) sobre un enlucido excesivamente alisado". ${ }^{188}$ Para Miarelli Mariani, los autores han sabido reconducir la exigencia del re-prístino, propuesto por la dirección científica, hacia la mínima intervención y la distinción discreta, pero no han sido capaces de llevarlo a cabo en la cornisa, produciéndose una diferencia de actuación respecto al resto del pórtico. ${ }^{189}$
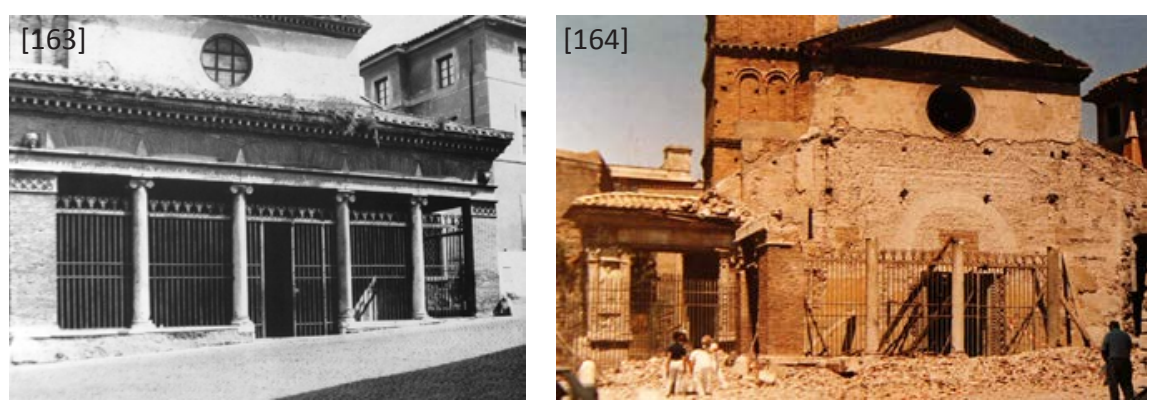

187 HERNÁNDEZ MARTÍNEZ, A.: Op. cit., 2007, pp.80-91

188 MIARELLI MARIANI, G.: "Qualche minuzia sul San Giorgio risanato". En: A.A.V.V.: La chiesa di San Giorgio in Velabro a Roma : storia, documenti, testimonianze del restauro dopo I'attentato del Iuglio 1993. Roma, Ed. Istituto poligrafico e Zecca dello Stato, 2002 , p. 12

189 MIARELLI MARIANI, G.: "Qualche minuzia sul San Giorgio risanato". En: A.A.V.V.: Op. cit., 2002, p. 12
[161] Frauenkirche. Vista de las ruinas, 1952. (BBC: <www.bbc.co.uk>)

[162] Frauenkirche. Vista tras la reconstrucción. (Geolinde: <www. geolinde.musin.de>)

[163] San Giorggio al Velabro. Vista anterior al atentado. (A.A.V.V.: 2002, p. 64)

[164] San Giorggio al Velabro. Vista tras el atentado. (A.A.V.V.: 2002,p. 90) 

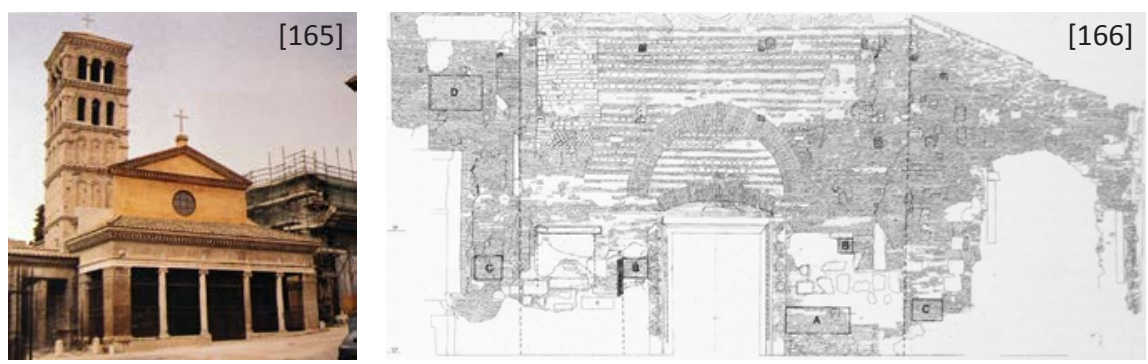

\section{Ejemplo 72. Reconstrucción del Duomo di Noto}

La iglesia barroca se inicia como reconstrucción de la anterior iglesia derruida en el terremoto de 1693 y se completa en 1776. El edificio sufre diversas intervenciones a lo largo del tiempo hasta que en 1996 un fuerte terremoto hacer caer los cuatro pilares de la nave noroeste, produciendo el colapso de las cubiertas de la nave central, nave lateral derecha y brazo derecho del transepto, así como dos tercios de la cúpula y la linterna. La destrucción reveló una construcción de las pilas de baja calidad a base de una hilada perimetral de sillares y un relleno de cantos rodados descohesionados.

La nueva intervención propone la repristinación del monumento para lo que se plantea mejorar la técnica constructiva para evitar futuros daños estructurales, pero empleando técnicas tradicionales. Tanto los pilares caídos como los supervivientes se reconstruyen con sillares de piedra, de manera que queden totalmente macizos. También se elimina el resto de cúpula superviviente y se construye enteramente nueva empleando fibra de carbono para mejorar la resistencia sísmica. Con todo ello se eliminan casi por completo los signos de la destrucción, y con ello se niega la presencia de parte de su historia.
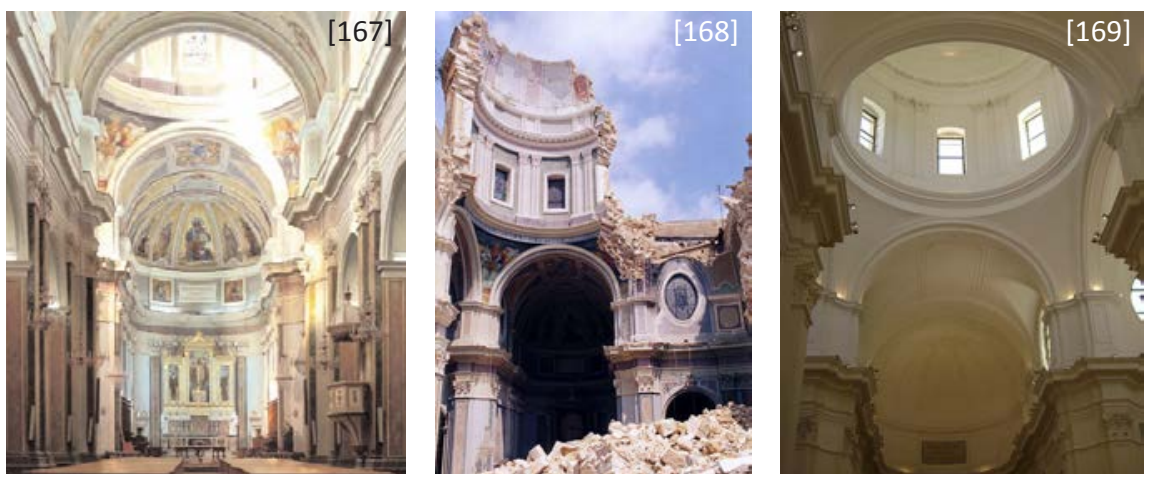

\section{Ejemplo 73. La Casa de Europa. Cesar Portela. 1998-2001}

La actuación consiste en la conversión de la Finca Vista Alegre en un parque público, en el que se insertan cuatro nuevos volúmenes destinados a usos educativos, así como la adaptación de la villa familiar en la Casa de Europa, con un uso de residencia para profesores invitados. 
La intervención sobre la villa tiene como objetivo recuperar y restaurar sus valores históricos dañados o desaparecidos así como introducir nuevos valores compatibles con los anteriores promovidos por las necesidades del nuevo uso. La actuación busca introducir los nuevos requerimientos espaciales y tecnológicos sin afectar a la armonía compositiva de la imagen histórica de la casa, abogando por defender el oficio constructivo presente, recuperando materiales y técnicas tradicionales, pero también investigando en materiales y técnicas nuevas.

La actuación sobre la galería, que se encontraba en muy mal estado de conservación, consiste en una restitución mimética del elemento para salvaguardar su valor histórico, sin embargo cabe mencionar el alto grado de esencialización que se observa en el nivel inferior del elemento.
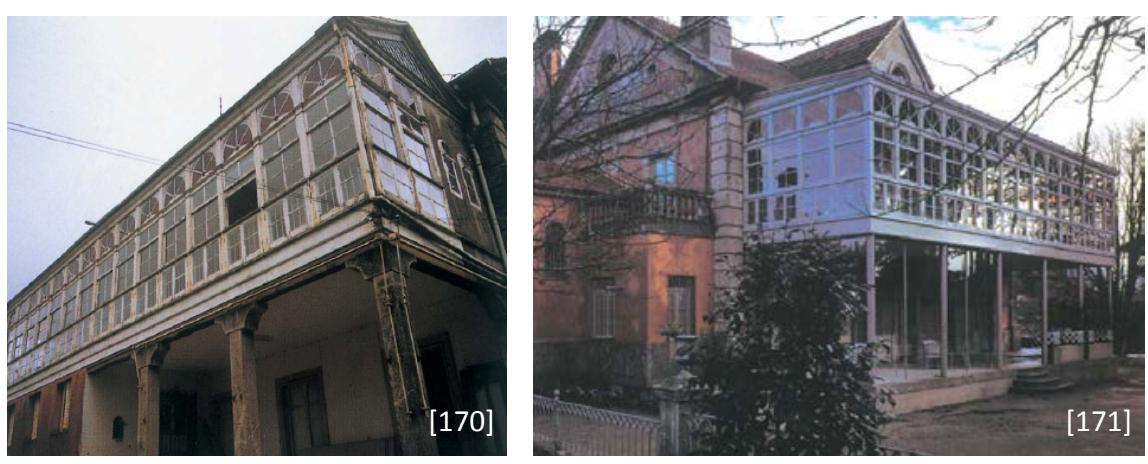

Debido al riesgo de falsificación y "pastiche", en general esta solución es más aceptada cuando la parte a restituir es pequeña en relación con la totalidad del conjunto sobre el que se actúa, o en construcciones realizadas con sillares, donde se pueden recomponer las piezas caídas. También se acepta en obras de gran valor, destruidas de manera traumática, o por ser monumentos de gran interés a nivel histórico. Otro recurso empleado es el de la simplificación formal del ornamento.

\subsection{La reinterpretación. De la recomposición a la innovación}

Esta vía busca situarse en una posición intermedia entre la pura conservación y la repristinación, de tal manera que entiende la preexistencia como una realidad sobre la que se debe actuar a través del proyecto arquitectónico para recuperar sus valores originales o aportarle otros nuevos que la mantengan con vida.

El ámbito de soluciones posibles es muy amplio y se observan dos tendencias diferenciadas en función de la orientación de la mirada a la hora de crear los nuevos elementos: en primer lugar están las actuaciones que se apoyan en la recomposición de la forma original, por entender que es fundamental recuperar su valor, pero lo hacen aplicando diferencias más
[170] La Casa de Europa. Aspecto de la galería acristalada antes de la restauración. (PORTELA: R\&R, $\mathrm{n}$ 은 72, 2003, p. 27)

[171] La Casa de Europa. Nueva y estilizada imagen de la galería una vez restaurada. (PORTELA: $R \& R, \mathrm{n}$ 72, 2003, p. 27) 
190 GRASSI, G.: “Un Parere Sul Restauro dei Monumenti (a proposito del Teatro di Sagunto) / Algunas Consideraciones Sobre la Restauración de los Monumentos. (A propósito del Teatro de Sagunto)", Cuadernos de Arquitectura Romana, vol. 2, 1993, pp. 47-50 / 239-240

191 GRASSI, G.: "Il carattere degli edifici". Casabella no722 maggio 2004, pp.4-15 o menos evidentes que aclaren la novedad de la intervención; en segundo lugar están las actuaciones que se relacionan con la preexistencia a través de elementos diferentes a los originales pero que buscan mantener cierta interacción entre lo nuevo y lo viejo.

\subsubsection{La atención a la preexistencia desde la mirada a su pasado}

Esta línea de actuación se apoya en las teorías de Bonelli y Brandi para defender la necesidad de recuperar la "eficacia evocativa" del edificio, y con ello su "unidad potencial". ${ }^{190}$ Esta vía va más allá del reconocimiento de la preexistencia, y se apoya en la lectura del pasado del monumento como criterio para la puesta en valor de las preexistencias, confiándose en la recuperación o la evocación de sus significados perdidos. Un respeto que se puede potenciar recuperando su uso original o proponiendo un nuevo uso que sea compatible con los valores simbólicos del monumento. Los tipos de intervención de esta línea de actuación se organizan en función de la escala de la pérdida y de la búsqueda de su mayor o menor reconstrucción.

Se apuesta por operaciones de distinción entre lo antiguo y lo nuevo a través de criterios de reinterpretación material o reproposición de las formas del pasado mediante simplificación formal, abstracción o evocación. Soluciones que debido a la diferente definición de la materia y de la forma producen espacios que pueden alejarse notablemente de los originales del monumento.

Estos criterios de distinción, regulados por las Cartas de Restauración desde finales del siglo XIX, tienen el riesgo de emplearse como una imposición lingüística y no como un mecanismo para potenciar ciertas intenciones arquitectónicas, pudiendo producirse resultados estéticos muy pobres sobre todo en el caso de grandes faltantes.

En esta vía es interesante mencionar la postura de Giorgio Grassi que defiende el criterio de recuperación del carácter de la arquitectura del pasado, frente a la creación de una nueva arquitectura sobre los restos preexistentes, comparando su obra del teatro romano de Sagunto con el museo romano de Mérida realizado por Rafael Moneo. Para Grassi el carácter de un edificio deriva de lo que expresa o evoca a través de su forma. Esta cualidad expresiva es una cualidad intrínseca de la arquitectura, pertenece a su forma antes de su aparición y es inescindible, no hay una diferencia entre lo que son y lo que parecen.

Así mientras que en Mérida el objeto del proyecto y el objeto de la evocación son claramente distintos, se contraponen, y a pesar de ello se superponen, sin embargo en Sagunto el objeto del proyecto y el de la evocación coinciden, incluso son la misma cosa. El proyecto de Mérida afirma que el carácter de un edificio consiste principalmente en su espectáculo, mientras que el proyecto de Sagunto afirma que el carácter de un edificio consiste exclusivamente en su realidad y que su espectáculo es sólo una consecuencia, un derivado, un subproducto. ${ }^{191}$ 
Esta línea de actuación consiste en la restitución imitativa de la imagen pero tratada con una materialidad distinta a la original, para expresar la autenticidad de la actuación. Esta solución busca reflexionar sobre la iconografía de la imagen y explora las posibilidades expresivas mediante la modificación de su construcción. Este es el caso de la reconstrucción del interior de la capilla de San Isidro en Madrid (ej.74), el proyecto de reconstrucción del castillo de Berlín (ej.75), la reconstrucción y restauración del museo de ciencias naturales también en Berlín (ej.76), o de la intervención en el museo nacional suizo (ej.77).

Ejemplo 74. Reconstrucción del interior de la capilla de San Isidro, en la iglesia de San Andrés, Madrid (1986-90), de J. Vellés, M. Casariego y F. Posada.

La capilla había quedado completamente arruinada debido a un incendio producido durante la guerra civil, y tan solo se había intervenido los yesos de la linterna y la cúpula. Los arquitectos se plantean llevar a cabo una reconstrucción lo más fiel posible al original, pero la materialidad la van modificando en función de la altura. Así, los basamentos se reconstruyen en la piedra original, las columnas y el entablamento se restituyen en madera con yeso estucado imitando los mármoles, y las decoraciones del tambor y la cúpula se recuperan mediante fingidos pintados. ${ }^{192}$ Con esta solución se busca devolver la imagen original, pero permitiendo identificar, a través del examen cercano, la contemporaneidad de la actuación. Se trata de una intervención que antepone la precisión de la percepción, a la calidad artesana del ornamento original, en un proceso de superposición que refleja una metamorfosis material de la realidad preexistente.
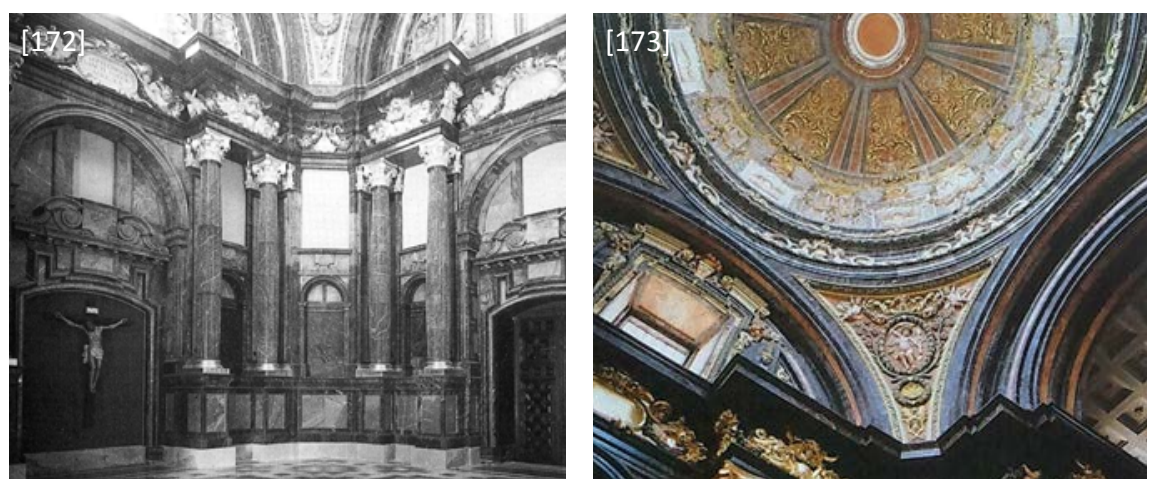

Ejemplo 75. Reconstrucción del castillo de Berlín. Franco Stella.

El castillo cuyos orígenes se remontan al siglo XV, es destruido por los bombardeos de la segunda guerra mundial, en 1945. Tras la reunificación alemana surge la intención de recuperar el edificio, lo cual tiene su primera tentativa en la reconstrucción virtual realizada en 1993-94 consistente en una representación pictórica de la fachada del castillo. En el año 2002 se aprueba la realización de una reconstrucción de tres de las fachadas del castillo recuperando la volumetría original, pero dejando la posibilidad de reinterpretación de la cara recayente al río Sprea. También se exigirá la reconstrucción de tres de los alzados del patio
192 CAPITEL, A.: "La arquitectura española más allá de la crisis". En: BALDELLOU, M. A.; CAPITEL, A.: Arquitectura española del siglo XX. Madrid: Espasa Calpe. 1995-2001, p. 556
[172] Capilla de San Isidro. Vista tras la restauración. (RIVERA. En: A.A.V.V.: 1997, p.163)

[173] Capilla de San Isidro. Vista tras la restauración. (BALDELLOU; CAPITEL: 1995-2001, p. 556) 
193 REDECKE, S.: "Il Castello di Berlino". Casabella, no 796, p. 86

194 Extraído de: HERNÁNDEZ MARTÍNEZ, A.: La Clonación Arquitectónica. Madrid: Ediciones Siruela, 2007, pp.128-132

de honor y la construcción de la cúpula. El nuevo edificio se configura como un gran espacio público que tendrá la función de impulsar la vida cultural del centro de Berlín mediante la inclusión de museos, bibliotecas, un centro multifuncional para actos culturales y científicos, restaurantes y tiendas.

Como indica Sebastian Redecke esta obsesión por restituir la imagen del castillo desaparecido "es sólo una seducción del pasado, imágenes nostálgicas de una forma que recuerda a las vistas y fotografías del centro histórico de Berlín antes de la guerra". ${ }^{193}$
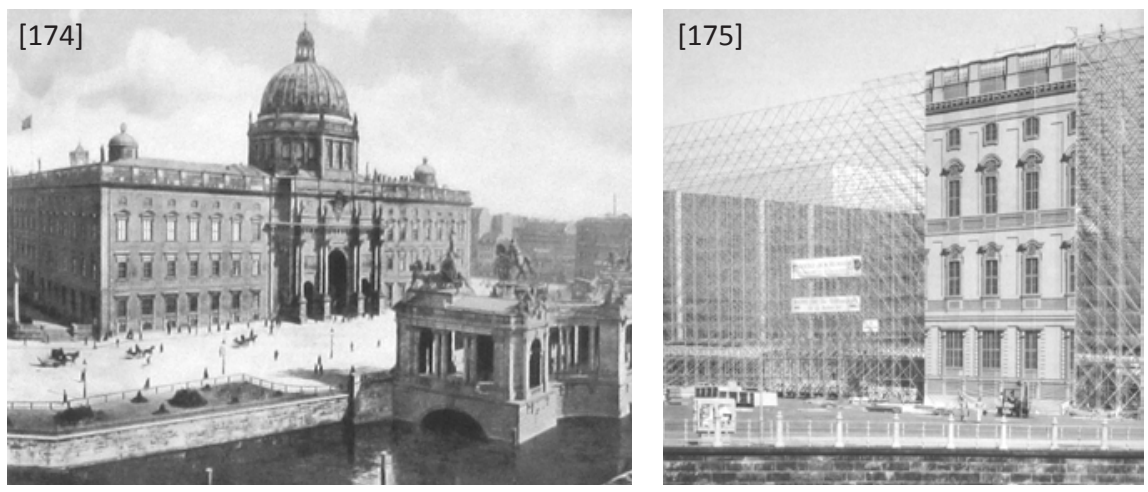

El proyecto de Stella cumple con rigor y claridad los requisitos del concurso. Sin buscar efectos de imagen se apoya en la construcción y en la abstracción tipológica para recrear los elementos desaparecidos. Una solución sin embargo que se vuelve algo árida y fría, tal vez como resultado del estricto cumplimiento de los requerimientos impuestos desde el concurso.

Algunos arquitectos como Philip Johnson defienden la actuación desde el punto de vista urbanístico al entender que frente al fuerte dominio de la arquitectura moderna de las últimas actuaciones realizadas en Berlín este edificio ayudará a "restaurar el efecto espacial de su relación con el histórico museo de Schinkel y la iglesia Friedrichswerder". ${ }^{194}$

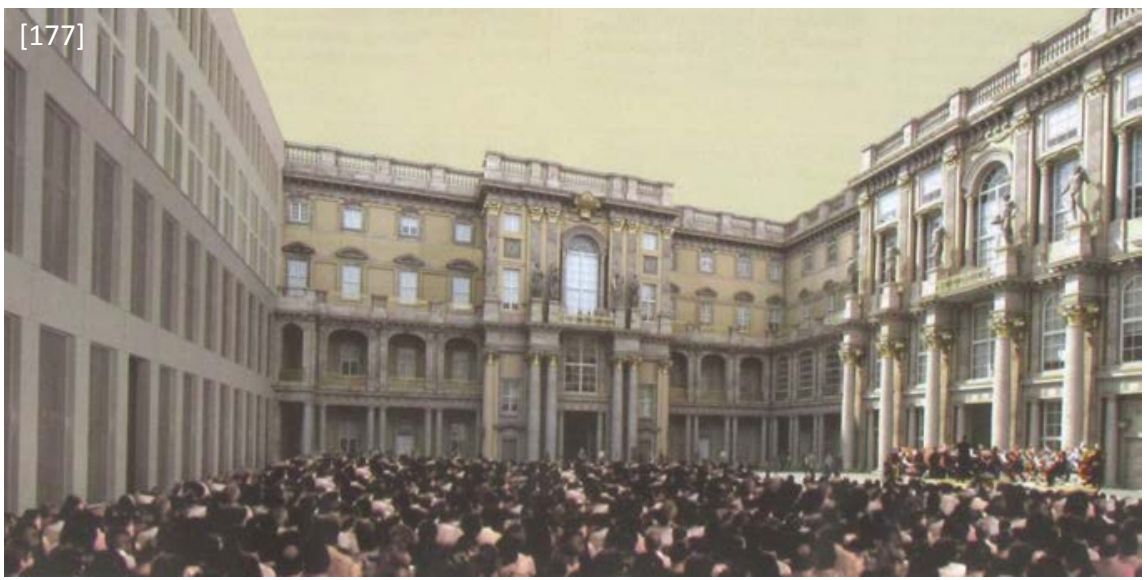


Ejemplo 76. Reconstrucción y restauración del museo de ciencias naturales. Berlín. Diener \& Diener

La intervención sobre el edificio, parcialmente destruido por los bombardeos de la guerra, propone la reconstrucción de la parte faltante, con un objetivo que lejos de preocuparse por el valor de la ruina, se ocupa del valor simbólico del edificio y del proceso de actuación. La solución consiste en la reproducción de la fachada mediante copias calcadas de los tramos existentes, y reproducidas en grandes módulos de hormigón armado blanco. Para Nicola Braghieri la precisión y abstracción del resultado parece remitir a los calcos empleados por los arqueólogos del XIX, "donde el juego de las sombras y la ausencia de colores acentúa las figuras puras y las proporciones de las formas". Las partes existentes se limpian hasta recuperar su fuerza material, renunciando con ello a la pátina del tiempo. Se trata de una actuación que busca emplear un proceso de anastilosis de piezas repristinadas, para recuperar la armonía del conjunto, reproduciendo hasta el más mínimo detalle formal, pero renunciando a su materialidad original, haciendo evidente en su cambio de tonalidad la nueva adición, como si por causa de la acción del tiempo, una parte se hubiera petrificado, como si la parte recompuesta fuera el resultado de una maqueta impresa tridimensionalmente. ${ }^{195}$
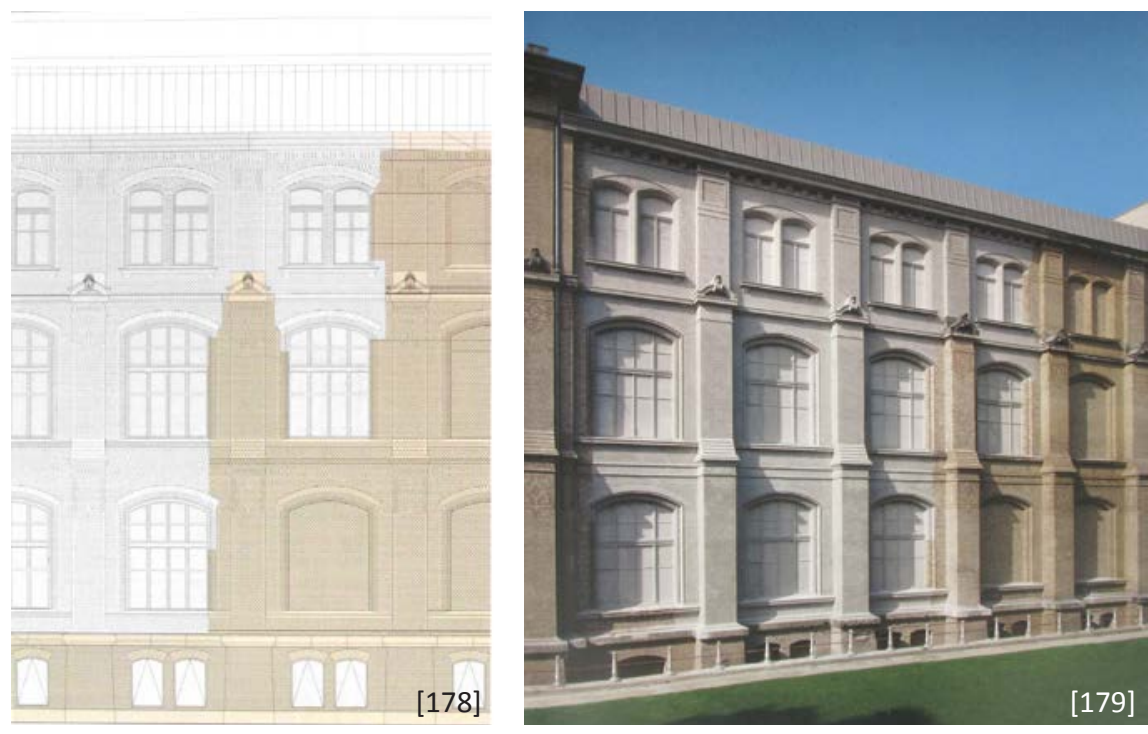

195 BRAGHIERI, N.: "Ricostruzione e restauro del museo di storia naturale a Berlino". Casabella no803, p.4-13

196 CHRIST \& GANTENBEIN.: "Swiss National Museum". Architectural Review, no 1354, diciembre 2009, pp. 84-86
[178 y 179] Museo de ciencias naturales. Alzado y vista exterior tras la intervención. (BRAGHIERI: Casabella, no 803 , pp. 10 y 13)

[180] Museo nacional suizo. Planta baja del proyecto de Christ \& Gantenbein. (CHRIST \& GANTENBEIN: The architectural review, no 1354, 2009, p. 86)
Ejemplo 77. Museo nacional suizo. Christ \& Gantenbein Architects. 2002-2013 ${ }^{196}$ La actuación consiste en la renovación y ampliación del museo nacional suizo construido en 1898. De la fase inicial de la actuación destaca la intervención de sustitución de las bóvedas del nivel inferior, siguiendo la forma de los elementos originales, pero indicando la novedad de la actuación mediante el empleo de hormigón armado con encofrado de tablillas de madera colocadas horizontalmente que transmiten la idea de una forma surgida como resultado de una estratificación pétrea.

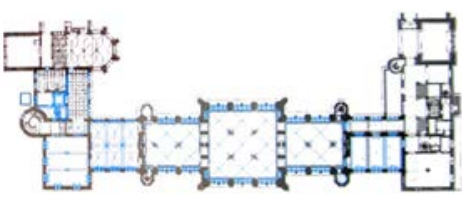

[180] 
197 ROCCA, A.: Questo non è un modello: il San Carlino di Lugano". Lotus no103, pp. 27-39
[181 y 182] Museo nacional suizo. Vistas interiores tras la intervención. (CHRIST \& GANTENBEIN: $<$ Www.christgantenbein.com>)

[183] Vista del modelo en madera ya construido. (di BELLO: Domus, no 820,1999, p. 9)

[184] San Carlo alle Quattro Fontane. Detalle. (BOTTA: 1999)
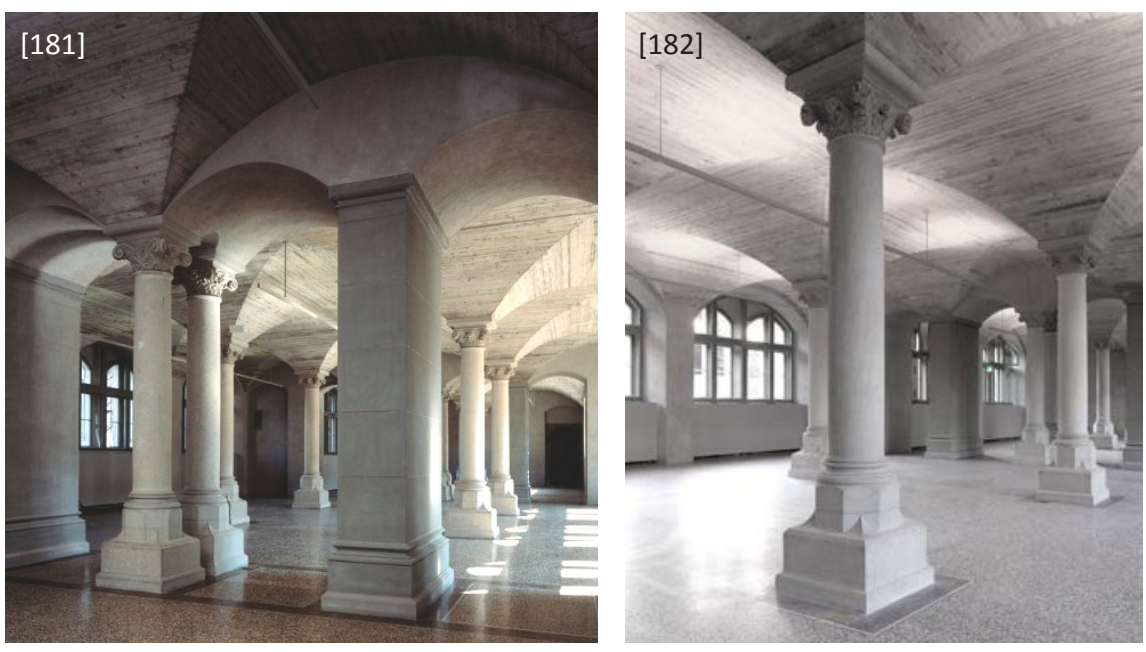

En relación con el tema de la reinterpretación de la imagen es interesante mencionar los trabajos de obra nueva que se apoyan en la forma original, pero modifican sustancialmente su construcción y materialidad para crear nuevas arquitecturas. Con ello se logra establecer una relación de imagen con la historia, pero aportando nuevos valores espaciales y materiales. Un caso significativo es el modelo en madera de la sección de la iglesia de San Carlo alle Quattro Fontane realizado por Mario Botta con ocasión de una exposición sobre el arquitecto barroco (ej.78).

Ejemplo 78. Modelo en madera de San Carlo alle Quattro Fontane. Mario Botta. ${ }^{197}$ Para la exposición sobre Borromini en el museo cantonal de arte de Lugano, Mario Botta propone completar la colección con un modelo a escala real de la sección de la iglesia de San Carlo alle Quattro Fontane de Roma ubicado sobre una plataforma flotante en el lago de Lugano.
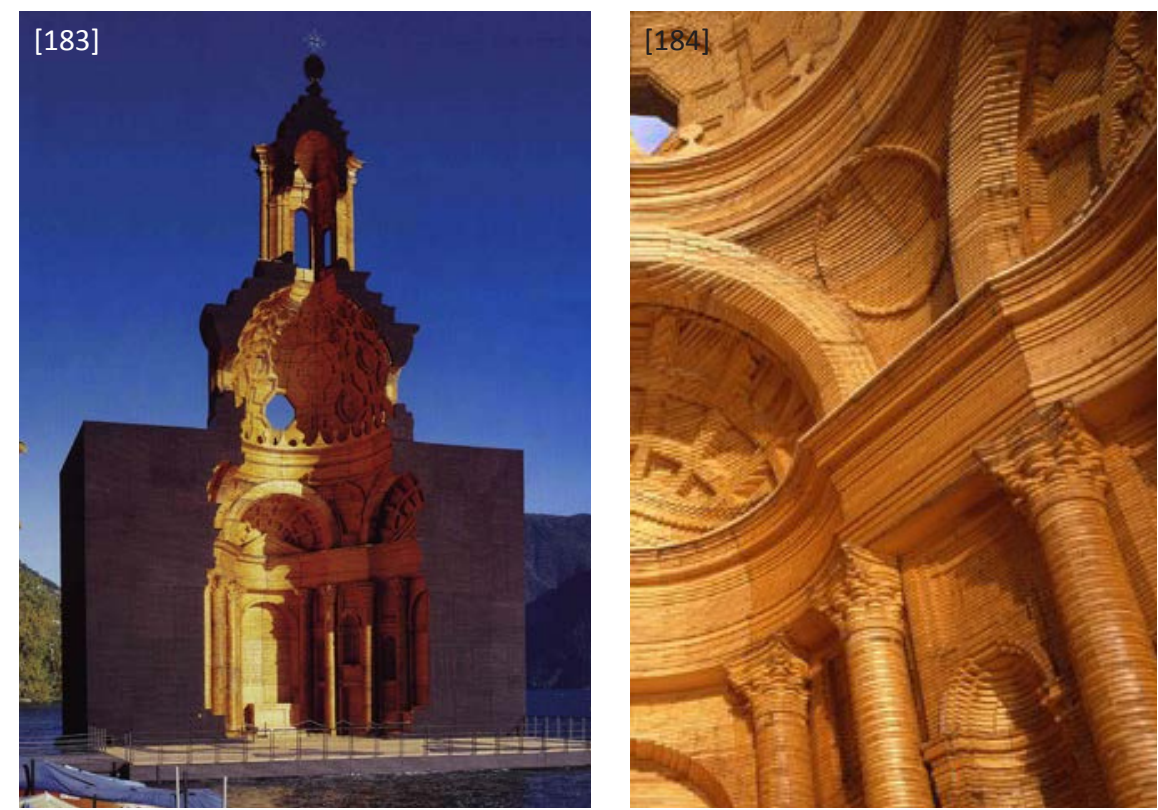
A través de una técnica de escaneado en tres dimensiones se obtiene un modelo informático del espacio central de la iglesia que se subdivide en secciones horizontales, como si se tratara de la representación de las curvas de nivel de un terreno. Estas secciones se emplean como plantillas para la construcción de las diferentes capas de madera de $4,5 \mathrm{~cm}$ de espesor, separadas entre ellas un centímetro para permitir las libres deformaciones potenciadas por la presencia de humedad. Las maderas se sostienen mediante una estructura interna de acero.

Con esta actuación Mario Botta está reivindicando que para que una reconstrucción pueda pertenecer a nuestro tiempo, es necesario realizar una reinterpretación que se apoye en los mecanismos propios de la arquitectura como, por ejemplo, la relectura material y constructiva del modelo original. Además colocándola sobre el agua -tal y como ya hiciera Aldo Rossi en el Teatro del Mondo- busca descontextualizar el modelo de toda relación con la realidad física, aumentando el carácter de virtualidad, una fantasía temporal evocadora que busca comunicar un símbolo de la historia de la arquitectura.
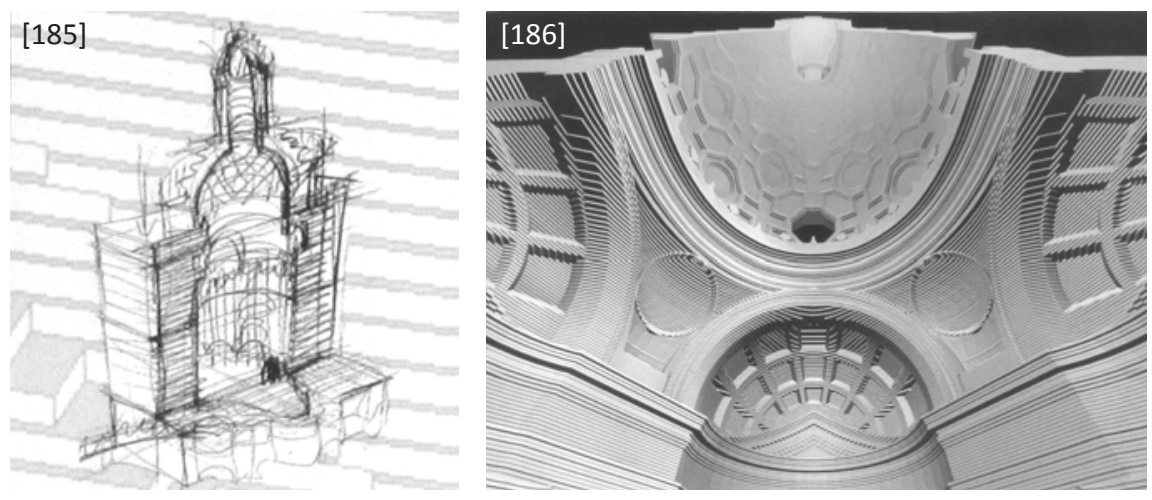

\section{Compleción mediante un lenguaje formal basado en la preexistencia:}

Otra situación distinta es la correspondiente a las actuaciones que buscan completar monumentos que nunca se han terminado, mediante un lenguaje formal basado en el preexistente. Este es el caso del proyecto de terminación de la Catedral de Nueva York (ej.79), la terminación de la sagrada familia de Gaudí (ej.80), la Terminación de la Iglesia de Montserrat, en Madrid (ej.81) o la ampliación del Banco de España en Madrid (ej.82).

Ejemplo 79. Terminación de la Catedral de Nueva York. Santiago Calatrava. 1992 Calatrava emplea su lenguaje, próximo a los criterios compositivos góticos, para relacionarse con cierta naturalidad con el edificio inacabado.

Para William Bryant el proyecto de Calatrava es algo más que una extraordinaria solución formal, pues representa la posibilidad de transportar el puro impulso gótico al nuevo siglo. Calatrava no quiere imitar los métodos y formas del gótico: "Los materiales, las técnicas, y nuestra comprensión de la vida han evolucionado
[185 y 186] Croquis y modelo de estudio del proyecto. (ROCCA: Lotus, no 103,1999, pp. 34 y 35) 
198 BRYANT LOGAN, W.: “II gotico secondo Calatrava. Completamento della cattedrale di New York". Lotus no72, p.64-69.

199 BONET I ARMENGOL, J.: “EI Templo de la Sagrada Familia. Nuevas aportaciones al estudio de Gaudí". Loggia no9, p. 129.
(...) y es por tanto imposible devolver a la vida la catedral gótica tal y como el gótico la concebía. Hacer revivir el impulso gótico significa reencontrar y transmitir su energía, aprovechando al máximo los materiales e ideas que se tienen a disposición". Sus pilastras articuladas recuerdan a las de Antonio Gaudí para la Sagrada Familia de Barcelona. ${ }^{198}$

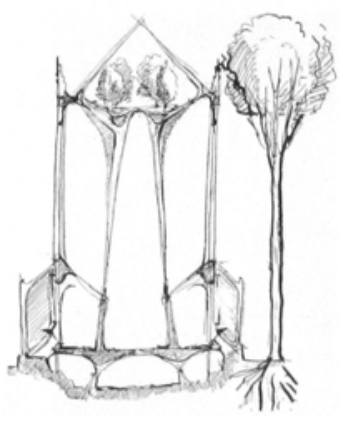

[187]

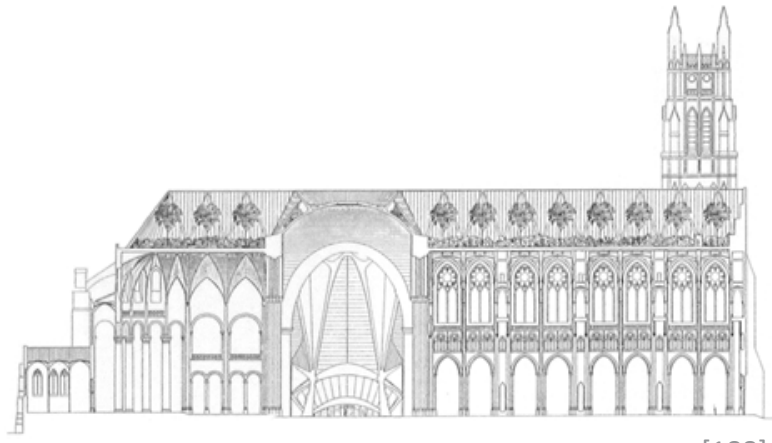

[188]

Ejemplo 80. Terminación del templo expiatorio de la sagrada familia de Barcelona. Jordi Bonet i Armengol

El proyecto del templo lo inicia el arquitecto Francisco de P. Villar en el siglo XIX bajo un lenguaje neogótico. A finales del siglo XIX lo retoma Gaudí ampliándolo en anchura y altura, y se apoya en las superficies regladas para construir un templo a semejanza de la naturaleza. El incendio de su estudio durante la guerra civil hizo desaparecer todos sus documentos excepto una maqueta de yeso a escala $1 / 10$ que sirvió de modelo para reproducir el volumen del templo. Bonet estudia la geometría del modelo y descubre las relaciones dimensionales y geométricas definidoras del lenguaje empleado por Gaudi, permitiéndole retomarlo para la conformación de los elementos del conjunto. Para ello se apoya en las herramientas informáticas de modelado tridimensional afirmando que "los dibujos informáticos de todos estos elementos muestran las posibilidades de estas geometrías, cuyo desarrollo es prácticamente exacto, sin apenas posibilidad de error". ${ }^{199}$
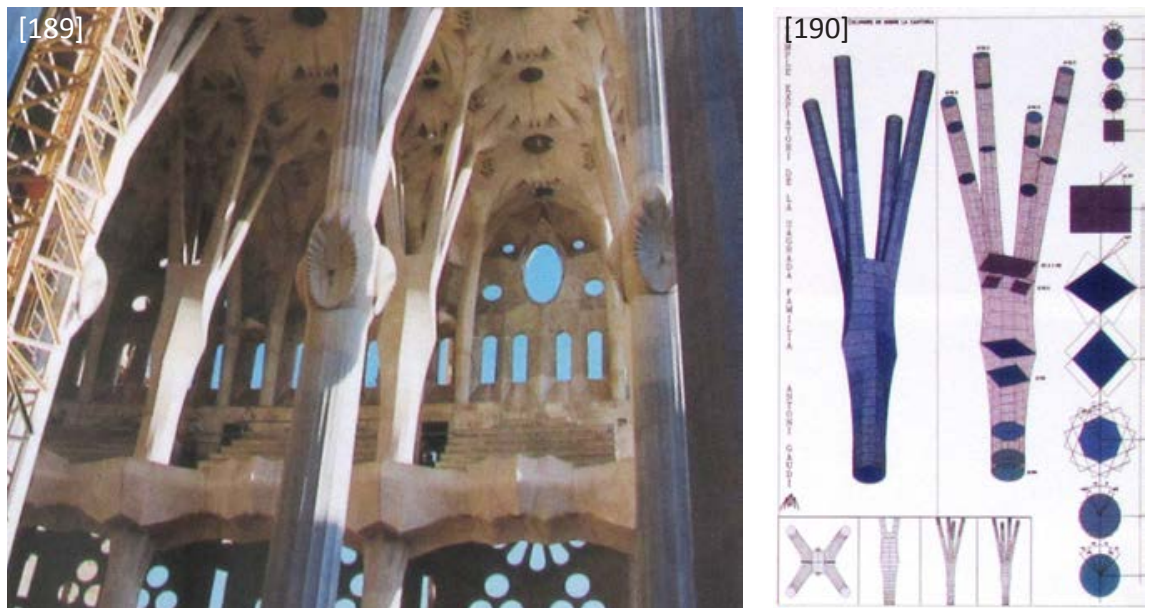
La actuación ha sido muy criticada por numerosos críticos de arquitectura. Así por ejemplo Paolo Favole no duda en afirmar que el proyecto a ridiculizado y empobrecido la obra de Gaudí eliminando su poética al interpretar literalmente una información que Gaudí habría leído creativamente. ${ }^{200}$

Ejemplo 81. Terminación de la Iglesia de Montserrat, en Madrid (1982-89), de Antón Capitel, Consuelo Martorell y Antonio Rivière

La intervención consiste en la construcción de una nueva capilla adosada al hastial de la nave, ocupando el espacio que debió haber albergado el crucero de la inacabada iglesia, convirtiendo el citado hastial en una nueva fachada. La condición de novedad de la capilla no viene dada ni por su forma ni por su materialidad, ambas continuadoras del estilo de la iglesia, sino por su ubicación, ocupando un lugar incoherente con el orden del edificio original. ${ }^{201}$ Esta transgresión pudiera entenderse como insuficiente en el ámbito de una cultura contemporánea, en la que el lenguaje clásico ha sufrido un proceso de depuración que no se refleja en la solución adoptada, y que por tanto pudiera dar la imagen de algo anacrónico.
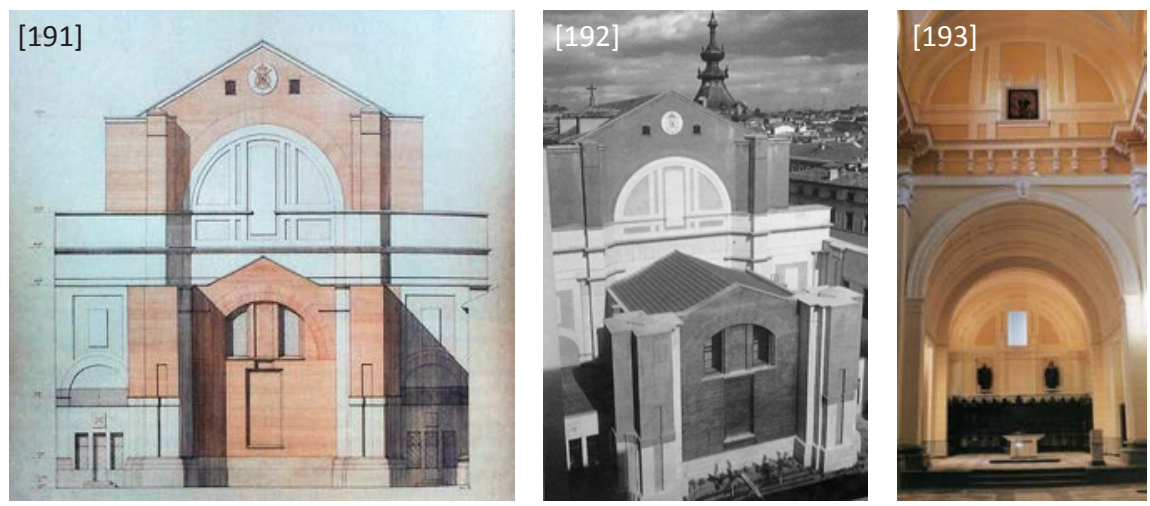

Ejemplo 82. Ampliación del Banco de España en Madrid. Rafael Moneo. 1978-2006 El edificio del Banco de España se ha ido ampliando en sucesivas actuaciones, desde la primera actuación de 1882 hasta la última de 1975, ocupando la práctica totalidad de una manzana del ensanche de Madrid. Rafael Moneo propone completar la pequeña porción restante siguiendo el mismo lenguaje neoclásico empleado en el resto del edificio a lo largo del tiempo, ya que entiende que se trata de una cuestión de escala, donde la nueva intervención ocupa una pequeña porción del conjunto, por lo que un cambio de lenguaje habría supuesto una perturbación. ${ }^{202}$
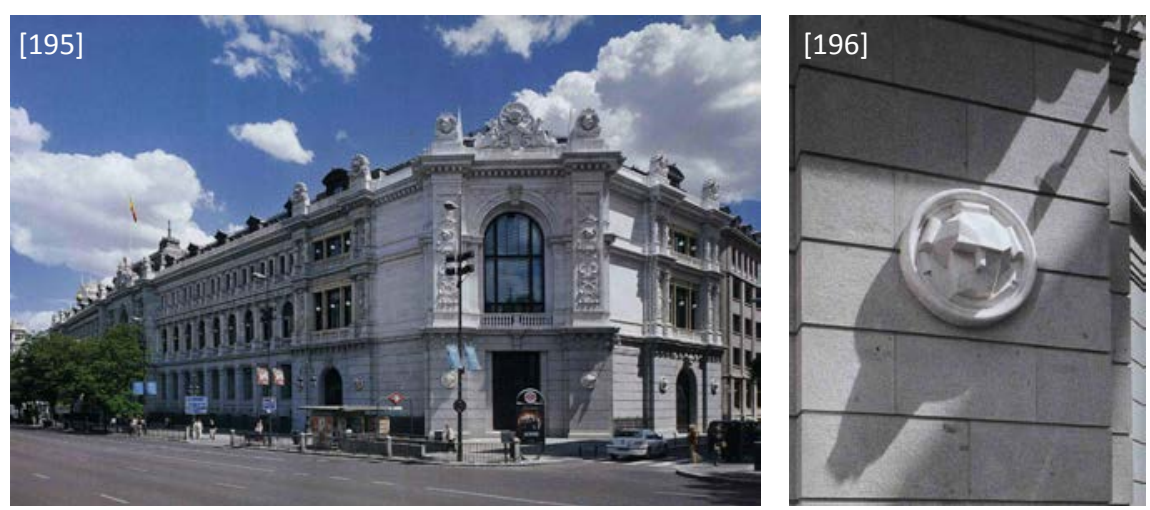

200 FAVOLE, P.: “La dis-Sagrada Familia", Progettare IX, 2010, 6, p.9. Extraído de CARBONARA, G.: Architettura d'oggi e restauro. Un confronto antico-nuovo. Torino, Ed. Utet, 2011, p. 117

201 CAPITEL, A.: "La arquitectura española más allá de la crisis". En: BALDELLOU, M. A.; CAPITEL, A.: Arquitectura española del siglo XX. Madrid: Espasa Calpe. 1995-2001, p. 554

202 SOUTO DE MOURA, E.: "Rafael Moneo. Completamento del banco de españa. Madrid". Casabella nำ754, Aprile 2007, p.15

[191] Iglesia de Montserrat. Proyecto del conjunto del testero oeste y el Nuevo Presbiterio. Alzado. (CAPITEL; MARTORELL; RIVIERE. En: ICRBC: 1990, p. 236)

[192 y 193] Iglesia de Montserrat. Vista exterior y vista interior tras la restauración. (CAPITEL; MARTORELL; RIVIERE. En: ICRBC: 1990, pp. 240 y 241$)$

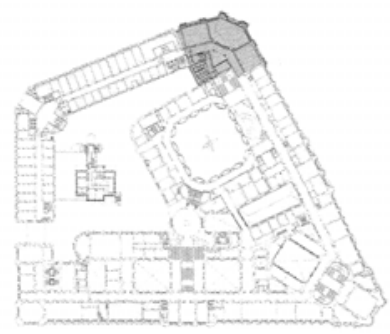

[194]
[194] Banco de España. Planta. (SOUTO DE MOURA: Casabella, no 754,2007 , p. 16)

[195 y 196] Banco de España. Vista de la fahcada y detalle, después de la restauración. (SOUTO DE MOURA: Casabella, no 754, 2007 pp. 19 y 20) 
203 SOUTO DE MOURA, E.: Op. cit., 2007, p.16-17

204 VARAGNOLI, C.: "Antichi edifici, nuovi progetti. Realizzazione e posizioni teoriche dagli anni Novanta ad oggi", En Ferlenga, Alberto; Vasallo, Eugenio; Schellino, Francesca. Antico e Nuovo. Architetture e architettura. II Poligrafo. 2007. Volumen 2. p. 847
La solución emplea los mismos criterios compositivos y materiales de las fachadas preexistentes, con la finalidad de conservar el sentido del conjunto. Los motivos lingüísticos se han simplificado formalmente, reinterpretándose en clave cubista. No se trata tanto de una operación de restauración, sino de una actuación que busca concluir algo inacabado, pero al mismo tiempo dejar las pistas suficientes como para que al analizar con detenimiento el nuevo elemento se observe que posee autonomía respecto al conjunto y responde a una identidad contemporánea. ${ }^{203}$

\section{Reconstrucción tipológica:}

En el caso de una búsqueda de reconstrucción total de una parte importante del edificio se puede recurrir a la denominada "reconstrucción tipológica". Esta práctica se apoya en el concepto de "tipo", analizado en profundidad por Aldo Rossi, para completar la arquitectura de la preexistencia.

Uno de los arquitectos que más la ha empleado ha sido Giorgio Grassi en proyectos de restauración como el castillo de Abbiategrasso(ej.83), el teatro romano de Sagunto(ej.84), el castillo de Valkhof(ej.85), o el teatro romano de Brescia entre otros (ej.86). Grassi entiende que la conservación del monumento depende, no tanto de mantener su función como de mantener su rol en el lugar. Lee en la ruina una virtualidad en la que el proyectista debe basarse, a través del análisis tipológico, para devolver al edificio "su razón de ser como arquitectura". ${ }^{204}$

En esta actitud no se busca tanto una reelaboración formal de la parte faltante, como una abstracción de su forma original, sometida a un proceso de relectura material esencializada. Se busca de alguna manera recuperar la presencia volumétrica del monumento en su contexto y su identificación tipológica.

El camino de la abstracción volumétrica, cuyos orígenes se remontan a la ilustración, opta por un lenguaje carente de ornamentaciones como reflejo de una estructura sustentante que se ha ido depurando a lo largo del tiempo, que no puede llegar a alcanzar la perfección de épocas pasadas. A ésta se suma la expresión material como mecanismo de apoyo al concepto de elemento inacabado, donde el juego de luces y sombras producido por las texturas de las fábricas vistas genera cierta riqueza visual.

Unmecanismoqueayudaa distinguirlaactuaciónsin renunciara recuperarsu forma original es el retranqueo hacia el interior de los nuevos muros respecto a los antiguos. Este retranqueo cobra mayor significado si se busca expresar la idea de que lo nuevo pertenezca a un estrato interior al preexistente. Un concepto que se aprecia en la actuación del teatro romano de Sagunto.

Otras actuaciones realizadas en esta línea son la reconstrucción de San Michele in Borgo en Pisa (ej.87), la reconstrucción de la iglesia de Santa Cruz en Median de Rioseco (ej.88), la reconstrucción del Neues Museum de Berlín (ej.89), la reconstrucción de la cúpula del palacio Omeya de Amann (ej.90), la actuación sobre la biblioteca de la Abadía de San Zeno Maggiore (ej.91), o la terminación de la iglesia de Daroca (ej.92). 
Un caso singular dentro de esta línea lo representa el arquitecto Antonio González, quien afirma con claridad que "restaurar es reconstruir". ${ }^{205}$ Para González la manera de transmitir la autenticidad de los monumentos pasa por recuperar el espacio desaparecido, siendo por tanto la reconstrucción un camino inevitable. Algo que ha venido aplicando en la gran mayoría de sus obras de intervención: desde su actuación en Sant Vicenç de Malla en 1983, pasando por la intervención en la iglesia de Sant Jaume de Sesoliveres en 1996, hasta la más potente de sus restauraciones materializada en la reconstrucción del monasterio de Sant Llorenç de Guardiola de Berguedà terminada en 2008 (ej.93-95).

Ejemplos 83-85. Castillo de Abbiategrasso (1970). Teatro romano de Sagunto (1989-92). Castillo de Valkhof (1997). Giorgio Grassi

Grassi afronta este proceso reconstructivo mediante una arquitectura elemental y esquemática, hecha sólo de cosas concretas y verdaderas, y que no necesita de interpretación. ${ }^{206}$ Para ello emplea un lenguaje lo más directo e inmediato posible renunciando a aquellos elementos de la construcción que con el tiempo se hayan transformado en elementos decorativos. Descarta por tanto la simplificación de la decoración por entender que se trata de un mecanismo para ocultar el vacío que existe detrás de sus formas. ${ }^{207}$

Por otro lado, Grassi busca expresar en sus edificios un carácter de elemento inacabado para mostrar su imposibilidad de serlo por las condiciones de la arquitectura actual. Por ello emplea materiales que interpretan lo rústico, como el ladrillo visto, y no materiales que interpretan lo acabado, como el revestimiento de piedra. Y si emplea la piedra es para indicar como podría haber sido el edificio si hubiese podido establecer una relación coherente y leal con el lugar, haciendo con ello más evidente su carácter incompleto. ${ }^{208}$

Grassi entiende que la actuación en Sagunto es una ocasión única para recuperar un teatro romano, debido a su situación en el núcleo de una ciudad viva, que explica su razón de ser y ayuda a conectarla con el castillo. Para ello se hace necesario lo que Bonelli llama la "liberación de su verdadera forma", la "forma representativa" en la ciudad, resolviendo además el problema de la vida del monumento al recuperar su uso de espacio teatral. Grassi matiza que se busca restituir sólo la unidad visible, sólo los elementos necesarios para el espectáculo, y no su totalidad, tratando de mantener un justo equilibrio entre lo que se deja ver y lo que viene solamente evocado a través de su "ausencia elocuente". ${ }^{209}$
205 GONZÁLEZ, A.: "Restaurar es reconstruir. A propósito del nuevo monasterio de Sant Llorenç de Guardiola de Berguedà (Barcelona)". E-rph, diciembre 2007.

206 GRASSI, G.: Una vita da architetto. Milano, Ed. Franco Angeli, 2008, pp. 28, 29

207 GRASSI, G.: Op. cit., 2008, pp. 38, 42

208 GRASSI, G.: Op. cit., 2008, p. 40

209 GRASSI, G.: "Un Parere Sul Restauro dei Monumenti (a proposito del Teatro di Sagunto) / Algunas Consideraciones Sobre la Restauración de los Monumentos. (A propósito del Teatro de Sagunto)", Cuadernos de Arquitectura Romana, vol. 2, 1993, pp. 47-50 / 239-240

[197] Teatro romano de Sagunto. (GRASSI: 2008, p. 106)

[198] Castillo de Valkhof. (GRASSI: 2008, p. 145)

[199] Castillo de Abbiategrasso. (GRASSI: 2008, p. 76)

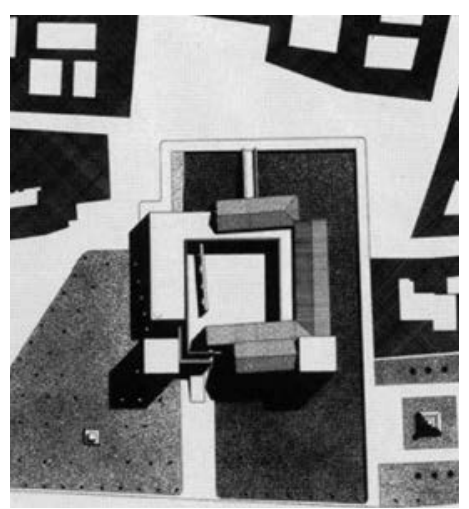

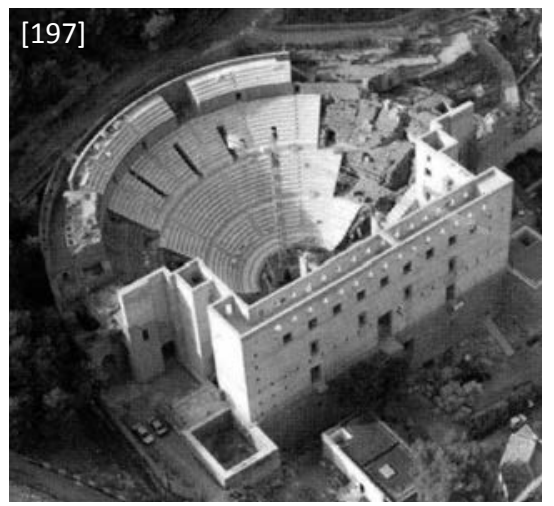

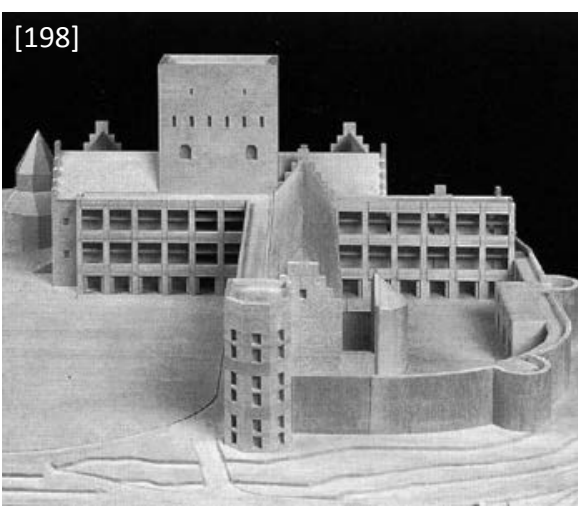


210 GRASSI, G.: "Ricostruzione del castello di Valkhof". Casabella no666, Aprile 1999, p. 54-56

211 GRASSI, G.: Teatro Romano di Brescia. Progetto di restituzione e riabilitazione. Milano, Ed. Electa, 2003, p.11

212 GRASSI, G.: Op. cit., 2003, p.58

213 GRASSI, G.: Op. cit., 2003, p.62

En el caso del Castillo de Valkhof Grassi se propone su reconstrucción al entender que se había perdido un elemento fundamental de la forma de la ciudad de Nimega, y el parque público que había ocupado su lugar había eliminado su memoria histórica. Pero Grassi entiende que la reconstrucción debe atender al equilibrio entre el castillo, el parque y el nuevo uso. Para Grassi la reconstrucción debe suponer el "hacer aparecer algo que es (...) nuevamente necesario". ${ }^{210}$

\section{Ejemplo 86. Teatro romano de Brescia. Giorgio Grassi. 2000}

De entre todos los proyectos destaca el del teatro romano de Brescia, por la evolución que se denota respecto a la intervención en el teatro romano de Sagunto, derivada en parte por las diferencias en los condicionantes de ambos proyectos. En este caso Grassi plantea el proyecto de Brescia como parte del tejido consolidado del centro histórico, renunciando a su imagen emergente original y buscando en consecuencia restituir solamente aquella parte de la scaenae frons romana que pudiera ubicarse dentro del volumen del palacio desaparecido bajo el que se ocultaban los restos. ${ }^{211}$
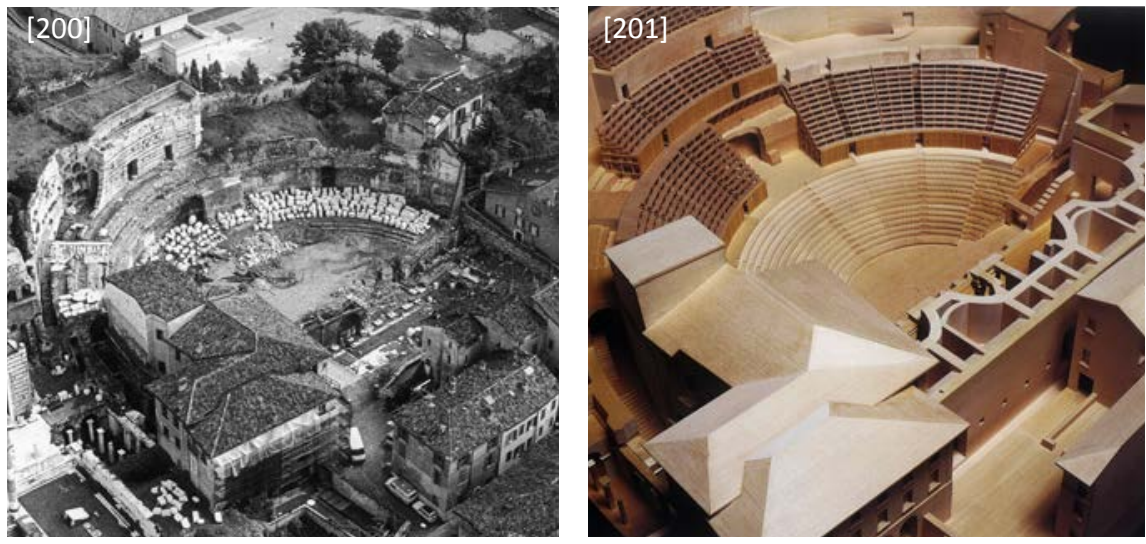

[200 y 201] Teatro romano de Brescia. Vista antes de la intervención y maqueta del proyecto de intervención. (GRASSI: 2003, p. 41)

[202] S. Serlio, sección del teatro en el Trattato sopra le scene, Secondo libro sulla Prospettiva, 1545. (GRASSI, 2003, p. 69)

[203] Teatro romano de Brescia. Modelo de estudio de proyecto. (GRASSI: 2003, p.73)
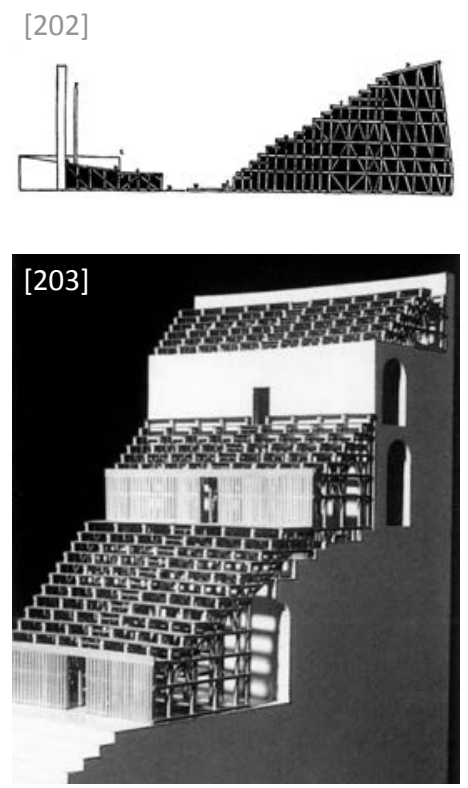

Grassi emplea la madera en la reconstrucción de la cavea desaparecida buscando la compatibilidad con los materiales originales mediante un sistema constructivo no extraño a la experiencia constructiva romana, pero manifiestamente distinto del utilizado en la construcción original, gracias a su carácter reversible, desmontable, provisional. Grassi justifica la solución con madera por ser una estructura robusta y elemental que tiene referencias técnicas y expresivas a lo largo de la historia de la arquitectura: desde teatros romanos móviles o provisionales (theatra lignea, teatro girabile de Curione), hasta teatros renacentistas cuya importancia deja constancia en la famosa sección de Serlio.212 Por otro lado, la parte de la cávea excavada se reviste con piedra superpuesta de forma reconocible sobre la estructura original.

Respecto a la actuación en el frente escénico, Grassi atiende, por un lado, a la construcción volumétrica del cuerpo escénico para medirse con su entorno, atendiendo a la construcción de la complejidad y riqueza presentes en el complicado sistema de muros, ménsulas, cornisas y demás elementos; y por otro lado, a la recomposición parcial de los elementos decorativos mediante la ubicación de los restos arqueológicos en su lugar original, a modo de anastilosis. ${ }^{213}$ 


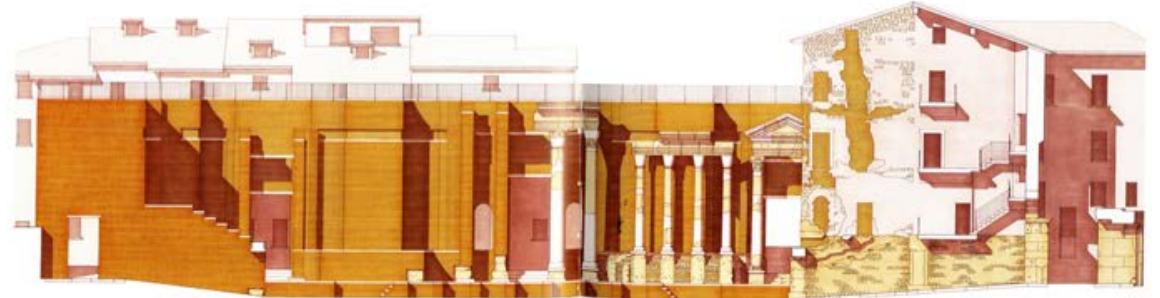

[204]

\section{Ejemplos 87. Reconstrucción del tejido de San Michele in Borgo en Pisa. Massimo Carmassi. 1979-2001}

Este proyecto consiste en la reconstrucción del tejido urbano que envuelve a la iglesia de San Michele in Borgo en Pisa. El resultado es fruto de un largo proceso de proyecto de más de 20 años en el que se denota una evolución desde la contraposición entre antiguo y nuevo de los primeros proyectos, debido al empleo de estructuras metálicas evidentes, hasta la búsqueda de equilibrio mediante la adopción de criterios constructivos similares a los antiguos.

En este sentido Carmassi afirma que "es necesario evitar que la restauración transforme el edificio antiguo, sea cual sea su valor, en un edificio nuevo, ya que las sugerencias y los estímulos de los espacios antiguos y de la materia antigua son irrepetibles". ${ }^{214}$

Los edificios totalmente desaparecidos se reconstruyen a partir de las cimentaciones localizadas en las excavaciones arqueológicas, y los restos parciales se completan sin demolerse. Para ello se emplean muros de fábrica de ladrillo, ya que para Carmassi es importante emplear "tecnologías no demasiado distantes de las existentes", de tal manera que "Ia nueva arquitectura tenga la capacidad de envejecer como los edificios circundantes". ${ }^{215}$

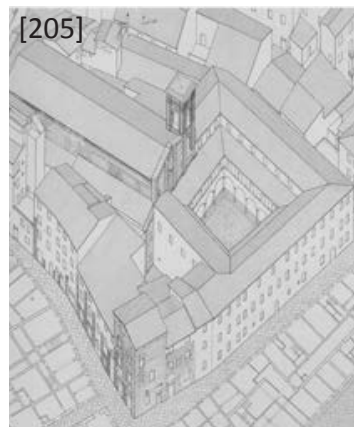

[206]
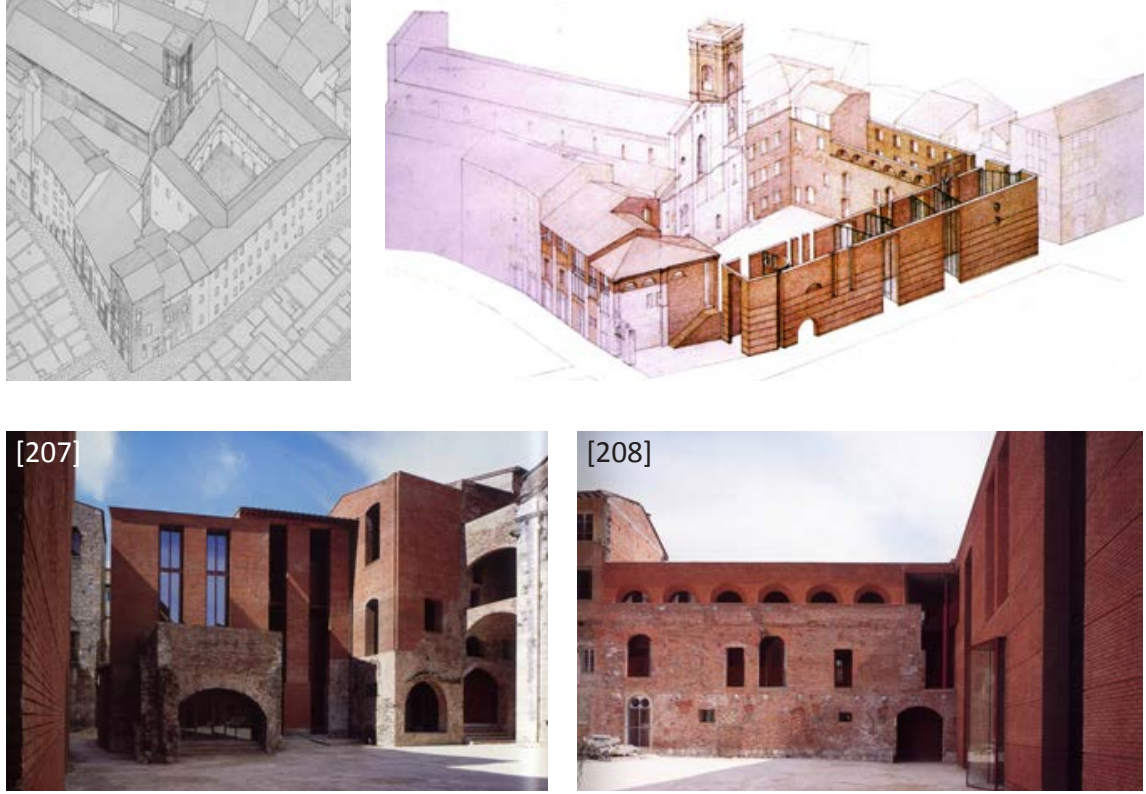

214 RAPPOSELLI, M.: "Nuovo e antico. Intervista a Massimo Carmassi". En: CORNOLDI, A.; RAPPOSELLI, M.: Massimo Carmassi : Pisa. Ricostruzione di San Michele in Borgo. Venecia, Ed. IUAV; Padova, Ed. II Poligrafo, 2005, pp. 16

215 RAPPOSELLI, M.: "Nuovo e antico. Intervista a Massimo Carmassi". En: CORNOLDI, A.; RAPPOSELLI, M.: Op. cit., 2005, pp. 15

[204] Teatro romano de Brescia. Alzado de proyecto. (GRASSI: 2003, p.108-109)

[205] Reconstrucción axonométrica del conjunto de San Michele in Borgo antes del derribo. (CORNOLDI; RAPOSELLI: 2005, p. 23)

[206] Axonometría del proyecto. (CORNOLDI; RAPOSELLI: 2005, p. 33))

[207 y 208] Vistas tras la intervención. (CORNOLDI; RAPOSELLI: 2005, pp.86 y 63) 
216 BOSCH, L.: “La Reconstrucción Parcial en la Rehabilitación del Patrimonio Arquitectónico en España desde los años 80". Arché no 4-5, 2010, pp. 397-406

217 LEPIK, A.; CHIPPERFIELD, D.: "David Chipperfield in conversation with Andres Lepik". En: REICHERT, M.: The Neues Museum - Berlin. Restoration, Repair and Intervention. The Soane Gallery. 2008
[209] Iglesia en Río Seco (LINAZASORO: Arquitectura, no 273, 1988, p.64)

[210] Iglesia en Río Seco (LINAZASORO: Arquitectura, no 273, 1988, p.69)

[211] Neues Museum. Croquis del proyecto. (CHIPPERFIELD: $R \& R, \mathrm{n}$ 은 108,2008, p.20)

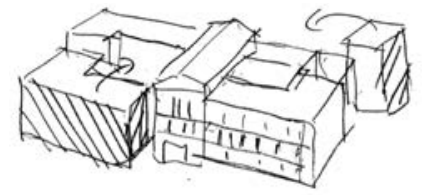

[211]
Ejemplos 88. Reconstrucción de la iglesia de Santa Cruz en Median de Rioseco. José Ignacio Linazasoro. 1985. .116 $^{21}$

En la Iglesia de Santa Cruz en Medina de Rioseco, se propone la reconstrucción de los elementos desaparecidos para recuperar la conformación espacial de la iglesia, buscando recomponer la identidad del edificio. La actuación propone diferentes sistemas adaptados a las circunstancias de cada uno de los tres elementos a reconstruir: las capillas laterales, los muros de cerramiento superior y la cubierta del conjunto. Mientras que al interior la intención es la de establecer una dualidad nave-bóveda que ordene el espacio, al exterior la actuación busca la reinterpretación de la imagen de la iglesia en la ciudad, una dualidad posible gracias a la autonomía del espacio interior frente al exterior propia de un edificio cerrado por muros.

En el interior se actúa sobre las capillas desde el criterio de la continuidad formal para mantener la simetría del espacio interior, mientras que sobre la bóveda se actúa reemplazando la original construida con lunetos y ornamentada con yeserías por una nueva bóveda de cañón construida en madera, que la reinterpreta desde el lenguaje contemporáneo, mediante un elemento más abstracto constructiva y formalmente, que refuerza la idea de espacio clásico y reemplaza la decoración barroca por la expresión tectónica de la materialidad del elemento.

En el exterior la solución adoptada propone un nuevo sistema compositivo que aporte a las fachadas laterales una mayor relación con la fachada principal, haciendo referencia a la totalidad y otorgando un carácter más civil al conjunto. Todo ello mediante una materialidad que aligere las cargas. Para ello se resuelve el cerramiento mediante unos arcos de medio punto y contrafuertes de ladrillo.
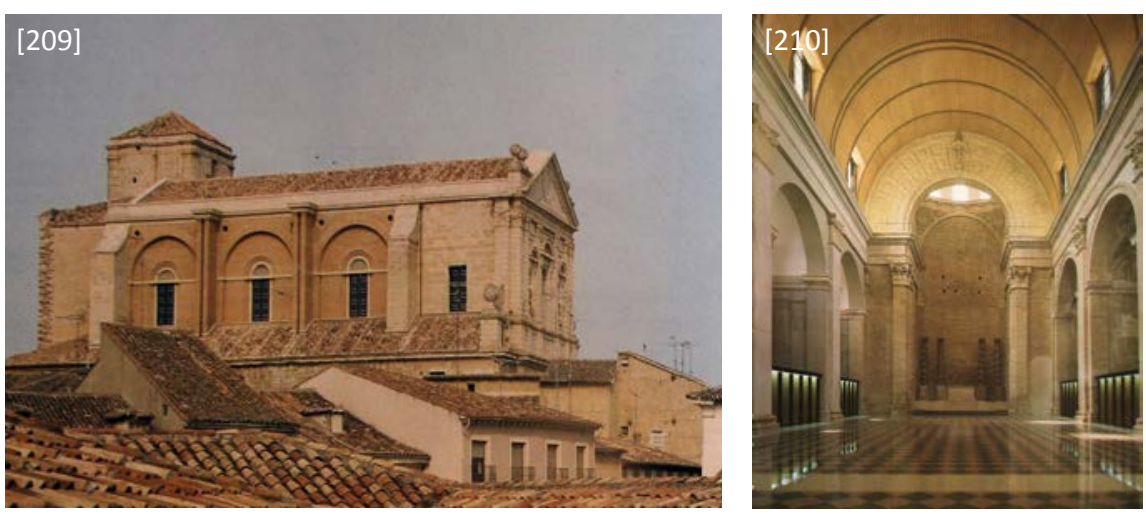

Ejemplos 89. Reconstrucción del Neues Museum de Berlín. David Chipperfield Chipperfield entiende que la actuación debe basarse en dos factores históricos: el edificio original de Stüler y su ruina presente en el lugar en el momento de la intervención. Entiende que no es apropiada la reconstrucción mimética del edificio original, ya que "el tiempo había creado un extraño monumento que no era ni un edificio ni una ruina, sino ambas a la vez". No se trataba de mantener reliquias como en un parque arqueológico, pero al mismo tiempo era necesario mantener los restos materiales porque estos constituían la conexión física con la historia. La atención del proyecto se enfoca sobre las superficies, procediendo espacio por espacio, trozo a trozo, pero al mismo tiempo tratando de mantener continuamente una idea de conjunto, de unidad. ${ }^{217}$ 
La reconstrucción de las partes faltantes se lleva a cabo buscando mantener una continuidad con la estructura existente, pero sin competir con la expresión formal y material de las preexistencias, sino tratando de enfatizarla, reflejando la pérdida pero sin imitarla. ${ }^{218}$

Para Fulvio Irace, Chipperfield "Ha conseguido evocar una presencia de extraordinaria sugerencia, contrastando la abstracción de la idea ordenadora con la sublimación de las roturas o fracturas, en la convicción de que <<es bueno tener no sólo aquello que los hombres han pensado y sentido, sino también aquello que sus manos han logrado, que su fuerza ha elaborado, que sus ojos han mirado cada día de sus vidas >> (Ruskin, The Seven Lamps of Architecture, p.186 y 202)". ${ }^{219}$

Para Ignacio Bosch Chipperfield consigue la continuidad material, formal e histórica sin utilizar la mímesis, pero aprovechando el poder evocador de la ruina. Emplea un sistema de orden capaz de conectar las partes y construir una nueva totalidad, un conjunto capaz de definir los nuevos espacios sin que los fragmentos pierdan su autonomía. ${ }^{220}$

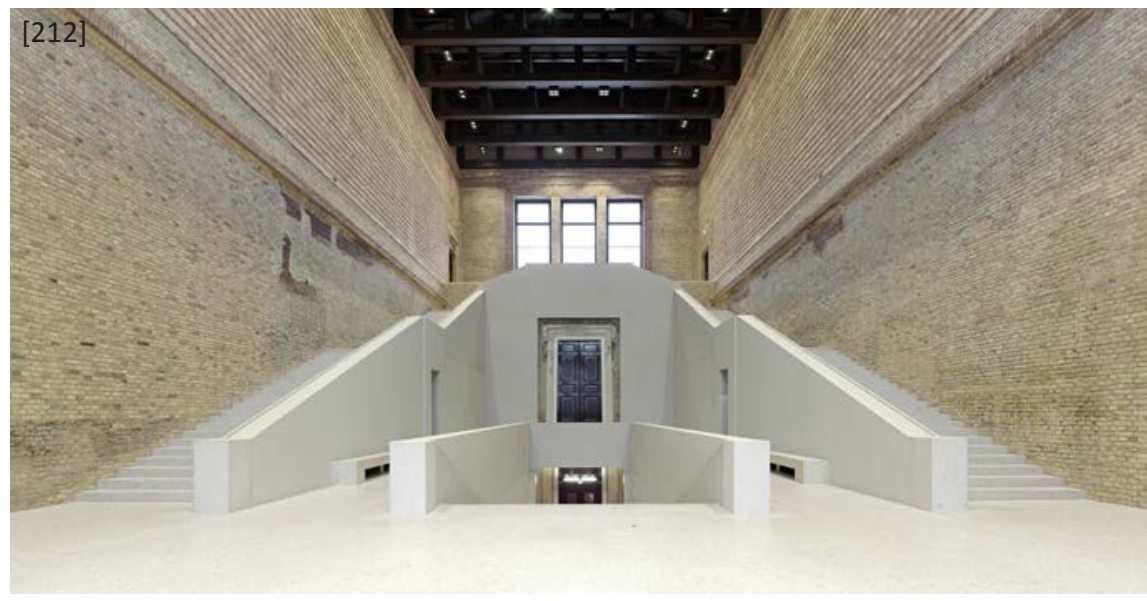

Ejemplos 90. Reconstrucción del vestíbulo de acceso al palacio Omeya de Amann. Antonio Almagro. 1978, 1995. ${ }^{221}$

En la reconstrucción de los muros se reponen los sillares faltantes con piedra similar a la original y se recolocan los elementos decorativos hallados. De tal manera que se completan las partes perdidas, pero se respetan aquellas que conservan suficiente integridad. También se sustituyen las restauraciones de mortero realizadas en los años 30 por nuevos sillares de piedra en los que se han reproducido las formas originales conocidas tales como molduras, dinteles, pilastrillas y arquivoltas.

Para devolver la experiencia espacial del espacio del vestíbulo se plantea la reconstrucción de la cúpula del vestíbulo, pero empleando materiales distintos que aclaren su actualidad. Además la actuación permite favorecer la conservación de los muros y decoraciones del interior y, al mismo tiempo, dotar al espacio de un uso para actividades culturales. La cubierta se propone inicialmente como una estructura ligera de tipo geodésica, pero finalmente se decide una solución de
218 CHIPPERFIEL, D.: "Neues Museum". Restauración y Reahbilitación, R\&R no112-113, p.23.

219 IRACE, F.: "Il restauro del Neues Museum di David Chipperfield". Lotus no 144, p.88-94

220 BOSCH REIG, I.: "Del fragmento al conjunto. De lo particular a lo general". Restauración y Reahbilitación, R\&R no112-113, p.4.

221 ALMAgro, A.: “Restauración del Alcázar Omeya". Loggia, no 11, Valencia, 2001, pp. 44-59

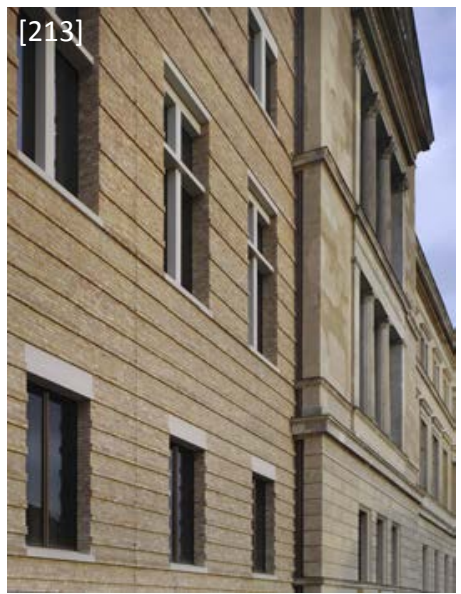

[212] Neues Museum. Vista interior tras la intervención. (CHIPPERFIELD: $R \& R, \mathrm{n}$ ㅇ 108,2008, p. 29)

[213] Neues Museum. Fachada Oeste después de la intervención. (CHIPPERFIELD: $R \& R, \mathrm{n}=108,2008$, p. 25) 
BOSCH, L.: Op. cit., 2010, pp. 397-

menor impacto en la relación con su contexto. Para ello se propone una solución que busca acercarse a la tradición constructiva islámica pero sirviéndose de la técnica actual de la madera laminada. Por otro lado la solución formal se integra con el monumento retomando el perfil de los arcos y semicúpulas sensiblemente apuntados presentes en el edificio. El elemento se resuelve como una pieza independiente y autoportante que se coloca sobre una chapa de anclaje apoyada en el muro, permitiendo su total reversibilidad. Al exterior se reviste con planchas de plomo envejecido para conseguir una armonía con la tonalidad de los sillares.
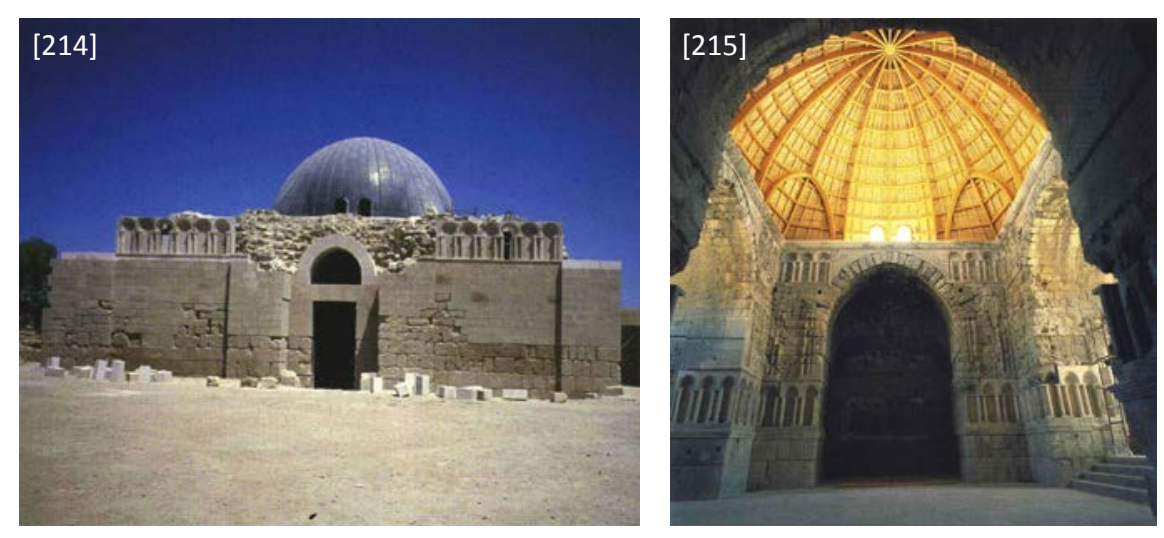

Ejemplos 91. Terminación de la iglesia de Daroca, en Zaragoza. Luis Burillo y Jaime Lorenzo. 1981. ${ }^{222}$

En la Iglesia de San Juan de Daroca, ante el derrumbe de gran parte de la nave central se plantea la recuperación de la volumetría inspirada en su fase original de época románica, mediante la reconstrucción de la cubierta, y los muros lateral y hastial desaparecidos. La propuesta busca mantener la unidad del conjunto y a la vez introducir nuevos elementos que aporten un renovado interés al espacio interior. Para ello se plantea por un lado, continuar la cubierta de teja hasta cubrir todo el espacio, y por otro lado resolver el nuevo elemento de cierre del muro hastial con un sistema que genera una nueva capilla y una nueva iluminación de la iglesia.

[214] Palacio Omeya de Amann. La fachada restaurada con la anastilosis de elementos decorativos. (ALMAGRO: Loggia, no 11, 2001, p. 53)

[215] Palacio Omeya de Amann. Interior del vestíbulo del palacio ya restaurado. (ALMAGRO: Loggia, no 11,2001 , p. 57)

[216] Iglesia en Daroca. Vista interior tras la intervención. (Imagen del autor.)

[217] Iglesia en Daroca. Estado actual y alzado proyectado. (Arquitectura, no 244, p. 66)
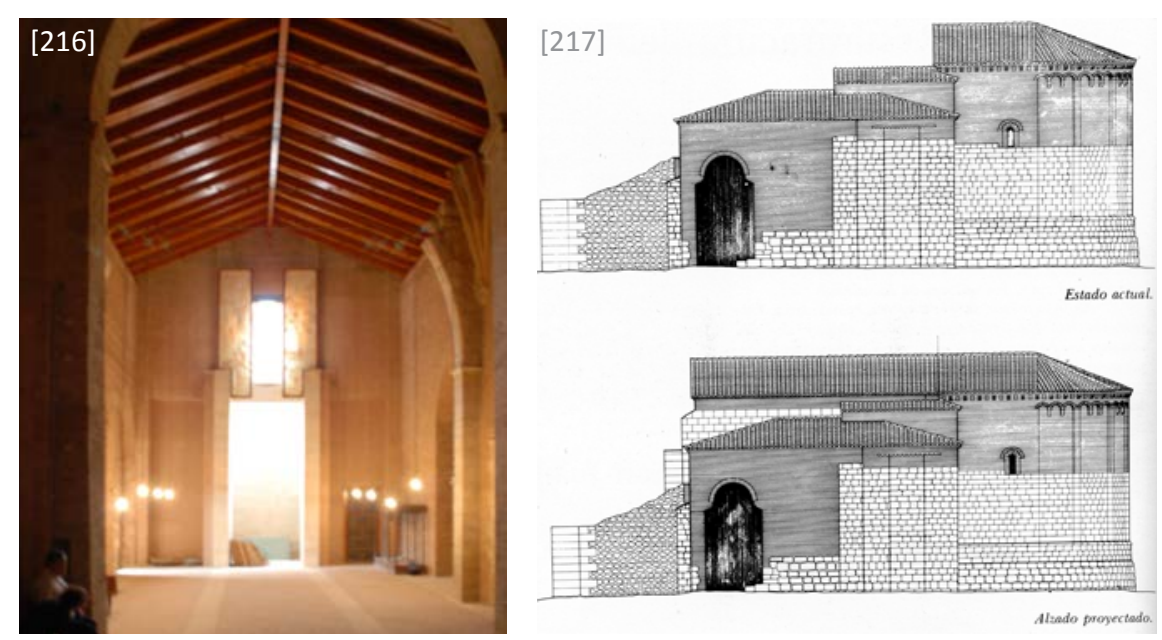
La solución del nuevo elemento busca la relación con la preexistencia en primer lugar mediante la esencialización del concepto de muro como elemento compositivo que se descompone generando la nueva forma, y en segundo lugar mediante el empleo del mismo juego material de piedra y ladrillo presente en la preexistencia. En el interior la luz se convierte en la auténtica protagonista del espacio. Su presencia apoyada por la composición del pavimento, remarca el eje principal dominado por las pinturas románicas del ábside.

\section{Ejemplos 92. Actuación sobre la biblioteca de la Abadía de San Zeno Maggiore.} Verona. Libero Cecchini. 1994-98

De las actuaciones en el complejo abacial de San Zeno en Verona, destaca la actuación de restitución espacial de los restos de lo que podría haber sido la biblioteca del conjunto. La actuación no busca reconstruir fielmente la antigua estructura, de la que no existía documentación gráfica ni elementos arquitectónicos de referencia, sino evocar "Ia imagen formal y espacial original a través de materiales explícitamente distintos, aislando la nueva intervención respecto a las paredes laterales y haciéndolo funcionar como elemento autoportante, como una especie de mueble colocado en el espacio libre". ${ }^{223} \mathrm{El}$ espacio longitudinal, organizado en tres naves, se cubre con unas bóvedas de crucería reinterpretadas mediante el empleo de listones horizontales de madera, y apoyadas sobre pilares de madera maciza. El muro de cerramiento recayente al oeste se reconstruye parcialmente siguiendo el concepto de bandas horizontales de piedra de dos tonos, presente en el resto del muro preexistente.
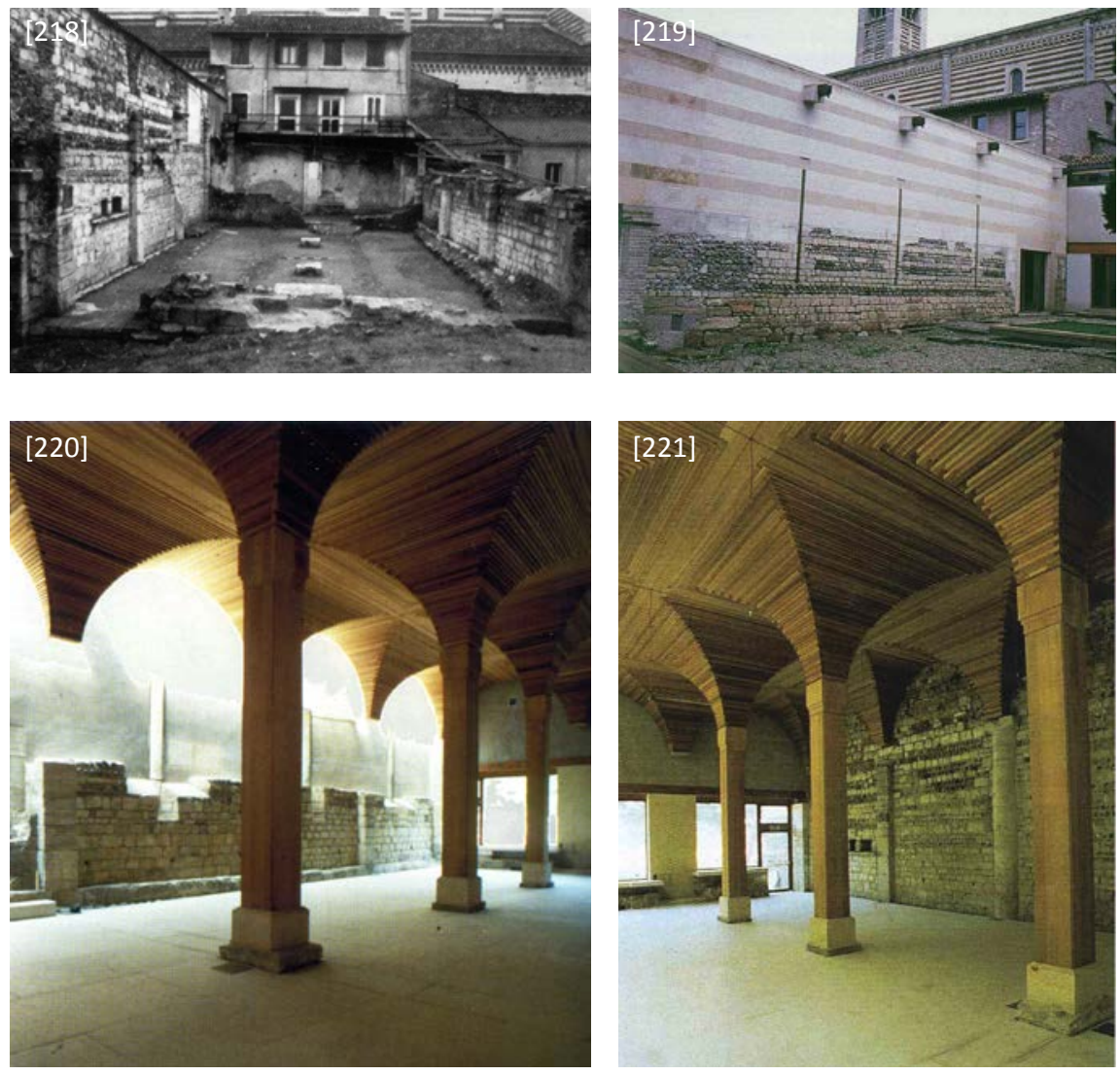

223 BOGONI, B.: Libero Cecchini. Natura e archeologia al fondamento dell'architettura. Firenze: Alinea editrice, 2009, p.226

[218] Vista anterior a la intervención. (BOGONI: 2009, p. 226)

[219] Alzado. (CECCHINI: Loggia, № 10,2000, p. 25)

[220] Vista interior tras la intervención. (BOGONI: 2009, p. 228)

[221] Vista interior tras la intervención. (CECCHINI: Loggia, no 10, 2000, p. 23)

[222] Sección de proyecto. (BOGONI: 2009, p. 228)

\section{[222]}

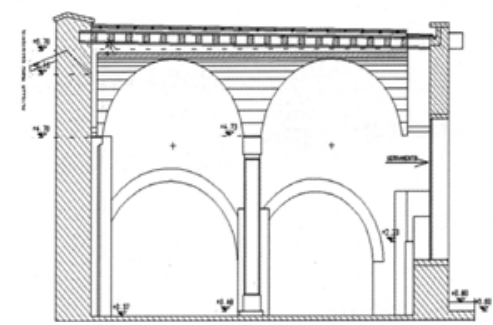


Ejemplos 93-95. Iglesia de Sant Vicenç de Malla (1983), iglesia de Sant Jaume de Sesoliveres (1993-96), monasterio de Sant Llorenç de Guardiola de Berguedà (1998-2008). Antonio González

En estos tres proyectos se observa una búsqueda por completar las partes faltantes mediante una reinterpretación formal y material de los elementos desaparecidos. Se aprecia una evolución hacia una mayor compatibilidad material entre lo antiguo y lo nuevo, mediante el paso del hormigón empleado en Sant Vicenç a los materiales pétreos de Sant Llorenç, así como una búsqueda de reversibilidad e independencia en las actuaciones interiores mediante el empleo de materiales ligeros como la madera y con formas que se separan de los muros exteriores para mostrar su autonomía.

[223] Sant Vicenç de Malla. Vista antes de la restauración. (GONZÁLEZ. En: ICRBC: 1987, p. 46)

[224] Sant Vicenç de Malla. Vista después de la restauración. (GONZÁLEZ. En: ICRBC: 1987, p. 47)

[225] Sant Jaume de Sesoliveres. Interior de la iglesia antes de iniciarse los trabajos de restauración. Imagen tomada el 9 de marzo de 1993. (GONZÁLEZ: Informes de la Construcción, vol. 48, no 445, 1996, p. 25)

[226] Sant Jaume de Sesoliveres. Interior de la iglesia después de la restauración. Puede observarse el desplome del muro de mediodía. Imagen tomada el 4 de octubre de 1995. (GONZÁLEZ: Informes de la Construcción, vol. 48, no 445, 1996, p. 30)

[227 y 228] Monasterio de Sant Llorenç de Guardiola. Vista exterior y vista interior del monasterio tras la restauración. (Pendís Bagà: <www. pendisbaga.com>)
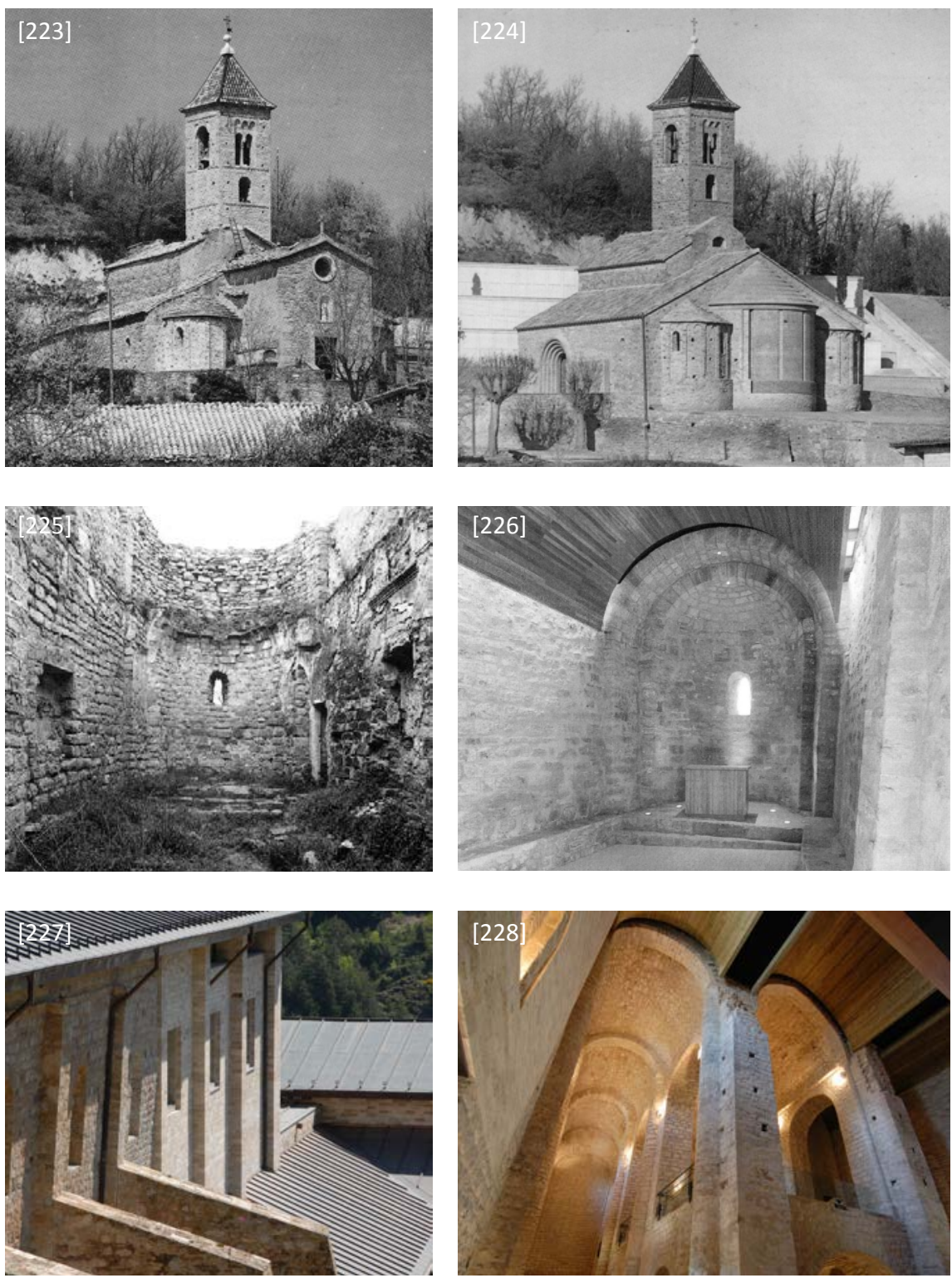

Evolución de los criterios de intervención en el patrimonio arquitectónico 
Reintegración de la imagen:

En la reintegración de la imagen, no se busca tanto el recuperar la tipología del edificio de una manera abstracta y esencializada, como evocar la imagen formal de los elementos desaparecidos de manera fragmentada y virtual para recuperar en cierta medida la unidad del monumento. Se muestra mayor preocupación por la imagen envolvente que por la consistencia formal original, produciendo un cierto carácter escenográfico, ya que se entiende que el impacto que tendría la reproducción completa de la parte desaparecida anularía los valores "románticos" de la preexistencia.

Debido al trabajo de reinterpretación formal y material se produce una alteración más o menos profunda del edificio original que aporta nuevos valores espaciales y lumínicos al monumento. En este sentido algunos de los ejemplos mencionados en la reconstrucción tipológica podrían incorporarse igualmente en esta categoría si nos fijamos en los juegos efectistas producidos en el interior del espacio.

Es un mecanismo que se emplea habitualmente en el caso de la recuperación de elementos de pequeñas dimensiones. Las soluciones varían en función de la mayor o menor definición formal del elemento evocado, y en función de su concreción material. Se hace fundamental en estos casos que el número de elementos sea suficiente para que la forma esté adecuadamente definida. La mínima expresión de la evocación la encontramos en la representación en el pavimento de las trazas de la parte desaparecida, tratando de dejar constancia de su existencia pasada.

En esta línea son interesantes las reflexiones de Remo Bodei sobre la poética de lo indefinido surgida a finales del siglo XVII, y que ha derivado en la apreciación moderna por el fragmento y la ruina, y su reconstrucción mental. Para Bodei el concepto de mímesis no significa tanto la representación exacta de algo, sino el suscitar su evocación. Para Giovanni Carbonara este concepto es análogo al empleado en la restauración de integración no imitativa que busca aludir a aquello que ha desaparecido. ${ }^{224}$

Carbonara defiende el empleo de este mecanismo haciendo hincapié en la simplificación formal de la reinterpretación, para evitar caer en la reproducción innecesaria de detalles. En este sentido destaca la actuación de la Torre de Salomon en Visegard (1963-66) en la que Sedlmayr busca reintegrar la imagen de las partes desaparecidas mediante materiales nuevos y soluciones abstractas, una actuación en la que para Carbonara "la documentación escrupulosa y el rigor científico se combinan con una decidida implicación creativa". ${ }^{225}$

En esta línea se pueden citar actuaciones que varían de soluciones más virtuales como la del Castillo de Kolding (ej.96), la intervención en la cubierta de la Manica Lunga del castillo de Rivoli (ej.97), la reconstrucción de la cúpula del Reichstag de Berlín (ej.98) o la actuación sobre el tempioduomo de Pozzuoli (ej.99); soluciones intermedias como la reconstrucción

224 CARBONARA, G.: Architettura d'oggi e restauro. Un confronto anticonuovo. Torino, Ed. Utet, 2011, p. 82

225 CARBONARA, G.: La Reintegrazione dell'immagine. Roma, Bulzoni Editore, 1976, fig. 13, 51-52 
de las bóvedas del oratorio boloñés de San Fillipo Neri, realizado por Pier Luigi Cervellati, o la intervención de Emanuele Fidone en la iglesia de San Pedro de Siracusa, analizados en profundidad en esta tesis; o soluciones mas definidas como la restauración del Corridore di Prato (ej.100) o la actuación sobre la capilla mayor de la iglesia de la Asunción de Elvillar en Álava (ej.101).

Ejemplo 96. Castillo de Kolding. Dinamarca. I. y J. Exner. 1972-94

Se busca evocar las estructuras originales desaparecidas mediante estructuras modernas esencializadas. Destaca la delicadeza empleada en la solución formal y material de los nuevos elementos.

[229 y 230] Castillo de Kolding. Vistas interiores tras la intervención. $(\mathrm{E}+\mathrm{N}:<w w w . e p l u s n \cdot d k>)$

[231] Castillo de Rivoli. Vista interior de La Manica Lunga. (BRUNO: 1996, p. 170)

[232 y 233] Castillo de Rivoli. Vista exterior y sección de La Manica Lunga. (BRUNO: 1996, pp. 168 y 170)

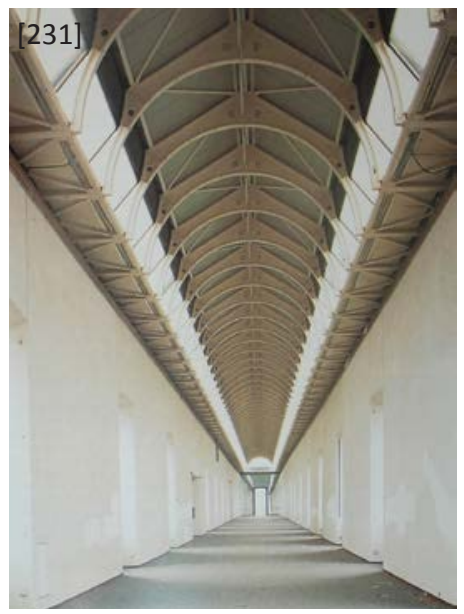

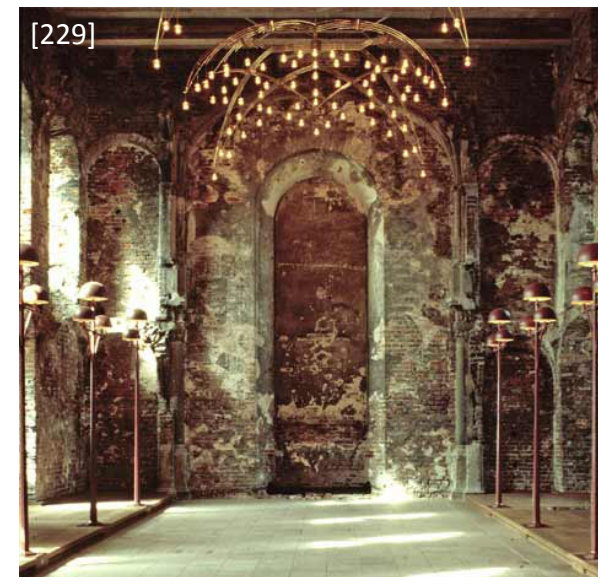

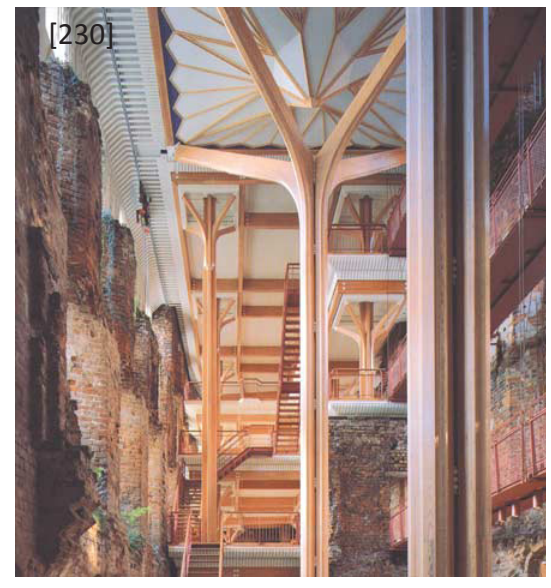

Ejemplo 97. La Manica Lunga del castillo de Rivoli. Andrea Bruno. 1986

El castillo de Rivoli, transformado por el propio Bruno en 1984 para su uso como museo, fue proyectado por Juvarra en 1718 pero su construcción quedó interrumpida en 1727. En el espacio restante se construirá durante el siglo XVIII el edificio de la Manica Lunga para albergar la Pinacoteca de Carlo Emanuele I. La intervención sobre este edificio plantea retomar su función original, sustituida por un uso militar, mediante su adaptación como sala del museo de
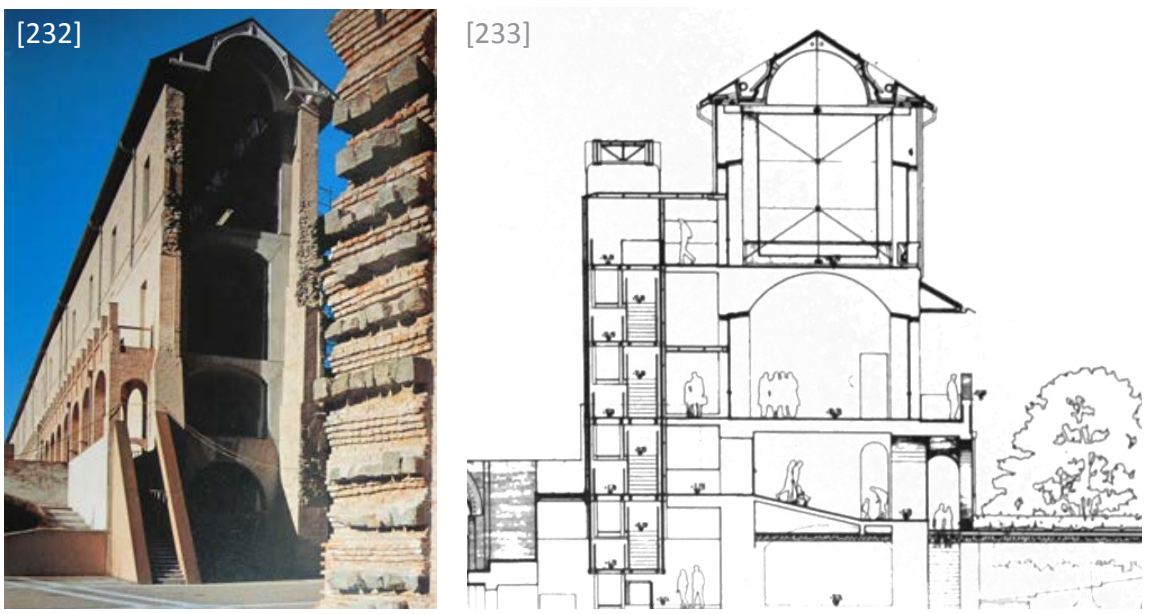

Evolución de los criterios de intervención en el patrimonio arquitectónico 
Arte Contemporáneo. La actuación comprende la repristinación de las ventanas originales, la eliminación de particiones interiores, la sustitución de la antigua cubierta por una nueva y la colocación de elementos de conexión vertical. Destaca la actuación en el techo, que se encontraba en estado ruinoso, consistente en la colocación de una sucesión de elementos metálicos con forma de arco, que crean una bóveda virtual con un lenguaje claramente nuevo. Las escaleras se sitúan como elementos independientes también con un carácter moderno y reversible.

\section{Ejemplos 98. Reconstrucción de la cúpula del Reichstag de Berlín. Norman Foster} El arquitecto inglés Norman Foster propone, en la reconstrucción de la cúpula del Reinchstag de Berlín, una reinterpretación de la forma desaparecida mediante una estructura de acero y vidrio que aporta un juego de transparencias y reflejos que reducen su presencia material. Una manera acertada de introducir un lenguaje moderno en la preexistencia, sin producir una distorsión. Cabe mencionar, sin embargo, que esta solución es el fruto de una reflexión proyectual motivada por las exigencias de evocación a la preexistencia introducidas por el cliente, lo que le Ilevan a acercarse a la propuesta planteada por Santiago Calatrava. Esto se aprecia en la evolución de la propuesta, inicialmente ajena a toda intención reconstructiva y de gran impacto sobre el monumento y el entorno.
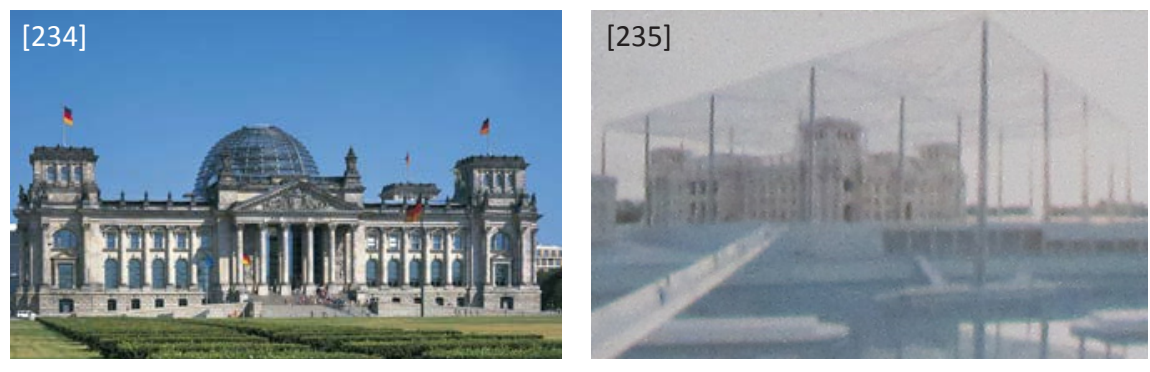

\section{Ejemplo 99. Tempio-Duomo de Pozzuoli. Marco Dezzi Bardeschi}

El proyecto para el Tempio-Duomo de Pozzuoli se enmarca dentro de un concurso internacional de proyectos, dirigido por Giovanni Carbonara. El concurso se plantea, con la intención de que las propuestas presentadas respondieran adecuadamente a las necesidades presentes en el monumento combinando por un lado una vertiente conservativa de los valores histórico-artísticos, y por otro lado una vertiente innovadora que atendiera a las cuestiones de puesta en valor y dotación de uso arqueológico y de culto religioso del monumento. ${ }^{226}$
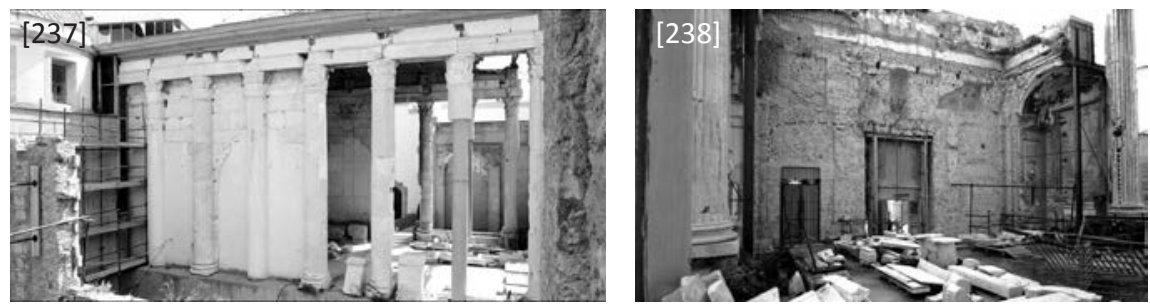

226 CARBONARA, G.: "La Chiesa Cattedrale-Tempio di Augusto a Pozzuoli: un innovativo concorso di restauro". En: GIANFRANCO, A. (ed.): Tempio-Duomo di Pozzuoli. Progettazione e restauro. Ed. Giannini, 2006, p. 19
[234] Cúpula del Reichstag. Estado actual. (Foster + Partners: <www. fosterandpartners.com>)

[235] Cúpula del Reichstag. Propuesta de Norman Foster. (Domus, no 748,1993, p. 5)

[236] Cúpula del Reichstag. Propuesta de Santiago Calatrava. (Domus, no 748,1993, p. 5)

[237 y 238] Tempio-Duomo de Pozzuoli. Imágenes anteriores a la intervención. (DEZZI BARDESCHI: $<$ www.marcodezzibardeschi.com>) 
227 DEZZI BARDESCHI, M.: “Elogio del palinsesto". En: GIANFRANCO, A. (ed.): Tempio-Duomo di Pozzuoli. Progettazione e restauro. Ed. Giannini, 2006, p. 25-35

228 CHIPPERFIELD, D.: "Tertium Quid". En: GIANFRANCO, A. (ed.): TempioDuomo di Pozzuoli. Progettazione $e$ restauro. Ed. Giannini, 2006, p. 97-107

[239 y 240] Tempio-Duomo de Pozzuoli. Vista exterior y vista interior después de la intervención. (DEZZI BARDESCHI: <www.marcodezzibardeschi.com>)

[241] Tempio-Duomo de Pozzuoli. Vista exterior del edificio tras la intervención. (DEZZI BARDESCHI: $<$ www.marcodezzibardeschi.com>)

[242] Tempio-Duomo de Pozzuoli. Vista exterior de la propuesta del equipo de David Chipperfield. (CHIPPERFIELD et al.: $A R$, no 60 , 2005)

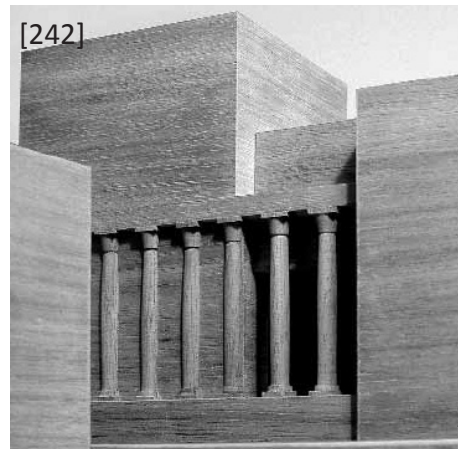

El proyecto vencedor, dirigido por el arquitecto Marco Dezzi Bardeschi, propone una actuación de máxima conservación de las preexistencias y mínima presencia de los añadidos, estos últimos dirigidos a evocar el templo romano desaparecido. Para ello se cierra el espacio con elementos de vidrio que permiten recrear la transparencia del espacio de la pronaos del templo, así como el ritmo de las columnas desaparecidas, aunque sin reponer el muro de separación de la cella. El elemento de cubierta respeta las cerchas metálicas preexistentes, construidas como parte del proyecto de intervención previo, respetando con ello la tipología del edificio romano. Las cerchas se ocultan mediante un falso techo de casetones en el interior y una cubierta de tejas de mármol blanco que evocan a las originales. En este caso la diferencia entre antiguo y nuevo no se manifiesta mediante la ligereza material, sino a través del recurso de la abstracción dada por la cubierta blanca. También destaca la atención a la superposición material de restos de diversas épocas, que se ponen en valor en las actuaciones de restauración de la preexistencia. 227

Dezzi Bardeschi evidencia su culto a la conservación de lo existente mediante exhaustivos trabajos de representación de su estratificación y degradación material, y proyecta los nuevos elementos mediante una estética tecnológica a base de acero y vidrio, que si bien persigue la mínima intervención sobre la materia, sin embargo su fuerte contraste produce una profunda alteración de la imagen de la preexistencia.
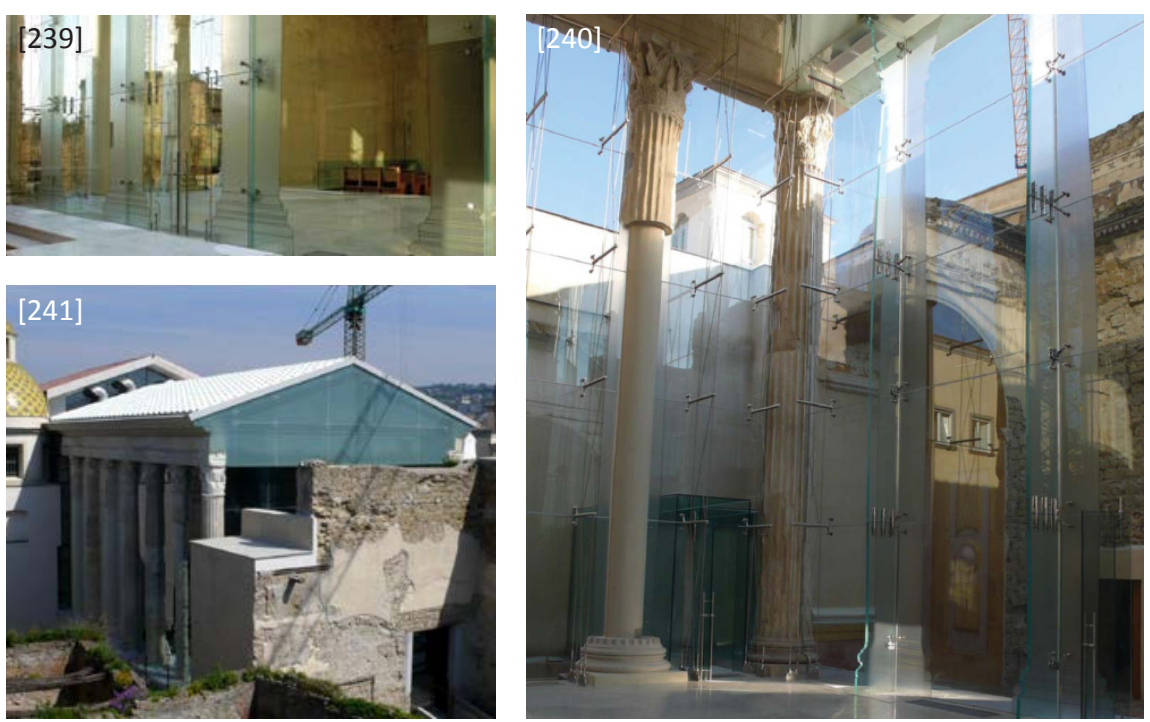

De entre las propuestas más creativas, destaca el proyecto del equipo de David Chipperfield, que propone "reordenar los fragmentos existentes y añadir los componentes faltantes con la finalidad de reconstituir el espacio de culto bajo los dictámenes del Concilio Vaticano II". Se propone, por tanto, una nueva idea espacial que integre la complejidad de las preexistencias del templo y de la iglesia, y configure la nueva catedral. Un nuevo proyecto que responde a un lenguaje contemporáneo, que propone dar una nueva unidad a través de un juego de volúmenes que transmiten una buscada disonancia visual respecto a los elementos del contexto, pero reproponiendo la fragmentación característica del lugar. ${ }^{228}$ La solución sin embargo modifica con rotundidad la imagen consolidada del edificio en la ciudad. 
Ejemplo 100. Recuperación de tramos del Corridore de Prato. R. Dalla Negra, P. Ruschi

Riccardo Dalla Negra actúa sobre las ruinas de una muralla, recuperando algunos tramos desaparecidos para permitir restablecer el recorrido peatonal original, cubierto la mayoría de sus tramos. Un recorrido que permite conectar dos partes de la ciudad, sin interferir con los viales, y poner en valor la fortificación, dotándola de un posible uso expositivo. Las actuaciones consisten en la creación de un puente de conexión entre dos tramos de la muralla, así como de dos accesos, uno en cada extremo del recorrido, con escaleras que conectan el nivel de la calle con el del recorrido. ${ }^{229}$

Dalla Negra entiende que la actuación para completar las partes faltantes, debe garantizar la lectura del texto arquitectónico mediante una solución en continuidad y fidelidad con lo antiguo, y al mismo tiempo con sensibilidad crítica e histórica contemporáneas. Una fidelidad que no significa imitación, réplica o falsificación, sino el empleo de nuevos elementos que dialogan con las preexistencias y a la vez resuelven las nuevas necesidades funcionales y tecnológicas. ${ }^{230}$

La forma de los nuevos elementos retoma la de los tramos originales, pero se modifica radicalmente el material empleando, en lugar de la piedra, madera al exterior y acero al interior. Cabe destacar la solución empleada para evidenciar el trazado de la muralla desaparecido mediante una pavimentación de adoquines y una fila de cipreses que orientan la mirada hacia el punto de conexión con el Castillo del Emperador. ${ }^{231}$
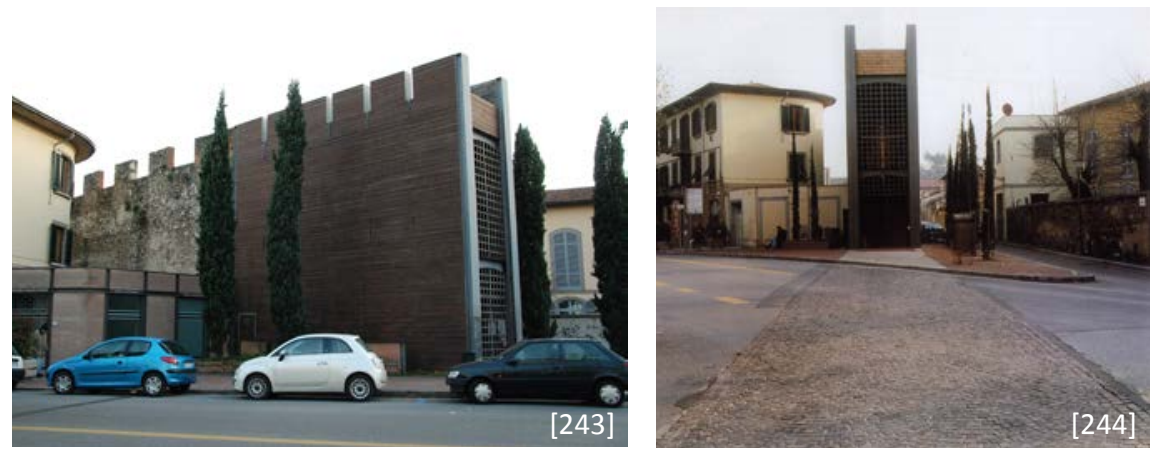

\section{Ejemplo 101. Capilla mayor de la iglesia de la Asunción de Elvillar en Álava}

La actuación plantea la reconstrucción de la bóveda de crucería de la capilla mayor de una pequeña iglesia gótica de una sola nave original del siglo XVI. La actuación propone respetar los elementos de hormigón de refuerzo construidos tras el derrumbe, y relacionarse compositivamente con el espacio abovedado colindante. La condición impuesta por las vigas de hormigón sugiere el empleo de un material delgado que permitiera aprovechar la reducida altura para obtener el efecto de concavidad de la bóveda desaparecida.

Por ello se decide reconstruir los nervios de la bóveda desaparecida mediante el empleo de tubo de acero trasdosado con pletinas que simulen la forma de los elementos originales. La plementería se resuelve con chapa de acero perforada, separada ligeramente de los nervios para acentuar la percepción de las líneas
229 DALLA NEGRA, R.; RUSCHI, P.: II Corridore di Prato : una fortificazione medievale restaurata. Firenze, Ed. Edifir, 2000, p.37

230 DALLA NEGRA, R.; RUSCHI, P.: Op. cit., 2000, p.35-36

231 DALLA NEGRA, R.; RUSCHI, P.: Op. cit., 2000, p.38

[243] Corridore de Prato. Vista lateral del encuentro entre la muralla original y el nuevo tramo. (Imagen del autor.)

[244] Corridore de Prato. Vista del trazado de la muralla desaparecida en el pavimento. (DALLA: 2000) 
232 LASAGABÁSTER GÓMEZ, J.I.: "Reconstrucción de la bóveda de la capilla mayor de la iglesia de la Asunción de Elvillar (Álava)". En: A.A.V.V.: Restaurar o Conservar?: BarcelonaCardona, del 17 al 20 de noviembre de 1993. Barcelona: Diputació de Barcelona. 1996, pp. 61-66

233 GIZZI, S.: "L’anastilosi tra restauro architettonico e restauro archeologico". En: GONZÁLEZ, A.; DIEZ, M.: I Bienal de la restauración: L'Hospitalet de Llobregat (Barcelona), del 23 al 26 de noviembre del 2000. Barcelona: Diputació de Barcelona. 2002, pp. 84, 90 de sombra de las bóvedas de piedra. De esta forma, con el mismo material pero perforado, se logran dos intensidades de color distintos en nervios y plementería. Por último, retomando las prácticas en retablos y bóvedas de ciertos templos riojanos, se opta por dorar la bóveda y así conferirle cierta armonía con el cálido tono de la piedra arenisca del interior de la iglesia. ${ }^{232}$
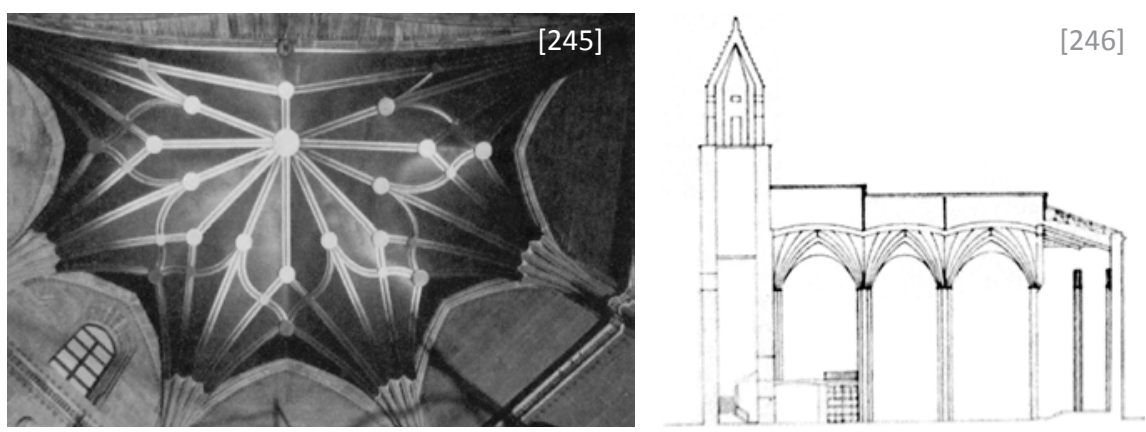

Restauración arqueológica:

Dentro del campo de la denominada "restauración arqueológica", es decir aquella en la que se conserva la ruina como resto dentro de un conjunto arqueológico, se pueden observar actuaciones que buscan evocar parcialmente la forma original para explicar de manera más didáctica la función de los elementos en el conjunto al que pertenecían. Para ello se puede optar por la anastilosis, que consiste en la recolocación de los elementos arruinados en su lugar original, o por la denominada "anastilosis indirecta" que consiste en emplear nuevos elementos para evocar de una manera más o menos evidente parte de los elementos originales.

Como afirma Stefano Gizzi la imagen parcial del monumento restituido es falsa porque presenta una realidad distinta a la original. Por ejemplo, la ciudad de Palmira en Siria, en la que el bosque de columnas realzadas presenta una transparencia irreal, ya que en origen éstas se recortaban contra los muros de las insulae circundantes. Se trata de una alusión parcial que de manera didáctica busca ejemplificar una parte que evoque el todo, una sugerencia de lo que fue, a través de una nueva realidad. ${ }^{233}$

Algo similar ocurre en el teatro romano de Ostia Antica, donde la anastilosis de las columnas de la escena sin recuperar el muro de la postscaenium permite crear una relación visual entre la cavea y el porticus post scaenam, produciendo una situación completamente distinta a la original pero de gran interés espacial. Estas circunstancias más o menos azarosas de los monumentos en ruina han servido de inspiración a numerosos arquitectos modernos a la hora de crear nuevas arquitecturas.

El caso de la anastilosis es muy habitual sobre templos y teatros romanos, en los que se recolocan las columnas y elementos ornamentales hallados en las excavaciones arqueológicas para tratar de mostrar parte de la 
volumetría original de los edificios. Es importante aclarar que para la recolocación de los restos es necesario el empleo de nuevos elementos intercalados entre los antiguos que permitan hacer de ligazón entre los fragmentos. Así se actúa en el Templo de Diana en Mérida (ej.102) y en el teatro romano de Cartagena (ej.103).

Algo diferente es la actuación de Alvaro Siza y Roberto Collovà sobre las ruinas de la iglesia Madre en Salemi, donde a través de intervenciones mínimas buscan evocar el edificio original para cualificar el espacio urbano del que han pasado a forman parte (ej.104).

\section{Ejemplo 102. Templo de Diana en Mérida. Dionisio Hernández Gil. 1985}

En esta obra se busca conservar la superposición histórica del palacio de los Corvos construido en el siglo XVI sobre el templo romano, gracias a la cual ha sido posible la supervivencia del edificio original a lo largo del tiempo. Las intervenciones de anastilosos del templo logran mostrar la totalidad del mismo pero sin perder la convivencia con el palacio, el cual demuestra en su manera de insertarse sobre el edificio romano la riqueza de la transformación de la arquitectura a lo largo de la historia. ${ }^{234}$

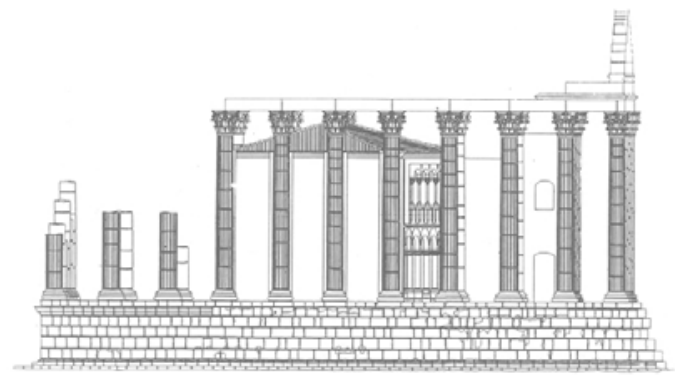

[247]

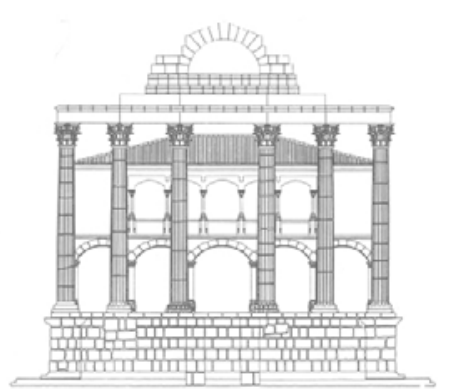

[248]
Ejemplo 103. Teatro romano de Cartagena. Rafael Moneo. 2004.235

La actuación sobre el teatro se centra en la recuperación parcial del elemento, haciéndolo visitable, de tal manera que se permita transmitir las señas de identidad de la Cartagena romana. La actuación se concibe desde una óptica de restauración eminentemente arqueológica, de tal manera que sin perder la imagen de ruina se pueda percibir la grandeza del teatro. Se busca por tanto establecer un acuerdo entre la reconstrucción arquitectónica del teatro y la constatación del conjunto como yacimiento arqueológico.
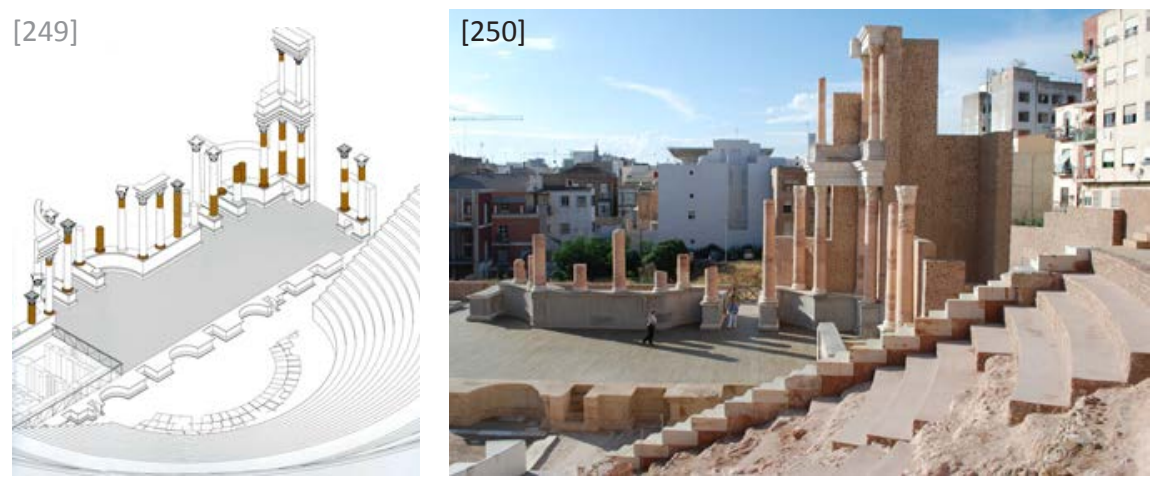

234 A.A.V.V.: Intervenciones en el Patrimonio Arquitectónico (1980-1985). Madrid: Dirección General de Bellas Artes y Archivos, 1990, pp. 398-400

235 BOSCH, L.: Op. cit., 2010, pp. 397406
[247 y 248] Templo de Diana. Alzado Oeste y Alzado Sur del Templo de Diana tras la restauración. (HERNÁNDEZ GIL. En: ICRBC: 1990, p. 105)

[249] Teatro romano de Cartagena. Axonometría de proyecto. (MONEO; RAMALLO: 2009, p. 52)

[250] Teatro romano de Cartagena. Vista tras la intervención. (Imagen del autor.) 
236 SIZA, A.; COLLOVÀ, R.: "Atti minimi nel tessuto storico. Salemi, 1991-98". Lotus nำ106, pp.104-109

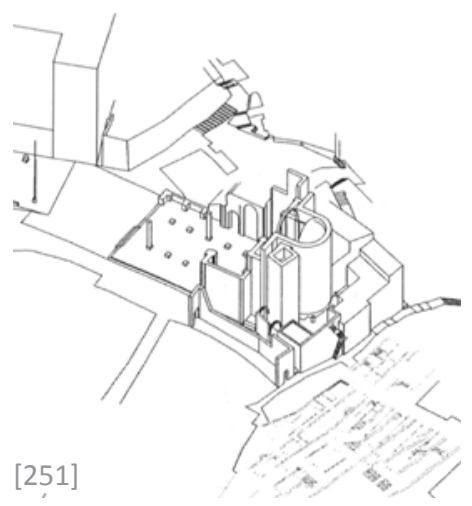

[251] Iglesia en Saliemi. Axonometría de proyecto. (PAVAN: 2004, p. 128)

[252] Iglesia en Saliemi. Vista aérea de la iglesia tras la intervención. (PAVAN: 2004, p. 128)

[253] Iglesia en Saliemi. Vista de la iglesia tras la intervención. (Lotus, no 106, p. 109)
La actuación en la escena se realiza buscando transmitir la escala del elemento pero manteniendo la idea de yacimiento. Para ello se actúa de tal manera que se pueden reconocer cada uno de los estratos que componen la escena, mediante un sistema compositivo que va incorporando capas progresivamente siguiendo una gradación lineal. Al igual que en la zona de las gradas o la orchestra, en la escena se incorporan restos originales hallados en las excavaciones dentro de la fábrica restituida con materiales que abstraen la textura y el color original para indicar con claridad la parte añadida pero configurando una unidad armónica.

\section{Ejemplo 104. Iglesia en Salemi. Alvaro Siza y Roberto Collovà. 1998}

La anastilosis de las columnas de la iglesia, la reconstrucción parcial de la bóveda del ábside y la definición del perímetro del templo permiten reconocer la totalidad virtual del edificio.

El proyecto modifica la relación entre plaza y sitio de la iglesia: el espacio de la plaza se extiende dentro del recinto de la iglesia, mientras que la colocación de elementos de expolio de la iglesia a lo largo de las dos directrices de la columnata, proyecta al exterior el orden de un nuevo espacio, originariamente interior. ${ }^{236}$
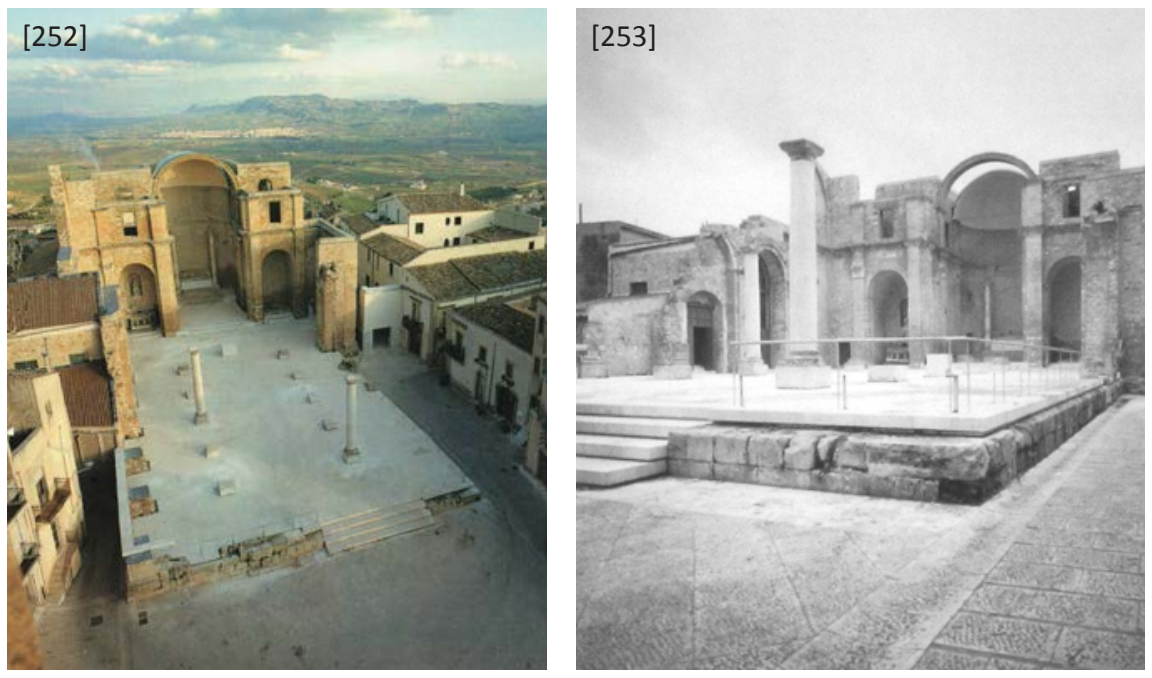

En el caso de la "anastilosis indirecta", el objetivo es el de recrear algunas de las trazas de la arquitectura desaparecida mediante el empleo de nuevos elementos para explicar de manera didáctica la forma original del monumento. Éstas presentan una manera de hacer que conecta con un lenguaje contemporáneo, estrechando las distancias con la composición arquitectónica. Las soluciones varían desde actuaciones más virtuales como es el caso de la intervención en el convento de San Francisco en Baeza (ej.105) o la reconstrucción virtual del Templo de Apolo en Veio (ej.106), hasta otras más definidas como la actuación sobre las ruinas de la iglesia de San Pedro en la fortezza di Osoppo (ej.107) o la recuperación del sitio arqueológico en el Castillo de San Jorge en Lisboa (ej.108). 
Una solución algo distinta es la empleada en la Crypta Balbi en Roma, donde se hace una anastilosis de restos reales mediante un soporte virtual dentro del entorno de un museo arqueológico (ej.109).

\section{Ejemplo 105. Convento de San Francisco en Baeza. Sebastián Araujo y Jaime Nadal. 1985-88. ${ }^{237}$}

En el Convento de San Francisco en Baeza, se busca recuperar el esplendor de la capilla mayor realizada por Andrés de Vandelvira a mediados del siglo XVI y derruida a causa de un movimiento sísmico a comienzos del siglo XIX. Tras desestimar la opción de protección de la capilla para generar un espacio interior, por producir una pérdida de la imagen de la ruina como elemento del paisaje urbano de Baeza, se propone la recreación de la capilla mediante la formalización de los mínimos elementos necesarios para hacer reconocibles los límites que describen su geometría espacial.

El objetivo es el de recuperar simbólicamente la importancia de la cúpula a nivel urbano, sin perder la imagen de la ausencia que recuerda el valor de la pérdida. No se trata por tanto de reconstruir el espacio interior de la capilla si no de recomponer los límites suficientes para comprender la grandeza del espacio desaparecido.

Con un lenguaje contemporáneo el proyecto opta por realizar una reconstrucción virtual del volumen mediante la materialización de los soportes, entablamentos y arcos que configuran la geometría de la capilla. La materialidad de los elementos potencia la búsqueda de diferencia con el lenguaje original de dos maneras distintas: hormigón armado para las columnas y entablamentos, y acero para los arcos de la cúpula.

La relación de ambos sistemas con la preexistencia es muy diferente. Mientras que los elementos de hormigón responden en cierta manera a la materialidad másica de la piedra, e incluso retoman en la cara interior del entablamento las molduras de la preexistencia; en la materialización de la cúpula los arcos de acero oxidado se alejan definitivamente de la materia pétrea del convento, en un intento de dibujar en el cielo los límites de la obra desaparecida.
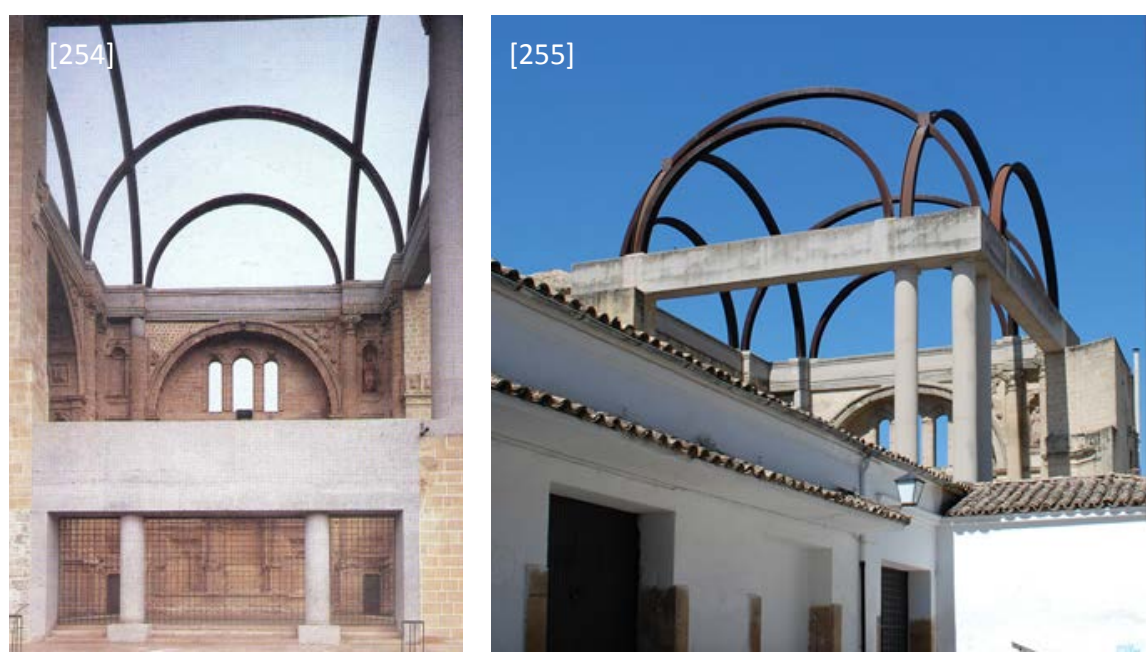

[254] Convento de San Francisco. Vista desde el interior de la capilla. (Arquitectura, № 280, 1989, p. 98)

[255] Convento de San Francisco. Vista desde el exterior tras la intervención. (Imagen del autor.)

[256] Convento de San Francisco. Alzado de proyecto. (Arquitectura, no 280,1989, p. 98) 
238 GRANDINETTI, P.: "II progetto di recupero della fortezza e del colle di Osoppo (Udine)". Casabella n634, Maggio 1996, p.22

[257] Iglesia de San Pedro. Alzado. (Autor: Pierluigi Grandinetti. Cortesía de Sandro Pittini.)

[258] Iglesia de San Pedro. Vista exterior tras la intervención. (Autor: Pierluigi Grandinetti. Cortesía de Sandro Pittini.)

[259] Iglesia de San Pedro. Vista interior tras la intervención. (Autor: Pierluigi Grandinetti. Cortesía de Sandro Pittini.)

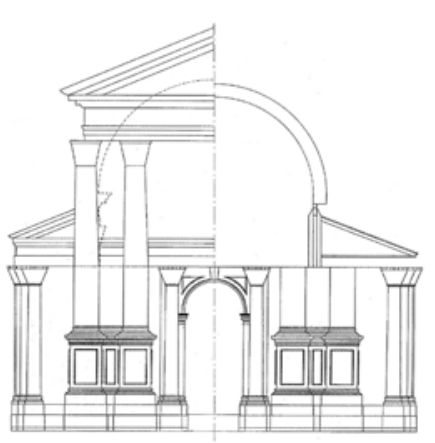

[257]
Así, los elementos de hormigón se configuran como elementos que se encajan perfectamente en la preexistencia, marcando la diferencia pero recomponiendo la continuidad formal, destacando pero sin distorsionar. Sin embargo, el fuerte contraste material y cromático de los nervios de acero produce una rotura de la continuidad formal así como una pérdida de la unidad de la capilla. A la vez que su escasa entidad y confusa lectura formal convierten al elemento en un artefacto extraño y postizo.

Ejemplo 106. Iglesia de San Pedro en la fortezza di Osoppo. Pierluigi Grandinetti. La actuación de restauración y terminación de la iglesia, originaria de principios del siglo XVIII, sufre diversos procesos de destrucción y reconstrucción a lo largo del tiempo, hasta que un terremoto la destruye en 1976. El proyecto propone la restauración, repristinación parcial y terminación de la iglesia, con la finalidad de proteger los restos presentes y recuperar su monumentalidad sin perder su imagen histórica de elemento incompleto. La intervención incluye actuaciones de restauración de las excavaciones arqueológicas, restauración y repristinación parcial de basamentos, pilastras, muros y pavimento de la primera iglesia, y la construcción de una nueva cubierta metálica que retoma la forma en bóveda de cañón de la iglesia original. ${ }^{238}$

La imagen artificial de la fachada, cortada horizontalmente a una determinada altura, junto con la materialidad metálica de aspecto fabril de la nueva cubierta añadida con un aspecto de elemento perfectamente definido, producen una sensación de cierta desarmonía en relación con la capacidad evocativa e indefinida de las ruinas de la iglesia.
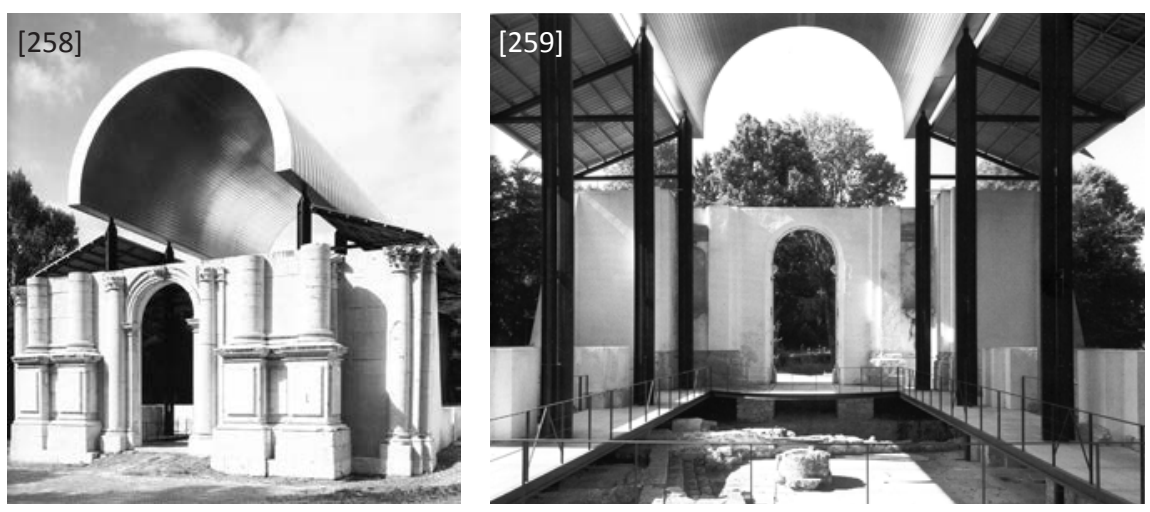

Ejemplo 107. Museo arqueológico en "Plaza nueva del castillo de San Jorge". Lisboa. Joäo Luís Carrilho da Graça, 2010.

La protección de los restos de unas estructuras domésticas musulmanas del siglo XI y sus mosaicos se propone mediante una hipotética reconstrucción de sus espacios. Estos se configuran como dos volúmenes prismáticos adosados, perforados con patios, que levitan sobre los restos para indicar con claridad su novedad. La abstracción formal y material y la iluminación de la separación entre antiguo y nuevo buscan dotar al efecto de un aspecto de irrealidad que apoye la idea de la evocación de una posible configuración espacial, marcando una distancia clara con cualquier hipótesis realista. 


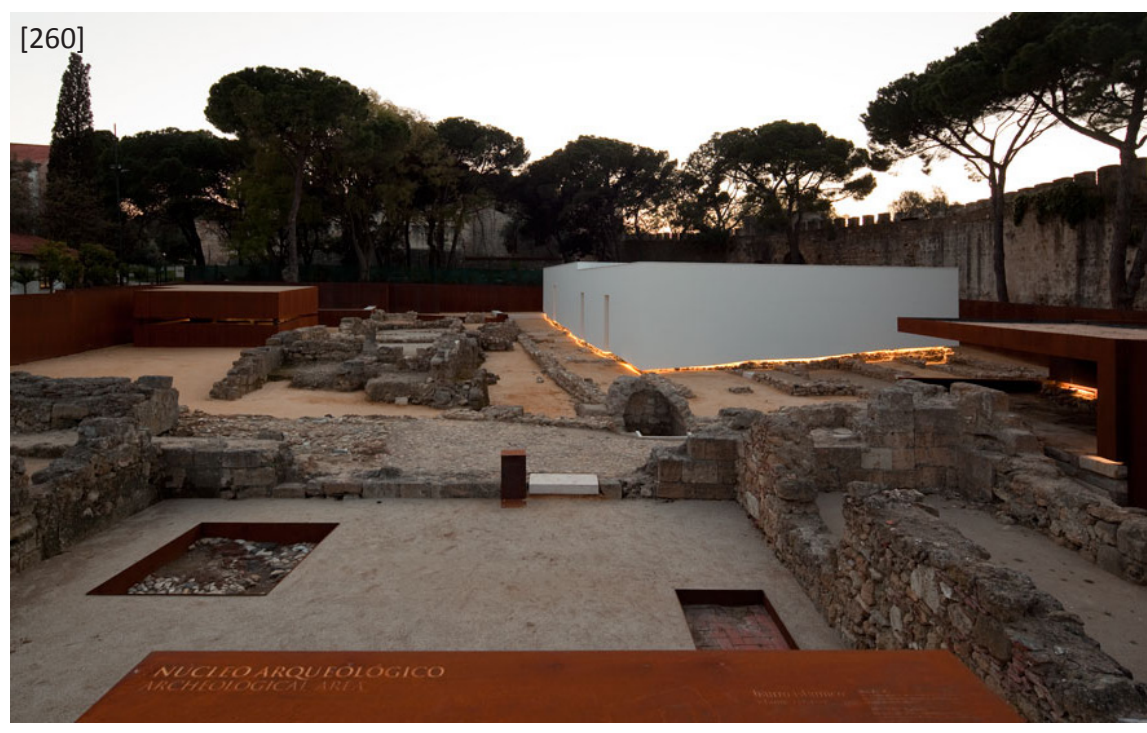

Ejemplo 108. Templo de Apolo en Veio. Franco Ceschi. 1993

La actuación surge como instalación temporal ligada a una exposición que durante cuatro meses debía explicar de forma didáctica la arquitectura del templo del que ya sólo restan sus ruinas. Pero debido al éxito de la solución se decide mantenerla e incluso restaurarla con ocasión de la celebración del jubileo en el año 2000.

Como afirma su propio autor, la solución surge precisamente de esta necesidad de provisionalidad temporal, por lo que si el encargo hubiera exigido la construcción de algo más duradero, el proyecto hubiera sido muy distinto al realizado, perdiendo con ello la "frescura e inmediatez que le dan fuerza". ${ }^{239}$

La idea de la actuación es la de evocar la forma sin perder la imagen de una ruina ubicada en un exuberante paisaje. Para ello la solución consiste en una delgada estructura alámbrica de acero, apoyada sobre la base de piedra preexistente o sobre dados de hormigón armado revestidos de madera, que recompone parte del perímetro de la volumetría del templo. En la parte superior se busca una mayor definición formal mediante la colocación de paneles de madera pintados que retoman de manera simplificada la decoración original, y rematadas de manera simbólica con la representación bidimensional de la famosa escultura del Dios Apollo. Una operación que permite, gracias al contraste, dotar de una mayor ligereza a la estructura definidora de los muros.
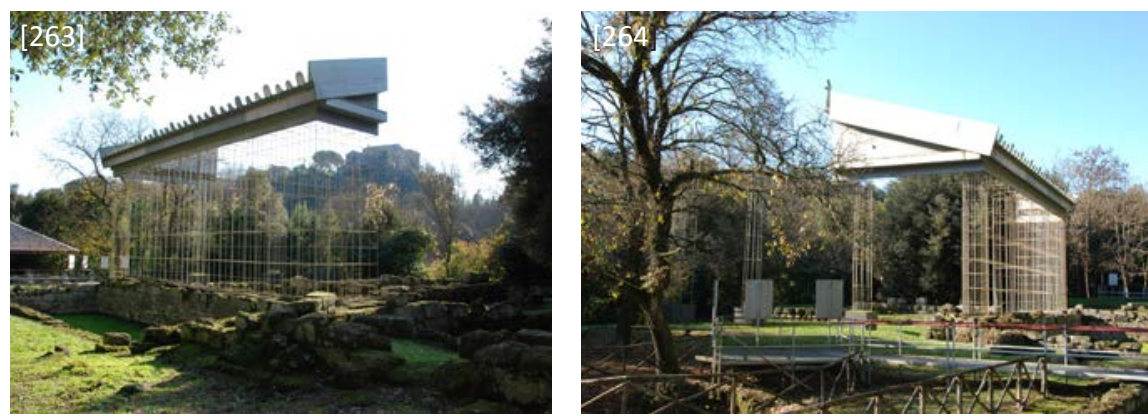
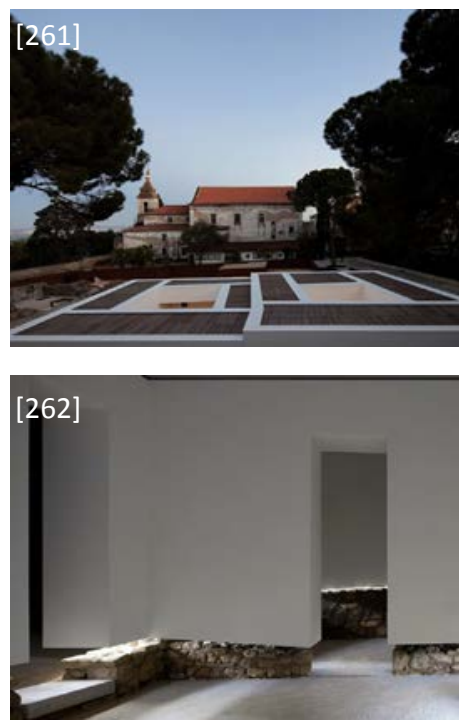

239 CESCHI, F.: "Musealizzazione di aree archeologique: il Tempio di Veio e la Crypta Balbi". En: arch.it.arch dialoghi di archeologia e architettura. Seminari 2005-2006. Edizione Quasar, Roma, 2009, p. 89

[260, 261 y 262] Museo arqueológico en "Plaza nueva del castillo de San Jorge". Vista exterior, vista de la cubierta y vista interior. (CARRILHO DA GRAÇA: <jlcg.pt>)

[263 y 264] Templo de Apolo. Vistas exteriores tras la intervención. (Imágenes del autor)

[265] Templo de Apolo. Alzado. (CESCHI. En: Dialoghi di archeologia e architettura: 2009, p. 92)

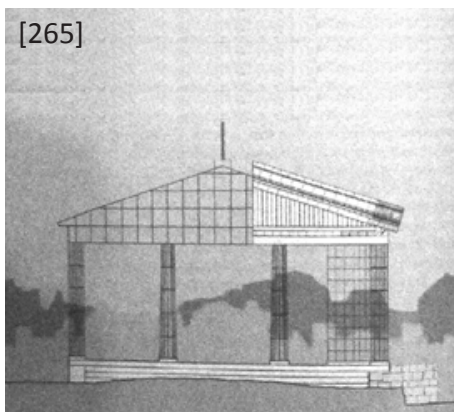


240 CESCHI, F.: "Musealizzazione di aree archeologique: il Tempio di Veio e la Crypta Balbi". En: arch.it.arch dialoghi di archeologia e architettura. Seminari 2005-2006. Edizione Quasar, Roma, 2009, pp. 96-99

[266, 267 y 268] Crypta Balbi. Imágenes tras la intervención. (CESCHI: <www.francoceschi.it>)

[269] Crypta Balbi. Planos de detaIle del proyecto. (CESCHI: <www. francoceschi.it>)
Ejemplo 109. Crypta Balbi, Roma. Franco Ceschi. 2000..$^{240}$

Ceschi retoma los concepto aplicados en el Templo de Apolo para dar una solución a la anastilosis de unos restos del pórtico del teatro de Balbo. Éstos se ubican en el subsuelo de unos edificios del centro de Roma, reconvertido en espacio museístico. De esta manera se logra colocar los restos en su hipotética posición original en el entorno de un espacio expositivo, haciendo fácilmente comprensible al visitante la arquitectura ausente del edificio romano.
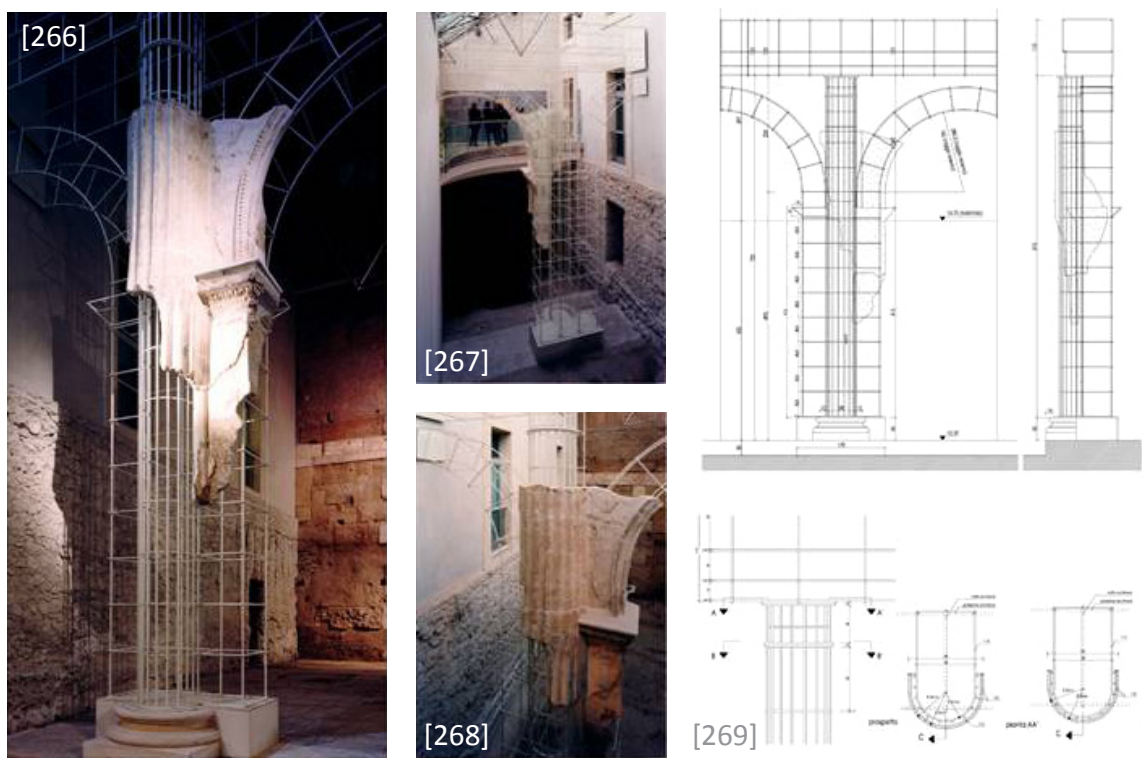


\subsubsection{La aportación de nuevos valores}

Además de la recuperación de los valores perdidos del monumento y la consolidación de los preexistentes, se puede plantear la posibilidad de aportar nuevos valores. Éstos pueden surgir como respuesta a las nuevas necesidades funcionales o venir sugeridos por los valores adquiridos por la preexistencia y sus posibilidades de transformación. En cualquier caso la aportación de estos nuevos valores supone establecer una relación entre antiguo y nuevo de cierta complejidad.

Se aboga por el respeto de las construcciones antiguas de calidad y la adición de partes nuevas, lo que permite avanzar hacia las nuevas necesidades sin perder las aportaciones históricas ni renunciar a las futuras. Una convivencia que se observa en numerosas construcciones a lo largo de la historia, como en la arquitectura medieval, y que enriquece mediante su multiplicidad el conjunto monumental.

Esta relación se plantea renunciando a recuperar la configuración original del edificio, pero tampoco se conforma con la pura conservación sino que tratan de establecer cierta interacción entre antiguo y nuevo. Como indica Franco Purini no se trata de contraponer la pura conservación con la experimentación contemporánea, sino de encontrar un punto de convergencia entre el edificio preexistente, suspendido entre pasado y presente, y la virtualidad que éste proyecta fuera de sí en cuanto potencialidad futura: "el pasado puro no puede volver mientras que el futuro, siendo una función de este pasado, somete las virtualidades de este pasado a un potente giro hacia el presente" ${ }^{241}$

Adriano Cornoldi indica que son tres las condiciones que toda restauración innovadora debería satisfacer: ${ }^{242}$

- lo nuevo debe incluir el sentido de pertenencia al lugar

- la nuevo debe tener una calidad proporcional a la de lo existente

- estos valores deben ser reconocibles

Las nuevas necesidades ayudan a mantener el monumento vivo en el tiempo, lo cual supone en ocasiones llevar a cabo transformaciones de cierto calado sobre la preexistencia. También las variaciones en el contexto de la preexistencia producidas por la evolución del entorno a lo largo del tiempo pueden exigir cambios que transformen la organización interna o externa de los restos.

Las soluciones se sitúan entre actitudes de búsqueda de armonía de lo nuevo con las formas y materia preexistentes, y aquellas que buscan establecer contrastes para indicar con claridad la nueva actuación. Probablemente es el juego equilibrado entre ambas posibilidades la actitud más interesante pero también la más complicada de lograr.
241 PIERI, E.: “Dell'architettura: 12 questioni per Franco Purini". Costruire in Laterizio no 077 , pp.28-30

242 CORNOLDI, A.: "Restauri non Conservativi. La Ricerca delle Regole". En: Ferlenga, Alberto; Vasallo, Eugenio; Schellino, Francesca. Antico e Nuovo. Architetture e architettura. II Poligrafo. 2007. Volumen 1. p. 283 
243 CARBONARA, G.: Architettura d'oggi e restauro. Un confronto anticonuovo. Torino, Ed. Utet, 2011, p. 38 y 86

244 CORNOLDI, A.: "Per una composizione critica". En: CORNOLDI, A.; RAPPOSELLI, M.; Massimo Carmassi : Pisa. Ricostruzione di San Michele in Borgo. Venecia, Ed. IUAV; Padova, Ed. II Poligrafo, 2005, pp. 11

245 CARBONARA, G.: Architettura d'oggi e restauro. Un confronto anticonuovo. Torino, Ed. Utet, 2011, pp. 26

246 CARBONARA, G.: Architettura d'oggi e restauro. Un confronto anticonuovo. Torino, Ed. Utet, 2011, p. 81

247 PORTOGHESI, P.: “Editoriale: riuso dell'architettura". Materia, no 49, 2006, pp. 20-23
Las actitudes más distantes respecto a la arquitectura preexistente buscan mayor libertad creativa de lo nuevo. Así Jean Nouvel defiende la necesidad de liberarse del peso de las herencias para poder afrontar un acto creativo, entendiendo que en la ruptura hay continuidad. ${ }^{243}$

Por otro lado las actitudes más cercanas a la arquitectura antigua estudian con atención la composición formal y la materialidad de los elementos presentes en el monumento, para tenerlos en cuenta en la definición de los nuevos elementos, de tal manera que se logre una mayor interacción entre las partes.

En esta línea Adriano Cornoldi menciona a arquitectos como Asplund, Korsmo, Lewerentz, Plečnik, Böhm, Döllgast, Schwarz, Steffann, Pikionis, Scarpa o Albini, que deducen de las preexistencias las reglas de composición de los nuevos añadidos, manteniendo las marcas del paso del tiempo, retomando los fragmentos para recomponerlos formando obras nuevas que evoquen al pasado. ${ }^{244}$

En cualquier caso se hace imprescindible intervenir estudiando con atención las necesidades de la preexistencia y del lugar, y dando solución a los problemas que plantean.

Carbonara destaca la opinión de Renato De Fusco para quien, la arquitectura italiana de calidad se relaciona adecuadamente con el contexto gracias a tres actitudes: que forma concinnitas con el ambiente, que es de pequeña dimensión, y que tiene un carácter clásico en el sentido de arqueológica y racional. ${ }^{245}$ También Franco Purini comenta estas características como presentes en la arquitectura italiana, de tal manera que la hacen presentarse dispuesta, tal vez mejor que cualquier otra, a crear una arquitectura de convivencia entre antiguo y nuevo, una relación abierta y equilibrada, capaz de situarse entre el rechazo a la historia y el historicismo. ${ }^{246}$

En esta línea Paolo Portoghesi destaca el valor de actuaciones realizadas en los años 50 por arquitectos como Albini, BBPR, Scarpa, Gardela o Michelucci, quienes con sus obras han demostrado, no sólo que es posible compatibilizar lo nuevo y lo antiguo, sino que además esta relación aporta riqueza a la arquitectura que surge del diálogo entre ellas. ${ }^{247}$

Se han organizado los diferentes tipos de intervención en función de la mayor o menor interacción, pudiendo darse actuaciones de cierta autonomía entre las partes, actuaciones de inclusión de una parte en el interior de la otra, o actuaciones de integración en las que se produce una mayor interrelación entre antiguo y nuevo. En los tres casos la intervención sobre la preexistencia puede variar desde actitudes más respetuosas hasta otras más transformadoras. 
Dado que elámbito de interés de esta tesis se centra en la máxima interacción entre las partes, se prestará mayor atención a la categoría de integración, mientras que de las otras dos categorías tan sólo se citarán algunos ejemplos.

En cualquier caso es importante aclarar una vez más que estas clasificaciones no representan límites estancos, sino que dentro de una misma obra lo más natural es que se produzcan en cierto grado y de manera simultánea varias de las actitudes indicadas. De la misma manera, es inevitable que en una intervención se combinen actuaciones de conservación, repristinación, reinterpretación de elementos del pasado y aportación de nuevos elementos. Por lo tanto lo que aquí se busca es atender a la actitud más predominante de las mencionadas, interpretada desde la mirada personal del autor.

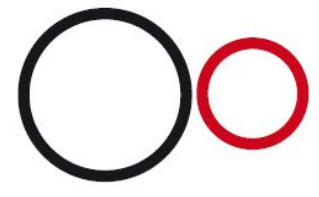

autonomía

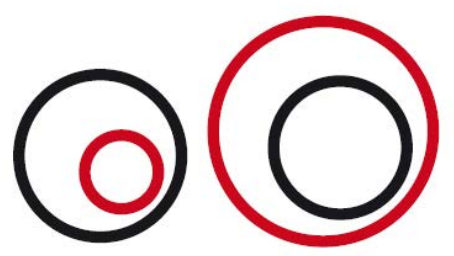

inclusión: contenedor / envolvente

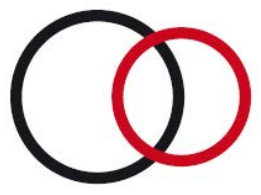

integración
248 ISOZAKI, A.: "Una loggia per gli uficci". Casabella no 664, febrero 1999, pp. 4-7
[270] Ampliación de la Galería de Yale, Kahn. (Fotografía de Christopher Gardner. En: Metalocus, diciembre 2012)

[271] Museo de San Telmo, Nieto y Sobejano. (Casabella, no 803, 2011, p. 18)

[272] Nueva salida de la Galería de los Uficci, loggia en Piazza Castellani, Arata Isozaki. (Casabella, no 803, p. 18)
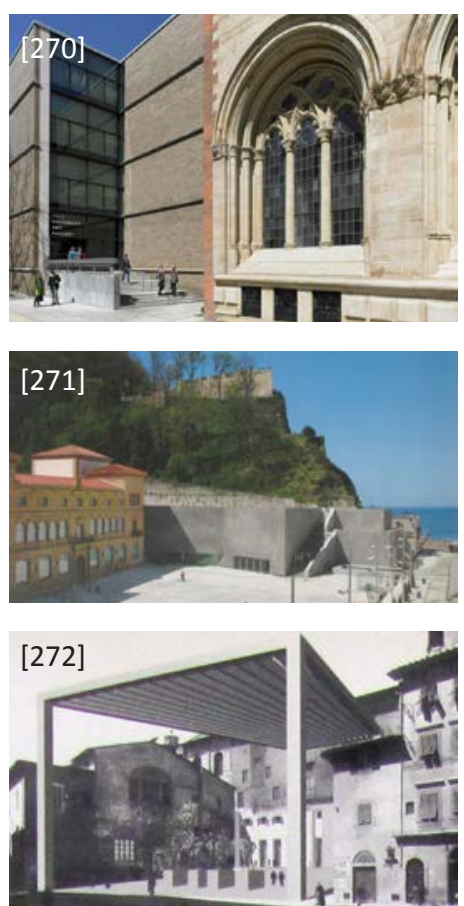
Inclusión

249 IBAÑEZ SÁNCHEZ, F.: “Baños árabes de Baza. Granada". R\&R no 111, pp. 32-41

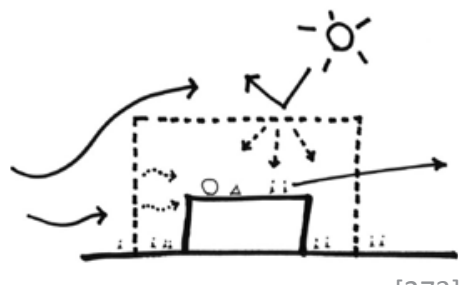

[273]

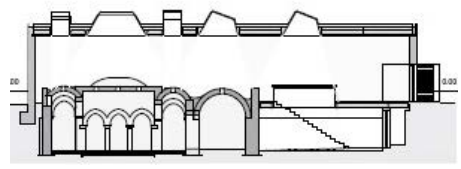

[274]

[273] Proyecto para la ampliación del IVAM, Sanaa. (R\&R, no 76, p. 39)

[274] Baños árabes de Baza, Francisco Ibáñez. (R\&R, no 111, 2009, p. 35)

[275] Punta della Dogana, Tadao Ando. (Casabella, no 778, 2009, p. 25)

[276] Espacio Torner, Paredes y Pedrosa. (R\&R, no 108, 2008, p. 40)
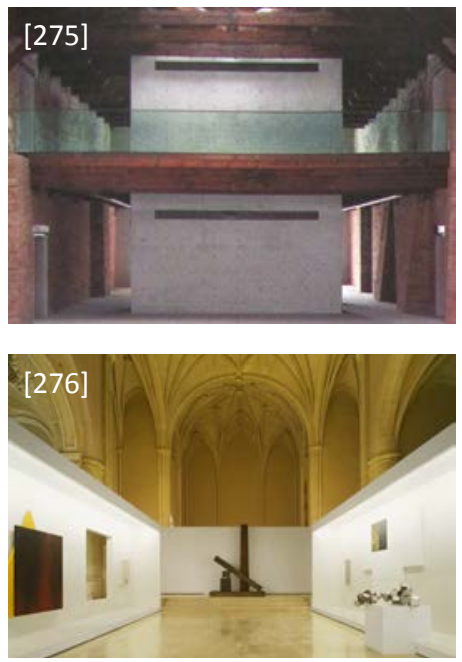

En esta línea se pueden mencionar dos maneras de actuar distintas, en función de la posición relativa de lo nuevo respecto a lo viejo: por un lado estaría la utilización de la preexistencia como contenedor de nuevas arquitecturas, ya sea reutilizando la configuración original de los espacios o transformándolos, y por otro lado la creación de una nueva imagen del monumento mediante una nueva envolvente exterior.

Por un lado la idea del contenedor entiende la preexistencia como un espacio en el que insertar nuevas arquitecturas, un concepto que recuerda a la idea expresada en el cuadro de San Jerónimo pintado por Antonello da Messina en 1456. La nueva arquitectura se oculta en el interior de la envolvente histórica, separándose de los límites interiores, en una actitud de respeto. Este criterio puede adquirir multitud de matices según la mayor o menor dimensión de las inserciones y el sistema de configuración de los mismos.

Un ejemplo interesante en esta línea, por su expresión conceptual, es el proyecto de "la casa dentro de la casa" de Naumann arquitectos, donde introducen una casa prefabricada de madera en el interior de un establo de piedra del siglo XVIII, generando un interior completamente nuevo que resuelve las necesidades pero que renuncia a parte de las posibilidades estéticas de los muros de piedra preexistentes, solo visibles desde el exterior.

Algunos ejemplos de esta vía de actuación son: el museo en las ex Scuderie Aldobrandini en Frascati de Massimiliano Fuksas (1991-2000), el Espacio Torner en Cuenca de Paredes y Pedrosa (2005), la actuación en la Punta della Dogana de Venecia de Tadao Ando (2006-09), el Castillo de la Luz en Las Palmas de Gran Canaria de Nieto y Sobejano (1998-2006), o el museo del vino en el Castillo de Peñafiel de R. Valle (2008).

Por otro lado la idea de la envolvente se relaciona con la forma de actuar "a la manera moderna" planteada por Alberti en el Templo Malatestiano de Rimini, y busca dar una nueva imagen exterior al edificio. Este es el caso de la actuación en los baños árabes de Baza de Francisco Ibáñez (200408), donde debido al incremento del nivel de la calle y los cambios de configuración de la trama, el edificio había perdido su escala en la ciudad. Ante esta situación se plantea devolver la presencia volumétrica del edificio original mediante la construcción de una envolvente de hormigón armado que resuelve el acceso, crea una atmósfera de transición entre exterior e interior y protege los restos matizando la luz natural. ${ }^{249}$

Otros ejemplos de esta vía de actuación son el proyecto para la ampliación del IVAM en Valencia de Sanaa (2000), la intervención en el claustro de los Jerónimos como parte de la ampliación del museo del Prado en Madrid de Rafael Moneo (1995-2997), o la actuación urbana en la plaza del templo de Diana en Mérida de J. Mạ Sánchez (2005-2008). 
Por último la idea de la integración entre antiguo y nuevo se puede plantear mediante actuaciones más o menos cercanas o distantes a la preexistencia, en función del empleo de mecanismos de relación o de contraste, que dependen de la atención prestada a conceptos como la geometría, escala, proporción o materialidad de la preexistencia, así como de la relación dimensional entre la preexistencia y lo nuevo.

En este sentido cabe distinguir dos conceptos que se relacionan con dos formas de interactuar con la preexistencia: la parte y el fragmento. Diferencia que aclara Massimo Cacciari indicando que mientras que la parte está subordinada a un entero, de tal manera que existe una relación irrevocable entre ellas, el fragmento es un trozo de algo que puede adquirir múltiples lecturas. ${ }^{250}$

Así por un lado la primera manera de actuar hace referencia a la intervención como un equilibrio de partes nuevas $y$ antiguas que conjuntamente constituyen un todo. Una actitud que Saenz de Oiza ve con claridad en la ampliación del Ayuntamiento de Goteborg donde Asplund alcanza una "trabada y elaborada composición" en la que lo antiguo y lo nuevo "ya no se pueden entender separados".251

Por otro lado, la segunda manera busca emplear el mecanismo de entender la preexistencia como una superposición de fragmentos que se van añadiendo a lo largo del tiempo o que se reutilizan para aportar a la nueva construcción valores de otras arquitecturas pasadas, potenciando en cierta medida la idea de una arquitectura abierta a futuras aportaciones. La idea de fragmento supone una reducción en la escala de los añadidos y una dispersión en el interior de la preexistencia que permite reducir su presencia y al mismo tiempo transmitir una idea de conjunto de la intervención.

Esta manera de actuar ya está presente en numerosos edificios a lo largo de la historia, como en la adaptación de templos clásicos a edificios de culto cristiano, así como en la conformación de nuevas arquitecturas en arquitectos como Piranesi o John Soane.

En estas coordenadas Franco Purini menciona el concepto de "simulaciones en el tiempo" a raíz de las obras de Carlo Scarpa o Giancarlo De Carlo, quienes en sus composiciones simulan la estratificación temporal típica de una definición formal obtenida de la suma de fases constructivas distintas a lo largo del tiempo, convirtiendo la expresión de estas fases en parte del significado formal de sus obras. Con ello Purini muestra como, del atento análisis de las características del patrimonio, se pueden extraer claves para producir una arquitectura moderna capaz de relacionarse con la preexistencia. ${ }^{252}$
250 CACCIARI, M. Casabella 2000, no 684-685. Extraído de: CAVALLERI, F.: "Un primo livello di riflessione: alcuni elementi concettuali". En Progettare per il costruito. Dibattito teorico e progetti in Italia nella seconda metà del XX secolo. Milano, Ed. CittàStudi Edizioni, 2008, p. 82

251 SAENZDE OIZA, F.J.: "Superposición y adaptación de nuevas estructuras en edificios antiguos". En: CABALLERO ZOREDA, L. (dir.): Curso de mecánica y tecnología de los edificios antiguos. Madrid: Colegio Oficial de Arquitectos de Madrid, 1987, pp. 123-135

252 PURINI, F.: Comporre l'architettura, 2006, pp.98, 99, 121. Extraído de: CARBONARA, G.: Architettura d'oggi e restauro. Un confronto antico-nuovo. Torino, Ed. Utet, 2011, p. 90 
253 MCGETRICK, B.: "Ningbo Historic Museum". Domus no921, p.67

[277] Castelvecchio, Scarpa. (BORIANI: 2008, p. 79)

[278] Castelvecchio, Scarpa. Solución expositiva para la estatua de Cangrande della Scalla. (BORIANI: 2008, p. 183)

[279] Museo de Historia de Ningbo, Wang Shu. (WÖHLER: The architectural review, marzo 2010.)
Una reflexión que se reconoce con claridad en el museo de historia de Ningbo, donde Wang Shu busca crear una arquitectura que tenga vida para llenar un entorno vacío. Mediante un sistema constructivo a base de fragmentos y formas diversas retomado de la tradición del lugar, se componen los muros conformando una realidad imperfecta, inacabada y heterogénea. El objetivo de Wang Shu es el de cargar de significado un lugar muerto, paralizado: "he diseñado este edificio para intentar reavivar la memoria". ${ }^{253}$
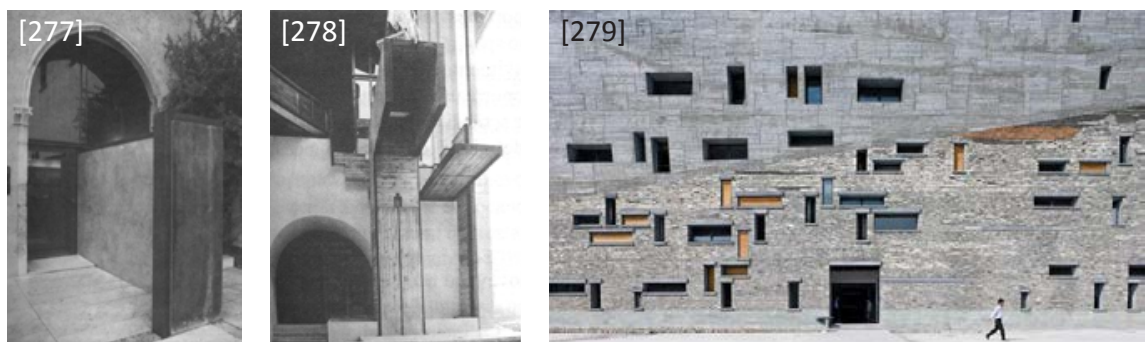

Por otro lado es importante mencionar que, más allá del resultado final, se pueden observar diferencias de actitud respecto a la preexistencia, variando desde soluciones de mayor conservación hacia otras de mayor transformación, en función de los valores que le son atribuidos.

Los ejemplos de este tipo de intervención son muy variados y complejos, y se pueden clasificar de múltiples maneras. En este caso se han reconocido cuatro grupos: soluciones que buscan cierta continuidad entre antiguo y nuevo, otras que buscan cierto equilibrio entre las partes, otras que se apoyan en la lectura de la preexistencia como fragmentos del nuevo conjunto, y por último aquellas que actúan sobre la preexistencia alterando su tejido para obtener nuevos valores.

Dentro de la búsqueda de cierta continuidad formal y material se pueden citar ejemplos como el parador en Santa María do Bouro (ej.110) o la muralla Nazarí de Granada (ej.111); dentro del equilibrio entre partes podrían estar la Iglesia de Valdemaqueda de José Ignacio Linazasoro (2001) o el museo del Patio Herreriano en Valladolid (analizado en profundidad en esta tesis); dentro de la evidencia de la preexistencia como fragmento estaría el museo en Gibellina (ej.112), el Instituto Hispano Luso de Zamora de Manuel de las Casas (1995-98), la biblioteca de las Escuelas Pías en Madrid (analizada en profundidad en esta tesis), el museo de Moritzburg en Halle (ej.113) o el museo Kolumba en Colonia (ej.114); y por último dentro de la alteración del tejido preexistente podría situarse el museo Can Framis (ej.115) o las Scuderie Medicee de Poggio en Caiano (ej.116). 


\section{Ejemplo 110. Parador en Santa Maria do Bouro. Souto de Moura}

Souto de Moura se propone construir un edificio contemporáneo a partir de los restos del monasterio de Santa Maria do Bouro. Para ello no trata de mostrar con sinceridad histórica las nuevas aportaciones sobre los restos preexistentes, sino que prioriza el valor de unidad armónica de una nueva arquitectura surgida como metamorfosis de otra más antigua. En palabras de Souto: "finalmente, no estoy restaurando un monasterio, estoy construyendo un parador con las piedras de un monasterio". ${ }^{254}$
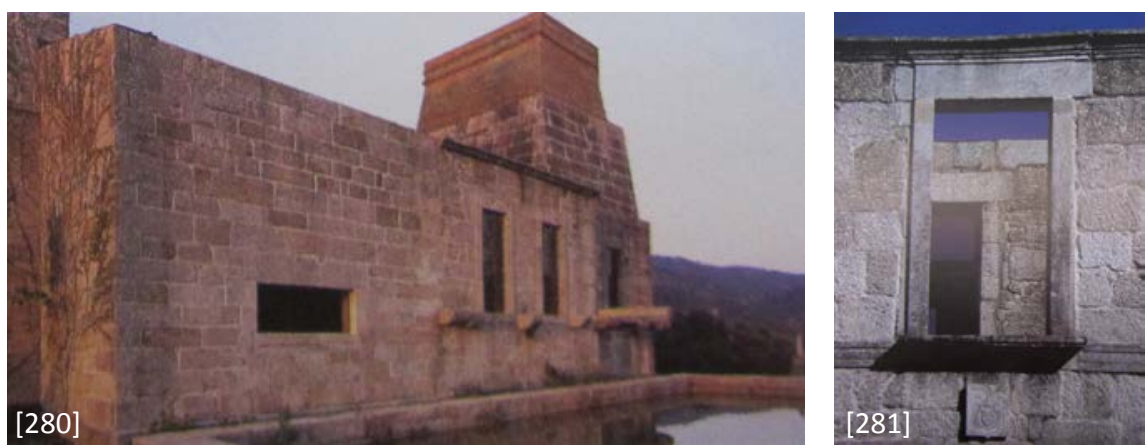

Ejemplo 111. Recuperación de la muralla Nazarí de Granada. Antonio Jimenez Torrecillas. ${ }^{255}$

Situado en el cerro de San Miguel Alto, entre el entorno urbano y el natural, se encuentra el brazo norte de la muralla nazarí, un lugar privilegiado con vistas a la Alhambra y al Generalife. Dentro de un amplio proyecto de preservación del paisaje surge la necesidad de reconstrucción de la muralla que presenta una fractura de unos cuarenta metros de longitud provocada por un terremoto a mediados del siglo XIX.
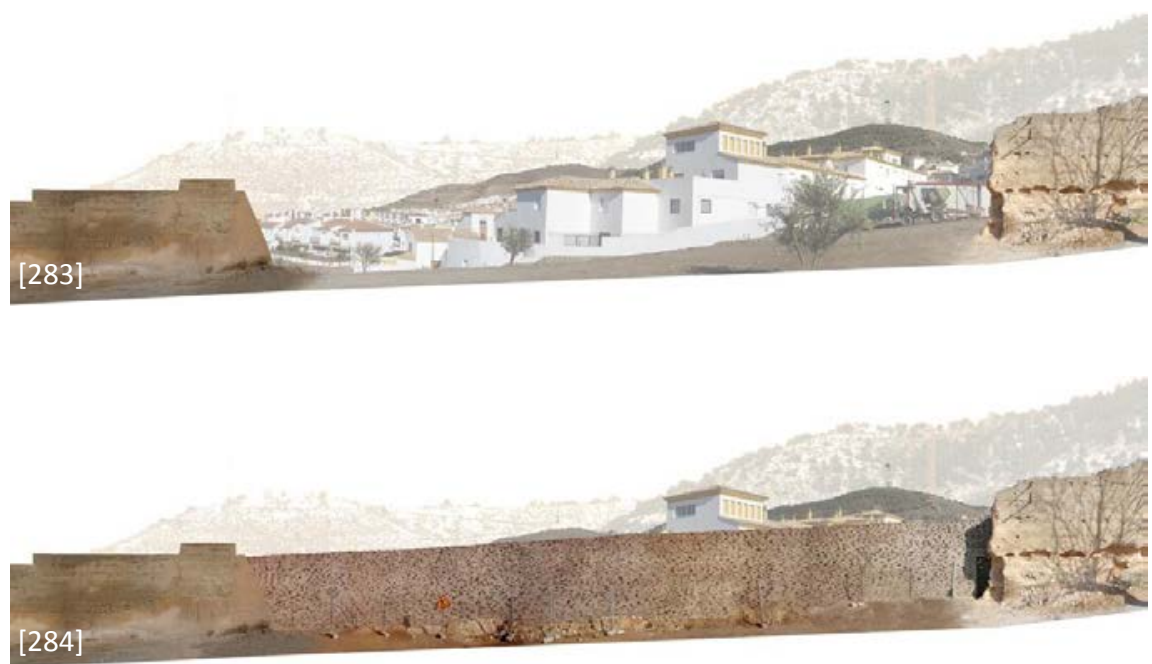

254 HERNÁNDEZ LEÓN, J.; COLLOVÀ, R.; FONTES, L.; MORAIS DE SOUSA, R.: Santa Maria do Bouro. Construir uma pousada com as pedras de un monasterio. Lisboa, Ed. White \& Blue, 2001, p.50

255 BOSCH, L.: Op. cit., 2010, pp. 397406

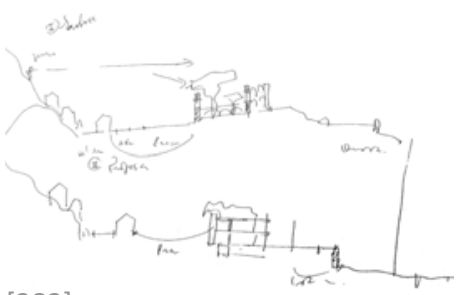

[282]

[280 y 281] Santa Maria do Bouro. Vista general y detalle tras la itervención. (HERNÁNDEZ; COLLOVÀ; FONTES; MORAIS DE SOUSA: 2001, p. 43)

[282] Santa Maria do Bouro. Bocetos. (HERNÁNDEZ; COLLOVÀ; FONTES; MORAIS DE SOUSA: 2001)

[283 y 284] Muralla Nazarí. Alzado del paño de muralla antes y después de la intervención. (TORRECILLAS: $R \& R, \mathrm{n}=101,2006$, p. 37) 


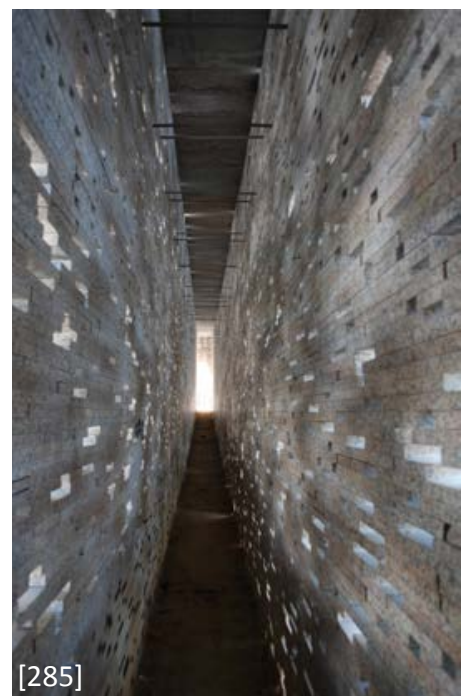

[285] Muralla Nazarí. Vista del espacio interior del nuevo tramo de muralla. (Imagen del autor.)

[286] Museo en Gibellina. Vista anterior a la intervención. (VENEZIA; SIZA: 1988-1992, p. 43)

[287] Museo en Gibellina. Vista después de la intervención. (VARAGNOLI: L'industria delle construzioni, no 368, 2002, p.13)

[288] Museo en Gibellina. Alzado de proyecto. (VENEZIA; SIZA: 19881992, p. 45)
El proyecto propone restablecer la continuidad lineal de la muralla y recuperar con ello la protección de su interior, aunque manteniendo su actual función de conexión con el exterior. La solución empleada resuelve la reconstrucción del tramo faltante mediante un nuevo elemento adosado al tramo histórico pero distanciado lo justo como para evitar el contacto con el monumento, en una actitud de máximo respeto hacia la preexistencia, lo que permite su completa eliminación sin afectar a la estabilidad y estructura del elemento preexistente.

La forma del elemento retoma la volumetría original configurando un prisma longitudinal que sigue la ligera pendiente de la loma, permitiendo recuperar con ello la unidad del conjunto en una visión lejana. Sin embargo en su interior, el elemento se vacía para alojar el recorrido que permite atravesar la muralla. Un recorrido estrecho y largo que evidencia la gran distancia existente entre los dos mundos que separa.

La materialidad empleada busca establecer una relación con el lugar mediante un lenguaje contemporáneo. A través del apilamiento de piezas de granito en forma de lajas, se genera una envolvente calada y vibrante que permite por un lado establecer una relación armónica con los paños de muralla preexistente y por otro lado crear un interesantísimo efecto de luces y sombras que recuerdan a la arquitectura de la Alhambra, haciendo así una referencia al lugar y a la historia desde una concepción contemporánea.

\section{Ejemplo 112. Museo en Gibellina. Francesco Venezia}

La actuación propone reutilizar los restos supervivientes del Palacio de Lorenzo, destruido por un potente terremoto, para la construcción de un museo en el entorno de la nueva ciudad. Venezia diseña un edificio con forma de patio en cuyo alzado interior integra el fragmento de fachada remontado, formando parte de una nueva arquitectura. Con ello el resto del palacio no queda visible desde el exterior, sino que es necesario adentrarse en el patio para poder descubrirlo.
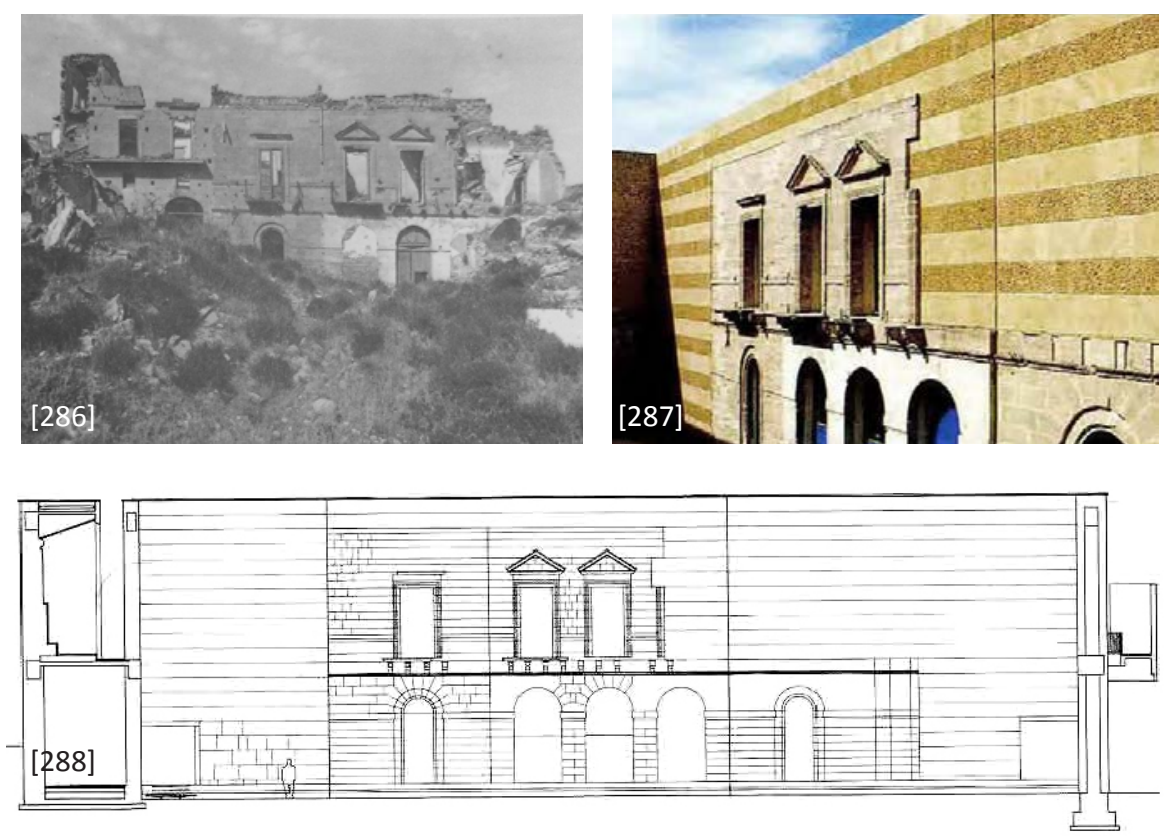

Evolución de los criterios de intervención en el patrimonio arquitectónico 
En cierta manera parece como si el patio fuera la primera sala del nuevo museo donde se expone un fragmento del monumento, abstraído de su contexto pero sometido a los cambios de luz propios de un espacio exterior. Un fragmento testigo de una historia hoy ya desaparecida, pero recreada como valor arquitectónico.

La materialidad de los nuevos elementos que configuran el patio busca crear un ambiente de cierta armonía con la preexistencia mediante el uso de diferentes tipos de piedra que contextualizan el fragmento del palacio en una nueva y verosímil realidad, sin perder la evidencia fragmentaria del resto recuperado.

\section{Ejemplo 113. Museo de Moritzburg en Halle, Alemania. Nieto y Sobejano.}

La intervención sobre un edificio militar de estilo gótico del siglo $\mathrm{XV}$, propone actuar sobre el ala más comprometida del edificio, conservando los muros semiderruidos, cubriendo el edificio con un elemento metálico plateado que se va plegando para conformar lucernarios y establecer una relación plástica con las cubiertas inclinadas del entorno y el tono grisáceo del cielo.

Con esta operación se produce un claro contraste entre antiguo y nuevo que pone en evidencia las consecuencias transformadoras del paso del tiempo. Los reflejos del entorno en los vidrios y revestimientos hacen desaparecer la actuación y la abstracción de la nueva intervención ayuda a destacar con gran evidencia el valor material de las preexistencias. De esta manera la intervención permite "devolver la voz a ruinas que la han perdido temporalmente". ${ }^{256}$
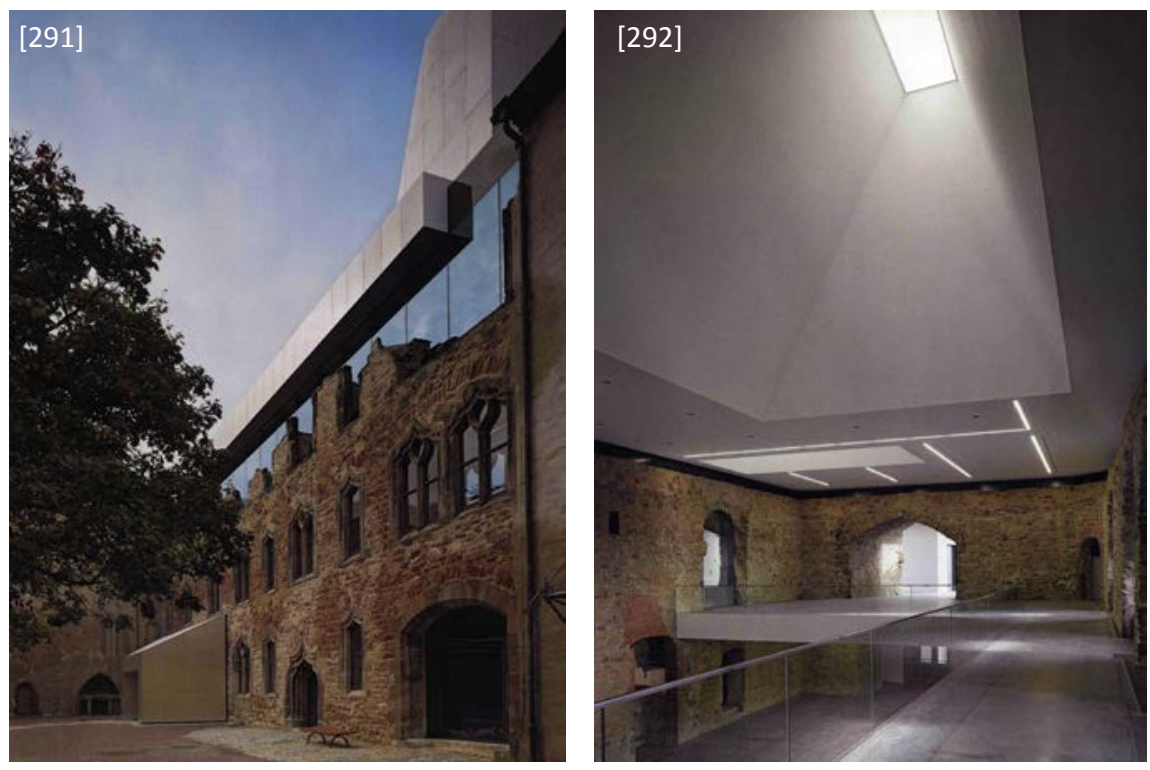

\section{Ejemplo 114. Museo Kolumba en Colonia. Peter Zumthor.}

Peter Zumthor emplea un lenguaje aparentemente sencillo fundado en la arquitectura del pasado para tratar de crear atmósferas desde "el mundo seguro de las cosas materiales". ${ }^{257}$ Una arquitectura nacida del lugar en el que se inserta y de la expresión material de una intención poética. Esta importancia dada a la realidad física de la arquitectura se muestra en el museo Kolumba donde se busca

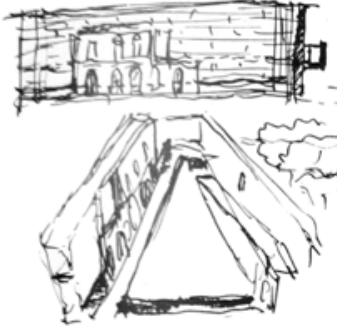

[289]

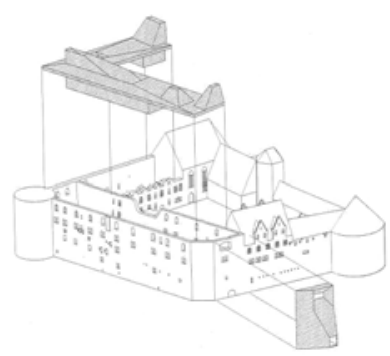

[290]

256 MARTIN, J.M.: "Le pietre parlano". Casabella no776, Aprile 2009, p.64

257 Achleitner, F.: “Ritorno al moderno? L'architettura di Peter Zumthor". Casabella no648, Settembre 1997, pp.52-55

[289] Museo en Gibellina. Croquis conceptuales de proyecto. (VARAGNOLI: L'industria delle construzioni, no 368,2002 , p.13)

[290] Museo de Moritzburg en Halle. Vista axonométrica conceptual del proyecto. (MARTIN: Casabella, no 776,2009 , p. 64)

[291 y 292] Museo de Moritzburg en Halle. Vista exterior e interior tras la intervención. (MARTIN: Casabella, no 776, 2009, pp. 67 y 69) 


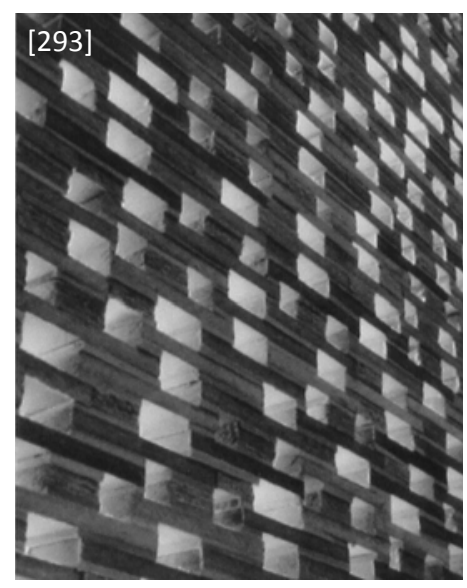

trabajar mediante el ladrillo para continuar las estructuras del pasado, un material por otro lado empleado tradicionalmente en Colonia para la restauración de edificios tras la segunda guerra mundial. Con ello logra relacionarse con los restos del convento y de la iglesia medieval, y crear un nuevo conjunto desde la armonía entre lo antiguo y lo nuevo.

El ladrillo empleado se crea específicamente para este museo. Se emplea un formato romano, lo suficientemente delgado como para adaptarse a los fragmentos de los muros medievales, de tal manera que permitiera que lo nuevo se fundiese con lo antiguo. Un ladrillo hecho a mano, con una junta de mortero mayor de lo habitual, para que expresara una textura más "blanda", frente a un ladrillo industrializado que hubiera presentado un aspecto demasiado duro en la relación con los restos antiguos. Así los nuevos muros se construyen de forma monolítica sin juntas de expansión -producto de una larga investigación-, sin revestimientos, sin material de aislamiento ni potentes instalaciones de acondicionamiento que afecten la imagen de su expresión material. ${ }^{258}$

258 BAGLIONE, CH.: "Costruire la memoria. Conversazione con Peter Zumthor". Casabella no728-729, Dicciembre 2004 - Gennaio 2005, pp.72-81

[293] Museo Kolumba. Detalle. (Arquitectura Viva, no 116, 2007, p.43)

[294 y 295] Museo Kolumba. Contacto entre la nueva arquitectura y los viejos muros. (Arquitectura Viva, no 116, 2007, p.41)

[296] Museo Can Framis. Imágenes conceptuales del proyecto. (BAAS: $<$ www.baas.cat $>$ )
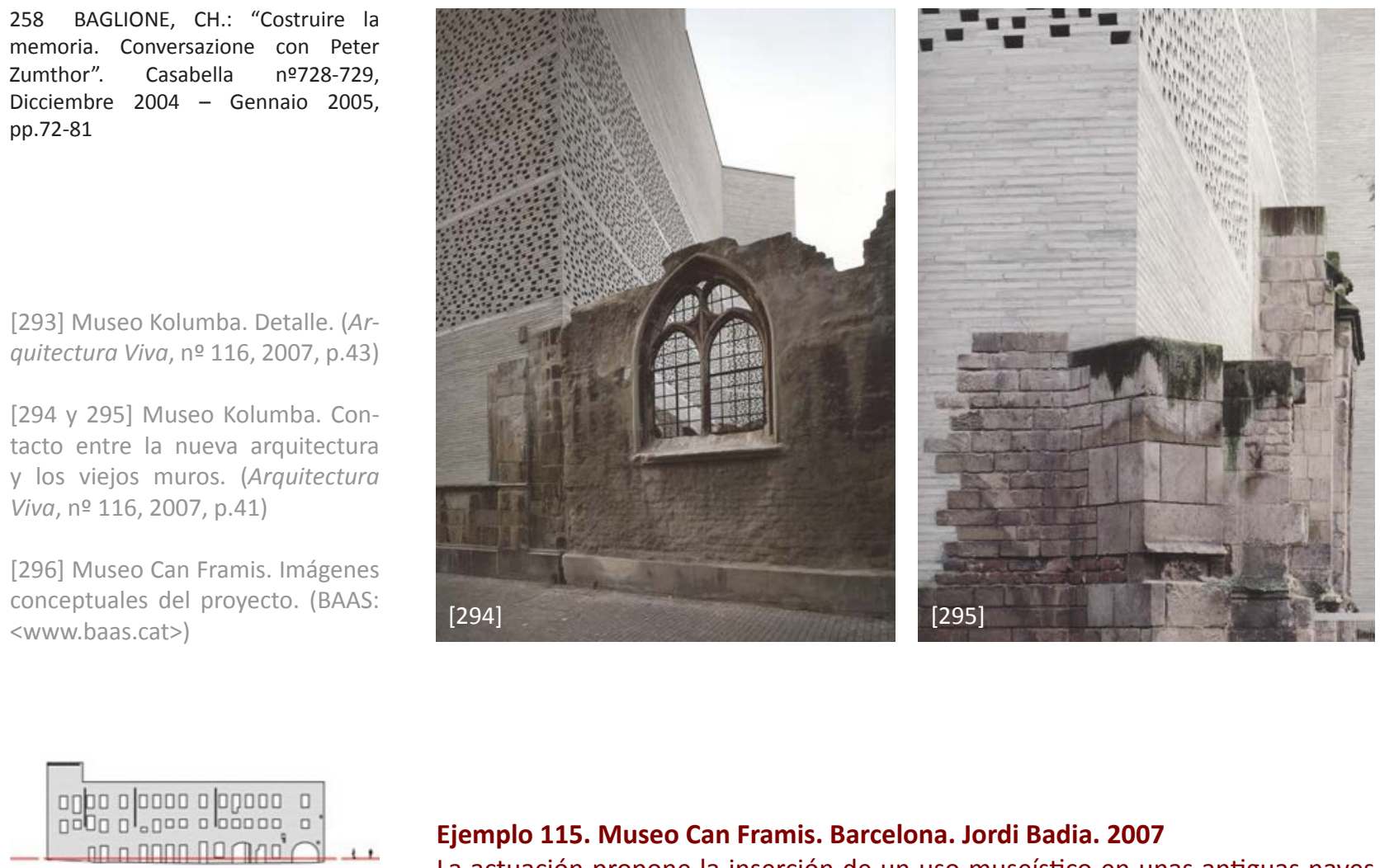

Ejemplo 115. Museo Can Framis. Barcelona. Jordi Badia. 2007

La actuación propone la inserción de un uso museístico en unas antiguas naves industriales ubicadas en el barrio de Poble Nou en Barcelona. La actuación toma las preexistencias como materia al servicio del proyecto. Los antiguos muros compuestos por heterogéneas fábricas se uniformizan mediante una veladura de color y los huecos preexistentes se tapian para configurar un lienzo de base sobre el que crear una nueva arquitectura. La operación permite recuperar grados de libertad sobre un tejido previamente definido, dando la posibilidad de adaptar la antigua materia renovada a las nuevas necesidades, pero sin borrar las huellas de su pasado que permanecen como parte de su naturaleza, registro de su memoria.

[296] 

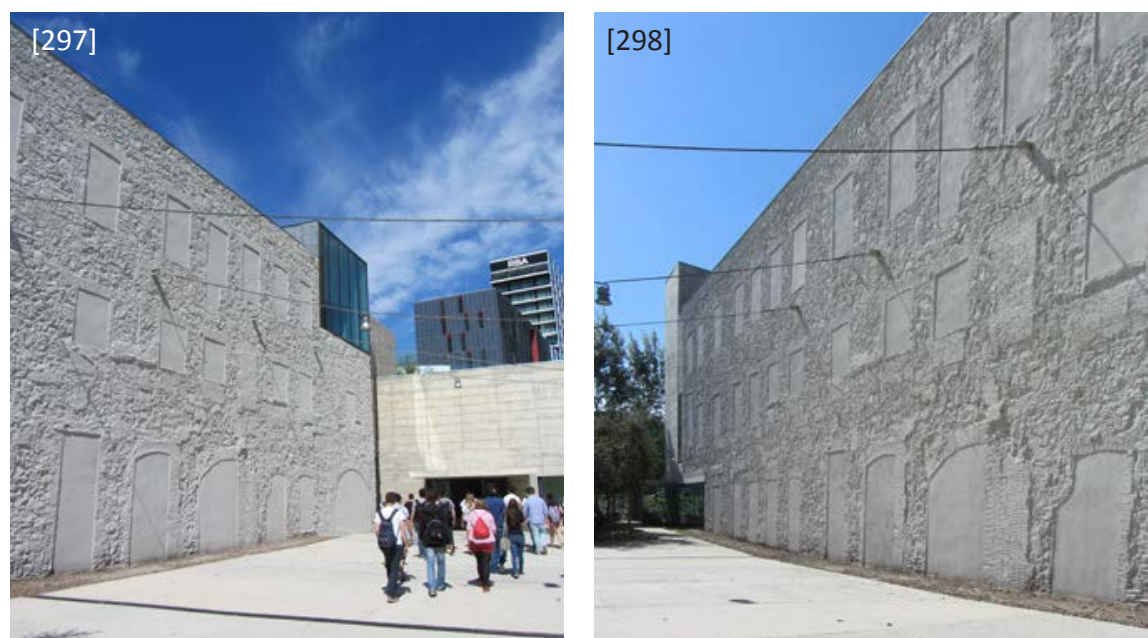

\section{Ejemplo 116. Intervención en las Scuderie Medicee de Poggio en Caiano. Franco Purini}

El proyecto se basa en la idea de intervenir en el edificio histórico por adición más que por compleción, tratando conferirle una nueva vitalidad. El nuevo elemento insertado en el edificio histórico se puede entender como un fragmento extraído de una posible reescritura contemporánea del edificio: "un resurgimiento en el presente de una configuración hipotética ya existida y al mismo tiempo eventual" ${ }^{259}$

El nuevo cuerpo se añade cerrando el lado septentrional del edificio, con total autonomía lingüística respecto al edificio histórico, para albergar una sala de conferencias y los locales técnicos. Un gran lucernario de vidrio señala, en la homogénea cubierta de teja, la presencia de la nueva estructura de hormigón y vidrio, y una gran lama se yuxtapone al frente oriental. Una estructura de pórticos de hormigón se inserta en el vacío con una traslación respecto a la estructura original del edificio para hacer evidente la inserción del nuevo elemento, introduciendo una distorsión oblicua dentro del orden longitudinal del edificio.
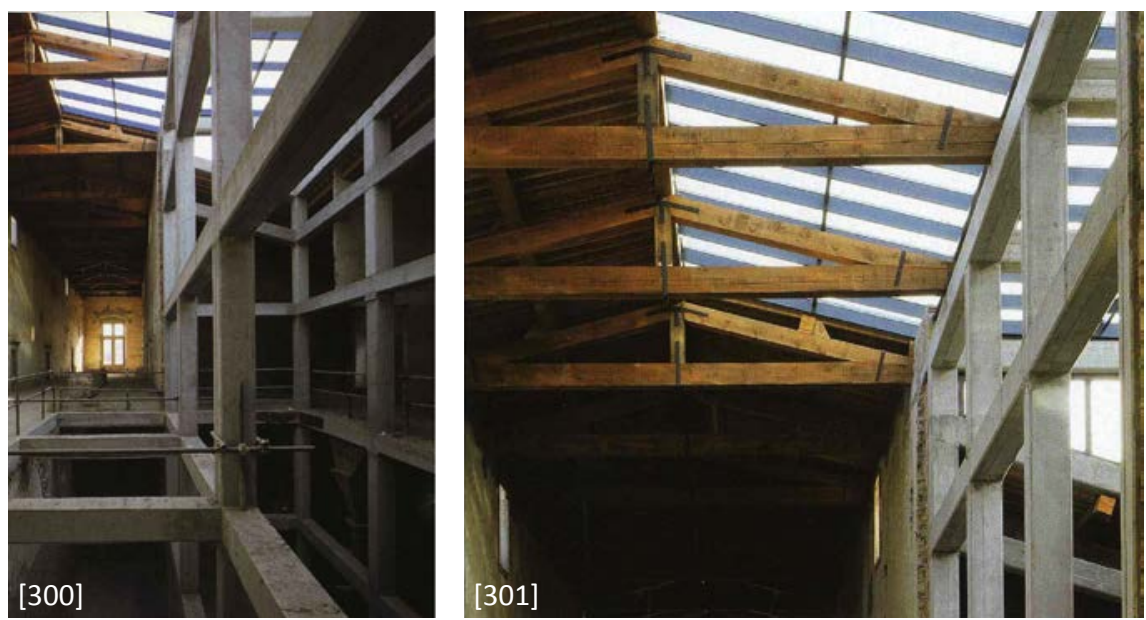

259 PIERI, E.: “Dell'architettura: 12 questioni per Franco Purini". Costruire in Laterizio no77, pp.28-30

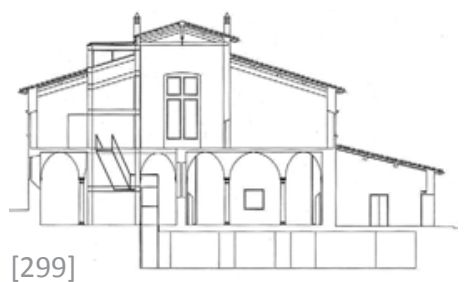

[297 y 298] Museo Can Framis. Vistas exteriores tras la intervención. (Imágenes del autor.)

[299] Scuderie Medicee de Poggio. Sección de proyecto. (PURINI: Casabella, $\mathrm{n}$ ㅇ 690,2000, p. 14)

[300 y 301] Scuderie Medicee de Poggio. Imágenes tras la intervención. (PURINI: Casabella, ㄲo 690, 2000, p. 12) 



\subsection{RECAPITULACIÓN DE LOS CRITERIOS DE INTERVENCIÓN EN LA REFLEXIÓN ACTUAL}

"Cualquier lugar es al mismo tiempo sede de preexistencias significativas, teatro de memorias perdidas, sujeto meritorio de expectativas". ${ }^{1}$

Adriano Cornoldi

A continuación se expone una recapitulación de las reflexiones actuales sobre los criterios de intervención en el patrimonio, enfocadas hacia un camino entre la pura conservación, la innovación y la mímesis que permita abordar el respeto a lo antiguo y su adaptación a las necesidades de la contemporaneidad.

\section{TRANSFORMAR PARA PERMANECER}

Entre las diversas reflexiones se observa la opinión generalizada de que para mantener los valores de la preexistencia es necesario hacerlos participar de las condiciones de la contemporaneidad.

Francisco Javier Saenz de Oiza ve en la historia el ejemplo de como la transformación de la arquitectura ha permitido su conservación: "la arquitectura es un proceso continuo de transformación del objeto arquitectónico". ${ }^{2}$ Luis Fernández Galiano es contundente con esta cuestión al afirmar que "la arquitectura detenida es una arquitectura muerta", y aclara que son los continuos cambios que sufren los monumentos a lo largo del tiempo los que les otorgan la juventud eterna, los que les dan una actualidad permanente. ${ }^{3}$

También Juan Calduch incide en esta aparente paradoja a través del concepto de duración, como reflejo de lo mutable y lo permanente: "la duración significa aunar de manera indisoluble la conservación y el cambio, la modificación que garantiza la pervivencia, la defensa de la continuidad a través de la renovación. La memoria que reconstruye el pasado y la identidad que acota el presente". ${ }^{4}$

Pero toda transformación supone una pérdida, por lo que surge la cuestión de qué modificar. Se acepta la necesidad de selección, renunciando así a parte de ambos mundos para lograr un nuevo conjunto en equilibrio. Lo que Pierluigi Spadolini denomina "conservación abierta", un concepto que acepte por un lado el respeto y la interpretación de lo antiguo, y por otro lado la capacidad de la intervención para darle un uso contemporáneo. ${ }^{5}$

En este sentido son esclarecedoras las reflexiones de Salvatore Boscarino sobre el tema de la memoria. Boscarino recuerda un cuento de Borges sobre un hombre que posee una extraordinaria capacidad de memoria, que le permite recordarlo todo pero, al mismo tiempo, esta capacidad le
1 CORNOLDI, A.: "Per una composizione critica". En: CORNOLDI, A.; RAPPOSELLI, M.; Massimo Carmassi: Pisa. Ricostruzione di San Michele in Borgo. Venecia, Ed. IUAV; Padova, Ed. II Poligrafo, 2005, pp. 10

2 SAENZ DE OIZA, F.J.: "Superposición y adaptación de nuevas estructuras en edificios antiguos". En: CABALLERO ZOREDA, L. (dir.): Curso de mecánica y tecnología de los edificios antiguos. Madrid: Colegio Oficial de Arquitectos de Madrid, 1987, p. 123

3 FERNÁNDEZ GALIANO, L.: "Monumento nuevo. Patrimonio materno, la restauración y sus géneros". En: A.A.V.V.: Restaurar 0 Conservar?: Barcelona-Cardona, del 17 al 20 de noviembre de 1993. Barcelona: Diputació de Barcelona. 1996, pp. 231232

4 CALDUCH, J.: "La duración: una alternativa de nuestra modernidad". En: A.A.V.V.: Rehabilitación en vivienda. Valencia: Pencil, 2007

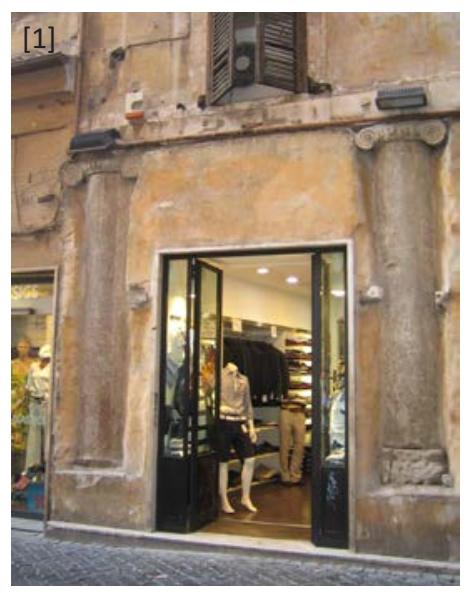


5 SPADOLINI, P.: “L'intervento sull'antico". En: PEREGO, F.: Anastilosi. L'antico, il restauro, la città. Ed. Laterza, 1987 , p. 14

6 Ver el cuento de Jorge Luis Borge: "Funes el memorioso", en Ficciones, 1944. BOSCARINO, S.: "La conservazione dei significati fra memoria ed oblio". En: Sul restauro architettonico : saggi e note. Milano, Ed. F. Angeli, 1999, p. 74

7 Boscarino retoma las reflexiones de H.G.Gadamer en su libro Verità $e$ metodo, 1983 (1960). BOSCARINO, S.: "La conservazione dei significati fra memoria ed oblio". En: Sul restauro architettonico : saggi e note. Milano, Ed. F. Angeli, 1999, p. 78

8 CASTILLA DEL PINO, C.: "La Memoria y la Piedra". En: GONZÁLEZ MORENONAVARRO, A. (dir.): Patrimonio: ¿Memoria o Pesadilla?. Memoria: 1990-1992. Barcelona: Diputació de Barcelona, 1995, p. 11

9 Claudio Varagnoli hace referencia al texto de Saverio Muratorio con título "Commento al I tema: Conservazione e restauri" publicado en Atti del VII congresso nazionale di storia dell'architettura (Palermo, 2430 settembre 1950), Palermo 1955. VARAGNOLI, C.: "Antichi edifici, nuovi progetti. Realizzazione e posizioni teoriche dagli anni Novanta ad oggi", En Ferlenga, Alberto; Vasallo, Eugenio; Schellino, Francesca. Antico e Nuovo. Architetture e architettura. II Poligrafo. 2007. Volumen 2. p. 844

10 de SOLÀ-MORALES, óp. cit. (1982), p. 37

11 CAPITEL, óp. cit. (1990), p. 66

[1] Detalle de reutilización de unas columnas antiguas en una vivienda del centro histórico de Roma. (Imagen del autor.) impide pensar. Con ello se hace evidente que para pensar es necesario seleccionar, y por tanto para recordar es necesario olvidar. Así, por extensión a nuestro ámbito de estudio, podemos deducir que para conservar es necesario descartar. ${ }^{6}$

Pero además Boscarino apunta que este olvido permite llevar a cabo un proceso de renovación de la tradición, produciendo una historia que no sea mera acumulación, sino creación a través de la interpretación crítica del pasado. ${ }^{7}$ Asumiendo una concepción de la historia como algo contemporáneo.

En esta línea el escritor y psiquiatra Carlos Castilla del Pino hace un símil entre la memoria de la historia y la del sujeto, y afirma que la clave está en elegir adecuadamente lo que se olvida, ya que "si olvidamos aquello que es, o puede ser útil para el presente y para el futuro, entonces no hemos aprendido". ${ }^{8}$

\section{UNA CUESTIÓN DE PROYECTO ARQUITECTÓNICO, Y DE GRAN SENSIBILIDAD}

Se observa unanimidad en entender que esta transformación debe producirse en el seno de un complejo proyecto arquitectónico. Durante el siglo XX surge una reivindicación a favor de la disciplina arquitectónica y de la figura del arquitecto sensible a los valores de la preexistencia debido tanto a la proliferación de violentas actuaciones modernas como de conservaciones acríticas o repristinaciones falsificadoras.

En este sentido Claudio Varagnoli recuerda la opinión del arquitecto italiano Saverio Muratori, quien sostenía que "el arquitecto restaurador debe ser todavía más arquitecto para poder tener la sensibilidad de dialogar con el pasado, hasta asumir la coincidencia entre proyecto de arquitectura y proyecto de restauración". ${ }^{9}$

También Ignasi de Solá Morales había reivindicado a principios de los años 80 la intervención proyectual como la única herramienta adecuada para establecer un diálogo entre la arquitectura del pasado y la del presente, advirtiendo de la imposibilidad de establecer unas leyes estéticas abstractas generales válidas. ${ }^{10}$

Antón Capitel también se muestra en esta línea, haciendo especial hincapié en la complejidad presente en una propuesta de intervención: "no es claro ni preciso de planteamiento, sino sutil y hasta resbaladizo la mayoría de veces, como todo problema arquitectónico superior, pero es amplio, dejando todavía ancho espacio a la libertad del proyectista que ha de optar entre las múltiples opciones que aparecen ante un planteamiento preciso". ${ }^{11}$ 
Saenz de Oiza defiende al arquitecto, ante los especialistas, como actor legítimo en las actuaciones sobre la arquitectura antigua, y al igual que Muratori matiza que para ser restaurador hay que ser un gran arquitecto, ya que "para actuar sobre un pasado tan difícil, es necesario tener una gran sensibilidad". ${ }^{12}$

Alberto Humanes alude a la necesidad de que todo arquitecto restaurador cuente con un profundo conocimiento de la historia del monumento, pues es el instrumento que posibilita interpretarlo adecuadamente, y al mismo tiempo con el convencimiento de que su actuación como arquitecto aporta inevitablemente una huella culturalmente significativa de su tiempo. ${ }^{13}$

Giovanni Carbonara afirma que ninguna actuación sobre una preexistencia puede ser neutra, sino que "se deberá buscar una solución figurativa haciendo arquitectura sobre arquitectura" a través de un proyecto arquitectónico atento al conocimiento material e histórico de la obra sobre la que se actúa. ${ }^{14}$

También Carbonara alude a la complejidad de la restauración indicando que "requiere a los arquitectos un plus de sensibilidad y de competencia, una capacidad de atención y de respeto (...) una cultura y una preparación especializada que debe ejercitarse en un ámbito (...) históricoarquitectónico". ${ }^{15}$

Adriano Cronoldi condiciona incluso la legitimidad de la actuación a la calidad del arquitecto, indicando que "cuanto menos esté dotado el proyectista de cultura, talento y experiencia, tanto menos deberá ser autorizado a introducir lo nuevo" ${ }^{16}$, y apunta que el proyecto crítico, por su propia naturaleza como práctica de confrontación, no puede proponer axiomas o reglas de actuación, siendo por lo tanto fundamental llevar a cabo una comparación crítica entre soluciones alternativas. ${ }^{17}$

Por otro lado Antonio Fernández Alba indica que la necesaria toma de conciencia de los valores de la preexistencia se debe hacer desde la colaboración del arquitecto con otras disciplinas, ya que "la pérdida de la totalidad y la exacerbación del análisis de documentos, a veces, convierte al arquitecto en un calígrafo incapaz de organizar el contenido compositivo y formal de un espacio". ${ }^{18}$

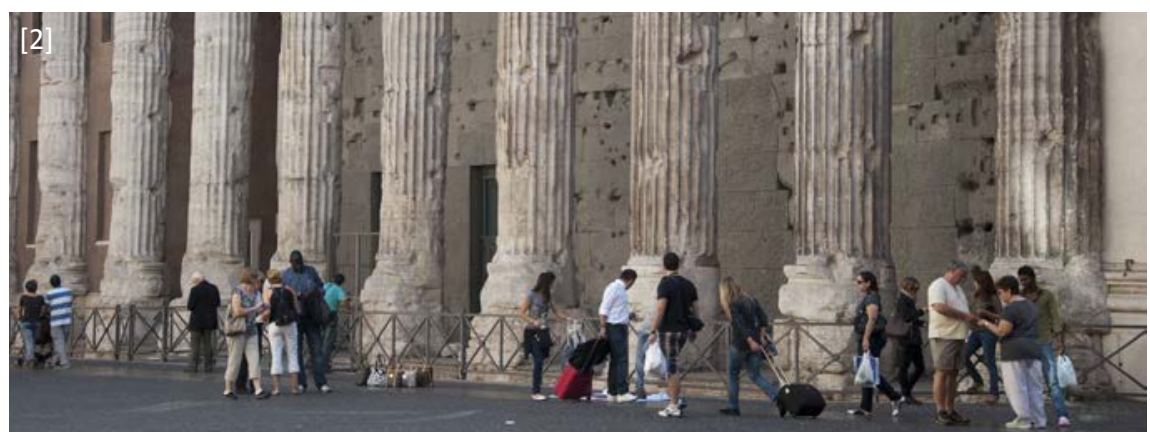

12 SAENZ DE OIZA, F.J.: "Superposición y adaptación de nuevas estructuras en edificios antiguos". En: CABALLERO ZOREDA, L. (dir.): Curso de mecánica y tecnología de los edificios antiguos. Madrid: Colegio Oficial de Arquitectos de Madrid, 1987, p. 134

13 HUMANES, A.: "Arquitecto conservador o Arquitecto restaurador". Arquitectura, no 307, Madrid, Ed. COAM, 1996, p. 12

14 CARBONARA, G.: Architettura d'oggi e restauro. Un confronto anticonuovo. Torino, Ed. Utet, 2011, p. 71

15 CARBONARA, G.: Architettura d'oggi e restauro. Un confronto anticonuovo. Torino, Ed. Utet, 2011, pp. 4

16 CORNOLDI, A.: "Per una composizione critica". En: CORNOLDI, A.; RAPPOSELLI, M.; Massimo Carmassi : Pisa. Ricostruzione di San Michele in Borgo. Venecia, Ed. IUAV; Padova, Ed. II Poligrafo, 2005, pp. 10

17 CORNOLDI, A.: "Per una composizione critica". En: CORNOLDI, A.; RAPPOSELLI, M.; Massimo Carmassi : Pisa. Ricostruzione di San Michele in Borgo. Venecia, Ed. IUAV; Padova, Ed. II Poligrafo, 2005, pp. 12

18 FERNÁNDEZ ALBA, A.: “1. Relaciones entre patrimonio históricoarquitectónico y proyecto de arquitectura". En: A.A.V.V. : Teoría e Historia de la Restauración. Madrid, MRRP, 1997, p. 44
[2] Vista de las columnas del Adrianeum de Roma. (Imagen del autor.) 


\section{LA VALORACIÓN DEL MONUMENTO. CASO POR CASO}

19 CORNOLDI, A.: "Restauri non Conservativi. La Ricerca delle Regole". En: Ferlenga, Alberto; Vasallo, Eugenio; Schellino, Francesca. Antico e Nuovo. Architetture e architettura. II Poligrafo. 2007. Volumen 1. p. 263

20 FERNÁNDEZ, R. "2. Notas para una introducción a la teoría y práctica restauradora". En: A.A.V.V. : Teoría e Historia de la Restauración. Madrid, MRRP, 1997, pp. 46-99

21 PIZZA, A.: "Ruinas, Forma, Proyecto". En: A.A.V.V.: Cuadernos IV. Arquitectura y Patrimonio. Junta de Anadlucía. 1994. p. 37

22 BOSCARINO, S.: "memoria e significati". En: Sul restauro architettonico : saggi e note. Milano, Ed. F. Angeli, 1999,

p. $81-82$

23 CORNOLDI, A.: "Per una composizione critica". En: CORNOLDI, A.; RAPPOSELLI, M.; Massimo Carmassi : Pisa. Ricostruzione di San Michele in Borgo. Venecia, Ed. IUAV; Padova, Ed. II Poligrafo, 2005, pp. 11

24 GASPARALI, P.: "Progetto sul costruito. Regolare il mutamento dell'edificato esistente. Tra le istanze di conservazione e le esigenze di trasformazione". Recupero e Conservazione, no 79, E-F 2008, p. 37

[3] Reintegración de columnas ubicadas en los Foros de Trajano en Roma. (Imagen del autor.)

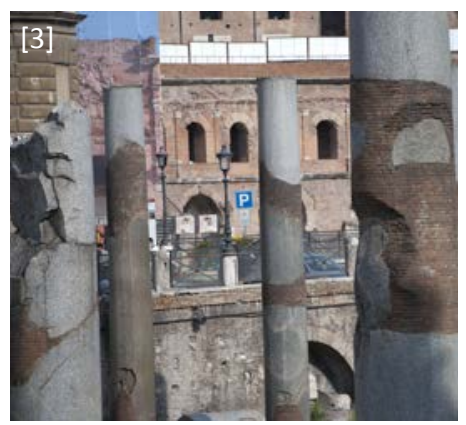

Una vez constatado que la arquitectura debe mutar para sobrevivir, se hace patente una gran responsabilidad a la hora de seleccionar lo que se elimina, pero también lo que se mantiene y lo que se añade. Así, para Adriano Cornoldi "apoyar la posibilidad de realizar transformaciones implica la necesidad de abandonar cómodos principios para aventurarse en la valoración de las situaciones caso por caso". ${ }^{19}$

Roberto Fernández recuerda que, según los conceptos de Alois Riegl, para que lo histórico sea materia susceptible de ser preservada es necesario que coincida el valor rememorativo, como testimonio, y el valor contemporáneo, como reconocimiento de su artisticidad. Sin embargo, matiza que en las últimas reglamentaciones el valor documental prevalece como criterio general, de tal manera que, aunque "puede obstruir la operatividad, al menos salvaguarda preventivamente numerosas y polémicas situaciones concretas". ${ }^{20}$

Ante esto último Antonio Pizza indica que estos valores no deben suponer una imposición, sino que se debe defender la pluralidad de interpretaciones de la historia y no imponer una "lectura privilegiada que quiere presentarse -por antonomasia-como 'verdadera' o fidedigna". ${ }^{21}$

En esta línea, Boscarino apuesta por la conservación de los significados cómo única estrategia que permite reconectar el legado vital entre una colectividad y su tradición, y así no reducir el acto de perpetuación de la memoria a una transmisión de contenedores vacíos. ${ }^{22}$

También Adriano Cornoldi apuesta por el valor significativo. Cornoldi se interesa por aquellas arquitecturas donde las cuestiones de estilo son secundarias respecto a la búsqueda de "formas capaces de evocar significados, de asumir una dimensión simbólica". Es lo que él llama la arquitectura de la interioridad, frente a la arquitectura de la exterioridad presente en los arquitectos estrella actuales. ${ }^{23}$

Para Paolo Gasparali, el problema de la intervención sobre lo construido no puede quedarse en "una irreconciliable y simplificadora contraposición entre conservación integral y sustitución edilicia, sino que se debe valorar caso por caso en función de la historia, la consistencia del edificio y del nuevo uso." El arquitecto debe leer los valores del edificio y analizar si se deben conservar o transformar, siempre con prudencia, sin certezas preconcebidas, mediante aproximaciones sucesivas y con el filtro de la experiencia. ${ }^{24}$

Se observa por tanto una mirada que bebe del recuerdo de lo que fue el monumento, del respeto por lo que queda de él y de la consideración de las nuevas necesidades y posibilidades que plantea. El grado de atención a su pasado, presente y futuro dependerá de la valoración crítica de sus potencialidades. 


\section{UNA BÚSQUEDA DE DIÁLOGO ENTRE PASADO, PRESENTE Y FUTURO}

En la reflexión por la búsqueda de una vía intermedia se observa una apuesta por establecer un diálogo equilibrado con lo preexistente. Este diálogo se plantea desde dos tendencias distintas: desde la mirada al pasado del monumento, a su historia, tratando de recuperar valores perdidos; desde la mirada a un nuevo futuro, distinto de su pasado concreto, apostando por nuevos valores. Pero en ambos casos siempre desde el respeto a los valores del presente.

Adriano Cornoldi alude a este diálogo, no a través de la suma de partes independientes y contrapuestas, sino como resultado de una intensa interrelación entre ellas. Cornoldi identifica la conservación, el repristino y la innovación como las tres vertientes de referencia, y aclara que se debe huir de los extremos para evitar el fetichismo, la falsificación o la violenta provocación. ${ }^{25}$

Varagnoli, retomando al filósofo Tzvetan Todorov, entiende que para que se produzca diálogo, ninguna de las partes debe ser "ignorada, menospreciada o suprimida", sino que, al contrario, debe ser reconocida en su diversidad. Para ello se deben rechazar las disonancias radicales. ${ }^{26}$

Para Giovanni Carbonara se debe tener una actitud proyectual que sea respetuosa con la memoria y con el lugar, una vía entre una "modernidad de vanguardia atópica y anti-histórica y una posmodernidad regresiva y falsificadora". ${ }^{27}$

Para Juan Calduch frente a la amnesia de la arquitectura de la tabula rasa y la pura contemplación de la arquitectura de la parálisis, "el verdadero reto está en encontrar el equilibrio entre conservar la memoria y enriquecerla con las propias aportaciones". ${ }^{28}$

Para Alberto Ustárroz "modernitas y antiquitas no pueden darse la espalda, porque cada una es ya la mitad necesaria de la otra para construir la imagen unitaria del presente ${ }^{\prime 2}$, algo que ya había expresado con claridad Beaudelaire al afirmar que "la modernidad no es más que la mitad del arte, la otra mitad es lo eterno y lo inmutable". ${ }^{30}$

Maria Piera Sette, retomando a su maestro Miarelli Mariani, indica que la clave está en "conmensurar lo que hay que hacer con lo ya hecho".

Para Antón Capitel se trata de buscar la armonía entre lo antiguo y lo nuevo. Así, en los casos en los que han de ejecutarse adiciones o terminaciones de lo incompleto, propone "tratar de encontrar instrumentos formales que, buscando para la obra una nueva unidad, como en la restauración en estilo, expresenarticuladamenteladiscontinuidaddelamismaencuantocompuesta de viejo y nuevo, y siguiendo en ello la tradición arqueológica moderna". ${ }^{31}$
25 CORNOLDI, A.: "Per una composizione critica". En: CORNOLDI, A.; RAPPOSELLI, M.; Massimo Carmassi : Pisa. Ricostruzione di San Michele in Borgo. Venecia, Ed. IUAV; Padova, Ed. II Poligrafo, 2005, pp. 10

26 VARAGNOLI, C.: "Edifici da edifici: la cicezione del passato nell'architettura italiana, 1990-2000". L'industria delle costruzioni, no 368, Ed. ANCE, 2002, pp. 5 y 14

27 CARBONARA, G.: Architettura d'oggi e restauro. Un confronto anticonuovo. Torino, Ed. Utet, 2011, p. 6

28 CALDUCH, J.: "La duración: una alternativa de nuestra modernidad". En: A.A.V.V.: Rehabilitación en vivienda. Valencia: Pencil, 2007

29 USTÁRROZ, A.: La lección de las ruinas. Barcelona, Ed. Fundación Caja de Arquitectos, 1997, p.

30 Beaudelaire, Le Peintre de la vie moderne, Paris, p. 33. Extraído de: USTÁRROZ, A.: La lección de las ruinas. Barcelona, Ed. Fundación Caja de Arquitectos, 1997, p.

31 CAPITEL, A.: "Apéndice. La práctica de la analogía formal". En: Metamorfosis de monumentos y teorías de la restauración. Madrid, Alianza Forma, 2009, pp.219-244

[4] Detalle de la cornisa del Templo de la Fortuna Viril. (Imagen del autor.)

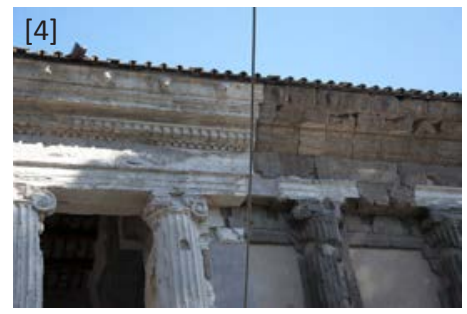


32 CARBONARA, G.: Architettura d'oggi e restauro. Un confronto anticonuovo. Torino, Ed. Utet, 2011, pp. 148149

33 CARBONARA, G.: Architettura d'oggi e restauro. Un confronto anticonuovo. Torino, Ed. Utet, 2011, p. 53

34 CARBONARA, G.: Architettura d'oggi e restauro. Un confronto anticonuovo. Torino, Ed. Utet, 2011, p. 70

35 VARAGNOLI, C.: "Antichi edifici, nuovi progetti. Realizzazione e posizioni teoriche dagli anni Novanta ad oggi", En Ferlenga, Alberto; Vasallo, Eugenio; Schellino, Francesca. Antico e Nuovo. Architetture e architettura. II Poligrafo. 2007. Volumen 2. Pp. 858-859

36 FERNÁNDEZ MUÑOZ, A.L.: “EI Proyecto como Condición de la Restauración Arquitectónica". En: FERNÁNDEZ MUÑOZ, A.L.: Restauración Arquitectónica. Valladolid: Universidad de Valladolid, 1992, p. 138

[5] Columnas reutilizadas en la iglesia de Santa Maria in Aracoelli. (Imagen del autor.)

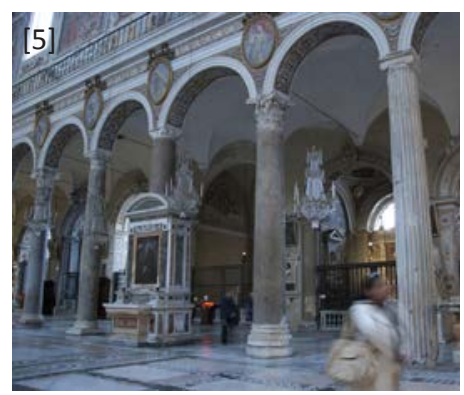

\section{LA ATENCIÓN A LA PREEXISTENCIA DESDE LA MIRADA A SU PASADO}

Esta vía se apoya en el pasado del monumento para actuar sobre la preexistencia. En todo caso esta mirada al pasado se hace desde nuestra cultura actual, por lo que esa valoración no puede ser única y verdadera sino que es cambiante y abierta. Surge la necesidad de desentrañar los valores de la preexistencia reconociendo sus leyes internas para emplearlos como material de proyecto.

Giovanni Carbonara retoma las consideraciones del filósofo alemán Hans Georg Gadamer acerca de la tradición, entendida como transmisión de lo antiguo desde lo nuevo, interpretando el pasado mediante una reproducción creativa. ${ }^{32} \mathrm{O}$ la opinión de la filósofa francesa Simone Weil, quien afirma que para construir el futuro es necesario poseer los tesoros heredados del pasado, digeridos, asimilados y recreados por nosotros. ${ }^{33}$

Para Carbonara es importante entender, tal y como ya expresó Cesare Brandi, que la conciencia histórica conquistada en el siglo XIX nos impide comportarnos frente al pasado, con la misma espontaneidad y libertad que los artistas anteriores a ese momento. ${ }^{34}$

Giorgio Grassi apuesta por la conformidad de lo nuevo con lo existente, estableciendo una relación lineal entre ellos que afirma la autorreferencialidad del objeto. Por contra se opone al concepto de conveniencia, ya que presupone un sujeto que observa y enjuicia el objeto desde fuera, transformando y sustituyendo el objeto mismo de la evocación. Mientras que el primer camino busca expresar la tipicidad del objeto, eliminando lo que estorba, el segundo apuesta por investigar nuevas relaciones a través de adiciones o sustituciones.

Varagnoli critica que entre los proyectistas es difícil "encontrar una intervención que nazca de una profunda lectura de la estructura interna de la obra", mencionando que parece descartada la posibilidad de respetar la semántica del edificio antiguo y "hablar la lengua antigua con nuevas palabras", sino que emplear la materia histórica para evocar nuevos significados. ${ }^{35}$

Ángel Luis Fernández Muñoz, opina que para acabar con la frustración del arquitecto frente a la restauración, es necesario "aceptar de modo natural la existencia de ciertas leyes internas del edificio, que son incluso anteriores a su propia forma final y que permiten, por ello, pero dentro de ellas, el más libre juego de la arquitectura". ${ }^{36}$ 


\section{LA ATENCIÓN A LA PREEXISTENCIA DESDE LA BÚSQUEDA DE NUEVOS VALORES}

En esta línea de intervención no se busca recuperar la historia pasada, sino aceptar los restos que han sobrevivido como realidad abierta a nuevas sugerencias y relaciones. No se busca explicar de manera didáctica la evolución de la historia, sino responder a las sensaciones que produce la percepción simultánea de sus restos. Se reinterpreta la historia para construir una nueva realidad.

Para Antonio Pizza, si bien a través de un estudio histórico se puede determinar el valor simbólico y la forma del monumento, sin embargo este hallazgo no debe suponer una imposición en el proyecto de intervención. "La elección de la actuación y las prioridades a tener en cuenta son responsabilidad del operador de turno, sin "justificaciones" ajenas; ésta es, en definitiva, su invención". ${ }^{37}$

Pizza se imagina un mundo conformado por arquitecturas incompletas cuya dimensión proyectual se basaría en una parcialidad intrínseca, en la ausencia de una configuración primigenia y definitiva. Y retoma el cuento de el "ángel" de Walter Benjamin, en el que "según Benjamin el anhelo del progreso se opone estructuralmente a todo lo que pretenda recomponer en un diseño unitario los fragmentos, lo que está definitivamente desmembrado". ${ }^{38}$

Franco Purini entiende la restauración como un proyecto de arquitectura que debe construir una interpretación "no conformista ni habitual". Así apuesta no tanto por una reconstrucción de una integridad perdida" o una "restitución crítica", sino por "la producción de un valor diferencial (...) una divergencia temática". Para Purini, a diferencia dela escultura, la arquitectura admite la adición de nuevos cuerpos: "es bello que la arquitectura tenga la posibilidad de evolucionar biológicamente en el tiempo" ${ }^{39}$

En esta línea Margherita Petranzan opina que en el proyecto de arquitectura no se trata tanto de tener en cuenta las condiciones de la historia sino de su presencia material. ${ }^{40}$

Fernández Alba apunta a la necesidad de indagar en nuevas metodologías proyectuales en las que cobre especial interés la noción constructiva de la restauración, de tal manera que sea la lógica de lo construido la que haga "coherente el proyecto de lo nuevo y la realidad material de lo existente". Así, el proyecto vinculado al proceso constructivo, se intuye como un itinerario sin determinaciones formales previas, soporte de acontecimientos, donde intervienen las interacciones tecnológicas, funcionales y simbólicas. ${ }^{41}$
37 PIZZA, A.: "Ruinas, Forma, Proyecto". En: A.A.V.V.: Cuadernos IV. Arquitectura y Patrimonio. Junta de Anadlucía. 1994. p. 37

38 PIZZA, A.: "Ruinas, Forma, Proyecto". En: A.A.V.V.: Cuadernos IV. Arquitectura y Patrimonio. Junta de Anadlucía. 1994. p. 38

39 Franco Purini, en De Fazio 2006, p.3. Extraído de: CARBONARA, G.: Architettura d'oggi e restauro. Un confronto antico-nuovo. Torino, Ed. Utet, 2011, p. 74

40 Margherita Petranzan, "Restauro", en La Biennale di Venezia, 10. 2006, pp.405-406. Extraído de: CARBONARA, G.: Architettura d'oggi e restauro. Un confronto antico-nuovo. Torino, Ed. Utet, 2011, p. 38

41 FERNÁNDEZ ALBA, A.: "1. Relaciones entre patrimonio históricoarquitectónico y proyecto de arquitectura". En: A.A.V.V. : Teoría e Historia de la Restauración. Madrid, MRRP, 1997, pp. 39-41

[6] Detalle de una restitución realizada en hormigón en la cornisa del Templo de la Fortuna Viril. (Imagen del autor.)

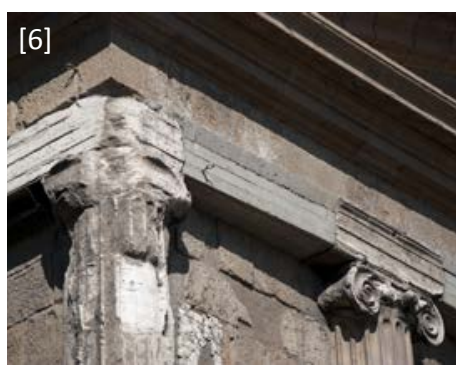


42 FERNÁNDEZ ALBA, A.: "1. Relaciones entre patrimonio históricoarquitectónico y proyecto de arquitectura". En: A.A.V.V. : Teoría e Historia de la Restauración. Madrid, MRRP, 1997, p. 44

43 FERNÁNDEZ ALBA, A.: "1. Relaciones entre patrimonio históricoarquitectónico y proyecto de arquitectura". En: A.A.V.V. : Teoría e Historia de la Restauración. Madrid, MRRP, 1997, p. 37

44 VARAGNOLI, C.: "Antichi edifici, nuovi progetti. Realizzazione e posizioni teoriche dagli anni Novanta ad oggi", En Ferlenga, Alberto; Vasallo, Eugenio; Schellino, Francesca. Antico e Nuovo. Architetture e architettura. II Poligrafo. 2007. Volumen 2. Pp. 843

45 AUGÉ, M.: Che fine ha fatto il futuro? Dai nonluoghi al nontempo, Elèuthera, Milano, 2009, p.51 (ed. Original 2008). Extraído de: CARBONARA, G.: Architettura d'oggi e restauro. Un confronto antico-nuovo. Torino, Ed. Utet, 2011, p. 32-33

46 Franco Purini, congreso sobre "Fare architettura in ambiente archeologico" en Pozzuoli realizado el 5 de mayo de 2006. Transcrito por Giovanna Tarasco en su Tesis Doctoral Oltre il restauro: la progettazione contemporanea sulle preesistenze, 2009. Extraído de: CARBONARA, G.: Architettura d'oggi $e$ restauro. Un confronto antico-nuovo. Torino, Ed. Utet, 2011, pp. 65-66
Hace hincapié en la necesidad de interrogar al monumento, y escuchar el discurso constructivo y arquitectónico de sus espacios. No se trata de trasladar "un determinado código estilístico o tipología mimetizada", ni un "ejercicio técnico de montajes escenográficos", sino de representar un "pensamiento elaborado, (...) la visión subjetiva de un cosmos, (...) un tránsito entre la ficción (...) y la construcción". ${ }^{42}$

\section{LA ATENCIÓN AL CONTEXTO}

Se observa una atención a las necesidades del contexto, y en consecuencia una crítica generalizada hacia aquella arquitectura más preocupada por su propia imagen que por resolver los problemas del lugar en el que se inserta. Por tanto en toda actuación se presenta como necesario reconocer los valores del lugar, planteando la intervención como un nuevo episodio histórico que tiene en cuenta el contexto en el que se inserta.

Antonio Fernández Alba hace hincapié en la atención al contexto, indicando que el proyecto arquitectónico no se puede entender como libre del "vínculo y la servidumbre del lugar construido". Para Fernández Alba se trata de entender el proyecto de lo nuevo en lo preexistente como "una reflexión desde la arquitectura para la transformación de un determinado ambiente", donde actuarán como referencias la escala, materialidad y composición de las preexistencias, y como elementos diferenciadores los nuevos usos de los espacios. ${ }^{43}$

Para Claudio Varagnoli, la falta de atención al lugar y a su historia se traduce en la producción de una arquitectura autorreferencial que utiliza la preexistencia sólo como pretexto para conducir el nuevo proyecto al interior de un contexto antiguo. ${ }^{44}$

Para el antropólogo francés Marc Augé, esta actitud deriva de la concepción del presente, no como reflexión del pasado o construcción de un futuro, sino como respuesta a la inmediatez de la sociedad de consumo. Siendo, por tanto, objetivos primordiales de esta actitud, el culto a la imagen, a la arquitectura de autor y un olvido de la historia. ${ }^{45}$

Franco Purini explica esta actitud diciendo que "hoy en día los lugares se han abolido, y por eso el edificio está obligado a hacerse lugar de sí mismo, auto-contextualizándose". La arquitectura rechaza el crecer sobre la historia y mira al arte como único ámbito posible para su regeneración. Obligada a superarse constantemente, la arquitectura admite cualquier gesto novedoso. ${ }^{46}$ 


\section{AUTENTICIDAD Y FALSO HISTÓRICO}

Las reflexiones sobre el concepto de autenticidad se debaten entre priorizar el respeto por la materialidad preexistente, en su estado degradado, o por su reparación y reintegración, devolviéndola a un estado completo anterior. En este sentido se aprecia una relativización del concepto, en función del punto de vista, llegando a adquirir incluso significados opuestos. En cualquier caso parece mostrarse más interesante no tanto el entrar a debatir sobre lo auténtico y lo falso, como atender a la interpretación de los valores de la preexistencia para la realización de una intervención de calidad.

Ascensión Hernández menciona el cambio de mentalidad que se ha producido acerca del concepto de autenticidad. Mientras que en las Cartas de Restauración, desde la de Atenas de 1931 hasta la italiana de 1987, se han venido rechazando las réplicas, respetando todas las etapas históricas del monumento y defendiendo la aportación de la arquitectura contemporánea donde fuera necesario, sin embargo en la Carta de Cracovia del año 2000, se admite la reconstrucción de un edificio en su totalidad, destruido por un conflicto armado o por desastres naturales, si hay motivos sociales o culturales excepcionales que estén relacionados con la identidad de la comunidad entera. ${ }^{47}$

Antonio González lo explica mediante la distinción entre autenticidad histórica y arquitectónica, afirmando que "la autenticidad arquitectónica puede justificar y exigir la reconstrucción de partes o edificios desaparecidos". Pone el ejemplo del Partenón, afirmando que cubrirlo y recuperar su policromía se vería como una falsedad histórica, pero al mismo tiempo mantenerlo al descubierto y blanco es perpetuar una falsedad arquitectónica. En el mismo sentido González ve la reconstrucción del Pabellón de Barcelona de Mies van der Rohe como auténtico dado que se ha recuperado su ubicación y materialidad originales, recuperando la significación cultural. ${ }^{48}$

Frente a esta postura arquitectos como Andrea Bruno denuncian que los primeros restauradores, empeñados en la búsqueda de la autenticidad primaria, destruyeron páginas enteras de la historia, sustituyendo monumentos medievales por falsificaciones gratuitas y esquemáticas. Restauraciones de Viollet-le-Duc o D’Andrade, tienen hoy en día un valor histórico como testimonio, pero también como "señal de alarma de los riesgos que el patrimonio histórico corre cuando el objetivo de la acción no es el respeto de la realidad compleja y diacrónica del lugar". ${ }^{49}$

Sin embargo Andrea Bruno matiza que el respeto a la autenticidad compleja del lugar no debe significar su conservacionismo o embalsamado. Al contrario alude al deber y responsabilidad del proyectista en el reconocimiento y selección de los valores de la preexistencia. Admite que la conciencia del sentido histórico de los eventos y alteraciones del pasado nos impide producir intervenciones radicales y destructivas, pero afirma
47 HERNÁNDEZ MARTíNEZ, A.: La Clonación Arquitectónica. Madrid: Ediciones Siruela, 2007, p.56

48 HERNÁNDEZ MARTíNEZ, A.: La Clonación Arquitectónica. Madrid: Ediciones Siruela, 2007, p.60-63

49 BRUNO, A.: "H.3.2. Aprocci Metodologici. Progetto di restauro critico". En: ZEVI L.: II manuale del restauro architettonico. Roma, Ed. Mancosu, 2001, H124

[7] Detalle del Templo de la Fortuna Viril. Se aprecian distintos criterios de restauración. (Imagen del autor.)

[8] Teatro de Marcello en Roma. (Imagen del autor.)
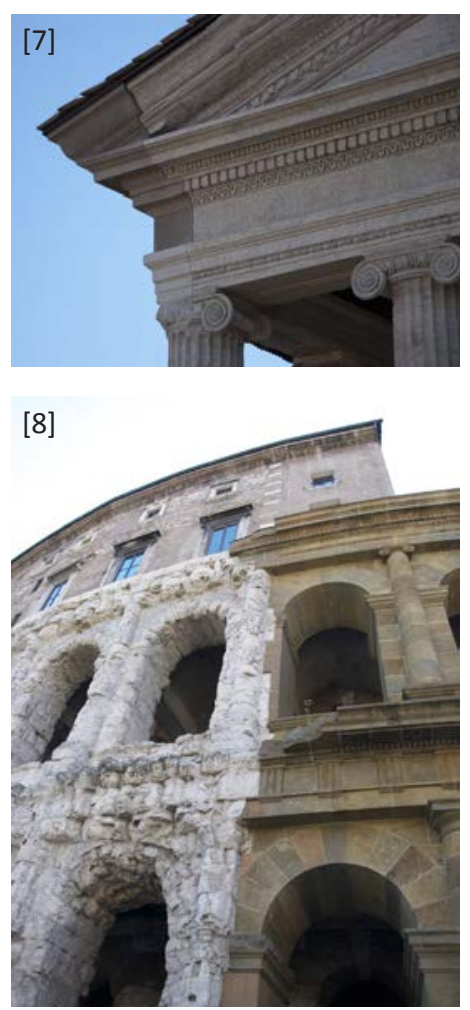
50 BRUNO, A.: "H.3.2. Aprocci Metodologici. Progetto di restauro critico". En: ZEVI L.: II manuale del restauro architettonico. Roma, Ed. Mancosu, 2001, H125

51 HERNÁNDEZ MARTÍNEZ, A.: La Clonación Arquitectónica. Madrid: Ediciones Siruela, 2007, p.60-63

52 JOKILHETO, J.: "Il problema della reintegrazione". En: SEGARRA LAGUNES, M.M.: La reintegrazione nel restauro dell'antico: la protezione del patrimonio dal rischio sismico : atti del Seminario di studi, Paestum, 11-12 aprile 1997. Roma, Ed. Gangemi, 1997, p.49

53 GONZÁLEZ, A.: "Para qué y para quién las ruinas". En: GONZÁLEZ, A.; LACUESTA, R.: Estudis històrics sobre patrimoni arquitectònic: Sant Pere de Torelló, Copons, Terrasa, Esparreguera, Sant Feliu de Llobregat, Tagamanent, Segur de Calafell. Barcelona: Diputació de Barcelona. 2000, pp. 131, 132

54 REPRESA BERMEJO, I.: "La expresión plástica en la degradación". En: REPRESA, I. (dir.): Restauración Arquitectónica II. Valladolid: Universidad de Valladolid, 1998, p. 151

55 REPRESA BERMEJO, I.: "La expresión plástica en la degradación”. En: REPRESA, I. (dir.): Restauración Arquitectónica II. Valladolid: Universidad de Valladolid, 1998, p. 144

[9] Reintegración simplificada en los capiteles del Templo de Vesta. (Imagen del autor.)

[9]

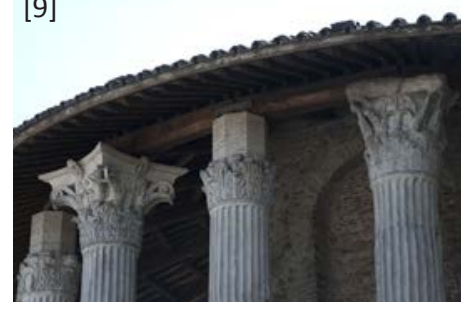

que comprender y restituir a la colectividad la memoria del pasado significa también aceptar y promover la destrucción de objetos insignificantes, de arquitecturas despreciables, de intervenciones horrendas que desfiguran un lugar o un monumento, ocultan el valor y el significado, reducen las potencialidades de uso. ${ }^{50}$

También Luis Fernández Galiano se muestra en contra de la "autenticidad arquitectónica" advirtiendo de que el peligro de la reconstrucción es que el mundo acabe siendo un enorme pastiche histórico, donde los centros históricos se conviertan en "réplicas afeitadas de sí mismos que los hagan digeribles al consumo turístico, mientras el desorden físico y simbólico desventura las periferias". ${ }^{51}$

Jukka Jokilheto hace referencia al valor de la pérdida, indicando que una laguna puede despertar nuestra imaginación de la misma manera que una composición puede inspirar a un artista diversas interpretaciones. Para Jokilheto cuantos más estímulos demos, más podremos esperar que los visitantes de los lugares de arte usen la imaginación y generen valores que les inspiren a reflexionar y a sentir algo auténtico. Cuanto más restauremos, reintegremos, y reconstruyamos, mayor es el riesgo de perder la fascinación de la autenticidad del lugar. ${ }^{52}$

\section{LAS SUGERENCIAS DE LA RUINA}

Cuando la preexistencia sobre la que se actúa se encuentra en estado de ruina, las opciones de actuación pueden ser muy variadas, según el valor que le otorguemos. Si valoramos su realidad material por ser parte de un momento histórico único, optaremos por su conservación y protección. Si las ruinas recuerdan un acto traumático y una pérdida insoportable de su valor, tal vez convenga reconstruir el edificio al que evocan y del que fueron parte en el pasado. Entre ambos extremos sería posible la solución que integre las ruinas dentro de un nuevo edificio, distinto al original, pero dotándoles de una nueva vida. ${ }^{53}$

Ignacio Represa asocia diferentes valores a cada una de estos tres situaciones: "lo auténtico será reconocido en lo degradado, lo didáctico en lo tipológico, y lo plástico (...) en lo abstracto." 54

Represa contrapone el valor expresivo de la degradación de la ruina, producido por las alteraciones superficiales y las pérdidas de definición formal, frente a la reconstrucción como un valor didáctico que transmite un "frío dato tipológico, de elemento cerrado en sí mismo", donde "una materialidad de juventud excesiva evidencia la artificiosidad de temporalizar formas del pasado como maquetas de sí mismas a escala natural" ${ }^{55}$ 
Además recalca que los nuevos equilibrios formales surgidos tras los procesos de degradación, generan nuevas formas espaciales, imprevistas en su origen, de gran sugerencia creativa. Situaciones que sugieren nuevos procesos de redefinición formal que se apoyan en la interacción entre las dos categorías intelectuales mencionadas, la del "código genético" y la de la "capacidad de evocación", para obtener las ideas rectoras que permitan formular el proyecto de restauración. ${ }^{56}$

Respecto a la concreción de nuevas formas Alberto Ustárroz clasifica en cuatro tipos los diversos mecanismos sugeridos por las ruinas: la alusión, la imaginación, la cita o la abstracción esencializadora. Y aclara que "no se trata (...) de obtener certezas unívocas, incontrastables, que las Ruinas afortunadamente no pueden dar (...) sino certezas verosímiles para la acción, para el drama constructivo."

Así Ustárroz apuesta por establecer una "dialéctica entre el análisis de las Ruinas y el proyecto que surge de ellas en el presente", imitando e innovando, sin rechazar lo antiguo ni lo nuevo, sintiéndose a la vez coautor con los antiguos y constructor del presente, buscando respuestas pero también planteando nuevas preguntas que permitan avanzar, un lugar de memoria e imaginación, una modernitas y antiquitas como parte del mismo proyecto. ${ }^{57}$

Para Ustárroz la mirada del arquitecto a las ruinas le permite hacer una obra original, en el sentido de volver al comienzo de la arquitectura, donde, como decía Mies, arquitectura y tecnología van juntas, siendo una expresión de la otra. O como decía Heidegger: "sólo cuando nos volvemos con el pensar hacia lo ya pensado, estamos al servicio de lo por pensar. (...) La Ruina aparece, según esta idea, como ese necesario paso atrás, asegurador de ese salto hacia lo que queda por pensar." ${ }^{58}$

Varagnoli recuerda las palabras de Rudolf Schwarz, en los años de la reconstrucción post-bélica en Alemania: "Nunca las iglesias de Colonia han estado tan bellas como después de haberse familiarizado con el fuego. La ruina invita a una cosa completamente distinta a la reconstrucción, invita a un nuevo nacimiento". ${ }^{59}$

\section{REFLEXIONES EN TORNO A LA MATERIALIDAD DE LA INTERVENCIÓN}

\section{Materialidad en las actuaciones de conservación.}

En las actuaciones de conservación se apuesta por la aceptación de la degradación material del monumento. Se valoran la ruina y la pátina como signos de identificación de lo que Riegl denomina el valor de antigüedad, que resalta la importancia del reflejo del paso del tiempo sobre el monumento, y por tanto de su pertenencia a una historia pasada. Se aprecia la superficie degradada de los materiales por aportar gran cantidad de matices de texturas, juegos de luces y de sombras, variaciones colorimétricas, etc.
56 REPRESA BERMEJO, I.: "La expresión plástica en la degradación". En: REPRESA, I. (dir.): Restauración Arquitectónica II. Valladolid: Universidad de Valladolid, 1998, p. 147

57 USTÁRROZ, A.: La lección de las ruinas. Barcelona, Ed. Fundación Caja de Arquitectos, 1997, p.13

58 USTÁRROZ, A.: La lección de las ruinas. Barcelona, Ed. Fundación Caja de Arquitectos, 1997, pp.19-20

59 VARAGNOLI, C.: "Antichi edifici, nuovi progetti. Realizzazione e posizioni teoriche dagli anni Novanta ad oggi", En Ferlenga, Alberto; Vasallo, Eugenio; Schellino, Francesca. Antico e Nuovo. Architetture e architettura. II Poligrafo. 2007. Volumen 2. p. 845

[10 ] Vista del atrio del Adrianeum en Roma. (Imagen del autor.)

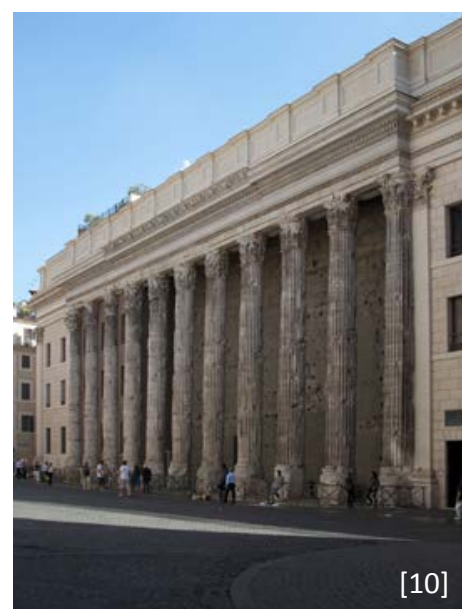


60 BORIANI, M.: Progettare per il costruito. Dibattito teorico e progetti in Italia nella seconda metà del XX secolo. Milano, Ed. CittàStudi Edizioni, 2008, pp. 289-296

61 Para más información sobre esta obra consultar: BORIANI, M.: Progettare per il costruito. Dibattito teorico e progetti in Italia nella seconda metà del XX secolo. Milano, Ed. CittàStudi Edizioni, 2008, pp. 223-230

62 SETTE, M.P.: II restauro in architettura: quadro storico. Torino, Ed. Utet, 2001, p. 195

[11] Pinacoteca do Estado en Sao Paulo, 1993-1998, de Paulo Mendes da Rocha. (BASULTO: "Plataforma en viaje. Sao Paulo-Parte 2." Plataforma arquitectura.)

[12] Nueva escalera del Palazzo della Regione en Milán, 2002-2003, de Marco Dezzi Bardeschi. (BARDESCHI: "Nuova scala di accesso dalla Piazza Mercanti al piano primo del Palazzo della Ragione". Europaconcorsi.)
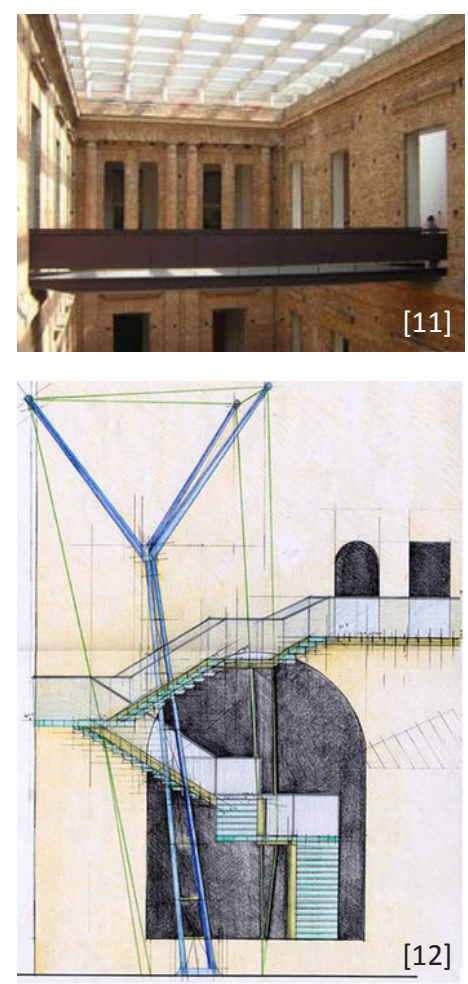

Las actuaciones más conservadoras muestran una admiración por la materia y su fragmentación y tratan de mantenerla mediante el empleo de pequeñas actuaciones, claramente reconocibles, y poco invasivas físicamente de tal manera que se pueda recuperar el estado previo a la intervención. Este es el caso de la actuación de Guido Canali en el Palazzo della Pilotta de Parma (1970-86) donde con pocos elementos refinadamente diseñados se logran resolver las nuevas circulaciones necesarias para la conversión en galería nacional de arte del espacio histórico. En esta misma línea también es interesante mencionar la actuación de Paulo Mendes da Rocha en la Pinacoteca do Estado, en Sao Paulo, realizada entre 1993-98.

El cuidado diseño de los nuevos elementos, su reducción al mínimo, y el empleo de la madera en el caso de necesidad de piezas de mayor dimensión, son criterios que ayudan a establecer una adecuada relación en estas actuaciones de conservación. Este es el caso de la intervención de Massimo y Gabriella Carmassi en una mina en Ravi di Gavorrano (19992001), para su conversión en parque.

La búsqueda por mantener la autenticidad material lleva en ocasiones a soluciones que producen fuertes contrastes en la percepción de lo nuevo junto a lo antiguo. Este es el caso del empleo de ciertos materiales metálicos o "transparentes", que producen el efecto contrario al de la mínima intervención ya que en función de la incidencia del sol se generan grandes reflejos que contrastan con la materialidad de la preexistencia. De esta manera se pierde el concepto de intervención mínima desde el punto de vista de la relación estética. Este es el caso de la actuación de Bruno Gabrielli en la iglesia de Santa Maria in Passione (1992-93), en Genova, donde cubre una parte del área conventual con una estructura de acero tubular recubierta con vidrio. ${ }^{60}$

Sin embargo cuando estos elementos se resuelven de manera completamente autónoma y externa a la preexistencia, y con gran delicadeza en el detalle, las relaciones son mucho más adecuadas, tal y como se observa en la nueva escalera para el Palazzo della Ragione en Milán (2002-03) realizada por Marco Dezzi Bardeschi. ${ }^{61}$

Para Bellini, esta actitud tiene la virtud de reconocer el valor de la preexistencia como elemento histórico y el valor de lo nuevo como reflejo de la contemporaneidad, demostrando con ello un valor ético. ${ }^{62}$

Otras actuaciones plantean el empleo de tecnologías modernas para reforzar las preexistencias evitando que los nuevos elementos se muestren al exterior y manteniendo así la imagen degradada del presente. Sin embargo estas actuaciones suponen transformaciones de la materia interna de la preexistencia, por lo que se vuelve imprescindible la compatibilidad física entre ambas partes de tal manera que se asegure un adecuado comportamiento a lo largo del tiempo. Este es el caso del empleo de fibras de carbono para el refuerzo de los sillares de piedra en la reconstrucción del Duomo di Noto. 
También surge la posibilidad de emplear nuevos materiales pero que reproduzcan o imiten la materialidad degradada de la preexistencia, para conseguir que pasen desapercibidos. En este sentido Javier Gómez-Pioz, valora la actuación de Dionisio Hernández Gil en el Teatro de Mérida frente a la actuación de Giorgio Grassi en Sagunto donde no se valora el poder de la ruina como objeto arquitectónico terminado. Hernández Gil, mediante la colocación de un graderío practicable construido con un material plástico que imita la piedra degradad, resuelve por un lado el problema del deterioro de los restos históricos por el uso público del teatro y por otro lado posibilita los trabajos futuros de investigadores y arqueólogos, consiguiendo con ello "reducir al mínimo las huellas de la intervención". ${ }^{63}$ Sin embargo cabe añadir a este respecto que mientras que Grassi actúa recurriendo con sinceridad a la materialidad de la arquitectura desaparecida, Hernández Gil para mantener el aspecto de ruina acude a materiales artificiosos que contrastan con la solidez romana.

\section{Restauración y repristinación de la materia original}

La restauración material de los elementos perdidos supone una actitud de repristinación que busca borrar las huellas del paso del tiempo. Esta actitud trata de recuperar la perfección de la belleza del pasado, tomando al monumento como si se tratara de una obra de arte cuyo valor exige su restitución. Un camino que se emplea en el caso de ornamentaciones de gran valor artístico o monumentos destruidos de manera traumática y de gran importancia para la colectividad. Este es el caso de la reconstrucción del pórtico de San Giorggio al Velabro donde, como indica Miarelli Mariani la perfección de algunas de las partes nuevas carece del valor de la pátina del tiempo de las partes antiguas.

En este camino se observa incluso la sustitución de partes degradadas de la obra con la finalidad de mejorarlas. Se justifican estas actuaciones al reconocer que los recursos necesarios para reforzar las deficiencias constructivas presentes en la obra son mucho mayores que los de su sustitución. Se emplean técnicas tradicionales que aseguran una compatibilidad con la arquitectura antigua, permitiendo la permanencia del conocimiento técnico y constructivo de elementos del pasado. Una actitud empleada en la reconstrucción de la catedral de Noto.

La actitud de la reconstrucción mediante el empleo de la materia original demuestra un rechazo a las posibilidades estéticas modernas, una actitud que a veces viene impuesta por la necesidad de curar heridas traumáticas. Un caso elocuente de esta situación es el de la actuación en el puente de Mostar sobre el rio Neretva, en Bosnia, donde Andrea Bruno propone una forma simplificada del puente original, a través de unos grandes arcos de acero. Sin embargo, en la solución final se opta por reconstruir el puente tal y como era, en una búsqueda por borrar las huellas de la guerra. Como dice Gianluigi de Martino, la propuesta de Bruno "era tal vez para la ciudadanía una propuesta demasiado evidente de la masacre de la guerra". ${ }^{64}$
63 GÓMEZ-PIOZ, J.: "Intervención en edificios históricos. (Paseo Crítico)". En: A.A.V.V.: Proyectos de Intervención en edificios y recintos históricos. Madrid: Colegio Oficial de Arquitectos de Madrid. 1987, p. 15

64 CARBONARA, G.: Architettura d'oggi e restauro. Un confronto anticonuovo. Torino, Ed. Utet, 2011, p. 56
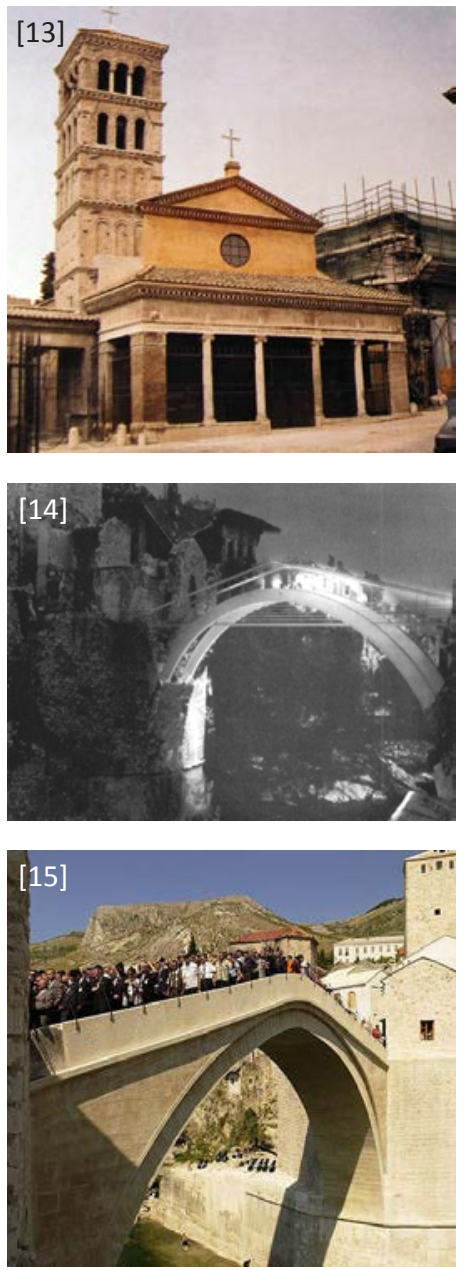

[13] Reconstrucción del pórtico de San Giorgio al Velabro. (A.A.V.V.: 2002,p. 86)

[14] Puente de Mostar. Proyecto de Andrea Bruno. (Cortesía de Marina Docci)

[15] Puente de Mostar sobre el río Neretva, en Bosnia. (ArqHys: "Historia y arquitectura del Puente de Mostar en Croacia".) 
65 GIZZI, S.: "L'anastilosi tra restauro architettonico e restauro archeologico". En: GONZÁLEZ, A.; DIEZ, M.: I Bienal de la restauración: L'Hospitalet de Llobregat (Barcelona), del 23 al 26 de noviembre del 2000. Barcelona: Diputació de Barcelona. 2002, p. 91

66 GIZZI, S.: "L'anastilosi tra restauro architettonico e restauro archeologico". En: GONZÁLEZ, A.; DIEZ, M.: I Bienal de la restauración: L'Hospitalet de Llobregat (Barcelona), del 23 al 26 de noviembre del 2000. Barcelona: Diputació de Barcelona. 2002, p. 92

67 GIZZI, S.: "L’anastilosi tra restauro architettonico e restauro archeologico". En: GONZÁLEZ, A.; DIEZ, M.: I Bienal de la restauración: L'Hospitalet de Llobregat (Barcelona), del 23 al 26 de noviembre del 2000. Barcelona: Diputació de Barcelona. 2002, p. 87

68 SPADOLINI, P.: "L'intervento sull'antico". En: PEREGO, F.: Anastilosi. L'antico, il restauro, la città. Ed. Laterza, 1987 , p. 14
[16] Centro cultural Templo de San Marcos y archivo municipal de Toledo, 1986-2000, Ignacio Mendaro. (Mendaro Arquitectos: <www.mendarocorsini.es $>$ )

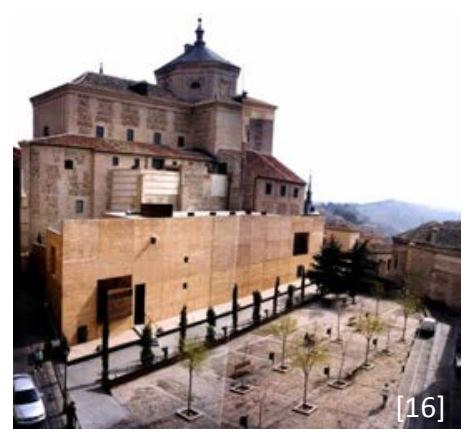

El efecto de novedad de un elemento fuera de su época, o que ignora los acontecimiento históricos, puede provocar una sensación de artificialidad, que impida la lectura natural de la historia. De esta manera se renuncia inicialmente al valor de antigüedad, confiando en que lo recupere con el paso del tiempo. Algo que se vuelve más evidente cuando la actuación es parcial y conviven elementos nuevos y antiguos, produciendo un efecto de desarmonía temporal, o también cuando se eliminan las pátinas por entenderlas como degradantes de la imagen de perfección original.

En el caso de las anastilosis Stefano Gizzi entiende que desde un punto de vista conceptual son justificables aquellas soluciones miméticas, como las empleadas por Korrès en el Partenón, quien afirma que "un añadido incluso mimético será siempre distinguible en el tiempo, así como nosotros mismos, a una distancia de dos mil años, conseguimos distinguir las restauraciones romanas de la antigüedad realizadas sobre los templos de la Acrópolis de Atenas". ${ }^{65}$ Pero Gizzi matiza que el problema surge cuando se emplea el ladrillo para integrar columnas que originalmente eran de ladrillo, ya que este material ha asumido el valor de un código en la restauración, y su empleo puede suponer introducir "confusión y equívoco entre la parte prístina y aquella añadida". ${ }^{66}$

Por otro lado Gizzi también destaca que las actuaciones de desmontaje y montaje "eliminan parte de lo fascinante de situaciones ligadas a la sedimentación de la pátina del tiempo sobre la arquitectura". ${ }^{67}$ Tal y como ocurre en la actuación de Valadier sobre el arco de Tito.

\section{La materialidad de los nuevos elementos}

La materialidad de los nuevos elementos puede ir encaminada a la búsqueda de analogía o de contrate con la preexistencia. En cualquier caso, la condición de relación física entre las partes supone una previsión del comportamiento de ambas realidades con el paso del tiempo. En este sentido Pierluigi Spadolini hace hincapié en que el proyecto en el caso de la intervención sobre el patrimonio "se desarrolla a nivel parcial, y esta parcialización de lo nuevo que valora contemporáneamente lo antiguo, sólo se puede conseguir con un profundo y especializado estudio de los materiales a emplear, y con el cuidado refinado del detalle". ${ }^{68}$

El uso de nuevos materiales como el acero, el vidrio y el hormigón ayudan a aclarar la actualidad de la intervención, pero el contraste entre antiguo y nuevo es el mecanismo de distinción más radical y su empleo puede producir situaciones violentas. Es por tanto un mecanismo de actuación que presenta ciertos riesgos, pero que bien empleado puede ayudar a potenciar los valores de antigüedad y novedad precisamente por el hecho de ponerlos en relación. 
Con el hormigón se busca expresar una reinterpretación moderna del material pétreo original, por lo que se hace fundamental el trabajo cuidadoso con los encofrados de tal manera que se logre una adecuada integración entre las texturas de lo antiguo y lo nuevo. También el trabajo con el color puede ayudar a la integración del nuevo material con los elementos preexistentes. Este es el caso del centro cultural Templo de San Marcos y archivo municipal de Toledo (1986-2000), de Ignacio Mendaro, donde siguiendo las trazas del claustro desaparecido se configura un nuevo volumen de hormigón coloreado que hace de gran zócalo, ocultando elementos no adecuados para ser vistos, y pone en valor la arquitectura de la iglesia. ${ }^{69}$

Con el acero y el vidrio se puede acudir a soluciones más o menos virtuales que busquen evocar la forma original sin definirla del todo. Se hace fundamental en este caso que el detalle constructivo resuelva la durabilidad de los materiales, y que su transformación no produzca daños en los preexistentes.

En este sentido cabe destacar la gran relevancia que a cobrado en los últimos años el empleo del acero corten, un material ligero pero de aspecto sólido, cuya textura vibrante, tonalidad cálida y materialidad cambiante ayudan a establecer relaciones con la materia degradada de la preexistencia. Sin embargo el óxido produce un rechazo en el contacto directo con el material y puede suponer el ensuciamiento de los elementos históricos sobre los que se asienta.

Un claro ejemplo de uso de este material es la actuación de reconstrucción del Pont Trencat realizada por Xavier Font en Tordera (2000-2004), donde se repropone la forma original de la parte faltante mediante el empleo de acero corten, contrastando con fuerza con la piedra original, y evocando en cierta medida la evolución tecnológica que este tipo de construcciones ha sufrido a lo largo de la historia. ${ }^{70}$ Por contra, en la actuación sobre la muralla de la Hoya, en la Alcazaba de Almería, se observa cierto abuso de este material al producir un fuerte contraste con la preexistencia, lo que ha supuesto un gran rechazo de la opinión pública. ${ }^{71}$

Otros ejemplos de uso del acero corten buscan la clara independencia formal de lo nuevo y lo viejo. Este es el caso del nuevo acceso a la torre Reichenberg en Tubre de Werner Tscholl (1998-2000), el instituto hispanoluso de Zamora de Manuel de las Casas, o el castillo de la luz de Fuensanta Nieto y Enrique Sobejano, en Las Palmas de Gran Canaria (2005).

Frente al empleo de materiales modernos, que buscan cierto contraste con la materia preexistente, se presenta el empleo de materiales tradicionales. Éstos tienen la ventaja de mostrar un comportamiento y expresión similar a los del monumento de tal manera que se pueden integrar con naturalidad y discreción en la obra, dejando a cargo de las formas y técnicas la aclaración de la actualidad de la actuación.
69 Información extraída de la página web del arquitecto. (www. mendarocorsini.es)

70 OTERI, A.M.: Rovine. Roma, Ed. Argos, 2009, p. 93

71 Para conocer estos episodios satíricos se recomienda visitar la web culturandalucia. Cabe aclarar que si bien no me identifico con todas las críticas que se hacen en esta página, en especial con las obras de Antonio Jiménez Torrecillas, si que reconozco la razón de las críticas en algunas de las obras mencionadas.

[17] Reconstrucción del Pont Trencat en Tordera, 2000-2004, Xavier Font. (BESOMI: Plataforma arquitectura, Mayo 2007.)

[18] Castillo de la luz en Las Palmas de Gran Canaria, 2005, de Nieto y Sobejano. (NIETO; SOBEJANO: $<$ www.nietosobejano.com>)
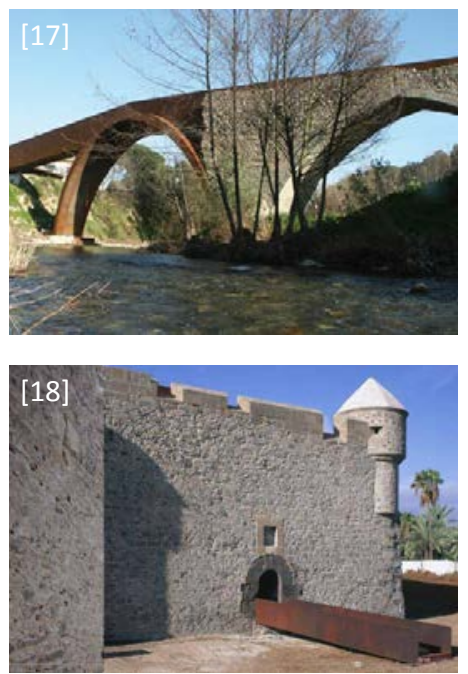
72 CORNOLDI, A.: "Restauri non Conservativi. La Ricerca delle Regole". En: Ferlenga, Alberto; Vasallo, Eugenio; Schellino, Francesca. Antico e Nuovo. Architetture e architettura. II Poligrafo. 2007. Volumen 1. p. 283

73 VARAGNOLI, C.: "Edifici da edifici: la cicezione del passato nell'architettura italiana, 1990-2000". L'industria delle costruzioni, no 368, Ed. ANCE, 2002, pp. 5 y 14

74 CORNOLDI, A.; RAPPOSELLI, M.: "Nuovo e antico. Intervista a Emanuele Fidone, Vicenzo Latina e Bruno Messina". En: CORNOLDI, A.; RAPPOSELLI, M.: Emanuele Fidone, Vincenzo Latina, Bruno Messina. 'Restauri' Iblei. Padova, II Poligrafo,2007, p. 18

75 NICOLIN, P.: “Lewerentz-Klippan: prefazione”. Lotus nำ3, pp.7-19

[19] Renovación y reconstrucción del castillo de Novara, estudio Zermani. (Fotografía de Mauro Davoli. En: FRANCO: Plataforma arquitectura, Enero 2013)

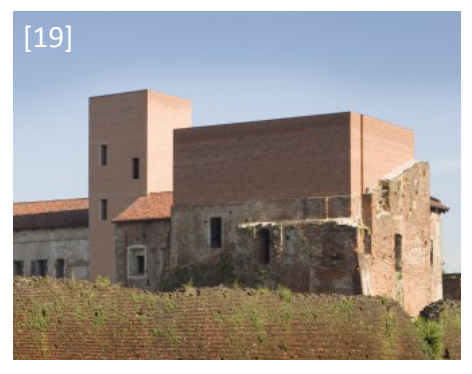

En esta línea Adriano Cornoldi entiende que la mejor relación con lo antiguo se logra a través de la distinción en el diseño y la afinidad material, en lugar de la renuncia al diseño y la contraposición tecnológica que produce la falsa ligereza del vidrio. ${ }^{72}$ Opinión que también comparte Claudio Varagnoli, para quien la sustitución de los materiales modernos como hormigones vistos y metales brillantes por materiales más tradicionales como la madera, el ladrillo o la piedra ayuda a dialogar con la materialidad de la preexistencia. ${ }^{73}$

El uso de la piedra en los nuevos elementos permite relacionarse con facilidad con las estructuras históricas. Este es el caso del pabellón de acceso a las excavaciones del Artemision en Siracusa, realizado por Vincenzo Latina, que como indica el propio autor "se concibe como un monolito de piedra caliza generado por el magnetismo de los vestigios subterráneos del Artemision y del adyacente Athenaion". Los materiales y la iluminación interior del pabellón buscan evocar una arquitectura excavada. ${ }^{74}$

Otro ejemplo interesante de uso de la piedra en contacto con la preexistencia es el del museo de Navarra de Jordi Garcés y Enric Soria (1986-90), donde la nueva fachada de piedra del museo engloba la portada de acceso de un antiguo hospital del siglo XVI, pero se diferencia con cierta sutileza mediante un cambio de textura.

En el uso de materiales tradicionales destaca el uso del ladrillo, un material empleado tradicionalmente en el ámbito de la restauración, como demuestran las actuaciones de Stern y Valadier en el Coliseo, y que por tanto se asocia con actividades restaurativas pero que al mismo tiempo también evocan a las construcciones romanas desornamentadas. Este es el caso de la intervención del estudio Zermani en la renovación y reconstrucción del castillo de Novara, donde la continuidad de la materia y la forma permite una relación entre antiguo y nuevo, aunque el empleo de un ladrillo industrializado mantiene una distancia que aclara con contundencia la actualidad de la actuación. También los arquitectos Massimo Carmassi y Guido Canali emplean el ladrillo en sus obras, pero mientras que el primero prefiere el uso de un ladrillo recuperado por su imperfección y vibración, el segundo apuesta por un ladrillo perfecto que exprese mayor abstracción.

La expresión de los materiales tradicionales, debido al reconocimiento de su procedencia natural, puede evocar relaciones con arquitecturas históricas o con elementos del paisaje. En este sentido Pierluigi Nicolín menciona que los muros de ladrillo de la iglesia de San Pedro en Klippan, del arquitecto Sigurd Lewerentz, presentan superficies en las que los ladrillos marrones de Helsingborg parecen aflorar del blanco lecho de mortero, remitiendo a las ruinas romanas o incluso a las manchas oscuras en la blanca corteza de los abedules presentes en el lugar. ${ }^{75}$ 
Por otro lado cabe destacar que en los últimos años ha cobrado gran importancia el uso de la madera por ser un material que es compatible, fácilmente manipulable, permite adquirir gran cantidad de formas, es reversible, y remite al origen primitivo de la arquitectura. Un ejemplo muy interesante de empleo de la madera como elemento estructural es el de la actuación de Tabuenca y Leache en la rehabilitación de la casa del condestable en Pamplona, donde en el patio de servicios reinterpretan las columnas de piedra del primer piso mediante pilares de madera, en un potente trabajo de esencialización. ${ }^{76}$

Otro ejemplo es el de la restauración del Castillo de Saliceto, donde se emplea la madera como material de revestimiento para crear nuevos volúmenes ligeros y cálidos que recomponen las formas perdidas y se relacionan con naturalidad con las estructuras históricas.

Además de los materiales modernos y tradicionales está la posibilidad de emplear revestimientos continuos que aporten una imagen abstracta a la nueva intervención. Estas actuaciones reflejan la conformación de un lienzo vacío que ha perdido su definición material, haciendo evidente las lagunas en el texto histórico. En función del tono y acabado de estos materiales de revestimiento se pueden obtener soluciones más contrastadas o más integradas con los restos. Por ejemplo en el caso de la actuación de la iglesia de San Antonio de Roberto Petrachi el empleo de un revestimiento blanco uniforme produce un fuerte contraste con la piedra preexistente, poniendo en valor la rusticidad del material tradicional y aclarando la aportación de los nuevos elementos. Frente a este contraste las actuaciones de Emanuele Fidone buscan mediante un revestimiento a base de cal y arcilla generar una superficie de tonalidad y textura que se integra con la materia preexistente.
76 TABUENCA, F.; LEACHE, J.: "La rehabilitación de la casa del condestable en Pamplona". En: A.A.V.V.: Día de la Arquitectura. XVII Congreso Internacional de Conservación y Restauración de Bienes Culturales. Castellón. Valencia, Editorial UPV, 2008, pp. 67-77

[20] Rehabilitación de la casa del condestable en Pamplona, de Tabuenca y Leache. (Delegación navarra del Colegio Oficial de Arquitectos Vasco-Navarros: "Convocatoria premios COAVN 2010”.)

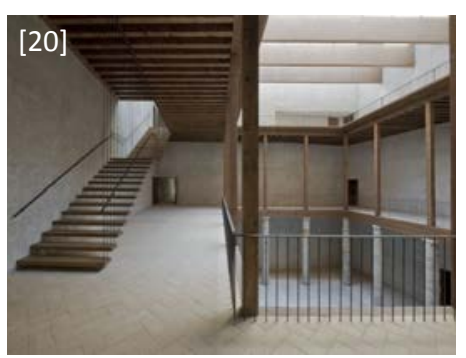




la recomposición de la pérdida en espacios abovedados 


\section{LA RECOMPOSICIÓN DE LA PÉRDIDA EN ESPACIOS ABOVEDADOS}

La premisa de actuar sobre edificios que han sufrido una pérdida parcial supone plantearse como abarcar la construcción de esa parte faltante, ya sea dirigiendo la mirada a la evocación de los elementos desaparecidos, o creando nuevas formas inspiradas en las posibilidades que ofrece la preexistencia para conformar un nuevo equilibrio arquitectónico.

Por otro lado, la elección del espacio abovedado como caso de estudio supone abarcar edificios cubiertos por un elemento de cierta complejidad formal, que aporta especial interés a la actuación ya que plantea el reto de reinterpretar desde la actualidad una forma empleada a lo largo de la historia. De tal manera que esta reinterpretación permite mantener una relación con la historia concreta del edificio, y al mismo tiempo establecer una relación con la historia de la arquitectura. Una reinterpretación que incluso se puede trasladar a la obra nueva, tal y como se observa en diversas actuaciones modernas, logrando con ello una mayor integración de la nueva arquitectura en entornos históricos.

En cualquier caso, como en toda operación arquitectónica, se cuenta con las múltiples fuentes que se han ido produciendo a lo largo de la historia como base para la definición de los nuevos elementos. Como afirma Marcello Rebecchini "el arquitecto debe tener una cultura profunda. (...) Las ideas válidas en arquitectura no nacen de la nada... nacen más bien del conocimiento, de la observación, de la experiencia y requieren una verificación en la construcción". ${ }^{1}$

A continuación se presentan comparativamente diversas intervenciones sobre espacios abovedados, organizadas no tanto desde el punto de vista del criterio de intervención, como desde la reflexión conceptual del tipo de espacio generado, tratando al mismo tiempo de establecer relaciones con las arquitecturas a lo largo de la historia.

\section{EL ESPACIO INTERIOR “EXCAVADO”}

Una primera manera de entender el espacio abovedado tiene que ver con la cueva, un espacio estereotómico, conformado por un sólido continuo de materia pesada, en el que la luz entra de manera escasa por pequeñas aberturas. Este es el caso de las arquitecturas primitivas construidas en piedra como las viviendas en forma de colmena del poblado mesopotámico de Arpasiyya, o más elaboradas como el tesoro de Atreo construido entorno a 1400 a.C, con una gran cúpula de 14,5m de diámetro, ambas construidas mediante la aproximación de hiladas sucesivas de piedra. En el espacio del tesoro, la escasa entrada de luz producida a través de un profundo hueco ubicado sobre el dintel de acceso, pone de manifiesto la pesadez y masicidad del conjunto.
1 CARBONARA, G.: Architettura d'oggi e restauro. Un confronto antico-nuovo. Torino, Ed. Utet, 2011, p. 35-36

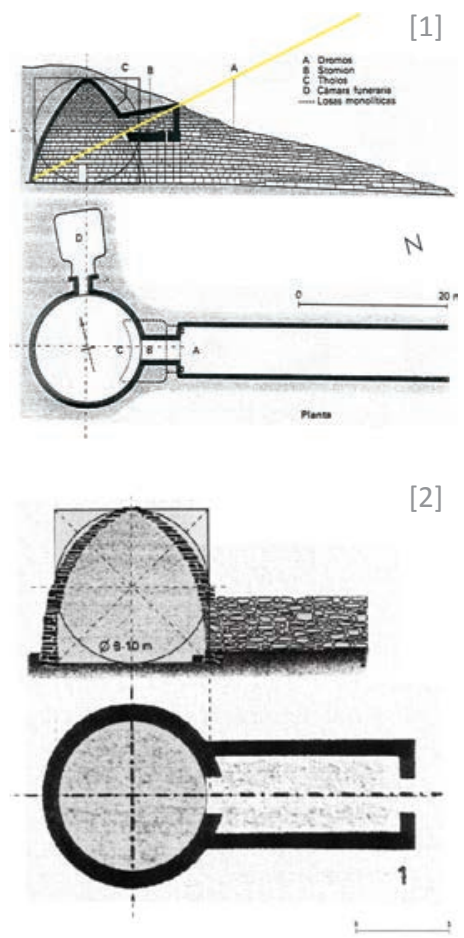

[1] Tesoro de Atreo. (BOSCH: 2006, p. 41)

[2] Vivienda del poblado mesopotámico de Arpasiyya. (BOSCH: 2006, p. 40) 
En la arquitectura romana el material empleado en la construcción de las bóvedas es el hormigón de cal, con puzolanas, conformado sobre encofrados de ladrillo y madera. En algunos casos el ladrillo se emplea formando un entramado de arcos que ayudan a la resistencia del conjunto.

En la sala octogonal de la Domus Area, construida por Nerón entre el 64 y el 68 d.C., una gran bóveda de 13,55m de diámetro construida en hormigón, de planta variable -desde un octógono a un círculo-, se eleva sobre gruesos y bajos muros perpendiculares al espacio. El espacio excavado adquiere mayor sensación de pesadez precisamente al elevarlo sobre un vacío, configurando un interesante juego de contraposición entre peso y levedad. A ello contribuyen el contraste entre la luz del gran óculo, que resalta la materialidad rugosa de la bóveda, y la oscuridad del nivel de apoyo, resuelto con unos inquietantemente delgados dinteles de ladrillo.

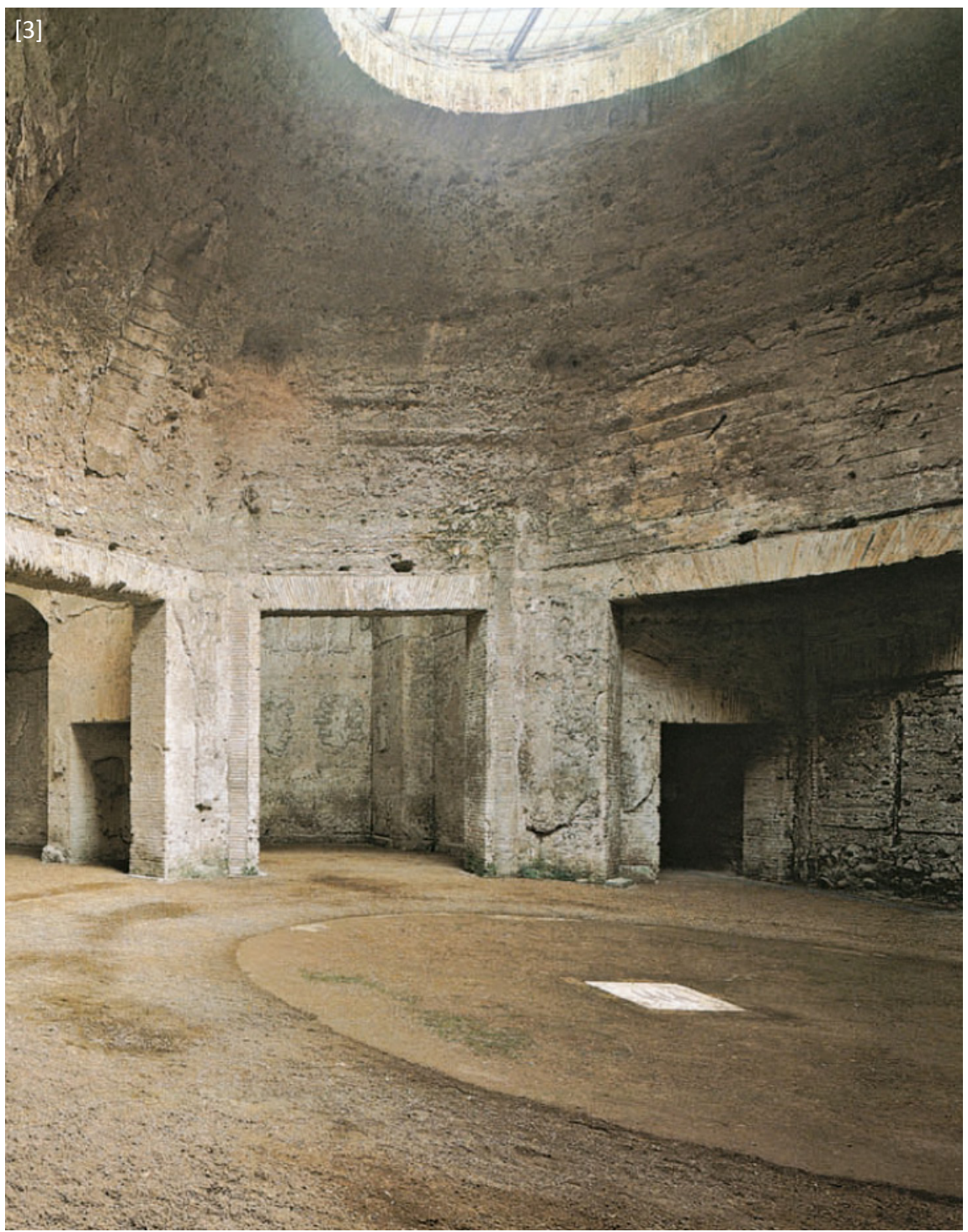


En el Panteón romano, construido por Adriano en el 118 d.C., se observa una evolución hacia un espacio más ligero, en respuesta a su función de santuario de todos los dioses simbolizado a través de la esfera celeste. El juego de llenos y vacíos de la base, y la descomposición de la gran cúpula de $43,3 \mathrm{~m}$ de diámetro en un sistema ordenado de paralelos y meridianos iluminada por un gran óculo de $8,72 \mathrm{~m}$ de diámetro, produce un espacio fragmentado y vibrante que busca la ligereza mediante la desmaterialización de los límites. Sin embargo el espacio se percibe aún como de gran pesadez, transmitiendo todavía la idea de un espacio interior tallado, en cuyo espesor se configuran subespacios que se muestran como excavados.

Este tipo de espacio está presente en catacumbas, deambulatorios de teatros, cisternas, naves de Iglesias románicas primitivas y otros espacios desornamentados donde la construcción másica es la encargada de dar expresión al espacio.

Este concepto de espacio interior pesado se relaciona con la intervención sobre espacios abovedados construidos con materiales másicos como la piedra, el hormigón o el ladrillo, en los que se respeta su estado degradado, de pérdida del revestimiento de acabado, y se muestra la expresión material de su construcción. Algo que en cierto modo ya plantea Miguel Ángel en la transformación de las termas de Diocleciano en la iglesia de Santa Maria degli Angeli de Roma.

Este es el caso de actuaciones de conservación, restitución parcial o reconstrucción tales como: la intervención de Giovanni Bulian en la sala octogonal de las termas de Diocleciano; la intervención de Giorgio Croci en los Mercados de Trajano, donde el cierre de un hueco abierto en

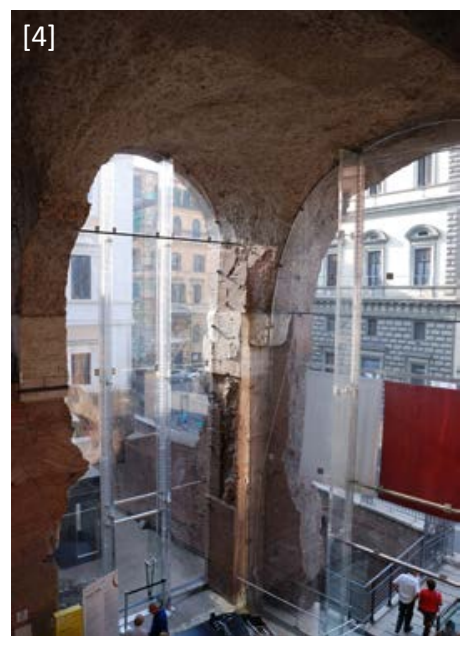

[4] Vista de la cúpula del Panteón. (PAWSON: 2003, p. 228)

[5] Intervención en los Mercados de Trajano, Giogio Croci. (Fotografía del autor.)

[6] Baños árabes de Baza. Bóveda reconstruida. (Fotografía de Fernando Alda. En: $R \& R$, no 111, 2009, p. 36)
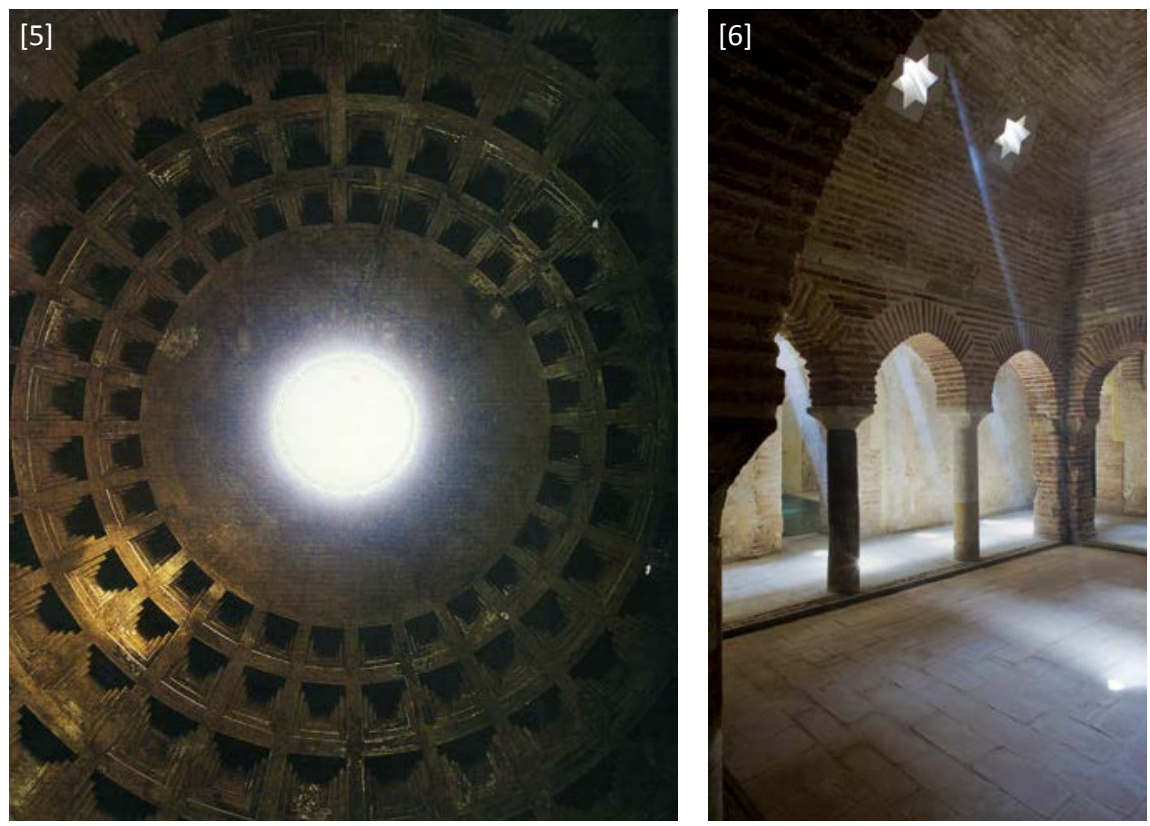


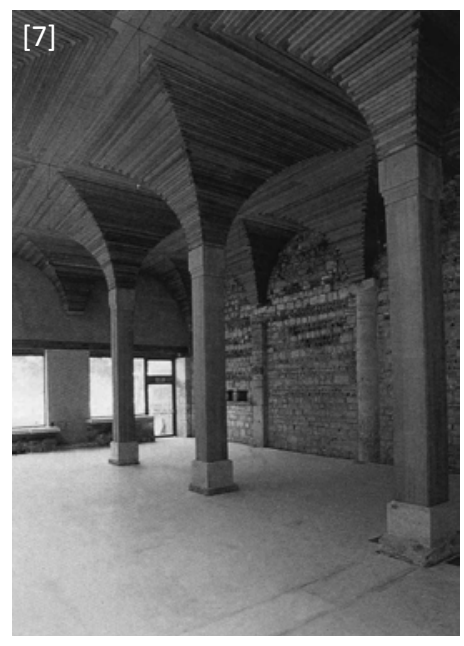

[7] Biblioteca de San Zeno. (Loggia, no 10,2000, p. 23)

[8] Neues Museum, David Chipperfield. Conservación y restitución parcial de la bóveda norte. ( $R \& R, \mathrm{n}$ 은 112-113, 2010, p. 71)

[9 y 10] Neues Museum, David Chipperfield. Vista de la sala de la cúpula sur en 1964 y cúpula sur tras la reconstrucción. $(R \& R$, $\mathrm{n}$ - 112113, 2010, p. 41) una de las bóvedas, producido por su uso anterior como iglesia, se hace imitando la materialidad preexistente de tal manera que la actuación no distorsione su valor de antigüedad; la intervención de Francisco Ibáñez en el interior de los baños árabes de Baza, donde se respeta la expresión constructiva de la preexistencia, incluso en el proceso de reconstrucción de las bóvedas faltantes; la conservación y restitución parcial de la bóveda norte y la reconstrucción de la bóveda sur de la actuación de Chipperfield en el Neues Museum, donde la forma original de cúpula sobre pechinas es abstraída convirtiéndola en una forma geométrica resultado de la transición entre un cuadrado y un círculo, retomando el concepto geométrico de la Domus Aurea; la reconstrucción de las bóvedas del semisótano del museo nacional Suizo, donde el encofrado horizontal del hormigón remite a estratos de piedra que contrastan con el revestimiento continuo de las bóvedas preexistentes; o la reconstrucción del espacio de la biblioteca de San Zeno, donde es a través de la madera como se produce ese efecto de estratificación horizontal, aunque la ligereza del material y la falta de apoyos en uno de los muros, potenciada por la entrada de luz, produce una sensación de levedad que contrasta con la pesadez presente en el resto de bóvedas.

Por otro lado es interesante destacar el empleo que hacen algunos arquitectos modernos de la bóveda, como mecanismo para la configuración de un espacio "excavado". Así por ejemplo Le Corbusier orienta el uso de la bóveda al espacio doméstico por representar la idea de bienestar transmitida por la calidez de sus materiales y por la relación de su forma con la idea de cueva.

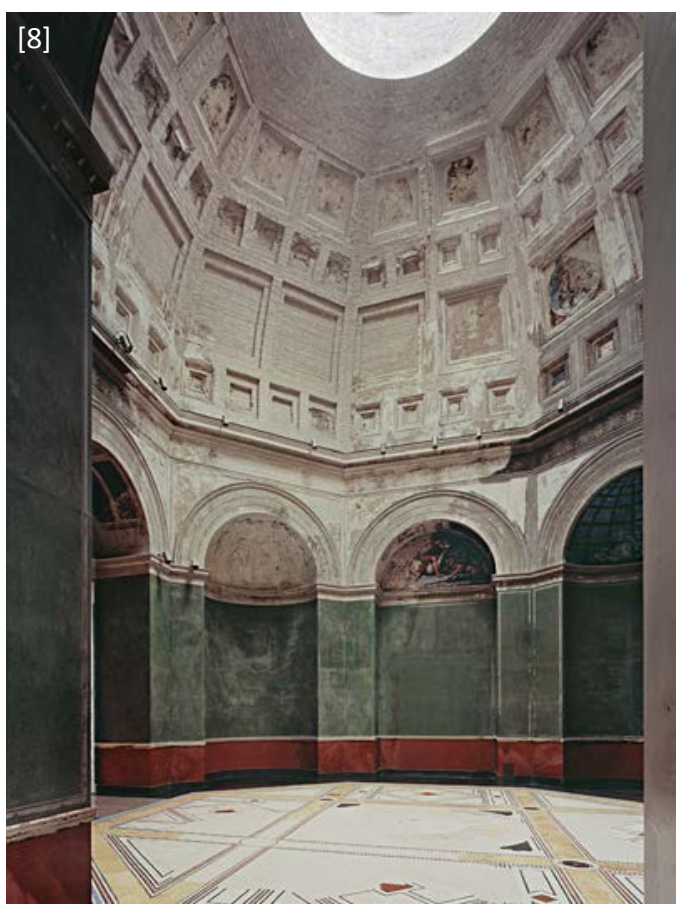

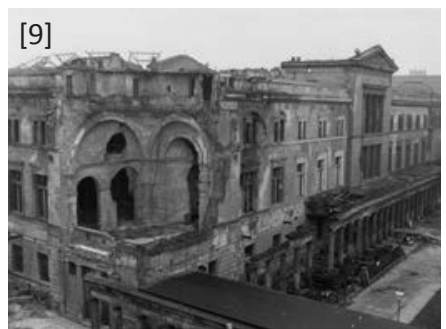

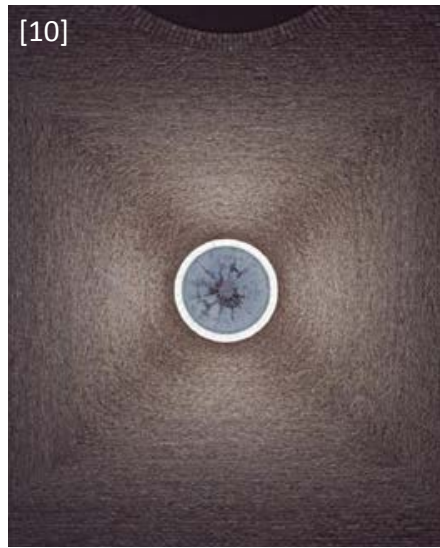


La bóveda en la obra de Le Corbusier ya está presente en el proyecto de la casa Monol de 1919, pero con el tiempo adquiere mayor expresividad material, como en la Maison Cherchel África (1940) o el complejo de vacaciones "Roq et Rob" en la Côte d'Azur (1948-1950) donde la bóveda aparece como un elemento natural, integrado en el paisaje. ${ }^{2}$ De igual manera en las maisons Jaoul en Neuilly (1951-54) Le Corbusier busca establecer una relación simbólica con la imagen de la primera vivienda humana en el interior de una cueva, buscando transmitir la idea de un refugio. Apuesta por la textura rugosa del ladrillo visto con las juntas gruesas de mortero y revestido con una fina capa blanca que deje apreciar su estado rudo. ${ }^{3}$

También Sigurd Lewerentz retoma la bóveda de ladrillo, pero la emplea en la construcción de espacios religiosos para dotarles de un ambiente primitivo, de reflexión interior, estableciendo con ello relaciones simbólicas con arquitecturas del pasado. Las iglesias de San Marcos en Björkhagen (1956) o de San Pedro en Klippan (1963) son claros ejemplos.
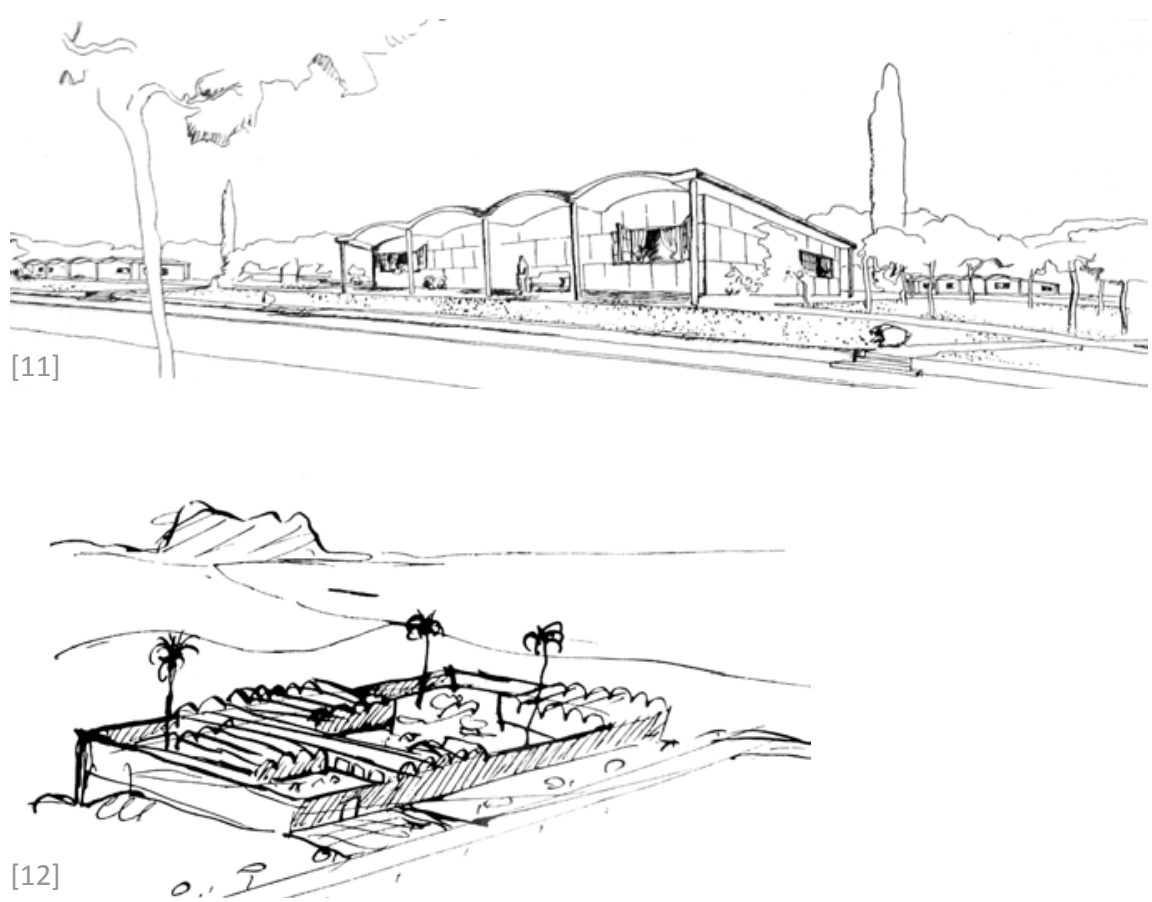

2 MANIAQUE BENTON, C.: Le Corbusier and the Maisons Jaoul. New York, Ed. Princenton Architectural Press, 2009, p. 43

3 MANIAQUE BENTON, C.: Le Corbusier and the Maisons Jaoul. New York, Ed. Princenton Architectural Press, 2009, pp. 40-41
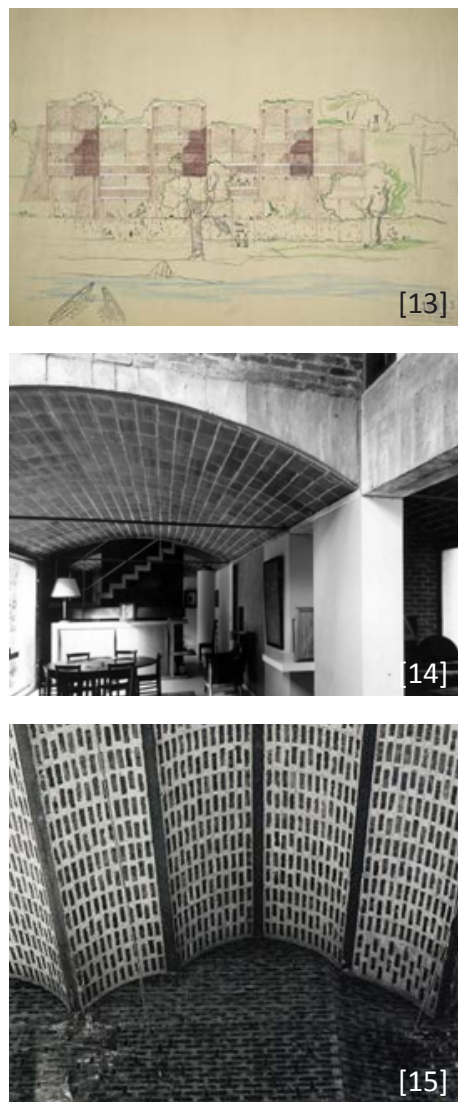

[11] Maison Monol, Le Corbusier, 1919. (BOESIGER; STONOROV: 1999, p. 30)

[12] Maison Cherchel en África, Le Corbusier, 1940. (BOESIGER: 1999,p. 117)

[13] Complejo de vacaciones Roq et Rob, Le Corbusier, 1948-1950. (Fondation Le Corbusier: <www.fondationlecorbusier.fr>)

[14] Maisons Jaoul, Le Corbusier, 1951-54. (Fondation Le Corbusier: $<w w w . f o n d a t i o n l e c o r b u s i e r . f r>$ )

[15] St. Mark's Church, S. Lewerentz. (DYMLING: 1997, p. 158) 


\section{EL ESPACIO INTERIOR “LIGERO”}

4 LINAZASORO, J.I.: “La Renovación Proyectual en el Bajo Imperio y la Crisis del Clasicismo Grecorromano" (diciembre-enero 1986-87). En: LINAZASORO, J.I.: Op. Cit., 2003, p. 21

[16] Santa Constanza. (<www.thesilideprojector.com>)

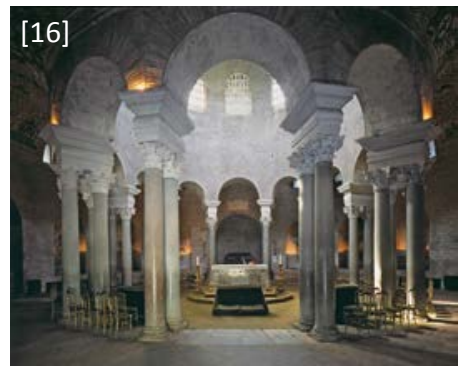

Este tipo de espacio busca adquirir mayor ligereza mediante la reducción de los elementos de apoyo y la abstracción material del elemento abovedado así como mediante revestimientos continuos claros o elaborados juegos de luces y sombras.

El modelo de la Domus Aurea y del Panteón evolucionarán hacia las construcciones de las grandes termas del imperio romano como Caracalla y Diocleciano, y hacia palacios y templos como los de Villa Adriana y Minerva Medica. La evolución consistirá en un progresivo abandono del dintel y el muro en favor del arco y la columna para tratar de aportar una mayor ligereza al elemento abovedado. En las termas surgirá el empleo de grandes naves cubiertas por bóvedas de arista que se apoyan compositivamente -que no constructivamente- sobre columnas despegadas de los muros, en una búsqueda de mayor ligereza y verticalidad. Un esquema que se repetirá en la basílica de Magencio. En esta misma línea se actúa en el vestíbulo de la Piazza d'Oro de Villa Adriana de Tívoli, donde una cúpula octogonal se apoya "compositivamente" sobre columnas a modo de un paraguas que aparenta que se ha despegado de los muros.

Como indica José Ignacio Linazasoro: "el apoyo de una bóveda [...] sobre un apoyo puntual, contrasta con el monolitismo de anteriores construcciones como el propio Panteón, en el que la cúpula descansaba constructiva y compositivamente sobre una pared continua". ${ }^{4}$

En época paleocristiana se avanza hacia la levedad del elemento abovedado y la expansión horizontal del espacio mediante la traslación del esquema de baldaquino y la sección escalonada del espacio. El Mausoleo de Santa Constanza (h. 350 d.C.) es un claro ejemplo de esta evolución donde el muro de apoyo de la cúpula se descompone en su base transformándose en arcos apoyados sobre columnas que aportan gran ligereza al conjunto. Además los empujes horizontales se contrarrestan con un deambulatorio y un porticado abovedados, concéntricos al espacio central, que permiten una expansión del espacio hacia el extradós. Por otro lado el espacio central queda inundado por la luz que penetra a través de 12 huecos situados perimetralmente por debajo del nivel de arranque de la cúpula, produciendo una cierta subdivisión del espacio. En esta misma línea se pueden citar edificios como el del Santo Sepulcro en Jerusalén o San Stefano Rotondo en Roma.

En la arquitectura bizantina se busca potenciar estos conceptos desdibujando los límites entre el espacio central cubierto con cúpula y los espacios perimetrales abovedados mediante el empleo de grandes arcos apoyados en elementos esbeltos y la construcción de exedras en el perímetro. El resultado son espacios centrales de gran complejidad que se expanden abarcando los espacios perimetrales, generando entre ambos una unidad fragmentada. La profusa decoración de los muros y 
bóvedas y la dispersión en múltiples huecos de la entrada de luz supone una descomposición de los límites lo que produce un ambiente de gran espiritualidad. Este es el caso de la iglesia de los Santos Sergio y Baco de Constantinopla o la iglesia de San Vital de Rávena, pero es la Basílica de Santa Sofía el ejemplo más espectacular, al adquirir el espacio vacío la condición de atmósfera etérea logrado mediante la fusión del espacio longitudinal y central, así como la levitación de la cúpula mediante la conformación de un plano horizontal de luz.

Como indica Luis Moyá Blanco "la construcción bizantina comprendió la capacidad resistente de la bóveda romana de ladrillo de rosca, sin necesidad de reforzarla con hormigón, y con esta idea pudo obtener una ligereza que pocas veces habían conseguido los propios romanos". ${ }^{5}$
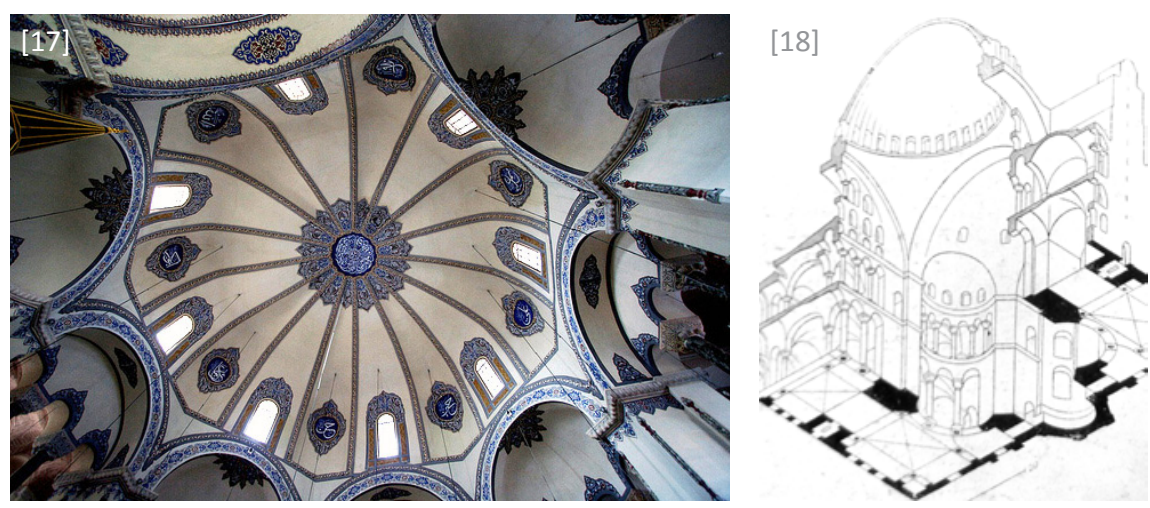

En el renacimiento el espacio abovedado ligero se vuelve más abstracto y estático, orientándose hacia la composición armónica y la perfección de la forma. La materialidad busca concretar una forma nítida, fácil de reconocer e independiente, y el espacio se vuelve homogéneo y autónomo. Conceptos que se observan en la galería abovedada del hospital de los inocentes de Brunelleschi (1419-27), donde una sucesión de bóvedas vaídas abstractas se elevan en uno de sus lados sobre delgadas columnas.

Esta búsqueda de ligereza a través de la bóveda se observa en numerosos arquitectos modernos como Asplund, con una cúpula blanca en la capilla del bosque del cementerio de Estocolmo (1918-20); Le Corbusier, con la generación de un espacio blanco y luminoso en su estudio del edificio Porte Molitor (1931-34); Eduardo Torroja con una gran cáscara de hormigón en el mercado de Aljeciras (1933) o en el hipódromo de la zarzuela (1935); Antonio Bonet Castellana, con un sistema de protección "ligera" e integración paisajística, en sus casas en Martínez (1941-42), casa Berlingieri (1947), o La Ricarda (1950-63); Oscar Niemeyer, con un sistema de gran sensualidad en la iglesia de San Francisco de Asis (194042); Eero Saarinen, con una protección ligera en el auditorio del Instituto de Tecnología de Massachusetts (1950-55).
5 MOYA BLANCO, L.: "Arquitecturas cupuliformes: el arco, la bóveda y la cúpula". En: CABALLERO ZOREDA, L. (dir.): Curso de mecánica y tecnología de los edificios antiguos. Madrid: Colegio Oficial de Arquitectos de Madrid, 1987, 102

[17] Iglesia de los santos Sergio y Baco en Constantinopla. (Flickr: < www.flickr.com>)

[18] Santa Sofía. (CURTIS: 1987, p. 28)

[19] Capilla del Bosque, Asplund. Vista interior. (Cortesía de Ignacio Bosch)

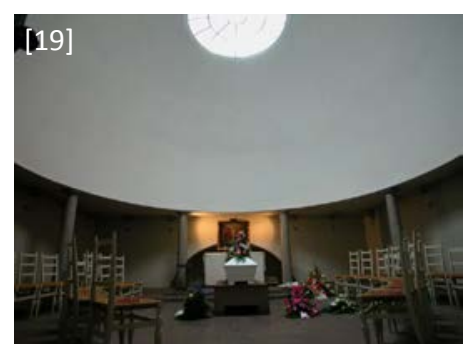


[20] Estudio de Porte Molitor, Le Corbusier, 1931-34. (Fondation Le Corbusier: <www.fondationlecorbusier.fr>)

[21] Casas en Martínez, Antonio Bonet Castellana, 1941-42. (ÁLVAREZ; ROIG: 1999, p. 138)

[22] Mercado de Aljeciras, Eduardo Torroja, 1933. (Colegio Oficial de Ingenieros de Caminos, Canales y Puertos de Madrid: 1979, p. 85)

[23] La Ricarda, Antonio Bonet Castellana, 1950-63. (WONG: <www. onbluepoolroad.com>)

[24] Hipódromo de la Zarzuela, Eduardo Torroja, 1933. (Colegio Oficial de Ingenieros de Caminos, Canales y Puertos de Madrid: 1979, p. 94)

[25] Auditorio del Instituto de Tecnología de Massachusetts, Eero Saarinen, 1950-55. (SERRAINO: 2006, p. 115)

[26] Iglesia de San Francisco, Oscar Niemeyer, 1940-42. (HEISER: <blog. frieze.com >)
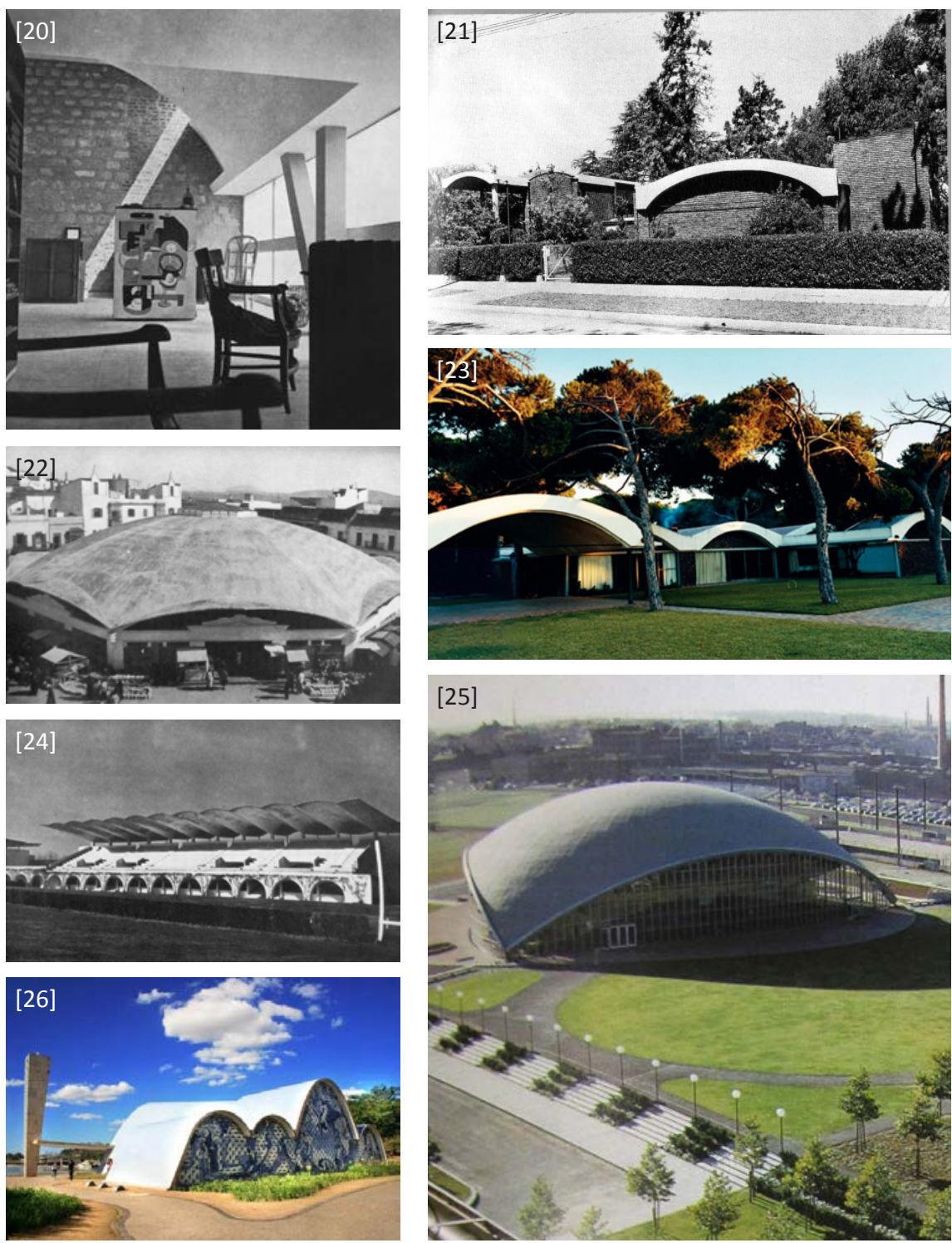
Y también en algunos arquitectos contemporáneos como Juan Navarro Baldeweg, con elementos de gran ligereza e ingravidez, como en los molinos del Segura (1984) o en el palacio de congresos de Salamanca (1985); Rafael Moneo, con elementos modulares ligeros, en el aparcamiento de la estación de Atocha (1985-88), o en el aeropuerto de Sevilla (198992); Alvaro Siza, con un elemento blanco iluminado artificialmente en la estación de metro Baixa-Chiado (1992-98) o con una gran bóveda perforada en el recinto deportivo Ribera-Serrallo (Cornellà de Llobregat, 2003-2005).

Este concepto de espacio interior ligero lo retoma Juan Carlos Arnuncio en su intervención sobre la capilla de los Condes de Fuensaldaña, analizada en profundidad en esta investigación.
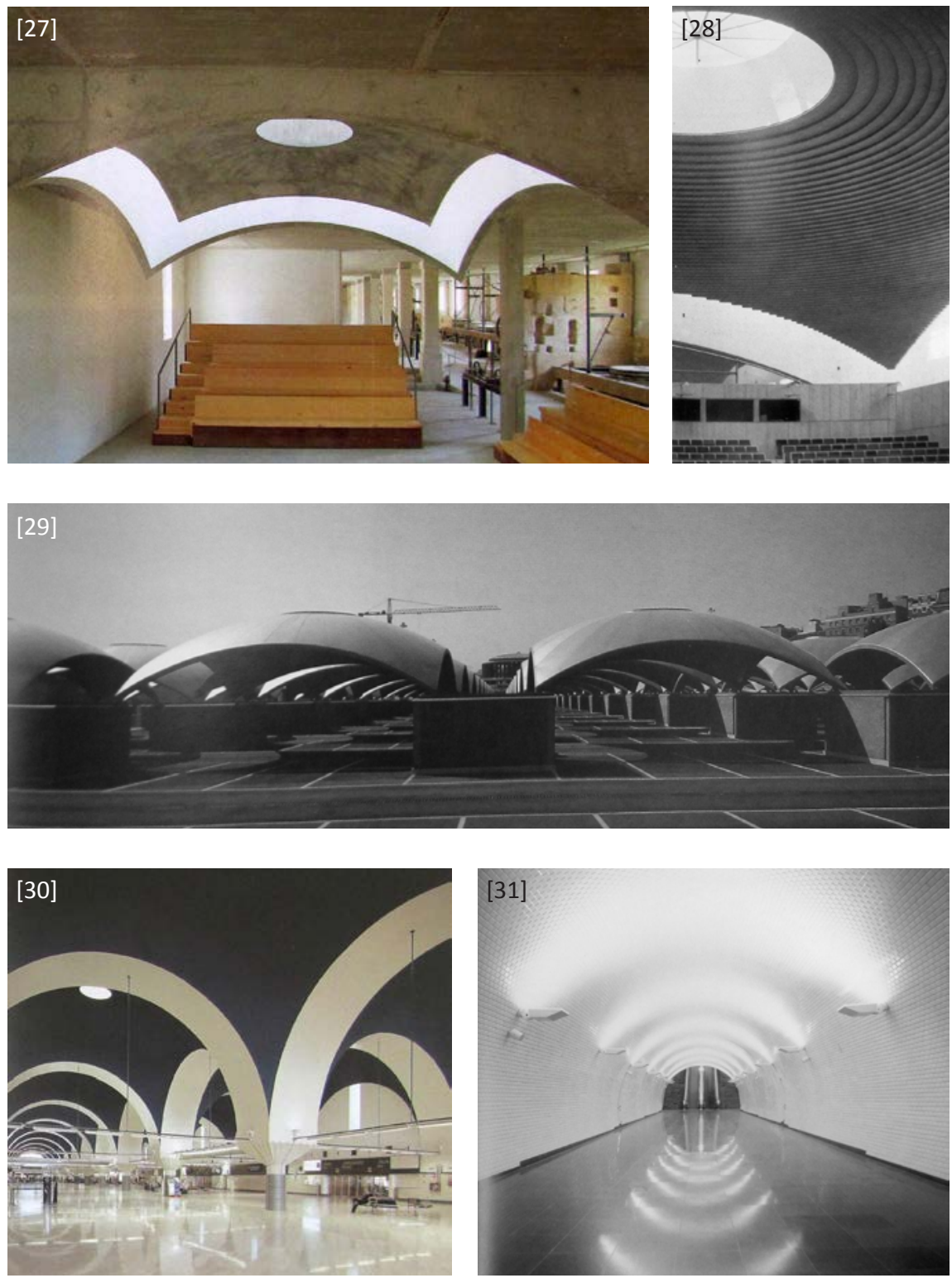

[27] Molinos del Segura, J. N. Baldeweg, 1984. (GONZÁLEZ; LAHUERTA; NAVARRO: 1993, p. 123)

[28] Palacio de Congresos de Salamanca, J. N. Baldeweg, 1985. (GONZÁLEZ; LAHUERTA; NAVARRO: 1993, p. 181)

[29] Aparcamiento de la estación de Atocha, R. Moneo, 1985-88. (El Croquis, no 64, enero 1997, p. 223)

[30] Aeropuerto de Sevilla, R. Moneo, 1989-92. (El Croquis, no 64, enero 1997, p. 241)

[31] Estación de metro Baixa-Chiado, A. Siza, 1992-98. (JODIDIO: 2003, p. 139) 


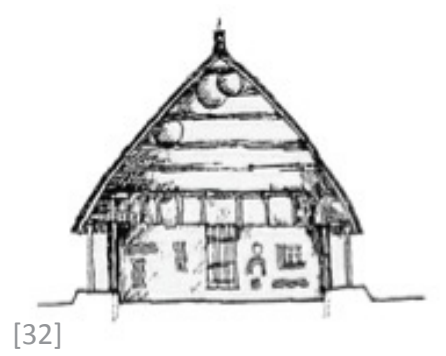

[32] Chozas de los Agnuak, Etiopía. (Cortesía de Ignacio Bosch)

[33] Yurta, Mongolia. (Sufisticated. blogspot.com, 03 mayo 2010.)

[34 y 35] Cúpula de Santa María del Fiore, Brunelleschi. (LÓPEZ: <conimaginacionesposible.blogspot. com>)

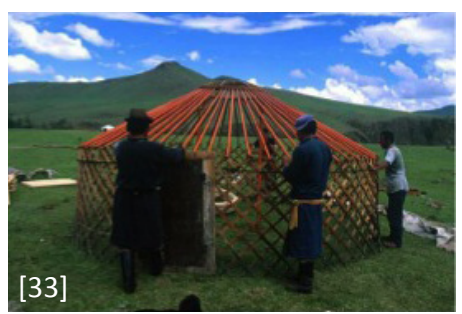

\section{EL ESPACIO INTERIOR “TECTÓNICO”}

Otra manera de entender el espacio abovedado nos remite a la cabaña, donde la "bóveda" es el resultado de un entramado estructural revestido con un cerramiento, produciendo la expresión de un espacio más ligero y dinámico que la cueva. Este es el caso de las arquitecturas primitivas como las chozas de los Agnuak en Etiopía o en las yurtas mongolas.

La bóveda en el románico y sobre todo en el gótico evoluciona, gracias al sistema de transmisión de empujes, desde el contrarresto por volúmenes pesados en Roma y el de superficies de bóvedas en el bizantino hacia el sistema de líneas de fuerza del gótico. La articulación del espacio mediante pilastras y arcos produce un progresivo debilitamiento del muro románico que culmina con las estructuras de esqueleto góticas.

En este sentido es interesante el caso de la cúpula para Santa Maria Dei Fiore, donde Brunelleschi logra combinar diversas técnicas para cubrir un espacio de grandes dimensiones sin medios auxiliares. Una bóveda interior de rosca de ladrillo en espina de pez le permite construir sin cimbras, tal y como se hace en la arquitectura bizantina, y unos nervios en el trasdós abrazan la cúpula actuando como contrafuertes que compensan los empujes.

En el barroco y en el rococó, la búsqueda de la armonía formal del renacimiento desencadenará una inquietud existencial que producirá la necesidad de introducir elementos formales dinámicos que interactúen con las fuerzas de la naturaleza. Las composiciones se complejizan, los órdenes abren los muros al exterior y la textura de los muros expresa la complejidad natural. El espacio abovedado barroco trata de plasmar estas cuestiones, mediante el empleo de formas nervadas complejas como se observa en obras de Borromini, como en la propuesta de bóveda para San Juan de Letrán y sobre todo en las de Guarino Guarini, como en la capilla de la Santissima Sindone en Turín (1668-1694).
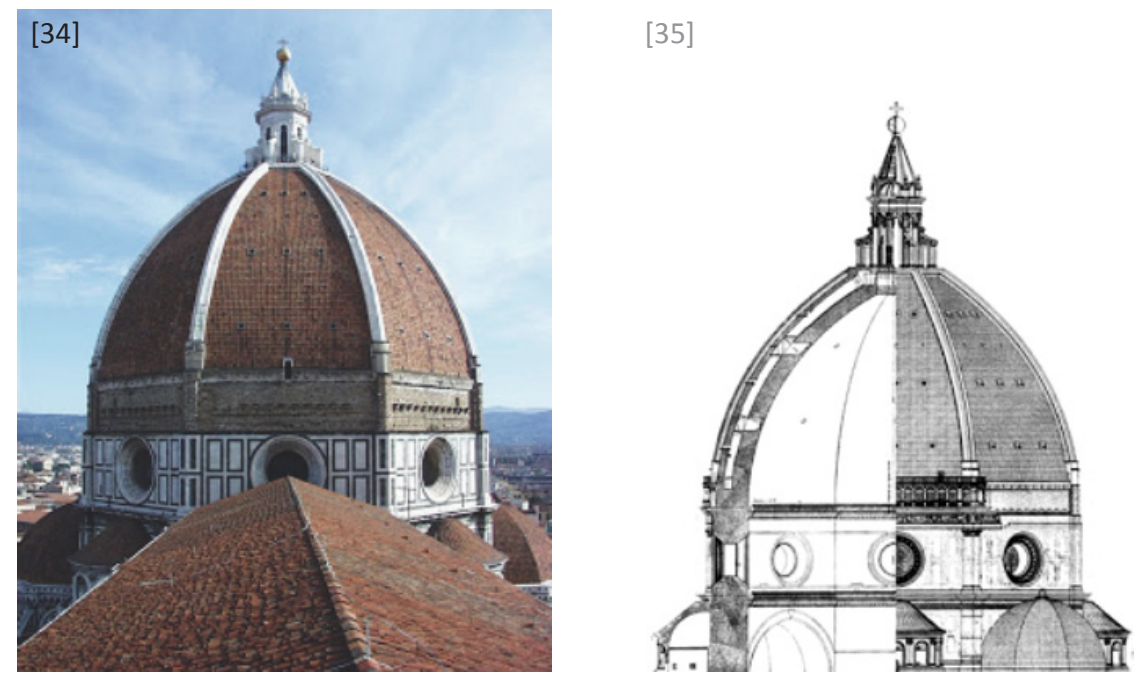
Por otro lado las construcciones de bóvedas en madera expresan en ocasiones su estructura al exterior. La madera empleada en la construcción de bóvedas remite, tal y como refleja Giampaolo Trotta, a la arquitectura de culturas de tradición naval cercanas al Océano Atlántico o al Mar del Norte como es el caso del castillo Dunois (Beaugency, Loira, s. XV) o la iglesia abacial románica del Mont Saint Michel (Baja Normandía), que ya en el siglo XVI serán recogidas por Filibert de l'Orme en su tratado de construcción "Nouvelles inventions pour bien batir et a petit fraiz" (1561). ${ }^{6}$
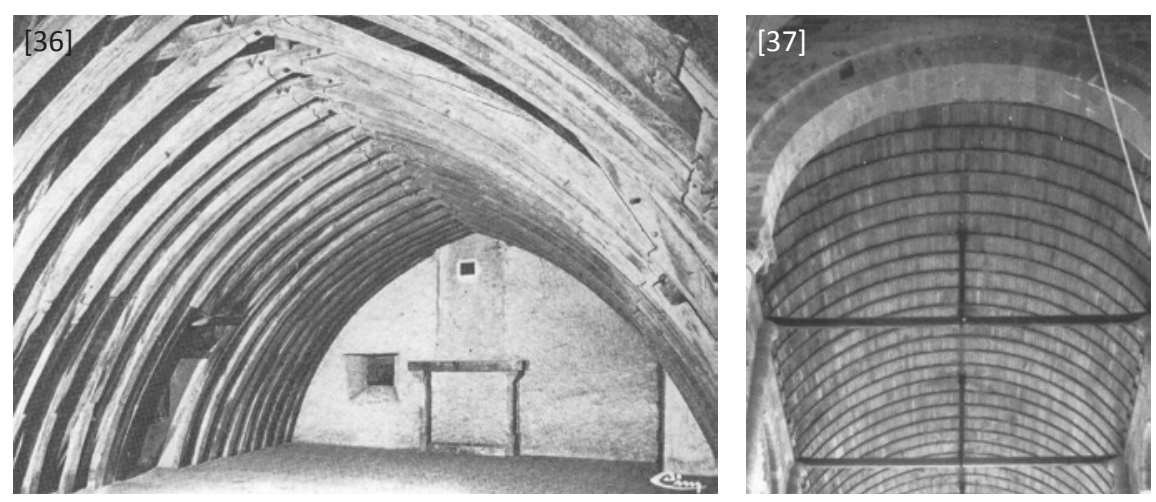

Este tipo de espacios abovedados recuerdan a las intervenciones de la bóveda de la Iglesia de Santa Cruz en Medina de Rioseco, la cúpula del vestíbulo de acceso al palacio Omeya de Amann o la bóveda de la capilla mayor de la Iglesia de la Asunción de Elvillar.

En la arquitectura moderna Frank Lloyd Wright retoma las construcciones de bóvedas con estructura vista en algunas de sus primeras obras como en la expansión de su casa en Oak Park (Illinois, 1895), o en la Susan Lawrence Dana House (Springfield, 1902). Por otro lado Pier Luigi Nervi empleará las estructuras abovedadas nervadas para la conformación de grandes espacios abiertos al exterior, como en el hangar de aviones de Orvieto (1935-42)
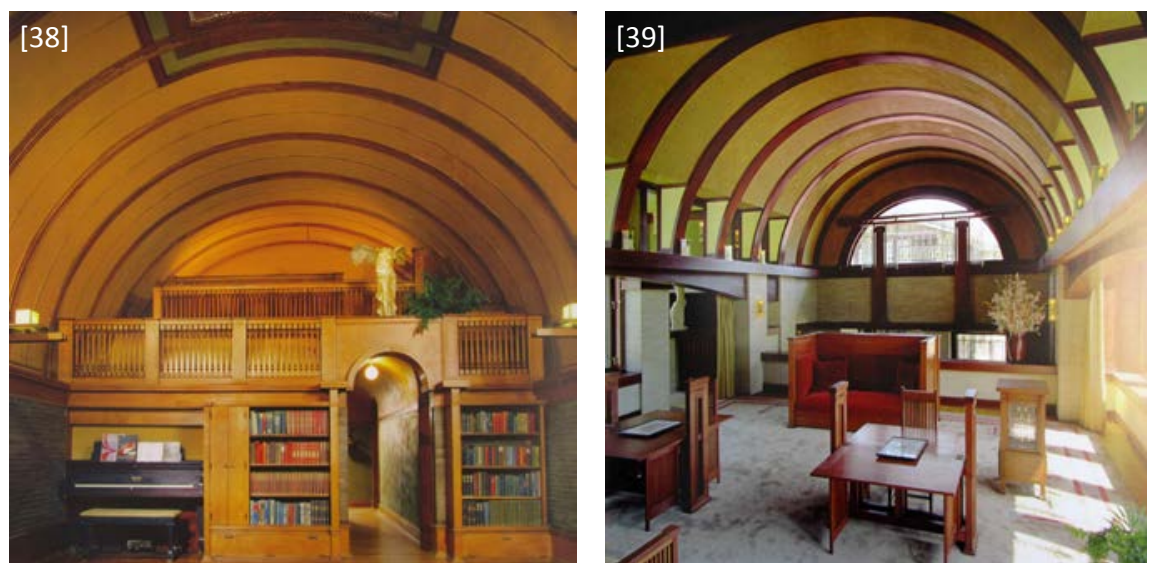

6 TROTTA, G.: "Alcuni esempi tipologici di coperture lignee nell'Occidente europeo". En: Tampone, G.: Legno e restauro. Firenze, Ed. Messaggerie Toscane, 1989, pp. 39-54

[36] Castillo de Dunois. (TROTTA. En: TAMPONE: 1989, p. 46)

[37] Iglesia del Mont Saint Michel. (TROTTA. En:TAMPONE: 1989, p.47)

[38 y 39] Casa en Oak Park, 1985, y Susan Lawrence Dana House, 1902, F. LI. Wright. (BROOKS: 2011, pp. 71 y 143)

[40] Iglesia de Santa Cruz. (LINAZASORO: Arquitectura, no 273, 1988, p.64)

[41] Cúpula del palacio Omeya de Amann. (ALMAGRO: Loggia, no 11, 2001, p. 57)

[42] Iglesia de la Asunción de Elvillar. (LASAGABÁSTER. En: IV Simposi de Restauración Monumental. Barcelona: 1996, p. 66)
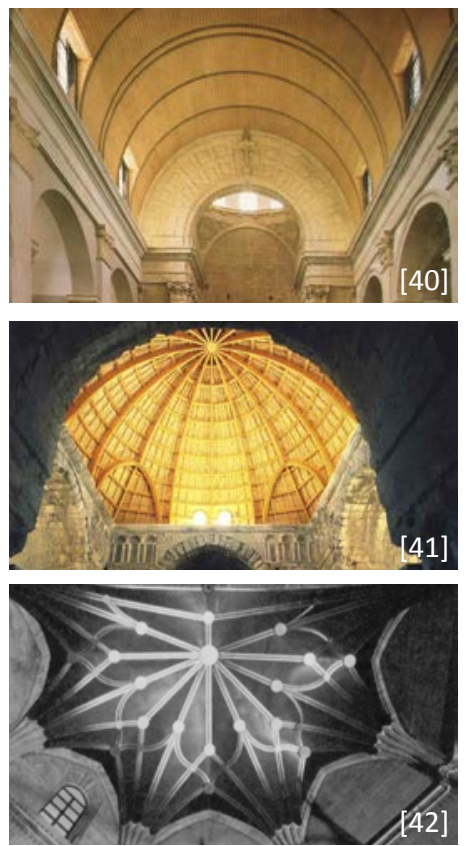


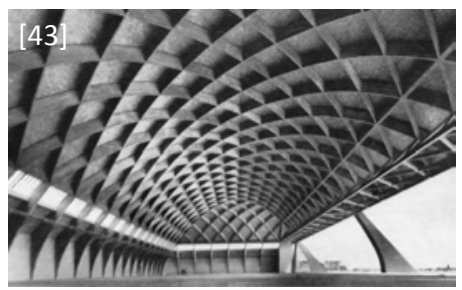

[43] Hangares de Orvieto, P. L. Nervi, 1935-42. (CHIORINO; OLMO: 2010, p. 29)

[44] Capilla de la Universidad Laboral de Gijón, Luis Moya, 1946-51. (Ministerio de Fomento: 2000, p. 33)

[45] Capilla de la Universidad Laboral de Zamora, Luis Moya, 1947-53. (Ministerio de Fomento: 2000, p. 31)
El empleo de la bóveda se popularizará en España tras la guerra civil debido a la escasez de materiales propios de la construcción moderna de hormigón armado, como demuestran las propias obras de Luis Moya que parecen sintetizar una arquitectura con influencias góticas y mudéjares, tal y como se observa en el empleo de los nervios de ladrillo en obras como la capilla de la universidad laboral de Zamora (1947-53) o en la capilla de la universidad laboral de Gijón (1946-51) cuyas nervaduras recuerdan a las de los palacios nazaríes de la Alhambra.

Las actuaciones de reinterpretación formal presentes en el proyecto de terminación de la Catedral de Nueva York o en la Sagrada Familia de Barcelona también siguen estos principios compositivos mencionados en el capítulo de criterios.
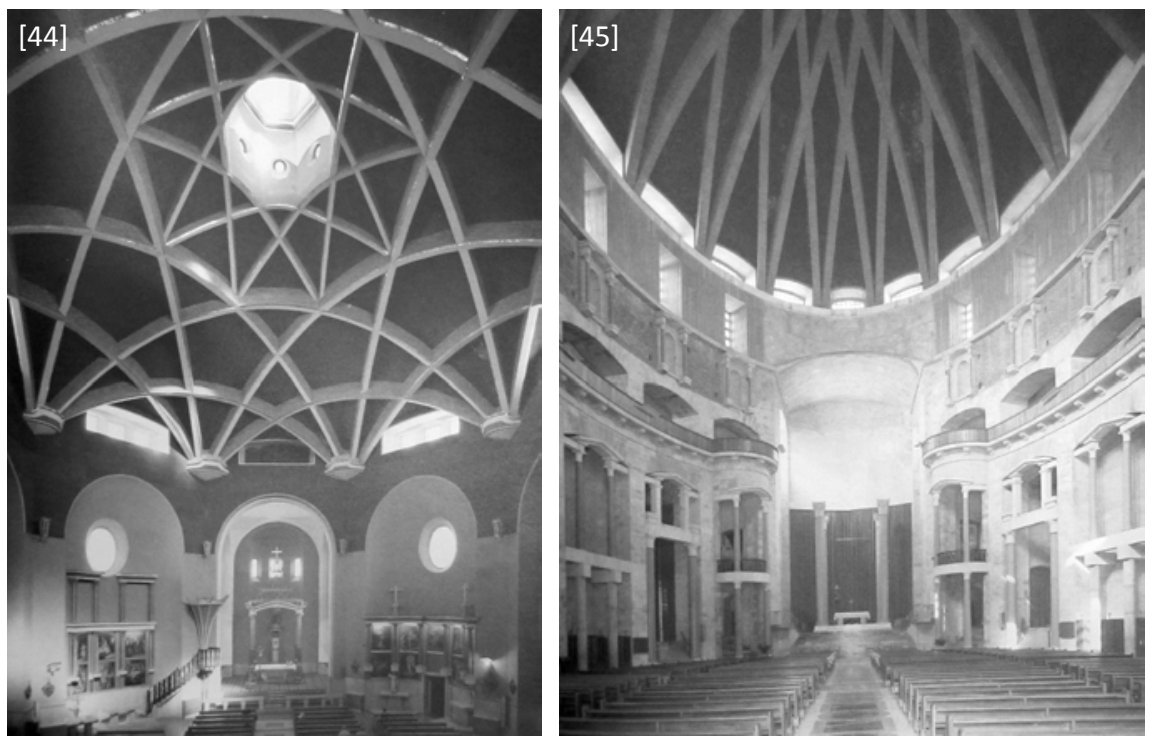

\section{EL ESPACIO “NATURAL” COMPLEJO, ORGÁNICO Y PROTECTOR}

El uso de formas curvas complejas construidas con hormigón, ladrillo o madera, remite a formas naturales, orgánicas, que aportan resguardo al espacio interior. En este sentido es interesante la actuación de Dionisio Hernández Gil en el monasterio de San Benito, donde reemplaza las desaparecidas bóvedas góticas construidas con piedra por unas bóvedas de ladrillo que remiten a una arquitectura natural anterior, como si fuera un estrato previo en la historia del monumento, una plementería moderna en cuanto formalmente abstracta.

A este respecto cabe mencionar, tal y como indica Luis Moya Blanco, el auge que tienen en el siglo XX las bóvedas de ladrillo "a la catalana", reinterpretadas formalmente gracias al empleo de nuevos materiales como la rasilla y el cemento. Arquitectos como Guastavino y Gaudí demuestran las grandes posibilidades de este material, donde la reducción de espesor 
de las bóvedas y los brillos producidos por el empleo de azulejos como revestimiento les aportará un carácter ligero. ${ }^{7}$ Gaudí, en la escuela de la Sagrada Familia, emplea una superficie ondulada sobre muros ligeros igualmente ondulados, para conseguir la resistencia al empuje sin hacer uso de contrafuertes.

En la arquitectura moderna, se experimentará a mediados del siglo XX con el empleo de formas curvas complejas. Para William Curtis, el primitivismo de las últimas obras de Le Corbusier debe verse como una búsqueda de las raíces de la arquitectura, en un intento por alcanzar la armonía con la naturaleza. Así, en la capilla de Notre-Dame-du-Haut en Ronchamp (1950-54) las curvas que conforman sus límites remiten a las lomas de la naturaleza circundante. ${ }^{8}$ Un concepto de transformación del elemento abovedado que retomará en obras como la iglesia de San Pedro de Firminy (Francia, 1960-65) o la escuela de bellas artes y arquitectura de Chandigard (India, 1964-69).
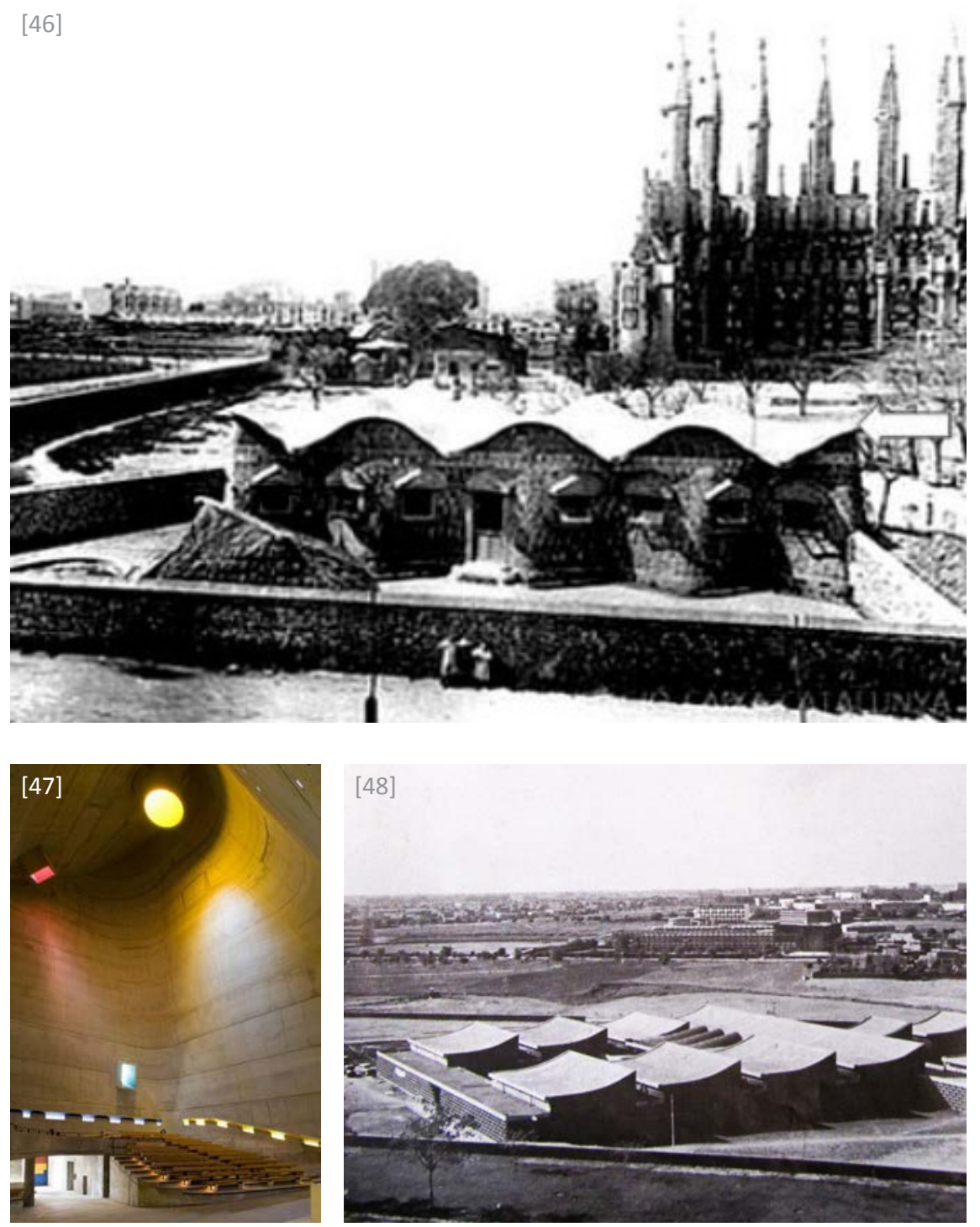

7 MOYA BLANCO, L.: "Arquitecturas cupuliformes: el arco, la bóveda y la cúpula". En: CABALLERO ZOREDA, L. (dir.): Curso de mecánica y tecnología de los edificios antiguos. Madrid: Colegio Oficial de Arquitectos de Madrid, 1987, 98

8 CURTIS, W. J. R.: Le Corbusier: Ideas y formas. Madrid, Ed. Hermann Blume, 1987, p.175

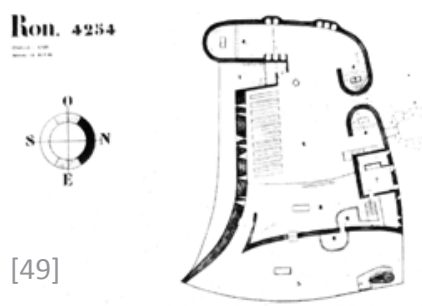

[46] Escuela de la Sagrada Familia, Gaudí. (ADELL: Informes de la Construcción, Vol. 56, no 496, marzoabril 2005, p. 32)

[47] Iglesia de San Pedro de Firminy, Le Corbusier, 1960-65. (Fondation Le Corbusier: <www.fondationlecorbusier.fr>)

[48] Escuela de bellas artes y arquitectura de Cahdigard, Le Corbusier, 1964-69. (BOESIGER: 1999, p. 102)

[49] Ronchamp, Le Corbusier, 195054. (BOESIGER: 1999, p. 76) 
También cabe mencionar otros arquitectos como Alvar Aalto, que busca la relación con la naturaleza mediante una superficie curva de madera en la biblioteca pública de Viipuri (1934-35); Eladio Dieste, que desafía el carácter pesado de la bóveda de ladrillo a través de formas curvas complejas construidas en combinación con el acero y el mortero de cemento, mediante la denominada "cerámica estructural", como por ejemplo en la iglesia de la Atlántida (Montevideo, 1952); o Felix Candela, que emplea formas complejas de cáscaras de hormigón en obras como el restaurante Xochimilco (1957).

Como indica Luis Moya, las ventajas de estas superficies donde se combinan espacios cóncavos y convexos se aprecian de manera notable en la acústica, un problema en los espacios tradicionales cóncavos que obligaba a revestirlos con materiales absorbentes como ornamentos, retablos, lienzos y tapices.

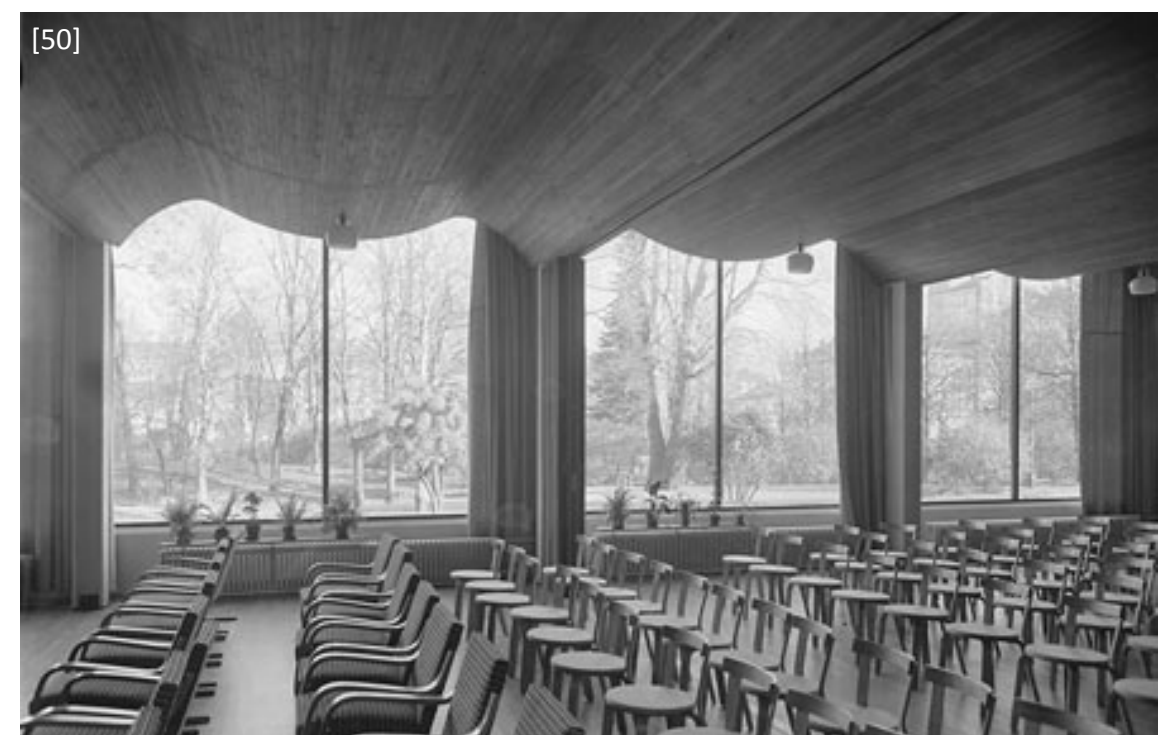

[50] Biblioteca de Viipuri, A. Aalto, 1934-35. (RIVADENEYRA: <www. arqred. $m x>$ )

[51] Restaurante en Xochimilco, F. Candela, 1957. (Plataforma arqutiectura: <www. plataformaarquitectura.cl >)

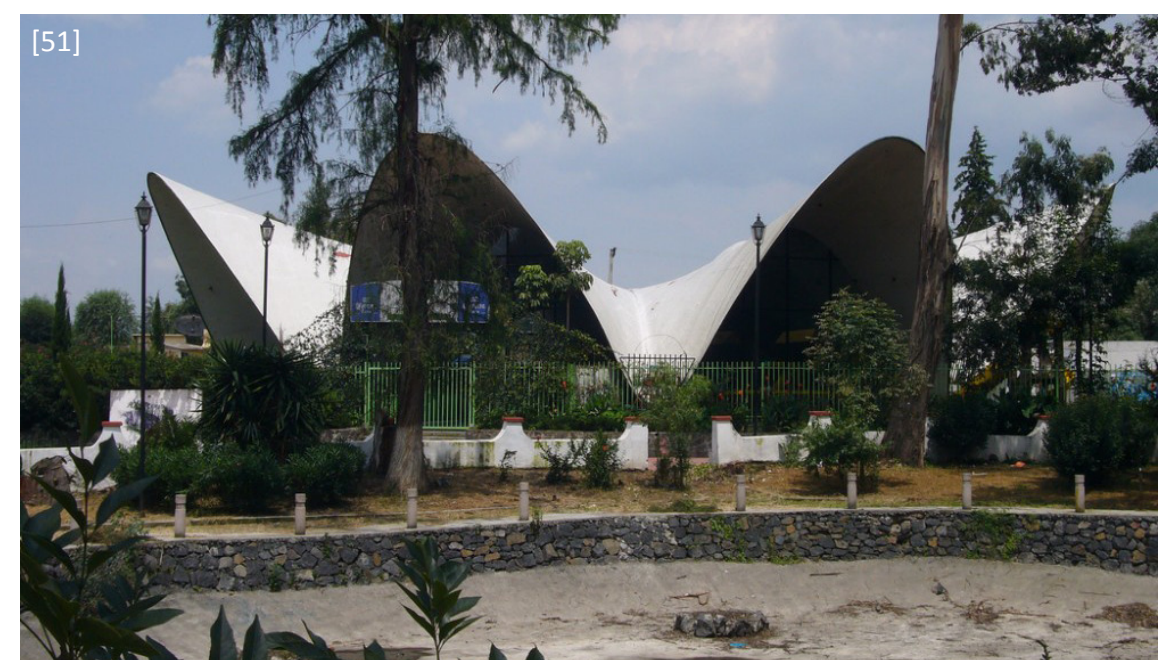


Otros ejemplos modernos de uso de espacios abovedados complejos son los de arquitectos como: Jorn Utzon como representación de las nubes en la ópera de Sidney (1956) o en la iglesia de Bagsvaerd (Copenhague, 1968-76); Miguel Fisac, como sistema de expresión formal a través de la conducción de la luz, como en la iglesia de Nuestra Señora de la Coronación (1958); o Eero Saarinen en la terminal de la TWA (Nueva York, 1956-62).
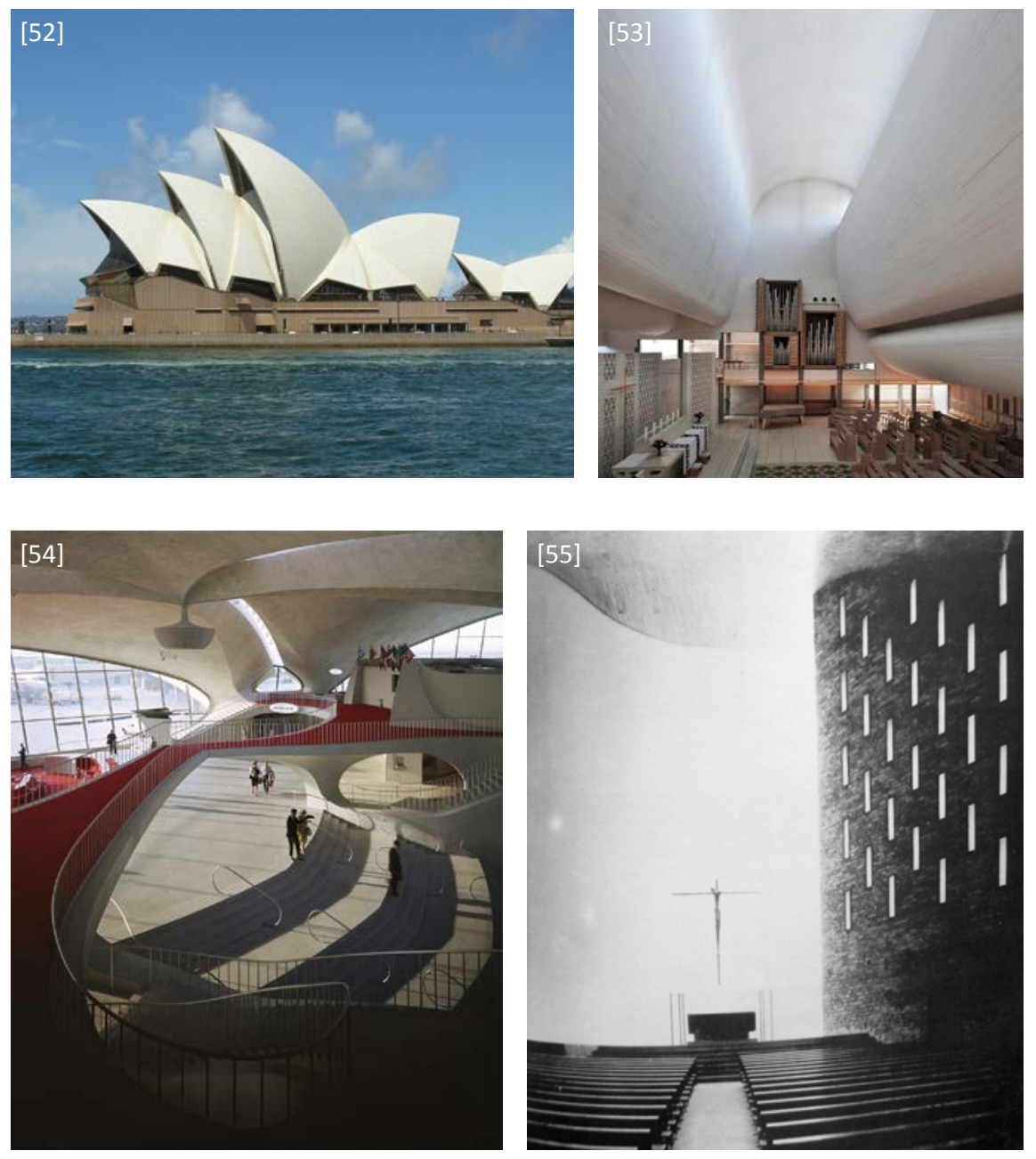

\section{EL ESPACIO INTERIOR EN CONTACTO CON EL EXTERIOR. LA VISIÓN DEL CIELO}

Cuando los restos mantienen la definición volumétrica de la arquitectura, restando sólo por completarse sus bóvedas, la presencia del cielo recortado en los muros preexistentes puede ser un valor a resaltar. El cielo se convierte en el nuevo "cerramiento" del espacio, en un juego que identifica la bóveda perdida con la bóveda celeste, permitiendo hacer realidad aquellas representaciones barrocas de Andrea Pozzo en la Basílica
[52] Opera de Sidney, J. Utzon, 1956. (Fotografía de F. Bandarin. En: UNESCO: <whc.unesco.org>)

[53] Iglesia de Bagsvaerd, J. Utzon, 1968-76. (Flickr: <www.flickr.com>)

[54] Terminal de la TWA, E. Saarinen, 1956-62. (Fotografía de Ezra Stoller. En: Bight creatives: <www. brightcreatives.nl>)

[55] Iglesia de Nuestra Señora de la Coronación, 1958. (MORALES: 1979, p. 93) 


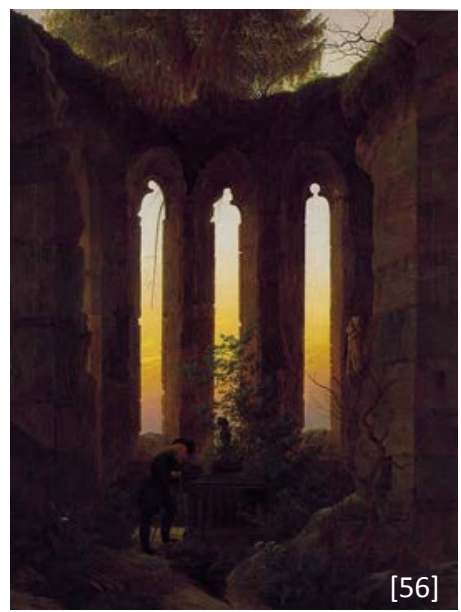

[56] Tumba de Hutten, G. D. Friedrich. (Caspar David Friedrich: $<$ www.caspardavidfriedrich.org $>$ )

[57] Iglesia del Convento de Sant Agustí. (Quaderns d'Arquitectura i urbanisme, $\mathrm{n}$ - 215, 2007, p. 129)

[58] Magnikirche de Braunschweig, tras los bombardeosde la segunda guerra mundial. (Universität Stuttgart: <elib.uni-stuttgart.de>, p. 301)

[59] Iglesia de Santa Maria dello Spasimo. (OTERI: 2009, p. 47)

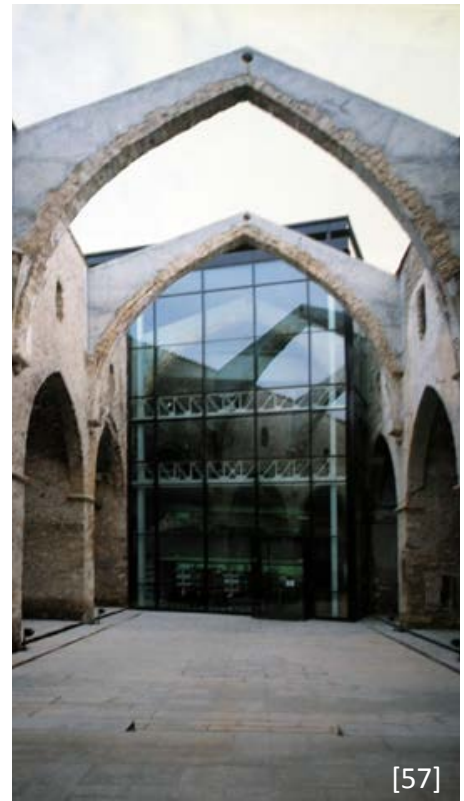

de San Ignacio de Roma. El espacio mantiene, aunque reducidas, sus posibilidades de uso, algo que se evidencia en la imagen de la celebración del Gottesdienst en la Magnikirche de Braunschweig, en 1947, tras ser derruida por los bombardeos de la segunda guerra mundial.

En la iglesia de Santa Maria dello Spasimo en Palermo, las operaciones de adaptación a auditorio al aire libre se han limitado a la pavimentación del espacio, dejando incluso la presencia interior de un árbol que, con su copa vegetal, genera una nueva "bóveda" natural, que aporta una nueva escala al espacio. Si bien en rigor es un espacio exterior, la alta definición de los límites y la presencia del árbol ayudan a darle un carácter interior. Una actuación que en cierto modo recuerda a la propuesta de Caspar D. Friedrich para la tumba de Hutten. Por otro lado el nuevo pavimento se integra con naturalidad en la ruina gracias a su materialidad y tonalidad acordes a la piedra preexistente.

Un caso extremo es el de la iglesia del convento de Sant Agustí (Lluís M. Vidal i Arderiu) en la que se inserta, ocupando dos crujías del edificio religioso, un nuevo edificio para albergar una biblioteca. El espacio de la iglesia adquiere un carácter de patio en el que se celebran actos culturales al aire libre. El eje de orden del nuevo edificio se gira respecto a la iglesia y su fachada se cierra con un muro cortina con la intención de establecer un diálogo entre lo antiguo y lo nuevo a través de los reflejos. Sin embargo el fuerte contraste formal y material produce una relación violenta que impide el equilibrio.
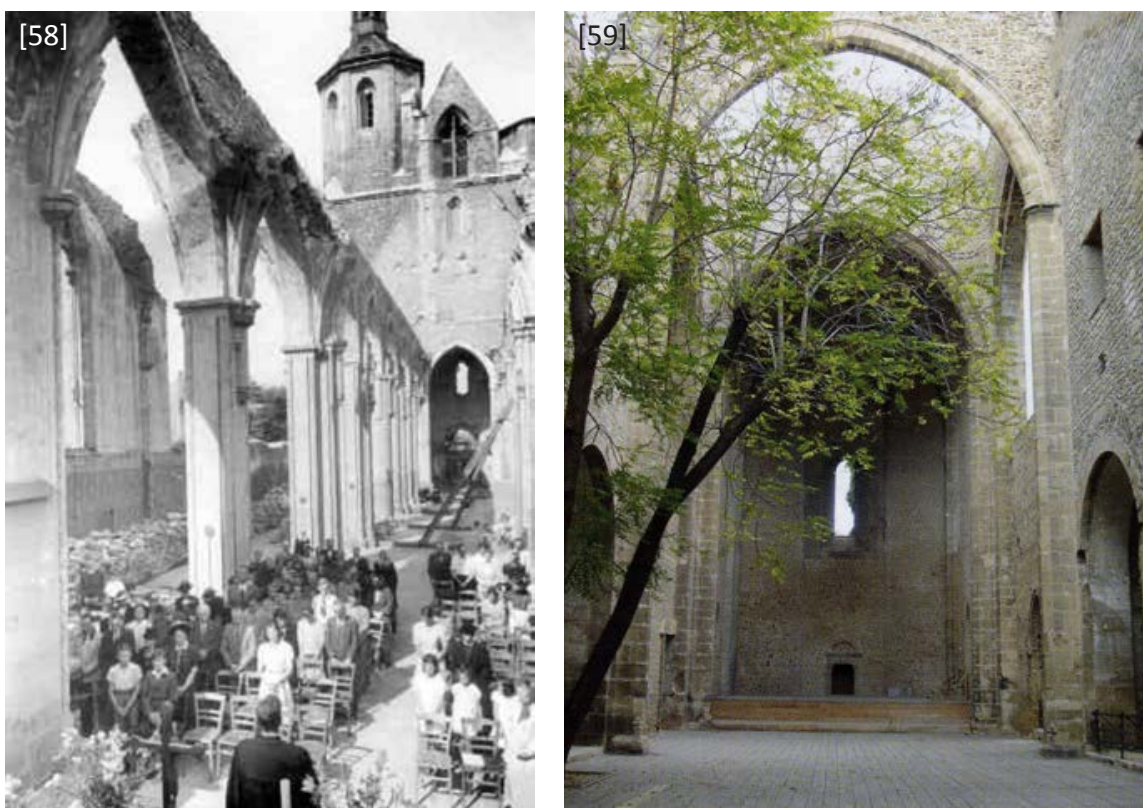
Este interés por el espacio abierto cenitalmente lleva en ocasiones a la solución de cerrar con un elemento transparente el espacio. Este es el caso de la iglesia abacial de Toussaint, reconvertida en el museo David d'Angers, donde la nueva cubierta de acero tubular y vidrio permite introducir una luz cenital que permite mantener la percepción de la bóveda celeste. Sin embargo la estructura metálica parece cobrar demasiada presencia, contrastando con la materialidad de la ruina y reduciendo con ello la validez del efecto.
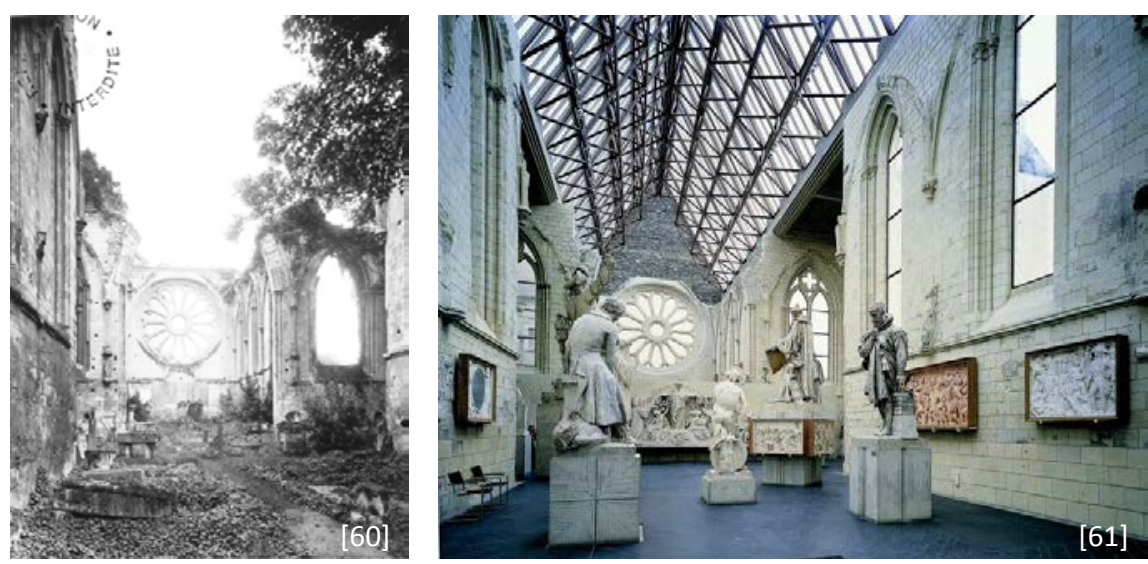

En una búsqueda por conjugar este concepto de iluminación cenital y transparencia, sin renunciar a la forma de la bóveda original surgen proyectos como el de la abadía de Gigean, en Francia, o la intervención de Franco Minissi en San Nicolò Regale donde se busca con materiales transparentes reproducir la envolvente de las bóvedas desparecidas. Sin embargo, la degradación material del derivado plástico empleado en San Nicolò ha supuesto su posterior sustitución por una nueva cúpula maciza. Esto nos muestra que, para dar validez a la creación de un "efecto" arquitectónico, éste debe de estar acorde con la durabilidad material de la preexistencia.
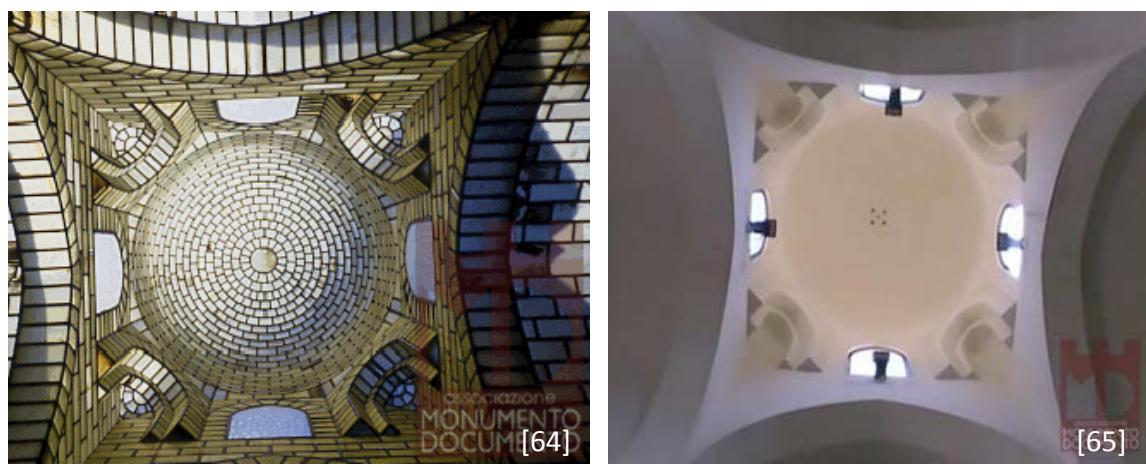

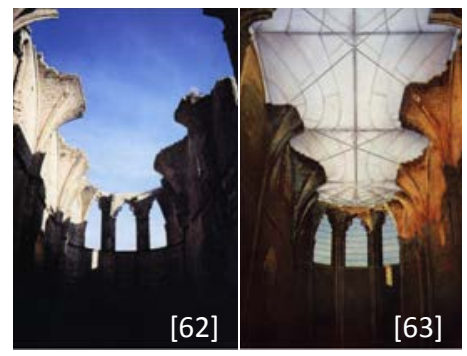

[60] Ilgesia abacial de Toussaint, en ruinas. (Région des Pays de la Loire, Service du Patrimoine: <docsig.angersloiremetropole.fr>)

[61] Ilgesia abacial de Toussaint. (Région des Pays de la Loire, Service du Patrimoine: <docsig.angersloiremetropole.fr $>$ )

[62 y 63] Abadía de Gigean, antes y después de la intervención. (Cortesía de Marina Docci)

[64] San Nicolo Regale, F. Minissi. (Universitá degli Studi di Palermo: $<$ www.unipa.it >)

[65] San Nicolo Regale, nueva cúpula maciza. (Universitá degli Studi di Palermo: <www.unipa.it>) 
9 RAPPOSELLI, M.: "Nuovo e antico. Intervista a Massimo Carmassi". En: CORNOLDI, A.; RAPPOSELLI, M.; Massimo Carmassi : Pisa. Ricostruzione di San Michele in Borgo. Venecia, Ed. IUAV; Padova, Ed. II Poligrafo, 2005, pp. 16

10 Instituto de Conservación y Restauración de Bienes Culturales (I.C.R.B.C.): Monumentos y proyecto: Jornadas sobre criterios de intervención en el patrimonio arquitectónico. Madrid, Ed. Dirección General de Bellas Artes, 1990

11 MOYA BLANCO, L.: "Arquitecturas cupuliformes: el arco, la bóveda y la cúpula". En: CABALLERO ZOREDA, L. (dir.): Curso de mecánica y tecnología de los edificios antiguos. Madrid: Colegio Oficial de Arquitectos de Madrid, 1987, 98
Este concepto de durabilidad puede entrar en conflicto con el controvertido concepto de reversibilidad establecido por las Cartas de Restauración. En este sentido Massimo Carmassi entiende que el concepto de reversibilidad no debe materializarse a través de elementos deteriorables, sino durables como el acero, latón, madera y vidrio de gran espesor. ${ }^{9}$

Así lo entiende también Norman Foster en la cúpula del Reichstag de Berlín, donde la nueva cúpula de acero y vidrio se construye de manera sólida pero ligera, aportándole permanencia en el tiempo y al mismo tiempo inmaterialidad en la percepción de su forma. O también Manuel de las Casas, Ignacio de las Casas y Jaime Lorenzo en el palacio de los condes de Benavente, en Valladolid, donde para dotar de luz a la nueva biblioteca se construye una larga bóveda de vidrio sobre la crujía oeste -reinterpretando la original desaparecida- que se trasdosa con otra de cobre y plexiglas para regular la temperatura interior y tamizar la iluminación de toda la sala. ${ }^{10}$

Este concepto de espacio "abierto" al cielo remite a los primeros ejemplos de arquitectura de hierro, producidos tras la revolución industrial. En 1800 Bélanger construye la gran cúpula acristalada del Halles aux Blés de París, y en 1850 Paxton construye la gran bóveda cilíndrica que cubre la mayor parte del enorme Palacio de Cristal de Londres. Para Luis Moya Blanco ambas obras logran unir "Ia perfección técnica con una gran belleza". ${ }^{11}$
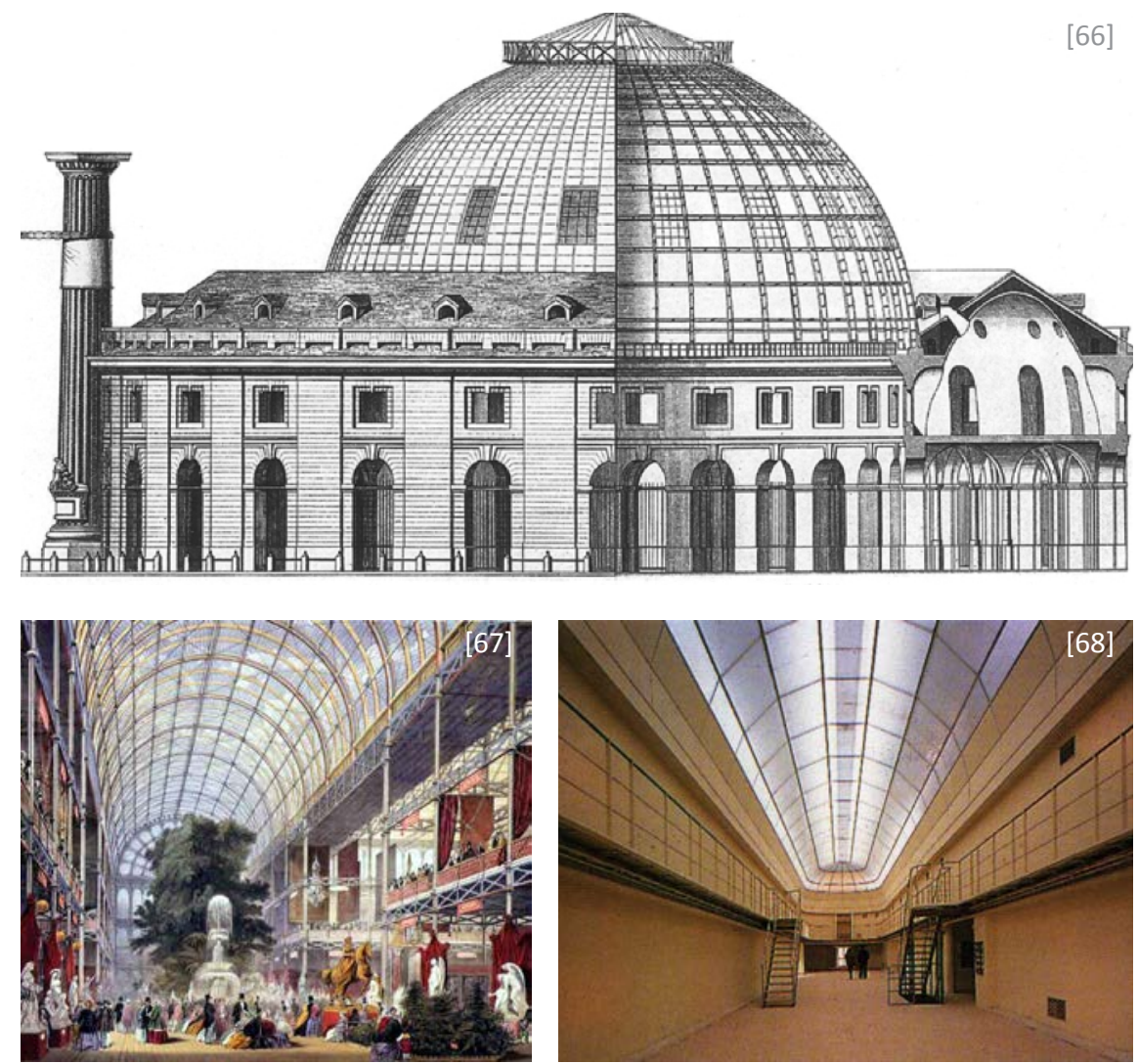

[66] Halles aux Blés de París, Bélanger. (<www.studyblue.com $>$ )

[67] Palacio de Cristal, J. Paxton. $<$ www.pielglobal.edublogs.org $>$ )

[68] Palacio de los condes de Benavente, Manuel de las Casas, Ignacio de las Casas y Jaime Lorenzo. (ICRBD: 1987, p. 151) 
Unas posibilidades técnicas que evolucionarán en el siglo XX hacia espacios más elaborados como la caja postal de Ahorros de Viena realizada por Otto Wagner (1903-1912); el pabellón de vidrio en Colonia de Bruno Taut (1914); diversas obras de Frank Lloyd Wright como el museo Guggenheim de Nueva York (1943), los laboratorios Johnson (1943) o la tienda Morris (1948); el pabellón americano de la Expo 67 de Buckminster Fuller (Montreal, 1967); o también en una arquitectura más cercana temporal y geográficamente como es la Escuela de Arquitectura de Valladolid de Antonio Fernández Alba (1975-78).

Por otro lado, y relacionado con el mecanismo barroco de representación ficticia del cielo, es interesante citar la actuación de Asplund en el cine Skandia (1922), en donde propone la construcción de una ligera bóveda pintada de azul oscuro con la idea de hacerla desaparecer en la oscuridad de la proyección. El espacio queda limitado exclusivamente por los palcos y las butacas acabadas en tonos vivos, mientras que la iluminación se resuelve con unas lámparas esféricas que flotan en el espacio, produciendo con todo ello un efecto de un lugar festivo bajo un cielo nocturno estrellado. ${ }^{12}$
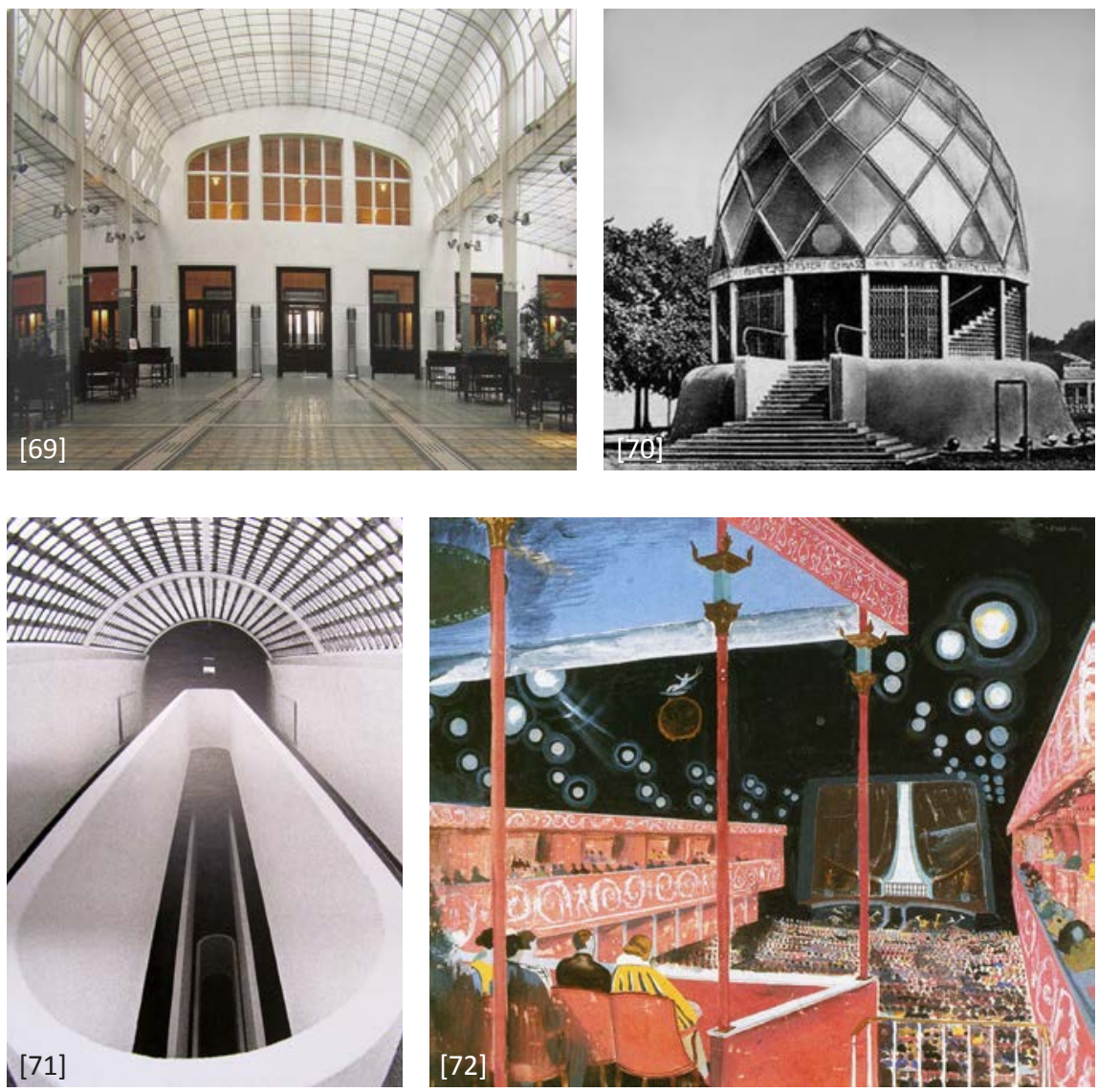

12 CORNELL, E.: "El cielo como una bóveda" En: CALDENBY, C.; HULTIN, O.: Asplund. Barcelona, Ed. Gustavo Gili, 1988, p. 26

[69] Caja postal de Ahorros, O. Wagner. (STARNITZ: 2005, p. 67)

[70] Pabellón de vidrio, B. Taut. (NERDINGER: 2001, p. 58)

[71] Escuela de Arquitectura de Valladolid, A. Fernández Alba. (Ministerio de Fomento: 2011)

[72] Cine Skandia, Asplund. (Commons wikimedia: <commons.wikimedia.org/>)

[73] Guggenheim de Nueva York, F. LI. Wright. (BROOKS: 2011, pp. 71 y 143)

[74] Tienda Morris, F. LI. Wright. (BROOKS: 2011, pp. 71 y 143)
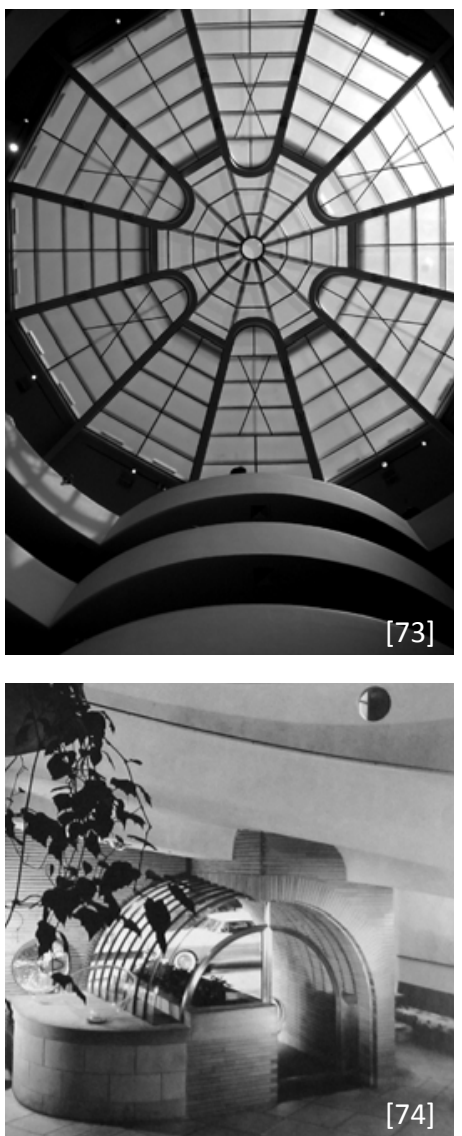
13 CORNELL, E.: "El cielo como una bóveda" En: CALDENBY, C.; HULTIN, O.: Asplund. Barcelona, Ed. Gustavo Gili, 1988, p. 28

14 CORNELL, E.: "El cielo como una bóveda" En: CALDENBY, C.; HULTIN, O.: Asplund. Barcelona, Ed. Gustavo Gili, 1988, pp. 27-28

15 REPRESA BERMEJO, I.: "La expresión plástica en la degradación”. En: REPRESA, I. (dir.): Restauración Arquitectónica II. Valladolid: Universidad de Valladolid, 1998, p. 150

16 CAPITEL, A.: "La arquitectura española más allá de la crisis". En: BALDELLOU, M. A.; CAPITEL, A.: Arquitectura española del siglo XX. Madrid: Espasa Calpe. 1995-2001, p. 550

[75] Instituto Hispano Luso, M. de las Casas.

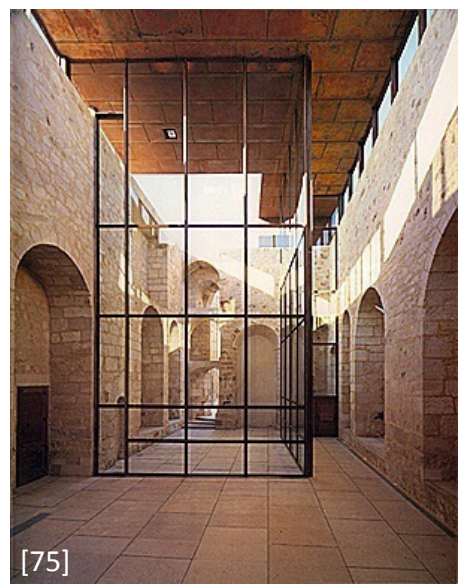

Con ello Asplund demuestra su interés por conformar un espacio con carácter de exterior. Para Hakon Ahlberg el concepto del cielo del cine Skandia proviene de recuerdos de sus visitas realizadas en 1914 al carnaval de Taormina o al espacio a cielo abierto del teatro griego de Siracusa, pero también de su viaje a Túnez donde escribió:

"Sobre nuestras cabezas un cielo claro y tan profundamente azul, con una tonalidad en el color como yo nunca había visto, dando la permanente impresión del cielo como una bóveda, una grandiosa cúpula pintada de azul". ${ }^{13}$

Para Elias Cornell, la solución en definitiva responde a una superposición entre lo tectónico y lo atectónico, donde el primero expresa su presencia constructiva para hacer comprensible la ausencia del segundo. Para Cornell, con ello Asplund "amplió las posibilidades de la arquitectura contemporánea al redescubrir relaciones olvidadas". ${ }^{14}$

\section{EL ESPACIO INTERIOR CON REMINISCENCIAS DE ESPACIO EXTERIOR. LA LUZ CENITAL FILTRADA}

En algunos casos se cubre el espacio de la ruina preexistente para controlar el espacio interior, pero se hace tratando de mantener un cierto aspecto de espacio exterior.

En el Instituto Hispano Luso, Manuel de Las Casas protege el espacio de la ruina de la antigua capilla mortuoria del Deán con una nueva cubierta plana de acero corten, para adaptar el espacio a sala de exposiciones. La autonomía del nuevo elemento de cubierta, la transparencia de sus límites y la continuidad del pavimento permiten mantener una cierta lectura de espacio exterior, conservando el carácter de ruina.

Por otro lado, la introducción de luz cenital en el espacio ayuda a evocar la luz exterior propia de la ruina. Este es el caso de la conversión en biblioteca del edificio de las Escuelas Pías de San Fernando, en Madrid, analizado en profundidad en esta investigación.

En este sentido es interesante la actuación de Rafael Moneo en el museo romano de Mérida (1981-85). Moneo se inspira en la secuencia de arcos presentes en las ruinas de uno de los accesos del anfiteatro romano de la ciudad para la definición de la estructura espacial de la sala expositiva del museo, remitiendo a la ruina al dejar entrar la luz entre ellos. ${ }^{15}$

Como señala Antón Capitel, mediante la repetición de muros paralelos perforados por un gran arco, de las mismas dimensiones que el Arco de Trajano de Mérida, Moneo logra crear la imagen virtual de un espacio abovedado romano. Este recurso inspirado en la mezquita de Córdoba, permite combinar la ilusión de un espacio romano con una organización museística de espacios contiguos. ${ }^{16}$ 
También la materialidad se muestra como fundamental para establecer relaciones con el mundo romano, gracias al empleo de muros de fábrica de ladrillo rellenos de hormigón. Sin embargo, tal y como observa Giorgio Grassi, las ruinas romanas presentes en el subsuelo quedan algo olvidadas bajo la gran construcción contemporánea, cobrando mayor importancia la ficción creada por el autor que la realidad preexistente. ${ }^{17}$

En el caso de una pérdida parcial del cerramiento superior del espacio, las connotaciones se matizan. La luz cenital procedente del exterior es más limitada y, además de introducir la idea de espacio exterior, la preexistencia parcial sugiere la destrucción producida. Este es el caso de la actuación de David Closes en el convento de San Francisco (2003-2011) donde el derrumbe de una de las bóvedas de la nave central permite la introducción de una luz cenital que transforma el espacio original.

En este sentido cabe recordar la actuación de Narciso Tomé en el Transparente de la Catedral de Toledo, donde para iluminar un nuevo grupo escultórico, perfora la bóveda gótica. Además al no percibirse la fuente de luz cenital, se produce un efecto de gran espiritualidad.
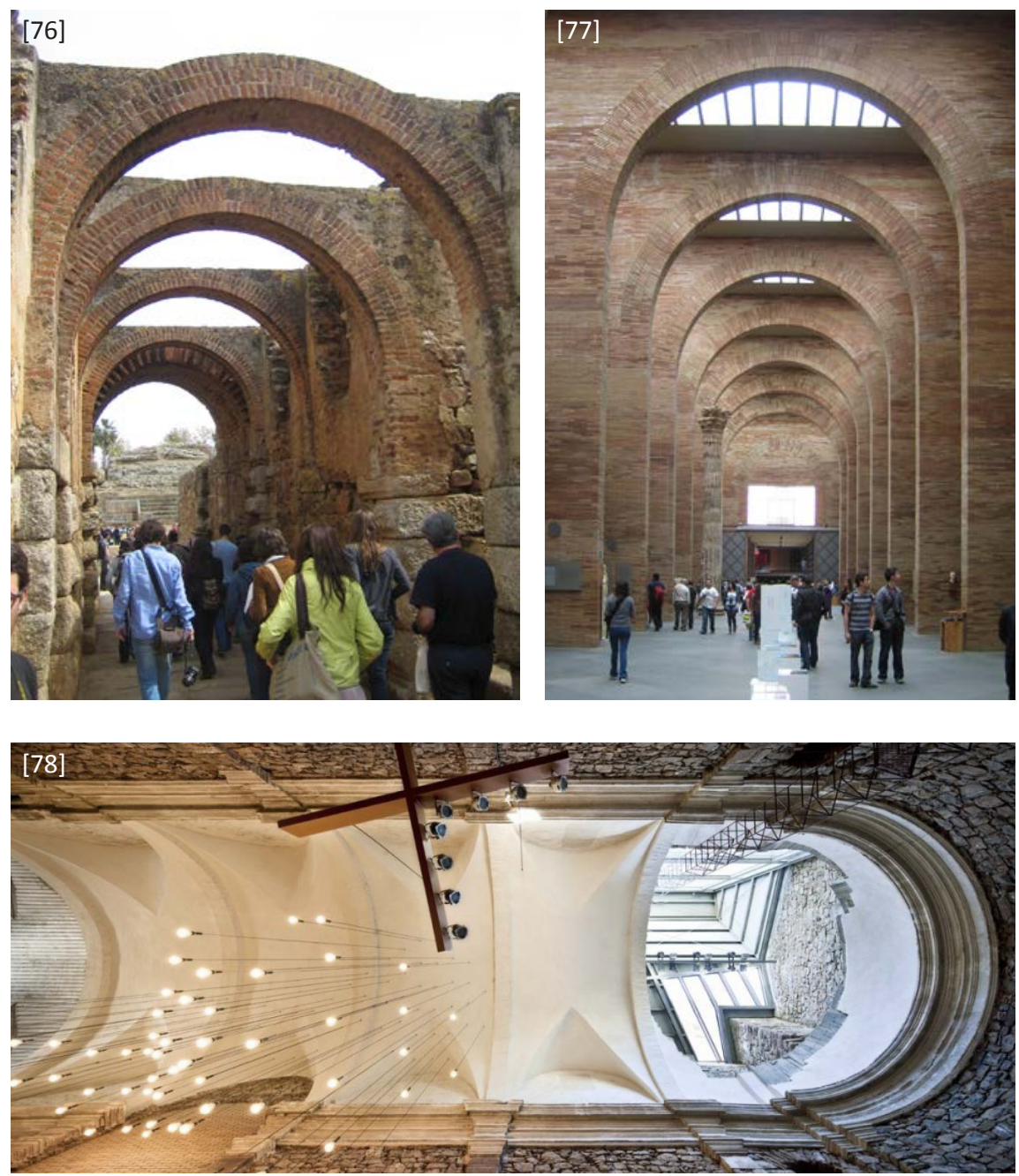

17 GRASSI, G.: "II carattere degli edifici". Casabella no722 maggio 2004, pp.4-15
[76] Secuencia de arcos presentes en las ruinas de uno de los accesos del anfiteatro romano de Mérida. (Fotografía del autor.)

[77] Museo de arte romano de Mérida, R. Moneo. (Fotografía del autor.)

[78] Convento de San Francisco, D. Closes, 2003-11. (Fotografía de Jordi Surroca. En: GORDON: 2012) 
18 UGOLINI, A.: "Ricomporre la rovina, conservare la rovina". En: UGOLINI, A.: Ricomporre la Rovina. Firenze, Ed. Alinea Editrice, 2010, p. 11
También en la Rehabilitación del convento de San Francisco, en Fregenal de la Sierra, Badajoz, (Vicente López Bernal. 2010) se busca sacar partido de la pérdida de las bóvedas para introducir la luz en el espacio de la nave, ahora convertido en biblioteca. Sin embargo el intento de materializar la entrada de luz mediante unas estructuras reticulares de madera laminada que se introducen en el espacio a través de las bóvedas desaparecidas, produce una sensación inquietante que se aleja de la imagen natural de una ruina, perdiendo el equilibrio entre antiguo y nuevo.

Por otro lado estas pérdidas parciales presentes en las ruinas generan espacios de gran sugerencia, capaces de evocar ideas para nuevas arquitecturas, tal y como ya hemos visto en la actuación de Moneo en Mérida. En este sentido es interesante la imagen de una bóveda del anfiteatro de Siracusa donde unos arcos de ladrillo, agregados en una actuación de consolidación a mediados del siglo XIX, producen un espacio de gran sugerencia que podría recordar a los estudios Olivier-Metra realizados por Auguste Perret en París (1921-1925) o incluso al frontón de recoletos de Zuazo y Torroja (1935). Una referencia a la ruina que está presente en las reflexiones de Perret, que incluso llegará a afirmar que "la arquitectura es aquello que hace bellas ruinas". ${ }^{18}$
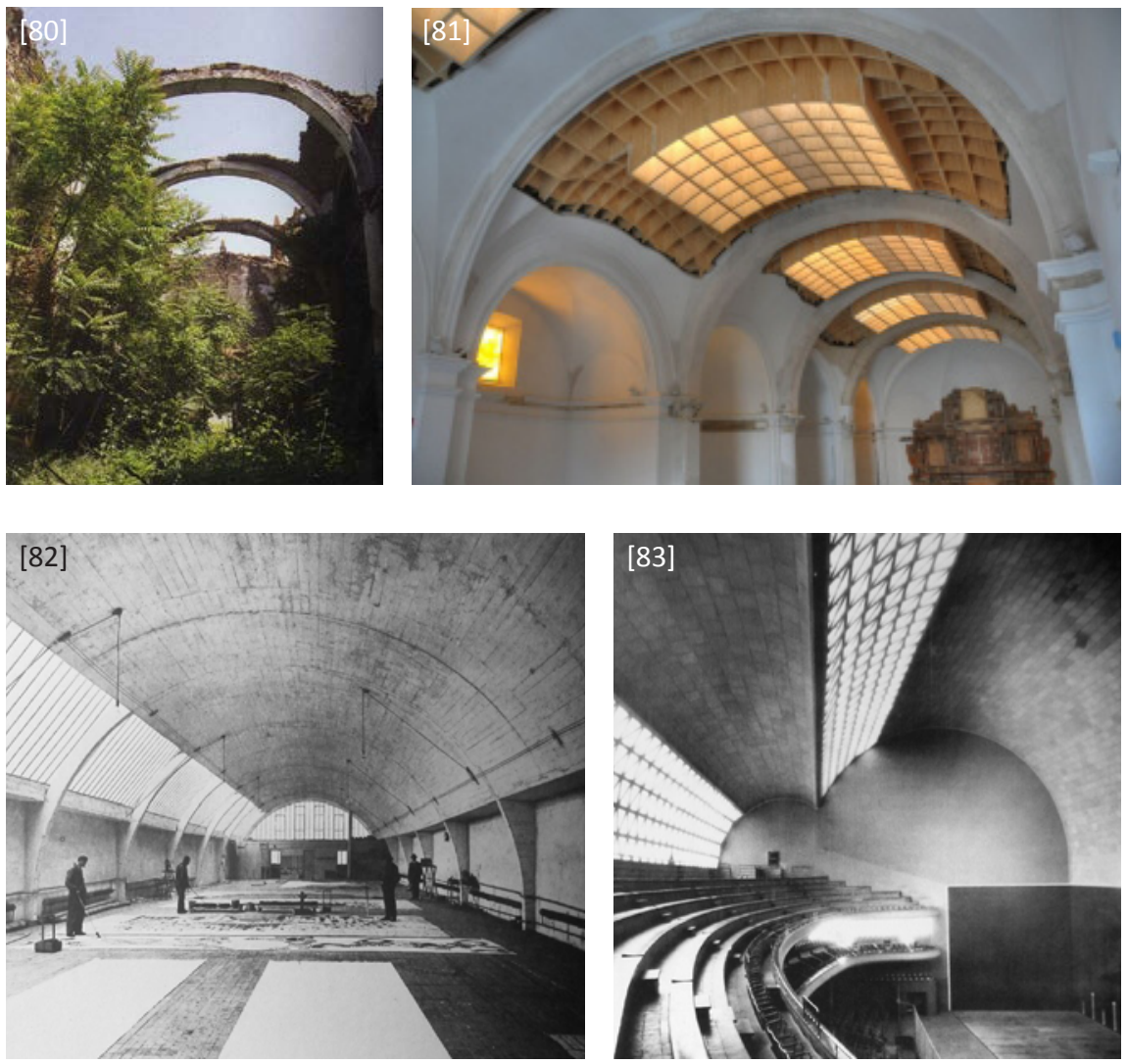
En esta misma línea es posible deducir que las bóvedas con grandes óculos empleadas por John Soane surgen de la reinterpretación de una bóveda que ha perdido parte de su plementería, con lo que Soane estaría inspirándose en las posibilidades expresivas aprendidas de la forma de la ruina para configurar sus arquitecturas, produciendo con ello una relación con la historia.

En la arquitectura moderna hay numerosos ejemplos de reinterpretación de estos conceptos para la conformación de nuevas arquitecturas. Un caso muy evidente es el del arquitecto Louis Kahn en la Asamblea Nacional de Dhaka dónde construye un gran vacío rodeado por fragmentos de elementos puros construidos en hormigón con líneas de mármol blanco. El espacio se cubre con una gran bóveda con forma de paraguas que deja pasar la luz cenitalmente como en una ruina, una forma retomada probablemente de sus apuntes sobre las bóvedas de Villa Adriana.

Estos conceptos nos llevan a las reflexiones de Le Corbusier sobre la bóveda como elemento de recepción y captación de luz, explorado desde sus primeras obras como en su proyecto de casa-taller (1929). Concepto que retoma en la iglesia de Ronchamp, en los elementos abovedados presentes en las tres torres de captación de luz. En su definición Le Corbusier se inspira en el sistema de iluminación cenital presente en el ábside de la exedra del Canopo de Villa Adriana en Roma, analizado por él durante su viaje a oriente en 1910, realizando con ello un trabajo de reinterpretación moderna de la historia. ${ }^{19}$

También Louis Kahn, explora la bóveda como sistema transformador de la luz en el museo de arte Kimbell (1966-72) donde una serie de bóvedas definen una cubierta que se extiende horizontalmente en el lugar. La forma abovedada adquiere por un lado un valor de módulo ordenador del espacio, ayudando a organizar las diferentes zonas de la exposición, y por otro lado un valor de elemento difusor de la luz natural que se introduce cenitalmente a través de una rasgadura lineal en la parte más alta de las piezas, adecuadamente controlada mediante unos difusores curvos en el interior. Kahn persigue con el empleo de la bóveda la idea de transmitir una atmosfera adecuada para la contemplación del arte, un ambiente de silencio y quietud que busca transmitir mediante la claridad constructiva de la estructura de láminas "cicloidales", "una solución unitaria, sencilla y completa". ${ }^{20}$
19 MANIAQUE BENTON, C.: Le Corbusier and the Maisons Jaoul. New York, Ed. Princenton Architectural Press, 2009, pp. $42-43$

20 KOMENDANT, A; FRAMPTON, K.; TENREIRO, O.: 18 años con el arquitecto Louis I. Kahn. Colegio Oficial de Arquitectos de Galicia, La Coruña, 2000, p. 185 
[84] Villa Adriana. (Italia: <www. italia.it>)

[85] Asamblea Nacional de Dhaka, L. Kahn. (KAHLER, N.: <nickkahler. tumblr.com>)

[86] Dibujos de Le Corbusier del sistema de iluminación de la exedra del Canopo de Villa Adriana en Roma. (Fondation Le Corbusier: $<w w w$.fondationlecorbusier.fr $>$ )

[87] Ronchamp. Vista interior. (PAWSON: 2003, p. 45)

[88] Proyecto de casa-taller, Le Corbusier, 1929. (Fondation Le Corbusier: <www.fondationlecorbusier. $\mathrm{fr}>$ )

[89] Museo de arte Kimbell, L. Kahn, 1966-72. (FRAMPTON; KOMENDANT; TENREIRO: 2000, p. 194)
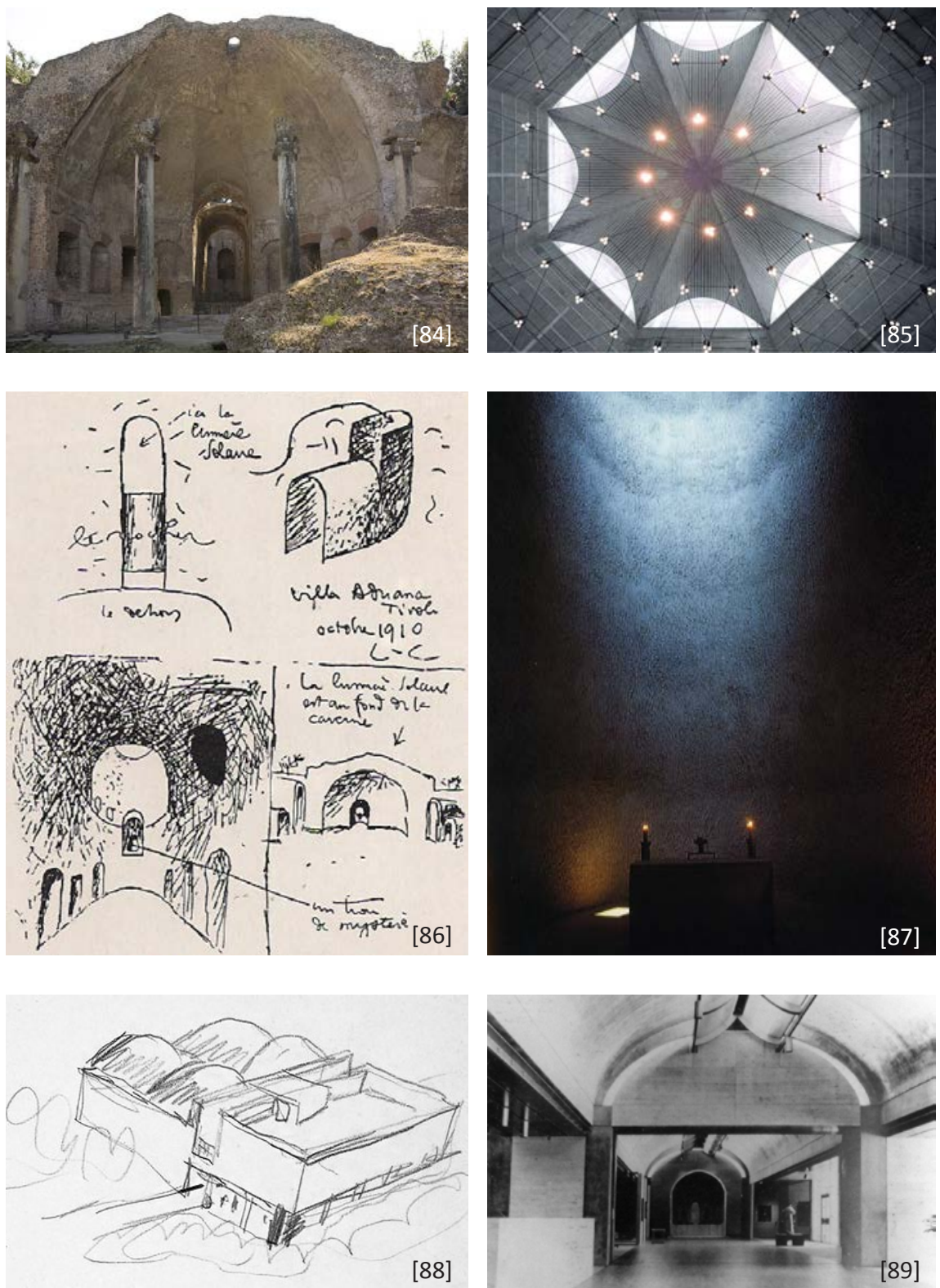


\section{EL ESPACIO INTERIOR ABSTRACTO}

Este camino aboga por la construcción de nuevos elementos que cierren el espacio sin la intención de recuperar o sugerir la forma abovedada. Los restos dejan constancia de la preexistencia de las bóvedas pero no se busca recuperar la literalidad formal del espacio original. Se produce con ello una esquematización del espacio que recuerda a arquitecturas más primitivas desde el punto de vista simbólico, como las basílicas romanas o las iglesias paleocristianas rematadas con techos planos, reflejo a su vez del sistema constructivo empleado a base de cerchas de madera.

Así en la actuación sobre la iglesia de San Agustín para su conversión en archivo municipal, de Primitivo González y Gabriel Gallegos (2001-2003), a través de un nuevo elemento plano, oscuro y definido por una suma de piezas lineales, se cierra el espacio de la nave central, sin una pretensión arquitectónica mayor. Un esfuerzo de contención que también se aprecia en la actuación en el espacio de la Cocina de la Reina, del monasterio de Carracedo.
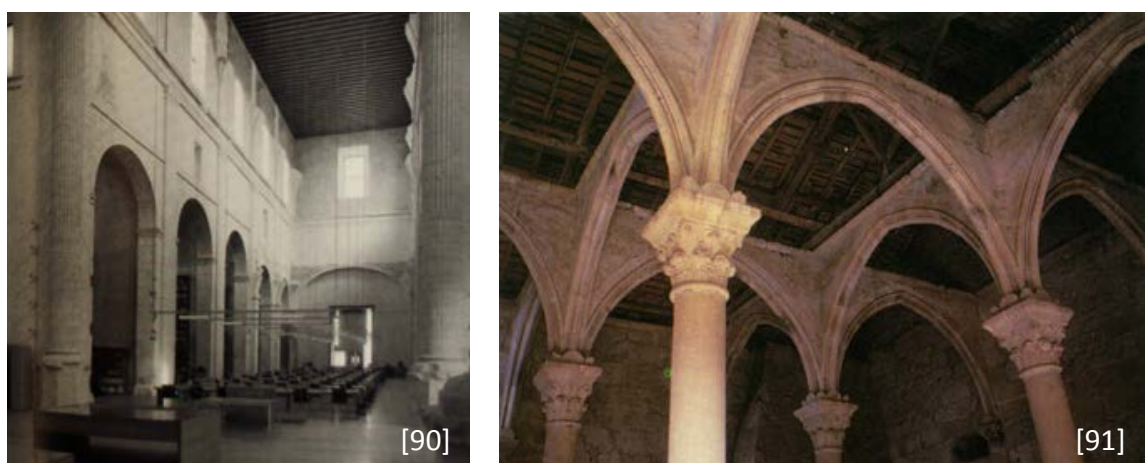

Estas soluciones recuerdan a la actuación de San Stefano Rotondo y a la polémica a la que hace referencia Francesco di Giorgio Martini sobre la pérdida de la supuesta cúpula original, que parece haber enmudecido la expresividad original del espacio. O también a la actuación de reconstrucción de Santa Clara de Nápoles, donde se recupera la forma medieval original, dejándose en el olvido la fase barroca posterior.
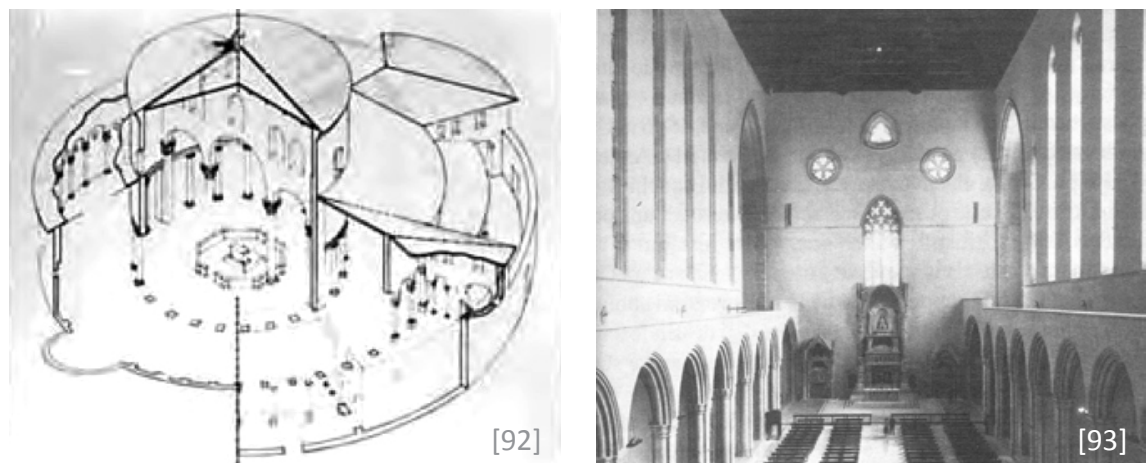

[90] Archivo municipal en la Iglesia de San Agustín, P. González y G. Gallegos, 2001-03. (Fotografía de R. González. En: Arquitectura, no 341p. 105)

[91] Monasterio de Carracedo, Cocina de la Reina. (ICRBD: 1987, p. 159)

[92] Santo Stefano Rotondo. Croquis de la intervención de Rosselino. (JOKILEHTO: 2005, p. 30)

[93] Iglesia de Santa Clara. (BORIANI: 2008, p. 15) 
21 ALONSO DELVAL, M.A.; HERNÁNDEZ MINGUILLÓN, R.J.: "Antigua biblioteca del monasterio de Fitero. Navarra".: On diseño, no 235, 2002, pp. 221-226

22 BURILLO LAFARGA, L.: "Palacio Episcopal de Tarazona". Arquitectura no 244, pp. 53-55

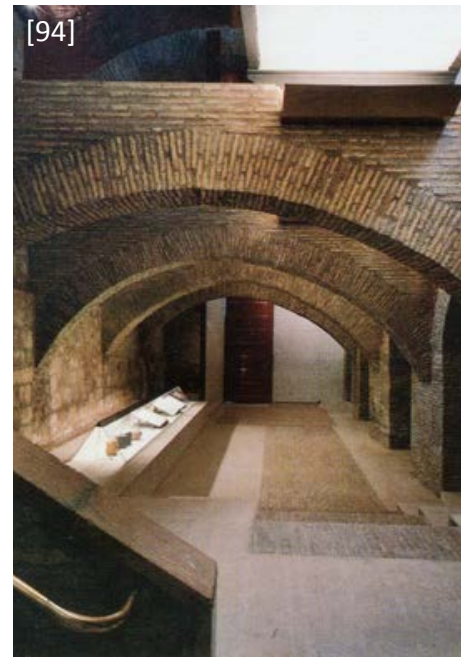

[94] Palacio episcopal de Tarazona, L. Burillo Lafarga. (Arquitectura, no 254, p. 66)

[95] Iglesia de Daroca. (Imagen del autor.)

[96] Monasterio de Fitero, Miguel A. Alonso del Val y Rufino J. Hernández Minguillón.
Por otro lado en la iglesia de Daroca o en el espacio de la cocina del monasterio de Fitero, de Miguel A. Alonso del Val y Rufino J. Hernández Minguillón, también se obvia la presencia de la bóveda original pero se repropone la cubierta de madera con una mayor intención expresiva que en los ejemplos anteriores, aportando en el primer caso una inquietante evaporación del tirante horizontal, y en el segundo caso una nueva entrada de luz cenital que ennoblece el espacio en respuesta a su nueva función como acceso al monasterio. ${ }^{21}$

En este último caso también se elude la reconstrucción del forjado intermedio, sugerido por los mechinales en los muros, para obtener un espacio de mayores dimensiones. Una solución que también lleva a cabo Luis Burillo Lafarga en los sótanos del palacio episcopal de Tarazona, donde aprovechando la pérdida de las bóvedas configura un espacio más noble para el nuevo uso como museo de historia. Sobre los arcos se construye una pasarela excéntrica que permite un recorrido del espacio a mitad altura. Para Burillo esta pasarela es fundamental para devolver a los arcos su condición simbólica de apoyo ya que, al haber eliminado la función sustentante de los arcos se les había vaciado de sentido convirtiéndolos en elementos decorativos. ${ }^{22}$
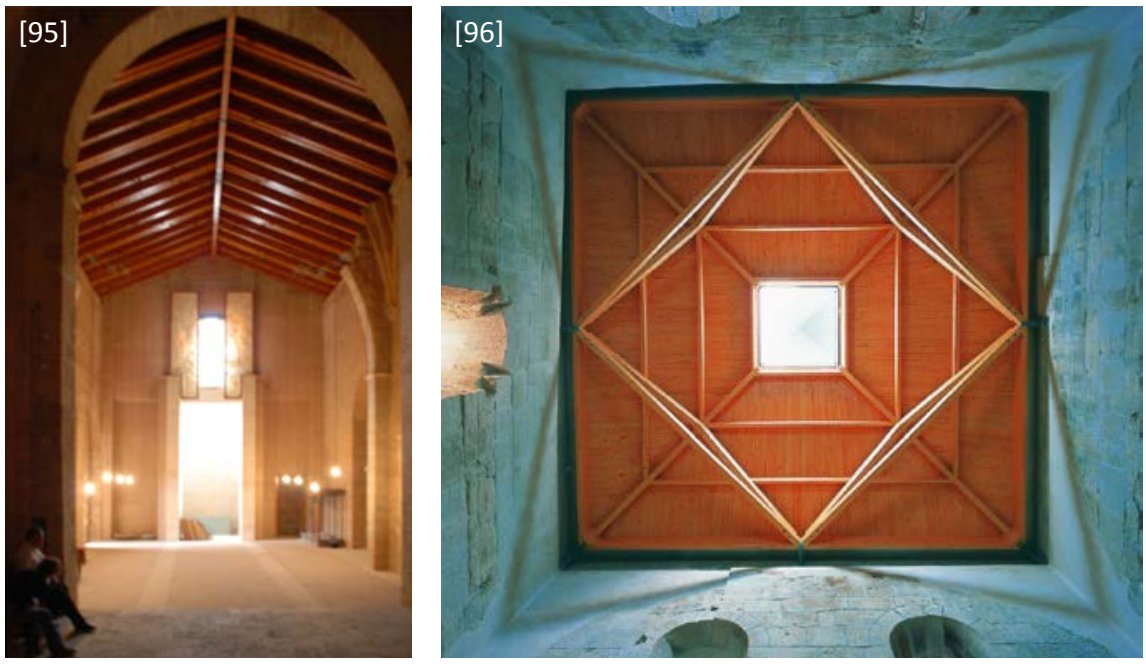

Respecto a este concepto de transformación de un espacio abovedado en otro más abstracto, es interesante hacer referencia a la evolución presente en la obra de Asplund. Así en el proyecto para la biblioteca de Estocolmo Asplund pasa de cubrir el espacio con una gran cúpula a optar por un elemento cilíndrico cubierto con techo plano. Asplund parece inspirarse en la arquitectura idealista de Boullée y Ledoux, pasando de la centralidad del espacio esférico a la proyección vertical del cilindro, retomado del proyecto para la Barrière de la Villette en París de Ledoux. 

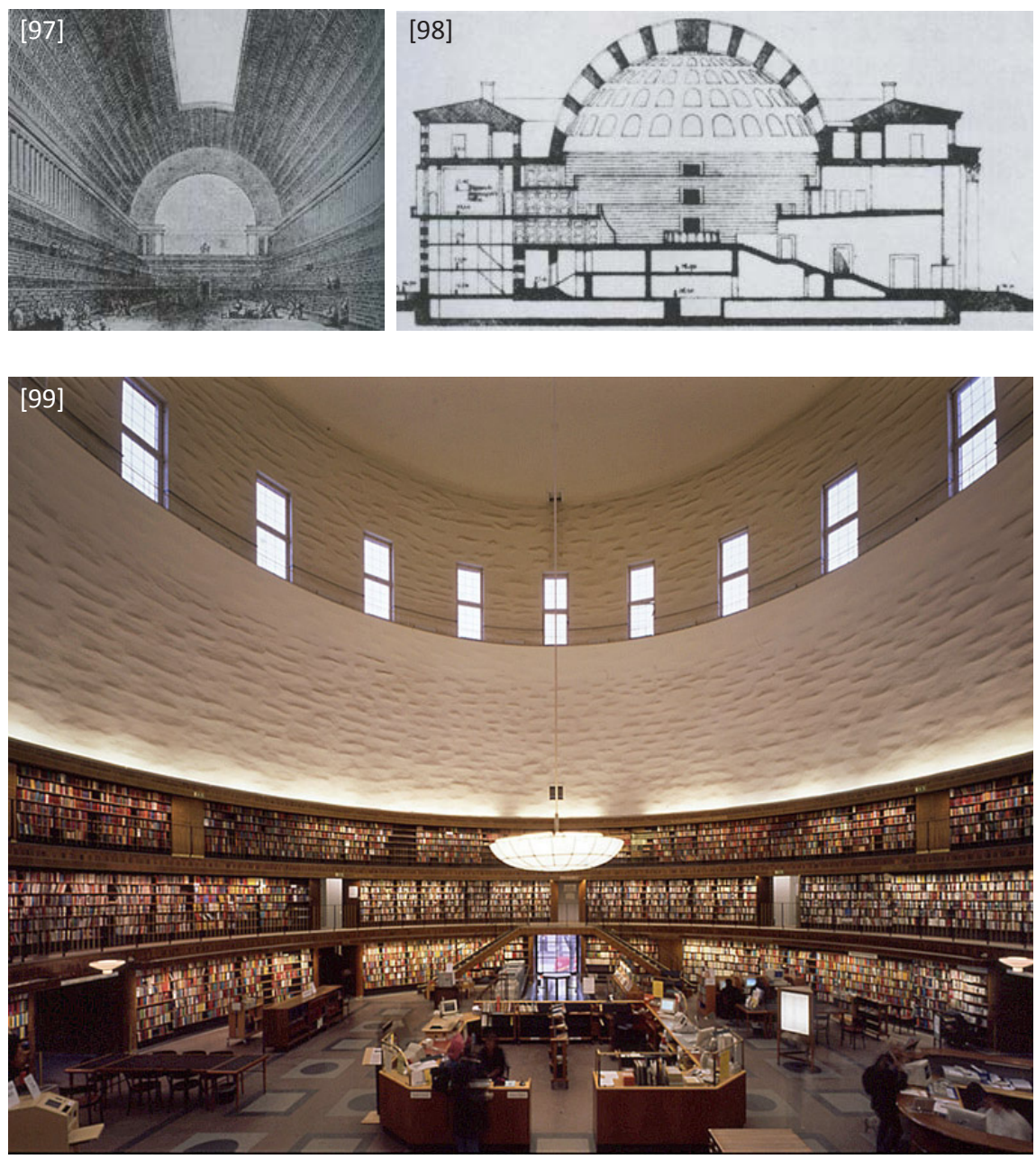

Para Elías Cornell Asplund busca alcanzar lo absoluto mediante el empleo de conceptos paradójicos. El mundo de lo determinado compuesto por el estrato de los muebles y los libros, frente al mundo de lo indeterminado compuesto por un espacio cilíndrico que se eleva desdibujando gradualmente los límites. ${ }^{23}$ Frente al límite celestial presente en el espacio con cúpula inspirado en el Panteón, Asplund introduce el límite racional en un proceso de abstracción espacial.

El concepto de abstracción de los límites evolucionará en la ampliación del ayuntamiento de Goteborg (1934-37), en el espacio iluminado mediante un gran lucernario y que encontrará su máxima expresión en el pórtico de acceso al crematorio del cementerio de Estocolmo (1940) donde construye un espacio completamente abierto al cielo. Como indica Alberto Ustárroz, en el crematorio Asplund funde poéticamente el templo griego y la casa romana, retomado de las ruinas de Sagesta, donde la ausencia de la naos inspira el interior desmaterializado de la iglesia del Crematorio. En definitiva, tal y como dice Alvar Aalto, Asplund "luchó por crear armonía en su trabajo, por tejer conjuntamente los lazos entre un futuro vivo y un pasado vivo". ${ }^{24}$
23 CORNELL, E.: "El cielo como una bóveda" En: CALDENBY, C.; HULTIN, O.: Asplund. Barcelona, Ed. Gustavo Gili, 1988, pp. 28-29

24 USTÁRROZ, A.: La lección de las ruinas. Barcelona, Ed. Fundación Caja de Arquitectos, 1997, p. 237

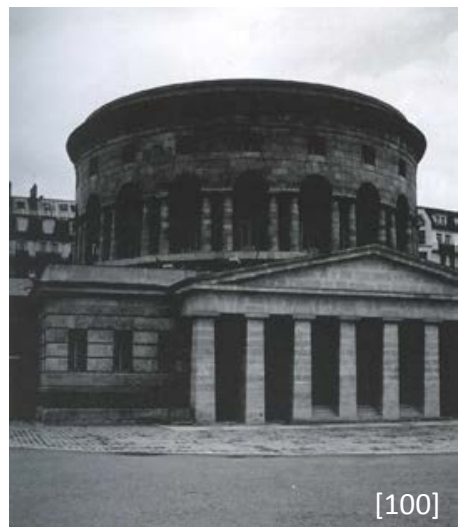

[97] Biblioteca Real, Boullée. (CAPITEL: 2005, p. 20)

[98] Primer proyecto de la Biblioteca de Estocolmo, Asplund. Sección. (CAPITEL: 2005, p. 21)

[99] Biblioteca de Estocolmo, E. G. Asplund. (Erik Gunnar Asplund: $<$ www.erikgunnarasplund.com>).

[100] Aduana de la Villete, Ledoux. (CAPITEL: 2005, p. 21)

[101] Ampliación del Ayuntamiento de Goteborg, E. G. Asplund, 193437. (Erik Gunnar Asplund: <www. erikgunnarasplund.com>)

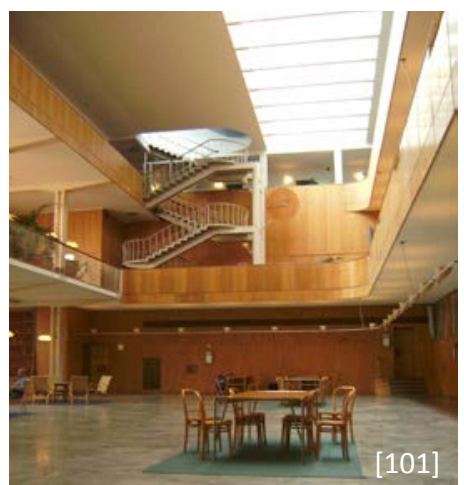




\section{LA EVOCACIÓN DEL ESPACIO ABOVEDADO INTERIOR}

Este camino acepta la construcción de un espacio interior abstracto pero no renuncia a la evocación del elemento abovedado original. La evocación, por su propia definición de incompleta, deja constancia de la novedad de la actuación y de la pérdida del elemento original.

Un camino es el de la definición de algunas líneas de su forma envolvente original, pero sin tratar de recuperar su función estructural, sino suspendidas de una nueva envolvente abstracta. Este es el caso del Castillo de Kolding donde en lo que era la capilla de Christian IV, ahora reconvertida en sala de exposiciones, se construye un nuevo forjado de madera del que se cuelga una estructura de delgados elementos metálicos que evocan, con su disposición formal, a las antiguas bóvedas góticas. Al mismo tiempo estas estructuras resuelven el sistema de iluminación del espacio, de tal manera que la luz de las bombillas crea una malla de puntos que permite leer la envolvente original.

En esta misma línea J. Sedlmayr en la Torre de Visegard cierra el espacio con una nueva estructura de cubierta de la que cuelgan unos planos de malla metálica que reproducen la forma de las plementerías de las bóvedas desaparecidas, pero dejando ausentes los nervios que ya no son necesarios para ejercer su función estructural de soporte.
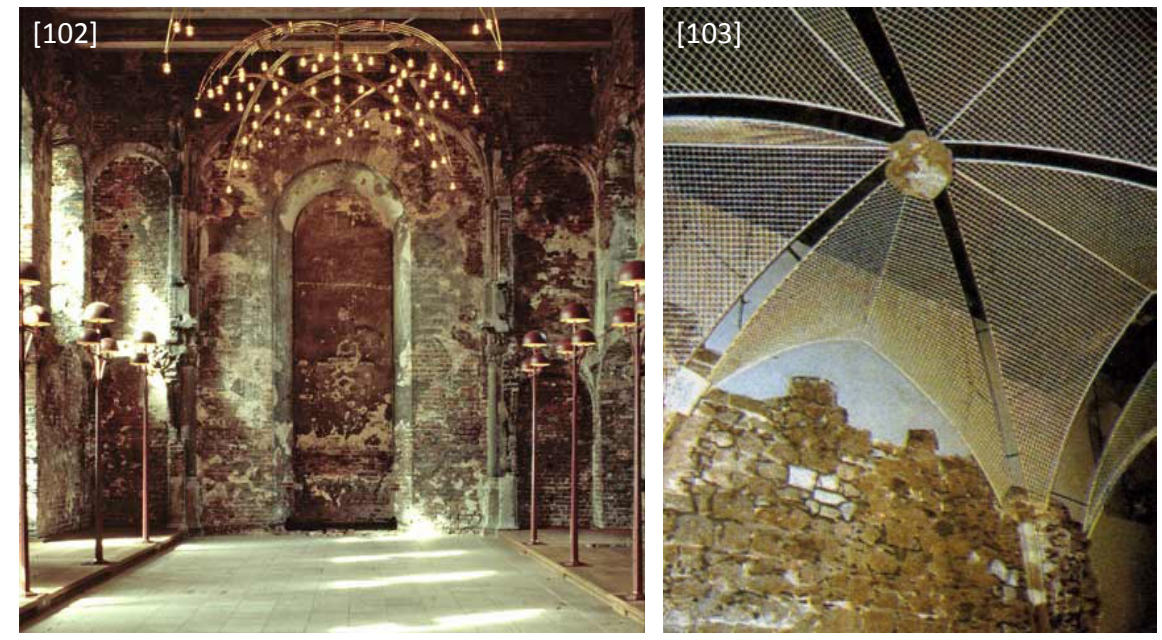

[102] Capilla de Chistian IV, Castillo de Kolding. ( $\mathrm{E}+\mathrm{N}$ : <www.eplusn. $\mathrm{dk}>$ )

[103] Torre Visegard, J. Sedlmayr. (CARBONARA: 1997, p. 287) 
Por otro lado en las actuaciones de intervención de Sant Jaume de Sesoliveres, o del monasterio de Sant Llorenç de Guardiola de Berguedà, las nuevas bóvedas se conciben como elementos independientes de madera. Se sustituye el material másico por otro más ligero como es la madera, y se independizan parcialmente los elementos de sus límites. Esto aporta al elemento abovedado un valor configurador de un espacio provisional dentro de otro espacio más permanente.
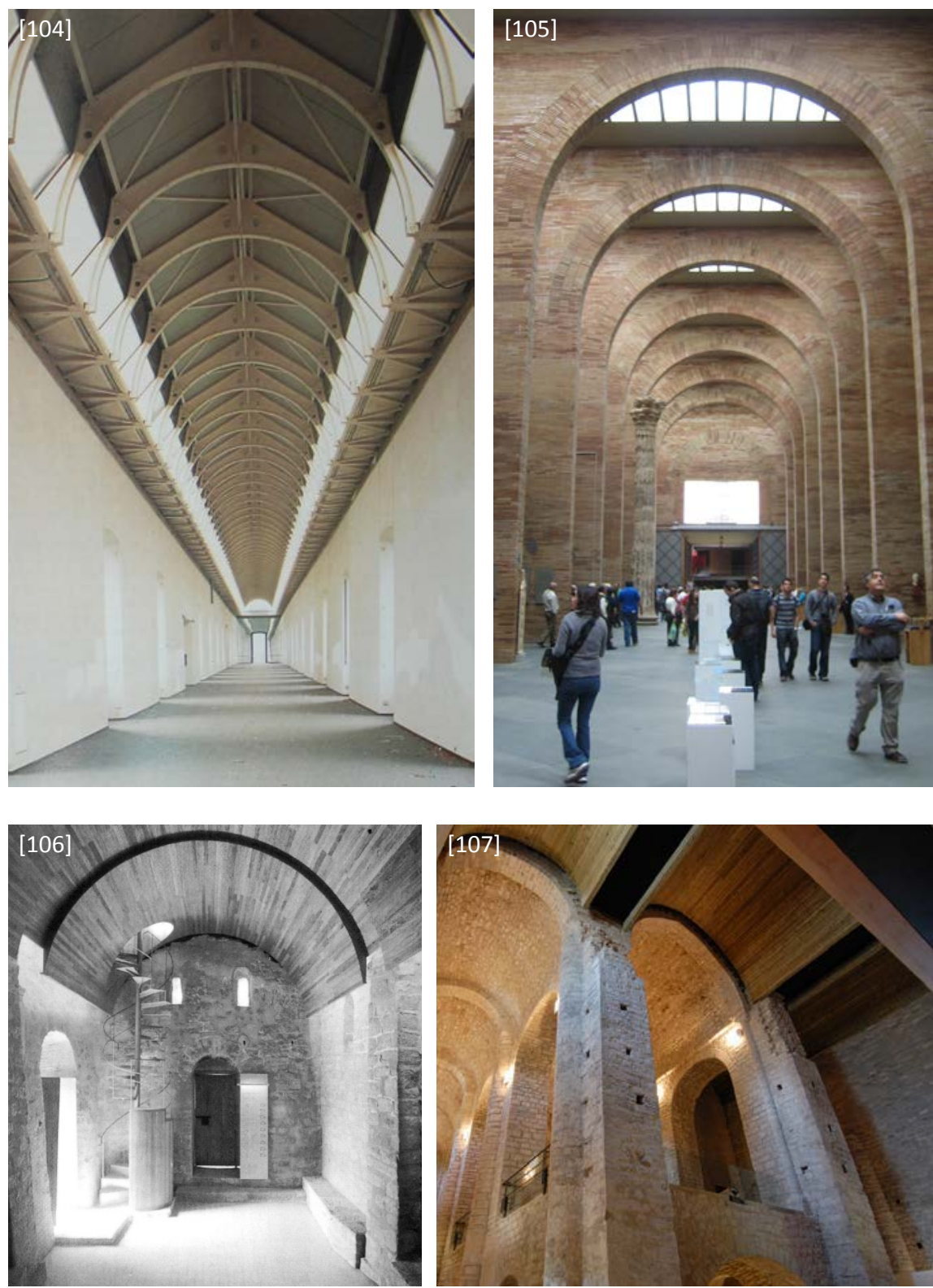

[104] Castillo de Rivoli. Vista interior de La Manica Lunga. (BRUNO: 1996, p. 170)

[105] Museo de arte romano de Mérida, R. Moneo. (Fotografía del autor.)

[106] Sant Jaume de Sesoliveres. (GONZÁLEZ: Informes de la Construcción, vol. 48, no 445, 1996, p. 30)

[107] Sant Llorenç de Guardiola. (Pendís Bagà: <www.pendisbaga. com>) 


estudio de casos 


\subsection{ORATORIO DI SAN FILIPPO NERI}

Construcción original:

Estilo Rococó. Alfonso Torregiani. 1723-33

Intervención incompleta:

Alfredo Barbacci. 1949-53

Nueva intervención:

Pier Luigi Cervellati. 1997-99

Lugar:

Bolonia, Italia.

El edificio se ubica en la via Manzoni, junto a la iglesia de la Madonna di Galliera y frente al museo cívico medieval. La calle es perpendicular a la via dell'independenza, eje norte-sur que conecta la plaza mayor con la estación de trenes.

\section{ANTECEDENTES}

\subsection{Evolución histórica ${ }^{1}$}

A principios del siglo XVII, el caballero boloñés Licinio Piò funda la Congregazione dell'Oratorio en Bolonia. A lo largo de más de un siglo, las reuniones se desarrollarán en diversas casas e iglesias hasta que, en 1705, el noble boloñés Sebastiano Sighicelli hace una importante donación para la elaboración del proyecto de la nueva sede. En 1723 se le encarga el proyecto al arquitecto Alfonso Torregiani (1682-1764), quien junto al maestro de obras Pietro Zanolini, estudia la integración entre formas arquitectónicas y elementos decorativos. Para ello se vale de grandes artistas como el escultor Angelo Piò, el estucador Carlo Nessi, el tallista Antonio Calzolari y el pintor Francesco Monti. Los trabajos durarán cerca de 10 años hasta que el 13 de agosto de 1733 el edificio será consagrado por el Cardenal Prospero Lambertini.

La actividad del Oratorio dura alrededor de 60 años, hasta que en 1798, en época de la república Cisalpina, el edificio adquiere un uso profano. En 1816 el oratorio es restaurado y reabierto al culto, manteniéndose activo hasta finales de 1866, momento en el que es requisado como parte de la supresión de las órdenes religiosas, pasando a ser de dominio militar. En 1905 es rescatado por Luigi Franceschini, miembro de la comunidad laica, retomando nuevamente las celebraciones religiosas.

El 29 de enero de 1944, el edificio es bombardeado, produciéndose la destrucción del cerramiento norte de la nave, la bóveda de cañón, la bóveda vaída y parte de la cúpula que cubría la zona del altar. Finalizada
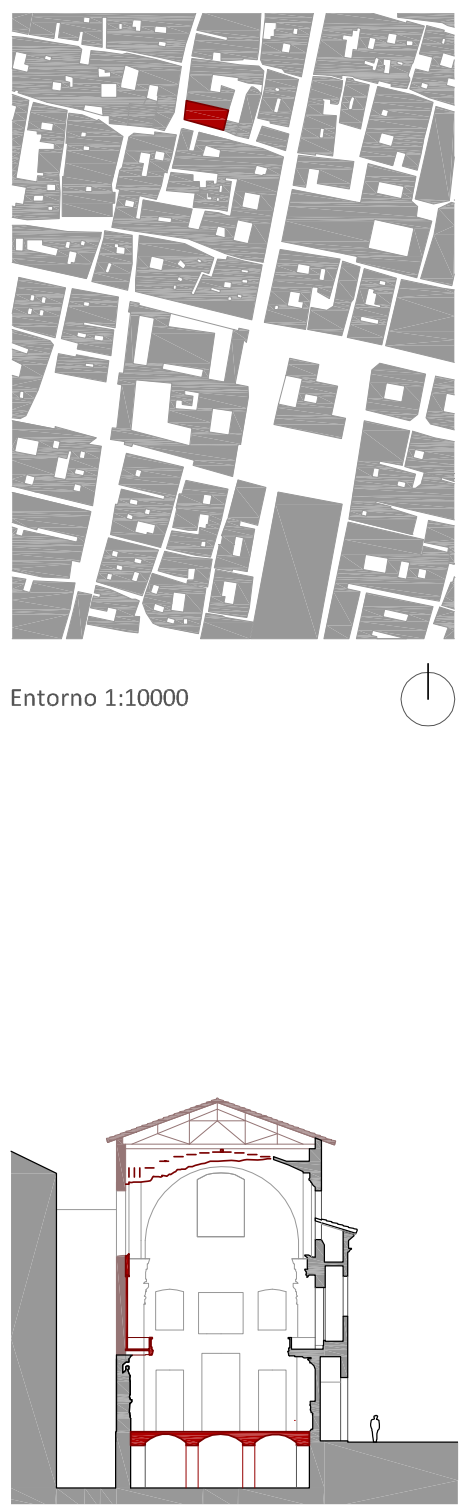

Fase 3. Cervellati 1997-1999.

Fase 2. Barbacci 1949

Fase 1. Torregiani 1723-1733.

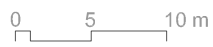


1 Cronología elaborada a partir los datos extraídos de las siguientes fuentes:

SIMONELLI, R.: "Oratorio di San Filippo Neri, Bologna: auditorium e sala espositiva". En: BORIANI, M.: Progettare per il costruito. Dibattito teorico e progetti in Italia nella seconda metà del XX secolo. Milano, Ed. CittàStudi Edizioni, 2008, p. 306

GIANNELLI, L.: “Oratorio di san Filippo Neri". En el sitio web de la Direzione Regionale per $i$ Beni Culturali $e$ Paesaggistici dell'Emilia-Romagna (Italia) [En línea]

Disponible en: <http://www. emiliaromagna.beniculturali.it $>$ [Consulta: 10-04-2012]

Fondazione del Monte. Oratorio: Storia [En línea]

Disponible en: <http://www. fondazionedelmonte.it> [Consulta: 1004-2012]

2 Término italiano con el que se denomina al responsable de la soprintendenza, delegación del ministerio de bienes culturales y ambientales que se encarga de tutelar el patrimonio artístico, cultural y arqueológico de una zona del país.

[1] Catastro pontificio, alrededor de 1800. Bolonia, Archivio di Stato. (CERVELLATI: 1999, p.34)

[2] Planta de un proyecto anterior al Oratorio, atribuida a Torreggiani. Bolinia, Archivio di Stato.(CERVELLATI: 1999, p.37)

[3] Planta de 1856 de Luigi Rizzoli. Bologna. Archivio dei Padri Filippini.(CERVELLATI: 1999, p.42)

la guerra, en 1949, el soprintendente ${ }^{2}$ Alfredo Barbacci (1896-1989), emprende los trabajos de restauración, que serán interrumpidos cuatro años más tarde sin poder finalizarse.

Entre los años 1955 y 1975, los Padres Filipinos alquilan la nave del oratorio a Walter Zapparoli, que lo emplea como depósito de materiales para la construcción.

El 4 de abril de 1997, la Fondazione del Monte de Bolonia y Ravena adquiere el oratorio y confía el encargo de la restauración a Pier Luigi Cervellati, quien se encargará de los trabajos hasta su finalización en 1999. La presente investigación se centra principalmente en el análisis de esta última intervención, llevada a cabo por Cervellati.
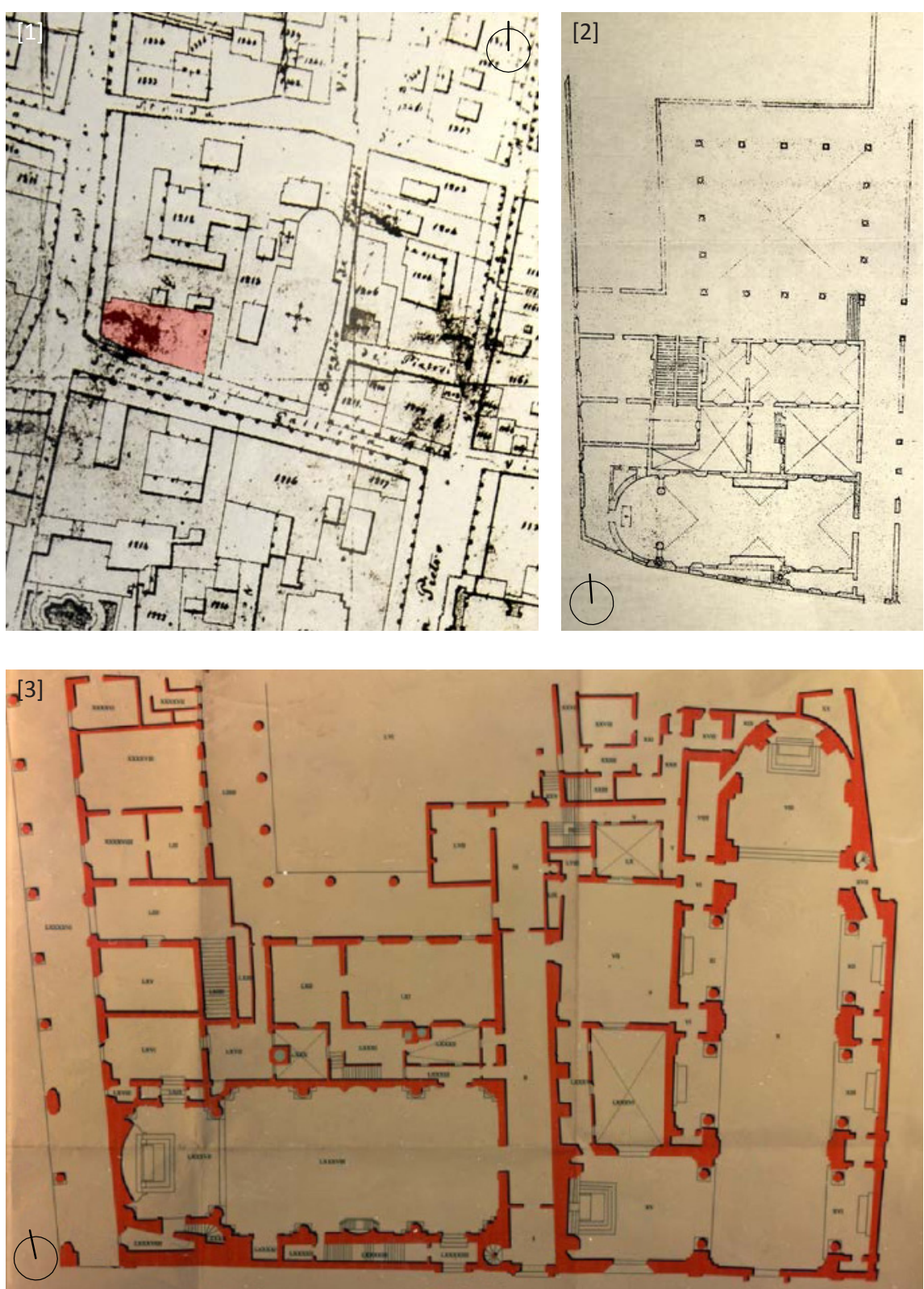


\subsection{Descripción del monumento}

El Oratorio se orienta en dirección este-oeste, en paralelo a la calle, aunque con una leve desviación que permite la conformación de un espacio estrecho y alargado que acoge circulaciones y accesos.

La entrada a la nave se produce a través de un pasaje previo, perpendicular a la calle, que en origen se adentraba en la manzana hasta conectar con un claustro, según se observa en el plano catastral de 1800 . Existe un segundo acceso al oratorio, directamente desde la calle, de menor importancia en la composición pero muy práctico debido al menor recorrido de ingreso que supone. En las plantas actuales del oratorio se puede constatar la recuperación de la importancia del sistema de acceso original, cuya disposición genera un interesante recorrido, a la vez que reduce la presencia de la fachada en la calle, evitando con ello restar protagonismo a la iglesia vecina.

El espacio del oratorio, construido en cuatro crujías, se estructura en dos partes, el presbiterio y la nave. La nave ocupa las tres primeras, siguiendo un ritmo A/B/A, siendo el módulo central el de mayor dimensión, mientras que el presbiterio ocupa la crujía del extremo oeste, rematando la composición.

El ritmo queda patente en la configuración de los paramentos y bóvedas. Dos módulos cubiertos con bóveda de cañón flanquean el elemento central, compuesto por una bóveda vaída generada por arcos de medio punto que descansan sobre columnas estriadas. Por último, el presbiterio, eje final de la composición, se remata con cúpula de planta elíptica apoyada sobre pechinas.
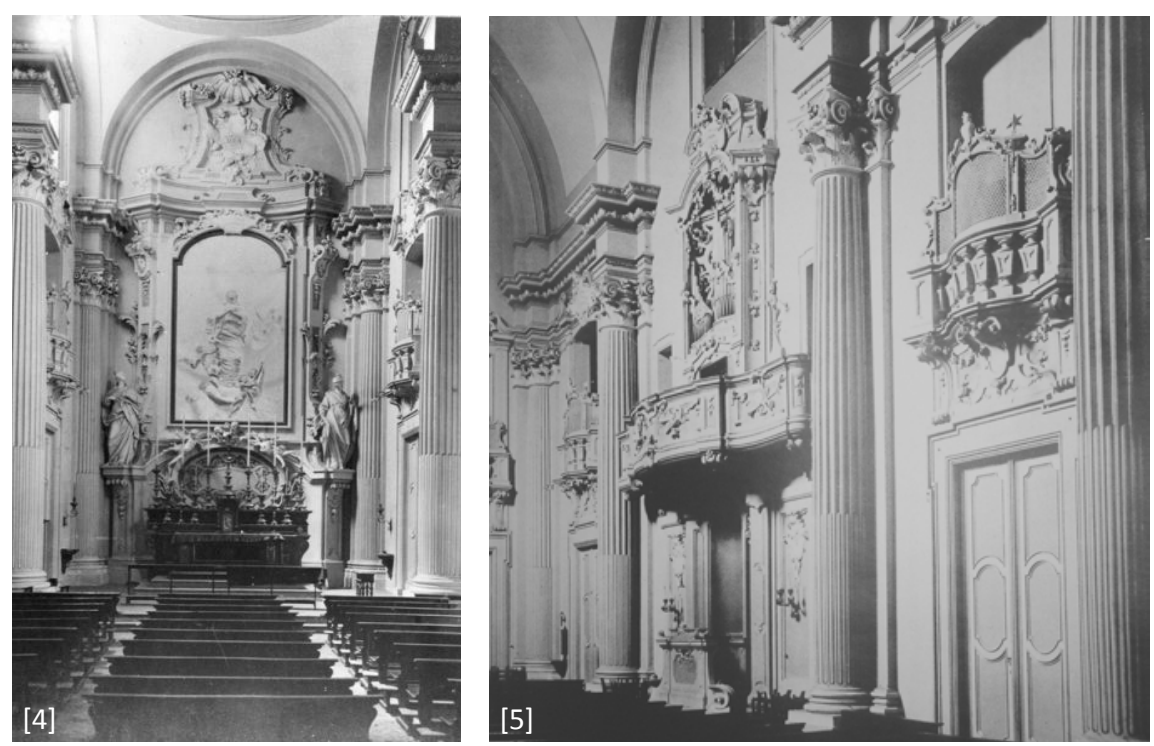

[4] Fotografía del presbiterio tras la restauración de 1905-1907 (Italia. Direzione Regionale per i Beni Culturali e Paesaggistici dell'EmiliaRomagna: <www.emiliaromagna. beniculturali.it $>$ )

[5] Imagen del muro norte del oratorio después de la intervención de 1905-1907. (CERVELLATI: 2009)

[6] Vista de la fachada. (Italia. Direzione Regionale per i Beni Culturali e Paesaggistici dell'EmiliaRomagna: <www.emiliaromagna. beniculturali.it>)

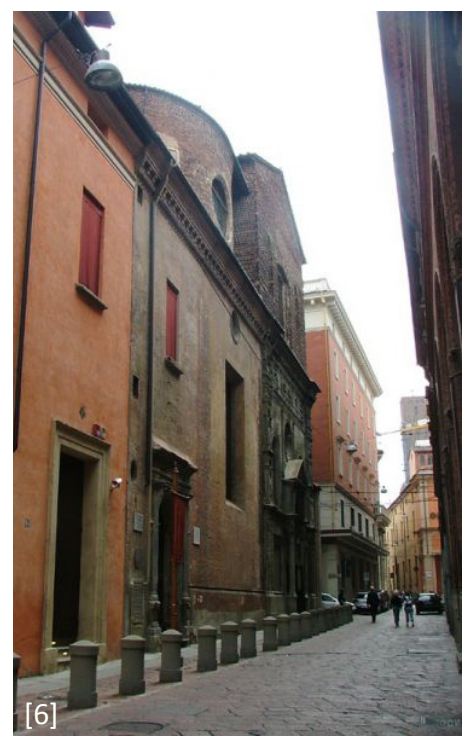


3 Italia. Direzione Regionale per i Beni Culturali e Paesaggistici dell'EmiliaRomagna: "Torreggiani Alfonso: Interno dell'oratorio di san Filippo Neri" [En línea]

Disponible en: <http://www. emiliaromagna.beniculturali.it/index. php?it/107/opere/59/torreggianialfonso-interno-delloratorio-di-sanfilippo-neri> [Consulta: 10-04-2012]
[7] Iglesia del noviziato di Sant'Ignazio. (Accademia di Belle Arti di Bologna: <www.ababo.it>)

[8] Iglesia de Sant Ivo alla Sapienza. (Imagen del autor.)

[9 y 10] Iglesia del monasterio benidictino. Johann Dientzenhofer. 1710-1719. Vista interior y planta.

Torregiani elabora el interior en colaboración con diversos artistas, estudiando la integración entre las formas arquitectónicas y decorativas. El resultado obtenido es un "ambiente agradable y poco solemne, ennoblecido por estucos vivos, con claras analogías a la iglesia del noviziato di Sant'Ignazio, también en Bolonia -ahora aula magna de la Academia de Bellas Artes-, realizada por el mismo Torregiani e inaugurada en 1726". ${ }^{3}$

En el módulo central se ubican los coros, y sobre ellos dos ventanales que, conjuntamente con el ventanal ubicado sobre el acceso, iluminan el espacio de la nave remarcando los ejes compositivos del conjunto.

Esta forma de organizar el espacio barroco-rococó se relaciona con la idea de la superación de la "fusión espacial" -conseguida a través de la valoración de la traza y de los paramentos, planteada en Sant'Ivo alla Sapienza, San Carlino alle Quattro Fontane, Sant'Andrea al Quirinale y San Lorenzo de Turín- para buscar el "espacio total", a través de la convexidad espacial. Un ejemplo representativo de esta forma de actuar, construido con anterioridad a este oratorio, es la Iglesia Abacial de Banz (1710), donde se consigue la fusión espacial direccional a través de la interpenetración secuenciada de espacios cóncavos y convexos.
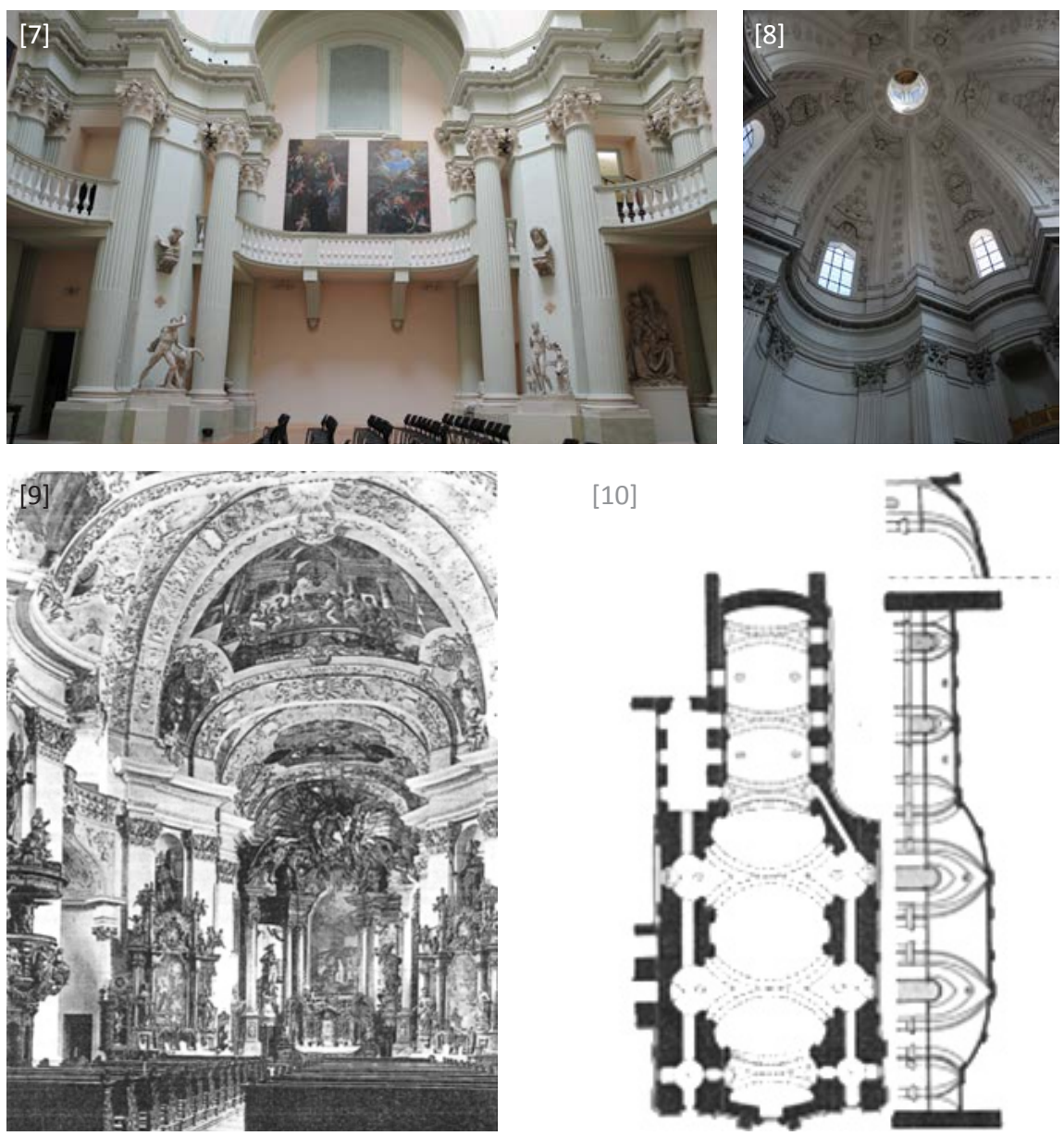


\subsection{La restauración de 1949}

Los bombardeos de la guerra habían destruido el lado norte de la nave y del presbiterio, y con ello gran parte de las bóvedas que cubrían el espacio -además de varios ambientes limítrofes y el pórtico recayente a la via Galliera-. La cúpula, gravemente dañada, es finalmente demolida en los trabajos de restauración.

Cervellati hace referencia a la duda que surge respecto al estado del forjado de planta baja, que tal como se observa en las fotografías previas a la restauración de 1949, aparenta estar en buen estado tras el bombardeo. Sin embargo, en los trabajos de intervención se optó por su demolición. Por otro lado, también menciona que existen planos detallados de levantamiento del estado del sótano, planos de diseño de una nueva losa de hormigón y una solicitud para dar uso de gimnasio al espacio. Esto sugiere su demolición por cuestiones funcionales, lo que demostraría una actitud muy poco conservativa.

La actuación del soprintendente Barbacci consiste en la reconstrucción en ladrillo del arco del presbiterio y el muro norte, de dos pies de espesor, ejecutados ambos con gran maestría. Por otro lado, se reconstruyen en hormigón armado las columnas del muro norte y la cornisa, asumiendo esta última la función de zuncho estructural. Tanto el diámetro de las columnas como el espesor del entablamento se hacen algo menores que los originales, tal vez para permitir su revestimiento posterior.

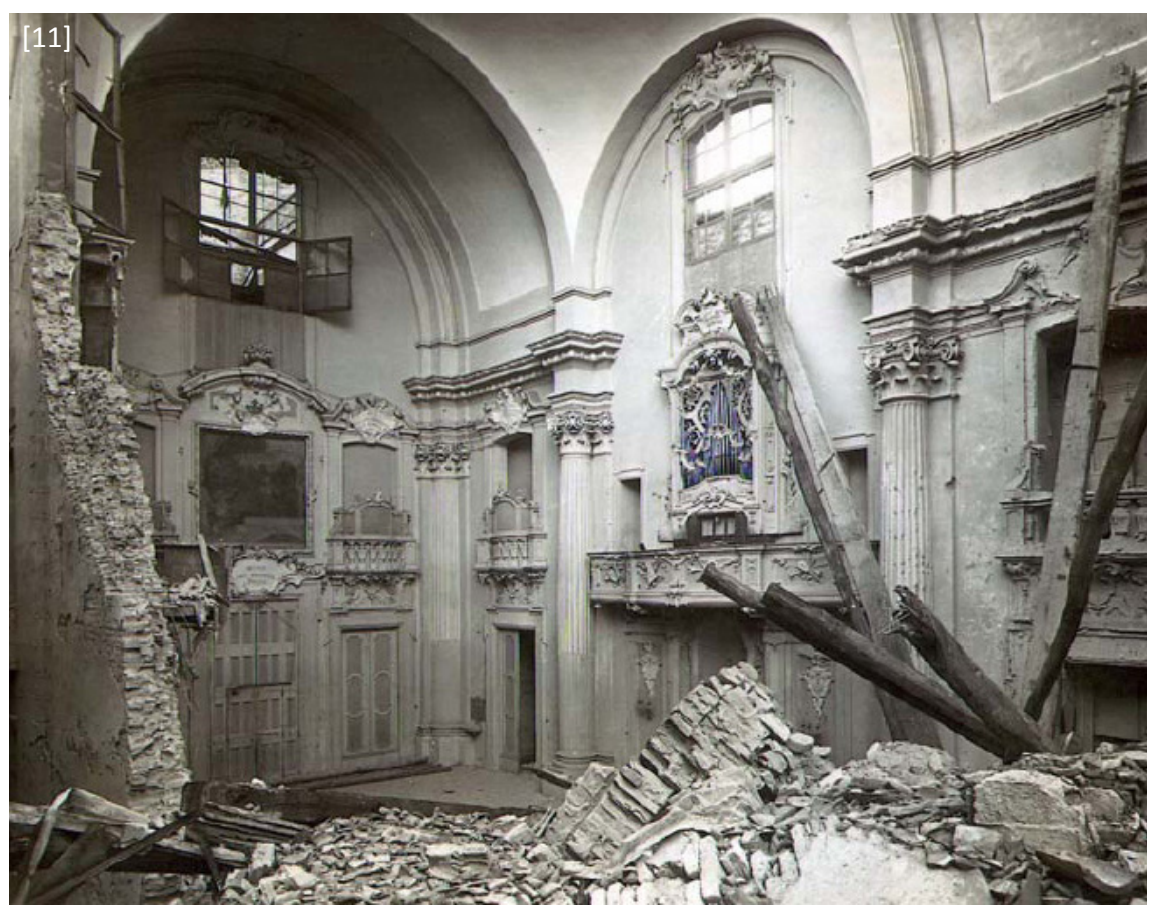

[11] Vista del oratorio tras los bombardeos. (CERVELLATI: 2009)

[12 y 13] Estado del muro norte en Enero de 1944, tras el bombardeo que causó el derrumbe de parte del edificio, y cincuenta años después, en 1997, antes de la intervención de Cervellati. (CERVELLATI: 1999)

[14 y 15] Estado del presbiterio el 29 de Enero de 1944 y cincuenta años después, en 1997. (CERVELLATI: 1999) 

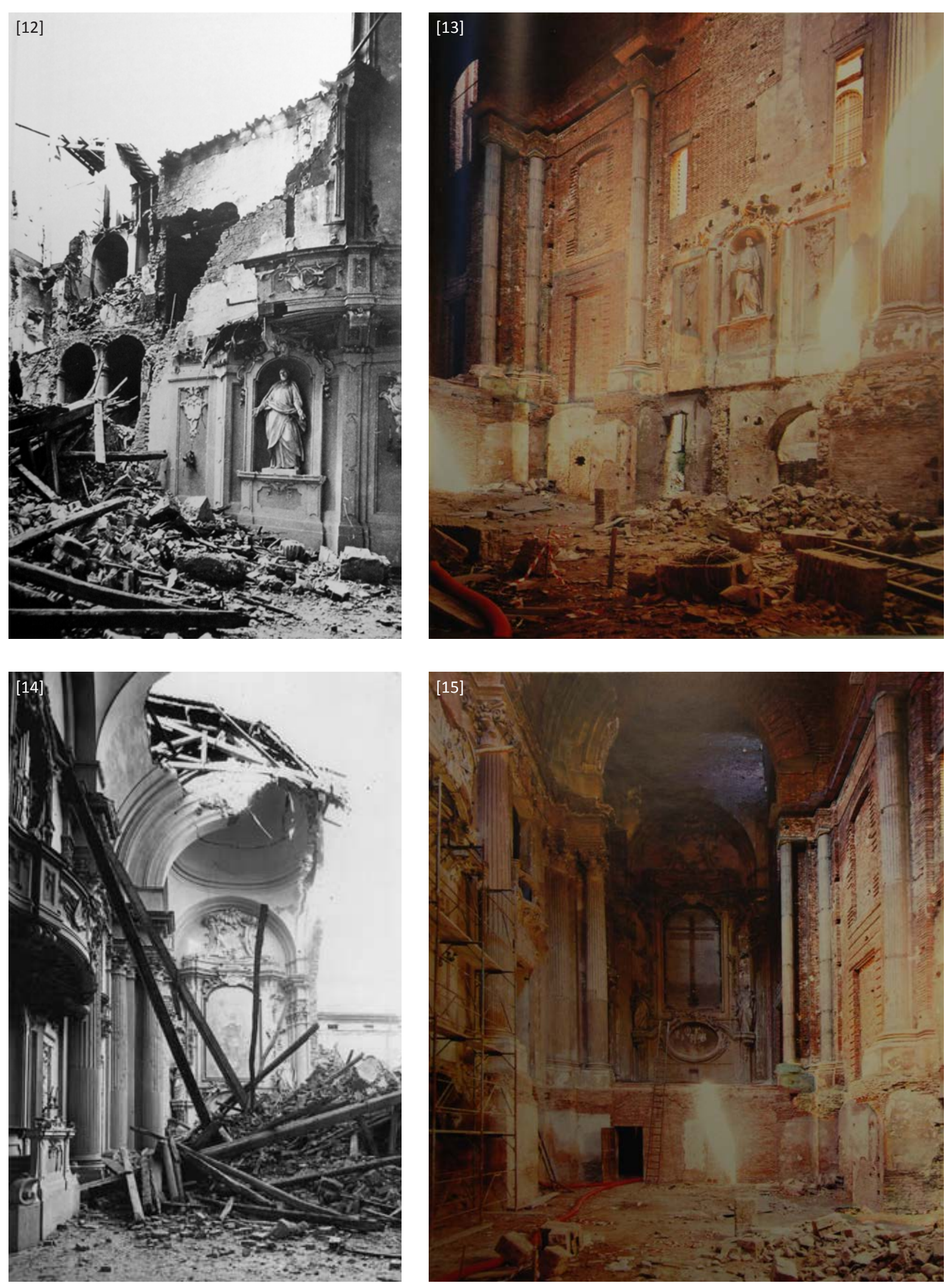
Dado que la restauración queda interrumpida, no se puede conocer con seguridad el criterio previsto en la actuación. Si bien en otras intervenciones Barbacci había empleado el "ripristino filologico", en este caso el uso del hormigón parece indicar la búsqueda de una intervención donde las partes nuevas destacaran con cierta claridad. ${ }^{4}$

En cualquier caso, las soluciones empleadas en la restauración contrastan con el leguaje original del oratorio. Los pesados muros y arcos de ladrillo, así como las desnudas columnas y entablamento de hormigón, chocan drásticamente con la suntuosa y refinada arquitectura del siglo XVIII. Un lenguaje de gran crudeza que inevitablemente pone de manifiesto la pérdida producida por el bombardeo de la guerra.

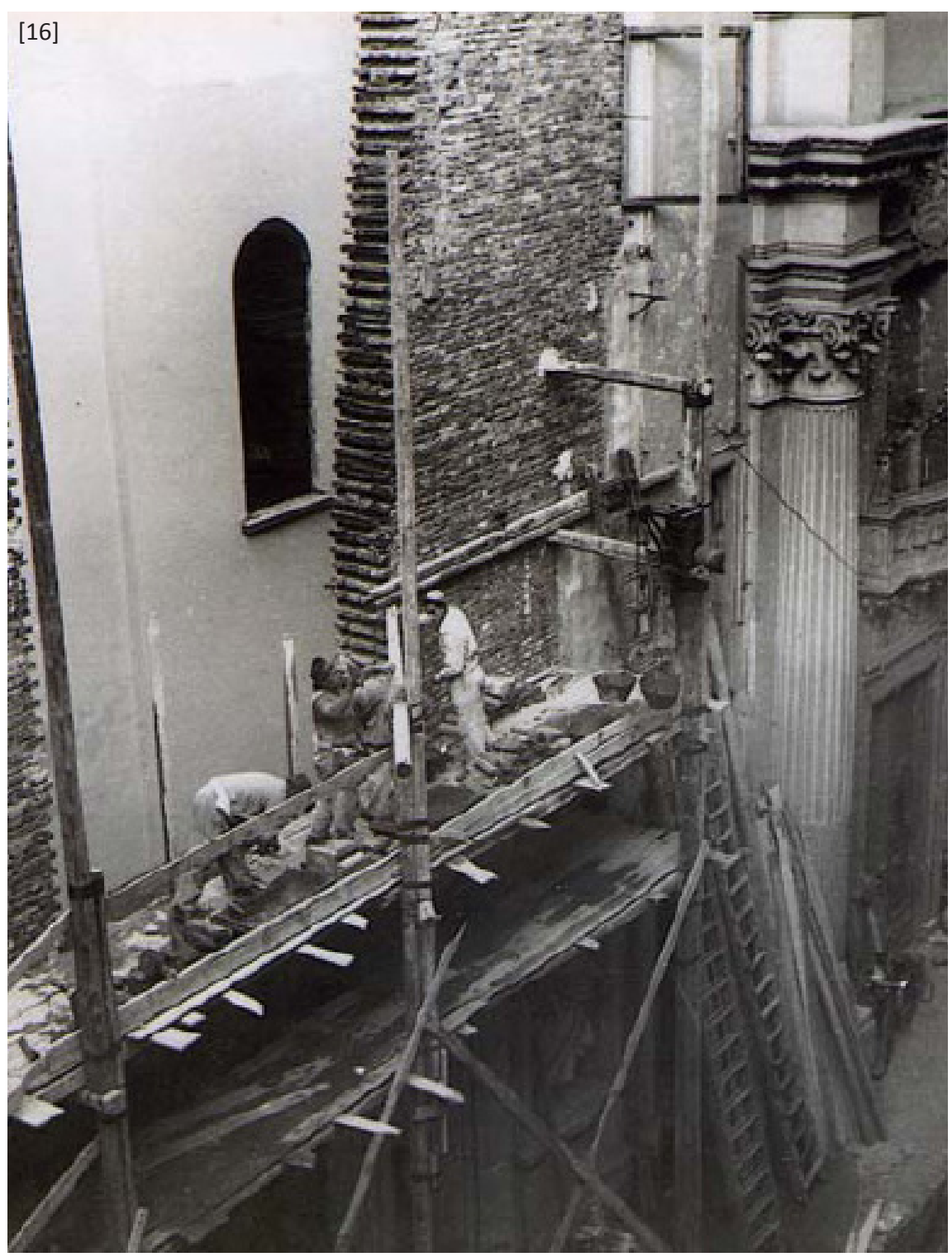

4 CERVELLATI, P.L.: L'ex oratorio di San Filippo Neri restituito alla città. Bolonia, Ed. Costa, 1999, p. 90
[16] Trabajos durante la restauración de 1949-1953. (CERVELLATI: 1999) 


\subsection{Necesidad de la intervención}

Desde el punto de vista constructivo, el edificio requería una intervención que recuperara el nivel de forjado desaparecido. Además, dada la precariedad de las cubiertas, también era necesaria su revisión para evitar filtraciones de agua. Y el estado ruinoso de las bóvedas exigía algún tipo de intervención de consolidación, al menos para frenar su deterioro.

Desde el punto de vista funcional, era necesario dotar al espacio de un nuevo uso que le devolviera la vitalidad. En ese sentido, la adquisición del edificio por parte de la Fondazione del Monte, para convertirlo en auditorio, suponía el empuje necesario para salvarlo del abandono. La adaptación al nuevo uso supondría toda una serie de necesidades funcionales que se deberían estudiar, para incorporarlas al edificio sin perjudicar su valor monumental.

Desde el punto de vista estético, el edificio requería una actuación que pusiera en relación el fuerte contraste existente entre las partes del edificio original, y las partes incorporadas durante los trabajos de restauración de mediados del siglo XX. Además las partes semiderruidas también habían pasado a formar parte de la estética del espacio y de la historia del edificio, por lo que podían interpretarse como elementos a mantener en el conjunto.

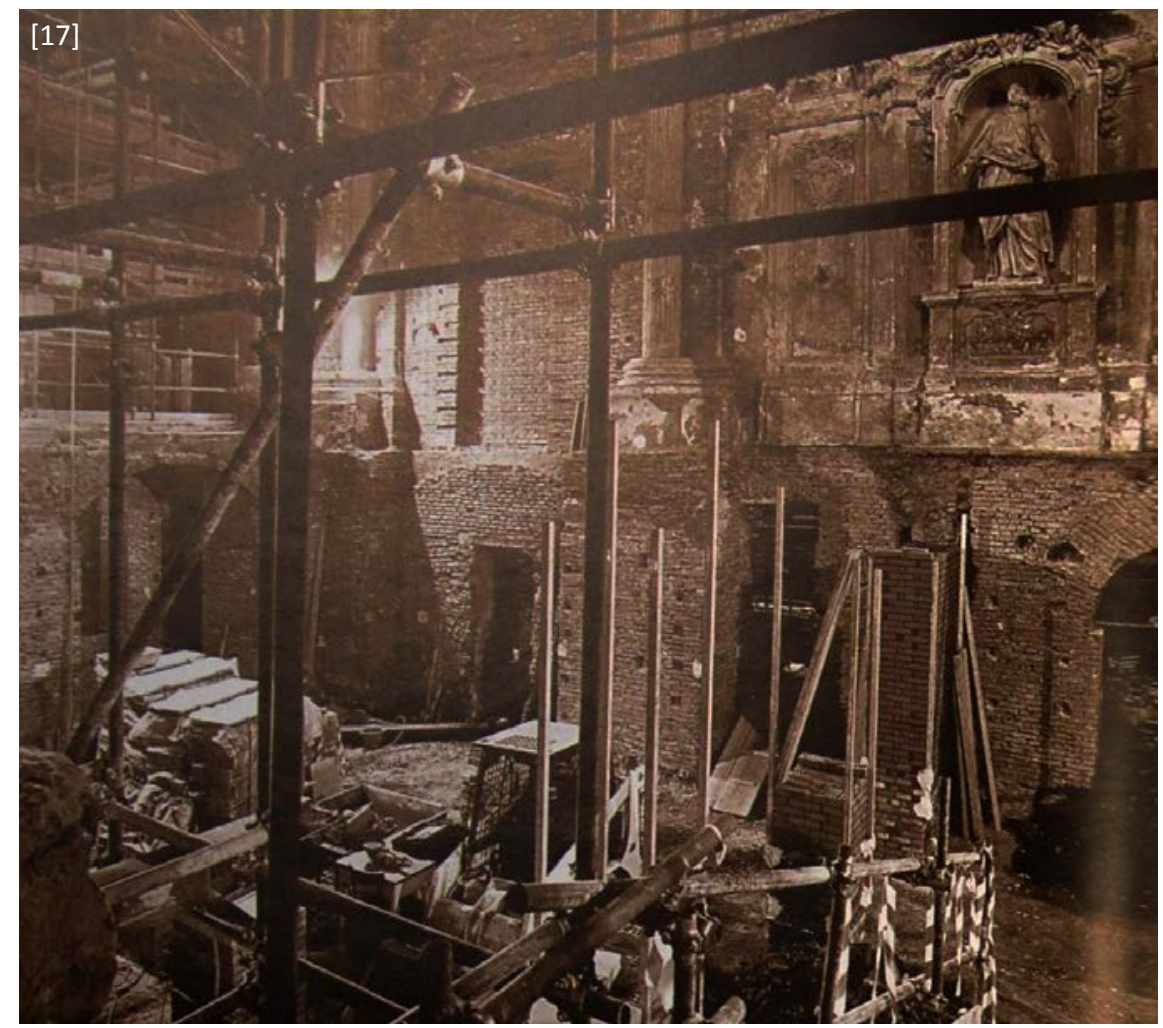




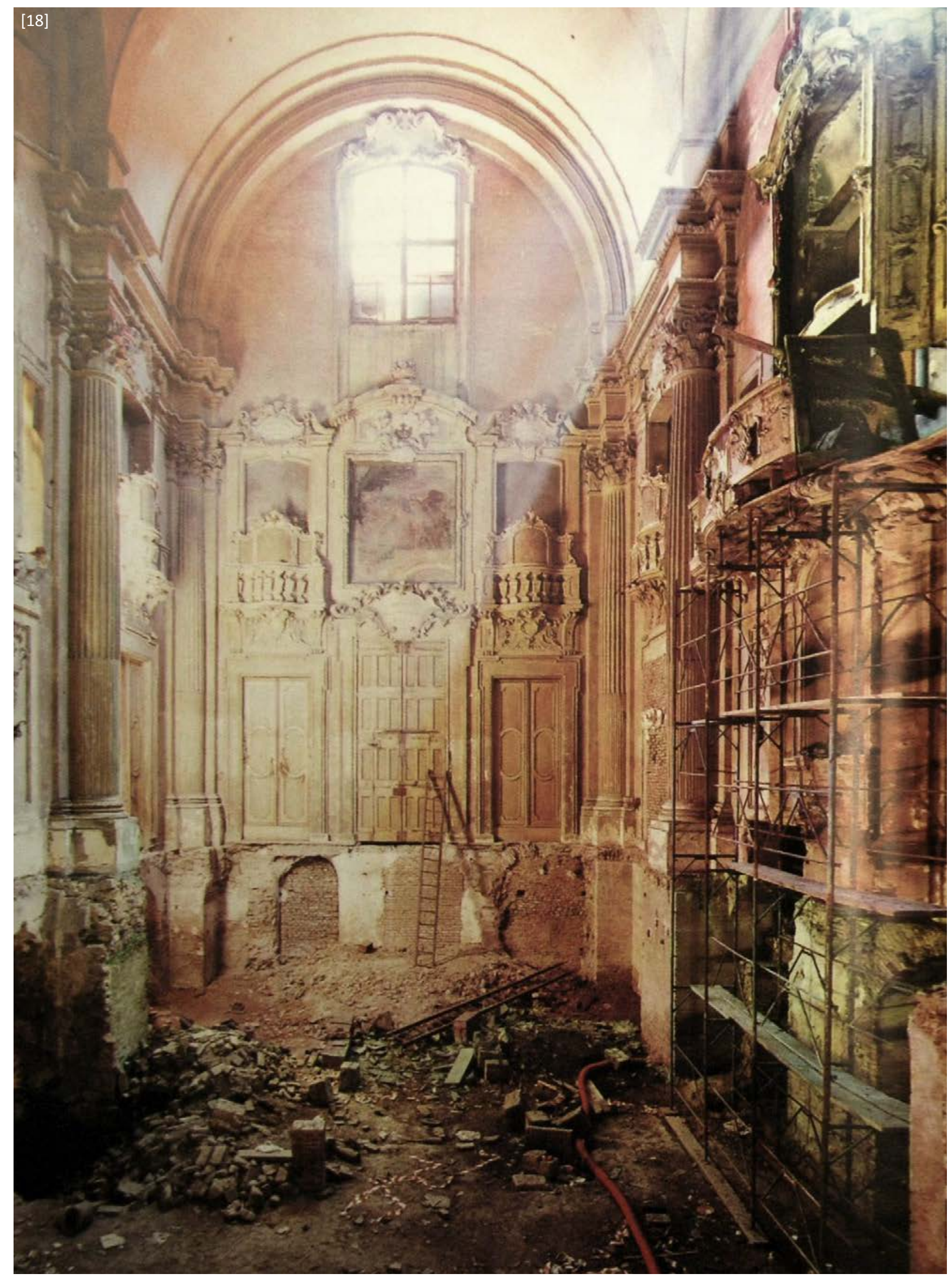




\section{EL ARQUITECTO RESTAURADOR}

5 El trabajo realizado en Bolonia queda patente en el libro: CERVELLATI, P.L. y SCANNAVINI, R.: Bolonia. Política y metodología de la restauración de los centros históricos. Barcelona, Ed. Gustavo Gili, 1976 (1973)

6 GAJA DÍAZ, F.: Teorías para la intervención urbanística en la ciudad preindustrial. Valencia, Ed. UPV, 2006 (1992), p. 36

7 CERVELLATI, P.L.: Op.Cit. 1999, p.89

[18] Visión del espacio de la nave hacia el acceso tras la restauración de Barbacci. (CERVELLATI: 1999)

[19] Pier Luigi Cervellati. (Verdiana Network: <www.verdiananetwork. com>)

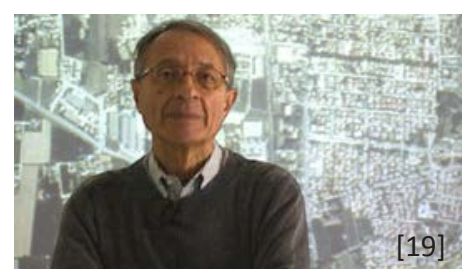

Pier Luigi Cervellati nace en Bolonia en 1936. Se gradúa como arquitecto en la Universidad de Florencia en el año 1961, donde trabaja como profesor ayudante entre 1963 y 1965. Entre 1965 y 1968 trabaja como profesor ayudante de la Escuela de Arquitectura de Venecia. En 1972 es nombrado responsable del departamento de urbanismo en la Universidad de Bolonia. Es profesor ordinario de urbanismo desde 1981 en el Instituto Universitario de Arquitectura de Venecia (IUAV), donde imparte la asignatura de "Recupero e riqualificazione urbana e territoriale".

Entre sus publicaciones cabe destacar las siguientes: Bolonia: Política y metodología de la restauración de centros históricos (1976), La città postindustriale (1984), La città bella (1991), L'arte di curare la città (2000).

\subsection{Experiencia como urbanista. El ripristino tipologico}

Desde 1964 hasta 1980 trabaja en Bolonia como asesor para la administración para llevar a cabo un proceso de restauración del centro histórico. Participa en la elaboración del "Piano di Edilizia Economica e Popolare" (PEEP), que considera al centro histórico no sólo como patrimonio cultural, sino también como un patrimonio socioeconómico que debía recuperarse para las clases populares que tradicionalmente lo habían ocupado. ${ }^{5}$

El eje del trabajo se centra en el estudio del diseño de las viviendas y la tipología de los edificios. Con ello se elabora una clasificación tipológicofuncional que deriva en una serie de sistemas de actuación que van desde la conservación integral hasta la reestructuración, proponiéndose incluso la demolición y reconstrucción. De los sistemas de actuación planteados, cabe destacar el "restauro filologico" para los edificios existentes y el "ripristino tipologico" para la reconstrucción de los espacios vacantes, con la finalidad de recuperar las tipologías de cada isolato [manzana]. ${ }^{6}$

Cervellati remarca la paradoja que existe al rechazarse la repristinación, por considerarla como un falso histórico, mientras que se acepta la falsificación de lo viejo mediante la construcción de nuevos edificios que imitan a los antiguos. En referencia a ello, señala que "en Bolonia la repristinación de algunas casas del siglo XVIII ha sido equiparado a una blasfemia. Una mutilación de la creatividad del arquitecto moderno. Incluso un acto inmoral". Pero Cervellati insiste en que "restaurar un centro histórico equivale a la repristinación de un monumento. No es un acto inmoral. Ni tampoco es un embalsamamiento". ${ }^{7}$ 


\subsection{Experiencia como arquitecto restaurador. Restitución reinterpretada de la obra}

En sus criterios de actuación sobre la arquitectura Cervellati refleja su respeto por la forma histórica. Sin embargo, tiene claro que "Ia restauración -precisamente porque pertenece a la esfera del proyecto- es siempre obra creativa". ${ }^{8}$ Por lo tanto, para Cervellati se debe combinar la lectura de la historia del monumento con la creatividad del proyecto arquitectónico.

Cervellati confronta las diversas visiones que se han tenido de la restauración a lo largo de la historia, pues entiende que cada una de ellas aporta luz sobre la manera de entender la intervención.

De los romanos, destaca la experiencia y capacidad que demostraban al copiar los edificios destruidos, aunque no aportaban invención proyectual. Del barroco, destaca el interés de actuaciones de artistas como Algardi o Bernini que transforman restos romanos en nuevas esculturas completas, aunque los resultados se considerarían hoy falsos históricos. De las "reconstrucciones interpretativas" de época napoleónica, destaca la búsqueda por recuperar la identidad y el carácter del edificio original. De Viollet-le-Duc, destaca el profundo estudio que realiza de las características tipológicas y constructivas del monumento en el proceso de intervención. ${ }^{9}$

A Cervellati le obsesiona la percepción que se tiene, a lo largo del siglo $X X$, del tema del "ripristino" [repristinación]. A base de ejemplos de actuaciones, establece argumentos a favor y en contra, buscando determinar el uso adecuado de este criterio.
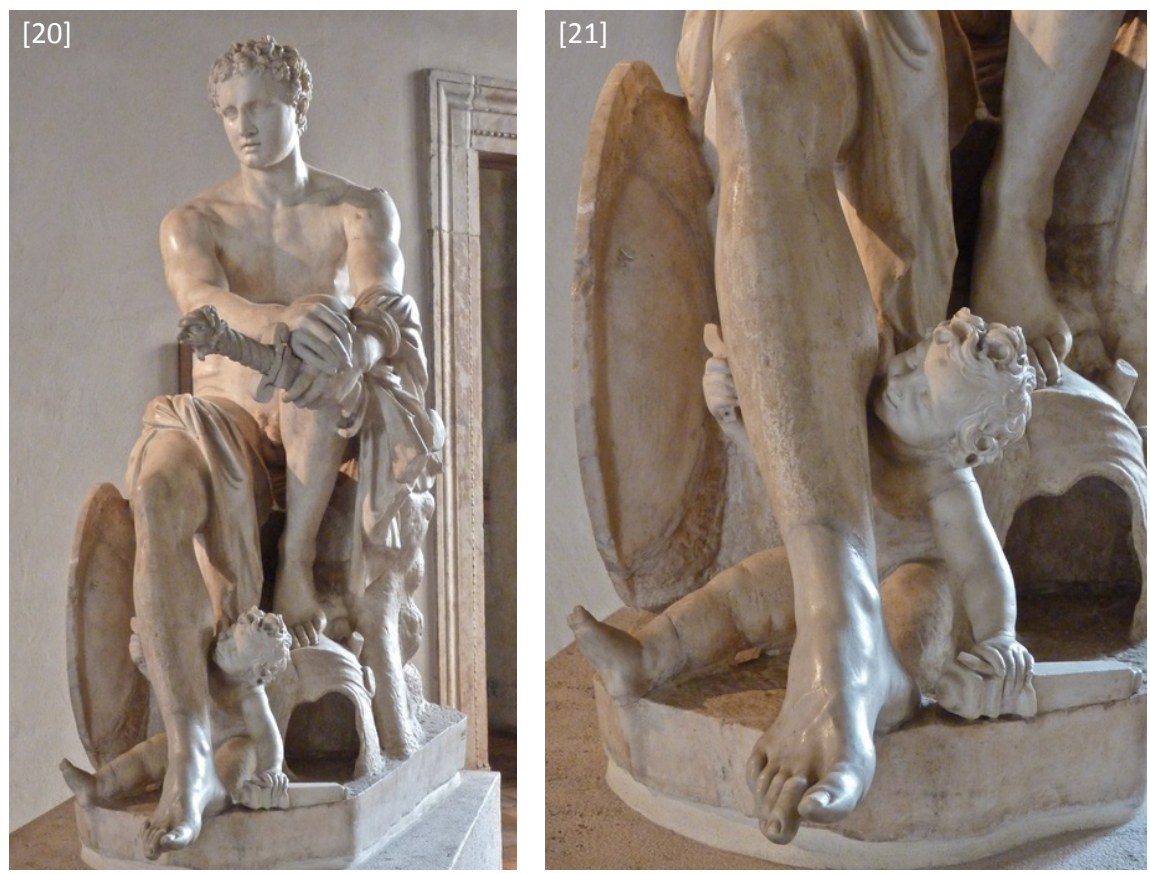

CERVELLATI, P.L.: Op. Cit. 1999, p.85

CERVELLATI, P.L.: Op. Cit. 1999, p.85 CERVELLATI, P.L.: Op. Cit. 1999,
[20 y 21] Imágenes del aspecto actual del Ares Ludovisi, restaurado por Gian Lorenzo Bernini en 1627. Se incorporan algunas partes perdidas: la nariz del dios, parte del escudo y parte de los pies, la cabeza de Eros y la empuñadura de la espada. (Fotografías de André Durand. En: André Durand Digital Gallery: $<$ durand-digitalgallery.com>) 
11 Italia, "Legge 1 giugno $1939 \mathrm{n}$. 1089. Tutela delle cose d'interesse artistico e storico" [Ley 1089/1939, de 1 de junio, de tutela de los bienes de interés artístico e histórico].

Disponible en: <http://www. edizionieuropee.it/data/html/1/ zn14_04_006.html\#_ftn1> [Consulta: 12-05-2012]

12 CERVELLATI, P.L.: Op. Cit. 1999, p.88

13 CeRVELLATI, P.L.: Op. Cit. 1999, p.90
Destaca la opinión que Roberto Longhi emite, en 1937, sobre la restauración de los frescos de Maso di Banco en la capilla Bardi de Florencia. Longhi ve la actuación demasiado "acabada", al eliminar todo rastro de daños con la pretendida intención de hacer más fluida la lectura de la obra, pero consiguiendo precisamente lo contrario, "la lectura, en lugar de más nítida, se vuelve más ambigua y confusa". ${ }^{10}$ Con ello Cervellati parece estar defendiendo como positiva la visión inacabada de la restauración, entendiendo que los daños constituyen las marcas de la historia a lo largo del tiempo, y por tanto la memoria del monumento.

Resalta también las indicaciones a favor de la respristinación contenidas en la ley 1089 del año '39,11 ley que fomentará la repristinación en las partes faltantes o destruidas, como método para recuperar el uso de los monumentos, algo muy necesario en la posguerra. $\mathrm{O}$ las opiniones de Giovannoni o Piacentini, que defienden el "proyecto en estilo" como método para generar una continuidad con el pasado (aunque no entienden que el "proyecto en estilo" sea equivalente a la repristinación). Sin embargo, Cervellati rechaza muchas de las obras realizadas en aquellos años, bajo el amparo de la repristinación: la eliminación del revestimiento para mostrar los muros de ladrillo, la eliminación de las capas barrocas, o la reelaboración en hormigón o acero de estructuras de madera.

Cervellati comenta el interés de algunas posturas intermedias -como la del arquitecto Alfredo Barbacci-que recomiendan un acercamiento "elástico" aceptando la repristinación de monumentos dañados por la guerra, pero evidenciando la nueva intervención. Pero recuerda que al amparo de este acercamiento se aplicarán todo tipo de criterios de actuación lo que supondrá una auténtica confusión en la lectura de los monumentos: ${ }^{12}$ criterios diversos como la reconstrucción integral, la consolidación estructural con métodos modernos, la conservación integral y la "limpieza estilística".

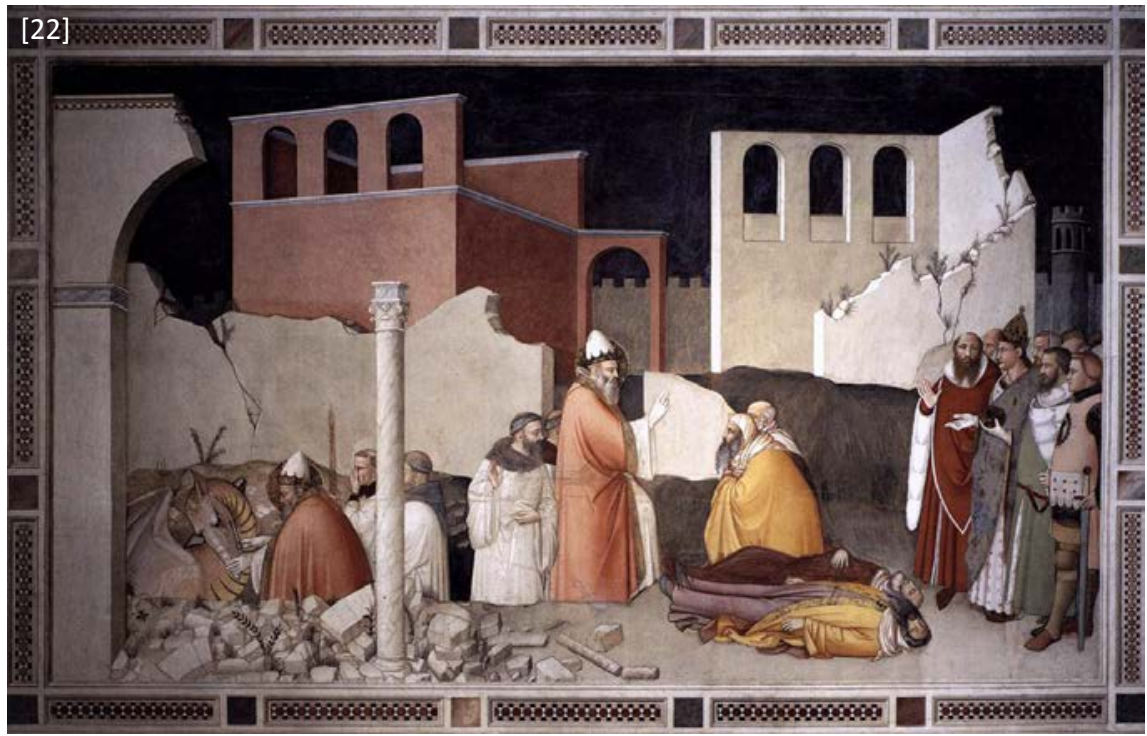

[22] Frescos de Maso di Banco en la capilla Bardi de Florencia. (Lib-Art: $<$ www.lib-art.com>) 
Cervellati advierte que a la vez que se tacha la repristinación de "inmoral", por razones de "dignidad histórica y claridad artística", se llevan a cabo nuevas construcciones que imitan los edificios históricos produciendo falsificaciones aún más indignas. Este es el caso de la reconstrucción del entorno del Ponte Vecchio, a ojos de Cervellati, una horrible falsificación de lo viejo y de lo nuevo.

Para Cervellati, estas diferencias de criterio aplicadas sobre los monumentos se deben, en parte, a la existencia de una valoración desigual del edificio en función de su estilo. Así lo indica en relación a la dura actuación y posterior abandono acaecido en el oratorio de San Filippo durante el siglo XX: "El oratorio de los Padres Filipinos no era valorado con el mismo criterio que los otros monumentos boloñeses, medievales o renacentistas. El pre-rococó de Torreggiani fue aún más censurado que el barroco". ${ }^{13}$

Finalmente Cervellati, agrupando todos estos conceptos, define lo que él entiende por "restauración", y su criterio de intervención en el oratorio:

“(...) Restauración - a parte de la consolidación, la limpieza de pátinas y polvo, con las oportunas repristinaciones en la medida que sean filológicamente adecuadas- se convierte en una actuación dirigida a restituir la obra dañada. Restauración por lo tanto entendida como restitución de una obra de arte mueble o de un monumento arquitectónico. Y para restituir es necesario entender y retomar el proyecto original. Evitando traspasar el límite entre restauración y reconstrucción interpretativa. ${ }^{14}$ El problema nace precisamente cuando las mínimas sustituciones progresivas no se han efectuado, o si te encuentras como en el ex oratorio de los Filipinos con que han pasado 50 años desde la suspensión de los trabajos. La reconstrucción no puede ser interpretativa. En muchos casos es necesario tener el coraje de consolidar aquello que queda y de mostrar la nueva intervención. Sin que esta última tergiverse lo existente" ${ }^{15}$

Con ello Cervellati defiende la restitución como el camino más adecuado para la restauración de un monumento. Restitución que requiere un exhaustivo análisis de la historia del monumento, pero que no puede limitarse a copiar lo que había, sino que requiere una reinterpretación que muestre su actualidad.
14 Cabe distinguir entre el concepto de "interpretación" y el de "reinterpretación". El concepto de "ricostruzione interpretativa" hace referencia a una reconstrucción que reproduce el original, en un sentido más próximo a la repristinación que a la reinterpretación. Esta diferenciación se entiende con claridad utilizando el ejemplo del director de orquesta, que interpreta una pieza musical que ha creado otra persona, mientras que una "reinterpretación" se entiende más bien como la creación de algo nuevo a través de la reelaboración de algo que ya existía, desde una postura creativa, que refleja la mirada particular y la manera de hacer de su creador.

15 CERVELLATI, P.L.: Op.Cit. 1999, p.89

[23] Visión del espacio de la nave hacia el altar tras la última restauración. (SERAFINI: L'industria delle construzioni, no 368, 2002, p. 47) 


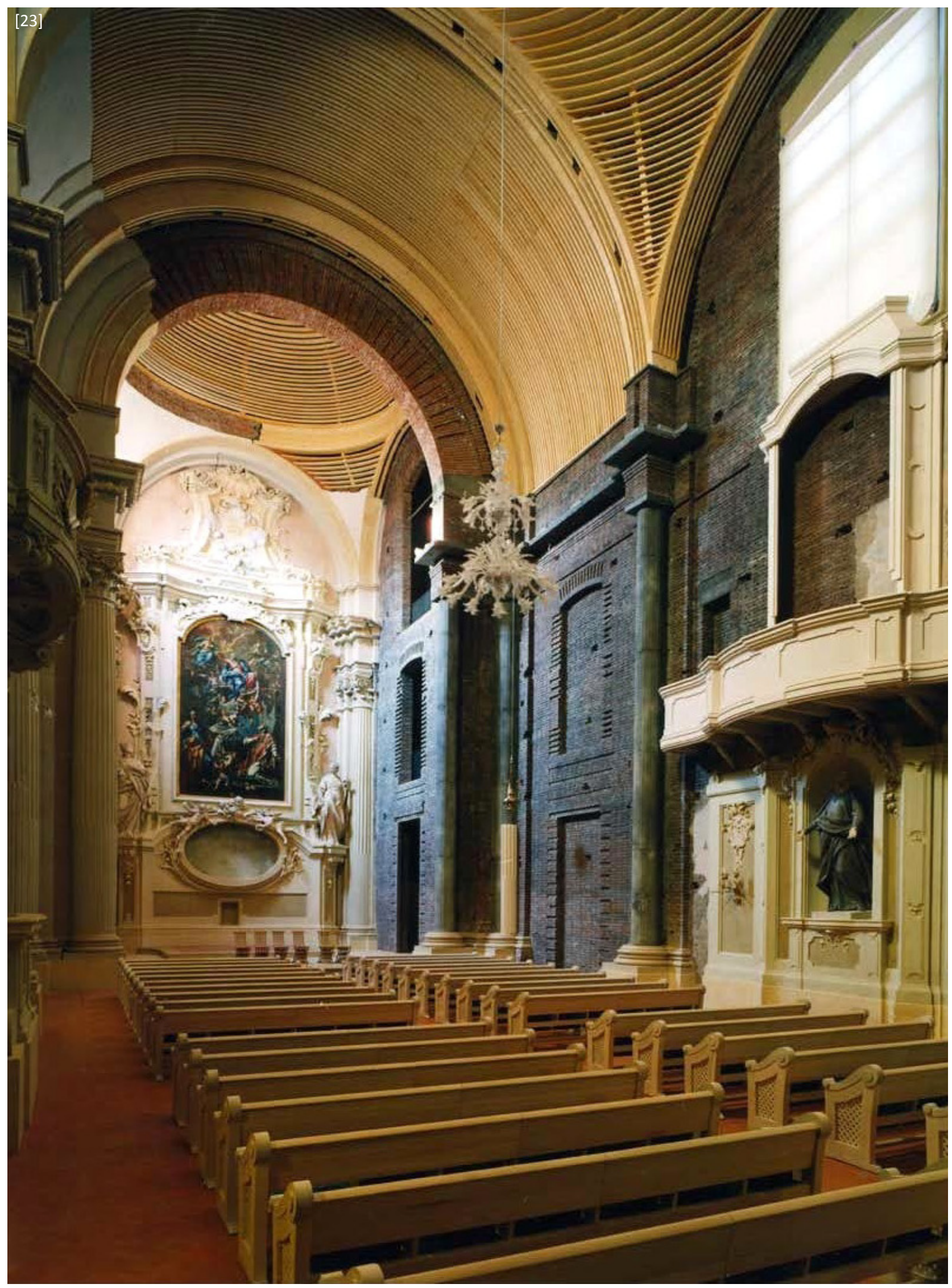




\section{DESCRIPCIÓN DE LA INTERVENCIÓN}

\subsection{Objetivos de la intervención}

El objetivo principal de la intervención es la restitución del monumento, y su adaptación a un nuevo uso para asegurar su pervivencia en el tiempo. Para ello, Cervellati se plantea varios caminos posibles.

Una opción era la repristinación integral. Tal vez el camino más fácil de recorrer, pero cuya aplicación comportaba la demolición de la restauración realizada por Barbacci en 1949, ya que "las columnas y las ménsulas de hormigón armado chocaban con la reelaboración de los estucos y muros" ${ }^{16}$ Por otro lado, la hipótesis de una repristinación integral -aunque hubiese sido posible, ya que Barbacci había dejado margen geométrico para la restitución de los revestimiento- para Cervellati se presentaba como impracticable, tanto por la gran extensión de las zonas decoradas a reconstruir, como por la calidad artística del modelo de referencia. A ello se sumaba que la eventual repristinación habría ocultado la sabiduría constructiva de los trabajos realizados en la primera restauración. Aunque quizá la verdadera razón para descartar la opción de una repristinación integral haya sido evitar la creación un "falso histórico".

Otra opción era continuar la restauración iniciada por Barbacci. Pero en este caso Cervellati encuentra una justificación en que "no existen documentos que ilustren cuales eran los criterios que se intentaba perseguir". Si bien en otros monumentos restaurados Barbacci emplea el criterio del restauro filológico, en este caso "el uso del hormigón hace presuponer una intervención en la que habrían estado, si no explícitas, si que ciertamente se habrían destacado cromáticamente o materialmente, las partes construidas 'ex novo'". ${ }^{17}$

Finalmente, la solución adoptada busca por un lado no eliminar ni completar arbitrariamente la restauración seguida por Barbacci, y por otro lado no alterar la obra rococó con "pseudo repristinaciones o con soluciones intermedias". ${ }^{18}$ La decisión de mantener la reconstrucción posbélica realizada por la soprintendenza responde al respeto por una fase de la historia del monumento, testimonio del carácter dramático de la guerra. Con más razón aún si se observan las restauraciones realizadas en otros monumentos, a menudo bajo criterios de "repristinación integral", de tal manera que "medio siglo después en Bolonia no quedan trazas de las bombas, de las heridas y de las lesiones que provocaron".19

La reconstrucción de los elementos destruidos por la guerra, así como la construcción de nuevos elementos derivados de las necesidades funcionales, se proponen mediante un lenguaje moderno, de tal manera que la restitución del monumento se entienda como la suma de partes añadidas a lo largo del tiempo. Un collage de actuaciones que recomponen el edificio expresando de manera explícita sus fases históricas, es decir

[24] Redibujo de la planta sótano y la sección longitudinal a partir de los planos del proyecto de intervención de Cervellati.

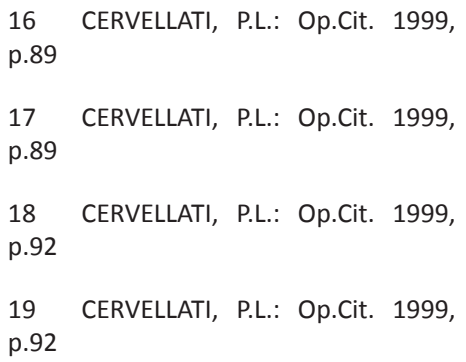




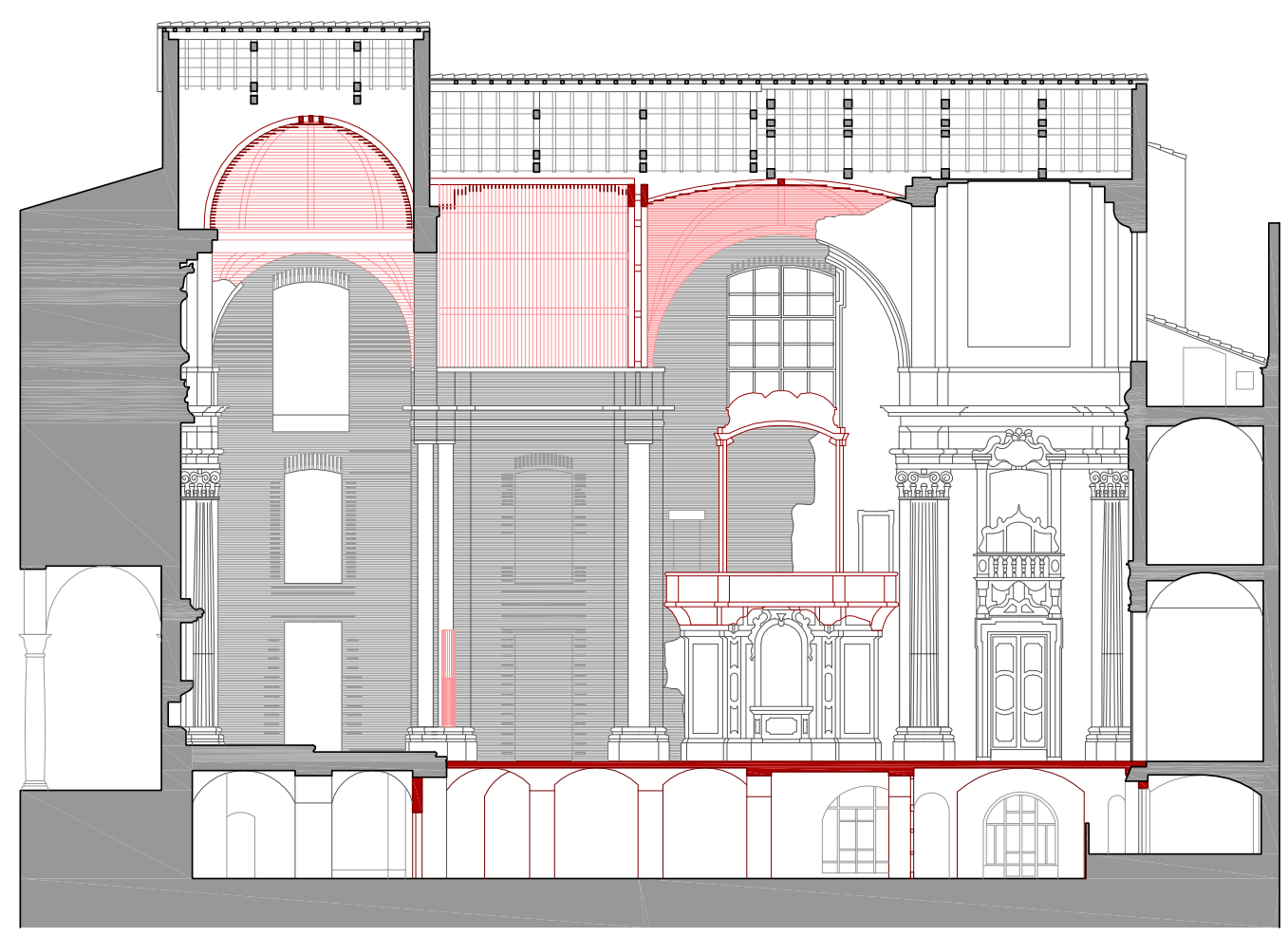

Sección Longtudinal
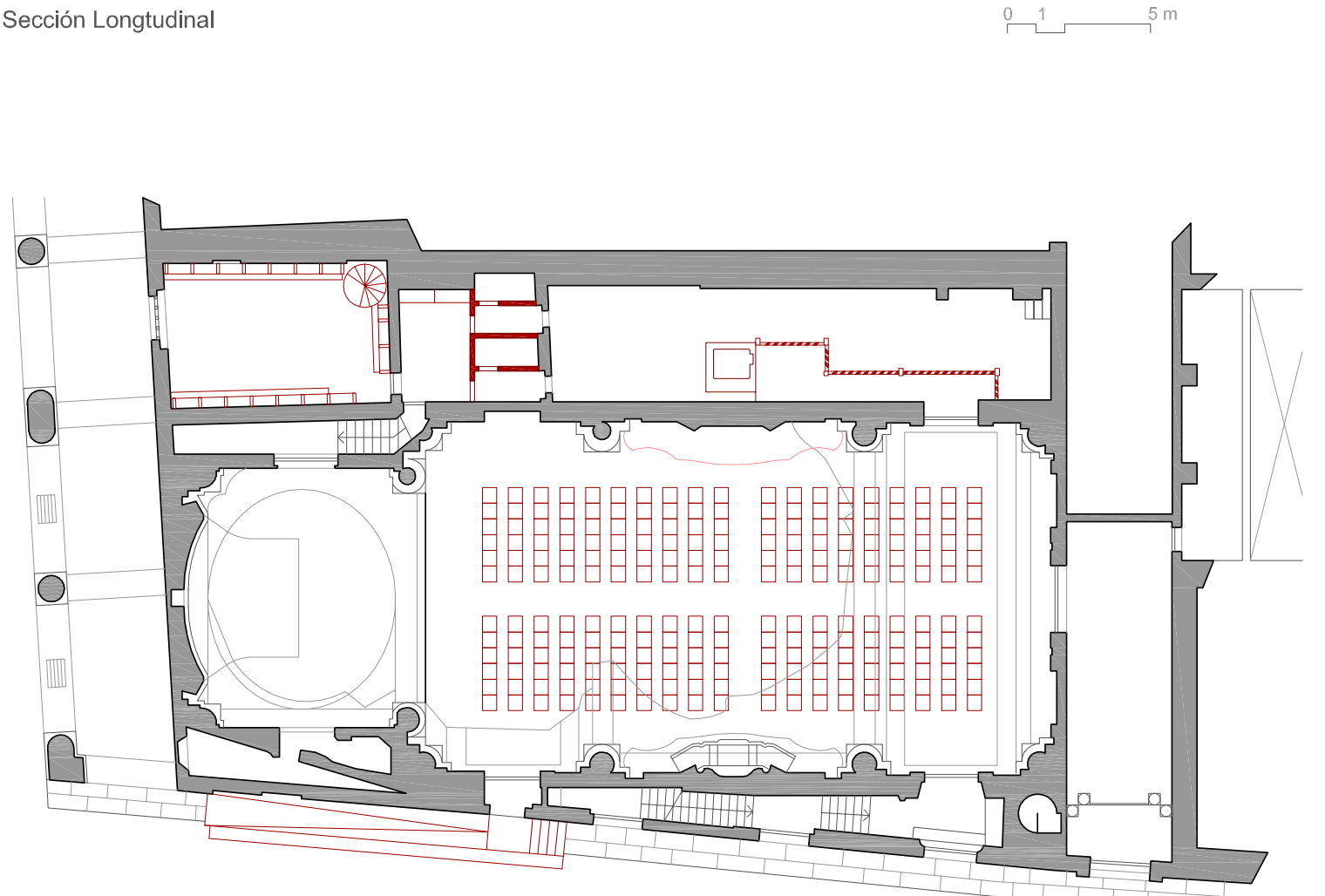

Planta Baja 
exponiendo de manera clara y didáctica los estratos de la historia del monumento, tanto los que son derivados de acciones destructivas -los bombardeos- como los que son fruto de intervenciones pensadas y ejecutadas con la finalidad de restaurar o restituir los daños. De este modo, la actuación de Cervellati se encadena en esta dinámica, planteándose como una nueva fase en la historia del edificio.

\subsection{Programa funcional}

La intención funcional de la actuación es la de adaptar el edificio al uso de auditorio. Esta adaptación se simplifica significativamente gracias a que el uso previsto es muy compatible con su uso original como oratorio, pero ello no exime de realizar algunas actuaciones para adaptarlo a las nuevas necesidades.

Además de la intervención en el espacio de la sala, se prevén otras actuaciones fuera del recinto principal del oratorio, para dotar al conjunto de un acceso para minusválidos, servicios higiénicos, archivo, biblioteca, oficinas y otros espacios de apoyo para las actividades que se desarrollan en la sala. Para ello se hace uso de la antigua sacristía, de la planta semienterrada, del patio presente junto al muro norte del edificio, y del espacio ubicado sobre el acceso, en la planta primera, en el que se actúa recuperando una antigua loggia.

Para mejorar la accesibilidad se plantean dos actuaciones. Por una lado, se coloca una rampa que permite salvar el desnivel existente entre la cota de calle y la cota de la sala del auditorio, que se adosa al edificio ocupando parte de la vía pública. Por otro lado, se coloca un ascensor que da acceso tanto a la planta inferior, como al nivel superior, a una cota desde la que se accede a los balcones y demás espacios. El ascensor se sitúa en el patio interior, adosado al muro lateral de la sala y acompañado de las circulaciones horizontales necesarias. La colocación de esta nueva pieza en el patio interior, contiguo a la nave, resuelve eficazmente la necesidad de conexión sin alterar la espacialidad de la sala, optando por "sacrificar" en cierto modo el patio, confiriéndole un cierto carácter de espacio de servicio.
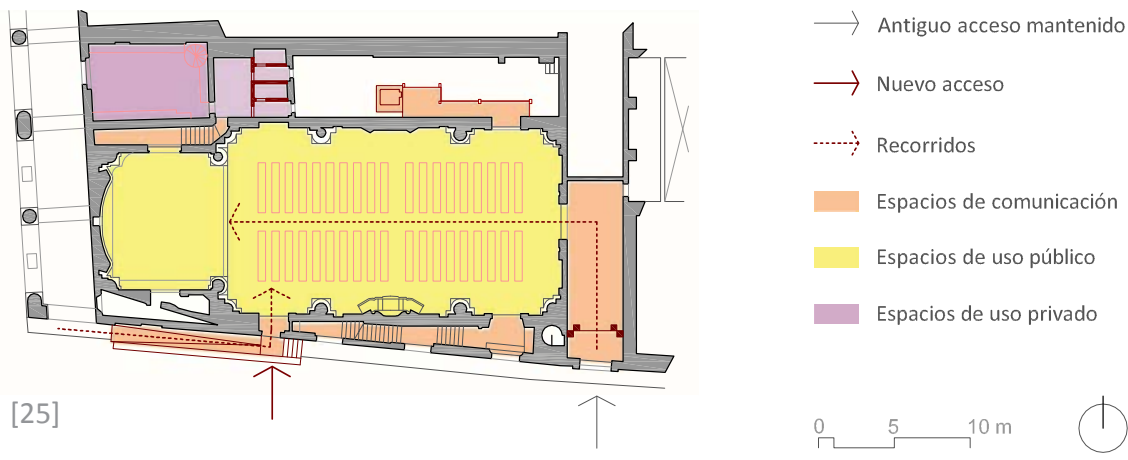

[25] Esquema de usos.

[26 y 27] Loggia situada en la planta primera, reabierta durante la intervención, que se convierte en local de apoyo para las actividades que se llevan a cabo en el auditorio y nueva biblioteca situada en el interior de la antigua sacristía, que se estructura en tres niveles de estanterías, aprovechando la altura libre de la sala. (SIMONELLI. En: BORIANI: 2008, p. 309)

[28] Vista del patio tras la intervención de Cervellati. (CERVELLATI: 2009)

[29] Redibujo a partir de los planos del proyecto de intervención de Cervellati.
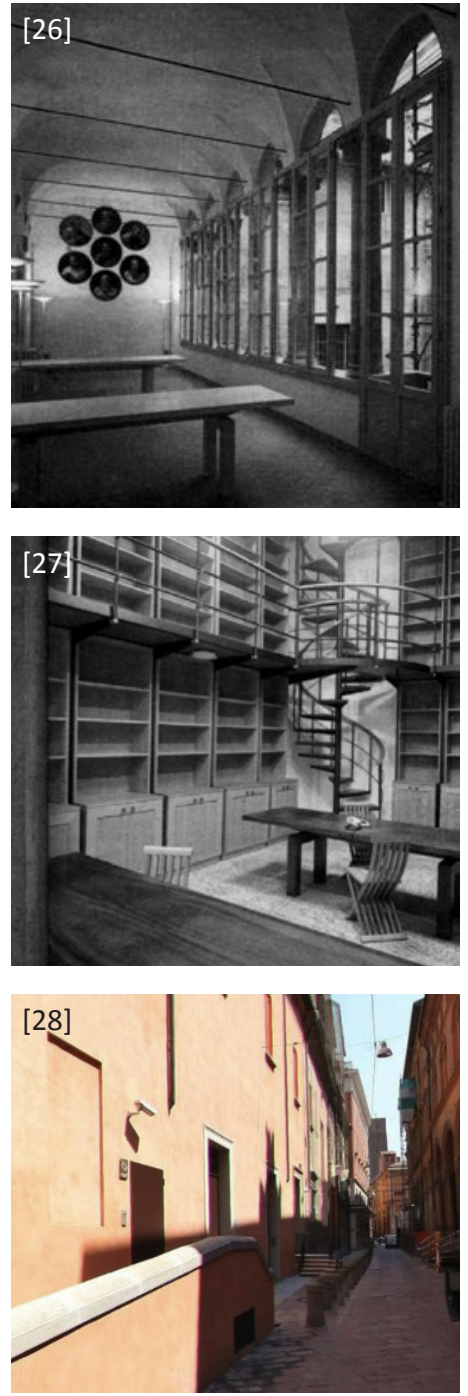


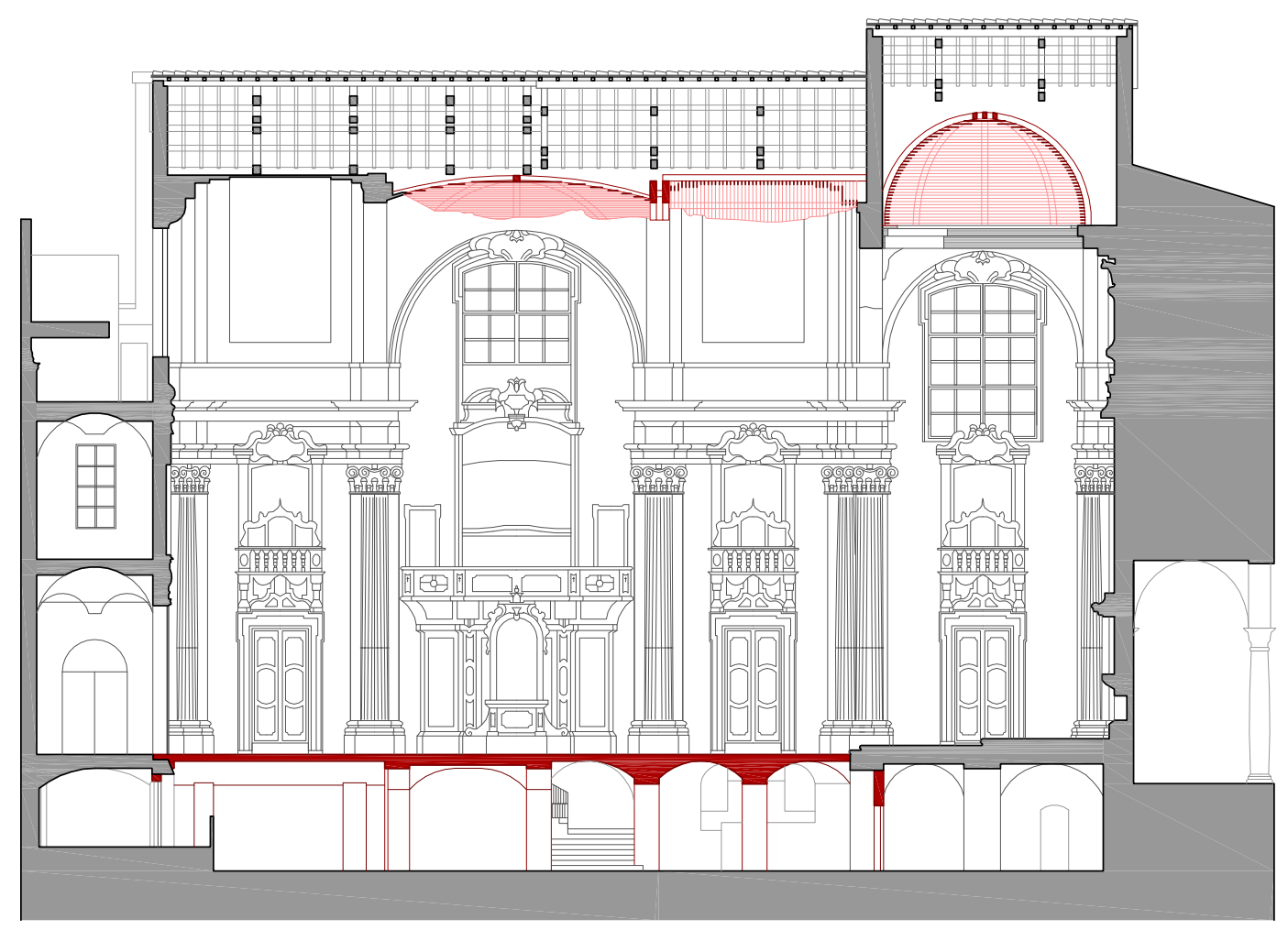

Sección Longtudinal
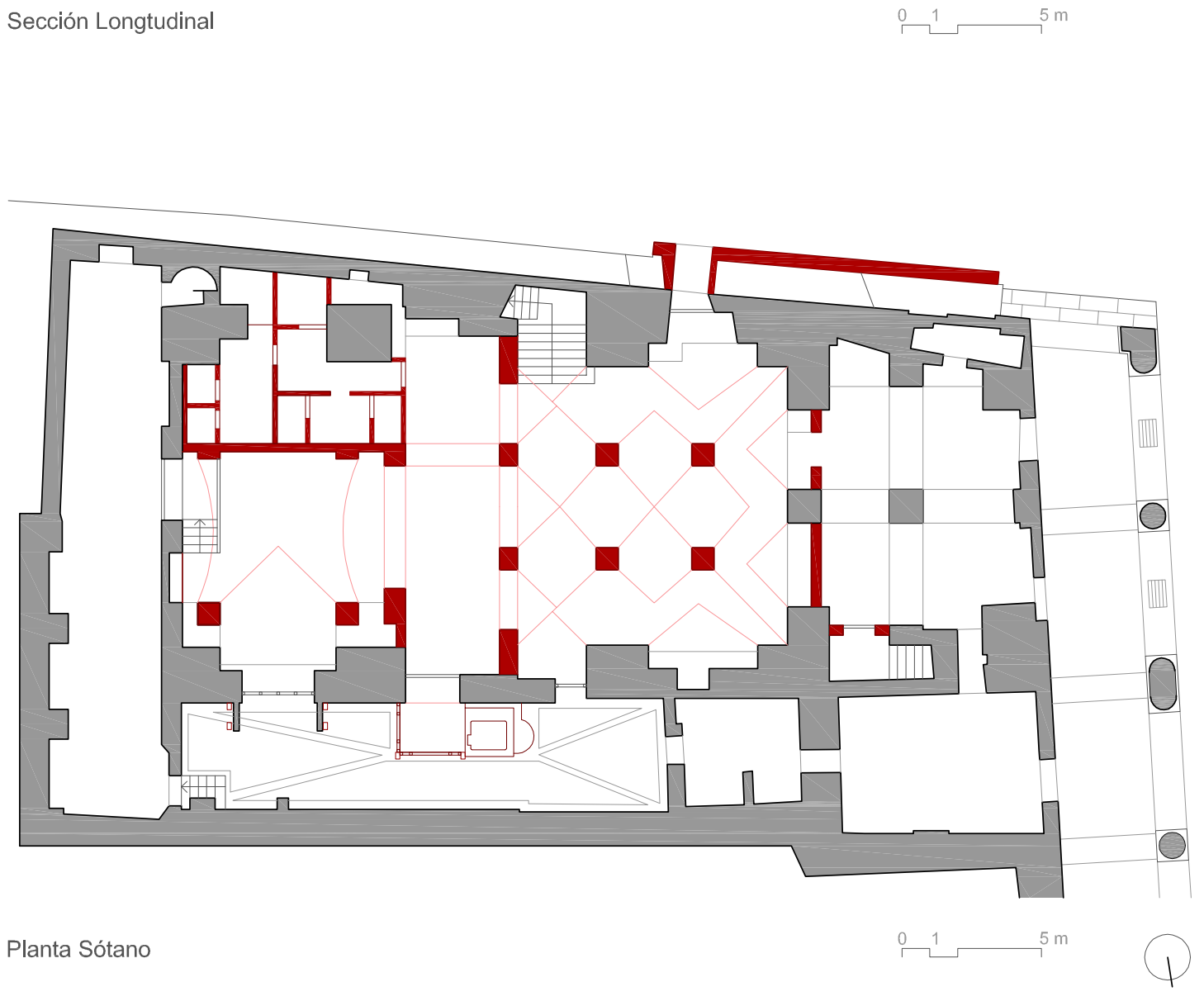


\subsection{Forma, espacio y luz}

La restitución del monumento se plantea completando la forma de las partes faltantes, para así recuperar la envolvente espacial interior del edificio.

La actuación sobre la parte original del monumento, proyectada por Torregiani, busca devolverle su esplendor original. El lenguaje pre-rococó, con un elaborado trabajo en la ornamentación, crea un interesante juego de luces y sombras, dentro de un ambiente de claridad y unidad. Por lo que la actuación se dirige, por un lado, a la restauración del ornamento dañado, con la máxima calidad artesanal posible, y por otro lado, a la recuperación de la entrada de luz natural a través de los cuatro grandes ventanales existentes, reabriendo el ventanal de la fachada norte, que había sido cegado en la reconstrucción anterior.

La actuación sobre la restauración realizada en el año 49, busca atenuar sutilmente su fuerte presencia en el espacio, cuyo carácter tosco contrasta con el refinamiento del rococó. Su aspecto inacabado, como en proceso de construcción, se trata de reducir mediante la inserción de elementos puntuales, situados estratégicamente, que devuelvan la terminación desaparecida. Para ello superpone, sobre una de las columnas de hormigón, una reproducción de un tramo del relieve acanalado de las columnas originales. En la misma línea, en la zona del coro, reconstruye el balcón desaparecido, restableciendo la simetría compositiva mediante una reproducción fiel del balcón original, cuyo modelo pervive en el coro situado justo enfrente, pero simplificando su decoración al prescindir de todas las figuras escultóricas que conforman su ornamentación.

La actuación sobre las bóvedas desaparecidas, busca hacer de enlace entre la parte original que permanece y la reconstrucción inacabada de 1949. La gran dimensión de la pérdida requiere una decisión de proyecto, y por tanto de aplicación de una estrategia de intervención, que permita recuperar la espacialidad del monumento. Cervellati opta por conservar los restos y completar los faltantes de manera esencializada, en lugar de derribar lo que quedaba de las bóvedas y reconstruirlas totalmente nuevas.
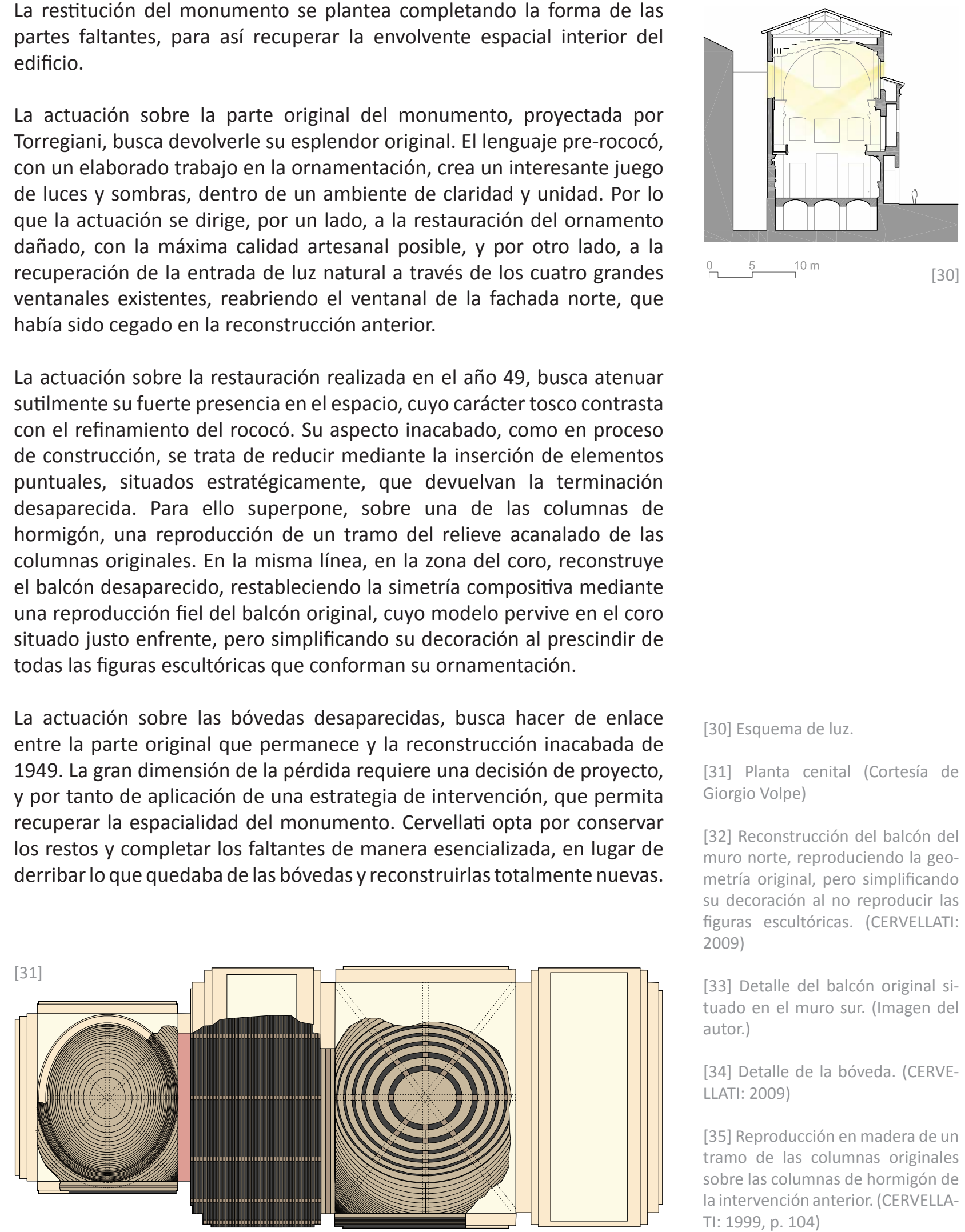

[30] Esquema de luz.

[31] Planta cenital (Cortesía de Giorgio Volpe)

[32] Reconstrucción del balcón del muro norte, reproduciendo la geometría original, pero simplificando su decoración al no reproducir las figuras escultóricas. (CERVELLATI: 2009)

[33] Detalle del balcón original situado en el muro sur. (Imagen del autor.)

[34] Detalle de la bóveda. (CERVELLATI: 2009)

[35] Reproducción en madera de un tramo de las columnas originales sobre las columnas de hormigón de la intervención anterior. (CERVELLATI: 1999, p. 104) 

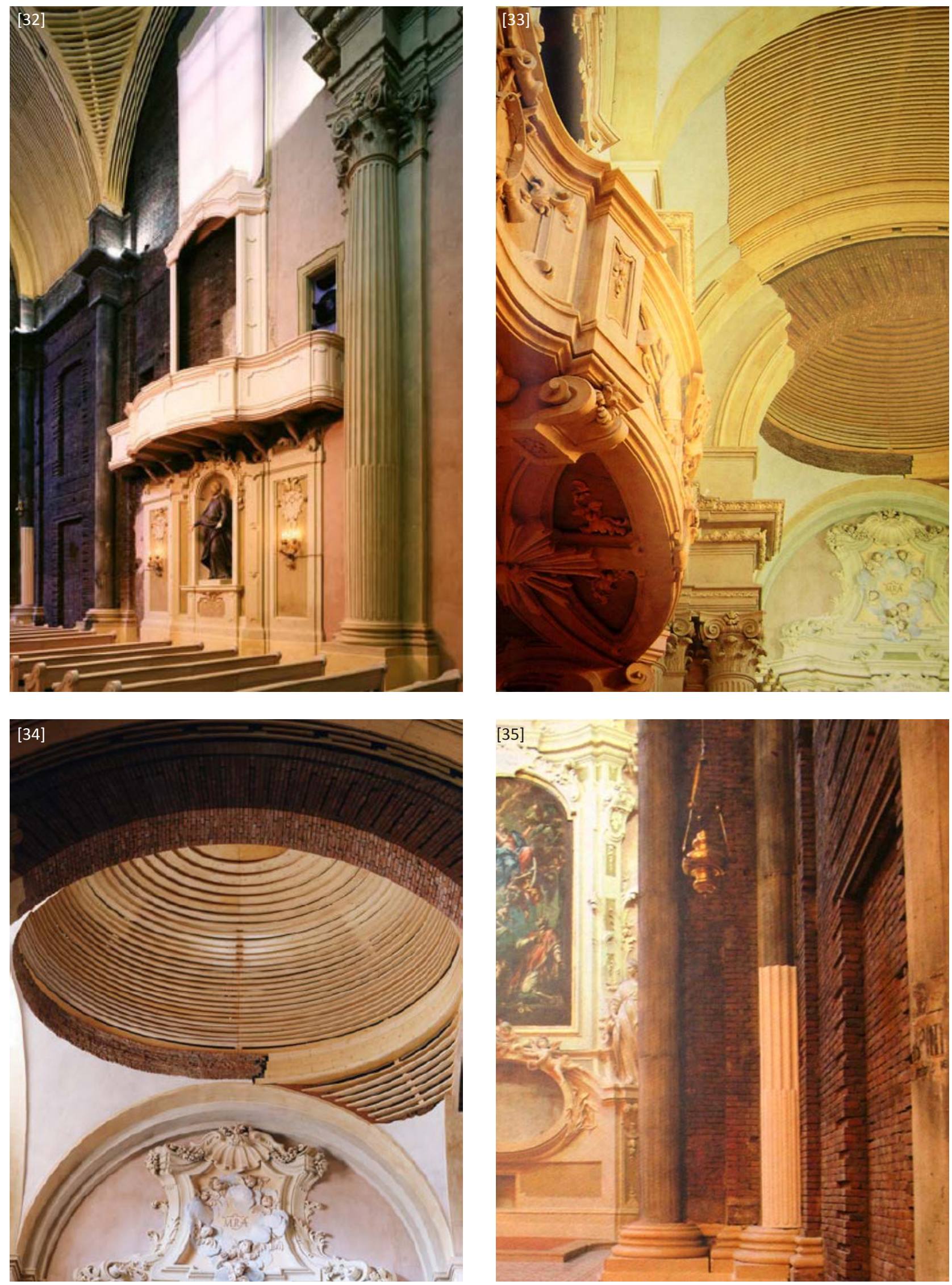
Con ello Cervellati no busca tanto la idea de completar la integridad de lo que falta, sino solamente las trazas necesarias para entender la forma de los elementos, de tal manera que la actuación permita mantener la lectura de la ruina y por tanto de la pérdida que sufrió en el pasado, evocando con lo nuevo el antiguo vacío.

La forma de los nuevos elementos se plantea como una nueva fase en la historia del monumento, capaz de dialogar con las dos realidades preexistentes, pero siendo fiel al lenguaje de su tiempo. La solución adoptada reconstruye las bóvedas y cúpula desaparecidas mediante la definición de una envolvente calada que recompone la geometría, pero que se retranquea respecto a la cara de acabado original, constituyendo una imaginaria estructura de soporte del material de revestimiento. Efecto que se ve reforzado al entrar en contacto con los restos de las bóvedas originales, cuya presencia hace aún más evidente la ausencia de las partes desaparecidas.

La restitución espacial se completa con la reconstrucción del nivel de suelo original. En este caso se opta por realizar una repristinación del forjado, recuperando la forma original del elemento. Este criterio se aplica por entenderse que su desaparición no se debe a los daños producidos por el bombardeo del 44, sino a las actuaciones llevadas a cabo por Barbacci en el 49 , tal y como queda documentado en las fotografías de 1997, previas a la intervención de Cervellati.

Por último, para permitir el acceso a personas con minusvalía, se han colocado en el patio un ascensor y unas pasarelas de conexión. Esta nueva pieza se ha ideado bajo el criterio de la clara independencia respecto a la estructura muraria original, mediante una solución ligera que remite a estructuras tradicionales adosadas, y con una clara componente horizontal. Las reducidas dimensiones del patio y su ubicación en el interior de la manzana, hacen pasar desapercibida esta actuación.

La adaptación del espacio de la antigua sacristía, para transformarlo en biblioteca, se resuelve también con los mismos criterios de ligereza mostrados en el conjunto de la intervención.
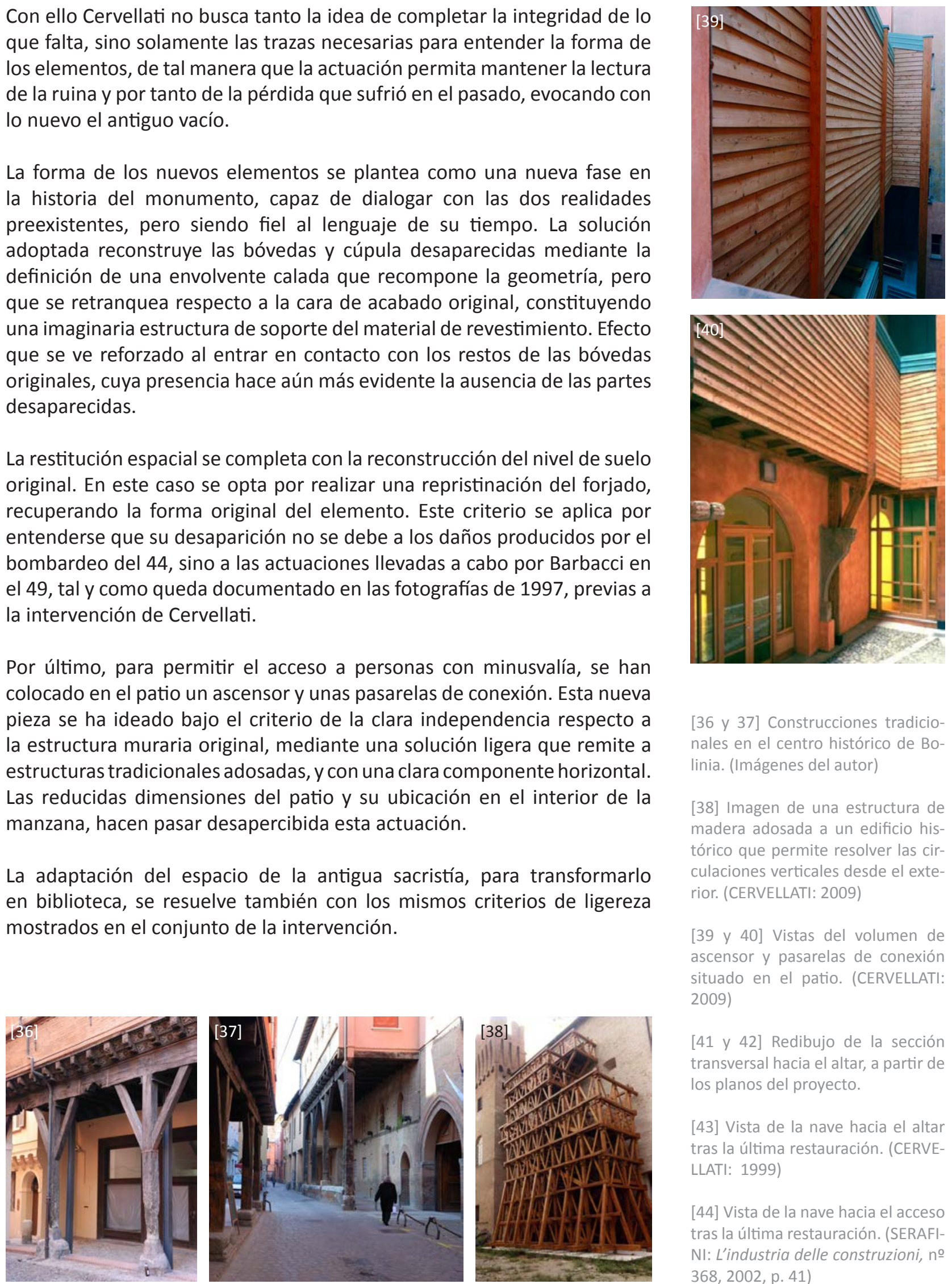

[36 y 37] Construcciones tradicionales en el centro histórico de Bolinia. (Imágenes del autor)

[38] Imagen de una estructura de madera adosada a un edificio histórico que permite resolver las circulaciones verticales desde el exterior. (CERVELLATI: 2009)

[39 y 40] Vistas del volumen de ascensor y pasarelas de conexión situado en el patio. (CERVELLATI: 2009)

[41 y 42] Redibujo de la sección transversal hacia el altar, a partir de los planos del proyecto.

[43] Vista de la nave hacia el altar tras la última restauración. (CERVELLATI: 1999)

[44] Vista de la nave hacia el acceso tras la última restauración. (SERAFI$\mathrm{NI}$ : L'industria delle construzioni, $\mathrm{n}$ ㅇ 368, 2002, p. 41) 


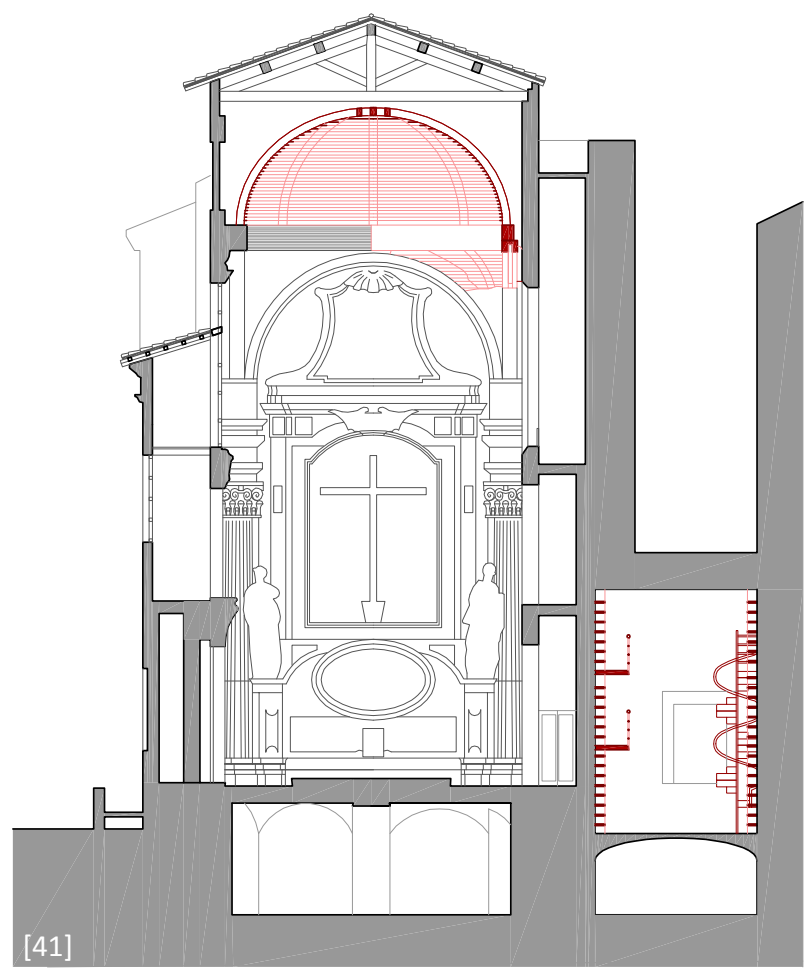

Sección transversal 02

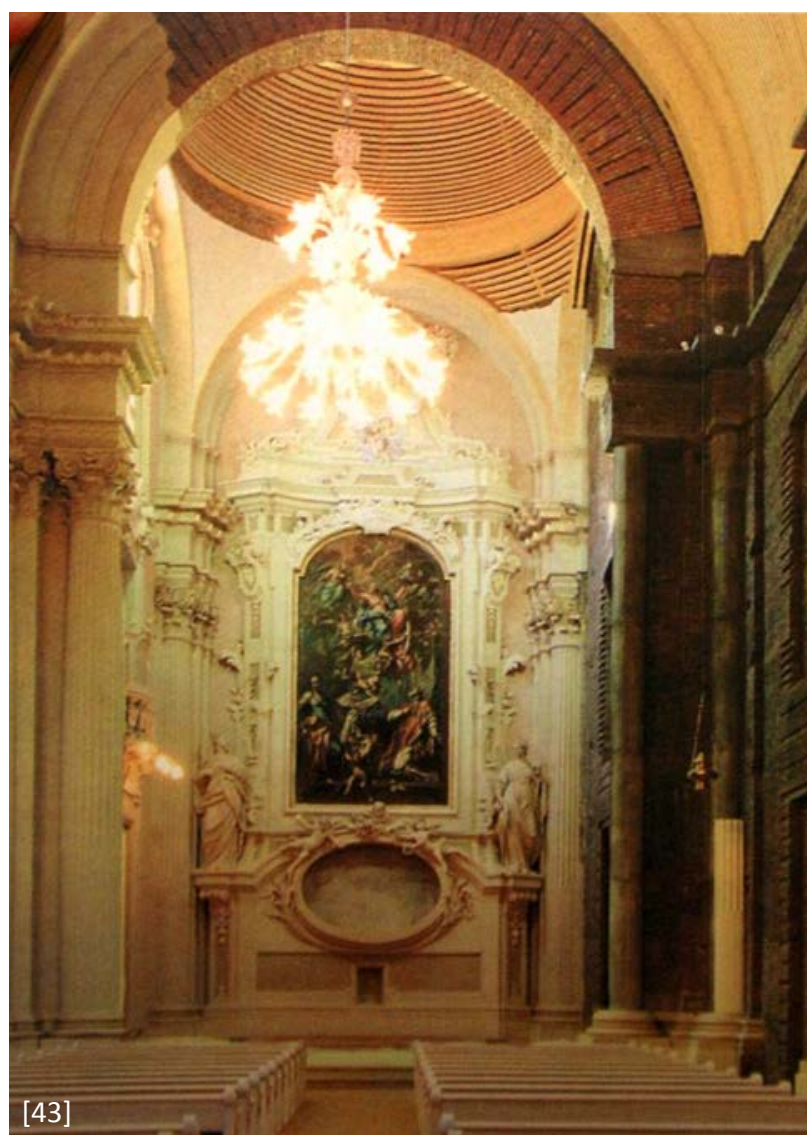

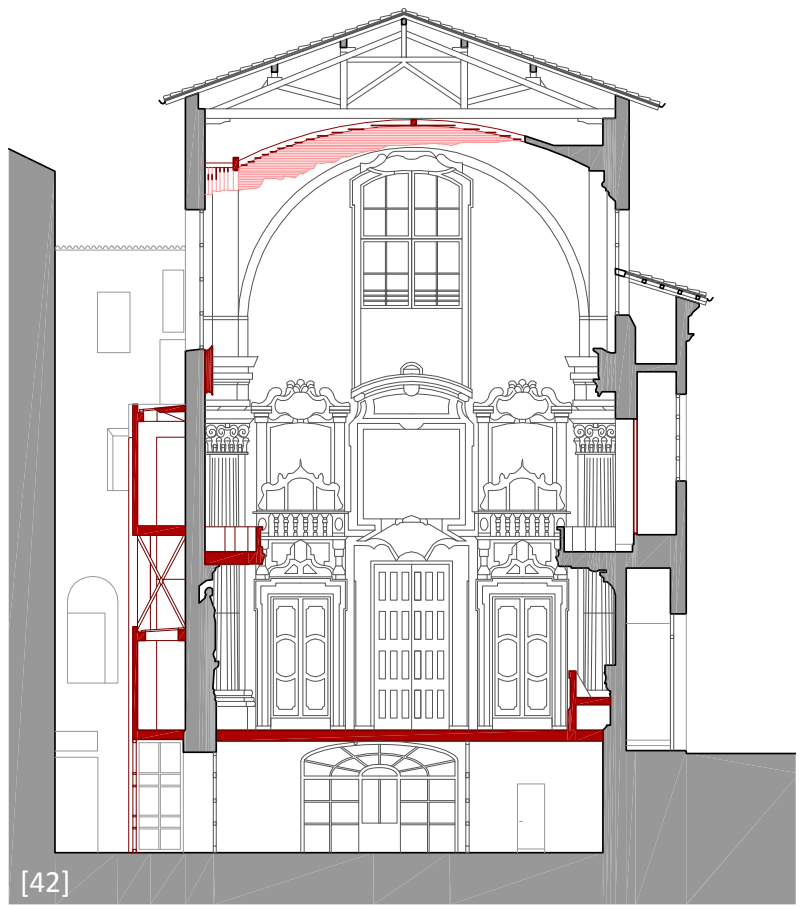

Sección transversal 01

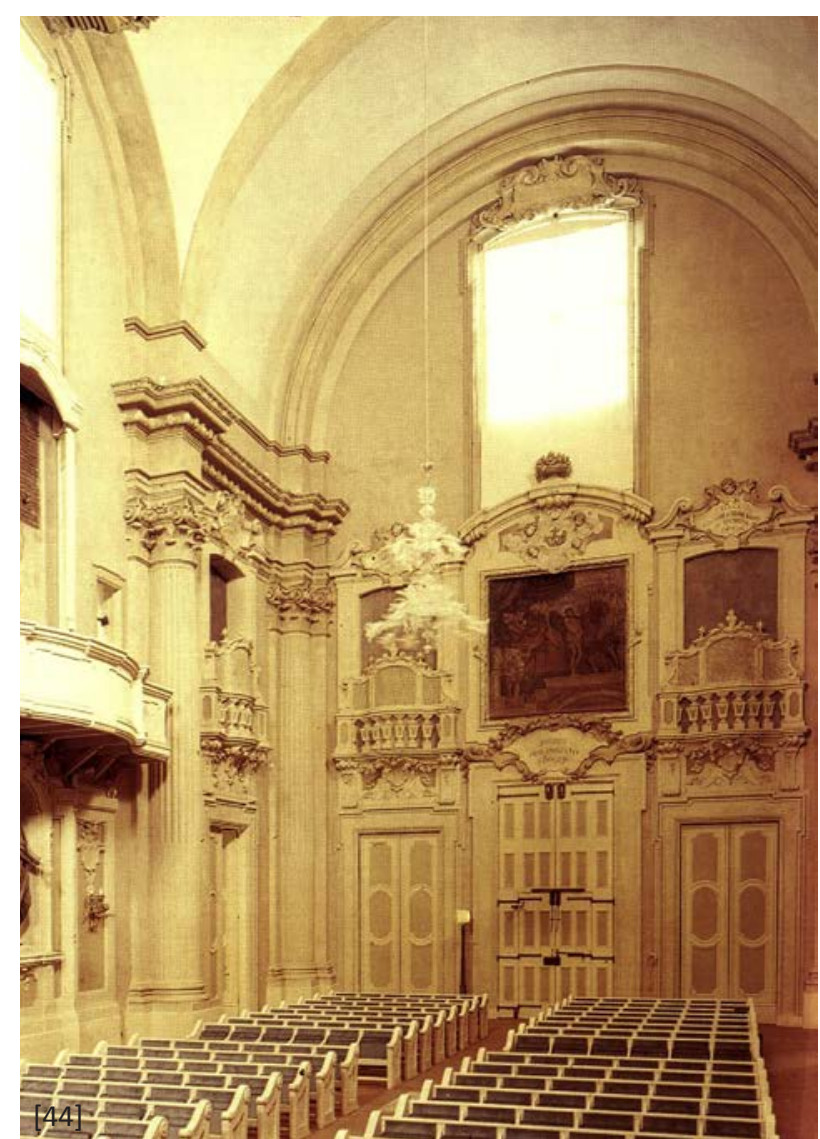

Oratorio di San Filippo Neri. Bolonia.1997-1999 

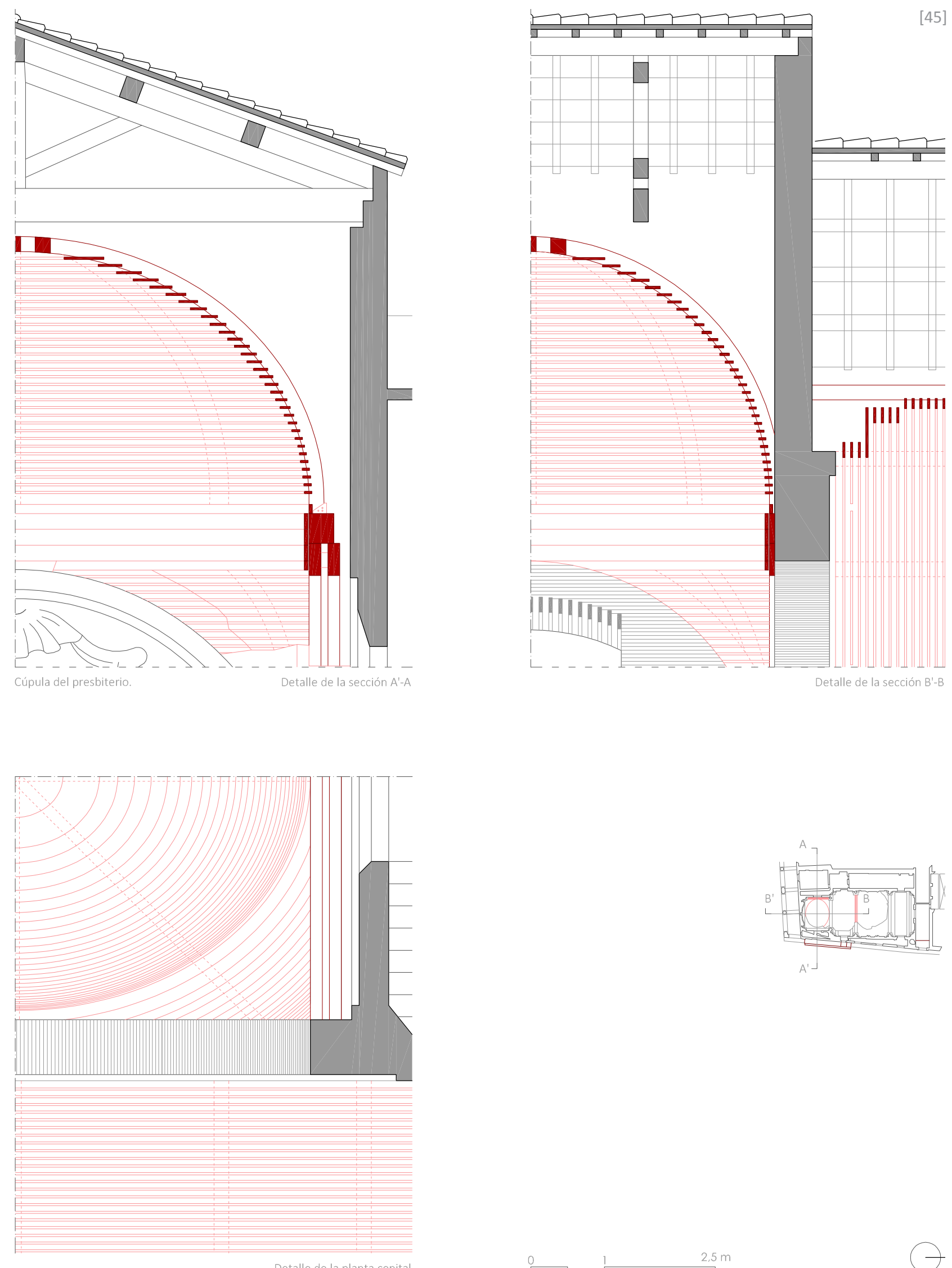

Detalle de la planta cenital 

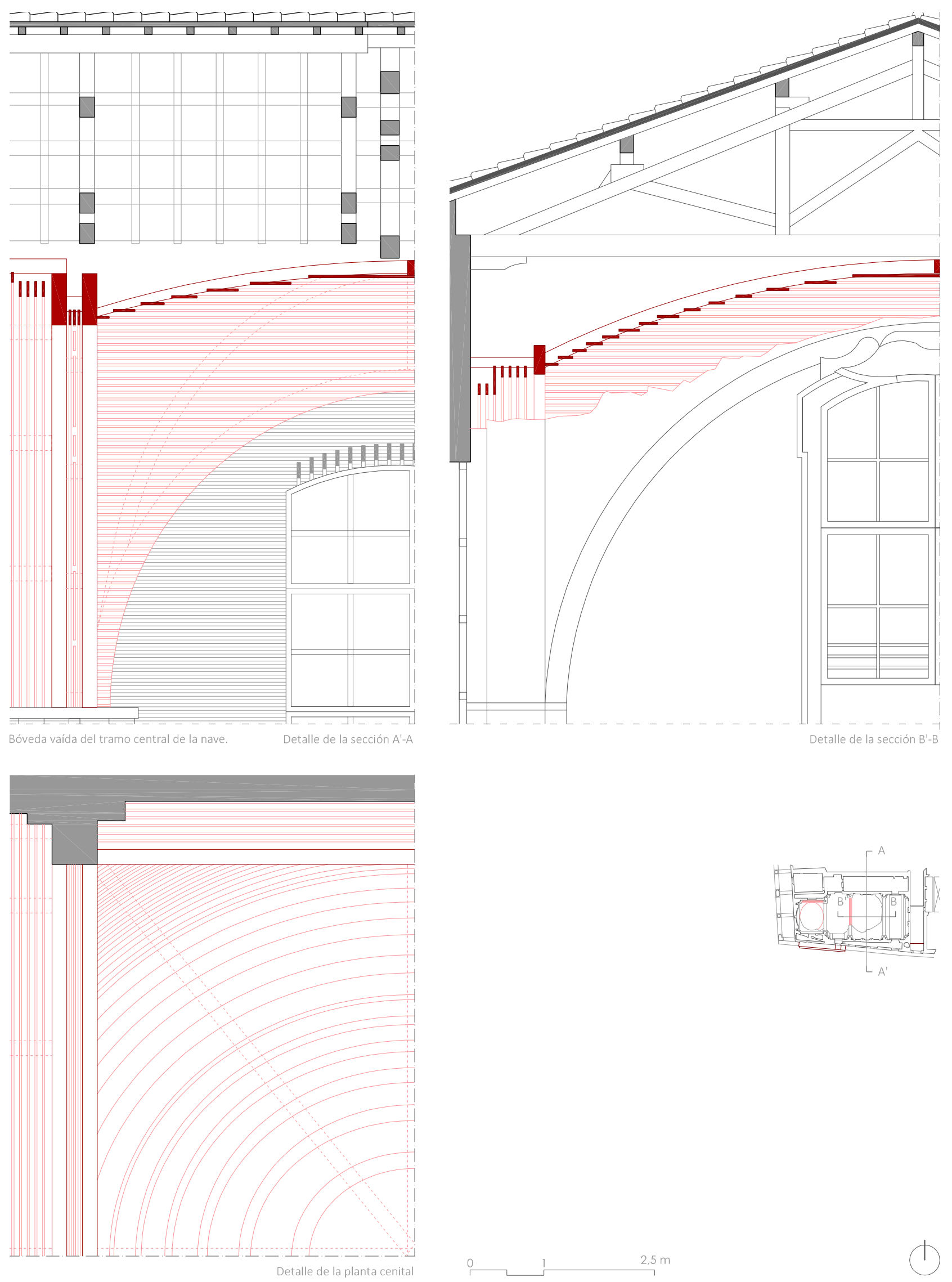


\subsection{Materialidad y detalle}

Desde el punto de vista material, la actuación se divide en dos tipos de intervención claramente distintos, en coherencia con los criterios establecidos.

Tanto en la restauración de las partes preexistentes como en la reconstrucción de la planta semisótano y el forjado de planta baja se emplean técnicas y materiales idénticos a aquellos preexistentes. Las actuaciones comprenden la reconstrucción de las pilastras y bóvedas de ladrillo que sustentan el forjado, así como la repristinación del pavimento original de la sala con baldosas cerámicas aparejadas en espina de pez. El espacio de la planta semienterrada se completa con pavimento de terrazo a la veneciana y estuco de cal en las paredes. Se opta por una reconstrucción artesanal, "en lugar de un forjado de hormigón armado, que -según Cervellati-anularía y banalizaría la planta enterrada". ${ }^{20}$

De estas actuaciones de restauración del estrato original, Cervellati destaca el trabajo de varios colaboradores, como el del estudio Biavati en el análisis estatigráfico, o el del escultor Mauro Mazzali, así como el paciente análisis de los documentos relacionados a Torreggiani y a su escuela Bolognesa, que han hecho posible "recuperar colores y formas no solo deterioradas por el abandono, sino también eliminadas por el neoclasicismo". ${ }^{21}$

El material empleado para la reconstrucción de los faltantes, desaparecidos por los bombardeos de 1944, trata sin embargo de mostrar una clara diferencia como reflejo de su contemporaneidad, pero sin intención de distorsionar en el conjunto, sino más bien tratando de hacer de puente entre las dos fases existentes en el monumento. Para ello, se elige el "abeto rojo" (abies picea), una madera clara que busca mediar entre la blancura de los estucos y las texturas del ladrillo. Producido en los bosques sostenibles de la Val di Fiemme, este material goza de una reconocida calidad por sus características físico-mecánicas y estéticas.
21 CERVELLATI, P.L.: Op.Cit. 1999, p.92

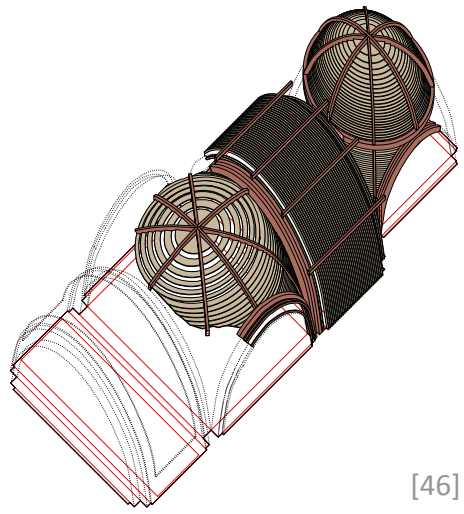

[45] Detalle constructivo, redibujado a partir de los planos del proyecto.

[46] Axonometría. (Cortesía de Giorgio Volpe)

[47] Hipótesis del estado original, estado del edificio tras el bombardeo, estado del edificio en el momento anterior al inicio de la última restauración y estado actual.
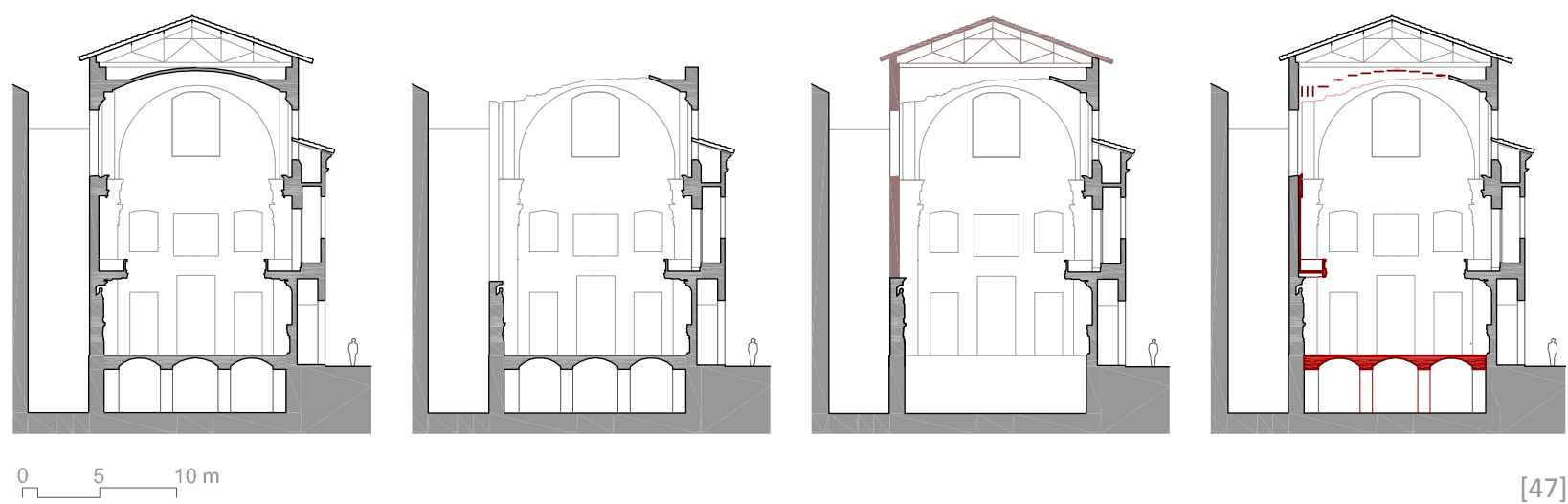


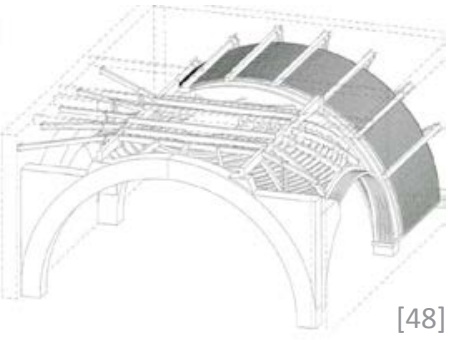

[48]

[48] Solución ejecutada finalmente en la bóveda vaída. (CERVELLATI: 2009)

[49] Imagen de la bóveda durante su construcción. (CERVELLATI: 2009)
La solución constructiva empleada busca intencionadamente el efecto de una construcción inacabada, en proceso, similar a como se muestra en las fábricas de Barbacci, pero con una materialidad más delicada, en cuanto que es reversible y que busca un mayor ajuste con la definición formal de los elementos restituidos. La solución quizá podría estar inspirada en las cimbras originales, empleadas para la construcción de las bóvedas, pero el despiece y disposición de los elementos que la configuran evitan una traslación literal de esta referencia.

La bóveda vaída y la cúpula se construyen mediante un entramado de grandes arcos de madera laminada que reproducen diversas secciones de la envolvente geométrica. A éstos se sujetan por la cara inferior una sucesión de delgadas láminas con la forma de las curvas obtenidas de las secciones horizontales del elemento, realizadas cada $10 \mathrm{~cm}$. Cabe mencionar que la solución ejecutada finalmente en la bóveda vaída difiere de la claridad estructural proyectada inicialmente, probablemente debido a problemas de ejecución y transmisión de cargas sobre los tramos preexistentes. En el caso de las bóvedas de cañón la superficie se genera mediante la repetición seriada de láminas de madera con la forma en arco de la generatriz geométrica del elemento, repetidos sucesivamente cada $10 \mathrm{~cm}$, y sujetos de unas piezas lineales colocadas transversalmente.

Las piezas de madera que definen la superficie en todos los casos son piezas de sección rectangular, a modo de tablas, pero varía la manera de colocarlas, mientras en la cúpula y bóveda vaída, las piezas se colocan horizontalmente -con su dimensión mayor paralela al suelo-, en los arcos y bóvedas de cañón, las piezas se colocan en sentido vertical. Este sistema constructivo, distinto del empleado tradicionalmente en las armaduras

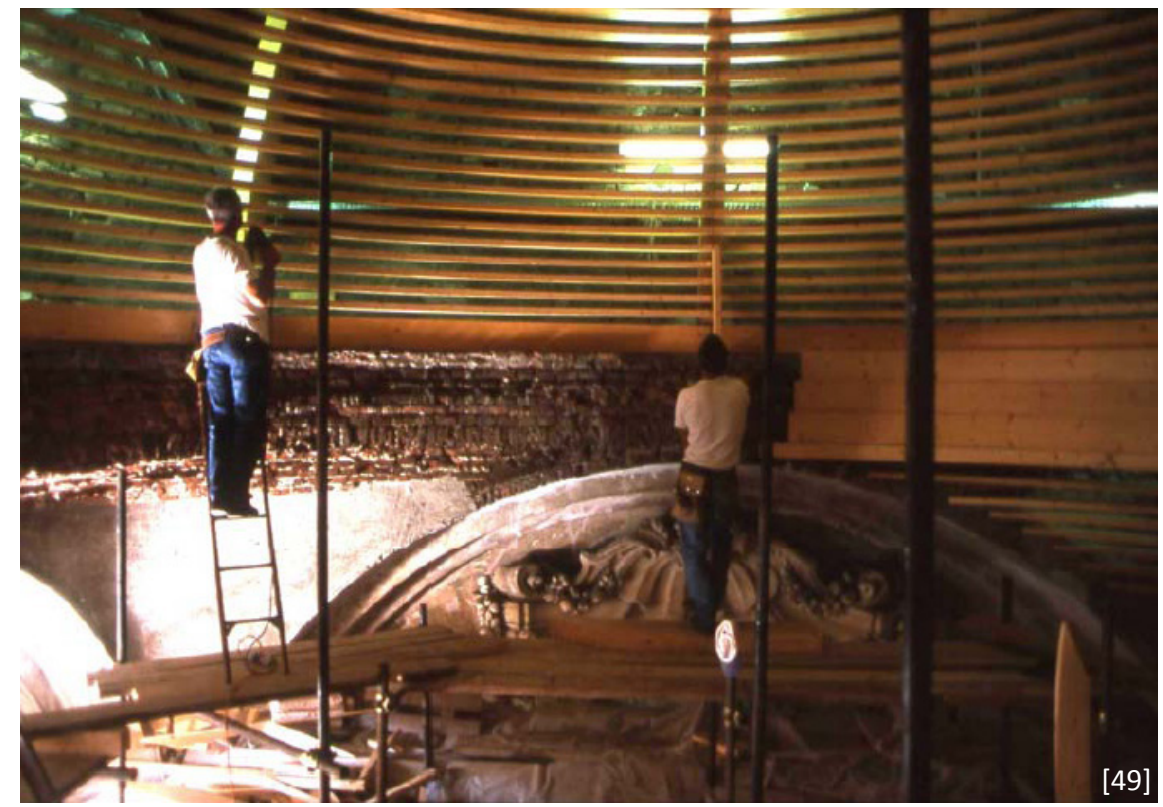


de cubierta, busca con su definición material recomponer la imagen de la envolvente a través de la generación geométrica de las bóvedas mediante la superposición de estratos de madera, ya sea a modo de anillos suspendidos que van reduciendo su diámetro para generar las cúpulas, o a modo de delgadas costillas que se repiten para generar la superficie de arcos y bóveda de cañón.

La misma madera también se emplea en los elementos reconstruidos puntualmente, colocados sobre las partes restauradas mediante hormigón y ladrillo en 1949. Pero estos elementos se trabajan como piezas talladas, reproduciendo de manera más o menos abstracta, la ornamentación original. El empleo de la misma madera que en las bóvedas permite identificar la unidad de la intervención, a la vez que la diferencia material con el fondo permite hacer evidente la superposición de las nuevas piezas sobre los elementos preexistentes.
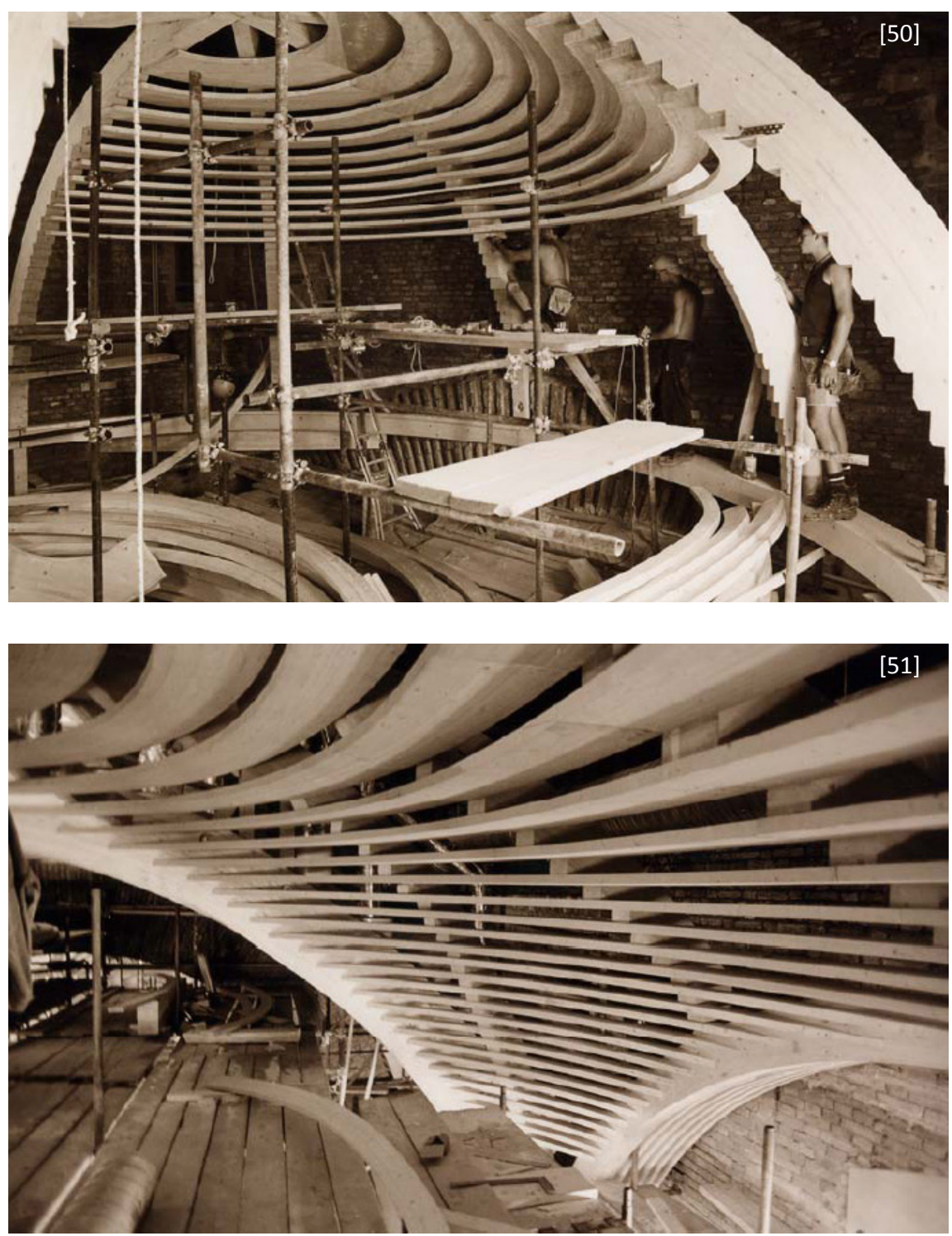

[50 y 51] Imágenes de la construcción de las bóvedas. (CERVELLATI: 2009) 
En este misma línea, la reconstrucción del balcón y de la ornamentación sobre los muros de ladrillo o sobre las columnas de hormigón de 1949, tienen el interés añadido de que se muestran de forma autónoma, como piezas "muebles" que se podrían quitar con la misma facilidad con la que se han colocado.

Por último cabe mencionar que el nuevo cuerpo de circulaciones situado en el patio se resuelve mediante una pieza volada adosada al muro, soportada por montantes vistos de madera y revestida con tablones horizontales. Este cuerpo se remata con planchas de cobre oxidado, material que también se emplea en el revestimiento del ascensor para conferirle un aspecto más tecnológico pero sin perder la referencia a la materialidad tradicional.

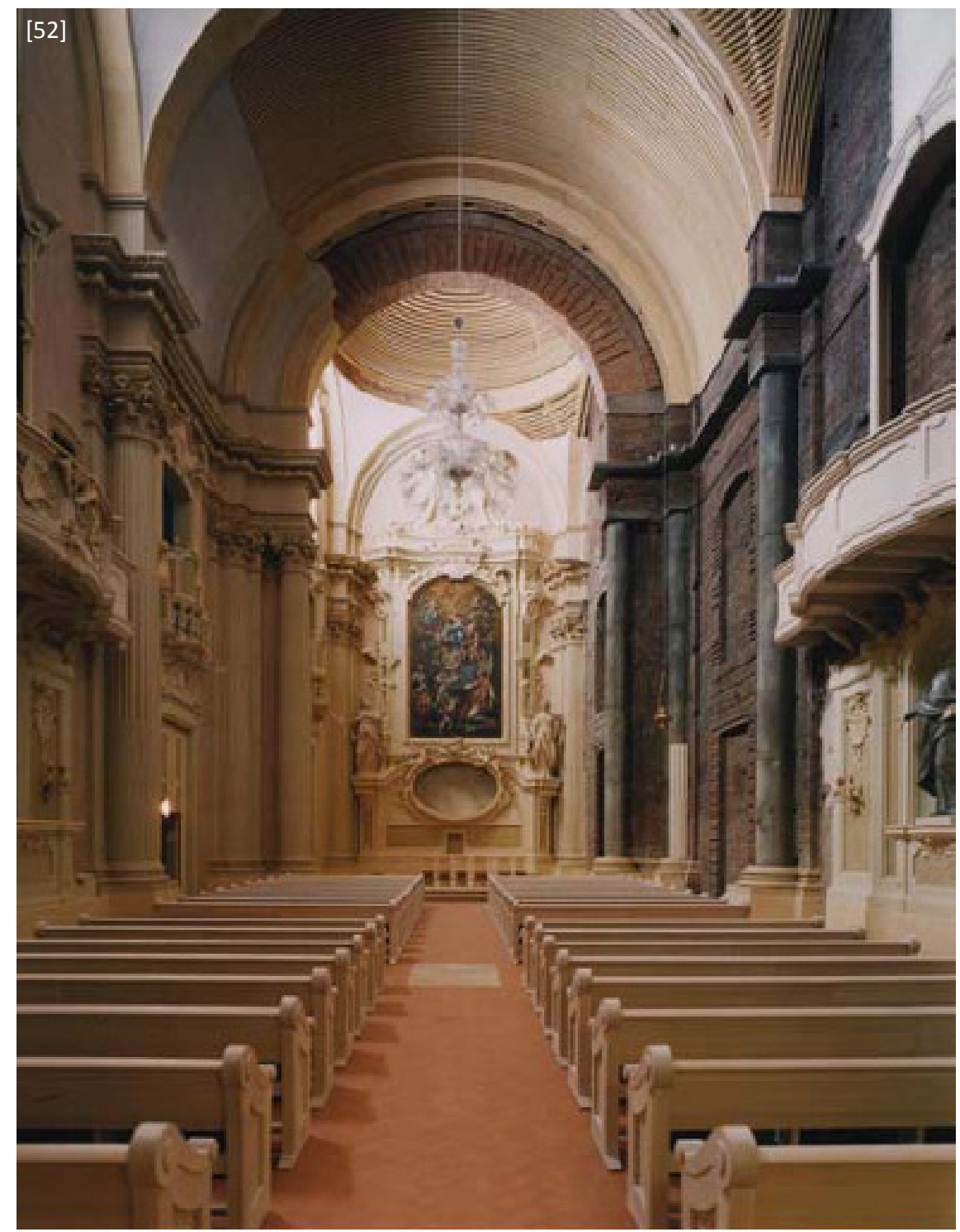




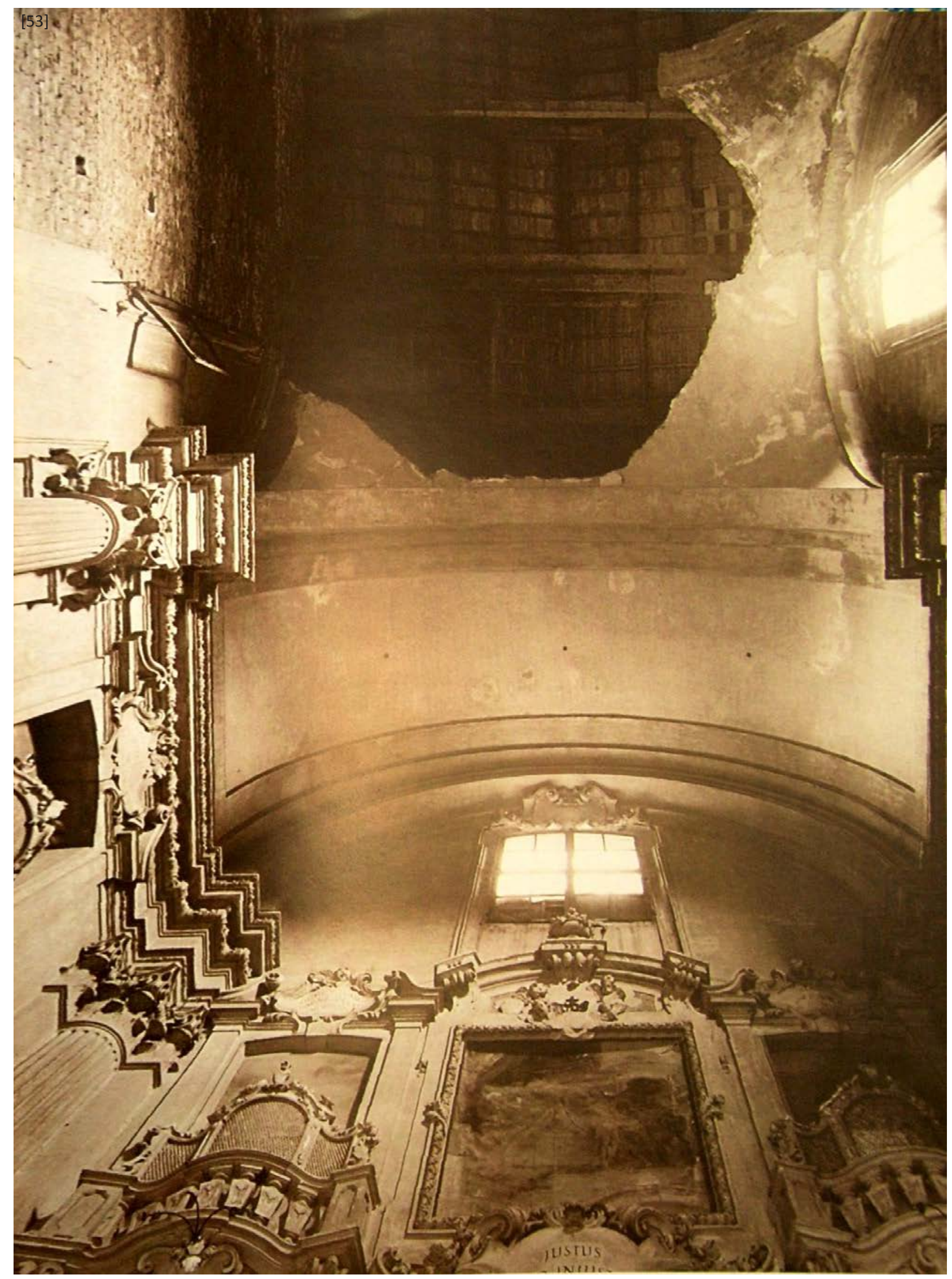




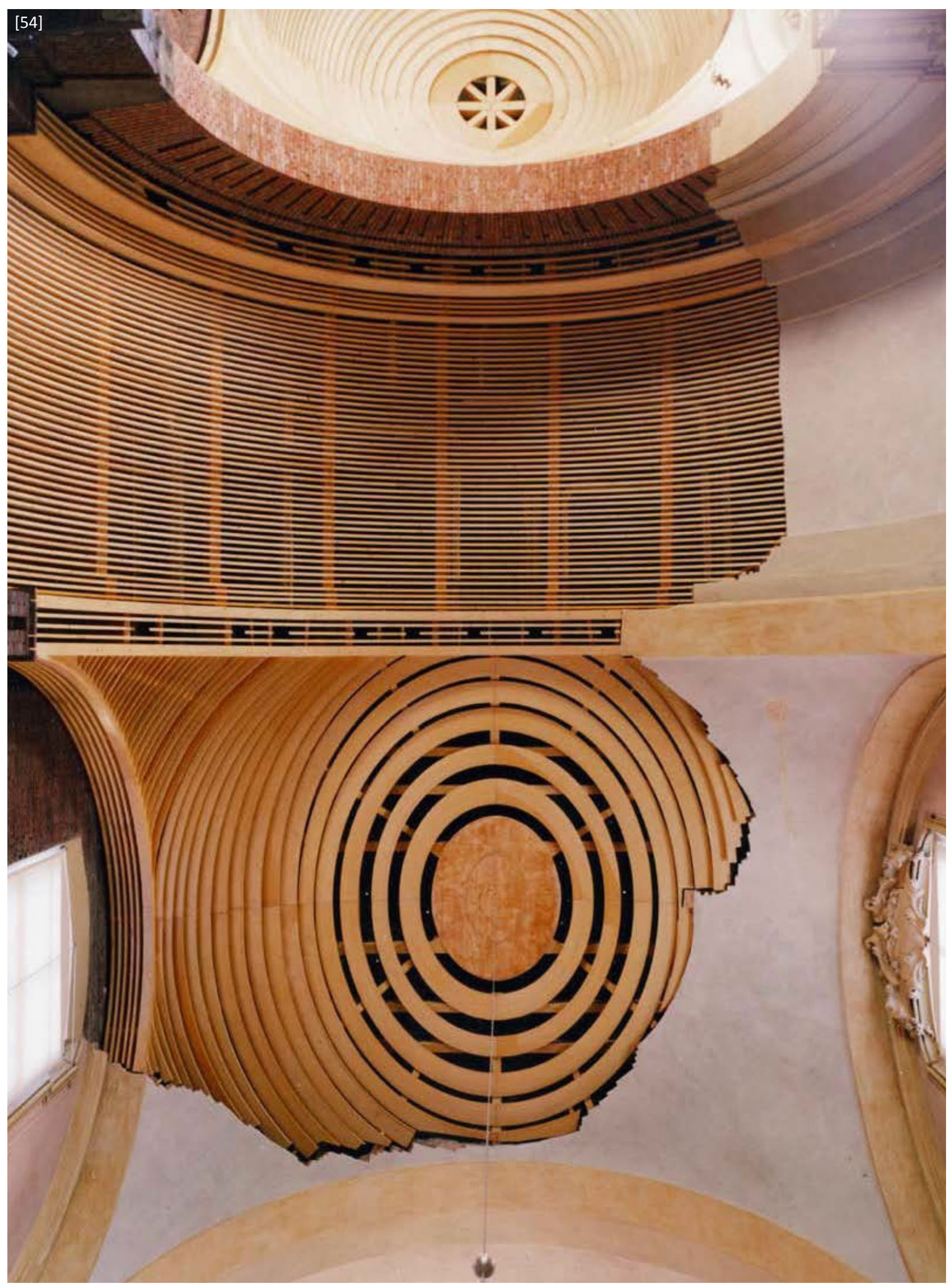




\section{ANÁLISIS CRÍTICO DE LA INTERVENCIÓN}

\subsection{El criterio de intervención}

La actuación sobre el Oratorio de San Filippo Neri cumple su cometido de restituir el Oratorio a la ciudad, manteniendo su historia, y añadiendo un nuevo episodio que, mediante una solución proyectual contemporánea, logra hacer de puente entre los distintos episodios, a la vez que representa en sí misma el dramatismo de la guerra. Su acierto ha despertado el interés de diversos críticos de arquitectura interesados en el mundo de la restauración.

Giovanni Carbonara destaca la relación que se logra entre lo nuevo y lo antiguo, gracias a completar los faltantes mediante lo que él denomina como "reintegración de la imagen", actitud que permite la "verdadera fusión diacrítica, una íntima fusión entre lo nuevo y lo viejo, pero sin confusión histórica, [...] verdadera expresión de un concepto críticoconservativo".22

Lucia Serafini destaca lo acertado de la actitud de Cervellati al valorar el monumento en su condición de "non finito". ${ }^{23}$ Así, Serafini comenta que, con la solución adoptada "no propone un edificio completo, sino en perenne devenir, capaz de contar el transcurrir del tiempo, y las heridas de su firmitas exhibidas con melancolía pero también con orgullosa consciencia". ${ }^{24}$

Cabe insistir en esta idea del "non finito", de resaltar el poder evocador de la ruina como una arquitectura descompuesta que sugiere mas que cuenta, y que se relaciona con la idea del tiempo en la arquitectura.

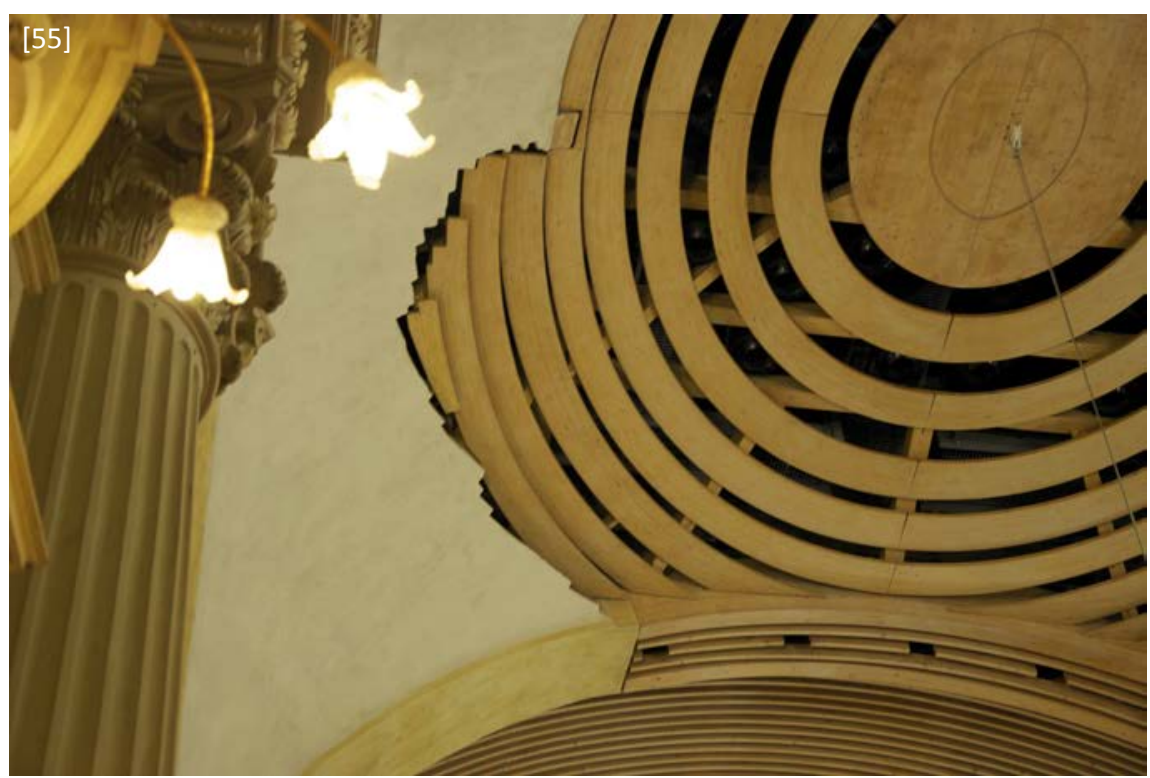

[55] Detalle del encuentro entre la nueva bóveda y la parte que sobrevivió al bombardeo. (Imágenes del autor)

22 CARBONARA, G.: Architettura d'oggi e restauro. Un confronto anticonuovo. Torino, Ed. Utet, 2011, p. 122

23 SERAFINI, L.: "Auditorium nell'ex oratorio di San Filippo Neri a Bologna". L'industria delle costruzioni, no 368, Ed.

ANCE, 2002, p. 41

24 SERAFINI, L.: Op.Cit. 2002, p.42 
25 POLI, M.; URBINI, S.: L'Oratorio di San Filippo Neri a Bologna. Bologna, Ed. Studio Costa, 2000

SERAFINI, L.: Op.Cit. 2002, p.42
Marco Poli destaca la potencia expresiva que adquiere el monumento al manifestar "los tres eventos fundamentales de la historia del edificio", produciendo en el visitante un "fuerte y sugerente impacto". ${ }^{25}$

Este criterio de mantener las distintas fases de la historia y añadir aquello que ha desaparecido, recuperando la envolvente del espacio original, pero remarcando su diferencia, permite un resultado conciliador, tanto con la historia como con la arquitectura del edificio. Pero este criterio supone afrontar la dificultad de ejecutar esos añadidos sin que produzcan una sensación de rechazo en relación con los elementos preexistentes.

Serafini entiende que esta comunión entre las fases se logra, en parte, gracias a que la recomposición de la nave se abarca sin que se produzca "una jerarquía entre las diferentes partes sino a través de un orden que las exalta de forma pareja", un orden que restituye su identidad gracias a la exhibición de su materialidad, produciendo con ello una nueva narración espacial. ${ }^{26}$

\subsection{La solución adoptada}

Es interesante destacar como Cervellati combina diferentes criterios de actuación en función de las necesidades de cada elemento, pero bajo un mismo objetivo común de restitución del monumento. Para ello se emplean desde actuaciones de mero mantenimiento, pasando por otras de restauración conservativa, hasta actuaciones de repristinación y reconstrucción de carácter contemporáneo.

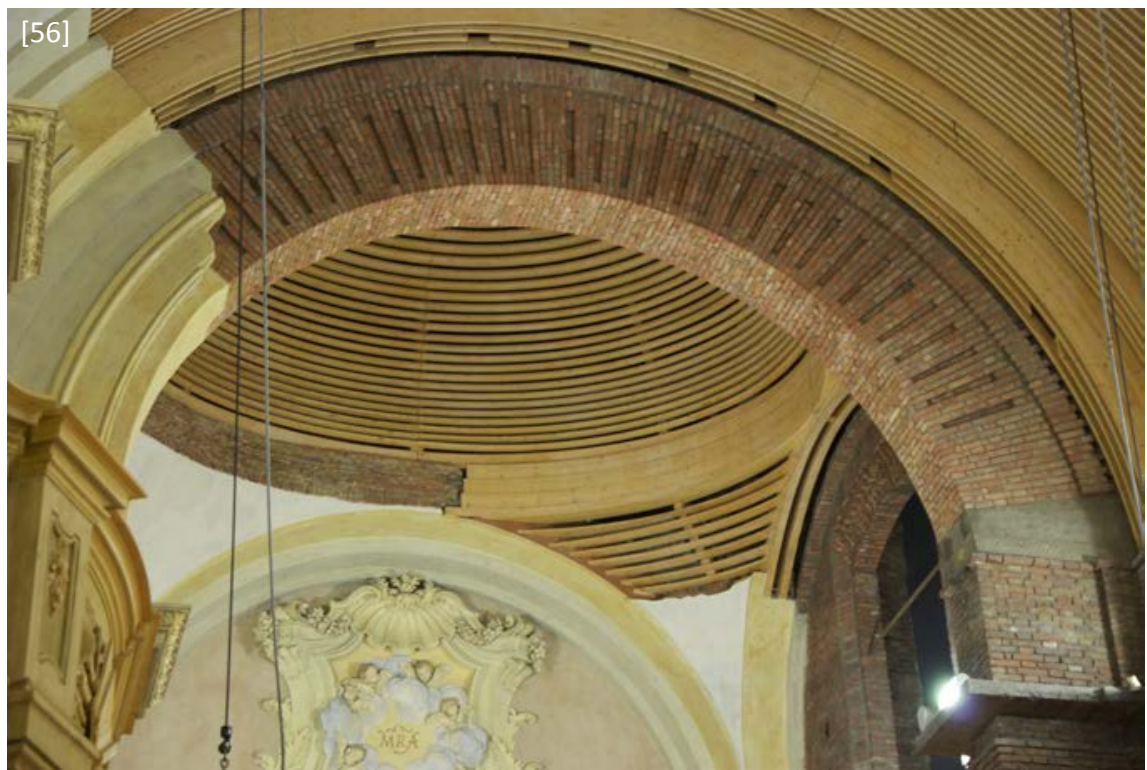


Respecto a la actuación sobre las preexistencias, Andrea Paglia, encargado de la empresa constructora, destaca el interés de Cervellati por obtener una armonía entre las fases, al comentar cómo se buscó atenuar el impacto visual del muro de ladrillo rojo, reconstruido en la intervención de 1949, mediante la aplicación de nerofumo ${ }^{27}$, una veladura de tono oscuro que matiza su crudeza estética en el espacio.

Paglia también hace hincapié en la complejidad existente en la recuperación de los elementos artesanales del semisótano, en los cuales en algunos casos se consiguieron resultados poco convincentes, como en la reconstrucción del forjado del suelo con bóvedas de yeso y cal, pero en otros casos se aprecian actuaciones de notable factura, como es el caso de los estucos o los pavimentos. ${ }^{28}$

También Poli pone especial énfasis en la complejidad de este tipo de intervenciones, destacando que hayan sido necesarios "solo 18 meses para llevar a término la difícil, cuidadosa y original restauración, que ha supuesto la colaboración de 50 oficios artesanales en diversos tipos de trabajos". ${ }^{29}$

Sin duda, uno no puede dejar de plantearse ciertas dudas sobre la actuación de repristinación llevada a cabo en el semisótano. La pregunta que uno se plantea es si la destrucción llevada a cabo por Barbacci en el año 49 justifica su reconstrucción mimética, sobre todo teniendo en cuenta que algunas de las actuaciones no han estado a la altura de las originales en el proceso de ejecución. Por otro lado una propuesta moderna no hubiera supuesto grandes distorsiones con el monumento, al ser un espacio totalmente
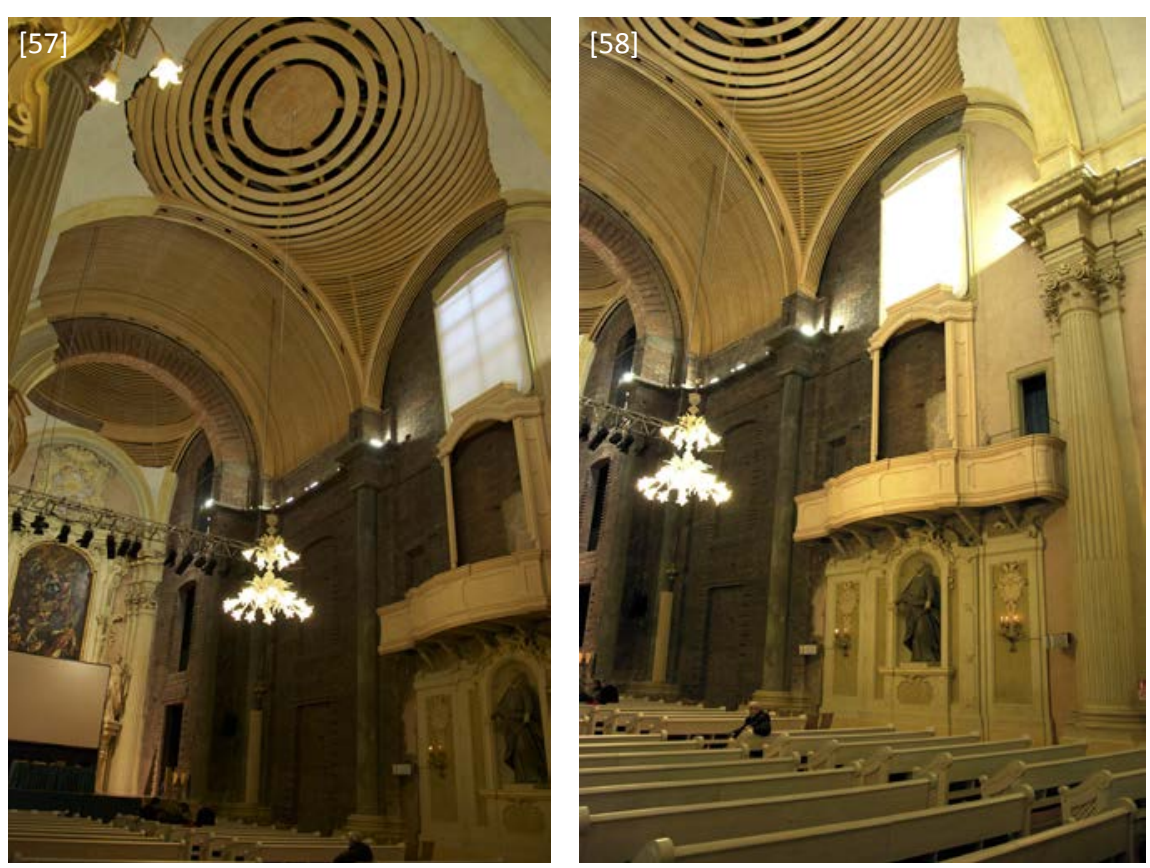

27 Negro de Carbón. Material producido por la combustión incompleta de los productos derivados del petróleo, que se emplea como pigmento.

28 PAGLIA, A.: "Il restauro dell'Oratorio di San Filippo Neri". La città del secondo rinascimento, no 38, Bologna, Ed. Associazione Culturale Progetto Emilia Romagna, marzo 2010, p.25

29 POLI, M.; URBINI, S.: Op.Cit. 2000
[57 y 58] Vistas de la nave en las que se aprecia el empleo de nerofumo. (Imágenes del autor) 
30 CORNOLDI, A.: "Restauri non Conservativi. La Ricerca delle Regole". En: FERLENGA, A.; VASALLO, E.; SCHELLINO, F.: Antico e Nuovo. Architetture e architettura. Volumen 1, Ed. II Poligrafo, 2007, pp. 261-284
[59] Intervención a cargo de Valadier en el Coliseo. (Imagen del autor.)

[60] Detalle de la intervención de Valadier. (Imagen del autor.)

[61] Detalle de la intervención a cargo de Stern en el arco de Tito. (Imagen del autor.) independiente respecto al resto del edificio. Por otro lado, los nuevos usos ubicados en el semisótano seguramente hubiesen encontrado un soporte adecuado en el marco de una reelaboración contemporánea del espacio desaparecido.

Adriano Cornoldi achaca esta actitud de Cervellati a una desconfianza en lo nuevo y a un "fetichismo del hallazgo" sostenido sobre cómodos principios imitativos. ${ }^{30}$ Este interés por la repristinación, claramente legible en el análisis de las inquietudes del arquitecto realizado en este estudio, se refleja en la solución de otros elementos del oratorio, como la reconstrucción del coro norte o el diseño de los bancos. Parece como si Cervellati asociara el criterio de mayor o menor literalidad hacia el original en función de la mayor o menor proximidad al nivel de suelo, y con ello, al usuario. Así pues se produce una gradación que va desde la imitación formal y material en el semisótano, forjado de planta baja y pavimento de la sala, pasando por una abstracción formal y material en bancos y coro, hasta llegar a la reinterpretación creativa de las bóvedas.

A propósito de la forma de actuar en la reconstrucción de las bóvedas, cabe destacar el compromiso que demuestra Cervellati tanto con la arquitectura histórica como con la contemporánea. La sutileza del lenguaje empleado expresa con gran claridad ese camino actual, conciliador, que busca alcanzar el equilibrio entre las partes. Es el detalle de la solución formal y constructiva dada a las nuevas piezas, así como la elección material y su adaptación a las distintas situaciones, lo que permite alcanzar esa sensación de armonía con el conjunto.

Cervellati no propone una actuación radicalmente moderna, sino en cierta manera heredera de intervenciones antiguas, ya que actúa como Valadier o Stern en el Coliseo o en el arco de Tito a principios del siglo XIX, es decir apoyándose en la reconstrucción de la forma original para garantizar un buen resultado: reproducen el original, utilizando otro material que remite a su materialidad interna, en un juego entre analogía y contraste que permite una relación equilibrada con la preexistencia. La diferencia está en la definición material de la forma, en este caso más abstracta y amable gracias a su carácter provisional, desmontable, incluso reciclable, que remite la idea de lo inacabado.
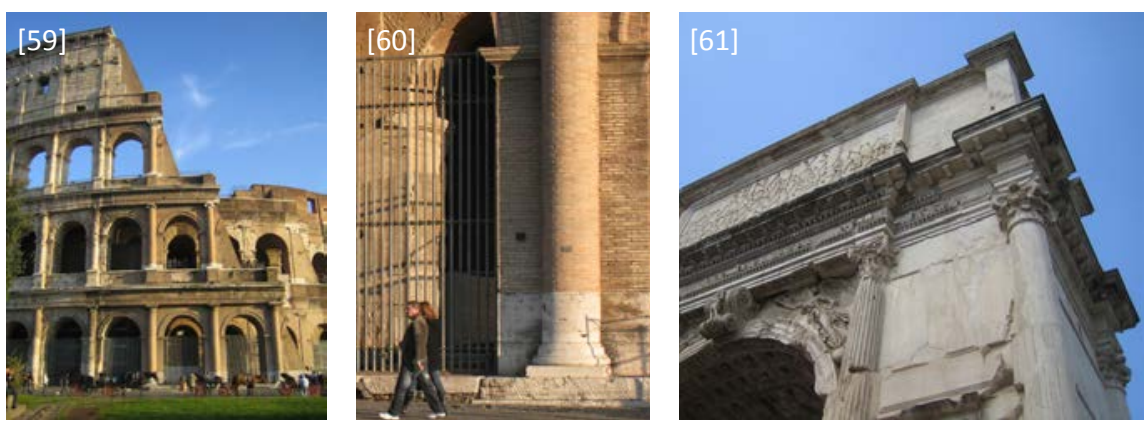
A esto se suma la búsqueda por hacer evidente el dramatismo de la pérdida, manteniendo los fragmentos rotos de las bóvedas o de la cúpula, transmitiendo al presente la historia de su destrucción. Un efecto que produce la inquietud de la inestabilidad material y la incomodidad de la violencia de la guerra. Efecto también evocado por Stern en el Coliseo, al detener en el tiempo la decadencia de las dovelas de piedra de un arco, convirtiendo en permanente la imagen del instante de un proceso de degradación.

Claudio Varagnoli interpreta la solución formal dentro de los códigos lingüísticos de la restauración, indicando que en el Oratorio la madera se emplea "rediseñando la geometría de las bóvedas destruidas con listones que, casi imitando el clásico rigatino (...) restituyen la envolvente espacial violada por las bombas". 31

Andrea Paglia destaca el desafío que ha constituido la solución constructiva de las bóvedas y la cúpula. "Cada lámina, de hecho, tiene un radio de curvatura diferente. Una idea ingeniosa, una integración entre lo antiguo y lo moderno que creo que constituye un valor añadido para el Oratorio". 32 Con ello Paglia relaciona la integración antiguo-nuevo con la complejidad de la solución empleada, aceptando que la delicadeza, calidad y creatividad demostradas ayudan en este proceso.

Con esta solución se ha logrado configurar una envolvente ligera, calada y cálida que media entre la arquitectura luminosa y completa del rococó y la dureza de la restauración del 49, sin borrar el dramatismo producido por las bombas de la guerra. El escrupuloso respeto por las partes que han sobrevivido, pone en evidencia la dramática ausencia de aquella bóveda lisa, blanca y perfecta que destruyó el bombardeo.

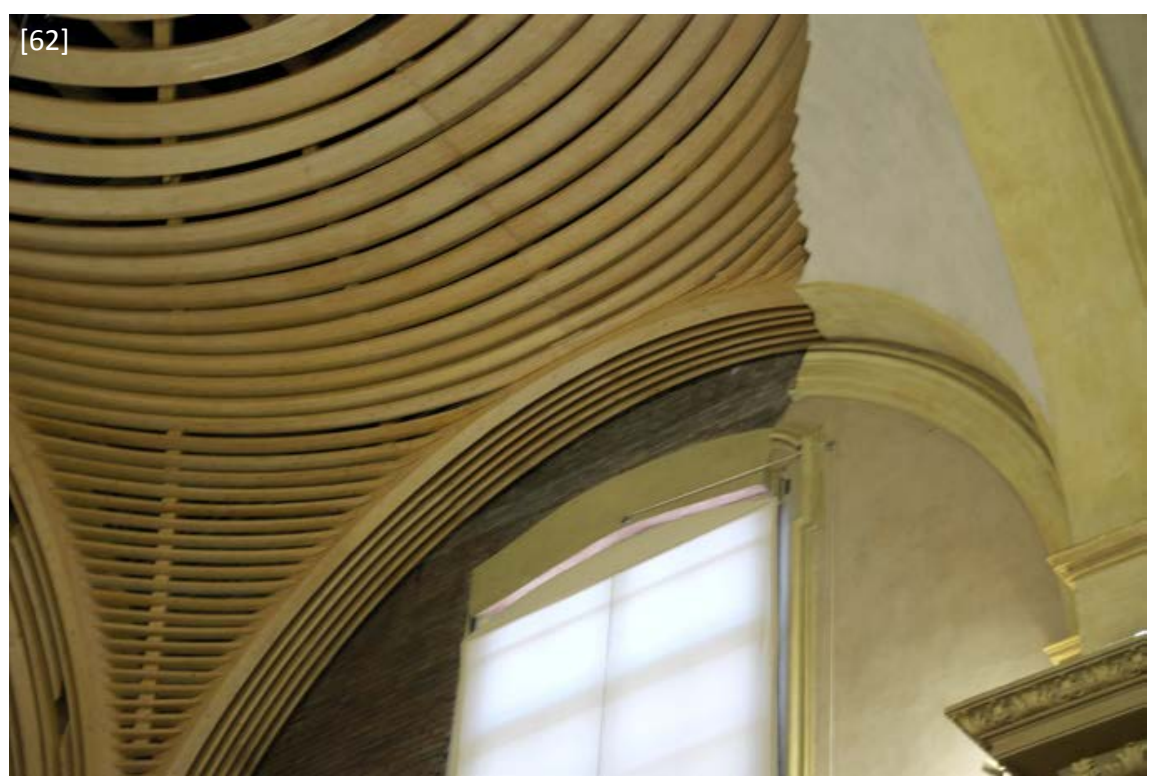

31 VARAGNOLI, C.: "Antichi edifici, nuovi progetti. Realizzazione e posizioni teoriche dagli anni Novanta ad oggi". En FERLENGA, A.; VASALLO, E.; SCHELLINO, F.: Antico e Nuovo. Architetture $e$ architettura. Volumen 2, Ed. II Poligrafo, 2007, p. 849

32 PAGLIA, A.: Op.Cit. 2010
[62] Detalle de las láminas de madera que componen la bóveda y sus diferentes curvaturas. (Imagen del autor) 

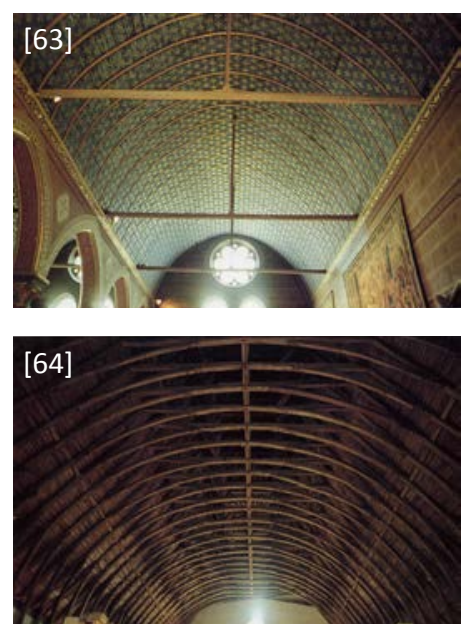

[63 y 64] Imágenes de bóvedas tradicionales de madera. Blois, Valle del Loira y Cluny, Borgogna. (TROTTA. En: TAMPONE: 1989)

[65] Bóveda del tesoro de Atreo. (VELOSO: <arkyotras.wordpress. com>)

[66] Imagen de las costillas de la quilla de un barco. (Imagen de Gabriel Hormaechea. En: Modelismo Naval: <www.modelismonaval. com>)

[67] Op-art.

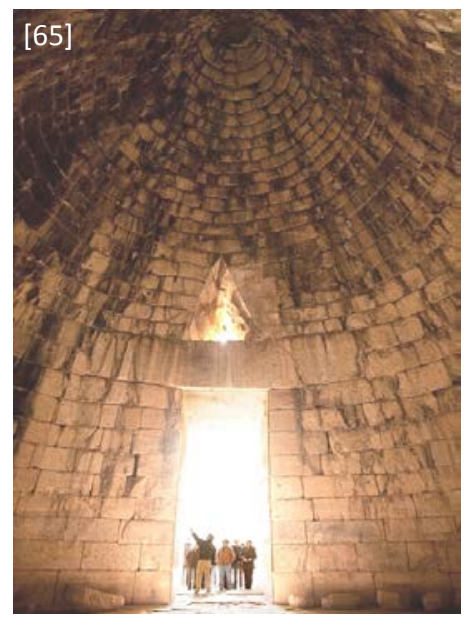

Esta actuación parece haberse concebido como tratando de dar un aspecto reversible, como un elemento que se introduce limpiamente en el hueco y que en todo momento puede retirarse. Algo que ayuda a reducir su impacto material en el conjunto.

\subsection{Referencias}

La actuación de Cervellati sobre las bóvedas se puede relacionar con un proceso de sedimentación de estratos presente en la naturaleza o en la arqueología, donde se superponen diversas épocas unas sobre otras, quedando los substratos inferiores solidificados en un momento de su proceso de descomposición, mientras que los substratos superiores se muestran con una materialidad más ligera como producto de su juventud.

Este concepto de superposición se podría relacionar con las construcciones de cúpulas realizadas por apilamiento de hiladas sucesivas presentes en las arquitecturas primitivas o antiguas como la bóveda del tesoro de Atreo. O con las bandas horizontales presentes en las bóvedas de hormigón romano, producidas por las tablas de las cimbras que se empleaban en el proceso constructivo.

La materialidad de estas bóvedas reconstruidas remite de manera inevitable a las construcciones tradicionales de bóvedas y cúpulas de madera, aunque como ya se ha apuntado, de una manera algo distinta a como se ha resuelto en este caso. Construcciones que remiten a su vez a elementos navales como las costillas de la quilla de un barco.

Por otro lado, el concepto de abstracción formal se puede relacionar con las representaciones simplificadas de elementos complejos, empleadas en diversas corrientes artísticas como el art nouveau, el neoplasticismo y el op-art. Corriente esta última surgida en los años 40 que buscaba crear ilusiones ópticas en el observador, induciéndolo a adoptar una actitud
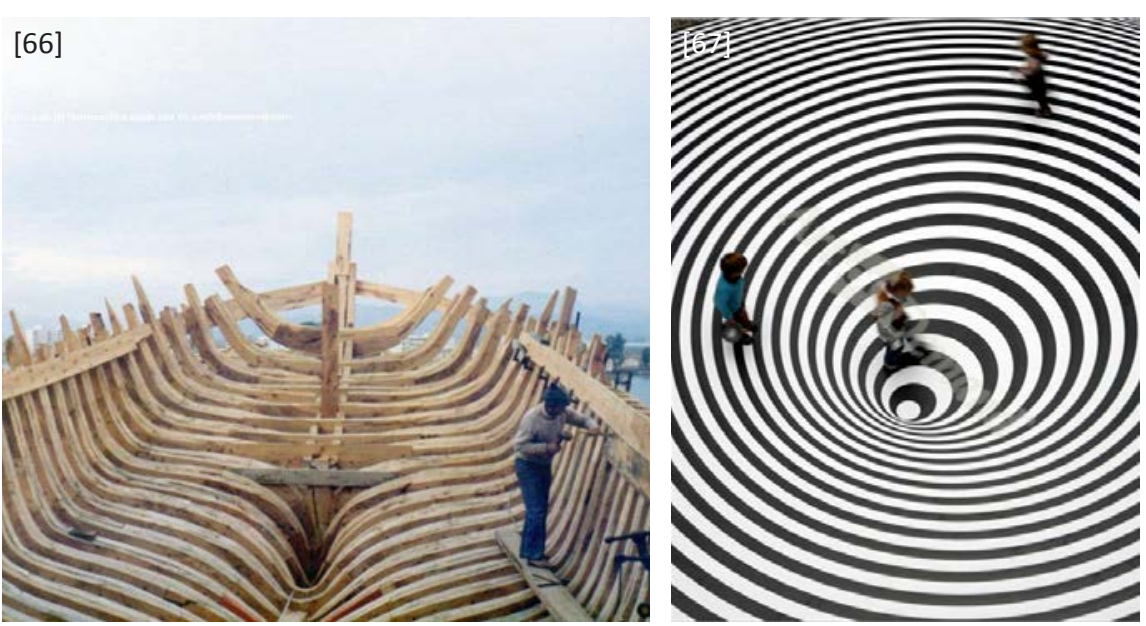

Oratorio di San Filippo Neri. Bolonia.1997-1999 
activa frente a la obra de arte. Algo que en cierto modo está presente en San Filippo, ya que la percepción de la bóveda cambia a medida que el observador se mueve por el espacio, y según el punto de vista, las bóvedas adquieren mayor o menor solidez.

Conceptos como la repetición de formas geométricas simples, como el círculo, que producen efectos de profundidad pero también de bidimensionalidad, como si la forma tridimensional se pudiera plegar, remiten a estos juegos ópticos presentes en el arte visual.

Estos juegos de ritmos, de claroscuros, están presentes en diversos arquitectos del siglo XX como Mackintosh, Wright, Scarpa, Portoghesi, Botta o Navarro Baldeweg. Precisamente en la obra de Juan Navarro Baldeweg está muy presente la definición geométrica de bóvedas a base de estratos horizontales sucesivos como es el caso de la bóveda del Palacio de Congresos de Salamanca. Aunque en el caso de Navarro Baldeweg la bóveda se construye como un cuerpo sólido que se descompone mediante el juego de luces y sombras que produce el escalonamiento de los anillos; mientras que en las bóvedas de Cervelati, el volumen se crea mediante láminas que flotan, produciendo el juego de luces y sombras mediante la alternancia de la superficie de madera y el vacío entre las láminas, confiriéndole a las bóvedas un carácter aún más ligero.
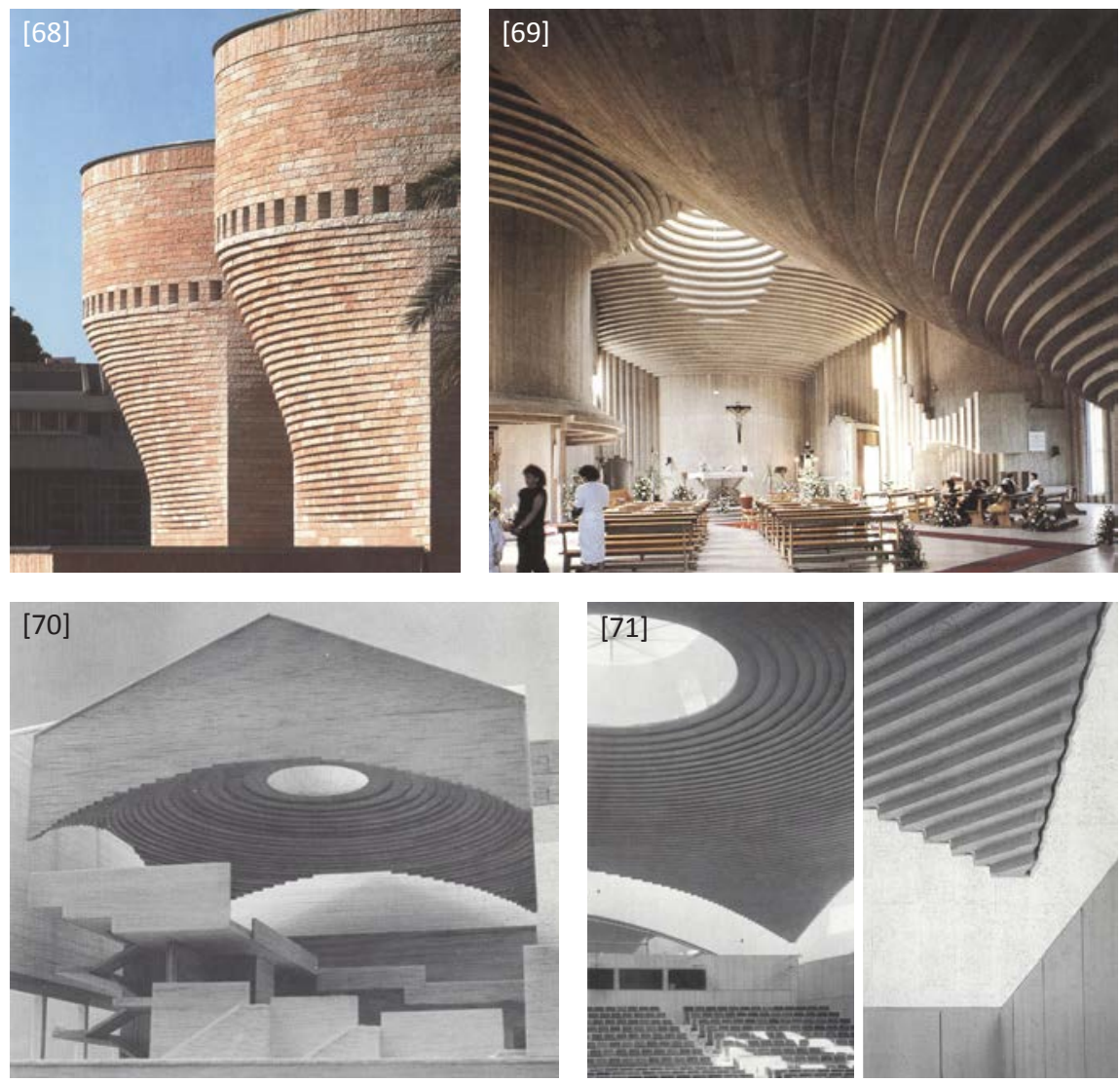

[68] Mario Botta. Sinagoga Cymbalista, 1996-1998. (Imagen de Pino Musi. En: ASENSIO; BOTTA: 2003, p. 25)

[69] Paolo Portoghesi. Iglesia de la Sagrada Familia. (BERNITSA; ERCADI: 2006, p. 63)

[70] Juan Navarro Baldeweg. Palacio de Festivales de Santander, 1984. (GONZÁLEZ; LAHUERTA; NAVARRO: 1993, p. 169)

[71] Juan Navarro Baldeweg. Palacio de Congresos de Salamanca, 1985. (GONZÁLEZ; LAHUERTA; NAVARRO: 1993, p. 181) 



\subsection{CAPILLA DE LOS CONDES DE FUENSALDAÑA}

Construcción original:

Estilo gótico. Juan Gómez Díaz. 1453-57

Intervención:

Juan Carlos Arnuncio, 1996-2002

Lugar:

Valladolid. España.

La capilla se ubica en el ángulo noroeste del edificio que configura el claustro del Monasterio de San Benito, situado en una manzana a unos metros al oeste de la plaza mayor, muy próximo al río y al archivo municipal, entre las calles de San Agustín y de la Encarnación.

El conjunto de la capilla, el Monasterio y un edificio de nueva creación conforman el Museo de Arte Contemporáneo Español, conocido como Patio Herreriano.

\section{ANTECEDENTES}

\subsection{Evolución histórica}

El origen del Monasterio se remonta a 1390, cuando Juan I dona a los monjes benedictinos un solar situado en el borde de la ciudad, donde se ubicaban los Reales Alcázares. Los monjes construirán una modesta iglesia medieval aprovechando la capilla del alcázar, hasta que entre 1499 y 1515 se construya la iglesia de San Benito.

Al conjunto se le añade la Capilla de los Vivero-Guzmán, Condes de Fuensaldaña, construida a los pies de la iglesia medieval y reemplazando una capilla anterior. La capilla la manda construir en 1453 Dạ Inés de Guzmán, como panteón familiar, para enterrar a su marido fallecido: " $Y$ en siete de junio de dicho año se concertó dicha señora con Gómez Díaz de

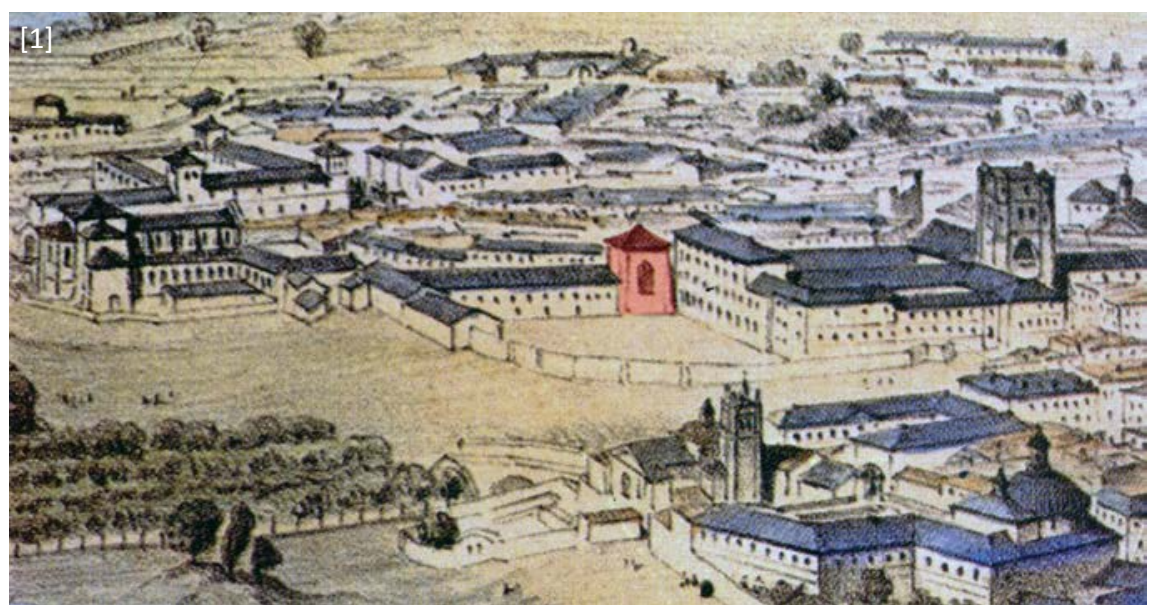

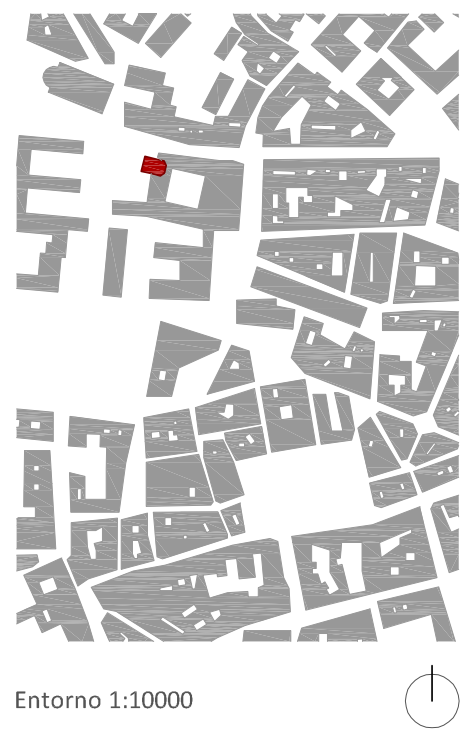

$1: 10000$
[1] Fragmento de la vista aérea de Valladolid, de Alfred Guesdon, realizada en 1854, donde se aprecia el conjunto de San Benito-San Agustín. (RIVERA: 1990) 
1 ANDRÉS ORDAX, S.: "La iglesia del monasterio: proceso constructivo $y$ análisis artístico". En: RIVERA, J. (dir): Monasterio de San Benito el Real de Valladolid: IV centenario, 13901990. Valladolid, Ed. Ayuntamiento de Valladolid, 1990, p. 152

2 RODRÍGUEZ MARTíNEZ, L.: Historia del Monasterio de San Benito El Real de Valladolid. Valladolid, Ed. Caja de Ahorros Popular de Valladolid, Ateneo de Valladolid, 1981, p. 99

[2] Ruinas de la capilla de los condes de Fuensaldaña. Arcos sepulcrales. (RODRÍGUEZ: 1981)

[3] Planta general del Monasterio de San Benito, proyectada por Juan de Ribero Rada entre los años 1582-84. (RODRÍGUEZ: 1981)

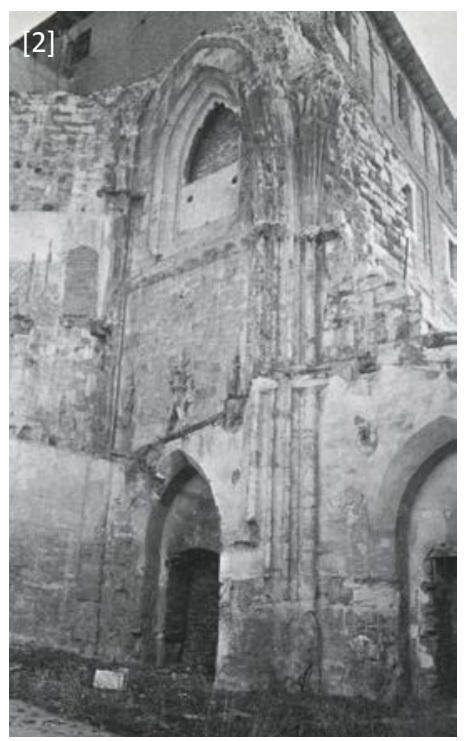

hacerle dos capillas en S. Benito de cal y canto... de 75 pies de largo y 40 pies de ancho, sin los huecos de las paredes... la una capilla ochavada y la otra quadrada, la principal con ocho claves y la otra con dos claves...". ${ }^{1}$ Tal y como queda citado, el maestro de cantería Juan Gómez Díaz, maestro mayor de la Catedral de Palencia, será el encargado de diseñar la capilla que terminará de construir en 1457.

Entre los años 1559 y 1573, Rodrigo Gil de Hontañón levanta el magnífico pórtico de la iglesia de San Benito y acomete reformas en el monasterio, que suponen la construcción de nuevos claustros demoliéndose parte de las antiguas estructuras.

Entre 1582 y 1584, el arquitecto Juan de Ribero Rada proyecta la planta general del Monasterio de San Benito, llevando a cabo la fachada principal y el denominado "Patio Herreriano", de fuerte influencia palladiana.

Es de destacar como la construcción del Monasterio invade parcialmente los muros de la Capilla de los Condes de Fuensaldaña, quedando ésta en parte embebida en el ala oeste.

En 1595, con motivo de unas obras de reconstrucción del paño norte del claustro, se abre una puerta a la capilla en la zona del altar, para permitir el acceso directamente desde el Monasterio. ${ }^{2}$ Poco después, en 1619, se reestructura el acceso original a la capilla por la calle de San Agustín, mediante la superposición de una portada barroca realizada por los maestros Pedro de Olano y Bartolomé Barreda.

En 1837 se desamortiza el edificio pasando sus bienes muebles al Museo Nacional de Escultura y el edificio a manos de los militares. Éstos realizan un gran número de obras produciendo la transformación del antiguo monasterio en una auténtica fortaleza.

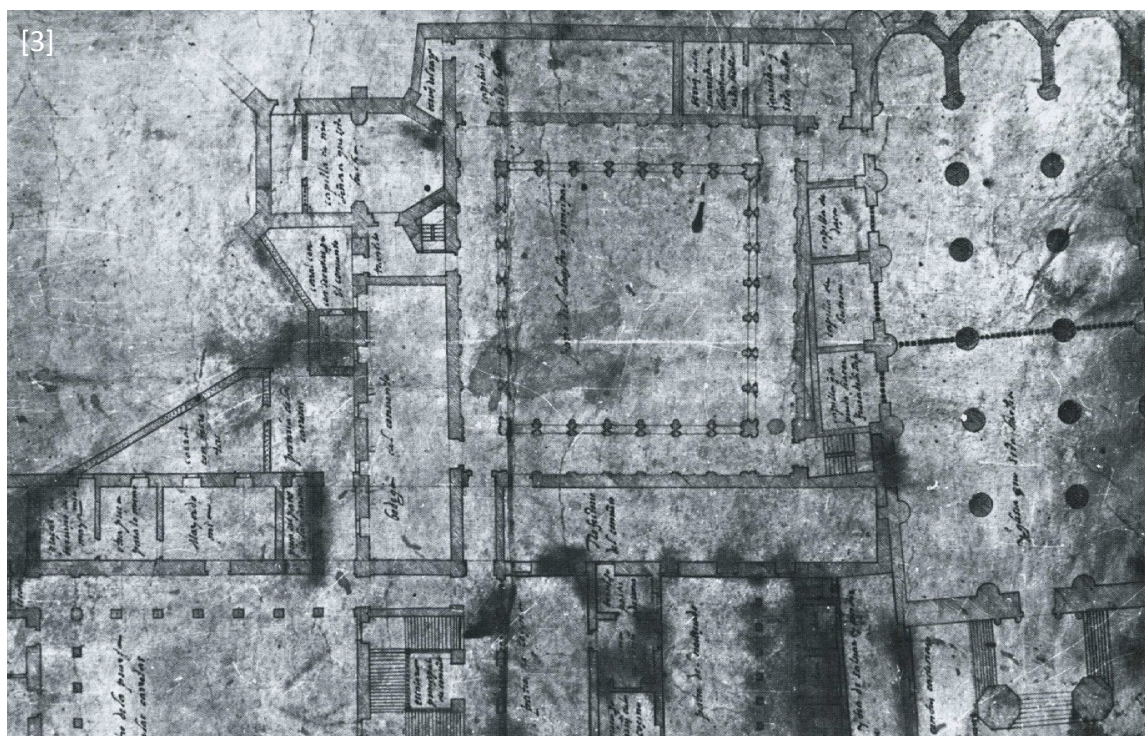

Capilla de los Condes de Fuensaldaña. Valladolid.1996-2002 
La Capilla de los Condes de Fuensaldaña cae en ruina, manteniendo exclusivamente su estructura muraria y perdiendo completamente su cubierta abovedada.

A raíz de los cambios de planeamiento llevados a cabo durante el siglo XX, se eliminan los anexos realizados por los militares y se construyen nuevos edificios que impactan en mayor o menor medida en el entorno del Monasterio. Este es el caso de la construcción de un edificio de viviendas en altura, que produce un inadecuado contraste con la arquitectura del conjunto monástico, tal como se aprecia en la fotografía de 1995. En contraposición con éste, destaca el Instituto Núñez de Arce, de Miguel Fisac, ubicado en la parcela opuesta, que se inserta adecuadamente en el contexto histórico mediante una pieza horizontal que permite mantener la jerarquía visual de los elementos patrimoniales.

En 1963 el cuartel pasa a manos del Ayuntamiento de Valladolid, que promueveobrasencaminadasaasegurarsuestabilidad.Deestaépocason las sustituciones de los forjados y artesonados originales de madera por nuevos forjados de hormigón, en las alas que conforman el claustro, que suponen una indiscutible pérdida pero que permiten mantener su estabilidad.

Finalmente en 1985, José María Pérez González, conocido como "Peridis", rehabilita parcialmente el monasterio -concretamente el patio de la Hospedería, en la zona sudeste- para destinarlo a dependencias municipales, mediante la creación de una escuela taller.

En el año 1996 el equipo de arquitectos formado por Juan Carlos Arnuncio, Clara Aizpún y Javier Blanco gana el primer premio del concurso de proyectos, promovido por el Ayuntamiento de Valladolid, inicialmente para la inserción del Museo de la Ciudad y espacios administrativos, y finalmente para la instalación del Museo de Arte Contemporáneo, en el conjunto del Monasterio de San Benito. Actuación que durará hasta el año 2002, momento en el que se inaugura el museo.

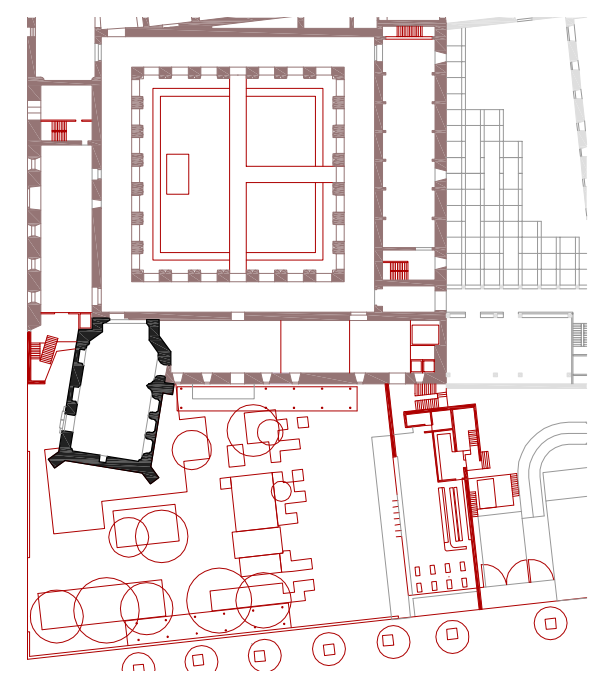

Fase 3. Juan Carlos Arnuncio, 1996-2002.

Fase 2. Juan de Ribero Rada, 1582-1584.

Fase 1. Juan Gómez Díaz, 1453-1457
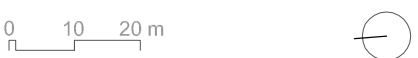
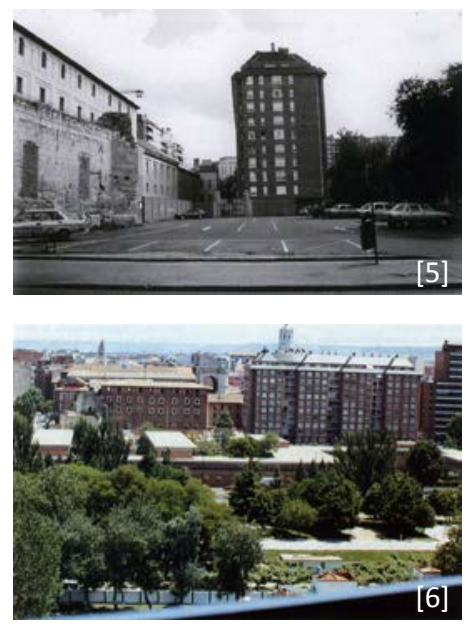

[4] Foto del entorno en 1995. (ARNUNCIO: 2012, p. 28)

[5] Vista del Monasterio desde el Oeste en 1990, donde se aprecia en primer plano la adecuada inserción del edificio de Fisac. (RIVERA: 1990)

[6] Plano de evolución histórica del edificio, en el que se especifican las actuaciones más relevantes. 


\subsection{Descripción del monumento}

3 Op. Cit. 1990, p. 152

La capilla se orienta en dirección este-oeste y queda parcialmente embebida en el cuerpo de la construcción del claustro del Monasterio, permitiendo que el acceso a la cabecera se realice directamente desde el deambulatorio.

El espacio de una sola nave se organiza en dos tramos, el correspondiente a la cabecera, con forma de $2 / 3$ de octógono, y el correspondiente a los pies, de forma cuadrada. A partir del reconocimiento del arranque de los arcos y de la documentación histórica se deduce que se trataba de un espacio con proporción de 3 a 2 entre la altura y la anchura, cubierto por una bóveda de crucería con terceletes en el tramo cuadrado, y una bóveda con tracería estrellada en la cabecera, "sugiriendo la amplitud espacial que entonces se iniciaba en Castilla". ${ }^{3}$ Ambos tramos quedaban separados por un potente arco perpiaño.

La materialidad de sus muros es a base de sillares de piedra con alma de cal y canto. En las dos esquinas libres del volumen se aprecian refuerzos de sección rectangular orientados a 45으, a modo de contrafuertes, para soportar los empujes de las bóvedas de crucería. En el lado norte se observa la presencia de una portada barroca superpuesta sobre la original gótica que, junto con el arco de medio punto presente en el muro de la cabecera, denotan las superposiciones propias de las transformaciones de los edificios a lo largo de la historia.

En el momento de la intervención la capilla se encuentra en ruinas, habiendo perdido completamente sus bóvedas, así como la mitad de la altura de gran parte de sus muros, quedando, sin embargo, en mejor estado, la zona embebida en la construcción monástica.

[7] Hipótesis del trazado de las bóvedas de la capilla de los Condes de Fuensaldaña. (RODRÍGUEZ: 1981)

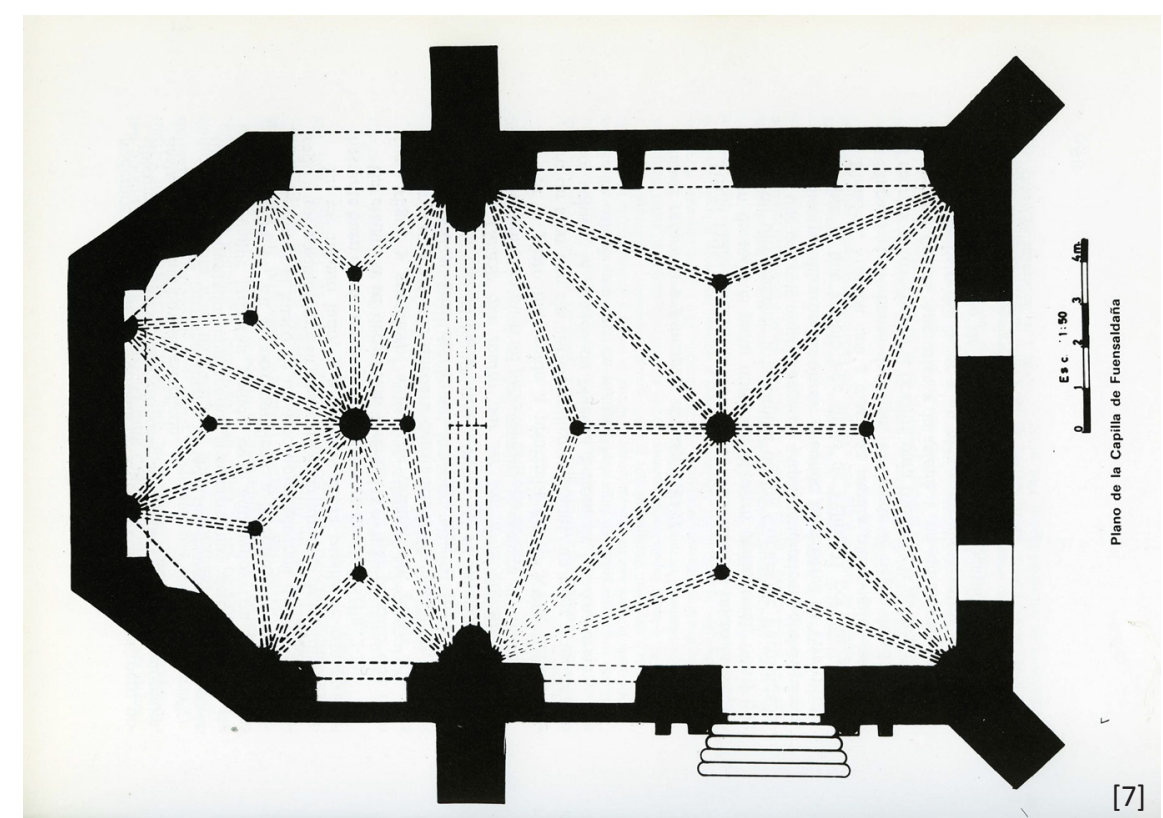




\subsection{Necesidad de la intervención}

La intervención en la capilla, objeto del análisis, forma parte del proyecto para el Museo de Arte Contemporáneo, propuesto por el Ayuntamiento de Valladolid para dotar de un nuevo contenido funcional a los elementos patrimoniales, y así permitir su restauración y conservación.

Los edificios habían sido maltratados desde su desamortización en 1837, mediante usos inadecuados que habían producido una aceleración de su deterioro, por lo que el nuevo uso daba la oportunidad de dotar de una nueva vida a los edificios históricos.

Por lo tanto, a las necesarias actuaciones de restauración del monumento, derivadas de los deterioros sufridos durante su ocupación militar y posterior abandono, se le añaden las actuaciones correspondientes a las instalaciones dirigidas a adecuar los espacios del monasterio a los exigentes requisitos de un museo de arte.

En lo que respecta a la capilla, el nuevo uso supone la transformación del monumento para su incorporación al complejo museístico, lo que conlleva tanto la restauración de las ruinas existentes como su adaptación al nuevo uso.

También cabe reseñar la necesidad de actuar sobre el espacio público existente junto a la capilla y al monasterio, empleado hasta ese momento como aparcamiento, e invadido por la presencia de elementos urbanos extraños.

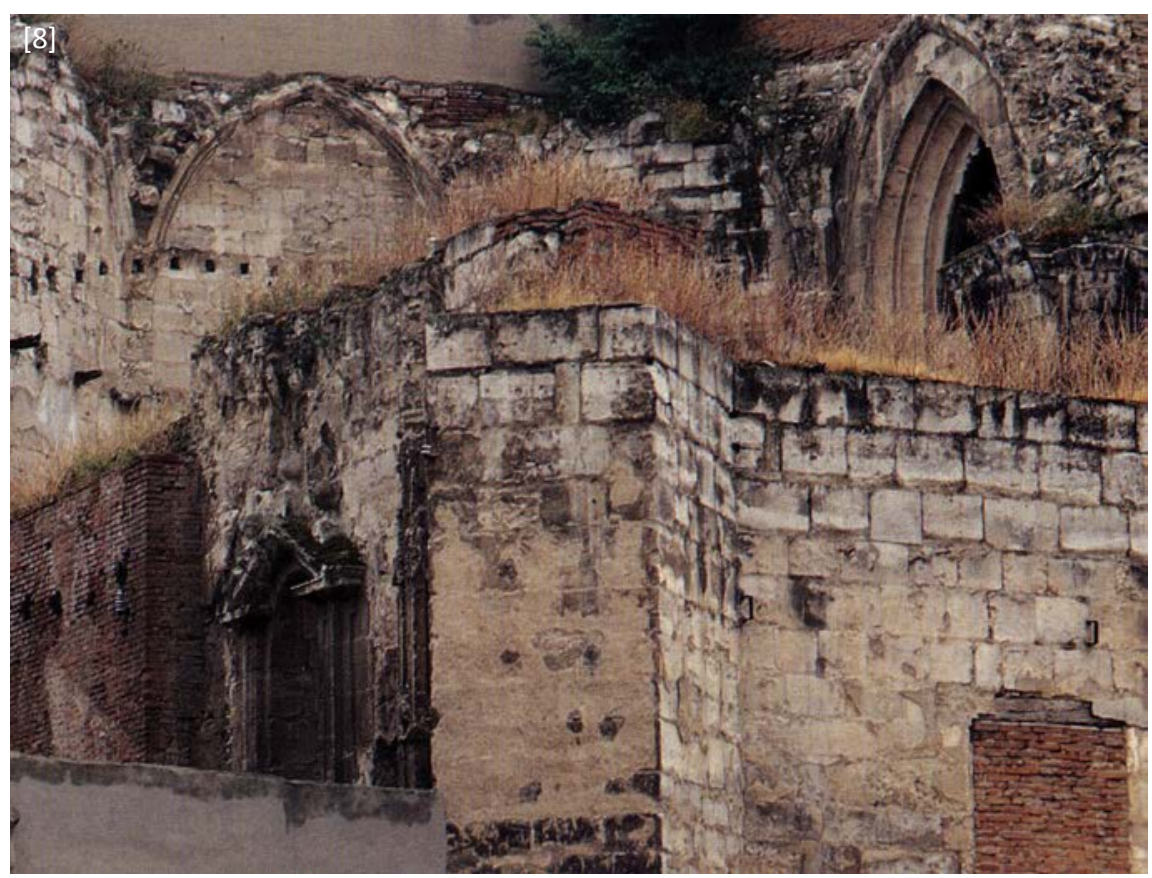

[8] Restos de la Capilla de los Condes de Fuensaldaña. (RIVERA: 1990)

[9] Interior de las ruinas de la capilla. Pueden apreciarse mechinales de forjado y la cubierta de su antiguo uso para estancias de la tropa. (Imagen de la colección TRYCSA. En: ARNUNCIO: 2012, p. 25)

[10] Restos de la portada de la capilla de los Condes de Fuensaldaña, realizada por Pedro de Olano y Bartolomé Barreda. (RODRÍGUEZ: 1981)

[11] Aspecto de las ruinas de la Capilla antes de la intervención. (Imagen de la colección TRYCSA. En: ARNUNCIO: 2012, p. 24)

[12] Alzado de las ruinas de la capilla. (Imagen del proyecto. En: ARNUNCIO: 2012, p. 27)

[13] Ruinas correspondientes a la cabecera de la capilla de los condes de Fuensaldaña. (RODRÍGUEZ: 1981) 

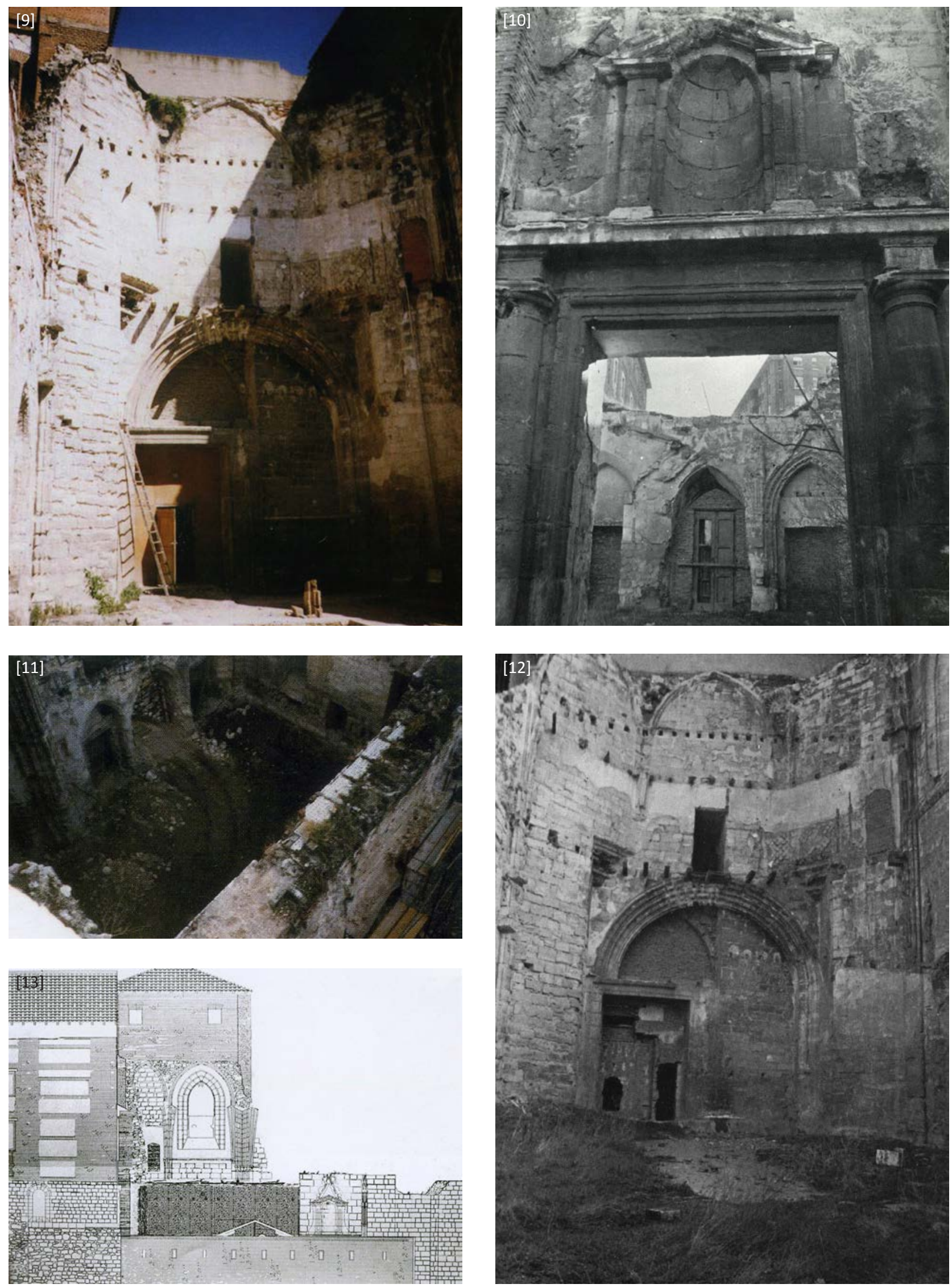


\section{EL ARQUITECTO RESTAURADOR}

Juan Carlos Arnuncio ${ }^{4}$ nace en Valladolid en 1951. Se gradúa como arquitecto en la E.T.S.A. de Navarra, con la especialidad de Urbanismo, en el año 1978. Obtiene el título de Dr. Arquitecto en la E.T.S.A. de Navarra en el año 1984. Ocupa el cargo de Director de la E.T.S.A. de Valladolid entre los años 1986 y 1990, y de Director del Departamento de Teoría de la Arquitectura y Proyectos Arquitectónicos entre los años 1991 y 1994. Obtiene la Cátedra de Proyectos Arquitectónicos en la E.T.S.A. de Valladolid en 1997, y la Cátedra de Proyectos Arquitectónicos en la E.T.S.A. de Madrid en 2010.

Entre sus publicaciones cabe destacar sus libros Peso y Levedad, notas sobre la gravedad a partir del Danteum (2007), Incursiones arquitectónicas (2009), Cosas del señor Francesco (2009).

\subsection{Humildad y Reflexión en Arquitectura. Una cuestión de actitud}

En su dilatada experiencia como Arquitecto, de casi 35 años de profesión, ha abarcado todo tipo de campos dentro de la disciplina: docencia, gestión, investigación y práctica arquitectónica. Arnuncio ha primado la componente social y la reflexión en sus proyectos, sobre la cualidad plástica y la producción vertiginosa: "La arquitectura tiene la obligación de resolver problemas, [...] por encima de todo". ${ }^{5}$

En esta preocupación por la reflexión arquitectónica tiene un papel fundamental su vinculación a la Escuela de Arquitectura de Valladolid, dónde ha sido profesor durante más de 30 años, y en la que el Departamento de Proyectos incluye al de Teoría de la Arquitectura, permitiendo que se produzca un interesante maridaje entre ambos.

Para Arnuncio, la historia es la base sobre la que se asienta su arquitectura: "Ia arquitectura se construye con la memoria,-comenta al ser interrogado sobre este asunto, y continúa-creo que todo lo que he hecho yo, se apoya en cosas que otros han hecho antes". ${ }^{6}$

Esta mirada a la historia, así como la mirada hacia el arte contemporáneo, tan presente en sus reflexiones, permite activar la reflexión sobre la arquitectura y buscar las respuestas a los problemas que surgen en un proyecto. Como él suele decir, citando a su profesor Curro Inza, "el proyecto de arquitectura es un problema con muchas más incógnitas que ecuaciones, por lo que es necesario hacerte preguntas inteligentes y obligarte a establecer estrategias de proyecto, inspirándote en las experiencias de otros creadores".7

Y la intervención en el patrimonio no deja de ser parte de ese ámbito del proyecto arquitectónico en el que surge un problema y hay que dar una respuesta concreta. Para Arnuncio no existe una receta porque la
4 Juan Carlos Arnuncio es el director del equipo de proyecto, junto a Clara Aizpún y Javier Blanco.

5 Entrevista realizada a Juan Carlos Arnuncio, en Valencia, en junio de 2012 (Ver anexo)

6 Entrevista realizada a Juan Carlos Arnuncio, en Valencia, en junio de 2012 (Ver anexo)

7 Entrevista realizada a Juan Carlos Arnuncio, en Valencia, en junio de 2012 (Ver anexo)

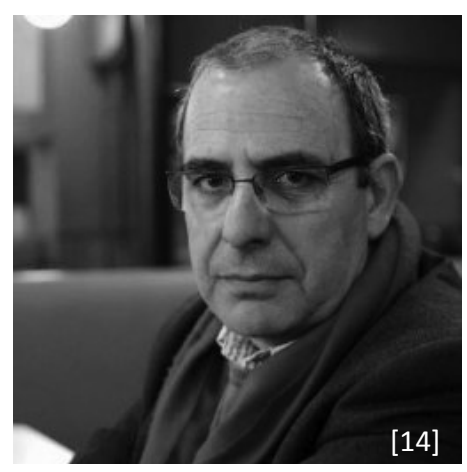

[14] Juan Carlos Arnuncio. (Fotografía de M. A. Santos. En: Elnortedecastilla.es, 20 de Febrero de 2009) 
8 Entrevista realizada a Juan Carlos Arnuncio, en Valencia, en junio de 2012, pregunta 4 (Ver anexo)

9 ARNUNCIO, J.C.: Patio Herreriano. Una Interpretación de la Arquitectura Histórica. Valladolid, Ed. Museo Patio Herreriano, 2012, p. 21 casuística es infinita, puesto que cada elemento patrimonial es distinto, pero apunta que la clave está en "saber callarse cuando hay que callarse y [...] saber hablar cuando hay que hablar".

Por otro lado, la diferencia con un proyecto de obra nueva está en la preexistencia, y en la complejidad que supone conocerla en profundidad para poder reconocer sus "solicitaciones", es decir sus problemas y valores, para introducirlas dentro de los objetivos del proyecto. Pero también en un proyecto de obra nueva debes analizar en profundidad las incógnitas, para poder darles respuestas adecuadas. Se trata en todo caso del análisis previo de reconocimiento del edificio, "saber lo que te estás jugando, saber lo que merece la pena y lo que no". Se trata, por tanto, de mostrar una "actitud frente a la arquitectura" de búsqueda inteligente de respuestas, adecuadas a cada caso.

En palabras del propio arquitecto:

"Intervenir en un edificio de valor histórico supone muchas cosas: supone, en primer lugar alterarlo, poco o mucho, dependiendo de su estado, de su valor, de su nuevo uso, de las nuevas solicitaciones que se establezcan con el lugar que ocupe, y del acierto. Supone, por lo tanto conocerlo. Descubrir las razones de su modo de ser, de su forma y de las circunstancias que lo llevaron a su situación en el momento en que debamos abordarlo. Supone, asimismo, conocer las condiciones de su nuevo uso; verificar hasta dónde es, o no, compatible con el edificio. Cuál es su esencia y cómo, con esas condiciones, transformar el edificio en la dirección correcta.

Supone dejar hablar al edificio, y si hemos de asumir su alteración, lograr que ésta ponga en valor lo esencial de aquél". ${ }^{9}$

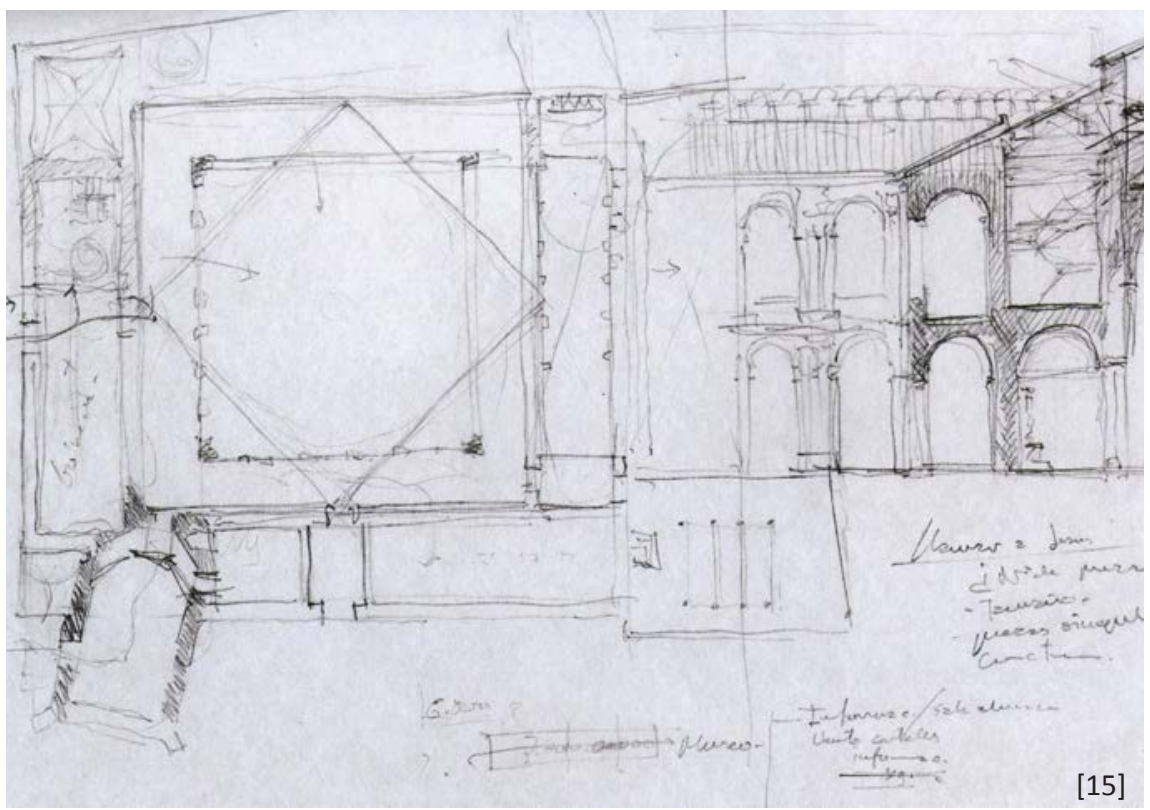




\subsection{Criterios de intervención en el patrimonio}

Ante la imposibilidad de encontrar criterios universales válidos para cualquier intervención, dado que cada caso es distinto, Arnuncio plantea reflexionar en torno a la naturaleza de las distintas "miradas al pasado" presentes a lo largo de la historia, que suponen distintos grados de alteración en relación al estado inicial. Para ello, Arnuncio introduce paralelismos con las intenciones pictóricas.

Así, la mirada al pasado de Viollet-le-Duc, consistente en la sublimación de lo pretérito hasta recuperar su estado ideal, se relaciona con los retratos de Napoleón o de Juana de Arco realizados por Ingres, que buscan exaltar episodios de la historia de dudosa fidelidad a la verdad.

Por otro lado, la mirada al pasado de John Ruskin, su defensa de la verdad por encima incluso del propio monumento, se relaciona con el cuadro "La Libertad guiando al pueblo" de Delacroix, que busca representar una escena de la realidad, exaltando el dramatismo de la guerra.

Cada una de ellas establece una jerarquía de valores distinta en el modo de entender y de intervenir en la arquitectura. Con ello Arnuncio nos hace ver que, al igual que podemos asumir y reconocer la validez de las pinturas referidas, independientemente de nuestra identificación con unas o con otras, también las opciones arquitectónicas que proponen Violletle-Duc y Ruskin no se agotan la una a la otra, sino que adquieren una dimensión diferente si ampliamos la idea de monumento desde el objeto específico arquitectónico hacia su entorno, su impacto en el territorio, sus condiciones de uso o su capacidad de adaptación a nuevas situaciones. ${ }^{10}$

Esta diversidad de criterios, derivada de las necesidades del proyecto, se aprecia con claridad en su propia obra.

\subsection{Experiencia como arquitecto restaurador}

Además del proyecto del Museo de Arte Contemporáneo, que aquí se analiza parcialmente, a lo largo de su trayectoria profesional Juan Carlos Arnuncio se ha enfrentado en diversas ocasiones a actuaciones de intervención en el patrimonio. Entre otras destacan el proyecto de reconstrucción de la casa Zúñiga (1989-1992), la intervención en el Palacio del Licenciado Butrón (1990), o la restauración de la Torre de Santa María del Campo en Burgos (2005-2008).

En la actuación de reconstrucción de la Casa Zúñiga ${ }^{11}$ en Valladolid, para su uso como dependencias universitarias, Arnuncio se encuentra con los restos de un edificio renacentista en ruinas, una construcción en forma de $U$ en torno a un patio, del que el lado recayente a la parte posterior de la parcela había desaparecido totalmente.
10 ARNUNCIO PASTOR, J.C.: "Las Miradas al Pasado". En: A.A.V.V.: Día de la Arquitectura. XVII Congreso Internacional de Conservación y Restauración de Bienes Culturales. Castellón, 20 de noviembre de 2008, Editorial UPV, 2008, pp. 45-46

11 ARNUNCIO, J.C.; SIERRA, V.: "Rehabilitación de la 'Casa de los Zúñiga' para sede del Departamento de Publicaciones y del Instituto de Ciencias de la Educación (ICE) de la Universidad de Valladolid". BAU, № 8-9, Valladolid, 1993, pp. 52-59
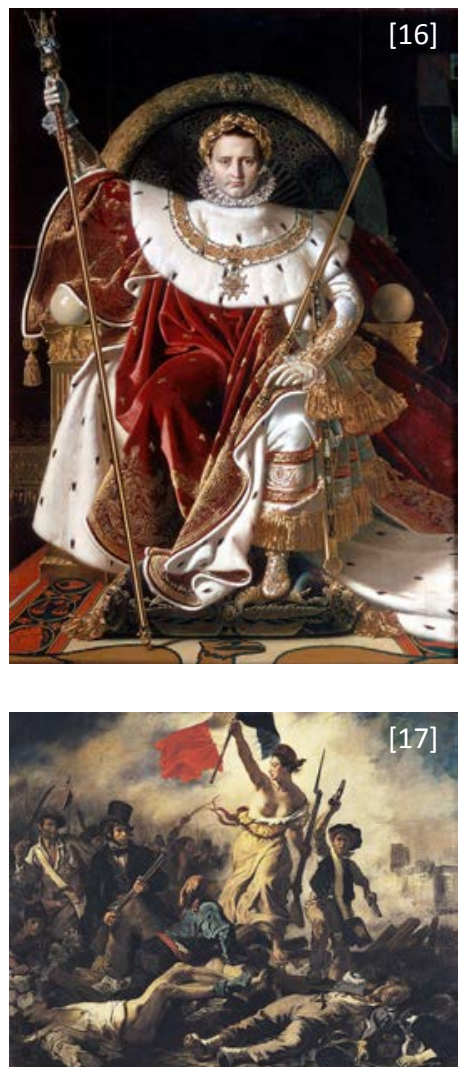

[16] Retrato de Napoleón realizado por Ingres. (Andrew Graham Dixon Archive. En: <www.andrewgrahamdixon.com $>$ )

[17] La Libertad guiando al pueblo. Eugène Delacroix. (Museo del Louvre: <www.louvre.fr>) 
[18] Casa Zúñiga. Vista de la fachada posterior. (ARNUNCIO; SIERRA: BAU. Revista de Arquitectura, $\mathrm{n}=8$ y 9,1993, p. 54)

[19] Casa Zúñiga. Vista del patio. (ARNUNCIO; SIERRA: BAU. Revista de Arquitectura, no 8 y 9, 1993, p. 58)

[20] Casa Zúñiga. Vista del interior del semisótano abovedado. (ARNUNCIO; SIERRA: BAU. Revista de Arquitectura, no 8 y 9, 1993, p. 56)
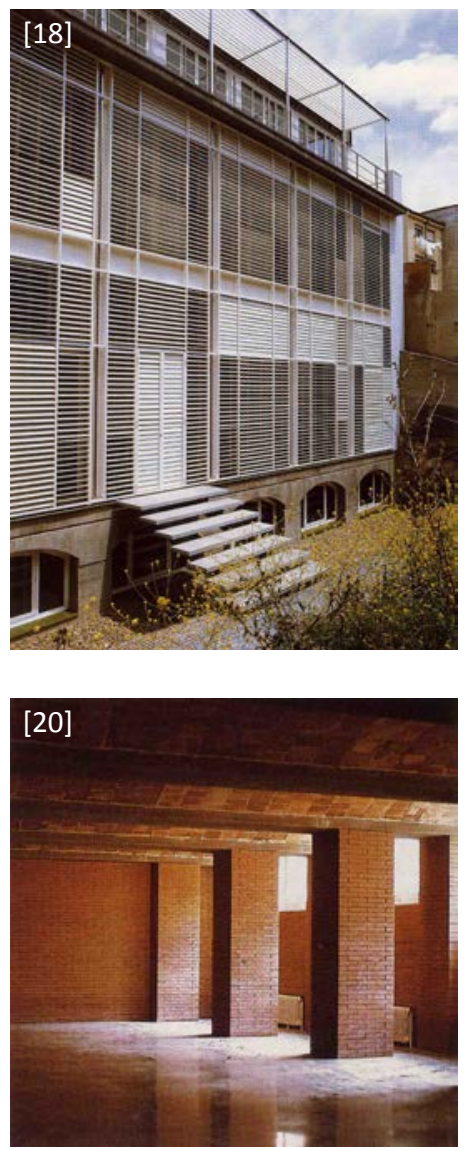

Por cuestiones de normativa, el criterio de intervención viene condicionado a la restitución del cuerpo desaparecido, por lo que se opta por una restauración tipológica, reponiendo los elementos conservados en el mismo lugar que ocupaban, a modo de anastilosis, y reconstruyendo el resto, pero asumiendo su nueva condición constructiva.

Los nuevos elementos se añaden tratando de establecer una relación unitaria en el conjunto: el muro de media sillería de piedra de Salamanca o la galería que recorre el patio buscan dialogar con el cuerpo existente, pero sin perder su carácter abstracto de elementos nuevos.

La fachada posterior se construye con un lenguaje decididamente moderno, tomando como referencia a las galerías existentes en los patios de manzana del casco histórico de Valladolid.

Por último se construye un semisótano que trata de unir las dos actitudes mediante una cubierta de bóvedas de rasilla, que reinterpreta de forma abstracta este tipo de espacios.

Con esta actuación, Arnuncio renuncia a la construcción de un edificio de nueva planta, en favor de mantener la huella, la memoria de un edificio que representa a muchos otros palacios que existían en la misma calle y que ahora ya han desaparecido.

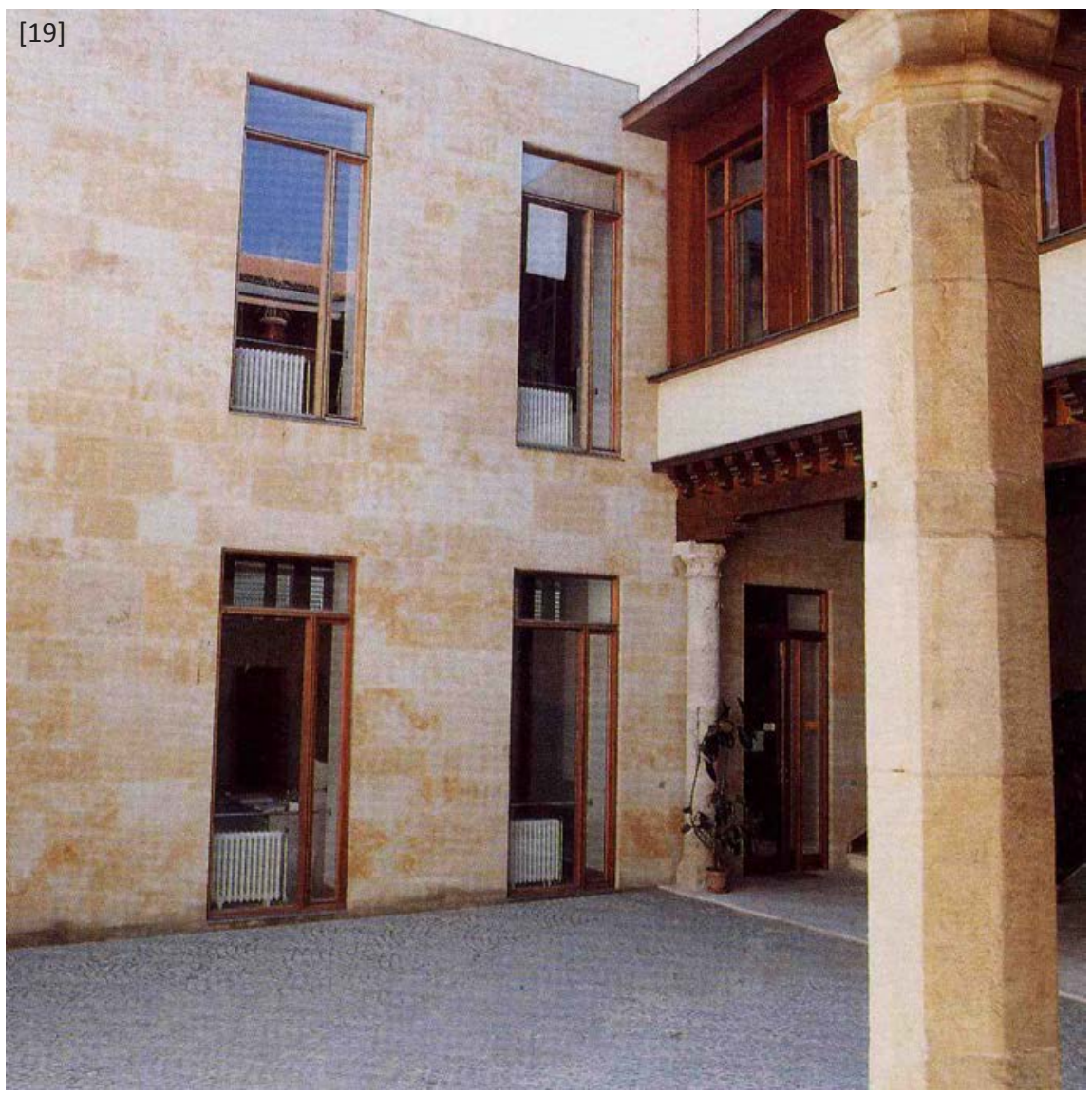


En la intervención sobre el Palacio del Licenciado Butrón para Archivo General de la Junta de Castilla y León, Arnuncio construye un nuevo prisma para albergar los archivos de libros sobre un espacio abovedado del siglo $\mathrm{XVI}$. Así pues se encuentra con el problema de cómo conectar un cuerpo del siglo XVI, de alturas de entre 4,5 y $5 \mathrm{~m}$, con artesonados de madera, con otro cuerpo nuevo con espacios de $2,30 \mathrm{~m}$ de altura y que en su planta baja contiene un espacio abovedado del siglo XVI, reconvertido en salón de actos.

Para ello, propone generar un gran vacío que recorre toda la altura, configurando el hall del salón de actos. El espacio se configura mediante un plano inclinado, para ocultar la entrada de luz que ilumina las plantas del depósito, y un plano alabeado, resultado del ensanchamiento de los descansillos de la escalera, para lograr un mejor anclaje de la fachada histórica adyacente. El resultado es un ámbito de gran complejidad espacial, donde la abstracción material permite multiplicar la intensidad expresiva, devolviéndole la dignidad al palacio renacentista.

Por último, en el proyecto de intervención sobre la Torre de Santa María del Campo, en Burgos, Arnuncio se limita a realizar actuaciones de limpieza y protección, y restitución de aquellos pequeños elementos faltantes, como gárgolas o balaustres, que repone imitando los elementos antiguos, tratando de recuperar la perfección de la torre renacentista.

En estas tres obras se observan tres criterios de intervención distintos: reconstrucción tipológica en la casa Zúñiga, inserción de un nuevo elemento de gran intensidad espacial en el Palacio del Licenciado Butrón, y restitución mimética de elementos faltantes en la Torre de Santa María del Campo, de tal manera que cada uno trata de responder adecuadamente a los problemas concretos existentes en cada caso.

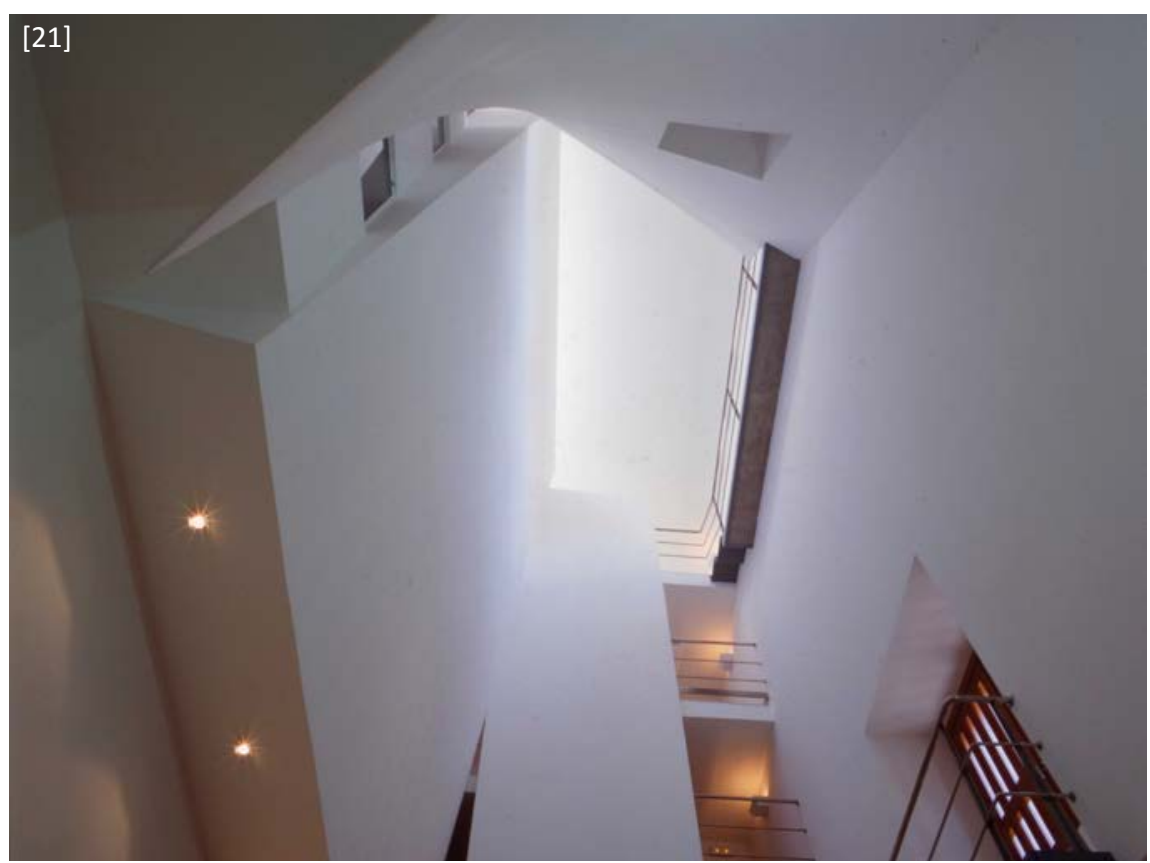

[21] Nuevo espacio del acceso al Palacio del Licenciado Butrón (ARNUNCIO: <www.arnuncio.es>)

[22 y 23] Imagen de la torre restaurada de Santa María del Campo (ARNUNCIO: <www.arnuncio.es>)

[24] Grabado de Eduardo Chillida. (Dolors Junyent. Galería d'art: <eng. dolorsjunyent.com>)

[25] Vista de los volúmenes del estudio de Juan Carlos Arnuncio desde la calle. (Cuartas Jornadas Arquitectónicas Materia y Forma 4. Catedra Blanca Valencia-CEMEX)

[26] Concurso para edificios de acogida de visitantes a los yacimientos de Atapuerca. (ARNUNCIO: <www. arnuncio.es $>$ )

[27] Concurso edificio para las Cortes de Castilla y León (ARNUNCIO: $<$ www.arnuncio.es $>$ )

[28] Conservatorio profesional de música y danza en Burgos (ARNUNCIO: <www.arnuncio.es>)
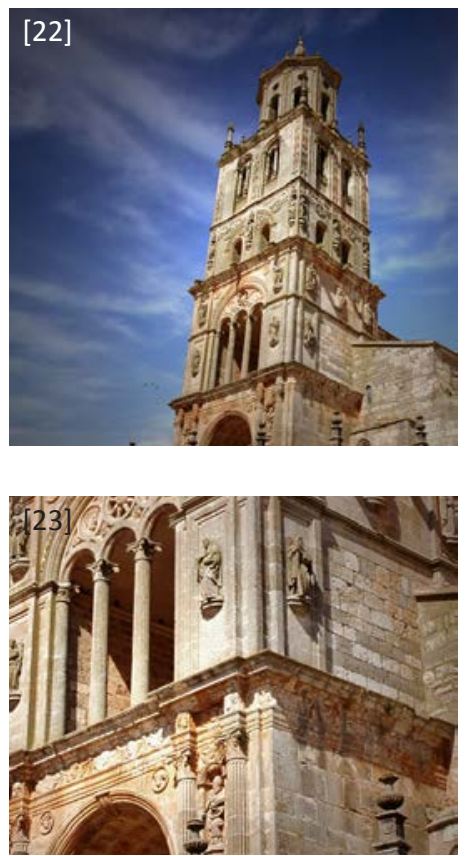

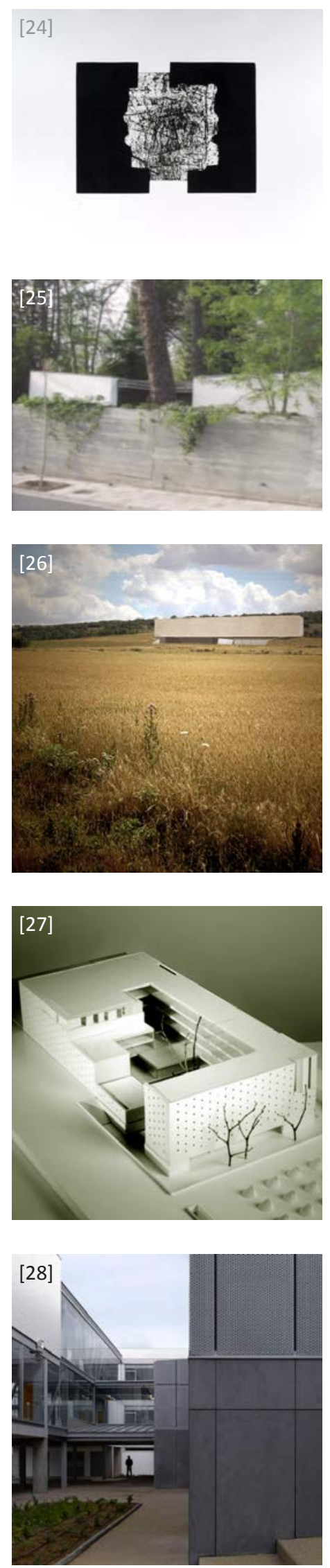

\subsection{El concepto de introversión en su arquitectura}

Si analizamos la obra de Juan Carlos Arnuncio se pueden observar una serie de invariantes, de actitudes, que se van repitiendo en la configuración formal de sus proyectos arquitectónicos. Uno de estos invariantes es el del concepto de "caja", de elemento abstracto en el exterior que encierra un efecto de sorpresa en su interior.

Arnuncio muestra en sus reflexiones una inquietud sobre esta cuestión presente en diversos arquitectos y artistas, de entre los que destaca a Eduardo Chillida, quien explora este concepto a través de sus esculturas y grabados, representando cajas herméticas hacia el exterior que esconden un mundo distinto en su interior, como si lo de dentro se tratara con más amabilidad que lo de fuera. Un elemento rudo, sobrio, que protege un interior amable.

Repasando sus obras y proyectos de nueva planta se puede reconocer esta actitud:

En su estudio (1997), ubicado en el jardín de su vivienda, Arnuncio plantea una pieza en forma de $U$ que se abre en torno a un patio, para permitir una relación visual de los espacios interiores, y se cierra al exterior, para mantener un ambiente de concentración y trabajo aislado del ocio familiar.

En el concurso para un centro de acogida de visitantes a los yacimiento de Atapuerca (2005), una gran losa sobre una loma verde hace de elemento protector para permitir la vida, produciendo un contraste entre la geometría recta de la pieza que alude a la inteligencia y el mundo de la naturaleza que alude a lo arbitrario.

En el concurso del edificio para las Cortes de Castilla y León (2001), una pieza se cierra sobre sí misma, hermética y muda, y oculta en su interior un patio mucho más habitable. Y de manera similar, en el Conservatorio de música y danza de Burgos (2005-2008) el edificio se pliega sobre sí mismo y se ubica en su interior el salón de actos, tratando de resguardarse de los ruidos de la ciudad, y generando una serie de patios que iluminan los espacios interiores.

Igualmente, esta actitud está presente en proyectos de intervención en el patrimonio como en el hall de acceso al Palacio del Licenciado Butrón, o en la Capilla de los Condes de Fuensaldaña del museo de arte contemporáneo, donde la serenidad del elemento exterior oculta un gran efecto en el interior.

Este concepto de introversión y de equilibrio de opuestos aparece en el pensamiento y la arquitectura de diversas culturas a lo largo de la historia. En la filosofía taoísta, el ser y el no ser son componentes de una misma entidad. En el cristianismo la riqueza interior, vinculada con la conexión con "Dios", debe estar encerrada en una actitud externa pobre y austera, 
como se observa con claridad en la arquitectura de los siglos IV al X, con ejemplos magníficos como Santa Constanza y Santo Stefano Rotondo en Roma, San Vitale de Rávena, la capilla palatina de Aquisgrán; o las diferentes iglesias románicas. Este mismo concepto está presente también en la arquitectura islámica, como se observa en los mausoleos fatimíes de Asuán, o la propia Alhambra.

En la modernidad también se ha utilizado con gran profusión el tema de los opuestos, y en especial la caja sencilla y abstracta por fuera que encierra el tesoro, la cualidad y complejidad del espacio en su interior como se observa, por ejemplo, en el proyecto de Giuseppe Terragni para el Danteum, intensamente estudiado por Arnuncio, donde unos grandes paramentos de piedra ocultan en el interior un complejo recorrido espacial en el que se busca transmitir al espectador, a través de la experimentación perceptiva y emocional, los lugares imaginados por la religión católica y evocados en la obra literaria cumbre de Dante Alighieri: la Divina Comedia. ${ }^{12}$

\subsection{La ficción arquitectónica. Referencias}

Otro de los invariantes en los proyectos de Juan Carlos Arnuncio, es la presencia de una actitud desprejuiciada en la búsqueda por elaborar efectos en la arquitectura, en confrontación con el concepto de sinceridad constructiva entendida como una exigencia ética. Arnuncio, en su continua investigación arquitectónica, encuentra especial interés por la fluctuación que existe, a lo largo de la historia de la arquitectura, entre la forma derivada de su exigencia constructiva y estructural, y cierto grado de libertad que se concede a sí misma, un amplio abanico de soluciones que varían entre la "literalidad y el sueño". ${ }^{13}$

Este interés queda patente en su libro Peso y Levedad ${ }^{14}$, en el que Arnuncio hace una reflexión sobre la gravedad en la arquitectura, entendida no tanto como un fenómeno físico, sino más bien como una condición con la que poder caracterizar la forma arquitectónica.

La búsqueda de la ingravidez ha sido una constante a lo largo de la historia de la arquitectura en los espacios abovedados, como una aspiración hacia lo espiritual, levedad que se ha potenciado en contraste con el evidente peso de los muros soportantes.

En este sentido, Arnuncio demuestra un interés por desentrañar las claves formales que se esconden detrás de tales efectos sensoriales, mostrando una especial curiosidad por ciertos autores que han empleado estos "mecanismos ilusorios" en la arquitectura.

Entre otras obras, Arnuncio analiza el caso del Teatro Olímpico de Vicenza de Andrea Palladio (1579-85), en el que se traspasa el mundo de la representación para introducir el artificio en el lado de la realidad, y así generar una sensación de espacio abierto; o el caso de los frescos de
12 ARNUNCIO, J.C.: Peso y Levedad. Notas sobre la gravedad a partir del Danteum. Barcelona, Ed. Fundación caja de arquitectos, 2007, p. 15

13 ARNUNCIO PASTOR, J.C.: “Materia y Forma". Conferencia impartida en Materia y Forma IV. Jornadas Internacionales de Arquitectura, en la Universidad Politécnica de Valencia, 2-4 de marzo de 2009

Disponible en el sitio web de Cátedra Blanca: <http://www.upv. es/catedrablanca/myf4/INICIO.htm> [Consulta: 15-05-2012]

14 ARNUNCIO, J.C.: Peso y Levedad. Notas sobre la gravedad a partir del Danteum. Barcelona, Ed. Fundación caja de arquitectos, 2007

[29] Teatro Olímpico de Vicenza. Andrea Palladio. (ARNUNCIO: 2007, p. 108)

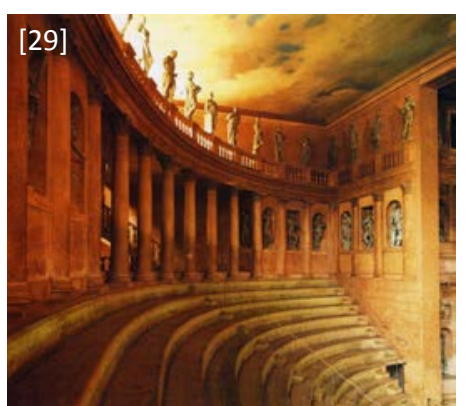




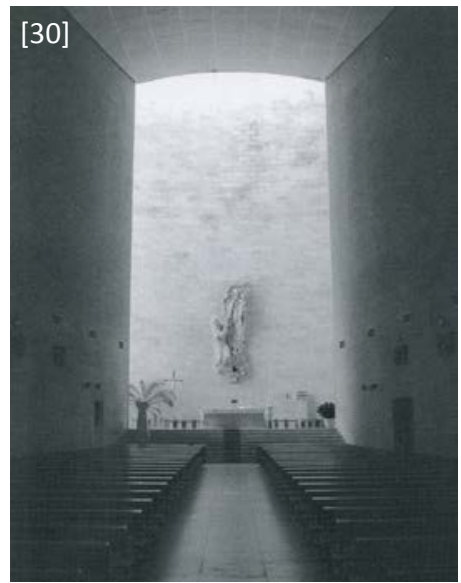

[30] Interior de la capilla del Colegio Apostólico de los Dominicos de las Arcas Reales. Valladolid 195254, Miguel Fisac. (ARNUNCIO: 2007, p. 114)

[31 y 32] Vista interior y sección de la Capilla Cuáquera, James Turrell. (ARNUNCIO: 2007, p. 112)

[33] Frescos de Andrea Pozzo en la bóveda de la iglesia de San Ignacio en Roma. (Fotografía del autor)
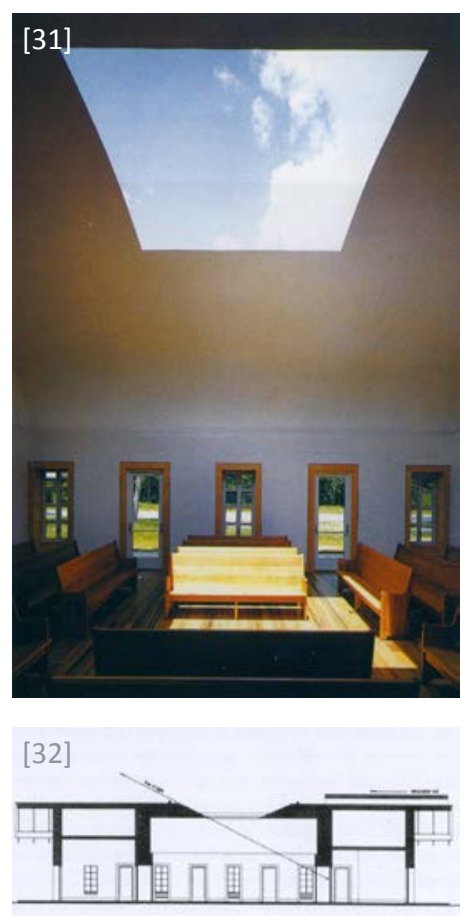

Andrea Pozzo en la bóveda de la iglesia de San Ignacio en Roma (1685-94), donde mediante la recreación de una arquitectura en correspondencia con la de la iglesia, prolonga el espacio verticalmente y lo deja abierto a la representación del cielo, desmaterializando el plano del techo, elemento "prescindible" bajo un cielo protector. En ambos casos, la prolongación de la arquitectura trata de dar verosimilitud a la ficción, a la vez que las figuras representadas descienden a la arquitectura "real" completando la interrelación entre ambos mundos. ${ }^{15}$

Otros ejemplos más actuales, en los que ya no se emplea la figuración para generar los efectos, sino a través de la propia arquitectura, son la capilla cuáquera en Houston de James Turrell, o la capilla del Colegio Apostólico de los Dominicos de las Arcas Reales en Valladolid de Miguel Fisac (1952$54)$, en los que se busca crear el efecto de una arquitectura sin espesor, produciendo una sensación de irrealidad.

Y así comprendemos el interés que muestra por arquitectos como Juan Navarro Baldeweg, Alvaro Siza, o incluso Paulo Mendes da Rocha, quien demuestra una gran habilidad para construir el efecto deseado con sinceridad material. Éste es el caso del proyecto para el Instituto de Educación Caetano de Campos (1976), donde Mendes introduce un prisma horizontal elevado sobre el terreno que se perfora en su interior, y en cuyo vacío se coloca un nuevo prisma; con todo ello se produce "un cruce de relaciones entre lleno y vacío, entre forma y huella, entre horizontalidad y verticalidad, cuya atadura formal podría ser cierta idea de peso y liviandad". ${ }^{16}$

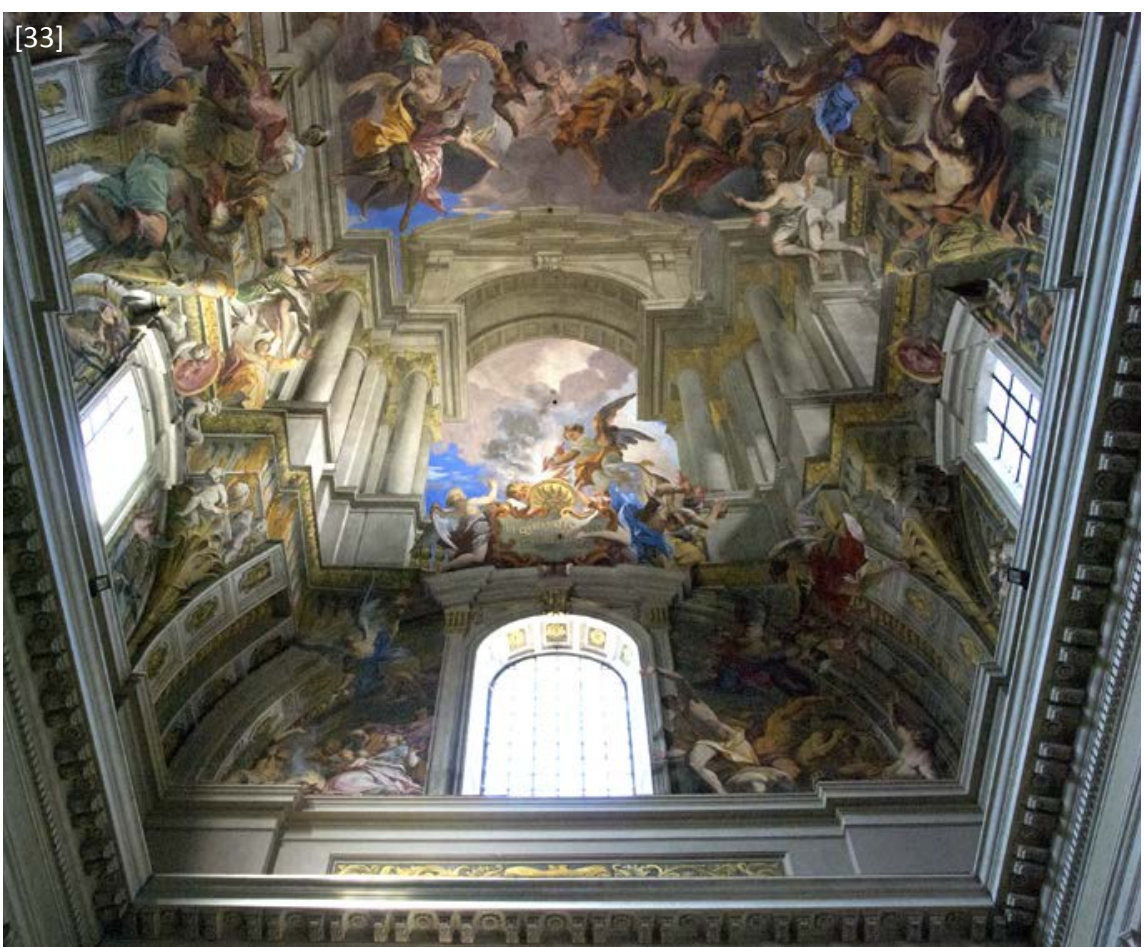

Capilla de los Condes de Fuensaldaña. Valladolid. 1996-2002 


\section{DESCRIPCIÓN DE LA INTERVENCIÓN}

\subsection{Objetivos de la intervención}

Desde el punto de vista de la gran escala, el proyecto de intervención propone devolver la dignidad al espacio urbano mediante tres cuestiones clave: conformar una gran plaza como espacio previo de acceso al museo; dejar en segundo plano la presencia desmedida del bloque de viviendas situado en la misma manzana; y por último reconstruir el volumen desaparecido de la capilla.

La conformación de la plaza de acceso debe resolver los desniveles existentes y generar un lugar tranquilo de preparación al visitante, necesario para contemplar un museo de arte. Para mitigar la desmedida presencia del bloque de viviendas se propone la construcción de un nuevo edificio abstracto que apoyara el contenido funcional del museo, albergando la cafetería, circulaciones verticales y nuevas salas de exposiciones. Por otro lado, la reconstrucción del volumen de la capilla busca recuperar su valor histórico en la ciudad y terminar de conformar los límites que definen la plaza ajardinada y el acceso al museo.

Desde el punto de vista del conjunto edificado, el objetivo es que se perciba de un modo homogéneo la compleja presencia de arquitecturas en situaciones distintas: en primer lugar el denominado "Patio Herreriano" del monasterio, elemento central del museo por su ubicación y su importancia, que se encontraba en un relativo buen estado; en segundo lugar la capilla -objeto de este análisis-, que se encontraba en ruinas, conservándose únicamente parte de la altura de los muros perimetrales y el arranque de una bóveda; y en tercer lugar el edificio de ampliación, elemento de nueva creación propuesto en el proyecto.
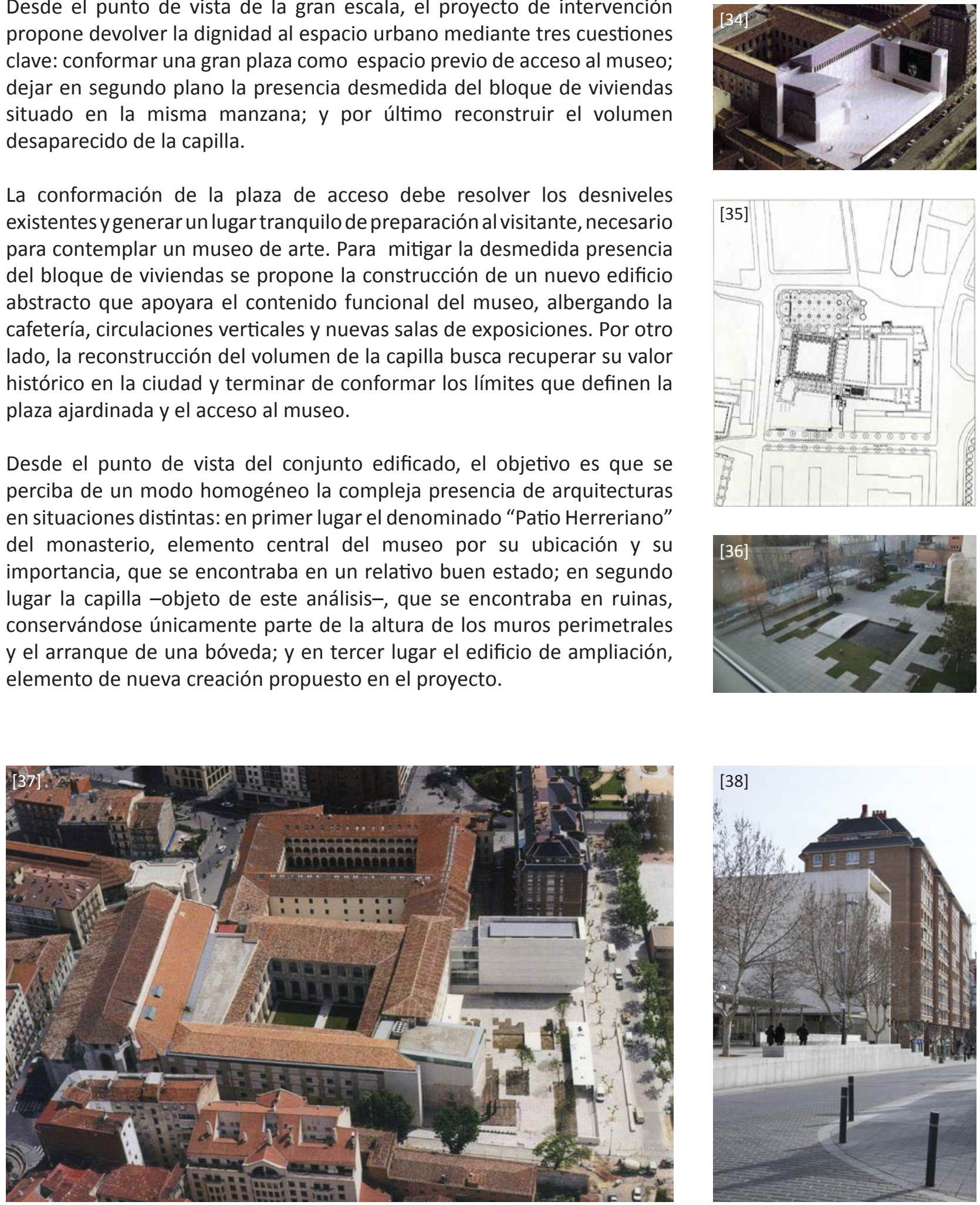
La actuación sobre la capilla se plantea como un camino intermedio entre el respeto por lo preexistente y su adaptación al nuevo uso. Así pues, se busca convertirla en sala de exposiciones pero manteniendo en todo momento su imagen de ruina. De tal manera que, al igual que ocurre con la puerta barroca que se superpone sobre la gótica en el muro norte, la nueva intervención debía diferenciarse de lo existente generando un nuevo estrato en la historia del monumento.

[34 y 35] Patio Herreriano. Maqueta y Plano de conjunto del proyecto. (ARNUNCIO; SIERRA: Arquitectua Viva, no 75, 2000, p. 44)

[36] Patio Herreriano. Vista de la plaza-jardín de acceso. (Imagen del autor)

[37] Patio Herreriano. Vista aérea del conjunto a la finalización de las obras. (Imagen de la colección TRYCSA. En: ARNUNCIO: 2012, p.40)

[38] Patio Herreriano. Vista del nuevo volumen que alberga la cafetería y nuevas salas de exposiciones. (Imagen del autor)

[39] Patio Herreriano. Redibujo de la planta del conjunto a partir de los planos del proyecto.

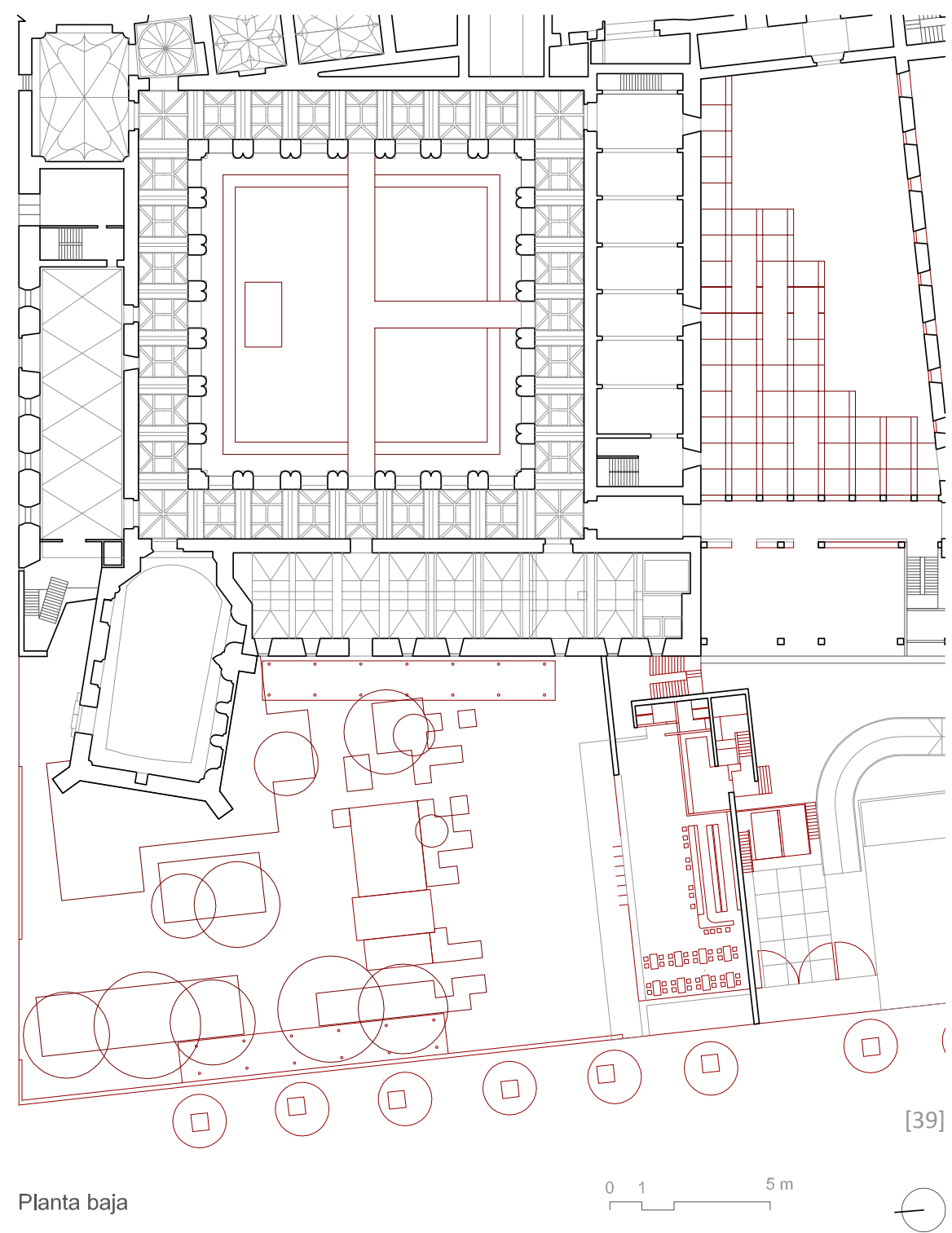


El criterio de intervención se puede resumir, en palabras de su autor, de la siguiente manera:

"[...] la intervención asume su necesidad de responder con arquitectura a lo que no son sino problemas de arquitectura, y hacer de la nueva configuración un todo, asumiendo, como en tantos ejemplos de nuestro patrimonio histórico -empezando por la propia historia del monasterio-, que los edificios pueden sufrir metamorfosis, y que a veces ese nuevo estado ofrece una nueva dimensión en su conocimiento. No se trata de hacer una nueva arquitectura 'a juego con la antigua', sino de asumirla como una nueva arquitectura en la que conviven pasado y presente". ${ }^{17}$

\subsection{Programa funcional}

El uso de museo requiere contar con la necesidad de conformar dos tipos de espacios distintos: espacios estáticos, donde se contemplan las obras de arte; y espacios dinámicos, encargados de albergar los recorridos para conectar los espacios de contemplación. El proyecto propone emplear
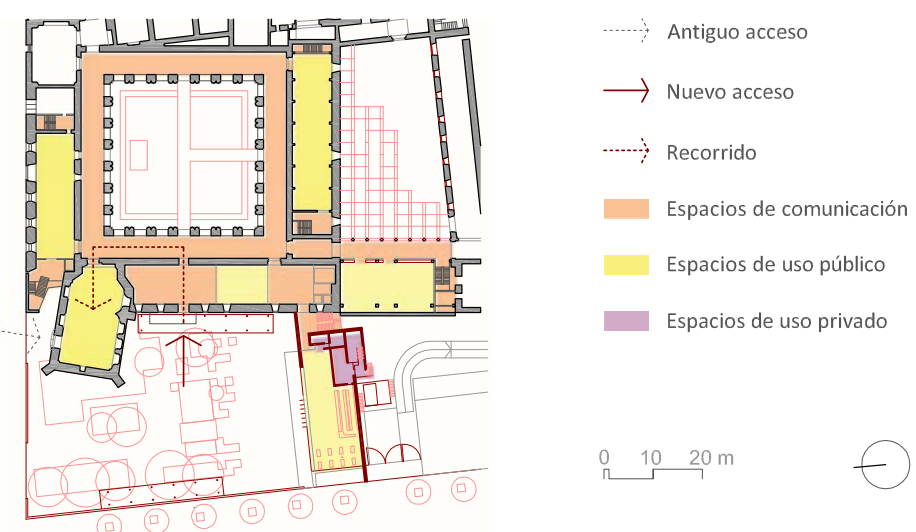

los elementos históricos más significativos para los espacios dinámicos, y en contraposición, definir los espacios de las salas expositivas como elementos neutros en los que la obra exhibida fuera la protagonista.

El espacio de la capilla se plantea como un espacio estático de exposición y contemplación, pero debido a su valor histórico, su fuerte carácter material y su gran dimensión, se trata como una sala especial dentro del conjunto, capaz de albergar instalaciones contemporáneas pero exigiendo a los artistas la necesidad de establecer un diálogo entre la obra y el espacio expositivo.
17 Op. Cit, 2012, p. 46
[40] Esquema de usos.

[41] Imagen del exterior de la capiIla. (Imagen del Archivo Fotográfico Museo Patio Herreriano. En: ARNUNCIO: 2012, p. 65)

[42] La presencia de tres tiempos en la capilla: la primitiva puerta gótica sobre la que se construye la barroca y finalmente, la intervención para museo que implicó el cerramiento superior de hormigón y vidrio. (Imagen del Archivo Fotográfico Museo Patio Herreriano. En: ARNUNCIO: 2012, p. 67)

[43, 44, 45 y 46] Croquis previos a la intervención en la capilla. Entenderla como una ruina y tratar de mantener su imagen como tal, llevaba implícito dibujar el contraste entre la primitiva fábrica y el cerramiento superior nuevo. (ARNUNCIO: 2012, p. 66)

[47] Imagen del interior de la capiIla. (Imagen de Ricardo González. En: ARNUNCIO: 2012, p. 70) 

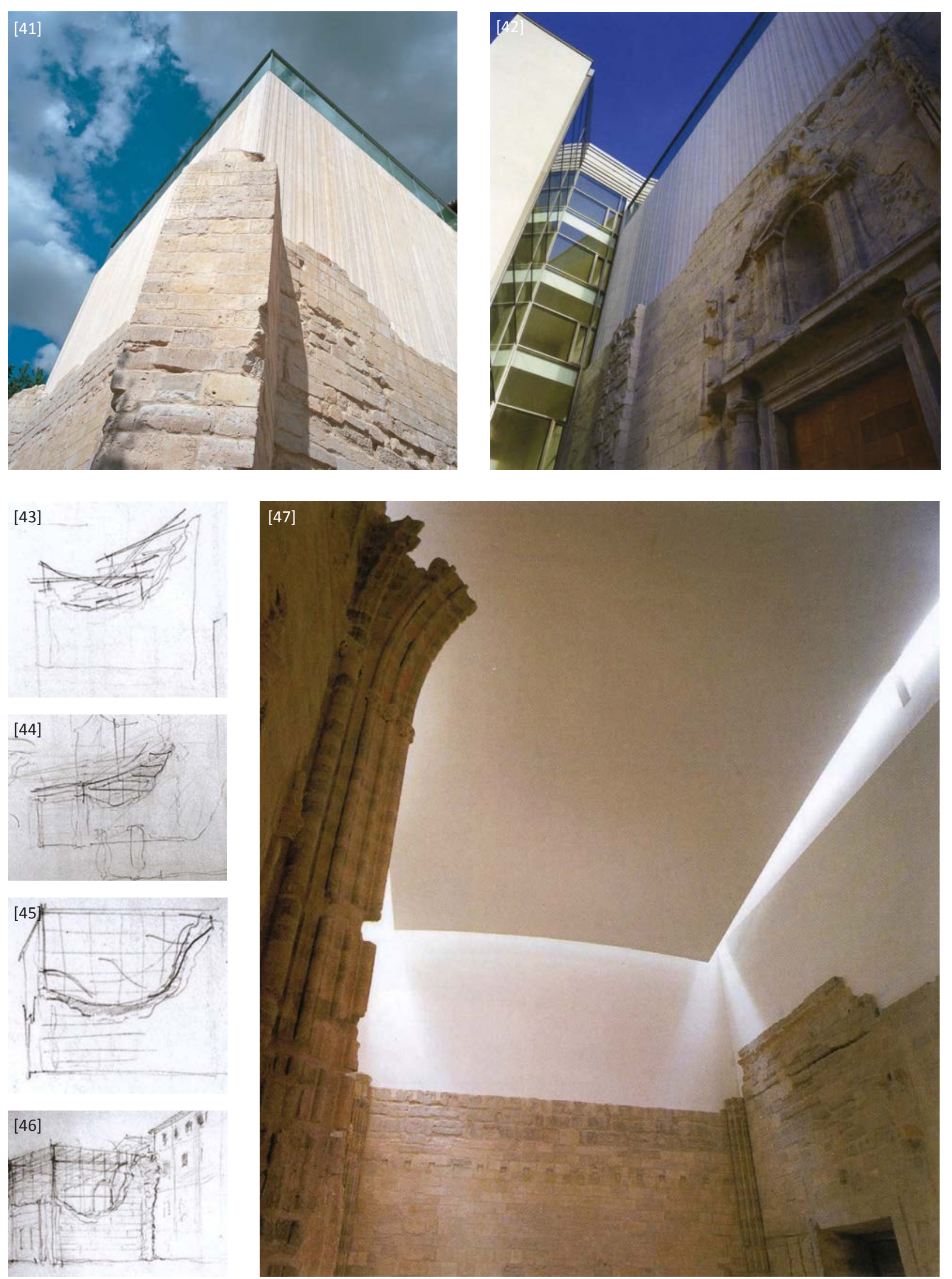


\subsection{Forma, espacio y luz}

Por un lado, la actuación sobre el conjunto se plantea a través de una arquitectura abstracta, de grandes superficies limpias, prestando especial atención al color y a las texturas en un intento de armonizar cromáticamente materiales distintos, para alcanzar con ello una homogeneidad en la intervención.

Por otro lado, la solución formal de la capilla busca plasmar dos ideas fundamentales: la intención de completar la ruina recuperando la cualidad másica de la capilla y su presencia en la ciudad -con su adecuada escala en relación con el espacio urbano, con la pieza conventual y el entorno- y la creación en el interior de un espacio que recupere la dignidad perdida.

Para ello se plantea un prisma abstracto e introvertido, que en su exterior busca recuperar la altura original de la capilla. Éste se retranquea respecto al plano exterior de los muros de piedra preexistentes, quizá queriendo dar a entender que lo que vemos es una capa interior del muro que ha perdido su terminación, acentuando la diferencia entre la fábrica primitiva y el cerramiento nuevo de la parte superior, y consiguiendo de esta manera mantener en un primer plano su imagen de ruina.

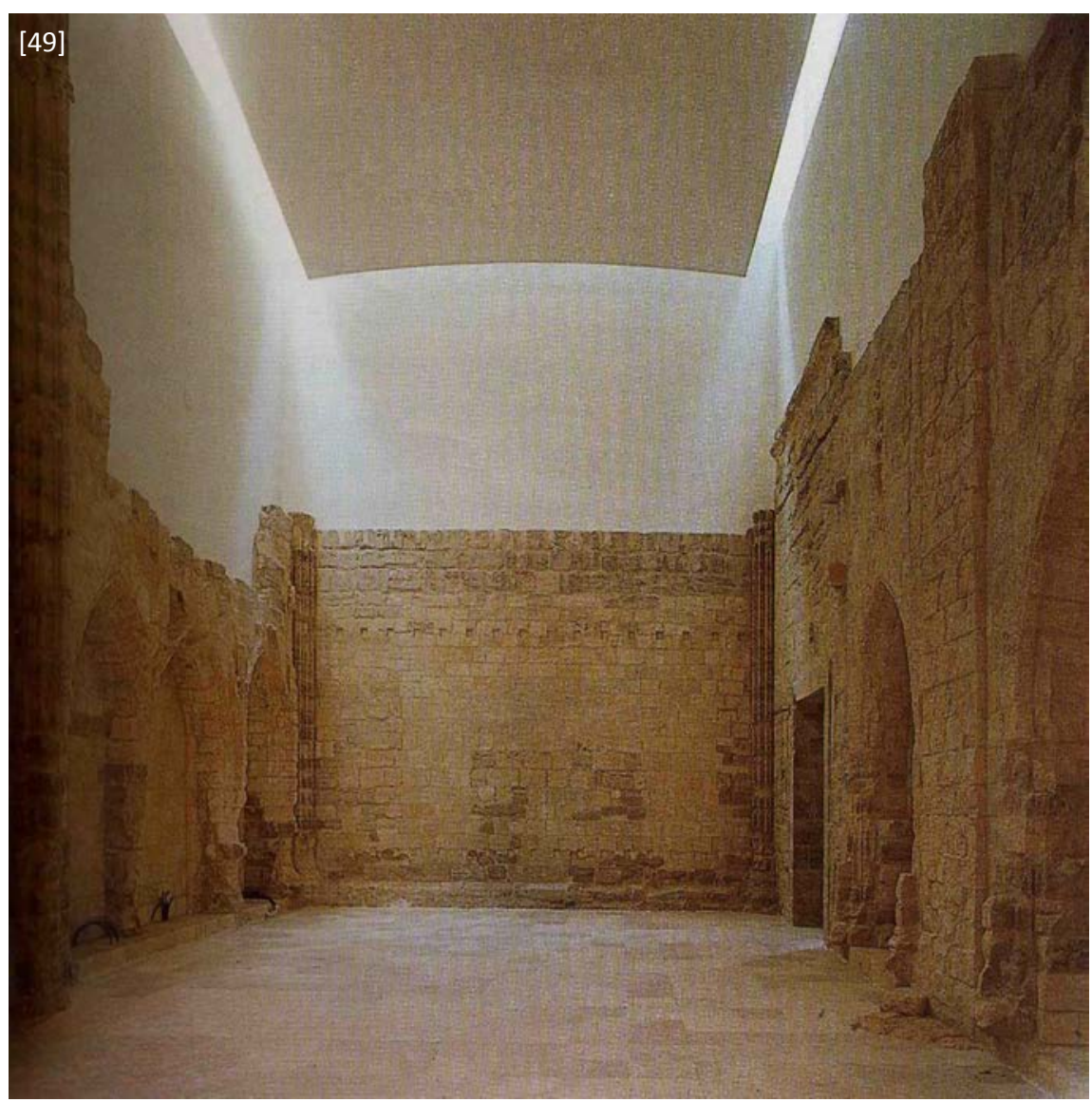

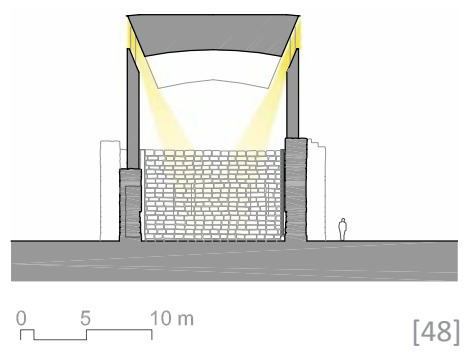

[48] Esquema que ilustra la entrada de luz. Sección transversal.

[49] Vista del interior de la capilla. (ARNUNCIO; SIERRA: Arquitectua Viva, no 75, 2000, p. 45) 
18 Entrevista realizada a Juan Carlos Arnuncio, en Valencia, en junio de 2012, pregunta 4 (Ver anexo)

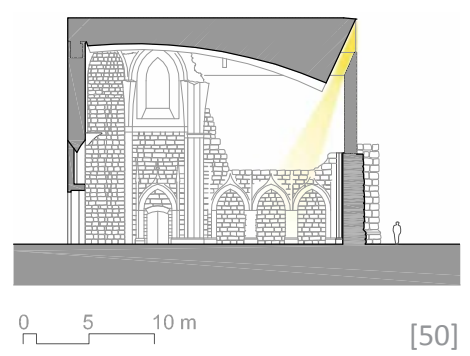

El nuevo prisma se descompone en dos partes, a modo de cuerpo y remate, siendo este último una pieza de vidrio corrida que culmina en una sutil "cornisa" reducida a su mínima expresión, en un gran esfuerzo constructivo que enuncia el "efecto" que se producirá en el interior.

En el interior de la capilla, una superficie cóncava abstracta y blanca parece levitar en el espacio. Se oculta intencionadamente el espesor del elemento, buscando producir la ficción de que el techo es una lámina curva extremadamente ligera que flota en el aire y te envuelve. La luz se cuela entre el plano curvo y los muros, iluminando el espacio con una luz indirecta que remarca la sensación de levedad de la lámina. Con ello genera en el observador una sensación de gran emotividad, donde el tiempo se detiene e invita al disfrute de los sentidos.

Con esta solución, Arnuncio trata de construir la idea de "convertir la parte superior en una representación del cielo". La geometría responde a un fragmento de un casquete esférico, como metáfora de la bóveda celeste. Como indica el propio autor, no se trata tanto de construir una pieza que flote, sino algo que no pese nada, como el cielo. Como una analogía de una vela de un barco al viento; o "[...] como las bóvedas, una bóveda renacentista de cañón blanca, estás viendo donde se apoya, sin embargo te induce a pensar que flota un poco, y en la capilla este efecto se produce con más fuerza, puesto que el apoyo no está". ${ }^{18}$

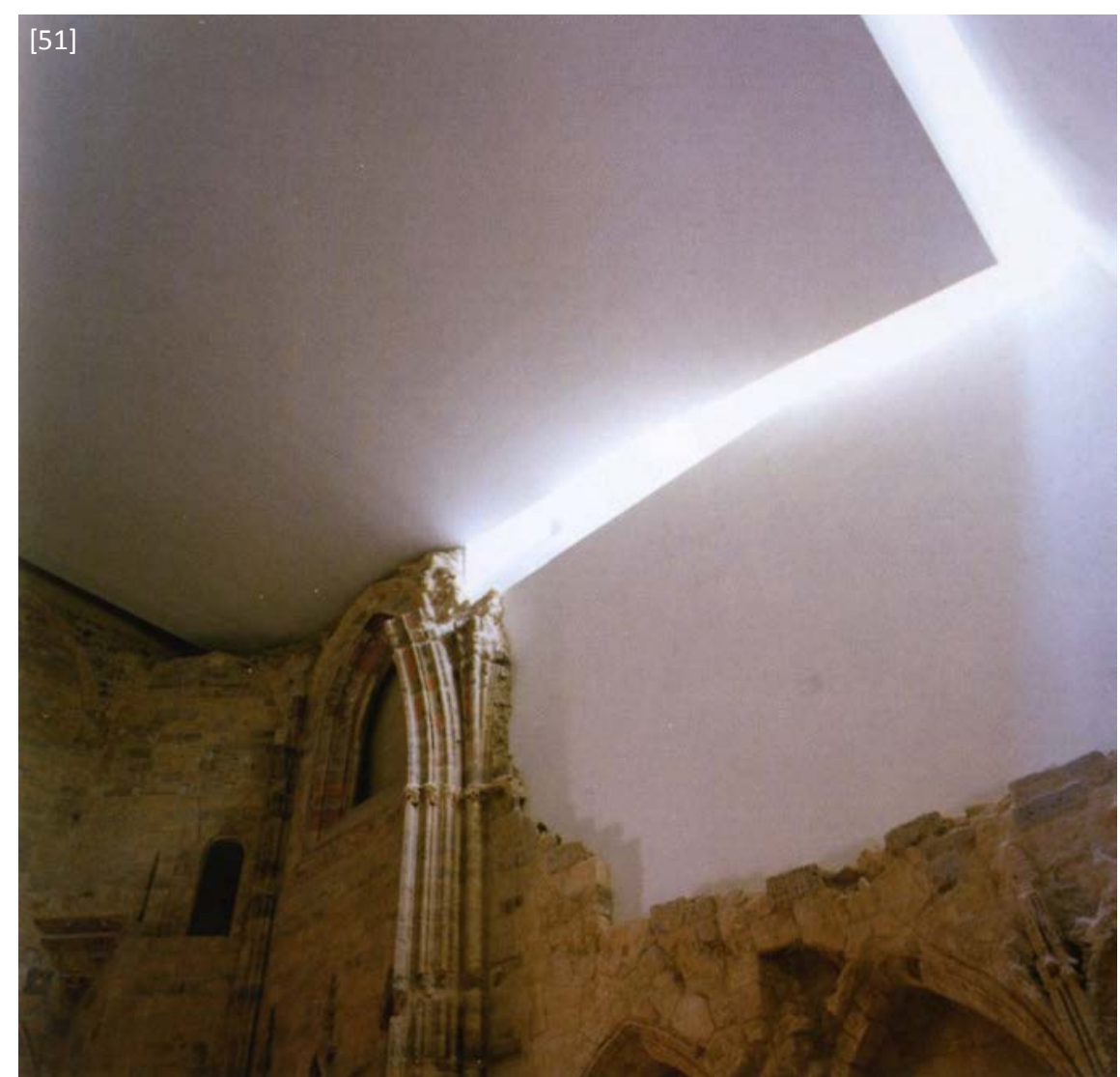


A medida que se va recorriendo la capilla longitudinalmente, el plano curvo va descendiendo, reduciendo la escala del espacio, y la pieza que lo conforma va adquiriendo dimensión hasta desvelar su profundidad. Como en los relojes blandos de Dalí, el tiempo se hace presente. Arnuncio lo justifica como una operación de control visual que trata de reducir la presencia del muro del fondo. La plasticidad del nuevo elemento, de gran abstracción material, genera un espacio sugerente que suscita múltiples interpretaciones metafóricas en el espectador. ${ }^{19}$

La concepción formal del elemento se relaciona con las reflexiones que expone Arnuncio en su libro Peso y Levedad, más concretamente en el apartado en el que reflexiona sobre "la representación del cielo y los límites de la nada"20, donde analiza, entre otras, las obras del Teatro Olímpico de Vicenza (Andrea Palladio, 1579-85) o la capilla cuáquera de James Turrell en Houston, ya comentadas anteriormente. Una reflexión sobre la construcción de un elemento que produzca un efecto perceptivo como metáfora del cielo, una sensación trascendental donde el tiempo se detiene y permite la reflexión y la introspección. Donde, a través de la arquitectura, se busca crear la sensación espiritual de la ingravidez, de lo luminoso, de lo infinito presente en el cielo.
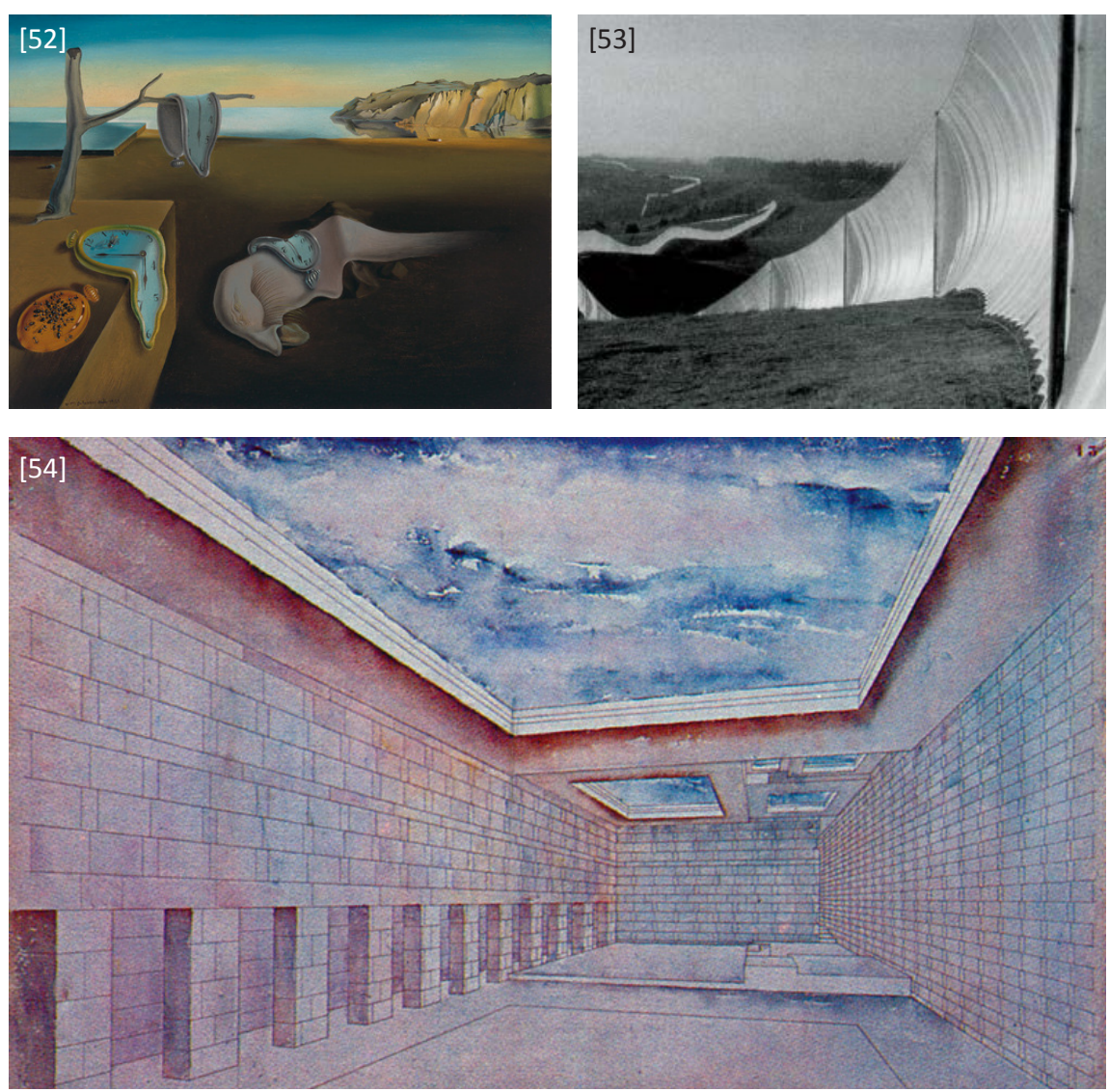

19 Entrevista realizada a Juan Carlos Arnuncio, en Valencia, en junio de 2012, pregunta 19 (Ver anexo)

20 Op. Cit, 2007, pp. 107-120
[52] La Persistencia de la Memoria, Salvador Dalí, 1931. (MOMA: $<$ www.moma.org $>$ )

[53] Running Fence, Christo, California 1972-78. Se trata de una pieza de Land Art generada a partir de un sistema modular de telas blancas que se hinchan con el viento como velas de barco. (ARNUNCIO: 2007, p. 158)

[54] Sala del Purgatorio. Acuarela de G. Terragni. (ARNUNCIO: 2007, p. 98) 


\subsection{Materialidad y detalle}

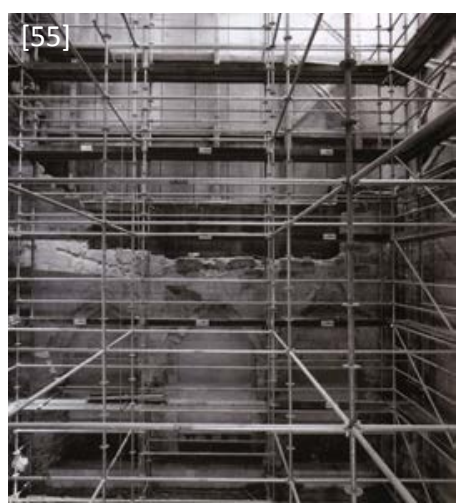

La actuación sobre los muros góticos consiste en un trabajo de restauración y restitución pétrea, mediante el relleno de huecos y faltantes, así como la reconstrucción de algunas de las pilastras del interior del espacio. Para ello se emplea piedra de tonalidad similar a la original, incluso practicándole roturas para conseguir una mayor integración con el aspecto de ruina de la preexistencia, pero sin ocultar su condición de nuevo añadido. También se ciegan los huecos de los mechinales, practicados por los militares durante su estancia en el monasterio, mediante mortero para dejar constancia de esta fase de su historia.

El gran espesor de los muros permite la construcción de un zuncho de hormigón en su coronación, a modo de cimentación de lo nuevo, que ocupa el espesor correspondiente al alma de cal y canto existente en el interior de los muros de piedra, de tal manera que el hormigón queda oculto a la vista. Sobre este zuncho se apoyan diez pilares metálicos, cinco en cada uno de los lados largos de la capilla, que se conectan entre sí con vigas, a modo de pórticos, conformando un armazón estable.

Sobre la estructura metálica se cuelgan, en el exterior, paneles de hormigón prefabricado de 7,2m de altura, con una textura de bandas verticales de anchos diversos y una tonalidad cromática que armoniza con la del material pétreo existente; mientras que en el interior, unos paneles blancos de cartón-yeso producen un acabado completamente liso y continuo. El espacio se completa con un pavimento de piedra caliza de Campaspero, análoga a la del patio.

[55] Imagen del interior en fase de constucción. Se observa el zuncho de hormigón en la coronación de los muros de piedra originales. (Imagen de Ricardo González. En: ARNUNCIO: 2012, p. 74)

[56] Redibujo de la sección transversal a partir de los planos de proyecto.
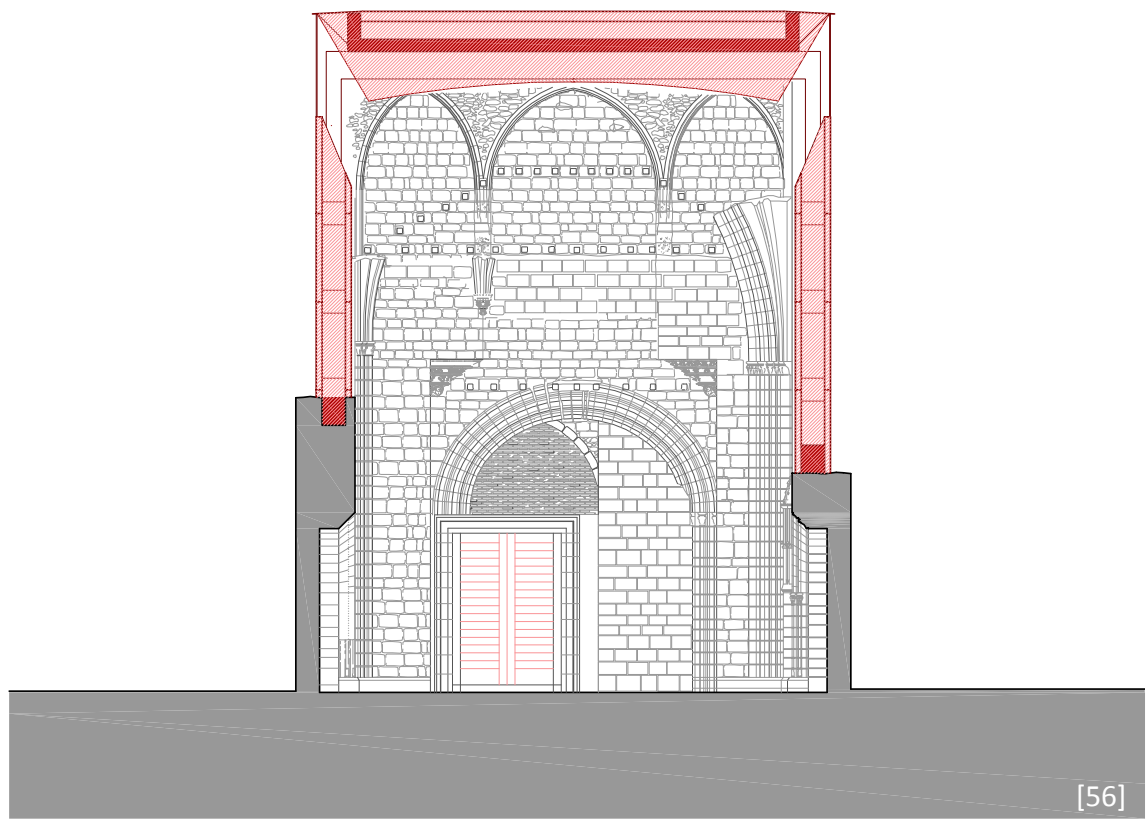
La materialidad exterior transmite un aspecto sólido, macizo, pesado, que se relaciona con naturalidad con la ruina. La textura de acabado introduce un juego de luces y sombras en los paramentos que se relaciona con la vibración lumínica presente en los muros de la ruina, consiguiendo con ello una cierta integración de lo nuevo con lo preexistente a partir del carácter material, sin renunciar a su clara diferenciación.

Según Arnuncio, existen dos referencias en la concepción material: por un lado la obra del artista Gustavo Torner, quien trabaja en el tema de la poética del contraste, de las sensaciones opuestas como "lo liso y lo rugoso, lo frío y lo caliente, el cielo y la tierra"21; y por otro lado la solución empleada por Raffaele Stern en el Coliseo de Roma, en la que introduce un refuerzo de ladrillo para detener la deformación de los arcos, produciendo un efecto de congelación de la ruina en el tiempo. Arnuncio también actúa consolidando la ruina, pero sin que ello nos prive de su dramatismo y de su poder evocador.

Respecto a la solución material, Arnuncio explica que durante el proceso de proyecto se realizaron pruebas con distintos materiales, que abarcaron desde un revestimiento de granito pulido negro, hasta elementos más o menos transparentes. La decisión final demuestra un trabajo de autocontención que busca reducir soluciones efectistas en favor de una mayor integración con la materialidad de la ruina, sin renunciar a la modernidad del nuevo elemento. ${ }^{22}$

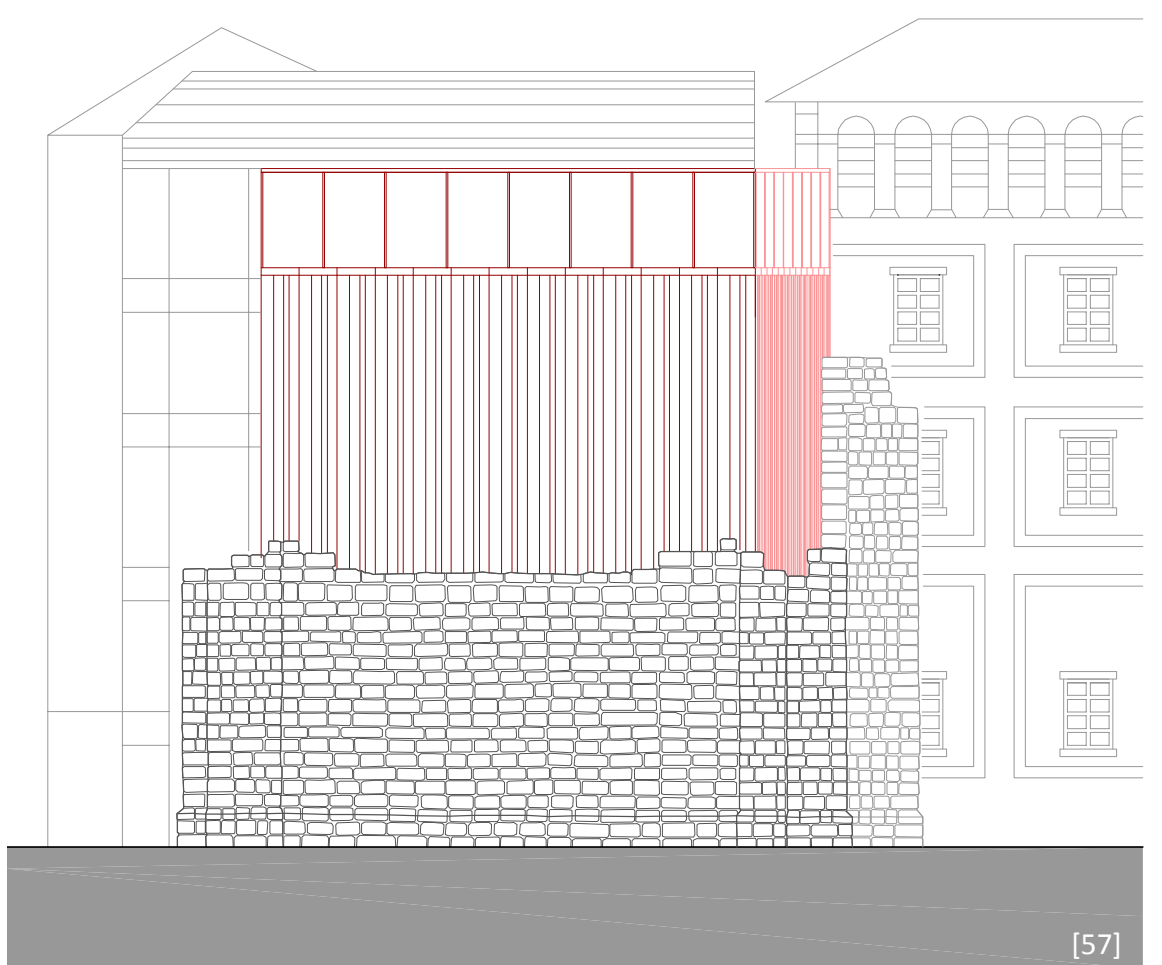

Alzado Oeste
21 Op. Cit, 2012, p. 64

22 Entrevista realizada a Juan Carlos Arnuncio, en Valencia, en junio de 2012, pregunta 13 (Ver anexo)
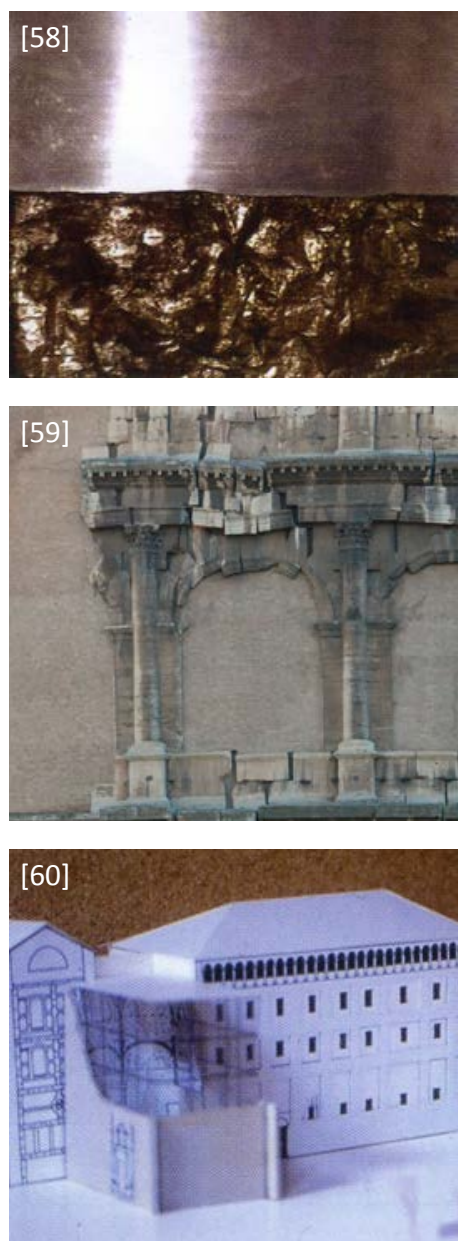

[57] Redibujo del alzado oeste a partir de los planos de proyecto.

[58] Obra de Gustavo Torner. La poética del contraste. (Imagen de Jorge Represa. En: ARNUNCIO: 2012, p. 64)

[59] Congelación de la ruina en el tiempo, que nos regaló Stern en la restauración del Coliseo romano. (Imagen del autor)

[60] Maqueta de la propuesta presentada a concurso. (Imagen del proyecto. En: ARNUNCIO: 2012, p. 28) 


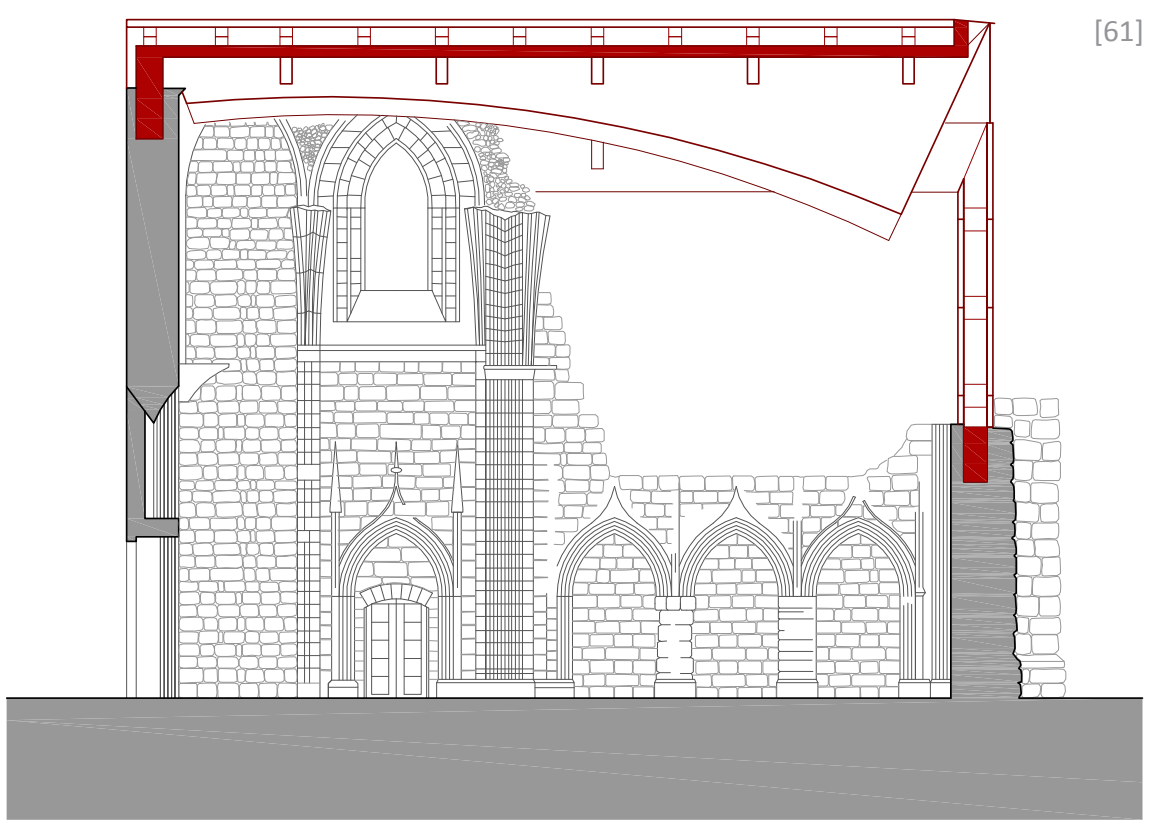

Sección longitudinal

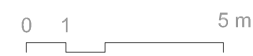

[61] Redibujo de la sección longitudinal y la planta a partir de los planos de proyecto.

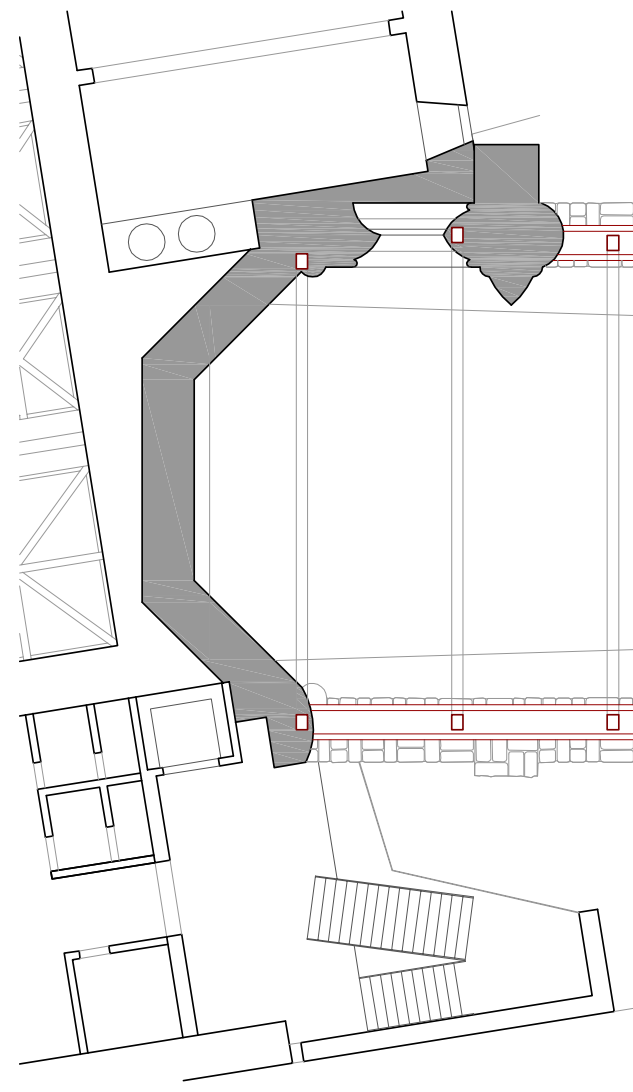

Planta tercera

61] $5 \mathrm{~m}$ 
Es interesante destacar la paradoja que existe entre la imagen de solidez exterior del nuevo prisma, que "reintegra" en cierto modo el volumen de la capilla, y su construcción mediante el montaje de elementos ligeros. De tal manera que la imagen de elemento pesado y macizo del exterior se construye mediante una estructura ligera de elementos metálicos revestida con paneles prefabricados, tal vez respondiendo en mayor medida al concepto de levedad del espacio interior.

En este sentido, Arnuncio entiende que, en el caso de la capilla, está por encima el efectismo que la sinceridad constructiva. $Y$, por otro lado, se desmarca de cuestiones "normativas" de las teorías de la restauración. Para Arnuncio, esta cuestión no tiene nada que ver con un tema de reversibilidad de lo añadido o de reducción de la "invasión" física de la ruina, sino simplemente con la construcción de una idea. ${ }^{23}$

Y para la construcción de esa idea, parece necesario huir de un planteamiento evidente, de una manifestación inmediata de su construcción. En cierta manera antepone la experimentación de un espacio mágico, un tanto irreal, a la sinceridad constructiva. Si bien es verdad que un observador agudo puede descubrir su planteamiento estructural, sólo se consigue situándose justo debajo de la fisura lateral, desde donde se pueden distinguir los pórticos que sostienen la cubierta, casi ocultos y pintados de blanco. De esta manera no trata de ocultar todo el efecto de manera obsesiva, sino que busca mostrar algo de su explicación para hacer cómplice del truco al espectador.

Tal vez en el detalle constructivo que resuelve la entrada de luz a la capilla, esté la clave del éxito de este proyecto. Desde el exterior, la cubierta se percibe como un elemento sin espesor, que se manifiesta en una arista, lo que transmite una idea de elemento abstracto, irreal, que define geométricamente un prisma perfecto. Desde el interior, la línea de la cubierta se revela como un gran plano curvo, sin espesor, que flota en el espacio ocultando la fuente de luz, produciendo una sensación de gran ligereza. Un gran detalle para un gran efecto.
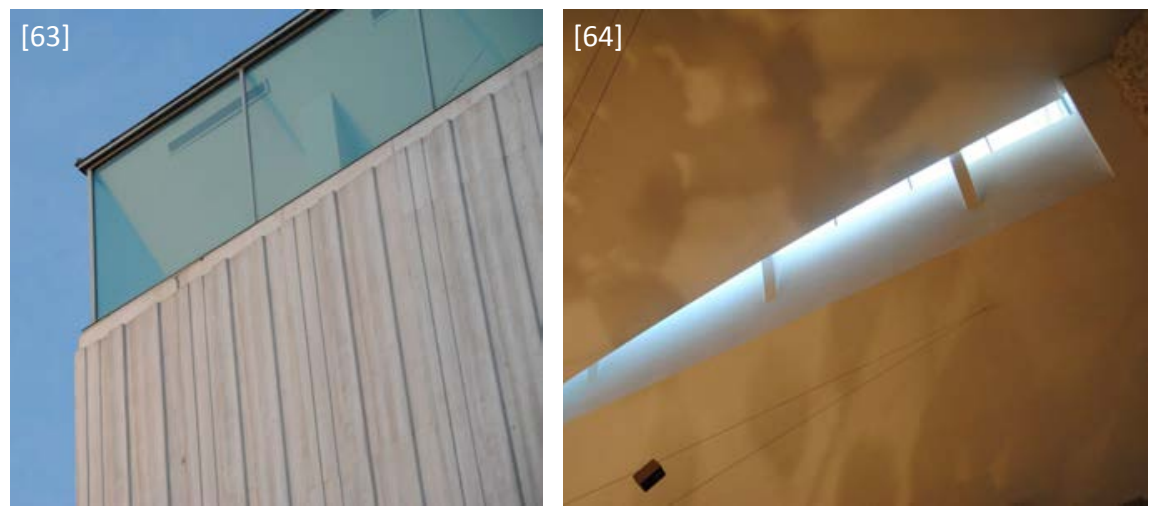

23 Entrevista realizada a Juan Carlos Arnuncio, en Valencia, en junio de 2012, pregunta 14 (Ver anexo)

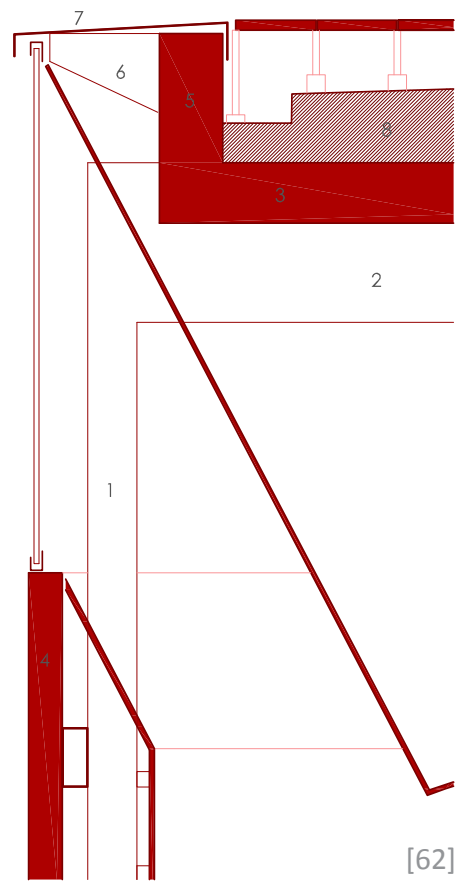

1. Pilares estructura principal

2. Vigas estructura principal

3. Forjado estructura principal

4. Paneles prefabricados de H.A.

5. Peto de H.A. para anclaje de carpintería

6 . Cartela de acero para fijación al peto

7. Vierteaguas de zinc

8. Formación de cubierta invertida practicable

[62] Esquema elaborado a partir de un detalle del proyecto inicial.

[63] Vista del planteamiento estructural desde el exterior.

[64] Vista del planteamiento estructural desde el interior.

$[65,66,67$ y 68] Vistas de detalle de la actuación. (Fotografías del autor)

[69] Interior de la capilla. (Imagen del Archivo Fotográfico Patio Herreriano. En: ARNUNCIO: 2012, p. 69)

[70] Interior de la capilla. (ARNUNCIO: 2007, p. 118) 

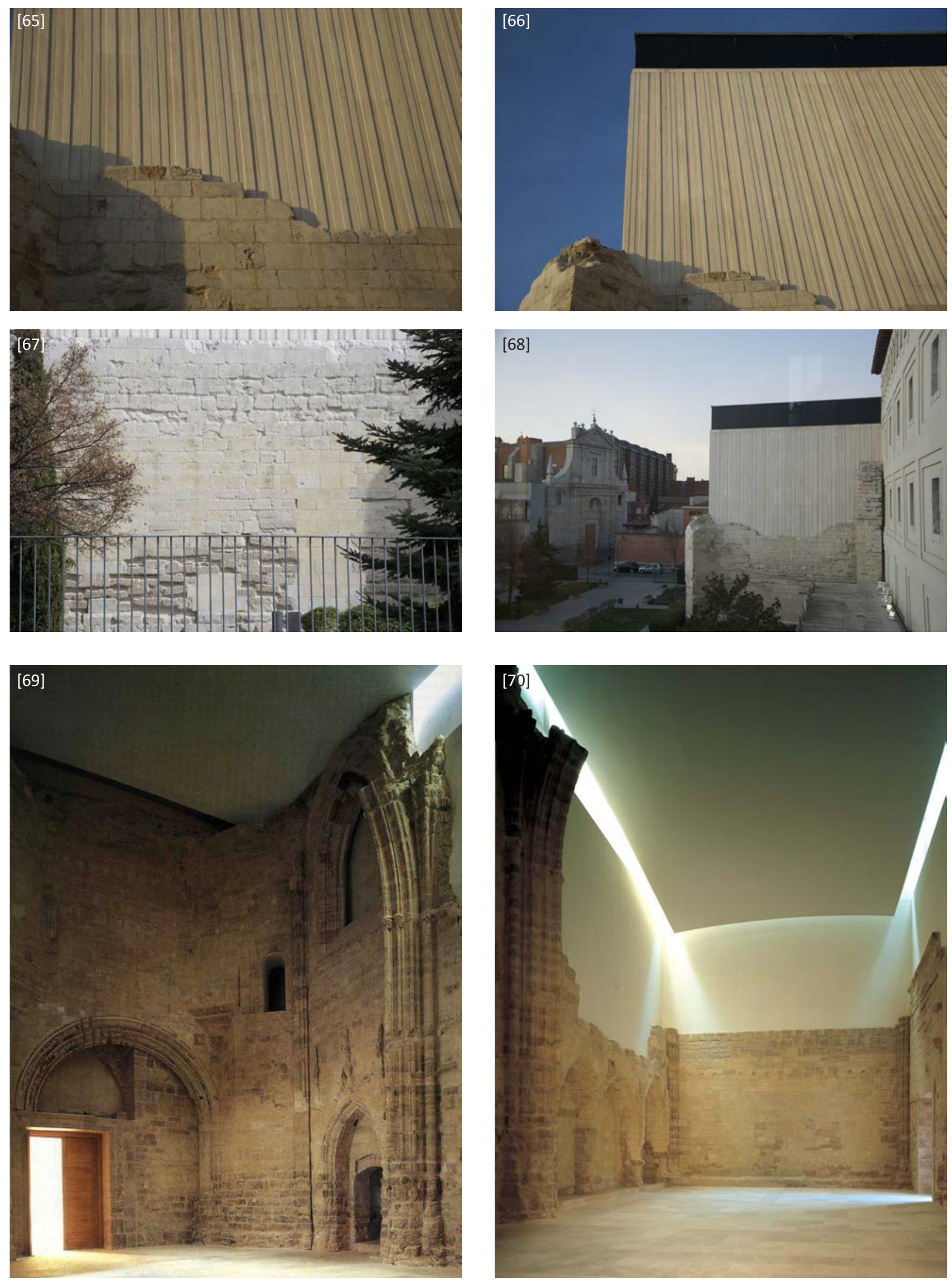


\section{ANÁLISIS CRÍTICO DE LA INTERVENCIÓN}

\subsection{Una actitud proyectual. Humildad y naturalidad}

La actuación sobre la capilla de los condes de Fuensaldaña consiste, ante todo, en una operación puramente arquitectónica, en la que hay unos condicionantes del lugar concretos y un programa funcional que hay que cumplir, sin dejarse llevar por debates éticos sobre intervención en el patrimonio.

Juan Carlos Arnuncio demuestra su gran habilidad profesional, y su conocimiento y respeto por la arquitectura y su historia, planteando un proyecto valiente que actúa, tal y como ha sucedido desde siempre, construyendo sobre lo construido. La búsqueda de la diferenciación de la nueva pieza respecto a la antigua, desde la armonía, se explica desde un profundo trabajo de reflexión.

Estudiando los croquis de la capilla, se aprecia el complejo proceso de evolución del proyecto. En los dibujos se observan diferentes intenciones que abarcan desde opciones que recomponen la volumetría con elementos más o menos transparentes, hasta alternativas que simplemente se limitan a cubrir los muros preexistentes, respetando en todo caso la actitud de mantener el aspecto de ruina de la pieza.

En este sentido, Arnuncio señala que incluso se hizo un estudio en la búsqueda de un material semitransparente, que permitiera producir un efecto de opacidad desde el exterior y transparencia desde el interior, pero finalmente se opta por un material de mayor presencia física que aportara un aspecto de mayor naturalidad. ${ }^{24}$

\subsection{La adaptación funcional}

La nueva función otorgada a las ruinas, ha permitido devolver la grandeza que un día tuvieron esas piedras. El proyecto de Arnuncio le ha dado una nueva vida a las ruinas del monumento desaparecido. Su uso como capilla ha desaparecido, pero su función de elevación espiritual se ha potenciado exponencialmente. Se ha sustituido el culto a la religión cristiana por el culto al arte contemporáneo, la búsqueda de paz interior a través de la devoción a Dios por la reinterpretación de la realidad como manera de reflexión personal.

En ambos casos el cielo está presente. En las bóvedas góticas, mediante la representación de lo ligero a través de lo pesado; en la "bóveda" contemporánea, a través de un efecto visual materializado con la luz. La función de su significado, de elemento irreal, infinito, inalcanzable se mantiene como mecanismo de reflexión.
24 Entrevista realizada a Juan Carlos Arnuncio, en Valencia, en junio de 2012 (Ver anexo)

[71] Instalación artística de Elena del Rivero en la capilla en el año 2007. (MAYORDOMO: <www.conchamayordomo.com>)

[72] Instalación "Transfigured Schönberg", de Dionisio González, del 2 de octubre de 2009 al 4 de abril de 2010. (nexo5.com, 7 de octubre de 2009: <www.nexo5.com>)

[73] Instalación "Ok. ok Let's talk" sobre diálogos imposibles, de José Bechara, del 8 de Febrero al 25 de Mayo de 2008. (BECHARA: <www. josebechara.com>)

[74] Instalación "Línea de Luz", de Carlos Schwartz, del 17 de Junio hasta el 14 de Octubre de 2010. (Instituto de Arte Contemporáneo: <www.iac.org.es>)

[75 y 76] Instalación "Poe Solution Curtain3", de Jaime de la Jara, del 19 de Junio al 20 de Septiembre de 2009. (nexo5.com, 29 de junio de 2009: <www.nexo5.com>) 

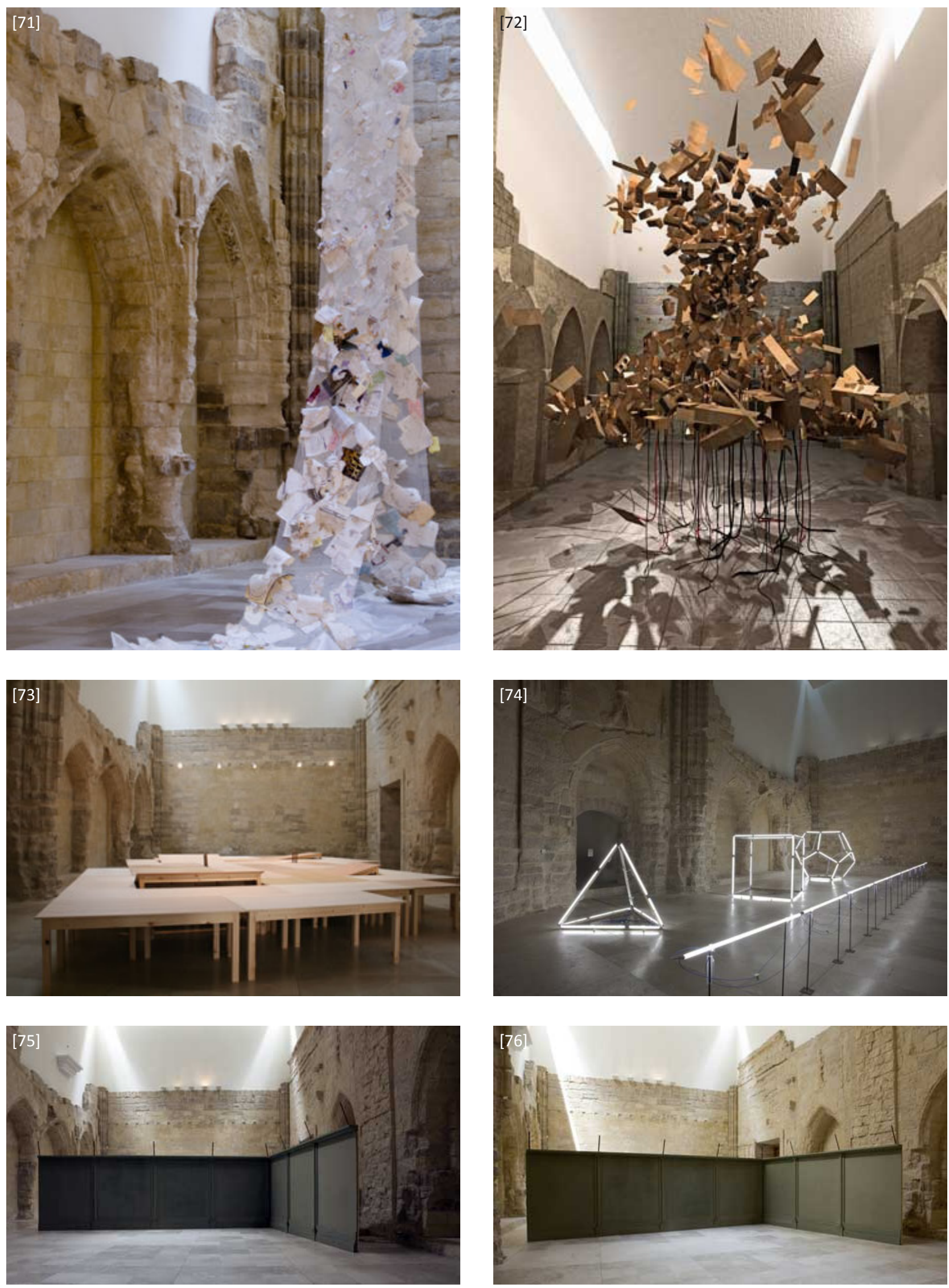
La apuesta por la luz en el espacio de la capilla ha producido, sin embargo, algunos problemas funcionales. La necesidad de absoluta oscuridad en algunas instalaciones artísticas, ha supuesto el cegado temporal de la entrada de luz, perdiéndose completamente la cualidad espacial que caracterizaba la intervención. Situación que pone de manifiesto las limitaciones que existen en la arquitectura, donde desafortunadas decisiones posteriores a la obra, y obviamente ajenas al arquitecto, por pequeñas que sean, pueden echar por tierra la esencia del espacio y hacer que gran parte de la obra pierda sentido.

Esto demuestra que toda arquitectura tiene sus limitaciones funcionales, a las que no se debe renunciar. La relación entre el uso y la arquitectura debe estar sujeta a unas reglas que permitan un diálogo equilibrado entre ambas, algo que puede resultar más complejo en una intervención en el patrimonio, ya que existen condicionantes derivados de la preexistencia. En el caso de un museo dentro de un edificio histórico, podría entenderse como algo necesario que el artista actuase en el espacio preexistente estableciendo un diálogo bidireccional, hablando pero también escuchando lo que el lugar quiere decirle, e incluso dicho espacio también podría considerarse como parte del contenido museístico -algo que ocurre sin duda en la capilla de los condes de Fuensaldaña, sobre todo si se contempla la cualidad espacial de la intervención, digna de ser contemplada en un museo de arte contemporáneo. ¿Tiene sentido plantear una instalación artística, que necesita un espacio completamente oscuro, en una capilla gótica?

\subsection{Criterios al servicio del proyecto}

Los criterios de intervención empleados, no buscan atender a reglas prefijadas en cartas o manuales de restauración, sino que se ponen al servicio de las necesidades del proyecto, un proyecto planteado desde el respeto a la realidad física de la preexistencia y a su significado histórico.

La conservación y consolidación de los restos de la capilla, busca recomponer su entidad formal y material como fragmento de un monumento desaparecido e irrecuperable en su conformación original. Así, se restituyen pequeños faltantes sin eliminar completamente las heridas que la historia ha producido en sus fábricas.

La construcción de la nueva actuación busca proteger los restos, devolverles su presencia volumétrica en la ciudad y recuperarlos como parte de la configuración de un espacio interior, donde el esfuerzo significativo logrado a través del plano del techo, evoca la grandeza que un día tuvo el edificio gótico.

Antiguo y nuevo dialogan de manera equilibrada, generando un nuevo conjunto indisoluble, en un juego compositivo de dos partes que constituyen un todo.

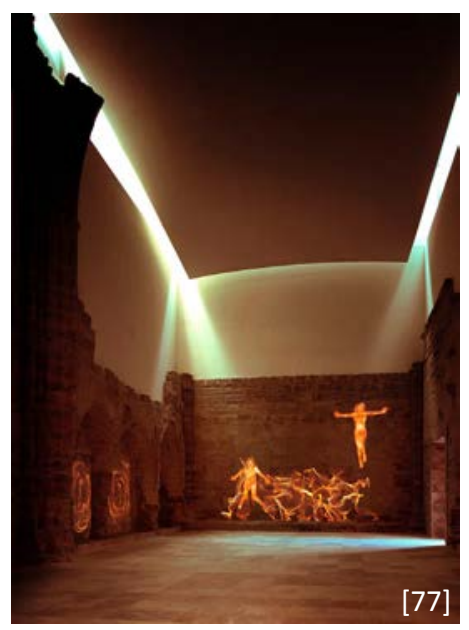

7] 
25 Op. Cit, 2012, p. 72

26 ARNUNCIO PASTOR, J.C.: "Museo de Arte Contemporáneo Español. Patio Herreriano. Valladolid". En: MAS, V. et al.: Materia y Forma IV. Jornadas Internacionales de Arquitectura. Valencia, Ed. UPV, 2009, p. 60-67

\subsection{Lectura de la preexistencia. La evocación de la ruina}

A Arnuncio le interesa la capacidad de evocación de la ruina, una arquitectura que ha perdido "su capacidad de establecer relaciones diversas entre su uso, su forma, su implantación y los problemas que resuelve. [...] Sus puertas, sus ventanas, sus estancias perdieron su razón de ser [...]. Son, más bien, una imagen de aquellas tallada por el tiempo. Un recuerdo. Un testimonio. La ambigüedad de su forma hace que podamos imaginarlas de muchos modos y es precisamente esa condición la que les otorga la capacidad de evocación que tienen". ${ }^{25}$

En las ruinas de la capilla "podía aún adivinarse algo de su pretérito esplendor". De hecho, su configuración recuerda a la de la Capilla de Fray Alonso de Burgos del Colegio de San Gregorio, situada a pocos metros de ésta, lo que podría haber generado la tentación de llevar a cabo su reconstrucción en estilo. Sin embargo Arnuncio no duda en plantear el proyecto de tal manera que "tanto desde el exterior como desde el interior la ruina se recortase, en un intento de mantener su condición de ruina" ${ }^{26}$

\subsection{Una solución entre modernidad y evocación}

Modernidad y evocación se combinan para conseguir constituir un nuevo conjunto en equilibrio.

El proyecto asume su modernidad mediante la abstracción, la materialidad, la concepción del espacio, el tratamiento de la luz y la utilización de la ruina como material con el que desarrollar la arquitectura. El proyecto también incorpora y valora el poder evocador de la propia ruina, al destacarla en la arquitectura resultante, tanto desde el interior como desde el exterior.

La cualidad másica, textura y cromatismo del nuevo material empleado en el exterior evoca la materialidad de la ruina, pero a su vez la modernidad está presente en el despiece, textura y proceso constructivo del nuevo sistema de paneles de hormigón.

La evocación surge de nuevo en la recuperación del volumen exterior original, para devolver al edificio su sentido en la ciudad. La modernidad se expresa en su abstracción formal.
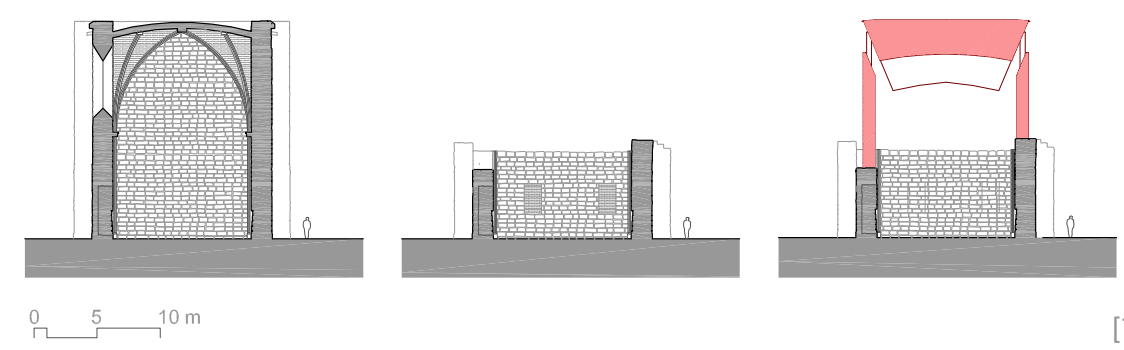
y estado actual.

[78] Hipótesis del estado original, estado del edificio en el momento
anterior al inicio de la intervención

\section{se expresa en su abstracción formal.}


En el interior, el espacio abovedado original quizá haya sugerido a Arnuncio una reflexión sobre la bóveda como representación del cielo. Un espacio gótico, vertical, con una gran entrada de luz directa procedente de lo alto, donde la delgada estructura de piedra se manifestaba explícitamente, desafiando las leyes de la gravedad y definiendo el carácter espacial. Esta nueva actuación propone la antítesis constructiva del espacio gótico original. Unos planos verticales definen un espacio de límites abstractos, en el que una lámina con forma de casquete esférico blanco, liso, sin espesor aparente, parece flotar gracias a la desaparición de la estructura, cuya ausencia está exacerbada por una entrada de luz perimetral.

El foco de la entrada de luz se oculta al espectador dando al efecto una cualidad mística. La estrecha abertura perimetral delimita con fuerza la separación entre el plano vertical y el horizontal, y los cambios de luz a lo largo del día y del año suavizan o perfilan su fractura.

La curvatura de la lámina, que se manifiesta principalmente en la dirección mayor, además de infundirnos la sensación de "protección", nos induce a recorrer su trayectoria de arriba hacia abajo -igual que la luz-, con lo que nos encontramos irremisiblemente con la ruina, como el material más sensible del espacio configurado.

Se produce un equilibrio, ninguna parte es protagonista absoluta, sino que ambas se apoyan para crear un nuevo conjunto. Se consigue con ello un camino intermedio entre el contraste y la analogía, mediante una unidad compositiva a base de partes distintas que constituyen un nuevo entero. No se trata de que lo nuevo haga juego con lo antiguo, sino de convertirlo un único problema de arquitectura, de tal manera que ahora ya no se pueda explicar una parte sin la otra. ${ }^{27}$

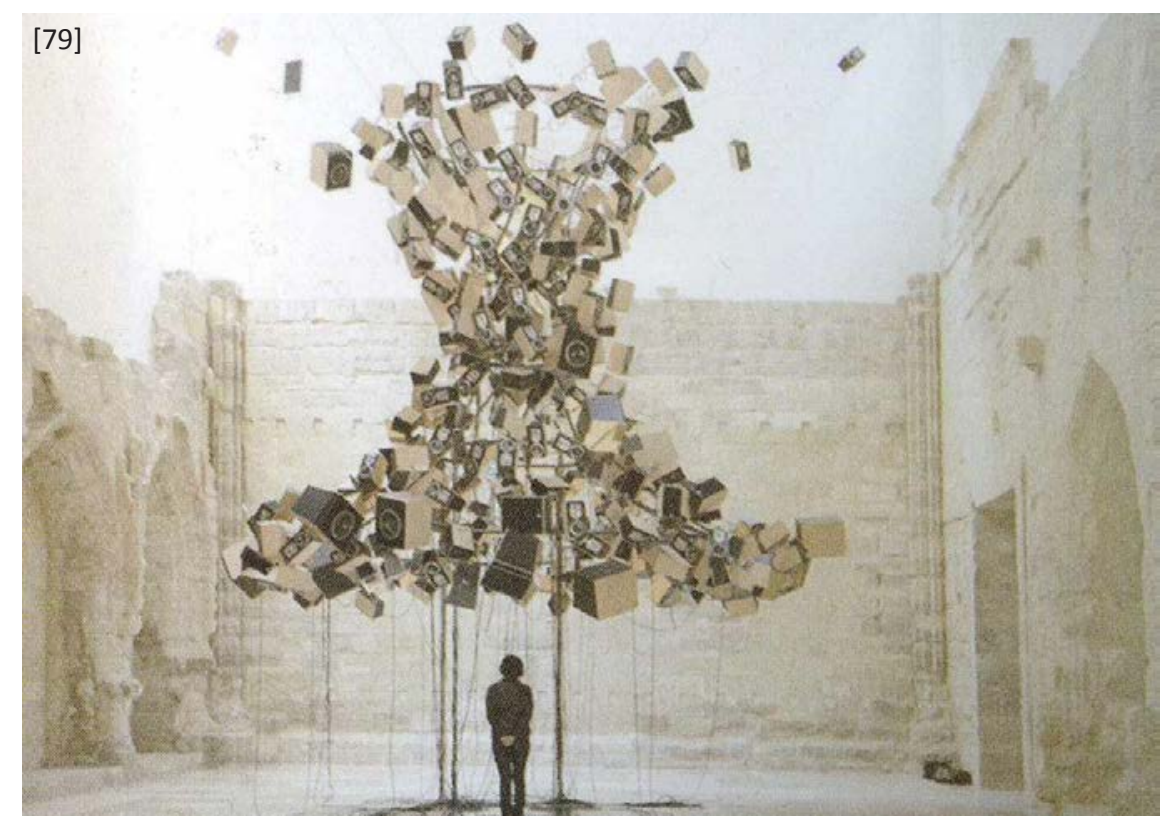

27 Entrevista realizada a Juan Carlos Arnuncio, en Valencia, en junio de 2012, pregunta 10 (Ver anexo)
[79] Vista del espaco interior de la capilla. (ARNUNCIO: 2012) 


\subsection{Referencias}

Arnuncio trata de fijar el concepto de ruina bajo el cielo abierto. Para ello busca materializar de manera abstracta una representación del cielo a través de un mecanismo de contraposición entre peso y levedad, que le permite percibir como realidad una ensoñación. Algo que además produce un juego entre protección de un espacio interior y conexión con un espacio exterior, entre introspección y reflexión sobre la pertenencia al mundo.

Un juego de opuestos empleado a lo largo de la historia de la arquitectura, ya sea mediante el efecto de la luz y la sombra, como por ejemplo en la cúpula de Santa Sofía de Constantinopla, en la Sala de Dos Hermanas de la Alhambra, o ya sea mediante los efectos "pictóricos" que modifican la condición real del espacio para convertirlo en un exterior como es el caso del salone della prospettive de la Villa Farnesina de Baldassare Peruzzi de 1505, el Teatro Olimpico de Vicenza de Andrea Paladio de 1579, la escalera y acceso al trono del palacio episcopal de Wursburg de Balthazar Neumann o la capilla de la iglesia de Weis de los hermanos Zimmerman (1754), en los que además se especula con el límite entre la arquitectura fingida y la arquitectura construida para dar mayor credibilidad al efecto.

[80] Salone della Prospettive de la Villa Farnesina de Baldassare Peruzzi, 1505. (Villa Farnesina: <www. villafarnesina.it>)

[81] Cúpula de Santa Sofía de Constantinopla. (NUTTGENS: 1988, p. 120)

[82] Escalera de acceso al trono del palacio episcopal de Wursburg de Balthazar Neumann. (ARNUNCIO: 2007, p. 110)

[83] Capilla de la iglesia de Weis de los hermanos Zimmerman, 1754. (ARNUNCIO: 2007, p. 110)
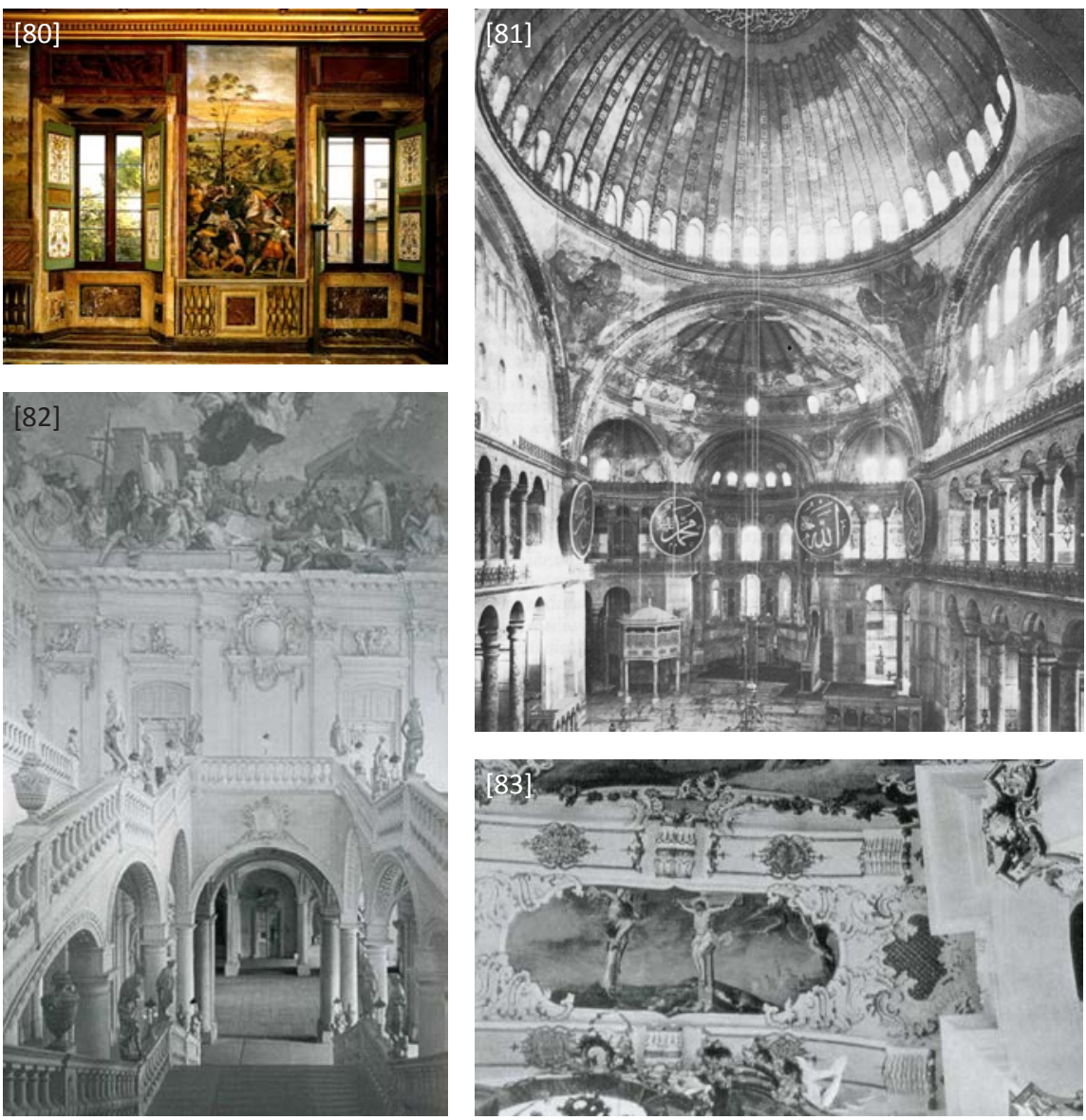
O también en numerosas obras de arquitectura moderna como en la iglesia de Ronchamp de Le Corbusier (1950-54) o en la Primera Iglesia Unitaria en Rochester (Nueva York, 1959-69) de Louis Kahn, en la que busca conseguir una luz misteriosa que entra en el espacio, inundándolo en su recorrido, y convirtiendo los límites del espacio en nuevos generadores de luz. Una idea que ya había plasmado con claridad y sencillez Vermer en algunos de sus cuadros, como el de "La lechera" de 1659, y que en determinados momentos se puede apreciar en la capilla.

Además Arnuncio se apoya en la definición de la forma para potenciar el efecto, ya sea a través de la pérdida de su espesor, de su abstracción material, o de su geometría abovedada ya que, como dice el propio Arnuncio, "quizá la representación más obvia del cielo sea la de considerar como bóveda celeste una semiesfera que nos cobije". ${ }^{28}$

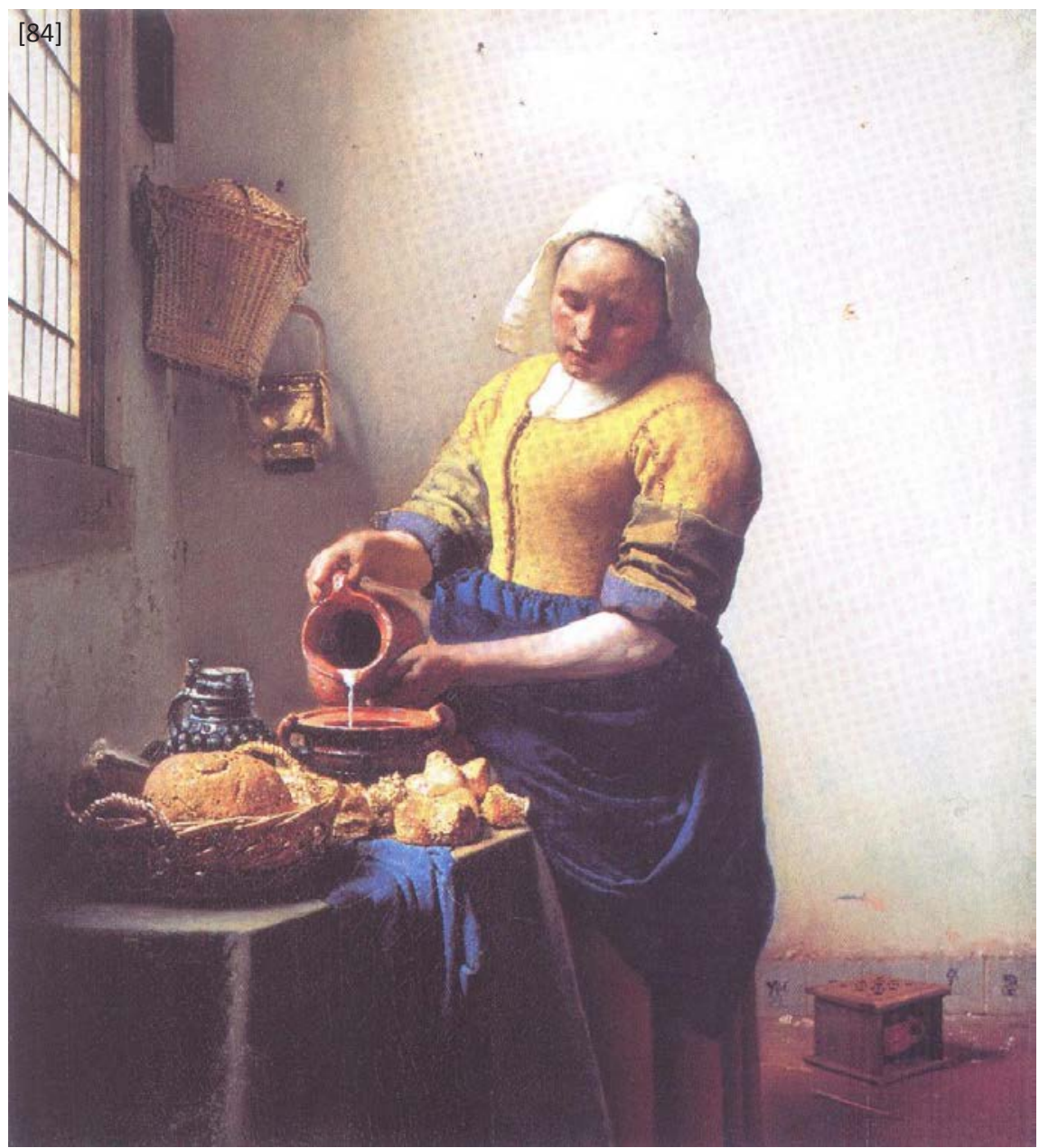

29 CORNELL, E.: "El cielo como una bóveda" En: CALDENBY, C.; HULTIN, O.: Asplund. Barcelona, Ed. Gustavo Gili, 1988 , p. 23

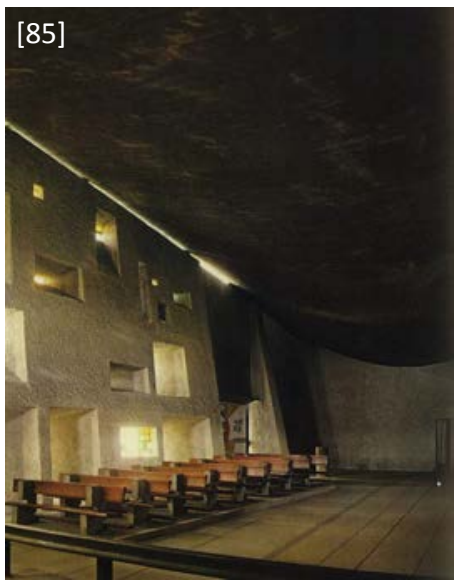

[84] La lechera, Johannes Vermeer, 1659. (Rijksmuseum: <www.rijksmuseum.nl>)

[85] Iglesia de Ronchamp, Le Corbusier, 1950-54. Vista del espacio interior y de la entrada de luz. (ARNUNCIO: 2007, p. 86) 
30 USTÁRROZ, A.: La lección de las ruinas. Barcelona, Ed. Fundación Caja de Arquitectos, 1997, p. 241

31 LAHUERTA, J.J.; GONZÁLEZ GARCÍA, A.: Juan Navarro Baldeweg. Obras y Proyectos. Ed. Electa, 1990

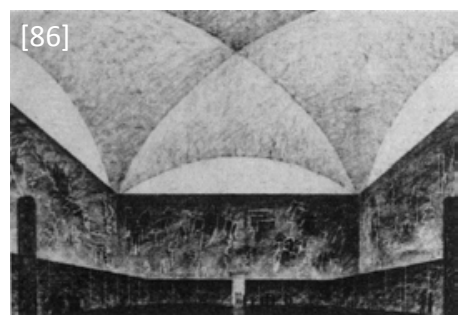

[86] Palacio de Congresos del EUR en Roma, Adalberto Libera, 193742. Bóveda de aristas sobre el gran cubo de recepción. (USTÁRROZ: 1997, p. 244)

[87] Palacio de Congresos de Salamanca de Juan Navarro Baldeweg. (MC 2. Estudio de Ingeniería: $<$ www.mc2.es $>$ )

[88] Capilla del Bosque, Asplund. (Erik Gunnar Asplund: <www.erikgunnarasplund.com>)

[89] Palacio de Congresos del EUR en Roma, Adalberto Libera, 193742. Interior del gran cubo de recepción. (USTÁRROZ: 1997, p. 244)
En este sentido se puede mencionar las formas abovedadas levitando en el espacio de la capilla del bosque en Estocolmo de Asplund (1918-20), el palacio de Congresos del EUR en Roma de Adalberto Libera (1937-42) o el palacio de congresos de Salamanca de Juan Navarro Baldeweg (1985). Si bien los óculos presentes en algunas de ellas las alejan de nuestro caso de estudio, la entrada de luz perimetral, consiguiendo el efecto de unas láminas suspendidas en el aire, las acercan de nuevo.

En Estocolmo mientras que en el exterior se subordina el edificio al exuberante entorno natural sobre el que se asienta, en el interior una cúpula abstracta con carácter inmaterial iluminada cenitalmente se eleva ingrávida sobre columnas para simbolizar la elevación del alma al cielo. ${ }^{29}$

En Roma Libera crea un gran cubo que presenta un primer orden de pilastras, que permite la expansión horizontal, un segundo nivel recubierto de una superficie calada que conforma un cuerpo de cierta vibración luminosa, y un tercer nivel conformado por una bóveda de aristas que gravita ligera sobre el espacio, como una vela al viento. ${ }^{30}$

Finalmente en Salamanca un gran dosel suspendido sobre el espacio, cuya forma pertenece al trazado de una cúpula esférica envolvente, se recorta en el vacío en una tensión equilibrada entre gravidez e ingravidez. La cúpula ya no se sostiene por sí misma, ha dejado de ser un elemento constructivo para convertirse en un artefacto al servicio de su inventor, un efecto de suspensión que se muestra gracias a la permanencia de la sombra, del contraluz. ${ }^{31}$
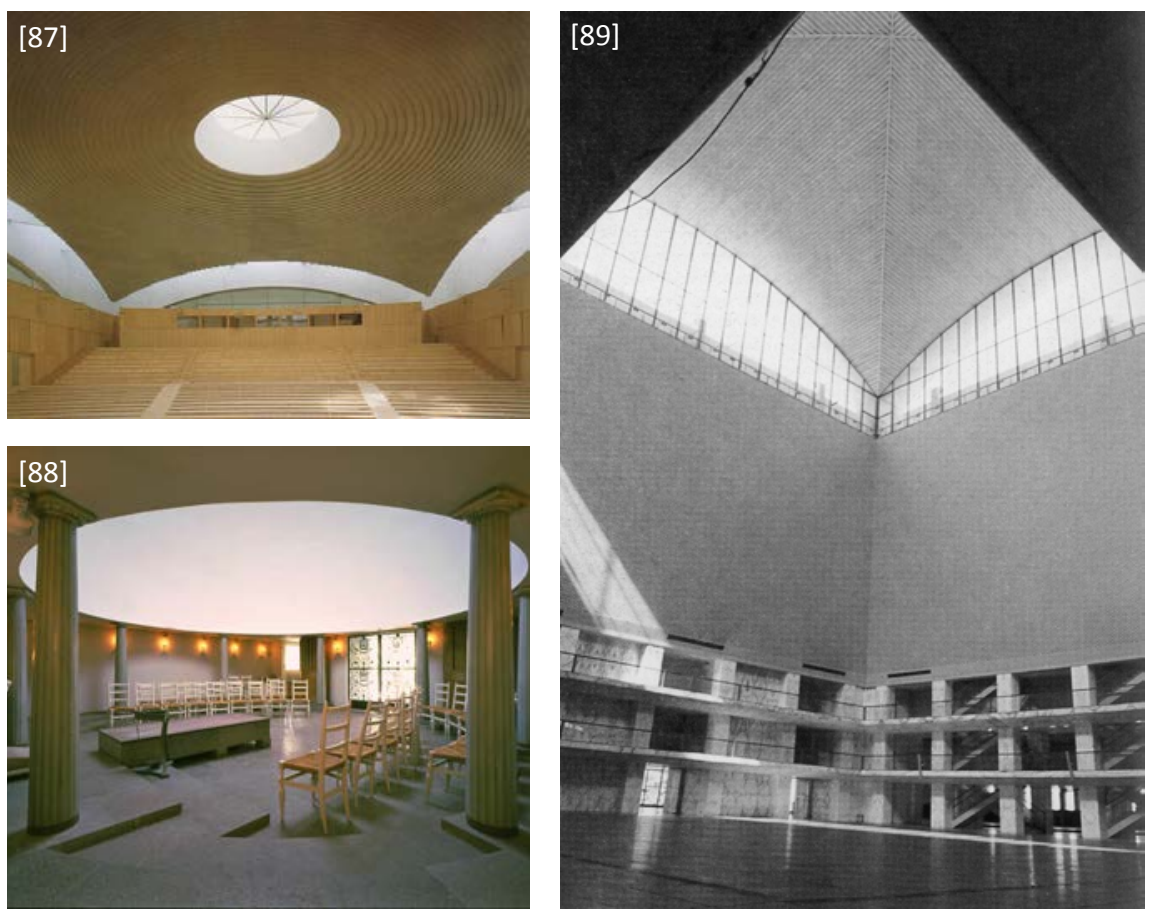

Capilla de los Condes de Fuensaldaña. Valladolid. 1996-2002 


\subsection{IGLESIA DE LAS ESCUELAS PÍAS DEL COLEGIO DE SAN FERNANDO}

Construcción Original:

Estilo barroco. Francisco Ruíz, 1734-1791

Intervención:

José Ignacio Linazasoro, 1996-2004

Lugar:

Madrid. España.

El edificio se ubica en la esquina delimitada por la calle Mesón de Paredes y la plaza de Agustín Lara, del barrio de Lavapiés.

\section{ANTECEDENTES}

\subsection{Evolución histórica}

El edificio de la iglesia de las Escuelas Pías formaba parte del Colegio de San Fernando, a cargo de los padres Escolapios, fundado en 1729, en la calle del Mesón de Paredes del barrio de Lavapiés.

La eficacia educativa de los escolapios propició el apoyo económico de la nobleza, lo cual, sumado al continuo incremento del número de alumnos, conllevó el sucesivo proceso de ampliación de su sede. El apoyo de los Reyes Carlos III y Carlos IV, a partir de 1761, contribuye a la construcción del nuevo templo, en sustitución de la modesta ermita preexistente. ${ }^{1}$

Francisco Ruíz proyecta en 1734 la traza del Colegio, del Convento y de su iglesia, comenzando su construcción tres años más tarde. Tras su muerte en 1744, José Álvarez continúa con las obras del conjunto que finalizarán en 1791. En su construcción participarán otros profesionales como el arquitecto Antonio Valcárcel o el aparejador Gabriel Escribano. ${ }^{2}$
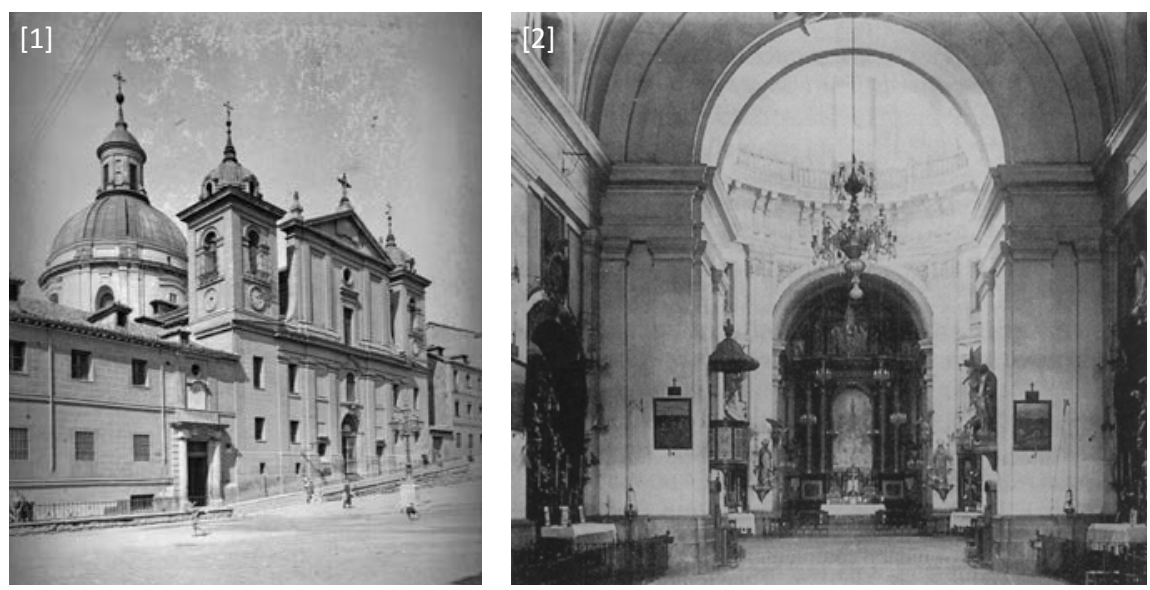

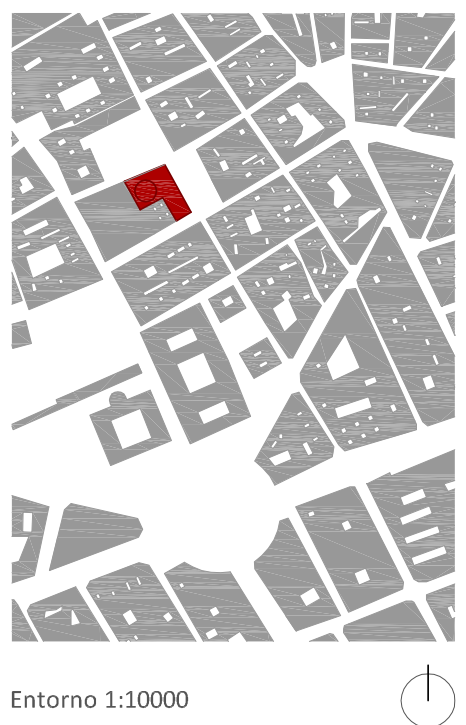

1 TOVAR MARTÍN, V.: “Nuevas consideraciones sobre el edificio singular del colegio madrileño de San Fernando". Anales de Historia del Arte, n. 4, Madrid, Ed. Complutense, 1993, p. 288

Disponible en: <http://revistas.ucm. es/index.php/ANHA/article/view/ ANHA9394110285A/31790> [consulta: 23-10-2012]

2 GÓMEZ, M.: "Escuelas Pías de San Fernando". Arte en Madrid. 8 de julio de 2012. [en línea]

Disponible en: <http://artedemadrid. wordpress.com/2012/07/08/escuelaspias-de-san-fernando/> [consulta: 2310-2012]
[1] Fachada del templo y puerta de acceso al colegio. (Imagen de A. Passaporte. En: GÓMEZ: <artedemadrid.wordpress.com>)

[2] Vista interior de la Iglesia de las Escuelas Pías del Colegio de San Fernando. (TOVAR: 1993, p. 166) 
3 TOVAR MARTíN, V.: Op. Cit., 1993, p. 290

4 TOVAR MARTíN, V.: Op. Cit., 1993, p. 286
Francisco Ruíz es discípulo de Felipe Sánchez, arquitecto autor de la primera traza del templo del Pilar de Zaragoza. Su prestigio y solidez profesional quedan demostradas con sus actuaciones en grandes obras, como es el caso de su participación en el edificio del Palacio Real de Madrid. ${ }^{3}$

En el siglo XIX se llevan a cabo varias obras de ampliación del Colegio para dotarlo de biblioteca, comedor, gabinetes de Historia Natural y de Física y otras instalaciones.

El edificio es incendiado por la Confederación Nacional del Trabajo un día después del estallido de la guerra civil española, el 19 de julio de 1936, después de que falangistas atrincherados en su interior dispararan contra los transeúntes.

La iglesia pierde sus cubiertas, parte de sus muros y casi toda su decoración, produciendo un aspecto decadente, pero cuya pérdida remite a la grandeza del pasado. En palabras de la historiadora Virginia Tovar:

"(...) la ruina del edificio, en esa situación de extraña manera de sobrevivir, nos recuerda la nostalgia de Poggio al contemplar Roma cuando expresaba su indignación al imaginar la grandeza de los edificios asolados y las vastas ruinas por la inconstancia y desaprensión de los hombres". ${ }^{4}$
[3] Vista exterior de la Iglesia de las Escuelas Pías del Colegio de San Fernando en ruinas. (GÓMEZ: <artedemadrid.wordpress.com>)

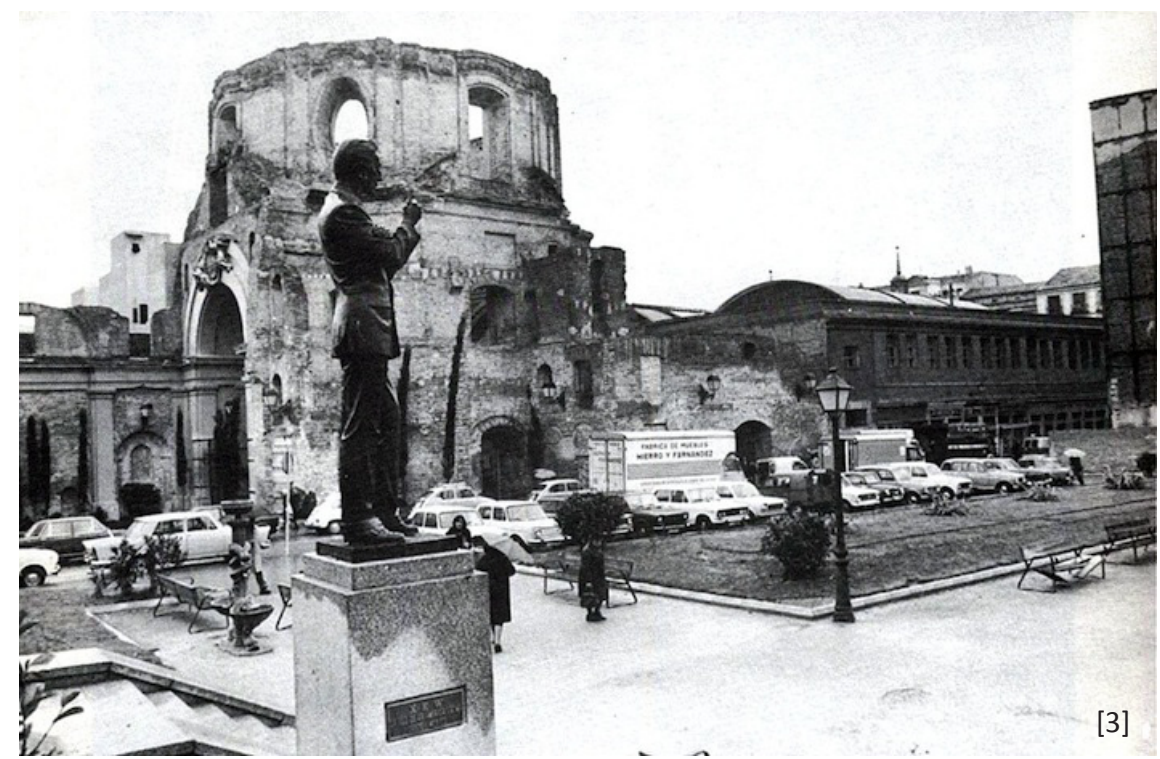

Iglesia de Ias Escuelas Pías del Colegio de San Fernando.1996-2004 


\subsection{Descripción del monumento}

El edificio de la iglesia es de planta longitudinal, con orientación noreste suroeste, definida por la dirección perpendicular a la calle Mesón de Paredes, a la que vertía su única fachada. Estaba compuesto por una serie de espacios con cierta autonomía encadenados a lo largo de un eje lineal: el espacio de acceso que conectaba con el edificio del colegio, una nave de traza rectangular cubierta con bóveda de cañón, un crucero de planta circular cubierto con cúpula y el espacio del altar de planta cuadrada que remataba el conjunto. Al edificio de la antigua iglesia se accedía desde la citada calle del Mesón de Paredes, en el extremo noreste, a través de una imponente fachada.

A pesar de la traza direccional del templo, la gran cúpula y sus imponentes machones de apoyo producían la subdivisión del espacio en dos ámbitos adyacentes jerarquizados, la nave y la rotonda, donde el espacio del crucero se convertía en el centro de gravedad de la composición. El tramo rectangular de la nave permitía dirigir la mirada hacia el robusto tambor de la cúpula, cuya blancura, luminosidad y verticalidad originales hacían que se desvaneciese, produciendo un efecto de ingravidez, otorgándole al espacio un carácter trascendental.

En el proyecto de la iglesia se detecta una influencia renacentista, e incluso romana. La solución del espacio de planta circular recuerda a edificios romanos como el templo de Minerva Medica, de gran presencia volumétrica, la suma de espacio a lo largo de un eje recuerda a Santa Ma delle Grazie de Milán, mientras que la fachada recuerda a la iglesia del Gesù de Vignola en Roma, un plano imponente, comedido en su ornamento, pera al que se la han añadido dos torres que otorgan al conjunto gran fuerza.

En el interior, la sobriedad formal y material del edificio se compensaba con la presencia de gran número de esculturas y superficies pictóricas que le aportaban el dinamismo barroco de la época a un espacio clásico heredado de los antiguos.

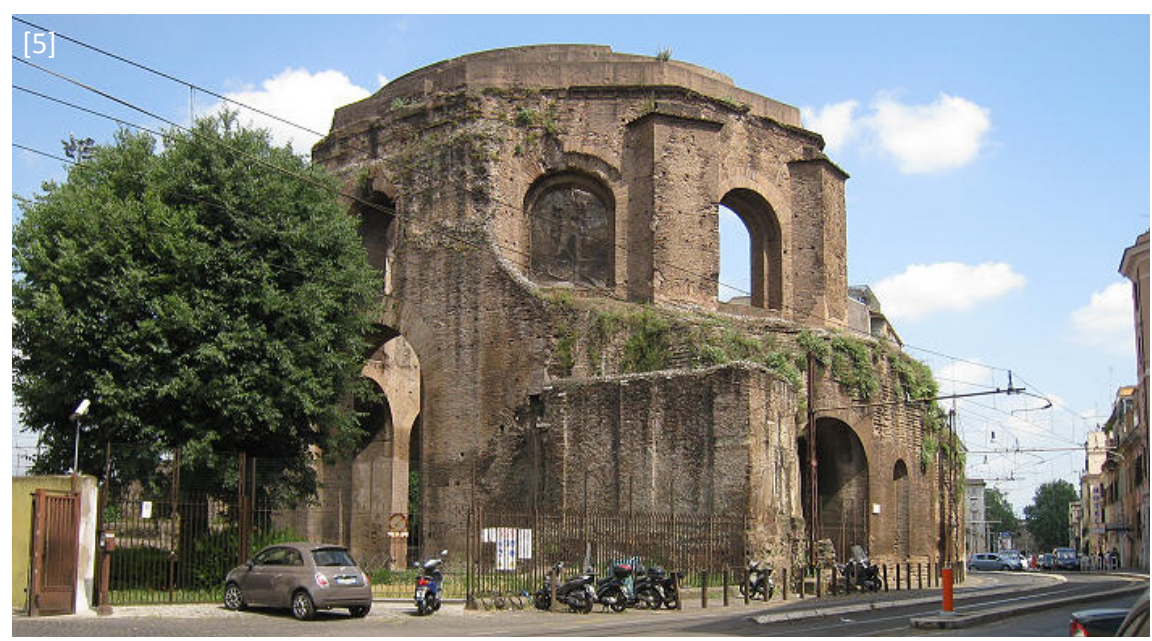

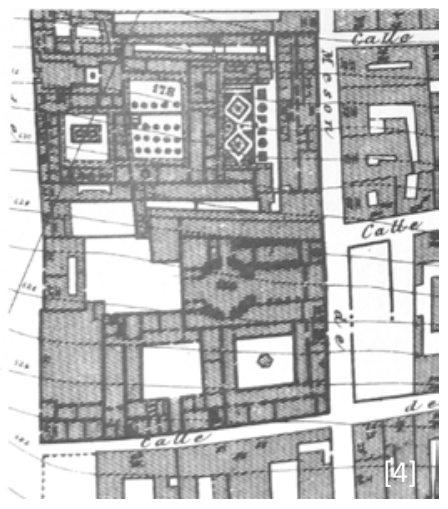

[4] Planta de la iglesia de las Escuelas Pías. (COAM: 1982, p. 161)

[5] Templo de Minerva Medica. (Fotografía de Roberto Piperno. En: MOORE: <www.romeartlover.it>)

[6] Vista exterior de la rotonda de la iglesia de las Escuelas Pías. (COAM: 1982, p. 161)

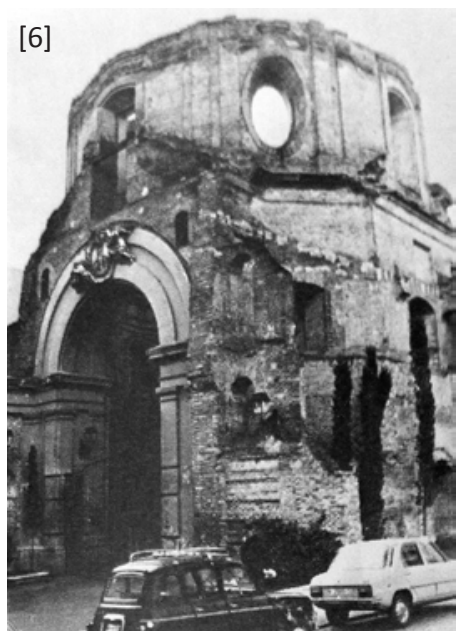




\subsection{Necesidad de la intervención}

Tras décadas de abandono, en el año 1996 se propone un concurso de intervención para dotar de un nuevo uso a los restos de la iglesia. El concurso, ganado por el arquitecto José Ignacio Linazasoro, se concreta, tras un largo proceso de debate, en la instalación de una biblioteca en los restos de la iglesia, un aulario en el solar adjunto y la inserción de un aparcamiento subterráneo en la plaza de Agustín Lara.

La dotación de un nuevo uso a las ruinas de la iglesia se convierte en una necesidad de primer orden para permitir su permanencia en el futuro. La adaptación de los restos a biblioteca pública requiere construir nuevos elementos, que completen los muros y cubiertas para conformar los nuevos espacios.

La diferencia de función propuesta requiere la configuración de nuevos espacios, con necesidades distintas a las del edificio original, dotados de las instalaciones adecuadas para cumplir las condiciones del nuevo uso.

Desde el punto de vista urbano, el cambio en el entorno de las ruinas, producido por la apertura de una plaza sobre lo que originalmente era tejido edificado, introduce la necesidad de completar las ruinas definiendo el nuevo límite urbano mediante un edificio que aporte una fachada al espacio público.

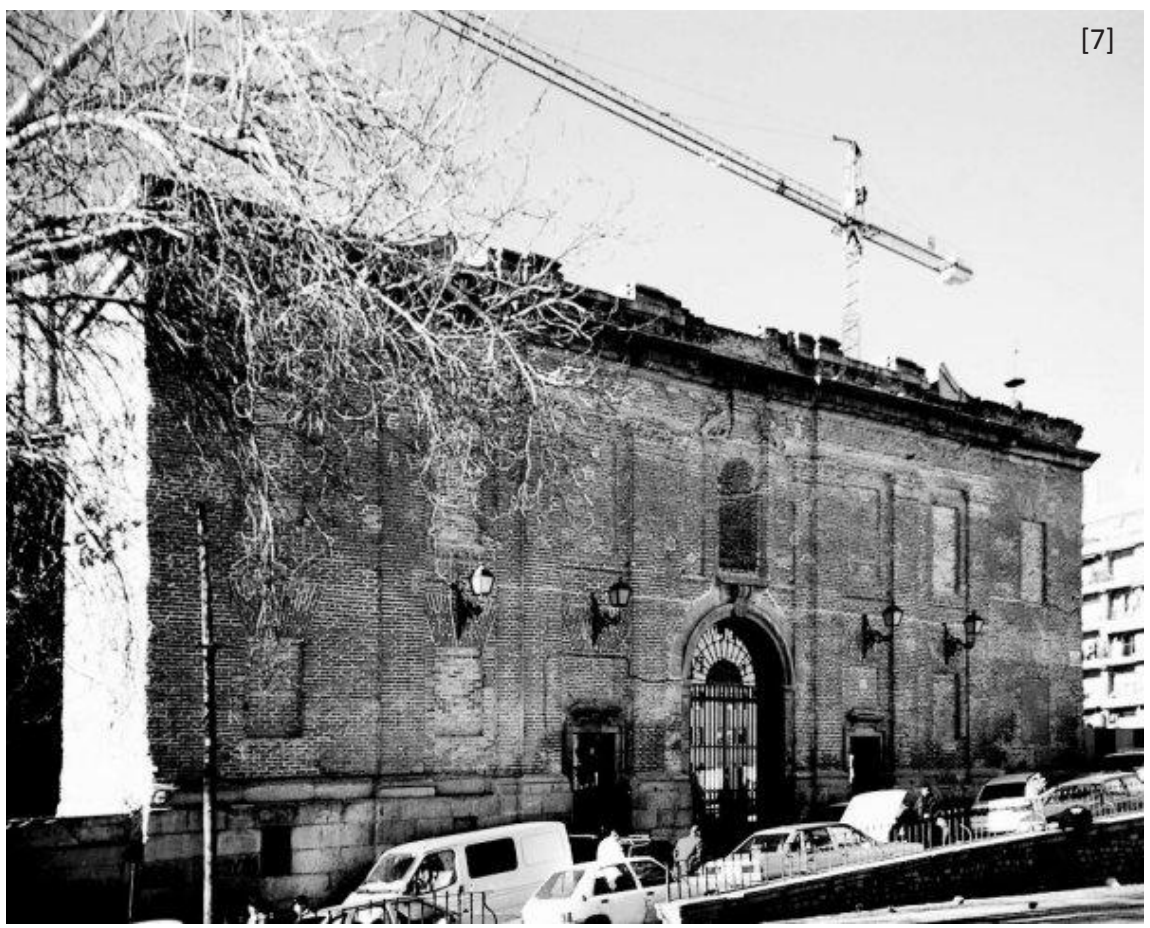




\section{EL ARQUITECTO RESTAURADOR}

José Ignacio Linazasoro nace en San Sebastián en 1947. Se gradúa en la Escuela de Arquitectura de Barcelona en 1972. Obtiene el título de doctor por la Escuela de Barcelona en 1980. Es catedrático de proyectos arquitectónicos en la escuela de Valladolid entre 1983 y 1997 y catedrático de la escuela de arquitectura de Madrid desde 1998.

Entre sus publicaciones cabe destacar: El Proyecto Clásico en Arquitectura (1980), Escritos 1976-89 (1989), Escrito en el Tiempo. Pensar la Arquitectura (2003) y J.I. Linazasoro (2012).

\subsection{De la aplicación de teorías apriorísticas a la creación de un universo personal}

En su libro El Proyecto Clásico en Arquitectura (1980) Linazasoro busca "objetivizar principios y reglas" ${ }^{5}$ de la arquitectura, para luego aplicar estas teorías en sus proyectos. De esta manera, en intervenciones sobre arquitecturas preexistentes, Linazasoro actúa desde un concepto de abstracción tipológica, en la línea de arquitectos como Giorgio Grassi. ${ }^{6}$

Este es el caso de la restauración de la iglesia de Santa Cruz en Medina de Rioseco (1988), donde Linazasoro indaga en la reinterpretación moderna de los sistemas constructivos antiguos, reemplazando los muros y bóvedas tradicionales, que habían desaparecido, por otros modernos. Retoma con ello los criterios analógicos ya utilizados por Valadier en el Coliseo de Roma, buscando reforzar la idea de unidad espacial y crear una cierta ambigüedad entre lo nuevo y lo viejo que evitara la exhibición del contraste. Linazasoro reconoce que esta solución de continuación de la ley del edificio, responde a su poca experiencia en actuaciones sobre preexistencias, y a ello se debe la elección de un camino seguro que le evitara equivocaciones. Pero, como él mismo afirma, "la posibilidad de las formas antiguas reducidas a construcción, se reveló en Medina (...) como excesivamente limitativa". ${ }^{7}$
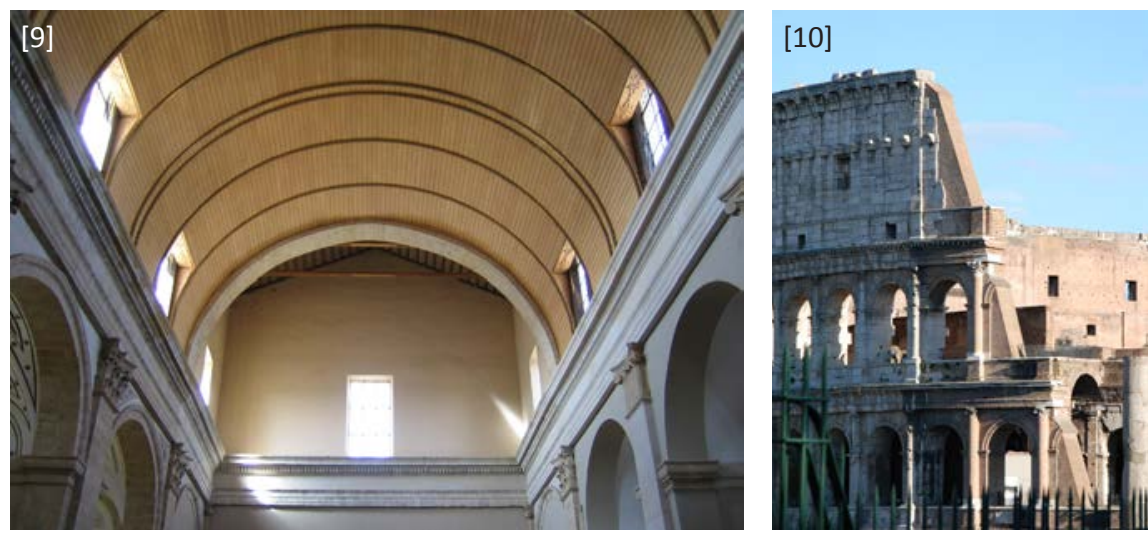

5 LINAZASORO, J.I.: "Introducción". En: LINAZASORO, J.I.: Escrito en el tiempo. Pensar la arquitectura. Buenos Aires, Ed. NobuKo-Universidad de Palermo, 2003, pp. 14-15

6 GARCÍA GRINDA, E.; LINAZASORO, J.I.: “Conversaciones" (1996-1997). En: LINAZASORO, J.I.: Op. Cit., 2003, pp. 91-92

7 GARCÍA GRINDA, E.; LINAZASORO, J.I.: "Conversaciones" (1996-1997). En: LINAZASORO, J.I.: Op. Cit., 2003, pp. 91-92

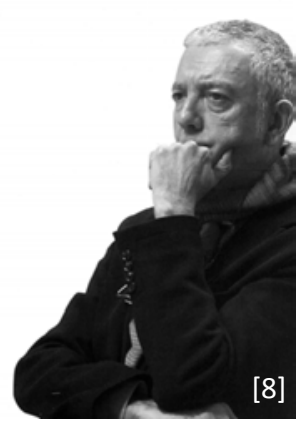

[8] José Ignacio Linazasoro (PRESI: 2012, p. 7)

[9] Vista del interior de la Iglesia de Santa Cruz en Medina de Río Seco tras la reconstrucción. J. I. Linazasoro, 1988-1991. (Imagen del autor)

[10] Intervención de Valadier en el Coliseo. 1828. (Imagen del autor) 
8 GARCÍA GRINDA, E.; LINAZASORO, J.I.: "Conversaciones" (1996-1997). En: LINAZASORO, J.I.: Op. Cit., 2003, pp. 91-92

9 LINAZASORO, J.I.: “Introducción". En: LINAZASORO, J.I.: Op. Cit., 2003, pp. 1415

10 de SOLÁ-MORALES, I.: “Imitación Esencial. La Arquitectura de José Ignacio Linazasoro" (1998). En: LINAZASORO, J.I.: Evocando la ruina. Sombras y texturas. Centro cultural en Lavapiés. Madrid, 2005, pp. 8-13

11 Linazasoro hace referencia a Hans Sdelmayr y su teoría de la descentralización del arte en la historia. SEDLMAYR, H.: El arte descentrado. Labor, 1959 (1948)

[11] Vista interior del Museo Kimbell en Fort Worth, Texas. Louis I. Kahn, 1967-1972. (FRAMPTON; KOMENDANT; TENREIRO: 2000, p. 194)

[12] Convento de Santa Teresa en San Sebastián. J. I. Linazasoro, 1988-1991. (LINAZASORO: <www. linazasoro-arquitecto.com>)
En las obras posteriores, Linazasoro se interesa por la arquitectura moderna, como fuente de recursos para responder a las necesidades concretas presentes en los proyectos. ${ }^{8}$ De esta manera, Linazasoro renuncia a establecer teorías que se deban seguir en la práctica, en favor de una reflexión sobre obras que le interesan, como proceso de creación de un universo personal. ${ }^{9}$

En su obra de intervención en el Convento de Santa Teresa en San Sebastián (1991), Linazasoro se enfrenta a un edificio construido en el que debe introducir nuevos elementos. Para ello actúa con una doble operación de reflexión: por un lado una reflexión sobre la arquitectura preexistente, reconociéndola para abrirla a nuevas posibilidades de comprensión; y por otro lado, una reflexión sobre la historia de la arquitectura que, como indica Ignasi de Solá-Morales, hace referencia a formas y significados de "arquitecturas de tiempos diversos, tales como las de Louis Kahn, Peter Behrens o John Soane". ${ }^{10}$
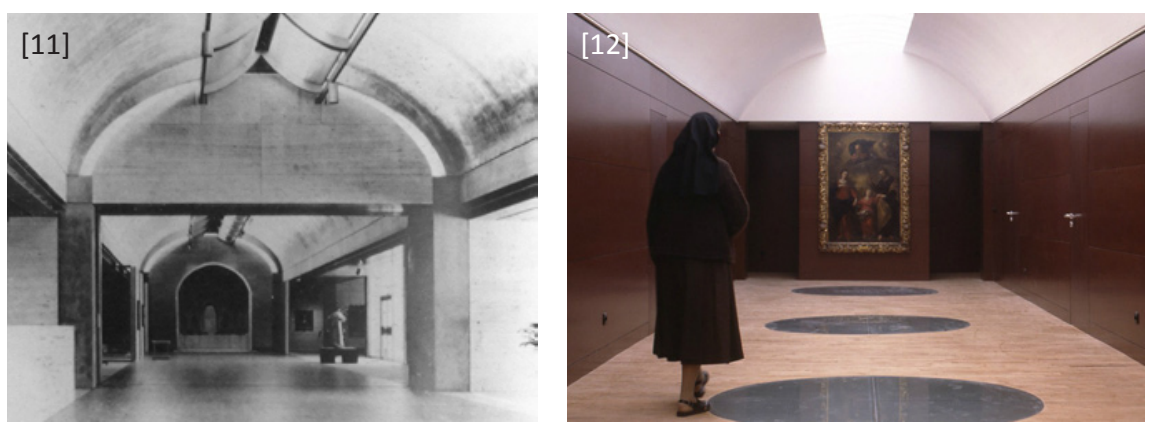

\subsection{El Orden incompleto, condición de la arquitectura}

Para Linazasoro la arquitectura es en gran medida la expresión del Orden incompleto.

En el pasado la arquitectura era la expresión de un Orden capaz de explicar la centralidad del hombre en el Cosmos y su relación con lo Sacro, sin embargo hoy, tras un proceso de secularización, existe una descentralización que le impide formularse en la seguridad de este Orden completo. ${ }^{11}$

Pero, dado que ese Orden es el fundamento de la identidad arquitectónica, éste se debe tratar de alcanzar mediante la articulación de diversos discursos, parciales, cuya suma sea capaz de evocar la totalidad. 
Este discurso, al no ser único y ser fragmentario, de alguna manera se articula mediante paradojas. Así, al igual que San Juan de la Cruz trata de explicar la idea de Dios, como unidad, desde distintos puntos de vista $^{12}$, en el caso del Orden de la arquitectura éste se trata de alcanzar también a través de discursos paradójicos que de alguna manera intentan aproximarse al problema. ${ }^{13}$

Por otra parte, esos fragmentos deben hacer referencia al pasado, entendido como identidad cultural, pertenecientes por tanto a la memoria colectiva. De esta manera el fragmento evoca tanto la totalidad original de donde proviene como la ausencia de lo que le falta. Así, a través de lo visible, lo invisible es evocado, en la traza de lo que ya no existe. ${ }^{14}$

Este interés de Linazasoro por lo inacabado lo refleja con gran claridad Marguerite Yourcenar cuando habla del interés por las esculturas clásicas incompletas por efecto del tiempo: ${ }^{15}$

"Nuestros antepasados no podían soportar ver mutiladas aquellas obras de arte, ver aquellas marcas de violencia y de muerte en los dioses de piedra. Los grandes aficionados a las antigüedades restauraban por piedad. Por piedad deshacemos nosotros su obra" ${ }^{16}$

En el campo de lo arquitectónico, este concepto lo ejemplifica Linazasoro con la arquitectura de Mies, en la que se expresa con claridad, a través de la ausencia, la imposibilidad de reconstruir la arquitectura clásica, profundizando con ello en el sentido intemporal de la arquitectura. ${ }^{17}$

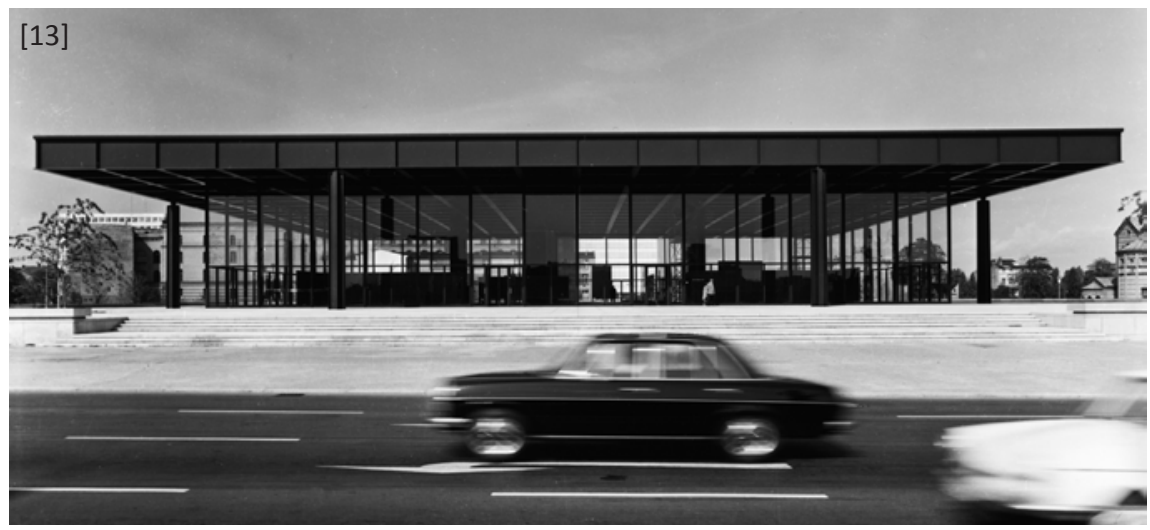

12 Linazasoro hace referencia al recurso retórico empleado por San Juan de la Cruz para hablar de lo espiritual: "música callada, soledad sonora". En: Cántico espiritual. 1542-1591

13 Entrevista realizada a José Ignacio Linazasoro, en Madrid, en diciembre de 2012, pregunta 8 (ver anexo)

14 LAROQUE, D.: "Conversazione con J.I. Linazasoro". En: PRESI, S. (dir): J.I. Linazasoro. Ed. Casa dell'Architettura, 2012, pp.10-12

15 LINAZASORO, J.I.: "El Tiempo y la Arquitectura" (Diciembre de 1999, Julio de 2000, Junio de 2001). En: LINAZASORO, J.I.: Op. Cit., 2003, pp. 80-88

16 YOURCENAR, M.: El Tiempo, Gran Escultor. Madrid, Alfaguara, 1999 (Ed. Original 1983), p. 69

17 LAROQUE, D.: “Conversazione con J.I. Linazasoro". En: PRESI, S. (dir): Op. Cit., 2012, p.14
[13] Neue Nationalgalerie. Mies van der Rohe, 1968. (Universität der Künste Berlin: <www.arch.udkberlin.de>)

[14] Dibujo de Le Corbusier, hecho en Pompeya en octubre de 1911. Les colonnes à contre jour sont ajoutées pour expliquer l'espace. (Fondation Le Corbusier: <www. fondationlecorbusier.fr $>$ )

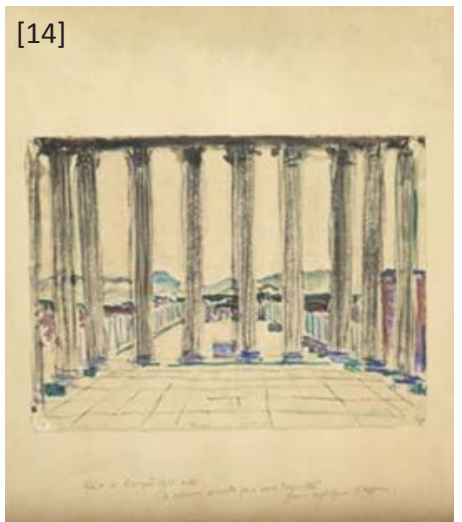




\subsection{La arquitectura como virtualidad de la construcción}

18 Entrevista realizada a José Ignacio Linazasoro, en Madrid, en diciembre de 2012, pregunta 8 (ver anexo)

19 LINAZASORO, J.I.: "Alcune riflessioni". En: PRESI, S. (dir): J.I. Linazasoro. Ed. Casa dell'Architettura, 2012, p. 30

20 LAROQUE, D.: "Conversazione con J.I. Linazasoro". En: PRESI, S. (dir): Op. Cit., 2012, p.14

21 LINAZASORO, J.I.: "Alcune riflessioni". En: PRESI, S. (dir): Op. Cit., 2012, p.26

22 LINAZASORO, J.I.: "Alcune riflessioni". En: PRESI, S. (dir): Op. Cit., 2012, p.32

[15] Detalle de carpintería en el Conjunto Parroquial en Klippan. Sigurd Lewerntz, 1962-1966. (QUINTANILLA, J.: "Sigurd Lewerentz, 1885-1975. Una transición nórdica a la Arquitectura Moderna. Desplazamiento gradual hacia el dominio de lo táctil" Universidad Politécnica de Cataluña, Departamento de Proyectos Arquitectónicos, 2004)

[16] Detalle de fachada del edificio Seagram. Mies van der Rohe, 19541958. (RODRÍGUEZ: <relatosdearte. blogspot.com>)

[17] Detalle de la escalera de acceso al altillo, Centro Cultural Escuelas Pías. J. I. Linazasoro, 1996-2004. (LINAZASORO, J. I.: Conarquitectura, no 12,2004, p.64)
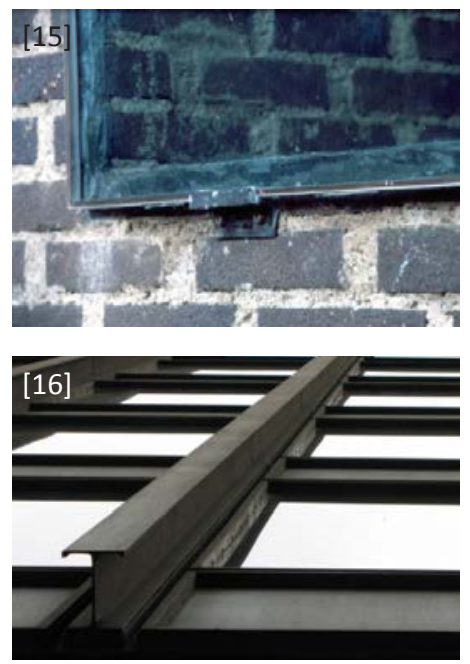

Linazasoro entiende que la arquitectura se basa en lo constructivo, es su lenguaje, no puede prescindir de él, pero matiza que no se identifica con él, sino que va más allá, es en cierto modo su forma poética. "La arquitectura no es una tékne es una arché, como dirían los griegos", de tal manera que la arquitectura se puede entender como una evocación de la construcción. ${ }^{18}$

Así por ejemplo con la estructura, esqueleto de la construcción, se puede buscar reforzar el carácter y la expresividad del espacio, llevándola más allá de su mera función estática. "No se trata tanto de hacer una traslación directa de la construcción a la forma, cuanto de que esta última pueda ser evocación de la técnica". ${ }^{19}$

Por otro lado, para Linazasoro el carácter artificial de la construcción, frente a las formas naturales, permite expresar la posición del hombre en el mundo. Ya que entiende que "la arquitectura no forma parte de la naturaleza, sino que hace de intermediaria entre ésta y el hombre". ${ }^{20}$

En este sentido, ve la arquitectura como un arte fundado en el oficio, más cercano del artesano que del artista, donde el objeto debe ser útil y duradero, y por tanto debe estar bien construido. Pero ciertamente, la arquitectura no es mera respuesta técnica o funcional a las necesidades humanas, sino que posee un carácter simbólico en cuanto imagen y reflejo de la vida humana y expresión del paso del tiempo, del transcurrir de la historia del hombre. ${ }^{21}$

También el detalle constructivo cumple, para Linazasoro, un papel de evocación y expresión de la solución técnica. Le interesan por tanto soluciones que expresen honestidad constructiva como las de Alejandro de la Sota o Lewerentz, pero también la sofisticación presente en la arquitectura de Mies, donde en todo caso los detalles tienden a desaparecer, absorbidos por el conjunto. ${ }^{22}$

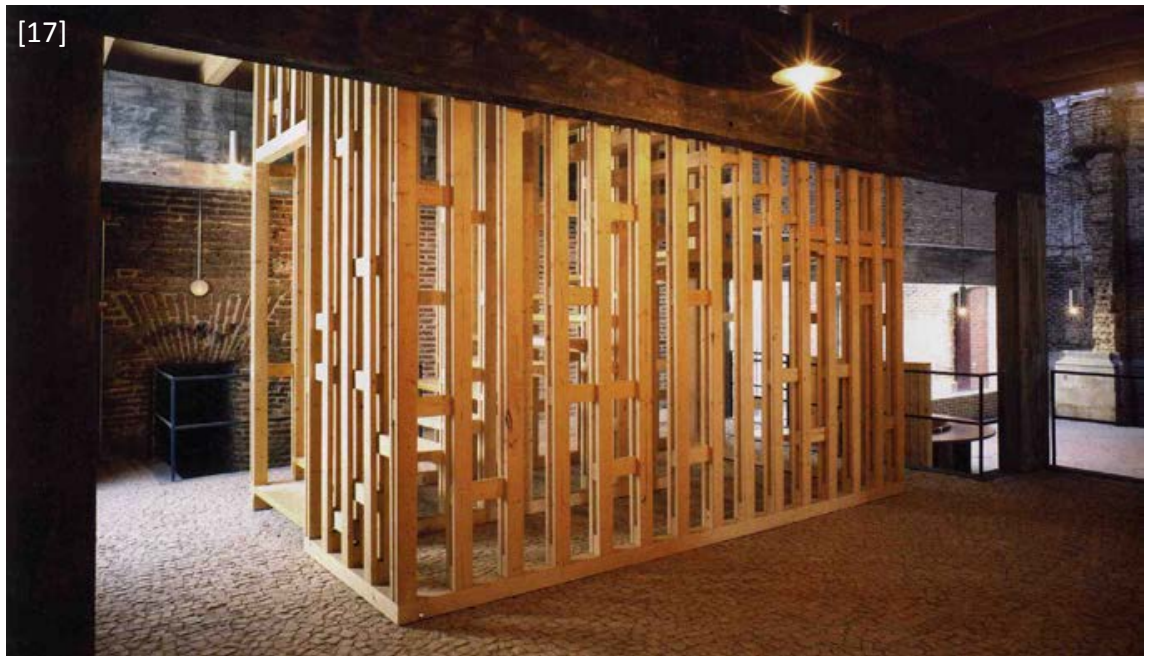

Iglesia de las Escuelas Pías del Colegio de San Fernando.1996-2004 


\subsection{Arquitectura intemporal. La esencialidad formal y su expresión material}

Para Linazasoro la esencialidad de la construcción presente en la arquitectura de los modernos, como Mies van der Rohe, Asplund, Lewerentz o Le Corbusier, es una manera de volver al origen de la arquitectura, y con ello alcanzar "un punto de encuentro entre la reafirmación de los fundamentos y la reinvención de la arquitectura". ${ }^{23}$ Configurando con esta continuidad una sensación de intemporalidad en la arquitectura.

En este sentido la abstracción presente en la Modernidad se puede entender como una consecuencia de la acción del tiempo. Un proceso de depuración formal que, como en una ruina -imagen de la permanencia de la arquitectura a lo largo del tiempo-, ha ido perdiendo su ornamentación hasta convertirse en la pura expresión de la construcción.

Pero también, Linazasoro entiende que esta esencialidad demuestra el cambio en el orden de totalidad de la arquitectura, de tal manera que en la contemporaneidad esta totalidad sólo puede expresarse a través de la conciencia de una ausencia. ${ }^{24}$

Unas reflexiones que le han llevado a la esencialización arquitectónica a través de un progresivo proceso de eliminación de capas, "dejando que sean los materiales los protagonistas de la arquitectura, encargados de comunicar expresividad al espacio que ellos mismos definen". ${ }^{25}$

Esta comprensión de la arquitectura como expresión de su construcción Linazasoro lo aprecia en la arquitectura de Schinkel donde "la 'firmitas' constituye una parte de su expresividad". ${ }^{26}$ También en la arquitectura de Adolf Loos, quien interpreta la arquitectura clásica, la arquitectura rural, o la nueva arquitectura americana, como arquitecturas derivadas de la expresión de la técnica, que le permiten distinguir lo importante frente a lo secundario, lo verdadero frente a lo falso. ${ }^{27}$
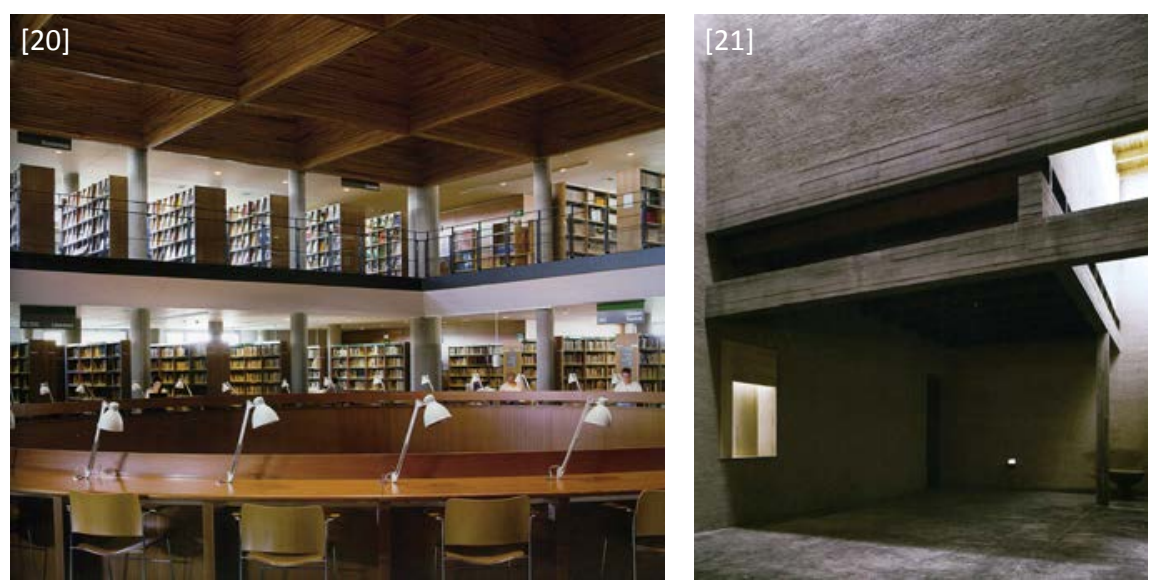

23 GARCÍA GRINDA, E.; LINAZASORO, J.I.: "Conversaciones" (1996-1997). En: LINAZASORO, J.I.: Op. Cit., 2003, p. 100

24 LAROQUE, D.: "Conversazione con J.I. Linazasoro". En: PRESI, S. (dir): Op. Cit., 2012, p.16

25 PRESI, S.: "Cuestiones de Arquitectura. Entrevista de Stefano Presi a José Ignacio Linazasoro". En: PRESI, S.: José Ignacio Linazasoro. Progettare e Costruire. Latina: Casa dell'Architettura, 2007, pp. 189-199

26 LINAZASORO, J.I.: "Vitrubio en la Modernidad o la Reconstrucción del Orden Perdido" (Mayo de 1986). En: LINAZASORO, J.I.: Op. Cit., 2003, p. 38

27 LINAZASORO, J.I.: "Forma y Cultura. La Arquitectura de A. Loos" (Enero de 1989). En: LINAZASORO, J.I.: Op. Cit., 2003, pp. 48-54

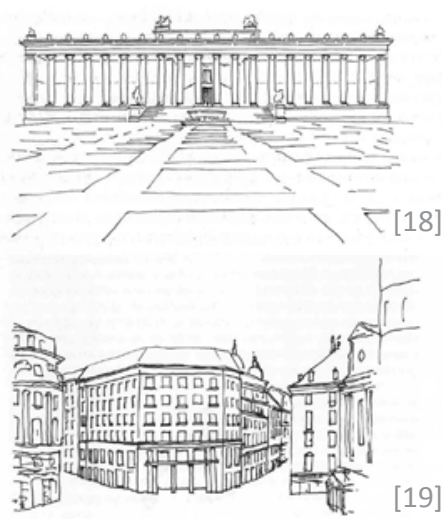

[18 y 19] Dibujos de J. I. Linazasoro. Arquitecturas de Schinkel y Loos. (LINAZASORO: 2007, pp. 216 y 230)

[20] Vista del espacio interior de la Biblioteca de la UNED. J. I. Linazasoro, 1989-1994. (PRESI: 2012, p. 39)

[21] Vista interior de la Iglesia de San Lorenzo en Valdemaqueda. J. I. Linazasoro, 1997-2001. (PRESI: 2012, p. 54) 
28 LINAZASORO, J.I.: "Alcune riflessioni". En: PRESI, S. (dir): Op. Cit., 2012, p.20

29 LOOS, A.: "La antigua y la nueva tendencia en arquitectura". p.201-205. En: SCHACHEL, R.: Ornamento y Delito y otros escritos. Barcelona, Gustavo Gili, 1972, p.202

30 LINAZASORO, J.I.: “El Tiempo Detenido. En torno a la arquitectura de Dom van der Laan" (Madrid, 1997). En: LINAZASORO, J.I.: Op. Cit., 2003, pp. 56-61

31 Entrevista realizada a José Ignacio Linazasoro, en Madrid, en diciembre de 2012, pregunta 5 (ver anexo)

32 de SOLÁ-MORALES, I.: "Imitación Esencial. La Arquitectura de José Ignacio Linazasoro" (1998). En: LINAZASORO, J.I.: Evocando la ruina. Sombras y texturas. Centro cultural en Lavapiés. Madrid, 2005, pp. 8-13

[22] Arquitectura de Dom van der Laan. (PÉREZ: <tetraedros.blogspot.com>)

[23] Centro Administrativo de Congresos en Troyes. (PRESI: 2012, p. 105)
Pero Linazasoro entiende la construcción más como espacio que como objeto, un medio para crear una atmósfera, un paisaje en el que las actividades humanas se desarrollen en el curso del tiempo. ${ }^{28}$ Un poco en la línea de lo que indica Adolf Loos sobre la arquitectura entendida como mecanismo para "provocar con ayuda de los materiales sensaciones que, en realidad, no son aún algo inherente al material". 29

En este sentido destaca la arquitectura de Dom van der Laan donde se observa una naturalidad y una cultura surgidas de "la depuración del lenguaje antes que la reinvención del mismo. (...) La sensación de equilibrio, de proporción, (...) la pregnancia de las texturas, la emotividad de los contrastes de luz y de sombra... nos acercan con gran evidencia a un pasado intemporal, esencial." Se trata de un proceso de depuración formal donde conviven realidad y abstracción, donde "el rigor geométrico y tipológico se expresa mediante sistemas constructivos directos y mediante texturas de enorme carga expresiva desde lo material", donde la imperfección de la construcción expresa la imperfección del hombre, donde las texturas irregulares se oponen a los brillos fugaces de la arquitectura contemporánea. ${ }^{30}$
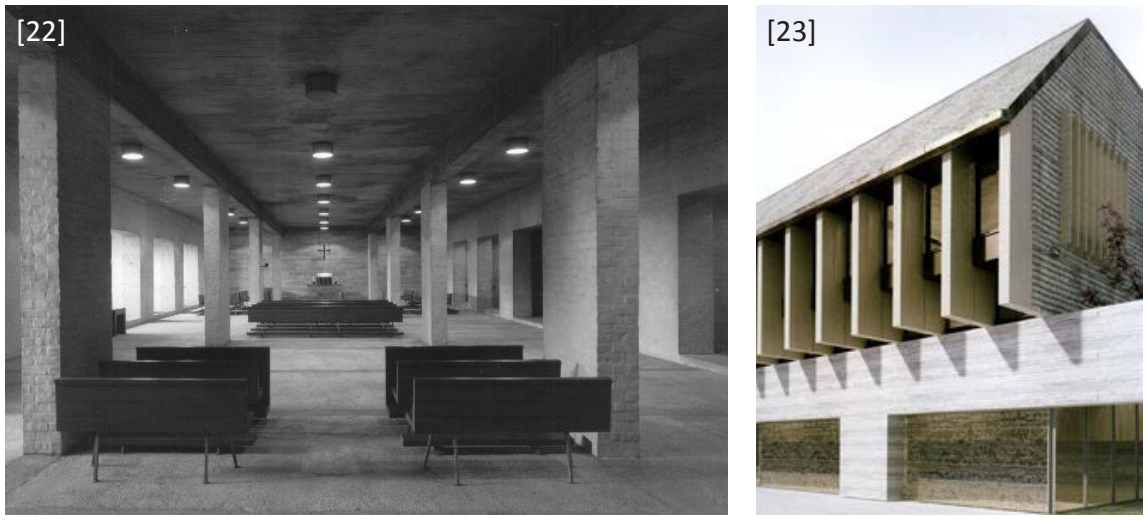

\subsection{La historia como memoria y referencia}

A Linazasoro le interesa la historia entendida como memoria, no como evolución. Le interesa aquello que permanece, con sus ausencias. No le interesa como era el monumento en el pasado, sino como ha llegado hasta nosotros: "si reconstruyéramos el Panteón tal y como fue en origen no nos gustaría, lo que nos interesa es el Panteón como está ahora". ${ }^{31}$

En este sentido a Linazasoro le interesa la historia como referencia para sus proyectos. Como dice Ignasi de Solà-Morales: "en Linazasoro la historia de la arquitectura, selectiva, reordenada una y mil veces, repensada como caudal permanente de referencia, es el objeto de la imitación" ${ }^{32}$ 
Así, Linazasoro se nutre en sus obras de referencias tomadas de arquitecturas de la historia, tanto clásicas como modernas. Pero estas referencias no se escogen al azar, sino que atienden a lo que Focillon denomina la famille spirituelle [familia espiritual], es decir, familias de arquitectos que beben unos de otros, debido a un interés común sobre las cosas, un interés por una misma idea de la arquitectura. ${ }^{33}$

Esta manera de actuar supone que exista en su obra algunos aspectos recurrentes que desvelan un cierto estilo personal. Pero Linazasoro matiza que éste estilo se entiende siempre como punto de llegada y no como presupuesto de partida, ya que cada proyecto propone preguntas distintas a las que dar respuestas siempre nuevas. ${ }^{34}$

Este juego de referencias se observa por ejemplo en el caso de la composición de los huecos de fachada en retícula presente en Asplund y Terragni, reelaborado en algunas de sus obras como el aulario de las Escuelas Pías y el centro de congresos de Troyes. O también el caso de la repetición de vigas de canto presente en el Pabellón de Venecia de Sverre Fehn, reelaborado en obras como la biblioteca de las Escuelas Pías, la iglesia de Valdemaqueda o en Troyes. O la superposición de un orden ligero sobre otro pesado retomado de la idea de palio empleada en el velarium de la sala Bleu del Ayuntamiento de Estocolmo de Östberg y en la Casa de los Hilanderos de Le Corbusier, y que la reinterpreta en el proyecto del pabellón de Castilla la Mancha de la Expo de Sevilla, en el Archivo Hospital del Rey de Melilla y en la sala del consejo de Troyes. ${ }^{35}$
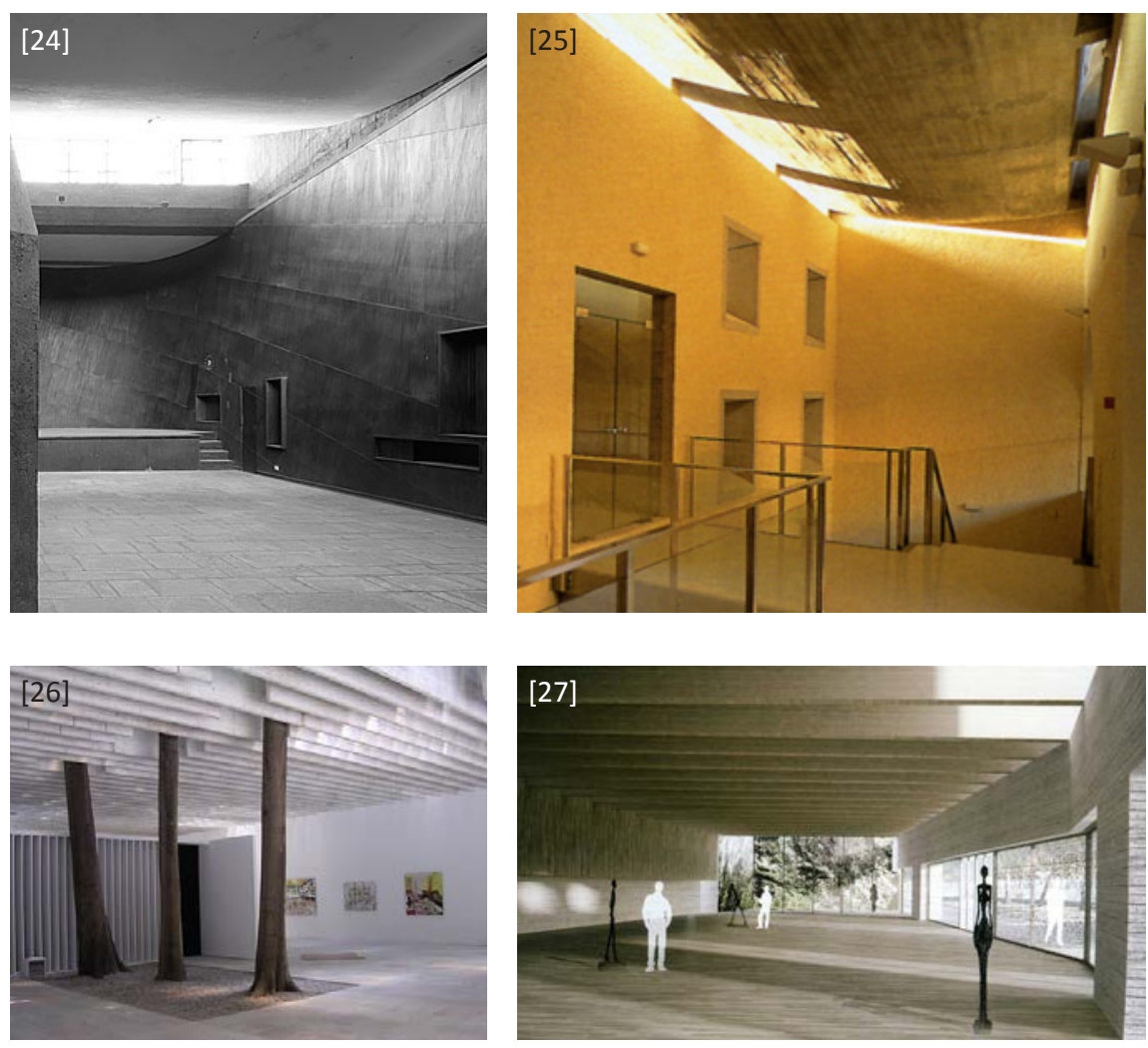

33 Linazasoro hace referencia a FOCILLON, H.: La vida de las formas. Xarait, Madrid, 1983 (1934)

34 LINAZASORO, J.I.: "Alcune riflessioni". En: PRESI, S. (dir): Op. Cit., 2012, p.26

35 Entrevista realizada a José Ignacio Linazasoro, en Madrid, en diciembre de 2012, pregunta 2 (ver anexo)

[24] Palacio de los Hilanderos, Ahmedabad. Le Corbusier, 1951. (Fotografía de Cemal Emden. En: Europaconcorsi: <europaconcorsi. com>)

[25] Restauración del Hospital del Rey, Melilla. J. I. Linazasoro, 19901996. (LINAZASORO: <www.linazasoro-arquitecto.com>)

[26] Pabellón Nórdico de la Bienal de Venecia. Sverre Fehn, 19581962. (ZABALBEASCOA, A.: <blogs. elpais.com>)

[27] Sala polivalente del Centro Administrativo de Congresos en Troyes. (PRESI: 2012, p. 105) 


\subsection{El lugar como palimpsesto de fragmentos}

36 GARCÍA GRINDA, E.; LINAZASORO, J.I.: "Conversaciones" (1996-1997). En: LINAZASORO, J.I.: Op. Cit., 2003, p. 96

37 LINAZASORO, J.I.: "Alcune riflessioni". En: PRESI, S. (dir): Op. Cit., 2012, p.26

38 LINAZASORO, J.I.: Tres proyectos sobre las preexistencias. Conferencia impartida en el marco del Workshop Internacional Construcción de la Memoria, en la Escuela Técnica Superior de Arquitectura de la Universidad Politécnica de Valencia, 12 de mayo de 2011, inédito

39 LINAZASORO, J.I.: "Apuntes de Viaje. Sicilia Marzo 1997". En: LINAZASORO, J.I.: Op. Cit., 2003, p. 71

40 LINAZASORO, J.I.: "Apuntes de Viaje. Siria marzo 1998". En: LINAZASORO, J.I.: Op. Cit., 2003, p. 75

41 LINAZASORO, J.I.: "Apuntes de Viaje. Kairouan abril 2001". En: LINAZASORO, J.I.: Op. Cit., 2003, p. 77

42 Entrevista realizada a José Ignacio Linazasoro, en Madrid, en diciembre de 2012, pregunta 10 (ver anexo)

[28] Mezquita de Kairouán. (GLANCEY: 2001, p. 50)

[29] Superposición de fragmentos en la Catedral de Siracusa. (FIDONE. En: CORNOLDI; RAPPOSELLI: 2007, p. 12)
A Linazasoro le interesa la ciudad entendida como lugar en el que son las permanencias las que configuran la estructura urbana. Ya en su libro Permanencias y Arquitectura Urbana (1978), estudia la reutilización y reinterpretación de muros antiguos y de ruinas para la configuración de nuevas arquitecturas. ${ }^{36}$

La pérdida del Orden canónico supone pasar de entender la arquitectura como algo ideal y aislado, a entenderla como una parte de un palimpsesto. La ciudad es en el fondo como un edificio colectivo realizado por múltiples autores y habitado por muchas personas a lo largo del tiempo. ${ }^{37}$

Esta lectura de la ciudad le lleva a considerar esa arquitectura heredada como una parte de su propia arquitectura, entendiendo que "el proyecto no es solamente lo que se hace, sino lo que se mira desde lo que se hace". ${ }^{38}$ De tal manera que la obra se compone de lo ya construido y lo nuevo, tratando de formar un todo. Por ello, entiende el proyecto como una aportación, un fragmento, una capa más de ese palimpsesto que constituye la ciudad.

En este orden de cosas, Linazasoro muestra gran interés por la superposición física que se advierte en muchos edificios de la historia tales como la Catedral de Siracusa, donde se ensamblan arquitecturas con evidente violencia física, ${ }^{39}$ la Mezquita Mayor de Damasco donde "Grecia, Roma, Bizancio y el Islam se superponen en un increíble palimpsesto arquitectónico en el cual no resulta difícil reconocer las piezas usadas y reutilizadas" 40 , o la Gran Mezquita de Kairouan, en la que "Ias viejas columnas romanas y bizantinas reutilizadas acentúan la sensación de modernidad: el triunfo de la materia sobre el ornamento". ${ }^{41}$

En este sentido Linazasoro comparte la idea, presente en arquitectos como Labrouste, de que se parte de una arquitectura pura en origen que se va contaminando mediante la acumulación de estratos a lo largo del tiempo, de tal manera que esa arquitectura se va enriqueciendo gracias precisamente a la aportación de esas impurezas. ${ }^{42}$ Admitiendo con ello su apertura y continua evolución.
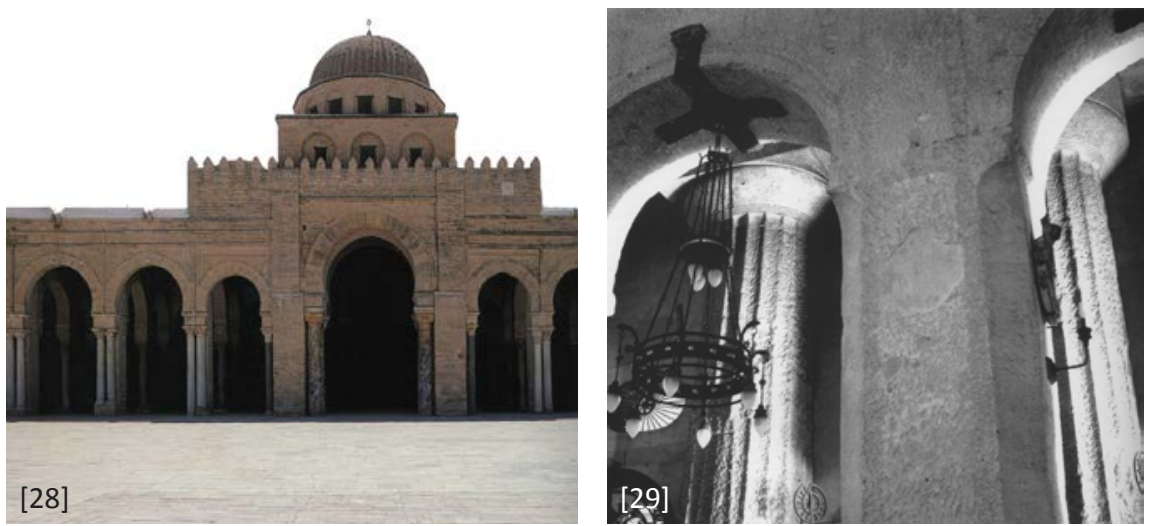

Iglesia de las Escuelas Pías del Colegio de San Fernando.1996-2004 
En cualquier caso, Linazasoro entiende la relación con la preexistencia como un problema de arquitectura, de definición de un programa claro que se relaciona con el lugar en el que se actúa, de tal manera que "el pasado (...) no es enemigo o amigo de lo nuevo, sino el terreno sobre el cual éste construye su necesidad". ${ }^{43}$ Por tanto, un proyecto no debe ser el resultado de una inspiración personal, sino del análisis del contexto: "se trata de saber escuchar lo que el lugar sugiere, en voz baja, como un secreto". ${ }^{44}$

En ocasiones puede ser que lo que convenga sea pasar desapercibido. En este sentido Linazasoro pone el ejemplo de su intervención en Rovereto o de la actuación de Alvaro Siza en la reconstrucción del Chiado, en Lisboa, en los que queda patente la prudencia en la resolución de los problemas de cada caso frente a la búsqueda por dejar "la impronta del arquitecto". ${ }^{45}$

En otras ocasiones la relación con ese contexto urbano supone medirse no solo con aquello que existe, sino con elementos ya desaparecidos pero presentes en la memoria colectiva o histórica. Así actúa en varias de sus obras como en Reims, donde el vacío dejado por los edificios desaparecidos se evidencia mediante plazas elevadas en el interior del espacio urbano, en Troyes donde se recupera una calle perdida como parte del nuevo proyecto, o en la protección de las ruinas romanas de Valdetorres, donde un gran impluvium recuerda la ausencia parcial de la casa romana. ${ }^{46}$

Pero también, cuando se trata de configurar un nuevo proyecto, éste se compone a partir de fragmentos que remiten a elementos de la ciudad, relacionando la nueva arquitectura con su contexto. Esto se observa con claridad en su proyecto en Troyes, de tal manera que el proyecto se puede contar desde una visita a la propia ciudad. ${ }^{47}$

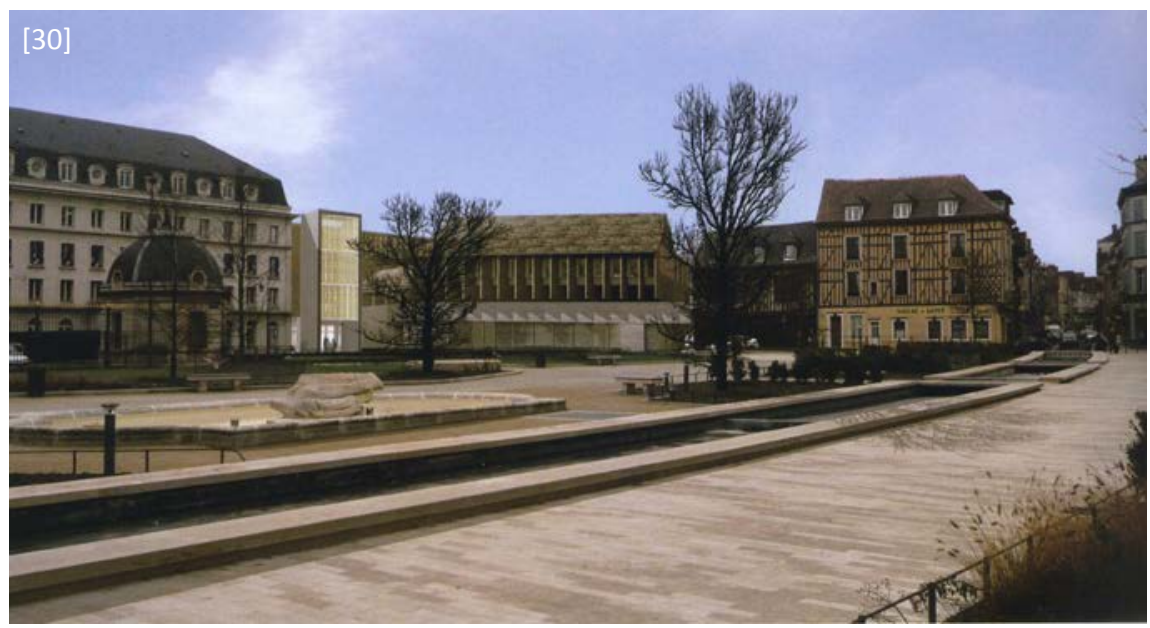

43 UGOLINI, A.; MESSINA, B.; FIDONE, E.; LINAZASORO, J.I.: "Progetto, Storia, Restauro. Riflessioni in forma di conversazione. Intervista a José Ignacio Linazasoro, Emanuele Fidone e Bruno Mesina". En: UGOLINI, A. (dir): Ricomporre la Rovina. Firenze, Alinea Editrice, 2010, p. 57

44 PRESI, S.: "Cuestiones de Arquitectura. Entrevista de Stefano Presi a José Ignacio Linazasoro". En: PRESI, S.: José Ignacio Linazasoro. Progettare e Costruire. Latina, Ed. Casa dell'Architettura, 2007, pp. 189-199

45 Entrevista realizada a José Ignacio Linazasoro, en Madrid, en diciembre de 2012, pregunta 4 (ver anexo)

46 LINAZASORO, J.I.: "Alcune riflessioni". En: PRESI, S. (dir): Op. Cit., 2012, p.24

47 Entrevista realizada a José Ignacio Linazasoro, en Madrid, en diciembre de 2012, pregunta 9 (ver anexo)

[30] Vista desde la plaza de la Liberazione del Centro Administrativo de Congresos en Troyes. (PRESI: 2012, p. 94)

[31] Croquis. (PRESI: 2012, p. 99)

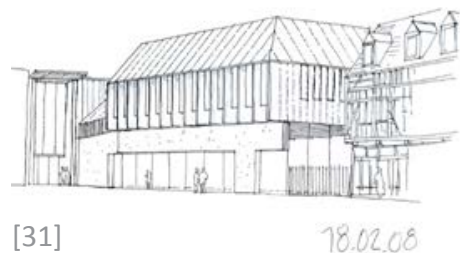


48 LINAZASORO, J.I.: "Alcune riflessioni". En: PRESI, S. (dir): Op. Cit., 2012, p.22

49 LINAZASORO, J.I.: "Alcune riflessioni". En: PRESI, S. (dir): Op. Cit., 2012, p.24

50 LINAZASORO, J.I.: "Alcune riflessioni". En: PRESI, S. (dir): Op. Cit., 2012, p.28

51 LINAZASORO, J.I.: "Alcune riflessioni". En: PRESI, S. (dir): Op. Cit., 2012, p.30

[32] Vista desde la nave hacia el espacio exterior. Centro Cultural Escuelas Pías, 1996-2004. (LINAZASORO: 2007, p. 184)

[33] Vista del Campus Universitario en Segovia. (LINAZASORO: <www. linazasoro-arquitecto.com>)
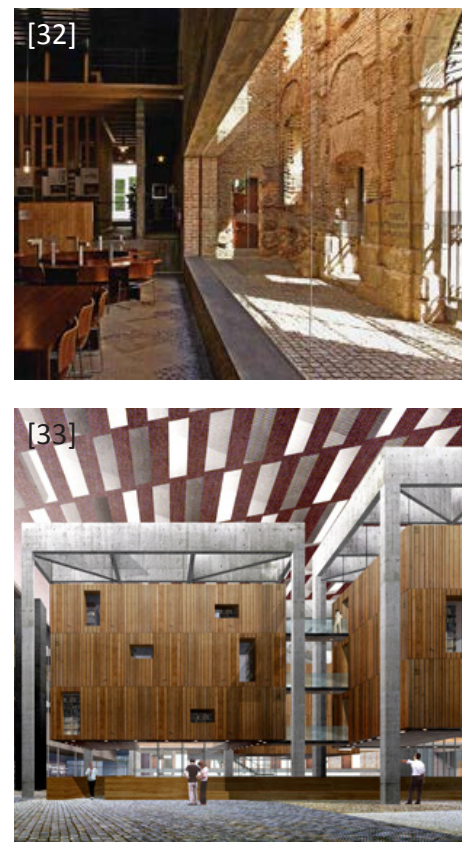

\subsection{Estrategias para relacionar los fragmentos del Orden incompleto}

Entendida la arquitectura por tanto como un non finito [inacabado] compuesto de fragmentos, cobran especial importancia conceptos que permiten enlazar unos elementos con otros, con la intención de crear un conjunto.

\section{La relación interior-exterior}

Linazasoro entiende que para resolver la relación entre partes de un contexto incompleto es necesaria la creación de un espacio de transición entre interior y exterior, un concepto ya presente en el atrio de la arquitectura de la antigüedad. ${ }^{48}$

Esta relación es de tipo espacial, no sólo visual, de tal manera que se busca romper los límites del edificio, haciendo que se disuelva en el paisaje en el que se encuentra. Con esta continuidad entre interior y exterior Linazasoro trata de potenciar la idea de non finito, donde el límite del edificio no está en sí mismo sino en la ciudad. ${ }^{49}$

Esto se observa en el extremo de la sala polivalente de Troyes, donde se observa una interrupción del elemento, haciendo evidente que su límite está en el edificio contiguo preexistente en la ciudad.

Pero Linazasoro matiza que no se trata tanto de una transparencia entre interior y exterior como de una continuidad, como si el edificio poseyese una condición ambigua entre dentro y fuera, algo muy presente en la arquitectura de la ruina.

Así, en el interior, esta idea se refleja mediante la consideración de una sucesión de ambientes, con características espaciales y arquitectónicas distintas, como reflejo de un paisaje urbano. Una realidad compuesta por estratos de diferente solidez material que representan los distintos momentos de una historia ficticia cuya suma permite mantener a la arquitectura abierta a nuevas necesidades y transformaciones..$^{50}$

Además estos estratos, se materializan como más o menos acabados, en función de su temporalidad, siendo los elementos de fondo más "antiguos", elementos desnudos que se expresan desde su materialidad, produciendo una imagen de un espacio exterior en el interior del edificio.

Estas reflexiones se pueden constatar en el edificio de la biblioteca de las Escuelas Pías, o en el edificio del Campus de Segovia. En este último se busca configurar un espacio público interior como si fuese un exterior, una plaza urbana conformada por volúmenes y cubierta por un elemento de apariencia provisional que filtra la luz natural. ${ }^{51}$ 
Linazasoro entiende que la relación entre los fragmentos puede satisfacerse reflexionando sobre el tema de la concinnitas albertiana, entendida como interpretación de la modernidad dentro de la tradición. Es éste, para Linazasoro, el camino adecuado para dar respuestas creíbles a las exigencias actuales.

Para Linazasoro esta armonía se logra mediante la asunción de la permanencia, de lo texturizado, de la justa escala, y no tanto mediante lo ligero, lo liso o lo monumental. En el fondo una búsqueda por insertarse en el contexto de manera natural, a través de un estrato superpuesto que aporta algo nuevo. Una búsqueda por crear una atmósfera habitable, más que por crear una suma de objetos autónomos. ${ }^{52}$

Esta actitud de humildad no es para Linazasoro una actitud servil, sino la expresión de una gran libertad. Una libertad por hacer una arquitectura segura, que no teme ser indiferente a la forma final, que acepta ser superada e incluso pone la atención en esta misma superación. ${ }^{53}$

Para Adriano Cornoldi, Linazasoro emplea una actitud que le lleva a medir la calidad de lo antiguo respecto a lo que se propone como nuevo, de confrontarse y dialogar con lo antiguo con distancia y al mismo tiempo con empatía, sin sumisión y al mismo tiempo sin estrépito, sin la confusión del mimetismo y sin el exhibicionismo del contraste. ${ }^{54}$

\section{Recorrido y repetición}

La nueva concepción del tiempo introduce la percepción en secuencia frente a la percepción estática, produciéndose la comprensión de la totalidad a través de la lectura secuencial de los diferentes fragmentos que la constituyen. Fragmentos que incluyen referencias a un todo que el espectador debe desentrañar para restituirlo. ${ }^{55}$
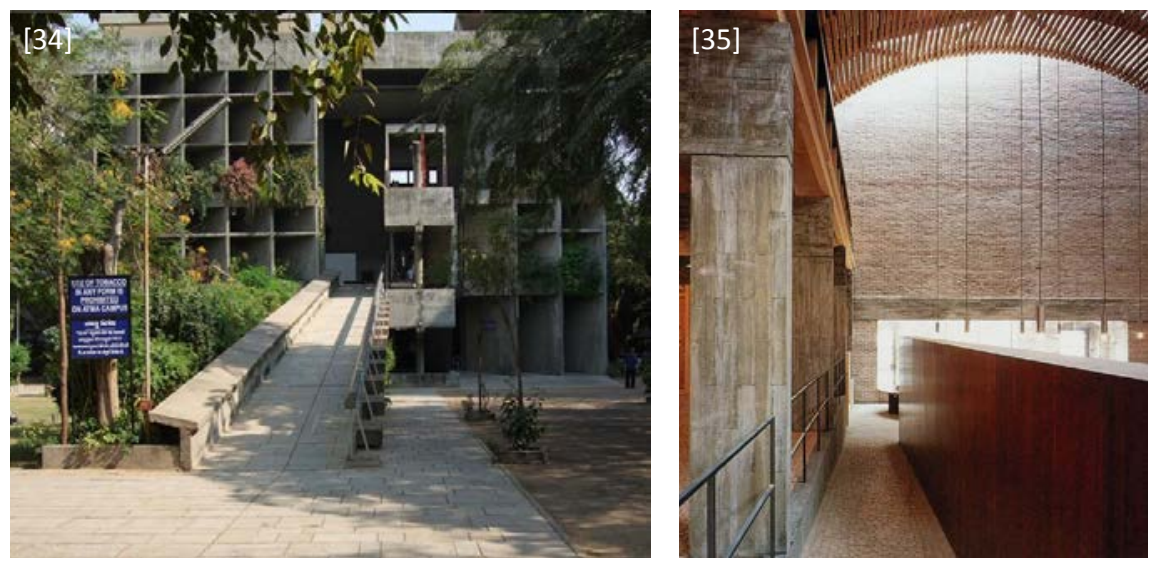

52 LINAZASORO, J.I.: "Alcune riflessioni". En: PRESI, S. (dir): Op. Cit., 2012, p.20

53 LAROQUE, D.: "Conversazione con J.I. Linazasoro". En: PRESI, S. (dir): Op. Cit., 2012, p.14

54 CORNOLDI, A.: "La Armoniosa Relación de lo Nuevo y de lo Antiguo". En: PRESI, S.: Op. Cit., 2007, pp. 239-243

55 PRESI, S.: Op. Cit., 2007, pp. 189199

[34] Vista de la rampa de acceso en el Palacio de los Hilanderos, Ahmedabad, 1951. (Fondation Le Corbusier: <www.fondationlecorbusier. $\mathrm{fr}>$ )

[35] Vista interior de la rampa de acceso en el Centro Cultural Escuelas Pías, 1996-2004. (LINAZASORO:2004, p. 58 ) 
56 GARCÍA GRINDA, E.; LINAZASORO, J.I.: "Conversaciones" (1996-1997). En: LINAZASORO, J.I.: Op. Cit., 2003, p. 101

57 LINAZASORO, J.I.: “EI Tiempo y la Arquitectura" (Diciembre de 1999, Julio de 2000, Junio de 2001). En: LINAZASORO, J.I.: Op. Cit., 2003, pp. 80-88

58 LINAZASORO, J.I.: "Los Túmulos de Uppsala" (Junio de 1998). En: LINAZASORO, J.I.: Op. Cit., 2003, p. 66

59 LAROQUE, D.: “Conversazione con J.I. Linazasoro". En: PRESI, S. (dir): J.I. Linazasoro. Ed. Casa dell'Architettura, 2012, p.16

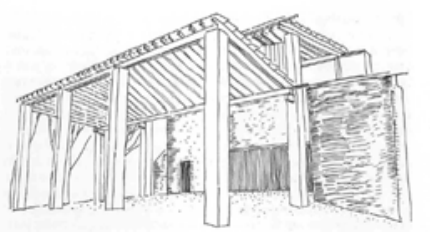

[36]

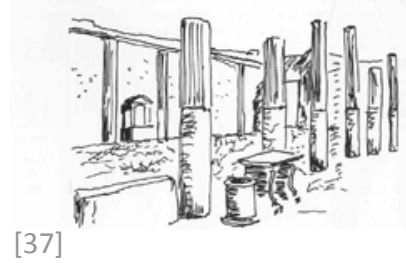

[36 y 37] Obra de Lewerentz en relación con las ruinas de un templo griego. (LINAZASORO: 2007, p. 225)

[38] Vista de los muros de hormigón en el Convento de la Tourette, 1953. (Fondation Le Corbusier: $<$ www.fondationlecorbusier.fr $>$ )

[39] Espacio en penumbra. Iglesia de San Pedro, Klippan. S. Lewerentz, 1962-1966. (Imagen de F. Galli. En: DYMLING, C.: 1997, p. 164)
Estos fragmentos responden a diversos mecanismos conceptuales que se repiten en distintas partes del edificio para facilitar, durante el recorrido, establecer nexos de relación entre los elementos.

Desde ese punto de vista, Linazasoro enfoca sus reflexiones hacia conceptos como el de la promenade architectural de Le Corbusier, o los recorridos presentes en Asplund, Lewerentz o Aalto, que hacen de ese paseo arquitectónico un proceso de integración de fragmentos, como alternativa a la jerarquía propia del orden antiguo, de suma de partes que constituyen un todo.

\section{La evocación de referencias a una totalidad}

Otra manera de relación es mediante el empleo de referencias que evocan la totalidad. En este sentido, a Linazasoro le interesa la arquitectura entendida como "virtualidad de la construcción", presente por ejemplo en la capacidad que tiene la ruina de evocar el espacio cubierto desaparecido; 56 de tal manera que el orden incompleto de los fragmentos que constituyen la obra se completa mentalmente mediante la referencia a un modelo.

Linazasoro aprecia este interés por la evocación de las ruinas en arquitecturas como las iglesias de S. Lewerentz, la casa en Muraatsalo de Alvar Aalto, los muros desnudos de hormigón en obras como La Tourette o Chandigard de Le Corbusier, o la obra de Khan inspirada en las ruinas de Villa Adriana. ${ }^{57}$ Así, en la iglesia de San Pedro en Klippan, Sigurd Lewerentz introduce espacios en penumbra envueltos por muros de carácter rústico, y cubiertas esencializadas e independientes, que sugieren la protección provisional de unas ruinas eternas. ${ }^{58}$

$\mathrm{Y}$, de la misma manera que los arquitectos modernos evocan la ruina en sus obras, Linazasoro la evoca en sus propios proyectos a través de referencias a estos arquitectos. Conformando con ello relatos a base de elementos, que va acumulando a lo largo del tiempo, y que retoma y reelabora para alcanzar una unidad..$^{59}$
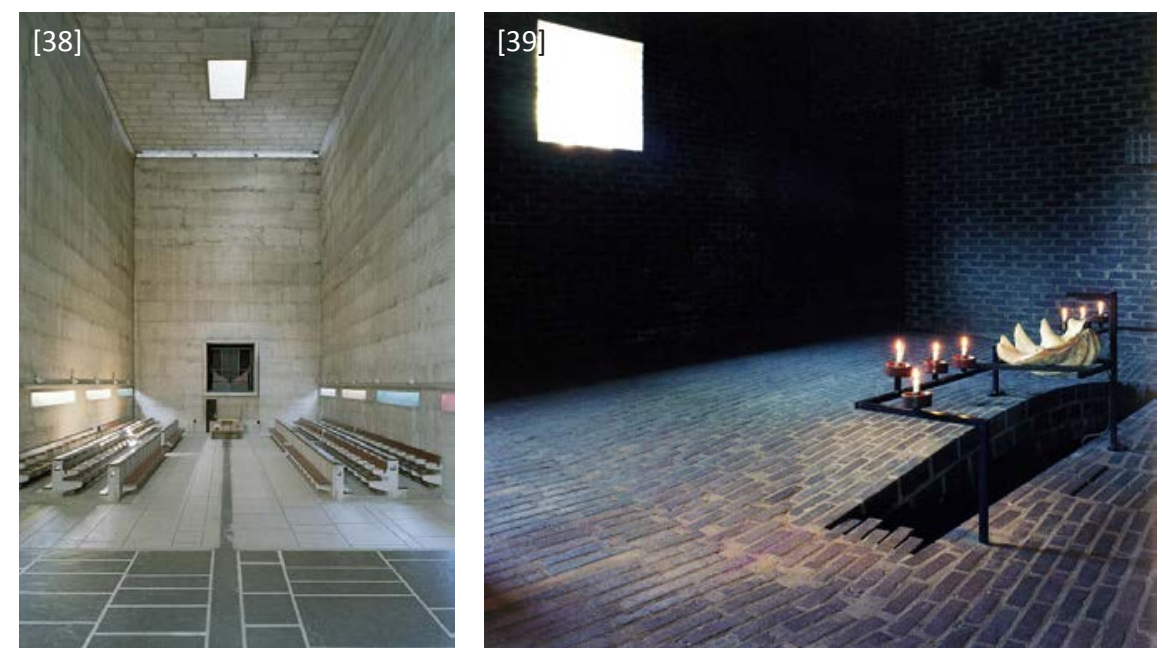

Iglesia de las Escuelas Pías del Colegio de San Fernando.1996-2004 


\section{La relación material}

Para Linazasoro la reflexión sobre los materiales y las técnicas con los que se han construido las preexistencias, es uno de los caminos para lograr una respuesta positiva a la "tensión entre la nostalgia al pasado y la necesidad de ruptura con el mismo". 60

En este sentido, Linazasoro entiende que el paso del tiempo marcado en las superficies de los monumentos, mediante pátinas y fracturas, debería conservarse, ya que estos "defectos" hacen más amable la imagen de los edificios. Pero Linazasoro advierte que la pátina es difícil de aceptar en la cultura occidental, y cita a Junichiro Tanizaki, quien en su libro El Elogio de la Sombra comenta que los occidentales rechazamos la pátina y preferimos los brillos, como si fuéramos incapaces de aceptar las condiciones que se producen en la vida por el paso del tiempo. ${ }^{61}$

Así, por ejemplo, Sigurd Lewerentz en la iglesia de Klippan emplea el ladrillo desnudo, carente de todo elemento decorativo, para dar unidad a un programa fuertemente fragmentado, un orden planteado como si se tratase de unas ruinas habitadas, cargadas de un sentimiento trágico por la nostalgia de una totalidad imposible. ${ }^{62}$

\section{La manipulación de la preexistencia y de su pasado}

En la intervención sobre las preexistencias, Linazasoro no busca reproducir la arquitectura original, ya que entiende que sería "anacrónico", pero tampoco busca contraponer los restos a una arquitectura "abiertamente moderna", porque resultaría banal. Por lo que opta por dirigir las nuevas intervenciones a transformar el edificio original, para adaptarlo a las nuevas necesidades funcionales y a las nuevas exigencias de relación con el lugar. Éste es el caso de proyectos como el Ayuntamiento de Segura (1985) o la restauración del Hospital del Rey (1996), donde trata de subvertir la organización del edificio primitivo, transformando un espacio secundario en el espacio fundamental, manipulando el carácter de los edificios. ${ }^{63}$

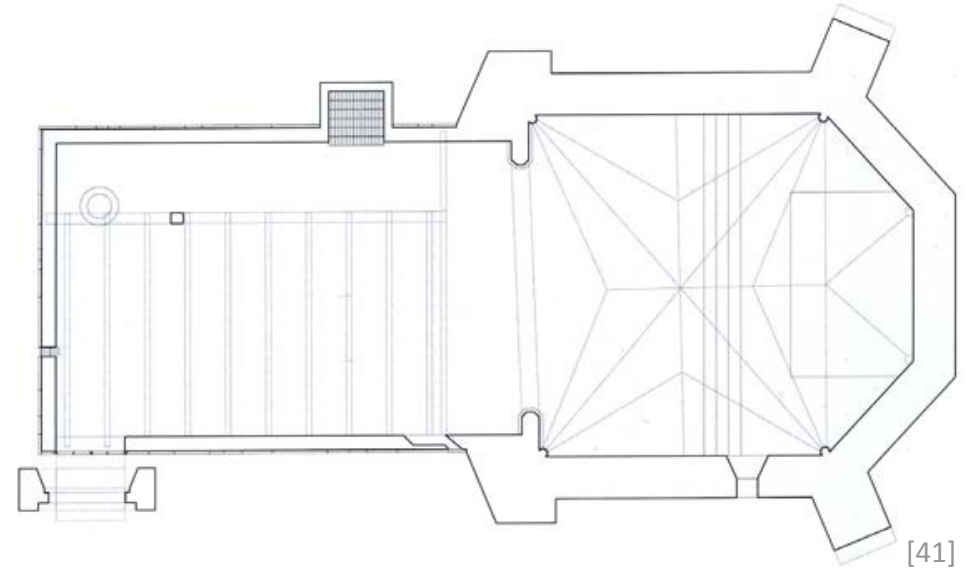

60 GARCÍA GRINDA, E.; LINAZASORO, J.I.: "Conversaciones" (1996-1997). En: LINAZASORO, J.I.: Op. Cit., 2003, p. 100

61 UGOLINI, A.; MESSINA, B.; FIDONE, E.; LINAZASORO, J.I.: "Progetto, Storia, Restauro. Riflessioni in forma di conversazione. Intervista a José Ignacio Linazasoro, Emanuele Fidone e Bruno Mesina". En: UGOLINI, A. (dir): Op. Cit., 2010, p. 55

62 LAROQUE, D.: "Conversazione con J.I. Linazasoro". En: PRESI, S. (dir): Op. Cit., 2012, p.16

63 GARCÍA GRINDA, E.; LINAZASORO, J.I.: "Conversaciones" (1996-1997). En: LINAZASORO, J.I.: Op. Cit., 2003. P. 98

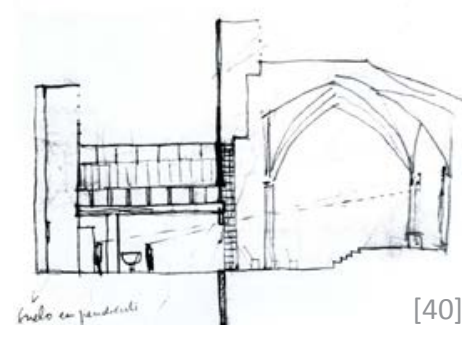

[40] Croquis del estudio de la sección. Iglesia de San Lorenzo de Valdemaqueda. J. I. Linazasoro, 19972001. (PRESI: 2012, p. 51)

[41] Planta de la Iglesia de San Lorenzo de Valdemaqueda tras la intervención. Nueva situación del acceso principal. (PRESI: 2012, p. 46) 
64 LINAZASORO, J.I.: "Hablan las Piedras. Entorno a Dimitris Pikionis". En: LINAZASORO, J.I.: Otras Vías: Pikionis, Lewerentz, Van der Laan. Buenos Aires, Ed. NobuKo, 2010, pp. 10-13

65 MACHADO, A.: Juan de Mairena. Buenos Aires, Losada, 1957, pp. 127128

66 GARCÍA GRINDA, E.; LINAZASORO, J.I.: "Conversaciones" (1996-1997). En: LINAZASORO, J.I.: Op. Cit., 2003, p. 98

67 Linazasoro hace referencia a las correspondance, soneto escrito por Charles Baudelair, en el que emplea el concepto de las sinestesias o asociación de sensaciones para comparar la naturaleza con un templo. BAUDELAIR, Ch.: Les Fleurs du mal. 1857

68 Entrevista realizada a José Ignacio Linazasoro, en Madrid, en diciembre de 2012, pregunta 9 (ver anexo)
[42] Imagen de la cisterna mirabilis de campi flegrei de Nápoles. (Fotografía de Grimaldo Ganzerli. En: Flickriver: <www.flickr.com>)

[43] Imagen de la cripta del aparcamiento. Plaza de Agustín Lara. J. I. Linazasoro, 1996-2001. (LINAZASORO: 2004, p. 23)
Un concepto presente en la arquitectura de Dimitris Pikionis, quien mediante el ensamblaje de fragmentos reutilizados configura un collage de objetos preexistentes que se reordenan para cumplir una nueva función. ${ }^{64}$

En esta línea de manipulación de la preexistencia surge también la idea de imaginar un pasado ficticio del lugar, y sobre esa ficción construir los edificios. Por tanto, el pasado se entiende como el recuerdo incorporado a un presente y proyectado hacia el futuro, un pasado moldeable sobre el que poder actuar, lo que Antonio Machado llama "pasado apócrifo". ${ }^{65}$ De tal manera que al intervenir sobre un edificio, Linazasoro busca apropiarse de él y de su pasado, y reescribirlo. El pasado es "ficticio" en cuanto que es una reinterpretación, una reelaboración de la realidad por parte del sujeto, que se nutre a su vez de otras realidades.

Para Linazasoro, el interés de esta manera de intervenir sobre las preexistencias reside precisamente en entender que el tiempo se ha detenido y que la arquitectura se ha de medir por sí misma. Frente a los valores estilísticos surgen los valores arquitectónicos de la permanencia, tales como el espacio, la luz y la materia. Y para ello se debe reflexionar "desde las cualidades materiales de los edificios y desde las sensaciones que ellos producen y no desde la oportunidad histórica". ${ }^{66}$

Así, por ejemplo, en las Escuelas Pías Linazasoro busca establecer "correspondencias" 67 con arquitecturas del pasado: la ruina del crucero la relaciona con la Minerva Medica y la cripta del aparcamiento le lleva a la cisterna mirabilis de campi flegrei de Nápoles. Cada uno de estos elementos adquiere una carga de intensidad en base a las referencias o vivencias personales, poniendo en relación unos fragmentos con otros a través de la memoria, y evitando en todo caso reconstruir una realidad que pudo haber existido en el pasado. ${ }^{68}$
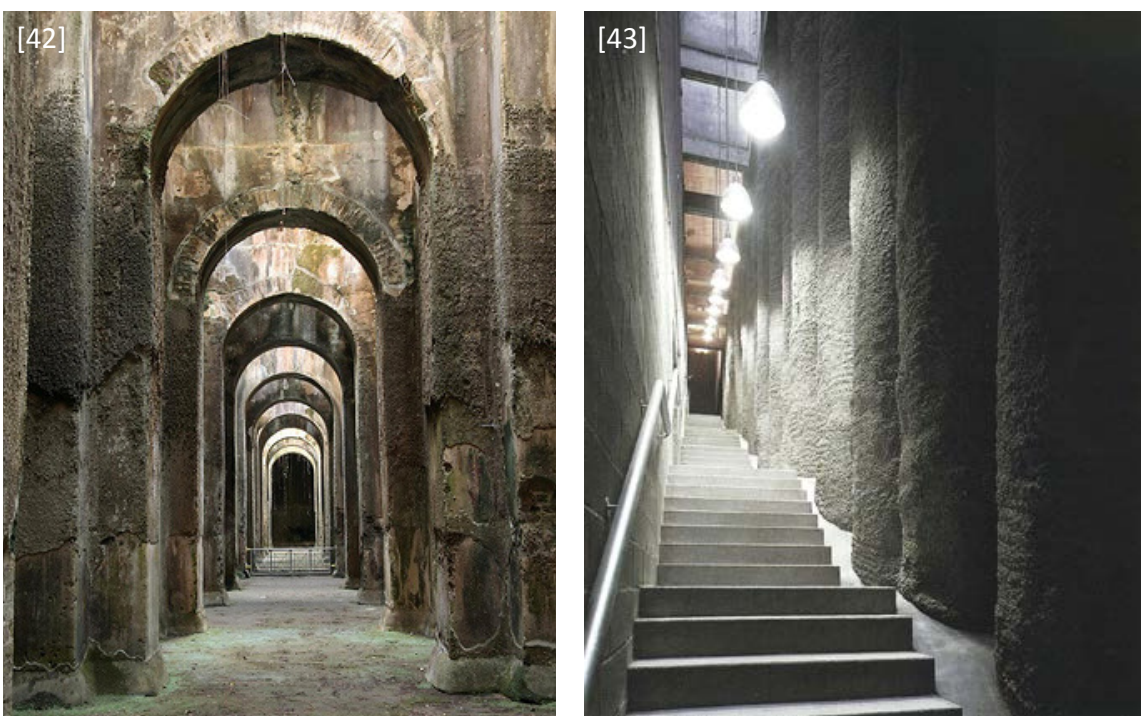

Iglesia de Ias Escuelas Pías del Colegio de San Fernando.1996-2004 
Otra estrategia que emplea Linazasoro en sus proyectos es la de la composición a partir de la relación entre conceptos opuestos.

Así, en la Biblioteca de la UNED en Madrid (1994), Linazasoro experimenta con la dialéctica entre el círculo y el cuadrado, lo central y lo lateral, lo transparente y lo opaco, y lo horizontal y lo vertical. Para Ignasi de SoláMorales, Linazasoro encuentra en estos conflictos el motor del proyecto, algo que, lejos de ser negativo, le permite "reflexionar sobre lo múltiple" en arquitectura. ${ }^{69}$

En este mismo sentido, Adriano Cornoldi comenta el equilibrio que alcanza Linazasoro en su obra a través de la dialéctica entre la retícula y el arco: la primera da orden, la segunda identidad. "La retícula destensa, el arco polariza: en conjunto sintetizan la arquitectura."70 Éste es el caso de la iglesia de San Lorenzo Mártir en Valdemaqueda (2001), de la que Francesco Venezia destaca que se consigue una gran obra de arquitectura mediante el enfrentamiento entre "dos geometrías, dos órdenes estructurales y dos sistemas constructivos diversos". ${ }^{71}$
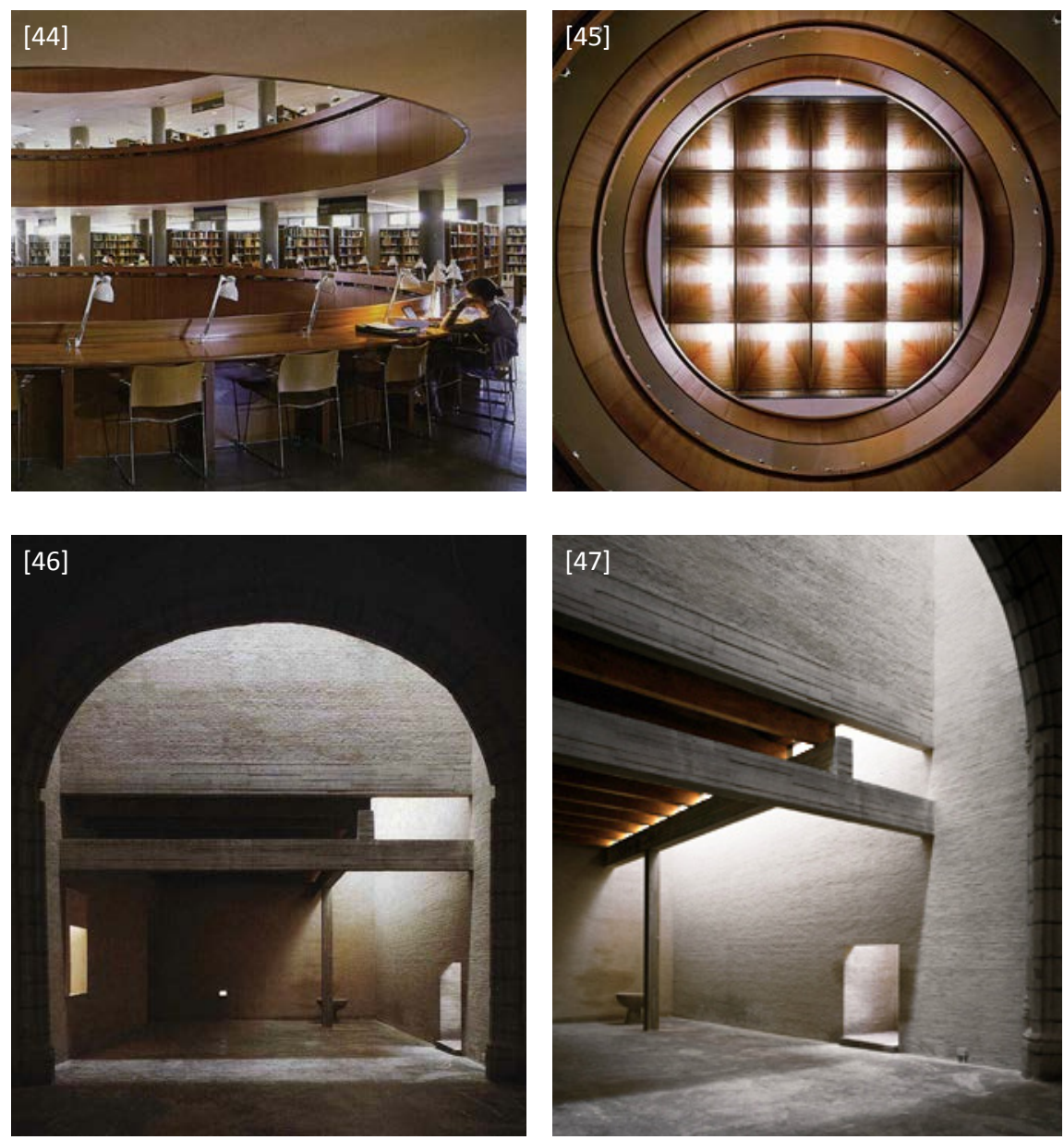

69 de SOLÁ-MORALES, I.: “Imitación Esencial. La Arquitectura de José Ignacio Linazasoro" (1998). En: LINAZASORO, J.I.: Op. Cit., 2005, pp. 8-13

70 CORNOLDI, A.: "La Armoniosa Relación de lo Nuevo y de lo Antiguo". En: PRESI, S.: Op. Cit., 2007, pp. 239-243

71 VenezIA, F.: "Una Composición Binaria". En: PRESI, S.: Op. Cit., 2007, p. 257

[44 y 45] Mesa de lectura y vista de los lucernarios de la Biblioteca de la UNED, 1989-1994. (PRESI: 2012, pp. 39 y 43 )

[46 y 47] Iglesia de San Lorenzo de Valdemaqueda, 1997-2001. (PRESI: 2012, p. 53) 
72 LINAZASORO, J.I.: “La Renovación Proyectual en el Bajo Imperio y la Crisis del Clasicismo Grecorromano" (diciembre-enero 1986-87). En: LINAZASORO, J.I.: Op. Cit., 2003, p. 31

73 Entrevista realizada a José Ignacio Linazasoro, en Madrid, en diciembre de 2012, pregunta 10 (ver anexo)
[48] Sección del Panteón. (CHING: 1995, p. 77)

\section{[49] Sección de Santa Sofía.}

[50] Iglesia en Río Seco (Arquitectura, no 273,1988, p.69)

[51] Iglesia de San Lorenzo en Valdemaqueda, 1997-2001. (LINAZASORO: <www.linazasoro-arquitecto.com>)
Algo que en cierta manera ya estaba presente en sus reflexiones sobre "Ia renovación proyectual en el bajo imperio y la crisis del clasicismo grecorromano" (1986-87). En este artículo Linazasoro analiza las claves que permiten hacer evolucionar la forma y el espacio, desde una posturas más estáticas y monolíticas hacia otras más ligeras, fragmentadas y complejas; desde el muro, la pilastra y el arquitrabe hacia la columna y el arco; desde el Panteón, en el que la cúpula descansaba, tanto desde el punto de vista constructivo como compositivo, sobre un muro continuo, hasta Santa Sofía, donde se alza por primera una cúpula "en el aire" sobre cuatro grandes arcos, lo que supone un gran alarde tecnológico. ${ }^{72}$
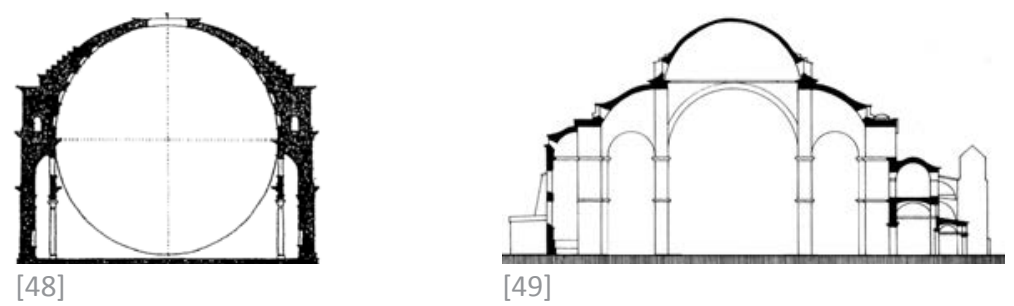

En esta línea Linazasoro entiende que en su obra se produce una reflexión continua sobre la superposición de estratos, de tal manera que se producen dos opciones: por un lado una relación tectónica, de un elemento apoyado, como en una estructura lineal clásica; y por otro lado una relación ilusionista de suspensión de un elemento en el aire, como un velarium o una bóveda bizantina. De tal modo que intenta compatibilizar los dos sistemas en sus proyectos en función de la necesidad. ${ }^{73}$

Este concepto se observa con gran claridad en obras como Medina de Rioseco, Valdemaqueda, Escuelas Pías, e incluso en Troyes. Actuaciones en las que estos estratos se interpretan como elementos de una acumulación temporal, donde las capas superiores son más ligeras y las capas inferiores se muestran más pesadas. De manera que unas se entienden como solidificación de las otras, tal y como ocurre en el proceso de petrificación de los órdenes de madera de los templos griegos.
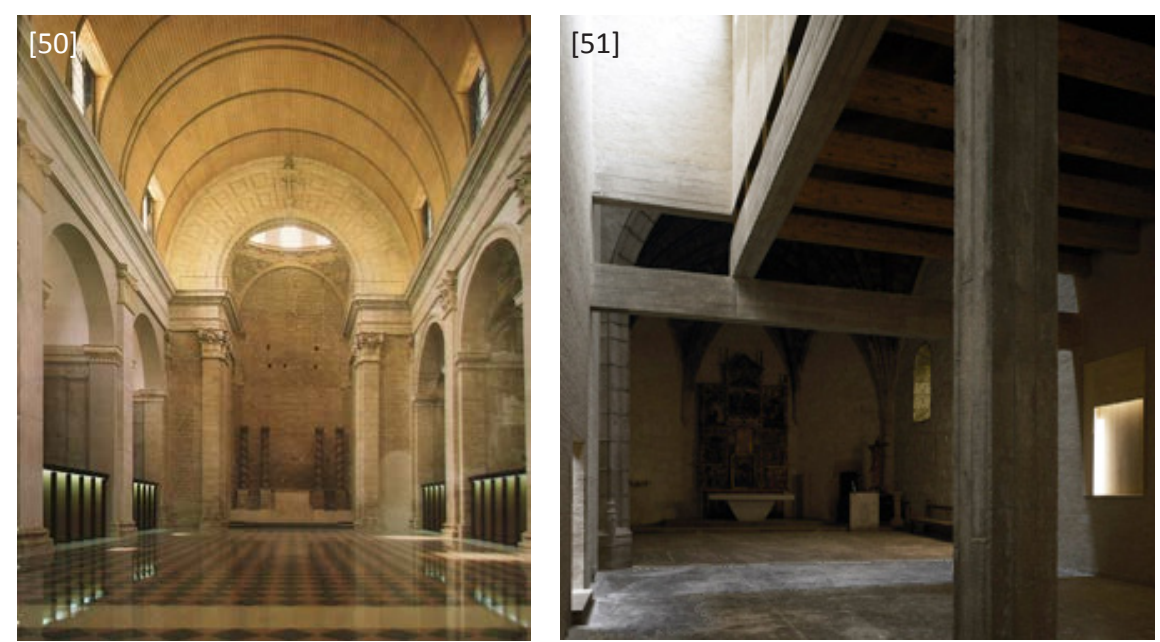

Iglesia de las Escuelas Pías del Colegio de San Fernando.1996-2004 


\section{DESCRIPCIÓN DE LA INTERVENCIÓN}

\subsection{Objetivos de la intervención}

El proyecto busca responder adecuadamente al carácter del lugar en el que se encuentra, un barrio en el que se produce una mezcla de estratos sociales y etnias diversas, y donde se vive el espacio público de la ciudad con gran intensidad. Un lugar en el que la gran solidez y desnudez de las ruinas de la antigua iglesia del Colegio de las Escuelas Pías surge con cierta armonía y naturalidad.

Es, por tanto, el aprendizaje de estas ruinas lo que se busca trasladar al proyecto para mantener esa adecuación al lugar. Un aprendizaje que se traduce en el empleo de "valores primarios, intemporales e indiscutibles, como el material, la construcción y la luz". ${ }^{74}$

En lugar de optar por una actitud artificiosa de contraposición estilística con la arquitectura preexistente, o por la recuperación del interesante edificio original barroco, se propone apropiarse del valor constructivo y material de la ruina, algo que para Linazasoro contiene una condición muy contemporánea. ${ }^{75} \mathrm{Y}$ con este respeto a la ruina, se busca también respetar la historia del monumento, que a lo largo del tiempo ha marcado con violencia a su arquitectura. ${ }^{76}$

Este respeto por la historia también se traduce en un respeto a la modernidad arquitectónica, entendida como base conceptual del lenguaje arquitectónico contemporáneo. Para ello, el proyecto busca establecer un diálogo entre la arquitectura moderna y la arquitectura del pasado, a través de la conformación de citas y alusiones a determinados edificios de la historia.

La intervención abarca diversas escalas, desde el entorno urbano hasta el diseño del mobiliario, y diferentes tipos de relación con lo construido, desde la intervención en lo existente hasta la construcción de nueva planta. ${ }^{77}$

Así pues, además de la actuación en los restos de la iglesia, el proyecto incluye también la construcción de un nuevo aulario en el solar adyacente a las ruinas de la iglesia, y la reurbanización de la plaza sobre la que vierten. A pesar de esta gran diversidad de circunstancias, Linazasoro busca una cierta unidad de actuación entre las tres intervenciones, mediante el empleo de elementos comunes, tanto formales como materiales.

[52] Redibujo del Alzado a la C/ Mesón de Paredes y de la planta del conjunto a partir de los planos originales del proyecto.
74 LINAZASORO, J.I.: “Biblioteca y Aulario en las antiguas Escuelas Pias, Madrid". Conarquitectura, no 12, 2004, pp. 53-64

75 LINAZASORO, J.I.: Tres proyectos sobre las preexistencias. Conferencia impartida en el marco del Workshop Internacional Construcción de la Memoria, en la Escuela Técnica Superior de Arquitectura de la Universidad Politécnica de Valencia, 12 de mayo de 2011, inédito

76 LINAZASORO, J.I.: Op. Cit., 2004, pp. 53-64

77 LINAZASORO, J.I.: "Biblioteca y Aulario en las antiguas Escuelas Pías". Arquitectura, no 357, Madrid, Ed. COAM, 2009, pp. 8-11 

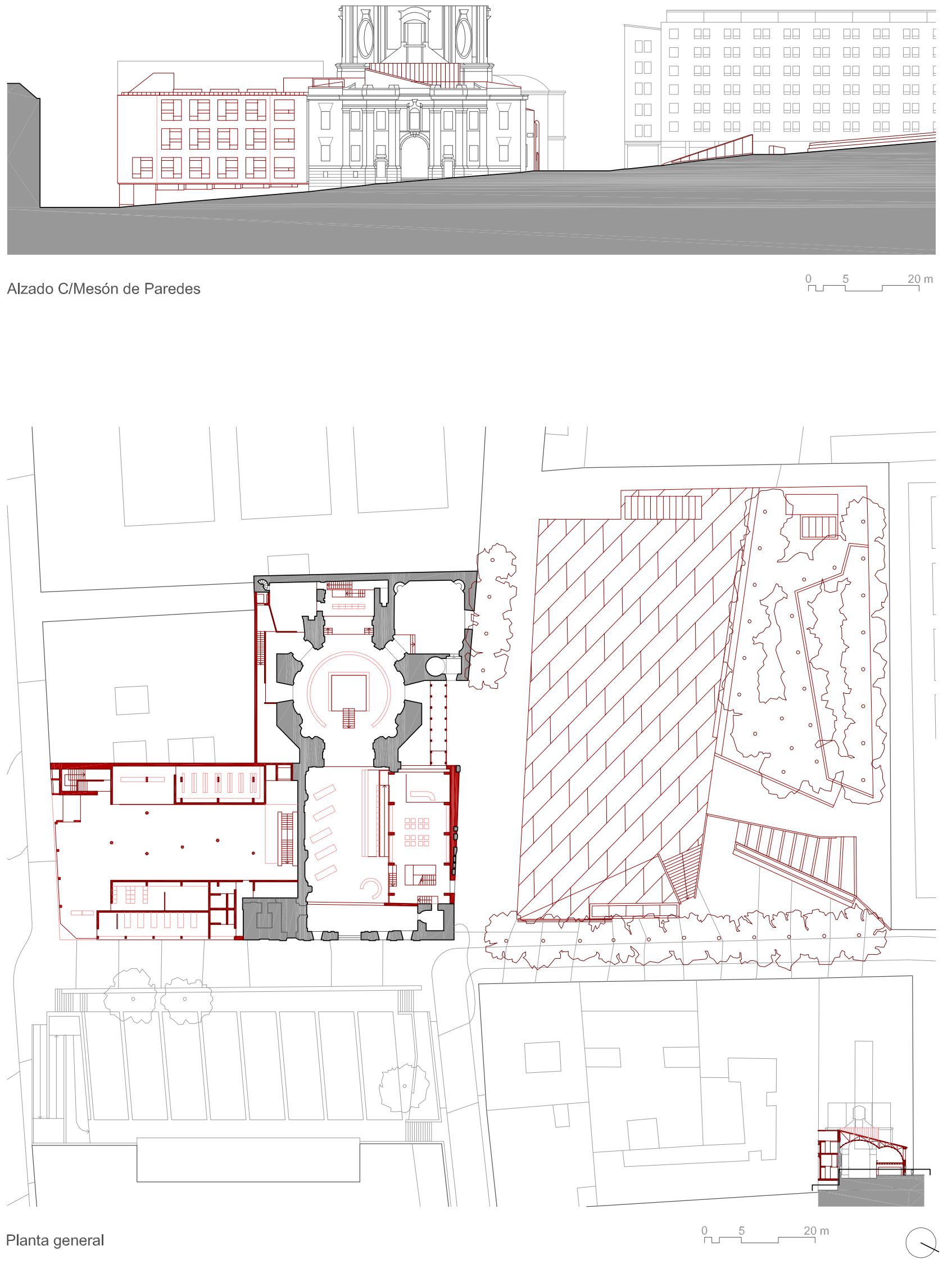


\subsection{Programa funcional}

El reto del proyecto de intervención en las Escuelas Pías está en incorporar el nuevo uso de biblioteca al antiguo edificio de la iglesia, pero sin buscar recuperar la arquitectura original, y a su vez sin perder el valor de la ruina. Para ello, Linazasoro estudia otros ejemplos de la historia, en los que se han aprovechado ruinas romanas para nuevos usos. Incluso el lema de su proyecto para el concurso de las Escuelas Pías es "Templo de Diana", nombre que remite a uno de estos ejemplos donde un templo romano es reutilizado como palacio renacentista, manteniendo las columnas del antiguo edificio. ${ }^{78}$

Al cambio de uso se suma la necesidad de un cambio de posición del acceso al edificio, sugerido por la modificación del entorno urbano a lo largo del tiempo. La apertura y reurbanización de una amplia plaza supone un nuevo centro de gravedad en la percepción del edificio, que sugiere que se acceda a la biblioteca desde este espacio urbano, sustituyendo al acceso original, situado en la fachada noreste, recayente a la calle de Mesón de Paredes.
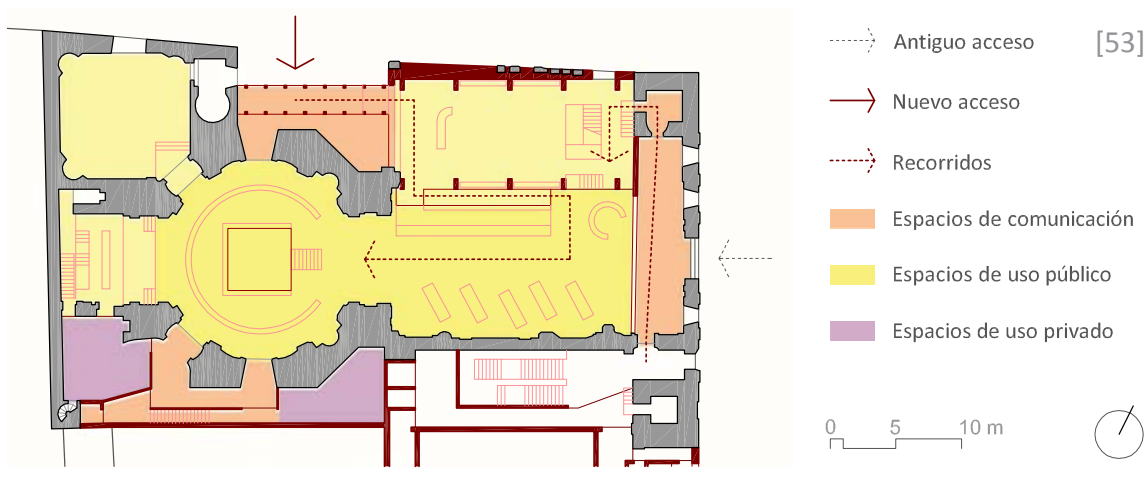

Estos cambios de uso y acceso suponen la configuración de un nuevo recorrido que modifica la secuencia original de percepción del espacio. Frente al recorrido axial a lo largo de la nave, el crucero, con su foco principal en el altar como punto de atención del culto religioso, se propone un recorrido que se inicia en una nueva "nave" lateral que alberga el control de acceso, préstamo y zona de consulta de libros, y desemboca en la nave, reconvertida en una gran sala de lectura.

Además, la nueva pieza adosada al lado noroeste del edificio permite recuperar el cierre de la nave-que había desaparecido-y con ello resolver la nueva fachada a la plaza, así como aumentar la superficie para puestos de lectura mediante la creación de un altillo.
78 LINAZASORO, J.I.: Tres proyectos sobre las preexistencias. Conferencia impartida en el marco del Workshop Internacional Construcción de la Memoria, en la Escuela Técnica Superior de Arquitectura de la Universidad Politécnica de Valencia, 12 de mayo de 2011

\section{[53] Esquema de usos.}

[54] Imagen del Templo de Diana. Este templo fue reutilizado como palacio renacentista, manteniendo las columnas del viejo edificio. (HERNÁNDEZ GIL: Revista de Arquitectura y Urbanisco del Colegio Oficial de Arquitecto de Extremadura, 2004)

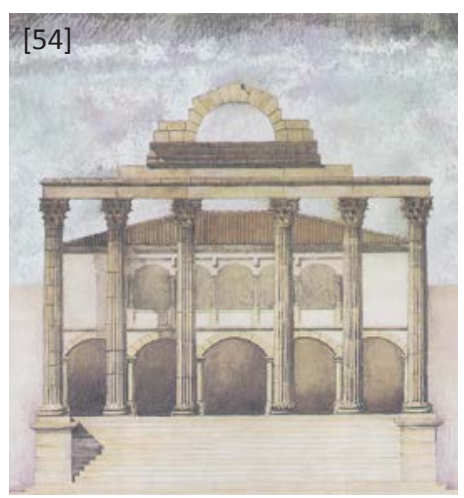


[55] Imagen de los puestos de trabajo. (LINAZASORO: 2004, p. 184)

[56] Vista desde el interior de la biblioteca hacia el nuevo muro. (Imagen del autor)

[57] Redibujo de la planta, el alzado hacia la plaza y las secciones longitudinales a partir de los planos del proyecto.

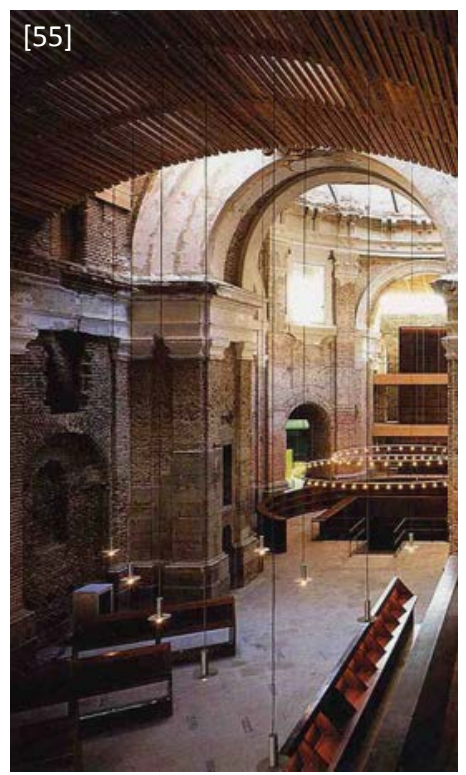

Un potente muro, paralelo a la fachada original, define un nuevo límite del espacio de la biblioteca, acotando una conexión entre ésta y el nuevo aulario. Un nuevo límite que impide el acceso pero no la relación visual, gracias a la creación de un gran hueco horizontal desde el que se puede recrear el eje compositivo original. Relación visual que se permite también en el muro de separación entre la nave y el edificio del aulario, gracias al acristalado de antiguos huecos. De esta manera, el vibrante ambiente de la biblioteca se vuelve un escenario atractivo para el observador de paso.

La jerarquía funcional de la iglesia se transforma en una yuxtaposición de usos, en los que el mobiliario logra conjugar la configuración formal de los espacios de origen sacro y su adaptación a las nuevas necesidades.

En la nave, las mesas con los puestos de lectura se ubican con una disposición que busca romper la axialidad original, mostrando independencia respecto al orden espacial. En el espacio de la rotonda, el mobiliario se dispone evocando la geometría circular de la arquitectura y la geometría cuadrada de una cripta, en un interesante juego de opuestos. Y en el espacio del altar, se albergan estanterías de libros a modo de retablo dedicado al conocimiento.

El elemento de acceso se plantea como parte del mobiliario urbano de la plaza, y hace la función de atrio de transición entre el gran espacio abierto de la plaza y el reducido ámbito en penumbra del vestíbulo, introduciendo al individuo de manera tangencial a la biblioteca.

El nuevo uso supone también un cambio de escala en el interior del espacio. La escala sacra del templo se transforma en una escala más humana donde se desarrolla la lectura, mediante la creación de un plano de luz artificial, ubicado a 2,30m de altura.

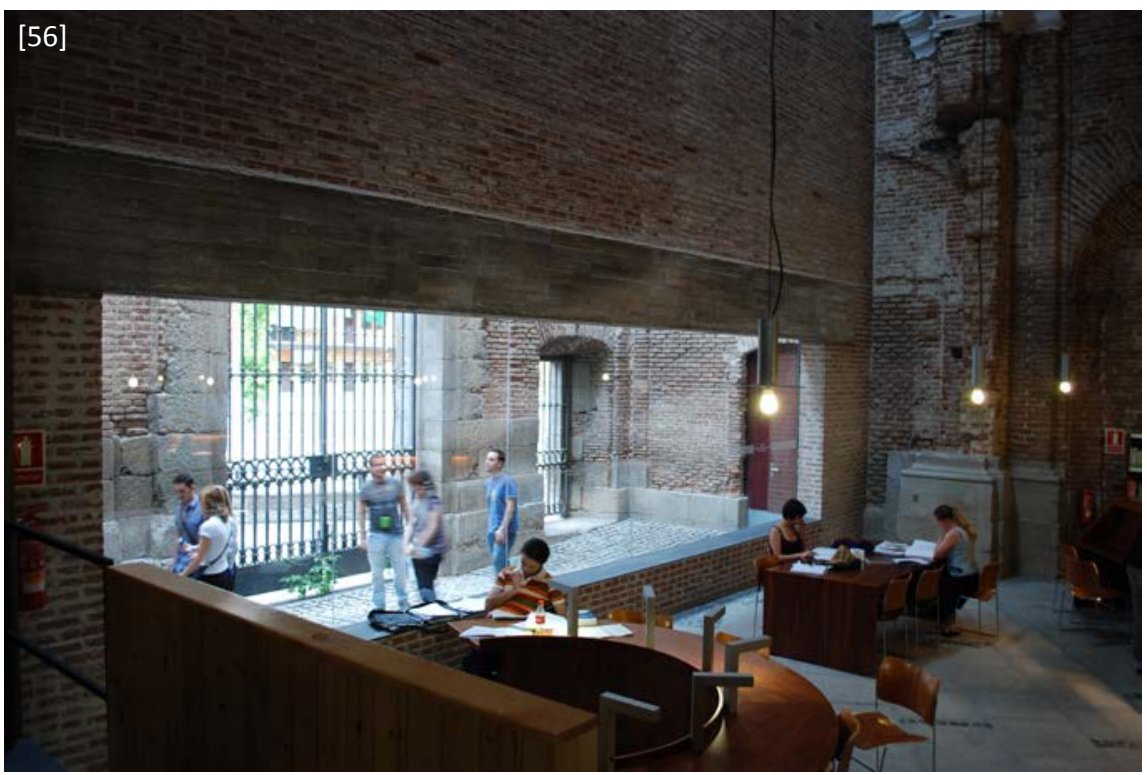

Iglesia de las Escuelas Pías del Colegio de San Fernando.1996-2004 


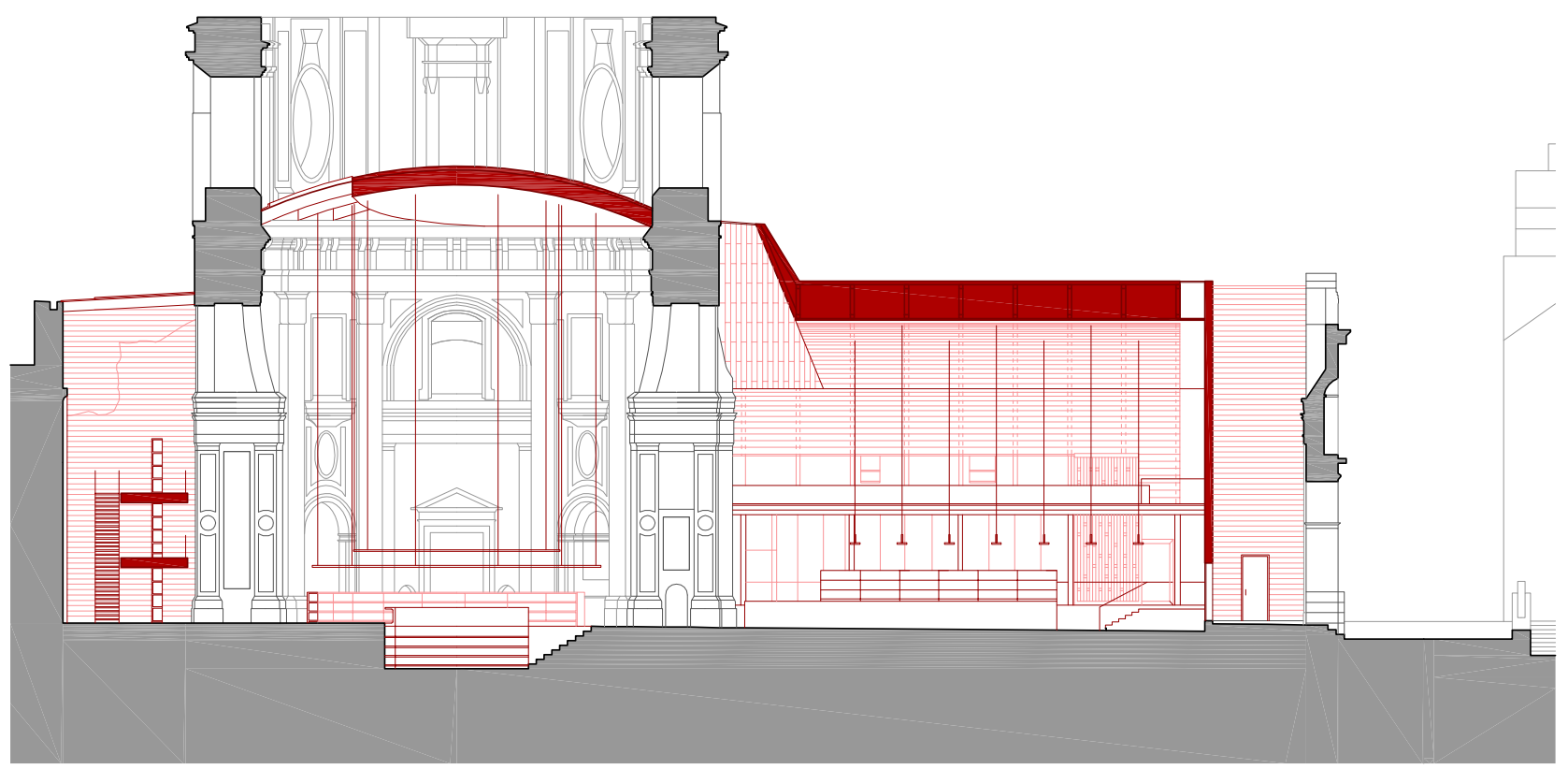

Sección Longitudinal

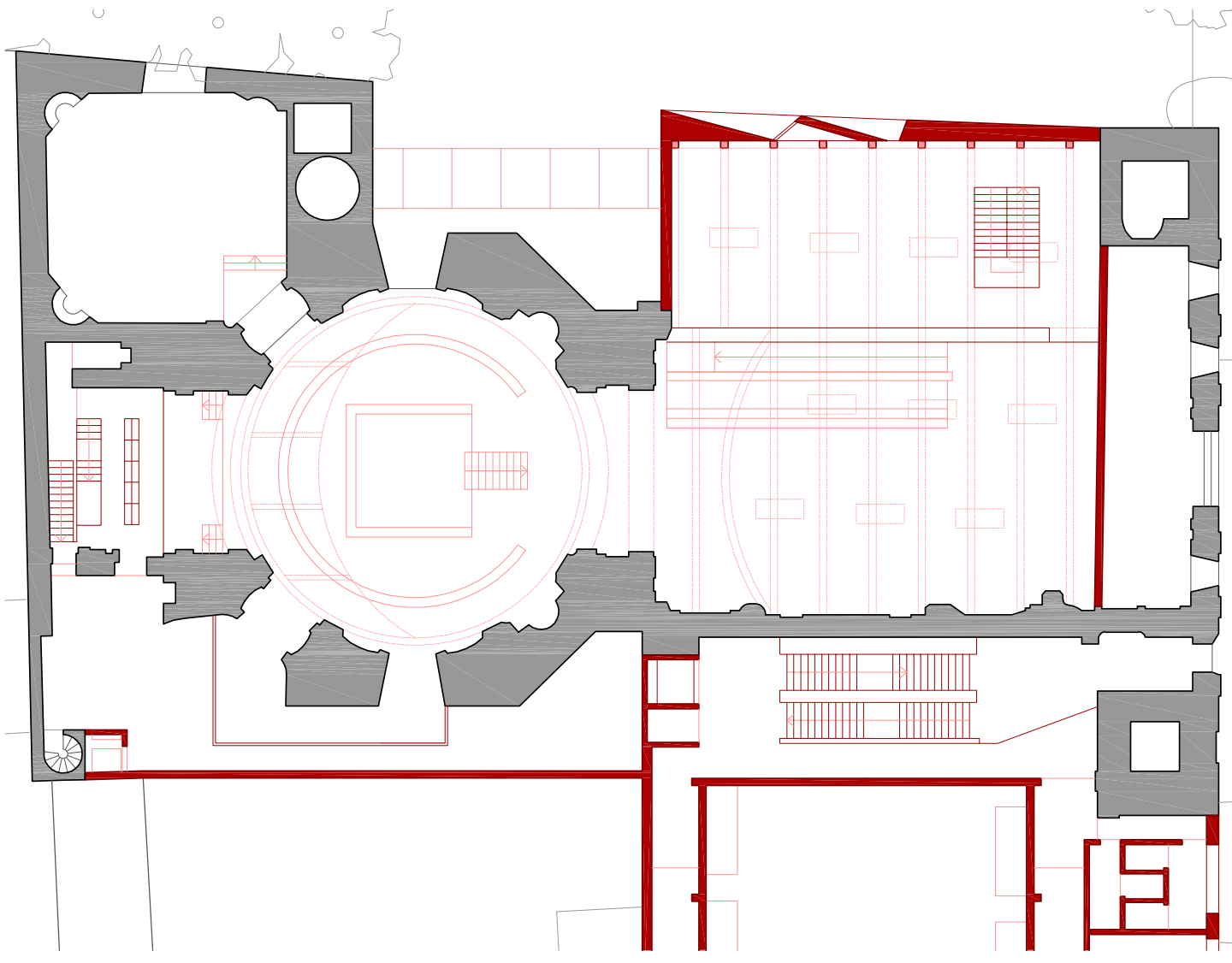

Sección Horizontal por la cota $+7,50$ (medida a partir de la calle Tribulete)

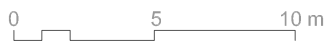




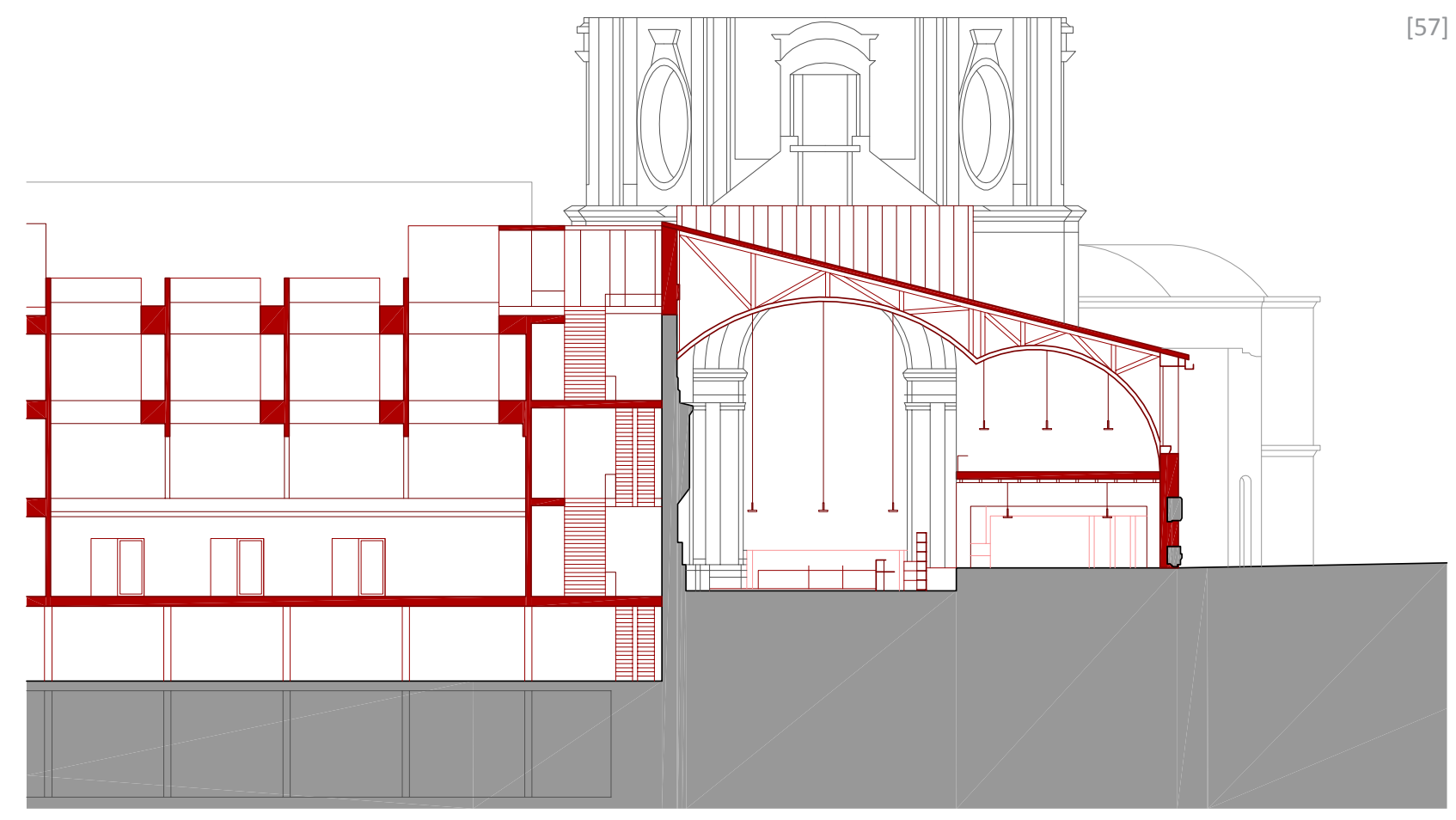

Sección Transversal
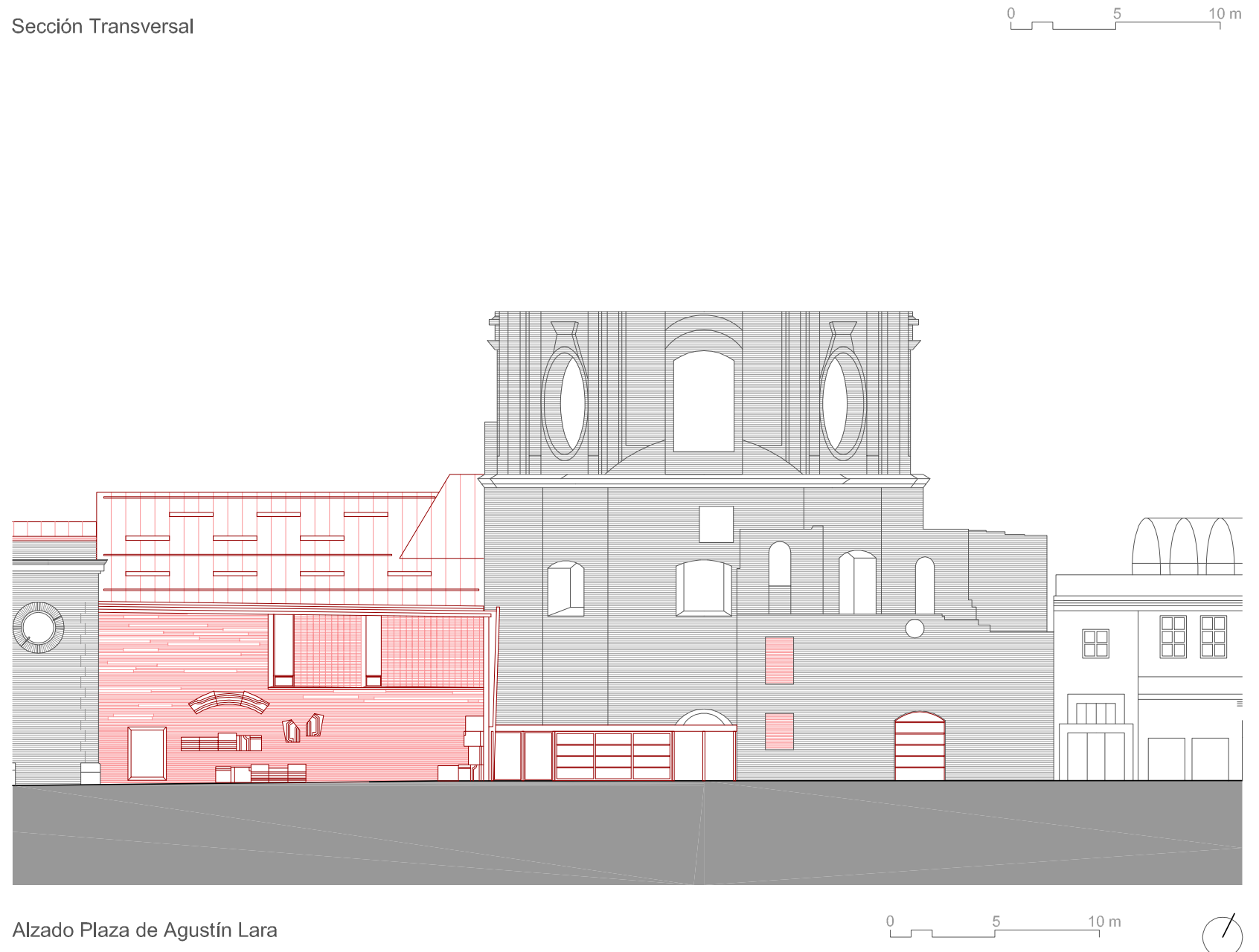


\subsection{Forma, espacio y luz}

Los nuevos elementos se insertan sobre los restos de la iglesia, como fragmentos que buscan poner en valor la ruina y configurar un nuevo espacio cargado de referencias a arquitecturas históricas.

La forma de los nuevos elementos se integra con los restos mediante la esencialidad geométrica, adoptando un carácter de provisionalidad o permanencia en función de su papel en la definición del espacio.

Así, por un lado, los nuevos límites verticales se materializan mediante muros másicos, con carácter permanente, que se integran con los muros preexistentes de manera natural. Y, por otro lado, los nuevos límites horizontales -tanto cubiertas como forjados-se plantean como elementos ligeros, de carácter más provisional.

En el interior, estos nuevos límites ligeros se insertan con sutileza entre los muros verticales, adquiriendo formas que remiten a arquitecturas del pasado y de la modernidad, en una equilibrada composición de fragmentos capaces de configurar un espacio armónico. En el exterior, el nuevo elemento de cubierta de las naves se resuelve como un plano inclinado, de aspecto industrial, que se superpone sobre los restos, a la manera de una cubierta provisional sobre unas ruinas.

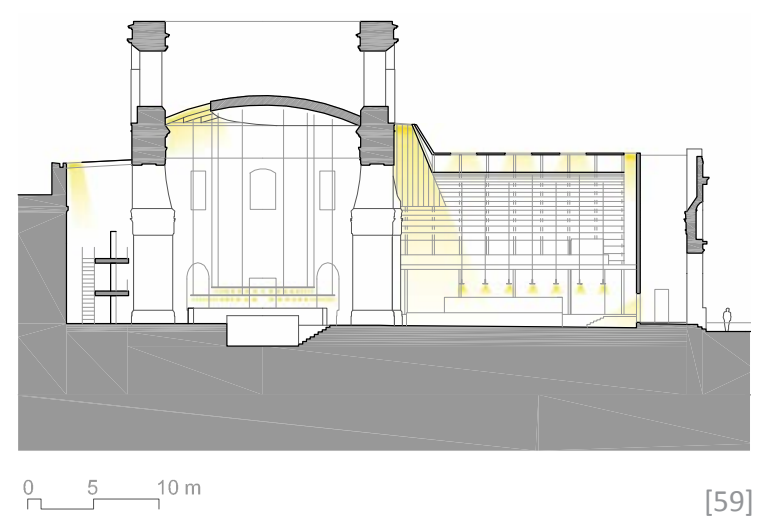

En la definición del espacio interior se busca crear un ambiente de proporciones más horizontales respecto al espacio original de la iglesia. Para ello, por un lado la nueva pieza de acceso se integra en el espacio de la iglesia como si de una nave lateral se tratara, y por otro lado, el gran espacio de la nave y este nuevo espacio lateral, se cubren con dos bóvedas rebajadas concatenadas, que ayudan a entender ambos espacios como una unidad. Esta tensión transversal se potencia mediante el escalonamiento que se produce entre el banco, la estantería y el altillo. Por otra parte, la nueva bóveda de la rotonda, ubicada en la zona inferior del cimborrio, también ayuda a atemperar la verticalidad original.

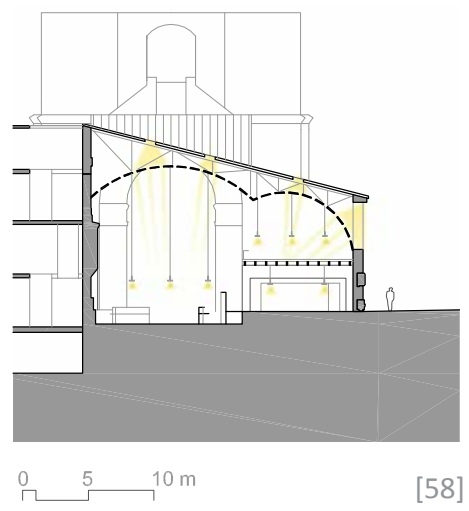

[58] Esquema que ilustra la entrada de luz natural, así como el plano de luz artificial que humaniza la escala. Sección transversal.

[59] Esquema que ilustra la entrada de luz natural, así como el plano de luz artificial que humaniza la escala. Sección longitudinal.

[60] Vista de la entrada de luz natural en el espacio de la rotonda y plano de luz artificial. (LINAZASORO: Conarquitectura, no 12, 2004, p. 58)

[61] Vista de la bóveda que cubre el altillo y la nave, y de la entrada de luz natural que baña el nuevo muro de ladrillo. (LINAZASORO: Conarquitectura, $\mathrm{n}-12,2004$, p. 59)

[62] Vista de la entrada de luz natural entre la nave y la rotonda. (LINAZASRORO: 2007, p. 181)

[63] Vista de la entrada de luz a través de la bóveda desde el altillo. (LINAZASORO: Conarquitectura, no 17,2006 , p. 51) 

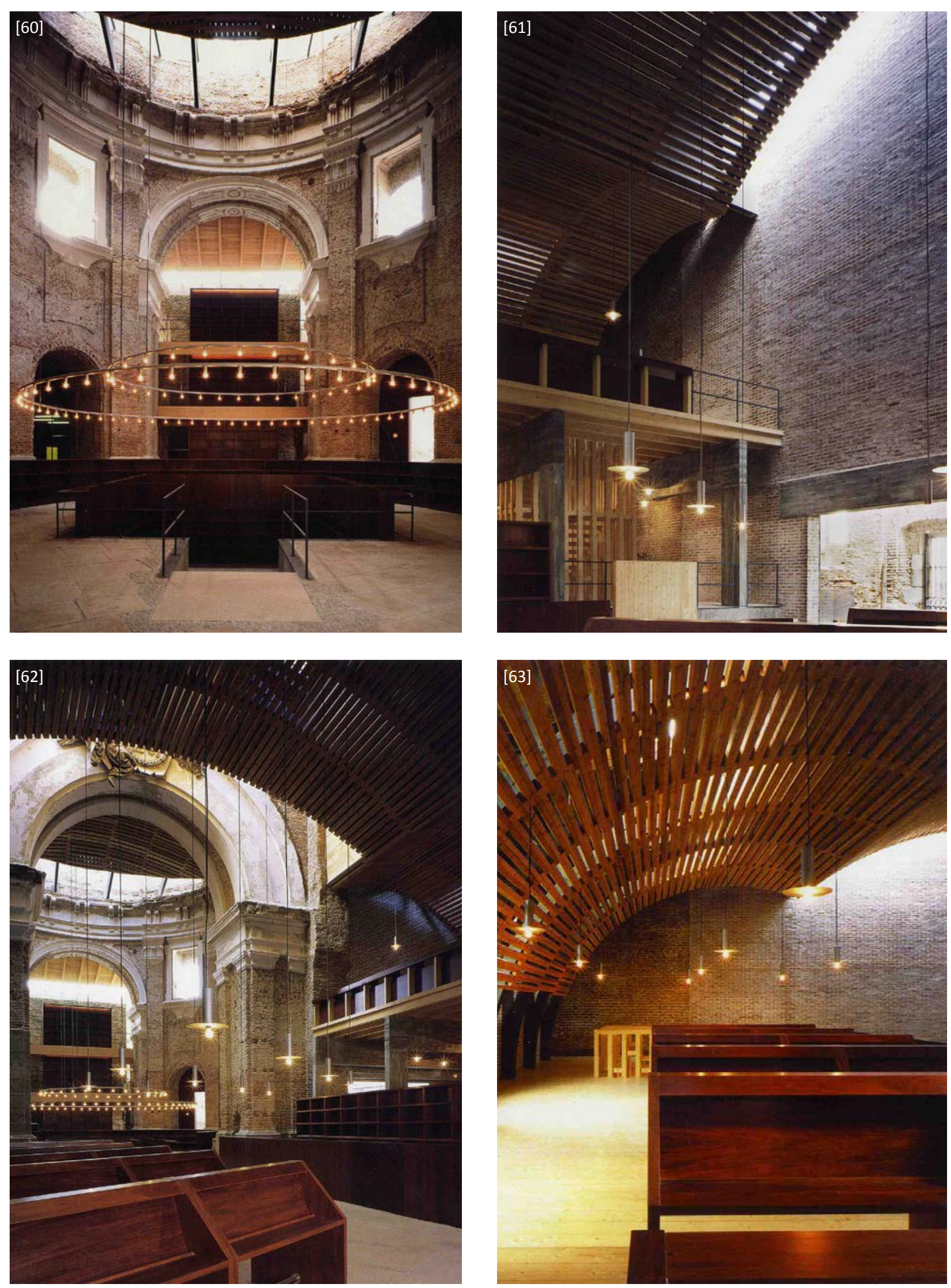
Además, Linazasoro busca rebajar la bóveda para evitar que se identifique con la reconstrucción de la antigua y para aportar tensión al recorrido, ocultando parcialmente el arco y el grupo escultórico del crucero y generando la necesidad de recorrer el espacio para descubrirlo. Linazasoro se llega a plantear la posibilidad de cerrar el espacio con una cubierta plana, pero finalmente se decide por un espacio abovedado por considerar "más atrevido jugar en este terreno de la ambigüedad", aunque pudiera ser acusado de historicista. ${ }^{79}$

La nueva iluminación del espacio busca modificar la luz original, para adaptarla a las nuevas necesidades, y al mismo tiempo mantener el ambiente heredado de su período como ruina. Así, unos pequeños y dispersos lucernarios practicados en la cubierta reemplazan la potente luz barroca por otra más atenuada que se filtra a través de las caladas bóvedas, reforzando el carácter de espacio descubierto e incompleto, propio de unas ruinas.

En algunos momentos las bóvedas se recortan para permitir un mayor paso de la luz, y así reforzar la lectura de los fragmentos murarios, ayudando a descomponer el espacio y aportar dramatismo al ambiente. Dramatismo que se enfatiza con la iluminación artificial, configurada a base de lámparas colgadas a una altura de $2,30 \mathrm{~m}$, constituyendo un techo virtual que reduce la dimensión del espacio al de la escala humana, y cuyos destellos producen unos contrastes que permiten potenciar un ambiente de penumbra.

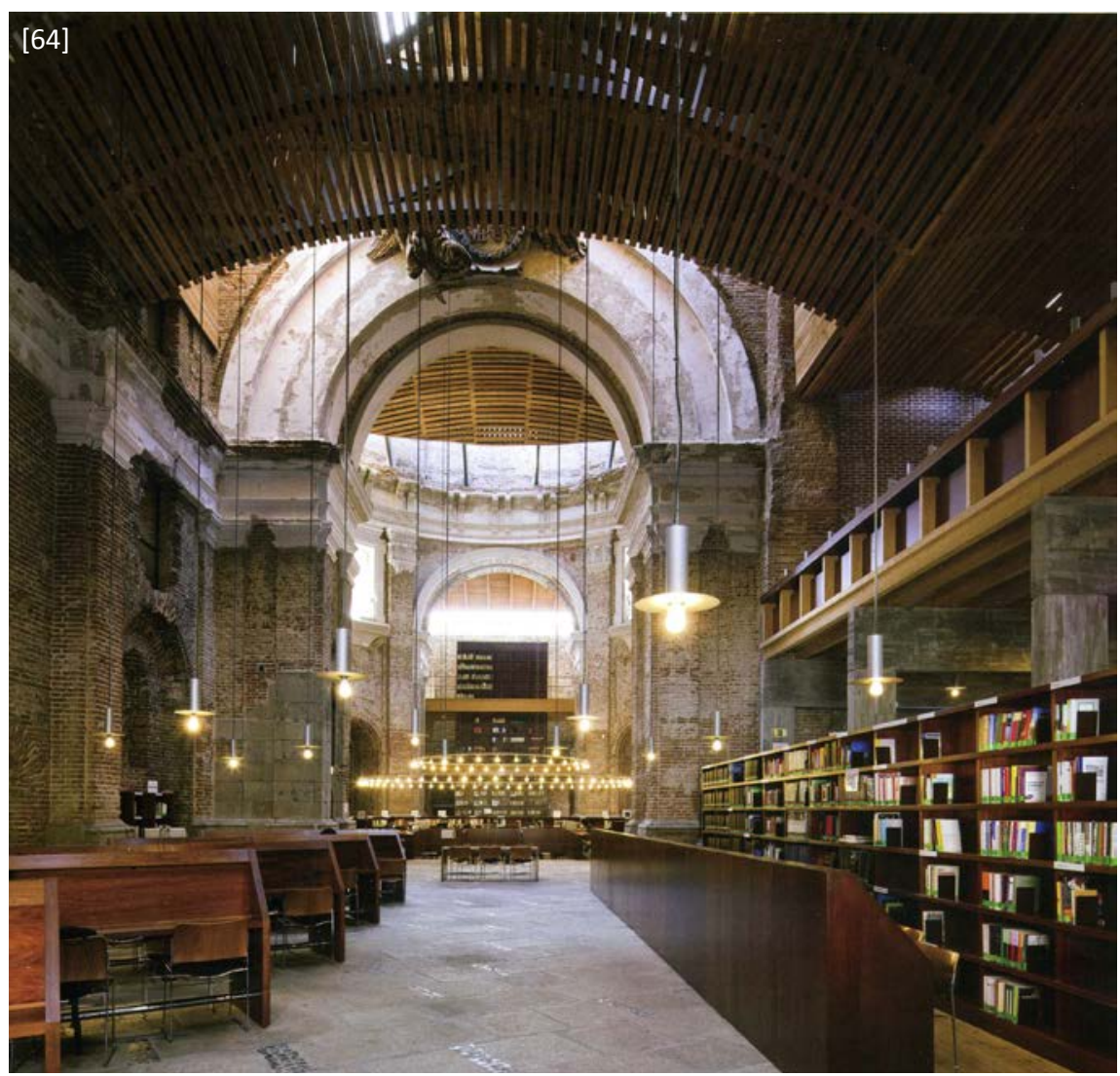

79 Entrevista realizada a José Ignacio Linazasoro, en Madrid, en diciembre de 2012, pregunta 15 (ver anexo)

[64] Vista desde la nave de la nueva iluminación del espacio. (PRESI: 2012, p. 71)

[65] Detalle del lucernario entre la rotonda y la nave. (PRESI: 2012, p. 72)

[66] Vista desde la nave hacia el altillo. (PRESI: 2012, p. 75)
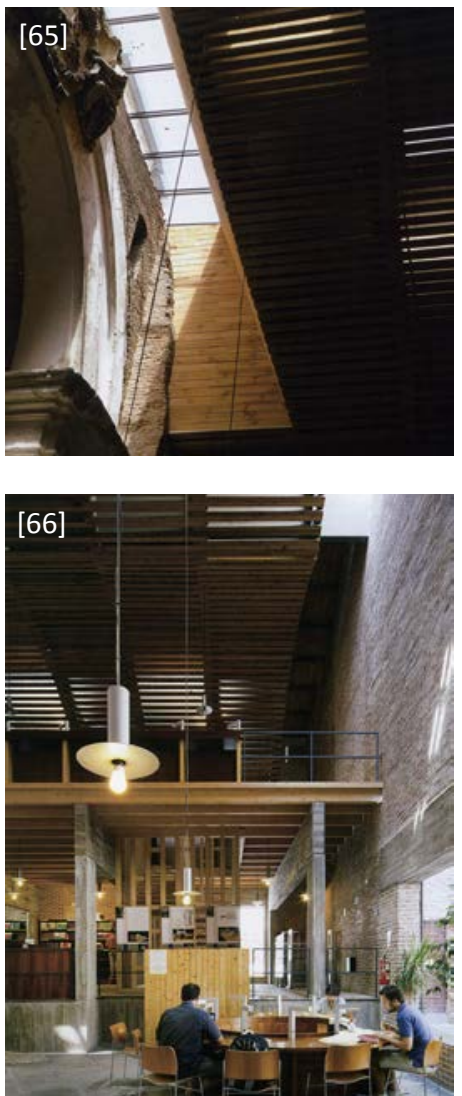
80 Entrevista realizada a José Ignacio Linazasoro, en Madrid, en diciembre de 2012, pregunta 14 (ver anexo)
La actuación sobre la materialidad de la ruina consiste exclusivamente en una limpieza general de los paramentos, y en la consolidación de los extremos superiores para una mejor conservación, sin pretender en ningún momento restituir faltantes de revestimientos o elementos decorativos. Solo se ha hecho alguna reposición puntual de ladrillo, pero no se modifican los huecos; cuando es necesario introducir puertas, por ejemplo, se dejan los huecos descarnados, y no se reconstruyen sus bordes. ${ }^{80}$

Con ello Linazasoro busca poner de manifiesto las sugerentes texturas y el carácter de non finito propio de las ruinas, pero a su vez se apropia de su materia y la incorpora al proyecto, utilizándola como base para la elaboración de una nueva arquitectura.

La materialidad de los nuevos elementos se plantea desde la esencialidad de su construcción, mostrándose sin revestimientos, como reflejo de la expresividad propia de las ruinas sobre las que se asientan. Cada nuevo elemento adquiere un material distinto en respuesta a su función constructiva: ladrillo para los muros, hormigón armado gris y madera pintada de gris oscuro para estructuras lineales portantes, madera clara para forjados y techos, madera oscura para carpinterías y mobiliario, piedra para pavimentos, y chapa de zinc para cubiertas y evacuación de aguas.

Algunos de estos materiales serán los que resolverán también el nuevo edificio de aularios ubicado en el solar contiguo, permitiendo que se produzca una relación natural entre las partes nuevas y preexistentes.

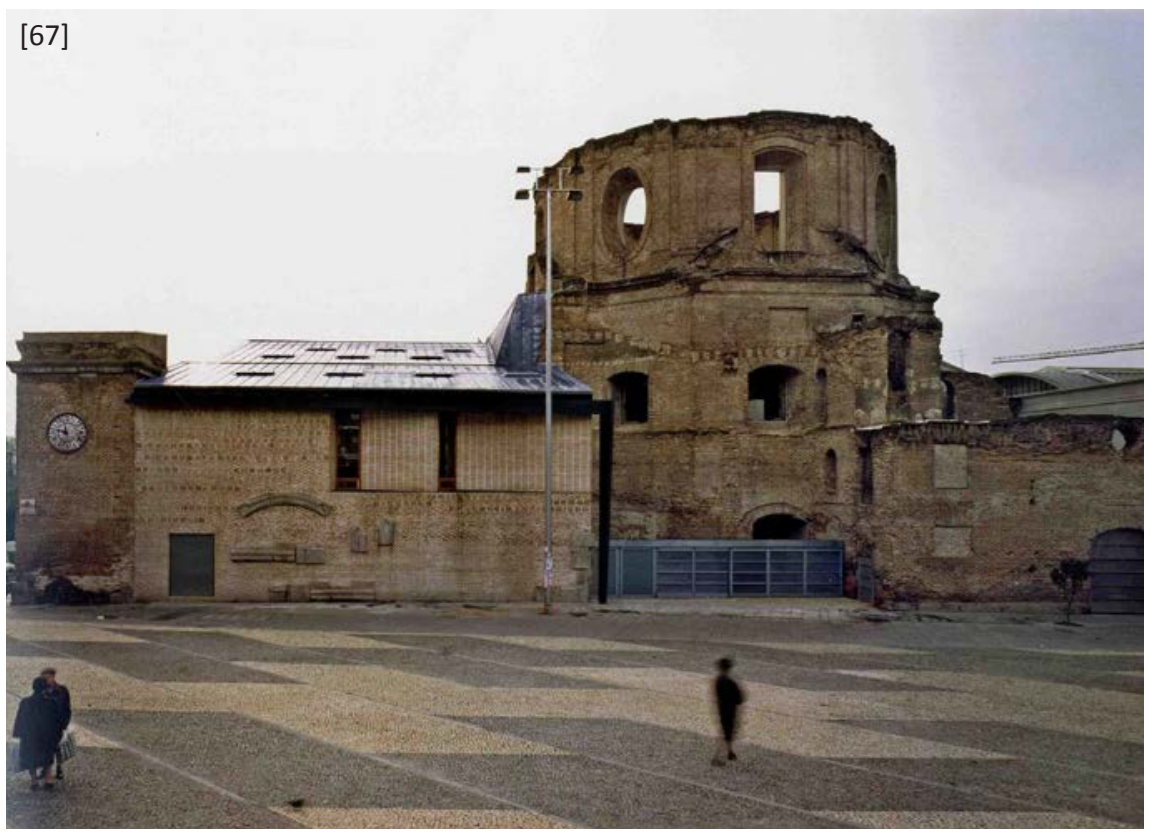


Los nuevos muros que delimitan el espacio se construyen a base de ladrillos recuperados, que dialogan con los muros preexistentes con naturalidad. En el caso de la nueva fachada que vierte a la plaza, y en respuesta a su valor representativo, la fábrica de ladrillo adquiere diversos aparejos e incorpora fragmentos que evocan el carácter del monumento original, y a su vez hacen referencia a otras arquitecturas del pasado que incorporaban restos romanos en sus fábricas.

Los huecos practicados en estos muros se resuelven con un lenguaje moderno que muestra con claridad el profundo espesor de los elementos. Unos grandes dinteles de hormigón en el muro situado a los pies de la nave y en el muro del nuevo acceso, o unos paños girados de ladrillo "apilado" en el muro de la nueva fachada, desvelan su origen contemporáneo.

Unos pesados pórticos de hormigón visto con encofrado de tablilla, configuran la estructura de soporte del altillo de acceso, mientras que unas ligeras estructuras de madera conforman el soporte de las bóvedas de listones de madera. Los pórticos, cercanos al suelo, expresan un carácter másico; las cerchas, cercanas al cielo, se muestran ligeras.

Los forjados y bóvedas se resuelven con piezas lineales de madera cedro rojo de Canadá, que buscan transmitir ligereza y provisionalidad a los elementos. Es interesante destacar el sistema compositivo de las bóvedas, en el que mediante el juego de solape entre las piezas de madera se genera una vibración de llenos y vacíos que potencia la desmaterialización del elemento. Este efecto se consigue mediante el ejercicio de prueba y error, primero mediante mucho trabajo en maquetas, y también mediante pruebas en obra. ${ }^{81}$

El mobiliario y las carpinterías adoptan un tono de madera más oscuro que ayuda a distinguir con claridad su función. Las carpinterías en los huecos del cimborrio se ocultan para mantener el carácter de ruina. ${ }^{82}$

El pavimento del suelo de la nave se resuelve con losas de granito recuperadas, de geometría imperfecta y bordes dañados por la manipulación, colocados de forma aparentemente algo descuidada. Con ello, el paso del tiempo y la mano del hombre se hacen presentes. ${ }^{83}$

Un adoquín rugoso, presente en los bordes de la plaza, rellena los intersticios entre losas y penetra en el vestíbulo de la biblioteca, transmitiéndole parte de su carácter de espacio exterior.

La pieza que configura el espacio previo de acceso se resuelve en acero, buscando formar parte del mobiliario urbano de la plaza.
81 Entrevista realizada a José Ignacio Linazasoro, en Madrid, en diciembre de 2012, pregunta 15 (ver anexo)

82 GARCÍA DEL MONTE, J.M.: “Centro Cultural en Lavapiés: de las virtudes de lo antiguo". Arquitectura, no 338, Madrid, Ed. COAM, 2004, pp. 38-47

83 GARCÍA DEL MONTE, J.M.: Op. Cit., 2004, pp. 38-47

[68] Piezas lineales de madera de pino que configuran la bóveda. (LINAZASORO: Arquitectura, no 357, 2009, p. 11)

[69] Pórticos de hormigón visto con encofrado a tablilla. Tono de madera más oscuro para el mobiliario. (PRESI: 2012, p. 75 )

[70] Detalle constructivo, redibujado a partir de los planos del proyecto.
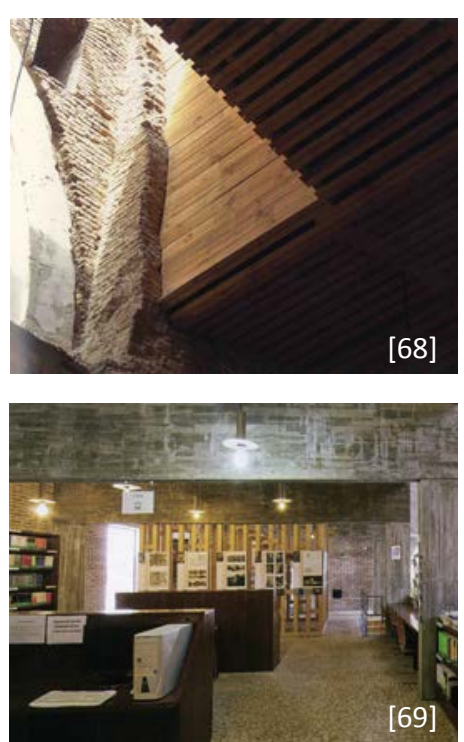

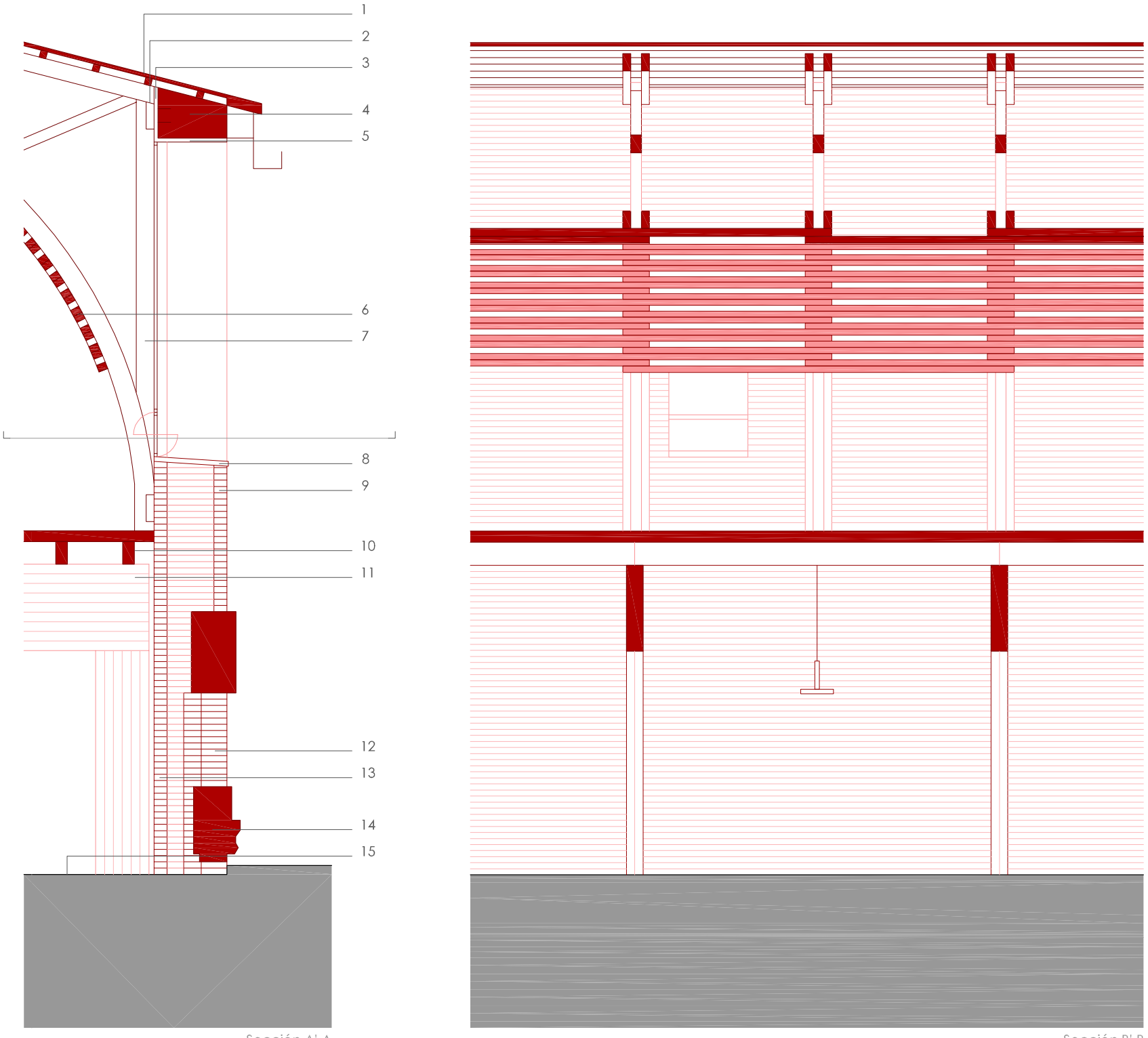

1. Cubierta de zinc

2. Chapa de anclaje de cercha de madera a zuncho de hormigón

3. Tablero de madera

4. Zuncho de hormigón armado para anclaje de cerchas de madera

5. Chapa de acero pintada con oxirón

6. Travesaños de madera de cerezo

7. Estructura de madera maciza

8. Vierteaguas de zinc

9. Cara exterior de muro de $1 / 2$ pie de ladrillo

nuevo y aprovechado

10. Estructura de madera maciza de pino

11. Pórtico de hormigón armado gris con

encofrado de tablillas de madera

12. Cara exterior de muro de 1 pie de ladrillo

hueco con aparejo a tizón

13. Cara interior de muro de $1 / 2$ pie con

acabado jarreado

14. Fragmentos de piedra recuperados

15. Adoquín de piedra

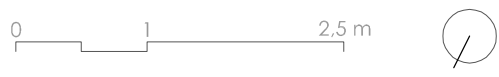

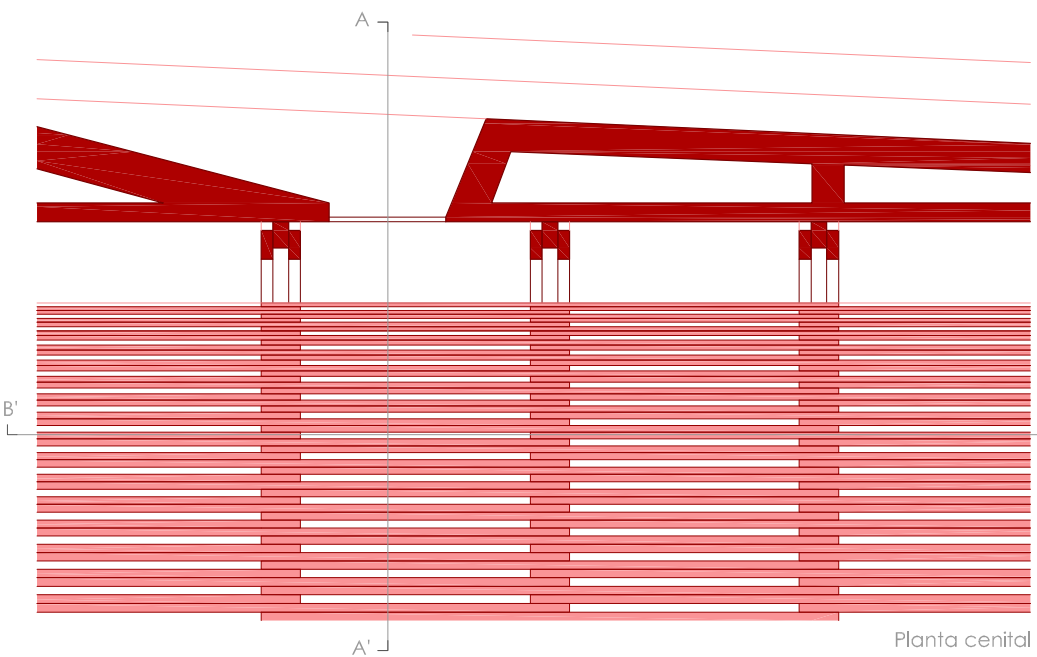

$A^{\prime}$ 


\section{ANÁLISIS CRÍTICO DE LA INTERVENCIÓN}

\subsection{Una arquitectura evocada por la realidad incompleta de la ruina}

En las Escuelas Pías, como en las últimas obras de Linazasoro, existe una búsqueda por responder al orden incompleto propio de la realidad actual. Un orden que viene evocado por la ruina preexistente en el lugar.

La ruina ofrece un presente abierto a la superposición de nuevos fragmentos, permitiendo con ello actualizar su pasado. "De ese modo, frente al objeto estático y hermético al que perteneció en su origen, la ruina introduce en el mismo un movimiento que permite una nueva acción hacia el presente". 84

Así, Linazasoro se muestra firme en la búsqueda por fijar la imagen de ruina que el tiempo ha producido, renunciando con ello a recuperar el esplendor pasado, pero afrontando esta nostálgica visión incompleta como oportunidad para la creación de una nueva arquitectura, nacida de la adición de fragmentos, "palimpsestos en una única unidad temporal". ${ }^{85}$

De esta manera Linazasoro interpreta los restos como materia a emplear en el proyecto, en la búsqueda de la configuración de una obra cuyos objetivos tienen que ver con cuestiones propias de la arquitectura, de tal manera que la relación con el lugar, la materialidad, el espacio o la luz son las variables que actúan en el proyecto.
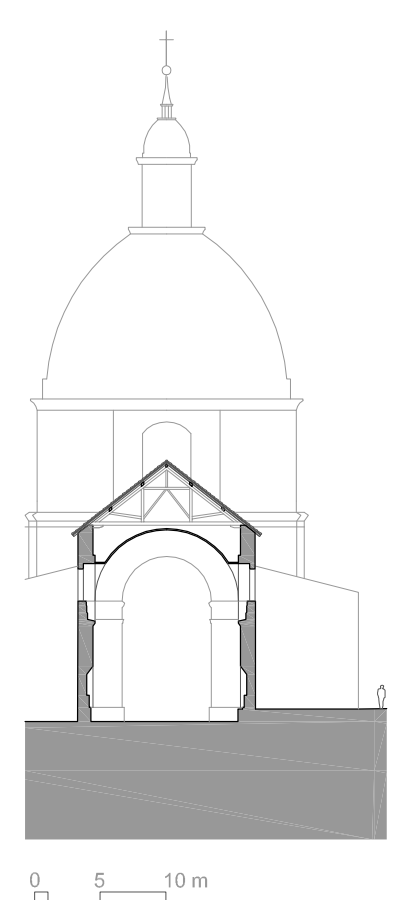
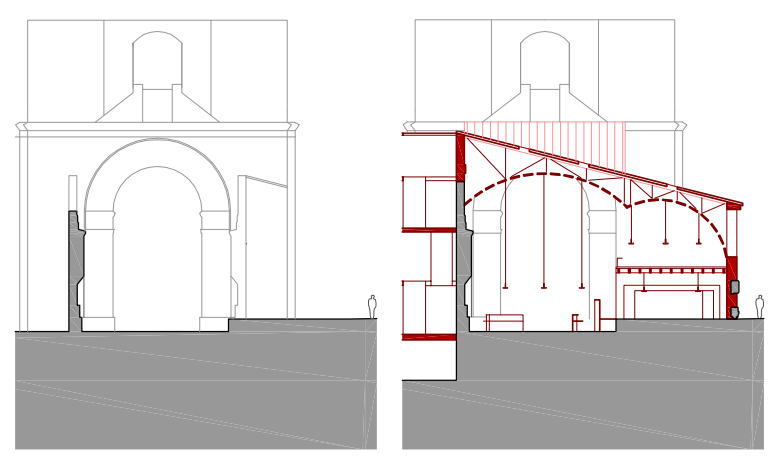

[72]
84 LINAZASORO, J.I.: "Ruinas". En: UGOLINI, A. (dir): Op. Cit., 2010, pp. 16-19

85 LINAZASORO, J.I.: "Ruinas". En: UGOLINI, A. (dir): Op. Cit., 2010, pp. 16-19

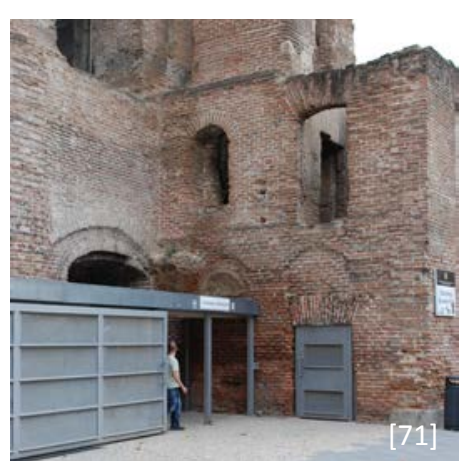

[71] Hipótesis del estado original, estado del edificio en el momento anterior al inicio de la intervención y estado actual.

[72] Imagen que pone de manifiesto el valor de la ruina. (Imagen del autor) 
86 SANZ NEIRA, E.: "Lo didáctico y lo operativo". Arquitectura, № 357, Madrid, Ed. COAM, 2009, pp. 12-15

87 SAINZ, V.: "Los Proyectos Urbanos de José Ignacio Linazasoro". En: PRESI, S.: Op. Cit., 2007, pp. 249-255
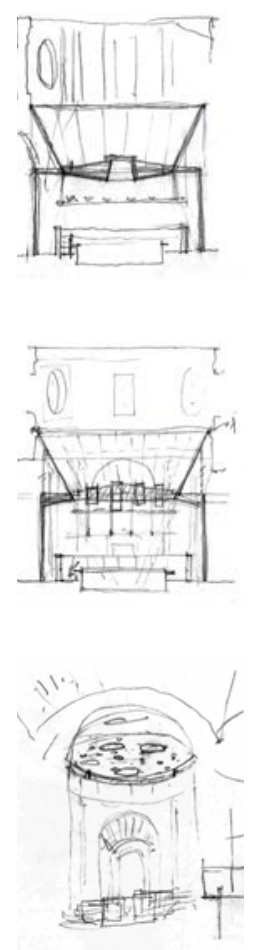

[73] Croquis que muestran la evolución del proyecto. (LINAZASORO: Arquitectura, no 357, 2009, p. 12)

[74] Vista de la intervención desde la plaza (Imagen del autor)

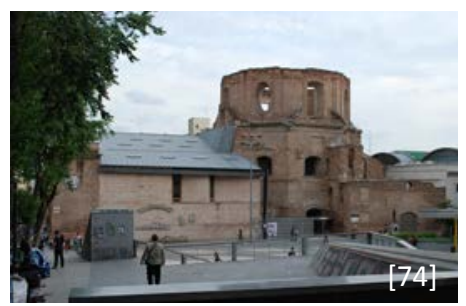

Estas variables son, en la obra de Linazasoro, el resultado de una reflexión de la arquitectura a lo largo de la historia enfocada hacia valores consolidados por el tiempo como la esencialización formal y expresión material, la permanencia e intemporalidad, la evocación y la memoria, la fragmentación temporal y la impureza, o la armonía y la naturalidad.

En este sentido Sanz Neira indica que con la evocación de la ruina Linazasoro busca alcanzar una arquitectura esencial donde el tiempo ha ido depurando todo lo accesorio. Una búsqueda de lo fundamental que conlleva una arquitectura anónima y universal, donde detrás de la arquitectura hay un hombre que no vemos. Además Sanz Neira destaca que este profundo proceso de reflexión supone un trabajo continuo, constante y prolongado que se observa con gran claridad en los croquis de evolución del proyecto. ${ }^{86}$

\subsection{Función, lugar y preexistencia}

Desde el punto de vista de la transformación funcional del edificio, la adaptación de las ruinas de la iglesia en biblioteca es una solución que permite recuperar los restos de un edificio inutilizados durante años, y así devolverlos a la ciudad reinterpretados para su adaptación a un nuevo uso.

Pero esta transformación se plantea sin alterar el carácter que la ruina había aportado al espacio urbano y a la memoria del lugar. Así, la potente imagen urbana del edificio protagonizada por el tambor de la desaparecida cúpula es para Linazasoro uno de los elementos fundamentales a destacar en el conjunto.

Para Victoriano Sainz, gracias a los desniveles presentes en el lugar, "Ios muros descarnados de la vieja iglesia (...) encuentran en el vacío de la plaza el marco que les permite afirmar su noble presencia". Recurso que repite Linazasoro en la azotea del aulario "convertida en una nueva atalaya, esta vez sobre los tejados del barrio (...) casi como si de un cuadro de Antonio López se tratara" ${ }^{87}$ Una repetición conceptual de elementos aplicada a diferentes partes de la intervención, para establecer nexos de unión que ayuden a comprender una cierta unidad en la diversidad.

La preexistencia, lejos de tener un destino marcado por su origen, se muestra como expresión de múltiples sugerencias para su adaptación a una nueva realidad distinta y distante respecto a la realidad inicial. Así Linazasoro interpreta los cambios de relación entre el edificio y el espacio público, y adapta la preexistencia a nuevos accesos y recorridos. Con ello modifica la lectura del edificio original, constituyendo una nueva secuencia espacial y relativizando el valor de un recorrido axial, hoy ya desaparecido y carente de sentido. 
En este sentido Linazasoro produce un recorrido de transición entre exterior e interior que permite huir del tiempo cíclico del presente, e introducirse en un mundo intemporal. A través de una sucesión de espacios de alturas que crecen progresivamente, de rampas que alargan el movimiento y de materiales de carácter exterior, se consigue enlazar ambas realidades de manera progresiva, con naturalidad.

\subsection{La interpretación del orden incompleto y la superposición temporal}

Linazasoro juega con el concepto de la unidad de lo múltiple para integrar la nueva intervención en la preexistencia, buscando crear entre ambos un conjunto fuertemente relacionado aunque incompleto. Así Linazasoro plantea la ruina como un telón de fondo complejo, lleno de sombras y texturas, "sobre el que se recorta lo añadido como figura", creando con ello un espacio distinto al original, ajeno a cualquier tipo de restauración. ${ }^{88}$

Materiales similares y diferentes de los preexistentes, así como alusiones y citas al pasado y a la modernidad, responden a este juego de fondo y figura que se articula mediante recorridos que conectan las diversas partes de la intervención. ${ }^{89}$ Se produce por tanto una relación mediante similitudes y diferencias, mediante analogías y contrastes que conforman una arquitectura incompleta, cuyo restablecimiento del orden queda en manos del espectador. ${ }^{90}$

Este equilibrio entre opuestos también se observa en la definición formal de los elementos. Por un lado se produce una simplificación formal que ayuda a una construcción más lógica, pero por otro lado se introducen algunos acentos de complejidad que aportan significado y ayudan a compensar la frialdad de la firmitas.

Por otro lado Linazasoro explica que el edificio se puede entender como compuesto por tres niveles distintos de estratos superpuestos a lo largo del tiempo: en primer lugar están los muros de la propia ruina, compuestos por ladrillos antiguos, así como los nuevos muros que completan el cerramiento del nuevo conjunto, construidos con ladrillo recuperado, de tal manera que ambos constituyen un estrato de un tiempo inmutable; en segundo lugar están las estructuras de la biblioteca construidas con materiales nuevos y distintos, como el hormigón y la madera, que constituyen un estrato de un tiempo actual y activo; por último están el mobiliario y el usuario a los que les corresponde una temporalidad efímera, cuya forma y posición puede variar sin influir sobre los otros niveles. ${ }^{91}$
88 LINAZASORO, J.I.: "Ruinas". En: UGOLINI, A. (dir): Op. Cit., 2010, pp. 16-19

89 LINAZASORO, J.I.: Op. Cit., 2009, pp. 8-11

90 LINAZASORO, J.I.: Op. Cit., 2003, pp. 80-88

91 LINAZASORO, J.I.: "Alcune riflessioni". En: PRESI, S. (dir): J.I. Linazasoro. Ed. Casa dell'Architettura, 2012, p.28
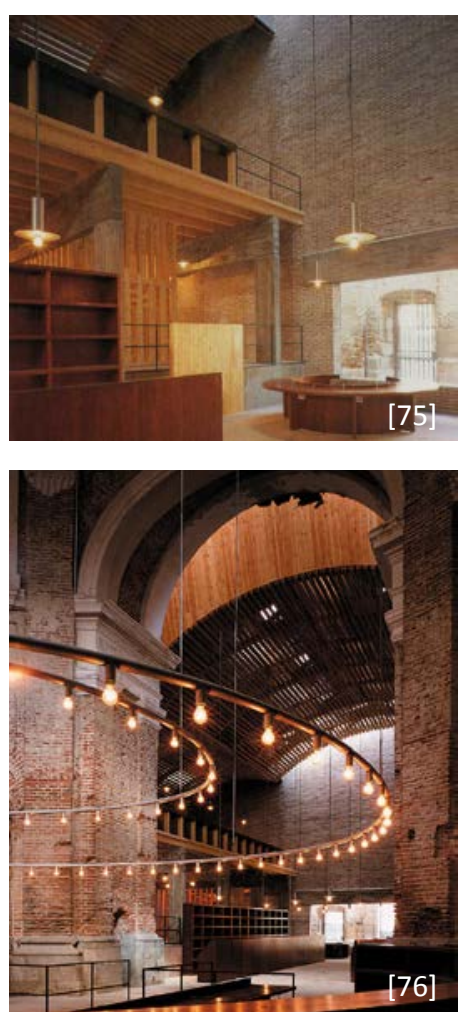

[75] Vista del mobiliario y el altillo. (LINAZASORO: 2004, p.63)

[76] Vista desde la rotonda hacia la nave. (MURUA: Construire in laterizio, no 143,2011 , p. 15) 
92 LINAZASORO, J.I.: Op. Cit., 2004, pp. 53-64

93 LINAZASORO, J.I.: Tres proyectos sobre las preexistencias. Conferencia impartida en el marco del Workshop Internacional Construcción de la Memoria, en la Escuela Técnica Superior de Arquitectura de la Universidad Politécnica de Valencia, 12 de mayo de 2011, inédito
[77] Vista del espacio de lectura de la biblioteca de Viipuri, de Alvar Aalto. (Alvar Aalto Museo: <www. alvaraalto.fi>)

[78] Vista del espacio de lectura situado en la rotonda. (LINAZASORO: 2004, p. 29)

[79] Detalle del juego de fragmentos en la arquitectura de Dimitris Pikionis. (SARRI: <www.webtopos. gr>)

[80] Detalle del juego de fragmentos en el pavimento interior. (Imagen del autor)

\subsection{El estrato inmutable}

Linazasoro emplea un gran esfuerzo en ocultar los nuevos elementos que inserta en la preexistencia, para mantener toda la potencialidad expresiva de la ruina. Algo que ha aprendido de la "Roma que retratan los grabados de Piranesi"92, o de la fuerza expresiva que mantienen los restos de la Minerva Medica.

Precisamente a este último ejemplo remite la imagen del elemento de la rotonda, convertida en pieza independiente como consecuencia de su estado de ruina. Linazasoro remarca esta relectura en el interior, mediante la creación de una gran entrada de luz cenital entre el cimborrio y la nave, que permite leer desde el interior el perímetro y la altura del elemento.

De esta manera se vale de la reinterpretación de la ruina para modificar la lectura original de continuidad espacial barroca, y sugerir una nueva visión de espacios yuxtapuestos que potencian la percepción del cimborrio como un espacio central paleocristiano. Lectura que se refuerza hundiendo el suelo del crucero, a modo de cripta, que al mismo tiempo recuerda al espacio de lectura de la biblioteca de Viipuri, de Alvar Aalto. ${ }^{93}$
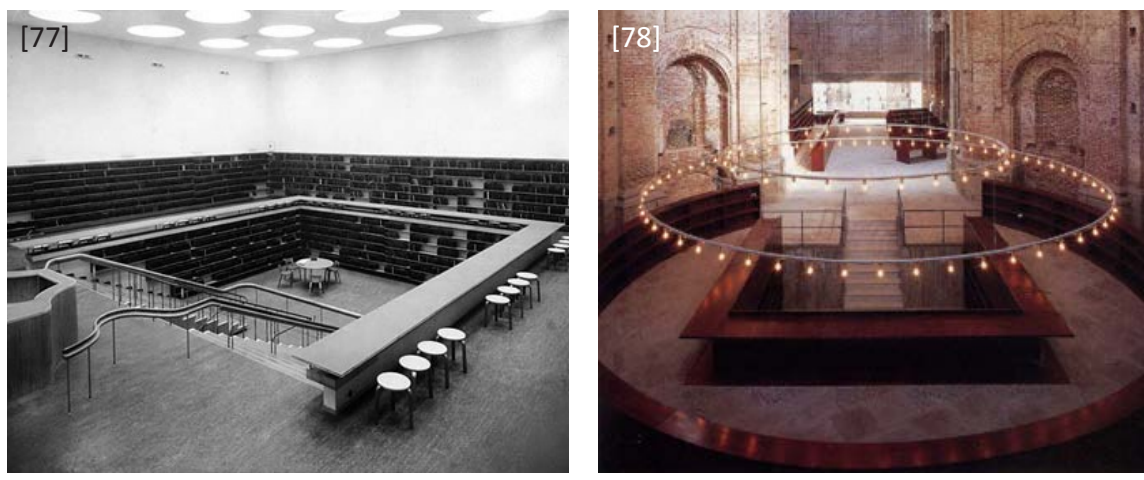

La fragmentación del pavimento interior, elaborado con materiales recuperados, recuerda a la suma de estratos de las excavaciones arqueológicas, algo ya reinterpretado magistralmente por arquitectos como Pikionis o Lewerentz.
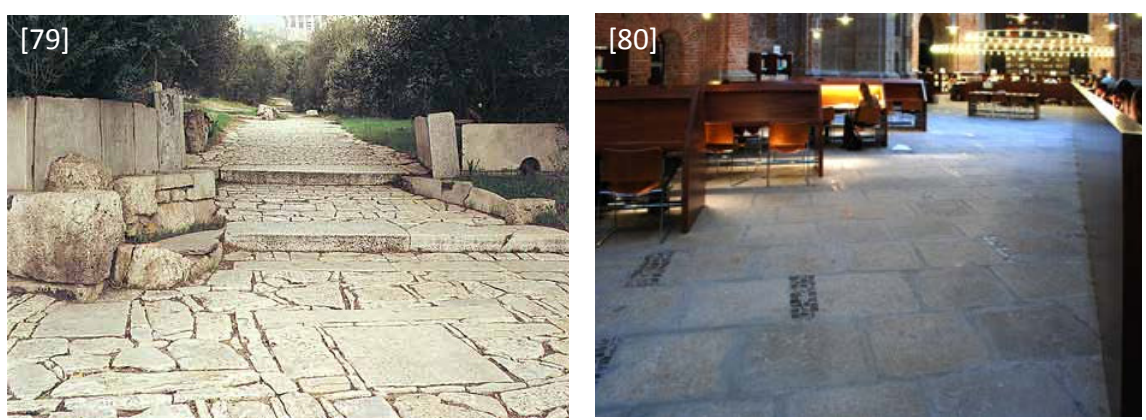

Iglesia de Ias Escuelas Pías del Colegio de San Fernando.1996-2004 
En el exterior, la creación de la nueva fachada se subordina a la ruina, buscando establecer una armonía con ella, pero a su vez reinterpretando formas utilizadas por los maestros modernos. Así el juego de aparejos de ladrillo ayuda a crear una imagen fragmentada que se integra con naturalidad en la ruina, un juego que recuerda a diversas arquitecturas como la de Alvar Aalto en Muraatsalo o Lewerentz en Klippan. También la manera de recortar el muro, transformando su sentido constructivo en un juego de composición abstracta, está presente en arquitectos como Lewerentz o Le Corbusier, un juego que recuerda a su vez a los huecos abocinados medievales.
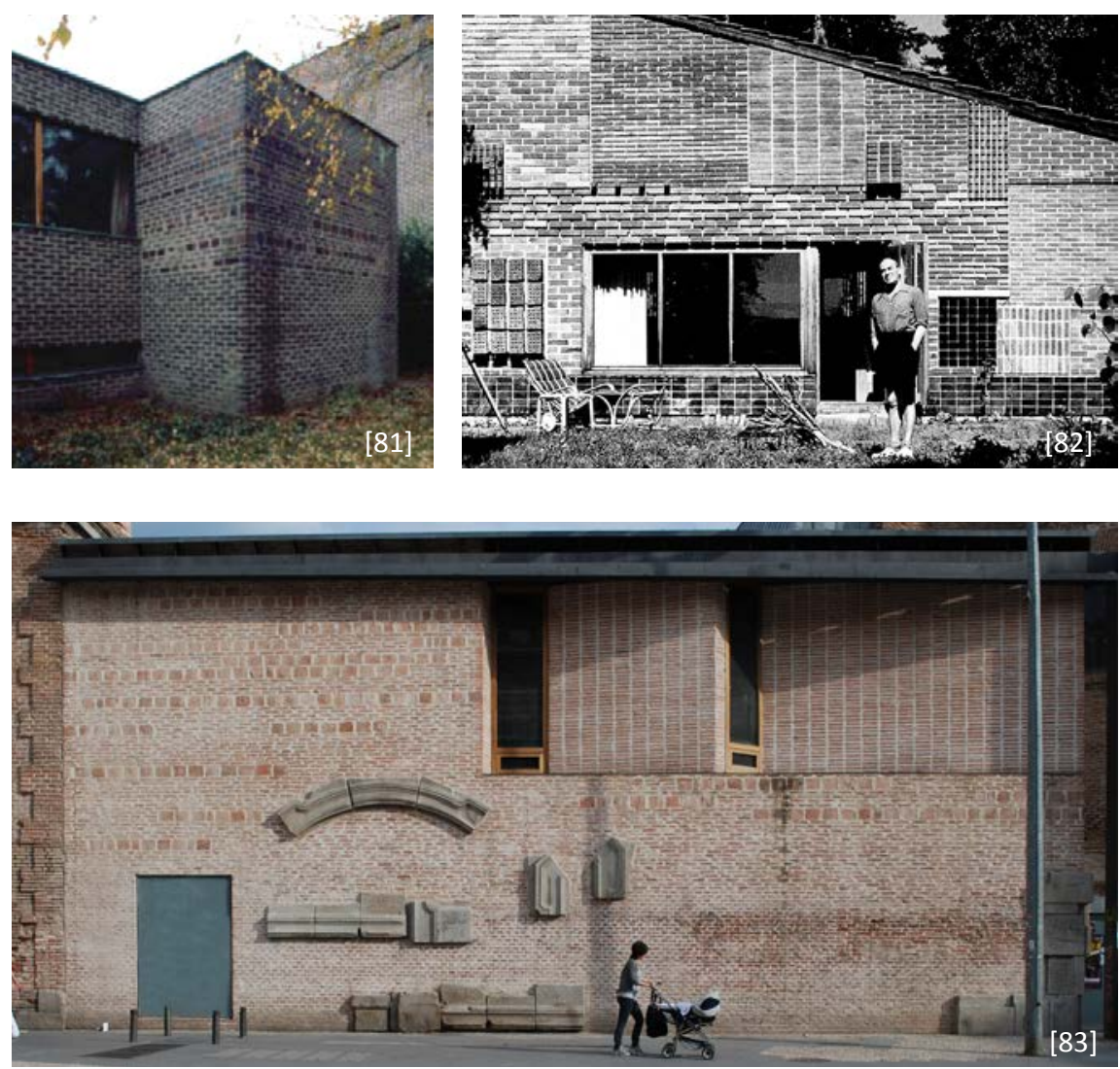

Otras referencias que se advierten en la fachada es el lapidarium de fragmentos recuperados e insertados en el muro a modo de cita que recuerda a ejemplos de la arquitectura paleocristiana, como en el pórtico de la basílica de Santa María en el Trastevere, reinterpretado por arquitectos como Plecnik o Kahn.

También las grandes cubiertas de zinc, que protegen los fragmentos de ruina, o el juego del gran canalón y la potente bajante, expresión formal de una necesidad funcional, recuerdan la manera de construir presente en las catedrales góticas o en las obras de algunos maestros de la arquitectura nórdica, como Sigurd Lewerentz.
[81] Juego de aparejos en la iglesia de San Marcos, Björkhagen. S. Lewerentz, 1956-1960. (QUINTANILLA, J.: "Sigurd Lewerentz, 18851975. Una transición nórdica a la Arquitectura Moderna. Desplazamiento gradual hacia el dominio de lo táctil" Universidad Politécnica de Cataluña, Departamento de Proyectos Arquitectónicos, 2004)

[82] Juego de aparejos en Muuratsalo, Alvar Aalto, 1952-1953.

[83] Juego de aparejos en la fachada del nuevo volumen. (Imagen del autor)

[84] Huecos abocinados en la arquitectura de Lewerentz. (Imagen de F. Galli. En: DYMLING, C.: 1997, p. 173)

[85] Cubierta de zinc en la arquitectura de Sigurd Lewerentz. (Imagen del autor)

[86] Cubierta del nuevo volumen. (LINAZASORO: 2007, p. 173)
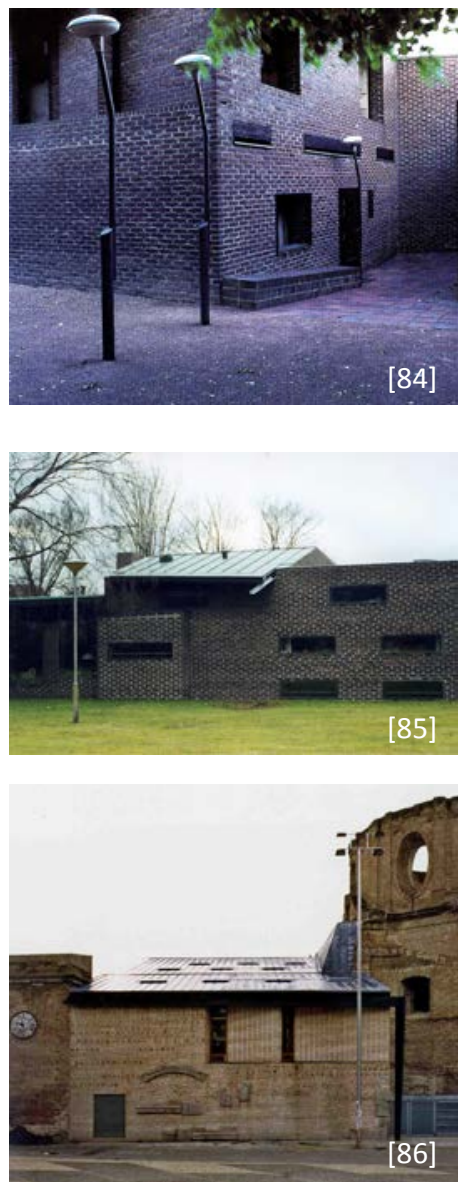


\subsection{El estrato actual. La superposición temporal y la relación entre opuestos}

94 Ideas extraídas de la entrevista realizada a José Ignacio Linazasoro, en Madrid, en diciembre de 2012 (ver anexo)
[87] Arquitectura griega del s. V a. C. (PAWSON: 2003, p. 84)

[88] Dibujo explicativo de un templo griego de madera. Piranesi. (PIRANESI: 1761. En: Universitätsbibliothek Heidelberg: <http://digi. ub.uni-heidelberg.de>)

[89] Arquitectura de Van der Laan. (AARTS; FOKKINK; KRUIJTZER: 2001, p.57)

[90] Vista bajo el altillo. Pórticos de hormigón con encofrado de tablilla y forjado de madera. (Imagen del autor)

[91 y 92] Vistas desde la nave hacia el altillo. (PRESI: 2012, pp. 75 y 71)

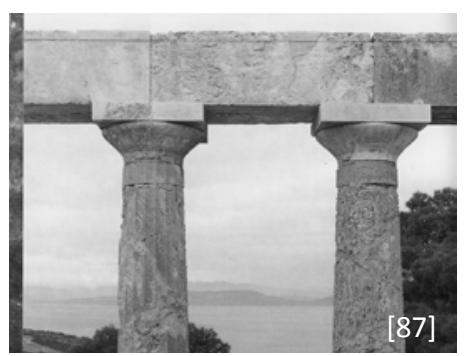

Los nuevos elementos que conforman el segundo estrato buscan distinguirse de los del fondo mediante materiales y sistemas constructivos modernos, tratados como piezas independientes que se insertan sin competir con la potencia expresiva de la ruina.

Linazasoro plantea dos mecanismos de actuación derivados de la relación entre la estructura y el apoyo en la historia: por un lado el sentido tectónico de superposición de elementos apoyados, por otro lado el sentido de ingravidez de superposición de un elemento que flota en el espacio. Linazasoro busca compatibilizar en sus proyectos estos dos sistemas de lo tectónico y lo ingrávido.

Lo tectónico se aprecia en la construcción de los altillos. En este caso, la conformación de los elementos se plantea desde la unidad a través de lo múltiple, mediante la suma de piezas ordenadas que constituyen conjuntos. Los nuevos pórticos de hormigón y estructuras de madera recuerdan un juego elemental de superposición constructiva de elementos lineales, presente ya en los templos griegos de madera, y retomado por arquitectos modernos como Van der Laan.
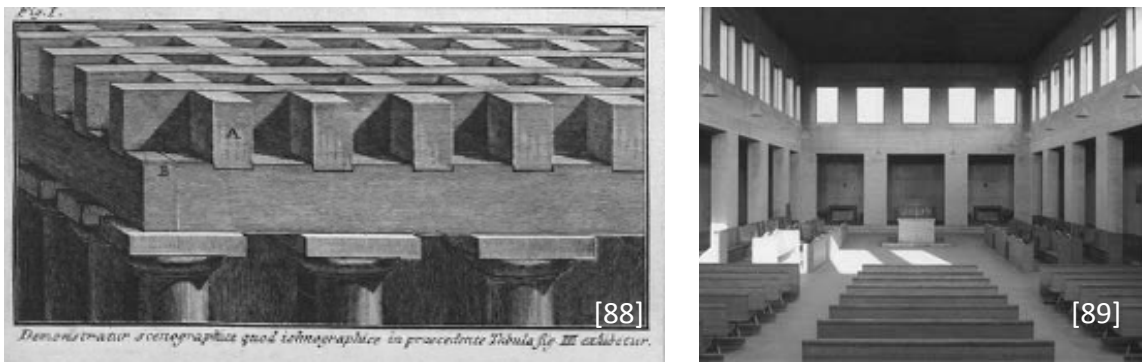

Para Linazasoro esta superposición tiene un sentido de acumulación temporal, retomado en cierta medida de las teorías de Vitruvio sobre la evolución de los órdenes clásicos. En primer lugar estaría el apoyo, en origen de madera, que se va solidificando con el paso del tiempo hasta convertirse en un material pétreo, recordado a través de las huellas de la madera grabadas en el hormigón. En segundo lugar, en un tiempo más reciente, el elemento apoyado todavía joven, mantiene su materialidad de madera. De esta manera, si el edificio revirtiera a la ruina, lo que quedaría finalmente sería el primer estrato. ${ }^{94}$
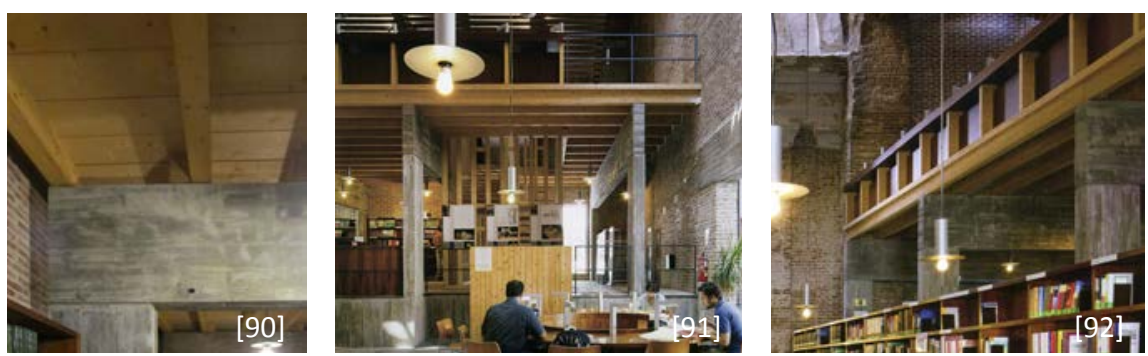
Lo ingrávido se aprecia en la construcción de la bóveda. Sobre el espacio "monomatérico" de la ruina, la bóveda se concibe como un gran baldaquino, un umbráculo cuya materialidad busca crear un ambiente de misticismo, y cuya forma remite al origen de su significado como protección natural de la intemperie y de la inmensidad de la naturaleza y del espacio exterior.

La semitransparencia de la nueva bóveda, con su carácter etéreo enfatizado por el efecto de la luz filtrada a través de las láminas de madera, consigue que este nuevo elemento en cierto modo se desmaterialice. Su presencia sutil, como si se tratase de un objeto que flota en el espacio, permite conjugar múltiples lecturas: la lectura de la ruina como espacio abierto-descubierto, la lectura de los muros que continúan por encima de la bóveda y hacen referencia a la existencia de un espacio de proporción y escala mayor, y la lectura del nuevo espacio, que de alguna manera se reelabora y actualiza, pero sin perder el valor de la memoria.

La bóveda de las Escuelas Pías encuentra sus referentes más antiguos en el sentido ilusionista de la arquitectura bizantina y paleocristiana, donde los elementos arquitectónicos se desmaterializan a través de complejos juegos lumínicos.

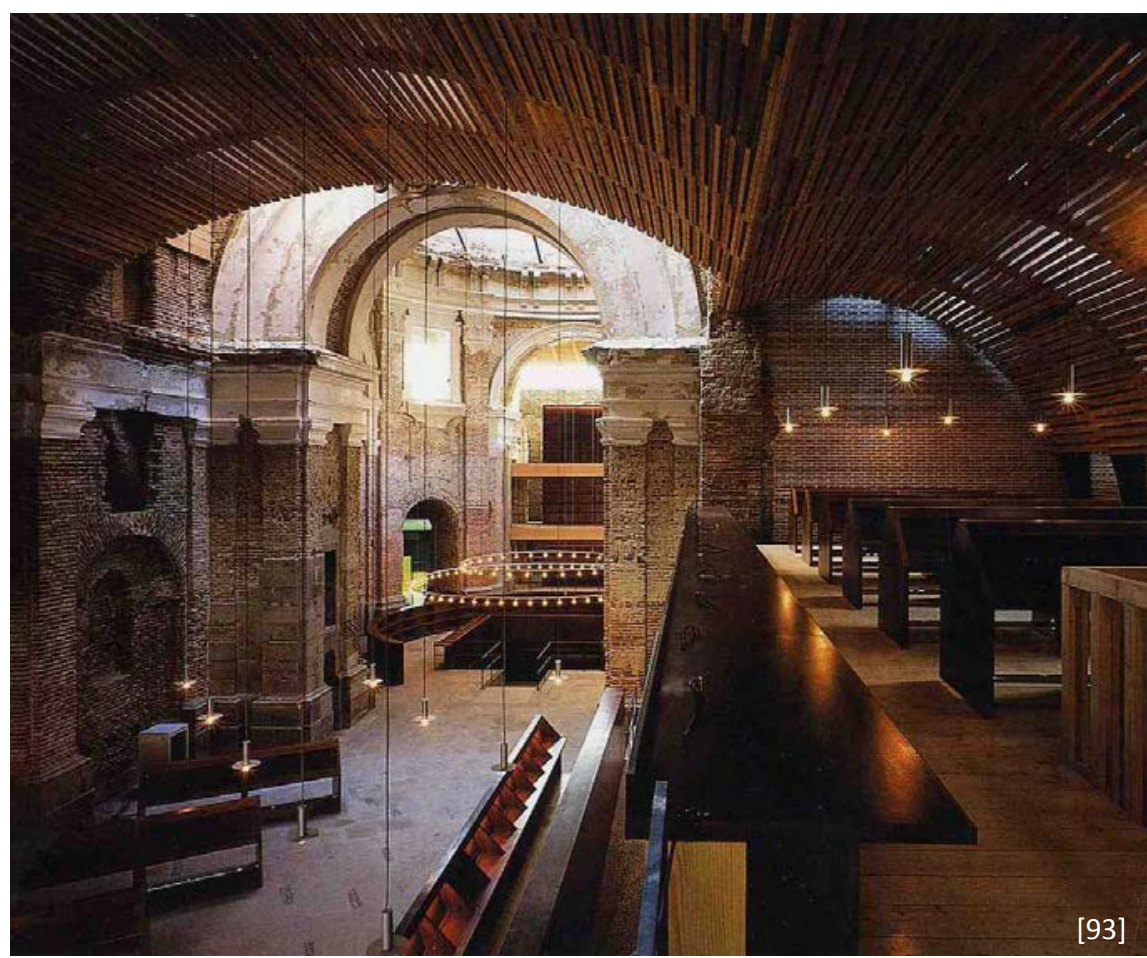

[93] Vista desde el altillo de la nueva bóveda. (LINAZASORO: 2007, p. 184)

[94] Boceto que muestra el espacio del altillo y las bóvedas. (LINAZASORO: 2004, p. 48)

[95] Bóvedas de la biblioteca de Sainte Genevieve de Labrouste. Dibujo de José Ignacio Linazasoro. (LINAZASORO: 2007, p. 219)

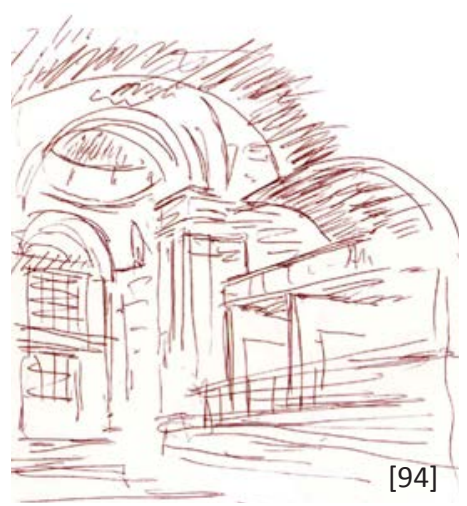


95 SANZ NEIRA, E.: Op. Cit., 2009, pp. 12-15

[96] Croquis de Le Corbusier, 1929. Ma maison, s'il me venait l'idée de devenir Propiétaire. (Fondation Le Corbusier: <www.fondationlecorbusier.fr $>$ )

[97] Croquis del paisaje entorno a la Biblioteca de Viipuri. Alvar Aalto, hacia 1930. (MUÑOZ: 2008, p. 80)

[98] Croquis de Jörn Utzon. (MONTENEGRO, N. En: BALLESTEROS, J: $<$ automaticoroboticocodificado. masterproyectos.com>)

[99] Vista interior de la iglesia de San Marcos. S. Lewerentz, 19561960. (Imagen del autor)

[100] Vista exterior de la iglesia de San Marcos. S. Lewerentz, 1956-1960. (Imagen de F. Galli. En: DYMLING, C.: 1997, p. 164)
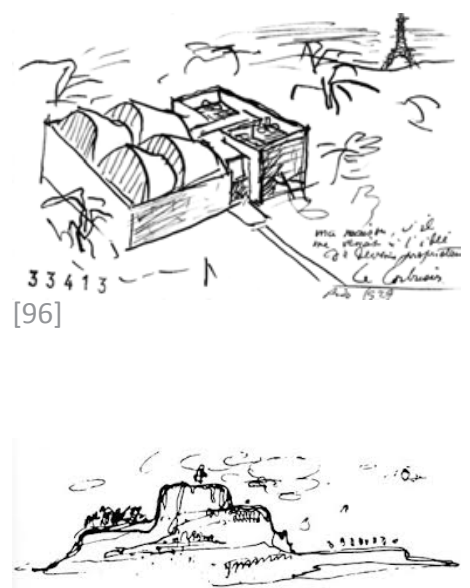

[97]

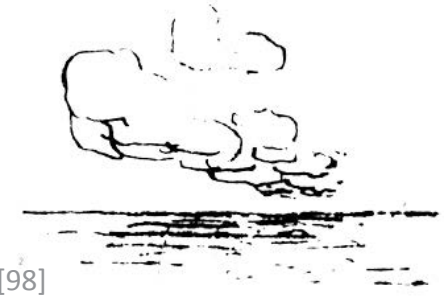

Tal vez este juego de opuestos está en la línea de lo que buscaba Alvar Aalto cuando dibujaba aquellos soles en las montañas, o Jörn Utzon cuando cubría sus dibujos de nubes, o Le Corbusier cuando compensaba las formas puras de sus proyectos con otras más "naturales" en busca de un equilibrio que hiciera más habitable el espacio y diera una tregua al incansable trabajo de la razón.

Sanz Neira relaciona esta búsqueda de ligereza con la pareja de bóvedas de la biblioteca de Sainte Genevieve de Labrouste, ${ }^{95}$ una arquitectura muy presente en las referencias de Linazasoro. Pero su forma también nos puede recordar a las "tejas" y pórticos concatenados de las iglesias de Lewerentz, cuya expresividad material está cargada de significado histórico.
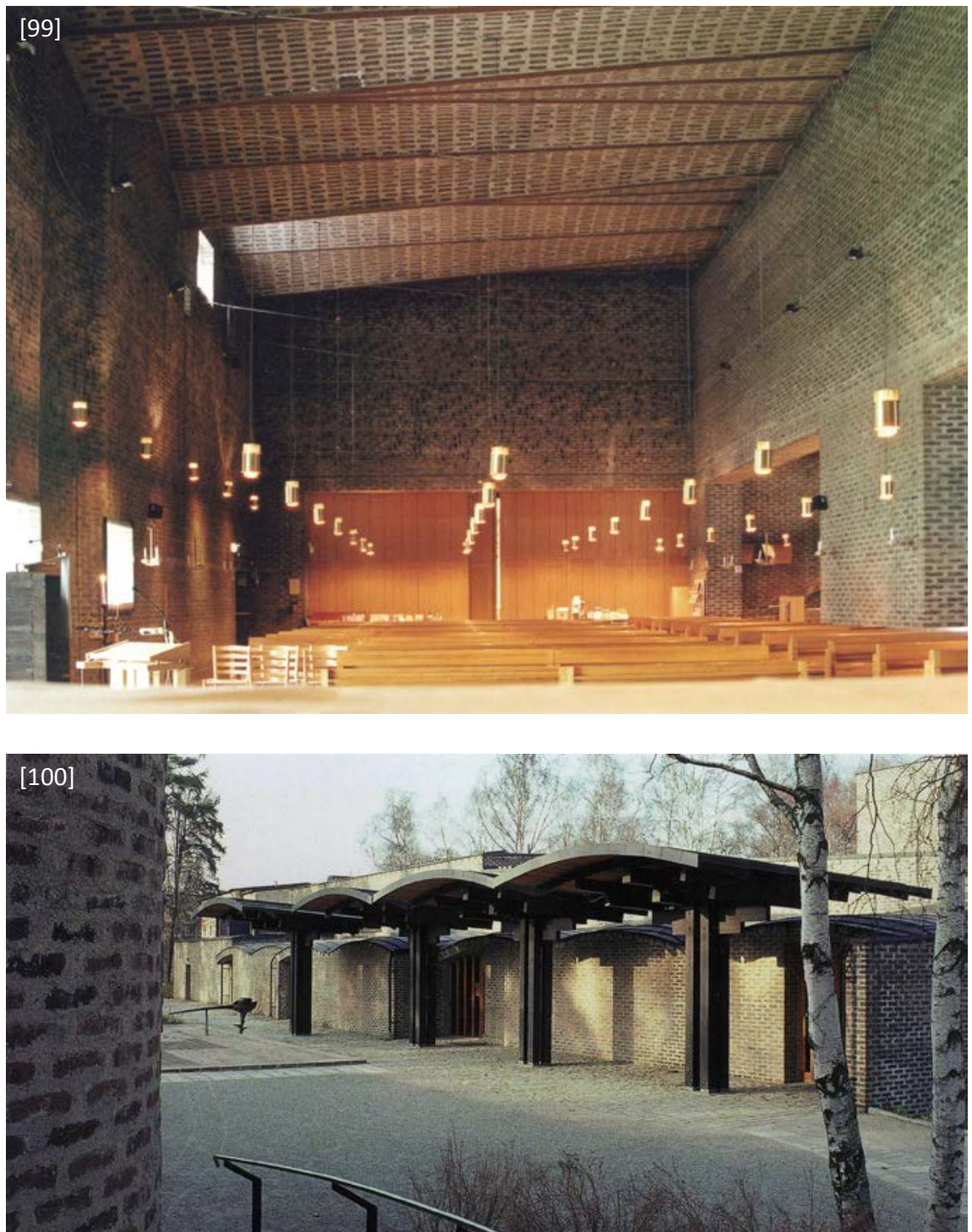

Iglesia de las Escuelas Pías del Colegio de San Fernando.1996-2004 
Linazasoro reconoce también la influencia de obras como la iglesia del cementerio de Turku, de Bryggman; la iglesia de Utzon en Bagsvaerd; o la iglesia de Almtuna en Uppsala, de Celsing; y reflexiona sobre un cierto carácter bizantino en estos espacios, quizá por proximidad, a través del contacto oriental con lo bizantino a través de Rusia. ${ }^{96}$

Es interesante destacar también la capacidad de la forma de la bóveda para delimitar dos ámbitos de distinta importancia, sin perder su relación espacial, algo que se aprecia con claridad en el desaparecido frontón de recoletos de Madrid, pero en cierto modo también recuerda al recurso empleado por Alvar Aalto en la maison Carré mediante la utilización de una superficie ondulada de madera, como elemento articulador entre espacios de configuraciones y escalas distintas. Algo presente también en Utzon y en Celsing.

Con su actuación Linazasoro consigue mantener viva la memoria de la bóveda barroca original, pero reinterpretada desde su memoria subjetiva. De alguna manera Linazasoro "reconstruye esta memoria", enriqueciéndola con su mirada y con sus experiencias, que incorpora al proyecto.

Para Tomás Carranza, el resultado es un "barroco reelaborado con apuntes de un viaje" donde se produce "el triunfo de la materia sobre el ornamento", un "texto inoportuno de un autor distante, ajeno al brillo de la novedad, a gusto con sus recuerdos, con sus sueños, con sus obsesiones". ${ }^{97}$
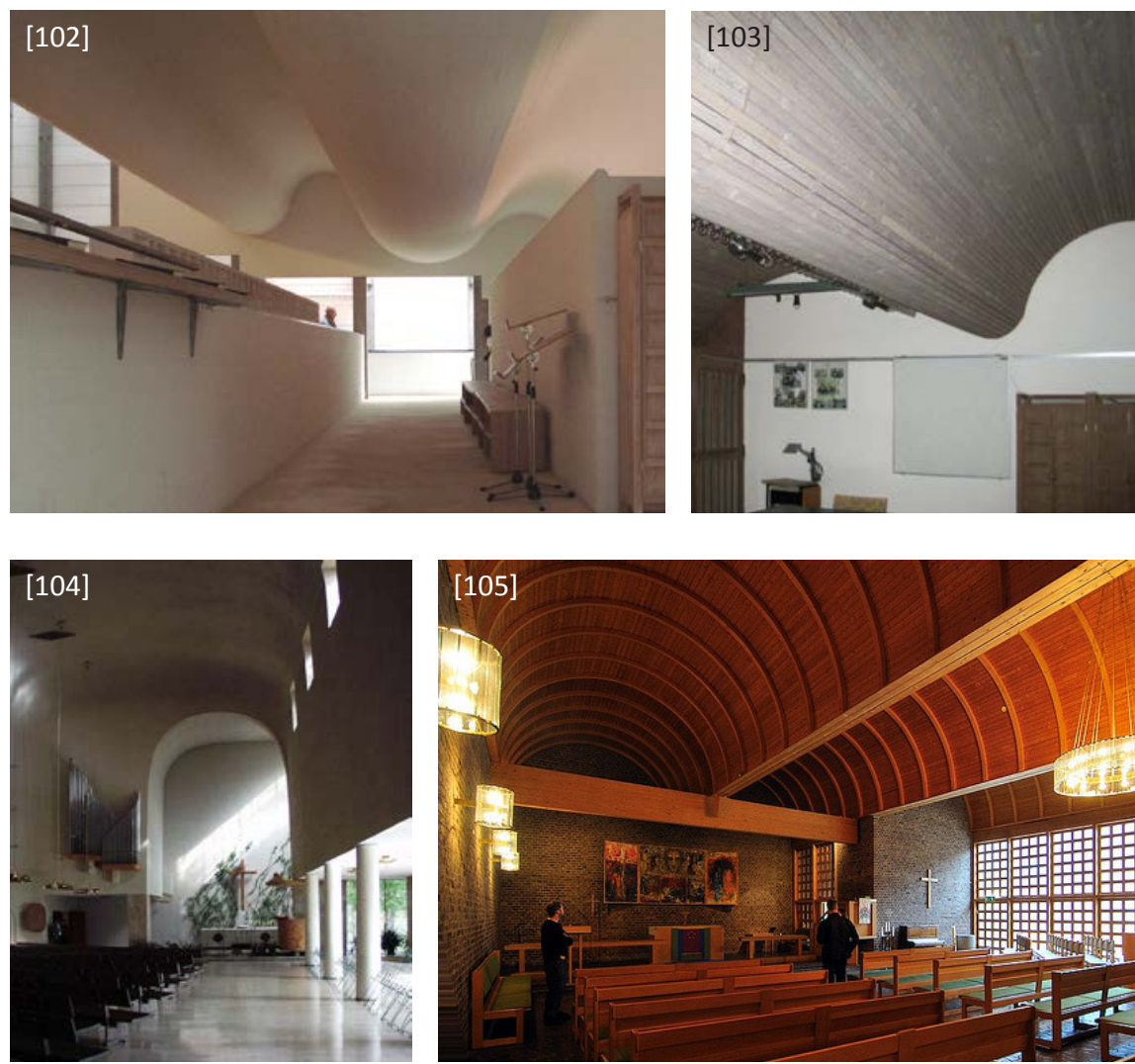

96 Ideas extraídas de la entrevista realizada a José Ignacio Linazasoro, en Madrid, en diciembre de 2012 (ver anexo)

97 CARRANZA, T.: "Recuerdos, Sueños y Obsesiones". En: LINAZASORO, J.I.: Op. Cit., 2005, p. 76

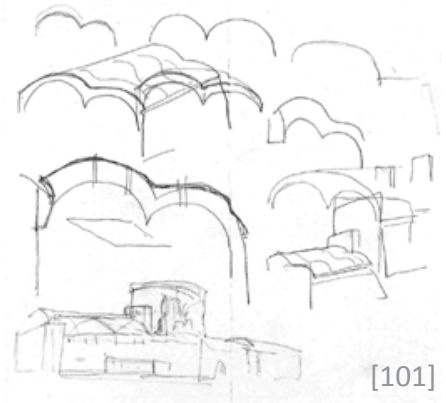

[101] Croquis para la nueva bóveda del Centro Cultural Escuelas Pías. (LINAZASORO: Arquitectura, no 357 , p. 15)

[102 y 103] Bóvedas de hormigón y madera en la iglesia de Bagsvaerd, Copenague. J. Utzon, 1976. (Imágenes del autor)

[104] Iglesia del cementerio de Turku. E. W. Bryggman, 1939-1941. (Imagen del autor)

[105] Iglesia en Almtuna. P. Celsing. (Fotografía de Arnout Fonck. En: Flickr: <www.flickr.com>) 



\subsection{BASÍLICA DE SAN PEDRO}

Construcción original:

Época Paleocristiana. 363 d.C.

Intervención:

Emanuele Fidone, 2002-2008

Lugar:

Sicilia, Italia.

El edificio se ubica en el barrio de la Spirduta, en la isla de Ortigia de la ciudad de Siracusa, en la esquina de una manzana del denso tejido urbano de la zona.

\section{ANTECEDENTES}

\subsection{Evolución histórica ${ }^{1}$}

Se trata de una de las primeras iglesias cristianas construidas en Siracusa, tras el edicto de Constantino del año 313 d.C., situándose su construcción en el año 363 d.C., por iniciativa del obispo Germano.

La iglesia primitiva consta de una nave central rematada en ábside orientado al oeste, y dos naves laterales. Las tres naves se cubren con bóvedas de cañón de piedra. ${ }^{2}$

Entre los siglos VII y VIII, se adosa un nuevo cuerpo de fábrica al lado Este de la iglesia, lo que según la hipótesis de algunos estudiosos respondería a la aplicación de los rituales bizantinos, cambiando la orientación del ábside hacia el Este. ${ }^{3}$ Este cambio habría supuesto el cierre del acceso original, produciendo la necesidad de introducir un nuevo acceso en la fachada lateral.

En el transcurso de los siglos XV y XVI se cambia la orientación del edificio a un nuevo eje Norte-Sur, modificándose los arcos que delimitan las naves y eliminando cuatro pilares. En el muro norte se cierra un acceso lateral de época suaba y se construye un nuevo portal en estilo gótico catalán. También en esta época se construye la nueva capilla del Santísimo Sacramento, alineada con el nuevo eje.

En época barroca, en torno a 1710, la nave central se sobreeleva y se abren cuatro nuevos huecos laterales para permitir la entrada de luz en el espacio. Además se le añaden a la iglesia decoraciones en estuco, frescos y altares propios de la época, así como nuevas bóvedas de yeso que, según los croquis de Fidone, se situarían a una mayor altura respecto a la bóveda de piedra original.

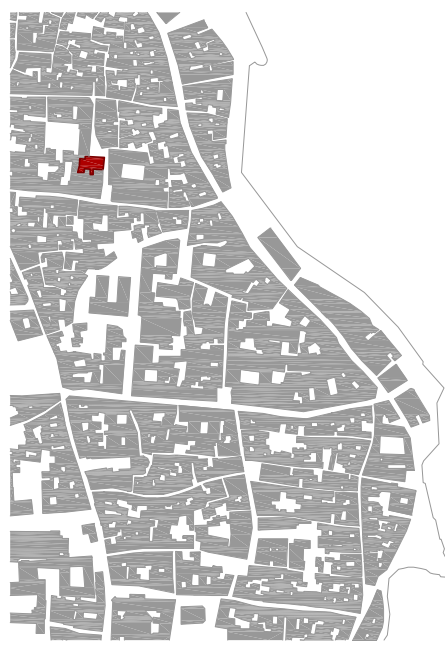

Entorno 1:10000
1 Información extraída de: FIDONE, E.: "Recuperación de la basílica paleocristiana de san Pietro". $R \& R$, no116-117 [en prensa]

2 Aunque resulta un tanto extraña la atribución de bóvedas de piedra a una basílica de época paleocristiana, aún se aprecian los arranques de esta bóveda en ambos muros de la nave central. Habiendo consultado a Fidone al respecto, afirma que esta interpretación se basa además en los datos históricos de estudios precedentes, realizados por Paolo Orsi, Giuseppe y Santi Luigi Agnello, y Linda Storaci. Estos estudios han confrontado esta iglesia con otras del mismo periodo: Sa Focà en Priolo y San Giovanni en Palagonia, en la Sicilia Oriental, y otras del área anatolia, todas cubiertas con este tipo de bóveda de piedra.

3 Existen ciertas controversias en cuanto al cambio de orientación del ábside en época bizantina. Se ha consultado a Emanuele Fidone sobre el tema, que ha aportado interesantes datos al respecto. Según la hipótesis de Giuseppe Agnello, el nuevo cuerpo que se adosa al Este constituiría un transepto, que se concluiría con un ábside. De todas formas, Fidone afirma que en las excavaciones realizadas no se han encontrado evidencias arqueológicas de la existencia de este ábside. 
Entre los siglos XVIII y XIX, el edificio es rodeado por edificaciones de vivienda que se adosan a la iglesia y la van colonizando, incluso llegan a ocupar parte del atrio interior.

Su degradación irá avanzando con los años, llegando incluso a ser tomado por los militares durante la primera guerra mundial, para su utilización como establo.
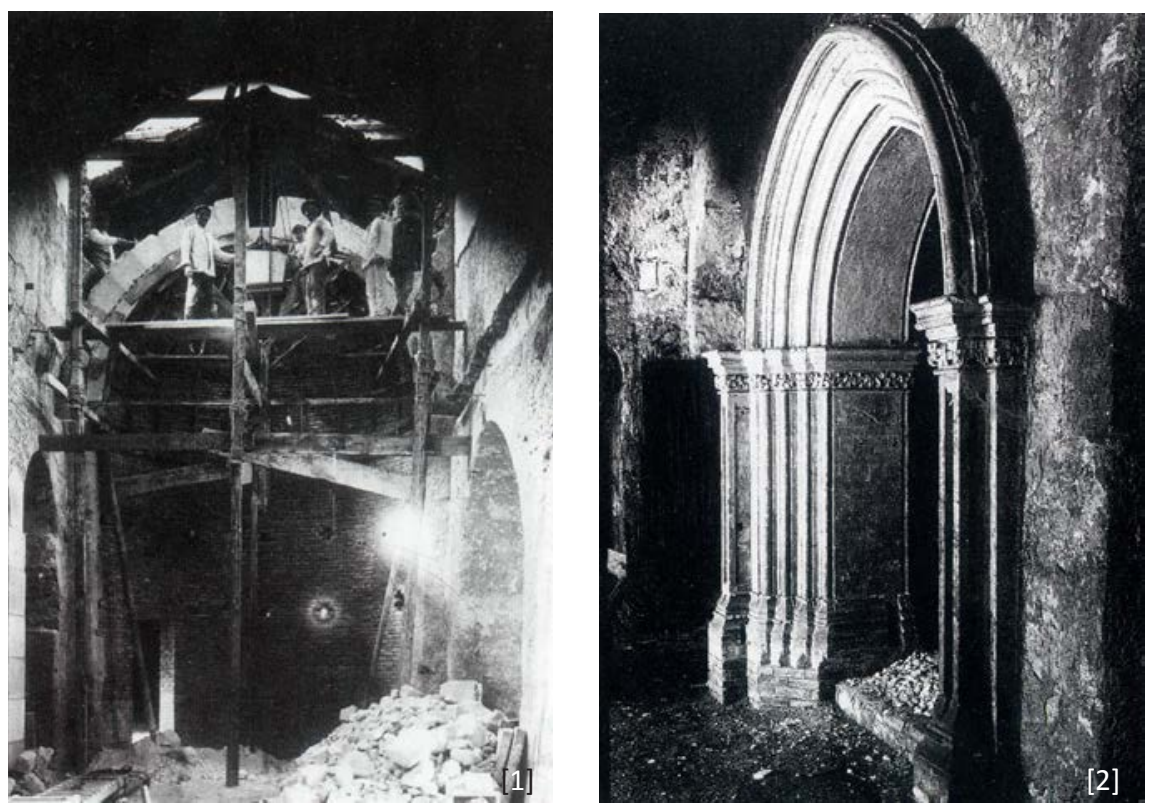

[1] Nave central. Trabajos Ilevados a cabo en los años veinte. (FIDONE: $R \& R, \mathrm{n}$ ㅇ 116-117, 2012)

[2] Interior de la nave sur donde se aprecia el portal gótico de acceso a la capilla del Santísimo Sacramento. (FIDONE: $R \& R, \mathrm{n}$ ㅇ 116-117, 2012)

[3] Vista exterior del portal de la fachada Este, tapiado. (FIDONE: $R \& R$, $\mathrm{n}$ 116-117, 2012)

[4] Vista del portal Este desde la nave central. (FIDONE: $R \& R$, $\mathrm{n}$ 은 116-117, 2012)
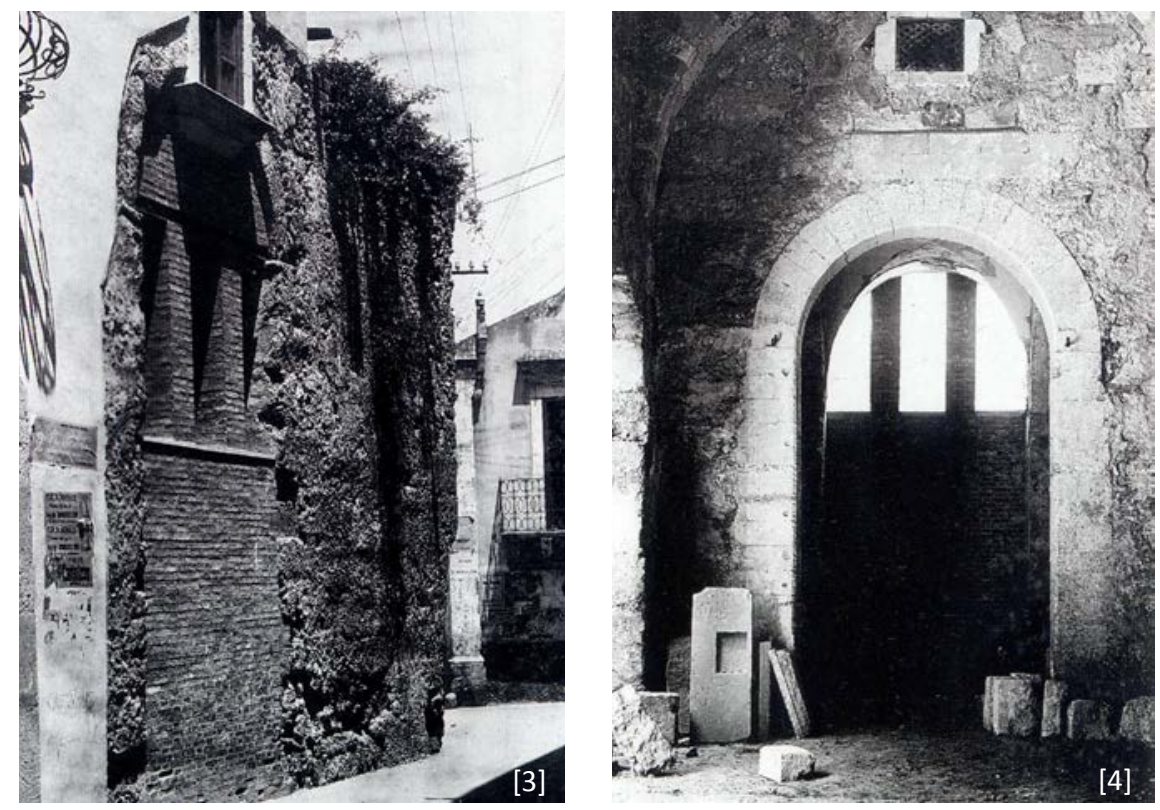
Finalmente, en los años veinte, se llevará a cabo una restauración filológica, que durará hasta los años cincuenta, y que estará encaminada a devolver la apariencia "original" de la iglesia paleocristiana, mediante unas operaciones que Fidone califica de agresivas, y que a su criterio suponen una alteración irreversible de la espacialidad interna. Entre estas actuaciones cabe destacar la eliminación de la bóveda de yeso barroca, dejando vistas las cerchas de madera que sustentan la cubierta, y la reconstrucción del ábside en el lado Oeste, siguiendo la traza del ábside original.

En los últimos años el espacio de la iglesia sufre un proceso de degradación generalizado, que se acentúa por su uso como sala de conciertos, función que supone la inserción de estructuras y añadidos impropios.
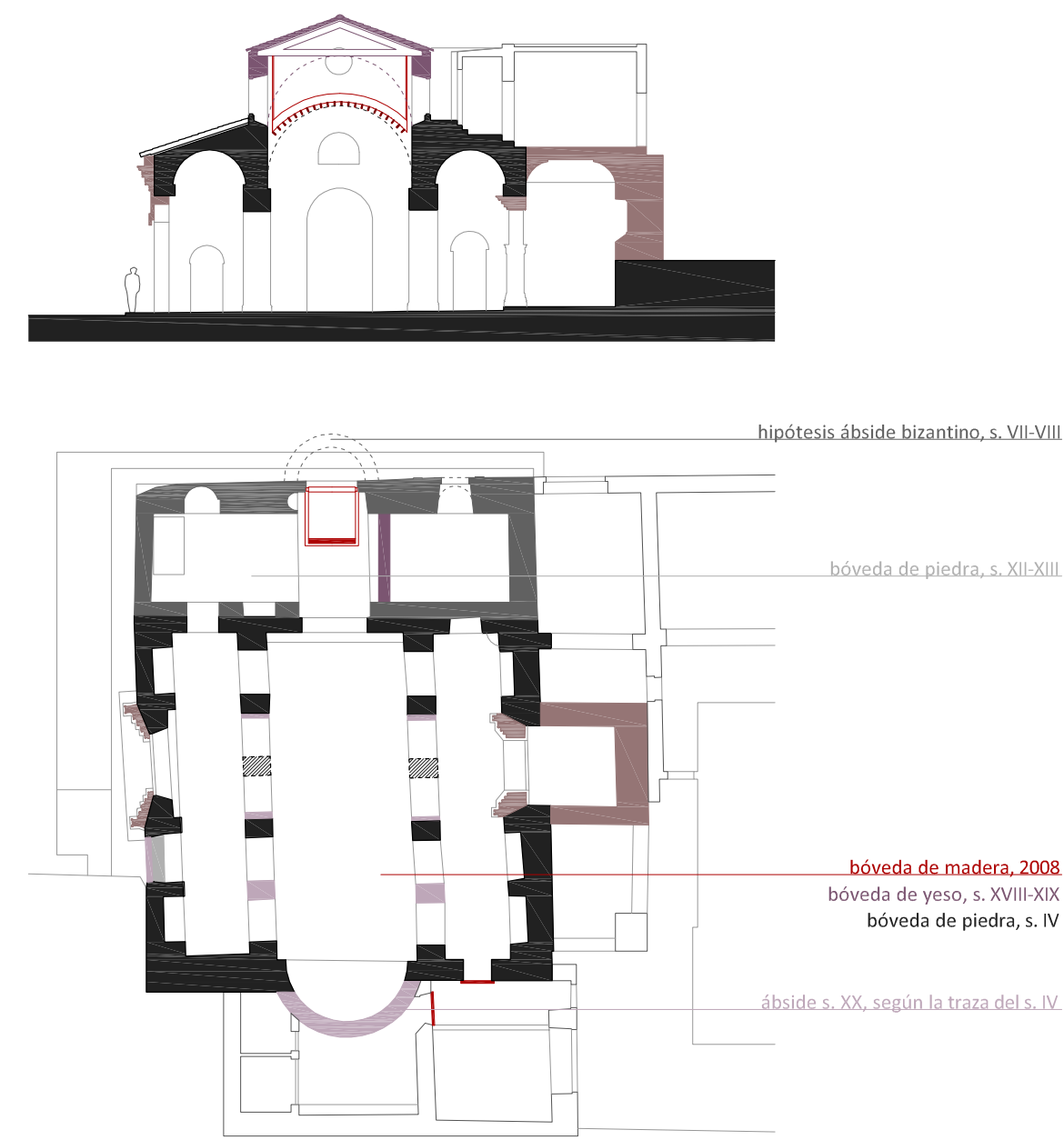

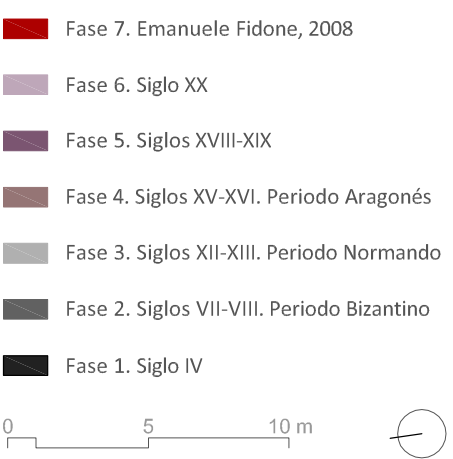


[5] Alzado Norte antes de la restauración. (FIDONE: $R \& R$, o 116-117, 2012)

[6 y 7] Levantamiento gráfico de la sección longitudinal y de la planta a cota $+1,5 \mathrm{~m}$. Estado previo a la intervención de Fidone. (FIDONE: $R \& R, \mathrm{n}$ ㅇ 116-117, 2012)

\subsection{Descripción del monumento}

Esta iglesia, cuyo origen se remonta a la época paleocristiana, se organiza en una nave central y dos laterales, orientadas en dirección este-oeste, con ábside semicircular en el extremo oeste. Las naves laterales se cubren con bóveda de cañón, mientras que la nave central sufre diversas transformaciones hasta configurarse como un espacio de mayor altura, con cubierta inclinada a dos aguas sobre cerchas de madera, e iluminado a través de cuatro huecos practicados en lo alto de los muros que lo delimitan.

En el extremo Este cuenta con una crujía de tres vanos, añadida en época bizantina, a modo de endonártex, con un ligero cambio de dirección respecto a la traza de las naves, que podría explicarse como una adecuación del nuevo cuerpo al trazado de la calle.

El espacio de la iglesia se completa con una capilla en el lado sur y una portada en el norte, que configuran un nuevo eje ordenador del edificio introducido entre los siglos XV y XVI. Este nuevo eje es transversal a las naves originales. Dicha modificación se hace evidente en los muros que delimitan la nave central, donde el ritmo de cinco huecos de época paleocristiana se altera para configurar huecos de mayor dimensión que apoyen el nuevo eje.
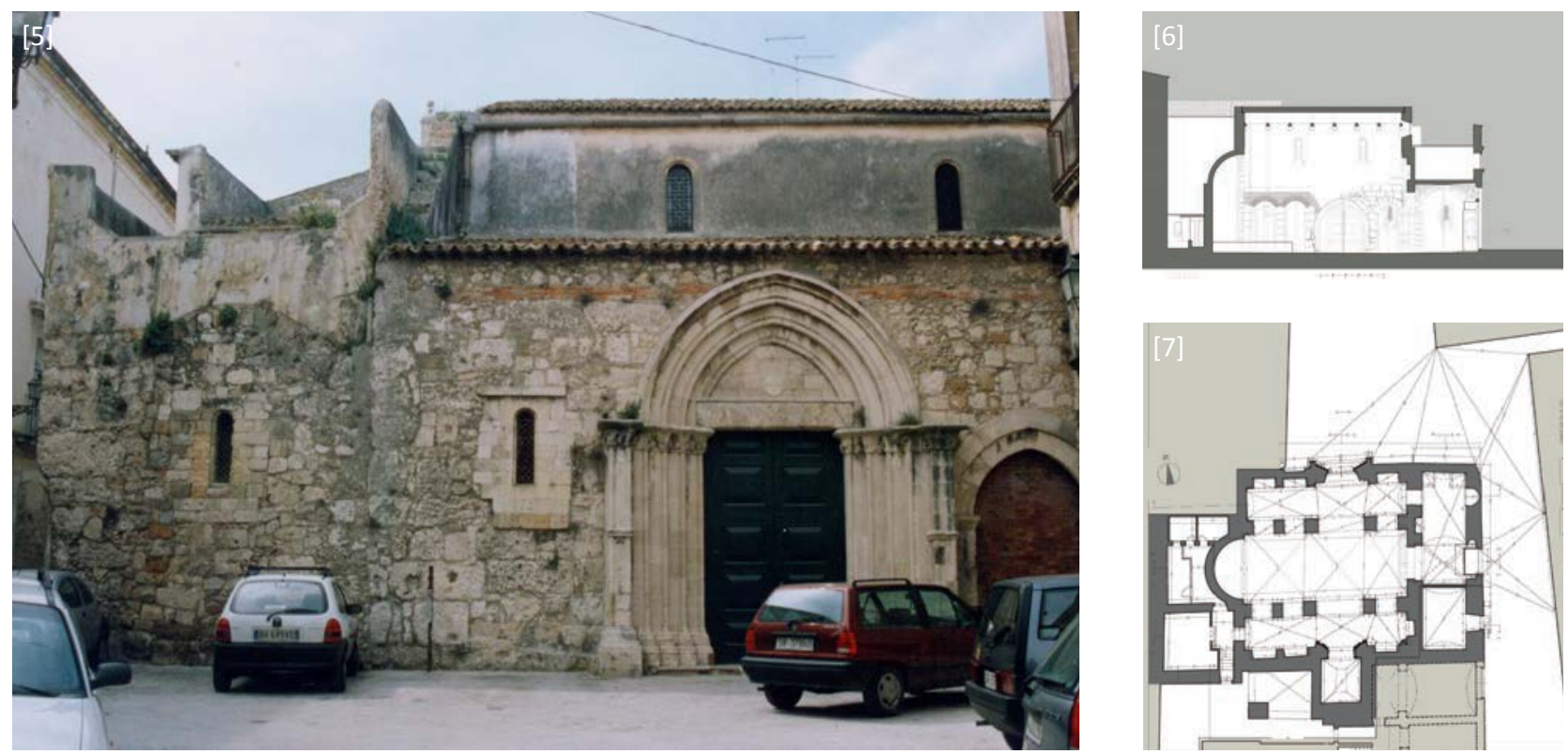


\subsection{Necesidad de la intervención}

Durante el siglo XX el edificio había sufrido una distorsión de su identidad. La actuación de restauración iniciada en los años veinte había eliminado los elementos de decoración barroca de la nave central, pero lo había hecho manteniendo en parte la nueva estructura formal introducida en el siglo XVIII, de mayor altura que la original.

Por un lado unas cerchas de madera soportaban una cubierta a dos aguas que remataban de forma banal el espacio. Por otro lado, la nueva altura había alterado la relación espacial entre las naves de la iglesia, produciendo una desconexión entre la horizontalidad de las naves laterales y la verticalidad de la nave central, y generando -según Fidone- una relación anómala entre las naves, que la nueva intervención debía mitigar.

Por otra parte, las intervenciones del siglo XX habían borrado gran parte de la historia del edificio, en su búsqueda por recuperar lo que consideraban la imagen original de la basílica. Una imagen que parece corresponderse más bien con la imagen ideal de una basílica paleocristiana, que con la realidad de lo que podría haber existido en origen en esta basílica en concreto.

Otra cuestión clave de la intervención es el tratamiento del endonártex, espacio a través del cual se producía el acceso a la iglesia en las primeras etapas de su evolución histórica. Durante la transformación de los siglos XV-XVI se había trasladado el acceso al lado Norte, cerrándose parcialmente el acceso original. Esta pérdida de importancia urbana, unida al aumento incontrolado de la densidad edificatoria, derivó en una invasión de la fachada por la expansión de las edificaciones vecinas. Las restauraciones de la primera mitad del siglo XX reabrieron el acceso colocando un gran portón de madera, sin tener en cuenta que el valor representativo y la escala de la fachada en relación con el contexto habían cambiado. Por lo que se hacía necesario dar una respuesta adecuada a las nuevas condiciones de este acceso.

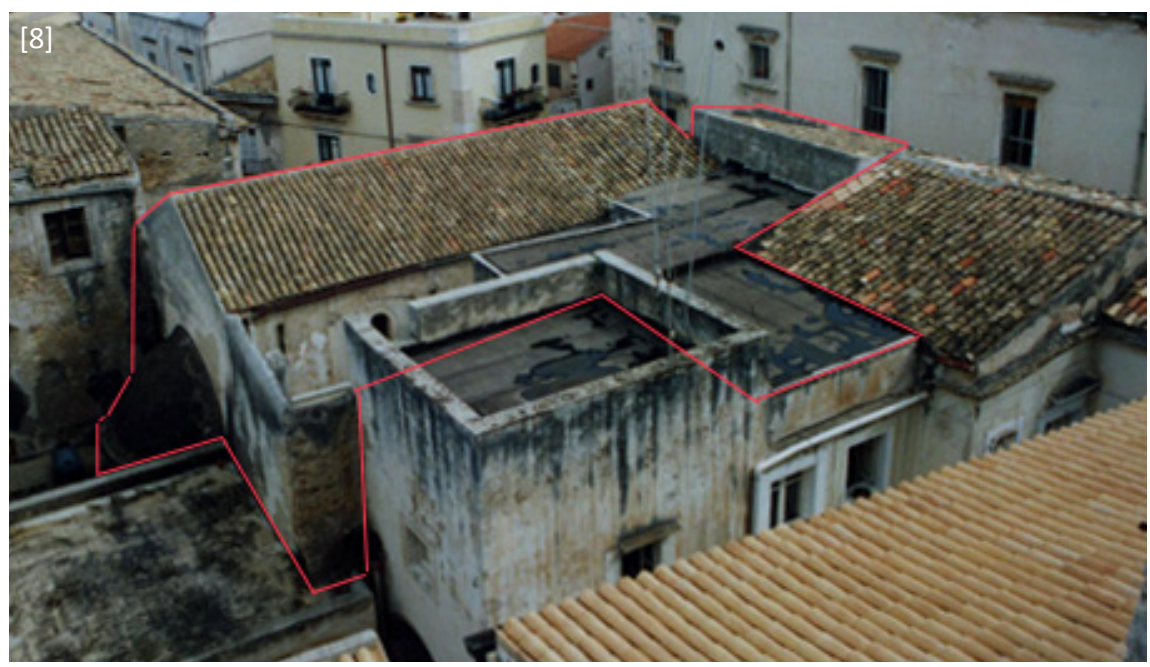

[8] Vista aérea antes de la restauración donde se aprecia la colonización de las edificaciones vecinas. (FIDONE: $R \& R$, $\mathrm{n}$ ㅇ 116-117, 2012)

[9] Fachada Este antes de la restauración. (FIDONE: $R \& R$, no 116-117, 2012)

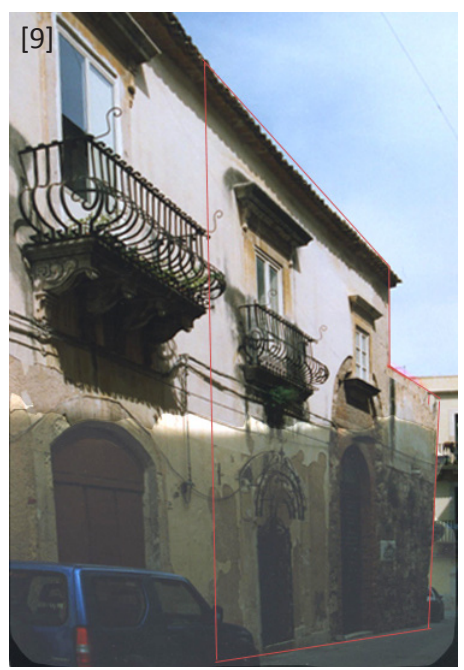




\section{EL ARQUITECTO RESTAURADOR}

4 FIDONE, E.: “Diario". D'Architettura, no35, abril 2008, p. 140

Disponible en: shttp://www.archinfo. it/whitepaper_library/Emanuele\%20 Fidone> [consulta 25-7-2012]

Para más información se puede consultar el libro de Emanuele Fidone titulado: From the Italian Vernacular villa to Schinkel to the modern house (Learning from), Cannitello (Reggio Calabria), Ed. Biblioteca del Cenide, 2002

5 FIDONE, E.: Op. Cit. 2008, p. 140

[10] Emanuele Fidone (Radiortm: $<$ www.radiortm.it $>$ )

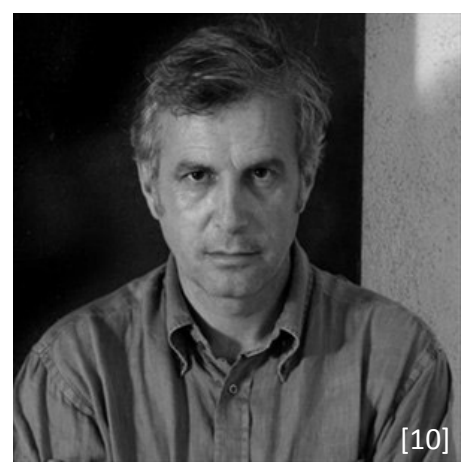

Emanuele Fidone nace en Modica, Sicilia, en 1957.

Estudia arquitectura en la Universidad de Venecia, donde se gradúa en 1984 con el profesor Mario Manieri Elia. A partir de este momento, desarrolla su carrera profesional como proyectista, investigador y docente.

Desde el año 2000 trabaja como profesor de proyectos arquitectónicos en la Facultad de Arquitectura de Siracusa (Università degli Studi di Catania), y desde el año 2008, como profesor contratado en la Facultad de Arquitectura Aldo Rossi, en Cesena (Università degli Studi di Bologna).

Entre sus publicaciones cabe destacar el libro From the Italian Vernacular villa to Schinkel to the modern house (Learning from), publicado en 2002.

\subsection{Relación con la historia y con la realidad física del lugar. La abstracción}

Fidone se gradúa en arquitectura con un trabajo de investigación sobre la arquitectura siciliana del siglo XVIII, en una búsqueda por volver a sus raíces y tender lazos con la historia de un contexto que había sido su entorno vital durante su infancia.

Este trabajo le lleva a interesarse por temas relacionados con la historia de la arquitectura, y no quedarse en el ámbito estricto de la composición arquitectónica. Esta inquietud se constata en sus proyectos, en los que se reflejaun interés porlahistoriay porsus huellas presentes en la realidadfísica.

En esta misma dirección, surge su interés por la figura de Schinkel, y los estudios que éste había realizado sobre la arquitectura vernácula en Sicilia. De su análisis extraerá interesantes conclusiones sobre las estrategias de relación entre las construcciones elementales del lugar y la morfología del paisaje sobre el que se asientan. Estrategias que, lejos de caer en lecturas nostálgicas, él mismo califica de "cargadas de una modernidad sorprendente". ${ }^{4}$

Esta actitud de Fidone, de búsqueda abstracta de relaciones con el lugar, queda patente en sus intervenciones sobre las preexistencias de la ciudad. Como él mismo afirma, actuar sobre el lugar no puede ser el resultado de la aplicación de teorías conceptuales o formalistas preconcebidas, sino que debe ser fruto de un proceso de análisis de la realidad construida y de la esencialización de sus valores espaciales y materiales. ${ }^{5}$ 


\subsection{Continuidad y equilibrio. Una relación dialéctica entre antiguo y nuevo}

Este proceso de análisis y abstracción traza un camino que huye tanto de actitudes de imitación como de contraste, y encuentra en la continuidad con lo antiguo su vía de actuación. Con ello, Fidone busca introducir en lo existente una mirada que ofrezca un nuevo equilibrio en la discontinuidad producida por el tiempo. ${ }^{6}$

Se trata de trazar una correspondencia entre nuevo y antiguo, que actúe de manera dialéctica, en los dos sentidos. De tal manera que la contextualización, la simplicidad formal y material, y la atención a las relaciones, se conviertan en referentes constantes del proyecto. ${ }^{7}$

En palabras de Fidone: "Trabajar sobre una preexistencia significa saber entretejer con ella un diálogo proyectual propositivo orientado a dar 'nuevo vigor', dar una respuesta creativa a la necesidad de transformación de lo existente, prefigurando de alguna manera un nuevo inicio". ${ }^{8}$

\subsection{La intención creativa}

Fidone se lamenta de que durante un largo período del siglo XX en Italia se haya abandonado el proyecto como herramienta de intervención, en favor de una defensa a ultranza de la historia del monumento, ya que esto ha supuesto una inhibición de la potencialidad creativa de lo nuevo sobre lo antiguo. Fidone entiende que es posible que, en ciertas ocasiones, las necesidades de la preexistencia exijan la repristinación de algunos elementos, la conservación en su estado de ruina o su reconstrucción, pero será en todo caso como resultado de una intención creativa de proyecto. ${ }^{9}$

Para Fidone, esta actitud de excesivo proteccionismo hacia la historia ha supuesto un rechazo de toda contaminación externa, provocando una situación ficticia. Una actitud que ha derivado, con cierta frecuencia, en un rechazo al proyecto en favor de "falsificaciones imitativas" que han distorsionado la autenticidad histórica del monumento. En este sentido, Fidone no duda en afirmar que "la realidad es algo vivo y mutable", y que se debe asumir que "lo antiguo sobrevive sólo si es continuamente reinterpretado". ${ }^{10}$
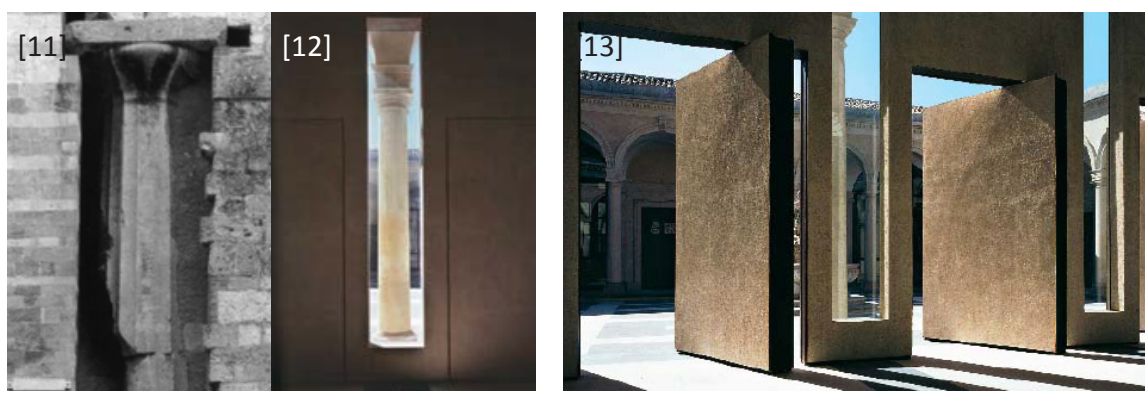

6 CORNOLDI, A.; RAPPOSELLI, M.: "Nuovo e antico. Intervista a Emanuele Fidone, Vicenzo Latina e Bruno Messina". En: Emanuele Fidone, Vincenzo Latina, Bruno Messina. 'Restauri' Iblei. Padova, Ed. II Poligrafo, 2007, p. 17

7 MULANZZANI, M.: "Basilica Paleocristiana di San Pietro, Siracusa. Spazio, materia e luce". Casabella, ำ780, Agosto 2009, p. 49

8 UGOLINI, A.: "Progetto, storia, restauro. Riflessioni in forma di conversazione intervista a José Ignacio Linazasoro, Emanuele Fidone e Bruno Messina". En: UGOLINI, A. (dir): Ricomporre la Rovina. Firenze, Alinea Editrice, 2010, p. 56

9 MULANZZANI, M.: Op. Cit. 2009, p. 49

10 CORNOLDI, A.; RAPPOSELLI, M.: Op. Cit. 2007, p. 14

[11 y 12] Columna dórica del templo de Atenea, formando parte de la estructura del Duomo de Siracusa, y columna del pórtico del Antiguo Mercado de Ortigia, vista desde el interior de la sala polivalente. (FIDONE. En: CORNOLDI; RAPOSELLI: 2007, pp. 72 y 73)

[13] Vista desde el interior de la nueva sala polivalente. (FIDONE. En: CORNOLDI; RAPOSELLI: 2007, p. 71) 


\subsection{Continuidad diacrónica}

11 FIDONE, E.: Op. Cit. 2008, p.140

12 UGOLINI, A.: Op. Cit. 2010, pp. 5354

13 CORNOLDI, A.; RAPPOSELLI, M.: Op. Cit. 2007, p. 19
Fidone dice que una de las cosas que ha aprendido en el trabajo sobre contextos antiguos, es "el valor del sentido de la continuidad diacrónica, de la lunga durata. Proyectar en un contexto estratificado significa comprender que cada estrato no es sólo forma o materia inerte sino que, por el contrario, es una especie de cristalización de un momento, de un tiempo preciso detrás del cual están la voluntad, el pensamiento y los deseos de los hombres que lo han realizado". ${ }^{11}$

En este sentido, Fidone se interesa por el valor significativo de las fases de la historia presentes en el monumento, entendiendo fundamental realizar una lectura profunda de cada una de estas etapas y de cómo se han materializado físicamente. Para Fidone, sólo partiendo de la comprensión de esta realidad, la nueva propuesta podrá ser capaz de encontrar una intensidad adecuada que introduzca un equilibrio en el conjunto.

\subsection{Concreción material}

Fidone le otorga gran importancia a la relación entre materia y espacio, más allá de la forma, de tal manera que entiende que, cuando trabajamos sobre una preexistencia, esta "materia viva" debe tener nuestra mayor atención.

Fidone hace hincapié en esta cuestión, advirtiendo que la historia más reciente ha producido un distanciamiento con la realidad física, que todavía hoy está presente en algunas visiones academicistas alejadas de la realidad. En su opinión, por un lado con el Movimiento Moderno se produce una abstracción del proyecto que descuida la complejidad de la realidad a nivel matérico, espacial y perceptivo; y por otro lado, a partir de la posguerra, se lleva a cabo una estandarización de las modalidades de intervención con el objetivo de alcanzar mayor "calidad", que produce un progresivo distanciamiento de la concreción del proyecto arquitectónico. ${ }^{12}$

En esta línea, Fidone defiende que en una intervención, la fase de proyecto es sólo una parte de la actuación, y destaca la importancia de su puesta en obra como una parte fundamental del proceso, de tal manera que el proyecto debe estar abierto a nuevos descubrimientos durante el proceso constructivo. Dentro de este proceso, los oficios juegan un papel fundamental, pues su profundo conocimiento de la práctica ayuda a que las ideas del proyecto puedan llevarse a cabo de la mejor manera posible. ${ }^{13}$

Para Fidone hasta las operaciones más simples, como la limpieza de un paramento, requieren de una reflexión crítica, de tal manera que la actuación siga la dirección de las intenciones proyectuales. En esta línea, Fidone rechaza la imagen de superficie limpia y nueva, en favor de la pátina, pues ésta es de alguna manera la sustancia misma del tiempo, y se debe entender como un valor añadido al proyecto. 


\subsection{Las referencias}

Como ya se ha comentado, Fidone muestra una especial atención hacia la figura de Schinkel, en concreto hacia los estudios que realiza sobre la arquitectura vernácula de Sicilia, una arquitectura capaz de relacionarse con el contexto a través de su definición constructiva.

Por otro lado, le interesan obras contemporáneas que aportan nuevas opciones de proyecto, como algunas obras de los arquitectos japoneses Tadao Ando o Kengo Kuma, que introducen nuevas maneras de relacionarse con la naturaleza.

Arquitectos como Albini, Gardella o Scarpa le interesan por la sabiduría que han demostrado al conjugar elementos de la tradición con elementos derivados del movimiento moderno. En particular destaca la labor de Carlo Scarpa, y el uso que hace de los materiales y soluciones constructivas en obras de restauración de forma innovadora, consiguiendo un "equilibrio admirable de fusión con la preexistencia".

De Francesco Venezia aprecia su integridad intelectual, defendiendo una actitud lejana de la fugacidad de las modas. Su obra apunta a una arquitectura atemporal que encuentra en la reinterpretación del pasado una "fuente inagotable de creatividad".

Rechaza, sin embargo, las obras que en un acto de ostentación formal o tecnológica, demuestran una autorreferencia que desequilibra la armonía con el entorno. $\mathrm{O}$ también rechaza a aquellos arquitectos que se escudan en la defensa de la historia como justificación para basar sus elecciones proyectuales, tratando de ocultar con ello una carencia de sensibilidad para la creación arquitectónica.

Un claro ejemplo de los problemas de las teorías arquitectónicas conservadoras queda reflejado en la propuesta realizada por Vittorio Sgarbi para la cubierta de la Villa del Casale en Piazza Armerina. Sgarbi elimina la cubierta transparente proyectada por Franco Minissi en 1957, y la sustituye por otra de madera que trata de reconstruir el volumen original. Con ello se configura un ambiente cerrado y un elemento pesado, que resulta ser mucho más inadecuado en el contexto que la abstracción de la estructura de acero y vidrio de Minissi. ${ }^{14}$
14 CORNOLDI, A.; RAPPOSELLI, M.: Op. Cit. 2007, p. 18

[14] Carlo Scarpa, Galleria Nazionale della Sicilia. Palazzo Abatellis, Palermo 1953-54. (CORNOLDI; RAPPOSELLI: Nuovo e Antico, no 03, 2007, p. 15)

[15] Franco Minissi, restauración de la Villa del Casale, Piazza Armerina 1970. (CORNOLDI; RAPPOSELLI: 2007, p. 19)
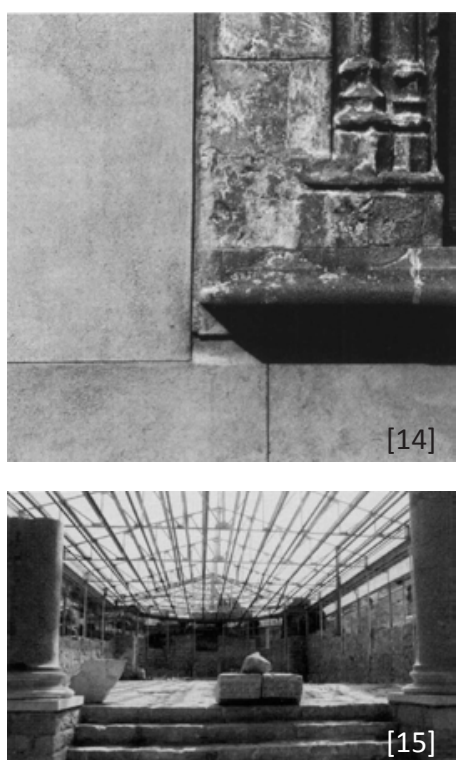


\subsection{La potencia renovadora de las ruinas ${ }^{15}$}

15 FIDONE, E.: "Framenti. II progetto e la potenza rinnovatrice delle rovine". En: UGOLINI, A.: Ricomporre la Rovina. Firenze: Alinea Editrice, 2010, pp. 26-31

16 Fidone cita a Marc Augé, en su libro Rovine e Macerie, Torino, 2004, p. 44

17 Fidone cita a Georg Simmel, en su libro La Rovina, 1981, pp. 121-127, originalmente publicado en 1909-1911.
En el texto "Framenti. II progetto e la potenza rinnovatrice delle rovine", Fidone muestra un gran interés por las ruinas, como elementos portadores de una fuerza particular. De las ruinas se desprende una especie de "tiempo puro, al margen de la historia", de tal manera que al contemplarlas parece que ayudan a comprender la existencia. ${ }^{16}$

Destaca el papel que tiene Georg Simmel a la hora de precisar la cualidad y las peculiaridades de la ruina en relación con el proyecto arquitectónico. A diferencia de la escultura, que emplea el mármol sólo como material para producir la obra, la arquitectura debe interactuar con las fuerzas de la naturaleza para poder existir.

Así, la arquitectura busca el equilibrio entre la fuerza de la gravedad y la resistencia de los materiales para alcanzar una "espiritualidad constructiva". Frente al peso del mundo se opone una levitación de la materia, logrando con ello "la más sublime victoria del espíritu sobre la naturaleza" ${ }^{17}$

Cuando se rompe este equilibrio, se produce la ruina. Pero la ruina establece un nuevo equilibrio generando una nueva forma estética estable y autónoma, esta vez producida por el capricho de la naturaleza, y no por la acción del hombre. Así, Simmel concluye que la arquitectura es el fruto de un pensamiento abstracto que no podrá nunca encontrar un vínculo positivo con la Naturaleza a menos que se transforme en ruina.

Otra cuestión que destaca Fidone, es la relación entre la ruina y el edificio en fase de construcción. A propósito de esta relación entre ruina y obra, Fidone menciona la figura del arquitecto John Soane.

Soane, al Terminar la obra del Banco de Inglaterra en Londres, hace pintar una representación a vista de pájaro del edificio reducido a estado de ruina. Con ello Soane parece estar queriendo exaltar la grandiosidad de

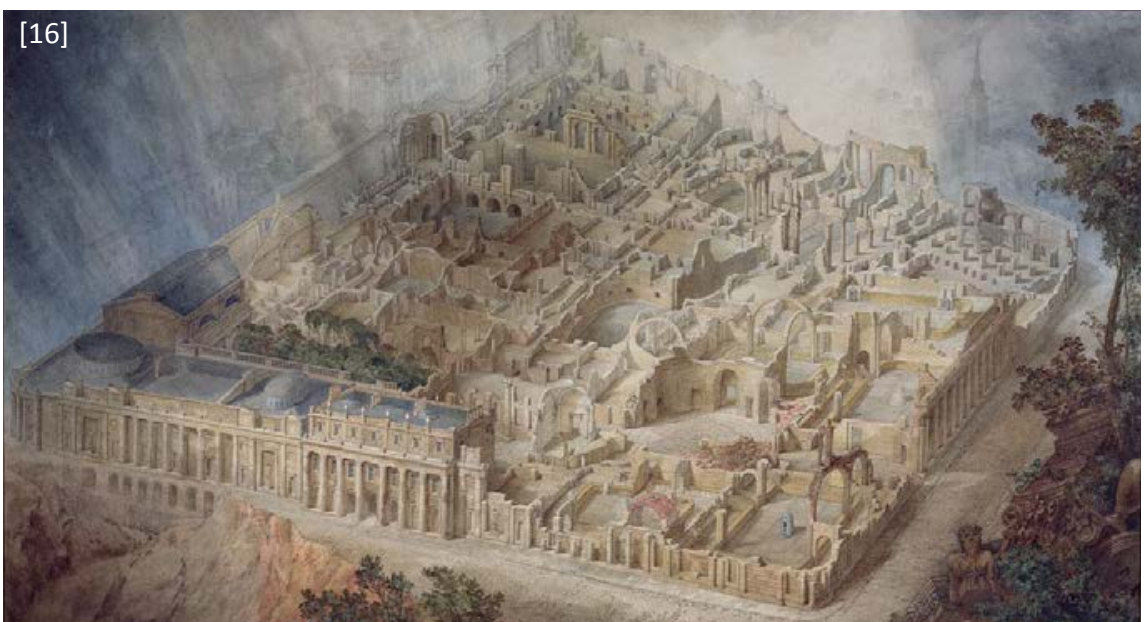

[16] Representación del Banco de Inglaterra en ruinas, Londres, 1830. Pintura de Joseph Michael Gandy. (Sir John Soane's Museum: <www. jeromeonline.co.uk>) 
la obra, a través de la fuerza que sólo el estado de ruina consigue evocar, mostrando su solidez constructiva y matérica. Pero también puede estar buscando hacer referencia a la idea de atemporalidad propia de las ruinas romanas, en una exaltación del concepto de tiempo indefinido.

El interés de Soane por las ruinas se aprecia con claridad en su casa de Lincoln's Inn Fields de Londres, donde introduce un inmenso número de fragmentos de diversas épocas. Soane llega a describir la casa como hallazgo de un hipotético arqueólogo del futuro. Esta vez, encarga un dibujo de la casa donde se representa el patio plagado de fragmentos e iluminado por una luz cenital proveniente de una bóveda perforada.

Con estas reflexiones, Fidone trata de indagar en la relación entre nuevo proyecto y ruina, en el tema de la continuidad entre pasado y futuro. Entiende que esta difícil confrontación puede ayudar a "reavivar los valores primigenios del hacer arquitectónico". Así pues, frente a la conservación acrítica de la ruina, Fidone apuesta por su reutilización a través de una "confrontación creativa de los principios de la contaminación y del injerto", posibilitando la aparición de nuevas e interesantes soluciones interpretativas.

En esta línea, Fidone recuerda las reflexiones de Giorgio Grassi a propósito de su intervención en el Teatro Romano de Sagunto, en las que presenta una visión de las ruinas del Teatro como una obra incompleta, que exhibe problemas abiertos, aún por resolver, y entiende que existe la posibilidad de formar parte de ese trabajo ya iniciado por los antiguos. ${ }^{18}$

Así, Fidone entiende que a través del proyecto se puede establecer un nuevo sistema de equilibrio entre "la dualidad de la percepción matéricotemporal de la ruina y la expresión de lo nuevo".

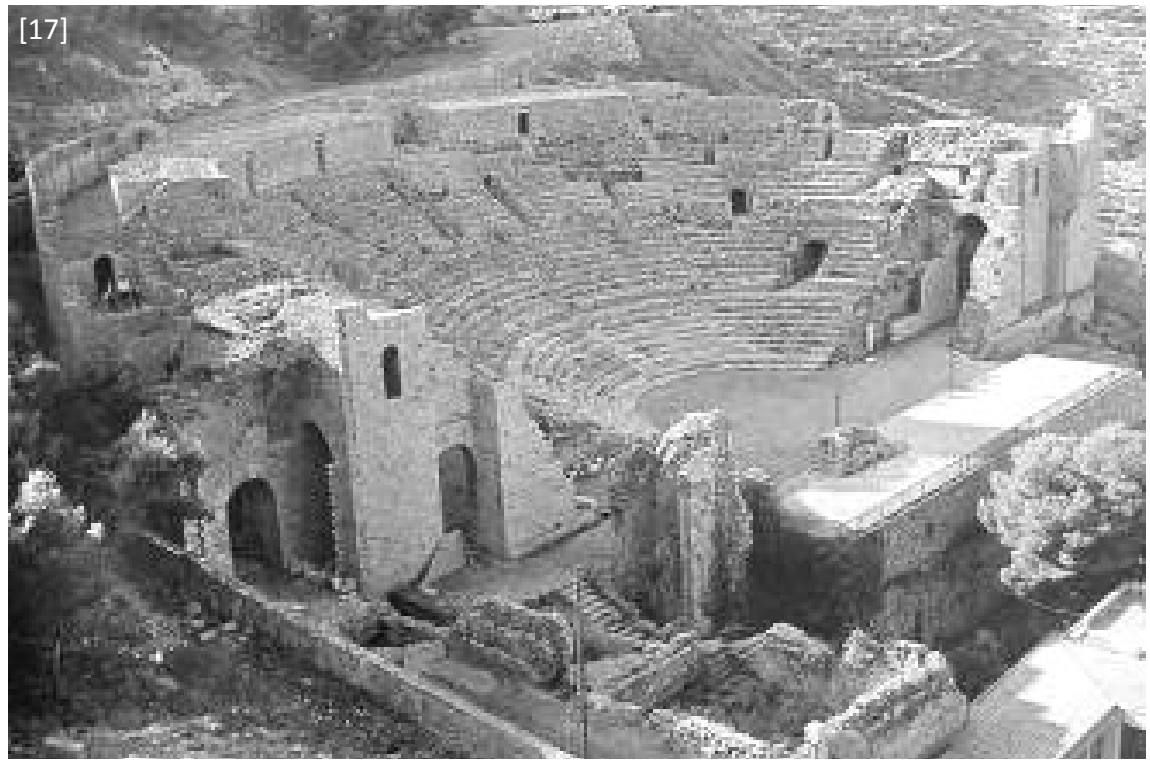

18 Fidone cita a Giorgio Grassi, por su artículo: GRASSI, G.: "Un Parere Sul Restauro dei Monumenti (a proposito del Teatro di Sagunto)" [Algunas Consideraciones Sobre la Restauración de los Monumentos. (A propósito del Teatro de Sagunto)], Cuadernos de Arquitectura Romana, vol. 2, 1993, pp. 47-50 / 239-240

[17] Ruinas del Teatro Romano de Sagunto tras las restauraciones realizadas en los 70. (BELTRÁN: <elpais.com>)

[18] Representación de la Casa de Soane, realizada por J.M. Gandy. Vista del área de la cúpula con la cripta. Londres, 1811. (FIDONE: Ricomporre la Rovina, 2010, p. 31)

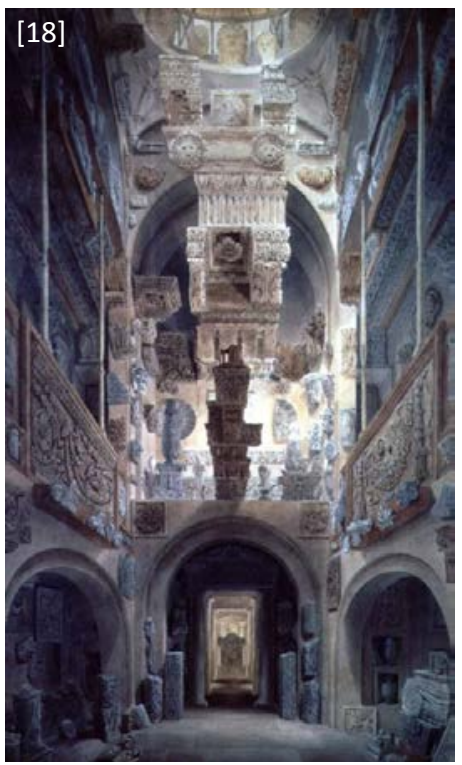




\subsection{Santa Maria del Gesù en Modica. 1992-96, 2005-07 ${ }^{19}$}

19 Para más información sobre esta obra consultar:

FIDONE, E.; MESSINA, B.: "Sistemazione del Convento di S. Maria del Gesù a Modica, Ragusa". L'industria delle costruzioni, ํㅡ 368, noviembrediciembre 2002, pp. 16-23;

FIDONE, E.; MESSINA, B.: "Restauro del convento di Santa Maria del Gesù". En: CORNOLDI, A.; RAPPOSELLI, M.: Emanuele Fidone, Vincenzo Latina, Bruno Messina. 'Restauri' Iblei. Padova, Ed.Il Poligrafo, 2007, pp. 88-115

[19] Santa Maria del Gesú, en Modica. Imagen exterior tras la intervención. (Fotografía de L. Rubino. En: FIDONE; MESSINA: Nuovo e Antico, n우 03, 2007, p. 95)

[20] Santa Maria del Gesú. Detalle de revestimiento en cocciopesto. (Fotografía de L. Rubino. En: FIDONE; MESSINA: Nuovo e Antico, no 03, 2007, p. 105)

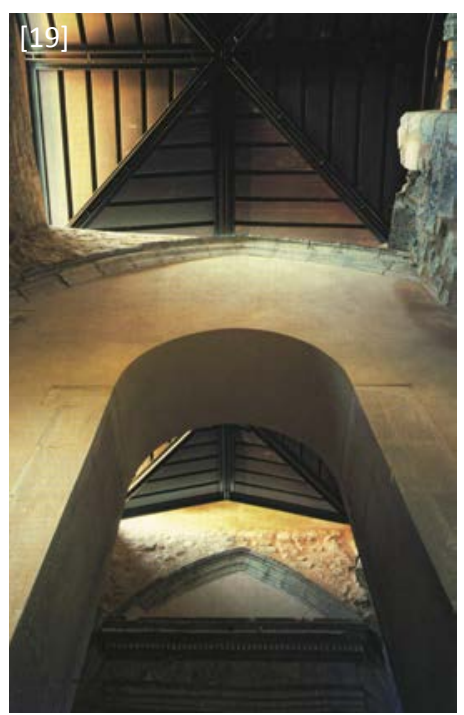

La actuación en la iglesia del complejo conventual de Santa Maria del Gesù, en Modica, de Emanuele Fidone y Bruno Messina, es un precedente a la actuación en San Pietro.

Aquí, Fidone se enfrenta a una situación en la que surge la necesidad de completar unos espacios abovedados que habían perdido su cierre superior, presentando un estado de ruina parcial.

Fidone busca dar una solución que se relacione con la preexistencia sobre la que actúa, planteando los nuevos elementos como nuevos estratos en la historia del monumento. Estos nuevos elementos se conforman como piezas ligeras y esenciales que se posan sobre los restos, respetando la materia de las partes preexistentes y reinterpretando las partes ausentes.

La actuación sobre la cubierta de la nave central de la iglesia busca evocar la espacialidad barroca conformada en el siglo XVIII. Unas vigas de madera laminada, con traza en forma de arco, permiten -gracias a la docilidad de la madera-adaptarse a las deformaciones dimensionales preexistentes de la antigua estructura de la nave.

La solución para la cubierta de las capillas laterales difiere de la anterior, en respuesta a su distinta referencia histórica. Las bóvedas de crucería originales se reinterpretan mediante una estructura de acero emulando los nervios, y con láminas de cobre oxidado haciendo las veces de plementería. Las nuevas cubiertas se elevan sobre los muros de la iglesia permitiendo la entrada de luz natural, reforzando con ello el concepto de elemento superpuesto sobre una ruina.

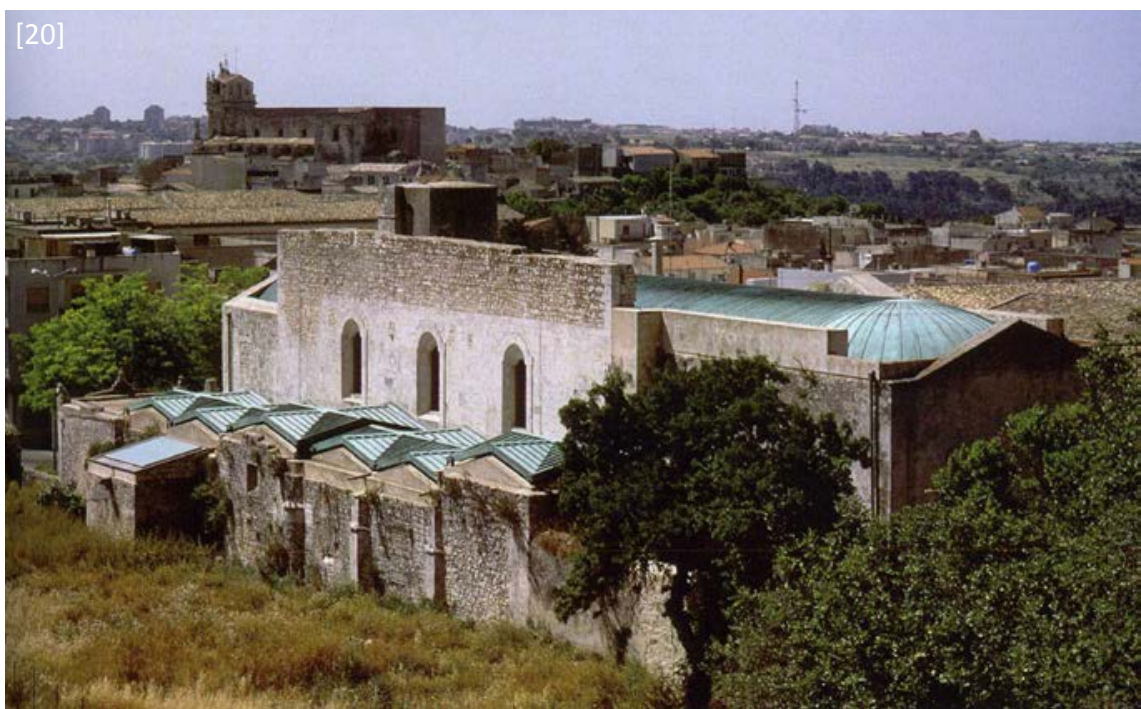


Las lagunas presentes en los muros se unifican con un revestimiento en cocciopesto que aporta una superficie abstracta, que mantiene identificables los faltantes sin producir distorsiones en el tono de los paramentos.

Es interesante observar cómo, mientras que la reinterpretación de la cubierta de las capillas laterales se inspira en la fase gótica originaria del convento, por permanecer como la etapa más evidente en su constitución formal, sin embargo la actuación en la nave central se basa en la reproposición de la fase barroca, evitando tratar de recuperar un origen gótico hoy completamente desaparecido.

De la solución propuesta para esta última, es interesante advertir cómo en el proyecto se habían previsto con detalle unos travesaños de madera que ayudaban a definir la geometría de los lunetos de la bóveda, y que hubieran permitido una mayor integración formal con el espacio. En cualquier caso, a mi entender, la solución adoptada transmite la sensación de que existe un problema en la definición de la bóveda, como si los elementos que la definen estuvieran fuera de escala, o como si su construcción hubiera quedado inacabada, faltando por colocar la superficie de terminación.

En contraste con esta solución, sorprende el diseño propuesto para el cierre de las capillas laterales, en el que se observa un detenido estudio de la geometría de las piezas que componen los nervios y la plementería, y donde el juego de luces y sombras que se produce entre las pletinas que conforman los elementos de las nuevas "bóvedas" permite constituir una solución refinada y elegante, en correspondencia con las evocadas bóvedas góticas.

Posiblemente, el objetivo de Fidone al hacer la cubierta-bóveda de la nave central, sea el de mostrar este nuevo estrato de la historia del edificio como una actuación "abierta y en proceso", que conecta perfectamente con la idea de la ruina, pero también con la certeza de que esa cubierta no está evocando la solución original, pues una evocación de la cubierta gótica hubiese excluido su fase barroca. Sin embargo en las capillas las cubiertas evocan la solución original gótica, aunque con una forma abstracta y autónoma, y mostrándose con un cierto carácter efímero.

Al exterior la solución también presenta diferencias entre ambos elementos. Si bien el material empleado es el mismo, la geometría y la expresión visual varían. Mientras que la cubierta curva de la nave central se oculta tras los muros que definen el perímetro de la iglesia, las cubiertas de las capillas laterales se muestran con claridad al exterior evidenciando su naturaleza de estrato superpuesto.
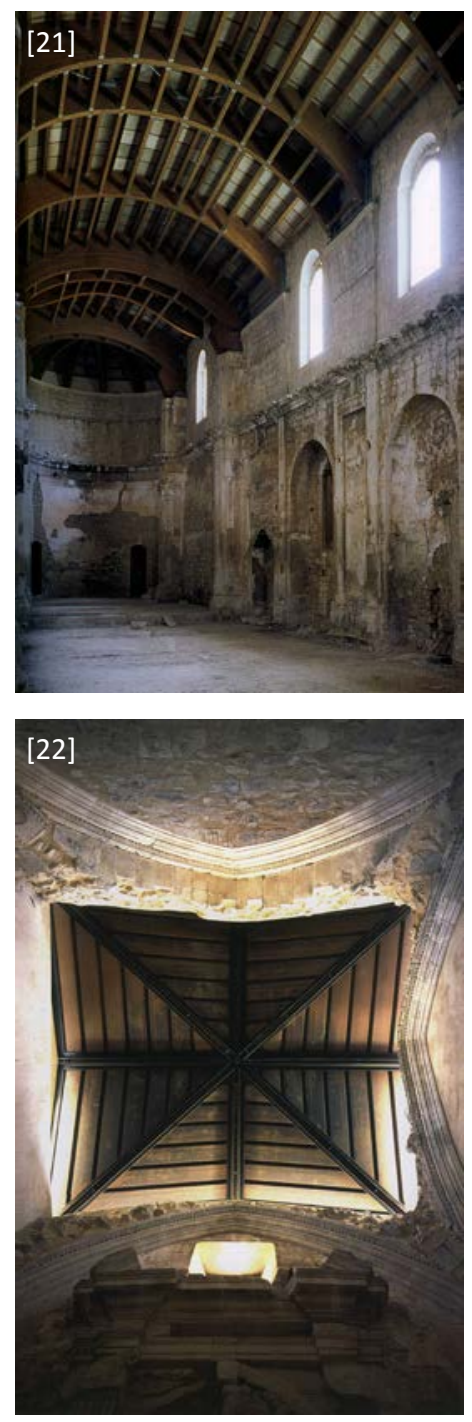

[21] Santa Maria del Gesú. Nuevo cierre de la nave central. (Imagen de L. Rubino. En: FIDONE; MESSINA: Nuovo e Antico, no 03, 2007, p. 99)

[22] Santa Maria del Gesú. Cierre de las capillas laterales. (Imagen de L. Rubino. En: FIDONE; MESSINA: Nuovo e Antico, no 03, 2007, p. 107) 


\subsection{Nuevo centro Turístico en el antiguo mercado cubierto de Ortigia. 1997-200020}

20 Para más información sobre esta obra consultar:

FIDONE, E.; MESSINA, B.: “Centro civico, Modica. Ex mercato coperto di Ortigia, Siracusa". Domus, n9929, octubre 2009, pp.112-119;

FIDONE, E.: "Polo servizi turistici nell'ex mercato coperto di Ortigia, Siracusa". En: CORNOLDI, A.; RAPPOSELLI, M.: Emanuele Fidone, Vincenzo Latina, Bruno Messina. 'Restauri' Iblei. Padova, Ed. II Poligrafo, 2007, pp. 58-87

[23] Antiguo mercado de Ortigia. Vista exterior. (Imagen de L. Rubino. En: FIDONE: Nuovo e Antico, no 03, 2007, p. 64)

[24] Antiguo mercado de Ortigia. Detalle de la restauración de la piedra en la parte del basamento exterior del muro sur. (Imagen de L. Rubino. En: FIDONE: Nuovo e Antico, no 03,2007, p. 87)

[25 y 26] Antiguo mercado de Ortigia. Planta y sección de conjunto del nuevo centro turístico en relación con el área arqueológica del Apollonion. (FIDONE: Nuovo e AntiCo, no 03,2007, p. 65)
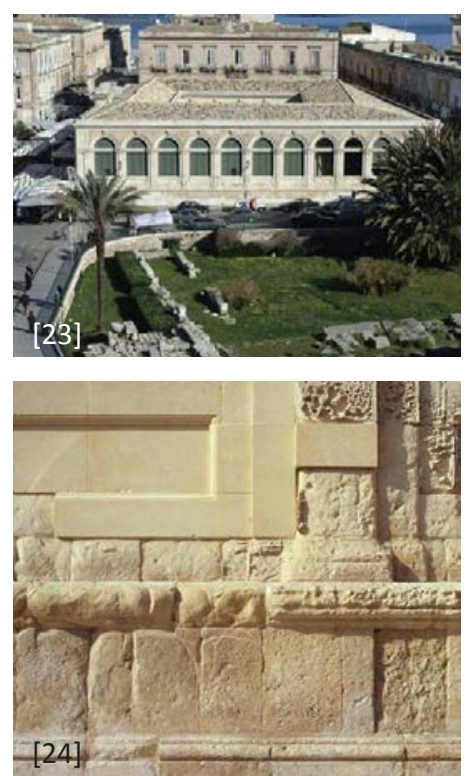

En este proyecto se busca introducir nuevas relaciones con los restos del vecino templo griego de Apolo mediante el trabajo con la materia, la transparencia y la memoria. Para ello se opta por el empleo de pocos materiales: piedra caliza, cocciopesto, vidrio, acero oxidado y yeso. Además su puesta en obra se realiza mediante soluciones sencillas que no tratan de ocultar los procesos constructivos de carácter artesanal.

El tratamiento de la piedra que compone la fachada del edificio, se lleva a cabo con un criterio de mínima intervención. Se sustituyen sólo los sillares necesarios para garantizar la estabilidad de la fábrica, tratando de mantener el máximo de degradación de los paramentos, por entenderse como una manifestación de la idea del paso del tiempo. De esta manera, el contrate entre los sillares degradados por la lluvia y el viento y los nuevos sillares, parecen mostrar dos fases distintas del mismo elemento, haciendo aún más patente el poder del tiempo como escultor.

La nueva sala polivalente, ubicada en una de las alas del edificio del mercado, se cubre con tres fragmentos de bóvedas de cañón, cuya disposición guía la mirada hacía el área del Templo, visible a través de las arcadas del muro de fachada. El empleo de estas formas abovedadas conecta con el concepto de la arquitectura del pasado, presente en la memoria colectiva.
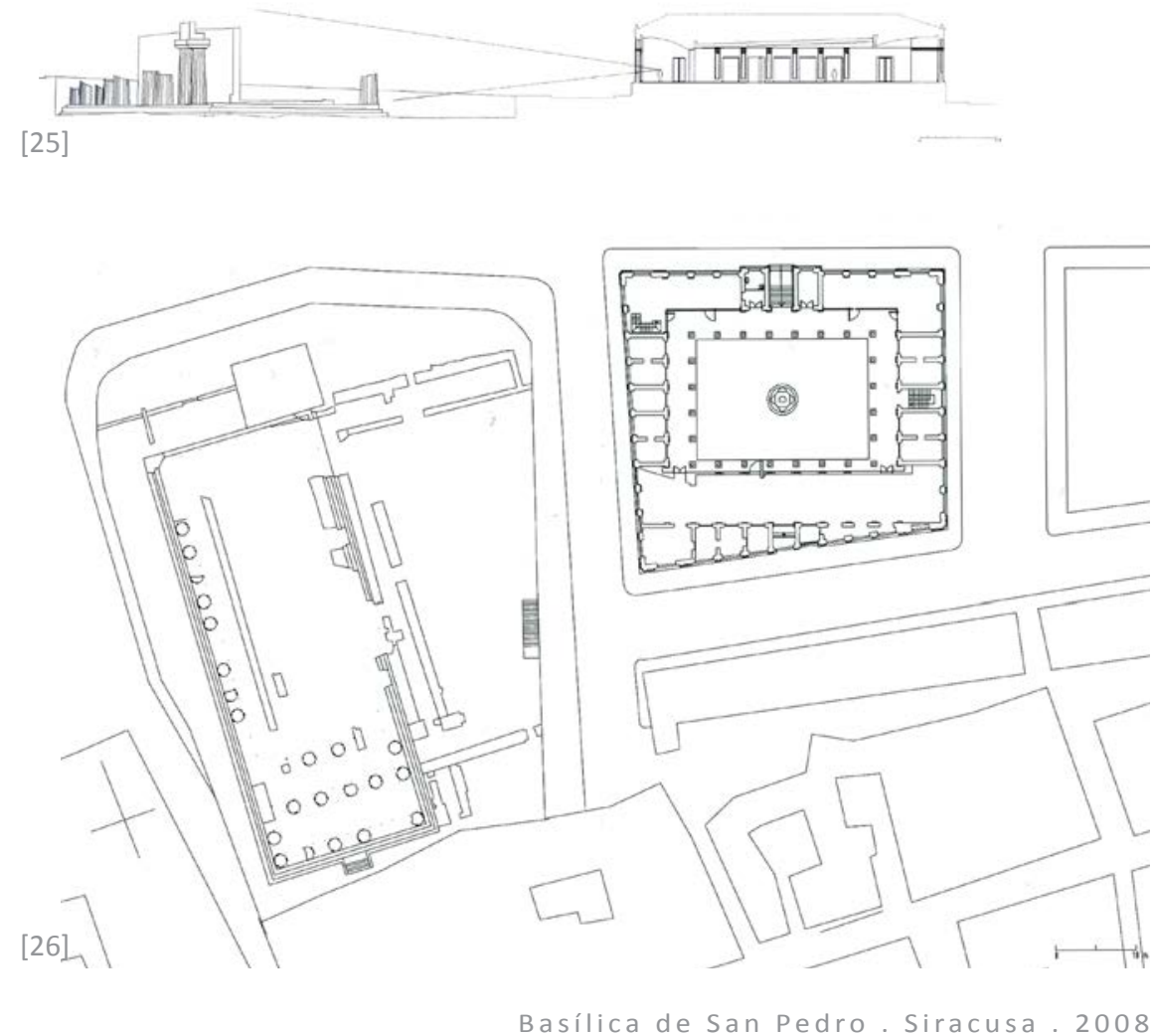
El cerramiento de la sala hacia el patio se resuelve con grandes paneles basculantes, alternados con piezas verticales de vidrio colocadas a eje de las columnas, creando un juego de luces y sombras que invierte la composición de llenos y vacíos del pórtico y permite establecer una relación visual directa entre el espacio de la sala y el claustro. La variación en la apertura de estos paneles permite regular la entrada de luz en la sala, así como el grado de presencia material del cerramiento, produciendo una transición que va desde el hermetismo del muro hasta la permeabilidad del pórtico.

Este elemento de cerramiento se presenta con una gran densidad de referencias: el revestimiento de cocciopesto permite establecer una unidad material con la piedra caliza del edificio; los huecos verticales de vidrio recuerdan las columnas del Templo de Atenea, atrapadas entre muros de la Catedral de Siracusa; y el espacio entre el pórtico y el nuevo elemento de cerramiento recuerda el pteron del Templo dórico de Apolo.

Por último, el ala norte del espacio porticado se delimita con un cerramiento de vidrio con carpintería de acero oxidado. Un elemento resuelto mediante la unión de perfiles elementales de acero, pero dispuestos de tal manera que se produce un complejo juego de luces y sombras que consiguen que se desmaterialice.
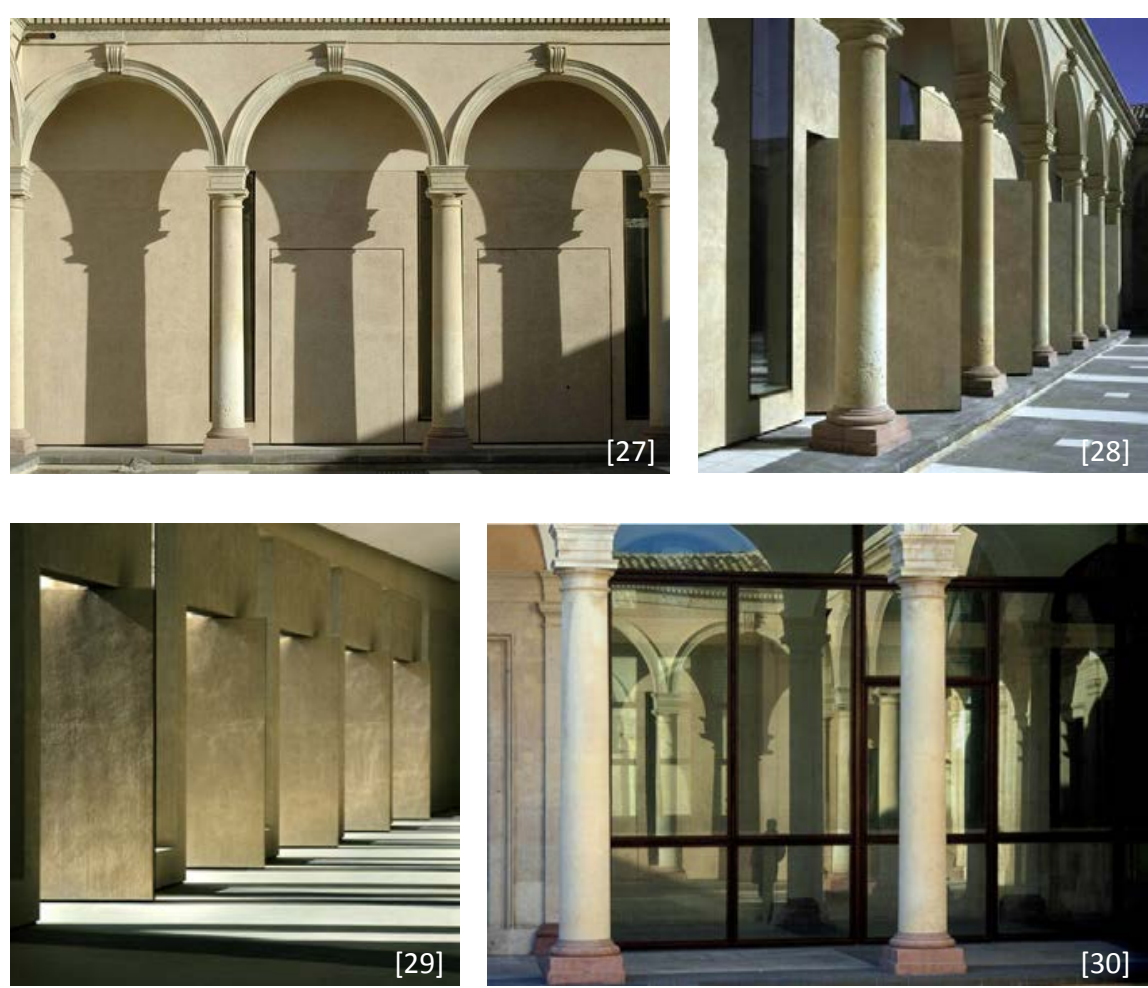

[27 y 28] Antiguo mercado de Ortigia. Imagen del pórtico tras la intervención. (Imagen de L. Rubino. En: FIDONE: Nuovo e Antico, no 03, 2007, pp. 68 y 69)

[29] Antiguo mercado de Ortigia. Vista del interior de la sala. Los paneles están abiertos y permiten la entrada de luz. (FIDONE: Nuovo $e$ Antico, no 03, 2007, p. 78)

[30] Antiguo mercado de Ortigia. Cerramiento de vidrio del ala norte. (FIDONE: Nuovo e Antico, no 03, 2007, p. 84) 


\subsection{Centro polivalente en Modica. 2002-08}

21 Para más información sobre esta obra consultar:

FIDONE, E.; MESSINA, B.: "Centro civico, Modica. Ex mercato coperto di Ortigia, Siracusa". Domus no 929, octubre 2009, pp. $112-119$

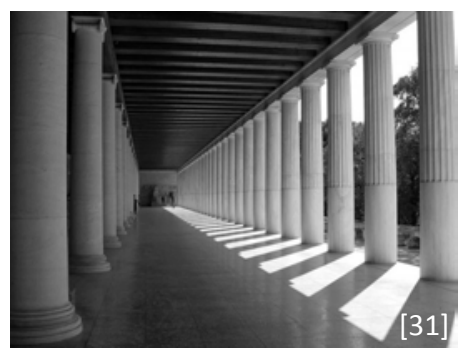

[31] Stoa de Attalos. (Triposo: $<$ www.triposo.com>)

[32] Centro cívico polivalente en Modica. Vista desde el edificio hacia el acceso. (Fotografía de Lamberto Ribino. En: FIDONE: Europaconcorsi)

[33] Centro cívico polivalente en Modica. Vista del acceso al centro polivalente. (Fotografía de Lamberto Rubino. En: FIDONE: Europaconcorsi)

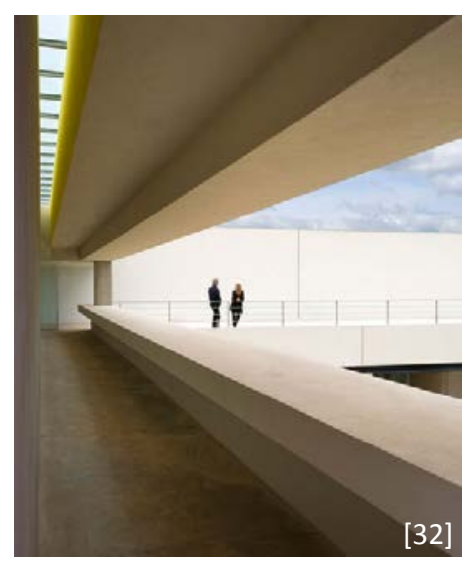

Las reflexiones sobre la arquitectura del pasado y la ruina, las incorpora Fidone en sus proyectos de obra nueva. Este es el caso del centro polivalente de Modica.

El edificio busca transformar el entorno existente, un lugar que se ha conformado a través de un crecimiento muy rápido pero sin un carácter urbano definido.

El edificio se concibe como una estructura abierta a la ciudad, según Fidone, creando una especie de gran stoa helenística en el borde de una gran plaza. Un concepto que se retoma reinterpretado para darle nuevos significados, transformando la estaticidad del elemento original en un mecanismo de mayor tensión y dinamismo.

Las formas del edificio se conciben de manera esencial, como elementos "arcaicos", como si fuesen una preexistencia atemporal. El acceso peatonal, ubicado en la parte alta del solar, se produce atravesando un pequeño pinar, que actúa de elemento natural de transición.

El edificio se compone a base de dos partes distintas: un basamento que resuelve los desniveles presentes en el lugar; y un cuerpo elevado que engloba la cubierta del deambulatorio y la sala.

La arquitectura, se muestra como un elemento másico, que se ha escindido en dos piezas, entre las que existe una ranura que introduce una fuerza gravitatoria que las separa al mismo tiempo que las une.

Muros abstractos, desnudos, construyen un nuevo recorrido a la vez que definen una gran plaza. Un lugar detenido en el tiempo, de aspecto árido, que contrasta con la exuberante naturaleza que nace salvajemente en el espacio aún sin urbanizar.

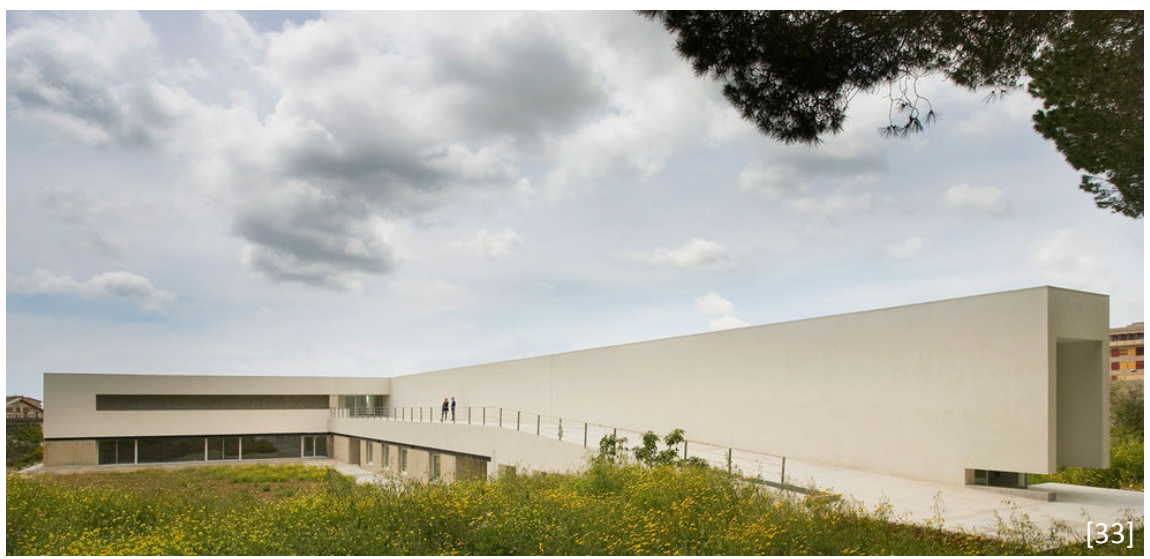




\section{DESCRIPCIÓN DE LA INTERVENCIÓN}

\subsection{Objetivos de la intervención}

El objetivo principal del proyecto es el de devolver la dignidad como espacio sacro, que según Fidone había perdido en las últimas intervenciones.

La intervención busca respetar la compleja historia del monumento, mostrando todas sus fases como expresión del paso del tiempo. Y, en coherencia con esta actitud, se plantean los nuevos añadidos como estratos de la historia del edificio.

Estos añadidos buscan aportar nuevos valores al edificio que potencien los ya existentes. Para ello, Fidone encuentra en la continuidad con la historia de la iglesia el motor de inspiración, tratando así de cerrar las heridas abiertas sin producir nuevos daños.

Junto con el análisis de las diversas configuraciones del edificio a lo largo de la historia, Fidone confía en el saber hacer acumulado por la arquitectura moderna, como guía para alcanzar un nuevo equilibrio en el edificio.

Las lecciones aprendidas sobre la abstracción arquitectónica producida durante el siglo XX, ayudan al objetivo de poner en valor temas esenciales como el espacio, la materia y la luz.

\subsection{Programa funcional}

La restauración se lleva a cabo sin un planteamiento funcional claro.

Ante esta indefinición programática, la propuesta busca una recuperación material y espacial del edificio original, permitiendo la lectura de su complejidad histórica, y creando un espacio con cierta flexibilidad que podría albergar diferentes usos futuros.

En la actualidad el edificio permanece cerrado.

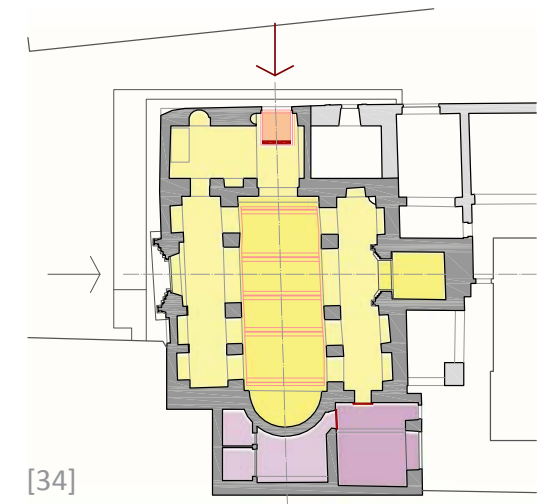

[34] Basílica de San Pedro. Esquema de usos.

[35 y 36] Basílica de San Pedro. Vista exterior del alzado Norte tras la intervención de E. Fidone. (FIDONE: $R \& R, \mathrm{n}$ ㅇ 116-117, 2012)

[37] Basílica de San Pedro. Vista del interior de la nave central hacia el acceso este. (FIDONE: $R \& R$, no 116 $117,2012)$

[38] Basílica de San Pedro. Vista del interior de la nave central hacia el ábside reconstruido en los años veinte, siguiendo el trazado original. (FIDONE: $R \& R$, $\mathrm{n}-116-117$, 2012)

[39] Basílica de San Pedro. Detalle de la fachada este. (FIDONE: $R \& R$, no 116-117, 2012)

[40] Basílica de San Pedro. Puerta de la antigua sacristía hacia la iglesia. (FIDONE: $R \& R$, $\mathrm{n}$ - 116-117, 2012)

[41] Basílica de San Pedro. Puerta de la antigua sacristía hacia el patio. (FIDONE: $R \& R$, $\mathrm{n}$ 116-117, 2012) 

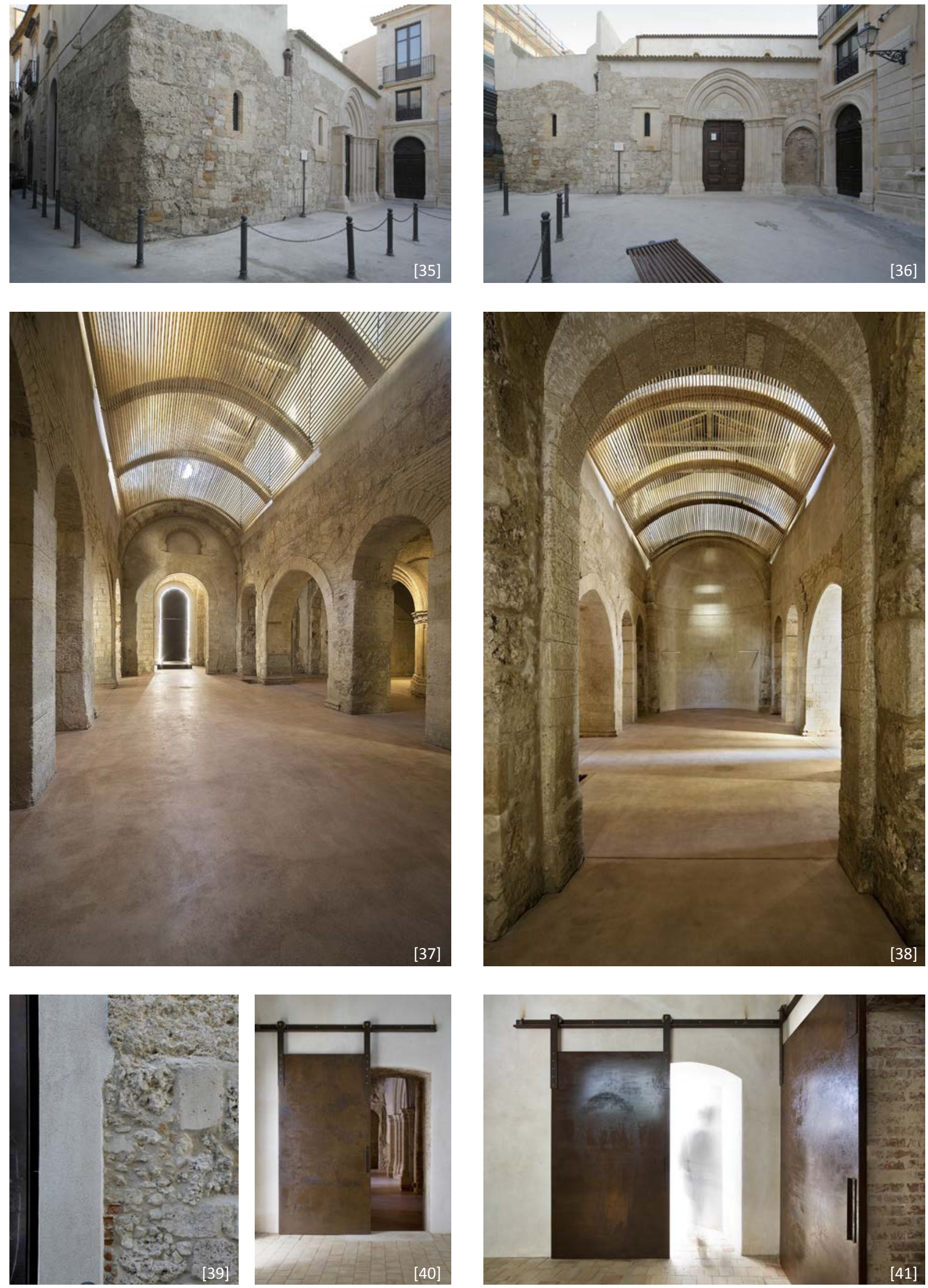
[42]

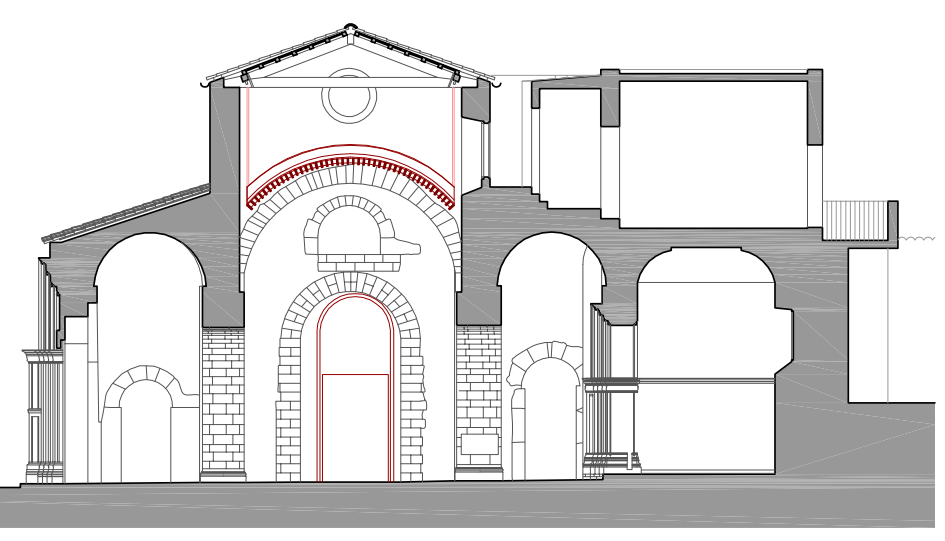

Sección Transversal
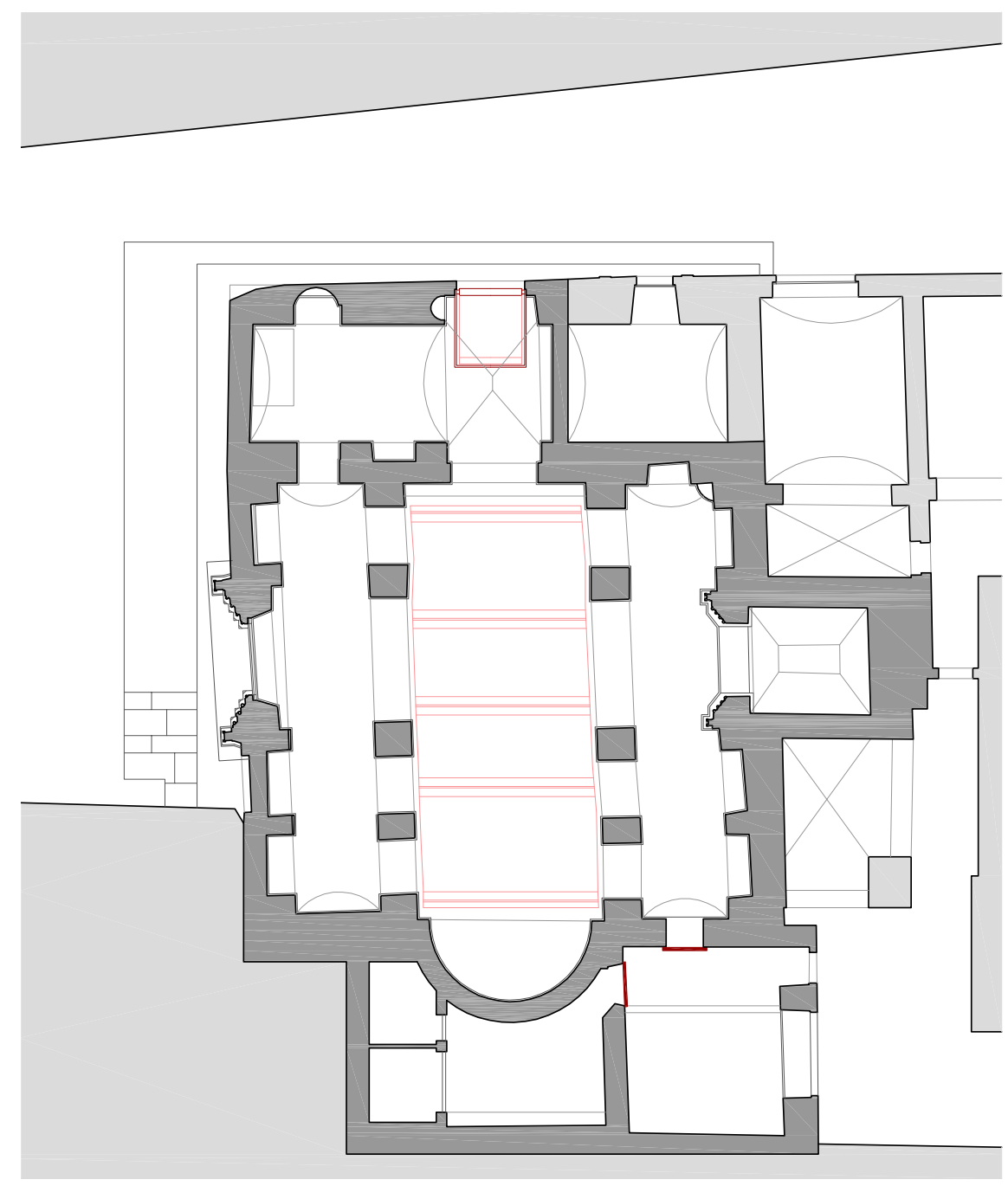

Janta Baja

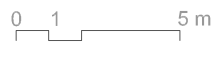

[42] Redibujo de la planta y la sección transversal a partir de los planos del proyecto.

[43] Vista desde la nave central hacia el acceso este. (FIDONE: $R \& R, \mathrm{n}$ 은 116-117, 2012)

[44 y 45] Vista del espacio de acceso. (FIDONE: $R \& R$, no 116-117, 2012)

[46] Vista desde la nave central. Se aprecian las cerchas sobre la nueva "bóveda". (FIDONE: Europaconcorsi)

[47] Redibujo del alzado Este a partir de los planos del proyecto.

[48] Vistas frontales de la puerta de acceso. Visión desde el exterior y desde el interior del edificio. (FIDONE: Europaconcorsi) 

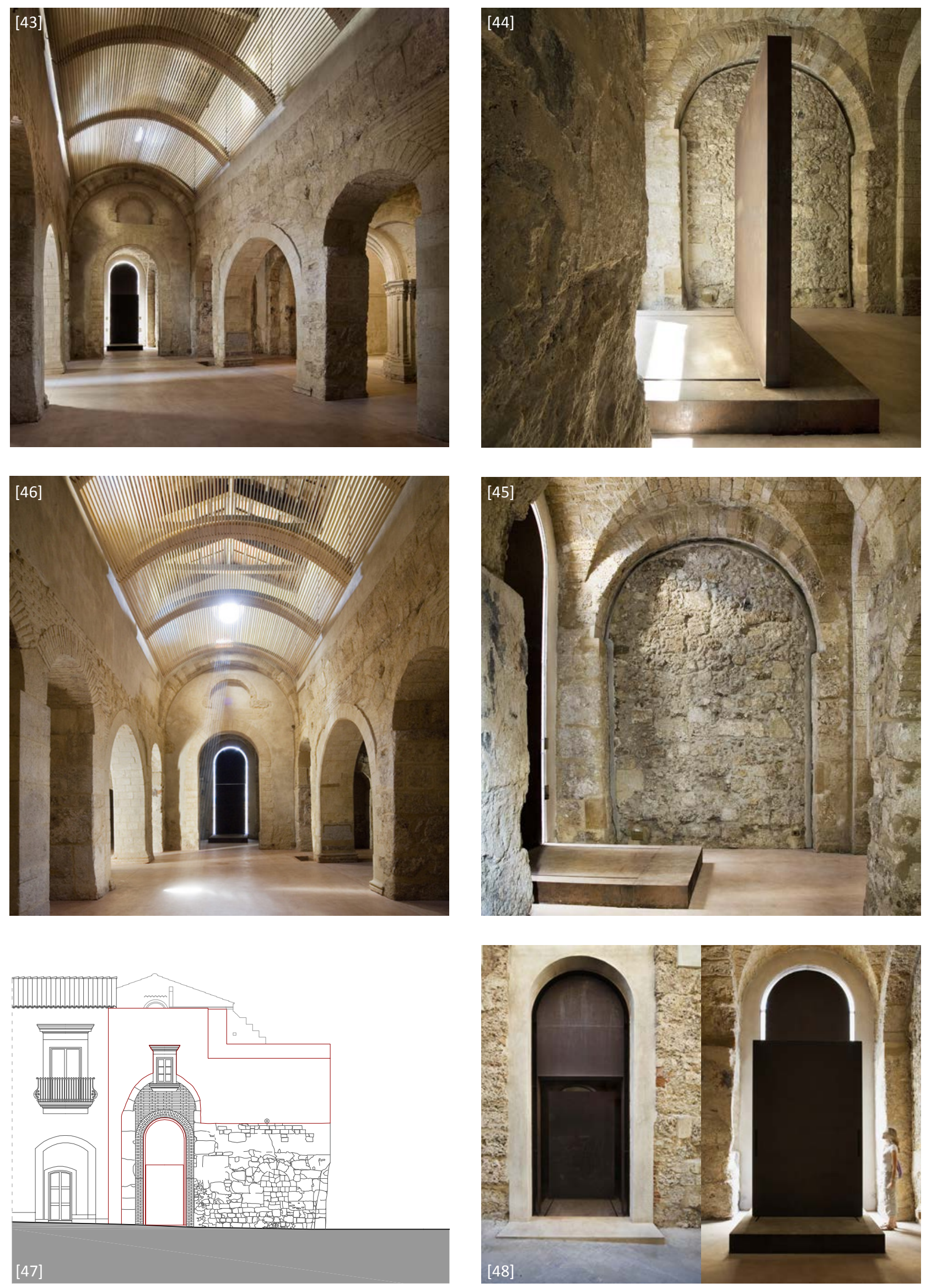


\subsection{Forma, espacio y luz}

La propuesta trata de resolver la distorsión espacial existente entre la nave central y las laterales, mediante la inserción de un nuevo elemento que reinterpreta la bóveda original de piedra, que se atribuye a la época paleocristiana, pero que, al mismo tiempo, permite mantener la lectura del espacio del siglo XVIII y la actuación del siglo XX.

Para ello, el nuevo elemento adopta una superficie calada, a base de elementos lineales separados que reproducen con cierta libertad la traza del perímetro interior de la bóveda original. Las piezas se colocan según la dirección longitudinal, siguiendo la tensión del eje principal del espacio de la nave central, y se disponen de manera radial.

La nueva "bóveda" se coloca a la altura de la original, pero separándose de los muros. Con ello se hace evidente la eliminación del nivel de apoyo original pero al mismo tiempo se permite leer las huellas que permanecen en los muros preexistentes.

Tras la eliminación del estrato de pavimento moderno, y la ejecución de las excavaciones arqueológicas, se define el nuevo pavimento. Este nuevo plano de suelo, unos cuarenta centímetros más abajo, permite percibir la verdadera proporción del espacio original.

La potente luz que penetra a través de las ventanas de época barroca, ubicadas en la zona alta del espacio de la nave, ilumina los muros situados en el trasdós de la "bóveda" potenciando el efecto de transparencia.

La proporción de lleno y vacío permite que gran cantidad de luz se cuele entre los elementos lineales, lo cual sumado a la disposición radial de estos elementos y al gran contraste lumínico con el resto del espacio, produce un efecto de desmaterialización de la nueva "bóveda".

Por otro lado la bóveda actúa como filtro ante el impacto visual de la estructura de cerchas de la cubierta y la potente luminosidad diurna que penetra a través de las ventanas superiores. Con ello la intervención busca recuperar la atmósfera del espacio original, definido por la bóveda de piedra. Un ambiente másico y en penumbra, concebido como excavado.

La puesta en valor de la estratigrafía de los muros potencia su aspecto de ruina, lo cual ayuda a entender este concepto de masa esculpida por el tiempo. Además, las sombras que aporta su textura y su cromatismo en tonos pardos ayudan a potenciar el ambiente de penumbra.

La solución propuesta para el acceso Este busca plasmar la dualidad presente en la historia del monumento, evocando las transformaciones de este espacio, que nace como espacio de tránsito, que luego se cierra

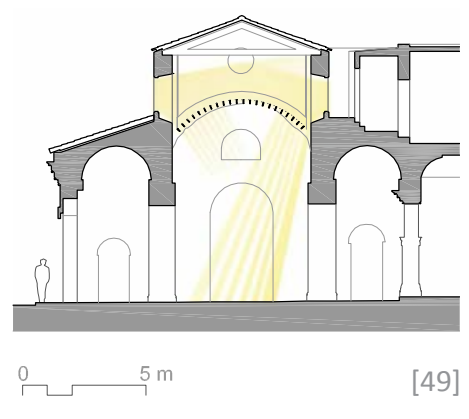

[49] Esquema que ilustra la entrada de luz. Sección transversal.

[50] Vista de la nave. Entrada de luz a través de la nueva "bóveda". (FIDONE: Europaconcorsi)

[51] Detalle de la entrada de luz filtrada a través de las piezas lineales de madera. (FIDONE: $R \& R$, $\mathrm{n}$ 116$117,2012)$

[52] Vista desde la nave lateral. Entrada de luz y puesta en valor de la estratigrafía de los muros. (FIDONE: $R \& R, \mathrm{n}$ ㅇ 116-117, 2012) 

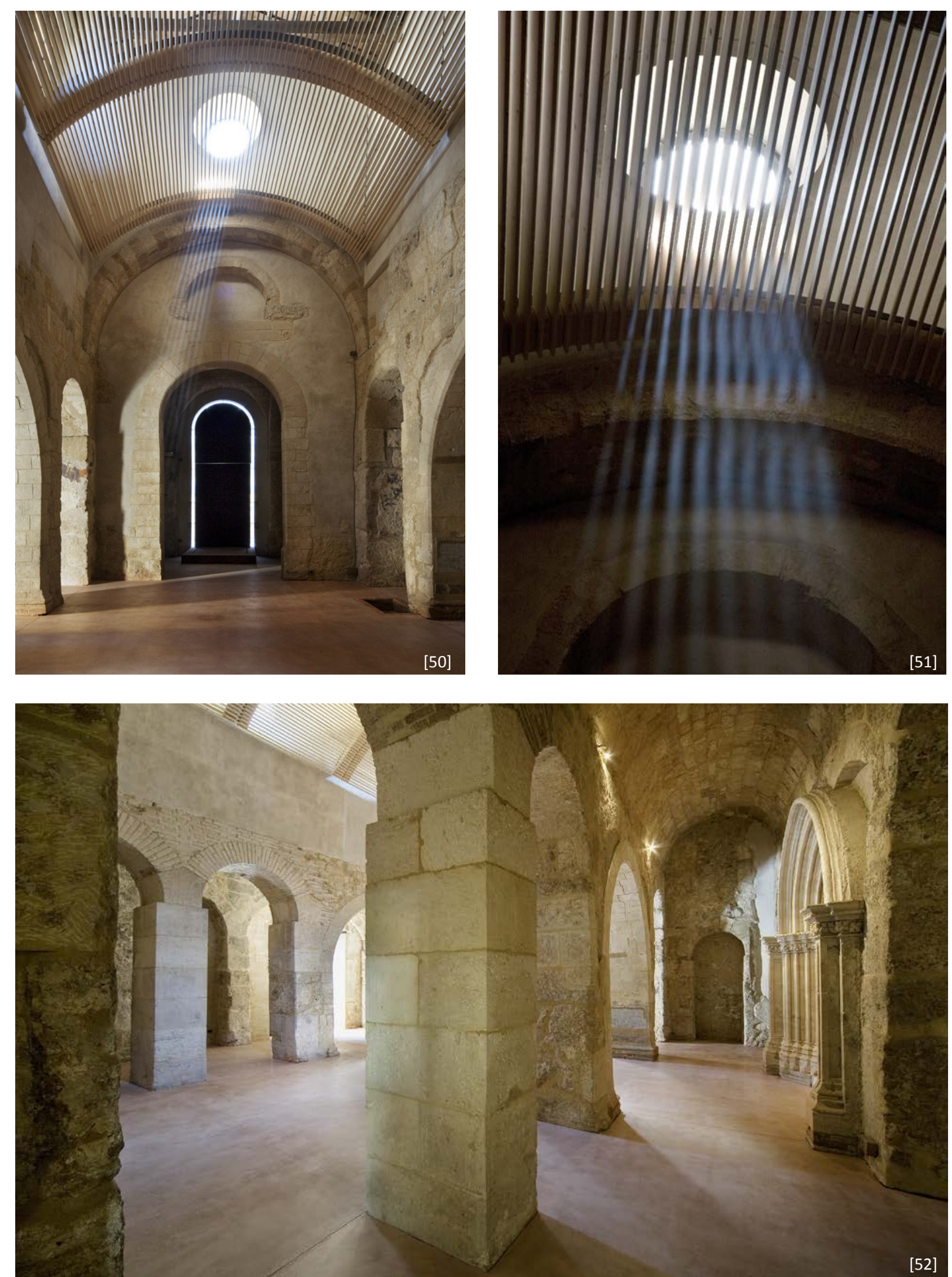
y luego se reabre mediante un portón de madera. Para ello se cierra el hueco de acceso con un plano abstracto de acero corten, cuya tonalidad recuerda al portón de madera, pero por otro lado su espesor también hace referencia -según Fidone- al muro que cerraba este acceso.

Este plano ciego se separa en todo su perímetro con una línea de vidrio, produciendo un efecto luminoso que remite al hueco del acceso original, enfatizando el carácter de tránsito, y consiguiendo que desde dentro se perciba como el acceso principal, lo que refuerza la idea de eje lineal, y entronca con la tradición "procesional" de las basílica paleocristianas.

Además, la apertura de la nueva puerta se realiza mediante un desplazamiento frontal que consigue, de manera muy sutil, evocar el nártex original de la basílica paleocristiana, de forma que cuando se accede, no se tiene la visión directa del espacio principal, sino de este espacio intermedio, que permite experimentar poco a poco la cualidad del espacio. De alguna manera, la nueva pieza de acceso actúa como filtro hacia la sacralidad del espacio interior.

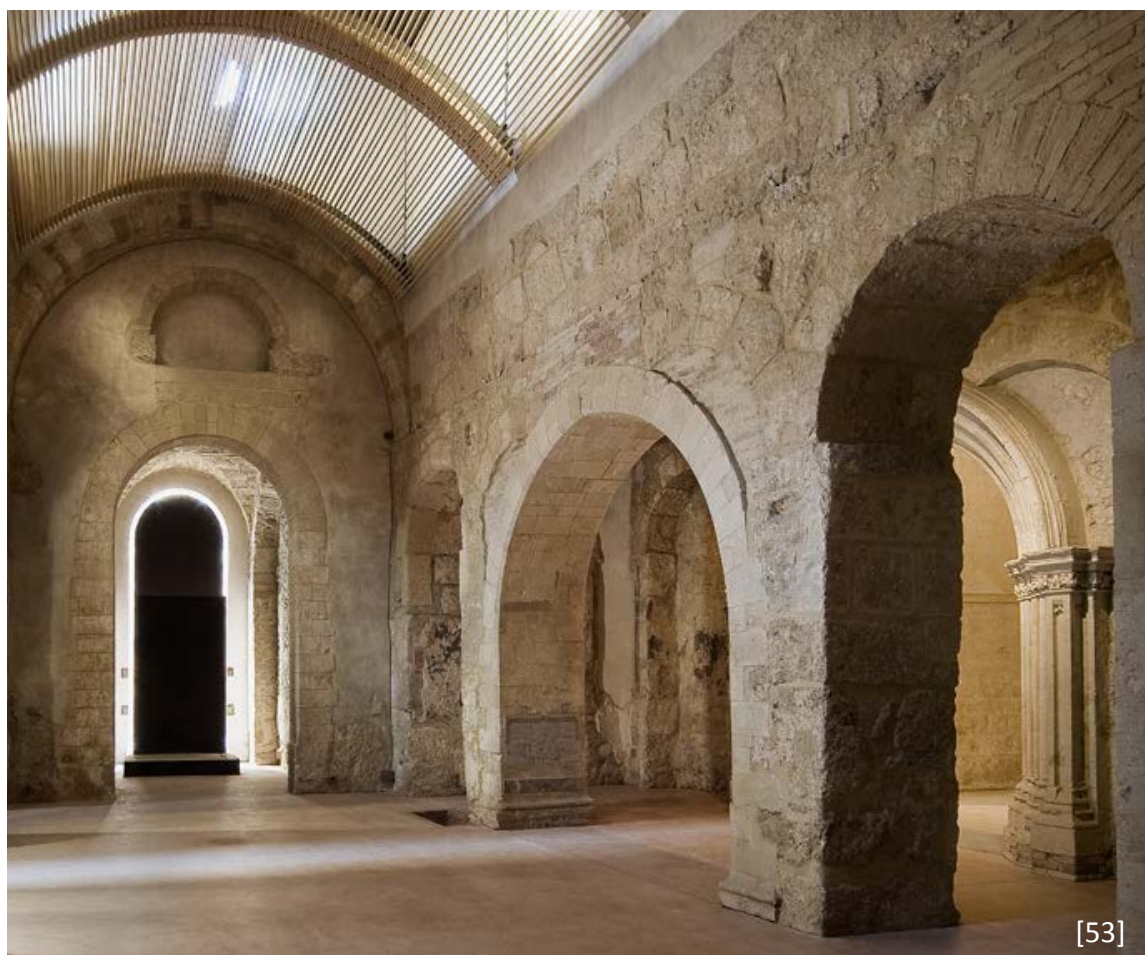

[53] Vista interior en la que se aprecian las diferentes fases del monumento. (FIDONE: R\&R, $\mathrm{n}$ 116-117, 2012) 


\subsection{Materialidad y detalle}

El tratamiento de las superficies busca poner en valor las diferentes fases a las que se ha visto sometido el monumento, consiguiendo una superficie vibrante que aporta carácter al espacio y se convierte en expresión de su memoria histórica.

Cada fragmento conservado cuenta parte de esa accidentada biografía. Este es el caso de los restos de frescos bizantinos que indican que en origen la iglesia debió estar totalmente recubierta por pinturas murales con un importante contenido iconográfico.

Para el acabado de las superficies de escaso valor material para ser vistos, como los muros barrocos o el pavimento, se opta por superficies tersas y continuas, cuya tonalidad y textura estén en armonía con el conjunto, buscando su integración cromática, sin pretender en ningún caso que los nuevos revestimientos resten protagonismo a las superficies conservadas.

En el caso del nuevo pavimento, se ha buscado un acabado que fuera "suave al tacto, cuya consistencia material y perceptiva se aproximase a la del cuero, una superficie que diese la idea del pasaje de un elemento mineral a uno biológico". ${ }^{22}$ La solución ha consistido en una superficie continua de cal y arcilla, conocido con el nombre de cocciopesto, técnica ya empleada por los fenicios y los romanos, como demuestran los restos arqueológicos presentes en Sicilia.

Con ello se obtiene un plano abstracto y continuo que armoniza con el tono de la piedra de los muros, pero que a su vez se manifiesta con cierta autonomía al separarse de los muros preexistentes mediante una sutil fisura.

[54] Detalle de los restos de frescos bizantinos. (FIDONE: $R \& R$, no 116$117,2012)$
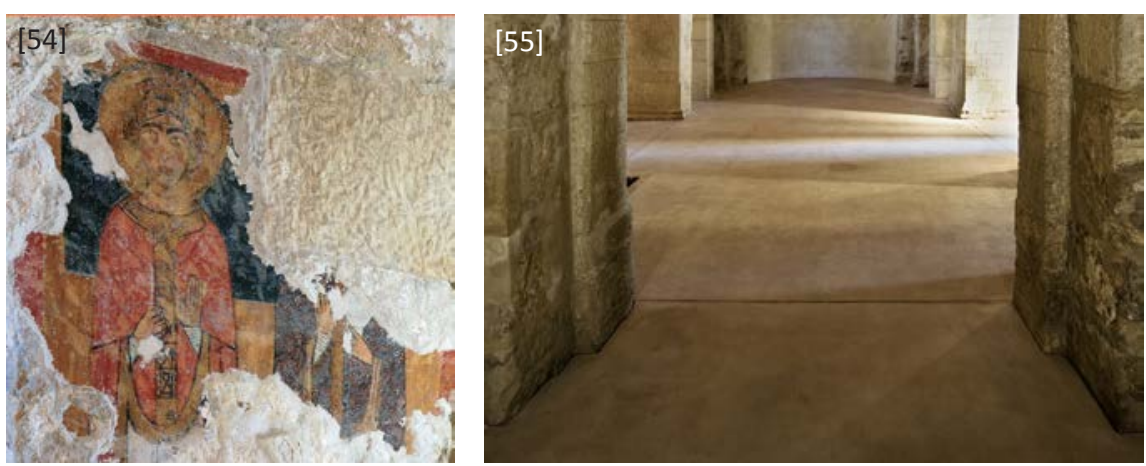
La "bóveda" se resuelve a base de ocho vigas de madera laminada, con forma de arco, que se sustentan mediante tirantes, sujetos a las cerchas que cubren el espacio. Bajo estas vigas se sujetan unos listones de sección rectangular de madera "desaturada y aclarada", que recorren el espacio longitudinalmente. Éstos se colocan separados entre sí en una proporción lleno vacío de $1 / 2$, para dar una sensación de ligereza y permitir la visión del espacio del trasdós, así como el paso de luz al espacio de la nave.

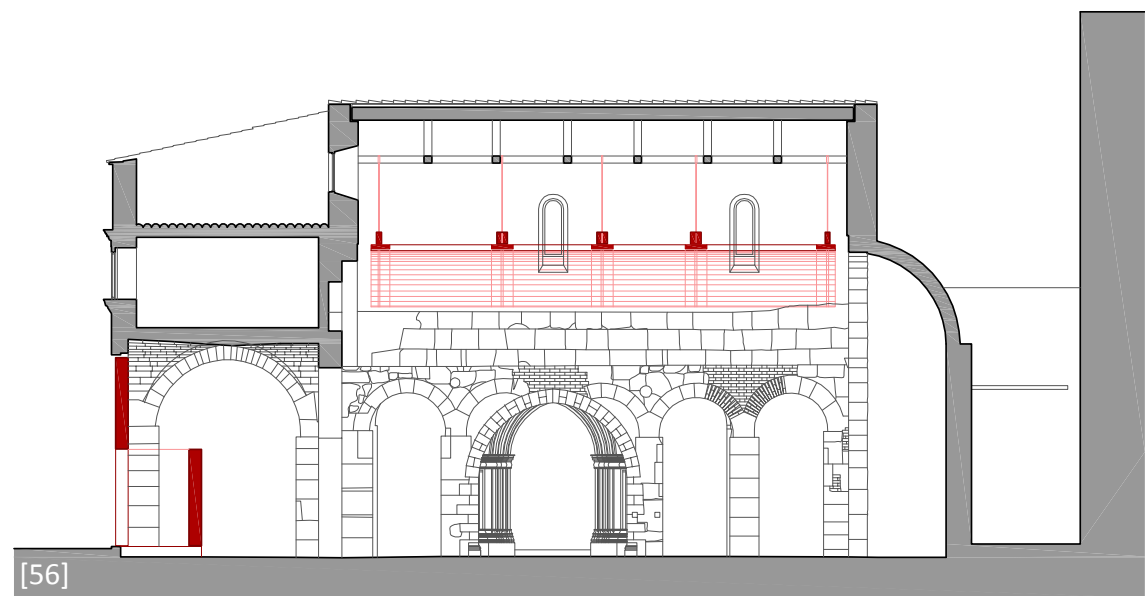

Sección longitudinal
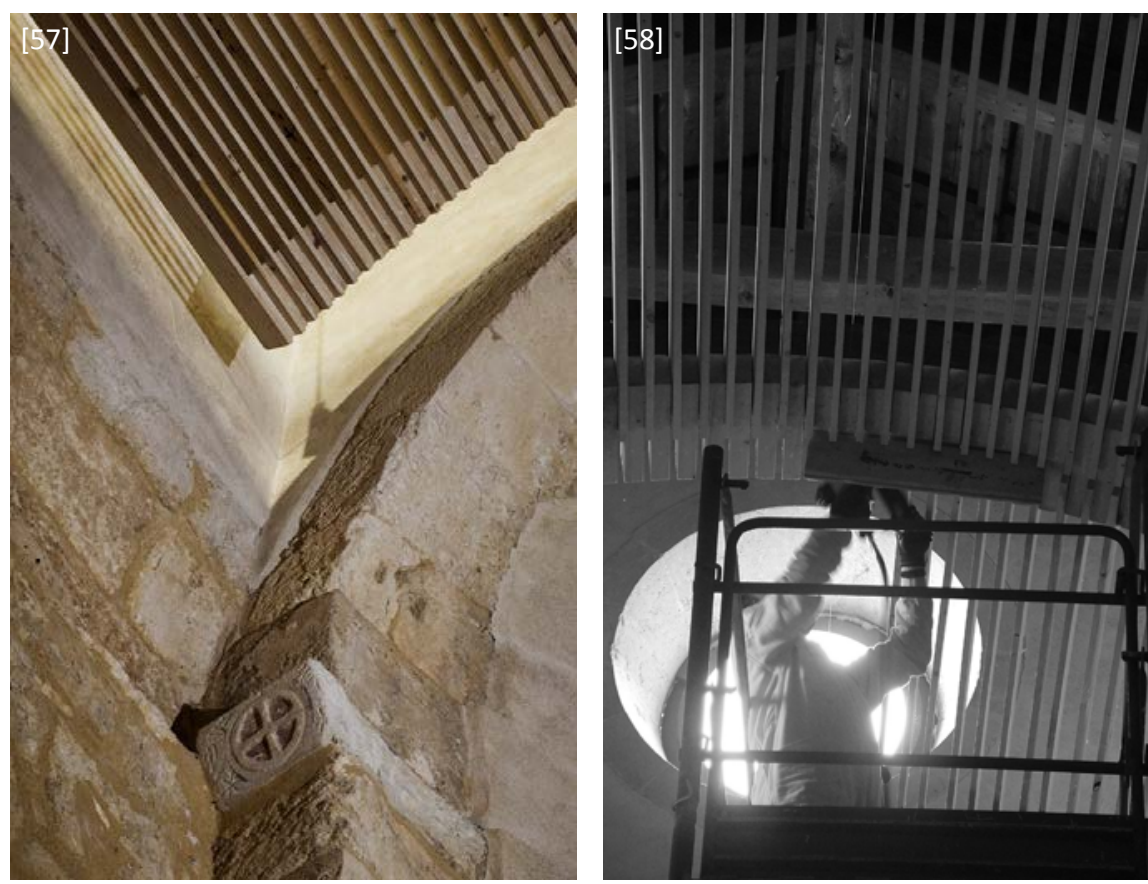

[56] Redibujo de la sección longitudinal a partir de los planos del proyecto.

[57] Detalle del encuentro entre la bóveda de piezas lineales de madera y el muro. (FIDONE: Europaconcorsi)

[58] Detalle de la construcción de la nueva "bóveda" (FIDONE: R\&R, no 116-117, 2012)

[59] Redibujo del detalle constructivo de la solución empleada para la construcción de la nueva "bóveda". 

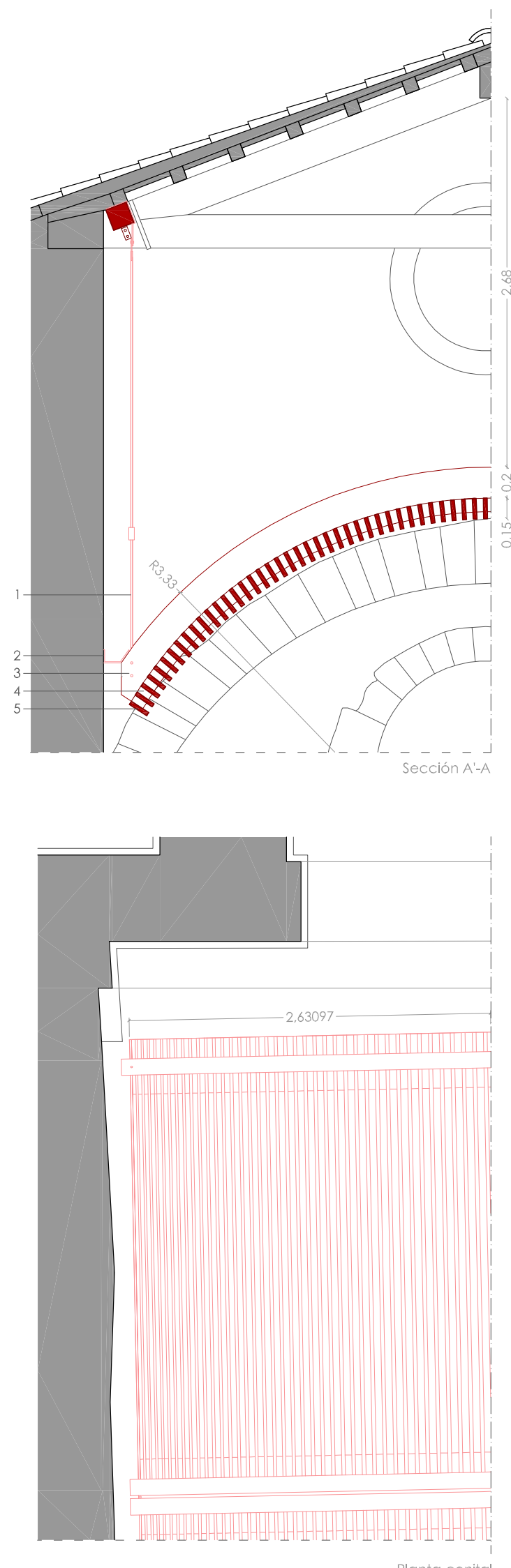

Tirante de conexión a la estructura de la cubierta con estructura de acero esmaltado en negro. 2. Separadores de acero galvanizado.

3. Doble viga curva de madera laminada.

4. Conexión de los listones a la viga, mediante piezas de madera.

5. Listones de madera desaturada y aclarada.

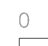
$2,5 \mathrm{~m}$ 
El elemento de cierre del acceso se resuelve mediante un plano de acero corten de $20 \mathrm{~cm}$ de espesor, subdividido en dos partes, una inferior con apertura mediante desplazamiento horizontal, y otra superior fija. El conjunto se separa del perímetro que define el hueco mediante dos pletinas de acero corten entre las que se alberga una línea continua de vidrio.

Con ello se constituye un plano abstracto cuyo acabado oxidado podría evocar un portón de madera. Por otro lado, la textura e imperfección del acero corten podrían evocar la idea del paso del tiempo, por tratarse de un material que se expresa como un elemento vivo, en proceso de oxidación.

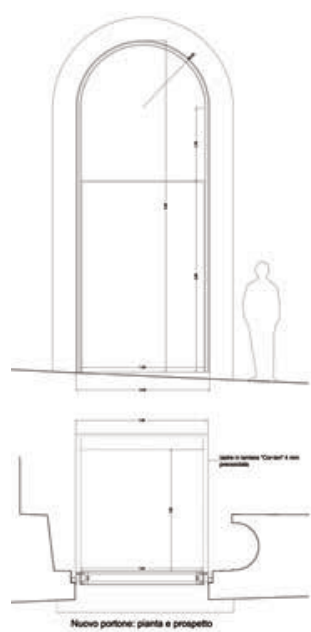

[60]

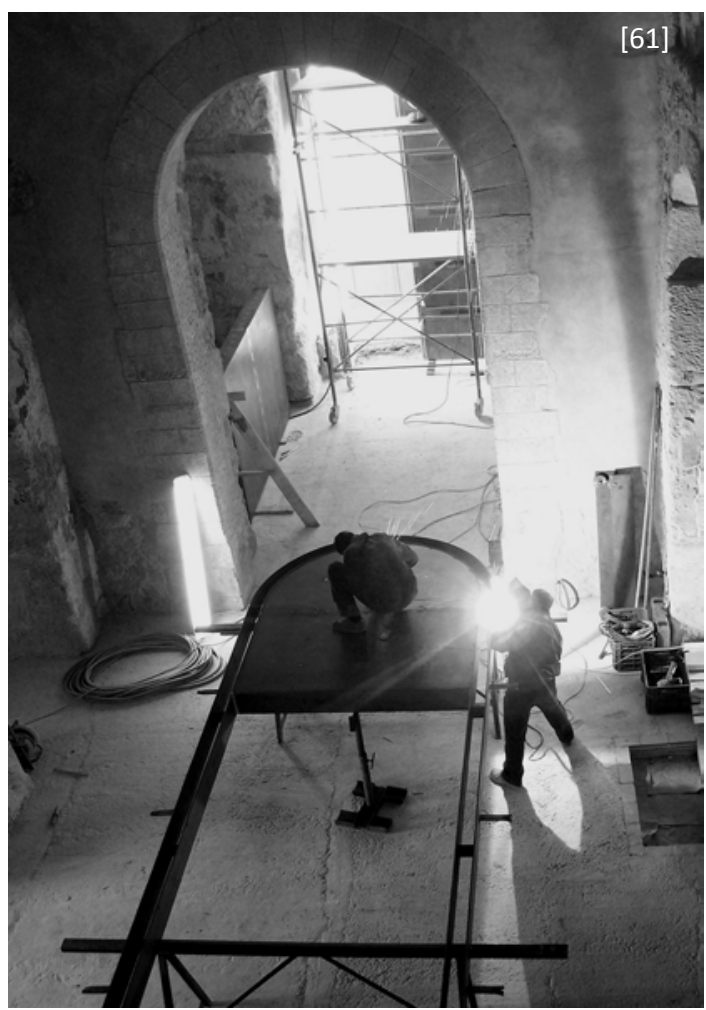

[60] Planta, alzado y detalle del nuevo elemento de cierre del acceso. (FIDONE: $R \& R$, no 116-117, 2012)

[61] Fotografía de la construcción del elemento de cierre del acceso (FIDONE: $R \& R$, № 116-117, 2012) 


\section{ANÁLISIS CRÍTICO DE LA INTERVENCIÓN}

\subsection{El problema del uso}

Dada la falta de programa funcional previsto, Fidone parece confiar en que, devolviendo la dignidad al espacio, el edificio podrá ser capaz de encontrar su propio destino de uso. Sin duda, actividades culturales y religiosas con aforos limitados podrían encajar a la perfección en este tipo de espacio.

El problema es que, en general, los edificios que no tienen un uso definido, a menudo terminan por no utilizarse, y eso conlleva un paulatino abandono que suele traducirse en deterioro. Además, el edificio no parece contar con ningún tipo de mobiliario de apoyo, con el que resolver las necesidades asociadas a un uso, por lo que probablemente sufrirá, antes o después, una intervención de adaptación que podría distorsionar las intenciones del proyecto ejecutado por Fidone.

En este sentido, creo que es fundamental que en una intervención sobre un edificio se tenga claro cual va a ser el destino del monumento, y que la definición de su programa funcional haya sido meditada y consensuada entre los diferentes agentes implicados, ya que su uso activo es la única garantía de su futuro. Sólo mediante la apropiación del edificio por parte de la sociedad, éste tiene garantías de permanecer vivo y no acabar en el olvido.

\subsection{Criterio de intervención}

Fidone asume que el edificio es el resultado de una serie de fases que han ido modificando el edificio original. Actuaciones que han supuesto distorsiones de mayor o menor intensidad sobre el monumento, y que se deben estudiar para descifrar lo que han supuesto en su arquitectura. En comprender las intenciones de estas fases se hallan las claves para producir una actuación adecuada.

[62] Hipótesis del estado original, estado del edificio en el momento anterior al inicio de la restauración y estado actual, tras la intervención. Esta hipótesis se ha formulado a partir de los dibujos y escritos de Emanuele Fidone.
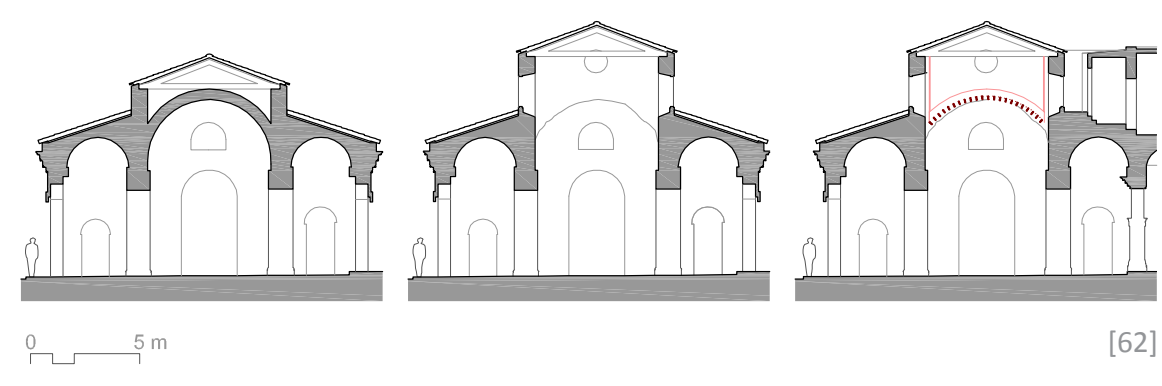

[62] 
Interpreta la suma de estratos de la historia como algo positivo y que se debe valorar. Para ello, pone en valor la materialidad de los muros que tienen interés estético, como es el caso de los distintos tipos de fábrica de piedra, o algunas partes construidas en ladrillo; mientras que en las zonas que considera de escaso valor constructivo, opta por enlucidos de material neutro, a fin de abstraer su complejidad sin distorsionar la armonía cromática.

Para Marco Mulanzzani, la eliminación selectiva de los estratos más recientes de materia, llevan a restituir una percepción fugaz del espacio original de la antigua basílica, ahora desaparecido. ${ }^{23}$ Además, Mulanzzani valora positivamente que esta actitud no se entienda como un objetivo a priori, de repristinación, sino que es el resultado de la lectura del monumento y la consiguiente interpretación creativa.

Al final, todos los estratos de la historia permanecen, algunos matizados y otros reforzados, pero sus diferentes capas pueden apreciarse, pues todas ellas constituyen, en mayor o menor medida, la personalidad del monumento. Fidone es fiel a su principio de "continuidad diacrónica", y respeta la evolución del edificio a lo largo del tiempo, y con ello las modificaciones que van creando su identidad.

\subsection{Nuevos elementos}

Desde un punto de vista constructivo, la construcción de la nueva "bóveda" no responde a una necesidad funcional básica, dado que el espacio ya está cubierto, pero Fidone lo entiende como una necesidad espacial y lumínica.

Fidone podría haberse limitado a realizar procesos de consolidación y limpieza, pero entiende que la adición de nuevos elementos puede aportar nuevos valores al monumento. $Y$ estos nuevos elementos deben plantearse como reflejo del lenguaje de nuestra época, pero en relación con las necesidades arquitectónicas del edificio. Es lo que Fidone llama "relación dialéctica entre lo antiguo y lo nuevo".

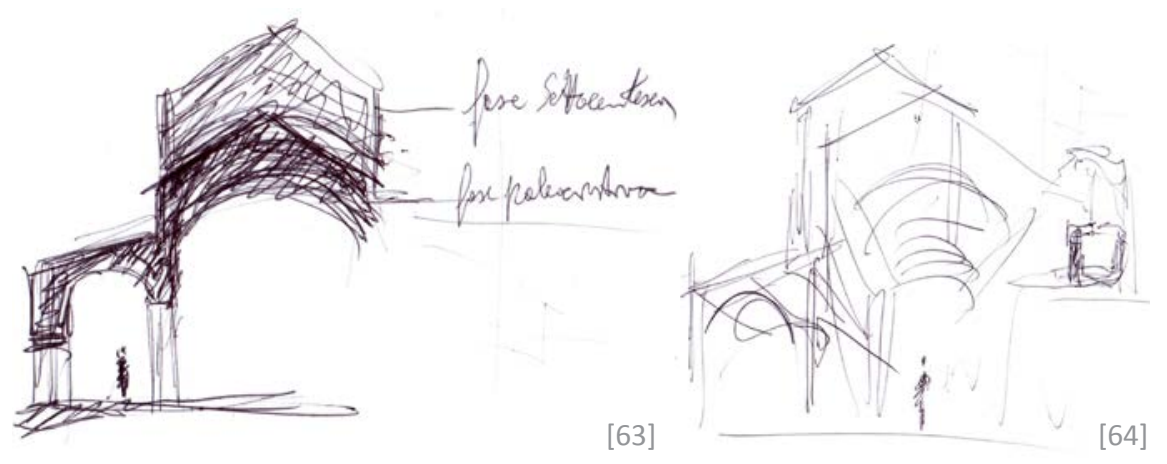

23 MULANZZANI, M.: Op. Cit. 2009, pp. $48-53$

[63 y 64] Bocetos del proyecto. (FI$\mathrm{DONE}: R \& R, \mathrm{n}$ 116-117, 2012) 


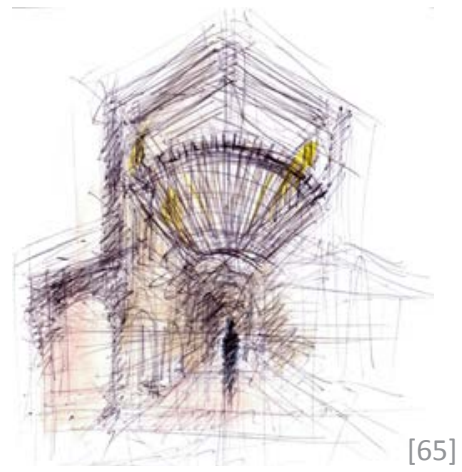

[65]
Fidone plantea las nuevas actuaciones a través de la abstracción formal y la expresión material y constructiva. La sencillez del detalle constructivo, dirigido a moldear la luz y la sombra, y la elección del material, son las claves de la relación con la complejidad de la arquitectura donde se inserta. Los nuevos elementos, aunque pueden reconocerse con total claridad, se insertan de una manera sutil, natural y equilibrada.

Así pues, Fidone plantea un nuevo elemento "abovedado" que, inspirándose en la historia del edificio, suaviza la altura del espacio de la nave central, y redistribuye la intensidad lumínica en el ambiente, con lo cual reduce el contraste y la jerarquía preexistentes, revalorizando las naves laterales, de menor altura y en penumbra.

En cierto modo, con la excusa de recuperar el ambiente original, establece un nuevo marco de relaciones en el espacio de la nave central, introduciendo un sugerente juego de transparencias que, reforzado por la luz, evoca el estado místico que experimentaban nuestros antepasados.

De igual manera, con el nuevo acceso Este, Fidone busca un elemento cargado de significado histórico, que lo ata irremediablemente al monumento, pero a través de un objeto completamente moderno en su definición formal y material, lo que lo ata a nuestro tiempo.

Los nuevos elementos en cierta manera reinterpretan la compleja historia del edificio apoyándose en el recurso de la ambigüedad: la bóveda que evoca el pesado cierre del espacio original se materializa como una pieza ligera y semitransparente que flota sutilmente en el espacio. Un juego similar se produce en la recuperación del acceso original, que busca evocar también las fases en que estuvo tapiado, pero siempre reforzando la su lectura como espacio de tránsito, mediante la línea de luz que separa la puerta de los muros preexistentes.

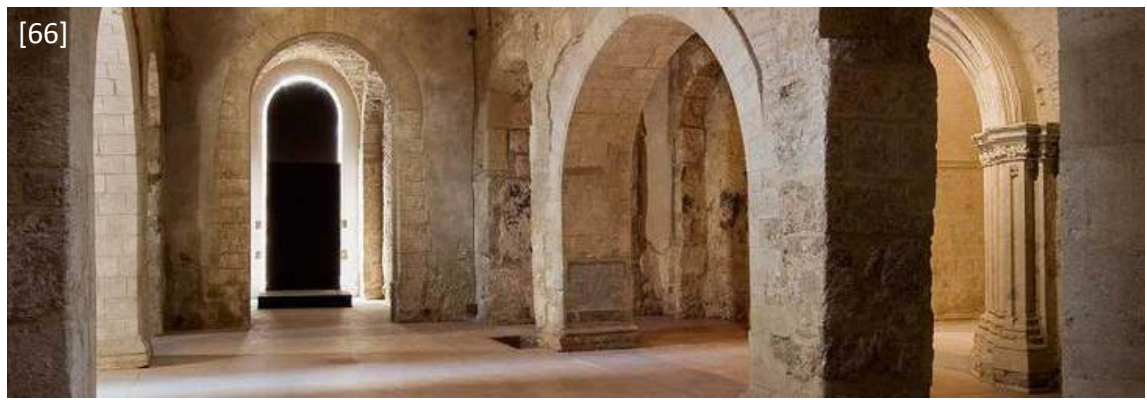




\subsection{Referencias}

Para Marco Mulanzzani, la solución del portón Este recuerda a las "juntas de luz" empleadas por Louis Kahn entre las bóvedas de hormigón y los cierres laterales de travertino, del museo Kimbell.

También podría decirse que recuerda a otros episodios modernos, como la puerta de acceso a Ronchamp, o a las juntas entre materiales formalizadas por Scarpa en sus proyectos.

El juego de transparencias que se consigue con la nueva "bóveda" y su manera de insertarse en el espacio, como elemento autónomo que flota en un espacio encerrado por muros de mayor altura, podría vincularse con las bóvedas que construye Linazasoro en las Escuelas Pías. Sin embargo en este caso su trazado se basa en las huellas de la bóveda primitiva, y en el caso de Linazasoro las nuevas bóvedas no pretenden en absoluto hacer referencia a un trazado preexistente, sino evidenciar su autonomía formal y crear un nuevo espacio.

En este sentido, esta obra, al igual que la de las Escuelas Pías, retoma el concepto de la dualidad en la construcción del espacio, mediante unos muros másicos, vinculados a la idea de lo permanente, que surge de la tierra, y una cubierta de naturaleza ligera, ingrávida, etérea, vinculada a la idea de lo efímero... que en ambos casos se materializa mediante una superficie calada de piezas lineales de madera, definiendo un trazado curvo.
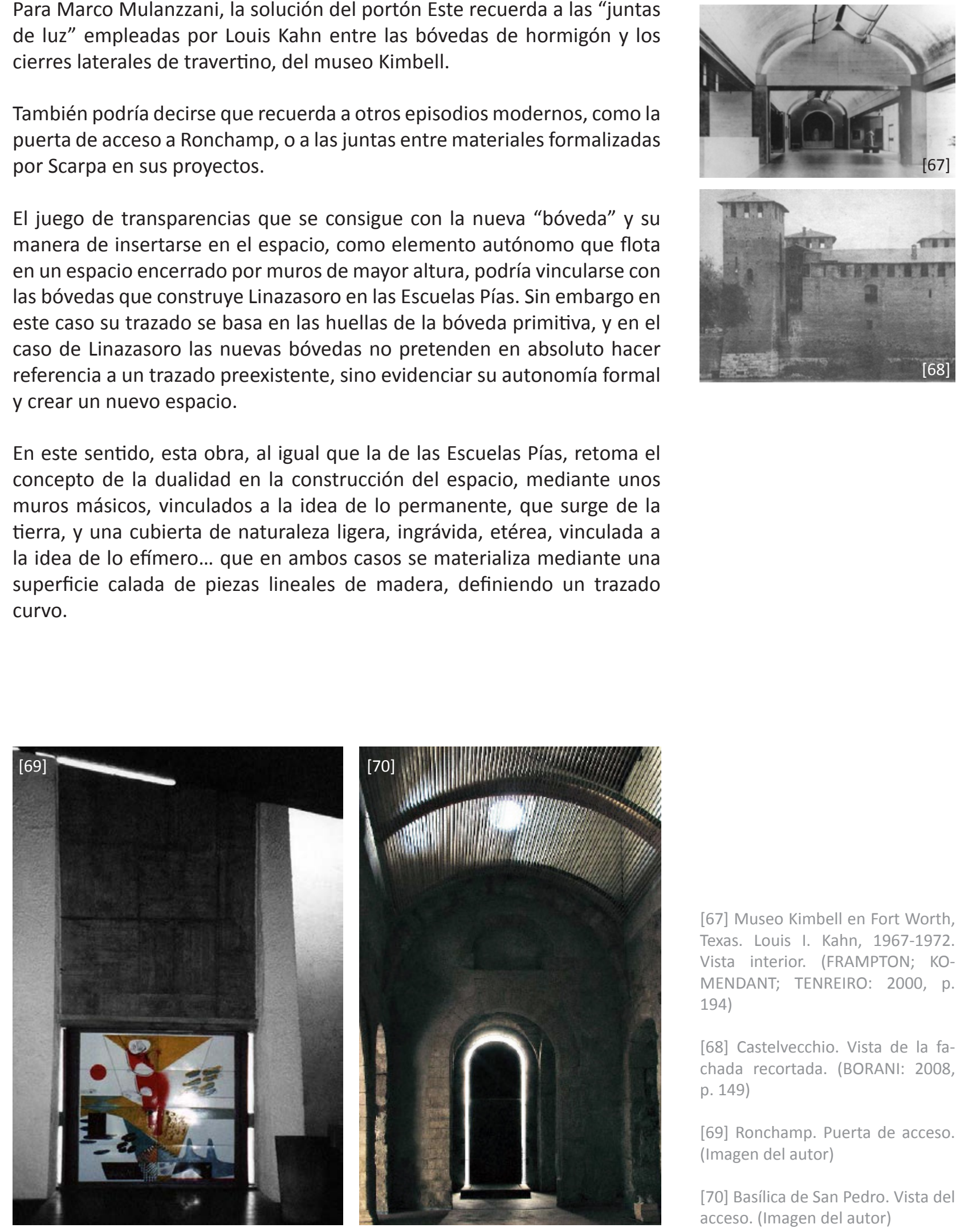

[67] Museo Kimbell en Fort Worth, Texas. Louis I. Kahn, 1967-1972. Vista interior. (FRAMPTON; KOMENDANT; TENREIRO: 2000, p. 194)

[68] Castelvecchio. Vista de la fachada recortada. (BORANI: 2008, p. 149)

[69] Ronchamp. Puerta de acceso. (Imagen del autor)

[70] Basílica de San Pedro. Vista del acceso. (Imagen del autor) 

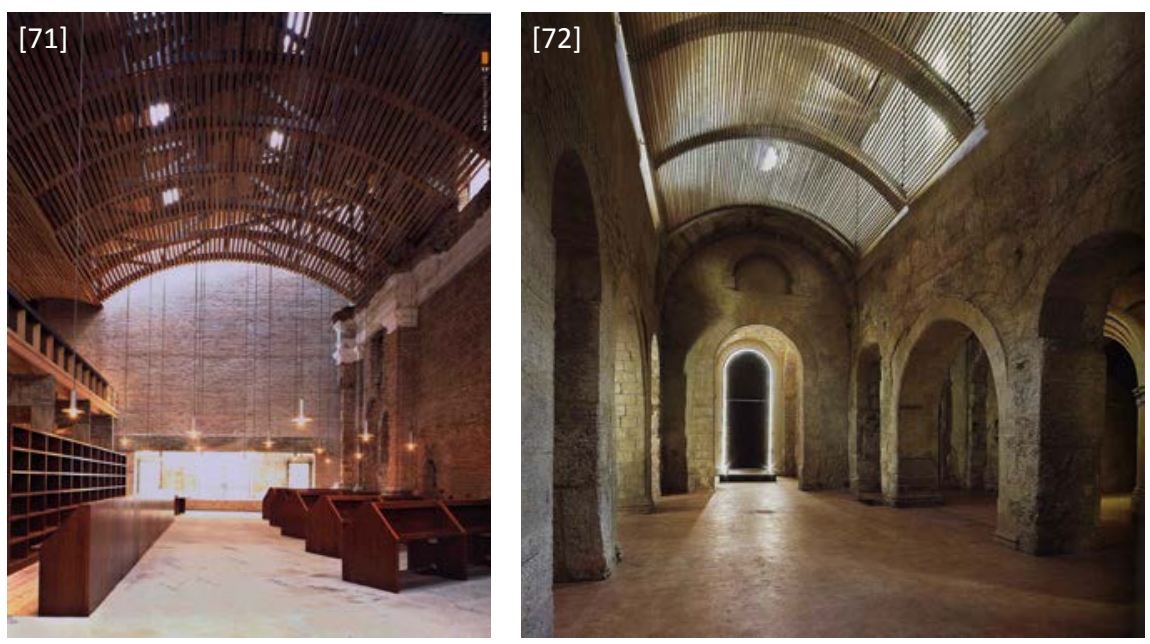

Por otro lado, se reconoce la influencia de su propia obra anterior, fundamentalmente Santa Maria del Gesù en Modica, donde se enfrenta a la necesidad de completar unos espacios abovedados que habían perdido su cierre superior, y experimenta en torno a la reelaboración de las bóvedas mediante un lenguaje actual, pero evocando las formas de lo que se había perdido -las espacialidad barroca de la nave central y las bóvedas de crucería góticas en las capillas laterales-. En este caso también se apoya en las referencias a la historia del edificio para definir las nuevas actuaciones, e intenta que la nueva actuación permita la lectura de las diferentes fases, incluso contemplando la lectura de la ruina. En cuanto a la materialidad, en este caso, al igual que en San Pietro, utiliza para las nuevas actuaciones principalmente la madera, el metal y el cocciopesto.

[71] Antigua iglesia de las Escuelas Pías. Vista de la nave central. (LINAZASORO: Conarquitectura, no 17, 2006, p. 57)

[72] Basílica de San Pedro. (CasabeIla, no 780, p. 49)

[73] Santa Maria del Gesú. Nuevo cierre de la nave central. (Imagen de L. Rubino. En: FIDONE; MESSINA: Nuovo e Antico, no 03, 2007, p. 100)

[74] Santa Maria del Gesú. Detalle de revestimiento en cocciopesto. (Fotografía de L. Rubino. En: FIDONE; MESSINA: Nuovo e Antico, $\mathrm{n}$ ㅇ 03, 2007, p. 105)
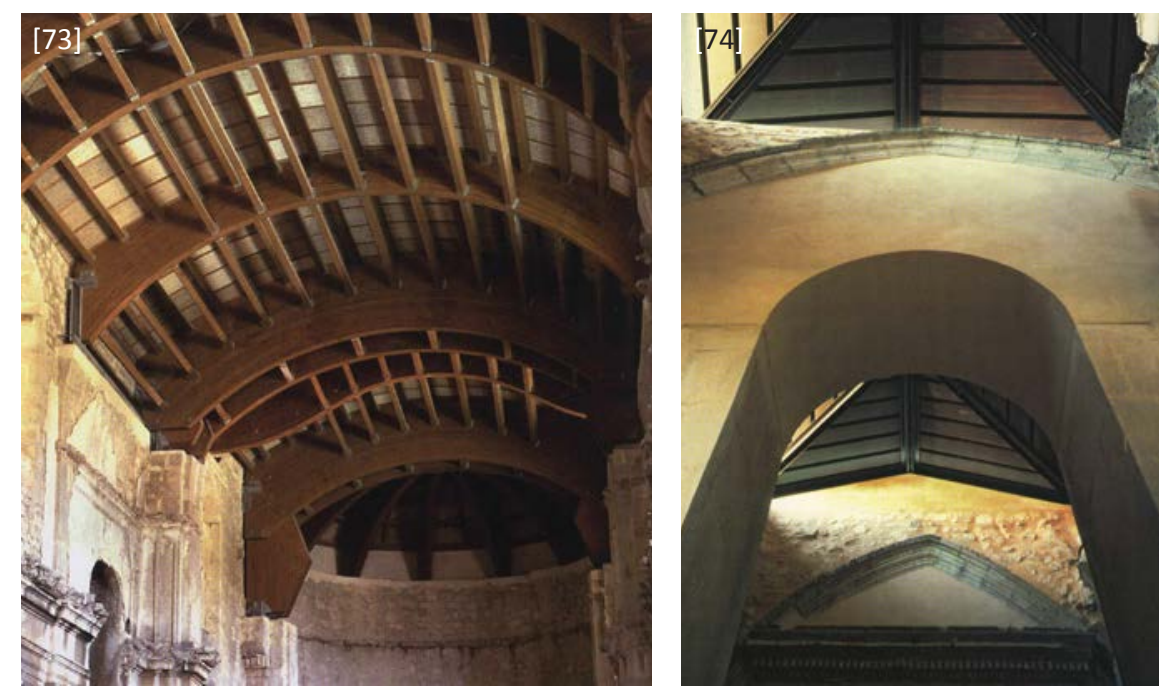



\section{estudio comparativo}




\section{ESTUDIO COMPARATIVO}

A continuación se realiza un estudio comparativo entre los cuatro casos analizados. El orden que se ha seguido ha sido el empleado en el análisis de casos. En primer lugar se abarca la historia y tipología del monumento, y el estado de la preexistencia y las necesidades de intervención sobre ella. En segundo lugar la experiencia y reflexión arquitectónica de los autores de las intervenciones. Por último se compara las soluciones adoptadas desde el punto de vista de la función, la forma, espacio y luz, y la materialidad.

\section{HISTORIA, TIPOLOGÍA Y PREEXISTENCIA DEL MONUMENTO}

Si bien los cuatro ejemplos analizados fueron en origen monumentos religiosos delimitados por muros y rematados con bóvedas, los valores que se otorgan a su historia y configuración original, así como la situación en la que llegan hasta el momento de su intervención los convierten en casos muy distintos unos de otros.

\subsection{Evolución histórica}

Desde el punto de vista de la evolución histórica de los monumentos se observa que a lo largo del tiempo han estado sometidos a diversas transformaciones que les han otorgado una serie de valores adicionales a sus formas originales.

El edificio más antiguo es el de San Pedro de Siracusa, de origen paleocristiano, el cual presenta muchas transformaciones a lo largo de la historia, pero es precisamente gracias a estas transformaciones dirigidas a adaptar el monumento a las necesidades de cada época, lo que le ha permitido sobrevivir hasta la actualidad. Sin embargo también cabe mencionar que algunas de estas modificaciones, como la "restauración estilística" emprendida a principios del siglo XX, supondrán la pérdida de algunos de estos estratos que por necesidad histórica se habían superpuesto sobre el monumento original.

También en San Felipe Neri la reutilización del espacio permitió mantener vivo el edificio, aunque en este caso, tanto su uso militar como de depósito de materiales para la construcción debió afectar al edificio en cierta medida. A su vez cabe destacar la gran importancia que tuvo la intervención de Alfredo Barbacci poco después de la destrucción producida por los bombardeos, que aunque interrumpida permitió que se reconstruyera la estructura necesaria para dar estabilidad al edificio y así garantizar su continuidad hacia el presente.

La experiencia de reutilización del patrimonio supuso el efecto contrario en el caso de la capilla de los Condes de Fuensaldaña donde su uso militar transformó profundamente su estructura produciendo el deterioro de sus muros y la pérdida de sus bóvedas de crucería. Sin embargo cabe resaltar 

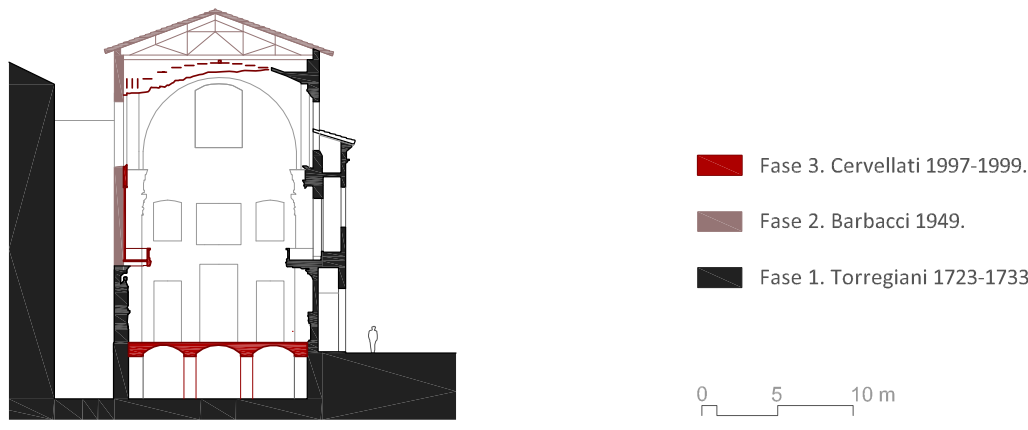

Fase 1. Torregiani 1723-1733.
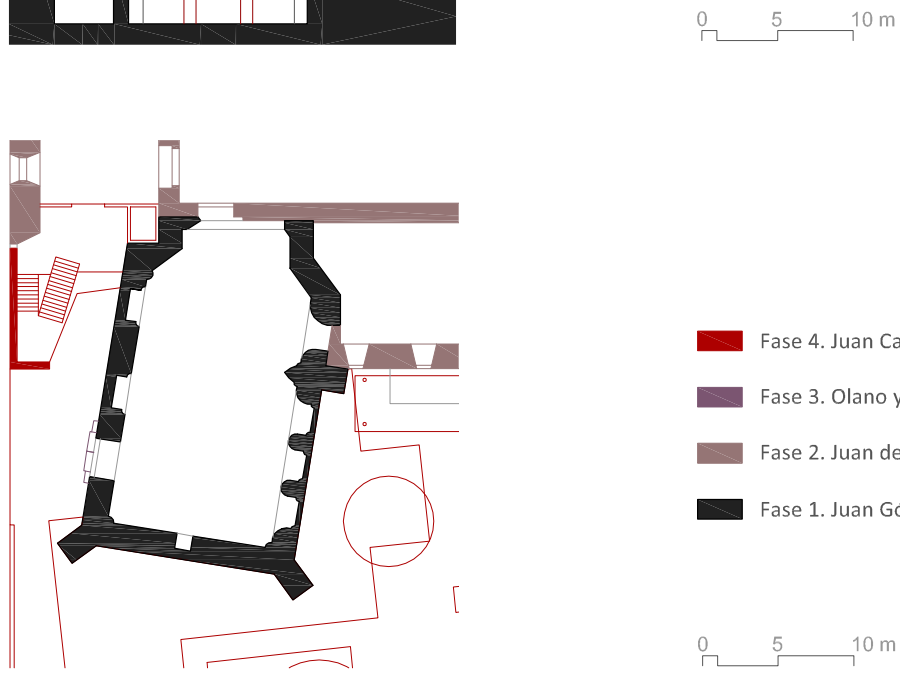

Fase 4. Juan Carlos Arnuncio, 1996-2002.

Fase 3. Olano y Barreda, 1619.

Fase 2. Juan de Ribero Rada, 1582-1584.

Fase 1. Juan Gómez Díaz, 1453-1457.

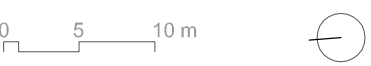

[1] Oratorio de San Felipe Neri. Evolución histórica.

[2] Capilla de los Condes de Fuensaldaña. Evolución histórica.

[3] Iglesia de las Escuelas Pías. Evolución histórica.

[4] San Pedro.Evolución histórica.

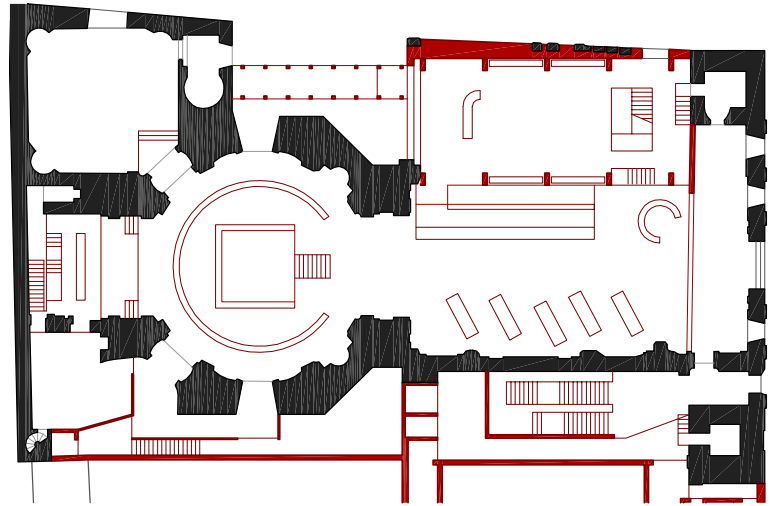

Fase 2. J. I. Linazasoro, 1996-2004.

Fase 1. F. Ruiz, 1734-1791.
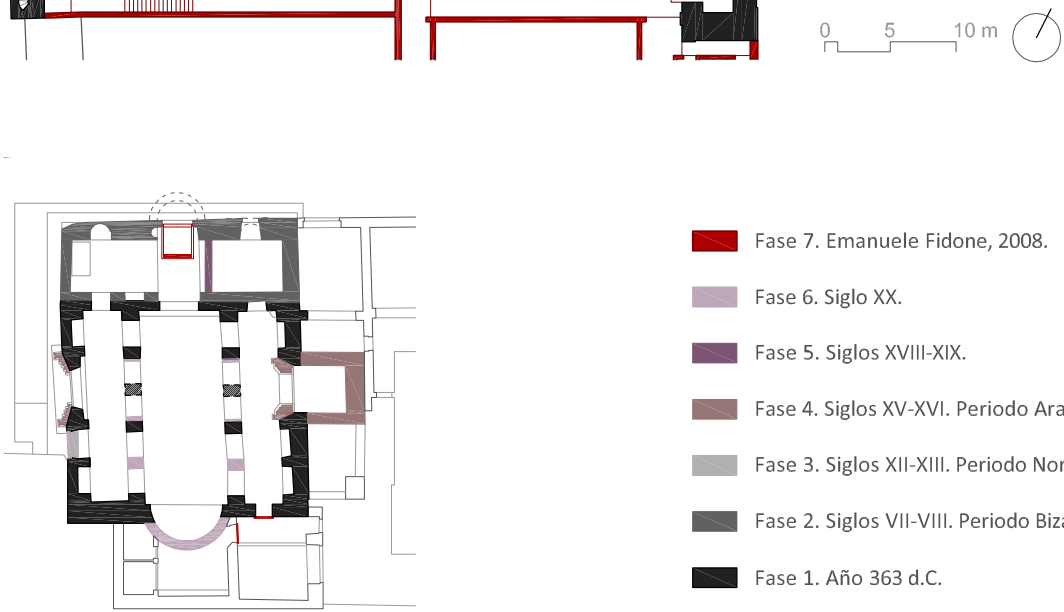

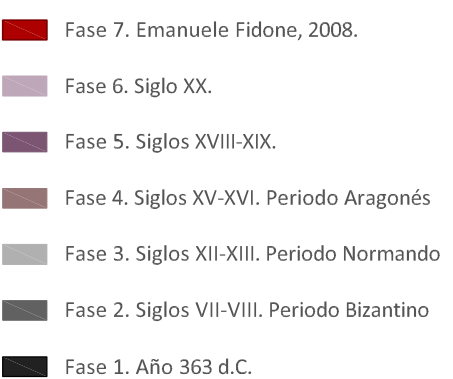

$\stackrel{5}{\square} \sqrt[5]{10 m} \quad-$ 
las interesantes superposiciones que se aprecian en algunas partes del monumento, como los diversos huecos y muros presentes en el ábside o la portada barroca superpuesta al muro norte, actuaciones producidas durante su período como edificio religioso y derivadas de las adaptaciones a las nuevas necesidades funcionales.

Finalmente, en la iglesia de las Escuelas Pías la evolución histórica pone de manifiesto por un lado la falta de reacción ante la destrucción del monumento durante la guerra civil, produciendo con ello la consolidación de su ruina como imagen de la colectividad, y por otro lado las sucesivas transformaciones presentes en su entorno próximo, traducidas en la apertura de una gran plaza desde la que el monumento, y particularmente su cimborrio, adquieren un potente valor de referente en la imagen de la ciudad.

En la comparación de los ejemplos vemos como a lo largo de la historia se producen ciertas transformaciones que ayudan a conservar el monumento aportándole nuevos valores, mientras que otras actuaciones más radicales producen su deterioro o incluso su destrucción y olvido. Entre ambos extremos se aprecia que la permanencia del monumento como ruina produce la consolidación de una nueva imagen, una nueva realidad que puede venir potenciada por la visibilidad de su presencia en el entorno próximo, y que puede adquirir un valor significativo en la colectividad que necesariamente debe ser considerado al plantearse las actuaciones para su permanencia.

En cualquier caso se constata que el cambio de necesidades a lo largo del tiempo produce transformaciones en los monumentos. Modificaciones que explican los valores de cada cultura a lo largo de la historia. Valores que siempre han confrontado lo antiguo con lo nuevo con el propósito de producir una arquitectura adecuada a las nuevas condiciones.

Tras el cambio de conciencia histórica producido a partir del siglo XVIII, la atención al valor de la historia se convierte en una condición irrenunciable en el proyecto. La búsqueda de diálogo con la materia preexistente y su pasado se imponen como condicionantes a incorporar al proyecto arquitectónico. Pero el objetivo no varía, se debe producir una arquitectura de calidad adecuada a las necesidades del momento.

Sin embargo, como hemos visto en el capítulo de criterios, esto no quiere decir que a lo largo de la historia no se haya prestado atención a los valores de la preexistencia y de su pasado, sino que se ha hecho de manera interesada, pues en el fondo la arquitectura es el resultado de un proceso evolutivo de adaptación a nuevas necesidades y culturas. Por lo que el estudio de los mecanismos de evolución histórica de la arquitectura del pasado se convierte en una fuente inagotable para el proyecto, que se debe valorar críticamente desde la nueva conciencia histórica.
[5, 6 y 7] Oratorio de San Felipe Neri. Evolución histórica.

[8, 9 y 10] Capilla de los Condes de Fuensaldaña. Evolución histórica.

$[11,12$ y 13$]$ Iglesia de las Escuelas Pías. Evolución histórica.

[14, 15 y 16] San Pedro. Evolución histórica. 

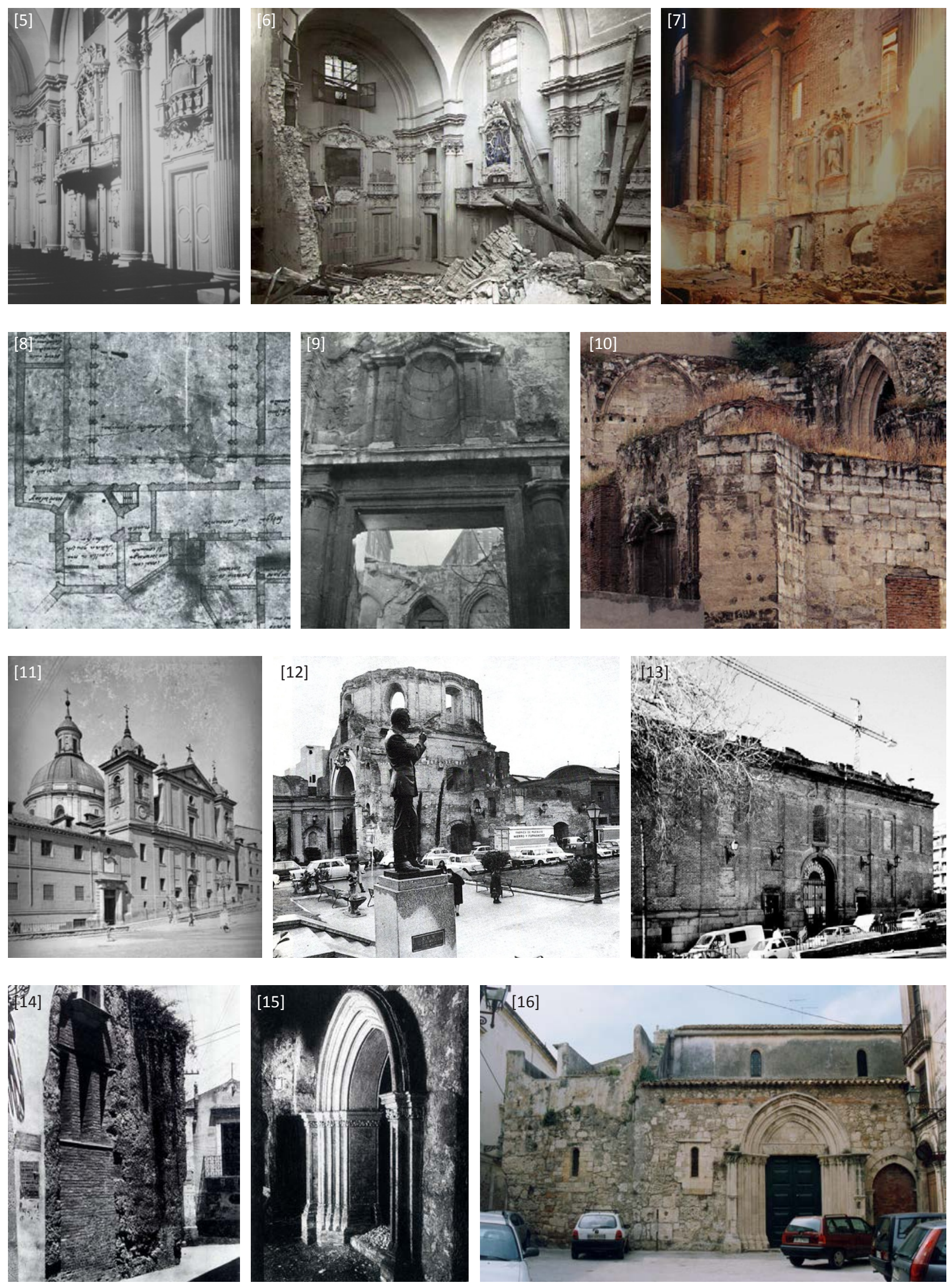


\subsection{Tipología formal y expresión material original}

Desde el punto de vista de la configuración original todos los ejemplos presentan una tipología longitudinal pero las dimensiones y composición varían en función del uso y el estilo.

Según Fidone, San Pedro presentaba en su origen un espacio de tres naves abovedadas, dos laterales y una central, de poca altura con un carácter interior de reducida iluminación fuertemente contrastada, así como una expresividad material muy explícita gracias a su construcción realizada con mampostería de piedra. Un conjunto de formas simples y pesadas que le conferían un aspecto de gran recogimiento y fuerte reminiscencia a un espacio ancestral y primitivo, como una cueva excavada en una roca, donde los restos de pinturas nos hacen recordar costumbres rupestres. Una remisión al origen de la arquitectura.

En la capilla gótica de Valladolid los sillares que conforman los muros transmiten también expresividad material, pero con una terminación mucho más refinada y estilizada. La expresión estructural de las complejas bóvedas góticas y la iluminación procedente de grandes huecos verticales conferían una solución mucho más sofisticada y monumental que la de San Pedro, pero aún dentro del mundo de la expresión de la construcción. Los nervios góticos se alejan del concepto estereotómico de la cueva y se acercan a conceptos tectónicos cuyos orígenes nos remiten a la cabaña primitiva.

En la iglesia de las Escuelas Pías las grandes dimensiones del espacio iluminado desde lo alto a través de grandes huecos y la abstracción material producida por el revestimiento continuo y blanco de sus muros, centraban la atención en la espacialidad y dinamismo apoyados por los efectos de luces y sombras de las decoraciones barrocas. Destaca la importancia de la rotonda originalmente cubierta con una cúpula de gran presencia en la ciudad, que en el interior del edificio actúa como elemento ordenador aportando jerarquía a la composición. Su composición remite a una arquitectura construida por fases, a lo largo del tiempo, donde a un espacio central inicial se le ha incorporado una nave longitudinal y un altar cuadrado siguiendo el orden de un eje longitudinal. Un mecanismo compositivo de suma de elementos que se aprecia ya en el Panteón, y que se emplea a lo largo de la historia de la arquitectura.

También en el oratorio de San Felipe Neri la abstracción material de las superficies interiores permitía centrar la atención en los juegos de luces y sombras producidos por la incidencia de la iluminación, procedente de grandes ventanales, sobre los elementos definidores de la forma interior. Una composición de cierto dinamismo, originada a partir de la sucesión de elementos ritmados a lo largo de un eje de simetría, rematada en el altar como foco de atención visual del conjunto. Un sistema compositivo que busca una totalidad compleja de elementos articulados, generando un espacio dinámico y complejo. 
1 FERNÁNDEZ ALBA, A.: "1. Relaciones entre patrimonio históricoarquitectónico y proyecto de arquitectura". En: A.A.V.V. : Teoría e Historia de la Restauración. Madrid, MRRP, 1997, p. 39

[17] Oratorio de San Felipe Neri. Fotografía del presbiterio tras la restauración de 1905-1907 (SERAFINI: L'industria delle construzioni, no 368,2002 , p. 46)

[18] Capilla de los Condes de Fuensaldaña. Fragmento de la vista aérea de Valladolid, de Alfred Guesdon, realizada en 1854, donde se aprecia el conjunto de San BenitoSan Agustín. (RIVERA: 1990)

[19] Iglesia de las Escuelas Pías. Vista interior de la Iglesia de las Escuelas Pías del Colegio de San Fernando. (TOVAR: 1993, p. 166)

[20] Iglesia de San Pedro. Nave central. Trabajos llevados a cabo en los años 20. (FIDONE: R\&R, no 116117, 2012)
El interés por la configuración original del monumento ayuda a aclarar la razón de ser inicial de los elementos preexistentes, lo cual puede ayudar a retomar sus formas o sus materiales originales, pero también a proponer nuevos elementos bien relacionados con los preexistentes.

El primer camino aporta cierta seguridad al proyectista a la hora de establecer una relación adecuada entre lo nuevo y lo preexistente, pero supone limitaciones creativas que reducen las posibilidades de aportar nuevos valores. Esta actitud es más cuestionables cuando la información sobre la configuración original es escasa. Ante la falta de información sobre las partes faltantes, históricamente se ha acudido a criterios analógicos, ya indicados por Prosper Mérimée en el siglo XIX, consistentes en copiar motivos de edificios similares, una solución ampliamente empleada en las restauraciones estilísticas de aquella época. Respecto a estas actitudes Antonio Fernández Alba cuestiona que para establecer una relación con la preexistencia se deba volver a estos métodos eclécticos del siglo XIX basados en la analogía formal del pasado, ya que mediante la mímesis de los modelos arcaicos se produce un proyecto de pura convención formal repleto de manifestaciones "arbitrarias e irracionales". ${ }^{1}$

El segundo camino, de mayor complejidad, supone conocer no sólo los mecanismos compositivos del edificio, sino conocer y proponer otros nuevos que aporten una nueva visión al edificio en respuesta a las nuevas necesidades.
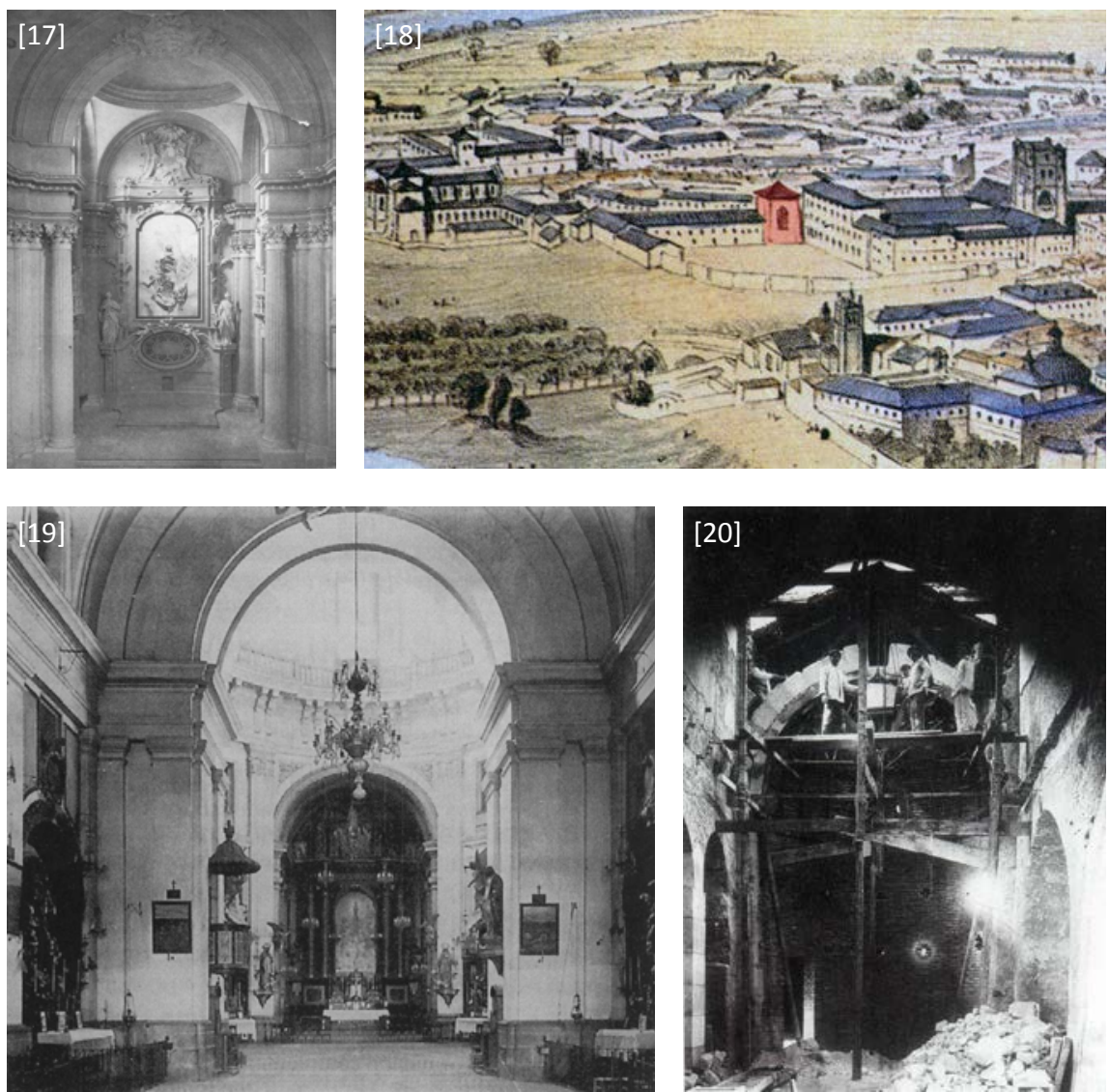


\subsection{Preexistencia}

Sin duda lo primero que llama la atención es la diferencia en la escala de la pérdida de cada uno de los ejemplos. Mientras que en Siracusa podría entenderse que la pérdida no suponía una condición para su habilitación funcional, en el caso de Bolonia pero sobre todo en Madrid y Valladolid el estado ruinoso de la preexistencia exigía una actuación de intervención que suponía la adición de nuevos elementos que completaran el espacio.

Esta diferencia parece afectar, de forma clara, a las soluciones adoptadas, siendo más cercanas a la conformación original cuando las perdidas son menores, y más lejanas cuando la parte a reproponer es de gran dimensión.

Otra cuestión interesante a reseñar está relacionada con la edad de la destrucción. En todos los casos la pérdida se había producido con suficiente anterioridad como para que la ansiedad reconstructora, que surge ante una transformación más o menos violenta, se impusiera como solución única para dar respuesta a la restitución de un trozo de memoria de la colectividad.

Esto se relaciona también con la pérdida del uso original del edificio, algo que se observa en los cuatro casos analizados, donde el paso del tiempo había ido desvaneciendo su necesidad inicial, produciendo un cambio en la percepción de su valor.

Así en San Felipe Neri el uso como almacén de materiales de construcción había ocupado el espacio sagrado "violando" su valor espiritual. También la ocupación como sala de conciertos de la iglesia de Siracusa había supuesto un cambio de uso del espacio sacro que había trasgredido la serenidad de su uso original. El caso más dramático es el de la capilla gótica de Valladolid en la que el abandono y el duro uso de su entorno había hecho olvidar casi por completo la presencia física del monumento. Sin embargo en Madrid, a diferencia de los casos anteriores, la presencia magestuosa de la ruina, identificada con mayor potencia en los rotundos muros de ladrillo de la estructura de la rotonda, había adquirido en valor positivo y en concordancia con su entorno, un barrio de fuerte carácter social.

Una situación común en los cuatro ejemplos tiene que ver con la necesidad de reproponer al menos el elemento abovedado desaparecido, o incluso, en los casos más deteriorados, las cubiertas y muros delimitadores del espacio. Ante esta situación se hace presente la necesidad de una reflexión sobre los elementos desaparecidos y los preexistentes que permita introducir los nuevos elementos sin que suponga una relación violenta, sino que logre un buen acorde con lo existente.
[21] Oratorio de San Felipe Neri. Visión del espacio de la nave hacia el acceso tras la restauración de Barbacci. (CERVELLATI: 1999)

[22] Capilla de los Condes de Fuensaldaña. Interior de las ruinas de la capilla. Pueden apreciarse mechinales de forjado y la cubierta de su antiguo uso para estancias de la tropa. (Imagen de la colección TRYCSA. En: ARNUNCIO: 2012, p. 25)

[23] Iglesia de las Escuelas Pías. [5] Vista exterior de la rotonda de la iglesia de las Escuelas Pías. (COAM: 1982, p. 161)

[24] Iglesia de San Pedro. Fachada Este antes de la restauración. (FIDONE: R\&R, $n$ ㅇ 116-117, 2012) 

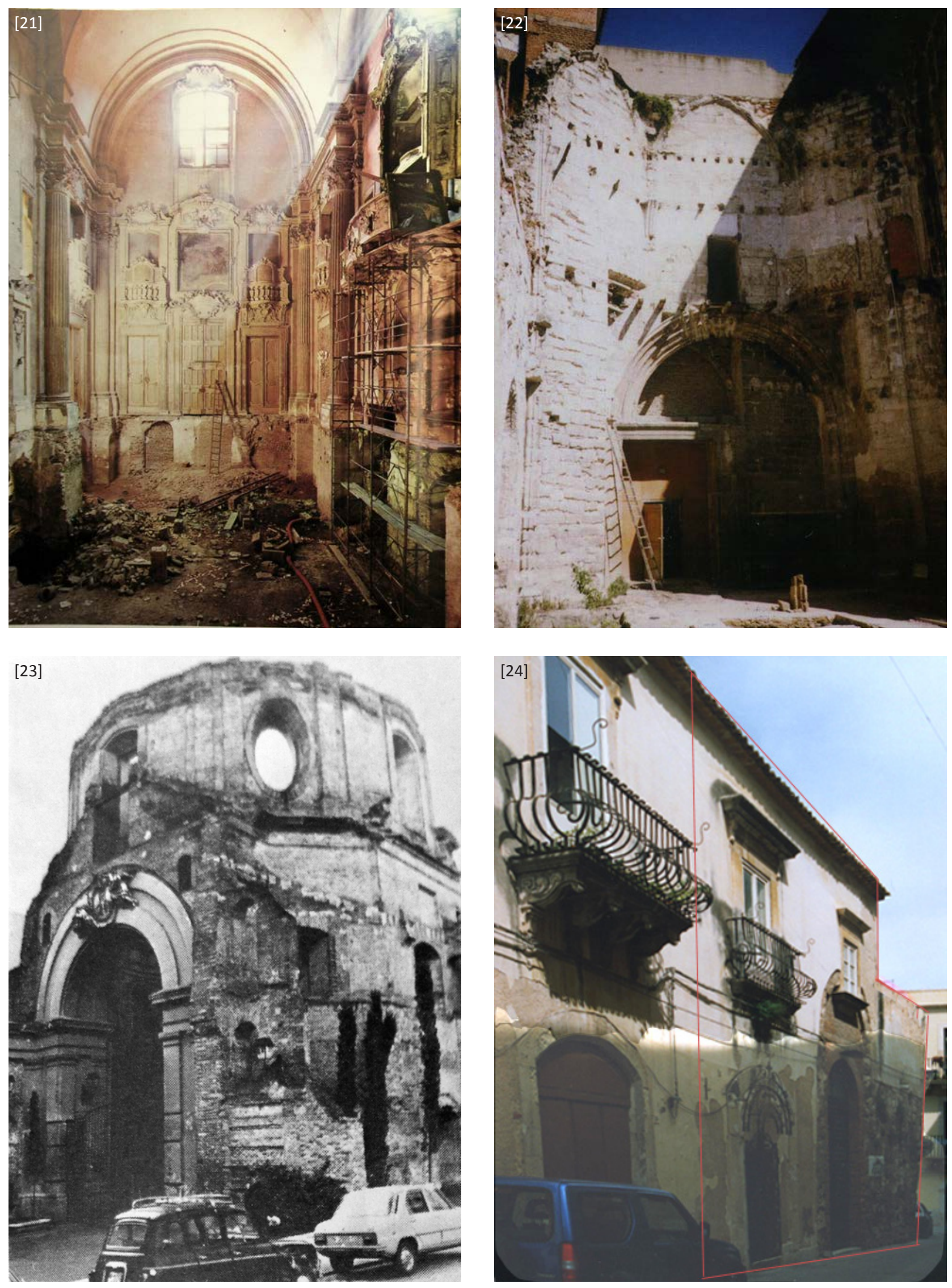


\section{EL ARQUITECTO RESTAURADOR}

\subsection{Criterios de intervención}

Cada uno de los arquitectos analizados presenta distintas peculiaridades en su manera de entender la arquitectura, algo que se transmite en las actuaciones que realizan sobre las preexistencias históricas. Los cuatro defienden la necesidad de actuar a través de un proyecto arquitectónico con un cierto carácter creativo, pero cada uno interpreta esta premisa mediante una relación distinta con el monumento.

Pier Luigi Cervellati entiende que es necesario reproducir ciertas formas del pasado para mantener el ambiente de armonía propio de los centros históricos, pero al mismo tiempo asegura que la restauración es un acto creativo en el entorno de un proyecto arquitectónico, por lo que se debe mantener un cierto equilibrio entre la referencia a la historia del monumento y la diferencia de la nueva actuación, en una actitud de respeto a la reglamentación lingüística marcada por las cartas del restauro. En este sentido aboga por la necesidad de restituir las partes faltantes, pero evidenciando la diferente temporalidad de cada fase ya que estas constituyen su memoria. Restitución, por tanto, mediante un exhaustivo análisis de la historia del monumento pero también mediante una reinterpretación que muestre su actualidad.

José Ignacio Linazasoro se aleja de esta lectura de la historia como instrumento de recuperación del pasado del monumento, y acepta la realidad impura de la preexistencia para continuarla mediante la adición de nuevos estratos, adecuados a la realidad actual, y capaces de soportar nuevas transformaciones futuras. Así, entiende que toda operación de arquitectura debe tender a la recomposición del orden arquitectónico mediante la suma de fragmentos, creados a partir de referencias a una cultura colectiva forjada a lo largo del tiempo. Un tiempo que ha esculpido la arquitectura, eliminándole capas, y devolviéndola a su origen constructivo, abstracto y esencial, que la ha transformado de manera continuada para adaptarla a las necesidades de cada momento, a base de superposiciones de estratos que con su locuaz presencia expresan la historia del monumento. Una concepción de la arquitectura que logra desenvolverse adecuadamente en las intervenciones sobre el patrimonio, ya que en el fondo tiene mucho que ver con el proceso de evolución arquitectónica presente a lo largo de la historia de la arquitectura, sobre todo en época medieval.

Juan Carlos Arnuncio apunta también hacia una actitud de reflexión actual sobre las necesidades del monumento sin la exigencia de su restitución original, donde es necesario plantear la nueva intervención mediante una actitud creativa adecuada a cada situación. Así afirma que todo proyecto de restauración es un problema de arquitectura, donde la única diferencia con un proyecto de nueva planta está en la presencia de una preexistencia que
[25 y 26] Imágenes del aspecto actual del Ares Ludovisi, restaurado por Gian Lorenzo Bernini en 1627. (Fotografías de André Durand. En: André Durand Digital Gallery: <durand-digitalgallery.com>)

[27] Frescos de Maso di Banco en la capilla Bardi de Florencia. (Lib-Art: $<$ www.lib-art.com>)

[28] Retrato de Napoleón realizado por Ingres. (Andrew Graham Dixon Archive. En: <www.andrewgrahamdixon.com>)

[29] La Libertad guiando al pueblo. Eugène Delacroix. (Museo del Louvre: <www.louvre.fr>)

[30] Nuevo espacio del acceso al Palacio del Licenciado Butrón (ARNUNCIO: <www.arnuncio.es >)

[31] Dibujo de Le Corbusier, hecho en Pompeya en octubre de 1911. (Fondation Le Corbusier: <www. fondationlecorbusier.fr $>$ )

[32] Mezquita de Kairouán. (GLANCEY: 2001, p. 50)

[33] Dibujo de J. I. Linazasoro. Arquitectura de Loos. (LINAZASORO: 2007, pp. 230)

[34] Columna dórica del templo de Atenea, formando parte de la estructura del Duomo de Siracusa, (FIDONE. En: CORNOLDI; RAPOSELLI: 2007, pp. 72)

[35] Antiguo mercado de Ortigia. Detalle de la restauración de la piedra en la parte del basamento exterior del muro sur. (Imagen de L. Rubino. En: FIDONE: Nuovo e Antico, $\mathrm{n}$ ㅇ 03, 2007, p. 87)

[36] Santa Maria del Gesù, en Modica. (Fotografía de L. Rubino. En: FIDONE; MESSINA: Nuovo e Antico, no 03,2007, p. 112) 

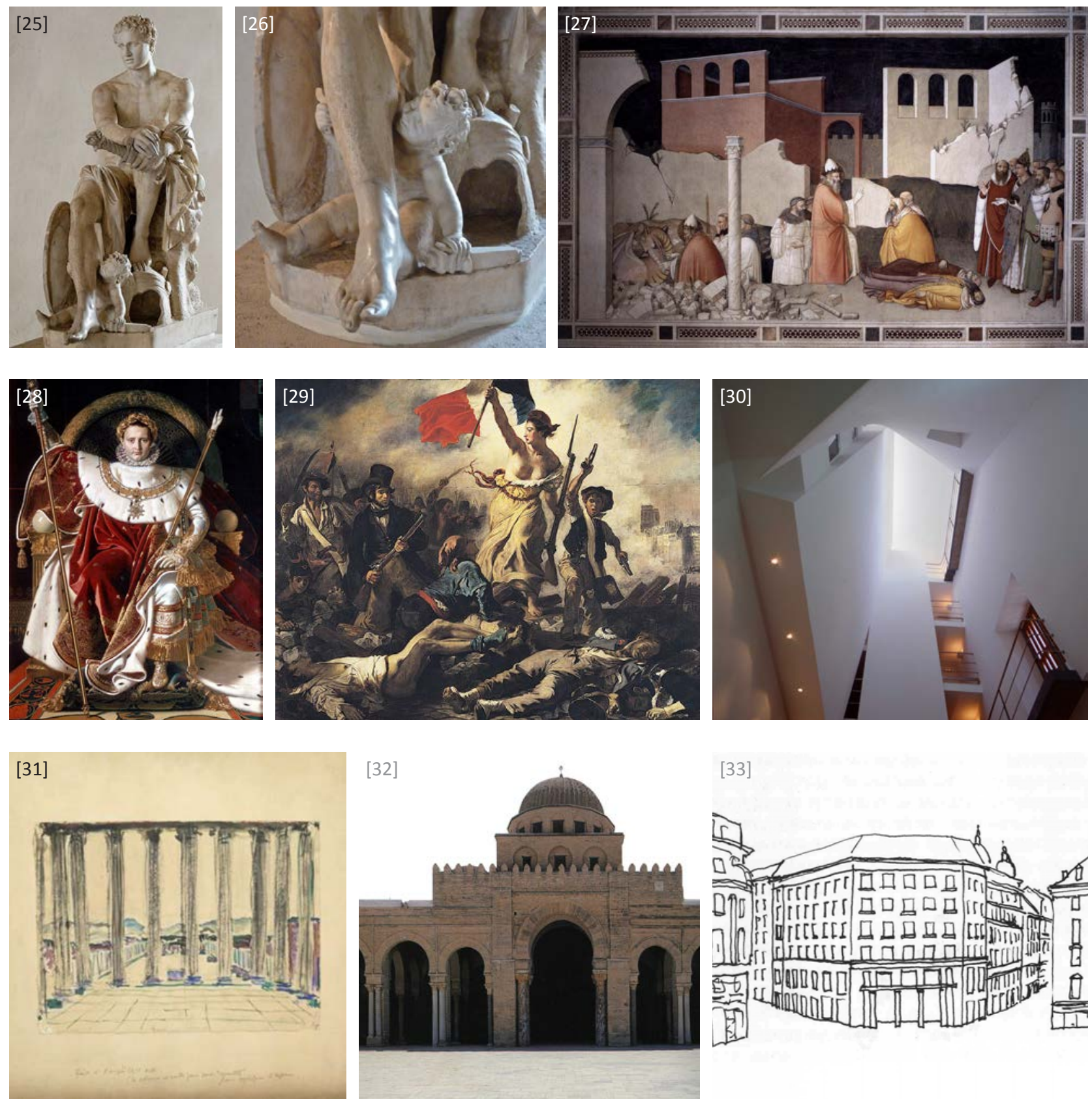

[33]
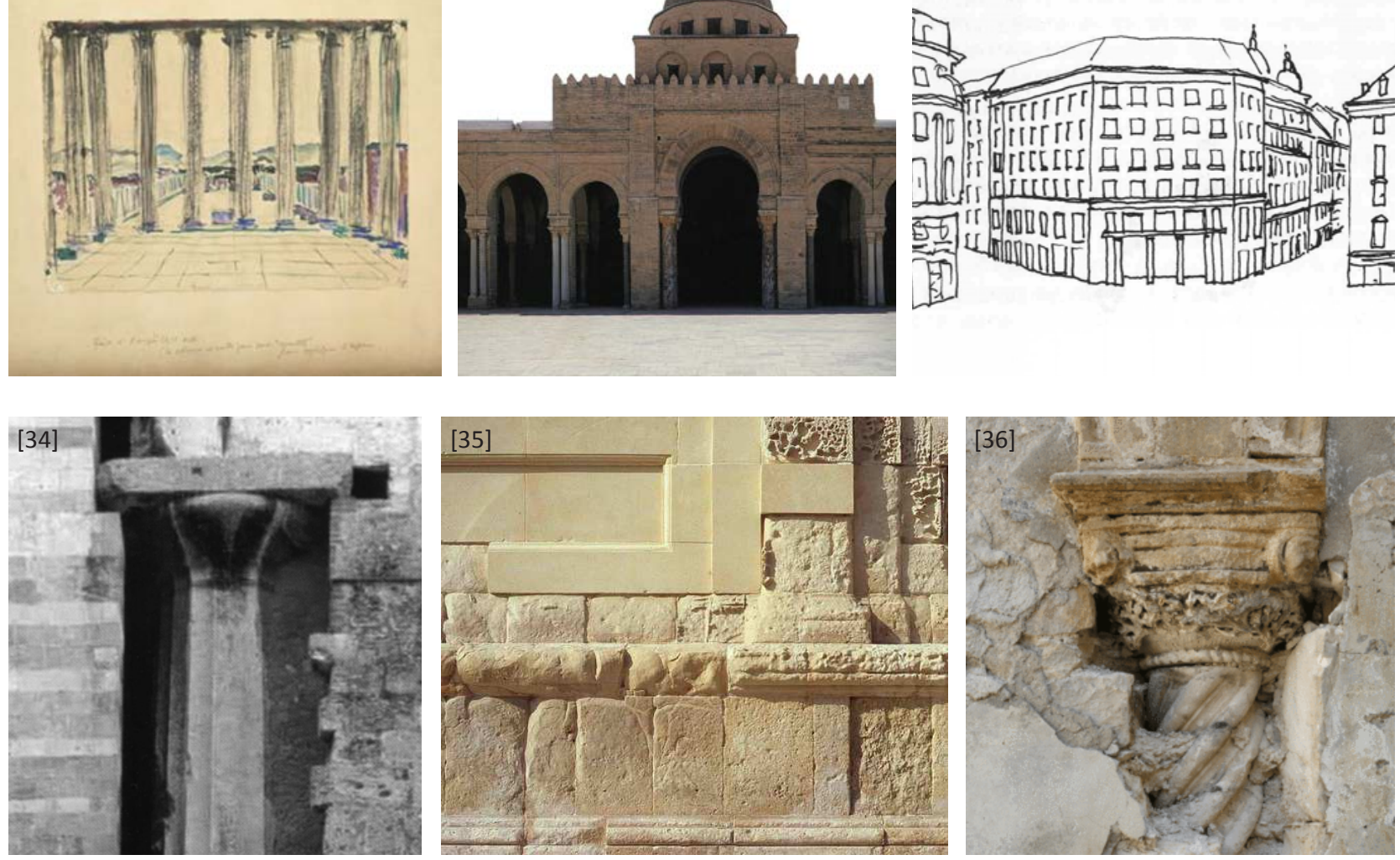
se debe interpretar adecuadamente, y donde cada proyecto es distinto y por tanto no se puede confiar en reglas preconcebidas. Arnuncio apuesta por buscar las respuestas en las experiencias de la arquitectura a lo largo de la historia, y defiende que siempre se debe actuar con inteligencia y humildad tratando de dar respuesta a las solicitaciones que presenta lo antiguo.

Emanuele Fidone se ubica en una posición intermedia entre Cervellati y los españoles. Manifiesta la búsqueda por establecer una continuidad y equilibrio entre las partes nuevas y antiguas mediante un diálogo bidireccional que aporte al pasado una nueva vida, entendiendo que la única manera de que lo antiguo sobreviva es transformándolo y reinterpretándolo desde el presente. En este sentido Fidone rechaza tanto aquellas actuaciones que buscan imponerse desde la ostentación formal o constructiva, como aquellas que se limitan a la imitación de la historia, y por tanto busca posicionarse en un punto intermedio que muestra una sensibilidad hacia la preexistencia y una formación proyectual creativa.

\subsection{Referencias}

Los cuatro destilan una reflexión e interés por la historia, algo que parece fundamental para poder actuar con acierto sobre un monumento histórico, pero cada uno enfoca sus inquietudes desde puntos de vista distintos. Cervellati se apoya en el urbanismo histórico y la restauración, Linazasoro en determinados arquitectos y arquitecturas con cierto carácter medieval, Arnuncio se interesa más por los distintos mecanismos de expresión artística, y Fidone se centra en la lectura del pasado trasformado y degradado a lo largo del tiempo.

Cervellati se apoya en su experiencia como urbanista, y su interés por la conservación del valor de los centros históricos. Sus trabajos en los años 60 y 70 sobre la ciudad antigua de Bolonia se encaminan a recuperar tanto la forma de la arquitectura histórica degradada como su uso, para devolverle la vitalidad y así asegurar su permanencia y mantenimiento. En este mismo sentido destaca las actuaciones realizadas sobre el patrimonio a lo largo del tiempo, llevadas a cabo según las diferentes épocas y culturas, en cuanto que fueron capaces de recuperar la historia perdida de los monumentos aunque se realizaran con carencias desde el punto de vista de la veracidad documental de la referencia.

Por otro lado Cervellati se apoya en referencias de la historia de la restauración, como por ejemplo las declaraciones de Roberto Longhi quien entiende que la eliminación de los daños de la obra de arte no ayudan a entender mejor la obra sino que la hacen más confusa. Con ello reconoce la necesidad de hacer evidente la actualidad de la nueva intervención y así evidenciar las diferentes fases históricas. Para ello aboga por acudir al carácter creativo de la restauración como parte de todo proyecto arquitectónico.
[37] Bóveda del tesoro de Atreo. (VELOSO: <arkyotras.wordpress.com>)

[38] Imagen de las costillas de la quilla de un barco. (Imagen de Gabriel Hormaechea. En: <www.modelismonaval.com>)

[39] Juan Navarro Baldeweg. Palacio de Festivales de Santander, 1984. (GONZÁLEZ; LAHUERTA; NAVARRO: 1993, p. 169)

[40] Salone della Prospettive de la Villa Farnesina de Baldassare Peruzzi, 1505. (Villa Farnesina: <www. villafarnesina.it>)

[41] Iglesia de Ronchamp, Le Corbusier, 1950-54. (ARNUNCIO: 2007, p. 86)

[42] La lechera, Johannes Vermeer, 1659. (Rijksmuseum: <www.rijksmuseum.nl>)

[43] Iglesia de San Marcos, Björkhagen. S. Lewerentz, 1956-1960. (Imagen de F. Galli. En: DYMLING, C.: 1997, p. 164)

[44] Arquitectura de Dom van der Laan. (PÉREZ: <tetraedros.blogspot.com>)

[45] Iglesia en Almtuna. P. Celsing. (Fotografía de Arnout Fonck. En: Flickr: <www.flickr.com>)

[46] Museo Kimbell. Louis I. Kahn, 1967-1972. (FRAMPTON; KOMENDANT; TENREIRO: 2000, p. 194)

[47] Iglesia de Ronchamp. Puerta de acceso. (Imagen del autor)

[48] Antigua iglesia de las Escuelas Pías. Vista de la nave central. (LINAZASORO: Conarquitectura, nㅇ 17, 2006, p. 57)

[49] Santa Maria del Gesú. Nuevo cierre de la nave central. (Imagen de L. Rubino. En: FIDONE; MESSINA: Nuovo e Antico, no 03, 2007, p. 99) 


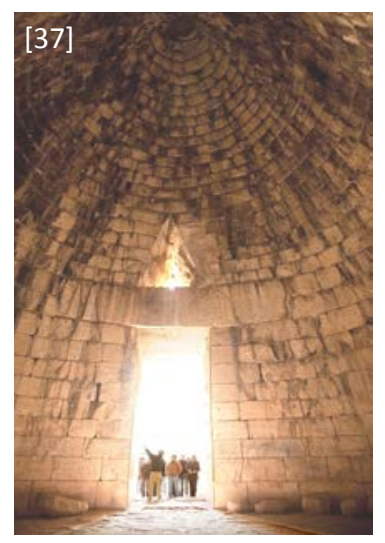

[38]
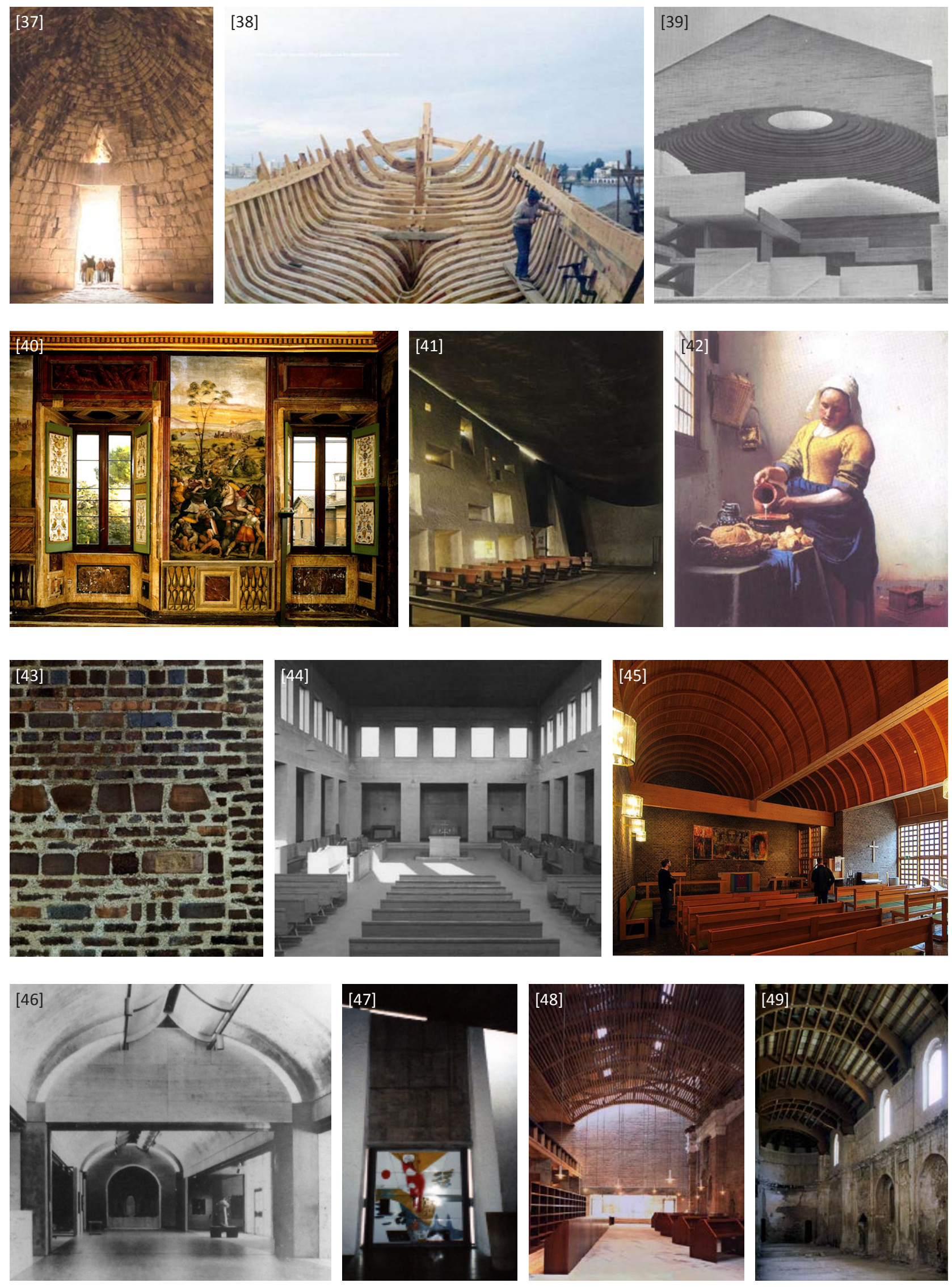
Linazasoro se vale del estudio de la arquitectura a lo largo de la historia como fuente de inspiración en sus actuaciones sobre las preexistencias. Se interesa por los mecanismo constructivos y formales presentes a lo largo de la historia y la reinterpretación que hacen de ello arquitectos modernos como Mies, Asplund, Lewerentz, Le Corbusier o Van der Laan, entre otros. Reconoce en la esencialidad formal y expresión material de la ruina las consecuencias del paso del tiempo, donde a través de un proceso de depuración devuelve a la arquitectura a su origen primitivo, poniendo en valor el carácter permanente de la arquitectura. Por otro lado le interesan la ciudad y las arquitecturas que la conforman entendidas como superposición de estratos de diferentes épocas, de tal manera que las nuevas actuaciones se relacionan con el contexto a través de referencias a estas arquitecturas y a sus mecanismos de estratificación.

Para Juan Carlos Arnuncio la historia es la fuente continua de inspiración de sus reflexiones sobre arquitectura. Entiende que la arquitectura es un problema con más incógnitas que ecuaciones, por lo que es necesario encontrar respuestas a estas variables dirigiendo la mirada a las experiencias de otros creadores.

Arnuncio demuestra en la orientación de esta mirada un interés por las creaciones que están a mitad de camino entre la expresión artística y la construcción arquitectónica, entendiendo que la arquitectura no consiste sólo en la resolución de un problema técnico sino que además, a través de sus formas, se transmiten emociones. Así pues se interesa tanto por el campo del arte como por el propiamente arquitectónico, en busca de mecanismos compositivos que le ayuden a expresar de forma adecuada a cada caso temas como la introversión o la producción de efectos.

Al igual que Cervellati Fidone se apoya en el pasado como fuente de inspiración para la solución proyectual, pero busca ir más allá del compromiso con la historia del monumento, entendiéndola como ámbito de inspiración para la creación de un elemento que se relacione adecuadamente con el edificio y le aporte una nueva vitalidad. El pasado es por tanto una fuente abundante de conocimiento que se puede retomar en la configuración de nuevos proyectos tras un proceso de esencialización de sus valores espaciales y materiales.

Por otro lado, al igual que Linazasoro, Fidone se apoya en la referencia de la ruina, destacando su valor como elemento mediador entre el trabajo abstracto de la arquitectura y el equilibrio de las fuerzas de la naturaleza, transmitiendo una imagen de una construcción intemporal e inamovible a mitad de camino entre lo artificial y lo natural. Por otro lado la imagen descarnada y fragmentada de la ruina se relaciona con la arquitectura en proceso de construcción definida por las estructuras sin revestir e inacabadas. Fidone busca en estas reflexiones referencias creativas que le ayuden a intervenir sobre la ruina, entendida ésta como una obra incompleta con problemas abiertos sin resolver, sobre la que se debe actuar para establecer un nuevo sistema de equilibrio que la devuelva a la vida. 


\subsection{Estrategias}

Cervellati se apoya por un lado en los instrumentos propios de la restauración, desde la limpieza y consolidación de las preexistencias, hasta la repristinación de fragmentos desaparecidos, y por otro lado en el lenguaje contemporáneo mediante la simplificación formal y abstracción material para tratar de restituir las partes faltantes expresando la diferenciación y reversibilidad de la intervención.

José Ignacio Linazasoro actúa buscando recomponer el orden incompleto de la arquitectura mediante referencias a arquitecturas que le interesan, referencias que a su vez se han interesado por las arquitecturas del pasado, pero también referencias a las arquitecturas y sugerencias del lugar donde se ubica la intervención. Con todo ello logra establecer vínculos entre el contexto y la historia que producen una unidad de gran naturalidad.

Así, la relación con el contexto es obra de un complejo proceso proyectual en el que intervienen diversas estrategias como la relación interior-exterior, el equilibrio entre analogías y contrastes, la creación de recorridos y la repetición de elementos, la evocación de la ruina a través de referencias cuyos fragmentos tienen implícita una totalidad conocida, la relación material, la manipulación de la preexistencia y de su pasado, la relación entre opuestos y la superposición temporal.

Juan Carlos Arnuncio defiende diversas estrategias de intervención en función de las necesidades, siendo factibles tanto la conservación y la inserción de lo nuevo, como la reconstrucción tipológica o mimética. Cada actitud aporta cuestiones distintas, la clave es saber cuando conviene emplear unas u otras.

Entre sus inquietudes proyectuales destacan dos cuestiones que se repiten de manera bastante insistente en toda su obra: la introversión y la ficción arquitectónica.

La primera tiene que ver con el concepto primitivo de la arquitectura como elemento protector que resguarda del exterior un interior hecho a la medida del hombre, un exterior árido, duro capaz de soportar las inclemencias de la naturaleza frente a un interior amable donde se producen efectos espaciales que aluden a los sentimientos más íntimos del ser humano. Esta actitud de sobriedad exterior se relaciona con facilidad con la arquitectura del pasado envuelta de gruesos y potentes muros lo que permite atender con armonía a la relación entre antiguo y nuevo.

La segunda cuestión se refiere a la necesidad de la arquitectura de ir más allá de la pura construcción, aludiendo a efectos que produzcan emociones, en un juego magnífico de volúmenes bajo la luz. Así Arnuncio explora en la historia de la arquitectura y en las artes plásticas conceptos como la búsqueda de ingravidez a través de la bóveda en la arquitectura como representación del cielo frente a la pesadez de los muros que la sustentan, y la interrelación entre lo real y lo ficticio para que se produzca una unidad verosímil entre ambos mundos. 
Fidone afronta el proyecto de intervención como una operación de reflexión compositiva sobre el edificio y su contexto. En esta valoración de la preexistencia entiende como fundamental la realidad material sobre la que se actúa. La mirada atenta y abierta durante el proceso de puesta en obra, la sabiduría práctica de los oficios y la pátina del tiempo en las superficies son valores que ayudan a relacionar lo nuevo con lo viejo. En este sentido Fidone aboga por el respeto de los diferentes estratos presentes en el monumento como reflejo de su valor diacrónico de evolución a lo largo del tiempo, donde cada transformación refleja la voluntad de una época. Una suma de significados que se debe analizar en profundidad para insertar adecuadamente el nuevo estrato.

En esta línea Fidone apuesta por la reinterpretación de los antiguos elementos desaparecidos mediante la esencialidad formal y expresión material para insertarse con armonía sobre la preexistencia pero con intención claramente transformadora, donde más allá de cuestiones normativas lo importante es resolver un problema a través de la arquitectura.

En resumen podemos decir que Cervellati se apoya en los mecanismos propios de la restauración, Linazasoro en la recomposición de fragmentos en armonía, Arnuncio en el equilibrio, la introversión y la producción de efectos, y Fidone en la relación con la materia degradada de la preexistencia. Diferentes maneras de enfrentarse a la intervención en el patrimonio, pero con un mismo objetivo producir una arquitectura de calidad donde exista una relación profunda entre lo antiguo y lo nuevo.
[50] P. L. Cervellati. Visión del espacio de la nave hacia el altar tras la última restauración. (SERAFINI: L'industria delle construzioni, no 368,2002, p. 47)

[51] J. C. Arnuncio. Imagen del teatro Olímpico de Vicenza. (ARNUNCIO: 2007, p. 108)

[52] J. I. Linazasoro. Imagen de la cisterna mirabilis de campi flegrei de Nápoles. (Imagen de Grimaldo Ganzerli. En: Flickriver: <www.flickriver.com>)

[53] E. Fidone. Centro Turístico en el ex-mercado cubierto de Ortigia. Detalle de la restauración de la piedra en la parte del basamento exterior del muro sur. (Imagen de L. Rubino. En: FIDONE: Nuovo e Antico, no 03, 2007, p. 87) 

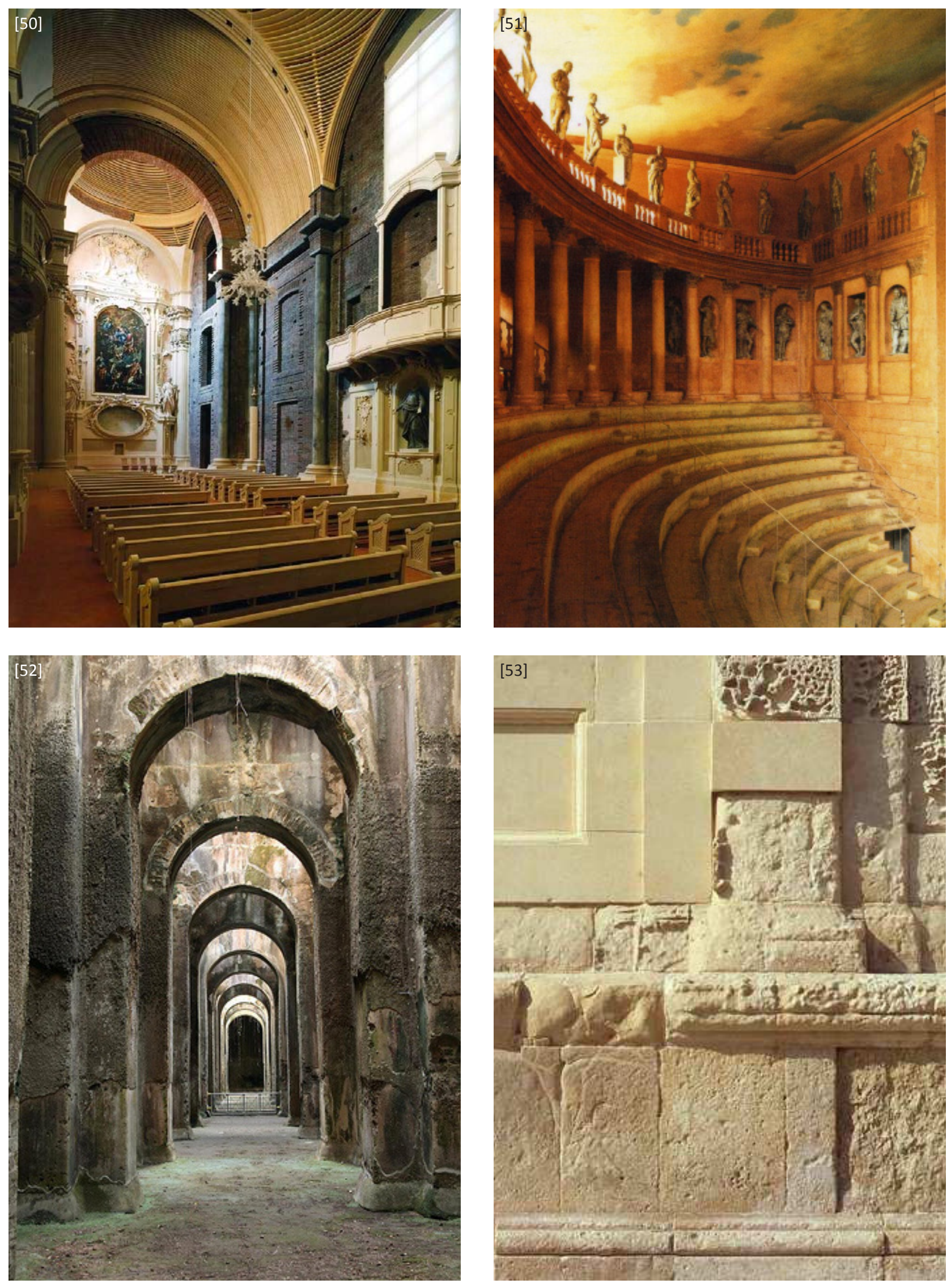


\section{INTERVENCIÓN}

\subsection{Objetivos}

Cervellati enfoca la intervención sobre el oratorio de San Felipe Neri desde la aceptación tanto de la pérdida de parte del monumento original como de la reconstrucción interrumpida de mediados del siglo XX. Ambos son episodios históricos que merecen ser respetados, como memoria de las acciones bélicas de la guerra y de los criterios restaurativos y habilidades constructivas de otra época. Por lo tanto la restitución de los elementos faltantes la plantea mediante un lenguaje moderno que evidencie su actualidad respecto al resto de partes del monumento.

También Fidone plantea la actuación en San Pedro desde el respeto de los estratos existentes y la recuperación de elementos perdidos, pero en este caso la pérdida no se debe a acciones bélicas sino a las transformaciones que a lo largo de la historia habían terminado por desvirtuar el equilibrio espacial del edificio. Los nuevos elementos se plantean como fragmentos inspirados en la historia del monumento pero desde una intención creativa moderna que indague en cualidades puramente arquitectónicas como el espacio, la materia y la luz, capaces de devolver la dignidad al espacio sagrado de la iglesia.

Arnuncio se aleja de la historia de la Capilla a la hora de plantear su intervención sobre el monumento, debido por un lado a los escasos restos preexistentes y a las nuevas necesidades funcionales, y por otro lado al deseo de mantener la fascinante presencia material de la ruina. Pero los objetivos buscan en cierto modo recuperar los significados presentes en el edificio original, de tal manera que se plantea una intervención que explora la dualidad entre interior y exterior propia de los edificios antiguos envueltos por muros: mientras que al exterior busca recuperar de manera esencializada la presencia volumétrica del monumento en la ciudad, en el interior el objetivo es reinterpretar el valor espiritual original. Una vez más, el lenguaje moderno se emplea para resolver los añadidos.

Por último Linazasoro en las Escuelas Pías acepta la realidad de la ruina como parte integrada de manera armónica en el contexto urbano, y propone la construcción de nuevos elementos entendidos como fragmentos que se relacionan con la realidad material de la preexistencia en una búsqueda por conformar una arquitectura diferente a la original. Una arquitectura inspirada en sus presencias y sus ausencias, pero también en las nuevas necesidades funcionales y del lugar, y en las inquietudes arquitectónicas de Linazasoro manifestadas a través de referencias a otras arquitecturas de la historia. Y todo ello envuelto bajo un lenguaje contemporáneo basado en la esencialidad formal y la expresión material.
[54] Oratorio de San Felipe Neri. Evolución histórica.

[55] Capilla de los Condes de Fuensaldaña. Evolución histórica.

[56] Iglesia de las Escuelas Pías. Evolución histórica.

[57] San Pedro. Evolución histórica. 

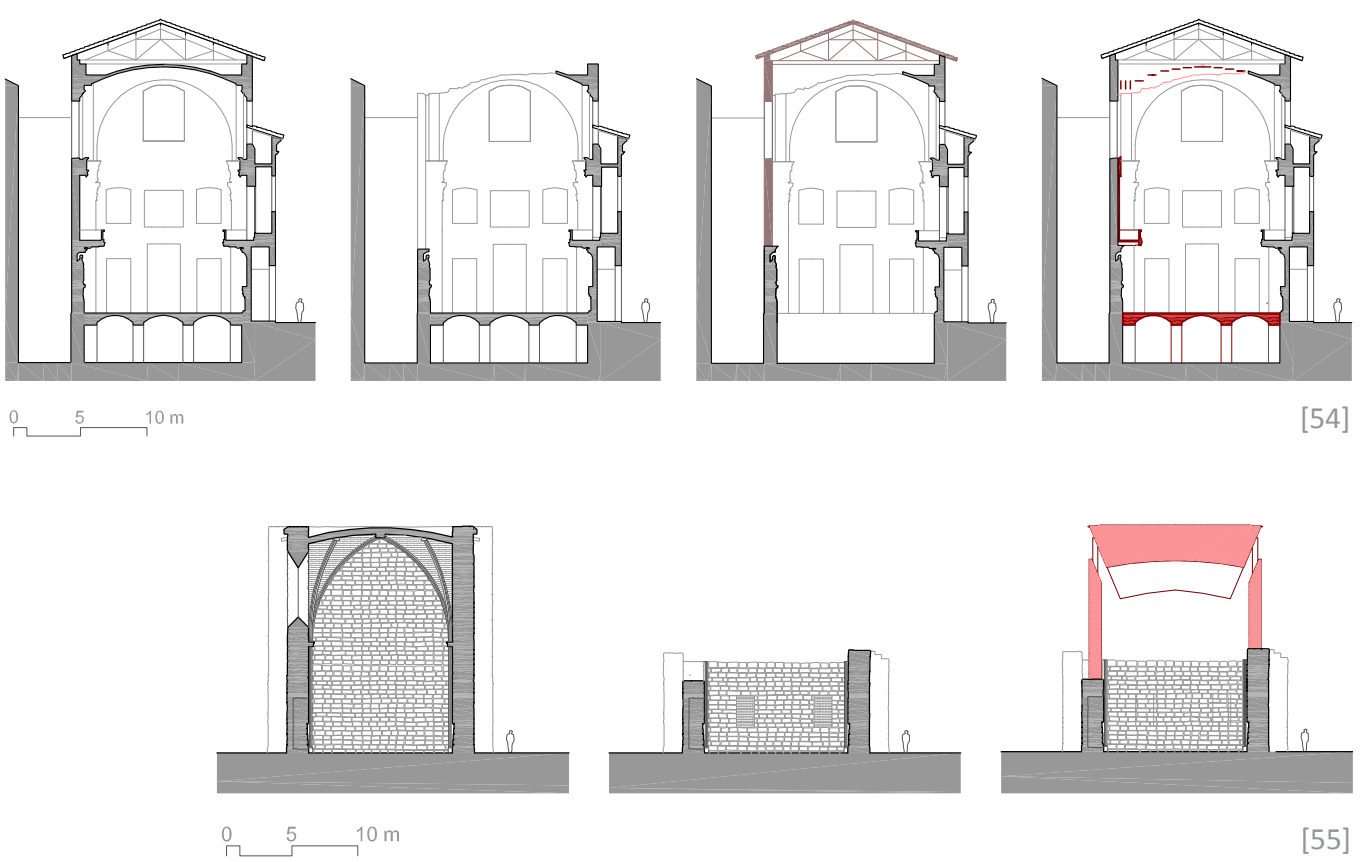

[55]
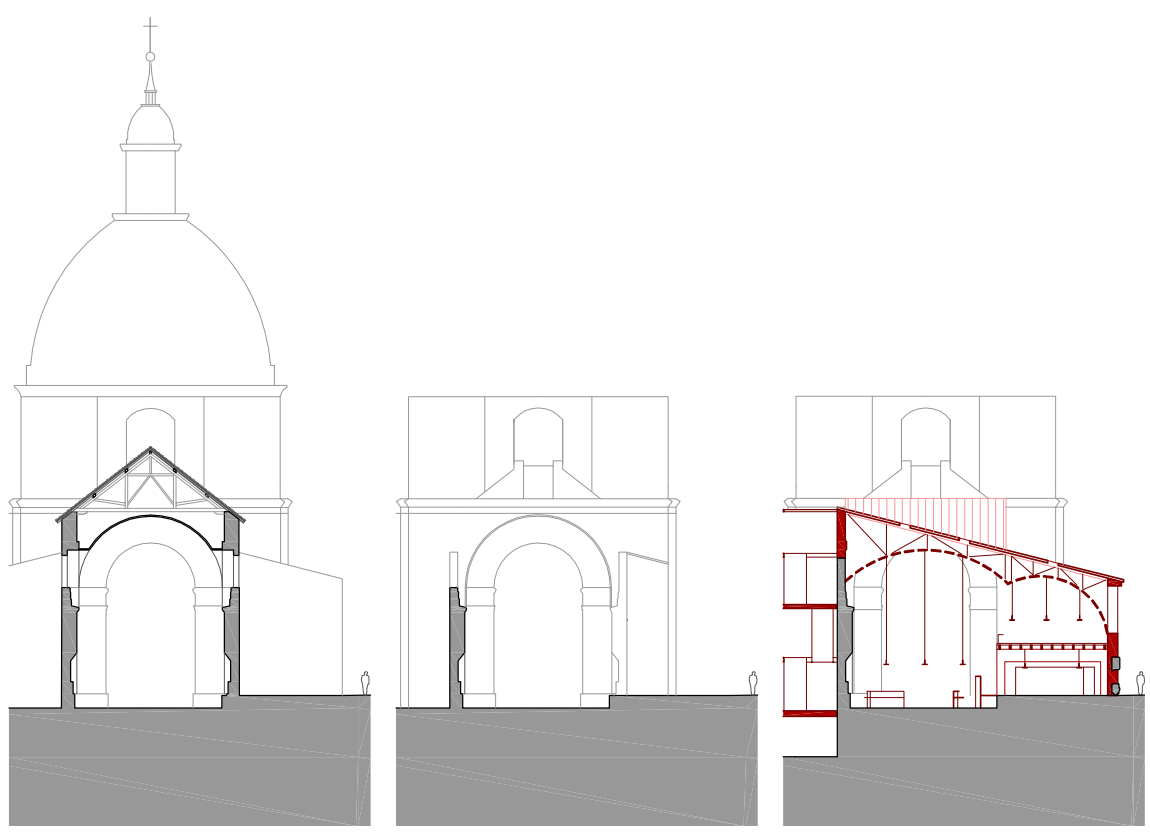

$\stackrel{0}{\square \quad} \square^{10 \mathrm{~m}}$

[56]

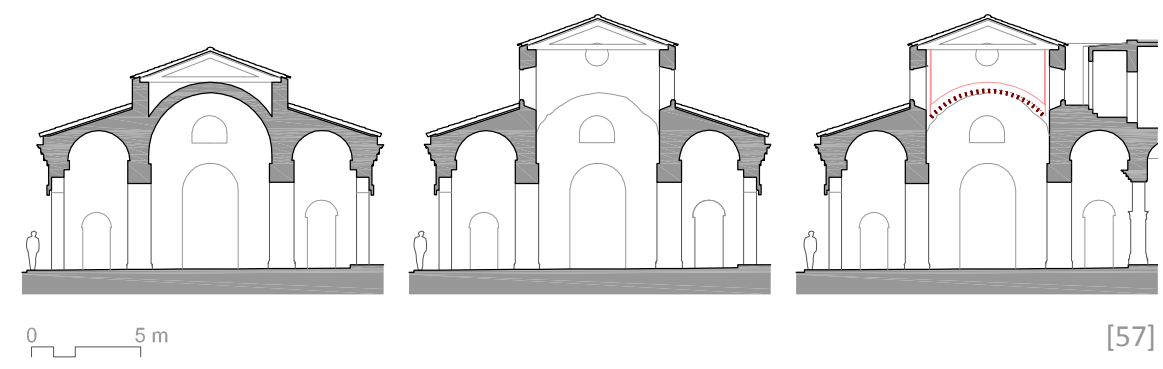


Vemos que se plantean una serie de objetivos comunes: el respeto a las diferentes fases de la historia que han perdurado hasta la actualidad; la aportación de nuevos valores mediante elementos con un lenguaje moderno; y la búsqueda de relación entre la preexistencia y los nuevos elementos, mediante una cierta reflexión sobre el monumento.

\subsection{Programa funcional}

La reasignación de una función nueva a las preexistencias se plantea como fundamental para su pervivencia en el presente. Pero al mismo tiempo se entiende que esta función debe ser compatible con la original, compartiendo parcialmente algunos significados comunes.

La actuación de menor impacto funcional respecto al uso original es la realizada por Fidone en San Pedro de Siracusa, donde ante la ausencia de un destino de uso claro se opta por recuperar su ambiente religioso original, con la intención de que el espacio sea el que sugiera la función y no al revés. El problema que supone este tipo de planteamiento es que por un lado el edificio queda cerrado a la espera de otorgarle un uso, y por otro lado que el edificio deberá sufrir la adición de elementos para soportar las nuevas exigencias funcionales, de tal manera que al no haberse incluido éstos en el proyecto de intervención podrían distorsionar la armonía arquitectónica generada.

Otra transformación funcional poco distante de la original es la realizada por Cervellati en el ex Oratorio. Un espacio pensado originalmente para la interpretación musical, el sermón y la oración se debía convertir en un auditorio con todos los requisitos tecnológicos actuales. Los vacíos presentes en el techo se presentan como el lugar idóneo para dotar de las nuevas necesidades acústicas, lumínicas y climáticas, mientras que la forma del espacio se adaptaba con facilidad a las exigencias de una sala de representación musical. Por otro lado otros elementos necesarios como aseos, biblioteca y oficinas se encajan en los espacios adyacentes a la sala. Por último los nuevos elementos de circulación se convierten en los elementos más invasivos por cuestiones de accesibilidad: por un lado la nueva rampa de acceso ubicada en la calle, y por otro lado las nuevas circulaciones y ascensor ubicados en el espacio del patio y resueltas mediante la construcción de un nuevo cuerpo de madera.

Por último tanto en Valladolid como en Madrid la adaptación funcional de los espacios sagrados parcialmente desaparecidos se orientan a usos relacionados con la cultura y por tanto con la cultivación del espíritu, lo que permite que se produzca una cierta compatibilidad entre la arquitectura original y la nueva propuesta.

Así en las ruinas de la capilla gótica Arnuncio convierte el antiguo espacio de culto religioso en un lugar para la experimentación del arte contemporáneo. Una transformación funcional donde permanece una búsqueda por dar 

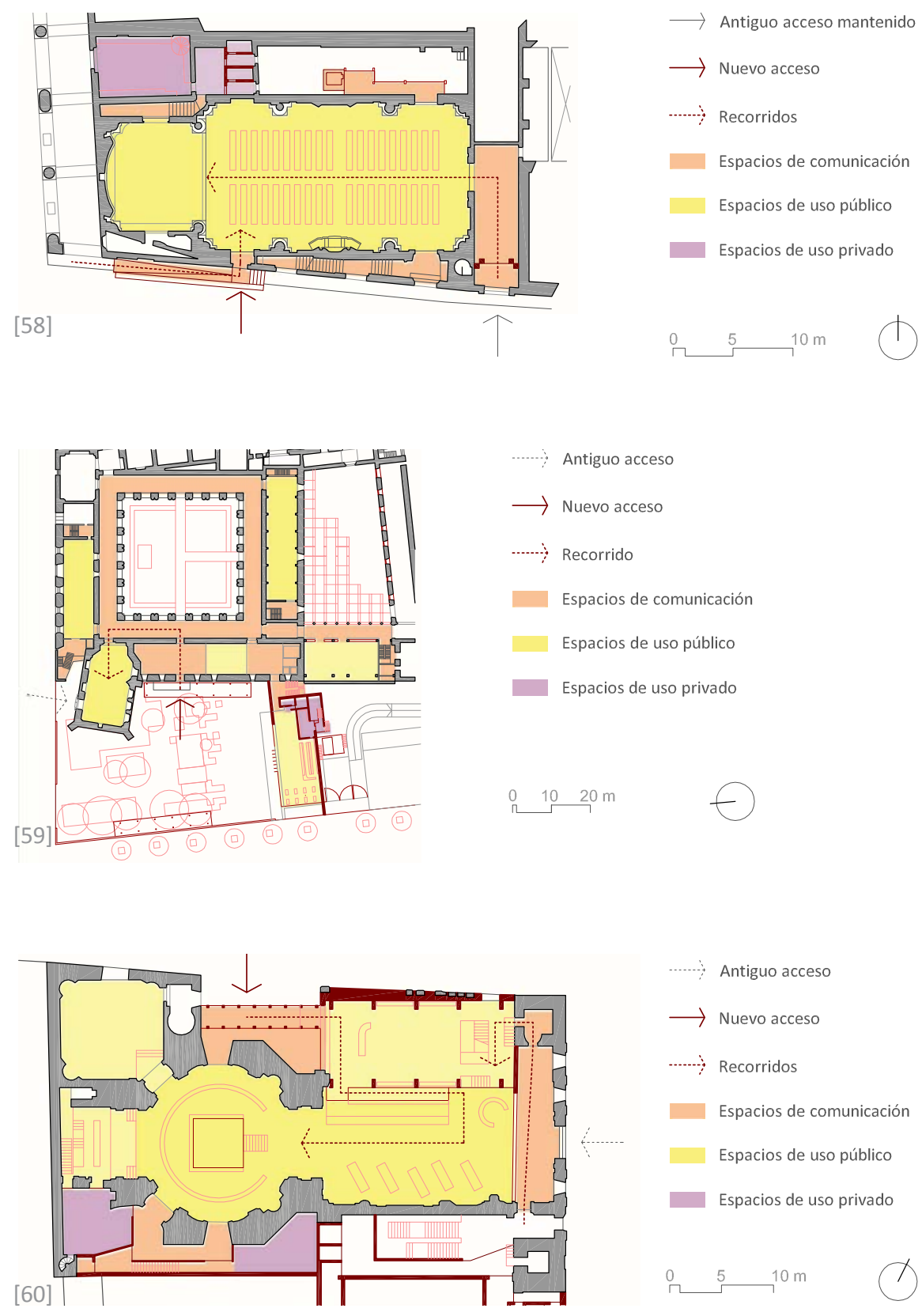

[58] Oratorio de San Felipe Neri. Esquema de usos.

[59] Capilla de los Condes de Fuensaldaña. Esquema de usos.

[60] Iglesia de las Escuelas Pías. Esquema de usos.

[61] Iglesia de San Pedro. Esquema de usos.
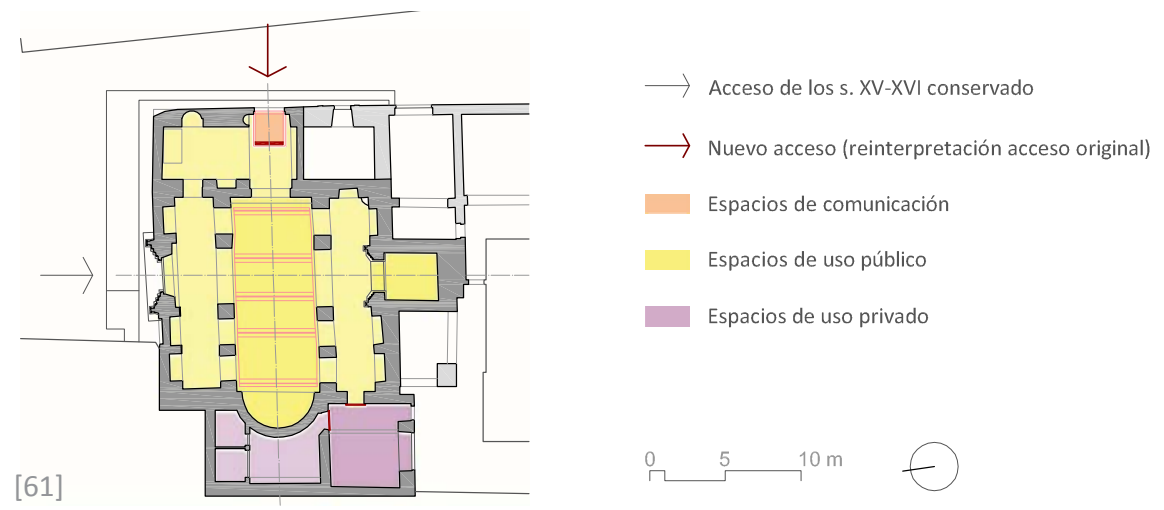
al espacio un significado trascendental, mediante una reflexión sobre el peso y la levedad de la forma cóncava como elemento protector que resuelve el cerramiento superior. Así la representación del cielo mediante la descomposición del espacio gótico en estilizados nervios de piedra se convierte ahora en la construcción de una "vela" soplada por el viento que acoge y protege con amplitud la reflexión artística contemporánea.

Por su parte Linazasoro transforma la función religiosa de la iglesia barroca en un espacio de lectura y estudio. Una operación que modifica la antigua búsqueda de la unidad, perfección e inmensidad divina conformada mediante una sucesión jerarquizada y ordenada de "tres" espacios, y propone una nueva visión múltiple, imperfecta y yuxtapuesta de estancias que acogen al individuo en su proceso de interiorización del conocimiento.

Mención especial requiere el trabajo realizado por cada arquitecto respecto a los accesos y recorridos principales de los monumentos.

En Siracusa Fidone busca recuperar la importancia histórica del acceso original pero sin renunciar a expresar su transformación posterior. Para ello recurre a un sistema de apertura que hace referencia por un lado a la transición exterior interior que existía en el pórtico original y por otro lado a la idea de muro presente en fases posteriores.

En Bolonia Cervellati busca recuperar el acceso principal al Oratorio ubicado a los pies del espacio longitudinal mediante la reutilización del pasaje interior de manzana como foyer del nuevo Auditorio, retomando con ello un interesante recorrido de transición desde el espacio exterior hasta el interior de la iglesia.

Arnuncio en Valladolid decide renunciar al acceso original que se producía directamente desde el exterior, manteniéndolo solo como introducción de material,yapuestaporelacceso desdelacabecera delacapillaparamantener un recorrido interior controlado. Con ello potencia la transgresión funcional del edificio al acceder por la parte más "noble" y enfocar la mirada hacia los pies de la capilla, punto donde se concentra el mayor efecto espacial.

Por último Linazasoro apuesta también por la transgresión del acceso original situado en el eje longitudinal de la iglesia, y crea un nuevo acceso desde la plaza en respuesta a las nuevas necesidades funcionales del lugar. Pero además esta transformación viene acompañada por un complejo proceso de acceso que se inicia de manera lateral a través de una especie de atrio moderno y que va recorriendo los diferentes espacios en un dilatado camino "procesional" que permite ir descubriendo poco a poco los diferentes ámbitos que componen el conjunto.

Respecto al mobiliario como sistema de apoyo de la función ni Fidone ni Arnuncio consideran necesarios los muebles en sus intervenciones. Sin embargo la diferencia entre Bolonia y Madrid es notable. Por un lado Cervellati diseña unos bancos con la misma madera del resto de la
[62] Oratorio de San Felipe Neri. Vista del espacio interior y el nuevo uso. (Fotografía del autor.)

[63] Capilla de los Condes de Fuensaldaña. Vista del espacio interior y el nuevo uso. Instalación "Transfigured Schönberg", de Dionisio González, del 2 de octubre de 2009 al 4 de abril de 2010. (nexo5.com, 7 de octubre de 2009: <www.nexo5. com>)

[64] Iglesia de las Escuelas Pías. Vista desde la nave hacia el altillo. (PRESI: 2012, p. 75)

[65] San Pedro. Vista del interior de la nave central hacia el ábside. (FIDONE: R\&R, $n$ ㅇ 116-117, 2012) 

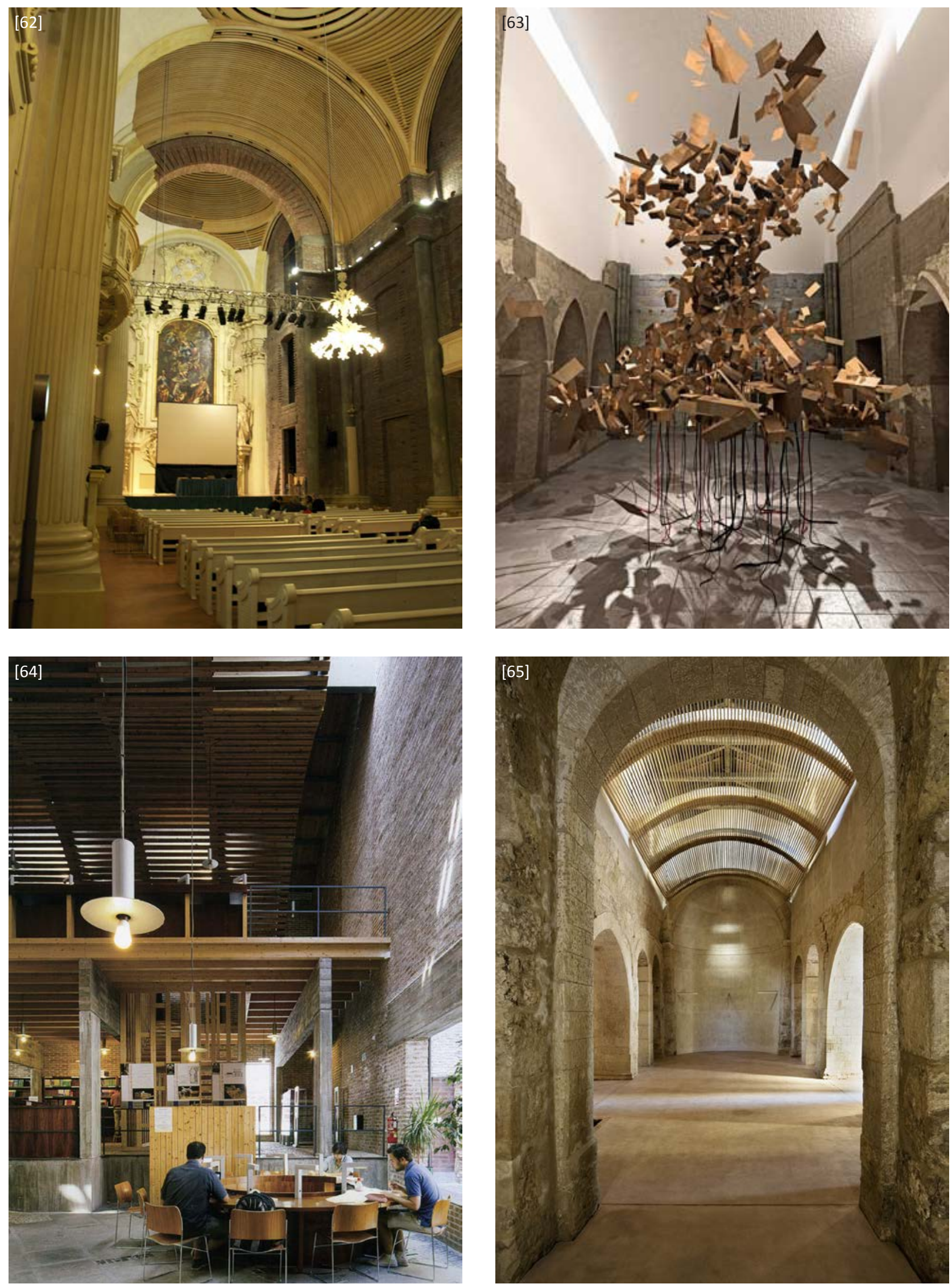
actuación pero con un lenguaje con aire rococó que buscan reconectar la nueva actuación con el ambiente del Oratorio original. Por otro lado Linazasoro plantea el mobiliario de dos maneras distintas, aunque siempre manteniendo su carácter de elemento mueble: por un lado aparece apoyando la geometría de la diferentes espacios donde se ubican, y por otro lado introduce unas escribanías en la nave deliberadamente giradas para transmitir una sensación de provisionalidad, y con una tipología algo "antigua" que permiten abstraen al lector de las distracciones de la contemporaneidad y lo transmiten un tiempo pasado.

\subsection{Forma, espacio y luz}

Las soluciones varían en función de la interpretación de la historia del monumento y por tanto del valor otorgado a cada una de sus fases. En unos casos se busca mayor literalidad de las formas históricas desaparecidas y en otros casos se pretende precisamente lo contrario pero sin perder cierta relación con los elementos originales para mantener un diálogo con la historia del monumento. Por otro lado se observa que en función de la condición de cada elemento se actúa de manera diferente, tratando de dar la respuesta adecuada a cada uno sin imponer criterios inflexibles que producirían soluciones inadecuadas. Soluciones que se mueven entre la analogía y el contraste tratando de mantener siempre un equilibrio en el conjunto, donde en líneas generales se observa una tendencia a un lenguaje contemporáneo apoyado en la simplificación y la abstracción formal.

Cervellati y Fidone se apoyan en las formas originales para plantear la definición de los elementos faltantes, sin embargo actúan de maneras distintas. Por un lado Cervellati se preocupa por completar la envolvente de las bóvedas desaparecidas mediante una solución con un carácter provisional e incompleto que hace evidente la destrucción de los elementos preexistentes y la ausencia de las partes faltantes. Con ello trata de introducir una solución que haga de mediadora entre el juego refinado y complejo de la parte rococó, y la actuación tosca e inacabada de la restauración de Barbacci. Una solución que hereda la abstracción formal moderna pero en cierta manera mantiene la complejidad formal del rococó, gracias a descomponer las bóvedas en una suma de elementos donde la nueva "ornamentación" se define por el cuidado diseño de cada una de estas piezas, creando unos efectos de luces y sombras que remiten a los efectos producidos por las formas artesanales del dieciocho.

Por otrolado Fidone se apoya en la historia del monumento como inspiración para la creación de un nuevo elemento que ayude a recuperar un ambiente espacial más equilibrado, con una escala más humana y una luz más intimista. La nueva bóveda se formaliza como un elemento calado, ligero y suspendido en el espacio que produce un gran efecto luminoso y permite mantener la lectura de los diferentes estratos históricos que componen el edificio. Un elemento de cierta complejidad pero con apariencia elemental que se relaciona bien con la sencillez de la arquitectura paleocristinana. 
Arnuncio y Linazasoro plantean soluciones que se alejan de las formas originales pero que en cierto modo las evocan. Por un lado en Valladolid la nueva superficie de cerramiento exterior busca retomar la presencia volumétrica original, pero de manera claramente distinta mediante una abstracción formal retranqueada de la antigua. En el interior se genera un nuevo espacio formalmente muy distinto al gótico, pero con ciertas relación conceptuales como es la búsqueda por conformar una representación del cielo, produciendo un efecto trascendental en el individuo.

Por otro lado Linazasoro actúa transformando con claridad el espacio de la iglesia y cuando se acerca a la arquitectura original no lo hace en relación a su perfección inicial si no a su estado depurado y contaminado por el paso del tiempo. Con ello va conjugando un juego de analogías y contrastes que modelan la arquitectura preexistente para conformar una nueva arquitectura pero siempre con cuidado de no distorsionar la armonía entre lo antiguo y lo nuevo. Así introduce nuevos límites verticales que modifican el espacio de la iglesia barroca pero que a su vez se relacionan con los grandes muros másicos desnudos preexistentes. O construye un umbráculo que evoca lo que podría ser el elemento abovedado original tras un proceso de transformación formal y material producto del envejecimiento.

El trabajo con la luz se enfoca a apoyar los objetivos ya enunciados. Cervellati recupera la iluminación original, Fidone trata de atenuar la existente para recuperar el ambiente de recogimiento paleocristiano, Arnuncio la emplea como parte esencial de búsqueda del efecto de levedad y Linazasoro la utiliza para enfatizar la fragmentación del espacio y mantener el carácter de ruina descubierta.

Si nos fijamos en la actuación sobre las partes preexistentes notamos ciertas diferencias de criterio en cada uno de los casos, variando desde soluciones más restauradoras a otras más conservadoras. Así, por ejemplo, Cervellati plantea un profundo trabajo de restauración de la ornamentación rococó preexistente, criterio que extiende a la restitución "mimética" del forjado de planta baja por entender que su desaparición no se debe a ningún acontecimiento histórico sino a una actitud completamente arbitraria del arquitecto Barbacci. Con ello busca recuperar el máximo esplendor del edificio original.

Por otro lado en las otras tres actuaciones se busca mantener o potenciar la imagen de ruina de la preexistencia. Así Arnuncio realiza un trabajo de restauración y restitución pero sin perder el concepto degradado y fragmentado de su estado actual, llegando incluso a reproducir los deterioros en la reposición de algunos sillares de piedra. También Fidone trata de destacar la vibración luminosa de las texturas históricas buscando reproducirlo en los nuevos revestimientos de las zonas enlucidas. Por último Linazasoro opta por las mínimas operaciones necesarias de limpieza y consolidación para mantener la ruina, pero sin restituir nada, conservando el estado degradado de las formas preexistentes. 

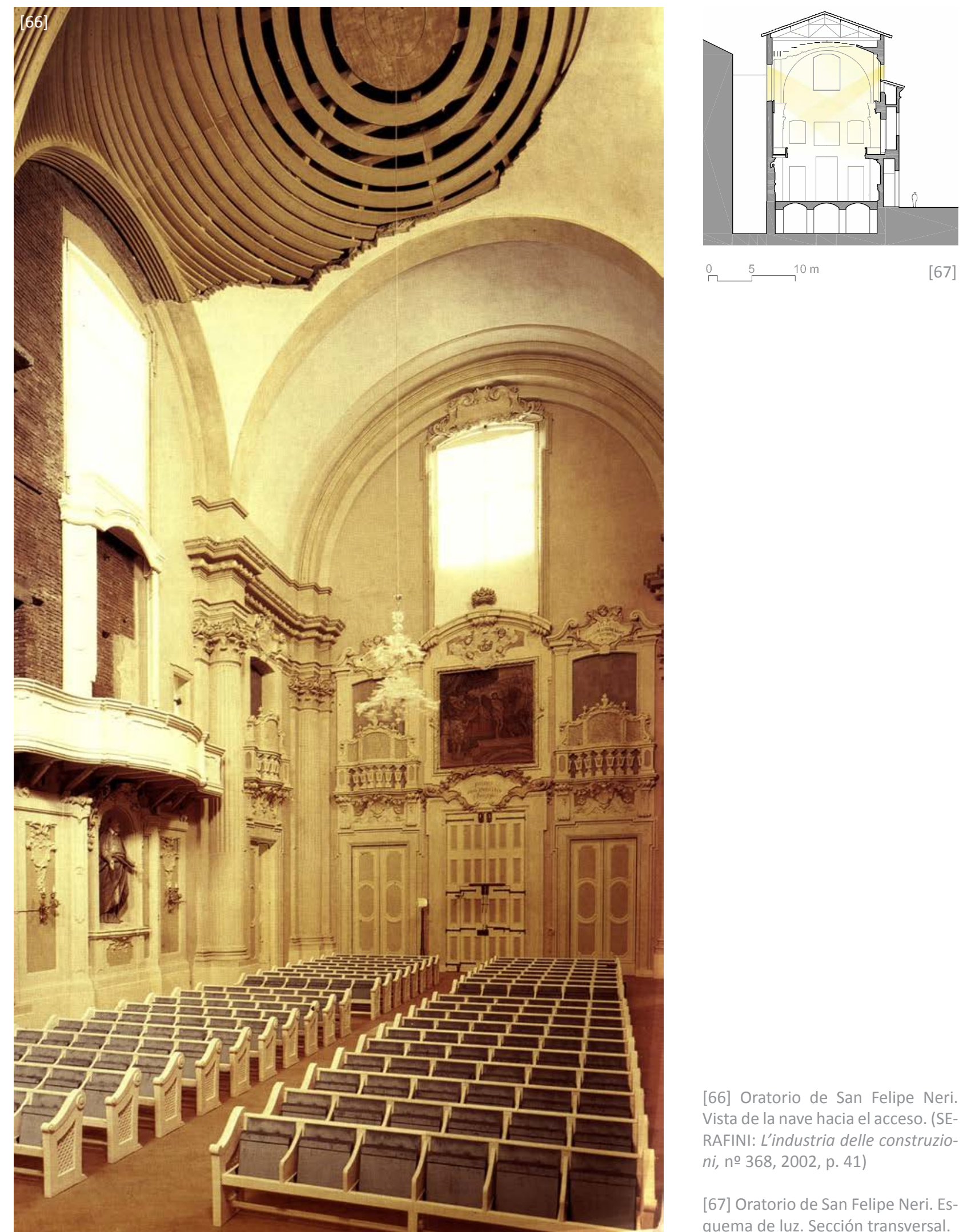

[66] Oratorio de San Felipe Neri. Vista de la nave hacia el acceso. (SERAFINI: L'industria delle construzioni, no 368, 2002, p. 41)

[67] Oratorio de San Felipe Neri. Esquema de luz. Sección transversal. 

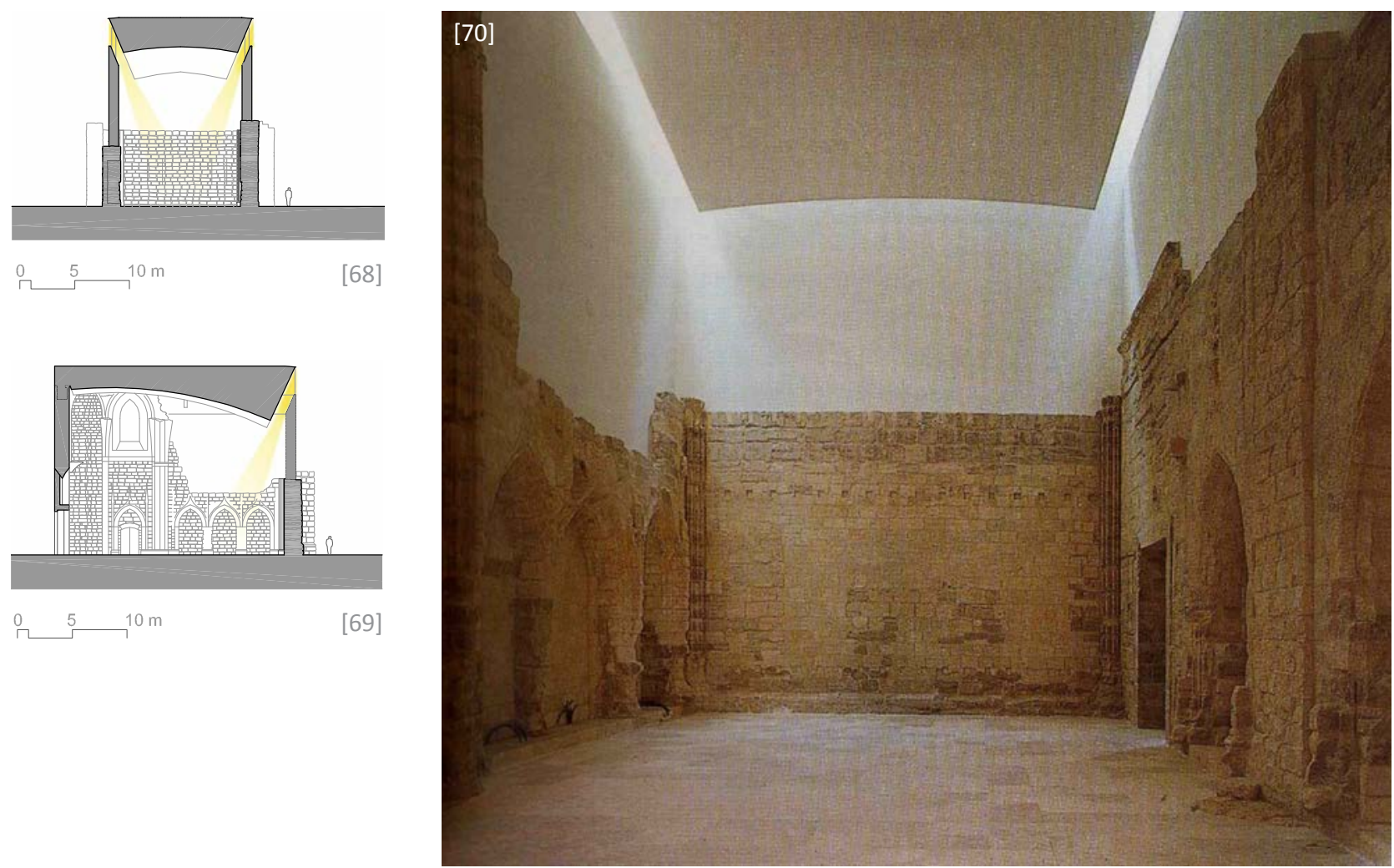

[68 y 69] Capilla de los Condes de Fuensaldaña. Esquemas de luz. Sección transversal y sección longitudinal.

[70] Vista interior de la capilla. (ARNUNCIO; SIERRA: Arquitectua Viva, no 75,2000, p. 45)

[71] Vista interior de la capilla. (Fotografía de Ricardo González. En: ARNUNCIO: 2012, p. 71)

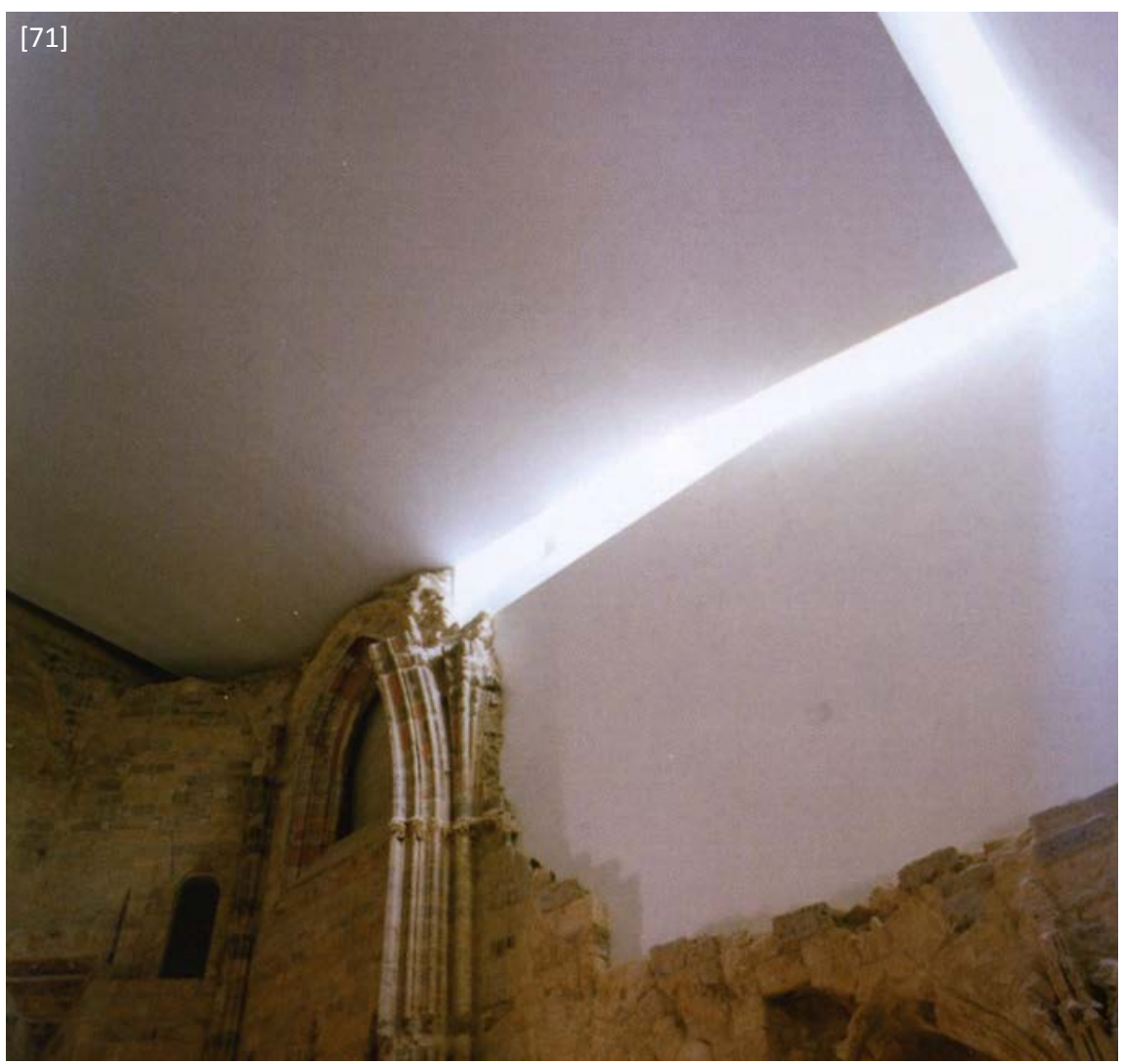



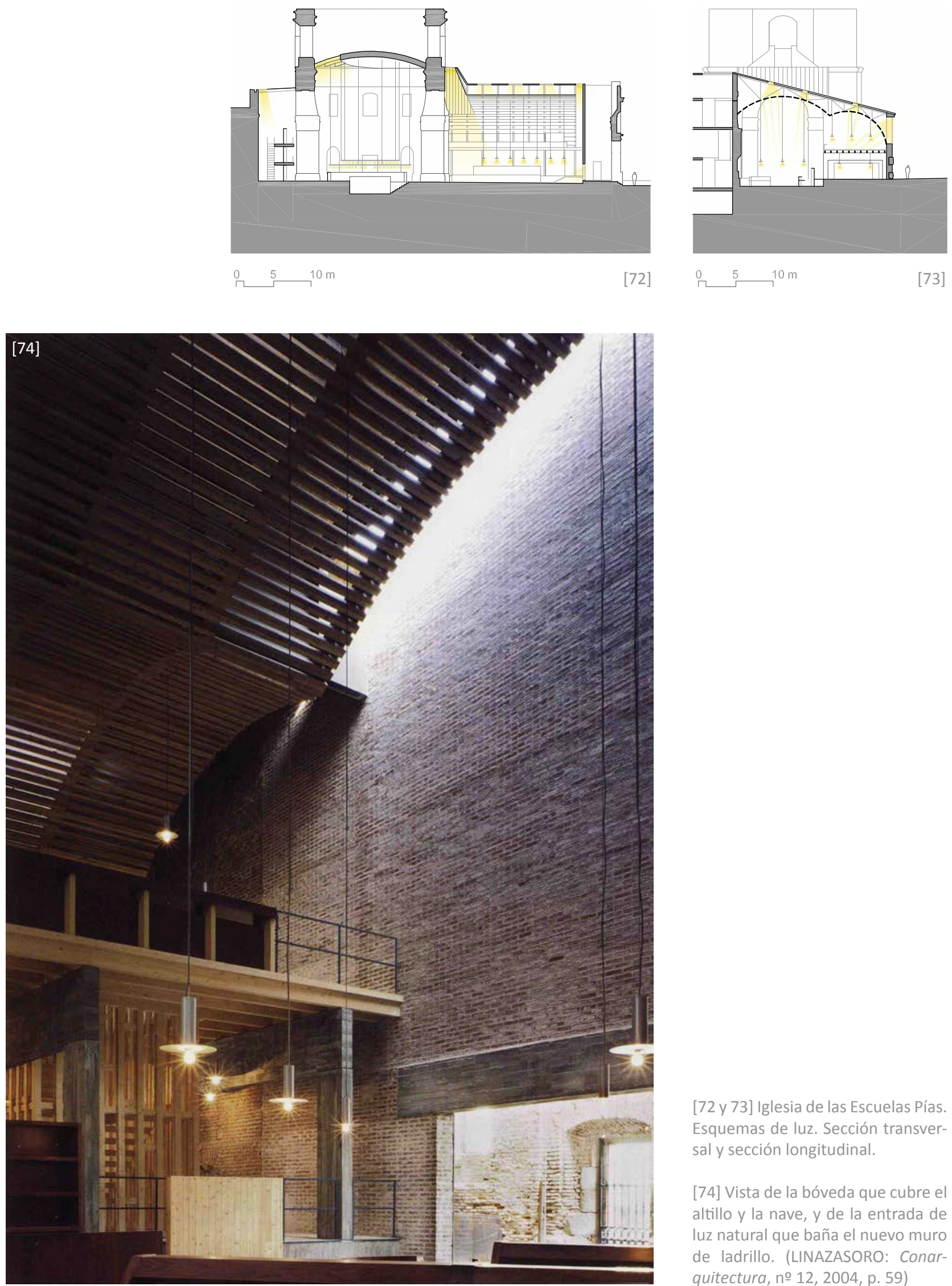

[72 y 73] Iglesia de las Escuelas Pías. Esquemas de luz. Sección transversal y sección longitudinal.

[74] Vista de la bóveda que cubre el altillo y la nave, y de la entrada de luz natural que baña el nuevo muro de ladrillo. (LINAZASORO: Conarquitectura, no 12,2004 , p. 59) 

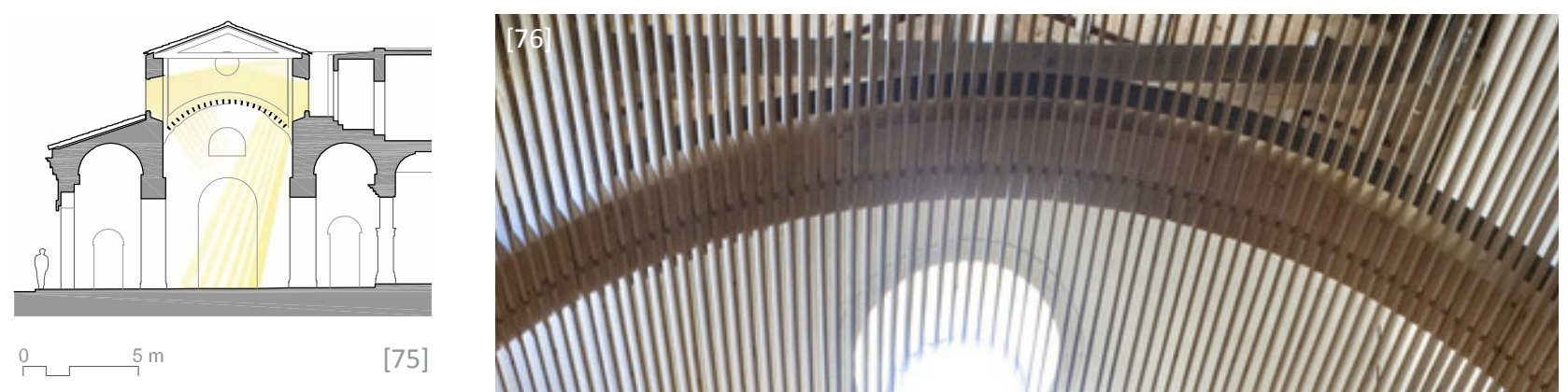

75]

[75] Iglesia de San Pedro. Esquema de luz.

[76] Vista de la nave y la nueva "bóveda”. (Europaconcorsi: <ec2.it/ emanuelefidone>) 


\subsection{Materialidad y detalle}

Desde el punto de vista de la materialidad llama la atención el empleo en tres de los cuatro ejemplos de elementos de madera, concretamente en la resolución de las bóvedas realizadas con piezas dispuestas de manera calada, aunque resueltas de tres maneras distintas.

Cervellati emplea la madera de abeto en la nave como único material para dar unidad e identidad a la nueva intervención, una madera clara que se relaciona bien con la blancura del rococó, y que al mismo tiempo permite cumplir el precepto de reversibilidad establecido en las cartas de restauración. Es interesante como plantea la construcción de la bóvedas, alejada de la técnica constructiva tradicional, y enfocada a la idea de transmitir el efecto de una imagen fragmentada de la forma original. Una reelaboración geométrica que aporta una visión claramente contemporánea. En definitiva un interesante trabajo plástico que busca recuperar los vibrantes juegos de luces y sombras de la ornamentación histórica, frente a la perfección de las superficies lisas y continuas.

Esta intención plástica supone emplear un sistema constructivo de gran complejidad, donde en el caso de la cúpula y la bóveda vaída cada "estrato" es diferente, una solución de carácter moderno en cuanto que se aleja de soluciones tradicionales, pero a su vez de carácter antiguo en cuanto que supone un proceso constructivo "artesanal" en la fabricación de cada fragmento.

También Fidone se plantea recomponer la geometría del elemento desaparecido, pero en este caso de forma mucho más abstracta y simplificada, sin buscar la exactitud de la forma desaparecida, sino tratando de evocarla con cierta libertad. Al igual que en Bolonia la solución constructiva se aleja de una construcción tradicional, con la intención de producir un efecto. Si bien se aprecian unas costillas transversales que siguen la forma del arco, sin embargo éstas se despegan de los muros y quedan colgadas mediante delgados tensores de las cerchas de cubierta produciendo una sensación de gran levedad. Además la separación de los cabirones entre sí deja pasar la luz y su diseño laminar y colocación radial hace que varíe la materialidad del elemento según la posición del punto de vista, generando un interesante juego entre la literalidad y la evocación.

En la actuación de José Ignacio Linazasoro también se emplea la madera, en este caso formando parte de un discurso de estratificación temporal, conformando el tiempo más reciente, y por tanto ubicada en las partes altas de los nuevos elementos. De entre ellos destaca el caso de la nueva "bóveda" que cubre el espacio principal. A diferencia de la solución de Cervellati y Fidone, no se busca tanto el recordar la forma de la bóveda desaparecida sino más bien el concordar con la forma del arco de la rotonda, y en dotar de significado simbólico al espacio. Con ello Linazasoro entra dentro de familias espirituales que permiten dotar de memoria histórica al monumento. La solución constructiva busca remitir a una cubierta primitiva compuesta por ramas que protegen un espacio de las inclemencias
[77] Oratorio de San Felipe Neri. Vista cenital de la reconstrucción de las partes de la bóveda que habían desaparecido. (SERAFINI: L'industria delle construzioni, $\mathrm{n}$ 은 368,2002 , p. 44)

[78] Capilla de los Condes de Fuensaldaña. Vista del interior de la capilla. (Imagen de Ricardo González. En: ARNUNCIO: 2012, p. 70)

[79] Iglesia de las Escuelas Pías.Vista de la entrada de luz a través de la bóveda desde el altillo. (LINAZASORO: Conarquitectura, no 17,2006 , p. 51)

[80] Iglesia de San Pedro. Detalle del encuentro entre la bóveda de listones de madera y el muro. (Europaconcorsi: <ec2.it/emanuelefidone>) 

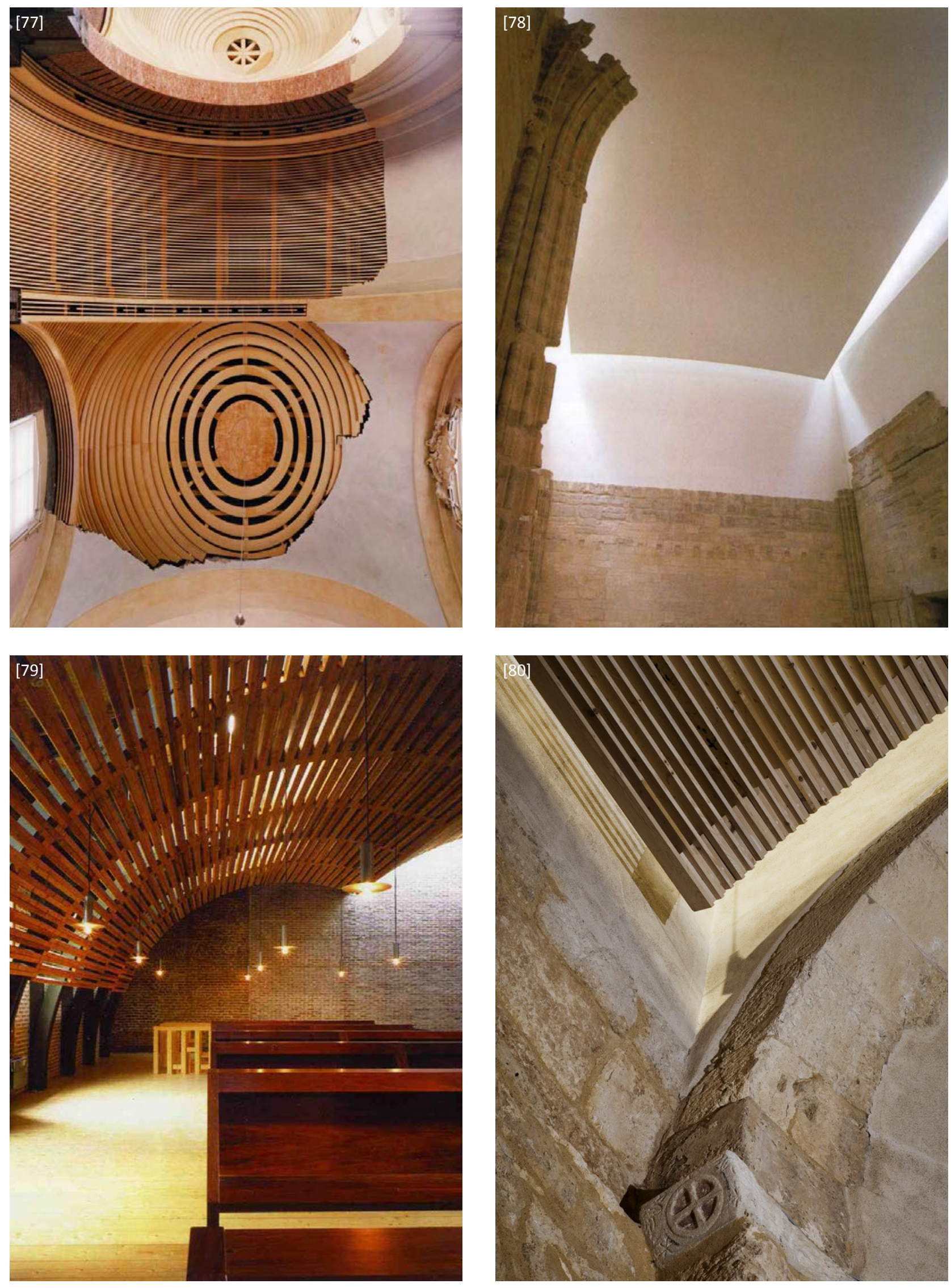
del tiempo. Las piezas de madera con una posición aparentemente aleatoria van cubriendo el espacio, sin impedir el paso de la luz entre ellas, y creando un interior que mantiene un cierto carácter exterior.

Por último Arnuncio se aleja de la solución en madera para la nueva "bóveda" y apuesta por una superficie lisa, continua, blanca y curva que busca enfatizar el efecto de un fragmento de bóveda celeste flotando en el espacio. Un elemento de aspecto macizo pero ligero al mismo tiempo. Un elemento denso que flota. Como una vela inflada por el viento. Esta materialidad abstracta se emplea también en los nuevos límites verticales que se recortan contra la ruina, explicando que forman parte de la misma naturaleza que el plano curvo, por lo que se puede entender también que este último se ha desprendido del primero produciendo una fractura por la que se introduce la luz. Como si un cielo nublado se fisurara para dejar pasar el sol, en una suerte de rompimiento de gloria. Donde la forma cóncava produce un efecto de espacio protector.

A diferencia de los otros tres casos aquí Arnuncio no se apoya en la sublimación de la construcción si no en su desaparición. Sin embargo la construcción "ligera" empleada para generar el efecto de negación del apoyo puede ser desvelada por el observador atento.

Si nos fijamos en la solución material de los nuevos elementos que delimitan el espacio las soluciones son diversas. Por un lado la actuación de Barbacci en Bolonia expresa la idea de un esqueleto constructivo al que le faltan las capas de ornamentación y acabado, capas que Cervellati insinúa con nuevos elementos de madera. En este mismo sentido actúa Linazasoro cuando construye los grandes muros de ladrillo delimitadores del espacio, como pertenecientes al mismo estrato inmutable de los muros de la iglesia, sin embargo en este caso la perdida del ornamento original permite que se establezca esta relación material, sin necesidad de revocarlo.

Por otro lado los muros de hormigón prefabricado que introduce Arnuncio en Valladolid evocan la cualidad másica de los muros de piedra desaparecidos, y el juego de texturas y su cromatismo ayudan a establecer una relación armónica con los preexistentes. Unos muros que componen un nuevo "telón" de fondo sobre el que se recorta la ruina.

Finalmente en Siracusa Fidone recurre al acero corten como material abstracto pero que expresa en su oxidación las consecuencias del paso del tiempo. Un nuevo portón remarcado por una línea de luz perimetral que evoca el eje de acceso original. Además el sistema de apertura busca mantener la idea de elemento clausurado y al mismo tiempo de espacio de transición, de recorrido indirecto al interior de la nave. 


\section{ANÁLISIS CRÍTICO COMPARATIVO}

Las cuatro actuaciones analizadas representan cuatro maneras de intervenir en el patrimonio distintas, pero con el mismo objetivo común, el de crear un espacio arquitectónico coherente. A partir de la preexistencia y apoyándose en la experiencia de la historia, se conforma una nueva arquitectura distinta a la original, pero igual de válida que aquella y adaptada a las nuevas necesidades actuales.

Cervellati quiere curar las heridas producidas por el tiempo en el resto original para que podamos imaginar como pudo ser aquel edificio en su máximo esplendor, pero no quiere renunciar a su traumática historia. Muestra su respeto por la reconstrucción moderna que expresa mediante el contraste el fuerte dolor de una generación marcada por la guerra. Y por último devuelve la envolvente del cerramiento superior del espacio con líneas de luz y de sombra que recuerdan el esplendor de otros tiempo sin olvidar la oscuridad de su historia. El nuevo elemento se posa de manera natural, ligera cubriendo el daño, para cobijar con dignidad a los nuevos moradores. El árbol de Caspar D. Friedrich se ha vuelto más preciso y sus ramas permiten reproducir con precisión el espacio interior, cosiendo al mismo tiempo las distintas fases de su historia. Entre la piel rococó y los huesos modernos, el injerto contemporáneo encaja con naturalidad. La sensibilidad de Cervellati hacia la arquitectura preexistente, sus conocimiento sobre la madera y su bagaje sobre el arte, le han permitido dar esta solución. Los diferentes criterios de intervención están al servicio del artífice para crear un todo coherente. La calidad del elemento añadido está a la altura de las preexistentes. La delicadeza del detalle. El trabajo artesanal con la madera.

¿Se debe acusar a Cervellati de imitar las formas antiguas? En el caso de la bóveda de la nave desde luego que no. Gracias a ello ha logrado un gran proyecto. Pero en el caso del semisótano, los esfuerzos realizados para restituir la arquitectura original probablemente tengan menos sentido, sobre todo siendo un espacio secundario y completamente perdido.

Emanuele Fidone entiende que la arquitectura preexistente sufre un problema de desequilibrio de luz y escala entre la nave central y las laterales. Su operación consiste en resolver ese problema apoyándose en el valor simbólico de una forma abovedada y en el valor espiritual de una luz indirecta, descompuesta y vibrante. Por otro lado valora la materialidad rugosa del espacio como expresión adecuada para un ambiente de reflexión interior. Al igual que en Bolonia, la forma se apoya en la historia del monumento, y la calidad del detalle constructivo del nuevo elemento está a la altura del edificio en el que se inserta. Su interés por la arquitectura a lo largo de la historia esta presente en sus obras y eso le permite tener las herramientas adecuadas a la hora de intervenir en el patrimonio. 
Ante las dudas sobre si la nueva bóveda es el reflejo de una anterior paleocristiana, la pregunta que hay que hacerse es si es tan importante que así sea. La nueva bóveda encaja a la perfección en el edificio ya que se relaciona con las bóvedas presentes en las naves laterales, y aunque pueda ser que nunca haya existido, al final eso es lo de menos ya que el nuevo elemento se puede entender con facilidad como el resurgimiento de una configuración hipotética. Respecto al problema de la falta de uso que mantiene el monumento cerrado, si bien Fidone es en parte responsable de su buen funcionamiento, no podemos achacarle que los promotores no sepan gestionar adecuadamente sus recursos.

La intervención de Linazasoro en Madrid es el reflejo de toda una filosofía personal sobre la cultura y la arquitectura, firmemente anclada en profundas reflexiones. El concepto del orden incompleto, ejemplificado en la ruina, le permite actuar con cierta libertad de ataduras reconstructivas. La ruina le ofrece la actualización del presente hacia el futuro pero también le muestra las permanencias del pasado. La ruina, descompuesta en fragmentos de materia en equilibrio natural, también le da las pautas compositivas de la nueva actuación. Libre de ataduras a normas preconcebidas, a Linazasoro sólo le queda la arquitectura: lugar, materia, espacio y luz al servicio de su filosofía. Una filosofía anclada en la reinterpretación de los valores de siempre, desde una visión moderna. Cada operación es una lección de arquitectura: el respeto a la imagen consolidada de la ruina en el lugar en una inteligente lectura de la arquitectura y su contexto, el recorrido progresivo de acceso que acompaña al individuo, el difícil pero interesante equilibrio de fragmentos antiguos y nuevos mediante analogías y contrastes, la virtualización de la construcción, la estratificación temporal de la materia, el peso y la levedad. En la intervención queda patente su interés por la arquitectura romana, paleocristiana, bizantina, románica o islámica, de espacios interiores, controlados, pero también por la arquitectura de los modernos, interesados a su vez por aquellas. Un arquitectura que remite a la naturaleza, ejemplificada en la "bóveda calada" que nuevamente nos lleva a las ramas del árbol de Hutten, pero que esta vez dejan pasar la luz cenital filtrándola, y aportando esa evocación a el espacio abierto de la ruina.

Arnuncio refleja en su obra de Valladolid la búsqueda de la materialización de una idea, sugerida por la ruina y por la arquitectura a lo largo de la historia: la protección del espacio habitable a través de una representación abstracta del cielo. Una búsqueda que es el reflejo de una profunda reflexión personal sobre la expresión de sensaciones en el espacio arquitectónico: la luz espiritual del cielo protector, el equilibrio compositivo entre partes distintas, lo pesado y lo ligero, antiguo y nuevo, modernidad y evocación. La conciencia del presente supone mirar al pasado, no desde la imitación de formas perdidas, sino desde la reinterpretación contemporánea de conceptos permanentes en la historia de la arquitectura. Pasado y presente se apoyan mutuamente en la conformación de una nueva unidad. Los muros góticos reviven bajo la vela moderna que los protege y les confiere una nueva vida.
[81] Oratorio de San Felipe Neri. Vista general de la nave tras la intervención de Cervellati. (CERVELLATI: 2009)

[82] Capilla de los Condes de Fuensaldaña. Vista interior tras la intervención. (ARNUNCIO: 2007, p. 118)

[83] Iglesia de las Escuelas Pías. Vista de la nave y de la nueva iluminación del espacio. (PRESI: 2012, p. 71)

[84] Iglesia de San Pedro. Vista de la nave central hacia el acceso este. (FIDONE: R\&R, no 116-117, 2012) 

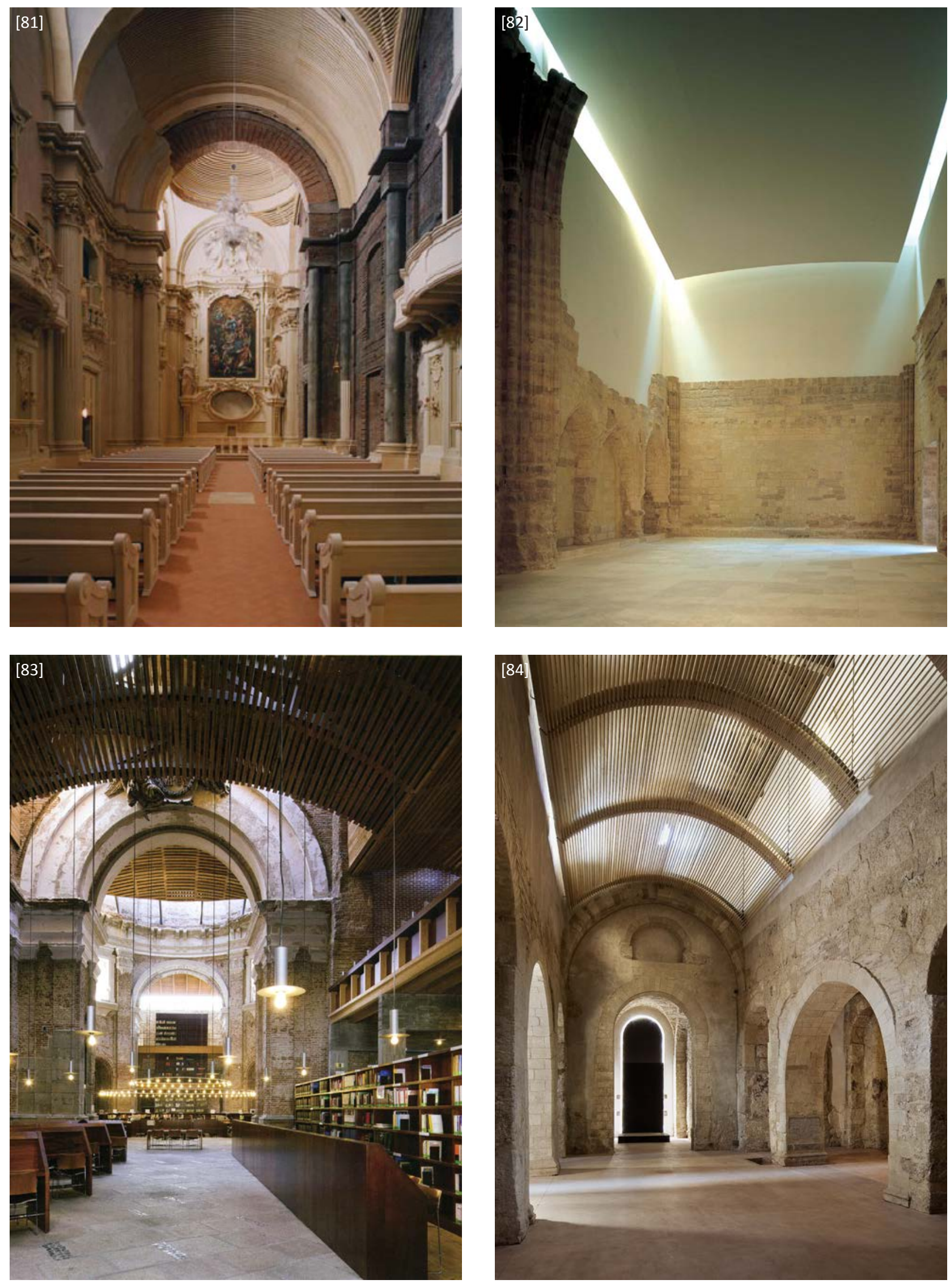

conclusiones 


\section{CONCLUSIONES}

\section{Criterios en la historia}

Toda intervención sobre el patrimonio es el resultado de un complejo proceso en el que intervienen gran variedad de cuestiones. Cuestiones que tienen que ver con la cultura de un lugar y de un momento determinado, así como con las diversas circunstancias que envuelven a un proyecto concreto.

En los ejemplos analizados se observa la lectura de sus valores pretéritos y actuales, con el objeto de producir nuevas arquitecturas de interés, que no hubieran sido posibles si en ellas no hubiesen participado arquitectos sensibles, con la necesaria libertad de acción dentro de las necesidades y condicionantes de cada proyecto.

El interés del análisis de las diversas intervenciones producidas a lo largo de la historia radica en su relectura desde el presente, identificando los mecanismos de actuación y las intenciones de estas arquitecturas, reinterpretando sus valores a fin de incorporarlos a nuevas actuaciones.

En la antigüedad destaca la búsqueda de perfeccionamiento de los templos, en un proceso de superación, sustituyendo los antiguos por otros nuevos que potencien su significado o modificándolos como símbolos del nuevo poder, pero manteniendo el valor del lugar en el que se hallan.

En la edad media es interesante la yuxtaposición y superposición de la nueva arquitectura sobre los restos materiales preexistentes, valorando las ruinas por sus características físicas y buscando incorporar la fuerza de la cultura clásica, creando con ello nuevos conjuntos imperfectos abiertos a futuras ampliaciones.

En el renacimiento se observan gran variedad de criterios de intervención que varían entre sustituciones, yuxtaposiciones, inserciones más o menos potentes, transformaciones profundas (a la manera moderna), reinterpretaciones (compromiso) o incluso soluciones en estilo (intervención retrospectiva). En todos los casos hay una cierta reflexión sobre el valor de la preexistencia, y sobre todo una búsqueda dirigida a la creación de una arquitectura de calidad, que establezca un cierto equilibrio y armonía entre la partes.

En el barroco se aprecian actuaciones que buscan crear una nueva envolvente interior o exterior, adecuada a las nuevas necesidades ornamentales, apoyándose en la preexistencia pero ocultándola.

En el siglo XVIII, surge una atención al valor material de lo antiguo, con sus imperfecciones, como testimonio del pasado. Aunque la regla general es la valoración de las ruinas como documentos, es interesante destacar la 
presencia de algunas figuras singulares -como Piranesi, y posteriormente Soane-que las interpretan como sugerentes composiciones de fragmentos capaces de inspirar nuevas arquitecturas. Frente a las exigencias de perfección de épocas pasadas, surge una mayor libertad creativa a base de la yuxtaposición de partes para conformar un nuevo conjunto.

En el siglo XIX, las diferentes maneras de valorar e interpretar el pasado derivan en diversas vías de actuación. Los hay que respetan el valor de los fragmentos de las ruinas por la fascinación que despiertan, fragmentos que reinterpretados se muestran como interesantes sugerencias para la creación de nuevas obras. Los hay que ven los fragmentos como restos de una arquitectura mutilada que debe repararse para recuperar el esplendor de su pasado, un pasado que debe interpretarse, y que puede llegar incluso a transformar los monumentos, convirtiéndolos en innovadoras reinterpretaciones arquitectónicas. Y los hay que se basan en el respeto hacia el pasado pero sin renunciar al presente, buscando mediante la diferencia lograr un equilibrio a través de procesos de simplificación formal o reinterpretación material, generando una cierta innovación arquitectónica. Sin embargo, también es importante resaltar que estas tres vías pueden producir sublimaciones románticas de los restos que en ocasiones derivan en arquitecturas inútiles, envoltorios estilísticos que generan meras escenografías, o distinciones lingüísticas sin intención arquitectónica.

Cabría destacar la importancia de la figura de Viollet-le-Duc, quien más allá de sus preferencias lingüísticas, entendió que la intervención sobre los monumentos debía partir de un riguroso estudio de sus preexistencias, pero no tanto como proceso de documentación sino de profundo conocimiento de la lógica del edificio, a fin de transformarlo para "perfeccionarlo" o adaptarlo a las nuevas necesidades.

De la primera mitad del siglo XX destacan los intentos por recuperar la arquitectura del pasado respetando la autenticidad de sus restos, buscando mecanismos de distinción entre lo nuevo y lo preexistente, respetando el contexto urbano y aprovechando las nuevas técnicas y materiales modernos. Asimismo, se entiende que por encima de todo, cada caso es distinto y que es imprescindible la calidad arquitectónica de la intervención, así como la búsqueda de armonía entre las partes.

Por otro lado, es interesante la reinterpretación que hacen los modernos y modernistas de las arquitecturas del pasado, así como la apreciación del valor de antigüedad resaltado mediante el contraste entre antiguo y nuevo. Mecanismos como la esencialidad formal, la reinterpretación del lenguaje, la cualidad material, el carácter de permanencia, el empleo en lo nuevo de semejanzas y diferencias con lo antiguo... permitirán crear interesantes equilibrios sin renunciar a soluciones propositivas en las intervenciones en el patrimonio. 
En los años de la posguerra, más allá de las actuaciones de repristinación, existen determinadas intervenciones excepcionalmente interesantes, en las que se busca de una manera creativa recuperar el edificio sin desatender el equilibrio del conjunto y la conformación de una arquitectura de calidad. La preexistencia se transforma con gran habilidad para adaptarla a las nuevas necesidades, y se introducen con maestría nuevos fragmentos para recomponer el conjunto.

Por otro lado, los ensayos con materiales ligeros demuestran que las diferencias de durabilidad y percepción superficial no acaban de relacionarse adecuadamente con las preexistencias y terminan por eliminarse o sustituirse. Soluciones que ponen en duda la aplicación universal de reglas como la mínima intervención, la reversibilidad o la compatibilidad física, así como la subjetividad en la aplicación de estos conceptos.

De las actuaciones llevadas a cabo en el cambio de siglo es interesante destacar la gran variedad de intervenciones donde, más allá de actitudes excepcionales de pura conservación o de repristinación, se nos muestra un amplio panorama de actitudes de reinterpretación de la preexistencia para la conformación de la nueva arquitectura, estableciendo una relación entre antiguo y nuevo. Una reinterpretación que busca en cierta medida dejar patente la actualidad de la intervención, ya sea a través de una mirada a los valores del pasado del monumento o a través de la búsqueda de nuevos valores. Dos vías que dependen de la lectura de las necesidades del lugar, de la preexistencia y del nuevo uso, pero también de la actitud del proyectista frente a la arquitectura.

En líneas generales se observa una predominancia de la mirada al pasado del monumento en las intervenciones italianas, como reflejo de la herencia teórica de los críticos del siglo XX, mientras que en las intervenciones españolas se observa una mayor libertad creativa evitando atender excesivamente a la historia del monumento y poniendo mayor atención en la preexistencia como materia evocadora de nuevas arquitecturas distintas a las originales.

En función de la mirada a la preexistencia, se observan criterios de reinterpretación que buscan vías más seguras a través de analogías formales: ya sea mediante la reproducción mimética, la relectura del lenguaje, la reconstrucción tipológica o la evocación de la imagen; o vías más complejas, mediante la inserción de nuevas formas, más o menos relacionadas con las leyes compositivas de lo antiguo y más o menos interconectadas físicamente.

Por otro lado, más allá de la intención de continuidad o ruptura con las formas del pasado, el trabajo con la materia puede ir encaminado a apoyar estas intenciones, o bien a hacer de contrapunto-expresando la diferencia dentro de la continuidad formal o compensando el contraste entre lo nuevo y lo viejo. En cualquier caso se observa la importancia de conceptos 
como el cuidado detalle de los elementos, la reflexión sobre la durabilidad de lo nuevo respecto a lo viejo, la relación entre texturas y brillos, entre técnicas tradicionales y nuevas tecnologías, entre la simulación y la autenticidad material, el significado que algunos materiales han adquirido a lo largo del tiempo, la atención al color en la relación antiguo-nuevo, la compatibilidad física, etc.

\section{La intervención desde el proyecto arquitectónico}

Recapitulando los criterios de intervención, podríamos decir que toda intervención sobre el patrimonio supone una transformación en la que se debe valorar, caso por caso, la preexistencia y su contexto, empleando el proceso metodológico del proyecto arquitectónico, con la mayor sensibilidad por parte del arquitecto, y tratando de establecer un diálogo entre pasado, presente y futuro.

En el caso de la reproposición de la pérdida se busca completar el monumento parcialmente para devolverle su valor como arquitectura. Esta actuación supone una transformación de su estado de ruina, pero al mismo tiempo permite su permanencia en el futuro.

Cada caso es distinto y se debe valorar en función de múltiples variables que atienden a la realidad de la preexistencia y su contexto, pero también a las sugerencias de su pasado y a las nuevas necesidades. Cuestiones objetivas como la escala de la pérdida, las propiedades de la materialidad y su estado de conservación, la adecuación de los espacios existentes a las nuevas funciones previstas, etc.; pero también cuestiones subjetivas como el valor significativo de los restos en la colectividad, la evocación de sus espacios perdidos, su potencial como sugerencia para la creación de nuevos espacios, etc.

Para ello es necesario emplear el proceso metodológico del proyecto arquitectónico. Un proceso creativo, de lectura crítica de los condicionantes, que parte del respeto a las preexistencias y se enfoca a la producción de un espacio arquitectónico de calidad, adecuado a las nuevas necesidades. Un proceso en el que se deben confrontar soluciones alternativas hasta alcanzar la más adecuada. Un proceso multidisciplinar que permite al arquitecto mantener una visión global del proyecto.

La intervención en el patrimonio supone un trabajo de gran dificultad, que requiere la mayor sensibilidad por parte del arquitecto, que debe ser capaz de reconocer los valores y las potencialidades presentes, pasadas y futuras. Se trata de un trabajo de cierto riesgo, pues es necesario discernir con acierto lo que conviene eliminar, mantener y añadir. Un trabajo que requiere decisión pero al mismo tiempo humildad y cautela, de tal manera que se establezca un discurso narrativo coherente entre pasado, presente y futuro, es decir entre la memoria perdida, la realidad preexistente, y las posibilidades futuras. 
El proyecto será el resultado de un diálogo en equilibrio, una armonía, una interrelación entre lo antiguo y lo nuevo, una conmensuración entre las partes, pues se necesitan las unas a las otras para responder adecuadamente al presente.

\section{$\underline{\text { La reproposición de la pérdida en espacios abovedados }}$}

Más allá de los criterios, el objetivo del proyecto de intervención debe ser el de conformar un espacio a partir de los restos preexistentes. Como hemos visto el espacio puede adquirir diversas configuraciones: espacio excavado, espacio ligero, tectónico, "natural", con visión del exterior, con sensación de exterior, abstracto, evocador del elemento abovedado desaparecido... Configuraciones que constituyen una gran variedad de posibilidades de cara a la reproposición del vacío. Soluciones que de alguna manera suponen una relectura del espacio abovedado a lo largo de la historia, de tal manera que se establece una conexión entre antiguo y nuevo, facilitando la integración de una parte con la otra.

\section{Estudio de casos}

En los cuatro casos analizados en profundidad se observan preexistencias con historias, problemas y necesidades distintos, y que por tanto requieren soluciones diferentes. Preexistencias condicionadas por variables como el impacto de la pérdida en el conjunto, el tiempo transcurrido desde su destrucción o los cambios de uso sufridos a lo largo del tiempo.

Preexistencias en las que se observa la presencia de un vacío producido por la pérdida, y un cierto aspecto de "ruina" producido por su degradación a lo largo del tiempo. Preexistencias que forman parte de un contexto que ha sufrido variaciones, y que por tanto sugiere cambios para la adaptación de los restos a las nuevas necesidades.

En los cuatro casos se observa, por un lado, un respeto a los diferentes estratos de la historia que han perdurado hasta la actualidad, y por otro lado una atención a los problemas y necesidades del presente, que se traducen en un proyecto arquitectónico que interpreta cada caso, planteando desde el presente soluciones reflexionadas con inteligencia y humildad, que buscan crear un espacio arquitectónico de calidad.

La reasignación de una nueva función a las preexistencias se plantea como una condición fundamental para su supervivencia. Pero se entiende que esta función debe ser compatible con las permanencias y debe guardar cierta relación con la función original, de tal manera que las adaptaciones necesarias puedan aprovechar significados comunes. 
Las necesidades surgidas a raíz de las nuevas funciones y los cambios en el contexto condicionan inicialmente, junto a las características de la preexistencia, la definición de los nuevos elementos.

En todos los casos se observa una reflexión meditada sobre el acceso al edificio. Se observa una búsqueda de la dilatación del recorrido permitiendo con ello una transición gradual entre exterior e interior. En algunas ocasiones se busca recuperar los accesos originales, y en otras crear nuevos accesos en respuesta a las necesidades funcionales del edificio y del lugar.

Las soluciones varían en función de la interpretación de la historia del monumento y por tanto del valor otorgado a cada una de sus fases. Se actúa de manera diferente sobre cada elemento, tratando de dar una respuesta adecuada a cada parte, sin imponer criterios inflexibles que producirían soluciones inadecuadas.

En estas intervenciones, los arquitectos proyectan sus conocimientos sobre la arquitectura y el arte a lo largo de la historia, siempre a través de una reinterpretación creativa que denota la actualidad de la intervención y al mismo tiempo logra una adecuada integración entre antiguo y nuevo, y entre la arquitectura y su contexto.

Esta integración se logra a través de dos vías claramente distintas: por un lado la mirada al pasado del monumento para subsanar esa pérdida, y por otro lado la aceptación de la pérdida y la creación de una nueva historia, distinta a la de su pasado. Dos vías que a su vez plantean diversos caminos. En el primer caso, desde la reintegración de las formas perdidas del monumento reinterpretadas materialmente (San Filippo Neri), hasta la evocación de las formas perdidas atendiendo a la degradación del presente (San Pedro). En el segundo caso, desde el equilibrio de partes claramente definidas que constituyen un todo (Capilla de Fuensaldaña), hasta la armonía entre fragmentos que conforman un conjunto abierto (Escuelas Pías).

La contemporaneidad de la actuación se muestra a través de la diferencia del nuevo estrato, definido mediante procesos de simplificación y abstracción formal, esencialización y expresión material. La evocación de la ruina hace de mediadora entre la arquitectura del pasado y el lenguaje abstracto del presente. La relación con el lugar, la separación y conexión interior-exterior, la creación de recorridos con espacios de transición, la repetición de elementos en diferentes partes del proyecto, la relación entre opuestos -como lo pesado y lo ligero, el cuadrado y el círculo, el fondo y la figura, la superposición, etc.- son algunos de los mecanismos que permiten establecer una integración entre los nuevos añadidos y las preexistencias. 
En los cuatro casos se reinterpreta el elemento abovedado desaparecido, a través de un elemento ligero que busca producir un determinado efecto en el espacio. Para ello, en tres de los casos se emplea la madera con detalles constructivos elaborados, que se alejan de soluciones tradicionales, y se acercan a reflexiones contemporáneas. Soluciones caladas que aportan un aspecto fragmentado, vibrante, inacabado, imperfecto, provisional, ligero, reversible, reciclable, compatible, natural, vivo... Con todo ello la madera demuestra grandes posibilidades de adaptación de lo nuevo con lo preexistente. En el cuarto caso se recurre a una abstracción material que nos remite a una forma ilusoria, inmaterial, ligera, que se aleja de la realidad de la ruina y se acerca a la del cielo, estableciendo una relación mediante la contraposición, un equilibrio a través de la dualidad. En el resto de elementos, se observa un cierto diálogo con la preexistencia a través de la materialidad, valiéndose de la expresividad de sus texturas, tonalidades, etc.

\section{$\underline{\text { Reflexiones finales }}$}

La valoración de una preexistencia en el marco de un proyecto arquitectónico de intervención sobre el patrimonio, puede atender a tres momentos: la restauración de su pasado parcialmente desaparecido, que puede deducirse a partir del estudio del propio edificio, de fuentes documentales y de otras arquitecturas; la conservación de su presente con unos valores más o menos consolidados a lo largo del tiempo; y la adaptación a las nuevas necesidades para dotarla de renovada vitalidad y así asegurar su permanencia en el futuro.

Estas tres miradas se pueden realizar a través de los tres aspectos fundamentales de la arquitectura -firmitas, utilitas y venustas-: aspectos funcionales, que abarcan desde cuestiones de uso hasta cuestiones significativas y simbólicas; aspectos formales, que se relacionan con temas compositivos y espaciales; y aspectos materiales, relacionados con temas de concreción física. Estos tres aspectos deberán ser considerados no sólo en cuanto a la preexistencia en sí misma, sino también en relación con su entorno, atendiendo a la presencia del monumento en la configuración del espacio de la ciudad.

En definitiva, a través de un complejo trabajo de equilibrio mediante analogías y contrastes, se buscará establecer un diálogo adecuado entre antiguo y nuevo para la conformación de un espacio arquitectónico. Un diálogo que tendrá en cuenta tanto el monumento y el lugar sobre el que se actúa, como las numerosas arquitecturas producidas a lo largo de la historia, de tal manera que a través de un proceso de reinterpretación contemporánea, se adquieran los mecanismos necesarios para lograr el equilibrio buscado. 
Pier Luigi Cervellati se encuentra con un edificio reconstruido parcialmente, cuya reconstrucción se ha realizado mediante formas simplificadas y una materialidad muy distante de la original; que a su vez presenta partes faltantes en los elementos abovedados, elementos de gran definición simbólica del espacio. Su respuesta se amolda a la realidad bipolar, y se convierte en traductora de las necesidades de ambas realidades, a través de un sistema que consigue enlazarlas con gran sensibilidad.

También Emanuele Fidone, se encuentra con una preexistencia donde se ha producido una ruptura en el diálogo entre fases de la historia, en este caso producida por una "restauración" inadecuada. Fidone, al igual que Cervellati, se ve en la necesidad de introducir un discurso que resuelva la transición entre dos ideas espaciales distintas, la "paleocristiana" y la "barroca". Su propuesta atiende al aspecto oscuro y matérico del espacio original pero, como en una ruina que ha perdido su protección, permite la entrada de luz cenital barroca, matizándola con un elemento contemporáneo pero de claras reminiscencias naturales. El nuevo umbráculo ligero adquiere en su conformación el perfil de una bóveda, como un eco de la cueva, como un eco de los espacios de las naves laterales.

José Ignacio Linazasoro halla en las ruinas de las Escuelas Pías y en su entorno nuevos valores que le remiten a sus profundos conocimientos sobre la antigua Roma, sobre los espacios interiores y yuxtapuestos de la arquitectura medieval, sobre las reinterpretaciones de la historia en arquitecturas de la modernidad. La dimensión del edificio requiere juegos complejos, más elaborados, múltiples fragmentos relacionados de maneras diversas que se ordenan con sabiduría en un nuevo conjunto moderno. La recuperación del pasado del edificio ya no tenía sentido en la nueva realidad del entorno y del nuevo uso previsto. La ruina se había convertido en parte de la identidad del barrio, y tras la intervención, el presente degradado del monumento ha adquirido una nueva vida con más valor en la realidad actual del lugar. En el interior el nuevo umbráculo de madera protege las ruinas bajo un cielo lejano.

Juan Carlos Arnuncio rescata unos muros olvidados y los recupera para una nueva arquitectura que propone reflexiones presentes a lo largo de la historia, y por tanto que recuerdan algunos conceptos de la arquitectura desaparecida. Conceptos como la introversión, que se relaciona con la austeridad exterior y la sorpresa interior, el tema del peso y la levedad que se relaciona con la superposición de un elemento ligero que cubre y protege el espacio, el tema de la admiración por la ruina y la búsqueda de fijarla sobre un fondo neutro, el tema de la luz indirecta que produce un ambiente de espiritualidad y misterio. Todo ello, reunido en una operación medida que muestra gran reflexión y sensibilidad, que refleja la preocupación por un trabajo bien hecho. 
La intervención en el patrimonio supone una reflexión sobre una arquitectura histórica. Esto a su vez produce una reflexión sobre nuestra propia arquitectura, la de nuestro tiempo. Se produce un trasvase, un diálogo entre lo que nos dicen los antiguos y lo que nosotros queremos contarles. Los antiguos, como nuestros abuelos, tienen mucho que enseñarnos, han vivido una larga vida, tienen el valor de la experiencia, una larga reflexión, consolidada a lo largo del tiempo. Nosotros, más jóvenes, queremos escucharles, pero también decirles que las cosas han cambiado. Experiencia de arquitecto viejo, entusiasmo de arquitecto joven. Juntos debemos componer una historia coherente. 


\section{CONCLUSIONI}

\section{Criteri nella storia}

Ogni intervento sul patrimonio è il risultato di un processo complesso nel quale intervengono una grande varietà di questioni. Questioni che hanno a che fare con la cultura di un luogo e di un momento determinato, così come con le varie circostanze che coinvolgono un particolare progetto.

Negli esempi analizzati si osserva la lettura dei suoi valori attuali e passati, al fine di produrre nuove architetture di interesse, che non sarebbero state possibile senza la partecipazione di architetti sensibili, con la necessaria libertà di azione all'interno delle esigenze e condizioni di ciascun progetto.

L'interesse delle analisi di vari interventi realizzati nel corso della storia radica nella sua rilettura dal presente, individuando i meccanismi di azione e le intenzioni di queste architetture, reinterpretando i loro valori al fine di incorporarle in ulteriori attuazioni.

Nell'antichità risalta la ricerca dei perfezionamento dei templi, in un processo di costante miglioramento, con la sostituzione dei vecchi con i nuovi, per potenziarne il significato, e la loro modifica come simboli del nuovo potere, pur mantenendo il valore del luogo in cui si trovano.

Nel Medioevo è interessante la giustapposizione e sovrapposizione della nuova architettura sui resti di materiale preesistente, valutando le rovine per le loro caratteristiche fisiche e cercando di incorporare la forza della cultura classica, creando così nuovi insiemi imperfetti aperti a future ampliazioni.

Nel Rinascimento si osservano una grande varietà di criteri di intervento che vanno da sostituzioni, giustapposizioni, inserimenti più o meno potenti, profondi cambiamenti (alla maniera moderna), reinterpretazioni (compromesso) o anche soluzioni in stile (intervento in retrospettiva). In tutti i casi vi è una sicura riflessione sul valore di preesistenza, e soprattutto una ricerca volta a creare un'architettura di qualità che stabilisce un buon equilibrio e armonia tra le parti.

Nel Barocco si apprezzano interventi che cercando di creare un nuovo rivestimento interno o esterno, adattato alle nuove necessita ornamentali, appoggiandosi al preesistente, ma nascondendolo.

Nel XVIII secolo, nasce un'attenzione al valore materico dell'antico, con le sue imperfezioni, come testimonianza del passato. Anche se la regola generale è la valorizzazione delle rovine come documenti, è interessante notare la presenza di alcune figure uniche - come Piranesi, e poi Soane che le interpretano come suggerenti composizioni di frammenti capaci di ispirare nuove architetture. Di fronte alle esigenze di perfezione di tempi passati, emerge una maggiore libertà creativa basata sulla giustapposizione di parti per formare un nuovo insieme. 
Nel XIX secolo, i diversi modi di valutare e interpretare il passato derivano da diversi modi di azione. Ci sono quelli che rispettano i frammenti delle rovine per il fascino che suscitano, frammenti che reinterpretati si mostrano come interessanti suggerimenti per la creazione di nuove opere. C'è chi vede i frammenti come resti di una architettura mutilata da riparare per ripristinare lo splendore del suo passato, un passato che deve essere interpretato, e può anche arrivare a trasformare i monumenti, rendendoli innovative reinterpretazioni architettoniche. E ci sono quelli che si basano nel rispetto del passato, ma senza rinunciare al presente, cercando attraverso la differenza di raggiungere l'equilibrio mediante processi di semplificazione formale o reinterpretazione materica, generando certa innovazione architettonica. Tuttavia, è anche importante risaltare che queste tre vie possono produrre sublimazione romantica dei resti che, in alcuni casi, derivano in architetture inutili, semplici involucri stilistiche che generano mere scenografie o distinzioni linguistiche senza intenzioni architettoniche.

Andrebbe sottolineata l'importanza della figura di Viollet-le-Duc, che al di là delle sue preferenze linguistiche, comprese che gli interventi sui monumenti dovevano cominciare da uno studio rigoroso del suo preesistente, ma non come processo di documentazione, bensì come conoscenza profonda della logica dell'edificio, per trasformarlo "perfezionandolo" o adattandolo alle nuove esigenze.

Nella prima metà del XX secolo risaltano i tentativi di recuperare l'architettura del passato, rispettando l'autenticità dei resti, alla ricerca di meccanismi di distinzione tra nuovo ed esistente, nel rispetto del contesto urbano e utilizzando le nuove tecniche e materiali moderni. Resta altresì inteso che soprattutto, ogni caso è diverso ed è essenziale la qualità architettonica dell'intervento, nonché la ricerca di armonia tra le parti.

D'altro canto, è interessante la rilettura che fanno i moderni e modernisti delle architetture del passato, così come l'apprezzamento del valore dell'antico evidenziato dal contrasto tra vecchio e nuovo. Meccanismi come l'essenzialità formale, la reinterpretazione del linguaggio, la qualità materica, il carattere di permanenza, l'impiego nel nuovo di somiglianze e differenze con l'antico ... permettono creare interessanti equilibri senza rinunciare a soluzioni propositive negli interventi sul patrimonio.

Negli anni del dopoguerra, al di là degli interventi di ripristino, ci sono alcune intervenzioni particolarmente interessanti, nelle quali si cerca in modo creativo di recuperare l'edificio senza trascurare l'equilibrio complessivo e la configurazione di un'architettura di qualità. La preesistenza si trasforma con grande abilità per adattarsi alle nuove esigenze, e si introducono con maestria nuovi frammenti per ricostruire il tutto.

Inoltre, i test con materiali leggeri, dimostrano che le differenze di durata e percezione superficiale non terminano rapportarsi adeguatamente con il preesistente e finiscono con essere eliminati o sostituiti. Soluzioni che 
mettono in discussione l'applicazione universale di regole come il minimo intervento, la reversibilità o compatibilità fisica, così come la soggettività nell'applicazione di questi concetti.

Delle realizzazioni svolte nel cambio di secolo è interessante notare la vasta gamma di interventi in cui, al di là di azioni eccezionali di pura conservazione o ripristino, ci viene mostrato un ampio panorama di casi di reinterpretazione del preesistente per dar forma alla nuova architettura, stabilendo un rapporto tra antico e moderno. Una reinterpretazione che cerca in qualche modo di chiarire la rilevanza dell'intervento, sia attraverso uno sguardo ai valori del passato del monumento o attraverso la ricerca di nuovi valori. Due vie che dipendono dalla lettura dei bisogni del luogo, del preesistente e del nuovo uso, ma anche dell'atteggiamento del progettista di fronte all'architettura.

Negli interventi italiani vi è, nel complesso una predominanza dello sguardo al passato del monumento, come riflesso dell'eredità teorica dei critici del XX secolo, mentre negli interventi spagnoli si osserva una maggiore libertà creativa evitando di soddisfare eccessivamente la storia del monumento e prestando maggiore attenzione alla preesistenza come materiale evocatore di nuove architetture diverse da quella originale.

In funzione dello sguardo al preesistente, si osservano criteri di reinterpretazione che cercano strade più sicure attraverso analogie formali: sia mediante la riproduzione mimetica, la rilettura del linguaggio, la ricostruzione tipologica o l'evocazione delle immagini; o mediante percorsi più complessi, inserendo nuove forme, più o meno correlate alle leggi della composizione dell'antico e più o meno fisicamente interconnesse.

D'altra parte, al di là della volontà di continuità o di rottura con le forme del passato, il lavoro con la materia può essere diretto a sostenere queste intenzioni, o può fare da contrappunto esprimendo la differenza nella continuità formale o compensando il contrasto tra vecchio e nuovo. In ogni caso si osserva l'importanza di concetti come la cura dei dettaglio degli elementi, la riflessione sulla durabilità del nuovo sul vecchio, il rapporto tra finitura superficiale e luminosità, tra tecniche tradizionali e nuove tecnologie, tra simulazione ed autenticità materiale, il significato che alcuni materiali hanno acquisito nel corso del tempo, l'attenzione al colore nel rapporto vecchio-nuovo, la compatibilità fisica, ecc.

\section{$\underline{\text { L'intervento parte dal progetto architettonico }}$}

Ricapitolando i criteri di intervento, si potrebbe dire che ogni intervento sul patrimonio suppone una trasformazione che deve essere valutata caso per caso, la preesistenza e il suo contesto, utilizzando il processo metodologico di progettazione architettonica, con la maggiore sensibilità da parte dell'architetto, e cercando di stabilire un dialogo tra passato, presente e futuro. 
Nel caso della riproposizione della perdita si cerca di completare il monumento parzialmente per restituirgli il suo valore architettonico. Questa attuazione rappresenta una trasformazione del suo stato di rovina, ma allo stesso tempo ne permette la permanenza nel futuro.

Ogni caso è diverso e deve essere valutato in base a variabili multiple che considerano la realtà della preesistenza e il suo contesto ma anche i suggerimenti del suo passato e le nuove esigenze. Questioni oggettive come la scala della perdita, le proprietà del materiale ed il suo stato di conservazione, l'adeguatezza degli spazi esistenti alle nuove funzioni previste, ecc.; ma anche questioni soggettive come il valore significativo dei resti nella comunità, l'evocazione degli spazi perduti, il suo potenziale come un suggerimento per la creazione di nuovi spazi, ecc.

Ciò richiede utilizzare il processo metodologico del progetto architettonico. Un processo creativo, di lettura critica delle condizioni, che parte dell'attenzione alle preesistente e si concentra sulla produzione di uno spazio architettonico di qualità, adatto alle nuove esigenze. Un processo dove si devono confrontare soluzioni alternative per ottenere quella più appropriata. Un processo multidisciplinare che permette all'architetto di mantenere una visione d'insieme del progetto.

L'intervento nel patrimonio costituisce un lavoro di grande difficoltà, che richiede la maggiore sensibilità da parte dell'architetto, che deve essere in grado di riconoscere i valori e le potenzialità presenti, passate e future. Questo è un lavoro di un certo rischio, poiché è necessario discernere correttamente ciò che deve essere eliminato, mantenuto e aggiunto. Un lavoro che richiede decisione, ma anche umiltà e cautela, in modo da stabilire una narrazione coerente tra passato, presente e futuro, cioè tra la memoria persa, la realtà preesistente, e le possibilità future.

Il progetto sarà il risultato di un dialogo in equilibrio, un'armonia, una interrelazione tra l'antico ed il nuovo, una commisurazione tra le parti, in quanto sono necessari reciprocamente per rispondere adeguatamente al presente.

\section{La riproposizione della perdita negli spazi a volta}

Al di là dei criteri, l'obiettivo del progetto di intervento dovrebbe essere quello di conformare uno spazio dai resti preesistenti. Come abbiamo visto lo spazio può assumere diverse configurazioni: spazio scavato, spazio leggero, tettonico, "naturale", con la visione dall'esterno, con sensazione esterna, astratto, che ricorda l'elemento voltato mancante... Configurazioni che rappresentano una vasta gamma di possibilità di fronte 
alla riproposizione del vuoto. Soluzioni che coinvolgono in qualche modo una rilettura dello spazio a volta nel corso della storia, in modo tale che si stabilisce un collegamento tra vecchio e nuovo, favorendo l'integrazione di una parte con l'altra.

\section{Caso di studio}

Nei quattro casi analizzati in profondità si osservano preesistenze con storie, problemi e esigenze diverse. Preesistenze condizionate da variabili come l'impatto della perdita nell'insieme, il tempo trascorso dalla loro distruzione o i cambiamenti di uso sofferti nel tempo.

Preesistenze nelle quali si osserva la presenza di un vuoto prodotto per la perdita, ed un certo aspetto di "rovina" prodotto per la sua degradazione del tempo. Preesistenze che fanno parte di un contesto che ha sofferto variazioni, e che pertanto suggerisce cambiamenti per l'adattamento dei resti alle nuove necessità.

Nei quattro casi si osserva, da una parte, un rispetto ai differenti strati della storia che hanno perdurato fino all'attualità, e d'altra parte un'attenzione ai problemi e necessità del presente che si traducono in un progetto architettonico che interpreta ogni caso, esponendo dal presente soluzioni riflesse con intelligenza ed umiltà che cercano creare un spazio architettonico di qualità.

La riassegnazione di una nuova funzione alle preesistenze si pone come una condizione fondamentale per la loro sopravvivenza. Ma si capisce che questa funzione deve essere compatibile con le permanenze e deve avere una certa relazione con la funzione originale, in modo tale che gli adattamenti necessari possano approfittare di significati comuni.

Le esigenze che sono sorte a seguito di nuove caratteristiche e cambiamenti nel contesto condizionano inizialmente, insieme con le caratteristiche della preesistenza, la definizione di nuovi elementi.

In tutti i casi si osserva una riflessione ponderata sull'accesso all'edificio. Si osserva una ricerca della dilatazione del percorso permettendo una transizione graduale tra esterna ed interno. In alcune occasioni si cerca recuperare gli accessi originali, ed in altre creare nuovi accessi in risposta alle necessità funzionali dell'edificio e del posto.

Le soluzioni variano in funzione dell'interpretazione della storia del monumento e pertanto del valore concesso ad ognuna delle sue fasi. Si agisce da maniera differente su ogni elemento, tentando di dare una risposta adeguata ad ogni parte, senza imporre criteri inflessibili che produrrebbero soluzioni inadeguate. 
In questi interventi, gli architetti proiettano le sue conoscenze sull'architettura e l'arte nel corso della storia, sempre attraverso una reinterpretazione creativa che denota l'attualità dell'intervento e contemporaneamente riesce un'adeguata integrazione tra antico e nuovo, e tra l'architettura ed il suo contesto.

Questa integrazione si riesce attraverso due vie chiaramente distinte: da una parte lo sguardo al passato del monumento per emendare quella perdita, e d'altra parte l'accettazione della perdita e la creazione di una nuova storia, distinta a quella del suo passato. Due vie che a sua volta espongono diverse strade. Nel primo caso, dalla reintegrazione delle forme perse del monumento reinterpretate materialmente (San Filippo Neri), fino all'evocazione delle forme perse servendo la degradazione del presente (San Pedro). Nel secondo caso, dall'equilibrio di parti chiaramente definite che costituiscono un intero (Cailla de Fuensaldaña), fino all'armonia tra frammenti che conformano un insieme aperto, (Escuelas Pias).

La contemporaneità dell'attuazione si mostra attraverso la differenza del nuovo strato, definito mediante processi di semplificazione ed astrazione formale, essenzializzazione d'espressione materiale. L'evocazione della rovina fa da mediatrice tra l'architettura del passato ed il linguaggio astratto del presente. La relazione con il luogo, la separazione e connessione internoesterno, la creazione di percorsi con spazi di transizione, la ripetizione di elementi in differenti parti del progetto, la relazione tra opposti -come la cosa pesata e la cosa leggera, il quadrato ed il circolo, il fondo e la figura, la sovrapposizione, etc.- sono alcuni dei meccanismi che permettono di stabilire un'integrazione tra i nuovi aggiunti e le preesistenze.

Nei quattro casi si reinterpreta l'elemento a volta scomparso, attraverso un elemento leggero che cerca di produrre un determinato effetto nello spazio. Per ciò, in tre dei casi si impiega il legno con dettagli costruttivi elaborati che si allontanano da soluzioni tradizionali, e si avvicinano a riflessioni contemporanee. Soluzioni traforate che apportano un aspetto frammentato, vibrante, incompiuto, imperfetto, provvisorio, leggero, reversibile, riciclabile, compatibile, naturale, vivo... Con tutto ciò il legno dimostra grandi possibilità di adattamento del nuovo con il preesistente. Nel quarto caso si ricorre ad un'astrazione materiale che ci rimette ad una forma illusoria, immateriale, leggera che si allontana dalla realtà della rovina e si avvicina a quella del cielo, stabilendo una relazione 


\section{Considerazioni finali}

La valutazione di una preesistenza nel contesto di un intervento architettonico sul patrimonio può rispondere a tre momenti: il restauro del suo passato in parte scomparso, che si può dedurre dallo studio dell'edificio, delle fonti documentali e d'altre architetture; la conservazione del suo presente con valori più o meno consolidati nel tempo; e l'adeguamento alle nuove esigenze per fornirla di rinnovata vitalità e quindi garantire la sua permanenza nel futuro.

Questi tre punti di vista si riflettono nei tre aspetti fondamentali dell'architettura -firmitas, utilitas e venustas-: aspetti funzionali: che vanno dalle questioni di uso alle questioni significative e simboliche; aspetti formali: che sono legati alle questioni compositive e spaziali; e gli aspetti materiali: le questioni relative alla realizzazione fisica. Questi tre aspetti devono essere considerati non solo in quanto preesistenza in sé, ma anche in relazione al suo ambiente, per ciò che riguarda la presenza del monumento nella configurazione dello spazio della città.

In definitiva, attraverso un complesso lavoro di equilibrio mediante analogie e contrasti, si cercherà di stabilire un dialogo adatto tra antico e nuovo per la formazione di uno spazio architettonico. Un dialogo che riguarderà sia il monumento ed il luogo sui cui se agisce, sia le numerose architetture prodotte nel corso della storia, in modo che attraverso un processo di reinterpretazione contemporanea, siano acquisiti i meccanismi necessari per raggiungere l'equilibrio ricercato.

Pier Luigi Cervellati si trova con un edificio parzialmente ricostruito, la cui ricostruzione è stata eseguita utilizzando forme semplificate ed una materialità lontana dall'originale, che ha inoltre dei parti mancanti nelle volte, elementi di grande definizione simbolica dello spazio. La sua risposta è conforme a questa realtà bipolare, e diventa mediatore tra le necessità entrambi realtà, attraverso un sistema che riesce a collegarle con grande sensibilità.

Inoltre Emanuele Fidone, trova una preesistenza dove è stata una frattura nel dialogo tra le fasi della storia, in questo caso prodotta da un "restauro" inadeguato. Fidone, come Cervellati, si vede nella necessità di introdurre un discorso che risolva la transizione tra due idee spaziali diverse, la "paleocristiana" e la "barocca." La sua proposta risponde all'aspetto oscuro e materico dello spazio originale ma, come in una rovina che ha perso la sua protezione, permette l'entrata di luce zenitale barocca, sfumandola con un elemento contemporaneo ma di chiare reminiscenze naturali. II nuovo ombracolo leggero acquisisce nella sua conformazione il profilo di una volta, come un'eco della grotta, come un'eco degli spazi delle navate laterali. 
José Ignacio Linazasoro trova nelle rovine delle Escuelas Pías e nel suo ambiente nuovi valori che rimettono alle sue profonde conoscenze sull'antica Roma, sugli spazi interni e giustapposti dell'architettura medievale, sulle reinterpretazioni della storia nelle architetture della modernità. La dimensione dell'edificio richiede giochi complessi, più elaborati, multipli frammenti relazionati in maniere diverse che si ordinano con saggezza in un nuovo insieme moderno. Il recupero del passato dell'edificio non aveva oramai senso nella nuova realtà dell'ambiente e del nuovo uso previsto. La rovina era diventata parte dell'identità del quartiere, e dopo l'intervento, la immagine degradata del monumento ha acquisito una nuova vita con un valore maggiore nella realtà attuale del luogo. Nell'interno il nuovo ombracolo di legno protegge le rovine sotto un cielo lontano.

Juan Carlos Arnuncio riscatta alcuni muri dimenticati e li recupera per una nuova architettura che propone riflessioni presenti nella storia, e pertanto che ricordano alcuni concetti dell'architettura scomparsa. Concetti come l'introversione che si riferisce all'austerità esterna e alla sorpresa interna, il tema del peso e la lievità che è legato alla sovrapposizione di un elemento leggero che copre e protegge lo spazio, il tema dall'ammirazione per la rovina e la ricerca di fissarla su un fondo neutro, il tema della luce indiretta che produce un ambiente di spiritualità e mistero. Tutto ciò, riunito in un'operazione misurata che mostra una grande riflessione e sensibilità, che dimostra la preoccupazione per un lavoro ben fatto.

L'intervento nel patrimonio suppone una riflessione su un'architettura storica. A sua volta questo produce una riflessione sulla nostra propria architettura, quella del nostro tempo. Si produce un trasferimento, un dialogo tra quello che ci dicono gli antichi e quello che noi vogliamo raccontare loro. Gli antichi, come i nostri nonni, hanno molto da insegnarci, hanno vissuto una lunga vita, hanno il valore dell'esperienza, una lunga riflessione, consolidata durante il tempo. Noi, più giovani, vogliamo ascoltarli, ma anche dire loro che le cose sono cambiate. Esperienza di architetto vecchio, entusiasmo di architetto giovane. Insieme dobbiamo comporre una storia coerente. 


glosario 


\section{GLOSARIO}

En este glosario se recogen las definiciones de algunos términos y expresionesutilizados en la presente investigación, con la finalidad deayudar a su comprensión, aportar matices según el punto de vista de diferentes autores, así como ilustrarnos sobre su origen etimológico. Se opta por incluir esta recopilación a fin de evitar las definiciones en el propio texto, situación reservada sólo para aquellas que se consideren más relevantes.

En todas las definiciones que no sean producto de elaboración del autor de esta investigación, está indicada su fuente de procedencia. Las fuentes más consultadas están referenciadas según las siguientes abreviaturas:

Bruno BRUNO, A.: "H.3.2. Aprocci Metodologici. Progetto di restauro critico". En: ZEVI L.: II manuale del restauro architettonico. Roma, Ed. Mancosu, 2001, H124

Calvo CALVO, A.: Conservación y restauración. Materiales, técnicas y procedimientos. De la A a la Z. Barcelona, Ediciones del Serbal, 1997

Contorni CONTORNI, G.: Erre come Restauro. Terminologia degli interventi sul patrimonio architettonico. Florencia, Alinea Editrice, 1993

DAU Dizionario di architettura e urbanística. Roma, Istituto editoriale romano, 1968-69 [Extraído de Contorni]

RAE

Real Academia Española: Diccionario de la lengua española (Vigésima segunda edición), 2001

Este glosario incluye la traducción de los términos a italiano e inglés, entendiendo que dicha traducción puede ser de utilidad para la correcta comprensión de textos en otras lenguas o como motor de búsqueda de información. Para dichas traducciones se han consultado las siguientes fuentes:

CONTORNI, G.: Erre come Restauro. Terminologia degli interventi sul patrimonio architettonico. Florencia, Alinea Editrice, 1993

Oxford University Press: Oxford Dictionaries. Oxford, Oxford University, 2013 [en línea]

Disponible en: www.oxforddictionaries.com

RICO,L.;MARTÍNEZC.(dirs.)et.al.:DiccionarioTécnicoAkalde Conservación y restauración de bienes culturales. EspañolAlemán-Inglés-Italiano-Francés. Madrid, Ed. Akal, 2003 


\section{ANASTILOSIS · ANASTILOSI · ANASTYLOSIS}

El significado originario del término se refería a la operación consistente en el levantamiento de columnas caídas, en el caso de edificios clásicos, volviendo a colocarlas en el mismo lugar. Con el tiempo, su significado se ha extendido a la recomposición de edificios, cuyos materiales originales se encontraban caídos sobre el mismo lugar. (Contorni)

"En general, reconstrucción -total o más frecuentemente parcial- de edificios antiguos, realizada mediante la reconexión de sus parte en ruinas, recuperadas y yacentes a pié de obra. Se efectúa generalmente con facilidad en los edificios construidos en cantería de piedra con unión en seco, gracias a las marcas de las uniones metálicas (técnica común en los edificios de la antigua Grecia), que permiten reconocer la disposición original de los elementos". (DAU)

\section{AUTENTICIDAD · AUTENTICITÀ · AUTHENTICITY}

"Acreditado de cierto y positivo por los caracteres, requisitos o circunstancias que en ello concurren." (RAE)

Se trata de un término muy controvertido. A propósito de este tema se recomienda consultar lo indicado en el capítulo 2.2. "Recapitulación de los criterios de intervención en la reflexión actual".

"Significa la suma de características sustanciales, históricamente determinadas: del original hasta el estado actual, como resultado de las varias transformaciones que han ocurrido en el tiempo". (Carta de Cracovia)

"Muchas veces, las operaciones de limpieza de obras de arte revelan elementos técnicos o formales que atestiguan su autenticidad o permiten distinguirlas de posibles copias, imitaciones o falsificaciones". (Giannini y Roani)

\section{COMPLETAMENTO · COMPLETION}

Es una palabra italiana que hace referencia a las actuaciones de intervención sobre monumentos que se encuentran incompletos, ya sea por interrupción de su construcción o por la pérdida parcial de sus fábricas, cuya finalidad es la de completar el conjunto, confiriendo a la obra un carácter de integridad, de objeto "completo".

La traducción en castellano podría ser la palabra "compleción", pero las que más se han utilizado han sido "complementación" empleada por autores como Salvador Lara ${ }^{1}$ y utilizada históricamente por la Academia de Bellas Artes, y “conclusión" empleada por Javier Rivera Blanco. ${ }^{2}$ 
Sin embargo algunos autores, prefieren emplear el vocablo castellanizándolo, a sabiendas de su inexistencia en el diccionario de la RAE, pero en la seguridad de que su comprensión es mucho más directa. Así emplean la palabra "completamiento" autores como Alberto Ustárroz, Javier Rivera, Roberto Fernández $z^{3}$ o Susana Mora ${ }^{4}$, o la palabra "completación" autores como Antón Capitel. ${ }^{5}$

De las cartas de la restauración emerge un rechazo hacia cualquier completamento analógico, es decir por analogía o "en estilo", operaciones que se habían considerado acertadas sobre todo en la segunda mitad del s. XIX. Sin embargo, se admite el completamento realizado mediante técnicas modernas, inmediatamente reconocible, y vinculado más bien a un nuevo proyecto que a una restauración, siempre que sea necesario por razones estructurales o estéticas. (Contorni)

\section{CONSERVACIÓN · CONSERVAZIONE C CONSERVATION}

"Mantener algo o cuidar de su permanencia." (RAE)

"Se entiende como tal el conjunto de operaciones y técnicas que tienen como objetivo prolongar la vida de los bienes culturales. Para conservar los objetos hay dos caminos: la prevención del deterioro (conservación preventiva o preservación), y la reparación del daño (restauración). La conservación se plantea como finalidad mantener las propiedades, tanto físicas como culturales, de los objetos para que pervivan en el tiempo con todos sus valores. [...] Se pretende conservar la integridad física y la funcional (capacidad de transmitir la información que encierra)". (Calvo)

"Conservación es el conjunto de actitudes de una comunidad dirigidas a hacer que el patrimonio y sus monumentos perduren. La conservación es llevada a cabo con respecto al significado de la identidad del monumento y de sus valores asociados." (Carta de Cracovia) ${ }^{6}$

La conservación presupone el mantener el bien intacto. (Bruno)

"A partir de la pregunta "¿Restaurar o conservar?", que planteaba Camillo Boito en el IV Congresso degli Ingegnieri ed Architetti italiani, se ha abierto un debate durante más de un siglo, que aún está vivo, y en el que se han ido interpretando estos términos -conservación y restauración- como antítesis, como complementariedad o como coincidencia." Las cartas de la restauración reflejan la evolución de este debate. (Contorni) 
LAGUNA - LACUNA - LACUNA/LOSS

Por laguna en una obra de arte se entiende un área, más o menos grande, donde la continuidad de la imagen se ha interrumpido o perdido. Una parte que no se ha completado nunca debería definirse como laguna. Para poder afirmar que algo se ha perdido, es necesario conocer la unidad de la obra en su forma precedente. ${ }^{7}$

"Actualmente los criterios de intervención se dirigen a realizar las operaciones necesarias para que los objetos perduren en el tiempo, más que a reparar su aspecto estético, aunque sin descuidarlo. [...] Sin embargo, en muchos casos, la reintegración de lagunas es necesaria no sólo para su estabilidad, sino también para entender su contenido. En cualquier caso las reintegraciones deben ser inocuas, reversibles, y fácilmente identificables sin necesidad de instrumentos especiales, además de limitarse exclusivamente al fragmento perdido". (Calvo)

\section{LIBERAZIONE · CLEARANCE}

Restuaro di liberazione: "Consiste en liberar al monumento de todos los elementos (sobreelevaciones, añadidos, etc.) que habían alterado el aspecto primitivo de la obra." (DAU)

Restuaro di liberazione: "Eliminación de añadidos y alteraciones". ${ }^{9}$

Restuaro di liberazione: Concepto que se refiere a cuando "se eliminan volúmenes amorfos que obstruyen o invaden el monumento, tanto en su exterior como en su interior, y éste recupera su aspecto de arte.... ${ }^{10}$

Este concepto registró gran acogida en los años '30 en Italia, como testimonian numerosísimos monumentos "liberados" en busca de una mejor visión y apreciación de su valor estético. Más tarde, los restauradores han sido más reticentes a este concepto de liberazione, ya que frecuentemente se ha demostrado su escaso cuidado hacia los valores históricos y ambientales en edificios sedimentados en el tiempo, que no pueden considerarse "volúmenes amorfos" a demoler sin ninguna preocupación. (Contorni) 


\section{RECOMPOSICIÓN · RICOMPOSIZIONE}

"Reparar, componer de nuevo". (RAE)

Reconstitución de la integridad.

Para Pevsner ${ }^{11}$, restauración de recomposición es sinónimo de "anastilosis". Contorni, sin embargo, señala que se diferencia de la anastilosis -que en rigor significa volver a poner en pie estructuras derruidas con los fragmentos originales yacentes en el lugar- porque implica igualmente la necesidad de añadir materiales, como por ejemplo mortero, o elementos diversos.

En esta investigación el verbo recomponer se emplea más en el sentido creativo, de volver a componer algo que se ha descompuesto o incluso perdido, no sólo con los restos materiales preexistentes sino también desde una reflexión sobre la forma y materia desaparecidas.

\section{RECONSTRUCCIÓN · RICOSTRUZIONE · RECONSTRUCTION}

\section{"Acción y efecto de reconstruir.}

Reconstruir:

1. Volver a construir.

2. Unir, allegar, evocar recuerdos o ideas para completar el conocimiento de un hecho o el concepto de algo". (RAE)

"Nueva construcción de una estructura o repristinación de su integridad". ${ }^{12}$

“Operaciones de repristinación de edificios, monumentos, obras de arte, complejos urbanísticamente relevantes, etc., destruidos o en avanzado estado de ruina, realizadas con intención de devolverlos a su estado original. Cuando la reconstrucción se cualifique formalmente como independiente de lo "preexistente" se prefiere el término reedificación. La reconstrucción puede ser puramente gráfica (en base a excavaciones, fuentes literarias, etc.) o propiamente material, parcial o inherente a la totalidad del edificio o conjunto monumental..." (DAU) Conviene mencionar que en las últimas décadas se ha extendido la práctica de las "reconstrucciones virtuales", mediante tecnologías informáticas vinculadas a la representación gráfica tridimensional, utilizada principalmente con fines divulgativos, como recursos museográficos, frecuentemente asociada a investigaciones arqueológicas.

"La reconstrucción es una intervención que se ha efectuado en periodos diversos tras eventos traumáticos, como la caída del campanile di $S$. Marco, en Venecia, o bélicos, como la reconstrucción del centro histórico de Varsovia y del Puente S. Trinità en Florencia, sobre todo si se contaba con documentación que permitiese la ejecución". (Contorni) 
Para Giorgio Grassi "reconstruir quiere decir construir (...) el objeto necesario y la forma correspondiente, la forma plasmada de la necesidad, pero también la expectativa que está ligada a aquella forma, el lugar que ocupa en la memoria colectiva. (...) construirlo dov'era e com'era sin alteraciones ni desviaciones (...), pero construirlo con nuestros ojos y con nuestros medios". ${ }^{13}$

\section{REGLAS $\cdot$ REGOLE $\cdot$ RULES}

Se indican en las Cartas de Restauro.

Son instrumentos útiles que deben ser cautamente interpretados, siendo toda la responsabilidad del intérprete.

Las reglas o criterios-guía más evocados en las Cartas suelen ser la distinción, la reversibilidad, la mínima intervención y el respeto por la autenticidad.

Una referencia normativa a las reglas es sin duda necesaria, pero extremadamente peligrosa paraquien nosabeadecuarlasnormasaloscasos particulares, y dado que todo caso es particular, el riesgo es grande. (Bruno)

\section{REHABILITACIÓN · RIABILITAZIONE · REHABILITATION}

"Acción y efecto de rehabilitar.

Rehabilitar: Habilitar de nuevo o restituir a alguien o algo a su antiguo estado". (RAE)

Recuperación de la funcionalidad, tanto para el mismo uso que poseía en su origen, como para un cambio de uso. Generalmente, la utilización de este término lleva implícitas connotaciones de transformación de la preexistencia, para adecuarla a las necesidades y exigencias del momento en el que se interviene.

Término poco usado en la lengua italiana, salvo en documentos traducidos de otras lenguas, su significado se corresponde con el del término recupero. (Contorni)

Recupero: "en su sentido más específico, significa adecuar a las necesidades de nuestro tiempo objetos creados para satisfacer necesidades diferentes, o creados para necesidades similares a las nuestras, pero que a causa de sus condiciones de degradación han quedado total o parcialmente inutilizables". ${ }^{15}$

Tanto en italiano como en castellano, se suele utilizar de manera imprecisa como sinónimo de "restauración". 


\section{REINTEGRACIÓN · REINTEGRAZIONE}

Reconstitución o restitución de la integridad perdida de algo.

"Acción y efecto de reintegrar o restituir una parte perdida. Técnica de restauración que permite integrar estéticamente una obra completando sus pérdidas, ya sean de soporte, de decoración o de policromía. Con independencia del criterio estético seleccionado, se limita exclusivamente a las lagunas existentes en la pieza, y se realiza con materiales inocuos, reversibles y reconocibles con respecto al original". (Calvo)

Las modalidades de ejecución de las reintegraciones especificadas en la Carta CNR consisten en la sobria diferenciación de los materiales o superficies nuevas respecto de las originales, según una filosofía ya presente en la Carta de Venecia (art. 12) y en la Carta italiana de 1972 (art. 7). (Contorni)

\section{REPRISTINACIÓN · RIPRISTINO - RESTORATION TO ITS ORIGINAL}

\section{STATE}

"Acción que tiene por objeto devolver a una obra artística su aspecto original, rehaciendo cuanto falte y arreglando todo lo deteriorado hasta dejarla como nueva. Es un criterio de restauración, hoy inadmisible, por lo que también la palabra ha caído en desuso". (Calvo)

Este término (no incluido en el diccionario de la RAE) proviene del italiano: "Ripristino", motivo por el cual este concepto con frecuencia se expresa mediante una adaptación de este término al español: "Repristino". Sin embargo se ha entendido más correcto en el ámbito de esta investigación traducirlo con el vocablo "repristinación".

\section{RESTAURACIÓN · RESTAURO - RESTORATION}

"Acción y efecto de restaurar.

\section{Restaurar:}

1. Recuperar o recobrar.

2. Reparar, renovar o volver a poner algo en el estado o estimación que antes tenía.

3. Reparar una pintura, escultura, edificio, etc., del deterioro que ha sufrido." (RAE)

Existe debate sobre su origen, según el contenido que se le de al concepto. Si lo entendemos como "rimettere in efficienza"[recuperar su eficiencia], es algo que se ha hecho siempre. Pero entendido como preservación de un testimonio del pasado, es un concepto moderno definido entre los siglos XVIII y XIX. 
En el primer caso podemos hablar de "poner al día las obras del pasado, adecuándolas a las exigencias espirituales, materiales y estéticas de la contemporaneidad" (M.P. Sette, 2001, p.3). Mientras que en el segundo caso se podría definir como "Operaciones con el fin de restituir un monumento a su mundo históricamente determinado" (Bonelli, 1963, col.344).

Restaurare: Voz latina, que en época imperial ha sustituido el verbo de origen desconocido instaurare en el significado de "recomenzar", luego de "restituir", por tanto de "renovar".

La restauración interviene sobre la materia y sobre la forma del objeto. Cuando se restaura se proyecta diferencia y en este sentido se realiza una mutación que es algo distinto de la aséptica conservación. (Bruno)

La restauración es una intervención dirigida sobre un bien patrimonial, cuyo objetivo es la conservación de su autenticidad y su apropiación por la comunidad. (Carta de Cracovia)

Para Giovanni Carbonara restauración es "cualquier intervención dirigida a conservar y a transmitir al futuro, facilitando la lectura y sin eliminar las trazas del paso del tiempo, las obras de interés histórico, artístico y ambiental". ${ }^{17}$

\section{RESTITUCIÓN · RESTITUZIONE · RESTITUTION}

"Acción y efecto de restituir.

Restituir: Restablecer o poner algo en el estado que antes tenía". (RAE)

"En la restauración arquitectónica, operación consistente en el conjunto de trabajos con el fin de devolver a una obra sus condiciones originarias. En general se refiere a edificios degradados o muy transformados, donde se opta por rehacer o reconstruir elementos, siempre con cautela y utilizando los criterios de restauración oportunos". (DAU)

"Reintegración de partes perdidas o desmembradas. Sinónimo de reintegración". También hace referencia a localización, volver a poner en su sitio. Acción de restablecer el estado completo de un objeto, perdido por accidente o por el paso del tiempo. (Calvo)

Según Contorni, este término -asimilable a ripristino- está en desuso dentro de la cultura de la restauración [en Italia]. 


\section{REVERSIBILIDAD $\cdot$ REVERSIBILITÀ · REVERSIBILITY}

Es un principio filosófico de voluntad de comunicación hacia la posteridad, para dar una sugerencia de lectura.

Reversibilidad no significa precariedad.

Una intervención reversible busca mostrar el respeto por las preexistencias, localizado en nuestro tiempo, sobre lo existente, de manera legible y auténtica.

El arquitecto debe ser consciente de que seguramente no será el último en actuar sobre un monumento.

Intervenir en sintonía con la materia existente de la obra es una elección que el proyectista debe hacer caso por caso y no hay regla precisa que valga de manera absoluta y cierta. 
1 LARA, S.: "El Teatro romano de Sagunto". En: A.A.V.V.: Restaurar o Conservar?: Barcelona-Cardona, del 17 al 20 de noviembre de 1993. Barcelona: Diputació de Barcelona. 1996, pp. 291-295

2 RIVERA BLANCO, J.: "Teoría e Historia de la Intervención en Monumentos Españoles hasta el Romanticismo" (1989). En: De varia restauratione. Teoría e historia de la restauración arquitectónica. Madrid: Abada editores, 2008, pp. 25-116

3 FERNÁNDEZ, R. "2. Notas para una introducción a la teoría y práctica restauradora". En: A.A.V.V. : Teoría e Historia de la Restauración. Madrid, MRRP, 1997, pp. 46-99

4 MORA ALONSO-MUÑOYERRO, S. : La Restauración Arquitectónica en España. Criterios y Teorías (1840-1936). Madrid, Kaher II, 2002

5 CAPITEL, A.: Metamorfosis de monumentos y teorías de la restauración. Madrid, Alianza Forma, 1988,2009 , p.14

6 Conferencia Internacional sobre Conservación "Cracovia 2000": Carta de Cracovia 2000. Principios para la conservación y restauración del patrimonio construido. RIVERA BLANCO, J.; PÉREZ ARROYO, S. (Versión española), Instituto Español de Arquitectura, Universidad de Valladolid, 2000

7 JOKILHETO, J.: "Il problema della reintegrazione". En: SEGARRA LAGUNES, M.M.: La reintegrazione nel restauro dell'antico: la protezione del patrimonio dal rischio sismico : atti del Seminario di studi, Paestum, 11-12 aprile 1997. Roma, Ed. Gangemi, 1997, p.47

9 PEVSNER, N.; FlEMING, J.; HONOUR, H.: Dizionario di architettura. PEDIO, R. (dir. ed. italiana), Torino, Ed. Einaudi, 1981 (ed. original en inglés: Londres, 1966). Extraído de Contorni.

10 GIOVANNONI, G.: [definición del término] "Restauro". En: Enciclopedia Italiana Treccani, 1936. Citado por Contorni.

11 Citado por Contorni.

12 DEVOTO, G.; OLI, G.C.: Dizionario della lingua italiana. Florencia, Ed. Le Monnier, 1980 (reimpresión ed. 1961). Extraído de Contorni.

13 GRASSI, G.: "Ricostruzione del castello di Valkhof”. Casabella no666, Aprile 1999, p. 56

15 MIARELLI MARIANI: "La città storica: alcuni nodi del recupero". En: Anastilosi. L'antico, il restauro, la città. Roma-Bari, 1987, pp. 264-269. Citado por Contorni.

17 CARBONARA, G.: Architettura d'oggi e restauro. Un confronto antico-nuovo. Torino, Ed. Utet, 2011, p. $100-101$ 



\section{bibliografía}




\section{BIBLIOGRAFÍA GENERAL}

A.A.V.V.: 50 Años de Protección del Patrimonio Histórico Artístico. 19331983. Madrid, Ed. Ministerio de Cultura, 1983

A.A.V.V.: Intervenciones en el Patrimonio Arquitectónico (1980-1985). Madrid, Ed. Dirección General de Bellas Artes y Archivos, 1990

A.A.V.V.: La chiesa di San Giorgio in Velabro a Roma: storia, documenti, testimonianze del restauro dopo l'attentato del luglio 1993. Roma, Ed. Istituto poligrafico e Zecca dello Stato, 2002

A.A.V.V.: Día de la Arquitectura.XVIICongreso Internacional de Conservación y Restauración de Bienes Culturales. Castellón, 20 de noviembre de 2008, Editorial UPV, 2008

ACHLEITNER, F.: "Ritorno al moderno? L'architettura di Peter Zumthor". Casabella, no 648, Settembre 1997, pp. 52-55

ALBERTI, L.B.: De Re Aedificatoria. (Traducción de Javier Fresnillo Núñez). Madrid, Ed. Akal, 1991

ALMAGRO, A.: "Restauración del Alcázar Omeya". Loggia, no 11, Valencia, 2001, pp. 44-59

ALONSO DEL VAL, M.A.: "La arquitectura como límite". Arquitectura, no 274, Madrid, Ed. COAM, 1988, pp. 24-35

ALONSO DEL VAL, M.A.; HERNÁNDEZ MINGUILLÓN, R.J.: "Antigua biblioteca del monasterio de Fitero. Navarra". On diseño, no 235, 2002, pp. 220-229

AMENDOLEA, B.: I siti archeologici: un problema di musealizzazione all'aperto. Secondo seminario di studi Roma gennaio 1994. Roma, Ed. Gruppo Editoriale Internazionale, 1995

ARNUNCIO, J.C.: Peso y Levedad. Notas sobre la gravedad a partir del Danteum. Barcelona, Ed. Fundación Caja de Arquitectos, 2007

BAGLIONE, CH.: "Costruire la memoria. Conversazione con Peter Zumthor". Casabella, no 728-729, Dicciembre 2004 - Gennaio 2005, pp.72-81

BELLANCA, C. Una didattica per il restauro. Roma, Atena Editrice, 2008

BILLECI, B.; GIZZI, S.; SCUDINO, D.: II rudere tra conservazione $e$ reintegrazione. Atti del Convegno Internazionale, Sassari, 26-27 settembre 2003. Roma, Ed. Gangemi, 2006 
BOGONI, B.: Libero Cecchini. Natura e archeologia al fondamento dell'architettura. Firenze, Alinea Editrice, 2009

BONET I ARMENGOL, J.: "El Templo de la Sagrada Familia. Nuevas aportaciones al estudio de Gaudí". Loggia, no 9, pp. 22-29

BORIANI, M.: Progettare per il costruito. Dibattito teorico e progetti in Italia nella seconda metà del XX secolo. Milano, Ed. CittàStudi Edizioni, 2008

BORTOLOTTO, S.; PALO, M.C.: "Basílica de S. Vincenzo, Galliano di Cantù (Como): la vetrata di chiusura della navata maggiore". En: BORIANI, M.: Progettare per il costruito. Dibattito teorico e progetti in Italia nella seconda metà del XX secolo. Milano, Ed. CittàStudi Edizioni, 2008, pp. 125-130

BOSCARINO, S.: Sul restauro architettonico: saggi e note. Milano, Ed. F. Angeli, 1999

BOSCARINO, S.: "Memoria e significati". En: Sul restauro architettonico: saggi e note. Milano, Ed. F. Angeli, 1999, pp. 81-82

BOSCH REIG, I.: Intervención en el Patrimonio: Análisis Tipológico y Constructivo: El Caso de la Real Capilla de la Virgen de los Desamparados de Valencia. Valencia, Editorial UPV, 2006

BOSCH REIG, I.: "La ruina como valor añadido en el patrimonio. El nonfinito". Ingeniería y territorio, no 92, Barcelona, 2011, pp. 86-95

BOSCH REIG, I.: "Intervención en el patrimonio: un continuo proceso de innovación". Restauración y Reahbilitación, $R \& R$, no 79, 2003, pp. 20-27

BOSCH REIG, I.: "Intervención en el patrimonio: un continuo proceso de innovación". En: A.A.V.V.: Las herramientas del arquitecto 2. Valencia, Ed. Ediciones Generales de la Construcción, 2004, p. 135-151

BOSCH REIG, I.: "Del fragmento al conjunto. De lo particular a lo general". Restauración y Reahbilitación, R\&R no112-113, 2010, p. 4

BOSCH ROIG, L.: "La Reconstrucción Parcial en la Rehabilitación del Patrimonio Arquitectónico en España desde los años 80". Arché, no 4-5, 2010, pp. 397-406

BRAGHIERI, N.: "Ricostruzione e restauro del museo di storia naturale a Berlino". Casabella, no 803, pp. 4-13

BRANDI, C.: Teoria del Restauro. Roma, Edizioni di Storia e Letteratura, 1963 (Versión en español: Teoría de la Restauración. Madrid, Ed. Alianza, 1988-89) 
BRUNO A. et al.: Oltre il restauro. Architetture tra conservazione e riuso. Progetti e realizzazioni di Andrea Bruno (1960-1995). Milano, Ed. Lybra immagine, 1996

BRUNO, A.: "H.3.2. Aprocci Metodologici. Progetto di restauro critico". En: ZEVI L.: Il manuale del restauro architettonico. Roma, Ed. Mancosu, 2001, $\mathrm{H} 124$

BRYANT LOGAN, W.: "Il gotico secondo Calatrava. Completamento della cattedrale di New York". Lotus, no 72, pp. 64-69

BURILLO LAFARGA, L.: "Palacio Episcopal de Tarazona". Arquitectura, no 244, pp. 53-55

CALDUCH, J.: "La duración: una alternativa de nuestra modernidad". En: A.A.V.V.: Rehabilitación en vivienda. Valencia, Ed. Pencil, 2007

CAMPO BAEZA, A.: "Giudici ingiusti e ignoranti". Domus, no 756, enero 1994, pp. 82-83

CANGELOSI, A.; VITALE, M.R.: Brandi e l' architettura. Atti della giornata di studio, Siracusa 30 ottobre 2006. Siracusa, Ed. Lombardi, 2008

CAPITEL, A.: Metamorfosis de monumentos y teorías de la restauración. Madrid, Ed. Alianza Forma, 1988

CAPITEL, A.: "La analogía como instrumento proyectual en los edificios históricos". En: POL, F. (dir.): Arquitectura Recuperada. Madrid, Ed. Universidad Internacional Menéndez Pelayo, 1989, pp. 13-16

CAPITEL, A.: "Proyectar para una arquitectura dada". El Croquis, no 42, Madrid, 1990, pp. 64-79

CAPITEL, A.: "En busca de la modernidad pendiente". En: BALDELLOU, M. A.; CAPITEL, A.: Arquitectura española del siglo XX. Madrid, Ed. Espasa Calpe, 1995-2001, p. 447

CAPITEL, A.: "La arquitectura española más allá de la crisis". En: BALDELLOU, M. A.; CAPITEL, A.: Arquitectura española del siglo XX. Madrid, Ed. Espasa Calpe, 1995-2001, p. 554

CAPITEL, A.: "Apéndice. La práctica de la analogía formal". En: Metamorfosis de monumentos y teorías de la restauración. Madrid, Alianza Forma, 2009, pp.219-244

CARBONARA, G.: La reintegrazione dell'immagine. Problemi di restauro dei monumenti. Roma, Ed. Bulzoni, 1976 
CARBONARA, G.: "Restauro fra conservazione e ripristino: note sui più attuali orientamenti di metodo". Palladio, Anno III, no6, Ed. Istituto Poligrafico e Zecca dello Stato, 1990, pp. 43-76

CARBONARA, G.: Trattato di restauro architettonico. Vol. 1. Torino, Ed. Utet, 1996

CARBONARA, G.: Avvicinamento al restauro. Teoria, storia, monumento. Napoli, Ed. Liguori, 1997

CARBonARA, G.: "La Chiesa Cattedrale-Tempio di Augusto a Pozzuoli: un innovativo concorso di restauro". En: GIANFRANCO, A. (ed.): TempioDuomo di Pozzuoli. Progettazione e restauro. Ed. Giannini, 2006, p. 19

CARBONARA, G.: Architettura d'oggi e restauro. Un confronto anticonuovo. Torino, Ed. Utet, 2011

CARMASSI, M.; MULANZZANI, M.: Recupero, Conservazione, Riuso. Un centro culturale nel Mattatoio di Roma. Milano, Ed. Electa architettura, 2011

CASTILLA DEL PINO, C.: "La Memoria y la Piedra”. En: GONZÁLEZ MORENONAVARRO, A. (dir.): Patrimonio: ¿Memoria o Pesadilla?. Memoria: 19901992. Barcelona, Ed. Diputació de Barcelona, 1995, p. 11

CAVALLERI, F.: "Un primo livello di riflessione: alcuni elementi concettuali". En: Progettare per il costruito. Dibattito teorico e progetti in Italia nella seconda metà del XX secolo. Milano, Ed. CittàStudi Edizioni, 2008, pp. 7188

CAVALLERI, F.: "Un terzo livello di riflessione: alcuni elementi costruttivi". En Progettare per il costruito. Dibattito teorico e progetti in Italia nella seconda metà del XX secolo. Milano, Ed. CittàStudi Edizioni, 2008, pp. 103121

CESCHI, F.: "Musealizzazione di aree archeologique: il Tempio di Veio e la Crypta Balbi". En: arch.it.arch - dialoghi di archeologia e architettura. Seminari 2005-2006. Roma, Ed. Edizione Quasar, 2009, pp. 96-99

CHIPPERFIELD, D.: "Tertium Quid". En: GIANFRANCO, A. (ed.): TempioDuomo di Pozzuoli. Progettazione e restauro. Ed. Giannini, 2006, p. 97-107

CHIPPERFIELD, D.: “Neues Museum”. Restauración y Reahbilitación, $R \& R$, no 112-113, pp. 20-45

CHRIST \& GANTENBEIN.: "Swiss National Museum". Architectural Review, no 1354, diciembre 2009, pp. 84-86 
CONTORNI, G.: Erre come restauro: terminologia degli interventi sul patrimonio architettonico. Firenze, Ed. Alinea, 1993

CORNELL, E.: "El cielo como una bóveda" En: CALDENBY, C.; HULTIN, O.: Asplund. Barcelona, Ed. Gustavo Gili, 1988, p. 26

CORNOLDI, A.; RAPPOSELLI, M.; Massimo Carmassi: Pisa. Ricostruzione di San Michele in Borgo. Venecia, Ed. IUAV; Padova, Ed. II Poligrafo, 2005

CORNOLDI, A.: "Per una composizione critica". En: CORNOLDI, A.; RAPPOSELLI, M.; Massimo Carmassi: Pisa. Ricostruzione di San Michele in Borgo. Venecia, Ed. IUAV; Padova, Ed. II Poligrafo, 2005, pp. 9-14

CORNOLDI, A.; RAPPOSELLI, M.: "Nuovo e antico. Intervista a Emanuele Fidone, Vicenzo Latina e Bruno Messina". En: Emanuele Fidone, Vincenzo Latina, Bruno Messina. 'Restauri' Iblei. Padova, Ed. II Poligrafo, 2007, pp. 13-19

CORNOLDI, A.: "Restauri non Conservativi. La Ricerca delle Regole". En: FERLANGA, A.; VASALLO, E.; SCHELLINO, F.: Antico e Nuovo. Architetture e architettura. Ed. II Poligrafo, 2007, Volumen 1, pp. 261-284

CURTIS, W. J. R.: Le Corbusier: Ideas y formas. Madrid, Ed. Hermann Blume, 1987

DALLA NEGRA, R.; RUSCHI, P.: // Corridore di Prato: una fortificazione medievale restaurata. Firenze, Ed. Edifir, 2000

DE LA ROCA, A. et al.: Aspetti urbanistici ed edilizi della ricostruzione. Viterbo, 2007

DESGODETS, A. B.: Les edifices antiques de Rome: dessinés et mesurés très exactement. Paris, Ed. Chez Jean Baptiste Coignard, 1682

Disponible en el sitio web de la Digital Library for the Decorative Arts and Material Culture: <http://digital.library.wisc.edu/1711.dl/DLDecArts. EdiAnt> [Consulta: 23-01-2012]

DEZZI BARDESCHI, M.: "H.1.2. Aprocci Metodologici. Progetto di conservazione. Cura del Costruito". En: ZEVI L.: II manuale del restauro architettonico. Roma, Ed. Mancosu, 2001, H30-H31

DEZZI BARDESCHI, M.: Conservazione \& Progetto. Undici concorsi 2000/2005. Ed. Restaura Venezia Fiere. Salone del Restauro dei Beni Culturali, 1-3 dicembre 2006 (Catálogo)

DEZZI BARDESCHI, M.: “Elogio del palinsesto". En: GIANFRANCO, A. (ed.): Tempio-Duomo di Pozzuoli. Progettazione e restauro. Ed. Giannini, 2006, p. 25-35 
España, "Ley 16/1985, de 25 de junio, del Patrimonio Histórico Español, art. 39". Boletín Oficial del Estado, no 155, 29 de junio de 1985, p. 20347 Disponible en el sitio web del Ministerio de la Presidencia:

<http://www.boe.es/buscar/doc.php?id=BOE-A-1985-12534> [Consulta: 23-07-2011]

ESTEBAN CHAPAPRÍA, J.: La Conservación del Patrimonio Español durante la II República (1931-1939). Barcelona, Ed. Fundación Caja de Arquitectos, 2007

FANTONE, C. R.: "Giovanni Bulian. Interventi di restauro e di progettazione museale nel complesso delle Terme di Diocleziano". Costruire in Laterizio, no 78, pp.10-19

FERLENGA, A.; VASALLO, E.; SCHELLINO, F.: Antico e Nuovo. Architetture e Architettura. Venecia, Ed. II Poligrafo, 2004

FERNÁNDEZ, R. "2. Notas para una introducción a la teoría y práctica restauradora". En: A.A.V.V.: Teoría e Historia de la Restauración. Madrid, Ed. MRRP, 1997, pp. 46-99

FERNÁNDEZ ALBA, A.: “1. Relaciones entre patrimonio históricoarquitectónico y proyecto de arquitectura". En: A.A.V.V.: Teoría e Historia de la Restauración. Madrid, Ed. MRRP, 1997, pp. 36-45

FERNÁNDEZ GALIANO, L.: "Monumento nuevo. Patrimonio materno, la restauración y sus géneros". En: A.A.V.V.: Restaurar o Conservar?: Barcelona-Cardona, del 17 al 20 de noviembre de 1993. Barcelona, Ed. Diputació de Barcelona. 1996, pp. 231-234

FERNÁNDEZ MUÑOZ, A.L.: "El Proyecto como Condición de la Restauración Arquitectónica”. En: FERNÁNDEZ MUÑOZ, A. L.: Restauración Arquitectónica. Valladolid, Ed. Universidad de Valladolid, 1992, p. 138

FERRARA, M.L.: "Il rudere archeologico. Tra anastilosi, reintegrazione e repristino". Recupero e conservazione, no84, N-D 2008, p.43

FIDONE, E.: "Framenti. II progetto e la potenza rinnovatrice delle rovine". En: UGOLINI, A.: Ricomporre la Rovina. Firenze, Ed. Alinea Editrice, 2010, pp. 26-31

GALLEGO FERNÁNDEZ, P.L.: “Viollet le Duc: La Restauración Arquitectónica y el Racionalismo Arqueológico Fin de Siglo”. En: FERNÁNDEZ MUÑOZ, A.L.: Restauración Arquitectónica. Valladolid, Ed. Universidad de Valladolid, 1992, pp. 35-39 
GARCÍA NAVARRO, J.J.: "Marceliano Coquillat y Llofriu, Restauración de Santa María de Elche". En: Catálogo de la Exposición "Les Empremtes del Temps". Elche, Ed. Ayuntamiento de Elche, 2009

GASPARALI, P.: "Progetto sul costruito. Regolare il mutamento dell'edificato esistente. Tra le istanze di conservazione e le esigenze di trasformazione". Recupero e Conservazione, № 79, enero-febrero 2008, p. 37

GIANFRANCO, A. (ed.): Tempio-Duomo di Pozzuoli. Progettazione e restauro. Ed. Giannini, 2006

GIZZI, S.: "L'anastilosi tra restauro architettonico e restauro archeologico". En: GONZÁLEZ, A.; DIEZ, M.: I Bienal de la restauración: L'Hospitalet de Llobregat (Barcelona), del 23 al 26 de noviembre del 2000. Barcelona, Ed. Diputació de Barcelona, 2002, p. 81

GIZZI, S.: "L'anastilosi tra restauro architettonico e restauro archeologico". En: GONZÁLEZ, A.; DIEZ, M.: I Bienal de la restauración: L'Hospitalet de Llobregat (Barcelona), del 23 al 26 de noviembre del 2000. Barcelona, Ed. Diputació de Barcelona, 2002, pp. 84, 90

GÓMEZ, L.; QUIROSA, V.: "Nuevas tecnologías para difundir el Patrimonio Cultural: las reconstrucciones virtuales en España". E-rph-Revista electrónica de Patrimonio Histórico, nㄴ4, Granada, 2009, pp. 150-173

GÓMEZ-PIOZ, J.: "Intervención en edificios históricos. (Paseo Crítico)". En: A.A.V.V.: Proyectos de Intervención en edificios y recintos históricos. Madrid, Ed. Colegio Oficial de Arquitectos de Madrid, 1987, p. 15

GONZÁLEZ, A.: "El monumento, documento y arquitectura. Apuntes sobre su posible restauración objetiva". En: REPRESA, I. (dir): Restauración arquitectónica II. Valladolid, Ed. Universidad de Valladolid, 1998, pp. 45-60

GONZÁLEZ, A.: La Restauración Objetiva: Método SCCM de Restauración Monumental: Memoria SPAL 1993-1998. Barcelona, Ed. Diputació de Barcelona, 1999

GONZÁLEZ, A.: "Para qué y para quién las ruinas". En: GONZÁLEZ, A.; LACUESTA, R.: Estudis històrics sobre patrimoni arquitectònic: Sant Pere de Torelló, Copons, Terrasa, Esparreguera, Sant Feliu de Llobregat, Tagamanent, Segur de Calafell. Barcelona, Ed. Diputació de Barcelona, 2000, pp. 131, 132

GONZÁLEZ, A. (dir): I Bienal de la Restauración Monumental. Hospitalet de Llobregat (Barcelona), del 23 al 26 de noviembre de 2000. Barcelona, Ed. Diputació de Barcelona, 2000 
GONZÁLEZ, A.: "Restaurar es reconstruir. A propósito del nuevo monasterio de Sant Llorenç de Guardiola de Berguedà (Barcelona)". E-rph-Revista electrónica de Patrimonio Histórico, no 1, Diciembre 2007

GRANDINETTI, P.: "Il progetto di recupero della fortezza e del colle di Osoppo (Udine)". Casabella, no 634, Maggio 1996, p. 12

GRASSI, L.: Lo "spedale di poveri" del Filarete. Storia e restauro. Milano, Ed. Università degli studi di Milano, 1972

GRASSI, G.: "Un Parere Sul Restauro dei Monumenti (a proposito del Teatro di Sagunto) / Algunas Consideraciones Sobre la Restauración de los Monumentos. (A propósito del Teatro de Sagunto)", Cuadernos de Arquitectura Romana, vol. 2, 1993, pp. 47-50 / 239-240

GRASSI, G.: "Ricostruzione del castello di Valkhof." Casabella, no 666, aprile 1999, pp. 54-59

GRASSI, G.: Teatro Romano di Brescia. Progetto di restituzione e riabilitazione. Milano, Ed. Electa, 2003

GRASSI, G.: “Il carattere degli edifici.” Casabella, nำ722, maggio 2004, pp.4-15

GRASSI, G.: Giorgio Grassi. Una vita da architetto. Milano, Ed. Franco Angeli, 2008

HERNÁNDEZ-GIL, D.: "Datos Históricos sobre la Restauración de Monumentos". En: A.A.V.V.: 50 Años de Protección del Patrimonio Histórico Artístico. 1933-1983. Madrid, Ed. Ministerio de Cultura, 1983, pp. 25-32

HERNÁNDEZ LEÓN, J.; COLLOVÀ, R.; FONTES, L.; MORAIS DE SOUSA, R.: Santa Maria do Bouro. Construir uma pousada com as pedras de un monasterio. Lisboa, Ed. White \& Blue, 2001

HERNÁNDEZ MARTÍNEZ, A.: La Clonación Arquitectónica. Madrid, Ed. Ediciones Siruela, 2007

HUMANES, A.: "Introducción". En: A.A.V.V.: Intervenciones en el Patrimonio Arquitectónico (1980-1985). Madrid, Ed. Dirección General de Bellas Artes y Archivos, 1990, pp. 15-18

HUMANES, A.: "Restauración arquitectónica. El diálogo entre lo antiguo y lo nuevo". Arquitectura, no 299, Madrid, Ed. COAM, 1994, pp. 8-11

HUMANES, A.: "Arquitecto conservador o Arquitecto restaurador". Arquitectura, no 307, Madrid, Ed. COAM, 1996, pp. 12-13 
Instituto de Conservación y Restauración de Bienes Culturales (I.C.R.B.C.): Monumentos y proyecto: Jornadas sobre criterios de intervención en el patrimonio arquitectónico. Madrid, Ed. Dirección General de Bellas Artes, 1990

IRACE, F.: "Il restauro del Neues Museum di David Chipperfield". Lotus, no 144, pp. $88-94$

ISOZAKI, A.: "Una loggia per gli uficci." Casabella, no 664, febrero 1999, pp. 4-7

JIMÉNEZ, A.: "Enmiendas parciales a la teoría del restauro. (I) Imágenes y palabras". Loggia, no 4, Valencia, 1997, pp. 10-19

JOKILEHTO, J.: "Il problema della reintegrazione". En: SEGARRA LAGUNES, M. M.: La reintegrazione nel restauro dell'antico: la protezione del patrimonio dal rischio sismico : atti del Seminario di studi, Paestum, 11-12 aprile 1997. Roma, Ed. Gangemi, 1997, pp.47-56

JOKILEHTO, J.: A History of Architectural Conservation. The University of York, 1986 (Edición PDF, 2005).

KOMENDANT, A; FRAMPTON, K.; TENREIRO, O.: 18 años con el arquitecto Louis I. Kahn. La Coruña, Ed. Colegio Oficial de Arquitectos de Galicia, 2000

LASAGABÁSTER GÓMEZ, J.I.: "Reconstrucción de la bóveda de la capilla mayor de la iglesia de la Asunción de Elvillar (Álava)". En: A.A.V.V.: Restaurar o Conservar?: Barcelona-Cardona, del 17 al 20 de noviembre de 1993. Barcelona, Ed. Diputació de Barcelona, 1996, pp. 61-66

LATINA, V.: "Architettura contemporanea e Antico. Microinterventi nell' isola di Ortigia, Siracusa". En: CORNOLDI, A.; RAPPOSELLI, M.: Emanuele Fidone, Vincenzo Latina, Bruno Messina. 'Restauri' Iblei. Padova, Ed. II Poligrafo, 2007, pp. 23-24

LEPIK, A.; CHIPPERFIELD, D.: "David Chipperfield in conversation with Andres Lepik". En: REICHERT, M.: The Neues Museum - Berlin. Restoration, Repair and Intervention. The Soane Gallery, 2008

LINAZASORO, J.I.: "La Renovación Proyectual en el Bajo Imperio y la Crisis del Clasicismo Grecorromano. Diciembre-enero 1986-87". En: LINAZASORO, J.I.: Escrito en el tiempo. Pensar la arquitectura. Buenos Aires, Ed. NobuKo / UP Universidad de Palermo, 2003, p.31

LOS, S.; FRAHM, K.: Carlo Scarpa. Köln, Ed. Benedikt Taschen, 1994

MANACORDA, D.: Arch.it.arch. Dialoghi di archeologia e architettura: seminari 2005-2006. Roma, Ed. Quasar, 2009 
MANIAQUE BENTON, C.: Le Corbusier and the Maisons Jaoul. New York, Ed. Princenton Architectural Press, 2009

MARCONI, P.; CIAMPI, M.: Del restauro. Quattordici case / Gabriella e Massimo Carmassi. Milano, Ed. Electa, 1998

MARCONI, P.: Materia e significato. La questione del restauro architettonico. Roma, Ed. GLF editori Laterza, 1999

MARCONI, P.: "H.2.1. Aprocci Metodologici. Ragioni del restauro di ripristino". En: ZEVI L.: Il manuale del restauro architettonico. Roma, Ed. Mancosu, 2001

MARTIN, J.M.: “Le pietre parlano". Casabella, no 776, Aprile 2009, pp. 62-75

MARTíNEZ LAPEÑA, J. A.: "Tiempos de reconstrucción". Documentos de Arquitectura, no3, Almería, Ed. Delegación de Almería del Colegio Oficial de Arquitectos de Andalucía Oriental, 1988, pp. 7-12

MATTEONI, D.; POLANO, S.; MULAZZANI, M.: Massimo Carmassi: architettura della semplicità. Milano, Ed. Electa, 1992

MIARELLI MARIANI, G.: "Historia de los criterios de intervención en el patrimonio arquitectónico". En Monumentos y proyecto. Jornadas sobre criterios de intervención en el Patrimonio Arquitectónico. Madrid, Ed. Ministerio de Cultura, 1990

MIARELLI MARIANI, G.: "Qualche minuzia sul San Giorgio risanato". En: A.A.V.V.: La chiesa di San Giorgio in Velabro a Roma : storia, documenti, testimonianze del restauro dopo l'attentato del luglio 1993. Roma, Ed. Istituto poligrafico e Zecca dello Stato, 2002, p. 12

MONEO, R.: "La vida de los edificios. Las ampliaciones de la Mezquita de Córdoba". Arquitectura, no 256, 1985, pp. 26-36

MORA ALONSO-MUÑOYERRO, S.: La Restauración Arquitectónica en España. Criterios y Teorías (1840-1936). Madrid, Ed. Kaher II, 2002

MORALES, J.: "La Construcción del Olvido. Memoria, Historia, Proyecto". En: A.A.V.V.: Cuadernos IV. Arquitectura y Patrimonio. Ed. Junta de Andalucía, 1994. pp. 45-63

MOYA BLANCO, L.: "Arquitecturas cupuliformes: el arco, la bóveda y la cúpula". En: CABALLERO ZOREDA, L. (dir.): Curso de mecánica y tecnología de los edificios antiguos. Madrid, Ed. Colegio Oficial de Arquitectos de Madrid, 1987, 102 
MULAZZANI, M.: Recupero conservazione riuso. Un centro culturale nel Mattatoio di Roma. Massimo Carmassi. Milano, Ed. Electa architettura, 2010

MUÑOZ, S.: Teoría contemporánea de la Restauración. Madrid, Ed. Síntesis, 2003

NATIVIDAD VIVÓ, P.; CALVO LÓPEZ, J.: "Levantamiento arquitectónico e hipótesis sobre la estereotomía de la bóveda aristada de las Torres de Quart de Valencia". X Congreso Internacional Expresión Gráfica aplicada a la Edificación, APEGA 2010.

NERDINGER, W.: "Hans Döllgast. Ricostruzione della Alte Pinakothek a Monaco". Casabella, no 636, Agosto-Luglio 1996, pp. 46-55

NICOLIN, P.: “Lewerentz-Klippan: prefazione." Lotus, no93, pp. 6-19

NORBERG-SCHULZ, CHR.: Arquitectura occidental. Barcelona, Ed. G.G., 2001 (1979)

OTERI, A.M.: Rovine. Roma, Ed. Argos, 2009

PANOFSKY, E.: Meaning in the Visual Arts. New York, 1955 (Versión en español: El significado de las artes visuales. Madrid, Ed. Alianza, 1983)

PAVAN V.: Nuova architettura di pietra in Italia. Ed. Faenza, 2004

PEREGO, F.: Anastilosi. L'antico, il restauro, la città. Ed. Laterza, 1987

PIERI, E.: "Dell'architettura: 12 questioni per Franco Purini". Costruire in Laterizio, no 77, pp. 28-30

PIZZA, A.: "Ruinas, Forma, Proyecto". En: A.A.V.V.: Cuadernos IV. Arquitectura y Patrimonio. Ed. Junta de Andalucía, 1994. pp. 29-40

PHILIPPOT, P.: "Historic Preservation: Philosophy, Criteria, Guidelines, I". En Preservation and conservation: Principles and Practices. Proceedings of the North American International Regional Conference, Williamsburg, Virginia and Philadelphia, Pennsylvania, 1972. Washington, D.C., Ed. Preservation Press, 1976

PORTOGHESI, P.: “Editoriale: riuso dell'architettura." Materia, no 49, 2006, pp. 20-23

QUATREMÈRE DE QUINCY, M.: Dictionnaire historique d'architecture. Paris, Ed. Librerie d'Adrien Le Clere et cie, 1832

Disponible en el sitio web del INHA: <http://bibliotheque-numerique. inha.fr/collection/> [Consulta 12-08-2012] 
RAPPOSELLI, M.: "Nuovo e antico. Intervista a Massimo Carmassi". En: CORNOLDI, A.; RAPPOSELLI, M.; Massimo Carmassi: Pisa. Ricostruzione di San Michele in Borgo. Venecia, Ed. IUAV; Padova, Ed. II Poligrafo, 2005, pp. 16

REDECKE, S.: "Il Castello di Berlino". Casabella, no 796, p. 86

REICHERT, M.: The Neues Museum - Berlin. Restoration, Repair and Intervention. Londres, The Soane Gallery, 2008

REPRESA BERMEJO, I.: "La expresión plástica en la degradación". En: REPRESA, I. (dir.): Restauración Arquitectónica II. Valladolid, Ed. Universidad de Valladolid, 1998, p. 145

RIVERA BLANCO, J.: "La Restauración Monumental en España. En el Umbral del Siglo XXI. Nuevas Tendencias: de la Carta de Venecia a la Carta de Cracovia". En: GONZÁLEZ, A. (dir): I Bienal de la Restauración Monumental. Hospitalet de Llobregat (Barcelona), del 23 al 26 de noviembre de 2000. Barcelona, Ed. Diputació de Barcelona, 2002, pp. 29-40

RIVERA BLANCO, J.: "Restauro y anastilosis del mundo antiguo: la reintegración de la forma en la arquitectura histórica". En: RIVERA, J.; DUPRÉ, J.: La fuente arcaica de Tusculum: Ideas para su conservación / Idee per la conservazione. Valladolid-Roma, Universidad de Valladolid, 2003, pp. 89-112

RIVERA BLANCO, J.: De varia restauratione. Teoría e historia de la restauración arquitectónica. Madrid, Abada editores, 2008

RIVERA BLANCO, J.: "Teoría e Historia de la Intervención en Monumentos Españoles hasta el Romanticismo" (1989). En: De varia restauratione. Teoría e historia de la restauración arquitectónica. Madrid, Ed. Abada editores, 2008, pp. 110-115

ROCCA, A.: "Questo non è un modello: il San Carlino di Lugano". Lotus, no 103, pp. 27-39

SAENZ DE OIZA, F.J.: "Superposición y adaptación de nuevas estructuras en edificios antiguos". En: CABALLERO ZOREDA, L. (dir.): Curso de mecánica y tecnología de los edificios antiguos. Madrid, Ed. Colegio Oficial de Arquitectos de Madrid, 1987, p. 133

SÁNCHEZ SIMÓN, I.: "Traza y montea de la bóveda de la Capilla del Real del convento de Santo Domingo de Valencia. La arista del Triángulo de Reuleaux entre las aristas de la bóveda". Actas del séptimo congreso internacional de historia de la construcción, Santiago 26-29 de octubre de 2011

SCHACHEL, R.: Ornamento y Delito y otros escritos. Barcelona, Ed. Gustavo Gili, 1972 
SEGARRA LAGUNES, M.M.: La reintegrazione nel restauro dell'antico: la protezione del patrimonio dal rischio sísmico. Atti del Seminario di studi, Paestum, 11-12 aprile 1997. Roma, Ed. Gangemi, 1997

SETTE, M.P.: "Un nodo del restauro: la reintegrazione fra notorietà, distinguibilità, reversibilità". Opus, n2, Dipartimento di Scienze, Storia dell'Architettura e Restauro, Unviersità G. D’Annunzio Chieti e Pescara, Roma, Ed. Editeam, 1990, pp. 243-254

SETTE, M.P.: Il restauro in architettura: quadro storico. Torino, Ed. Utet, 2001

SIZA, A.; COLLOVÀ, R.: "Atti minimi nel tessuto storico. Salemi, 1991-98". Lotus, no 106, pp. 104-109

de SOLÁ-MORALES, I.: "Teorías de la intervención arquitectónica". Quaderns d'Arquitectura i Urbanisme, no 155, Ed. Col-legi d'Arquitectes de Catalunya, 1982, pp. 30-37

de SOLÁ-MORALES, I.: "Del contraste a la analogía. Transformaciones en la concepción de la intervención arquitectónica". Lotus international, no 46, 1985, pp. 36-45

SOUTO DE MOURA, E.: "Rafael Moneo. Completamento del Banco de España. Madrid". Casabella, no 754, Aprile 2007, p.15

SPADOLINI, P.: "L'intervento sull'antico". En: PEREGO, F.: Anastilosi. L'antico, il restauro, la città. Ed. Laterza, 1987, p. 14

TABUENCA, F.; LEACHE, J.: "La rehabilitación de la casa del condestable en Pamplona”. En: A.A.V.V.: Día de la Arquitectura. XVII Congreso Internacional de Conservación y Restauración de Bienes Culturales. Castellón. Valencia, Ed. UPV, 2008, pp. 67-77

TORRES BALBÁS, L.: “Los Monumentos Históricos y Artísticos: Destrucción y Conservación. Legislación y Organización de sus Servicios y su Inventario". En: A.A.V.V.: Cuadernos de Restauración V. Madrid, Cuadernos del Instituto Juan de Herrera de la Escuela de Arquitectura de Madrid, 1998, pp. 34-46

TROTTA, G.: "Alcuni esempi tipologici di coperture lignee nell'Occidente europeo". En: TAMPONE, G.: Legno e restauro. Firenze, Ed. Messaggerie Toscane, 1989, pp. 39-54

USTÁRROZ, A.: La lección de las ruinas. Barcelona, Ed. Fundación Caja de Arquitectos, 1997

VALADIER, G.: Narrazione artistica dell'operato finora nel Restauro dell'arco di Tito. Roma, 1822 
VARAGNOLI, C.: "Edifici da edifici: la cicezione del passato nell'architettura italiana, 1990-2000". L'industria delle costruzioni, no 368, Ed. ANCE, 2002, pp. 4

VARAGNOLI, C.: "Antichi edifici, nuovi progetti. Realizzazione e posizioni teoriche dagli anni Novanta ad oggi". En: FERLENGA, A.; VASALLO, E.; SCHELLINO, F.: Antico e Nuovo. Architetture e architettura. Padova, Ed. II Poligrafo, 2007, Volumen 2, pp. 849-860

VIOLLET-LE-DUC, E.: Dictionnaire raisonné de l'architecture française du XI au XVI siecle, Paris, B. Bance Editeur, 1854-68

VON RAUCH, F.; CHIPPERFIELD, D.: Neues Museum. Ed. Hatje Cantz, 2009

ZARAGOZÁ CATALÁN, A.: Arquitectura gótica valenciana. Valencia, Ed. Generalitat Valenciana, 2000.

ZEVI, L.: Il manuale del restauro architettonico. Roma, Ed. Mancosu, 2001 


\section{PUBLICACIONES PERIÓDICAS CONSULTADAS PARA LA SELECCIÓN DE OBRAS A ANALIZAR}

ARQUITECTURA. Madrid, Ed. COAM

[Revista del Colegio de Arquitectos de Madrid.]

CASABELLA. Milano, Ed. Electa

[Publicación que se inicia en 1928 y, tras algunas interrupciones y cambios de dirección editorial y título, continúa hasta la actualidad.]

COSTRUIRE IN LATERIZIO. Associazione Nazionale degli Industriali dei Laterizi (A.N.D.I.L.) Disponible en: <http://www.laterizio.it/index. php?option=com_content $\&$ view=article\&id=222\&ltemid=91>

[Publicación fundada en 1959]

DOMUS. Milano, Ed. Domus

E-RPH-REVISTA ELECTRÓNICA DE PATRIMONIO HISTÓRICO. Departamento de Historia del Arte, Universidad de Granada.

Disponible en: <http://www.revistadepatrimonio.es/>

EL CROQUIS Madrid, Ed. El Croquis

LOGGIA Departamento de Composición Arquitectónica, Universidad Politécnica de Valencia, Valencia, Ed. UPV

LOTUS. Milano, Ed. Electa

[La revista se funda en 1963 y, tras algunas interrupciones y cambios de dirección editorial y título, continúa hasta la actualidad.]

PALLADIO. Centro Internazionale di Studi di Architettura Andrea Palladio. Disponible en: <http://www.cisapalladio.org/cisa/annali.php?sezione=3>

QUADERNS D'ARQUITECTURA I URBANISME. Colegi Oficial d'Arquitects de Catalunya, Barcelona, Ed. Colegi Oficial d'Arquitects de Catalunya.

R\&R-RESTAURACIÓN \& REHABILITACIÓN. Revista Internacional del Patrimonio Histórico. Instituto Universitario de Restauración del Patrimonio, Universidad Politécnica de Valencia, Valencia, Ed. UPV 


\section{BIBLIOGRAFÍA ESPECÍFICA SOBRE LAS OBRAS ANALIZADAS}

\subsection{Oratorio di San Filippo Neri}

CERVELLATI, P.L. y SCANNAVINI, R.: Bolonia. Política y metodología de la restauración de los centros históricos. Barcelona, Ed. Gustavo Gili, 1976, (1973)

CERVELLATI, P.L.: "El proyecto de la conservación". En: CIARDINI, F. y FALINI, P. (Ed): Los centros históricos. Política urbanística y programas de actuación. Barcelona, Ed. Gustavo Gili, 1983 (1978), pp. 103-113

CERVELLATI, P.L.: L'ex oratorio di San Filippo Neri restituito alla città. Bologna, Ed. Costa. 1999

CERVELLATI, P.L.: "Splendore rinnovato. Un auditórium nell'ex Oratorio". MateriaLegno, n2, Milan, Ed. promo_legno, marzo 2010, pp.

CORNOLDI, A.: "Restauri non Conservativi. La Ricerca delle Regole". En: FERLENGA, A.; VASALLO, E.; SCHELLINO, F.: Antico e Nuovo. Architetture e architettura. Volumen 1, Ed. II Poligrafo, 2007, pp. 261-284

Fondazione del Monte. Oratorio: Storia [En línea]

Disponible en: <http://www.fondazionedelmonte.it> [Consulta: 10-042012]

Italia, “Legge 1 giugno 1939 n. 1089. Tutela delle cose d'interesse artistico e storico" [Ley 1089/1939, de 1 de junio, de tutela de los bienes de interés artístico e histórico].

Disponible en: < http://www.edizionieuropee.it/data/html/1/ zn14_04_006.html\#_ftn1> [Consulta: 12-05-2012]

Italia. Direzione Regionale per i Beni Culturali e Paesaggistici dell'EmiliaRomagna: "Torreggiani Alfonso: Interno dell'oratorio di san Filippo Neri" [En línea]

Disponible en: <http://www.emiliaromagna.beniculturali.it> [Consulta: 10-04-2012]

GAJA DÍAZ, F.: Teorías para la intervención urbanística en la ciudad preindustrial. Valencia, Ed. UPV, 2006 (1992)

GIANNELLI, L.: "Oratorio di san Filippo Neri”. Direzione Regionale per i Beni Culturali e Paesaggistici dell'Emilia-Romagna (Italia) [En línea]

Disponible en: <http://www.emiliaromagna.beniculturali.it> [Consulta: 10-04-2012] 
PAGLIA, A.: "Il restauro dell'Oratorio di San Filippo Neri". La città del secondo rinascimento, $\mathrm{n}$ ㅇ 38, Bologna, Ed. Associazione Culturale Progetto Emilia Romagna, marzo 2010, pp. 25

POLI, M.; URBINI, S.: L'Oratorio di San Filippo Neri a Bologna. Bologna, Ed. Studio Costa, 2000

SERAFINI, L.: "Auditorium nell'ex oratorio di San Filippo Neri a Bologna". L'industria delle costruzioni, no 368, Roma, Ed. Ance, noviembre-diciembre 2002, pp. 40-47

SIMONELLI, R.: "Oratorio di San Filippo Neri, Bologna: auditorium e sala espositiva". En: BORIANI, M.: Progettare per il costruito. Dibattito teorico e progetti in Italia nella seconda metà del XX secolo. Milano, Ed. CittàStudi Edizioni, 2008, pp. 305-312

VARAGNOLI, C.: "Antichi edifici, nuovi progetti. Realizzazione e posizioni teoriche dagli anni Novanta ad oggi". En FERLENGA, A.; VASALLO, E.; SCHELLINO, F.: Antico e Nuovo. Architetture e architettura. Volumen 2, Ed. II Poligrafo, 2007, p. 849

Verdiana Network: "Idee per Firenze y Bologna: Intervista a Pier Luigi Cervellati” [En línea]

Disponible en: <http://www.verdiananetwork.com/idee-per-firenze-ebologna-intervista-a-pier-luigi-cervellati.html> [Consulta: 08-04-2012]

\subsection{Capilla de los Condes de Fuensaldaña}

ANDRÉS ORDAX, S.: "La iglesia del monasterio: proceso constructivo y análisis artístico". En: RIVERA, J. (dir): Monasterio de San Benito el Real de Valladolid: IV centenario, 1390-1990. Valladolid: Ayuntamiento de Valladolid, 1990, pp. 152

ARNUNCIO, J.C.; SIERRA, V.: “Rehabilitación de la 'Casa de los Zúñiga' para sede del Departamento de Publicaciones y del Instituto de Ciencias de la Educación (ICE) de la Universidad de Valladolid". BAU, nㅇ 8-9, Valladolid, 1993, pp. 52-59

ARNUNCIO, J.C.; AIZPÚN, C.; BLANCO, J.: "Patio Herreriano. Museo de Arte Contemporáneo Español de Valladolid”. On Diseño, no 235, 2002, pp. 242251

ARNUNCIO, J.C.: Peso y Levedad. Notas sobre la gravedad a partir del Danteum. Barcelona, Ed. Fundación caja de arquitectos, 2007 
ARNUNCIO PASTOR, J.C.: "Las Miradas al Pasado". En: A.A.V.V.: Día de la Arquitectura. XVII Congreso Internacional de Conservación y Restauración de Bienes Culturales. Castellón, 20 de noviembre de 2008, Editorial UPV, 2008, pp. 43-49

ARNUNCIO PASTOR, J.C.: "Materia y Forma". Conferencia impartida en Materia y Forma IV. Jornadas Internacionales de Arquitectura, en la Universidad Politécnica de Valencia, 2-4 de marzo de 2009

Disponible en el sitio web de Cátedra Blanca: <http://www.upv.es/ catedrablanca/myf4/INICIO.htm> [Consulta: 15-05-2012]

ARNUNCIO PASTOR, J.C.: "Museo de Arte Contemporáneo Español. Patio Herreriano. Valladolid". En: MAS, V. et al.: Materia y Forma IV. Jornadas Internacionales de Arquitectura. Valencia, Ed. UPV, 2009, pp. 60-67

ARNUNCIO, J.C.: Patio Herreriano. Una Interpretación de la Arquitectura Histórica. Valladolid, Ed. Museo Patio Herreriano, 2012

LAHUERTA, J.J.; GONZÁLEZ GARCÍA, A.: Juan Navarro Baldeweg. Obras y Proyectos. Ed. Electa, 1990

RODRÍGUEZ MARTÍNEZ, L.: Historia del Monasterio de San Benito El Real de Valladolid. Valladolid, Ed. Caja de Ahorros Popular de Valladolid, Ateneo de Valladolid, 1981

\subsection{Iglesia de las Escuelas Pías del Colegio de San Fernando}

GARCÍA DEL MONTE, J.M.: "Centro Cultural en Lavapiés: de las virtudes de lo antiguo". Arquitectura, no 338, Madrid, Ed. COAM, 2004, pp. 38-47

GÓMEZ, M.: "Escuelas Pías de San Fernando". Arte en Madrid. [En línea], 8 de julio de 2012. Disponible en: <http://artedemadrid.wordpress. com/2012/07/08/escuelas-pias-de-san-fernando/> [Consulta: 9-07-2012]

LINAZASORO, J.I.: Permanencias y arquitectura urbana: las ciudades vascas de la época romana a la Ilustración. Barcelona, Ed. G. Gili, 1978

LINAZASORO, J. I.: El Proyecto Clásico en Arquitectura (1980)

LINAZASORO, J. I.: Escritos 1976-89 (1989)

LINAZASORO, J.I.: Escrito en el tiempo. Pensar la arquitectura. Buenos Aires, Ed. NobuKo-Universidad de Palermo, 2003 
LINAZASORO, J.I.: "Biblioteca y Aulario en las antiguas Escuelas Pias, Madrid". Conarquitectura, no 12, 2004, pp. 53-64

LINAZASORO, J.I.: Evocando la ruina. Sombras y texturas. Centro cultural en Lavapiés. Madrid. Madrid, 2005

LINAZASORO, J.I.: "Biblioteca y Aulario en las antiguas Escuelas Pías". Arquitectura, no 357, Madrid, Ed. COAM, 2009, pp. 8-11

LINAZASORO, J.I.: Otras Vías: Pikionis, Lewerentz, Van der Laan. Buenos Aires, Ed. NobuKo, 2010

LINAZASORO, J.I.: "Tres proyectos sobre las preexistencias". Conferencia impartida en el marco del Workshop Internacional Construcción de la Memoria, en la Escuela Técnica Superior de Arquitectura de la Universidad Politécnica de Valencia, 12 de mayo de 2011

LINAZASORO, J.I.; BOSCH ROIG, L.: Entrevista realizada a José Ignacio Linazasoro. Madrid, Diciembre de 2012 [Inédita]

MACHADO, A.: Juan de Mairena. Buenos Aires, Losada, 1957

PRESI, S.: José Ignacio Linazasoro. Progettare e Costruire. Latina, Ed. Casa dell'Architettura, 2007

PRESI, S. (dir): J.I. Linazasoro. Ed. Casa dell'Architettura, 2012

SANZ NEIRA, E.: "Lo didáctico y lo operativo". Arquitectura, no 357, Madrid, Ed. COAM, 2009, pp. 12-15

de SOLÁ-MORALES, I.: "Imitación Esencial. La Arquitectura de José Ignacio Linazasoro" (1998). En: Linazasoro, J.I.: Evocando la ruina. Sombras y texturas. Centro cultural en Lavapiés. Madrid, 2005, pp. 8-13

TOVAR MARTÍN, V.: "Nuevas consideraciones sobre el edificio singular del colegio madrileño de San Fernando". Anales de Historia del Arte, n.ㅇ 4, Madrid, Ed. Complutense, 1993, p. 288. Disponible en el sitio web de la Universidad Complutense de Madrid:

<http://revistas.ucm.es/index.php/ANHA/article/view/ ANHA9394110285A/31790> [consulta 11-04-2012]

UGOLINI, A. (dir): Ricomporre la Rovina. Firenze, Alinea Editrice, 2010

YOURCENAR, M.: El Tiempo, Gran Escultor. Madrid, Alfaguara, 1999 (Ed. Original 1983) 


\subsection{Iglesia de San Pedro}

ARMILLOTTA, F.: "Restauri 'leggeri'. L'uso del legno per la lettura dello spazio e della storia". Legnoarchitettura, no 8, Monfalcone, EdicomEdizioni, julio 2012, pp. 89-95

CORNOLDI, A.; RAPPOSELLI, M.: "Nuovo e antico. Intervista a Emanuele Fidone, Vicenzo Latina e Bruno Messina". En: Emanuele Fidone, Vincenzo Latina, Bruno Messina. 'Restauri' Iblei. Padova, Ed. II Poligrafo, 2007, p. 17

FIDONE, E.: From the Italian Vernacular villa to Schinkel to the modern house (Learning from), Cannitello (Reggio Calabria), Ed. Biblioteca del Cenide, 2002

FIDONE, E.; MESSINA, B.: "Sistemazione del Convento di S. Maria del Gesù a Modica, Ragusa”. L'industria delle costruzioni, no 368, noviembrediciembre 2002, pp. 16-23

FIDONE, E.; MESSINA, B.: "Restauro del convento di Santa Maria del Gesù". En: CORNOLDI, A.; RAPPOSELLI, M.: Emanuele Fidone, Vincenzo Latina, Bruno Messina. 'Restauri' Iblei. Padova, Ed.Il Poligrafo, 2007, pp. 88-115

FIDONE, E.: "Polo servizi turistici nell'ex mercato coperto di Ortigia, Siracusa". En: CORNOLDI, A.; RAPPOSELLI, M.: Emanuele Fidone, Vincenzo Latina, Bruno Messina. 'Restauri' Iblei. Padova, Ed. II Poligrafo, 2007, pp. 58-87

FIDONE, E.: "Diario". D’Architettura, n이, abril 2008, p. 140

Disponible en: $\leq$ http://www.archinfo.it/whitepaper_library/Emanuele\%20 Fidone> [consulta 25-7-2012]

FIDONE, E.; MESSINA, B.: "Centro civico, Modica. Ex mercato coperto di Ortigia, Siracusa”. Domus, no 929, octubre 2009, pp. 112-119

FIDONE, E.: "Framenti. II progetto e la potenza rinnovatrice delle rovine". En: UGOLINI, A.: Ricomporre la Rovina. Firenze: Alinea Editrice, 2010, pp. 26-31

FIDONE, E.: "Recuperación de la basílica paleocristiana de san Pietro". $R \& R, \mathrm{n}$ 116-117 [en prensa]

MULANZZANI, M.: "Basilica Paleocristiana di San Pietro, Siracusa. Spazio, materia e luce". Casabella, no780, Agosto 2009, p. 49

UGOLINI, A.: "Progetto, storia, restauro. Riflessioni in forma di conversazione intervista a José Ignacio Linazasoro, Emanuele Fidone e Bruno Messina". En: UGOLINI, A. (dir): Ricomporre la Rovina. Firenze, Alinea Editrice, 2010, p. 56 


\section{FUENTES DE IMÁGENES}

En el pie de foto de cada una de las imágenes incluidas en la presente investigación está indicada su autoría o su fuente de procedencia.

En este apartado se indican las fuentes consultadas exclusivamente para la obtención de imágenes, que no hayan sido incluidas en los apartados anteriores

\subsection{Criterios de intervención}

A.A.V.V.: Teoría e Historia de la Restauración. Madrid, Ed. Munilla-Lería, 1997

ArqHys: "Historia y arquitectura del Puente de Mostar en Croacia". [En línea] Disponible en: <http://www.arqhys.com/fotos-del-puente-de-mostarcroacia.html> [Consulta: 02-05-2012]

ALMAGRO, A.: "Restauración del Alcázar Omeya de Amman". Loggia, no 11, Ed. UPV, 2001, p.44

Arquitectura, no 244-245, 1983, Madrid, Ed. COAM

Arquitectura, nำ280, 1989, Madrid, Ed. COAM

Arquitectura Viva, no 116, 2007, Madrid, Ed. Avisa

Associazione culturale Monumento-Documento: "San Nicolò Regale." [En línea]

Disponible en: <http://www.unipa.it/monumentodocumento/ villadelcasale/> [Consulta: 25-04-2012]

BAAS Arquitectura: "Museo Can Framis." [En línea]

Disponible en: <http://www.baas.cat/es/equipamientos/museo-canframis> [Consulta: 25-04-2012]

BARDESCHI: "Nuova scala di accesso dalla Piazza Mercanti al piano primo del Palazzo della Ragione". Europaconcorsi. [En línea]

Disponible en: <http://europaconcorsi.com/projects> [Consulta: 02-052012]

BASULTO: "Plataforma en viaje. Sao Paulo-Parte 2". Plataforma arquitectura. [En línea]

Disponible en: <http://www.plataformaarquitectura.cl/2007/02/14/ plataforma-en-viaje-sao-paulo-parte-2/> [Consulta: 02-05-2012] 
BBC: “In Pictures. Dresden's Frauenkirche." [En línea]

Disponible en: <http://news.bbc.co.uk/2/shared/spl/hi/pop_ups/05/ europe_dresden0s_frauenkirche/html/2.stm> [Consulta: 10-04-2012]

di BELLO: Domus, no 820, 1999

BESOMI: "Reconstrucción del Pont Trencat, Barcelona. Plataforma arquitectura, Mayo 2007. [En línea]

Disponible en: <http://www.plataformaarquitectura.cl/2007/05/06/ reconstruccion-del-pont-trencat-barcelona/> [Consulta: 02-05-2012]

Biblioteca Digital Dioscórides. Universidad Complutense de Madrid: Vedute di Roma disegnate ed incise da Giambattista Piranesi Architetto Ve[nez]iano. [En línea]

Disponible en: <http://dioscorides.ucm.es/proyecto_digitalizacion/index. php?b19511164> [Consulta: 04-04-2012]

BLUNT, A.: Borromini. Madrid, Ed: Alianza, 1982

BOTTA, M. et al.: Borromini sul lago. Milano, Ed. Skira, 1999

BRANDOLINI: Lotus, no 103, 1999, p. 46

CANALLI, G.: "Reupero dell'ospedale di Santa Maria della Scala a Siena." Construire in laterizio, no 100, 2004, pp. 122-123

CARRILHO DA GRAÇA, J. L.: Work. Praça nova. Castelo de Sao Jorge. [En línea] Disponible en: <http://jlcg.pt/work_events> [Consulta: 15-04-2012]

Casabella, no 778, 2009, p. 25

Casabella, no 803,2011, p. 18

Caspar David Friedrich: "Hutten's Tomb." [En línea]

Disponible en: <http://www.caspardavidfriedrich.org/Hutten's-Tomb. html> [Consulta: 10-04-2012]

C.O.A.M.: Proyectos de intervención en edificios y recintos históricos. Madrid, Ed. C.O.A.M., 1987

Commons wikimedia. "Cúpula Basílica Santa María de Elche." [En línea] Disponible en: <http://commons.wikimedia.org/w/index.php?search=C\% C3\%BApula+Bas\%C3\%ADlica+Santa+Mar\%C3\%ADa+de+Elche\&button=\&t itle=Special\%3ASearch $>$ [Consulta: 15-04-2012] 
Commons wikimedia. "Quirinale Dioscuri." [En línea]

Disponible en: <http://commons.wikimedia.org/w/index.php?search=qui rinale+dioscuri\&title=Special\%3ASearch $>$ [Consulta: 15-04-2012]

CECCHINI: "Restauración de la abadía y claustro de San Zeno en Verona". Loggia, no 10, Ed. UPV, 2000, p. 25

Census Database: Speculum Romanae Magnificentiae. [En línea]

Disponible en: <http://census.bbaw.de/jumpto/CS_ DocumentSearch/248483 ?eadb_frame=top\&select_id=248483> [Consulta: 10-04-2012]

Census Database: De'Cavalieri/Dosio 1569. [En línea]

Disponible en: <http://census.bbaw.de/jumpto/CS_ DocumentSearch/44161 ?eadb_frame=top\&select_id=44161> [Consulta: 10-04-2012]

CESCHI, F.: Museo Nazionale Romano. Crypta Balbi. [En línea]

Disponible en: <http://www.francoceschi.it/progettirealizzazioni.htm> [Consulta: 04-04-2012]

CHING, F.D.K.: Diccionario visual de la arquitectura. Barcelona, Ed. Gustavo Gili, 1995

CHIPPERFIELD, D. et al.: "Tertium Quid". AR, n 6, Ed. Prospettive Edizioni, 2005 (luglio-agosto). [En línea]

Disponible en: <http://www.prospettivedizioni.it/ar/page/4/> [Consulta: 15-04-2012]

CHIPPERFIELD, D.: “Neues Museum". R\&R, nํ 108, Valencia, Ed. UPV, 2008, pp. 20-45

CHRIST \& GANTENBEIN: Swiss National Museum, Zurich, 2002-2009 [En línea] Disponible en: <http://www.christgantenbein.com/index.php/main/ projects> [Consulta: 09-04-2012]

Delegación navarra del Colegio Oficial de Arquitectos Vasco-Navarros: “Convocatoria premios COAVN 2010". [En línea]

Disponible en: <http://www.coavna.com/concursos-coavn-mostrar. asp?idioma=1\&id=9> [Consulta: 02-05-2012]

DEZZIBARDESCHI, M.: "Protagonistidella nuova museografia: Franco Minissi a Piazza Armerina". L' ingegnere edilizia ambiente territorio, № 11, 2007 
DEZZI BARDESCHI, M.: Pozzuoli (Napoli). Tempio Duomo. [En línea]

Disponible en: <http://www.marcodezzibardeschi.com/_Progetti/Incorso. html> [Consulta: 15-04-2012]

Domus, no 748,1993, p. 5

E-peristilo. "Transparente de la Catedral de Toledo." [En línea]

Disponible en: <http://peristilo.wordpress.com/2009/07/05/arquitecturaespana-3/> [Consulta: 08-04-2012]

E + N: Projekter. Nyt \& gammelt. Koldinghus. [En línea]

Disponible en: <http://www.eplusn.dk/Dansk/Projekter/Nyt\%20-\%20 gammelt.aspx> [Consulta: 08-04-2012]

Erik Gunnar Asplund: "Extension to Gothenburg Townhall 1913-1937". Gallery 8. [En línea]

Disponible en: <http://www.erikgunnarasplund.com/eng/gallery8tillbyggnadengoteborgsradhus.asp $>$ [Consulta: 04-04-2012]

Foster + Partners: Projects. Reichstag. New German Parliament. [En línea] Disponible en: <http://www.fosterandpartners.com/projects/reichstagnew-german-parliament/> [Consulta: 25-04-2012]

Fotografía de Christopher Gardner. En:Metalocus, diciembre 2012. [En línea] Disponible en: <http://www.metalocus.es/content/es/blog/finalizadala-ampliaci\%C3\%B3n-de-la-yale-university-art-gallery> [Consulta: 13-012013]

Fotografía de Mauro Davoli. En: FRANCO, J.T.: "Renovación y reconstrucción del castillo de Novara". Plataforma arquitectura, Enero 2013. [En línea] Disponible en: <http://www.nietosobejano.com/> [Consulta: 27-01-2013]

GONZÁLEZ, A.: "La restauración de la iglesia de Sant Jaume Sesoliveres. Igualdada, Barcelona, España". Informes de la Construcción, vol. 48, no 445, 1996, pp. 23-32

GONZÁLEZ MORENO-NAVARRO, A.; DÍEZ, M.: I Bienal de la Restauració Monumental: L'Hospitalet de Llobregat, del 23 al 26 de noviembre del 2000. Barcelona, Ed. Diputació de Barcelona, 2002

Iglesia de San Juan del Hospital. Museo: Historia del Conjunto Histórico de San Juan del Hospital. [En línea]

Disponible en: <http://www.sanjuandelhospital.es/museo/index. php?id=20> [Consulta: 10-04-2012] 
Instituto de Conservación y Restauración de Bienes Culturales (I.C.R.B.C.): Monumentos y proyecto: Jornadas sobre criterios de intervención en el patrimonio arquitectónico. Madrid, Ed. Dirección General de Bellas Artes, 1990

Laboratorio città e territorio: "La Cattedrale di Noto. Crollo e fondazioni." [En línea]

Disponible en: <http://www.lct-architettura.it/progetti_cattedrale_noto_ crollo.htm> [Consulta: 09-04-2012]

Laboratorio città e territorio: "La Cattedrale di Noto. Interni ed esterni." [En línea]

Disponible en: <http://www.lct-architettura.it/progetti_cattedrale_noto_ interni_esterni.htm> [Consulta: 09-04-2012]

Lainformacion.com: "La Roma fantástica de Piranesi. Grande pianta del Campo Marzio". [En línea]

Disponible en: <http://especiales.lainformacion.com/panoramicas/ piranesi/> [Consulta: 04-04-2012]

LASAGABÁSTER. En: IV Simposi sobre restauració monumental: BarcelonaCardona, del 17 al 20 de novembre de 1993. Barcelona, Ed. Diputació de Barcelona, 1996, p.63

Manchester School of Architecture: "Andrea Palladio 500 anni: La grande mostra." Continuity in architecture. 14 octubre 2009. [En línea]

Disponible en: <http://www.msa.mmu.ac.uk/continuity/index.php/ category/andrea-palladio/> [Consulta: 15-04-2012]

MARCONI, P.: "Vicenza, Basílica Palladiana." [En línea]

Disponible en: <http://www.paolomarconiarchitetto.it/template. jsp?pagina=galleria\&catld=7> [Consulta: 13-04-2012]

MARTÍNEZ: "El transparente de la Catedral de Toledo". Manuelblas. 8 enero2013. [En línea]

Disponible en: <http://manuelblasmartinezmapes.blogspot.com. es/2008/01/monumentos-el-transparente-de-la.html> [Consulta: 10-042012]

de la MATA SACRISTÁN, J.L.: "La catedral de Siracusa." Mis viajes por la historia. 18 junio 2009. [En línea]

Disponible en: <http://misviajesconhistoria.blogspot.com.es/2009/06/lacatedral-de-siracusa.html> [Consulta: 08-04-2012]

Mendaro Arquitectos: "Archivo Toledo". [En línea] Disponible en: <http://www.mendarocorsini.es/> [Consulta: 04-05-2012] 
MONEO, R.; RAMALLO, S.: Teatro romano de Cartagena. Murcia, Ed. Fundación CajaMurcia, 2009

MORA, S. Basa, no 13, 1990, p. 12

MORA ALONSO-MUÑOYERRO, S. En: III Simposi sobre restauració monumental : Barcelona, del 19 al 21 de novembre de 1992. Barcelona, Ed. Diputació de Barcelona, 1993

Museo de Bellas Artes de Valencia: La Seo de la ciudad: catálogo de planos, trazas y dibujos del archivo de la catedral de Valencia. Valencia, Ed. Generalitat Valenciana, 1997

Museo Nacional del Prado: "Portada del Nacimiento de la Catedral de Sevilla". Galería online. [En línea]

Disponible en: <http://www.museodelprado.es/coleccion/galeria-online/> [Consulta: 08-04-2012]

NIETO; SOBEJANO: "Museo y castillo de la Luz". [En línea]

Disponible en: <http://www.nietosobejano.com/> [Consulta: 04-05-2012]

NOGUERA GIMÉNEZ, J.F.: Composición II. Teorías de intervención.

Selección de textos. Valencia, Ed. Servicio de Publicaciones UPV, 1989

NORBERG-SCHULZ, C.: Arquitectura occidental. Barcelona, Ed. Gustavo Gili, 1999

Recupero e conservazione, $\mathrm{n}=80,2008$, p. 45

Ocio y cultura: "Catedral de Burgos". [En línea]

Disponible en: <http://deocioycultura.blogspot.com.es/2010/09/catedralde-burgos.html> [Consulta: 09-04-2012]

OTERI, A. M.: Visioni, teorie, restauri del rudere in architettura. Roma, Ed. Argos, 2009

PAVAN, V.: New stone architecture in Italy, Ed: Basel: Birkhäuser, 2004

Pendís Bagà: "Restauració y reutilizació de l’antic monestir de Sant Llorenç prop Bagà”. [En línea]

Disponible en: <http://www.pendisbaga.com/index.php/es/projectes/ obra-privada/obra-nova/item/74-reutilitzacio-antic-monestir-de-santIlorenc-prop-baga> [Consulta: 04-04-2012]

PEVSNER, N.: Ruskin and Viollet le Duc. Londres, Ed. Thames \& Hudson, 1969

PORTOGHESI, A.: Francesco Borromini. Milano, Ed: Electa, 1990 
PURINI: Casabella, no 690, Milano, Ed. Electa, 2000, p. 12

$R \& R, \mathrm{n}=76,2003, \mathrm{p} .39$

$R \& R, \mathrm{n}=108,2008$, p. 40

$R \& R, \mathrm{n}=111,2009$, p. 35

REPISHTI. Lotus, 2010, no 144, p. 128

Repro Arte: “Joseph Michael Gandy. Sir John Soane's Museum." [En línea] Disponible en: <http://www.reproarte.com/cuadro/Joseph+Michael_ Gandy/Sir+John+Soane\%C2\%B4s+Museum/13001.html> [Consulta: 0904-2012]

RODRÍGUEZ, V. et al: Informe que hizo el arquitecto de S.M. D. Ventura Rodríguez, en el año de 1768, de la Santa Iglesia de Valladolid: planos de las intervenciones de Ventura Rodríguez en la S.I. Catedral y en el Palacio de Santa Cruz de Valladolid. Valladolid, Ed. Colegio Oficial de Arquitectos de Valladolid, 1987

TAMBURRINO, R.: La Cattedrale adornata. Ed. Dipartimento della Protezione Civile, 2011, p. 28

Disponible en: <http://www.protezionecivile.gov.it/jcms/it/view_pub.

wp?contentld=PUB32872> [Consulta: 13-04-2012]

TORRECILLAS: "Intervención en la Muralla Nazarí". $R \& R$, no 101, Valencia, Ed. UPV, 2006, p. 37

Universitätsbibliothek Heidelberg: Le Antichità Romane. [En línea] Disponible en: <http://digi.ub.uni-heidelberg.de/diglit/piranesi1784ga> [Consulta: 09-04-2012]

VAES: Lotus internacional, no 65, Milano, Ed. Electa, 1990, pp

VARAGNOLI: L'industria delle construzioni, $\mathrm{n}=368,2002$, p.13

VENEZIA, F; SIZA, A: Francesco Venezia. Barcelona, Ed. Gustavo Gili, 19881992.

WÖHLER, T.: Ningbo Museum by Pritzker Prize Winner Wang Shu. The architectural review, marzo 2010. [En línea]

Disponible en: <http://www.architectural-review.com/ningbo-museumby-pritzker-prize-winner-wang-shu/5218020.article> [Consulta: 13-012013]

WREDE, S.: The architercture of Erik Gunnar Asplund. Cambridge, Ed. M.I.T. Press, 1983 


\subsection{La recomposición actual en espacios abovedados}

ADELL, J. M.: "Gaudí y las bóvedas de las Escuelas de la Sagrada Familia." Informes de la Construcción, Vol. 56, no 496, marzo-abril 2005, p. 32.

ÁLVAREZ;ROIG:AntonioBonety Castellana. Barcelona, Ed.Santa\&Cole,1999

Archidialog.com: "Zaha Hadid and Le Corbusier playing musical chairs". [En línea]

Disponible en: <http://archidialog.com/tag/ronchamp-chapel/> [Consulta: 23-04-2013]

Arquitectura, no 341, p. 105

Arquitectura, no 254 , p. 66

BOESIGER:LeCorbusier.Oeuvrecomplète1938-46. Basel,Ed.Birkhäuser,1999

BOESIGER, W.; STONOROV, O.: Le Corbusier et Pierre Jeanneret. Oeuvre complète 1910-29. Basel, Ed. Birkhäuser, 1999

Bright creatives: "Ezra Stoller, a pioneer in the field of architectural photography." [En línea]

Disponible en: <http://www.brightcreatives.nl/2012/04/ezra-stollerpioneer-field-architectural-photography/> [Consulta: 15-05-2012]

BRITTON, K.: Auguste Perret. Londres, Ed. Phaidon, 2001, p. 84

BROOKS, B.: Frank Lloyd Wright: 1885-1916: The complete works. Köln, Ed. Taschen, 2011

CHIORINO, C.; OLMO, C.: Pier Luigi Nervi: Architecture as a chalenge. Milano, Ed. Silvana, 2010

CAPITEL, A.: Las formas ilusorias de la arquitectura moderna. Madrid, Tanais Ediciones, 2005

Caspardavidfriedrich.org: Hutten's Tomb. [En línea]

Disponible en: <http://www.caspardavidfriedrich.org/Hutten's-Tomb. html> [Consulta: 07-05-2012]

Colegio Oficial de Ingenieros de Caminos, Canales y Puertos: La modernidad en la obra de Eduardo Torroja: Catálogo de la exposición celebrada en el Colegio de Ingenieros de Caminos, Canales y Puertos. Madrid. Junio de 1979. Madrid, Ed. Colegio Oficial de Ingenieros de Caminos, Canales y Puertos, 1979. 
Commons Wikimedia: "Skandiateatern, Asplund, 1922". [En línea]

Disponible en: <http://commons.wikimedia.org> [Consulta: 07-07-2012]

DUQUE, K: "Clásicos de Arquitectura: Restaurante Los Manantiales, Félix Candela." En: Plataforma arquitectura. [En línea]

Disponible en: <http://www.plataformaarquitectura.cl/2011/07/05/ clasicos-de-arquitectura-restaurante-los-manantiales-felix-candela/> [Consulta: 11-05-2012]

El Croquis, no 64, enero 1997, p. 223

El Croquis, no 64, enero 1997, p. 241

Erik Gunnar Asplund: "Extension to Gothenburg Townhall 1913-1937". Gallery 8. [En línea]

Disponible en: <http://www.erikgunnarasplund.com/eng/gallery8tillbyggnadengoteborgsradhus.asp $>$ [Consulta: 04-04-2012]

Europaconcorsi: "Baños árabes de Baza." [En línea]

Disponible en: <http://europaconcorsi.com/projects/162638-Ba-osrabes-de-Baza> [Consulta: 06-07-2012]

Fondation Le Corbusier: "Projets. Porte Molitor." [En línea]

Disponible en: <http://www.fondationlecorbusier.fr/corbuweb/ morpheus.aspx ?sysld=71\&sysLanguage $=$ fr-fr\&itemPos=1\&sysParent $l d=7$ 1\&clearQuery=1> [Consulta: 11-05-2012]

Fondation Le Corbusier: "Ma maison, sans lieu, 1929"

Disponible en: <http://www.fondationlecorbusier.fr/corbuweb/ morpheus. aspx ? sysld=13\&IrisObjectld $=5921$ \& sys Language $=\mathrm{fr}$ fr\&itemPos=9\&itemSort=fr-fr_sort_string1\%20\&itemCount=39\&sysParen tName=Home\&sysParentld=65 > [Consulta: 10-12-2012]

Flickr: "Iglesia de San Sergio y San Baco". [En línea]

Disponible en: <http://www.flickr.com/photos/sitomon/5586317366/> [Consulta: 11-05-2012]

GIAVARINI, SAMUELLI, VODRET: Construire in Laterizio, no 78, p. 77

GONZÁLEZ GARCÍA, A.; LA HUERTA, J. J.: Juan Navarro Baldeweg. Obras y proyectos. Madrid, Ed. Electa, 1993.

GORDON, K.: "Convent de San Francesc, David Closes". Plataforma arquitectura. 26 julio 2012. [En línea]

Disponible en: <http://www.plataformaarquitectura.cl/2012/07/26/ convent-de-sant-francesc-david-closes/> [Consulta: 30-07-2012] 
HEISER, J.: “Oscar Niemeyer: 1907-2012". Frieze. Diciembre 2012. [En línea] Disponible en: <http://blog.frieze.com/oscar-niemeyer-19072012/> [Consulta: 10-12-2012]

Italia: "Villa Adriana, la dimora dell'Imperatore". [En línea] Disponible en: <http://www.italia.it/it/idee-di-viaggio/siti-unesco/villaadriana-la-dimora-dellimperatore.html> [Consulta: 28-07-2012]

JODIDIO, P.: Alvaro Siza. Colonia, Ed. Taschen, 2003

KAHLER, N.: "Louis Kahn, National Assembly Building, Dhaka." El laberinto. 17 septiembre 2010 [En línea]

Disponible en: <http://nickkahler.tumblr.com/post/1136849158> [Consulta: 28-07-2012]

LÓPEZ, I.: "Santa Maria del Fiore II. Cúpula." Con imaginación es posible. 17 febrero 2011. [En línea]

Disponible en: <http://conimaginacionesposible.blogspot.com.es> [Consulta: 17-05-2012]

MAURE, L.: Secundino Zuazo y Eduardo Torroja. Frontón de Recoletos. Madrid, 1935. Madrid, Ed. Rueda, 2004.

Ministerio de Fomento: Luis Moya Blanco: Arquitecto, 1904-1990. Madrid, Ed. Ministerio de Fomento, 2000

Ministerio de Fomento: Antonio Fernández Alba: Premio nacional de arquitectura 2003. Madrid, Ed. Ministerio de Fomento, 2011

MORALES SARO, M. C.: La arquitectura de Miguel Fisac. Ciudad Real, Ed. Colegio de Arquitectos, 1979

NERDINGER: Bruno Taut: 1880-1938. Milano, Ed. Electa, 2001

RégiondePaysdelaLoire,ServiceduPatrimoine:"AbbayeToussaint." [Enlínea] Disponible en: <http://docsig.angersloiremetropole.fr/merimee/ |A49000789.html> [Consulta: 11-05-2012]

RIVADENEYRA, A.: "5 obras de Alvar Aalto." Arquitectura en red, septiembre 2009. [En línea]

Disponible en: <http://www.arqred.mx/blog/2009/09/14/5-obras-alvaraalto/> [Consulta: 17-05-2012]

SERRAINO, P.: Eero Saarinen: 1910-1961: un expresionista estructural. Colonia, Ed. Taschen, 2006.

STARNITZ: Ed. Taschen, 2005 
UNESCO: "Sydney Opera House." [En línea]

Disponible en: <http://whc.unesco.org/en/list/166/gallery/> [Consulta: 11-05-2012]

UniversitätStuttgart: “Beiträge zum Kirchenbau von 1945 bis 1950" [En línea] Disponible en: <http://elib.uni-stuttgart.de/opus/volltexte/2003/1465/> [Consulta: 15-05-2012]

WONG, P.: "La Ricarda." On bluepoolroad. 23 febrero 2011. [En línea] Disponible en: <http://www.onbluepoolroad.com/2011/02/for-flor-laricarda.html $>$ [Consulta: 07-05-2012]

\subsection{Oratorio de San Filippo Neri}

Accademia di Belle Arti di Bologna. [En línea]

Disponible en: <http://www.ababo.it/ABA/segreteria/> [Consulta: 13-032012]

André Durand Digital Gallery: "Ares Ludovisi, Palazzo Altemps, Rome." [En línea]

Disponible en: <http://durand-digitalgallery.com/2012/photography/ sculpture/museo-nazionale-palazzo-altemps/ares-ludovisi-altempspalazzo-altemps-rome-palazzo-altemps-rome-plazzo-altemps/> [Consulta: 12-02-2012]

ASENSIO CERVER, F.; BOTTA, M.: Mario Botta. Madrid, Ed. Kliczkowski, 2003, p.25

BERNISTA, P.; ERCADI, M.: Paolo Portoghesi. Milano, Ed. Skira, 2006, p.63

CERVELLATI, P.L.: "Auditorium San Filippo Neri". En: Promolegno: Atti del convegno: case ed edifici in legno. Construire in securezza su terreni sensibili. Peruggia, 8 maggio, 2009 [En línea]

Disponible en: <http://www.promolegno.com/convegni/convegni-2009/ perugia-8-maggio-2009.htm> [Consulta: 12-03-2012]

GONZÁLEZ GARCÍA, A.; LAHUERTA, J.J.; NAVARRO BALDEWEG, J: Juan Navarro Baldeweg. Obras y proyectos. Madrid, Ed. Electa, 1993, p.181

Italia. Direzione Regionale per i Beni Culturali e Paesaggistici dell'EmiliaRomagna: "09. Oratorio di san Filippo Neri" [En línea] Disponible en: <http://www.emiliaromagna.beniculturali.it/index. php?it/108/ricerca-itinerari/12/97> [Consulta: 10-04-2012]

Lib-Art: "Maso di Bianco, Pope St. Sylvester's Miracle, 1340." [En línea] Disponible en: <http://www.lib-art.com/artgallery/2383-pope-stsylvester-s-miracle-maso-di-banco.html> [Consulta: 07-02-2012] 
Modelismo Naval: "Astilleros tradicionales." [En línea]

Disponible en: <http://www.modelismonaval.com/magazine/ astillerostradicionales/galeria1.html> [Consulta: 11-02-2012]

TROTTA, G.: "Alcuni esempi tipologici di coperture lignee nell'Occidente europeo". En: Tampone, G.: Legno e restauro. Firenze, Ed. Messaggerie Toscane, 1989, pp. 39-54

VELOSO, B.: "Arquitectura griega IIIb. Arquitectura Micénica." Arkyotras wordpress. [En línea]

Disponible en: <http://arkyotras.wordpress.com/2011/08/07/ arquitectura-griega-iiib-arquitectura-micenica/> [Consulta: 07-02-2012]

\subsection{Capilla de los Condes de Fuensaldaña}

Andrew Graham Dixon Archive. Napoleón on his Imperial Throne. [En línea] Disponible en: < http://www.andrewgrahamdixon.com/archive/ readArticle/259> [Consulta: 20-02-2012]

ARNUNCIO. [En línea]

Disponible en: <http://www.arnuncio.es/ES/00/index.htm> [Consulta: 0602-2012]

BECHARA: Ok, Ok Let's Talk. [En línea]

Disponible en: <http://www.josebechara.com/en/ok-ok-lets-talk/> [Consulta: 05-01-2013]

Elnortedecastilla.es, 20 de Febrero de 2009. Fotografía de M. A. Santos. [En línea]

Disponible en: <http://www.elnortedecastilla.es/20090220/cultura/ arquitectura-servicio-debe-estar-20090220.html> [Consulta: 16-03-2012]

Erik Gunnar Asplund: Woodland Chapel [En línea]

Disponible en: <http://www.erikgunnarasplund.com/eng/gallery5skogskapellet.asp> [Consulta: 10-01-2012]

Instituto de Arte Contemporáneo: "El Museo de Arte Contemporáneno inaugura la instalación Línea de luz de Carlos Schwatz" [En línea]

Disponible en: <http://www.iac.org.es/el-museo-patio-herrerianoinaugura-la-instalacion-\%E2\%80\%9Clinea-de-luz\%E2\%80\%9D-de-carlosschwatz> [Consulta: 03-01-2013]

masdearte.com, 26 de diciembre de 2012 [En línea]

Disponible en: <http://www.masdearte.com/index.php?option=com content\&view=article\&id=16687> [Consulta: 03-01-2013] 
MAYORDOMO: “Mujeres en el arte. Elena del Rivero." [En línea]

Disponible en: <http://www.conchamayordomo.com/es/node/148> [Consulta: 03-01-2013]

M.O.M.A.: The Persistence of Memory. [En línea]

Disponible en: <http://www.moma.org/collection/browse_results. php?criteria> [Consulta: 06-04-2012]

Museo del Louvre. La Libertad guiando al pueblo. [En línea]

Disponible en sitio web del Museo del Louvre: <http://www. andrewgrahamdixon.com/archive/readArticle/259> [Consulta: 06-042012]

nexo5.com, 29 de junio de 2009 [En línea]

Disponible en: <http://www.nexo5.com/n/len/0/ent/1370/poesolutioncurtain3-jaime-de-la-jara-exhibe-un-proyecto-creadoespecialmete-para-la-capilla-de-los-condes-de-fuensaldana-en-el-patioherreriano> [Consulta: 05-01-2013]

nexo5.com, 7 de octubre de 2009 [En línea]

Disponible en: <http://www.nexo5.com/n/len/000000/ent/1445/ transfigured-schonberg-en-el-museo-patio-herreriano-dionisio-gonzalezrealiza-una-intervencion-en-la-capilla-sobre-el-arte-de-no-caer> [Consulta: 05-01-2013]

Rijkmuseum: Het melkmeisje. [En línea]

Disponible en: <https://www.rijksmuseum.nl/en/ search?v=\&s=\&q=vermeer> [Consulta: 10-01-2012]

Villa Farnesina: "Sala delle Prospettive." [En línea]

Disponible en: <http://www.villafarnesina.it/?page_id=39> [Consulta: 1001-2012]

MC2. Estudio de Ingeniería: "Palacio de Congresos de Salamanca." [En línea] Disponible en: <http://www.mc2.es/ficha_proyecto.php?id=171\&idcateg oria $=5 \& \mathrm{i}=\mathrm{es} \&$ nav $=02>$ [Consulta: $10-01-2012$ ] 


\subsection{Iglesia de las Escuelas Pías del Colegio de San Fernando}

AARTS, J.; FOKKINK, R.; KRUIJTZER, G.: "Morphic numbers". En: Niew Archief voor Wiskunde, maart 2001, p.57 [En línea]

Disponible en: <http://www.nieuwarchief.nl/serie5/toonnummer. php?deel=02\&nummer $=1 \&$ taal $=0>$ [Consulta: $25-04-2013$ ]

Alvar Aalto Museo: "Viipuri library. The building." [En línea]

Disponible en: <http://www.alvaraalto.fi/viipuri/building.htm> [Consulta: 25-04-2012]

GÓMEZ, M.: “Escuelas Pías de San Fernando." Arte de Madrid. [En línea] Disponible en: <http://artedemadrid.wordpress.com/2012/07/08/ escuelas-pias-de-san-fernando/> [Consulta: 23-04-2012]

MONTENEGRO, N.: "El volumen de una nube. Nubes automáticas." En: BALLESTEROS, J: Automático, robótico, codificado. 6 abril 2008. [En línea] Disponible en: <http://automaticoroboticocodificado.masterproyectos. com/2008/04/06/el-volumen-de-una-nube-nubes-automaticas/> [Consulta: 23-04-2012]

CHING, F.D.K.: Diccionario visual de la arquitectura. Barcelona, Ed. Gustavo Gili, 1995, p. 77

C.O.A.M.: Guía de Arquitectura y Urbanismo de Madrid. Tomo I, El casco antiguo. Madrid, Ed. C.O.A.M., 1982, p.161

DYMLING, C.: Architect Sigurd Lewerentz. Phothographs of the work. Stockholm, Ed. Byggförlaget, 1997

Europaconcorsi: "Palais des Filateurs." [En línea]

Disponible en: <http://europaconcorsi.com/projects/197525-Palais-desFilateurs> [Consulta: 06-05-2012]

GLANCEY, J.: Historia de la arquitectura. Barcelona, Ed. Blume, 2001, p.50

Flickriver: "Piscina mirabilis." Fotografía de Grimaldo Ganzerli. [En línea] Disponible en: <http://www.flickr.com/photos/neapolis/2975196894/> [Consulta: 18-04-2012]

Fondation Le Corbusier: "Dessins \& Papiers collés. Pompéi." [En línea] Disponible en: <http://www.fondationlecorbusier.fr/corbuweb/ morpheus. aspx ?sys $I d=71 \&$ sysLanguage $=$ fr-fr\&itemPos=1\&sysParent $l d=7$ 1\&clearQuery=1> [Consulta: 19-05-2012] 
Fondation Le Corbusier: "Projets. Couvent Sainte-Marie de la Tourette." [En línea]

Disponible en: <http://www.fondationlecorbusier.fr/corbuweb/ morpheus. aspx?sysld=13\&|risObjectld=5037\&sysLanguage=frfr\&itemPos $=42 \&$ itemSort=frfr_sort_string $1 \% 20$ \&itemCount $=78 \&$ sysParentName $=\& \mathrm{~s}$ ysParentld=64> [Consulta: $19-05-2012$ ]

Fondation Le Corbusier: "Projets. Ma maison." [En línea]

Disponible en: <http://www.fondationlecorbusier.fr/corbuweb/ morpheus.aspx?sysld=13\&IrisObjectld=5921\&sysLanguage=enen\&itemP os=90\&itemSort=enen_sort_string1\%20\&itemCount=215\&sysParentNam e=\&sysParentld=65> [Consulta: 18-04-2012]

Fondation Le Corbusier: "Projets. Palais des Filateurs." [En línea] Disponible en: <http://www.fondationlecorbusier.fr/corbuweb/ morpheus.aspx?sysld=13\&|risObjectld=5037\&sysLanguage $=$ frfr\&itemPos $=42 \&$ itemSort $=$ frfr_sort_string $1 \% 20 \&$ itemCount $=78 \&$ sysParentName $=\& \mathrm{~s}$ ysParentld=64> [Consulta: 22-04-2012]

FRAMPTON, K.; KOMENDANT, A.; TENREIRO, O.: 18 años con el arquitecto Louis I. Kahn. La Coruña, Ed. Colegio Oficial de Arquitectos de Galicia, 2000, p.194

HERNÁNDEZ GIL: Revista de Arquitectura y Urbanismo del Colegio Oficial de Arquitectos de Extremadura, 2004

LINAZASORO. [En línea]

Disponible en: < http://www.linazasoro-arquitecto.com/> [Consulta: 1405-2012]

MUÑOZ: 2008, p. 80

QUINTANILLA, J.: "Sigurd Lewerentz, 1885-1975. Una transición nórdica a la Arquitectura Moderna. Desplazamiento gradual hacia el dominio de lo táctil" Universidad Politécnica de Cataluña, Departamento de Proyectos Arquitectónicos, 2004

MOORE, R.: "Ruine del Tempio di Ercole Callaico." Rome art lover. [En línea] Disponible en: <http://www.romeartlover.it/Vasi49b.html> [Consulta: 2204-2012]

PAWSON, J.: Minimum. Londres, Ed. Phaidon, 2003.

PÉREZ, J.M.: "Números mórficos. El número plástico. Dom Hans van der Laan." Poliedros, 1 mayo 2010. [En línea]

Disponible en: <http://tetraedros.blogspot.com.es/2010/05/numerosmorficosel-numero-plasticodom.html> [Consulta: 22-04-2012] 
PIRANESI, G. B.: Della Magnificenza. Roma, 1761, t-23 a t-26. En: Universitätsbibliothek Heidelberg. [En línea]

Disponible en: <http://digi.ub.uni-heidelberg.de/diglit/piranesi1761?act ion=fulltextsearch\&ft_query=\&navmode=fulltextsearch> [Consulta: 1405-2012]

PIRANESI, G. B.: Le Antichità Romane: Divisa In Quattro Tomi. Roma, 1784. En: Universitätsbibliothek Heidelberg. [En línea]

Disponible en: <http://digi.ub.uni-heidelberg.de/diglit/piranesi1784bd1? sid=f4023d2e2f6a27246917604bc4d91d31> [Consulta: 14-05-2012]

RODRÍGUEZ, C.: "Rascacielos de cristal". Relatarte. [En línea] Disponible en: <http://relatosdearte.blogspot.com.es/2012/05/ rascacielos-de-cristal_5807.html> [Consulta: 19-05-2012]

Universidad Complutense de Madrid: "Biblioteca Histórica. Portada Piranesi." [En línea]

Disponible en: <http://pendientedemigracion.ucm.es/BUCM/foa/47308. php> [Consulta: 25-04-2012]

Universität der Künste Berlin: "Entwerfen und Baukonstruktion I, Archiv: Exkursionen." [En línea]

Disponible en: <http://www.arch.udk-berlin.de/riegler/index. php?pageid=5> [Consulta: 23-04-2012]

SARRI, K.: "Dimitris Pikionis. Acrópolis surroundings." Webtopos. [En línea] Disponible en: <http://www.webtopos.gr/eng/art/artists/p/pikionis/ index.htm> [Consulta: 23-04-2012]

Flickr: "Iglesia en Almtuna." Fotografía de Arnout Fonck. 15 agosto 2008. [En línea]

Disponible en: <http://www.flickr.com/photos/21581622@ N07/2835824262> [Consulta: 22-04-2012]

ZABALBEASCOA, A.: "Obras maestras de bolsillo. Ni dentro ni fuera, el lugar del verano." El País, 02 septiembre 2011. [En línea]

Disponible en: <http://blogs.elpais.com/del-tirador-a-la-ciudad/2011/09/ obras-maestras-de-bolsillo-7-ni-dentro-ni-fuera-el-lugar-del-verano. html> [Consulta: 19-04-2012] 


\subsection{Iglesia de San Pedro}

FIDONE, E.: "Progetti". Europaconcorsi. [En línea]

Disponible en: <http://ec2.it/emanuelefidone> [Consulta: 20-07-2012]

Radiortm: "Modica: II progetto del recupero del complesso conventuale di S. Maria del Gesù finalista alla Medaglia D'oro dellarchitettura italiana". [En línea]

Disponible en: <http://www.radiortm.it> [Consulta: 21-10-2012]

BELTRÁN,A.: "Elimposiblerescatedelaruina".EIPaís.27enero2008. [Enlínea] Disponible en: <http://elpais.com/diario/2008/01/27/ cultura/1201388405_850215.html> [Consulta: 21-10-2012]

Triposo: "Stoa of Atalos". [En línea]

Disponible en: <http://www.triposo.com/poi/Stoa_of_Attalos> [Consulta:

21-10-2012] 




\section{anexos}




\subsection{ENTREVISTA A JUAN CARLOS ARNUNCIO.}

Junio de 2012.

Luis Bosch Roig

P.1: En tu dilatada experiencia como Arquitecto, de casi 35 años de profesión, has abarcado todo tipo de campos dentro de la disciplina: docencia, gestión, investigación, práctica arquitectónica. Se diría que has buscado tener una experiencia completa de la Arquitectura. ¿Como ha afectado este complejo bagaje en tu práctica arquitectónica? ¿Reconoces en tu caso una consciente transferencia de conocimiento de la teoría a la práctica?

R.1: En los temas de gestión no reconozco en absoluto un aporte de conocimiento. El asumir en un momento dado la dirección de la Escuela, con 34 años, me vino bien pero desde otros puntos de vista. Profesionalmente eso lo considero como un paréntesis de la vida, en el que aprendes de otras cosas.

Respecto a la vertiente teórica, creo que forma parte del pensamiento que te vas construyendo y creo que sí que incide en la práctica arquitectónica y, es más, no sabría precisar dónde acaba una cosa y donde empieza la otra.

Nunca he abandonado la Escuela por el ejercicio profesional, siempre he ganado algún concurso de algo, algún edificio más o menos importante, y eso me ha tenido activo, sobre todo al final, al principio mi labor como profesional era pequeña, se fue incrementando un poco con el tiempo.

...y eso te ha permitido también reflexionar un poco más las obras que has ido haciendo... en contraste con la velocidad reinante en la arquitectura española...

Velocidad estresante que no comparto para nada. El desarrollo de la arquitectura en España, por un lado tremendamente brillante y, por otro lado, mucho fuego artificial en torno a muchas cosas, y paralelamente una industria de la construcción lamentable, por decirlo de algún modo. Es decir, tenemos cierta propensión a sacar pecho con la arquitectura española, pero si analizamos las periferias de nuestras ciudades, el desarrollo de las costas, yo creo que nos tendríamos que poner un poco colorados.

Ha habido mucho exceso, se olvida con frecuencia que la arquitectura tiene una componente social grande, que la arquitectura tiene una obligación de resolver problemas, que es lo que es ante todo, por encima de todo. Creo que a veces se ha puesto muy por delante esa dimensión artística entre comillas, esa dimensión en el fondo hedonista y personal de la arquitectura. 
P.2: Tu interés por la arquitectura clásica se remonta casi a tus primeros escritos, conferencias y cursos. Tu participación en el Escorial en los cursos "Juan de Herrera y la arquitectura del siglo XVI" o "Juan de Villanueva y la Arquitectura de la razón" en 1985; los cursos impartidos en la ETSAV entre 1986-88 sobre los clasicismos y las transgresiones; la beca para la estancia en la Academia de España en Roma en 1988; o tu último libro dedicado a la figura de Francesco Borromini publicado en 2009.

¿En qué sentido ha influido este interés por la arquitectura clásica en tu práctica arquitectónica? ¿Sientes en tu arquitectura o en tu reflexión teórica una mirada hacia la arquitectura histórica?

R.2: Mirada hacia la arquitectura histórica, seguro, entre otras cosas porque yo creo que la arquitectura se construye con la memoria, y entonces me interesa absolutamente la historia de la arquitectura, no me creo esas visiones que de repente niegan la historia, porque no creo que estemos en condiciones de inventar todo el rato. Creo que todo lo que he hecho yo se apoya en cosas que otros han hecho antes. Y creo que la historia es un baúl de cosas que está ahí para que lo miremos, para que lo conozcamos y para que lo utilicemos. Por ejemplo, en el Patio Herreriano, muchos detalles, muchos aspectos de la organización de la entrada del edificio de la ampliación, por ejemplo, tienen que ver con cosas aprendidas del barroco.

Si me preguntas por el Clasicismo como tal, yo creo que ya menos, menos como un -ismo. Desde luego la arquitectura clásica me ha interesado siempre, es una referencia, es que es Occidente, es como decir a estas alturas que te interesa Aristóteles, pues sí, qué te voy a decir, podré saber más o menos, pero es que es nuestra cultura y nuestro mundo.

\section{¿Y respecto a los cursos de clasicismo y transgresiones?}

Sí, en este punto quiero recordar que en la Escuela de Valladolid, hubo dos personas que hicieron una gran labor más allá de su labor cotidiana, Simón Marchán y José Ignacio Linazasoro, y alguno más también como José Luis de Miguel. No es casualidad el hecho de que la Escuela de Valladolid tenga en proyectos el mayor porcentaje de profesores numerarios con relación a no numerarios, que es una excepción en comparación con el resto de las escuelas españolas. $Y$ eso hace que hayamos tenido una visión de la docencia muy profesional, en el mejor sentido de la palabra. Sí, hicimos unos cursos de postgrado que tenían por objeto salir del atolladero de que no había suficientes doctores y por lo tanto no se podían generar nuevos doctores. Los cursos permitieron invitar a profesores de fuera y se financiaron con la ayuda de la Junta de Castilla y León. 
$\mathrm{Si}$, ha sido un maridaje feliz. Esos cursos se organizaron entre el área de Composición y el de Proyectos y, luego, con la nueva organización departamental acabaron por unirse en el "Departamento de Teoría de la Arquitectura y Proyectos Arquitectónicos". Creo que en Valladolid ha venido dando resultado esa unión.

P.3: Otra influencia apreciable en tu obra arquitectónica y en tus escritos es la del arte. Leyendo tus textos o viendo tus conferencias uno se de cuenta enseguida de que existe un bagaje cultural muy importante en tu formación personal. Las referencias a artistas como Chillida, Gustavo Torner, James Turrell, etc. ¿Dedicas mucho trabajo a conocer el arte? ¿Cómo afecta a tu trabajo de arquitecto?

R.3: Creo que eso tiene que ver quizá con la manera de entender el proyecto, hay una cita de Curro Inza, que fue profesor mío, que decía que eso de proyectar tenía mucho que ver con resolver un sistema de ecuaciones que tuviese muchas más incógnitas que ecuaciones y que entonces en nosotros estaba el inventarnos ecuaciones con las que poder salir al paso, que es una manera divertida de aludir a la necesidad de hacerte preguntas inteligentes y de obligarte a establecer estrategias de proyecto. $Y$ esas estrategias de proyecto tienen que ver con la mirada a la historia, la mirada al arte de los contemporáneos, la mirada a la naturaleza, son elementos donde bucear, donde activar la reflexión sobre la arquitectura...

...la mirada a la naturaleza, ¿a qué te refieres? ¿a las formas de la naturaleza?

...no como tal, no me refiero a la mirada frívola, me refiero por ejemplo a las líneas actuales de abordarlo. Por ejemplo la mirada que hace Le Ricolais en base a la geometría de cosas naturales, al entender que la forma puede analizarse no directamente desde un parámetro formal, sino desde las acciones; un río lo defines mejor diciendo qué cosas han pasado sobre él o cómo es la tierra que va generando, que tratando de decir que es una sinusoide, la naturaleza activa el pensamiento en esa dirección.

P.4: La intervención realizada en el denominado Patio Herreriano de Valladolid para su transformación en Museo de Arte Contemporáneo Español es una actuación en la que se plantea la interacción con el patrimonio arquitectónico construido. Ésta no es tu primera incursión en este ámbito de la arquitectura. Recordemos por ejemplo tus trabajos en la casa Zúñiga o en el Palacio del Licenciado Butrón, así como obras de restauración posteriores en la Torre de Santa María del Campo en Burgos y en la Catedral de Segovia. ¿Cómo resumirías tu experiencia en este campo de la disciplina arquitectónica? 
R.4: Yo lo suelo explicar poniendo el ejemplo del patrimonio, de lo que heredas de una abuela. La casuística infinita que se genera, es decir, tu de una abuela puedes heredar un mueble que es un horror, pero te viene muy bien para guardar unas cosas, puede heredar una joya que no te la pondrás nunca porque es un "joyón" de esos que no puedes verlo por ningún lado, pero que a lo mejor tiene un valor intrínseco enorme, puedes heredar un abanico muy feo pero que le tienes un cariño grande porque te recuerda a tu abuela, puedes heredar un mueble que está muy bien pero que es una pena que no te quepa... es decir, la casuística, es infinita, y yo creo que con el patrimonio arquitectónico pasa lo mismo, con lo cual a partir de ahí, la intervención en el patrimonio pasa a ser automáticamente un problema tan infinito como la arquitectura, y pasa a ser un problema directamente de arquitectura.

¿Alguien puede meter en el mismo saco el criterio para la reproducción del Pabellón del 29 o de un castillo del s. XIII que tiene muros de dos metros y medio de espesor...? es que es un problema que no tiene codificación posible... por eso no me creo demasiado cuando se acude a los términos del cientifismo, porque detrás del cientifismo tu puedes hacer atrocidades... como cuando se habla de arquitectura neutra...bueno $y$, ¿qué es eso?

Entonces yo creo que hay que saber callarse cuando hay que callarse y que hay que saber hablar cuando hay que hablar, ese es el tema.

\section{¿Y detectas grandes diferencias respecto al proyecto de arquitectura nueva?}

En la obra nueva tu puedes poner lo que te sabes, en una intervención sobre otra arquitectura, aparte de lo que te sabes, tienes que saberte la del otro, lo cual implica que tienes que tener un conocimiento determinado constructivo, que tienes que tener un conocimiento de unas técnicas. Esto no quiere decir que para poder intervenir en una restauración tengas que hacer antes otra carrera, también para hacer un polideportivo me tengo que enterar de cómo son las dimensiones, la pendiente de una grada, cómo funciona, si la cancha de baloncesto es la misma que la de balón-bolea, cada una tiene sus reglas de juego y a veces son de gran complejidad. Pero, quiero decir que, un buen arquitecto que ha restaurado mucho en un lugar y sabe mucho de los oficios de ese lugar, si es bueno yo creo que le ponen a rehabilitar o a restaurar algo en Japón, o en un lugar con otras técnicas constructivas distintas, y estoy seguro de que se entera y da una respuesta correcta.

En definitiva es una cuestión de actitud frente a la arquitectura. 
P.5: En ésta misma línea, a propósito de la intervención en el patrimonio, comentas en un artículo que ésta tiene "como objeto de reflexión la naturaleza de la mirada a la historia que lleva implícita". Y hablas de la naturaleza de la perfección en la mirada de Viollet o Ingres frente a la naturaleza de la defensa de la verdad del pasado en la mirada de Ruskin o Delacroix. Y por otro lado reflexionas sobre las diferencias que existen entre los monumentos sobre los que se actúa. Para concluir que por un lado es imposible encontrar criterios universales en la intervención sobre el patrimonio y por otro lado que es de destacar la vigencia que pueden tener las actitudes defendidas por los pioneros de la restauración. ${ }^{1}$ ¿Existe en J.C. Arnuncio una mirada a la historia predefinida, o unos invariantes, para enfrentarse a las distintas situaciones presentes en una intervención, o cada caso supone un replanteamiento total de esta mirada?

R.5: Supongo que hay algo que permanece. Por ejemplo, me explico a mi mismo, mucho mejor la Capilla del Patio Herreriano, con un espacio concreto que plantee con una razón totalmente distinta, en el Palacio del licenciado Butrón. Creo que hay algo de actitud, o esa idea de abstracción del espacio, que evidentemente una es heredera de la otra, pero también es cierto que no de una manera quizá consciente, ya que de eso me he dado cuenta después.

A veces te das cuenta de que haces las cosas de una manera. Yo procuro enterarme de cuál es el problema. Por ejemplo, en Santa María del Campo, el problema era simplemente adecentar y quitar unas cosas peligrosas que podía tener la torre, una torre que es maravillosa, que es de los mejores ejemplos del Renacimiento en torres de toda España y por lo tanto te limitas a limpiarlo, protegerlo, no poner nada y facilitar el mantenimiento posterior.

...que no se vea la mano del arquitecto...

...exacto, que no se vea nada... las únicas decisiones fueron que en una de las gárgolas, faltaba la mitad y algunos de los balaustres estaban echados a perder... a mí me importa la perfección de la torre desde abajo y puse alguna gárgola nueva, con algún símbolo para identificar su novedad, me parece más importante mantener la integridad y el perfil de esa torre que una especie de escrúpulo...

...ahí entra el tema de la escala, de la percepción visual...a la distancia a la que se percibe...

...claro, como al que le falta un diente, pues si te falta un diente hace feo, te pones uno..., yo creo que no pasa nada...
1 ARNUNCIO PASTOR, J.C.: "Las Miradas al Pasado". En: A.A.V.V.: Día de la Arquitectura. XVII Congreso Internacional de Conservación y Restauración de Bienes Culturales. Valencia: Editorial de la UPV, 2008, p. 

en función de la parte sobre la que se actúa (el patio, la capilla y la ampliación). Esta heterogeneidad de criterios se busca unificar con un único "criterio formal homogéneo de modo que la presencia en el museo se sintiese como única, independientemente del lugar". ${ }^{2}$

Para ello comentas que se parte de una arquitectura abstracta, de grandes superficies limpias en el que hay un intento de armonizar cromáticamente materiales distintos.

¿En qué consiste este criterio de unidad?

R.6: Hay una heterogeneidad de situaciones, hay un sitio donde la arquitectura está, que es el patio... ¿qué falta? Pues que el suelo está mal, que le han crecido plantas, que hay paramentos con ladrillo entre los paños de piedra y hay que acabarlos, pero el patio está entero. Este es un nivel de intervención. Mientras que la capilla es un término medio, hay una ruina, falta la mitad, es un nivel que no tiene nada que ver con el del patio; también hay otro que es la ampliación, y habría otro que son los espacios del edificio en los que, en unas obras de los años 60, se les puso la estructura de hormigón por lo que no había ni un solo forjado de madera en el monasterio.

Entonces vas respondiendo a los problemas que son diferentes porque son diferentes las situaciones. Lo que sí que me preocupaba era el hecho de que la atmósfera, una vez intervenidas esas situaciones, no fuese la misma.

En el fondo es un problema de arquitectura, no es un problema ni siquiera de historia. Cómo hacer que un espacio tenga un grado de coherencia. Un espacio que además es un museo, que además tienes que ponerle calefacción, que además tienes que ponerle seguridad, etc...

No me creo ese respeto... Cuando en un momento dado, en la pintura por ejemplo, falta una parte, ha habido quien sostenía esa teoría de colocar una línea roja que divida muy bien la parte nueva de la parte medio inventada, manifestando claramente qué es lo nuevo y qué lo viejo. Detrás de esa idea de respeto yo creo que pueden cometerse auténticos despropósitos, por eso es muy difícil precisar en estos temas. Las palabras, yo creo que pueden ser muy traicioneras. Palabras como respeto, neutralidad, etc.. es casi como no decir nada. Cada obra establece sus propias reglas de juego.

P.7: Observando el proyecto de "reconstrucción" de la casa de los Zúñiga se observa dos criterios formales muy distintos en las dos fachadas nuevas: una galería acristalada de acero y vidrio que se abre a un jardín, frente a un muro de piedra pesado con seis huecos volcando al patio interior. Además se construye un nuevo semisótano cubierto con bóvedas de ladrillo en alusión al carácter de ese tipo de espacios. ¿Es este un claro ejemplo de esta heterogeneidad de criterios que comentas? ¿En este caso no es necesario el criterio de unidad? 
R.7: Este es un caso particularísimo. Cuando a nosotros nos encargan el proyecto, el proyecto se llama rehabilitación. Era un palacio al que sólo le que quedaba en pie, y a cielo abierto, una "L" uno de cuyos brazos da a la fachada y el otro genera perpendicular a fachada un patio. Evidentemente el edificio tenía una parte posterior, pero que desconocíamos cómo era.

Lo único que quedaba sano eran las columnas de piedra del patio, la escalera estaba hundida, era una escalera un poco modesta pero con una balaustrada de madera, no creo que fuese de la época del palacio original pero, en todo caso, tenía su dignidad. Lo compró la Universidad de Valladolid pensando que podrían aprovecharlo mucho, pero, si el palacio se restringía a la parte que estaba arruinada, no cabía nada, era prácticamente la escalera de entrada. Entonces, estudiando la normativa, vimos la posibilidad de que si se demostraba arqueológicamente que el edificio llegaba más allá de la construcción, podríamos levantar el volumen del edificio original que encontráramos.

Y efectivamente, al excavar aparecieron los muros del palacio. Por lo que teníamos medio palacio que se sabía exactamente cómo era porque estaba dibujado y además estaban las columnas, y otro medio palacio del que no se sabía nada, sólo el tamaño de su planta. Yo tenía el convencimiento de que sólo dos de los lados eran porticados, mientras que el tercero (estaba convencido por alguna intuición) no estaba porticado. Posterior a esa decisión José Martínez González, catedrático de historia entonces, ya fallecido, de la Universidad de Valladolid, me dio una foto antigua donde efectivamente el tercer lado no estaba porticado y era un muro.

Por lo que el problema era que nos teníamos que inventar dos palacios, pero uno de ellos con la obligación de tener que reproducir el palacio histórico. El problema era por un lado que teníamos que hacer la imagen de un palacio, sin caer en un pastiche, así que nos interesó, simplemente, una lectura tipológica.

Por lo que se mantuvieron los muros y las columnas exactamente dónde estaban. Aunque es cierto que la galería es reinventada, podría parecerse más a una galería de Wright que a una galería del XVI, pero el objetivo no era inventarnos una galería del XVI, sino hacer una galería que resolviese los problemas y conformase un todo con el resto, fuese del XVI o de cuando fuese.

Por el contrario, la parte posterior es una caja añadida que quiere dialogar. Es un muro inventado, nuevo, con una media sillería con piedra de Salamanca, aunque respetando escrupulosamente la tipología. Pero, por ejemplo, reprodujimos un muro que originalmente era de adobe de casi 1'10 de ancho para separar dos habitaciones, pero aprovechamos para esconder unas escaleras en ese muro, de tal manera que la traza del muro se mantiene y se resuelven unas escaleras que solucionan media planta. 
...Bueno es que era una fachada que era un patio de manzana de casas mucho más altas y por lo tanto simplemente es una galería. Todas las manzanas del casco histórico de Valladolid antiguas acaban siendo galerías. Por eso te digo que es un enunciado en sí mismo como divertido, como insólito. Me preocupaba mucho más la parte de delante, en la que teníamos una obligación absoluta, porque se suponía que teníamos que reproducirla literalmente, pero conseguimos evitarlo. Perotipológicamente sí que fue un edificio respetuoso. La clave también está en el sótano, en el que decían que había estado encerrado Álvaro de Luna, y que tenía significación histórica. Yo creo que ahí no había nada. Hicimos un sótano muy bonito, que une las dos actitudes, con unas bóvedas de rasilla que creo quedaron muy bien.

\section{...y aquí el tema este de la unidad de la intervención...}

En este caso no hay unidad posible. Quizá yo ahora lo hubiera hecho de nueva planta todo. Al final te alegras también, porque está la memoria, está la calle..., es que en Valladolid esa calle, que es la calle Juan Mambrilla, cuando yo iba al colegio de pequeño, estaba llena de palacios toda entera, y eso es lo único que queda. Es decir, casi todos los palacios, con esa tipología del s. XVII, con un patio interior, han desaparecido. Han pervivido las puertas cuando eran de sillería de medio punto como puerta de acceso al garaje, si entraba el coche, y las demás fuera. De hecho ha habido un expolio importante, yo creo que muchos chalets tienen columnas y otros elementos de los palacios derribados. Entonces, desde ese punto de vista, me alegro de que al menos quede la huella o la memoria de un edificio como aquel.

\section{Aquí en Valencia también había muchísimos más palacios de los que quedan. Quedan muy pocos.}

En España se hizo una locura, en los años 60. Valladolid tuvo la mala suerte, desde este punto de vista, de tener mucho dinero en ese momento. Prácticamente duplicó la población en una década y en vez de crecer hacia afuera, lo hizo hacia dentro, porque Valladolid es una ciudad que había tenido mucho convento... lo que derivó en la utilización del espacio de las antiguas huertas en suelo edificable generándose la sistemática que caracterizó ese Valladolid; sistemática que, no se detuvo en el espacio de las huertas, así que se perdieron muchas de aquellas casas. Era un problema cultural que afectó a toda España pero más a las ciudades que, por sus circunstancias, tuvieron que crecer deprisa. En la catalogación del Plan General del 82, había un plano que era tremendo, que señalaba en rojo los edificios históricos desaparecidos en los últimos años y era de no creer. Había en pie del orden de 200 y pico o 300 palacios o palacetes y quedan 20. 
P.8: En el Museo de Arte Contemporáneo Español, parece que hay una primera decisión, de gran escala, que busca "devolver la dignidad al espacio urbano", ${ }^{3}$ mediante la configuración de una gran plaza.

¿Es ésta escala la primera cuestión a tener en cuenta en una intervención arquitectónica?

R.8: No sé si es la primera, aquí lo era. En otros casos, depende. En alguna medida todo tiene una pequeña y una gran escala. Por ejemplo, la torre de Santa María del Campo, también tiene una gran escala que es la territorial. Esa torre es maravillosa allí aislada y si empezamos a hacer cosas altas por los alrededores, evidentemente cambia.

Pero en el museo había un problema urbano tremendo y evidente. En un sitio históricamente muy importante, muy vinculado al origen de la ciudad y muy maltratado. Esto mismo está presente en el edificio que hay de Fisac justo al lado. Fisac en su día entendió muy bien la cornisa, la silueta, el alzado de Valladolid en ese sitio. Allí hizo el Instituto Núñez de Arce, un edificio docente, que es un muro de ladrillo casi ciego que da al exterior de la ciudad y es como una peana sobre los palacios, monasterios y demás edificios, que había allí en ese punto. Él lo hace muy bien, pero luego el edificio ha sido maltratado, desaparecieron las vértebras aquellas características de la cubierta de Fisac, debía tener problemas de humedades, el caso es que la imagen está muy deteriorada, pero mantiene esa dignidad. Y luego, sin embargo, en el 75 hicieron un edificio de viviendas tremendo. Estas viviendas generaban el problema de escala al que me refiero.

P.9: Dentro de la actuación realizada en el Museo, destaca la capilla de los Condes de Fuensaldaña. Comentas que "la intervención evita el imposible intento de recuperar su pretérita configuración [...] evita toda tentación de recuperar la configuración original de su arquitectura y, por el contrario, se propone únicamente que el nuevo volumen dibuje la ruina preexistente mediante la luz indirecta, que confiere unas características particulares al espacio interior de la antigua capilla...". ${ }^{4}$ ¿Se tuvo la tentación de plantear en algún momento de la fase de proyecto la posibilidad de reconstruir la volumetría original, o tal y como se comenta, se tuvo claro desde el principio que era imposible o que era más interesante mantener la condición de ruina?

R.9: No, yo no la tengo en ningún momento. Lo que pasa es que hay una capilla casi idéntica en Valladolid, que está perfecta. Es una capilla que es una preciosidad, la Capilla del museo de San Gregorio, y tipológicamente es clavada, tienes el modelo al lado, bueno es algo más grande la del Patio Herreriano, pero son iguales de planteamiento, de tipo, y sin embargo me parece que desde el principio yo tenía claro lo del planteamiento como una ruina. Y me alegro cien veces de haberlo hecho.
3 ARNUNCIO PASTOR, J.C.: Conferencia Materia y Forma IV. Jornadas Internacionales de Arquitectura. 2-4 de Marzo de 2009. http://www.upv.es/ catedrablanca/myf4/INICIO.htm

4 ARNUNCIO, J.C.; AIZPÚN, C.; BLANCO, J.: "Patio Herreriano. Museo de Arte Contemporáneo Español de Valladolid". On Diseño, no 235, 2002, pp. 242-251 
5 ARNUNCIO PASTOR, J.C.: “Museo de Arte Contemporáneo Español. Patio Herreriano. Valladolid". En: MAS, V. et al.: Materia y Forma IV. Jornadas Internacionales de Arquitectura. Valencia, Ed. UPV, 2009, p.

6 ARNUNCIO PASTOR, J.C.: Conferencia Materia y Forma IV. Jornadas Internacionales de Arquitectura. 2-4 de Marzo de 2009. http://www.upv.es/ catedrablanca/myf4/INICIO.htm
Y la ruina estaba abandonada. Creo que en Italia sí que esas cosas las tienen más cuidadas...

Bueno, pero yo también he visto en Italia muchos edificios maravillosos, con una pensión encima del dórico. No lo digo como crítica. Creo que parte de la fascinación de Roma es ver cosas maravillosas con esa cercanía y esa cotidianeidad. A mí me pasó que nos invitaron, cuando estaba en la Academia, a una beatificación de una monja catalana. Y entonces, en la Embajada española frente a la Santa Sede, dieron una copa y era una especie de recepción divertida en el sentido de que era lo más heterogéneo que he visto en mi vida. Había personajes de Roma, señoras como..., parecía como de Fellini, cardenales, invitados de muy diferentes facturas,...había de todo, y en esa atmósfera de pronto al ir a dejar la copa te das cuenta que estás dejando el whisky al lado de un busto de Bernini, esa especie de cercanía..., yo no tengo ningún Bernini en mi casa, esa cotidianeidad tan fantástica que bueno...Un busto como ese de Bernini en cualquier otro lado justifica casi un museo y ahí estaba como en un rincón de la embajada, maravilloso y..., bueno, y tu dejas el whisky al lado. A eso me refiero cuando hablo de la cotidianeidad del arte.

P.10: Mencionas la búsqueda de que "tanto desde el exterior como desde el interior, la ruina se recortase, en un intento de mantener visualmente su condición de ruina". ${ }^{5}$ Y comentas la actuación de Robert Stern en el Coliseo, una "fábrica de ladrillo que interrumpe, congela en el tiempo una imagen". ${ }^{6}$ Sin embargo, Ilama la atención el gran prisma abstracto que emerge sobre los muros arruinados de la capilla, como tratando de recordar la presencia másica del elemento arquitectónico en la ciudad. ¿Se busca un camino intermedio entre el romanticismo de la ruina y la reconstrucción reintegradora?

R.10: Sí, de hecho se ha respetado la altura que tenía antes la capilla. Si te fijas en la foto de la cabecera de la capilla, en la parte de arriba ves la ojiva y es una altura constante. Hay un grabado en el que se ve la altura, y lo retomamos porque sí, es una decisión que ya estaba tomada. De todos modos en un momento dado estuvimos tentados de bajarlo y acompañar a la ruina. Tuvimos la duda de si hacer algo medio transparente, como una especie de mancha de aceite que si la ves desde fuera es opaca, pero si la ves al trasluz es transparente. De haber conseguido una piel que desde fuera por la noche se viese el interior y durante el día fuese una caja muda y al revés, que era lo que me interesaba en el fondo. Lo que pasa es que al final no había manera de tener garantías de cuál debía ser esa piel para que produjese ese efecto, y además me parecía más riguroso y más serio el poner un material, que, aunque sea el hormigón, en el fondo tiene tanto el color como la textura y pasa desapercibido, forma parte de ese mundo cromático y de ese mundo de cosas con mucha más elegancia, elegancia en el sentido de no frivolidad o de asumirlo con más naturalidad. 
Se buscaba entonces un camino intermedio entre el romanticismo de la ruina y la reconstrucción reintegradora, no es ni una cosa ni otra...

El romanticismo está muy reflexionado desde el interior, mientras que desde el exterior, evidentemente cuando ya hay un volumen tan grande no es ruina, hay una reconstrucción. En ese sentido sí que me valía lo de Stern del Coliseo, bueno, está en ruina pero hay un edificio. Lo que pasa es que la idea de ruina se hace explícita dentro, con la luz, cuando en el fondo lo que quieres construir es el cielo. Hay un problema de luz, ese es el tema. $Y$ de hecho el dentro-fuera establece un cierto problema que resolvimos tratando de llevar la ventana, que es la que genera toda la luz de dentro, lo más arriba posible, para tener encima de la ventana sólo el espesor de la carpintería el cual tiene una reflexión constructiva atípica.

P.11: La actitud del proyecto asume el nuevo elemento como un estrato más en la vida del monumento. De igual modo que hay "una puerta barroca maclada en una puerta anterior gótica", la nueva pieza contemporánea se añade a los muros en ruina de la capilla. Pero este nuevo estrato mantiene respeto por los anteriores, sin buscar excesivo protagonismo los pone en valor. Se produce un equilibrio. Ninguno es protagonista absoluto, ambos se apoyan para crear un nuevo conjunto. Se consigue con ello un camino intermedio entre el contraste y la analogía, mediante una unidad compositiva a base de partes distintas que constituyen un nuevo entero. ¿Estás de acuerdo con esta apreciación, o entiendes la ruina más como un fragmento desenlazado del conjunto?

R.11: Esa era la filosofía, esa era la voluntad, desde luego... me alegra que digas lo que has dicho porque así lo quería entender yo todo el rato. En el fondo convertirlo en un único problema de arquitectura, es decir, no se trata de una cosa que haga juego con lo antiguo, sino de entenderlo casi en el fondo como una única cosa, es decir, yo creo que ahora, por ejemplo en el interior, ya no se puede explicar lo de arriba sin lo de abajo, con lo cual me parece que si puedes decir eso es que algo está bien.

P.12: A la hora de actuar en el patrimonio es fundamental la lectura e interpretación del monumento. Reconocer los valores para introducirlos dentro de los objetivos del proyecto. Tu mencionas el concepto de "solicitación", y reconoces en la actuación sobre la capilla la existencia de dos de ellas: el poner en valor la ruina existente y producir un gran efecto en el espacio interior. También se reconoce una tercera, que es la de elemento configurador de la estructura urbana y en cierto modo de recuperación de la memoria, de la importancia histórica, de la capilla en la ciudad. ¿Cómo se establece esta jerarquía de valores a la hora de afrontar el proyecto? 
R.12: En ese sentido yo creo que aquí lo teníamos fácil. Creo que esa es una de las labores, el análisis previo al reconocimiento del edificio, saber lo que te estás jugando, saber lo que merece la pena y lo que no. Y en este caso se trata de un edificio en el que las cosas eran muy claras. Un patio que es una preciosidad, que es una maravilla, una capilla, etc. Así que yo que creo que, desde el punto de vista intrínseco de aquello, todos hubiéramos coincidido en el análisis, no había trampas.

P.13: En la solución concreta del elemento construido se observa que se han tomada varias decisiones de proyecto. Entre ellas la ubicación de los límites del prisma, retirados de la línea que define la fachada de los muros de piedra original, para reducir su presencia.

R.13: En cierto modo esto también tiene una respuesta de carácter técnico en el sentido de que si pudimos hacerlo es porque el muro tenía metro y algo de espesor, y eso nos permitió poder hacer una cimentación arriba en el muro, como una especie de zuncho corrido de hormigón, con una rigidez enorme, para que repartiera bien la carga por todo el perímetro y luego los pilares apoyaran sobre él. Quitamos alguna hilada para poder hacerlo y volvimos a ponerla, por un problema de ejecución. Sólo hay pilares en dos de los lados, pilares que luego los arriostramos para no transmitir momentos.

Y por otro lado la materialidad exterior con aspecto sólido, macizo, pesado, que se relaciona con naturalidad con la de la ruina; y la textura de acabado que introduce una vibración de luces y sombras en los paramentos tal y como ocurre en los muros de la ruina, aunque introduciendo una nueva dirección de la sombra (me recuerda al tratamiento de lagunas en obras pictóricas), textura que se repite en el testero del nuevo edificio que remata el conjunto del museo.

Sí, lo hice para que tuviese textura, y que vibrase la luz. Tiene como un encofrado de madera, hecho con un prefabricado de goma, y tiene una trama definida.

¿Cuáles han sido las directrices de proyecto que han llevado a esta solución? ¿Se tuvieron en cuenta referencias para llegar a esta solución?

En concreto ninguna, es más yo creo que llegué a pensar en todo lo posible sobre esa piedra, incluso hasta poner un acabado negro, una especie de granito pulido negro, también forma parte de las pruebas que vas haciendo, como la del cristal, o la de la transparencia o la de esa idea de contraste, y en el fondo fue todo un proceso de autocontención. 
P.14: Existe una paradoja entre la imagen del nuevo prisma que "reintegra" el volumen de la capilla y su construcción. Si bien, como ya se ha comentado, la imagen es la de un elemento sólido, pesado, macizo, sin embargo su construcción se ha llevado a cabo mediante una estructura ligera de elementos metálicos revestida al interior por paneles blancos y al exterior con paneles prefabricados de hormigón de 7,2m de altura. Tú mismo comentabas, en la conferencia que diste en las jornadas de Materia y Forma, que se puede apreciar en la historia de la arquitectura una fluctuación entre la forma derivada de su exigencia constructiva y estructural, y cierto grado de libertad que se concede a si misma, entre la literalidad y el sueño. ${ }^{7}$ Álvaro Siza nos tiene acostumbrado a este tipo de "escenografías" que ocultan complejos sistemas estructurales, con la finalidad de producir formas de gran emotividad. Hace casi una categoría formal de esto. Por otro lado Juan Navarro Baldeweg comenta que no le parece que la "libertad formal consiga el objetivo final de la arquitectura". La arquitectura va más allá del continente, es antes contenido.

¿Te preocupa esta incoherencia entre la imagen y su realidad constructiva o lo entiendes como parte del complejo juego de la arquitectura, un artificio al servicio del arquitecto que se viene empleando desde siempre en la historia?

R.14: Suelo hablar de estos temas en clase. Pongo el ejemplo de la catedral gótica en la que hay una evidencia formal, la forma viene determinada en ese caso por la estructura. $Y$ hay situaciones en las que se oculta la estructura por las razones que sean, como en algún espacio de Siza, en el que el espacio viene determinado por la luz, por la cualidad de ese espacio y resulta imposible determinar su conformación estructural y constructiva. En Santiago de Compostela por ejemplo, no hay manera de saber dónde está la estructura, ni cómo se aguanta, es todo un tema abstracto de luz. Por eso creo que se puede explicar la historia de la arquitectura, o es uno de los parámetros desde el que lo puedes explicar, desde esa preocupación de la literalidad o la no literalidad entre forma y razón construtiva.

Y en este caso tú cuentas con ello y lo aportas al proyecto...

Concretamente en este caso, evidentemente está por encima el efectismo de esa capilla que cualquier otra cosa. Desde dentro no se sabe cómo se sujeta aquello, no me interesa nada contarlo. ¿Qué es escenográfico? ¿Qué tiene algo de escenográfico? Pues puede que sea algo escenográfico pero a mí me parece muy bien.

¿Tiene que ver con una cuestión de reversibilidad de lo añadido, o tal vez con reducir la "invasión" física de la ruina?

...para nada, te confieso que nada de eso estaba presente en ella..., también es cierto que no hubiera tirado nada, o sea, me interesaba la ruina... es más, podría dar más rabia que no hubiese algún roto más, para que se pareciese más a lo de Stern..., se jugó sin trampa en ese sentido.
7 ARNUNCIO PASTOR, J.C.: Conferencia Materia y Forma IV. Jornadas Internacionales de Arquitectura. 2-4 de Marzo de 2009. http://www.upv.es/ catedrablanca/myf4/INICIO.htm 
P.15: Al fijarnos en el detalle del muro de piedra que conforma el cerramiento preexistente de la capilla se observan unas zonas de piedra más deterioradas que otras. ¿Se han llevado a cabo trabajos de restitución pétrea en partes con faltantes o se debe a procesos de deterioro desiguales?

R.15: En el interior hay una restauración seria de la ruina. Por ejemplo, los fondos de los arcosolios estaban rellenos con ladrillo hueco doble, las pilastras entre los arcosolios estaban absolutamente deshechas, por lo que se lleva a cabo una reconstrucción, pero se hace sin ocultar la condición de nuevo, aunque con piedras que están rotas. Pero se aprecia que son rotas nuevas. Y una de las dos pilastras importantes del interior de la capilla, situada en la división de la planta entre el cuadrado y el octógono, tenía la piedra descarnada, estaba el calicastro de dentro y había bajantes de las letrinas de los cuartos de oficiales que había arriba durante su etapa militar, evidentemente la pilastra no la reprodujimos pero pusimos una piedra, rota adrede, pero se ve que esa ruptura es nueva, es decir, no oculta su condición de nuevo pero trata de responder con dignidad. Si te fijas se ve bastante claro.

Está restaurada la piedra y hay algún sillar nuevo. Luego también estaban los mechinales del forjado que tuvo, los hemos tapado con un mortero, pero siguen estando.

Y los huecos de los arcos, ¿se llegó a pensar alguna vez en abrirlos o siempre se quiso mantener cegados?

En un momento dado se planteó hasta la posibilidad de entrar por ellos al museo, lo que pasa es que me gustaba mucho más preservar la identidad de ese espacio como cerrado, un poco mágico. Además si abres ahí una entrada, automáticamente tienes que poner una garita de información, etc.

...aunque sí que hay una puerta que es para entrar la obra...

Sí hay una puerta, la barroca, que se puede abrir, pero en el otro lado hay una puerta, que el edificio del monasterio tapa, y parte del conocimiento que se tiene de la capilla es por el pleito que los condes de Fuensaldaña, los propietarios de la capilla, pusieron al monasterio porque les había cercenado la puerta...

P.16: Desde un punto de vista de organización interna del museo. El nuevo uso supone una relectura de los espacios históricos, pasando de ser espacios de estancia a espacios de recorrido donde se contemplan obras de arte. Esto conlleva nuevas necesidades que se reflejan en la arquitectura: condiciones de iluminación, temperatura, humedad, accesibilidad, superficie expositiva, etc. ¿Qué suponen estas cuestiones en el espacio de la capilla? 
R.16: La prioridad explícita siempre ha sido el museo vivo..., el museo tiene que funcionar como tal. Lo que pasa es que en la capilla no se puede colgar un cuadro, porque no hay manera de que salga bien parado, pero es un espacio que tiene tal intensidad que el uso que hace el museo de él está muy bien, que es ofertarlo a artistas para que dialoguen como puedan con él. Pero a veces genera situaciones que a mí me han indignado un poco como la actual, que está tapada la entrada de luz para una instalación en la que no se aprecia el espacio; es todo oscuro. Para eso no hace falta la capilla, bastaría una sala apagada.

¿Y se aprovecha para instalaciones toda esa gran cámara que se genera en la pieza nueva?

No, simplemente ventila por ahí. En la cubierta siempre está la zona de calefacción porque era el sitio más adecuado, el único sitio casi que no se ve desde ningún lado. Encima de la cabecera hay una zona, que desde el patio se ve en algún punto, pero en los riñones de la capilla no hay nada, simplemente todo colgado y ligero.

\section{P.17: En la conferencia que diste en Valencia, en las jornadas de Materia y} Forma IV, comentabas el tema de la "Caja", como elemento que encierra algo de sorpresa. Esa idea de introversión, de entender que lo de dentro está tratado con más amabilidad que lo de fuera. Mencionas el proyecto del Palacio del Licenciado Butrón, donde un lucernario abierto en el interior del edificio ilumina una superficie blanca y alabeada produciendo un efecto mágico e inesperado. De igual manera en la capilla, se actúa "de tal manera que al exterior es sólo una pequeña fisura la que nos induce a pensar que en el interior puede suceder algo, pero que finalmente se produce un gran efecto". ¿Es este un tema fundamental en tu arquitectura?

R.17: Lo de la introversión es un tema incluso más amplio que todo eso, está relacionado con otras cosas que no tienen nada que ver con la restauración y me he dado cuenta de que es una mirada que haces de una manera probablemente inconsciente, hasta que un día lo tienes que contar todo, lo pones en orden y te das cuenta de que estás haciendo lo mismo, -el conservatorio de Burgos, mi propio estudio, algún concurso fallido, como las Cortes de Castilla y León- edificios muy introvertidos, muy volcados hacia dentro, como un poco de pudor hacia el exterior, por la razón que sea.

En mi estudio era un tema de relación visual, de me abro hacia una parte, y me niego hacia otra parte del jardín, por los niños. En el caso del Conservatorio de música y danza de Burgos, bueno, yo creo que porque me pareció que era muy adecuado al mundo de la música el hacer un mundo un poco introvertido, una de las cosas que tienes que hacer es evitar todos los ruidos. Es un edificio que los profanos en esto de la arquitectura se sorprenden cuando entran, porque como por fuera lo ven todo como mudo, muy cerrado, y cuando entran de repente aparecen patios muy luminosos. 
En el museo también está presente, pero de manera distinta, porque la propia forma del museo viene determinada por parámetros más importantes, como la situación urbana, pero en el fondo la capilla se puede analizar desde ese punto de vista, como una pieza introvertida.

Y esta cuestión de la sorpresa del espacio interior respecto a la sobriedad exterior es algo que también ocurre en el Palacio del Licenciado Butrón.

Sí, también hay algo de eso, en el sentido de que te encuentras un espacio sorprendente en un sitio dónde por lógica no lo habría. Lo que pasa es que en este caso había un problema de gran intensidad que consistía en pasar de un espacio de salas de $5 \mathrm{~m}$ de altura, de una dignidad tremenda con unos forjados maravillosos de madera, a un depósito de 2'30m de altura libre con las instalaciones vistas, que es el archivo propiamente. Entonces esa frontera era una manera de tratar de darle dignidad sin recurrir a la moldura, sin recurrir a la forma explícita, sino desmaterializando un espacio...

P.18 En el interior de la capilla lo que más llama la atención es la solución formal del cerramiento superior del espacio y el sistema de iluminación generado. Una superficie cóncava abstracta y blanca parece levitar en el espacio. Se oculta intencionadamente el espesor del elemento, buscando producir la ficción de que el techo es una lámina. La luz se cuela entre el plano curvo y los muros, iluminando el espacio con una luz indirecta que remarca la sensación de levedad del plano. Con ello se obtiene una sensación de serenidad donde el tiempo se detiene y permite disfrutar con plenitud de la obra de arte expuesta y de la propia arquitectura. Comentas la idea de "convertir la parte superior en una representación del cielo contra la que la ruina debería recortarse". Mencionas una obra de Gustavo Torner, "un acero arrugado configurando un horizonte con otro acero completamente liso. Esa especie de planteamiento formal, de encontrar una poética a partir del contraste entre dos realidades, de la tierra y el cielo..." ¿Cómo se llega a esta solución formal?

(Referencias del libro "Peso y Levedad": Teatro Olímpico de Vicenza de Andrea Palladio; Capilla Cuáquera de Houston de James Turrell; Colegio Apostólico de los Dominicos de las Arcas Reales en Valladolid de Miguel Fisac).

R.18: Al techo de la capilla le dimos muchísimas vueltas, yo me harté de dibujarlo. Lo que pasa es que es imposible de dibujar, y también hasta imposible de hacer bien una maqueta ya que no es una superficie reglada, es un casquete esférico. Es de esos espacios en los que las dimensiones no las tienes controladas, así que fue uno de esos ejercicios en los que tienes que tratar de imaginártelo previamente todo el rato. El hecho de haber inclinado el techo, cuando entras no eres muy consciente de que está inclinado, pero sin embargo la altura es enorme, son casi $16 \mathrm{~m}$, pero no lo parece, es de esas cosas que llevó muchísimo tiempo pensarlas. 
Sí... buscas... dices bueno, si fuese convexo pesaría, aquí entras en las especulaciones del libro Peso y Levedad. Dices bueno, si es convexo y dejo la iluminación, pues pasa como en Ronchamp, que la luz te permite la paradoja, pero yo no quería que pareciese que flotase, yo quería que no pesase nada, directamente que fuese un poco el cielo. Era un poco una analogía de una vela de un barco al viento. Ahí hay una paradoja, es como las bóvedas, una bóveda renacentista de cañón blanca, la estás viendo donde se apoya, sin embargo te induce a pensar que flota un poco, y en la capilla este efecto se produce con más fuerza puesto que el apoyo no está. Luego había cosas que te podían resultar familiares, espacios como los de John Soane, o Juan Navarro en Salamanca o en Murcia, pero no era lo mismo, porque ahí Juan Navarro siempre tiene un agujero de luz, como las de John Soane, y lo que yo buscaba era otra cosa, o sea que tampoco me servía como reflexión.

Pero a veces se separa de todo el perímetro.

Sí, se separa del perímetro pero la luz no es cenital, sigue siendo por la pared.

P.19: A medida que se va recorriendo el espacio el plano curvo va descendiendo, reduciendo la escala del espacio y adquiriendo dimensión hasta desvelar su profundidad. Como en los relojes blandos de Dalí, el tiempo se hace presente. ¿Qué se busca con esta variable?

R.19: Se hace por un problema de percepción del fondo, me preocupaba que el fondo fuese tremendamente agresivo, como un frontón. Y quería quitarle importancia a aquello y darle importancia a la verticalidad. Engaña muchísimo, no recuerdo si hay casi 4 o $5 \mathrm{~m}$ de diferencia de cota, toda la longitud que tiene inclinada. Desde ese vértice hasta arriba.

Por otro lado me alegra que me digas eso por una razón, yo creo que está pasando. Yo nunca he pensado para nada en los relojes de Dalí, además los veo como blandos y como para abajo y yo creo que esto lo veo más como una vela. Pero el hecho de poder pensar en eso quiere decir que opera, a lo mejor, como las nubes, en las que tú puedes encontrar un mapa de la Guayana francesa como decía Snoopy o cada uno ve lo que ve, la cara de alguien, entonces, de algún modo, es un espacio sugerente en el sentido literal de la palabra, que a uno le sugiere unas cosas u otras.

P.20: Este plano se introduce en el espacio como un elemento suspendido, abstracto, plástico. Me vienen a la mente múltiples referencias arquitectónicas que trabajan con el tema de la ingravidez: 
8 ARNUNCIO PASTOR, J.C.: Conferencia Materia y Forma IV. Jornadas Internacionales de Arquitectura. 2-4 de Marzo de 2009. http://www.upv.es/ catedrablanca/myf4/INICIO.htm las bóvedas de J.N. Baldeweg, ya comentadas, algunas piezas de P. M. Da Rocha, las cáscaras de Felix Candela o Eladio Dieste, la luz de Tadao Ando, la sensualidad de Alvaro Siza, el Danteum de Terragni. ¿Cuáles son tus referencias, cuales son tus maestros? ¿Es la gravedad el tema fundamental de la arquitectura?

R.20: De los que estás mencionando, de Juan Navarro me gustan muchísimas cosas y muchas de las reflexiones que hace. Paulo Mendes Da Rocha también, no tanto estas cosas de las que hemos estado hablando hoy, quizá me gustan mucho las especulaciones que tiene con el suelo, con el territorio, la manera de encontrarse con la naturaleza, que en el fondo tiene que ver también con lo que estábamos hablando, la idea esa de abstracción o del prisma, de lo introvertido, esa especie de diálogo, cada vez me interesa más ese tema. Y luego tengo cierta debilidad quizá por el mundo ambiguo de alguna arquitectura moderna y local, es decir, algunos episodios de esos como Carlos Raúl Villanueva o como Clorindo Testa y esta gente que me divierte. De los que has citado yo creo que tanto Juan Navarro como Mendes Da Rocha desde luego. Félix Candela me interesa de otra manera, me interesa porque me interesa, pero no tanto como referencia, otra cosa es que en algún momento dado alguna cosa de estas parece que en cuanto introduces una superficie alabeada te está Félix Candela esperando.

Ahora que mencionabas a Carlos Raúl Villanueva me acuerdo de las piezas de Calder estas que tiene en un gran salón de actos, no sé si te acuerdas...

En la biblioteca en la Escuela de Arquitectura de Caracas hay un Calder. Es que es maravilloso, a mí me encanta esa especie como diferencia de cota con una celosía y con el Calder ahí, es que es uno de los espacios que a mí me han parecido..., y además como tremendamente amable, como delicado, la escala, la luz, todo..., yo recuerdo ese sitio como fantástico.

P.21: Una vez más, al igual que ocurre en la construcción de los muros de la capilla, se acude al artificio para obtener un efecto perceptivo. La cubierta con apariencia de elemento continuo y sólido se construye mediante una estructura ligera de elementos de acero revestida con paneles. En el Conservatorio profesional de música y escuela profesional de danza en Burgos aparece la estructura tal y como es, en una zona de la pieza perimetral. Se produce así "un giño en el que el edificio muestra su interioridad en un punto, como en esa actitud que quiere ser pudoroso y de repente ahí uno le descubre sus tripas, era una manera de resolver con cierta solvencia un problema, a la vez que ayuda a que el Salón de Actos se hiciese presente desde algún punto del exterior". ${ }^{8}$ ¿Se trata de una evolución hacia la sinceridad constructiva, o en este caso el proyecto lo necesitaba mientras que en la Capilla se exigía ocultar el truco para evitar romper el efecto? 
R.21: Me divierten las trampas aunque se note que son trampas, quiero decir, me parecen lícitas. Por ejemplo, en el Teatro de Vicenza, las calles de Tebas de Scamozzi y de Palladio, es evidente que son trampas, y está muy bien porque es en el mundo de la representación, en el mundo del sueño, en el lado del escenario de la imaginación. Entonces me divierte muchísimo y me interesa tremendamente el que luego en el lado de la realidad del espectador, no de la ficción, haga otra trampa y la trampa la veas la desveles, y no pasa nada. Pero lo importante en la trampa no es engañarte, es generar una situación, es hacer un artificio del que te vales. $Y$ algo pasa de eso en la capilla, tú miras y está la nube colgando pero no me he molestado en tapar los pilares que si te asomas los ves, los seis pilares, y los ves por el otro lado, podría haberlos tapado con escayola pero me parece irrelevante, pero no por una voluntad de sinceridad constructiva en los términos de las vanguardias, aquella cosa como una ética de la construcción, sino casi como un intento de naturalidad de ciertas cosas, es decir, el efectismo me interesa hasta donde me parece razonable.

\section{O sea, que no se convierta en un manierismo.}

Claro, en una especie de cosa forzada. Concretamente en el tema del Conservatorio de Burgos, yo creo que la ruptura casi pone más en evidencia su condición cerrada, esto es como cuando haces una ventana en un muro de piedra que es un ventanuco pequeño, pues paradójicamente la ventana parece que enfatiza la condición muraria, que es sierva del muro, entonces adivinas la profundidad, es como la huella. Pues a otra escala y de otra manera yo creo que también pasa un poco eso. Un lado que de repente lo rompes, cosa que aparecía también en el concurso de las Cortes de Castilla y León de otra manera.

Este tema a mí me parece muy bonito, me está gustando al final, el rastrear estas cuestiones del engaño y de los recursos de la arquitectura para resolver según qué tipo de problema me parece que es fantástico. Y lo puedes perseguir en mucha gente, en maestros. Es una gozada el verlo, la libertad con la que juegan. El problema está en el hasta dónde desvelar los secretos y hasta dónde no. Yo antepongo una cierta naturalidad ante las cosas. Cuando lo llevas al límite me parece que se empieza a convertir en una afectación. Se pueden hacer analogías hasta con los vestidos femeninos y no femeninos, con los tirantes, y hay un punto de naturalidad que me parece importante en la arquitectura, no sé si tiene que ver con la idea de desabillé que decía Sota pero me parece importante. 



\subsection{ENTREVISTA A JOSÉ IGNACIO LINAZASORO}

Madrid, 28 de diciembre 2012.

Luis Bosch Roig y Valeria Marcenac ${ }^{2}$

P.1: En su currículum se aprecia una formación docente e investigadora muy precoz, llegando a ser catedrático de proyectos de la Escuela de Valladolid con tan sólo 36 años. Esto supone adquirir en poco tiempo una gran experiencia no sólo de la práctica proyectual sino también de la teoría. ¿Cómo influye esta formación en su arquitectura?

R.1: Seguramente influye bastante. Cuando acabé la carrera no construí mucho sino que más que nada me dediqué a proyectar y a hacer concursos. Pero al mismo tiempo entré en una Comisión de Cultura del Colegio de Arquitectos, donde hice unos trabajos de investigación sobre las ciudades medievales del País Vasco, llevando a cabo levantamientos y trabajos relacionados con la evolución de esas ciudades históricas. Por lo que, aunque me he dedicado mucho más al proyecto que a la investigación teórica, siempre ha habido una reflexión que ha acompañado a mis proyectos.

\section{P.2: A lo largo de su vida y de su carrera de arquitecto se ha ido desplazando entre diversas ciudades: San Sebastián, Barcelona, Valladolid, Madrid. También sus proyectos se reparten por diversos lugares de la geografía nacional e internacional. ¿Qué le aporta a su obra este continuo proceso de conocimiento de nuevos contextos geográficos y culturales?}

R.2: Me resulta bastante interesante y coherente con lo que yo pienso de la arquitectura, ya que la concibo siempre como ligada al lugar. El cambio de lugar que se produce en cada proyecto me aporta reflexiones particulares. En ese sentido, no solamente el hecho de haber vivido en Madrid y San Sebastián, pues en Valladolid no llegué a vivir nunca, sino también el haber construido en Castilla, en el País Vasco o en Madrid, y sobre todo fuera de España, es lo que me ha dado una mayor oportunidad de reflexionar sobre determinados lugares.

He tenido la oportunidad de construir delante de la catedral de Reims, o en otras ciudades de Francia como Troyes, en la que estoy haciendo ahora un proyecto, o incluso en Paraguay, donde he realizado la embajada. En cualquier caso para mí el lugar concreto siempre es un punto de apoyo necesario, por lo que procuro rastrear el lugar donde construyo. Por otro lado intento conocer nuevos lugares, intento viajar y analizar obras que me puedan llegar a interesar de los Países Nórdicos, Italia o incluso de Oriente Medio, lugares que aportan indudablemente aspectos que se reflejan en mi arquitectura.
1 En la presente transcripción se han omitido aquellas preguntas de la entrevista que no tenían relación directa con la investigación.

2 Los comentarios realizados por Valeria Marcenac han sido indicados con las iniciales V.M./ 
Sí, son elementos que se van decantando. Por ejemplo, el proyecto que estoy haciendo ahora en Francia, que está en proceso de construcción, es como un relato bastante sintético de muchas cosas que de alguna forma aparecen en otros proyectos anteriores. Por ejemplo el tema de las ventanas que recuerdan a las de las Escuelas Pías, y otros elementos que recuerdan a proyectos míos más antiguos, son repeticiones de temas que voy acumulando a lo largo del tiempo, pero sin una predeterminación. Es decir que yo no intento hacer arquitectura autobiográfica por principio, sino que de alguna forma son elementos que yo conozco y que voy utilizando como un repertorio, elementos que tienen orígenes distintos y a los que les voy introduciendo variaciones.

Por ejemplo el empleo de vigas de canto en la sala polivalente de Troyes, es un tema que ya aparece en la Iglesia de Valdemaqueda, o en el vestíbulo de las Escuelas Pías, pero que también a su vez está relacionado con el famoso Pabellón de Venecia de Sverre Fehn. Si bien en Troyes el orden es mucho más grande que en los otros proyectos, sin embargo sigue respondiendo a ese principio de una viga de hormigón con unos apoyos más o menos puntuales y con una cubierta siempre de madera.

Además en Troyes aparece un elemento abuhardillado, que quizá es un tema nuevo, pero que tiene que ver con la idea de un elemento de remate del edificio. Un concepto que aparece también en el Bar de Gaudeamus de las Escuelas Pías, consistente en un elemento más ligero que se contrapone a una estructura más pesada. En el caso de Troyes consiste en una estructura de madera muy ligera, revestida de yeso, de tal manera que se configura como si fuera un velarium que se apoya en unos pilares macizos metálicos. Con ello busco dar respuesta al uso como Sala del Consejo del Parlamento.

Es una solución que hace referencia al velarium que hay en la Sala Bleu del Ayuntamiento de Estocolmo de Östberg, pero que también tiene que ver con el elemento de aspecto ligero que aparece en la Casa de los Hilanderos de Le Corbusier. Es decir que voy cogiendo referencias y las voy manipulando.

Es un poco por el significado que encuentra en ellas, que parece que le interesa transmitirlo, más allá de su forma concreta.

Claro, se trata de transmitir el significado del elemento. El edificio tiene peso en su parte inferior y va adquiriendo ligereza a medida que va creciendo. A mí siempre me ha gustado esa imagen del Congreso de los Diputados, de cuando llega el Rey y le ponen una especie de gran alfombra sostenida, como un palio que remite a una imagen muy antigua, con orígenes orientales o persas. Así que es como si los políticos estuvieran bajo palio. 
Es un mecanismo un poco inconsciente, que en ocasiones descubro en proyectos míos muy antiguos. Por ejemplo casualmente el otro día viendo un libro vi que ya aparecía ese elemento en un proyecto que hice en el año 90 para el Pabellón de Castilla la Mancha de la Expo de Sevilla, pero el proyecto no se llegó a construir porque el concurso lo ganó Manolo Casas. Más tarde traduje ese concepto en una forma maciza de hormigón para un proyecto en Melilla, pero la solución de Troyes recuerda más a la original del Pabellón de Castilla la Mancha. Es curioso, son cosas que vuelven, son datos articulados, imágenes que se van cogiendo de un lado o de otro.

\section{P.3: Su obra ha despertado interés en varias partes del mundo. En concreto en Italia, dónde ha sido invitado a dar varias conferencias y dónde se han publicado diversas monografías. Parece que cierta arquitectura española es muy valorada en este país. ¿Cómo ve comparativamente la calidad de las intervenciones sobre el patrimonio en España e Italia?}

R.3: La verdad es que yo conozco más los ejemplos antiguos que los que se hacen ahora. Quizá lo que más conozco es lo que han hecho Francesco Venezia, Massimo Carmassi y Giorgio Grassi, tres arquitectos que tienen formas diferentes e interesantes de entender la arquitectura. Los tres tienen una gran cultura, y un gran conocimiento de la arquitectura del pasado y de la arquitectura moderna.

Me parece que Grassi opera desde una postura más esencial, más conceptual, por ejemplo en el caso de Sagunto busca construir cuál es la idea del teatro original, o en el caso del Castillo de Abbiategrasso busca construir la idea de un castillo entendido de una forma moderna. En el caso de Francesco Venecia yo creo que es más intuitiva, es más matérica, interviniendo más desde los materiales, desde la textura, más mediante una apropiación de la materia que del concepto. Y en el caso de Carmassi no lo conozco tan a fondo, solamente recuerdo la intervención que hizo en Pisa que quizá está más cercana a la obra de Francesco que a la de Giorgio.

Hace unos tres años me invitaron a un ciclo en el que participaban estos arquitectos, y un arquitecto que se llama Luca Arcangeli y que estaba haciendo el doctorado en Roma hizo un trabajo interesante intentando diferenciar a cada uno de nosotros desde una postura distinta. Mientras que a Grassi lo identificaba con una tipología, a mí me veía de manera distinta, como intentando integrar en una unidad los fragmentos del pasado y del presente, creando una especie de relato, sobre todo teniendo en cuenta la intervención en las Escuelas Pías. Y este concepto quizá también tiene que ver con el edificio que estoy haciendo en Troyes que aunque es de nueva planta en el fondo es un poco lo mismo. 
3 GARCÍA GRINDA, E.; LINAZASORO, J.I.: "Conversaciones. 1996-1997". En: LINAZASORO, J.I.: Escrito en el tiempo. Pensar la arquitectura. Buenos Aires, NobuKo / UP Universidad de Palermo, 2003, p.92

4 TARASCO, G.: Oltre il restauro: la progettazione contemporanea sulle preesistenze. Tesis de doctorado de investigación en Riqualificazione e recupero insediativo, XXI ciclo, "Sapienza" Università di Roma, Facoltà di Architettura "Valle Giulia", 2009, p.71. (Extraído del libro CARBONARA, G.: Architettura d'oggi e restauro. Un confronto antico-nuovo. Torino, Ed. Utet, 2011, p.82) como en Italia, produce un efecto paralizante de la creatividad, mientras que su defecto, como en España, conlleva actuaciones demasiado autorreferenciales. Más que la aplicación de teorías, me parece que es el estudio meditado de casos lo que ayuda a tomar decisiones. ¿Es este último el camino a seguir?

R.4: Yo creo que la teoría de alguna forma es necesaria para tener una posición ante la arquitectura. La intervención sobre algo construido es doblemente complicada, porque por una parte requiere un entendimiento de la arquitectura que de alguna forma tiene que estar personalizado, no puede ser una abstracción general, pero por otra parte está la realidad sobre la que se interviene que es como una especie de herencia a la que hay que proteger, por lo que se debe de trabajar teniendo en cuenta la situación concreta de cada proyecto, que no es la misma en unos casos que en otros.

Por ejemplo, en Rovereto hemos hecho un proyecto de intervención sobre un edificio con una fábrica austrohúngara del diecinueve que está en bastante buen estado. Se trata de un proyecto muy prudente en el que hacemos muy pocas cosas. Pero hace poco tuve que dar una conferencia en el Colegio de Arquitectos explicando el proyecto y el presidente del Colegio se mostró sorprendido porque no habíamos dejado "la impronta del arquitecto". Para mi eso es lo peor que puede ocurrir. Lo que nosotros buscábamos era actuar de una manera natural intentando resolver los problemas, viendo qué debíamos hacer en cada caso. En la charla puse como ejemplo lo que hizo Siza en el Chiado, donde no aparece la impronta del arquitecto, porque ese no era el objetivo.

Supongo que también depende de la situación que uno se encuentre. $\mathrm{Si}$ el edificio sobre el que se actúa ya tiene un valor, tal vez uno deba someterse. Otro asunto sería que el edificio hubiera perdido su valor.

Claro es que es distinto Rovereto, o el Chiado que las Escuelas Pías. En las Escuelas Pías había un problema de otro tipo, había que habilitar una ruina, era necesario hacer algo, se tenía que notar la impronta del arquitecto.

Y aún así está bastante integrado...

Por cierto este tema me ha recordado a un comentario de Francesco Venezia, a propósito de su obra en Gibellina, donde dice que la idea de crear un patio no le surge visitando el lugar, sino que era una idea previa. ${ }^{4}$ Pero claro, lo que allí quedaba eran sólo unas piedras...

En el fondo son distintos puntos de vista. Francesco quizá opta por hacer su propio proyecto modificando incluso el solar si es necesario. Yo lo haría de otra manera, pero eso no quiere decir que Francesco no lo haga muy bien. 
P.5: Respecto al tema de la historia, usted comenta en una entrevista que ésta "siempre ha estado presente en todos los grandes arquitectos". ${ }^{5} \mathrm{Su}$ interés por la historia se remonta a sus años de formación: el redibujado de iglesias románicas, su investigación sobre las permanencias, su interés por la arquitectura clásica. ¿Es la reinterpretación de la historia la clave de una actuación equilibrada en entornos condicionados por las preexistencias?

R.5: Hasta cierto punto sí. Pero yo la historia la entiendo más como la memoria. Por ejemplo a mí no me interesa la historia como le pueda interesar a Moneo, entendida como un mecanismo de evolución. Sino que a mí me interesa como tradición en el sentido latino de traducere, de lo que dice Maurice Halbwachs de la Mémoire collective, de la idea de la continuidad de las cosas, de lo que permanece. De tal manera que me interesan más las similitudes que las diferencias.

Por ejemplo una iglesia románica no me interesa tanto cómo era sino cómo ha llegado a nosotros, reconociendo qué es lo que permanece, qué tiene de actualidad. En el fondo yo me he dado cuenta de que todo lo que vemos, lo vemos desde nuestra mirada. Podemos hacer una reconstrucción histórica pero en realidad lo que nos interesa no es eso. Por ejemplo si reconstruyéramos el Panteón tal y como fue en origen no nos gustaría, lo que nos interesa es el Panteón como está ahora.

En cierto modo la memoria es una actualización de la historia, es lo que permanece. En este mismo sentido yo no creo en el futuro, sino que creo en el presente en cuanto actualización del pasado.

\section{¿Se debe insistir en este tema en la formación de los arquitectos?}

Por supuesto que sí. Lo que pasa es que la formación de los arquitectos cada vez es más escasa, y desgraciadamente está muy influida por las revistas y la moda. Hace poco en un máster que estoy dando me encontré con un arquitecto que venía de Siria y me dijo que no estudiaban ni a Le Corbusier, ni las antigüedades sirias, sino que sólo estudiaban a Zaha Hadid, lo cual es terrible. Evidentemente yo creo que vamos por mal camino.

\section{V.M./Y parece que no sólo en la Arquitectura porque se está planteando} también lo de eliminar las enseñanzas de las lenguas clásicas, va todo hacia la inmediatez.

Va todo en la misma línea. La inmediatez, la pérdida de la cultura en el fondo. Acabaremos en una edad media tecnológica o algo parecido.

P.6: En su arquitectura se observa una atención a la acción del paso del tiempo. Cuestiones como la esencialidad formal y material, la superposición de estratos, o las arquitecturas inacabadas, remiten a la arquitectura de la ruina. Una arquitectura que, ha ido perdiendo su
5 GARCÍA GRINDA, E.; LINAZASORO, J.I.: "Conversaciones. 1996-1997". En: LINAZASORO, J.I.: Escrito en el tiempo. Pensar la arquitectura. Buenos Aires, NobuKo / UP Universidad de Palermo, 2003, p.95 
ornamentación hasta convertirse en la pura expresión de su construcción, de tal manera que son los materiales los encargados de mostrar la expresividad en la arquitectura. Una arquitectura producto de la suma de los distintos estratos depositados a lo largo del tiempo, derivada de las diversas metamorfosis del monumento a lo largo de la historia. Una arquitectura fragmentada e inacabada, abierta a la recepción de nuevos añadidos. ¿Es éste el camino para la buena relación entre la historia y la modernidad, entre la preexistencia y los nuevos añadidos?

R.6: Yo diría que es una fatalidad. De alguna forma la arquitectura moderna, como la cultura moderna, es una cultura fragmentaria. No hay un único relato, sino que hay muchos pequeños relatos fragmentarios que de alguna forma están condicionados por el sujeto que los realiza. De tal manera que la arquitectura se ve como una forma fragmentaria, parcial, y la relación con el pasado también forma parte de esa relación parcial y de esa reinterpretación parcial de las cosas. Por lo tanto creo que hoy en día es imposible recuperar una unidad, una totalidad como la que pudo haber en el clasicismo antiguo.

Pero, por otra parte, también se debe tener en cuenta la referencia al pasado como tradición, como memoria, igual que pasa con el lenguaje o con la cultura en todos los sentidos. Para no caer en un adanismo tenemos que contemplarnos en el pasado, en lo que somos, pues somos lo que hemos sido. En ese sentido, aunque sepamos que no podemos recuperar el sentido de lo que era la arquitectura del pasado, ni nos interesa porque tenemos otros condicionantes que nos han venido dados desde la ilustración, sí que de alguna forma, cuando hacemos arquitectura contemporánea, debemos tener en cuenta cómo era esa arquitectura del pasado, pero a través de la memoria y no a través de la reconstrucción del pasado.

P.7: La inserción de estos añadidos se realiza a base de diversos fragmentos allá donde son necesarios, buscando mantener un ambiente de armonía con la ruina, instalándose con naturalidad, sin producir disonancias. ¿Cómo se logra este resultado? ¿Parece fruto de un largo trabajo, meditado y detenido?

R.7: Los proyectos que he hecho, en general, por circunstancias ajenas a mi voluntad, siempre me han durado mucho tiempo. Quizá porque han sido proyectos un poco complicados, de gestión difícil. Por ejemplo el proyecto de Las Escuelas Pías fue un concurso que fue desarrollándose muy lentamente. Desde que se hizo el concurso hasta que se acabó el proyecto pasaron ocho años. También en el proyecto de Troyes el concurso lo ganamos hace cuatro años y todavía le queda un año para acabarse, por lo que habrán pasado cinco años desde que se empezó. De tal manera que da tiempo a darles bastantes vueltas a los proyectos y a pensar bastante las cosas. Por lo que la experiencia se va acumulando a lo largo del tiempo. En definitiva, yo creo que es el tiempo lo que hace que esas cosas vayan cuajando mejor o peor. 
Claro, y de alguna forma, una vez que has aprendido a quitarlas en un proyecto, en el siguiente ya no las vuelves a hacer, sino que incluso sigues quitando más capas, de hecho en Troyes ya sólo quedó el hormigón visto, es decir que ya se quedó sin capas. Por lo tanto sí que es verdad que ese quitar, ese pulir, es acción del tiempo y también acción de la experiencia que se va acumulando.

P.8: Ante esta realidad, surge la necesidad de introducir sistemas de conexión entre los fragmentos. Estrategias como el recorrido, las referencias a un todo que evocan los fragmentos, la esencialidad material. En el caso de las referencias, alguna vez ha mencionado el tema de la arquitectura entendida como una virtualidad de la construcción. ¿Puede aclarar un poco en qué consiste este tema? ¿Cómo se materializan estos conceptos?

R.8: Son temas un poco complejos. Yo partiría de la idea de que la arquitectura no es construcción, sino que es imitación de lo constructivo. Es decir, metáfora de la construcción más que construcción, pero siempre entendiendo que el lenguaje de la arquitectura parte de la construcción. Se trata por tanto de una paradoja. La arquitectura no es una tékne es una arché, que dirían los griegos. Por lo que en cuanto a arché supone algo que va más allá de lo constructivo pero que se basa en lo constructivo. El hecho artificial de la construcción, de alguna forma, es el lenguaje propio de la arquitectura, que no puede prescindir de él. Por eso yo no creo en la arquitectura de la imagen, la arquitectura de la ballena, o la arquitectura de la nube, sino que realmente creo en la arquitectura como metáfora de la construcción siempre.

En algunos casos he hablado de la paradoja de la construcción, por ejemplo a propósito de Lewerentz. En realidad la paradoja tiene que ver también con la situación contemporánea de la imposibilidad de articular un único discurso. Ese discurso, al no ser único y al ser fragmentario, de alguna manera se articula mediante paradojas. Es un poco como lo que pasa con la teología negativa o con la mística, como cuando San Juan de la Cruz habla de la música callada o de la soledad sonora, donde introduce conceptos en cierto modo contradictorios. Soledad y sonora, música y callada, son paradojas que de alguna manera intentan abarcar la idea de totalidad, la idea de Dios, del uno, visto desde distintos puntos de vista contradictorios. De la misma manera, en el caso del orden de la arquitectura, en cuanto que ese uno, esa unidad, es algo escondido o desaparecido, se articula también mediante discursos paradójicos y parciales, que de alguna manera intentan aproximarse al problema desde distintos puntos de vista. 
P.9: Otras estrategias empleadas son la manipulación de la preexistencia y de su pasado. Por ejemplo a través de la transformación de la organización original del edificio para adaptarla a las nuevas necesidades funcionales y las nuevas exigencias de relación con el lugar, o mediante la "interpretación de un pasado ficticio proyectado hacia el futuro". Parece que se prefiere evocar a diversas arquitecturas de la historia, más que a la historia concreta de la arquitectura sobre la que se actúa. ¿Puede poner algún ejemplo de este último tipo de transformación?

R.9: Esto del pasado ficticio yo lo he mencionado anteriormente en relación con una cita de Machado en su obra "Juan de Mairena". Un pasado ficticio es ficticio en cuanto que es una reinterpretación. Es decir, que no existe una realidad absoluta, sino una realidad tamizada por la experiencia del sujeto, que se nutre a su vez de otras realidades, de otras experiencias. Con lo que cualquier análisis de la realidad es un análisis ficticio.

Por ejemplo en Troyes toda la fragmentación que tiene el proyecto -la parte del palacio, el edificio del auditorio, etc.- de alguna manera yo la pongo en relación con otras experiencias -la relación con las iglesias góticas, con el tejido urbano, con la idea de la alineación, lo plano-. De tal manera que me encuentro con que en la ciudad está lo que yo he hecho. Incluso cuando tuve que explicar el proyecto a las asociaciones de defensa del patrimonio lo hice con ejemplos extraídos de la ciudad, y para mi resultó muy fácil porque es así como yo lo veo. $Y$ en cierto modo esta es una lectura ficticia.

Estoy pensando que en las Escuelas Pías nunca se propone volver a la gran iglesia barroca sino que, al contrario, parece que los fragmentos están evocando otros mundos.

Sí, es como lo que decía Baudelaire de las Correspondances. Establezco otras correspondencias entre fragmentos. Por ejemplo la rotonda me lleva a la Minerva Medica, a su implantación al lado de la Estación Termini de Roma; la cripta del aparcamiento me lleva a las catacumbas o a la cisterna mirabilis de campi flegrei de Nápoles, etc. De tal manera que cada elemento adquiere una carga de intensidad en función de referencias o vivencias personales.

Pero no son solamente referencias personales, sino que parece que están también en la propia colectividad...

Claro, no son imaginaciones mías, sino que son reelaboraciones de la realidad. Para mí el ejercicio consiste no tanto en reconstruir realidades que ya existían sino en transportar fragmentos presentes en la colectividad a una nueva realidad, tratando de ponerlos en contacto unos con otros. 
P.10: También está muy presente en sus obras el juego compositivo de relación entre conceptos opuestos, lo que Ignasi de Solá-Morales describe como la "asunción del conflicto como motor del proyecto". ${ }^{6} 0$ también lo que Adriano Cornoldi define como el equilibrio entre la retícula y el arco, donde la primera da orden y la segunda identidad. ${ }^{7}$ Concepto que está presente en la iglesia de San Lorenzo Mártir en Valdemaqueda, en las Escuelas Pías con el juego entre el nuevo altillo y las bóvedas, en el concurso para la catedral de Ischia, o en su escrito de "La renovación proyectual en el bajo imperio y la crisis del clasicismo grecorromano". ${ }^{8}$ ¿Qué significado tiene para usted este juego en su arquitectura?

R.10: Este tema tiene que ver con un concepto bastante clásico y tradicional de cubrición del espacio, de entender la arquitectura como una superposición de dos órdenes, de tal manera que existe siempre un basamento y sobre éste algo que se apoya encima. Este concepto se aprecia con diversos matices en el proyecto de Troyes: mientras que en la sala polivalente se produce una articulación de superposiciones, sin embargo en la sala del consejo se introduce un elemento que flota sobre el espacio. Pero en ambos casos hay una reflexión sobre el tema de la cubierta y la base, por una vía más o menos tectónica.

En las Escuelas Pías por ejemplo, la supuesta bóveda tiene también un carácter no completamente tectónico. Es más parecido a un umbráculo, como algo que flota. Mientras que en la sala polivalente de Troyes, o en Valdemaqueda, se produce claramente una superposición. Pero en cualquier caso siempre hay dos elementos: el muro y la superposición encima del muro. En mis proyectos siempre intento adoptar una postura bastante esencial respecto a este tema, en el fondo es el resumen de algunos aspectos de la arquitectura que he ido elaborando a lo largo del tiempo.

Estos temas ya me los planteo en el artículo que hice en los años 80 sobre la época tardorromana -que es un artículo bastante central dentro de la evolución de mi arquitectura-, en el proyecto de la iglesia de Santa Cruz de Medina de Río Seco, o en la cubierta de la biblioteca de la UNED.

En resumen, reconozco dos principios compositivos que se producen a lo largo de la historia: en primer lugar la relación entre la estructura y el apoyo, en un sentido clásico, tectónico, y en segundo lugar la solución más ilusionista del velarium, del no apoyo, de la construcción de la bóveda en el aire. Así por un lado, en Santa Sofía y en lo paleocristiano esta relación es más ilusionista, porque los elementos arquitectónicos pierden la materialidad, y aquí entraríamos en el discurso de Sedlmayr sobre las formas etéreas o no tan tectónicas de la arquitectura paleocristiana pero sobre todo de la arquitectura bizantina al revestirse de materiales brillantes. Y por otro lado está la idea clásica, más tectónica de los apoyos. Por lo que yo intento compatibilizar en mis proyectos los dos sistemas en función de las sugerencias de cada caso.
6 de SOLÁ-MORALES, I.: "Imitación Esencial. La Arquitectura de José Ignacio Linazasoro", 1998. En: Linazasoro, J. I.: Evocando la ruina. Sombras y texturas. Centro cultural en Lavapiés. Madrid, 2005, pp. 8-13

7 CORNOLDI, A.: "La Armoniosa Relación de lo Nuevo y de lo Antiguo". En: PRESI, S.: José Ignacio Linazasoro. Progettare e Costruire. Latina: Casa dell'Architettura, 2007, pp. 239-243

8 LINAZASORO, J.I.: “La Renovación Proyectual en el Bajo Imperio y la Crisis del Clasicismo Grecorromano. diciembre-enero 1986-87". En: LINAZASORO, J.I.: Escrito en el tiempo. Pensar la arquitectura. Buenos Aires, NobuKo / UP Universidad de Palermo, 2003, pp.18-33 
Al mismo tiempo se produce una reflexión sobre la permanencia de estos estratos, en un sentido de acumulación temporal, que remite a una idea fundacional de la arquitectura, en la línea de lo que comenta Vitruvio sobre el origen de los órdenes. En este sentido se podría entender que existe un origen de madera que con el tiempo se convierte en un material pétreo, que en este caso es el hormigón, y que de alguna forma guarda el recuerdo a través del encofrado, de la tablilla que reproduce el origen de la primitiva arquitectura de madera. Y luego habría un segundo tiempo más reciente en el que se apoyaría la madera sobre el hormigón, de tal manera que si ese edificio revirtiera a la ruina, lo que quedaría finalmente sería el muro de hormigón, pero desaparecería la madera e incluso la cubierta. Por lo que en definitiva se produce una acumulación de tiempos distintos dentro del propio edificio.

\section{Es como si los materiales fueran solidificando con el tiempo...}

Sí, y el más antiguo sería el que ya se ha convertido en pétreo, y el último sería la cubierta de yeso que, como en el caso de la sala del consejo de Troyes, envuelve el espacio con una componente de ingravidez.

\section{Muy interesante el discurso...}

Son discursos que no se pueden reducir al problema de la restauración, sino que también se pueden aplicar a la arquitectura en general, aunque es interesante destacar que tal vez son problemas que han surgido desde la restauración. Es decir que a lo mejor estos problemas me los he tenido que plantear cuando he tenido que operar en esas situaciones en las que había una reflexión sobre la superposición a lo largo del tiempo. Por lo tanto estaríamos haciendo un discurso ficticio pero que viene de un discurso real. De hecho, por ejemplo, no es extraño que arquitectos como Zumthor, que empezaron haciendo restauraciones, luego hayan ido evolucionando a una arquitectura que tiene que ver con la arquitectura del pasado.

V.M./ Es particularmente interesante también este tema por esta especie de separación que hay, sobre todo en Italia, entre los arquitectos que restauran y los arquitectos que proyectan obra nueva, como si fuesen dos mundos que no se tocan ni lo más mínimo, y sin embargo se pueden enriquecer muchísimo.

Yo entiendo que sí. Estuve viendo una exposición de Labrouste en París hace 15 días - de la que hay un catálogo muy bueno- y pude comprobar que en su discurso sobre los levantamientos de las ruinas de Paestum está toda su arquitectura. Sus dos proyectos para las bibliotecas solamente se explican si se entiende lo que él pensaba sobre cómo había evolucionado la arquitectura antigua, que frente a la visión academicista de producción de una arquitectura cada vez más purista, propone una visión de la arquitectura en la que lo purista es lo primero y la contaminación de la realidad lo va 
haciendo cada vez más impuro. Con lo cual se entiende que la arquitectura es un campo que se puede extender porque va confrontándose con la situación particular de cada lugar. Al leer estas reflexiones de Labrouste me sentí absolutamente identificado con él -Labrouste es una arquitecto que siempre me había interesado muchísimo, incluso tengo dibujos de sus bibliotecas-. Esta idea de que las cosas se pueden ir enriqueciendo a base de hacerse, no perfectas, sino más impuras, es algo que yo comparto, como dicen los italianos yo condivido.

Que además es una manera también de permitir la apertura a nuevas adiciones, a la evolución.

Efectivamente, eso es lo que te da esperanza de poder seguir haciendo cosas.

V.M./ Es un poco el tema de la continuidad, no sólo continuidad entre partes sino también el tema de la continuidad histórica. En el fondo, un edificio inacabado que continuará transformándose y que de alguna manera seguirá vivo.

Es como la genial actuación de Alberti en el Templo Malatestiano, en la que Matteo de' Pasti hace la intervención interior de la iglesia en estilo tardogótico, y a la vez Alberti hace las fachadas exteriores. Y en el proceso hay un momento en el que Matteo de' Pasti le indica a Alberti que los ejes de las ventanas góticas no coinciden con los ejes de los arcos renacentistas, pero a Alberti le da igual, no le importa que se vean los desplazamientos de las ventanas y que se evidencie la superposición de los dos estratos. Con lo que se observa que Alberti no era un purista sino todo lo contrario, le interesaba la concinnitas, la suma y confrontación entre fragmentos.

Hace poco leí una conferencia de Moneo que hablaba sobre el lenguaje. A Moneo le interesa muchísimo el lenguaje. Sin embargo yo pienso que a Alberti no le interesaba nada el lenguaje, sino todo lo contrario. Si bien tanto en el siglo XIX como en las vanguardias se busca un lenguaje, sin embargo yo creo que en un principio el lenguaje no era una búsqueda, sino algo con lo que uno se encontraba. Alberti quería hacer la arquitectura de los romanos y utiliza el lenguaje de los romanos, pero no quiere hacer una arquitectura basada en el lenguaje, sino una arquitectura como la que hacían los romanos, que es otra historia mucho más profunda.

P.11: En las actuaciones de intervención sobre el patrimonio, se le suele dar un valor fundamental al levantamiento minucioso del estado de las preexistencias, y a la evolución histórica del monumento a lo largo del tiempo. Pero algunos arquitectos comentan que estos estudios pueden producir excesivos vínculos con la realidad, coartando la visión subjetiva del arquitecto. ¿Cómo ha planteado el proceso de toma de datos en el caso de las Escuelas Pías? ¿Existe un interés por analizar en profundidad cómo era el edificio original? 
R.11: En realidad a mí me ha pasado una cosa muy curiosa, y es que tanto en las Escuelas Pías como en Medina de Río Seco, no he tenido mucho acceso a una documentación previa. En las Escuelas Pías porque realmente hay muy poca información sobre cómo era realmente ese edificio. Fue un edificio que se construyó en un tiempo bastante dilatado, en el que hubo dos arquitectos que intervinieron. Yo creo que se acabó ya en el siglo XIX, porque de hecho la portada de acceso a los claustros del edificio escolar era una portada neoclásica.

En el fondo yo me sentí fascinado por la ruina, me pareció que era lo más atractivo, entender la ruina como actualización de la memoria. Pero depende de cada proyecto. En otros casos tal vez sea necesario un análisis más profundo, pero de cualquier modo no creo que el análisis conduzca necesariamente a una solución de proyecto. La actitud de Francesco Venezia me parece que está en el polo opuesto, pero es que en realidad Francesco opera con un conocimiento del pasado muy profundo. En realidad no necesita hacer este tipo de análisis porque ya los tiene asimilados, y ese conocimiento le permite operar con naturalidad. No es una persona extraña a ese mundo sino que forma parte de ese mundo.

Sin embargo es verdad que el análisis pormenorizado no lleva a nada. Este es un debate que se planteó en Italia en los años 70, bajo la denominada Relazione analisi-progetto, que defendía que era necesario un análisis para llegar al proyecto. Se trataba de una teoría apoyada por Muratori, pero que al final llevaba a repetir casi los tipos arquitectónicos del pasado actualizándolos a la contemporaneidad, algo que realmente tampoco tenía mucho sentido. Por lo tanto yo creo que si bien es necesario conocer las preexistencias, ese conocimiento no es suficiente, se debe producir un salto.

Los arquitectos restauradores italianos lo tienen como un paso imprescindible del proyecto, y parece que vierten muchísima energía en este proceso y luego es como que el proyecto se resiente.

Sí, porque luego también eso puede crear incluso cierta restricción a la hora de intervenir. De todas maneras, por suerte o por desgracia, en general, en casi todos los países europeos hay cada vez más conciencia de la protección de las cosas. Es verdad que también la alternativa puede ser peligrosa. En el fondo se trata un poco de aquello que dijo Richard Neutra cuando le llevaron a Ávila y le preguntaron: ¿usted cómo haría aquí un edificio?; y respondió: yo llamaría a un buen arquitecto. Al final se trata de eso.

\section{La calidad del arquitecto...}

No es exactamente así, pero al final algo de eso tiene que haber. 
P.12: El proyecto de intervención sobre las ruinas de la iglesia de las Escuelas Pías, opta por proponer nuevos elementos sobre los preexistentes, sin pretender reconstruir el edificio original tal y como era. ¿Se llega a plantear, en algún momento del proceso de proyecto, la posibilidad de la reconstrucción de la forma original?

R.12: No, en ningún momento, me parecería anacrónico. El otro día me comentaron que en Málaga estaban planteando la posibilidad de completar la Catedral, de construir la torre que le falta y de cubrirla con una cubierta a dos aguas. ¿Pero qué sentido tiene hacer una torre neoclásica hoy en día? Pero si ni siquiera Viollet-Le-Duc se atrevió a reconstruir las agujas de Nôtre Dame o de la catedral de Reims! Todavía en el diecinueve se confiaba en el neogótico como un estilo contemporáneo, pero ahora el neoclásico no es un estilo contemporáneo.

Pero tampoco tiene sentido la reconstrucción en estilo moderno, porque el problema es que, como diría Sedlmayr, la "tarea rectora" de hoy no es hacer torres. Por la misma razón tampoco tenía sentido reconstruir la iglesia de las Escuelas Pías tal y como era. Puede haber algún caso excepcional como por ejemplo lo que se ha hecho en Dresde con la Frauenkirche, pero eso ya es una reconstrucción de algo que realmente había existido y que se había derruido. O por ejemplo puede que también tenga sentido la reconstrucción de la Bauakademie de Schinkel, pero una cosa que nunca se había hecho, que nunca se había construido... Además en el caso de las Escuelas Pías tampoco creo que la iglesia fuera un cappo lavoro como para reconstruirla.

\section{Si, digamos que está en cierta manera relacionado con la motivación. Por ejemplo si hay una acción bélica o traumática que destruya de forma violenta un monumento, parece como que está en cierta manera justificada su reconstrucción.}

Imaginemos que hay un terremoto y se cae la Catedral de Burgos, pues a lo mejor tiene sentido reconstruirla. Porque sabemos todo como era perfectamente. Tenemos las piedras, la reconstruimos y se acaba el problema, tampoco tenemos porqué plantear las cosas desde un punto de vista ético hasta ese extremo sólo porque sea una construcción gótica.

También cabría otra solución interesante como por ejemplo la de la linterna de la Catedral de Burgos construida inicialmente por Juan de Colonia, y reconstruida posteriormente por Juan de Vallejo. Se trata de una solución que, si uno se fija en los detalles, es totalmente renacentista, pero si uno ve la linterna desde lejos parece gótica. De tal manera que Juan de Vallejo es capaz de hacer algo con apariencia gótica pero que en un estudio minuciosos es capaz de desvelar su origen del siglo XVI. Este concepto también está presente en la fachada de la Catedral de Toledo, en la que hay elementos clásicos pero dentro de una intervención con apariencia gótica, o también en la actuación en la Abadía de Westminster donde las torres son de Christopher Wren del diecisiete. Se reconstruye una parte pero dándole un cierto testimonio de su época. 
También en Noto, en Italia, han reconstruido la catedral, que un terremoto había derruido. Pero parece que la reconstrucción tal y como era no aporta nada desde el punto de vista del proyecto.

Respecto a este tema se produjo un debate muy interesante que se planteó en Alemania, concretamente en Colonia. En Colonia estaba Rudolf Schwarz que defendía la postura de reconstruirlo todo de una forma moderna, pero manteniendo la imagen del pasado, y por otro lado estaban los conservacionistas a ultranza que querían reconstruirlo todo como era. Al final se optó por una solución intermedia, de manera que las iglesias románicas que normalmente eran obras maestras como St. Maria im Kapitol, San Gedeón, etc., se reconstruyeron tal y como eran, mediante anastilosis, sin embargo en otras se hicieron cosas más mixtas. En esta línea intervino también Dominikus Böhm.

Me ha venido a la memoria también la intervención en la Alte Pinakothek...

La Alte Pinakothek de Döllgast es una actuación muy interesante, de una solución intermedia. En el fondo esto tiene que ver también con el criterio de la restauración de la Catedral de Uppsala de Lewerentz que busca desrestaurar lo neogótico y volver a la situación anterior. En el caso de Döllgast se busca volver a la idea de muro desnudo y hacer desaparecer los órdenes superpuestos.

P.13: La función de biblioteca adoptada para el edificio de las Escuelas Pías no era la prevista inicialmente. Seguramente la solución adoptada hubiera sido distinta si la función de iglesia se hubiera mantenido. ¿En que medida ha influido el uso en la arquitectura, y en qué medida debe influir el arquitecto en la elección del uso de los edificios?

R.13: Sí, evidentemente influye, porque forma parte sustancial de la arquitectura el que un edificio sea una iglesia o sea una biblioteca. Son cosas muy diferentes y seguramente habría influido. Sin embargo pienso que aunque hubiese sido una iglesia no la habría reconstruido tal cuál. Pero seguramente no habría sido exactamente igual que una biblioteca, porque de hecho, como ya he comentado alguna vez, el uso como biblioteca supuso una serie de transformaciones a nivel de escala, al ocuparse el espacio por una escala más humana que no era la escala de lo sacro. Por lo tanto yo creo que el uso habría influido en la forma de hacer el proyecto sin ninguna duda.

Aunque sí que tiene un cierto ambiente de iglesia, quizá no barroca, pero sí un poco medieval.

Quizá influyen mis tendencias románicas. Tal vez al final los edificios que hago acaban siendo un poco templarios. 
P.14: ¿Qué actuaciones se han realizado sobre las fábricas de la ruina de las Escuelas Pías?

R.14: Sobre la ruina muy poco. La ruina se consolida un poco en las partes superiores, pero prácticamente no se hace nada más, porque incluso cuando se introducen las puertas y carpinterías los huecos se dejan descarnados y no se reconstruyen. En realidad la ruina sirve más como un material de apoyo que de reconstrucción.

Sí, además de alguna manera la presencia de la textura ayuda a entender mejor el concepto de elemento fragmentado. Porque si se hubiera planteado la restauración, como hacen a lo mejor en Italia, restituyendo todos los ornamentos, tal vez habría cambiado completamente el concepto.

Claro.

P.15: En sus obras y escritos aparecen múltiples referencias a arquitecturas de la historia, desde elementos clásicos a elementos modernos. En el caso de las Escuelas Pías se reconocen referencias a arquitecturas romanas, paleocristianas o románicas, pero también a obras de arquitectos modernos como Le Corbusier, Aalto, Pikionis, Van der Laan o Lewerentz. Obras que a su vez miran a aquellas primeras.

R.15: Sí, eso que dices está bien visto. En realidad eso es precisamente lo que yo comento sobre lo que indica Focillon de las famille spirituelle. Se trata de entender la idea de que hay familias de arquitectos, que de alguna manera bebemos unos de otros, de forma que hay un sustrato o unas miradas sobre temas comunes, que producen una comunidad de intereses familiares.

Pero a mi modo de ver la familia es algo distinto a la idea del eclecticismo, porque en el fondo tanto en las Escuelas Pías como en Troyes no se trata tanto de una suma de cosas distintas, como de una comunidad de intereses que de alguna manera hace que esas distintas referencias estén articuladas ya en un principio. Porque, en cierto modo, el hecho de constituir una familia o formar parte de esa familia hace que tú ya de una forma natural veas esas cosas que han visto los demás con su misma mirada o con una mirada común. Con lo que no existe el peligro de que aparezcan elementos sueltos.

Efectivamente, si uno piensa en Pikionis, también ve uno los fragmentos, las ruinas y las piedras viejas reutilizadas. Es decir, esa mirada sobre ese material ya se había producido en Pikionis, o se había producido en los arquitectos que has citado, o incluso en Le Corbusier que es bastante acumulador, explorador de muchos mundos. En el fondo yo creo que las referencias no pueden ser referencias eruditas en el sentido negativo, sino erudición positiva en el sentido de acumulación de conocimientos. 
Si nosotros analizamos nuestro lenguaje encontramos que las palabras tienen orígenes diferentes: hay palabras de origen latino, de origen griego, de origen germánico, pero todas estas palabras están articuladas en un lenguaje, no son elementos dispersos, sino que forman parte del lenguaje. Entonces, en la medida en la que uno forma parte de esa familia, ese lenguaje ya se tiene, no es necesario buscarlo. En el fondo se trata de acumular una lengua materna que tú ya controlas, mejor o peor, incluso con sus imperfecciones, o quizá precisamente gracias a sus imperfecciones es un lenguaje particular.

¿Y existe una referencia concreta en la elaboración de la materialidad de las bóvedas empleadas para cubrir el espacio de las Escuelas Pías?

Pues, concreta no. Son cosas que van saliendo, producto de la experiencia del oficio. Recuerdo que la contrata quería quitar madera, pero yo hice una prueba y me di cuenta de que aquello no funcionaba, y me empeñé en que tenía que ser como en el proyecto. Pero venía dado de un proceso de prueba y error. Se hicieron dos maquetas globales y varias maquetas parciales de la bóveda, hubo mucho trabajo de ese tipo.

\section{¿Y respecto a la forma del perfil que recuerda a una bóveda rebajada?}

El perfil rebajado venía dado por la idea de crear una tensión en el recorrido, y también para tratar de que no fuera exactamente igual que la bóveda antigua. De alguna manera se conseguía el efecto de que cuando uno caminara por dentro de la nave se encontraría con el grupo escultórico parcialmente oculto, provocando la necesidad del recorrido para poder verlo completo.

Y lo de que fuera una bóveda y no un elemento plano yo creo que también remite al significado de esa bóveda original.

Sí, tiene que ver. En el proyecto para el concurso ya aparecía esa bóveda pero era una solamente, luego ya se hizo la otra por la necesidad de ampliar la nave lateralmente. Pero yo creo que la forma también tiene que ver con la presencia del arco. Recuerdo que tuve dudas, Incluso tengo algún dibujo de una cubierta plana manteniendo el arco debajo. Si bien entendía que la cubierta plana era más segura, sin embargo me pareció que era más atrevido jugar en este terreno de la ambigüedad, donde incluso podía ser acusado de historicista. En cierto modo, también hay que jugar a arriesgar un poco.

La verdad es que tuve dudas hasta que la vi construida, incluso me planteé si tenía que haber sido un poco más esencial en este asunto. Hice dibujos de una solución más similar a la empleada en Valdemaqueda, pero había un cambio de dimensión tan importante que me pareció que transportar esa idea de Valdemaqueda podía quedar fuera de escala. Los dos proyectos se hicieron casi a la vez, el proyecto de Valdemaqueda es 
un poco posterior, pero la ejecución se acabó antes. En cierta manera en Valdemaqueda tuve ocasión de experimentar a pequeña escala cosas para las Escuelas Pías, puesto que hay ideas comunes en los dos proyectos. La bóveda venía del proyecto de las Escuelas Pías, incluso en algún croquis inicial de Valdemaqueda tuve esa bóveda, luego la quité en Valdemaqueda, pero la mantuve en las Escuelas Pías. Podría ser interesante contar los dos proyectos en paralelo, analizando cómo fueron evolucionando. Son dos proyectos que tienen que ver, pero de distinta escala, y además uno sigue siendo una iglesia y el otro no.

V.M./ A mí la bóveda me hace pensar en la arquitectura de Alvar Aalto, quizá en la Maison Carré, puesto que está bastante clara esa dualidad entre lo másico y lo ligero.

Sí, Bryggman también lo emplea en la iglesia del cementerio de Turku y también Utzon en Bagsvaerd. Sí, quizá estas obras también estaban presentes cuando hice el proyecto. Es un tema que está en esas coordenadas.

\section{V.M./ En definitiva es la interpretación de lo bizantino.}

Sí, incluso muchas iglesias de Juha Leiviskä, o de Alvar Aalto tienen que ver con lo bizantino tal vez debido a la conexión que se produce a través de Rusia.

Yo había pensado como referencia en el frontón de recoletos de Madrid. Pero en realidad creo que es más una cuestión funcional. Construir una doble bóveda para cubrir un espacio central y uno lateral.

Sí, eso ya lo ha comentado alguno, pero es absolutamente casual, aparte que estructuralmente no funciona igual. Podía haber sido intencionado, no me hubiera importado nada reconocerlo. Esto te plantea si realmente hay cosas que se parecen porque el arquitecto se ha fijado en ellas o porque han surgido por casualidad, porque también es verdad que hay un número limitado de opciones y hay que escoger alguna.

Tal vez la incorporación de la segunda bóveda tiene que ver, aunque formalmente no se parece, con la iglesia de Almtuna en Uppsala de Celsing, donde construye tres bóvedas contiguas. En realidad surge por la necesidad de hacer una nave lateral, y también por darle al edificio un sentido transversal frente a la idea de axialidad. Si uno se pone en el centro de la nave mirando hacia la nave lateral puede apreciar un escalonamiento entre el banco, la estantería y el altillo que acompaña a la bóveda. 
Por otro lado también la solución de la bóveda me recuerda a las cubiertas de grandes tejas que utiliza Lewerentz, o a los pórticos de madera que tiene en la iglesia de Björkghagen.

Sí, también tiene que ver con lo de Lewerentz. Eso curiosamente se parece muchísimo a un sistema que hizo Tadao Ando para el Pabellón de la Expo, que tenía unos pilares con el mismo sistema. Yo creo que eso sí que está basado en lo de Lewerentz. Sí, sí, eso también recuerdo que lo vi, lo manejé en aquel momento, en realidad también es de la familia. 


\subsection{ENTREVISTA A GIORGIO GRASSI.}

Valencia, 12 de mayo de 2011.

Luis Bosch Roig, Valeria Marcenac y María José Ballester Bordes

Tras muchos años sin visitar Valencia, Giorgio Grassi aceptó la invitación a participar en el WorkShop Internacional "Construcción de la Memoria", organizado en el marco del Máster Oficial en Conservación del Patrimonio Arquitectónico, y así es como se ha reencontrado con estas tierras valencianas, donde ha cultivado amistades y compartido su sabiduría, no sólo a través de la docencia sino también a través de sus obras, que han tenido gran repercusión y han dado lugar a acaloradas polémicas...

Grassi siempre ha sido considerado por las universidades españolas, y especialmente por las escuelas de arquitectura, como un referente teórico y práctico a la hora de enfrentarse a las actuaciones sobre las preexistencias. En el momento actual, de crisis y desconcierto en general, y particularmente en el campo de la arquitectura, en el que vemos que las actuaciones de arquitectos-estrella han ido convirtiendo nuestras ciudades en "parques temáticos", nos parece oportuno recoger la opinión de un referente como Giorgio Grassi.

Breve reseña biográfica:

Giorgio Grassi (Milán, 1935), es profesor ordinario de Proyectos Arquitectónicos en la Facoltà di Architettura Civile del Politecnico di Milano, aunque también ha enseñado en la Facoltà di Architettura di Pescara, en la ETSA (Escuela Técnica Superior de Arquitectura) de Valencia, en la EPF (École Polytechnique Fédérale) de Lausanne y en la ETH (Eidgenössische Technische Hochschule) de Zúrich. Es miembro de honor del BDA (Bund deutscher Architekten) y de la Internationale Bauakademie de Berlín.

Ha ganado numerosos concursos de arquitectura y ha realizado interesantes obras como sus intervenciones en los castillos de Abbiategrasso (1970) y de Fagnano Olona (1980-84); la casa del estudiante en la Università di Chieti (1976-79); el plan de recuperación del centro histórico de Teora (1981-84) y su iglesia Madre (1983); en Xàtiva, la intervención en el Almudín (1983-85) y en el tramo de muralla del Vellveret (1983); la intervención en el Teatro Romano de Sagunto (1985-92); la biblioteca municipal de Groningen (1989), la biblioteca de la Universidad de Valencia (1990); el complejo edilicio del área ABB Roland Ernst en Potsdamerplatz, en Berlín (1993-2001); entre otras... Por sus obras ha recibido importantes premios, como el "Premio de arquitectura de la Comunidad Valenciana" (1985), la "Heinrich Tessenow Medaille in Gold" de la Stiftung FVS de Hamburgo (1992) y el "Architektur-Preis Berlin" (2003).

Fue miembro de la redacción de la revista Casabella entre los años 1961 y 1964, dirigida por E.N. Rogers. Entre sus escritos cabe destacar La costruzione logica dell'architettura (Padova, 1967; Barcelona, 1973; Nijmegen, 1997; Torino, 1998; Milán, 2008), L'architettura come mestiere 
e altri scritti (Barcelona, 1979; Milán, 1980; Bruselas, 1983), Architettura lingua morta (Milán, Hamburgo y Nueva York, 1988; Barcelona 2003), y más recientemente Scritti scelti 1965-1999 (Milán, 2000; Lucerna, 2001), Leon Battista Alberti e l'architettura romana (Milán, 2007) y Una vita da architetto (Milán, 2008); y entre las publicaciones sobre su obra, cabe destacar Giorgio Grassi opere e progetti (Milán, 2004).

L.B./ Para comenzar, nos gustaría que nos hablara de sus primeros pasos en la arquitectura: usted fue discípulo y colaborador de Ernesto Nathan Rogers, podría contarnos su experiencia durante aquellos años...

Ernesto Nathan Rogers era el único profesor que nos hablaba de arquitectura en la escuela. Desde el primer año hasta el quinto, íbamos a oír sus lecciones los sábados por la mañana, que era cuando daba sus clases. Él daba un curso llamado "Caratteri stilistici dell'architettura" [Características estilísticas de la arquitectura], era algo así como un curso de historia, al final del cual los estudiantes tenían que hacer una pequeña tesis. Rogers contaba con cuatro asistentes: dos de ellos eran de la vieja escuela [Liliana Grassi y Carlo Perogalli], discípulos de Ambrogio Annoni - un viejo profesor que escribió libros muy importantes sobre restauración-, y los otros dos eran mas jóvenes, uno era Silvano Tintori y el otro Vittorio Gregotti.

Rogers enseñaba en tercer año, pero la costumbre era que los estudiantes que tenían particular interés hiciesen el examen de su curso como último examen de la carrera, como si fuera una especie de tesis final. Y yo hice esa tesis sobre Berlage y su Bolsa de Amsterdam. Al final del curso, me llamó Vittorio Gregotti y me dijo que quería publicar la tesis en la revista Casabella, y luego me preguntó si estaba interesado en ser asistente en la escuela y colaborar en Casabella. Y estuve enseñando durante dos años junto a Gregottiy Tintori en el curso de Rogers. Pero después de dos años trabajando en el curso, por varios motivos también personales, dejé la escuela.

\section{L.B./ A partir de ahí empieza su relación con la revista Casabella...}

Sí, pero trabajé durante poco tiempo en la redacción de la revista. Lo más importante fue la relación con los que ya trabajaban en Casabella (Gregotti, Tentori, Rossi, Semerani y Tintori), un poco más mayores que yo. Y ahí comenzó mi amistad con Aldo Rossi. Poco después abrí un estudio con él, durante una temporada bastante corta, de 4 años. Hicimos algunas cosas por la escuela, con dinero del CNR (Consiglio Nazionale delle Ricerche), estudios sobre tipología, y algunos proyectos, de los cuales el más conocido es la Unidad Residencial San Rocco, en Monza. Además, cuando contrataron a Aldo Rossi para dar clase, me preguntó si estaba interesado en retomar la escuela. $Y$ así fue como volví a enseñar en la Politécnica de Milán.

Con Aldo estábamos muy ilusionados por hacer lo que queríamos, trabajamos juntos desde el ‘65 hasta el ‘68 aproximadamente. 
En esa época no teníamos trabajo. Escribí el libro para obtener la "Libera Docenza", un concurso de universidad para ser confirmado como asistente ordinario, era algo así como el doctorado de hoy. Habiendo ganado la plaza de asistente ordinario tenías cinco años para obtener la Libera Docenza, y si no lo hacías, perdías tu plaza.

Si obtenías la Libera Docenza, la Universidad para la cual la habías solicitado debía asignarte horas de docencia, para enseñar libremente. Era una forma muy bonita de enseñar, ahora eso ha quedado muy lejos...

Además este examen, que versaba fundamentalmente sobre la producción académica (escritos y proyectos), se hacía en Roma, con un tribunal de cinco catedráticos. En mi tribunal, el más joven era Aymonino, que era mi amigo. Al final de este examen había una exposición oral de cincuenta minutos, sobre un título que te daban 24 horas antes. Al finalizar, uno de estos profesores me dijo: - usted el año que viene va a enseñar en Pescara. La facultad de Pescara era una institución nueva, y allí pasé unos cuantos años. Esta experiencia fue muy interesante, sobre todo debido a los estudiantes, que estaban muy interesados, eran activos y por lo tanto muy estimulantes, a pesar de los muchos problemas prácticos y de la difícil situación política (eran los "anni di piombo" y de la "contestazione studentesca"), etc..

En el mismo periodo estuve enseñando también en Milán, siempre proyectos.

V.M./ ¿Cuál cree que es la mejor manera de enseñar a proyectar? ¿Cómo cree que se transmiten mejor los conocimientos en materia de proyectos?

La única cosa que hago yo con los estudiantes es inculcarles el principio de Adolf Loos, que afirma que "un arquitecto es un albañil que ha estudiado latín". Es una afirmación contundente, muy clara e inequívoca, que debe entenderse en el sentido de que un arquitecto no es un "artista" (como parece pensarlo la mayoría de nuestros contemporáneos), un arquitecto es un albañil que ha estudiado y conoce la historia. Esto es muy importante, porque los estudiantes nunca han estudiado en este sentido, tampoco se han metido en este problema y no son conscientes de lo que no saben. Es lo único que les enseño. No es algo baladí estudiar latín (la historia), sino una necesidad práctica, un instrumento para uno mismo. Si uno ha estudiado latín por su propia necesidad, luego puede hacerlo todo, incluso hacer de albañil, pero esto viene después. Creo que éste es el problema de los estudiantes de hoy, se nota por ejemplo en los estudiantes que vienen del liceo clásico, que se ven favorecidos por los estudios hechos, porque se encuentran mejor preparados y más abiertos que los que vienen de otra rama. 
Cuando yo era estudiante teníamos muchas ganas e interés, y naturalmente una gran preocupación e inquietud por "conocer". Si alguien nos hablaba de un personaje o de un libro que no conocíamos, esa misma noche lo leíamos, sentíamos la obligación de conocerlo, de hacerlo propio en seguida. Es justo lo que dice Loos: ante todo intentar poseer lo que atañe a tu proprio interés, o sea conocer tu propia materia y oficio. Y esto no es algo que se pueda conseguir sin dificultad, ni sin trabajo.

Como consecuencia, en arquitectura la escuela de los grandes números en realidad es un engaño. También porque se trata de un trabajo que no puede prescindir de sus implicaciones en el plano ético y moral, porque intervine en un ámbito que es ante todo público, o sea colectivo; la arquitectura es antes que nada obra colectiva, o sea su trabajo presupone una elección previa, relativa a esta prioridad de la cuestión ética y moral en el trabajo de la arquitectura. - Puesto que se trata de un trabajo que afecta a la vida cotidiana, que su producto es algo que se impone, que no se puede evitar, algo que nos obliga, etc. - Para mí, la elección moral es primordial, porque tenemos que saber muy bien lo que vamos a hacer, y que eso que vamos a hacer es algo que va a pertenecer a todos. $Y$ reconocer también que esta prioridad es tan conflictiva, tan evidentemente ajena a lo que la mayoría de los arquitectos de hoy piensa y hace, que nos obliga a ver nuestra postura como secundaria y nada influyente (en absoluto).

V.M./ En su arquitectura se percibe una necesidad de ser auténtica, una búsqueda de verdad, de responder a una necesidad, ¿cree que esto es una constante en su obra?

No sé si lo he conseguido, pero mi máximo deseo ha sido siempre hacer cosas "necesarias". Solamente esto. No es mucho, pero es bastante difícil mantenerse fiel a este objetivo sin desviarse. Porque hoy uno tiene que enfrentarse a un público que cree que ser arquitecto quiere decir confiar sobre todo en su propia creatividad y fantasía para hacer algo nuevo y diferente, un público que está convencido de que la arquitectura es sobre todo una obra de arte. Puede ser que el resultado final sea también una obra de arte, pero esto no es lo primordial, lo primordial es que sea necesario en el sentido más amplio; luego puede ser que otros digan que lo que has hecho tiene algo que ver con lo que definimos como "arte". Yo pienso que todo lo que se ve ahora en el campo de la arquitectura difiere mucho de lo que era esta tarea en su origen, hoy asistimos a un prevalecer absoluto de la "forma" en el proceso de proyecto. Hoy el trabajo de la arquitectura se ha convertido en algo totalmente diferente. Yo pienso que los jóvenes tienen que tomarse muy en serio este problema, estudiárselo bien y formarse su propia convicción sobre su oficio, sobre cuál tiene que ser su elección frente a esta absurda situación en la cual se encuentra hoy en día la arquitectura. 
A pesar de que hoy se ha convertido en un lugar común, nunca se trata de un problema de forma, la forma en el proceso de proyecto tiene siempre que aparecer al final. Si tú empiezas por la forma, estás ya perdido, fuera de juego. Por eso, a mí no me interesan las arquitecturas que se ven en las revistas, ni tampoco me gusta discutir sobre ellas. Hay ya suficientes ejemplos de arquitectura en la historia, lejana y más reciente, para aprender lo que es importante e intentar que tu trabajo pueda medirse en serio con ellos.

\section{L.B./ ¿Y en ese aprendizaje cómo se empieza? ¿Mirando hacia el clasicismo?}

Mirando hacia toda arquitectura que enseña, que habla de sí misma, que se mide con su experiencia, es decir con sus modelos, que te hace aprender y te reafirma en tus elecciones, en lo que tú piensas que tiene que ser la arquitectura en el mundo de hoy. Mirando hacia toda arquitectura que en tu opinión interpreta el mundo de hoy, lo que piensas que tiene que ser el mundo de hoy.

Por ejemplo, el mundo representado por la arquitectura de Niemeyer es diferente del mundo que representa la arquitectura de Mies van der Rohe. Es evidente que tenían objetivos (además de sus obsesiones) muy diferentes. Hablar de arquitectura, o sea de arquitectos, siempre quiere decir poner en relación la obra con una idea de vida (en la cual la obra irrumpe), es decir una idea del mundo. Si tú piensas en elegir como maestro, por ejemplo, a Mies van der Rohe, debes entender que toda su arquitectura está marcada por la búsqueda de una simplicidad idealizada, es decir un mundo idealizado, algo que nunca se mide con la vida, sino con una forma idealizada de ella. Entonces es algo que no pertenece a la vida: puedes encontrarte seducido por las formas de esa arquitectura, pero también tienes que ser consciente de esta particular elección.

Para mí la arquitectura es un trozo inextricable de la vida, para la arquitectura no hay otra razón de ser que la vida, la vida de los hombres, la vida cotidiana. Para mí, por ejemplo, esta postura de la arquitectura muy estilizada, reflejo ideal de una vida igualmente idealizada, no es lo que la vida espera de la arquitectura. La arquitectura no es eso, la arquitectura es materia que irrumpe en la vida y que va a modificarla; no es un cuadro, una escultura o un dibujo, es una cosa cuyo destino es durar, que tiene que estar ahí por mucho tiempo y que por tanto no tiene que plantearse como algo muy provisional, o incluso parecer que va a caerse o arruinarse, como hoy a menudo parece. Para mí está bastante claro lo que tiene que ser la arquitectura, todo lo contrario de lo que se ve, de lo que se construye y se fomenta ahora.

Yo no soy optimista. Cuando alguien me dice "quiero ser arquitecto", yo le contesto que es una manera como cualquier otra de hacerse daño, dado que ahora la arquitectura se ha convertido en un trabajo totalmente 
diferente. Esto se ve por ejemplo en los proyectos de los estudiantes, que nunca saben dibujar una sección vertical, pero éste no es un problema técnico, es un problema de sabiduría... Uno cuando piensa en un proyecto, tiene que olvidarse de la forma y pensar en la construcción, pensar que es algo que se construye, midiéndose con los materiales, con su conocimiento y con su experiencia; se trata de poner una cosa sobre la otra, para que no se caiga, teniendo en cuenta las leyes físicas más elementales de la arquitectura, las que definen su necesidad desde siempre, y no complicar la vida, en lo posible intentar ayudarla, simplificarla.

\section{L.B./ Para usted, ¿̇la figura del maestro es muy importante en la formación del arquitecto?}

Mis maestros, los que influyeron en mi aprendizaje, empezaron a interesarme por sus obras, a través de las revistas alemanas de arquitectura de los años veinte que yo tenía en casa (donde me encontré por primera vez las obras de Mies y Hilberseimer, las de Oud y de Tessenow). Pero en algún momento me di cuenta de que me interesaban obras cuyo interés no derivaba directamente de sus formas.

Mis maestros fueron Rogers, maestro en la escuela, por su carisma y el de sus escritos; después Tessenow, a quien yo traduje su libro "Hausbau und Dergleichen" (un libro que se convirtió en una especie de biblia para mis estudiantes), que era interesante por su postura original frente al deber del arquitecto, y porque había reducido toda la polémica del Movimiento Moderno contra el historicismo ottocentesco a sus raíces mas concretas, Tessenow presentaba un punto de vista totalmente diferente al de todos los otros - de Mies a Gropius, etc. - , un punto de vista que anulaba toda postura formalista, que a la forma oponía el valor, el sentido, la relación de la forma con la vida, por eso me interesó, por su postura frente al sentido de las formas mucho mas que sus obras, que siempre eran elocuentes, Tessenow me interesaba por ese motivo. Para mí esto estaba bien porque si consigues no fijarte en las formas en sí mismas, no te dejas encantar por las obras y te quedas sólo con la lección (que es lo único que te sirve).

Después Oud, otro maestro, me interesó mucho por una razón análoga. Yo traduje un librito suyo, en el año 1961, publicado después en Casabella, que se llamaba "Mi vida en De Stijl" (él me escribió una carta dándome las gracias). Me interesó porque él, siendo uno de los mayores representantes del M.M. (sus obras más conocidas pertenecían a su periodo en De Stijl), al final hizo un edificio, el edificio de la Shell, que transgredía totalmente los principios del M.M., y también sus propios principios. Escribió que se había equivocado, que la arquitectura era mucho más que lo que se entendía en la arquitectura propugnada por el M.M., que comprendía mucho más, no solamente los problemas de una nueva forma, problemas de renovación y creatividad -lo que eran los dogmas del movimiento moderno-; que la arquitectura era también muchas más cosas, que tenía que responder a muchas más preguntas de la vida, etc. E hizo este proyecto, 
que era la expresión directa de sus nuevos principios. Y lo atacaron muchísimo, especialmente desde la crítica americana. Él se defendió diciendo sólo que el edificio de la Shell era su obra preferida. Esto fue muy importante para mi, porque él, siendo uno de los máximos exponentes del movimiento moderno, que había construido durante este periodo obras universalmente reconocidas como maestras, tuvo el coraje de cambiar totalmente su línea de acción y comenzar de nuevo. El edificio de la Shell es como la obra de un aprendiz, de alguien que está empezando de nuevo; y esto me dejó una huella muy importante, porque me obligó a considerar que el ser arquitecto era también esto. Si dudas, tienes que poner lo que has hecho en discusión cada vez, tienes que empezar de nuevo cada vez.

V.M./ En otras palabras, se trata de ser crítico con uno mismo, volver a plantearse las cosas cuando ya se ha construido un personaje en torno a una persona, en el momento en que ya está idealizada la figura, de golpe...

Sí, esto es, pero es el único caso tan claro y ejemplar que conozco. Por eso lo he elegido como maestro.

También elegí a Loos, porque era un señor que hablaba muy poco de arquitectura, pero era como si hablara de arquitectura cuando hablaba de zapatos, cuando hablaba de carros o de música... (era una manera de hablar de arquitectura, como si fuera - y en realidad lo es- una actividad artesanal como otras, como hacer zapatos o componer una sonata).

M.B./ Cambiando un poco de tema, ¿cómo se plantearía usted la intervención sobre obras de estos maestros del movimiento moderno? Pongamos por ejemplo la villa Tughendat, ¿cómo se podría intervenir sobre ella? ¿Cómo actuaría, por ejemplo, sobre la valla oxidada? ¿Cree que existe menos prejuicio a la hora de intervenir sobre edificios clásicos, que sobre los modernos?

Para mi la restauración es, o bien una cuestión técnica, que es el caso que tu comentas, o es una cuestión de arquitectura, que es proyectar. Si es un problema solamente técnico, entonces se llama a un ingeniero...

M.B./ Sí, pero también influye el uso, porque estas obras en general están deshabitadas, y parece que la única manera de conservarlas es convertirlas en un museo de sí mismas. ¿Qué opina al respecto?

Éste es otro problema. Yo con una villa de Mies van der Rohe podría hacer... no sé... una gasolinera, se puede hacer lo que quieras... ¿̇uál es la diferencia en cuanto a expresividad y elocuencia entre la villa Tughendat y el pabellón del Barcelona?

Rogers hizo de joven una gasolinera en Trieste, pequeña y sencilla, que ahora se ha convertido en un pequeño museo en el que se hacen eventos culturales. Pero no se trata de una obra de peregrinaje, simplemente está utilizada, pocos saben que esta gasolinera es obra de Rogers... Porque 
ahí se puede hacer lo que quieras, no cambia el edificio. Para intervenir en estas obras no hace falta un arquitecto. Éste es un falso problema. El problema se plantea si una obra está incompleta, en este caso se puede completar, y se debe hacer. Si se quiere completar, esto es trabajo del arquitecto, que tiene toda su libertad y toda su sabiduría para enfrentarse al problema. Tiene que partir del problema, pero no del problema de la pérdida, porque la obra está ya completa y sólo le falta un trozo, tiene que enfrentarse con el problema de su proyecto original.

\section{L.B./ Y para usted, esa manera de actuar ¿siempre ha sido la reconstrucción? ¿cree que es la única manera de actuar?}

Sí, es la única, porque las demás maneras llevan a un ajuste invariablemente falso. Reconstruir, naturalmente con los medios, la cabeza y las condiciones de tu tiempo (esto es lo que hemos intentado en el teatro de Sagunto). Ya no estamos en tiempos de Viollet-le-Duc, cuando hacer revivir el gótico era una manera de afirmar una pertenencia sincera y positiva: todo esto hoy ya no tiene sentido.

\section{L.B./ El teatro romano de Sagunto es una obra muy querida por usted, ¿es su obra preferida? - aparece en la portada de su último libro...}

Sí, yo pienso que es una de mis obras más importantes, y también de las más discutidas por mí mismo, y en la que más he profundizado. Es una obra importante porque me obligó a enfrentarme con la arquitectura romana de una manera tan directa y comprometida, como sin alternativas. Es decir, me obligó a asumir la diferencia que hay entre una arquitectura que refleja un periodo histórico de manera totalmente global, y la arquitectura de hoy, que sólo es reflejo del pensamiento de un individuo que no sabe bien qué hacer, ni lo que hace... La arquitectura romana era algo de gran importancia (social y política) en el mundo romano, por eso estaba reducida a sus raíces y caracteres más necesarios y elocuentes. Se hacían teatros en todas partes del mundo, con albañiles muy distintos, que tenían que emplear materiales muy diferentes de un sitio a otro... para ello tuvieron que fijar normas muy estrictas, pero sólo las necesarias. Todos los teatros del mundo romano son iguales, pero a su vez cada uno es diferente del otro, porque están las manos de los que lo han hecho. Pero esto no cambia nada, porque los teatros que están en Europa, en África o en Medio Oriente, los que están más o menos bien construidos, obtienen el mismo resultado que un teatro hecho en la propia Roma.

Esto es lo máximo para la arquitectura, tener estas obras que no tienen necesidad de estar construidas por estar definidas en todos sus caracteres, hasta los detalles. Es el principio del manual de arquitectura, es el único período histórico en el que no había otra arquitectura, la arquitectura era la romana, en todos los sitios. Era un problema de construcción, todo estaba pensado de la misma manera, pero se actuaba en condiciones diferentes y con gente diferente. Esto es lo máximo que se puede esperar alcanzar 
en arquitectura. Los griegos eran otra cosa completamente distinta, no les interesaba la ciudad. A los romanos les interesaba solo la ciudad y las obras de arquitectura solo en función de la ciudad. A los griegos les interesaba la obra en sí, por eso los griegos desarrollaron modelos de capiteles. A los romanos esto les daba igual, cogieron los capiteles griegos y los utilizaron, sin preocuparse por cambiarlos.

\section{L.B./ Es como si en el diseño del teatro no hubiera un arquitecto detrás. Ya hubo un arquitecto inicialmente, que desarrolló la tipología del teatro, y a partir de ahí...}

Sí, eso es fantástico. Poder construir sin preocuparse por problemas secundarios, como la expresividad personal, de dejar su huella, etc. Sin embargo hoy los arquitectos ven las cosas de manera totalmente diferente: consumidos por su protagonismo, se han convertido en artistas, en creadores, igual que los modistos.

\section{V.M./ En su conferencia de esta mañana, en la Escuela de Arquitectura de Valencia, nos ha enseñado algunas de sus obras, entre ellas sus bibliotecas... A la biblioteca de Valencia, la ha definido como "un castillo en defensa del libro"...}

Sí, un castillo en defensa del libro (en defensa frente al avance del libro virtual) pero también un monumento al libro, a su materialidad y a su larga historia (el gran espacio interior está totalmente forrado de libros en toda su altura). Años antes yo había hecho una biblioteca en Holanda, en Groningen, y estaba muy ilusionado porque era la primera biblioteca que hacía. Pero en Holanda, las bibliotecas públicas son más bien un sitio donde se prestan libros para llevarlos a casa, es decir, no es un sitio para leer rodeado de libros, la gente se sienta en el suelo, mira los libros, los coge... Entonces fue en parte una desilusión, era más como una tienda que como una biblioteca... Cuando hicimos la biblioteca de Valencia, pusimos todo nuestro interés en hacer un sitio en el que se consiguiera una relación agradable y adecuada con el mundo de los libros, y al mismo tiempo un lugar en el que fuera evidente la absoluta centralidad del libro.

\section{L.B./ Pero en la actualidad, muchas bibliotecas se han convertido en salas de estudio y no tanto de lectura...}

Sí, Pero estudiar es también leer. Lo singular es vivir la experiencia única de estar sumido en los libros. Yo también he estudiado durante años en una biblioteca, en Milán, en la biblioteca Borromeo, una antigua biblioteca, que tenía un fondo de arquitectura muy importante y que incluye también una pinacoteca. Se llama biblioteca Ambrosiana. Si vais a Milán, tenéis que visitarla, porque también tiene una galería muy importante, donde por ejemplo está el gran dibujo (a escala 1:1) de la escuela de Atenas de Rafael, y es increíble, aunque casi nadie lo sabe... es el dibujo a mano de Rafael, al que le falta solo la arquitectura. Es por ello que dicen que la arquitectura es de Bramante, y puede ser que lo sea... 
